Российская академия наук

Институт археологии 

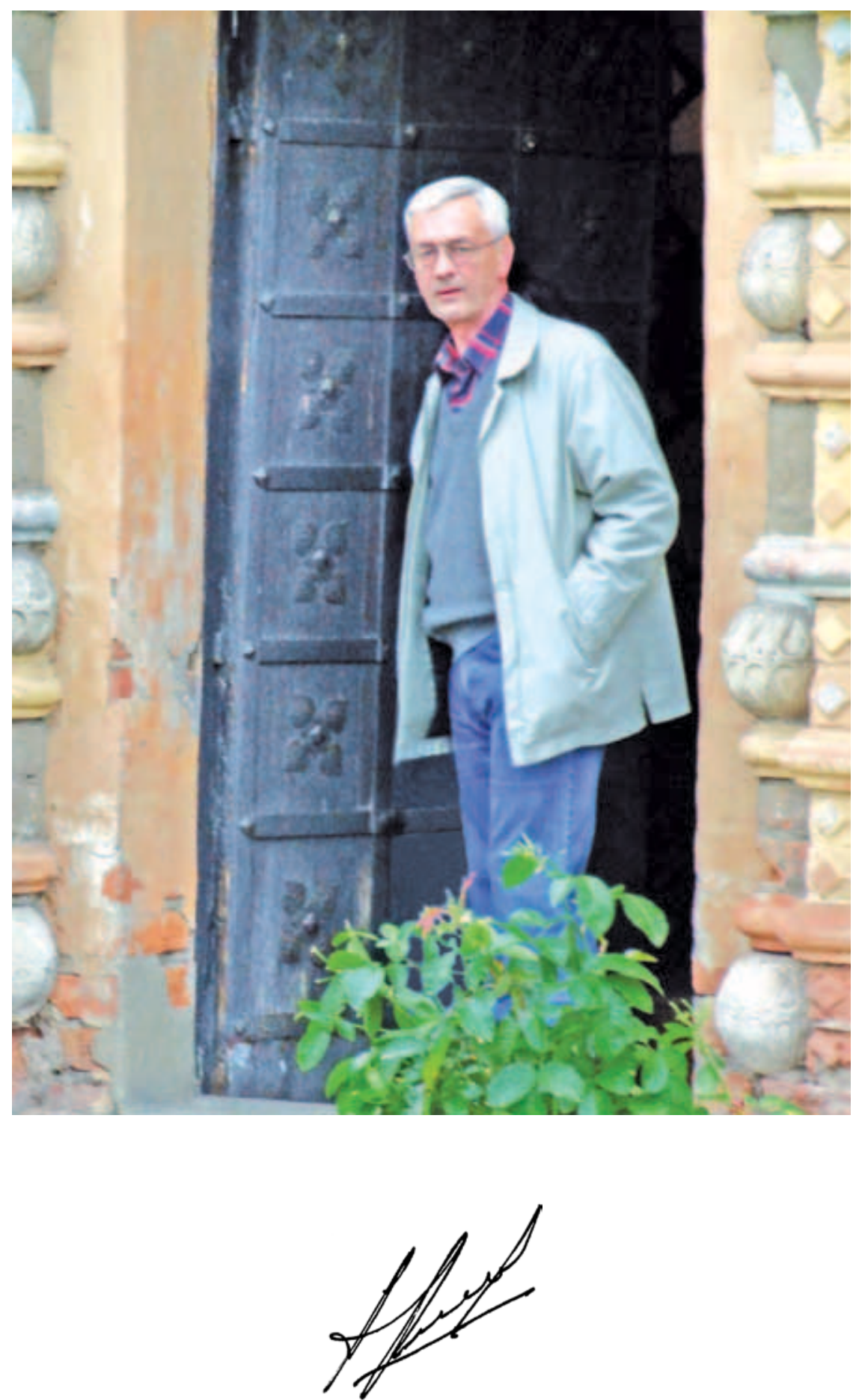
Российская академия наук

Институт археологии

Земли родной минувшая судьба...

К юбилею Андрея Евгеньевича Леонтьева

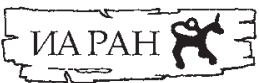

Москва

2018 
Утверждено к печати на заседании Ученого совета Института археологии Российской академии наук

Ответственный редактор: доктор исторических наук $A . B$. Чернецьов

Редактор-составитель: И.Н. Кузина

Рецензенты:

доктор исторических наук А. М. Обломский; кандидат исторических наук 3.Х. Царикаева

\section{3-52 ева - М.: Институт археологии РАН, 2018. 328 с.}

ISBN 978-5-94375-262-9

В новый сборник трудов отдела средневековой археологии РАН вошли статьи его сотрудников, работающих над коллективной темой «Динамика исторической жизни и культурная идентичность в Восточной Европе от эпохи Великого переселения народов до Московской Руси - археологическое измерение». В связи с юбилеем ведущего научного сотрудника отдела А. Е. Леонтьева в сборник включены также работы коллег из других научных организаций.

Статьи охватывают широкий круг проблем средневековой археологии Восточной Европы, древнерусского государства, главным образом его северо-восточных территорий. Анализируются новые вещевые находки, некоторые из них уникальны. Блок статей знакомит читателя с современной точкой зрения на происхождение городов и их развитие. Большинство предлагаемых читателю тем, отраженных в статьях сборника, в той или иной степени соприкасаются с исследованиями А.Е. Леонтьева.

Для археологов, историков, искусствоведов.

В оформлении обложки использованы фрагмент карты Ростовского уезда Ярославской губ. 1916 г. и находки из раскопок А. Е. Леонтьева на Сарском городище.

УДК 902/904

ББК 63.4

ISBN 978-5-94375-262-9

DOI: 10.25681/IARAS.2018.978-5-94375-262-9

(C) Федеральное государственное бюджетное учреждение науки Институт археологии РАН, 2018

(C) Коллектив авторов, 2018 


\section{Содержание}

\section{Кашкин А. B.}

Поздравляем друга и коллегу ...……………………................................................................. 7

Михайлова Л.А.

А.Е. Леонтьев - директор музея-заповедника «Ростовский кремль» ………........................................ 9

К биографии ученого ..................................................................................................... 11

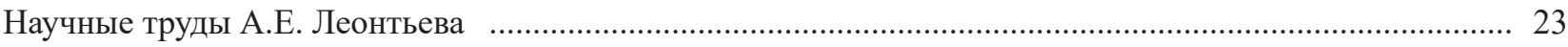

Макаров Н. А., Гайдуков П.Г.

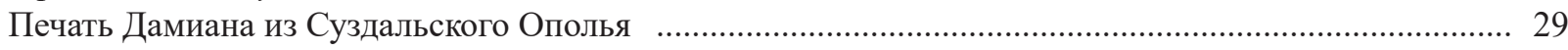

Лапшин В. A.

Североевропейские находки на селище Гнездилово-2 под Суздалем …………................................. 34

Чернецов А.В.

К изучению феодальной эмблематики и юридических знаков

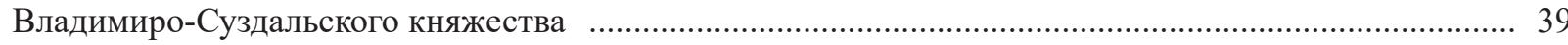

Астатова Н.И.

Борисоглебские энколпионы в собрании Исторического музея ………………................................ 48

Седов Вл. В.

Скульптурный фрагмент с мордой зверя из Боголюбова

Беляев Л. А., Глазов В. П., Зыков П. Л., Иоаннисян О.М.

Погребальные сооружения XII-XV веков на месте собора Рождества Богородицы

во Владимире (по материалам работ 1997-2000 годов)

Зайцева И.Е., Столярова Е.К.

Об одном погребении могильника Шекшово в Суздальском Ополье ...………………………......... 73

Комаров К.И.

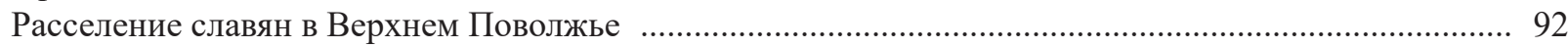

Нефёдов В. С.

Послесловие. О статье Константина Ивановича Комарова ………………………………................. 98

Моргунов Ю. Ю.

Еще раз о «полезной площади» городищ

Мальгин П.Д.

$\mathrm{O}$ «парах» и «переносах» городов древней Руси

Петрухин В.Я.

«Начаша владъти сами собъ и городы ставити»: археология и источники варяжской легенды

Курмановский В.С.

Территориальные структуры центральных районов Смоленской земли в XI-XV веках

К постановке проблемы

Ениосова Н.В., Пушкина Т.А., Столярова Е.К.

Стеклянные игральные фишки из раскопок в Гнёздове 


\section{Гомзин А. А.}

Вторая часть Мшагского клада куфических монет

Медынцева А. А.

Еще раз о Воймерицком кресте

Олейников О.М.

К вопросу о письменной культуре средневекового Новгорода

Дубровин Г.Е.

Музыкальные инструменты с Федоровского раскопа в Новгороде

Коваль В. Ю.

Импортная поливная керамика Житного раскопа в кремле Переяславля Рязанского

Бадеев Д.Ю.

Христианские древности с территории ремесленно-торгового района золотоордынского Болгара

Жилина Н.В.

Орнаментальный мир древнерусских тканей X-XI веков

Завьялов В. И., Терехова Н.Н.

Славянская технологическая традиция в формировании модели

древнерусского кузнечного ремесла

Кызласов И.Л.

Новое в жизни Восточной Европы в XI-XII веках. (Влияние Великого Сибирского пути, открытое археологией)

Янишевский Б. Е.

Раскопки на месте церкви св. Анастасии в Переславле-Залесском 251

Буров В. А.

К реконструкции монашеских лавок Соловецкого монастыря

Армарчук Е.A.

Деревянные изделия из раскопок храма у села Весёлое под Адлером

Сапрыкина И.А.

Цинкосодержащие сплавы в цветной металлообработке лесной и лесостепной зон конца I тысячелетия до н.э. - первой половины I тысячелетия н.э.: «индекс романизации»

Исланова И.В.

Ермоловское городище (материалы раннего железного века)

Кашкин А. В., Комаров К. И.

Итоги мониторинга памятников археологии Ростовского района

Кренке Н. А.

Керамика Подболотьевского могильника из раскопок В.А. Городцова 310

Зеленцова О.В.

О ранней дате и месте гривен глазовского типа в древностях поволжских финнов 


\section{ПОЗДРАВЛЯЕМ ДРУГА И КОЛЛЕГУ}

В августе 2018 г. отметил свой 70-летний юбилей ведущий научный сотрудник Института археологии РАН доктор исторических наук Андрей Евгеньевич Леонтьев.

А.Е. Леонтьев родился 17 августа 1948 г. в Таллине в семье морского офицера. После окончания школы он хотел поступать в мореходку, но по зрению не прошел медкомиссию. Судьба распорядилась иначе, и Андрей Леонтьев поступил в 1966 г. на исторический факультет МГУ, который успешно окончил в 1971 г. Обратим внимание, что А. Е. Леонтьев, еще будучи студентом, первым из археологов всего нашего курса получил в 1969 г. свой первый открытый лист и провел самостоятельные разведочные работы в Ярославской области.

По окончании аспирантуры на кафедре археологии в 1974 г. А.Е. Леонтьев защитил кандидатскую диссертацию «Сарское городище в истории Ростовской земли (VIII-XI вв.)». Его научным руководителем был профессор Даниил Антонович Авдусин.

В 1974 г. А.Е. Леонтьев пришел в Институт археологии АН СССР в новостроечный отдел. Позднее судьба связала его на долгие годы с отделом славяно-русской археологии, ныне - средневековой археологии. Здесь он прошел путь научного становления от младшего до ведущего научного сотрудника.

Тогда же, в 1970-е годы, начались масштабные полевые работы А.Е. Леонтьева в Верхнем Поволжье. В 1977 г. он основал Волго-Окскую экспедицию, активно работающую и поныне. На территории четырех верхневолжских областей А.Е. Леонтьев обследовал несколько сотен памятников археологии различных эпох. Интереснейшие научные результаты принесли раскопки посада Сарского городища в Ярославской области (1980-1982 гг.), городища Попово в Костромской (1980-1984 гг.), городища Выжегша во Владимирской (1983-1986 гг.), городища Еськи в Тверской области (1997 г.), мерянских и древнерусских поселений на озерах Неро и Плещеевом. Публикации результатов этих исследований стали классикой археологической литературы.
В 1983 г. Волго-Окская экспедиция, возглавляемая А.Е. Леонтьевым, начала исследования древнерусского Ростова. К настоящему времени вскрытая раскопками площадь в городе составляет около 4000 кв. м.

А.Е. Леонтьев - крупнейший специалист по проблемам археологии и истории Северо-Восточной Руси, археологии финно-угорских народов Поволжья. В 1991 г. он защитил докторскую диссертацию «Археология мери. К предыстории СевероВосточной Руси», опубликованную монографически в 1996 г. В ней подведен итог многолетним исследованиям, позволившим очертить границы расселения летописной мери, проследить этапы древнерусской колонизации и особенности формирования первоначальной территории и городских центров Ростовского княжества в конце IX - первой половине XI в.

К настоящему времени А.Е. Леонтьев опубликовал около 200 научных работ, в том числе пять монографий, в основном посвященных проблемам средневековой археологии и истории Верхнего Поволжья.

Результаты полевых исследований А.Е. Леонтьева помимо печатных работ легли в основу его многочисленных докладов на научных конференциях и съездах.

В 1999 г. Андрей Евгеньевич становится директором государственного музея-заповедника «Ростовский кремль». В этой должности он проработал 10 лет, оказавшихся весьма продуктивными в жизни музея и его нового директора. При этом А.Е. Леонтьев не прекращал археологические изыскания: при его научном руководстве в этот же период (с 2000 по 2010 г. с некоторыми перерывами) Волго-Окская экспедиция провела масштабные спасательные археологические раскопки на территории реконструируемого здания Конюшенного двора, входящего в музейный комплекс.

В 2010 г. А.Е. Леонтьев вновь полностью включается в работу Института археологии РАН, возвращаясь к активному исследовательскому процессу и полевой практике, становится членом ученого совета, руководит аспирантами и соискателями. 
Достижения Андрея Евгеньевича отмечены научной общественностью. В 2000 г. он стал лауреатом Премии Президиума РАН им. И.Е. Забелина, а в год нынешнего юбилея награжден Грамотой Российского исторического общества.

Андрей Евгеньевич пользуется неизменным авторитетом у коллег, среди которых у него много друзей, приобретенных за долгие годы совместной работы. Помимо чисто человеческих качеств коллеги ценят в Леонтьеве-ученом научную честность и принципиальность, способность оценить достоинства чужого исследования. Основу настоящего сборника, посвященного юбилею ученого, составляют статьи сотрудников отдела средневековой археологии ИА РАН, где А.Е. Леонтьев трудится поныне. Их дополняют работы коллег по Институту и из других научных организаций, с радостью откликнувшихся на предложение поздравить его таким образом.

Позвольте пожелать дорогому юбиляру от имени коллег из Института археологии РАН и от себя лично долгих лет жизни, новых творческих успехов, новых статей и книг.

А.В. Кашкин, Институт археологии РАН, г. Москва 


\section{А.Е. Леонтьев - директор музея заповедника «Ростовский кремль»}

В 1999 г. приказом министра культуры РФ А.Е. Леонтьев был назначен директором Государственного музея-заповедника «Ростовский кремль», федерального учреждения культуры. В этой должности он прослужил десять лет. По определению сотрудников и большого круга друзей музея, для Ростовского кремля это время было поистине золотым десятилетием.

Для Андрея Евгеньевича Ростов Великий и его музей был знаком с 1969 г., когда студентом истфака МГУ он впервые приехал в город и посетил музей. С этого времени научные интересы А.Е. Леонтьева были связаны с археологией Ростова и его округи.

Работа директора такого крупного, одного из старейших музеев России, основанного в 1883 г., чрезвычайно многогранна. Комплекс кремля XVII в. (бывшего архиерейского дома), с пятью расписанными фресками церквями, государскими хоромами, башнями, переходами, требовал масштабной научной реставрации. Поэтому в 2000е годы заменили лемеховое и тесовое покрытие башен и переходов, купола церквей и их покрытие; постоянно реставрировали фрески XVII в., завершилась реставрация особняка для Музея ростовского купечества. Все работы проводились после предварительных научных исследований объектов с привлечением академических и других научно-исследовательских институтов. При подготовке к реставрации Конюшенного двора обследованы фундаменты, проведены масштабные археологические раскопки совместно с ИА РАН. Найденный во время раскопок значительный по объему материал по первоначальной истории Ростова пополнил фонды музея.

О директоре говорили, что он «все делает по науке»: если архитектурный комплекс XVII в., значит, и травяное покрытие территории должно соответствовать Средневековью, и в прудах должна быть соответствующая водная растительность. С этой задачей справлялись садовники, которые продолжали заниматься и восстановлением Митрополичьего сада. Мощная служба мониторинга следила не только за температурно-влажностным режимом в экспозициях и хранилищах, но и на- блюдала за уровнем грунтовых вод. Последнее для памятников архитектуры чрезвычайно важно, так как все здания кремля стоят на дубовых сваях.

В большинстве своем обновлена инфраструктура всего комплекса кремля. Новое оборудование поступило в музейную библиотеку, фондовые хранилища, компьютеризированы все отделы музея.

Особое внимание Андрей Евгеньевич уделял пополнению фондов, реставрации икон, картин и предметов декоративно-прикладного искусства. В результате значительно преобразилась экспозиция древнерусского искусства, обновились картинная галерея и Музей финифти. Открылись новые экспозиции: «Ямские колокольчики и бубенцы», «Сияет злато и лазурь», Музей ростовского купечества. Регулярные тематические выставки постоянно привлекали внимание ростовцев и большого количества гостей Ростова.

Изучение фондов и архивных материалов поддерживалось интенсивной издательской деятельностью музея: каталоги икон, картин, кружевных сколков, фресковых росписей церквей кремля и церквей Ростовского р-на, «Кириллических книг Ростово-Ярославской земли» (совместно с МГУ и Ярославским музеем). Выходили ежегодные сборники научных трудов, а по итогам ежегодной научной конференции «История и культура Ростовской земли»-«Сообщения Ростовского музея». Неизменным спросом пользуются книги по истории ростовских улиц, о ростовском купечестве, каталог «Иконы Ростова Великого» и др., авторами которых являются сотрудники музея.

Не случайно на XI Всероссийском фестивале «Интермузей-2009» возглавляемый А.Е. Леонтьевым ГМЗ «Ростовский кремль» одержал победу в номинации «Наука в музее».

Bсе десять лет под руководством Андрея Евгеньевича музей вел многостороннюю научно-просветительскую работу. При музее работали Детский центр, детская изостудия «Семицветик». Музыкальный фестиваль «Живая старина» собирал исполнителей и ценителей древнерусской музыки многих городов России. В программу этого 
фестиваля входили мероприятия не только в Ростовском кремле, но и обязательные благотворительные концерты в одном из ближайших городов, концерты в детских домах, домах инвалидов Ростовского p-на. Количество посетителей музея ежегодно увеличивалось.

Столь плодотворная и многогранная работа музея была бы невозможной без серьезных высокопрофессиональных кадров научных сотрудников, реставраторов, хранителей, экскурсоводов, обслуживающего персонала. Кадровая политика для дирек- тора с самого начала была на первом месте. Многие сотрудники регулярно повышали свою квалификацию на стажировках, более десяти человек получили высшее образование (заочно), восемь защитили кандидатские диссертации, в основу которых легли исследования музейных фондов и архивов. Для небольшого районного города с древней историей, каким является Ростов Великий, ГМЗ «Ростовский кремль» стал своего рода гуманитарным университетом, выполняющим научно-исследовательскую, хранительскую и просветительскую функции.

Л.А. Михайлова, 2. Ростов, Ярославская обл. 


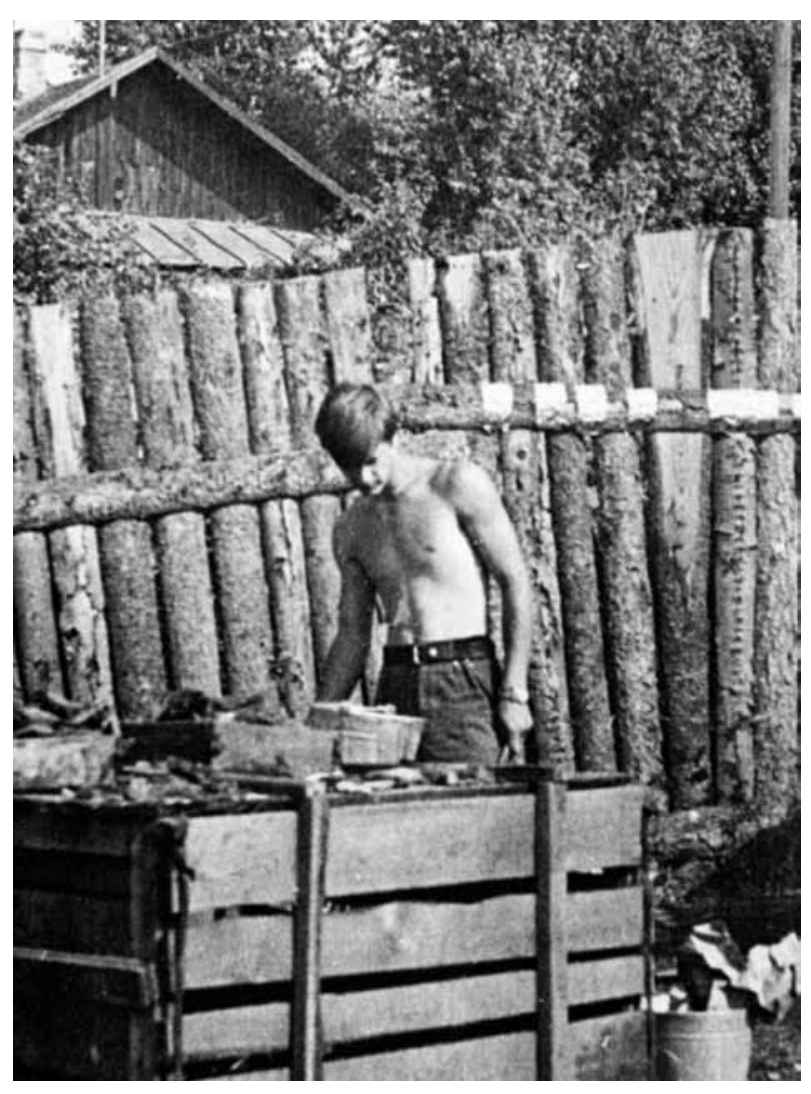

Смоленск, раскоп УС-IX, разбор и подсчет массового материала. 1967 г.

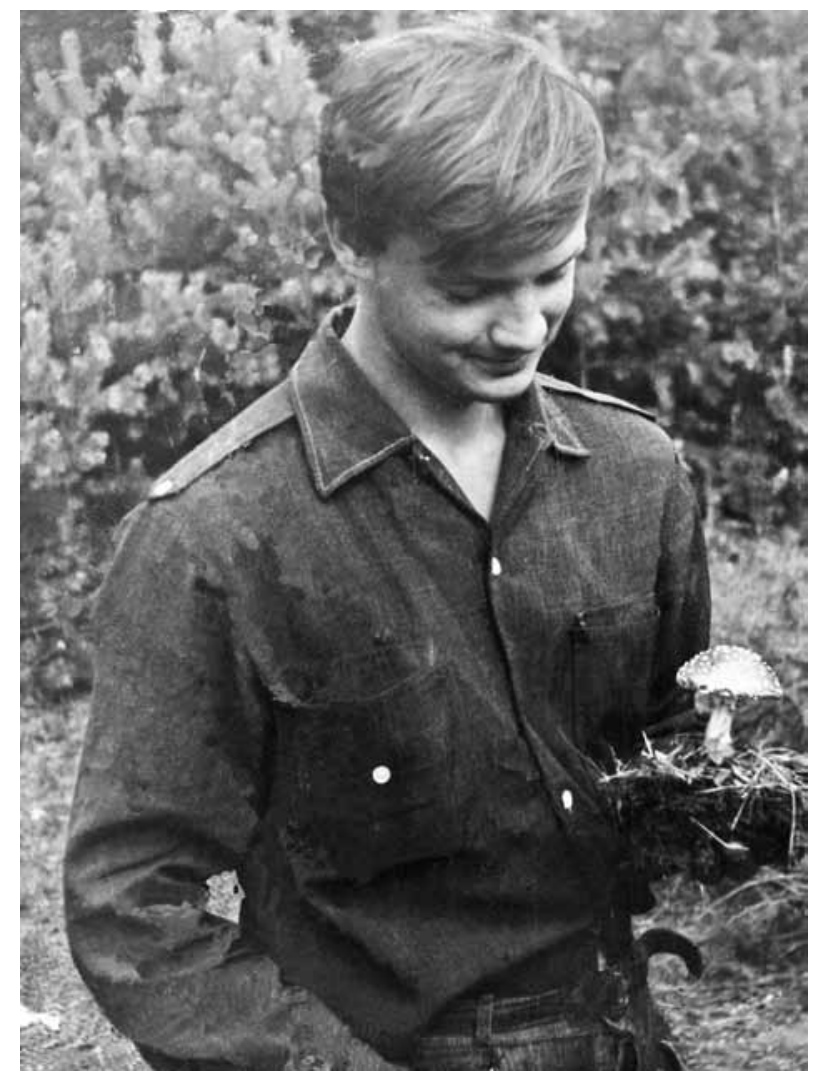

Смоленская экспедиция, Гнёздово. 1969 г.

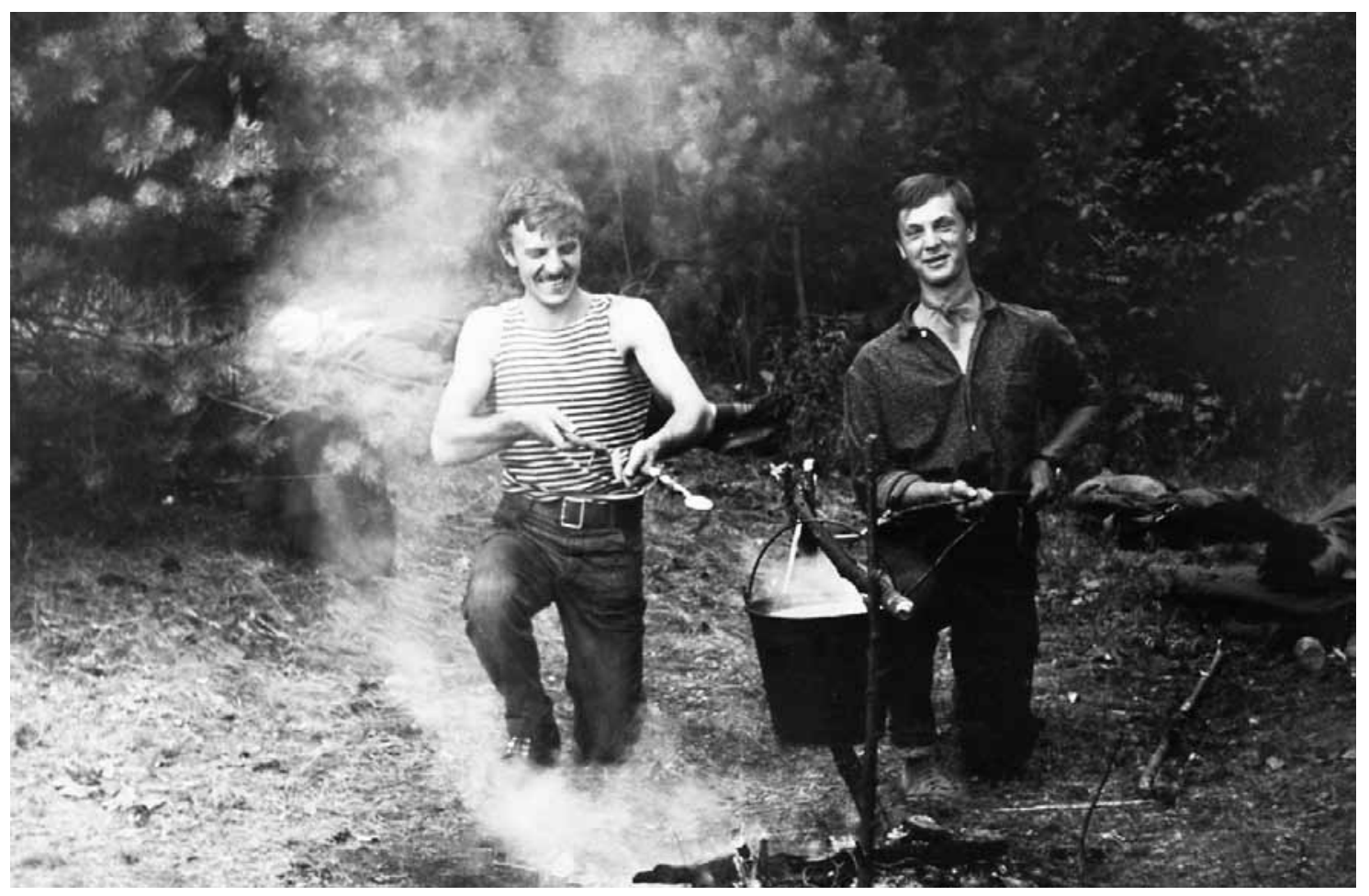

С. Кормилец и А. Леонтьев. Смоленская экспедиция, Гнёздово. 1969 г. 


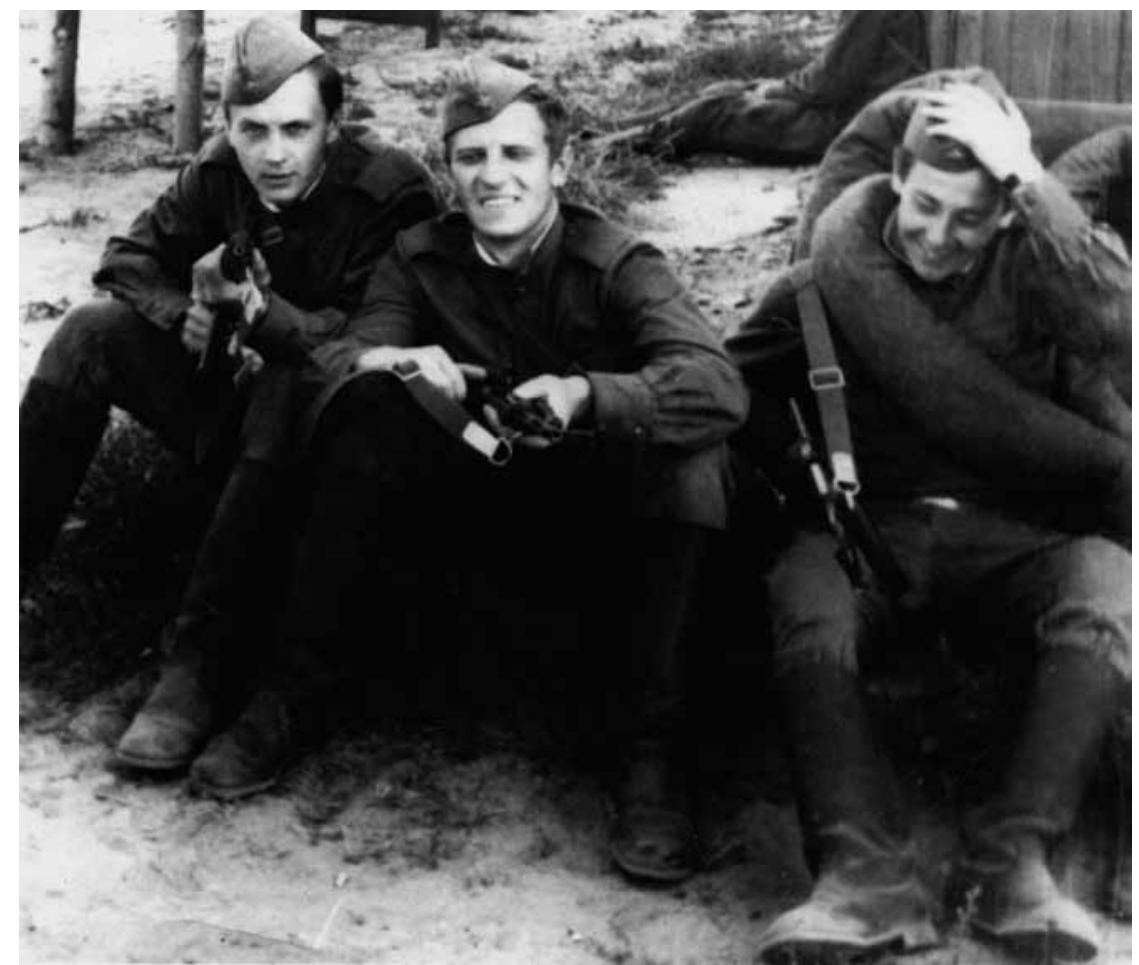

Студенты А. Леонтьев, С. Кормилец, Е. Пивовар в военных лагерях. 1970 г.

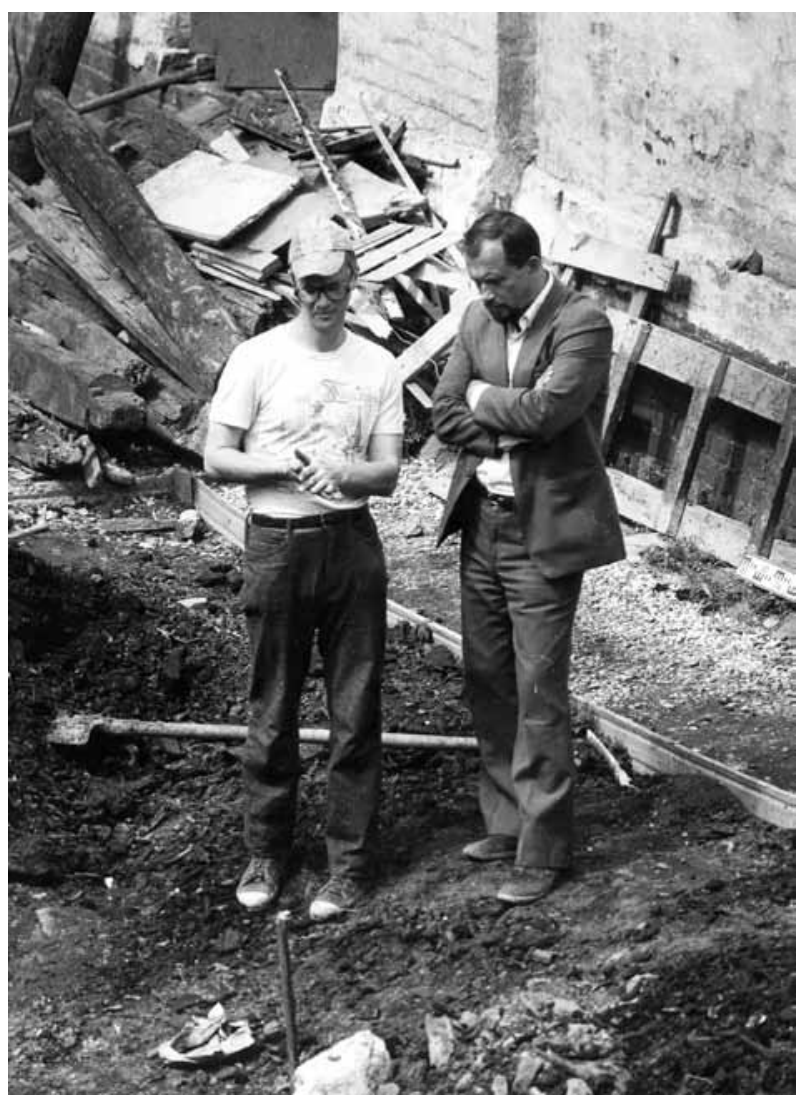

А.Е. Леонтьев и В.А. Ким на месте шурфа у церкви Спаса на Сенях в Ростове. 1983 г. 


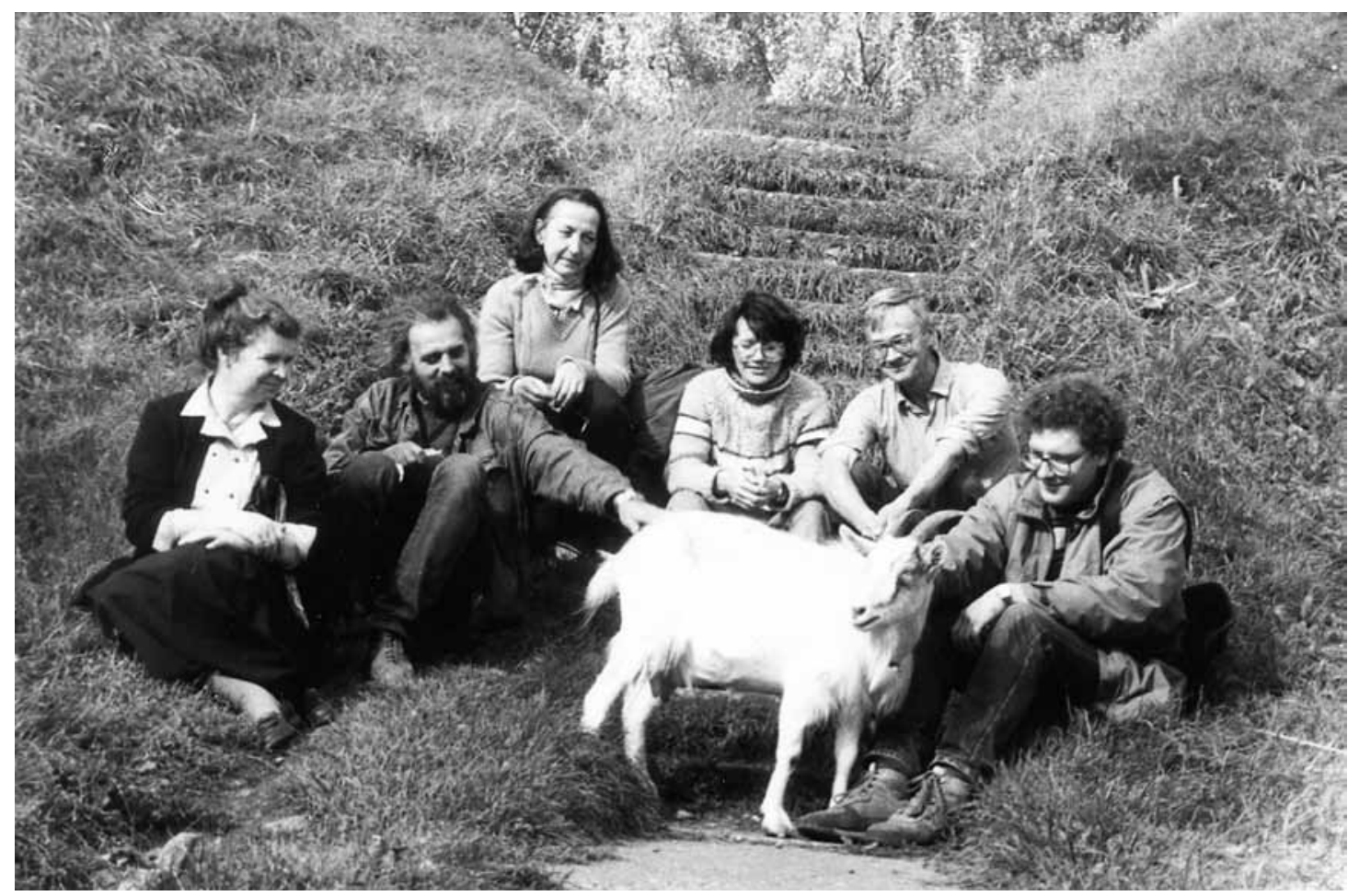

А.Е. Леонтьев с коллегами на валу Переславля-Залесского.

По правую руку от него сидят Т. А. Пушкина, Л. А. Михайлова и О. М. Иоаннисян. 1996 г.

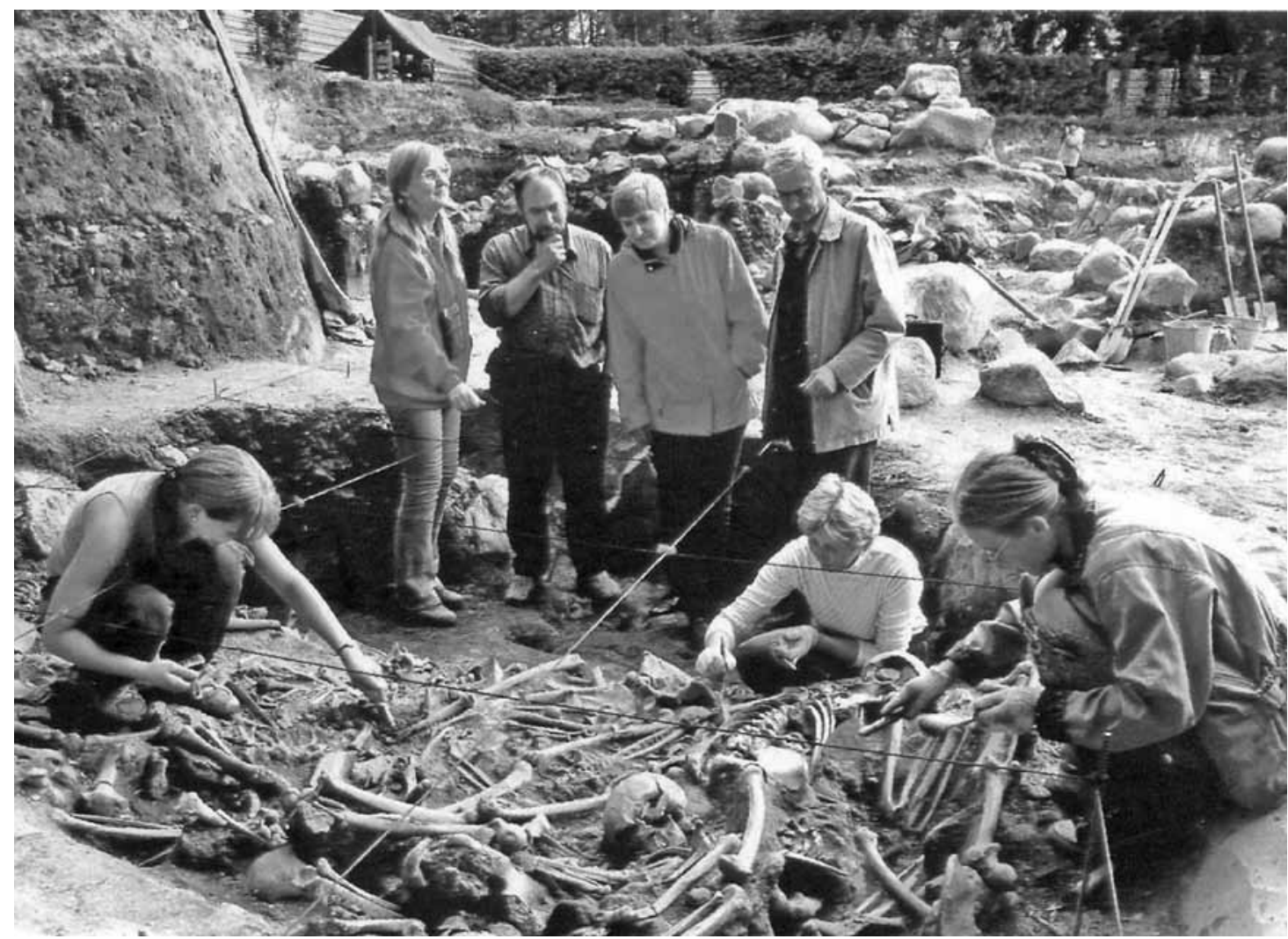

Раскопки в Ярославле. Стоят: Н. Н. Фараджева, Д. О. Осипов, А. В. Энговатова, А. Е. Леонтьев. 2004 г. 


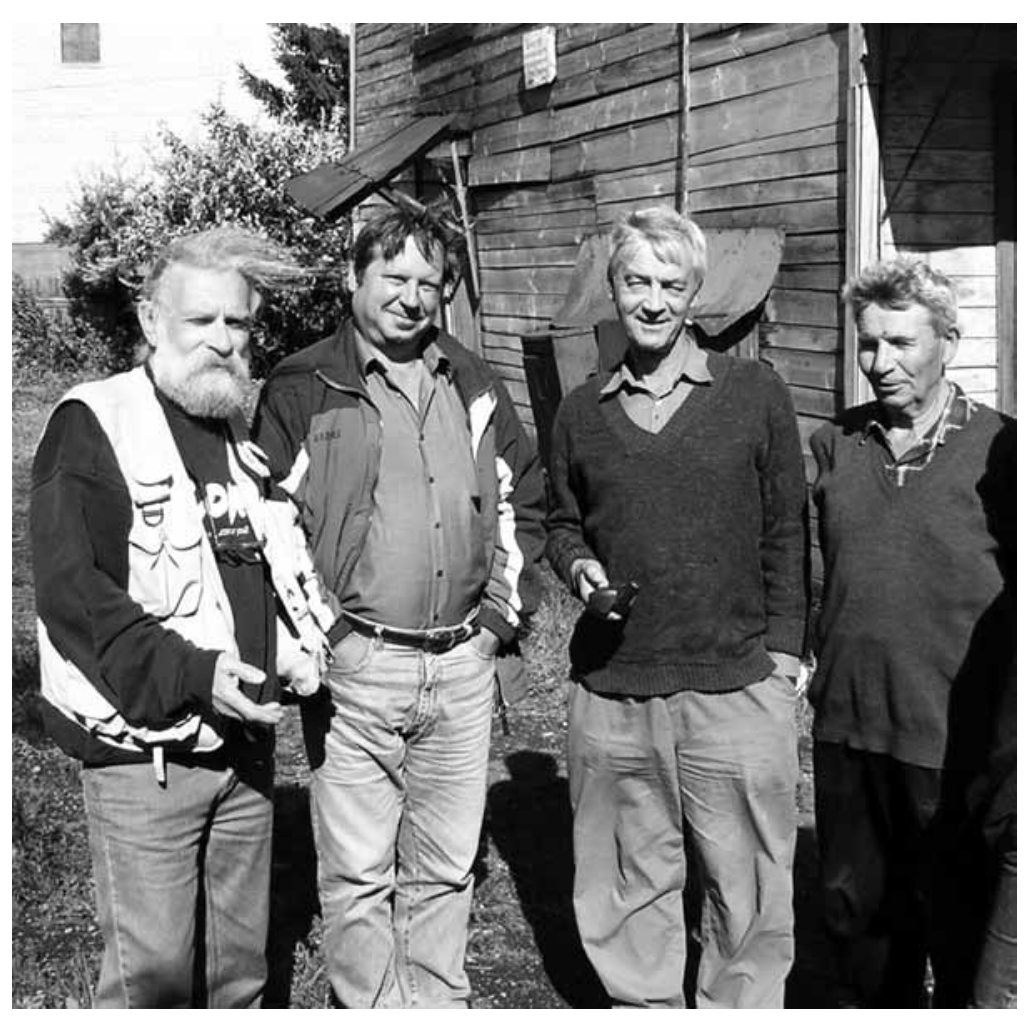

Ю.А. Смирнов, М.В. Фролов, А.Е. Леонтьев, К.И. Комаров на базе Волго-Окской экспедиции в Ростове. 2004 г.

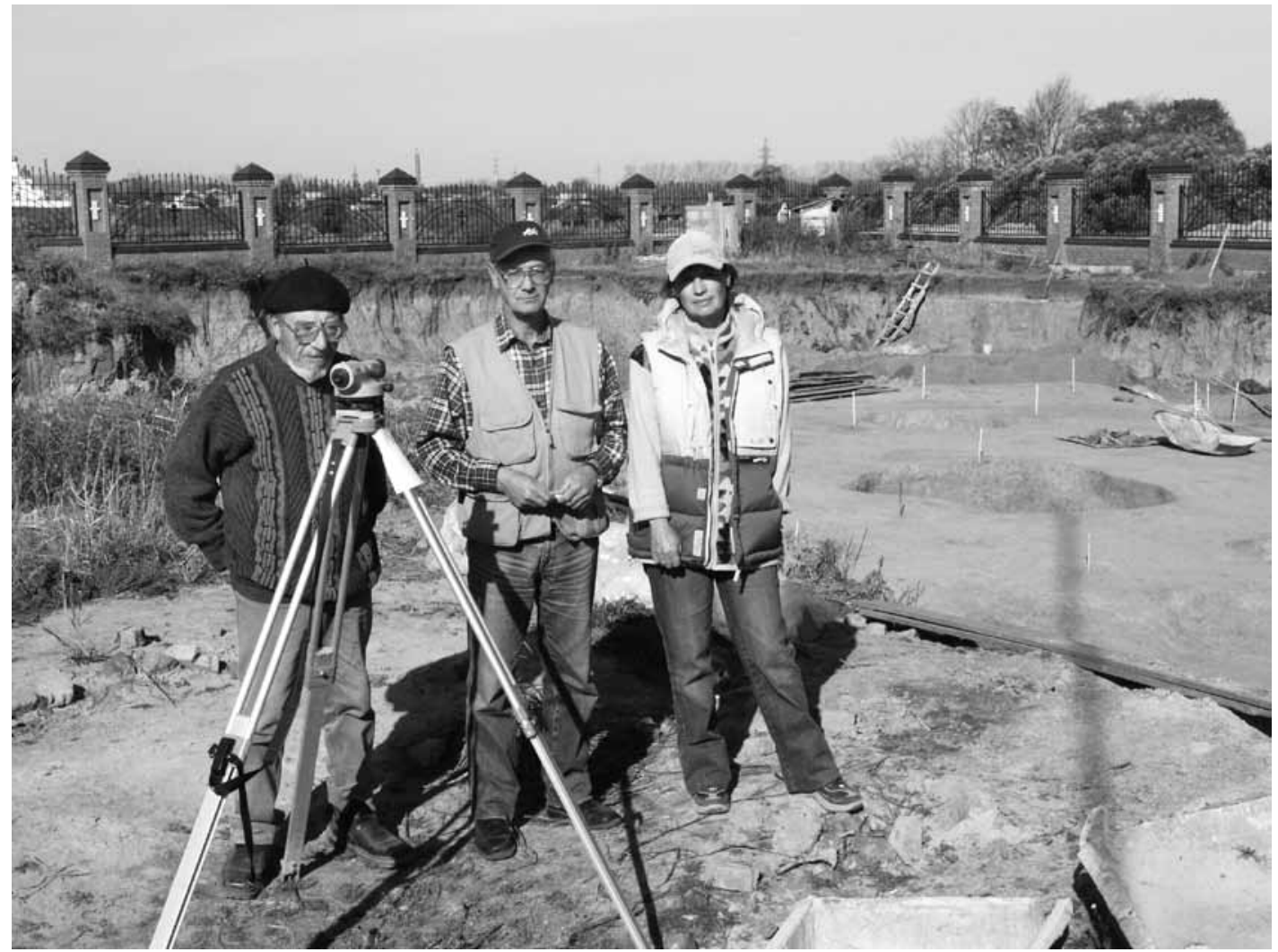

В.П. Глазов, А.Е. Леонтьев и Н.Г. Самойлович на селище Михали в Суздале. 2006 г. 


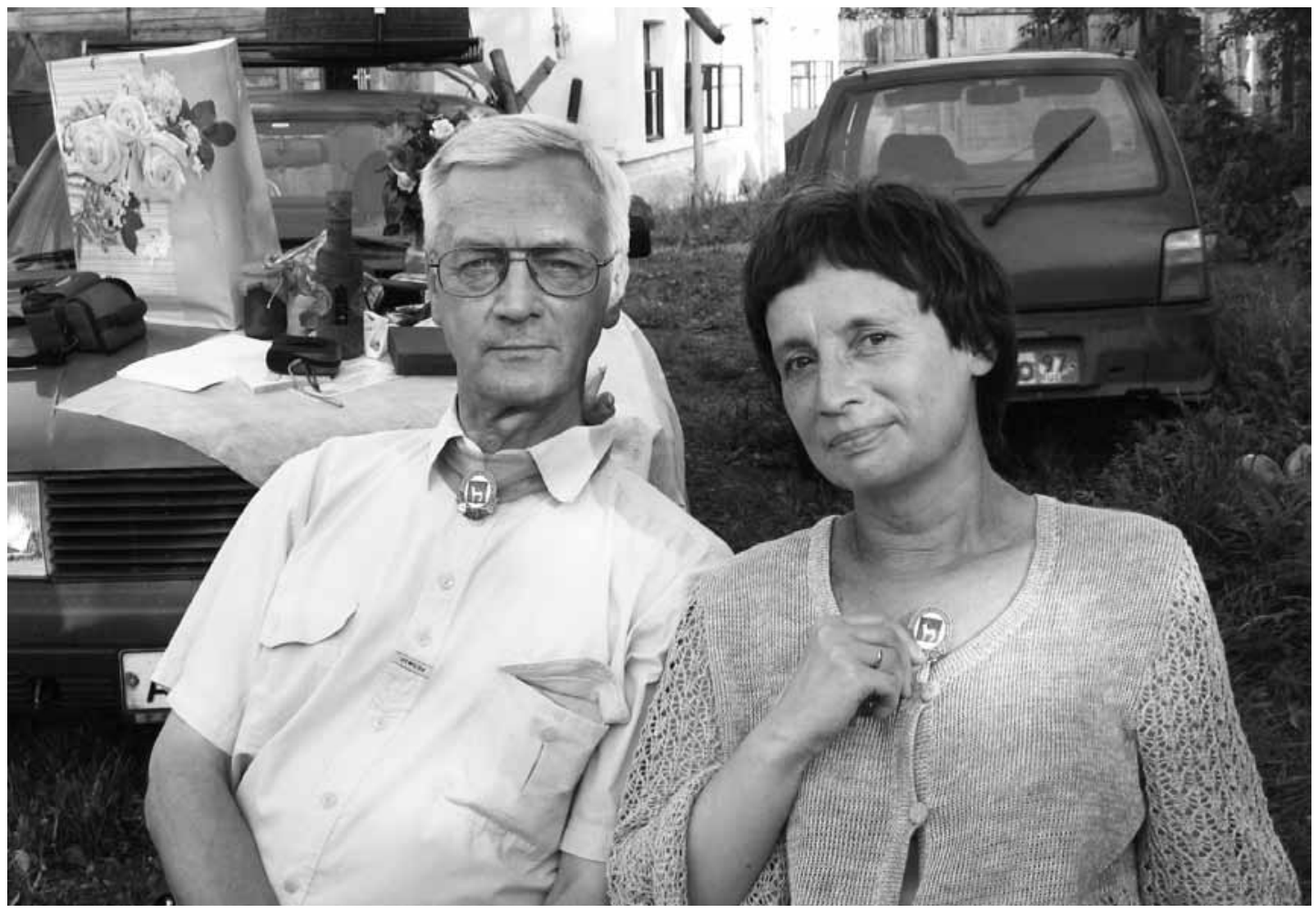

А.Е. Леонтьев и Н.Г. Самойлович в день празднования 30-летия Волго-Окской экспедиции. 2008 г.

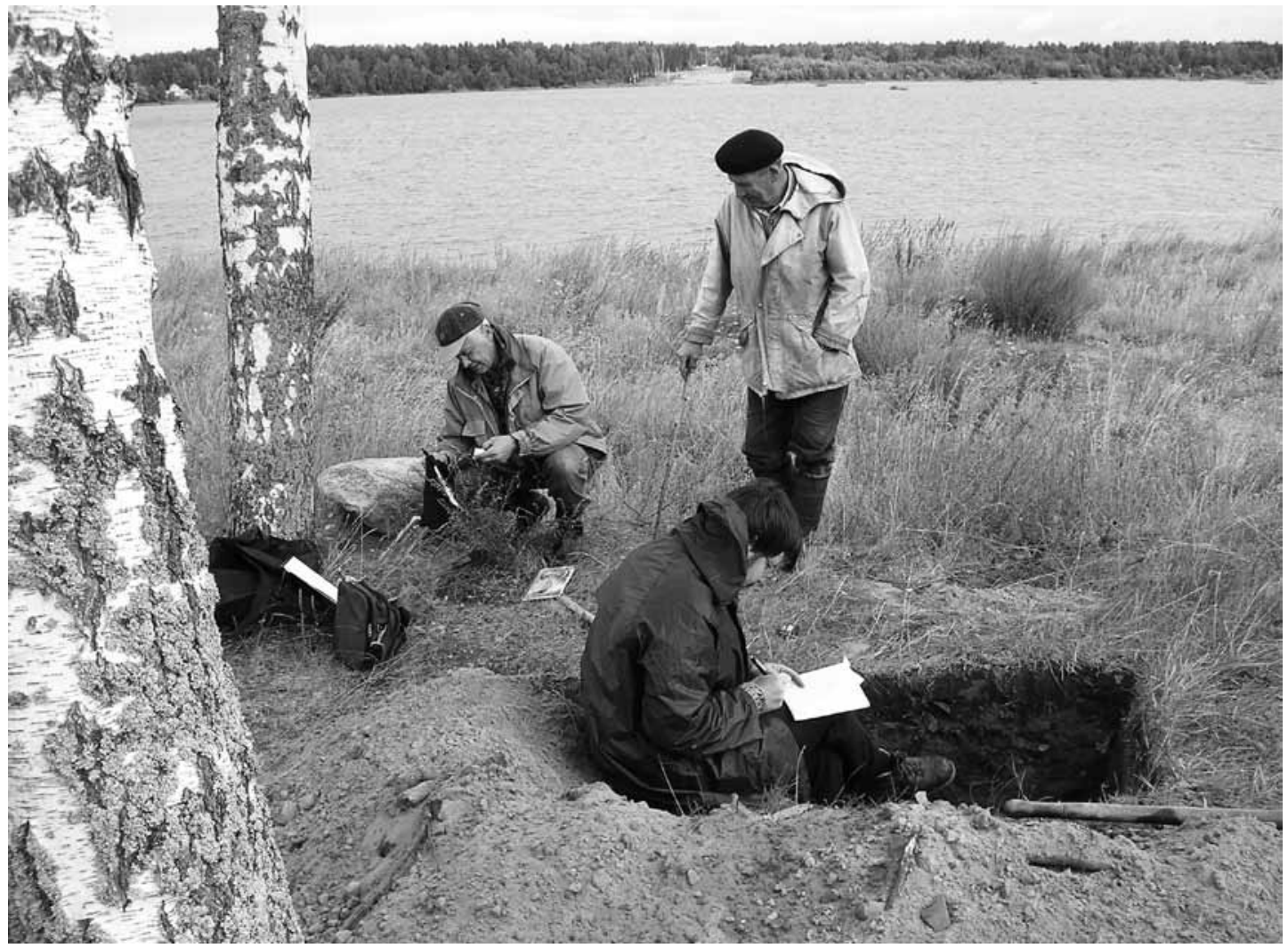

А.Е. Леонтьев, К.И. Комаров и В.С. Нефёдов в разведке в Мышкинском районе Ярославской области. 2008 г. 


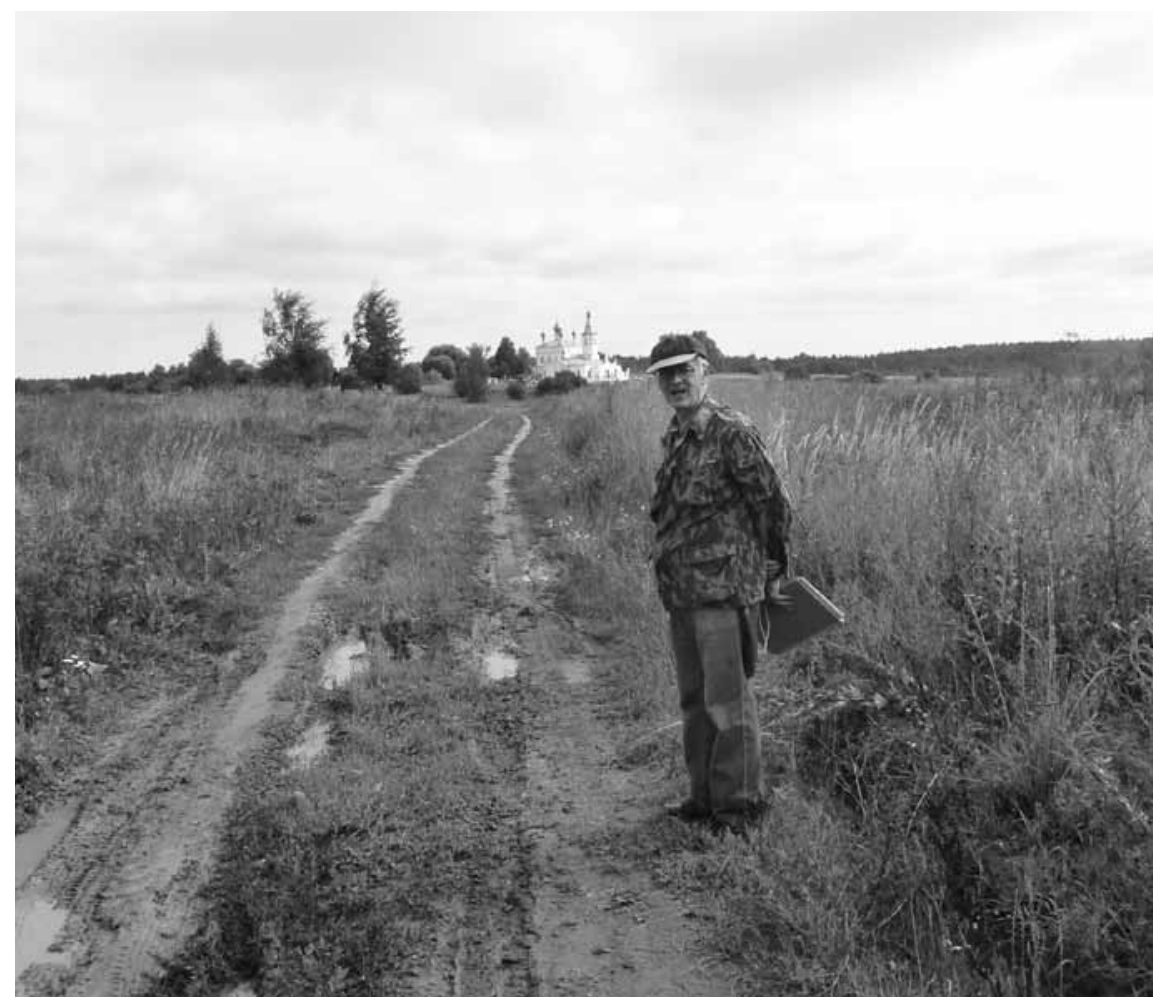

В разведке в Ярославской области. 2010 г.

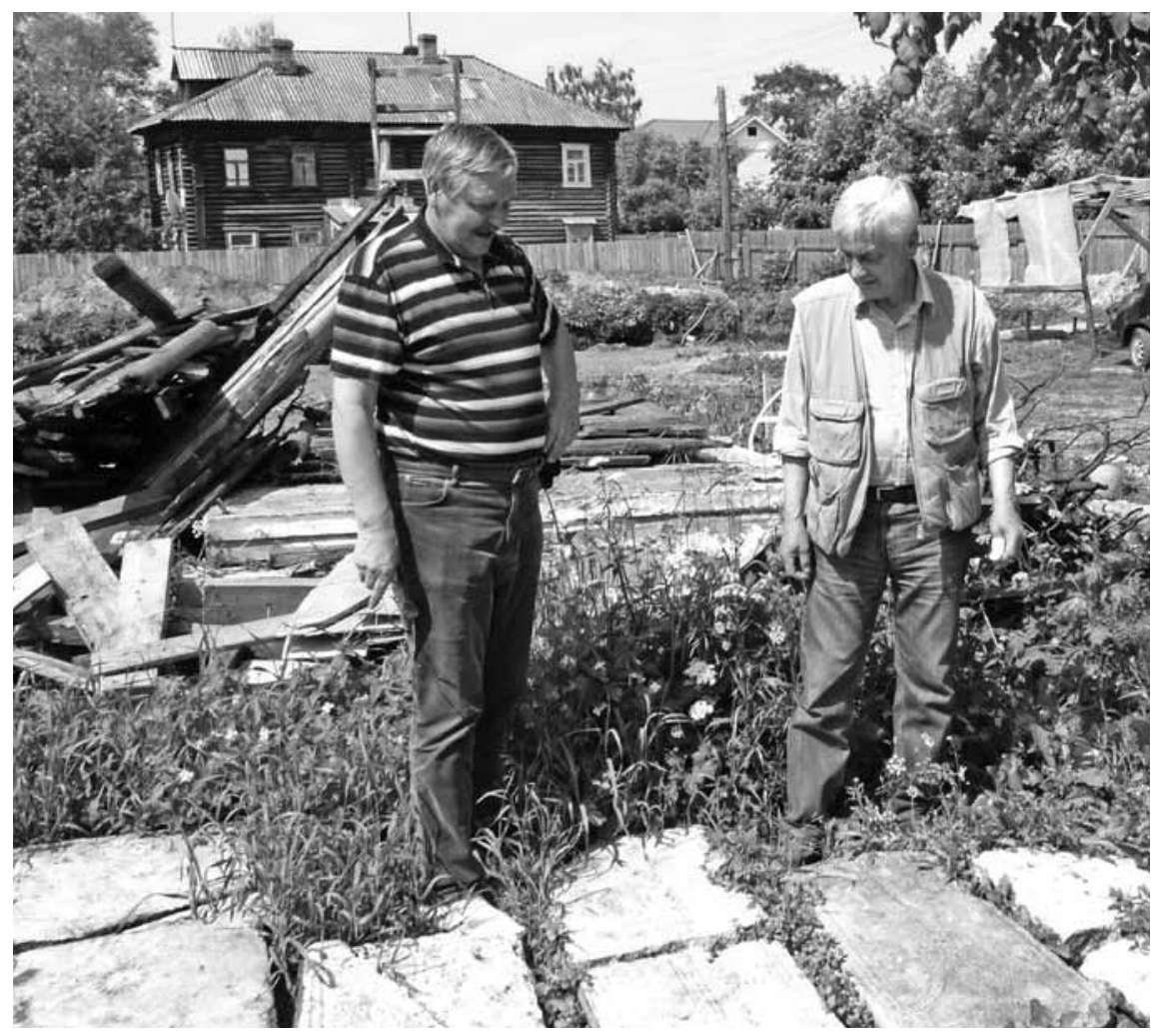

А. В. Кашкин и А.Е. Леонтьев осматривают надгробные плиты из раскопок Б. Е. Янишевского в Переславле-Залесском. 2012 г. 


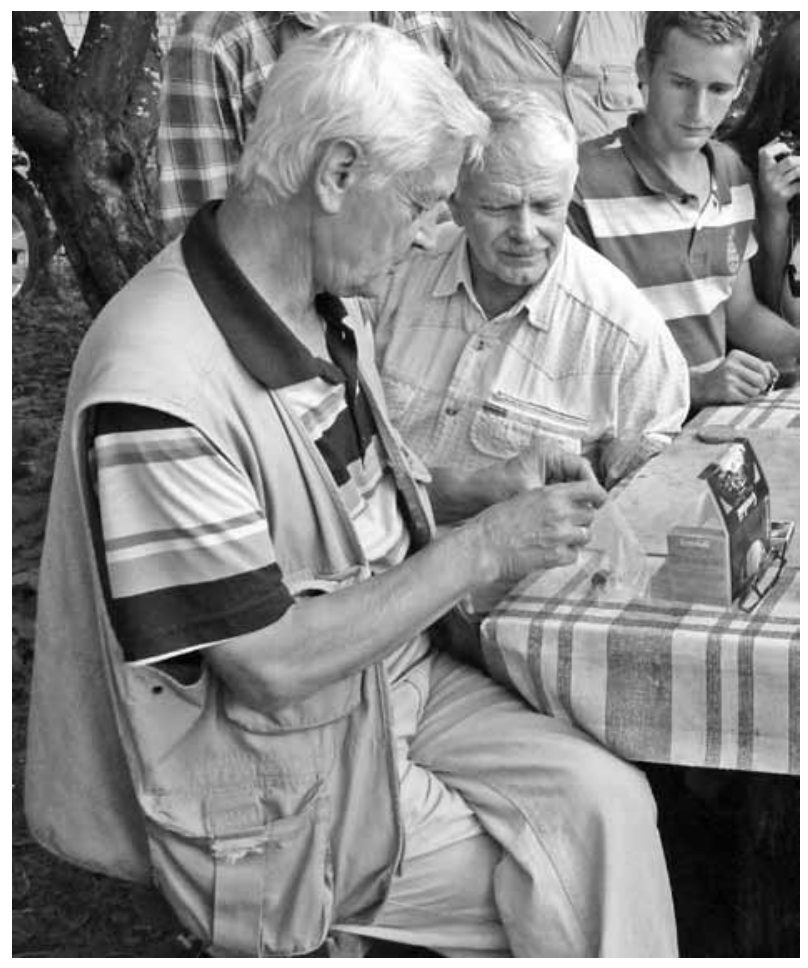

А.Е. Леонтьев демонстрирует находки Волго-Окской экспедиции. 2013 г.

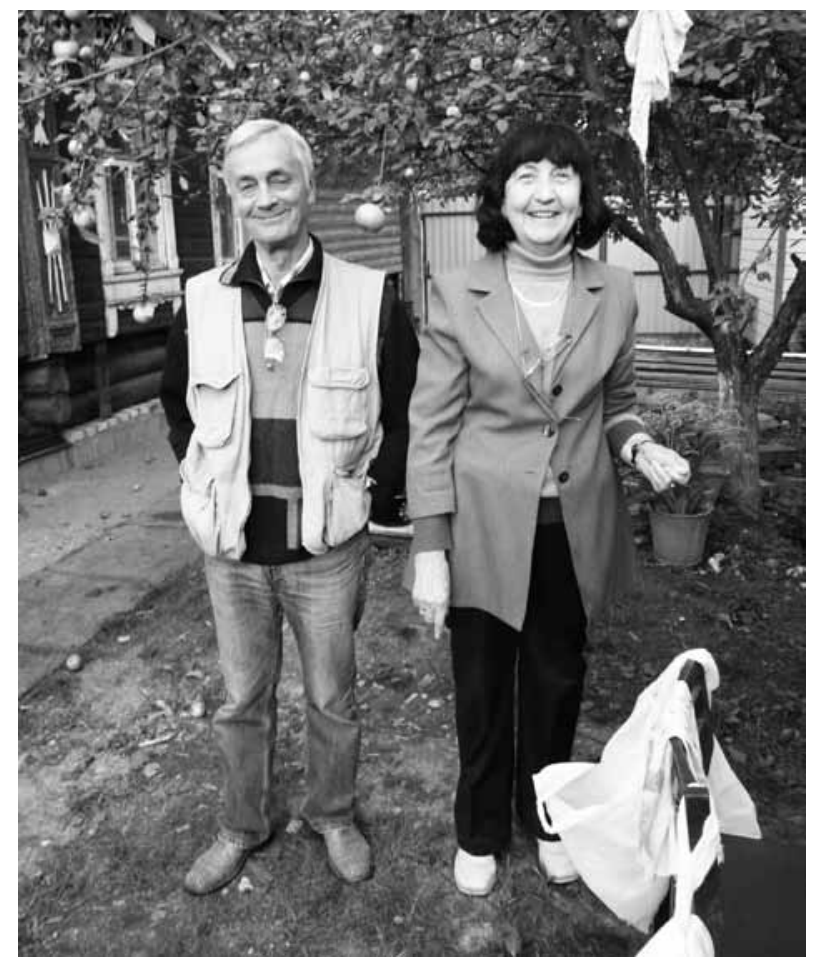

А. Е. Леонтьев и Л.А. Михайлова на базе Волго-Окской экспедиции в Ростове. 2014 г.

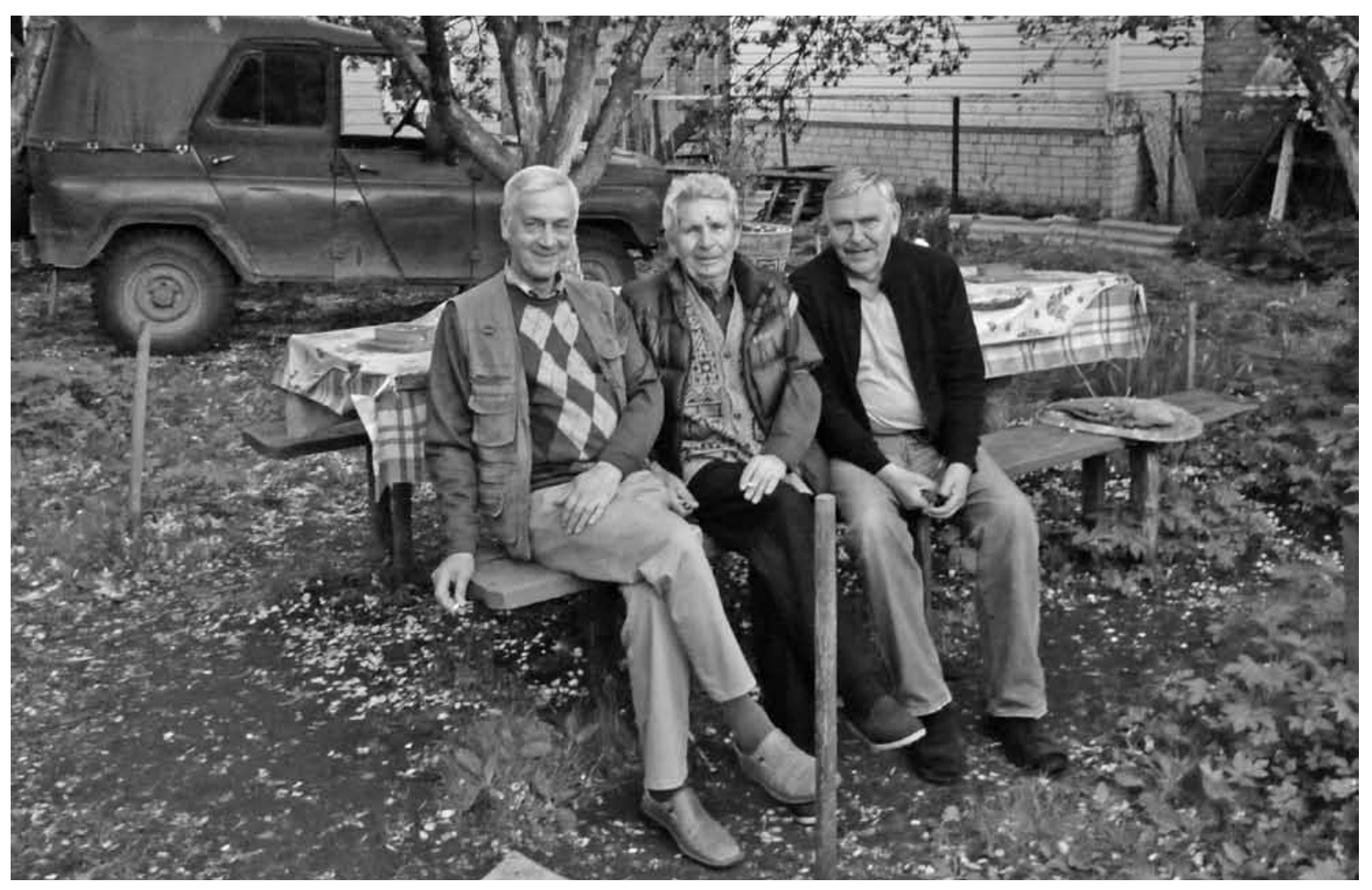

А.Е. Леонтьев, К.И. Комаров, А. В. Кашкин на базе Волго-Окской экспедиции в Ростове. 2016 г. 


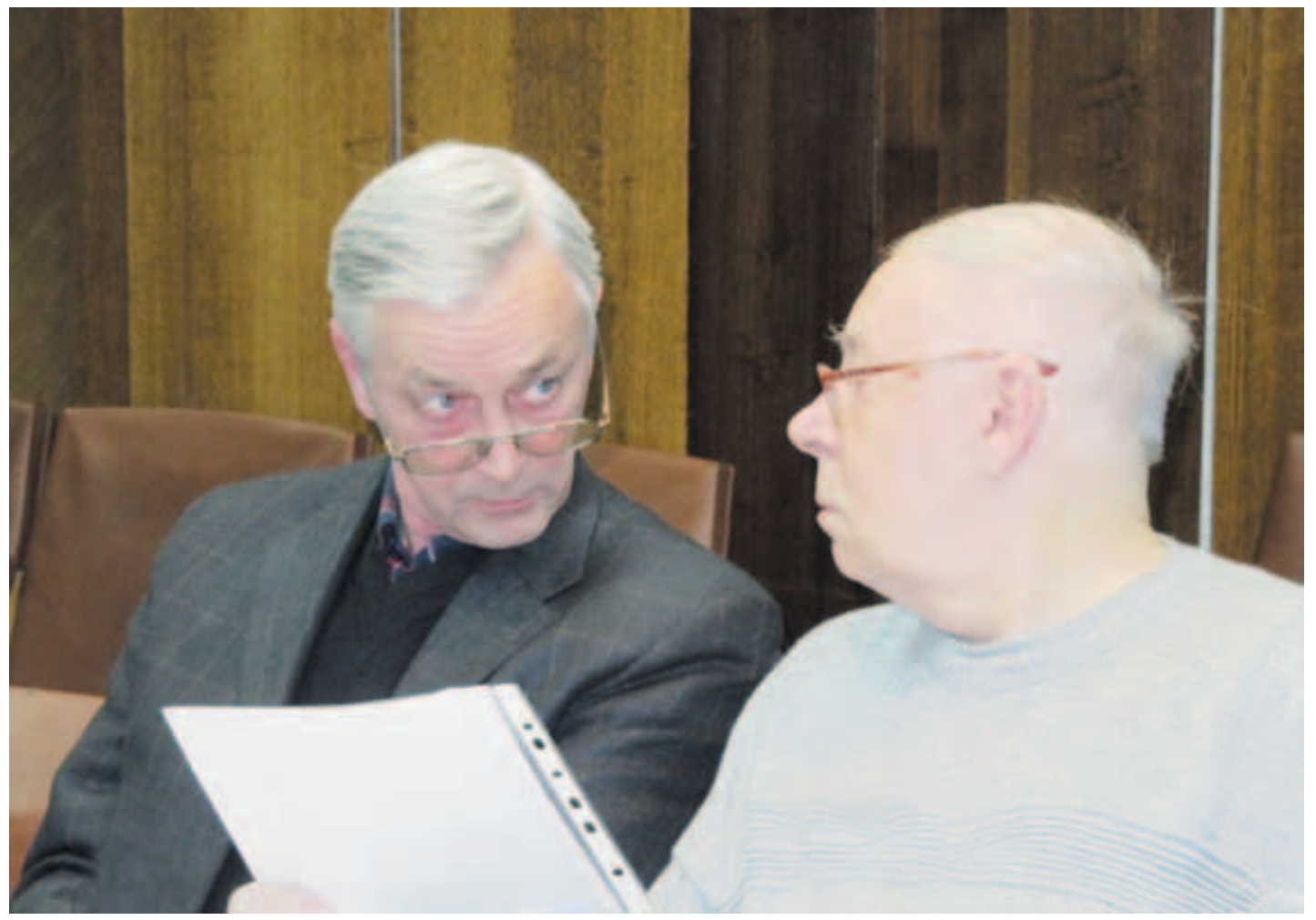

А.Е. Леонтьев и В.П. Даркевич на заседании отдела славяно-русской археологии. 2010 г.

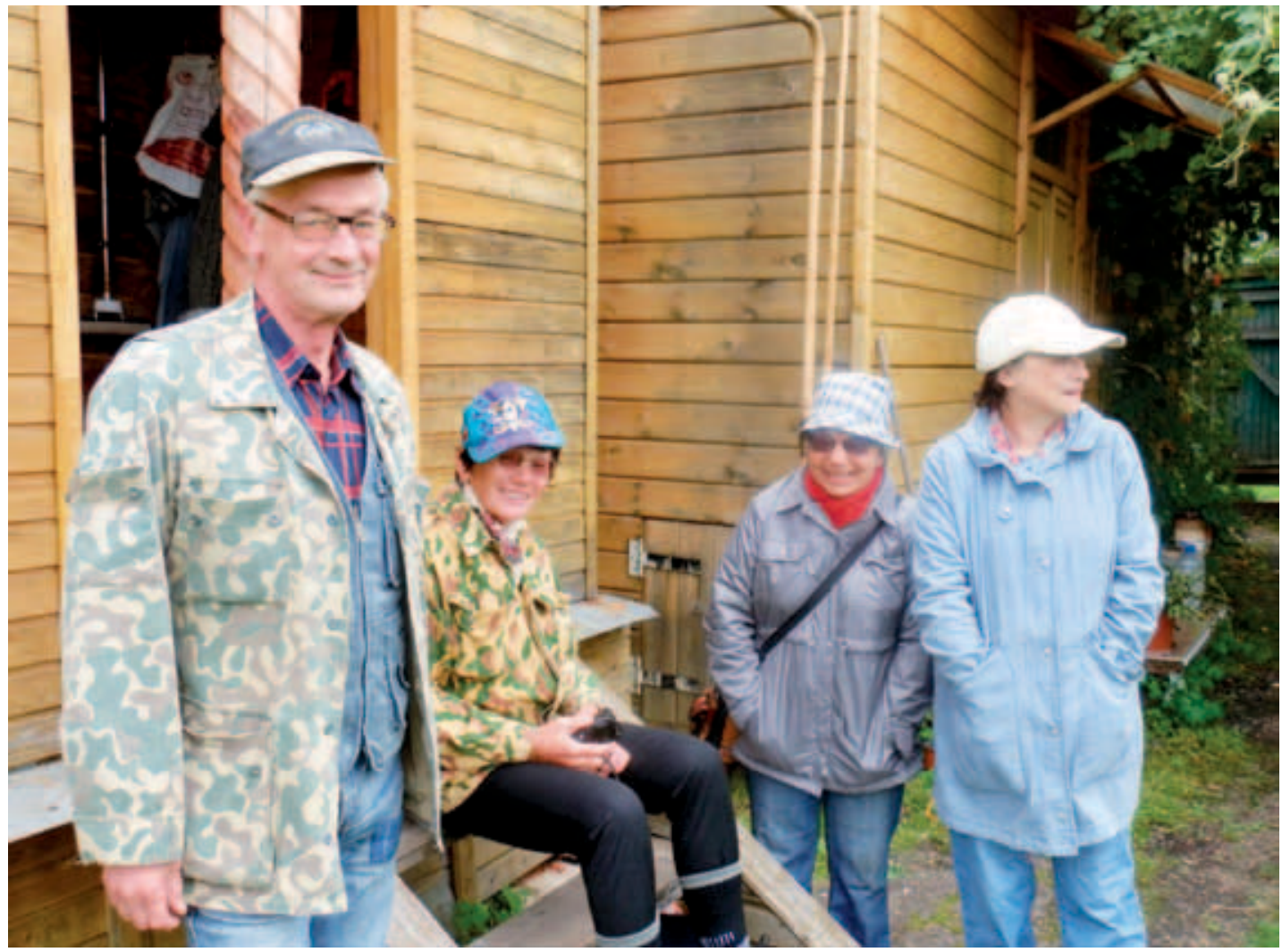

А. Е. Леонтьев, Т. А. Пушкина, Н.И. Асташова, Н. Г. Самойлович в Ростове. 2015 г. 


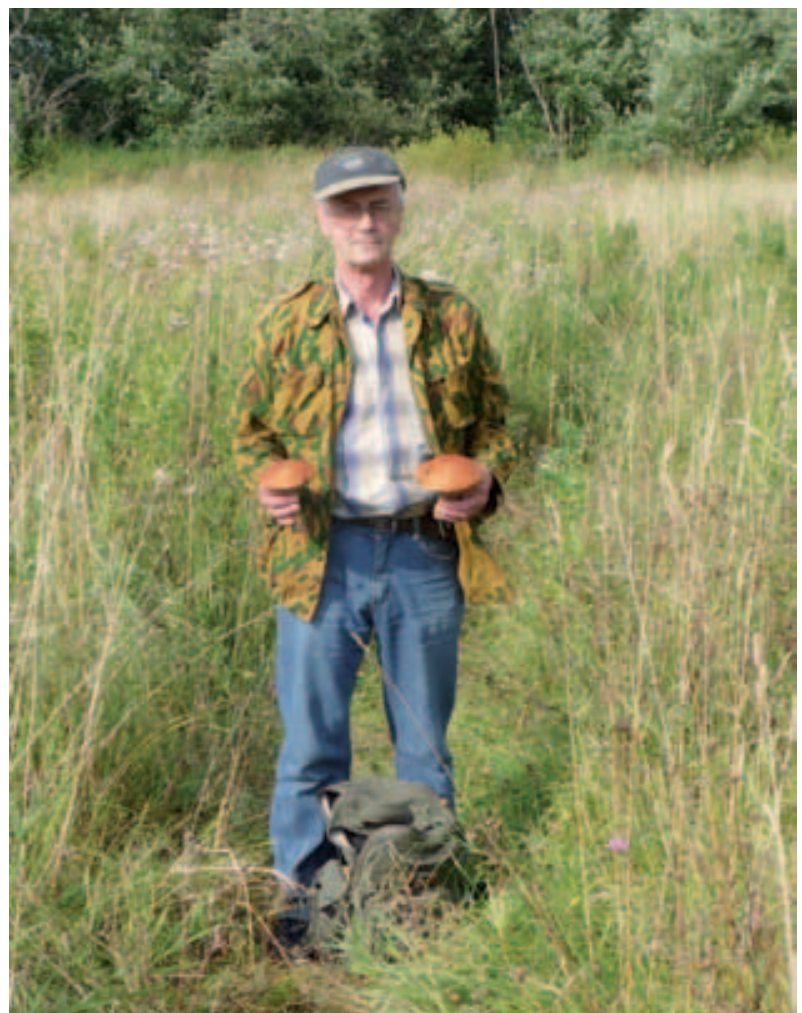

Разведки в Ярославской обл. 2009 г.

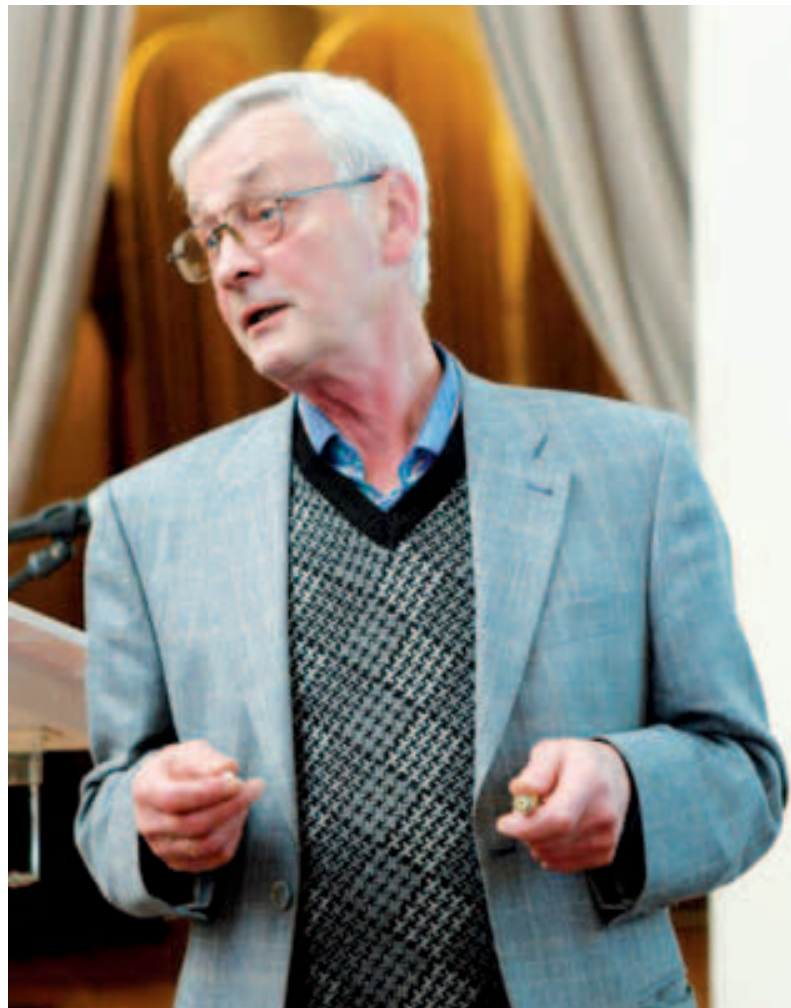

Доклад в музее в Ярославле. 2010-е

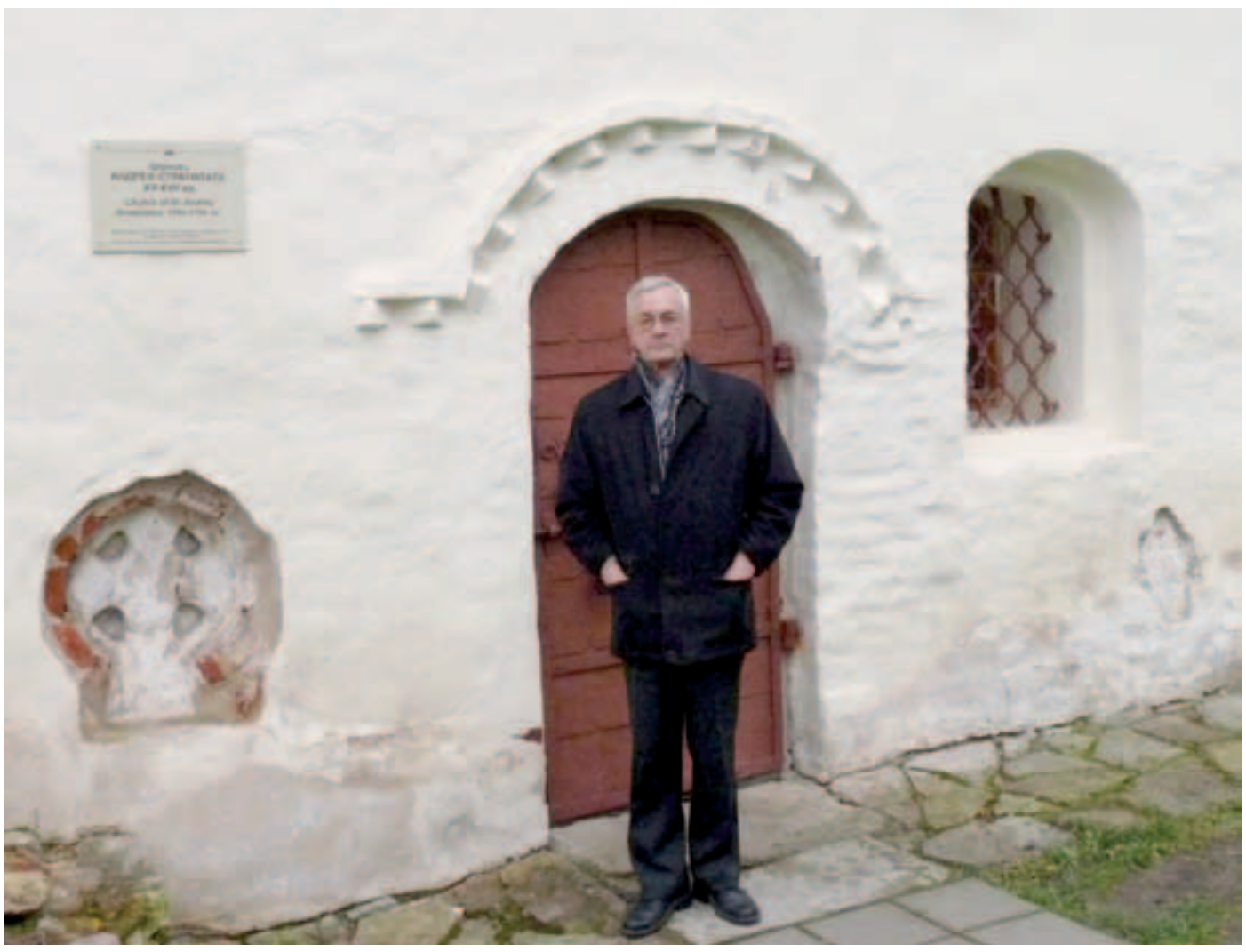

Новгород, октябрь 2011 г. 


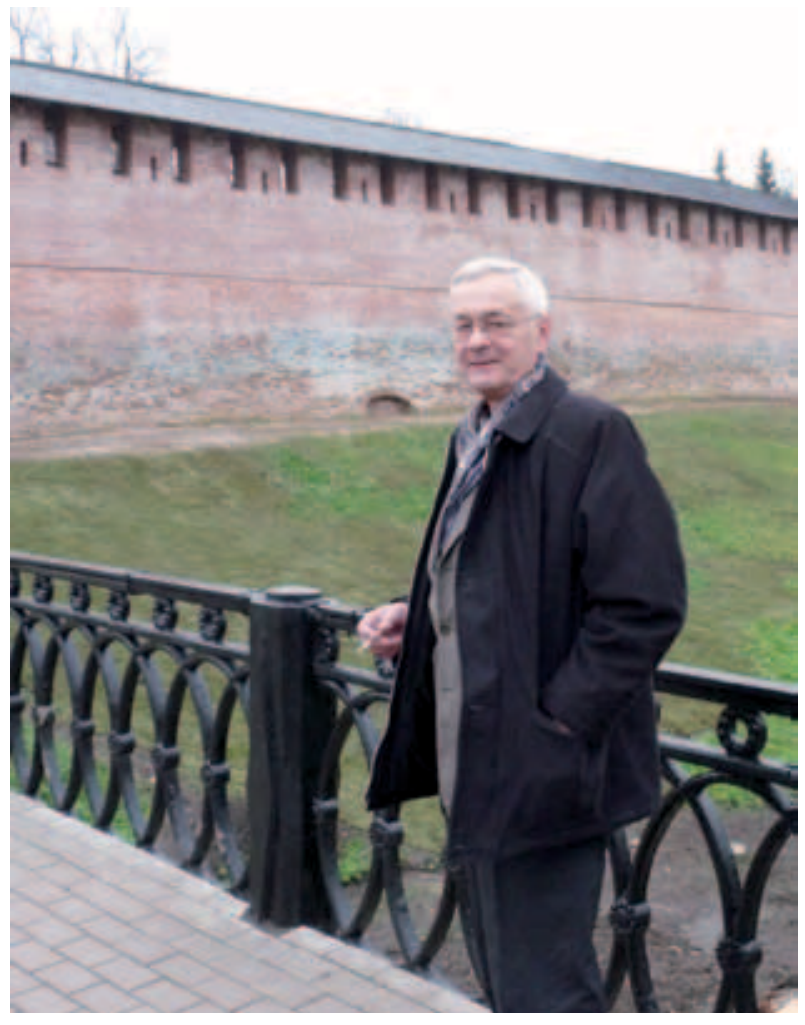

Новгород, октябрь 2011 г.

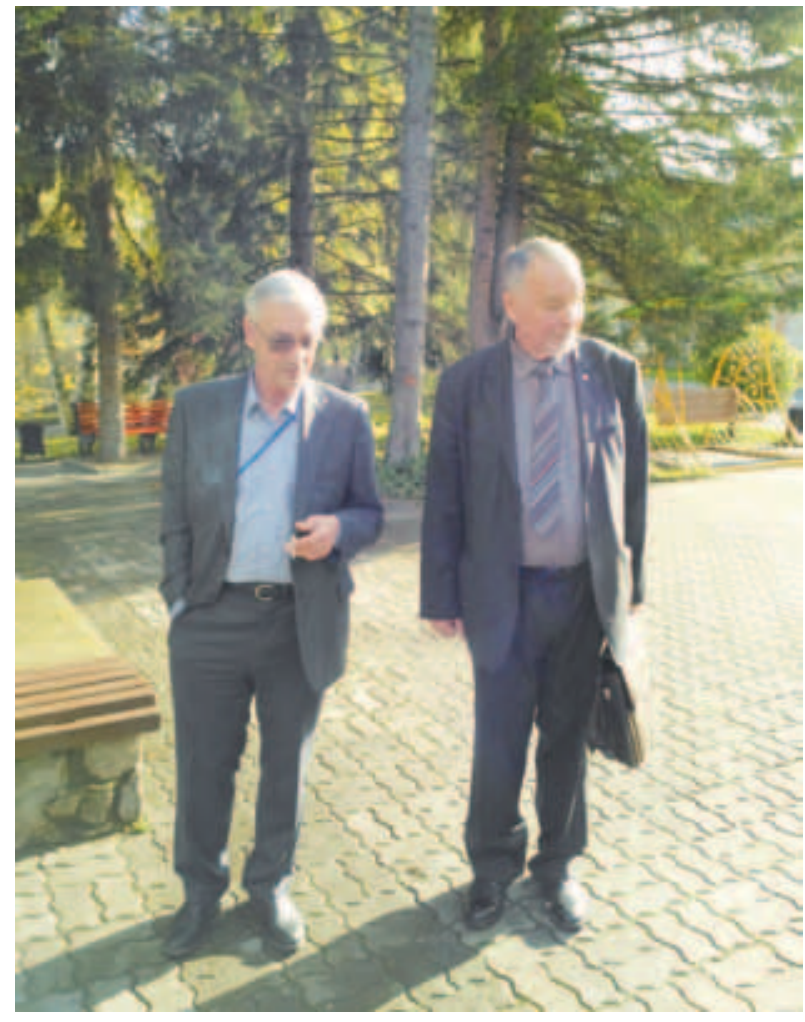

C А.В. Чернецовым в дни работы V Всероссийского археологического съезда. Белокуриха, октябрь 2017 г.

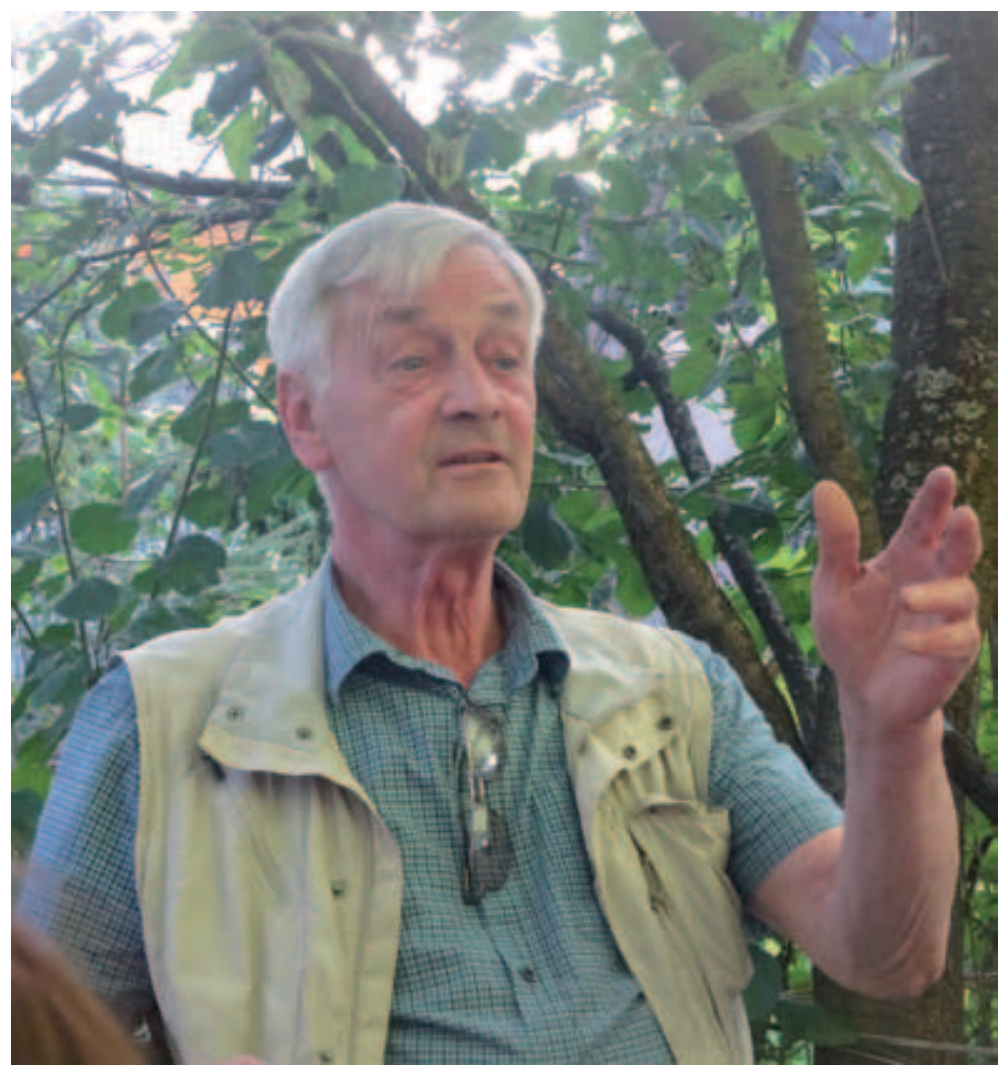

Ростов, август 2018 г. 


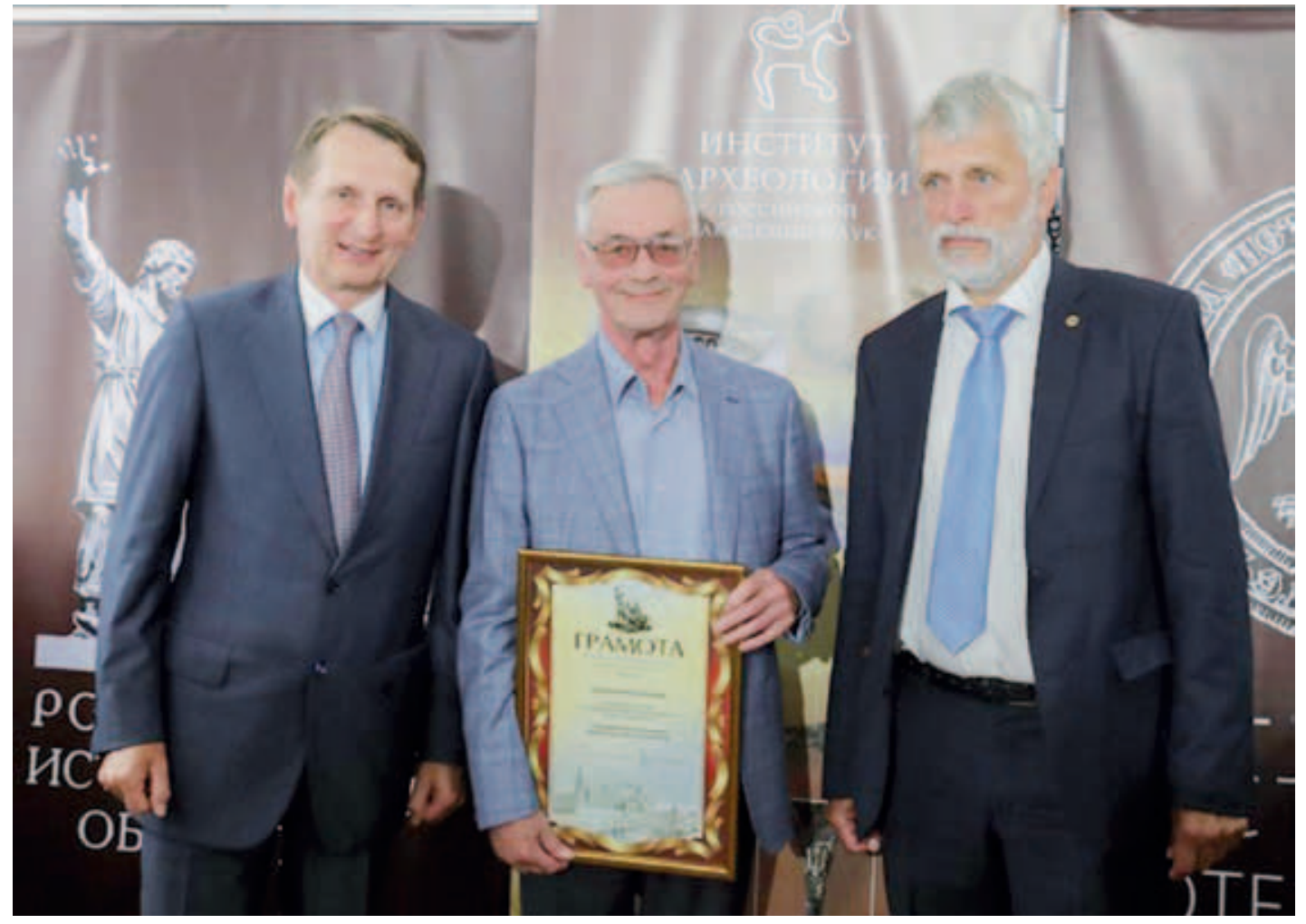

С. Е. Нарышкин, А.Е. Леонтьев и Н.А. Макаров на открытии выставки «Археология: годы, события, люди...». Москва, 22 августа 2018 г. А. Е. Леонтьев награжден грамотой Российского исторического общества

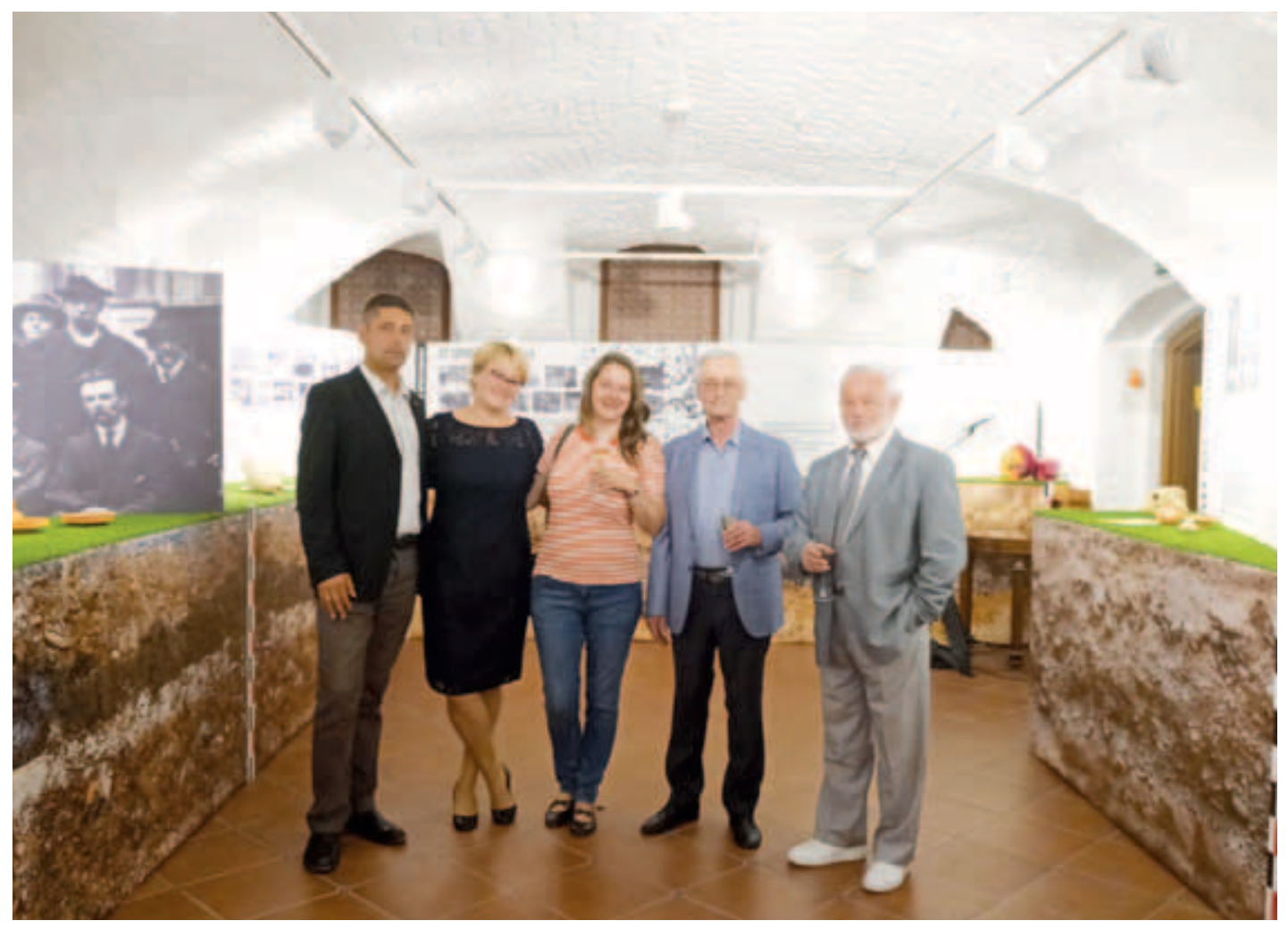

С коллегами из ИА РАН на открытии выставки «Археология: годы, события, люди...». Москва, 22 августа 2018 г. Слева направо: С. В. Ольховский, О. В. Зеленцова, И. А. Сапрыкина, А. Е. Леонтьев, Л. А. Беляев 


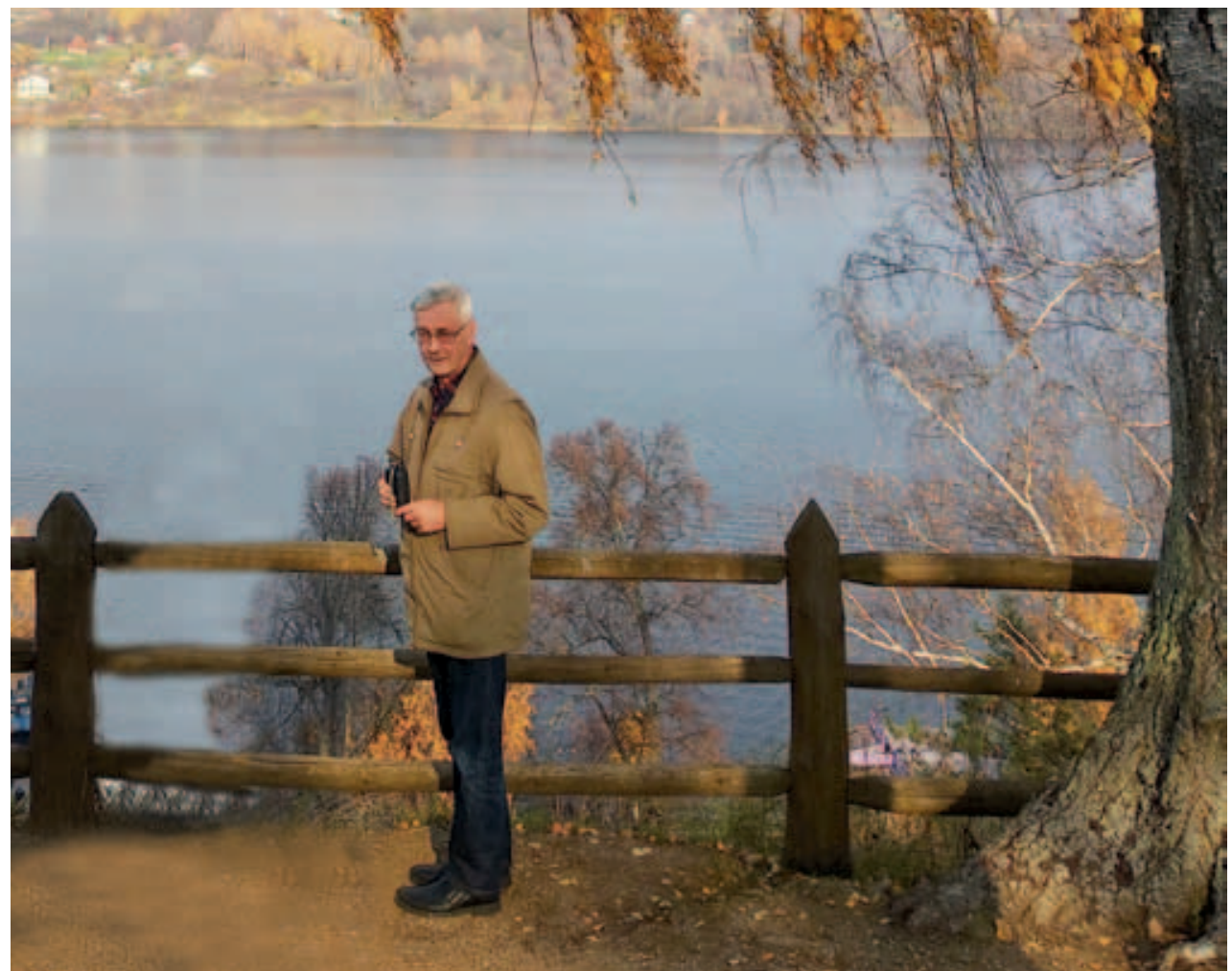

В дни работы научного семинара «Археология Владимиро-Суздальской земли». Плёс, октябрь 2018 г.

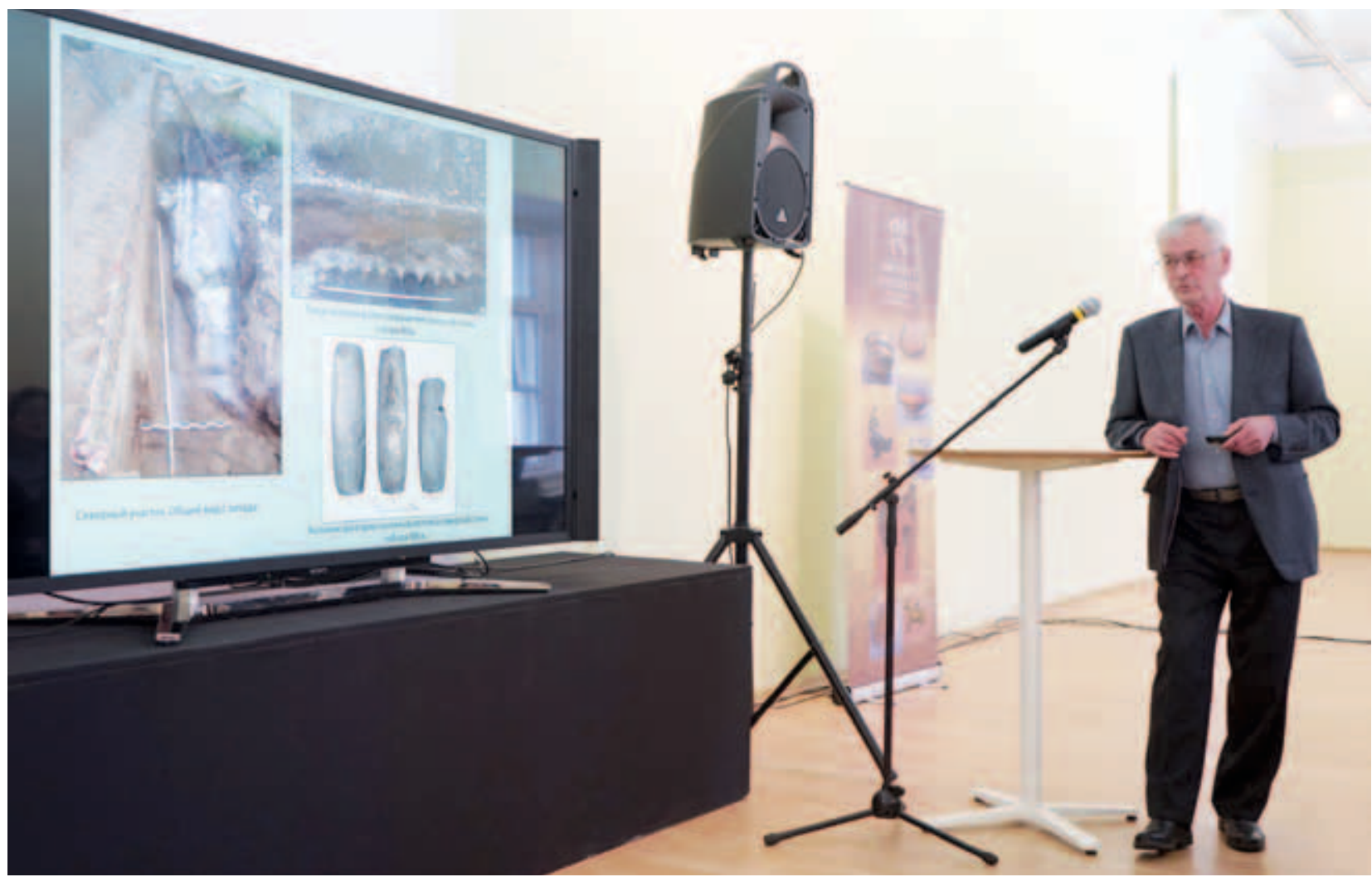

Доклад на заседании научного семинара «Археология Владимиро-Суздальской земли». Владимир, октябрь 2018 г. 


\section{Научные труды А.Е. Леонтьева}

\section{Монографии, авторефератьл}

Сарское городище в истории Ростовской земли (VIII-XI вв.). Автореф. дисс. ... канд. истор. наук. М.: МГУ, 1974.

Археология мери. К предыстории Северо-Восточной Руси. Автореф. дисс. ... док. истор. наук. М.: ИА РАН, 1991.

АКР. Владимирская область. М.: ИА РАН, 1995. 381 с. (в соавт. с М. П. Зиминой, Ю. А. Красновым, Л.А. Михайловой, Н.Г. Самойлович, М. В. Седовой).

Археология мери: к предыстории Северо-Восточной Руси. М.: Геоэко, 1996. 340 с. (Археология эпохи великого переселения народов и раннего средневековья; вып. 4).

Археология Костромского края. Кострома: ГНПЦ по сохранению, реставрации и использованию историко-культурного наследия Костромской области, 1997. 276 с. (В соавт. с К. И. Комаровым, С. В. Ошибкиной, Е.А. Рябининым).

Меря // Финно-угры Поволжья и Приуралья в средние века/Ижевск: Удмурт. ин-т истории, языка и лит. УрО РАН, 1999. С. 18-66.

Главы коллективной монографии: На берегах озер Неро и Плещеево. С. 162-177; Восточноевропейские пути сообщения и торговые связи в конце VIII - X в. С. 382-401 (в соавт. с Е.Н. Носовым) // Русь в IX-X веках. Археологическая панорама. М.-Вологда: Древности Севера, 2012. 496 с. (1150 лет российской государственности) / Die Rus' im 9-10 Jahrhundert: ein Archäologisches Panorama. Kiel, 2017. 541 s. (Studien zur Siedlungsgeschichte und Archäologie der Ostseegebiete. V. 14).

\section{Статьи, публикацчии, тезись}

Результаты археологической разведки в районе Ростова Великого // АО 1969. М., 1970. С. 74 (в соавт. с Т. А. Пушкиной).

Исследования средневековых памятников в долине р. Прони // АО 1969. М., 1970. С. 76-78 (в соавт. с Малым В.А., Недошивиной Н.Г., Поляковой Г.Ф., Фехнер М.В.).
Работы на Сарском городище // АО 1972. М., 1973. С. 73.

«Город Александра Поповича» в окрестностях Ростова Великого // ВМУ. Сер. 9: История. 1974. № 3. С. 85-96.

Раскопки Сарского городища и разведки в Ярославской области // АО 1973. М., 1974. С. 63.

О времени возникновения Сарского городища // ВМУ. Сер. 9: История. 1974. № 5. С. 68-74.

Классификация ножей Сарского городища // СА. 1976. № 2. С. 33-45.

Работы новостроечного отряда Верхневолжской экспедиции // АО 1975. М., 1976. С. 72-73.

Древнерусские памятники района озеро Верестово // СА. 1978. № 2. С. 272-282 (в соавт. с Г.Н. Прониным).

Волго-Окская новостроечная экспедиция // АО 1977. М., 1978. С. 70.

Узменские жернова Х века // СА. 1979. № 2. C. 271-274.

Работы Волго-Окской экспедиции // АО 1978. М., 1979. С. 70.

Этапы и формы ассимиляции летописной мери // СА. 1980. № 2. С. 67-79 (в соавт. с Е.А. Рябининым).

Работы Волго-Окской новостроечной экспедиции // АО 1979. М., 1980. С. 60.

Исследования Волго-Окской экспедиции // АО 1980. М., 1981. С. 61.

Могильник и городище у д. Попово на р. Унже // AO 1980. М., 1981. С. 62-63 (в соавт. с Рябининым Е.А.).

Скандинавские вещи в коллекции Сарского городища // Скандинавский сборник. Таллин: Ээсти Раамат, 1981. Вып. 26. С. 141-149.

Рец.. на кн.: Булкин В.А., Дубов И.В., Лебедев Г.С. Археологические памятники Древней Руси IX-XI веков. Л., 1978 // СА. 1982. № 2. С. 277-288 (в соавт. с Кузой А. В., Пушкиной Т. А.).

Древнерусские поселения Верхней Мологи // Археологические исследования в Верхневолжье. Сб. науч. трудов. Калинин: Калининский гос. университет, 1983. С. 56-71.

Работы в Ярославской и Костромской областях // АО 1981. М., 1983. С. 68. 
Новые данные о Костромских курганах // СА. 1984. № 4. С. 176-196.

Поселения мери и славян на оз. Неро // КСИА. Вып. 179. 1984. С. 26-32.

Работы Волго-Окской экспедиции // АО 1982. М., 1984. С. 65.

Историческая топография Ростова Великого // Тез. докл. Всесоюз. археологической конф. «Достижения советской археологии в XI пятилетке». Баку, 1985. С. 215.

Ростов. Предпосылки образования древнерусского города // Тез. докл. советской делегации на $\mathrm{V}$ Междунар. конгрессе славянской археологии. М., 1985. С. 58.

Стратиграфия и хронология культурного слоя Ростова Великого // Археологические памятники Европейской части РСФСР. М.: ИА АН СССР, 1985. С. 105-112.

Археологические памятники в районе оз. Неро // Археологические исследования в зонах мелиорации. Итоги и перспективы их интенсификации. Тез. науч.-практ. конф. ИИМК РАН. Л.: Наука, 1985. С. 50-51 (в соавт. с Сидоровым В. В.).

The finno-ugric population of the Kostroma Volga area in the second half of the $1^{\text {st }}$ millennium AD / Congressus Sextus internationalis Fenno-Ugristarum. Тезисы, Thesen, abstracts. Vol. IV. Сыктывкар: Коми филиал АН СССР, 1985. С. 7-8 (в соавт. с Рябининым Е.А.).

Волжско-Балтийский путь в IX в.// КСИА. Вып. 183. 1986. С. 3-9.

Волго-Окская экспедиция в 1977-1983 гг.// КСИА. Вып. 188. 1986. С. 3-20 (в соавт. с Ислановой И.В., Сидоровым В.В.).

Волго-Окская экспедиция // АО 1984. М., 1986. C. 74 .

Ростов: предпосылки возникновения древнерусского города // Tp. V Междунар. конгресса славянской археологии. М.: Наука, 1987. Т. 1. Вып. 2a. C. 151-157.

Волго-Окская экспедиция // АО 1985. М., 1987. C. 68 .

Археологические памятники ростовской мери // Проблемы изучения древнерусской культуры: расселение и этнокультурные процессы на СевероВостоке Руси. М.: ИА АН СССР, 1988. С. 6-32.

Городище Выжегша и происхождение выжегшевского клада // Проблемы изучения древнерусской культуры: расселение и этнокультурные процессы на Северо-Востоке Руси. М.: ИА АН СССР, 1988. C. 94-102.

Исследования Волго-Окской экспедиции // АО 1986. М., 1988. С. 74-75 (в соавт. с Сидоровым В.В.).
Финно-угорское население Костромского Поволжья во 2-й половине I тыс.н.э. // Матер. VI Междунар. конгресса финно-угроведов. Т. 1. М.: Наука, 1989. С. 64-68 (в соавт. с Е. А. Рябининым).

Тимерево. Проблема исторической интерпретации археологического памятника // СА. 1989. № 3. C. 79-86.

Поповское городище // Раннесредневековые древности Верхнего Поволжья. Матер. работ Волго-Окской экспедиции. М.: ИА АН СССР, 1989. С. 6-106.

Железные изделия городища и могильника у д. Попово // Раннесредневековые древности Верхнего Поволжья. Матер. работ Волго-Окской экспедиции. М.: ИА АН СССР, 1989. С. 171-184 (в соавт. с Л.С. Розановой и Е.А. Рябининым).

Рец̧. на кн.: Рябинин Е.А. Костромское Поволжье в эпоху средневековья. Л., 1986 // СА. 1989. № 2. С. 277-279.

Дьяковская культура и летописные финские племена Верхнего Поволжья // Матер. Третьей науч.-практ. конф.: Проблемы изучения Плёса. Плёс, 1990. С. 22-23.

Керамика Ростова X-XIII вв. // Керамика раннего железного века и средневековья Верхневолжья и соседних территорий. Тверь: ТвГУ, 1991. С. 56-66 (в соавт. с Н. Г. Самойлович).

Заметки о ранней истории Ростова // СРМ. Вып. 1. Ростов, 1991. С. 3-7.

Новые данные археологии об истории ростовского Успенского собора // ИКРЗ 1991. Ростов, 1991. C. 3-5.

Так кто же насыпал Ярославские курганы // Краеведческие записки. Ярославль: Верхне-Волжское книжное издательство, 1991. № 7. С. 12-15.

Любилковские курганы // Археологические памятники Волго-Клязьминского междуречья / Ивановское обл. отд. ВООПИиК, НПЦ ОПИиК. Вып. 5. Иваново: Бюро ОП Ивоблупрстат, 1991. С. 3-5.

Ростовская подвеска времен Ярослава Мудрого // СРМ. Вып. III. Ростов, 1992. С. 129-130.

Древний Ростов и Успенский собор в археологических исследованиях 1992 г. (Предварительное сообщение) // ИКРЗ 1992. Ростов, 1993. С. 163-166.

Археологические наблюдения в Ростовском Успенском соборе // СРМ. Вып. V. Ростов, 1993. С. 162-171.

Подписные пряслица из Ростова Великого // СРМ. Вып. V. Ростов, 1993. С. 157-161 (в соавт. с А. А. Медынцевой).

Ладейные шпангоуты X в. из Ростова // ИКРЗ 1993 г. Ростов, 1994. С. 177-178.

Новые исследования памятников древнерусского зодчества XIII в.// Искусство Руси, Византии 
и Балкан XIII в. Тез. докл. конф. Москва, сентябрь 1994 г. СПб.: Дмитрий Буланин, 1994. С. 33-35 (в соавт. с О. М. Иоаннисяном, П. Л. Зыковым).

Дьяковские и мерянские поселения озер Неро и Плещеево (система расселения) // Проблемы средневековой археологии волжских финнов. Йошкар-Ола: Изд-во МарНИИЯЛИ, 1994. С. 9-12.

Архитектурно-археологические исследования памятников древнерусского зодчества в Ростове Великом // СРМ. Вып. VI. Ростов, 1994. С. 189-217 (в соавт. с О.М. Иоаннисяном, П.Л. Зыковым, Е.Н. Трошиным).

«Гора Святой Марии» // СРМ. Вып. VI. Ростов, 1994. С. 218-230.

Некоторые данные о топографии Ростова X-XIV вв. (по материалам археологических иследований) // ИКРЗ 1994. Матер. науч. конф., посвященной 150-летию со дня рождения А. А. Титова. Ростов, 1995. С. 36-42.

Архитектурно-археологические исследования в Ростове Великом и Новгороде // Отчетная археологическая сессия Гос. Эрмитажа. Тез. докл. СПб., 1995. С. 36-40 (в соавт. с Иоаннисяном О. М., Торшиным Б. Н., Зыковым П. Л.).

Некоторые вопросы начальной истории Северо-Восточной Руси // VI Междунар. конгресс славянской археологии. Тез. докл. советской делегации. М., 1996. С. 41.

Частные аспекты хронологии Ростова (по результатам дендрохронологического анализа материалов археологических раскопок)//ИКРЗ 1995. Ростов: Фонд гражданских инициатив «Содействие», 1996. С. 3-7 (в соавт. с Н. Г. Самойлович, Н. Б. Черных).

A Sample of Criminal Decapitation from Medieval Russian Town $/ / 14^{\text {th }}$ Meeting of the International Association of Forensic Sciences (IAFS). Abstracts. Tokyo, Japan, 1996. P. 207 (with Buzhilova A., Goncharova N.).

Втульчатые височные кольца // Древности Русского Севера. Вып. І. Вологда, 1996. С. 159-162.

Работы Волго-Окской экспедиции // АО 1995. М., 1996. С. 157-158 (в соавт. с Аграфоновым П.Г., Асташовой Н. И., Кадиевой Е. К., Михайловой Л. А., Самойлович Н.Г.).

Ростов в X-XI вв.// Славянский средневековый город. М.: ИА РАН, 1997. С. 210-217. (Тр. VI Междунар. конгресса славянской археологии; т. 2).

Территория летописной муромы по археологическим данным // Исследования П. Д. Степанова и этнокультурные процессы древности и современности. Матер. Междунар. науч. конф., посвященной 100-летию П. Д. Степанова. Саранск: Тип. «Красный Октябрь», 1998. С. 14-17.
Ростов эпохи Ярослава Мудрого (по материалам археологических исследований) // Историческая археология. Традиции и перспективы. (К 80-летию со дня рождения Даниила Антоновича Авдусина). М.: Памятники исторической мысли, 1998. С. 135-153.

Случай из ростовской жизни ХІ столетия // СРМ. Вып. IX. Ростов, 1998. С. 9-12 (в соавт. с А.П. Бужиловой, Н. Н. Гончаровой).

Археологические исследования в Ростове // Вестник РГНФ. М., 1998. № 1. С. 48-54.

Рец.. на кн.: Останина Т. А. Население среднего Прикамья в III-V вв. Ижевск, 1997 // Финно-угроведение. Йошкар-Ола, 1998. № 3-4. С. 145-151 (в соавт. с Кузьминых С. В.).

Из истории ростовской соборной площади // ИКРЗ 1998. Ростов, 1999. С. 26-33.

Меря и мурома: материалы к изучению систем расселения // Новые исследования по средневековой археологии Поволжья и Приуралья. Ижевск - Глазов: УИИЯЛ УрО РАН, 1999. С. 46-51.

Детали судов и лодок X-XIII вв. в археологической коллекции Ростова Великого // Археологический сборник. Памяти Марии Васильевны Фехнер. М.: ГИМ, 1999. С. 159-166. (Тр. ГИМ. Вып. 111).

Внешние связи Северо-Восточной Руси в IXXI вв. (по материалам Сарского городища и Ростова) // Древнерусская культура в мировом контексте: археология и междисциплинарные исследования. Матер. конф. / РРГУ, ИА РАН. М.: РГГУ, 1999. С. 86-95.

Памятники древнерусского зодчества XIIXIII вв. в Ростове Великом // История и культура древних и средневековых славян. М.: Едиториал УРСС, 1999. С. 252-264 (в соавт. с О.М. Ионнисяном, П.Л. Зыковым, Е.Н. Торшиным). (Тр. VI Междунар. конгресса славянской археологии; т. 5).

К истории археологического изучения мери // Российская археология: достижения XX и перспективы XXI вв. Материалы научной конференции «75 лет со дня рождения В.Ф. Генинга». Ижевск, 28-30 марта [2000 г.]. Ижевск: УдГУ, 2000. C. $150-152$.

Ростов Великий. Динамика изменения территории и этапы истории города // Русь в XIII веке: континуитет или разрыв традиций. Тез. докл. М.: ИА РАН, 2000. С 62-64.

Sarskoe et Rostov: Deux Centres de la Rus' du Nord-Est aux $\mathrm{IX}^{\mathrm{e}}-\mathrm{XI}^{\mathrm{e}}$ siècles // Les Centres protourbains russes entre Scandinavie, Byzance et Orient. Actes du Colloque International tenu au Collège de France en octobre 1997. Paris, 2000. S. 199-214.

Еськи. «Археологический заповедник» // ТАС. Вып. 4. Т. ІІ. Тверь, 2001. С. 139-145 (в соавт. с А.Г. Купцовым, А. А. Узяновым). 
Археология Владимирской области // АКР. Очерки археологии регионов. Кн. 1. М.: Наука, 2001. С. 33-78 (в соавт. с Л. А. Михайловой).

Еськи на Мологе. Топография и стратиграфия археологических памятников (от мезолита до средневековья) // РА. 2002. № 2. С. 142-151 (в соавт. с А. Г. Купцовым, С. А. Сычевой).

Рец. на кн.: Макаров Н.А., Захаров С.Д., Бужилова А.П. Средневековое расселение на Белом озере. М., 2001 // РА. 2002. № 3. С. 171-175.

Предисловие // Титовы: Ростов - Париж - Москва. Живые голоса. Ростов: ГМЗ «Ростовский кремль», 2002. С. 4-6.

Ножи из Ростова Великого: к вопросу о различии производственных традиций в железообрабатывающем производстве городов на Севере и Юге Руси в домонгольский период // Русь в IX-XIV веках: взаимодействие Севера и Юга. Тез. докл. науч. конф. М.: ИА РАН, 2002. С. 52-54 (в соавт. с Л. С. Розановой).

На могильном ложе // Родина. 2002. № 11-12. С. 118-122 (в соавт. с Н. А. Макаровым, С. В. Шполянским).

Раскопки в Ростове Великом// АО 2001. М., 2002. С. 201-202 (в соавт. с Самойлович Н.Г., Асташовой Н. И., Комаровым К. И.).

От столицы княжества к уездному городу (Материалы к исторической топографии Ростова X-XIV вв.) // Русь в XIII в.: Древности темного времени. М.: Наука, 2003. С. 34-47.

Забытые карты раскопок 1854 г. // Археология: история и перспективы. Первая межрегиональная конференция. Ярославль, 2003. С. 161-168.

Исследование средневековых селищ в Суздальском Ополье // АО 2002. М., 2003. С. 149-152 (в соавт. с Н. А. Макаровым, С. В. Шполянским).

Раскопки в Ростове Великом // АО 2002. М., 2003. С. 168-170 (в соавт. с Н.Г. Самойлович, Н.И. Асташовой, А.В. Кашкиным, Орловым В.).

Исследования в Суздальском ополье // АО 2003. М., 2004. С. 165-170 (в соавт. с Макаровым Н.А., Шполянским С. В., Федориной А. Н.).

Раскопки в Ростове Великом// АО 2003. М., 2004. С. 193-195 (в соавт. с Н.Г. Самойлович, Н.И. Асташовой, А.В. Кашкиным).

Средневековое расселение в Суздальском Ополье // РА. 2004. № 1. С. 19-34 (в соавт. с Н. А. Макаровым, С.В. Шполянским).

Пойменное «городище» Еськи // Взаимодействие культур в Среднем Поволжье в древности и средневековье. Йошкар-Ола: МарНИИЯЛИ, 2004. С. 68-71. (АЭМК. Вып. 27).

Меря в Ростове // Формирование, историческое взаимодействие и культурные связи финно-угор- ских народов. Матер. III Междун. истор. конгресса финно-угроведов. Йошкар-Ола: МарНИИялИ, 2004. С. 132-133.

Последний курган из группы у с. Веськово на Плещеевом озере // Восточная Европа в Средневековье. К 80-летию Валентина Васильевича Седова. М.: Наука, 2004. С. 193-199 (в соавт. с В.И. Вишневским).

Ростовские ножи X-XIII вв. Технология производства и типологический анализ // Русь в XIXIV веках. Взаимодействие Севера и Юга. М.: Наука, 2005. С. 153-162 (в соавт. с Л. С. Розановой).

Сельское расселение в центральной части Суздальской земли в конце I- первой половине II тыс.н.э.: новые материалы// Русь в XI-XIV веках. Взаимодействие Севера и Юга. М.: Наука, 2005. С. 196-215 (в соавт. с Н.А. Макаровым, С.В. Шполянским).

Раскопки в Ярославле // АО 2004. М., 2005. С. 175-177 (в соавт. с А. В. Яковлевым, Н.Н. Фараджевой, А. В. Ягановым).

Обследование селищ в Суздальском Ополье // AO 2004. М., 2005. С. 179-182 (в соавт. с Н. А. Макаровым, С. В. Шполянским, А. А. Карпухиным).

Исследования Волго-Окской экспедиции в Ростове Великом и в Ярославской области // АО 2004. М., 2005. С. 207-209 (в соавт. с Н. Г. Самойлович, А. В. Кашкиным, Н.И. Асташовой, К. И. Комаровым).

Юность Ростова Великого // Московский журнал. История государства Российского. 2005. № 3. С. 50-55.

Склоны на ровном месте // Склоны на исторических территориях. Матер. VII Междун. науч.практ. семинара «Комплексное изучение и сохранение исторических территорий». Рязань: РГИAM3, 2006. С. 35-40 (в соавт. с А. Г. Купцовым).

История Успенского собора и Соборной площади Ростова Великого (по данным охранных археологических раскопок) // Природные условия строительства и сохранения храмов православной Руси. Сб. тез. 3-го Междун. науч.-практ. симпозиума. Московская Патриархия, Троице-Сергиева лавра. Сергиев-Посад: Загорская тип., 2006. С. 89-91.

Раскопки у северных ворот Ростовского кремля // Археология Верхнего Поволжья (к 80-летию К. И. Комарова). М.: ИА РАН, 2006. С. 225-243.

Н.Н. Воронин и археологическое изучение $\mathrm{Ce}$ веро-Восточной Руси // КСИА. Вып. 221. 2007. С. 3-5 (в соавт. с Н.А. Макаровым).

Археологические данные об утверждении христианства в Ростове // Археология: история и перспективы. Третья межрегиональная конф. Сб. ст. 
Ярославль: Ремдер, 2007. С. 133-141 (в соавт. с Н.Г. Самойлович).

Исследования в Ростове Великом // АО 2005. М., 2007. С. 224-225 (в соавт. с Самойлович Н. Г., Асташовой Н. И., Кашкиным А. В.).

Пужбол, Шурскол и Согило: археологические данные к истории поселений ростовской округи // Сельская Русь в IX-XVI веках. М.: Наука, 2008. С. 74-81.

Погребения XI в., церковь Иоанна Предтечи в Ростове и история саркофага св. Леонтия Ростовского // Московская Русь. Проблемы археологии и истории архитектуры. К 60-летию Леонида Андреевича Беляева. М.: Наука, 2008. С. 43-51 (в соавт. с О.М. Иоаннисяном).

Виктор Петрович Глазов // АВСЗ. Вып. 2. М.: ИА РАН, 2008. С. 219-221.

Предисловие // Титов А. А. Ростовский уезд Ярославской губернии. Историко-статистическое описание. М.: В Синодальной тип., 1885. IX, 631 с., 10 л. ил., 1 л. карт, 1885 / Репринтное изд. Ростов: [б. и.], 2008. С. 1-5.

Ростов Великий // Институт археологии. Новые полевые исследования. М.: ИА РАН, 2010. С. 86-87.

Работы Волго-Окской экспедиции // АО 2007. М., 2010. С. 127-129 (в соавт. с Кашкиным А. В., Самойлович Н. Г., Асташовой Н. И., Комаровым К. И.).

О времени строительства в Ростове первого христианского храма // Археология древнерусского города XI-XV веков. Проблемы источниковедения, становления государственности и культурогенеза. Тез. докл. междунар. науч. конф. М.: ИА РАН, 2011. С. 42-44.

«Мерянское начало» Ростова // Труды III (ХІХ) ВАС/ИИМК РАН, СПб.; ИА РАН, М.; ИАЭ СО РАН, Новосибирск, 2011. СПб.: ИИМК РАН, 2011. С. 64-65.

Археология финно-угорских народов Поволжья IX-XIII вв. Программа лекционного курса // Археология на Историческом факультете. Программы учебных курсов. Уч. пособие. М.: МГУ, 2011. С. 269-273.

Работы Волго-Окской экспедиции // АО 2008. М., 2011. С. 149 (в соавт. с Кашкиным А.В., Асташовой Н. И., Комаровым К. И., Самойлович Н.Г.).

Археологические исследования в ростовском Петровском монастыре в 2009 г.// Археология: история и перспективы. Пятая межрегиональная конф. Ярославль, 2012. С. 116-136 (в соавт. с Н.Г. Самойлович, А. В. Ягановым).

Ранняя история ландшафтов древнейших русских городов // Русь в IX-X вв. Общество. Государство. Культура. Тез. докл. междун. науч. конф.
М.: ИА РАН, 2012. С. 7 (в соавт. с А.Л. Александровским, Н. А. Кренке, А. В. Долгих).

«Неопознанные археологические объекты» в Муромском районе Владимирской области // АВСЗ. Вып. 4. М. - СПб.: Нестор-История; ИА РАН, 2012. С. 116-124.

Ростовская крепость 1632 г. От постройки до современности // Вопросы истории фортификации. Вып. 3. СПб: Изд. центр «Остров», 2012. С. 95-102 (в соавт. с Л. В. Печкиной).

Ростов Великий // 1150 лет российской государственности: Средневековая Русь в археологических исследованиях РАН [Электронный ресурс]. 2012. Российская академия наук: [сайт]. Электронные коллекции. URL: http://www.ras.ru/archaeology/68c 6e9fb-d070-4d12-95aa-fab0e51b41dc.aspx?hidetoc $=0$. C. $60-68$.

Смоленск в XVI-XVIII вв.: археологический комментарий к истории города // От смуты к империи. Новые открытия в области археологии и истории России XVI-XVIII вв. Тез. докл. науч. конф. М.: ИА РАН, 2013. С. 27 (в соавт. с Г.Н. Прониным, В.Е. Соболем).

Ростовские поливные сосуды XVI века // АП. Вып. 10. М.: ИА РАН, 2014. С. $452-459$ (в соавт. с Н.Г. Самойлович).

Керамика с налепным валиком на территории Северо-Восточной Руси // Славяне и иные языцы... К юбилею Натальи Германовны Недошивиной. М.: ГИМ, 2014. С. 309-317. (Тр. ГИМ. Вып. 198).

Ранняя история ландшафтов древнерусских городов (становление культурного ландшафта) // Русь в IX-XII веках. Общество, государство, культура. М. - Вологда: Древности Севера, ИА РАН, 2014. С. 99-107 (в соавт. с А. Л. Александровским, Н. А. Кренке, А. В. Долгих).

Предисловие // Русь в IX-XII веках. Общество, государство, культура. Москва - Вологда: Древности Севера, 2014. С. 8-13 (в соавт. с Н. А. Макаровым).

Археологические данные к истории Ростова в X-XI вв. // Tp. IV (XX) ВАС в Казани. T. III. Казань: Отечество, 2014. С. 286-290.

Раскопки на городище у села Еськи в 1997 г. // КСИА. 2014. Вып. 236. С. 144-149.

Городище Еськи на р. Мологе. Укрепления в пойме // Вопросы истории фортификации. Вып. 5. СПб.- М.: Изд. центр «Остров», 2015. С. 114-118.

Раскопки в Смоленске // АO 2010-2013 гг. М.: ИА РАН, 2015. С. 208-212 (в соавт. с Г.Н. Прониным, В.Е. Соболем).

Раскопки в Ростове Великом // АО 2010-2013 гг. М.: ИА РАН, 2015. С. 194-196 (в соавт. с А. В. Кашкиным, Н.Г. Самойлович). 
Археологические данные к истории Ростовской епархии // Города и веси средневековой Руси. Археология, история, культура. К 60-летию Николая Андреевича Макарова. М. - Вологда: Древности Севера, 2015. С. 45-52.

Памятники эпиграфики из раскопок Петровского монастыря в Ростове Великом // Вопросы эпиграфики. Вып. VIII. М.: РФСОН, 2015. С. 285-306 (в соавт. с А. Г. Авдеевым).

О «мерянской гипотезе» В.В. Седова // КСИА. Вып. 240. 2015. С. 112-123.

Изотопный анализ и вопросы реконструкции палеодиеты домашних животных в средневековых городах Восточной Европы // КСИА. Вып. 241. 2015. С. 380-387 (в соавт. с Л.В. Яворской, Е. Е. Антипиной, А. В. Энговатовой).

Ростов (археология, история до XVII в.) // Большая Российская энциклопедия. Т. 28. М.: БРЭ, 2015. С. 689-691.

Археологические данные к истории монастырей и церквей Ростова // Археология сакральных мест России. Тез. докл. науч. конф. с международным участием. Соловки: Соломбальская тип., 2016. С. 164-168 (в соавт. с Н. Г. Самойлович).

«...На реце Саре у святеи Марии...». Археологические памятники народного памятного места // КСИА. Вып. 244. 2016. С. 425-436.

Сасанидская печать из Ростова Великого // КСИА. Вып. 245. 2016. С. 275-281.

90-летний юбилей Константина Ивановича Комарова // РА. 2016. № 4. С. 182-183 (в соавт. с Кашкиным А. В., Самойлович Н.Г.).

Памяти Ольги Николаевны Енуковой // PA. 2016. № 3. С. 191-192 (в соавт. с Винниковым А.3., Кашкиными А.В., Обломским А.М., Пушкиной Т.А.).
Работы в Ростове Великом и в Ярославской области // АО 2014. М., 2016. С. 111-113 (в соавт. с Кашкиным А. В. Самойлович Н. Г.).

Городище Лазаревское // De mare ad mare. Apxeoлогия и история: сб. ст. к 60-летию Н.А. Кренке. М. - Смоленск: Свиток, 2017. С. 31-39 (в соавт. с А.Л. Александровским).

Раннесредневековое городище Выжегша по результатам исследований 2016 г. // Тр. V (XXI) ВАС в Барнауле - Белокурихе. Т. II. Барнаул: АлтГУ, 2017. С. 190-193.

Ростовские находки скандинавских вещей // Культурний шар. Статті̀ на пошану Гліба Юрійовича Ївакі̀на. Київ: Laurus, 2017. С. 299-306. (в соавт. с Т.А. Пушкиной).

Городище-торжище Еськи на Верхней Мологе // Памятники средневековой археологии Восточной Европы. К юбилею М. Д. Полубояриновой. М.: ИА РАН, 2017. С. 196-200.

Работы В Ростове и Ростовском районе // AO 2015. М., 2017. С. 125-128 (в соавт. с Кашкиным А. В., Самойлович Н. Г.).

Городище Выжегша. Археологический памятник начального периода истории Северо-Восточной Руси // V (XXI) ВАС [Электронный ресурс]: сб. науч. трудов. Барнаул: АлтГУ, 2017. С. 620-621.

Технологическое изучение круговой керамики Ростова (по материалам раскопок Конюшенного двора 2013 г.) // ТАС. Вып. 11. Тверь, 2018. С. 61-70 (в соавт. с Шаргановой О. Л.).

Леонтьев А.Е., Успенский собор и Соборная площадь в Ростове Великом // Городища, селища, могильники. Раскопки 2017. М.: ИА РАН, 2018. С. 174-179. (Материалы спасательных археологических исследований; т. 25). (в соавт. с Кашкиным А. В., Орловым В. Н., Самойлович Н. Г.).

Н. Г. Самойлович, И.Н. Кузина Институт археологии РАН, г. Москва 
Н.А. Макаров, П.Г. Гайдуков

Институт археологии РАН, г. Москва

\section{Печать Дамиана из Суздальского Ополья}

Находки актовых печатей на землях СевероВосточной Руси значительно более редки, чем в Новгороде, Пскове или Среднем Поднепровье. Сфрагистическая коллекция из раскопок Суздаля, одного из древнейших городских центров Северо-Восточной Руси, охваченного широкими раскопками, до недавнего времени насчитывала лишь три печати (Седова, 1997. С. 86, 217. Рис. 22), еще одна булла происходит из недавних раскопок в окольном городе Суздаля. За 17 лет полевых работ в Суздальском Ополье, в ходе которых экспедицией Института археологии РАН было обследовано более 340 селищ и собрано около 13 тыс. средневековых предметов, найдены лишь три буллы XII-XIII вв. (Макаров, Гайдуков, 2013). Летом 2018 г. эта скромная коллекция пополнилась новой находкой: на одном из селищ найдена свинцовая подвесная печать, на лицевой стороне которой помещена четырехстрочная греческая надпись, а на оборотной - погрудные изображения двух святых (рис. 1; 2).

Печать представляет собой круглую пластину высотой 23 мм, шириной 25,5 мм и толщиной около 2 мм. Святые изображены анфас, их лица округлые, молодые, безбородые, у левого кудрявые волосы. Правая рука левого святого показана в благословляющем жесте, положение левой неясно. У правого святого в правой руке находится какой-то вытянутый предмет, возможно, кодекс или сосуд, левая рука поднята. Святые облачены в хитоны, просматриваются складки одежды на груди и на плечах. По сторонам изображений колончатые надписи, у левого святого - КОСМ[А], у правого - ДАМИАН. Головы святых в точечных нимбах, в центре печати над нимбами две буквы

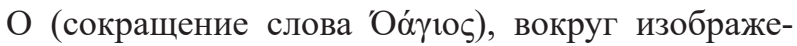
ния - точечный ободок. Парные изображения мучеников Космы и Дамиана, почитавшихся как целители-бессребреники, хорошо известны в визан- тийской и русской иконографии. Они изображались с крестами в правых руках и с «сосудцами» для лекарств в левых или с «перьями», использовавшимися в Средневековье для нанесения лекарственных мазей. Сохранность суздальской печати не позволяет прояснить все детали изображений, однако очевидно, что мученики изображены без крестов и без «перьев» в правых руках. Сходный иконографический вариант изображения святых бессребреников, представляющий Косму с правой рукой в благословляющем жесте, представлен на крышке хранящейся в музеях Московского Кремля Филофеевской ставротеки - ящичка для хранения частиц Святого Креста, «Честного древа». Ставротека изготовлена в Византии в XII в., попала на Русь в XIV в. и стала одной из родовых святынь московского княжеского дома (Банк, 1958. С. 237, 240, 241. Рис. 7; 1966. С. 312. Рис. 195; 1971. С. 136 . Рис. 6,$5 ; 8,3)$.

На лицевой стороне печати помещена четырехстрочная греческая надпись $K \in B O|\mathrm{H} \Theta \mathrm{HT} \omega \mathrm{C}|$

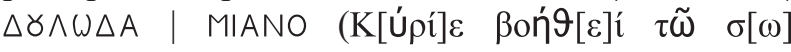
$\left.\delta[о] v \lambda \omega \Delta \alpha \mu \alpha_{\alpha} \alpha v\right)$. Она переводится как «Господи, помоги рабу своему Дамиану» и дает ясное указание на имя лица, скреплявшего документы печатью. Его звали Дамианом.

В каталоге древнерусских актовых печатей ранее была издана лишь одна печать с изображением Космы и Дамиана, оттиснутая той же матрицей. Она происходит с Новгородского (Рюрикова) городища (Янин, Гайдуков, 1998. С. 120. № 66а.) Предположительно отнесена к юрьевскому епископу Дамиану, современное место хранения печати неизвестно. Еще одна печать этих матриц находится в собрании Государственного Эрмитажа (приобретена как находка из Белоозера), она введена в научный оборот В.И. Булгаковой как византийская булла (Bulgakova, 2004. S. 107-108. № 1.5.1a). Три буллы с изображением Космы 


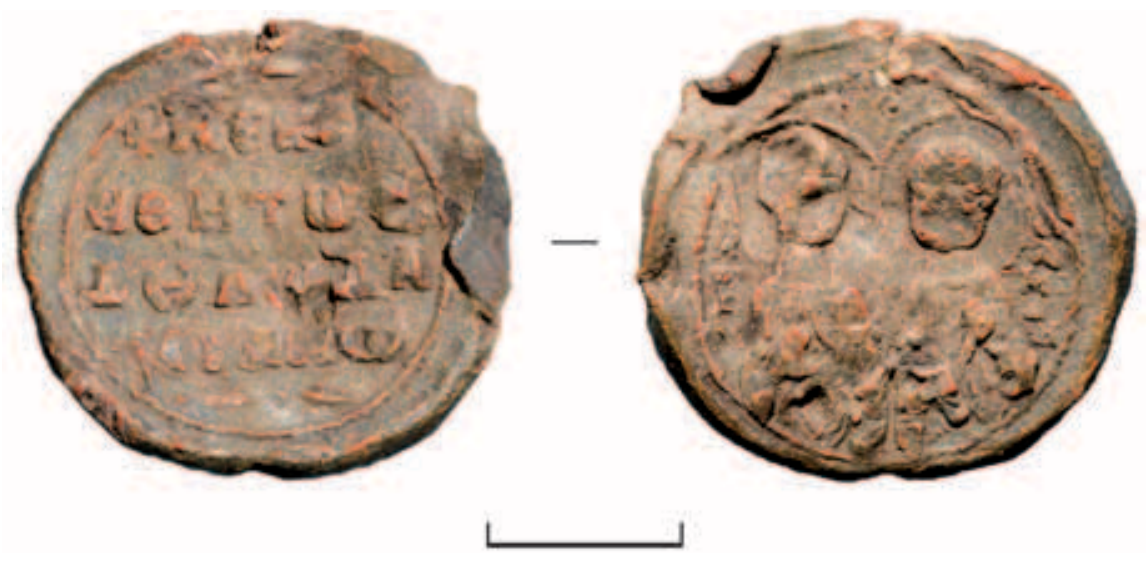

Рис. 1. Печать Дамиана со средневекового поселения в Суздальском Ополье. Фото А. С. Пахунова

и Дамиана находятся в частных коллекциях и документированы как грабительские находки 2006, 2010 и 2018 гг. из Суздальского Ополья и округи Плещеева озера ${ }^{1}$. Находка 2018 г. из Суздальской округи - единственная печать этого типа, полученная в результате легитимных археологических исследований, и единственная находка, контекст которой надежно документирован. Хотя достоверность определения четырех других булл Дамиана как находок из Северо-Восточной Руси не может быть строго доказана, представляется, что деятельность владельца печати была связана преимущественно с ростово-суздальскими землями.

Косвенным свидетельством этого можно считать находки на Северо-Востоке Руси круглых металлических образков с погрудным изображением парных святых, точно копировавших изображения святых на печати (рис. 3), (Макаров, Зайщева, 2018. С. 119-121. Рис. 2, 1, 2, 3). На этих образках нет надписей, обозначающих имена святых, долгое время они идентифицировались как Петр и Павел (Седова, 1982. С. 62; Макаров, 1990. С. 73). Однако на вновь найденных экземплярах, выделяющихся лучшим качеством отливки, отчетливо видно, что святые безбородые и не могут быть идентифицированы как первоапостолы. Сопоставление суздальской печати с Космой и Дамианом с образками не оставляет сомнения в том, что иконки воспроизводят изображения на моливдовулах. Находки круглых иконок с изображением Космы и Дамиана происходят из различных областей Руси, от Среднего Поднепровья до Новгорода, однако более по- ловины экземпляров (13 из 24) происходит с территории Северо-Восточной Руси. Несколько таких образков найдены в последние годы на селищах Суздальского Ополья (Макаров, Зайцева, 2018. С. 119-121).

Тип печати с греческой благопожелательной надписью на лицевой стороне и изображением святого патрона владельца на обороте хорошо известен в русской сфрагистике. Таким образом оформлялись буллы князей, начиная с печати Всеволода Ярославича (1054-1093). Печати с краткой легендой в четыре или в три строки, подобные суздальской, атрибутированы В.Л. Яниным как буллы князей, находившихся на столах во второй половине ХІ - начале XII в. (Янин, 1970. С. 14-33). В каталоге В.Л. Янина и П.Г. Гайдукова приведены данные о 10 типах подобных печатей, наиболее ранняя из них - печать Игоря Ярославича (1054-1060), наиболее поздние - печати Святополка Изяславича Киевского (1093-1113) (Янин, Гайдуков, 1998. С. 24-25. 115-117. № 31a-39a). Греческие благопожелательные надписи помещались также на печатях церковных иерархов XI - начала XIII в., при этом на оборотной стороне моливдовулов епископов и митрополитов помещались, как правило, изображения Богоматери как символа Церкви, но известны также печати с изображением святых патронов иерархов. Суздальскому моливдовулу типологически наиболее близки печати с краткой благопожелательной надписью и изображениями св. Иоанна Крестителя (Янин, 1970. С. 174. № 41), атрибутированные как печати митрополита

${ }^{1}$ По материалам сфрагистического архива П.Г. Гайдукова. 


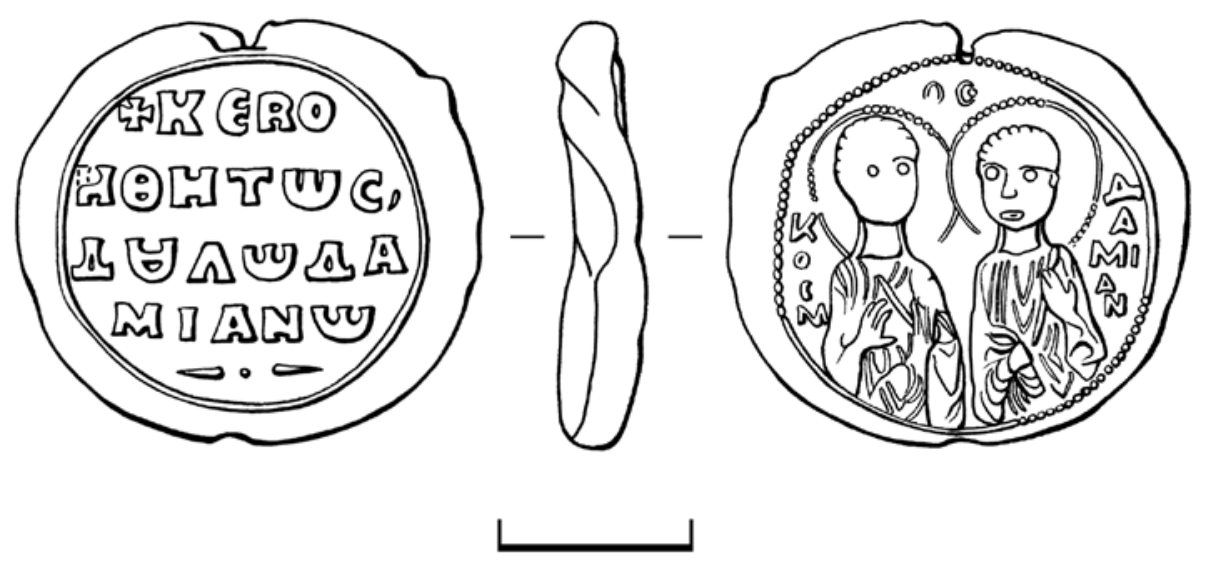

Рис. 2. Печать Дамиана со средневекового поселения в Суздальском Ополье. Рис. А.С. Дементьевой

Феопемпта (1037 - ок. 1043) и св. Георгия (Янин, 1970. С. 174. № 43), которые были определены как буллы митрополита Георгия (ок. 1068-1073) (Янин, 1970. С. 44-48; Янин, Гайдуков, 1998. С. 27). Согласно предположению В. Л. Янина, некоторые печати византийского облика с краткими благопожелательными греческими надписями и изображениями святых на обороте могли принадлежать не самим князьям, а княжеским советникам (печатникам) (Янин, Гайдуков, 1998. С. 25-26).

Печать Дамиана была обнаружена на селище Вышеславское 3, небольшом поселении (площадь около 3 га), приуроченном к вершине одного из оврагов в верховьях р. Каменки. При обследовании селища на распаханной поверхности и в шурфе собрано около 180 фрагментов венчиков средневековых сосудов и около 150 предметов из железа, цветного металла, камня и кости. Вся керамика круговая, в керамической коллекции преобладают фрагменты сосудов с невысокой шейкой и отогнутым наружу венчиком со скругленным и загнутым внутрь краем и сосуды с высокой раструбовидной шейкой (типы VIII A-B и VI по классификации В.А. Лапшина (1992)), характерные для XII - первой половины XIII в., но представлены также отдельные фрагменты венчиков с S-образным и секировидным профилем, верхняя граница бытования которых не выходит за рамки первой половины XII в. Фрагменты лепной посуды, остававшейся в употреблении вместе с круговой в Суздальском Ополье до конца XI в., в коллекции не представлены. Среди хронологически определимых предметов из металла преобладают бытовые вещи, украшения и предметы христианского культа - хроноиндикаторы середины XII - первой половины XIII в., но присутствует также несколько украшений и предметов личного благочестия, получивших распространение в более ранний период. К числу последних относятся, в частности, бронзовый грушевидный крестопрорезной бубенчик, крест скандинавского типа и круглая подвеска с погрудным изображением святого Георгия и трезубцем на оборотной стороне. В шурфе площадью 6 кв. м, заложенном вблизи места находки печати, выявлены культурный слой мощностью до 40 см и материковая яма с круговой керамикой XII - первой половины XIII в. Очевидно, поселение возникло на рубеже XI-XII вв. и прекратило существование в середине XIII в.

Учитывая особенности оформления буллы и общую датировку культурного слоя на поселении, печать Дамиана может быть датирована второй половиной XI-началом XII в. Князья с крестильным именем Дамиан неизвестны в летописях, рассказывающих о событиях XI-XII вв. Очевидно, обладатель печати - высокопоставленный представитель княжеской власти, в управлении которого могли находиться суздальские земли, советник князя или церковный иерарх. В истории Ростовской епархии и списке епископов, занимавших ростовскую кафедру, есть значительные пробелы, приходящиеся на конец XI - начало XII в., период между последним упоминанием в летописи епископа Исайи (1089) и первым упоминанием епископа Нестора (1147). Оформление буллы дает равную возможность для атрибуции ее как печати светского и духовного лица. 


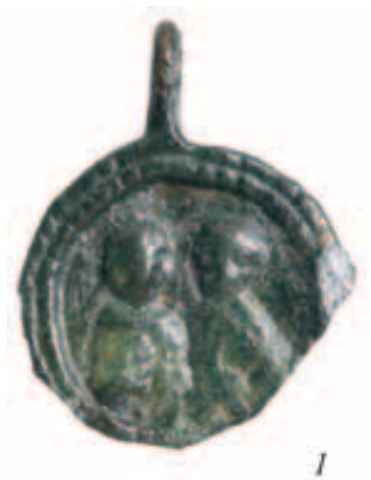

1

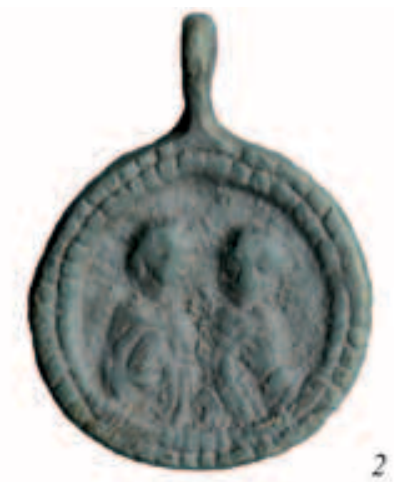

2

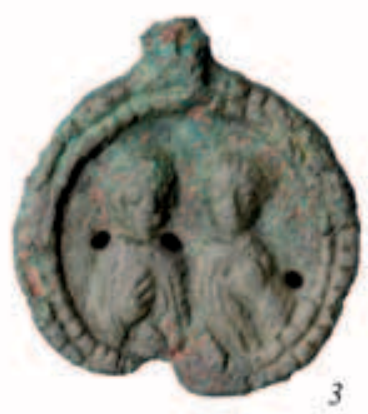

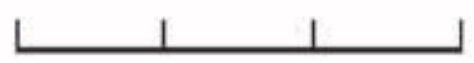

Рис. 3. Образки с изображением свв. Космы и Дамиана из Суздальского Ополья 1 - селище Михали 3; 2 - селище Кубаево 7; 3 - селище Павловское 2. Фото А.С. Пахунова

Значение суздальской находки в том, что она открывает новое имя в ранней истории Северо-Восточной Руси, которая крайне бедна какими-либо сведениями о реальных действующих лицах, находившихся на исторической сцене. Немногие известные нам имена, упомянутые в летописных статьях XI - первой половины XII в., посвященных событиям в Ростово-Суздальской земле, - это преимущественно князья, принадлежащие общедревнерусской истории. Появление нового исторического персонажа в этой ситуации - большая удача. При всей неясности места Дамиана в иерархических институтах и обстоятельств его присутствия на северо-востоке очевидно, что он не был статистом в историческом действии. Печать, известная уже в шести экземплярах, оформленная в классической византийской традиции и использовавшаяся для удостоверения документов на окраинах Руси, известных консерватизмом своего бытового уклада и социального устройства, - существенный штрих к характеристике культурного взаимодействия и личности Дамиана.
Находка печати на сельском поселении, за пределами города, хорошо согласуется с наблюдениями последних лет, выявившими на суздальских селищах представительные серии предметов, связанных с повседневной жизнью элиты, письменностью, сферой управления и военным делом (Makarov, 2013). На селище Вышеславское 3, из культурного слоя которого происходит печать, найден целый ряд находок этого круга, в том числе металлическая накладка на сумку с плетеным орнаментом, бронзовый позолоченный колт с изображением фантастического животного и амулетзмеевик, на лицевой стороне которого помещено изображение Богоматери с младенцем на троне, а на обороте-изображение Горгоны. Очевидно, подобные находки маркируют присутствие на сельских поселениях дворов княжеских слуг, бояр и других представителей социальной элиты, местопребывание которой археологи привычно ограничивают городами и поселениями с дерево-земляными укреплениями.

\section{Литература}

Банк А.В., 1958. Византийские серебряные изделия XI-XII вв. в собрании Эрмитажа. 2. Серебряная ставротека // ВВ. Т. XIV. С. 234-242.

Банк А.В., 1966. Византийское искусство в собраниях Советского Союза. Л.-М. 391 с.

Банк A.B., 1971. Опыт классификации византийских серебряных изделий X-XII вв. // ВB. T. XXXII. C. 131-141.
Лапшин В.А., 1992. Керамическая шкала домонгольского Суздаля // Древнерусская керамика / Отв. ред. С. А. Плетнева. М.: ИА РАН. С. 90-102. Макаров Н.А., 1990. Население Русского Севера в XI-XIII вв. М.: Наука. 215 с.

Макаров Н.А., Гайдуков П.Г., 2013. Печать князя Михалки Юрьевича из Суздальского Ополья // КСИА. Вып. 231. С. 224-231. 
Макаров Н.А., Зайцева И.Е., 2018. Христианская металлопластика Суздальской земли XII-XIV вв.: новые находки // Нескончаемое лето. Сб. ст. в честь Елены Александровны Рыбиной / Отв. ред.-сост. В.К. Сигх. М.-Великий Новгород. С. 119-130.

Седова М.В., 1981. Ювелирные изделия древнего Новгорода (X-XV вв.). М.: Наука, 1981. 194 с.

Седова М.В., 1997. Суздаль в X-XV вв. М.: Русский мир. 320 с.

Янин В.Л., 1970. Актовые печати Древней Руси $\mathrm{X}-\mathrm{XV}$ вв. T. I. Печати X-начала XIII в. M.: Наука. 326 с.
Янин В.Л., Гайдуков П.Г., 1998. Актовые печати Древней Руси X-XV вв. T. III: Печати, зарегистрированные в 1970-1996 гг. М.: Интрада. $505 \mathrm{c}$.

Bulgakova V., 2004. Byzantinische Bleisiegel in Osteuropa. Die Funde auf dem Territorium Altrusslands. Wiesbaden: Harrassowits Verlag. 349 s. (Mainzer Veröffentlichungen zur Byzantinistik 6).

Makarov N., 2013. Social elite at rural sites of Suzdal region in North-Eastern Rus' // Ruralia IX. Hierarchies in rural settlements / Ed. Jan Klápště. Praha: Brepols. P. 371-386. 


\section{В. А. Лапшин \\ Институт истории материальной культуры, г. Санкт-Петербург}

\section{Североевропейские находки на селище Гнездилово-2 под Суздалем}

В фундаментальной монографии, посвященной археологии мери, А.Е. Леонтьев много внимания уделил хронологии скандинавских древностей и их распространению на территории Северо-Восточной Руси (Леонтьев, 1996). Сарское городище по праву стало считаться эталонным памятником и заняло почетное место во многих обзорных работах по ранней истории Руси (см., напр.: Франклин, Шепард, 2009. С. 45). Если для возникшего в VII в. городища появление в начале IX в. вещей североевропейского происхождения - свидетельство включения в международные связи и определенный этап развития, то для древнерусских поселений, появляющихся в течение $\mathrm{X}$ в. на территории Волго-Клязьминского междуречья, немногочисленные скандинавские находки приобретают характер хронологических реперов, указывающих на их вероятную раннюю дату (Лапиин, 1981).

Таким репером могут стать находки североевропейских вещей, сделанные при раскопках на селище Гнездилово-2 в 5 км южнее Суздаля. Селище типично для первого этапа освоения территории Суздальского Ополья древнерусским населением в X-XI вв. (Макаров, 2012). В 1980-1987 гг. на нем было раскопано 990 кв. м. Площадь селища -7 га, толщина культурного слоя-в среднем 0,4 м. Оно длительное время распахивается, местами до материка. В пахотном слое преобладает лепная керамика, ее доля колеблется на разных участках от 83 до 91\%, в предматериковом слое - от 92 до 99\%, в материковых ямах - от 96 до 100\%. В верхней части слоя встречаются единичные фрагменты развитой гончарной керамики. Большая часть материковых ям датируется по вещевым находкам X-XI вв. или, где по- зволяет материал, Х в. (Лапшин, 1989). По углю из материковых ям 1987 г. сделана серия радиокарбоновых анализов, давшая значительный разброс дат, что неудивительно, поскольку мы имеем дело с фактически открытыми комплексами (в верхней части заполнения некоторых ям X в. встречены отдельные венчики XII-XIII вв.). Более надежные данные дает суммарный анализ группы датировок (табл. 1): ямы первой группы № 8 и 14/1987 датируются второй половиной $\mathrm{X}$ в., а ямы второй группы № 47, 49 и 51/1987 - первой третью XI в.

Две группы ям различаются не только хронологически, но и по форме, представляя, по-видимому, разные домостроительные традиции (Лапиин, 2015).

Наиболее яркой находкой является ременная бляшка, найденная вне комплексов ям в предматериковом слое (рис. 1, 1). Бляшка подквадратная, $3,7 \times 3,5$ см. Отлита по резной восковой модели из бронзы, позолочена. Оборотная строна плоская, без следов шпеньков. Орнаментирована в стиле Борpe. Точные аналогии мне неизвестны. По классификации В.В. Мурашевой ее можно отнести к классу XXXIV, группе 1, виду 1B (Мурашева, 2000. С. 49. Рис. 69). По не вполне четкому рисунку в публикации бляшку можно сопоставить с находкой ${ }^{1}$ из гнездовского кургана IX в. (?), раскопанного В.И. Сизовым (Мурашева, 2000. С. 118). Техника отливки по восковой модели, подправленной резцом, характерная для выполненных в стиле Борре накладок, исключает полную идентичность бляшек в деталях, каждый экземпляр индивидуален (Мурашева, 1989. С. 85).

Позолоченные ременные бляшки эпохи викингов очень редки, они встречаются только в составе наиболее богатых кладов, таких как клад X в. из Ворбю (From Viking... 1992. Р. 79, 234. № 27;

${ }^{1}$ ГИМ. Оп. 241/273. 
Таблица 1. Суммарный анализ датировок комплексов (на базе построения гистограмм подпрограммы CALHIS калибровочной программы Groningen 20)

\begin{tabular}{|c|c|c|c|c|}
\hline Анализируемый комплекс & $\begin{array}{c}\text { Общее кол-во } \\
\text { учитываемых } \\
\text { датировок }\end{array}$ & № образцов & $\begin{array}{l}\text { Суммарный } \\
\text { возраст по }{ }^{14} \mathrm{C}\end{array}$ & $\begin{array}{c}\text { Суммарный календарный } \\
\text { интервал, 1б, cal AD }\end{array}$ \\
\hline Ямы № 8, 14 / 1987 & 3 & $\begin{array}{l}\text { ЛЕ-4443 } \\
\text { ЛЕ-4444 } \\
\text { ЛЕ-4446 }\end{array}$ & $1078 \pm 22$ & $\begin{array}{l}895-915(0.19) \\
950-995(0.81)\end{array}$ \\
\hline Ямы № 47, 49, 51 / 1987 & 3 & $\begin{array}{l}\text { ЛЕ-4433 } \\
\text { ЛЕ-4435 } \\
\text { ЛЕ-4442 }\end{array}$ & $992 \pm 26$ & $1004-1035$ \\
\hline
\end{tabular}

Graham-Campbell, Kidd, 1980. P. 56-57. Fig. 23). Как правило, покрывались позолотой серебряные украшения. Обычно и прежде всего украшения в стиле Борре сравнивают с комплексом находок, давшим название самому стилю - из разрушенного кургана в Борре с сожжением в ладье и датированного около 900 г. Комплекс содержит бронзовые позолоченные ременные бляшки (From Viking... 1992. P. 178. Fig. 2; P. 272-273. No 169). Однако его датировка основана на аналогии украшений с комплексом кургана из Гокстада (From Viking... 1992. P. 272. No 168), для которого получены две дендродаты - 900 и 905 гг. Датировка стиля Борре в целом остается дискуссионной - от 850/875-925/950 гг. (From Viking... 1992. Р. 178) до конца IX - конца X в. (обзор литературы см.: Андрощук, 2013. C. 122). Кроме того, для бляшек из Борре характерен ободок «из перлов» (ложной скани), связываемый с влиянием на скандинавских ювелиров искусства Каролинской империи (Мурашева, 2008. С. 9). На бляшке из Гнездилова, как и на экземпляpe из гнездовского кургана, такой ободок отсутствует. Бляшка из Гнездилова отличается большей массивностью (размер стандартных ременных бляшек этого типа около $2 \times 2 \mathrm{cm)} \mathrm{и} \mathrm{отсутствием}$ шпеньков для крепления на кожаную основу.

Железное кольцо с тремя подвесками (рис. 1, 2) входит в круг скандинавских подвесок-амулетов. Аналоги (из серебра, бронзы или железа) встречены на поселениях, в погребениях и кладах Дании, Швеции и Финляндии, а на территории Руси - на Рюриковом городище, Белом озере (Никольское V) и в Гнёздове. Их датировка не выходит за пределы Х в. (Дорофеева, 2010).

Костяной односторонний составной гребень, скрепленный бронзовыми штифтами (рис. 1, 3), относится к группе II по классификации О.И. Давидан. Гребни этой группы встречены в Старой Ладоге в слое Д и датируются концом IX - X в. Аналоги широко распространены в Северной Европе (Скандинавия, Польша, Германия) и на памятни- ках Северной Руси (Давидан, 1962. С. 100-101). На гребне процарапано изображение трех переплетенных треугольников - знак Одина (Мурашева, 2008. С. 10-11; ср.: Ениосова, Мурамева, Пушкина, 2009. С. 375. Рис. 5, 4).

Самая массовая металлическия находка на селище - железные ножи. Для металлографического анализа было отбрано 67 ножей. Они представлены как целыми экземплярами (41), так и обломками (26). Распределение исследованных ножей по технологическим схемам следующее: 15 изготовлено в простых схемах (целиком из железа и сырцовой стали), 52 сварных. Преобладают ножи, изготовленные в трехслойной технологии (49), а в технологии торцовой наварки стального лезвия на железную основу - три орудия. Исследователи связывают с местной финской ремесленной традицией шесть ножей, с древнерусской - пять. Преобладает скандинавская группа, включающая 30 экземпляров, из которых 25 выполнены в технологии трехслойного пакета, два - пятислойного пакета и три - в технологии вварки стального лезвия в железную основу (Завьялов, Розанова, Терехова, 2012. С. 219-223). Технология трехслойного пакета была выработана в Скандинавии в вендельскую эпоху (VI-VIII вв.), в эпоху экспансии викингов эти изделия появляются в Англии, Ирландии и Северной Руси (Завьялов, Розанова, Терехова, 2012. С. 37-53). В Старой Ладоге технология трехслойного пакета преобладает с момента возникновения поселения в середине VIII в. (Розанова, 1994). По мнению исследователей, население селища Гнездилово пользовалось в основном привозными ножами, и только на заключительном этапе существования поселения начинают поступать и ножи древнерусского облика, скорее всего, из Суздаля (Завьялов, Розанова, Терехова, 2012. С. 223).

Гнездилово-2 - единственное пока поселение Северо-Восточной Руси, в материалах которого присуствует западнославянская раннегончарная керамика типов Менкендорф и Фельдберг 


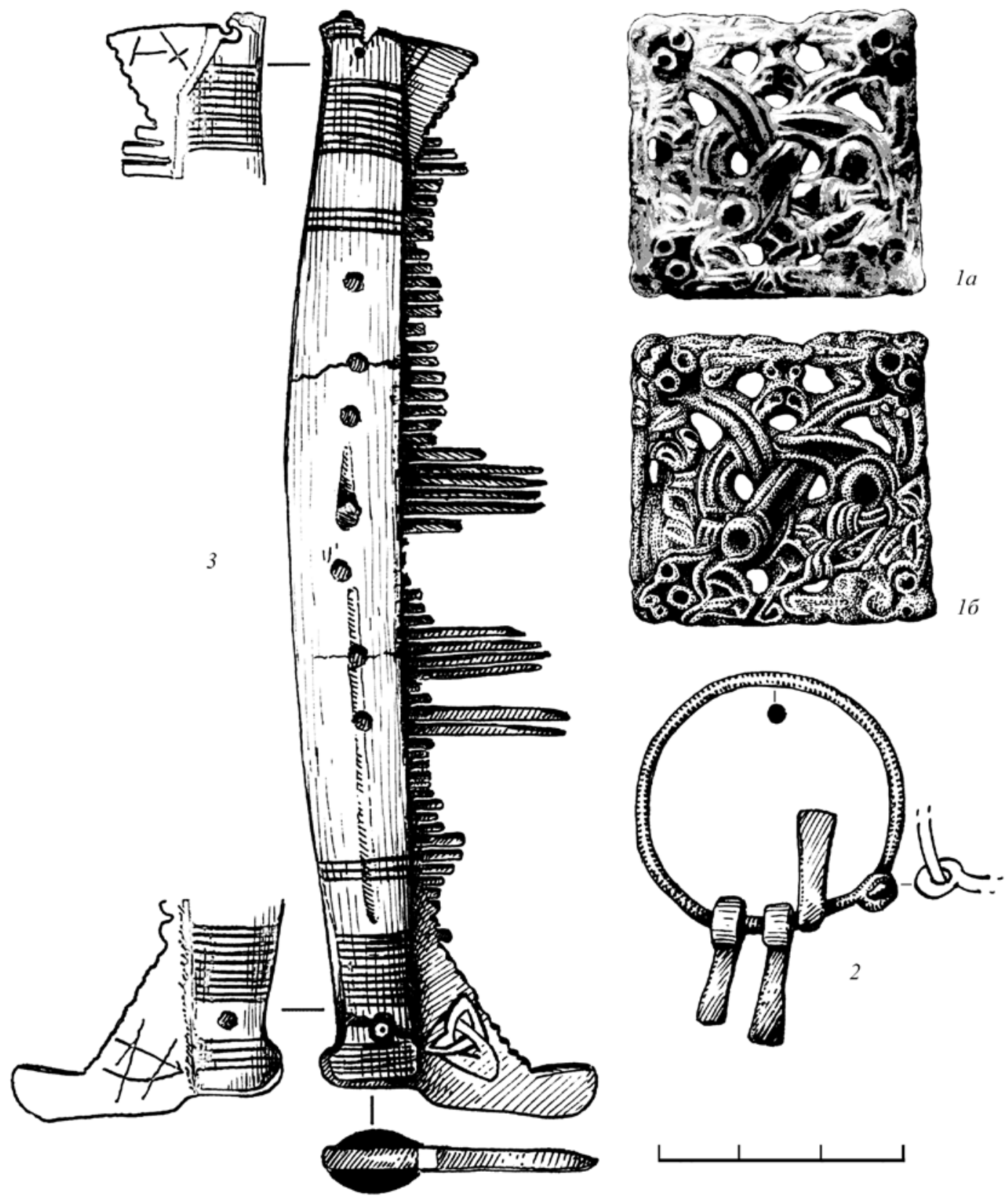

Рис. 1. Гнездилово-2. Находки скандинавского происхождения

1 - бронзовая с позолотой ременная бляшка в стиле Борре (1 $a$ - фото; 16 - рисунок);

2 - железная подвеска-амулет; 3 - костяной гребень с граффити

(Горюнова, Лапшин, 2004). Особый интерес представляет яма № 25/1986, фрагменты раннегончарной керамики из которой принадлежат исключительно западнославянским формам (рис. 2). В данном случае мы имеем дело с условно закрытым комплексом. Нижняя часть отложений с фельдбергской керамикой перекрыта угольной прослойкой, в которой была найдена круглая поясная бляшка, имеющая аналогии в венгерских памятниках с узкой датировкой - 30-е годы X в.
(Мурашева, 2000. С. 29. Рис. 32. Класс III, группа 1, вид 1А). Таким образом, комплекс можно датировать временем не позднее первой трети Х в., что не противоречит ранней дате владимирских курганов - вторая четверть Х в. (Лапшин, 1981).

Находки ножей-пакетов и раннегончарной керамики говорят прежде всего о связях с Северо-Западом (для первой половины X в. западнославянская керамика известна только в Старой Ладоге, на Рюриковом городище и в Городке на Ловати; 
Горюнова, 2011. С. 230). Но амулет с подвесками не мог быть предметом торговли, как и гребень с переплетением треугольников, начерченным твердой рукой. Можно сравнить его с граффити, неумело процарапанным на обороте псалий из Супрутского клада, бесспорно принадлежавшего скандинаву (Мурашева, 2008. С. 10). Повидимому, скандинавы в Гнездилове в Х в. присутствовали со времени возникновения поселения. Смена домостроительной традиции, которая, впрочем, не была скандинавской, в первой трети XI в. позволяет предполагать и смену населения после подавления Ярославом Мудрым в 1024 г. восстания под руководством волхвов, разрушения первоначальных укреплений Суздаля и строительства нового кремля (Седова, 1997. С. 47-50).

Исследования селища Весь-5 в 4 км к северу от Суздаля, проведенные в 2004-2007 гг. Суздальской экспедицией ИА РАН, позволили по находкам стеклянных бус, дирхемов и украшений из цветных металлов, с учетом радиоуглеродных дат, отнести начало формирования новой сети поселений, связанной с включением территории Суздальского Ополья в сферу международной торговли, ко времени «не позднее второй половины IX в.». Для раннего этапа жизни поселения - IX (?) - X вв. - характерно сочетание украшений поволжско-финских типов, в том числе типов, появившихся во второй половине - конце I тысячелетия н.э., с находками, связанными с трансъевропейской торговлей и бытовыми предметами «северных типов» (Maкаров, Захаров, Шполянский, 2010. С. 132-133). По-видимому, на раннем этапе селище Весь-5 относилось к группе финских по этническому составу поселений, включенных в международную торговлю до начала древнерусской колонизации, таких как Сарское городище (Леонтьев, 1996. С. 96-192) и городище Выжегша (Леонтьев, 1996. С. 196-209).

В материальной культуре селища Гнездилово-2 хотя и присутствуют элементы, присущие финно-
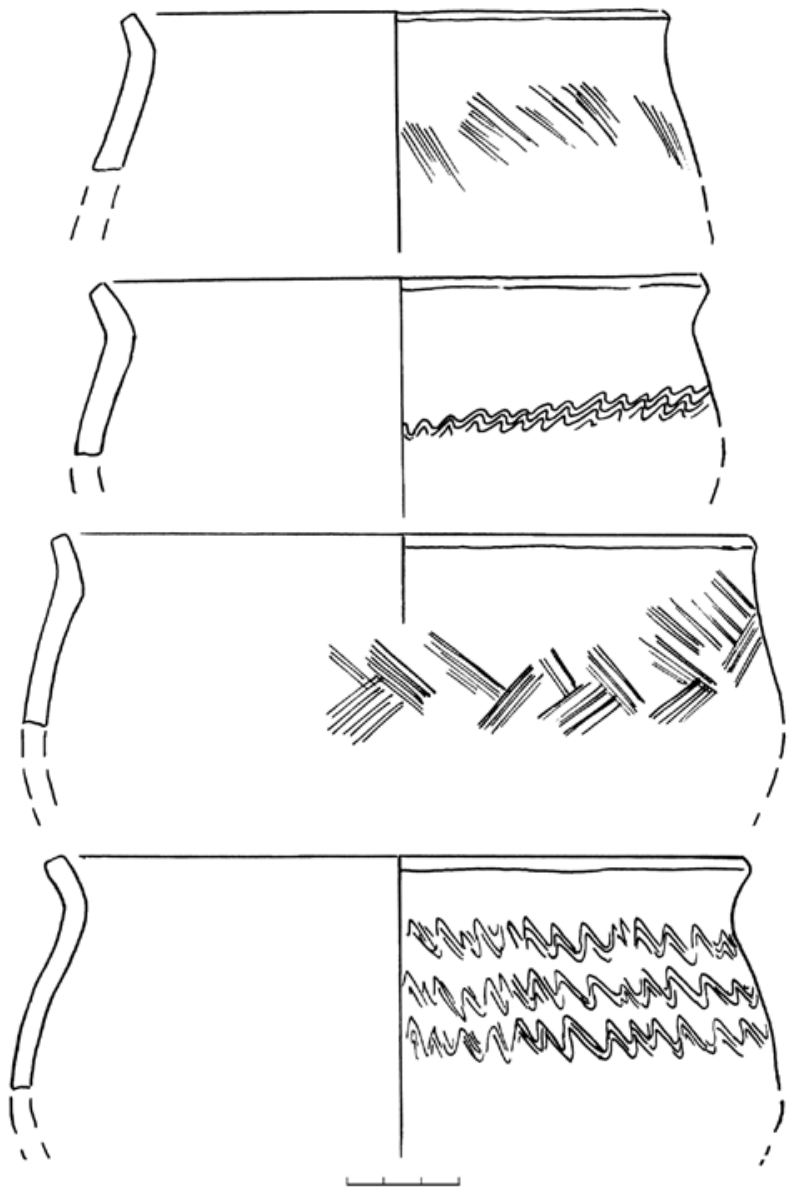

Рис. 2. Гнездилово-2. Заполнение ямы № 25. Раннегончарная керамика типа Фельдберг

угорскому населению (Лапиин, 1989. С. 69. Рис. 2 , 6-10, 16-19), однако преобладают предметы древнерусской материальной культуры. Поселение относится к следующему, древнерусскому этапу формирования системы расселения Суздальского Ополья. Начало этого процесса документировано ранними датами владимирских курганов (вторая четверть $\mathrm{X}$ в.) ${ }^{2}$ и селища Гнездилово-2 (первая треть X в.).

\section{Литература}

Андрощук Ф.А., 2013. Мечи викингов. Київ: Простір. 712 c.

Горюнова В.М., 2011. О западнославянских формах керамики в Северной Руси первой половины Х в. (время и причины появления) // АИППЗ. М.-Псков. С. 228-237.
Горюнова В.М., Лапшин В.А., 2004. О появлении раннекруговой керамики в Северо-Восточной Руси // Археология, история, нумизматика, этнография Восточной Европы. Сб. памяти И.В. Дубова. СПб.: СПбГУ. С. 55-72.

\footnotetext{
2 Отметим, что основанием для ранней даты владимирских курганов стала находка парных скорлупообразных фибул типа $51 \mathrm{~b}$ по Я. Петерсену именно в курганном могильнике у д. Весь (курган 4) под Суздалем (Лапиин, 1981. С. 46), рядом с которым находится селище Весь-5.
} 
Давидан О.И., 1962. Гребни Старой Ладоги// АСГЭ. Вып. 4. Л.: ГЭ. С. 95-108.

Дорофеева Т.С., 2010. Скандинавский амулет с Городища под Новгородом // Диалог культур и народов средневековой Европы: к 60-летию со дня рождения Евгения Николаевича Носова. СПб.: Дмитрий Буланин. С. 28-34.

Ениосова Н.В., Мурашева В.В., Пушкина Т.А., 2009. Исследования Гнездовского комплекса археологических памятников // Археологические открытия 1991-2004 гг. Европейская Россия. М.: ИА РАН. $476 \mathrm{c.}$

Завьялов В.И, Розанова Л. С., Терехова Н.Н., 2012. Традиции и иновации в производственной культуре Северной Руси. М.: Анкил. 376 с.

Лапшин В.А., 1981. Ранняя дата Владимирских курганов // КСИА. Вып. 166. С. 45-48.

Лапшин В.А., 1989. Археологический комплекс у с. Гнездилово под Суздалем // КСИА. Вып. 195. C. 66-71.

Лапшин В.А., 2015. Две группы построек селища Гнездилово-2 под Суздалем // Археология Владимиро-Суздальской земли. Вып. 5. М.: ИА РАН. C. 141-146.

Леонтьев А.Е., 1996. Археология мери (К предыстории Северо-Восточной Руси). М.: Геоэко. 340 с.

Макаров Н.А., 2012. Суздальское Ополье // Русь в IX-X веках: археологическая панорама.
М.: ИА РАН; Вологда: Древности Севера. C. 194-211.

Макаров Н.А., Захаров С.Д., Шполянский С. В., 2010. О датировке средневекового поселения Весь 5 под Суздалем // Диалог культур и народов средневековой Европы: к 60-летию со дня рождения Е.Н. Носова. СПб.: Дмитрий Буланин. С. 113-141.

Мурашева В.В., 1989. Технология изготовления поясных накладок из Гнездова // Вестник МГУ. Сер. «История». № 2. С. 85-91.

Мурашева В.В., 2000. Древнерусские ременные наборные украшения (X-XIII вв.). М.: УРСС. $136 \mathrm{c}$.

Мурашева В. В., 2008. Супрутский клад. Из раскопок 1969 г. М. 48 с. (Тр. ГИМ. Вып. 175).

Розанова Л.С., 1994. К вопросу о технологических приемах изготовления железных изделий из Старой Ладоги в докняжеский период // Новгородские чтения. Новгород. С. 175-179.

Седова М. В., 1997. Суздаль в X-XV веках. М.: Русский мир. 320 с.

Франклин С., Шепард Д., 2009. Начало Руси: 7501200. СПб.: Дмитрий Буланин. 670 с.

From Viking to Crusader (The Scandinavians and Europe 800-1200). Exhibition catalogue. Uddevalla, $1992.429 \mathrm{p}$.

Graham-Campbell J., Kidd D., 1980.The Vikings. L.: British Museum. 200 p. 
А. В. Чернецов

Институт археологии РАН, г. Москва

\section{К изучению феодальной эмблематики и юридических знаков Владимиро-Суздальского княжества}

Известно, что феодализму более свойствен язык жеста, чем сказанного или письменного слова. Отвлеченные идеи власти, воинской доблести, владельческих прав настоятельно требовали материализации в ритуалах, символических объектах, образах, знаках. Соответственно, степень зрелости общества этой эпохи отражается в становлении связанной с подобными идеями символики. При этом речь идет и о символике, связанной с носителями верховной власти, государственности, так и о символике, связанной с владельческими и иными правами частных лиц. Как покажет дальнейшее изложение, эти две сферы тесно взаимосвязаны. Символика легко перетекает с одного иерархического уровня на другой, что вполне объяснимо структурой феодального общества, в котором крупные образования сосуществовали с более мелкими (удельными), с политическим могуществом высшего боярства.

Древнейшие символы, связанные с великокняжеской властью правителей рубежа X-XI вв., - это княжеские знаки (Рыбаков, 1940; Белеикий, 2000). О том, что они имели государственное значение, свидетельствует их наличие на монетах Владимира Святославича, Святополка Окаянного и Ярослава Мудрого. Так называемые лично-родовые знаки русских князей представляют собой условные символы, являющиеся юридическими, в первую очередь владельческими знаками. Во многих традициях подобные знаки использовались преимущественно для клеймения скота, прежде всего коней. Действительно, в Краткой Правде упоминается клейменый конь, причем именно княжеский («княжь конь иже той с пятном»; Правда Русская, 1940. С. 72). Очевидно, речь идет о клеймении знаками, близкими по начертанию к встречающимся на монетах. Клейма, использовавшиеся для таврения животных, носят в письменных источниках названия «пятнъ» и «знамя». В дальнейшем кня- жеские знаки изменчивых очертаний встречаются в Северо-Восточной Руси на объектах домонгольского времени (печатях, перстнях, строительных материалах, оружии и т.п.). Сравнительные материалы, в частности позднейшие восточнославянские, свидетельствуют о том, что юридические знаки издавна широко использовались не только князьями, но и представителями других слоев населения (Чернецов, 2017).

Если связь значительной подборки княжеских знаков с державной символикой и обоснованием владельческих прав очевидна, то попытки связать с государственной и феодальной символикой часть древнерусских зооморфных изображений не всегда достаточно обоснованы. Если речь идет, например, о множестве звериных мотивов на стенах соборов Владимиро-Суздальского княжества, то вопрос о том, отражают ли они светскую феодальную идеологию или так или иначе связаны с религиозным назначением украшенных ими храмов, во многих случаях остается спорным.

Многочисленные и разнообразные монетные типы XIV-XV вв., несомненно, были призваны отражать представления о власти русских князей и городских властей, от лица которых осуществлялась чеканка монеты, и об их праве чеканить монету (монетной регалии; Chernetsov, 1983). Вместе с тем на монетах отдельных княжеств практически не встречаются специфические мотивы, которые можно было бы рассматривать как герб того или иного города (княжества).

О том, что образы хищников и чудовищ могли связываться с идеей власти и воинской доблести, свидетельствует ряд памятников древнерусской письменности, в частности, «Моление Даниила Заточника» и Ипатьевская летопись. Они могли использоваться в качестве государственных и владельческих символов, что отчетливо отражено в тексте «Повести о Вавилоне граде», связанной 

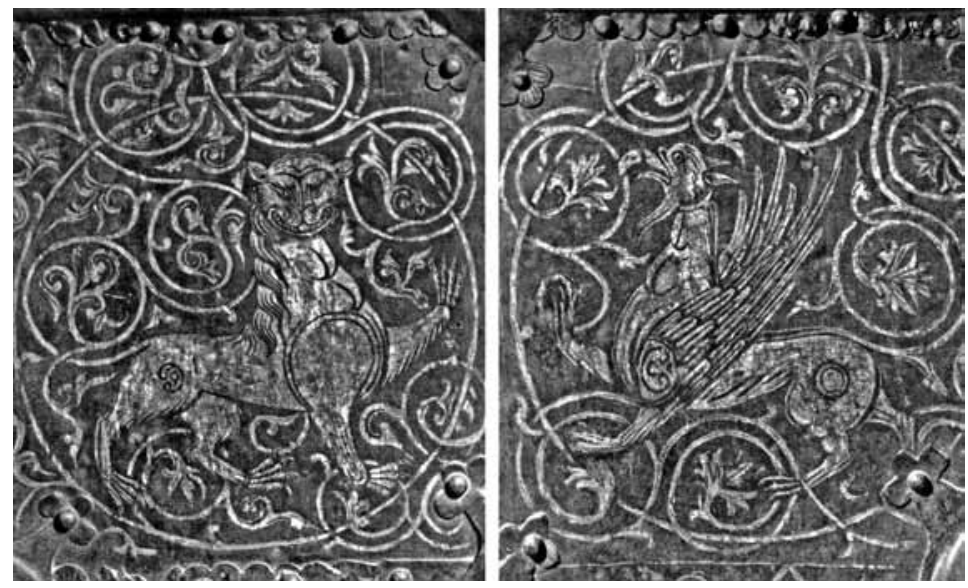

Рис. 1. Лев и грифон на правой створке южных золоченых дверей собора Рождества Богородицы в Суздале (по: Овчинников, 1978)

с начальным этапом формирования идеологии Русского централизованного государства. «И повеле Навходоносор царь во всем Вавилоне граде знамя учинити на платье, и на оружии, и на конях, и на уздах, и на седлах, (при повторном перечислении подобных объектов добавлено «и [на] всякой воинской зъбруе») и на хоромах, и на всяком бревне, и на дверех, и на окошках, и на судах (сосудах), и на ставцах, и на блюдах, и на лошках, и на всяких судах, и на всяком скоту знамя свое все змии» (Хрестоматия... 1947. С. 220-222). Очень любопытно перечисление объектов, на которые нужно было наносить изображение змея-дракона. Существенно, что в этот список входит скот, в частности кони. Упомянуты и части построек, среди них двери зданий. Очевидно, что изображения змея в данном тексте воплощают идею государственной, царской власти. Характерно использование термина «знамя», известного со времен Русской Правды для обозначения юридических знаков. В той же «Повести...» говорится, что Навуходоносор повелел, кроме того, «урядити и по полком знамена львовы». То есть, согласно тексту «Повести...», наряду с образом фантастического змеядракона государственная и воинская эмблематика включала и образ льва - царя зверей.

Существует ряд научных публикаций, в которых обосновывается существование зооморфных феодальных эмблем в домонгольское время, в частности, во Владимиро-Суздальском княжестве. Речь идет прежде всего об образах льва и грифона, символике которых посвящены специальные исследования (Некрасов, 1928; Вагнер, 1962). Сама возможность использования образов зверей и чудовищ в светской феодальной символике сомнений не вызывает. Однако по отноше- нию к их изображениям на стенах христианских храмов необходима достаточная информация, свидетельствующая, что эти изображения по своему содержанию были связаны со светской, а не религиозной символикой.

Попытки удревнения русской геральдики не могут быть признаны достаточно обоснованными, если понимать термин «геральдика» в соответствии с западноевропейскими стандартами. Последние имеют в основе так называемую геральдику щита и включают устойчивость геральдических изображений, присвоенных тому или иному знатному роду, городу, территориальному образованию. В допетровской России прослеживаются только зачаточные формы подобной геральдической традиции.

В этой статье рассматриваются домонгольские изображения реальных и фантастических животных владимиро-суздальского происхождения, непосредственно связанные с символикой юридических знаков. Это представленные на южных золоченых дверях собора Рождества Богородицы в Суздале (так называемые Суздальские златые врата; Овчинников, 1978) изображения львов и грифонов.

Двери западного и южного порталов собора украшены в технике огненного золочения. Каждая створка церковных дверей состоит из двух рядов прямоугольных пластин, на большинстве из которых помещены священные изображения. На западных дверях это в основном композиции, связанные с наиболее почитаемыми, так называемыми двунадесятыми праздниками; на южных - сцены, связанные с культом архангела Михаила. Самые нижние пластины ввиду того, что их могли касаться ноги верующих, не могли быть украшены священ- 
ными изображениями. Здесь на каждой створке обеих дверей представлена пара зооморфных образов - лев и грифон. Из четырех зооморфных пар на дверях двух порталов храма внимание привлекает одна, помещенная на правой створке южных дверей (рис. 1; Овчинников, 1978. Илл. 129, 130).

Особенностью этой пары зооморфных образов является наличие на крупах обоих животных вписанных в круг декоративных мотивов, несомненно, представляющих собой подобие клейм, использовавшихся для таврения домашнего скота. На крупе льва это растительный мотив (разновидность трилистника или пальметки), на крупе грифона - сплошной золоченый диск, ограниченный черной круговой полоской, вписанной во внешнее золотое кольцо. Клеймо на крупе грифона представлено на черном фоне, выделяющем его на фоне позолоченного бедра грифона. Рассматриваемые детали нельзя считать чисто орнаментальными. Они, несомненно, сознательно размещены на тех местах, где располагались клейма на домашних животных. Вместе с тем эти изображения клейм никак не могут трактоваться как отражение реальности. О клеймении хищников в средневековых зверинцах ничего не известно; едва ли необходимо указывать на то, что клеймение грифонов не могло осуществляться в действительности.

Таким образом, перед нами использование формы клеймения домашних животных юридическими знаками не по основному назначению. При этом наличие подобного мотива в данном случае ясно указывает на то, что рассматриваемые знаки имели значение маркировки.

Вопрос осложняется тем, что эти клейма нанесены на изображения существ, которые сами могут рассматриваться как мотивы феодальной и государственной символики. Ранее отмечалось, что в «Повести о Вавилоне граде» подобные изображения могли фигурировать под названием «знамя», использовавшимся для владельческих знаков. Образ льва, безусловно, мог играть роль в феодальной эмблематике, выступая в роли некоего предшественника герба. На это указывает, в частности, изображение льва на щите св. Георгия над главным порталом Георгиевского собора в Юрьеве Польском (Вагнер, 1964. Табл. I). Это - один из немногочисленных отзвуков знакомства с западноевропейской геральдикой (так называемой геральдикой щита) в древнерусском изобразительном материале домонгольского времени.

Связь образа грифона с идеей монархической, княжеской власти также неоспорима. Об этом недвусмысленно свидетельствуют изобра- жения грифонов, попирающих травоядных, по сторонам изображения царя Давида на стенах Дмитриевского собора во Владимире (Алпатов, 1955. C. 80,81$)$, а также фигуры грифонов, которые запряжены в колесницу Александра Македонского в композициях, изображающих его полет/вознесение, символизирующих триумф монархической власти (Чернецов, 2008).

Конечно, изображения как львов, так и грифонов могли наделяться и иным, в частности религиозным, содержанием. Однако повторяющиеся парные мотивы львов и грифонов в нижней, периферийной части церковных дверей скорее можно рассматривать как своеобразный автограф высокопоставленных заказчиков, представителей княжеского рода. Наличие на крупах двух из них мотива, вызывающего однозначную ассоциацию с владельческими знаками, свидетельствует в пользу подобного светского, феодального истолкования этих зооморфных изображений.

Поскольку образы реальных и фантастических зверей (в частности, львов и грифонов) могли носить характер государственных и/или владельческих символов, наличие на их изображениях клейм представляет собой некое удвоение подобной символики (своеобразное контрмаркирование, контрасигнатура). Подобное явление достаточно широко известно в нумизматике - практика нанесения надчеканок. Оно отражает достаточно сложные, изощренные правовые взаимоотношения. Еще один пример неоднозначной ситуации с использованием юридических знаков фигурирует в Ипатьевской летописи под 1170 г. Речь идет о попытке незаконного клеймения чужих коней. «Покрале кони Мстиславли у стаде и пятны свое въсклале рознаменовываюче» (ПСРЛ, 1962. Т. II. С. 541). Слово «рознаменовываюче» указывает на замену клейм законного владельца иными. Тот же глагол фигурирует в Русской Правде по отношению к бортным знаменам («аже разнаменаеть борть»; Правда Русская, 1940. С. 112). По-видимому, аналогичное преступление упоминается в Краткой Правде как «перетес» (Правда Русская, 1940. С. 72). Подобное правонарушение фигурирует и в позднейшем судебнике 1550 г. («кто... грань ссечет»; Судебники... 1952. С. 140, 172. Ст. 87). В средневековой японской «Повести о доме Тайра» при описании событий последней четверти XII в. упоминаются случаи злонамеренного клеймения чужих боевых коней (Повесть... 1982. С. 197, 201). Любопытно, что рассматриваемые юридические казусы также находят параллель в нумизматике - случаи перечеканки. 
Приняв допущение, что изображения львов и грифонов являются символами власти вкладчиков, представителей правящей княжеской династии, мы встаем перед вопросом, могут ли они при этом рассматриваться и как юридические, владельческие символы. Ведь двери храма, очевидно, находились в собственности церкви и духовенства. Однако в условиях средневекового общества права собственности и распоряжения имуществом, в частности храмовым, могли быть ограничены. Знаменитые кратеры из ризницы новгородского Софийского собора, несомненно, являлись вкладными, принадлежали церкви (Рыбаков, 1964. С. 23-25). Бесспорно, что они предназначены исключительно для церковного, литургического использования. Тем не менее кратеры украшены владельческими надписями (именно владельческими, без упоминания о вкладе). По-видимому, это свидетельство того, что вкладчики частично сохраняли свои права по распоряжению этими ценностями. Ограничение прав духовенства, храмов и монастырей по отношению к вкладному имуществу отражено в надписи на кресте Ефросинии Полоцкой, в которой содержится запрет выносить крест из храма и монастыря под угрозой проклятия (Рыбаков, 1964. С. 32, 33). Подобные ограничения вполне соответствуют правовому сознанию эпохи Средневековья, в котором преобладающей формой владения было условное держание, а не наследственная неограниченная частная собственность.

Обращаясь к клеймам на крупах льва и грифона, необходимо учитывать, что они никак не могут совпадать по своему назначению с клеймами домашних животных. Подчеркнуто скромное, малозаметное место, которое они занимают, указывает на то, что эта маркировка связана с людьми, занимавшими не первостепенное место в социальной иерархии, очевидно, подчиненное по отношению к тем, кого могли символизировать львы и грифоны. Очевидно, перед нами своеобразные подписи мастеров, работавших над украшением драгоценных дверей. Нет достаточных оснований судить о том, носили ли эти знаки характер личной подписи или являлись знаком принадлежности к мастерской, артели.

Отметим, что в надписях на таких известных памятниках, как новгородские кратеры и крест Ефросинии Полоцкой, указаны как имена заказчиков/вкладчиков, так и единичных мастеров. На так называемых Корсунских (Сигтунских) дверях новгородской Софии, изготовленных в Магдебурге в XII в., имеются изображения заказчиков, представителей духовенства и наряду с ними двух немецких мастеров - Риквина и Вайсмута. При ремонте дверей в XV в. в декоре дверей появилось добавление - фигура русского мастера Аврама (Даркевич, 2010. С. 30). Эти и другие примеры показывают, что представления об анонимности средневекового искусства не полностью соответствуют действительности, поскольку можно отметить яркие примеры исключений из этого правила.

Клейма на крупах изображений животных, наделявшихся эмблематическим значением, можно было бы попытаться связать не с ремесленниками, а с заказчиками. В таком случае следовало ожидать появления на них княжеских знаков известных типов (очевидно, именно такими знаками клеймили княжих коней «с пятном», упоминаемых в Русской Правде). Ничего подобного на рассматриваемых клеймах мы не видим. В одном случае (на крупе льва) изображен орнаментальный мотив, образчик художественной манеры мастера, являющийся как бы его подписью. Во втором случае (на крупе грифона) клеймо отмечено предельной условностью, оно представляет собой позолоченный круг. Можно полагать, что таким образом изображен знак одного из ремесленников, поскольку среди традиционных юридических знаков в любой традиции можно найти большое число знаков самых простых очертаний. Возможно и другое объяснение особенностей этого клейма. Можно допустить, что, соскребая черный лак с места для изображения клейма, мастер расчистил его с запасом, предполагая в дальнейшем нанести лаком дополнительные штрихи, соответствующие начертанию рисунка тамгообразного или иного знака, но эта работа осталась незавершенной. Признаки использования такой техники, в частности, не получившие окончательной отделки позолоченные участки (например, недоработанные надписи), встречаются на древнерусских золоченых дверях (см.: Чернецов, 1992. С. 24).

Вопрос об истолковании рассматриваемых деталей декора золоченых дверей не может быть решен в отрыве от более общего вопроса о смысловом значении всей совокупности изображений. Очевидно, львы и грифоны, помещенные на самых нижних пластинах, играют подчиненную роль в ряду изображений, на которых преобладают священные композиции и отдельные образы святых. Можно было бы предположить, что изображения львов и грифонов не были наделены сколько-нибудь значительным смысловым содержанием. В таком случае и представленные на их крупах мотивы должны рассматриваться как чисто декоративные. Некоторые особенности рассматриваемых образов действительно наводят на мысль 
об их декоративном характере. Звери вписаны в плетения растительного орнамента, более того, их хвосты непосредственно переходят в процветшие растительные побеги.

Орнаментализации подвергаются не только хвосты изображенных существ, но и отдельные участки их тел. У грифона с клеймом на крупе на правой створке южных дверей имеется орнаментальный (растительный) мотив у основания крыла (на его плечевом отделе; Овчинников, 1978. Илл. 130). Орнаментальные мотивы на этой части крыльев птиц и фантастических существ в древнерусском искусстве встречаются довольно часто. На крыле рассматриваемого грифона с клеймом на крупе представлен тот же самый мотив, как и на клейме у парного по отношению к нему изображения льва (пальметка, украшающая крыло грифона, несколько крупнее, имеет более развитую форму). Скорее всего, мастер повторяет излюбленный мотив-автограф. Сходным образом трактованы крылья еще двух грифонов в нижней части западных дверей (Овчинников, 1978. Илл. 56, 58).

Второй грифон на левой створке южных дверей изображен с крылом, лишенным растительных мотивов, оно полностью покрыто оперением. Однако орнаментальный мотив присутствует и на этом изображении. Здесь он представлен в виде декоративного бордюра на шее грифона, вдоль хребта (там, где у грифонов иногда изображали гриву; Oвчинников, 1978. Илл. 128). Орнаментальный мотив в данном случае не растительный, а геометрический. Его основу составляют ряды заштрихованных треугольников. Можно полагать, что этот мотив, помещенный на необычном месте, представляет собой автограф другого мастера, принимавшего участие в работе. Характерно, что в стилистическом плане мотив пальметки на правой створке и геометрический орнамент угловатых очертаний резко контрастируют между собой. Скорее всего, мастера сознательно обращались к разнотипным мотивам для обозначения своего авторства.

Орнаментальные мотивы, украшающие части тела зооморфных образов, могли отражать подобные представления, но могли быть и чисто декоративными элементами. Но что касается мотивов, вписанных в круги и помещенных на крупе, то здесь ассоциация с клеймами, владельческими знаками, возникает сама собой и, несомненно, должна была возникать в сознании средневекового зрителя.

Лев и грифон на левой створке южных дверей не имеют отчетливо трактованных изображений клейм на крупах (Овчинников, 1978. Илл. 127, 128). На бедре грифона видны два дугообразных мотива, которые можно попытаться трактовать как клеймо примитивных очертаний. Но эта деталь может быть понята и как условное изображение мускулатуры. Рассматриваемые мотивы смещены по отношению к нормальному расположению клейма на крупе животного книзу. На крупе льва имеется еще менее выразительный дугообразный мотив. На крупах львов и грифонов, представленных в нижней части главных, западных дверей собора, нет никаких мотивов, сходных с клеймами (Овчинников, 1978. Илл. 55-58). Их крупы разделаны орнаментализированными штрихами, включающими завитки. Растительный мотив, помещенный на крыльях грифонов и на этих дверях, охарактеризован выше.

Возвратимся к иерархической позиции рассматриваемых мотивов в контексте декора дверей храма. Все изображения зооморфных мотивов занимают нижнее, наименее почетное положение в контексте общей иконографической программы. Иерархическое превосходство композиций из основного фонда христианской иконографии продемонстрировано предельно наглядно. Из двух церковных дверей парадными являются западные, расположенные напротив алтаря и украшенные наиболее почитаемыми композициями (преимущественно из цикла двунадесятых праздников). В нижней части этих дверей представлена только феодальная эмблематика (зооморфные мотивы). Южные двери собора имели менее важное значение; они украшены особым, сравнительно редким набором священных композиций. Именно на них, причем только на одной створке на крупах эмблематических животных изображены клейма, очевидно связанные с индивидуальными мастерами или отдельной мастерской. Вероятно, мастера в соответствии с христианской заповедью смирения специально выбрали наиболее скромное место для размещения маркировок, удостоверяющих их авторство.

Насколько известно автору, изображения клейменого скота, в частности коней, не были широко распространены в древнерусском искусстве. Вместе с тем нельзя сказать, что изображения таких клейм в нем не встречаются. Автор не берется уверенно сказать, сколько таких изображений можно отыскать. Во всяком случае, их довольно много на изображениях Александра Македонского XVI-XVIII вв. Дело в том, что многие древнерусские книжники понимали имя коня Букефал («с головой быка») как «с клеймом в виде головы быка [на крупе]», так его и изображали. Серия подобных изображений включена в Лицевой летописный свод Ивана Грозного (70-е гг. XVIв.). 

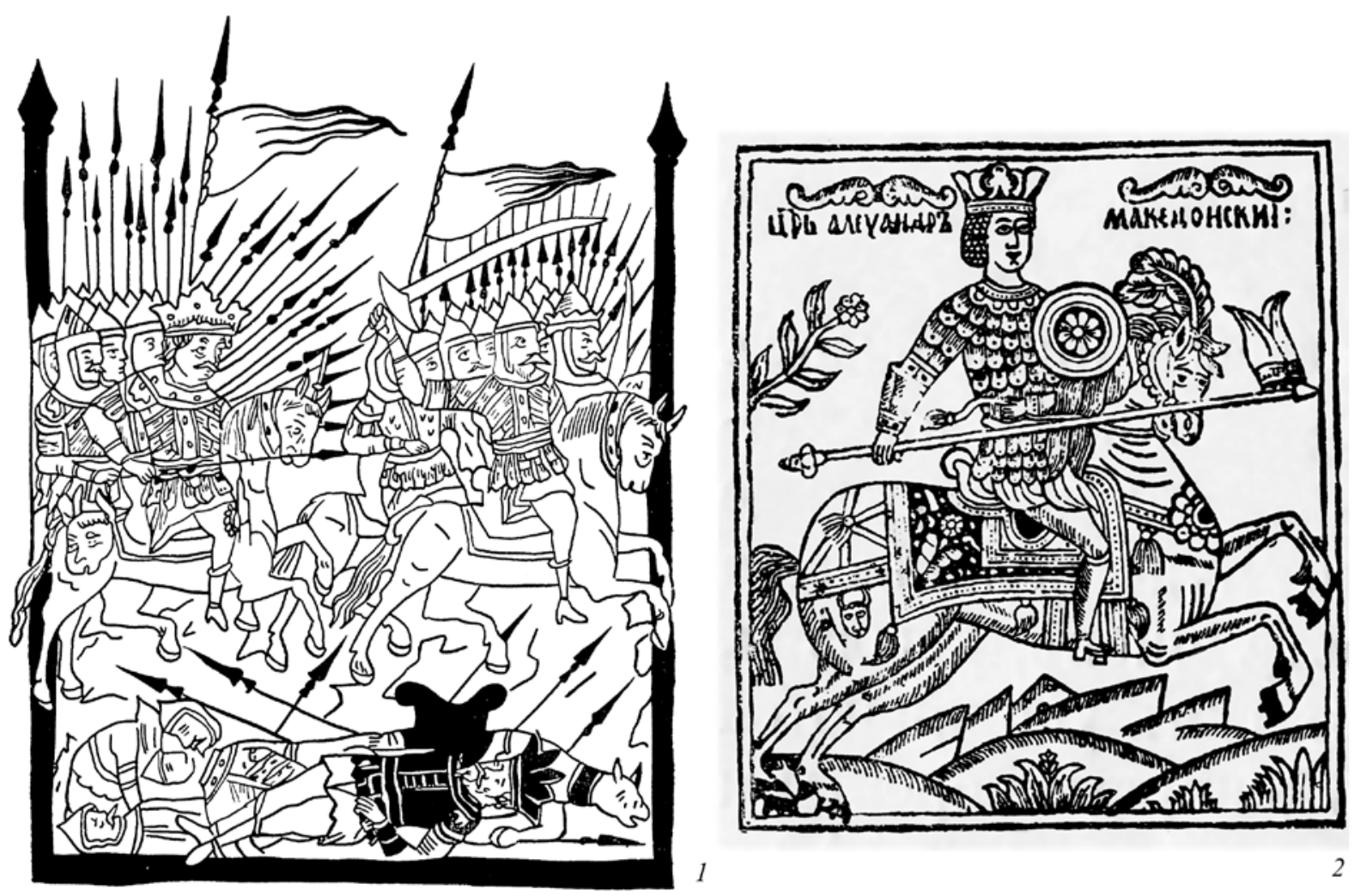

Рис. 2. Изображения Александра Македонского на коне с тавром на крупе 1 - миниатюра XVII в. (по: Хрестоматия... 1947); 2 - лубок XVIII в. (по: Ровинский, 1900)

В Хронографическом томе РНБ (17.17.9) насчитывается 327 миниатюр, посвященных легендарной истории Александра (Амосов, 1998. С. 279). Клейменые кони македонского завоевателя известны и на миниатюрах XVII в. (рис. 2, 1), а также на лубочных картинках XVIII в. (рис. 2, 2; Ровинский, 1900. Стб. 131, рис. 141; Стб. 292, 293, табл. XV).

Наконец, в 2005 г. на Новгородском городище в перемешанном слое был обнаружен фрагмент каменной иконки XII-XIII вв. с изображением святого всадника (рис. 3; Мусин, 2007). На груди коня в круге клеймо со знаком, соответствующим одной из разновидностей лично-родового княжеского знака. Возникают трудноразрешимые вопросы: почему клеймо расположено на плече, а не на крупе коня? Что обозначает княжеский, владельческий знак на коне, принадлежавшем святому воину? На второй вопрос можно предположительно ответить, что, вероятно, был изображен святой, тезоименный князю и в силу этого ассоциировавшийся с последним. Во всяком случае, эта находка указывает на то, что изобразительный мотив коня с клеймом был известен в домонгольской Руси, и на то, что одной из сфер применения княжеских знаков Рюриковичей было клеймение боевых коней.
Предложенные соображения не дают оснований для однозначных выводов. Рассмотренные материалы показывают, что наряду с бесспорными символами власти и юридическими знаками, обозначавшими владельческие права, существует примыкающая к ним группа знаков и изображений, обнаруживающая с ними несомненную близость. Клейма на теле домашних животных могли иметь своих «двойников» в изобразительном искусстве, наделявшихся другим смыслом, не использовавшихся для таврения животных и не имевших отношения к владельческим правам. Знаки, связанные с правом собственности или представляющие собой меты мастеров, могли иметь вид орнаментальных мотивов. При этом не всегда есть возможность отличить юридические знаки от чисто декоративных элементов.

Таким образом, границы явления, условно определяемого как юридические знаки, оказываются расплывчатыми. Это обстоятельство хорошо известно и фиксируется в самых разных традициях. Среди юридических знаков встречаются орнаментальные мотивы, пиктограммы и изобразительные элементы, буквы и буквообразные знаки, монограммы (см., напр.: Чернецов, 2017. С. 229, 233; Humphrey, 2010. Р. 292, 293; Нямаa, 2005. 
С. 76-83 и др.). Сходство элементов кавказской орнаментики и ряда родовых тамг из того же региона рассмотрены в специальных публикациях (Пожидаев, 1948; Perrin, 2010. P. 47, fig. 12). Основные мотивы декора туркменских ковров и даже детали их орнаментальной каймы, как известно, содержат информацию о племенной и родовой принадлежности изготовивших их мастериц (Мошкова, 1946; Царева, 2013). Изучение элементов орнаментики и традиционных юридических знаков свидетельствует об их тесной взаимосвязи. При этом один и тот же мотив мог как наделяться конкретным юридическим смыслом, так и полностью его утрачивать. Сходный феномен имеет место во взаимных отношениях амулетов и украшений (Райан, 2006. С. 310). Действительно, амулеты могут легко превращаться в утратившие свое первоначальное значение украшения и, наоборот, наделяться сакральным и магическим значением и утрачивать его. Данное обстоятельство указывает на известную расплывчатость понятия «юридические зна-

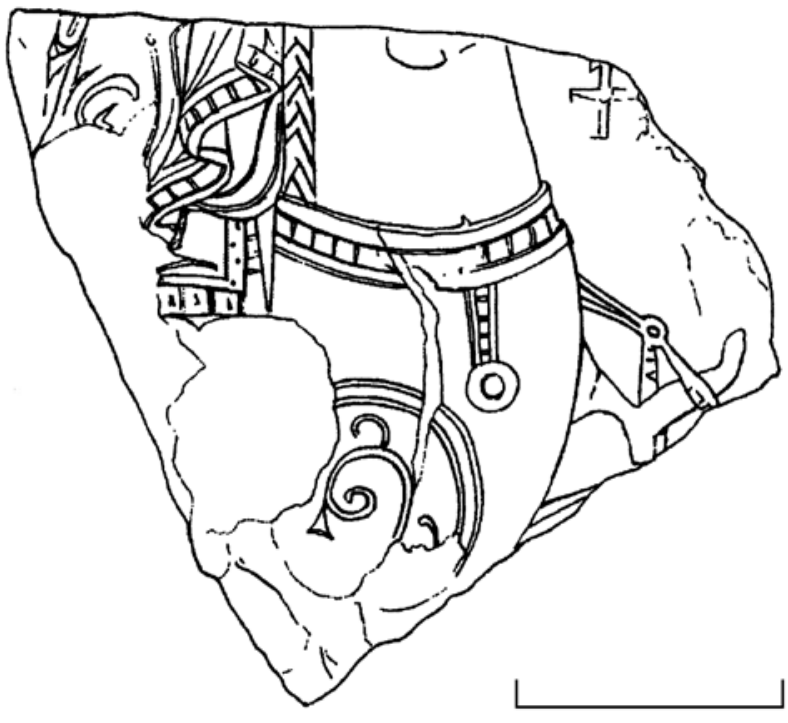

Рис. 3. Фрагмент каменной иконки XII-XIII вв. с Рюрикова городища с изображением конного святого воина. Клеймо на плече животного включает личнородовой княжеский знак (по: Мусин, 2007)

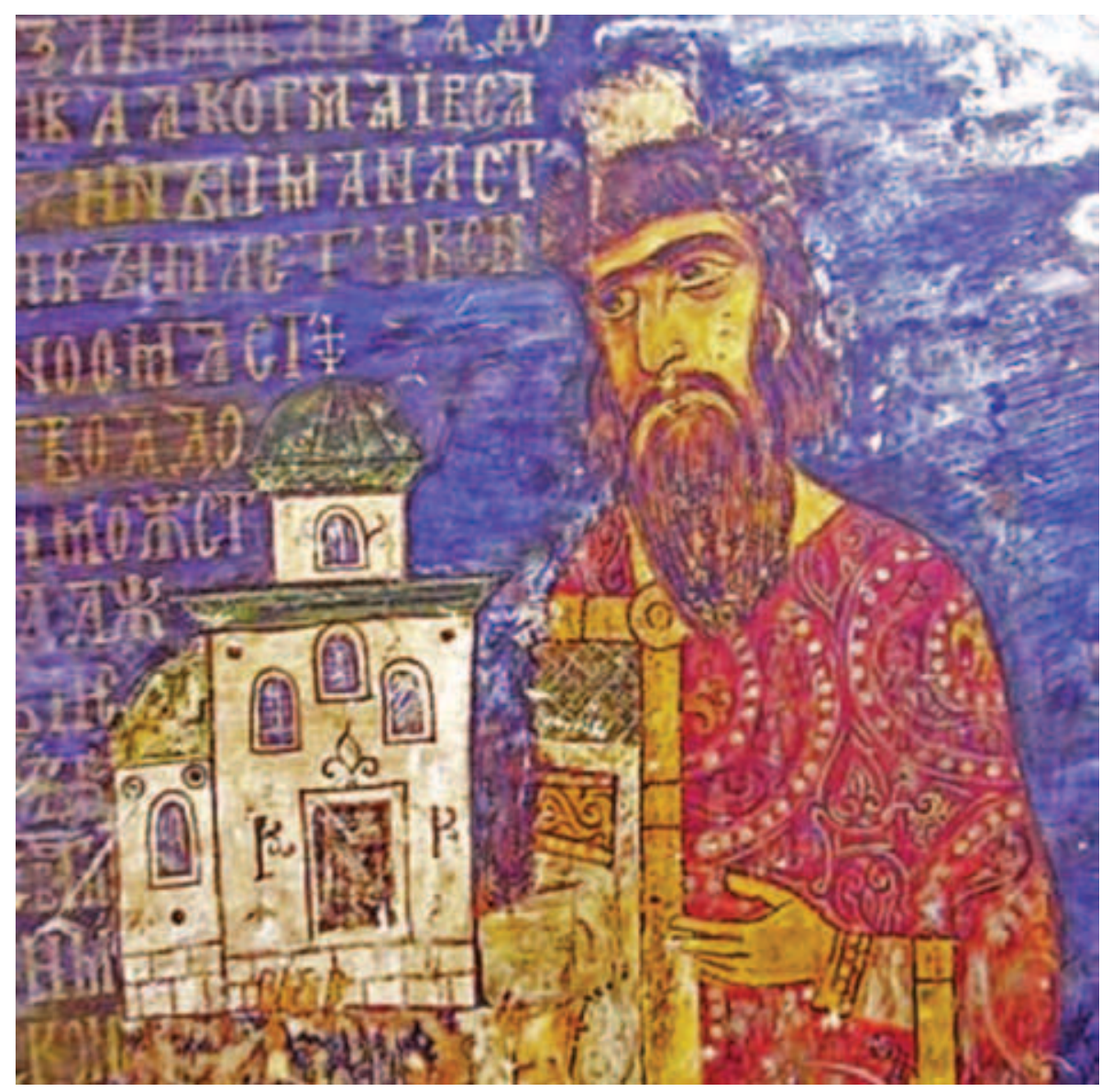

Рис. 4. Ктиторская фреска собора Спаса Нередицы. На модели храма в руках князя-донатора по сторонам портала видны княжеские знаки в виде багра (копия Л. А. Дурново; по: Щербатова-Шевякова, 2004) 
ки» и заставляет осторожно относиться к статистическому подходу к их исследованию.

Рассмотренный материал представляет интерес для изучения двух важных научных вопросов. Один из них связан с преодолением представлений о средневековом искусстве как безличном. Постепенно расширяется число подписных памятников художественного ремесла. К ним примыкают безымянные произведения, которые можно связать с одним мастером на основании идентификации почерков имеющихся на них надписей (Медынцеева, 2011), вещи, происходя- щие из разных комплексов, но отмеченные признаками тождественной художественной манеры трактовки отдельных элементов (Чернецов, 2014. С. 72-77). Второй вопрос связан с возможностями пополнения фонда юридических знаков за счет отдельных, на первый взгляд чисто декоративных элементов, включавшихся в состав сюжетных и орнаментальных композиций. Здесь уместно напомнить о выявленных А. В. Кузой (Куза, 1966; Щербатова-Шевякова, 2004. С. 229, рис. 238) княжеских знаках на ктиторской фреске Нередицкого храма (рис. 4).

\section{Литература}

Алпатов М. В., 1955. Всеобщая теория искусства. T. III: Русское искусство с древнейших времен до начала XVIII в. М.: Искусство. 416 с.

Амосов А. А., 1998. Лицевой летописный свод Ивана Грозного: комплексное кодикологическое исследование. М.: Эдиториал УРСС. 392 с.

Белеикий С. В., 2000. Знаки Рюриковичей. Часть 1. $\mathrm{X}-\mathrm{XI}$ вв. Уч. пособ. // Исследования и музеефикация древностей Северо-Запада. СПб. Вып. 2. $120 \mathrm{c}$.

Вагнер Г.К., 1962. Грифон во Владимиро-Суздальской фасадной скульптуре // СА. 1962, № 3. C. 78-90.

Вагнер Г.К., 1964. Скульптура Владимиро-Суздальской Руси. Юрьев Польской. М.: Наука. $184 \mathrm{c.}$

Даркевич В.П., 2010. Художественное ремесло средневекового Запада (X-XIV вв.). М.: КРАСАНД. 112 с.

Куза А. В., 1966. Родовой знак Всеволода III Большое Гнездо // Культура Древней Руси. М.: Наука. С. 97-100.

Медыниеева А. А., 1991. Подписные шедевры древнерусского ремесла: очерки эпиграфики XIXIII вв. М.: Наука. 240 с.

Мошкова В.Г., 1946. Племенные «гӧли» в туркменских коврах // СЭ. 1946, № 1. С. 145-162.

Мусин А.E., 2007. Каменная иконка с образом святого всадника из находок на Новгородском (Рюриковом) городище: вопросы интерпретации // У истоков русской государственности. Историко-археолог. Сб.: Матер. междунар. науч. конф. 4-7 октября 2005 г. Великий Новгород. СПб.: Дмитрий Буланин. С. 148-165.

Некрасов А.И., 1928. О гербе суздальских князей // Сб. статей в честь А. И. Соболевского. Л., 1928. С. 406-409.
Нямаа Б., 2005. Монголын эзэнт гүрний зоосон мөнгө ба хаадын овгийн тамга (XIII-XIV зуун). Улаанбаатар: Монгол улс. 254 с. (Nyamaa B., 2005. The Coins of Mongol Empire and Clan Tamgha of Khans (13-14 cent) Ulaanbaatar).

Овчинников А.Н., 1978. Суздальские златые врата. М.: Искусство. 36 с., илл.

Пожидаев В.П., 1948. Кабардино-черкесская тамга и кавказский орнамент // Ученые записки Кабардинского НИИ. Нальчик. № 4. С. 239-265.

Правда Русская. Т. І. М.-Л.: Изд-во АН СССР, $1940.506 \mathrm{c}$.

Повесть о доме Тайра / Пер. И. Львовой. М.: Художественная литература, 1982. 703 с.

ПСРЛ. Т. ІІ. Ипатьевская летопись. М.: Изд-во восточной литературы, 1962. 938 стб.

Райан В.Ф., 2006 Баня в полночь. Исторический обзор магии и гаданий в России / Отв. ред. тома А.В. Чернецов. М.: Новое литературное обозрение. 720 с. (Cep. Historia Rossica.)

Ровинский Д. А., 1900. Русские народные картинки. СПб.: Изд. Р. Голике. Т. I, II. 520 стб.

Рыбаков Б.А., 1940. Знаки собственности в княжеском хозяйстве Киевской Руси // СА. T. VI. C. 227-257.

Рыбаков Б.А., 1964. Русские датированные надписи XI-XIV вв. М.: Наука. 34 с., илл.

Судебники XV-XVI веков. М.-Л.: Изд-во АН CCCP, 1952. 618 c.

Хрестоматия по древней русской литературе XI-XVII веков / Сост. Н.К. Гудзий. М.: Учпедгиз, 1947. 504 с.

Царева Е.Г., 2013. Ковер как источник: к истории формирования художественного облика и структурных особенностей туркменских ковров XVI начала XX вв. // Вестник археологии, антропологии, этнографии. Тюмень. № 3. С. 165-174. 
Чернецьов А.В., 1992. Золоченые двери XVI в. (соборы Московского Кремля и Троицкий собор Ипатьевского монастыря в Костроме). М.: Наука. 216 с.

Чернецзов А. В., 2008. «Полет Александра Македонского»: новые материалы к иконографии // Московская Русь: проблемы археологии и истории архитектуры. М.: ИА РАН. С. 52-63.

Чернецов A.B., 2014. К характеристике иконографических и стилистических особенностей украшений из клада 2005 г.// Старая Рязань. Клад 2005 года / Отв. ред. А.В. Чернецов. СПб. - М.: Нестор-История. С. 69-79.

Чернецуов А.В., 2017. К изучению древнерусских знаков собственности // Tp. V (XXI) BAC в Барнауле - Белокурихе. Сб. науч. ст. В 3-х тт. / Отв. ред. А.П. Деревянко, А.А. Тишкин. Барнаул: АлтГУ. Т. II. С. 228-234.
Щербатова-Шевякова. Т. С., 2004. Нередица. Монументальные росписи церкви Спаса на Нередице. М.: Галарт. 256 с.

Chernetsov A. V., 1983. Types of Russian Coins of the Fourteenth and Fifteenth Centuries: An iconographic study. Oxford: B.A.R. 191 p. (BAR International series; 167.)

Humphrey C., 2010. Horse brands of the Mongolians. A System of Signs in a Nomadic Culture // Traditional Marking Systems: A Preliminary Survey / Ed. by J. Evans Pim, S. A. Yatsenko, O. T. Perrin. L. - Dover: Dunkling Books. P. 289-307.

Perrin O.T., 2010. Tamgas and Space: Territorial Mark and Mnemotechnik // Traditional Marking Systems: A Preliminary Survey / Ed. by J. Evans Pim, S.A. Yatsenko, O. T. Perrin. L. - Dover: Dunkling Books. P. 23-59. 
Н.И. Асташова

Государственный исторический музей, г. Москва

\section{Борисоглебские энколпионы в собрании Исторического музея}

Нагрудные кресты-энколпионы составляют одну из самых ярких и своеобразных групп древнерусской мелкой литой пластики. В последние десятилетия особенно возрос интерес к ним со стороны историков, археологов и искусствоведов ( шова, Петрова, Сарачева, 2013; Гнутова, 1993; Гнутова, Зотова, 2000; Корзухина, Пескова, 2003; Липатов и др., 2006; Пескова, 2006; Пуичко, 1993; Шемаханская, 2000; Шемаханская и др., 1996).

Практически одновременно, в конце XIX в., кресты-мощевики стали объектом пристального внимания собирателей как частных, так и музейных коллекций. Отдельные собрания этих предметов насчитывают несколько сотен экземпляров. К ним относится и коллекция реликвариев, хранящаяся в археологическом отделе ГИМ (около 200 экз.). Ее основу составляют кресты, несомненно, древнерусского происхождения, с округлыми концами и рельефными изображениями Распятия и Богородицы (Асташова, Сарачева, 2006). Наряду с ними в коллекции присутствуют кресты-энколпионы с образами святых князей-братьев, свидетельствующие о непростой истории сложения борисоглебской иконографии.

Культ первых русских святых князей Бориса и Глеба широко отражен в произведениях литературы и искусства Руси. Все исследователи энколпионов считают, что прототипами их иконографии служили изобразительные источники - живописные и мозаичные.

В богатом собрании ГИМ хранится 26 экземпляров борисоглебских энколпионов, представленных тремя иконографическими вариантами.

На ранних вариантах борисоглебских крестов XII в. располагаются рельефные изображения князей в рост, держащих модель храма. Князь Борис держит в правой руке модель одноглавого храма, у Глеба в левой руке модель пятикупольного храма (рис. 1, 1, 2). По мнению М. Х. Алешковского, в такой позе изображались фигуры предстоящих. Поэтому икона, послужившая образцом для наших крестов, имела трехчастную композицию: по сторонам центральной фигуры стоят предстоящие (Алешковский, 1972. С. 106). Сюжет трактуется исследователями как мотив святых покровителей христианства, опоры русской Церкви (см., напр.: рис. 2, А) (Смирнова, 2009. С. 119).

Размеры этих крестов - 5,5-7×4,5-4,9 см, они относятся к средним.

О распространении культа братьев-страстотерпцев свидетельствует появление во второй половине XII в. энколпионов небольшого размера с округло-приостренными концами. Размеры $3,8-4,7 \times 3,5$ см, поэтому они относятся к миниатюрным крестам.

На лицевой створке изображено Распятие с простым крестом в возглавии, на оборотной створке представлена фигура Глеба (рис. 1, 3). Один экземпляр происходит из раскопок погребения № 4 грунтового могильника, изученного у с. Пески Вологодской обл. (Ошибкина, 1972. С. 65-69). В погребении обнаружен достоверный комплекс находок с узкой датой: в его составе стеклянные бусы, две из которых желтого стекла эллипсоидной формы, третья относится к группе бус с пластическим декором раннего варианта. Согласно классификации Ю. Л. Щаповой, подобные бусы бытуют с первой трети до конца XII в. (Щапова, 1972. С. 91). Таким образом, начало производства этих энколпионов датируется второй половиной ХІІ столетия.

Изображение святого Глеба на энколпионах нового типа, распространенных на территории лесной полосы, свидетельствует о правоте М.X. Алешковского, предполагавшего преимущественное почитание Глеба в XII-XIII вв. (Алешковский, 1972. С. 111-113).

Возникающий в конце XII - начале XIII в. вариант иконографии святых князей Бориса и Глеба с крестом, символом мученичества, и мечом, воинской принадлежностью, получает свое воплощение на энколпионах следующего столетия. Это абсолютно новый 

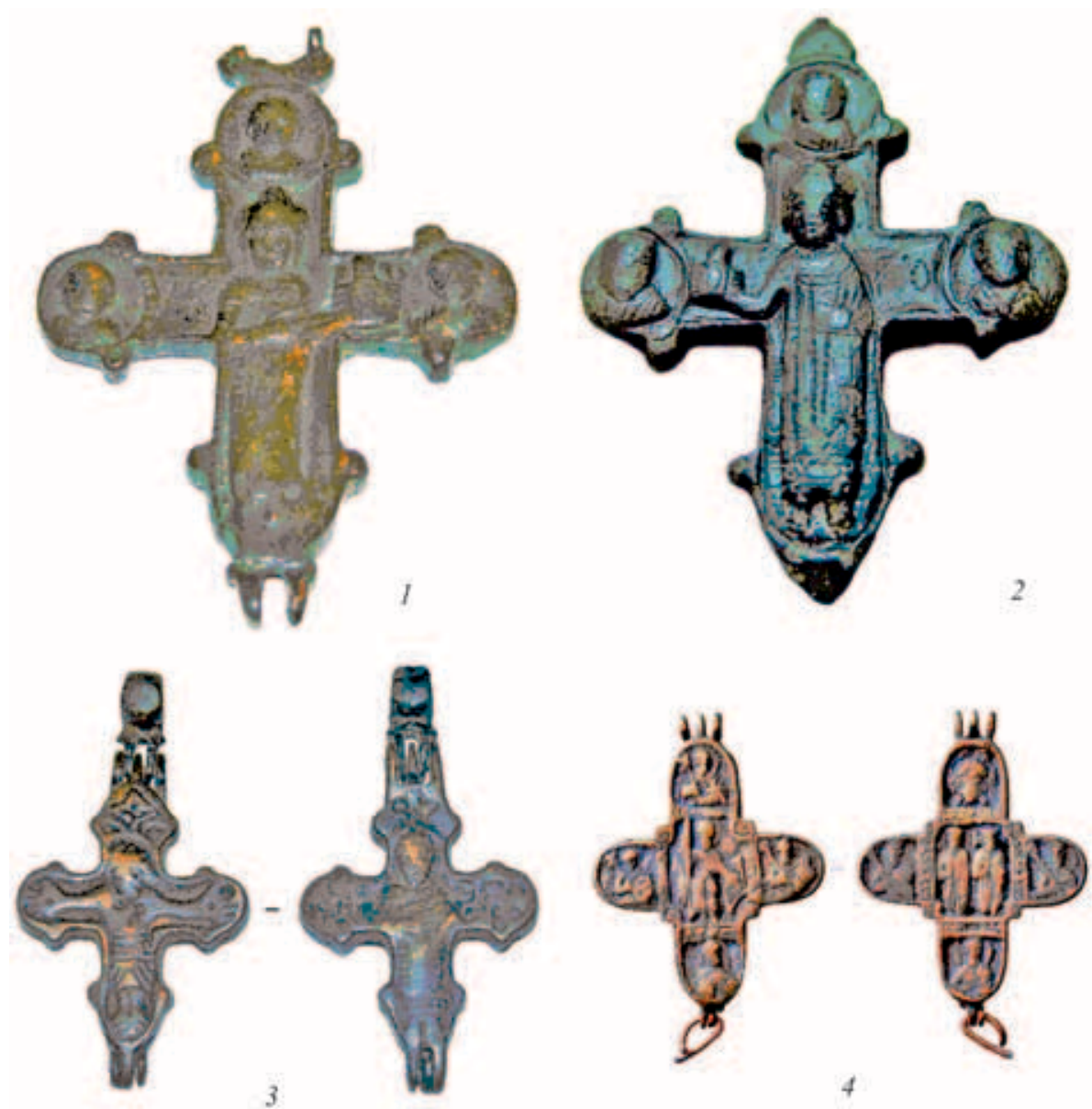

Рис. 1. Энколпионы с фигурами Глеба и Бориса

1, 2 - энколпионы с фигурами Глеба и Бориса. Сплав на основе меди; литье по оттиску готового изделия. XII в. Херсон. Раскопки 1890 г.; 3 - энколпион с изображением Распятия на лицевой стороне и фигурой кн. Глеба на оборотной. Оловянно-свинцовая бронза; литье по оттиску готового изделия. ХІІ в. Тверская обл.; 4 - энколпион с изображением св. Федора Стратилата на лицевой стороне и парные фигуры кн. Бориса и Глеба в рост с крестом и мечами. Оловянносвинцовая бронза; литье по оттиску готового изделия. XIV в. Местонахождение неизвестно

тип креста квадрифолийной формы с рельефными парными изображениями Бориса и Глеба на одной створке и Федора Стратилата на другой (размеры $7 \times 6$ см; рис. 1, 4). Центральные фигуры располагаются на выделенном прямыми углами средокрестии створок с округлыми концами. Форма квадрифолия существует в прикладном и монументальном искусстве в IX-XV вв. В XIV в. его варианты получают распространение среди наперсных крестов-мощевиков.

Святые Борис и Глеб держат крест в правой руке, а вертикально опущенный меч - в левой. Изображение воинов-мучеников креста - известное явление в искусстве художественной обработки металла XIV в. Фигуры князей заключены в рамку из литых столбчатых и строчных надписей с завитками; на концах ветвей представлены изображения архангелов Михаила и Гавриила, а также святителя Николая. Наверху - образ Спаса Нерукотворного в крестчатом нимбе.

Все энколпионы нашей коллекции выполнены литьем, в том числе и надписи в виде букв, иногда встречающиеся на таких крестах. Основной материал - свинцово-оловянистая бронза.

Таким образом, иконография святых братьев включает три варианта. Причем их датировки перекрещиваются: наряду с образами князей в рост с моделями храмов в руке существуют одновременно (XII в.) с изображением Бориса и Глеба с прямо стоящими мечами на полях иконы св. Николая Мирликийского из Новодевичьего монастыря (рис. 2, Б). Икона датируется рубежом XII-XIII вв. Это самое раннее из известных нам подобное изображение. Исследователи относят эту икону к новгородским произведениям. 

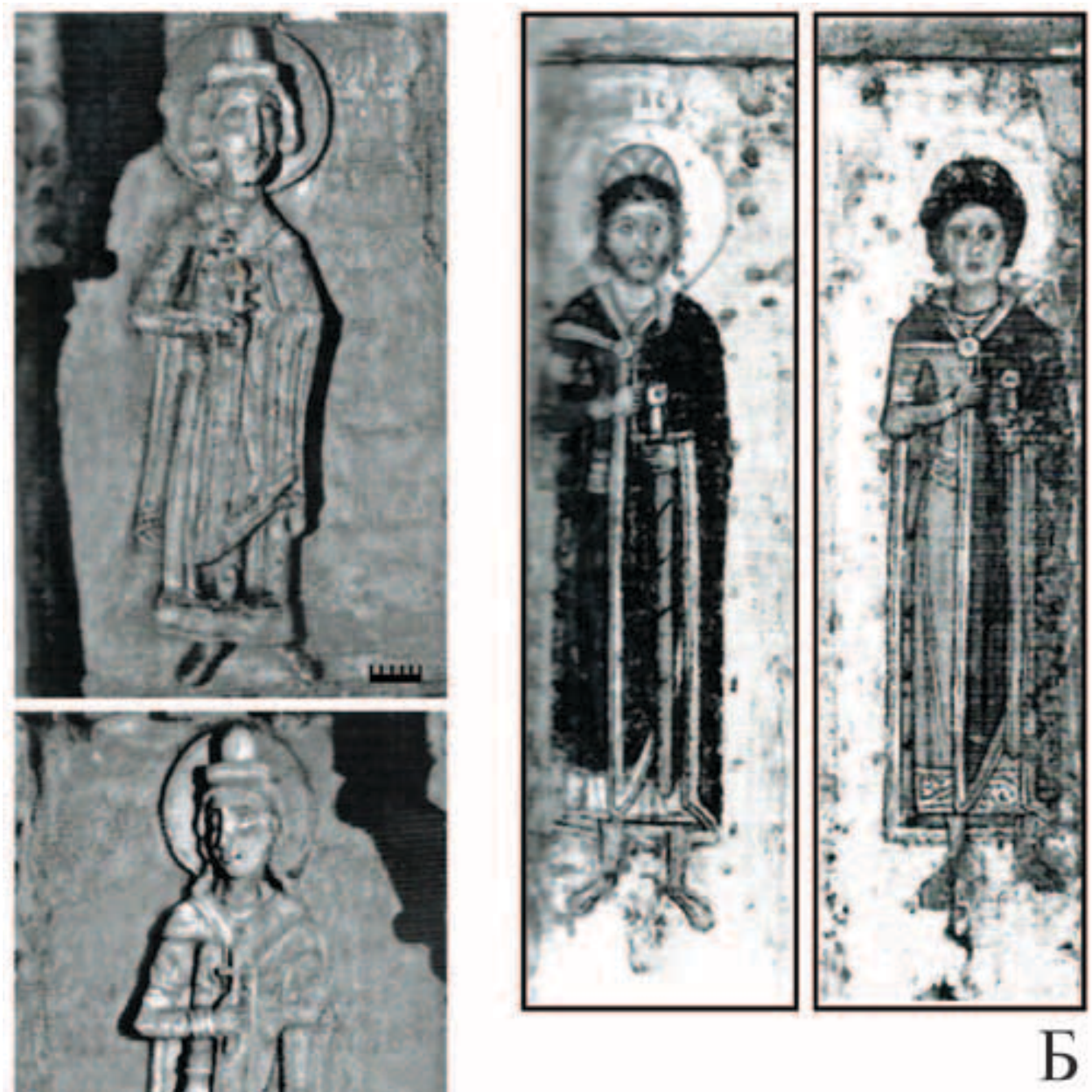

Рис. 2. Святые Борис и Глеб

А - детали колончатого фриза на северном фасаде Дмитровского собора во Владимире. 1190-е годы; Б - фигуры на полях иконы «Св. Николай Мирликийский». Кон. XII в.

К концу XII - началу XIII в. относится еще один вариант иконографии князей. Это находка пластины на Рюриковом городище, иконка из Копыси и каменные иконки из Солотчинского монастыря и Тамани и другие. Как на металлических, так и на каменных произведениях образы Бориса и Глеба представлены в рост с крестом в правой руке и мечами, висящими под углом, которые поддерживаются левой рукой. Отмечу только: на городищенской пластине фигуры князей расположены по сторонам креста (нижняя часть его не сохранилась), что сближает пластину с византийскими образцами (Spinei, 2011. P. 122).
То есть XII в. и начало XIII в. - это время, когда иконография князей-мучеников была совсем неустойчивой. При этом та небольшая часть энколпионов, что были обнаружены при раскопках, дают следующую картину: кресты первого варианта известны в Среднем Поднепровье и Новгороде, а малые кресты находят на территории лесной зоны. Создается впечатление, что разные иконографические варианты каким-то образом связаны с разными ветвями княжеского рода. И только в XIII в. начинает складываться новый тип иконографии, который в XIV в. становится постоянным. 


\section{Литература}

Алешковский М.X., 1972. Русские глебоборисовские энколпионы 1072-1150 годов // Древнерусское искусство. Художественная культура домонгольской Руси. М.: Наука. С. 104-125.

Асташова Н.И., Петрова Л.А., С Сарачева Т.Г., 2013. Кресты-энколпионы. Из собрания Государственного Исторического музея. М.: РИП-холдинг. $320 \mathrm{c.}$

Асташова Н.И., Сарачева Т.Г., 2006. Древнерусские рельефные энколпионы из собрания Государственного исторического музея // Славяно-русское ювелирное дело и его истоки. Тез. докл. Междун. науч. конф., посвященной 100 -летию со дня рождения Г.Ф. Корзухиной (Санкт-Петербург, 10-16 апреля 2006 г.). СПб.

Асташова Н.И., Сарачева Т. Г., 2010. Химико-технологическое изучение древнерусских рельефных энколпионов из археологического собрания Государственного Исторического музея // Славяно-русское ювелирное дело и его истоки. Матер. Межд. науч. конф., посвященной 100-летию со дня рождения Гали Федоровны Корзухиной (Санкт-Петербург, 10-16 апреля 2006 г.). СПб.: Нестор-История. С. 317-329.

Гнутова С. В., 1993. Медная мелкая пластика Древней Руси (типология и бытование) // Русское медное литье. Вып. 1. М.: Сол Систем. С. 7-20.

Гнутова С.В., Зотова Е.Я., 2000. Кресты, иконы, складни. Медное художественное литье XI - начала XX века. Из собрания Центрального музея древнерусской культуры и искусства имени Андрея Рублева. М.: Интербук-бизнес. 127 с.

Корзухина Г.Ф., Пескова А.А., 2003. Древнерусские энколпионы. Нагрудные кресты-реликварии XI-XIII вв. СПб.: Петербургское востоковедение. 432 с. (Тр. ИИМК РАН; т. 7).

Липатов А.А., Медникова Е.Ю., Мусин А.Е., Пескова A.A., 2006. Священные вложения древнерусских энколпионов в контексте литургической практики: возможности комплексного анализа // Христианская иконография Востока и Запада в памятниках материальной культуры Древней Руси и Византии: Памяти Т. Чуковой. СПб.: Петербургское востоковедение. C. 291-308. (Slavica Petropolitana).

Ошибкина C.B., 1972. Могильник Пески в Вологодской области // КСИА Вып. 129. С. 65-69.

Пескова А.А., 2006. Истоки иконографии древнерусских энколпионов // Христианская иконография Востока и Запада в памятниках материальной культуры Древней Руси и Византии: Памяти Т. Чуковой. СПб.: Петербургское востоковедение. С. 121-162.

Принцеева М.Н., 1983. Памятники мелкой меднолитой пластики в собрании Государственного музея истории религии и атеизма // Научно-атеистические исследования в музеях, использование культовых предметов в атеистических экспозициях. Л.: ГМИРИА. С. 35-49.

Пуцуко В.Г., 1993. О системном изучении русского художественного литья малых форм // Русское медное литье. Вып. 1. М.: Сол Систем. С. 21-33.

Смирнова Э. С., 2009. Ранние этапы иконографии святых князей Бориса и Глеба. Вопрос византийских образцов и сложения русской традиции // Борисо-Глебский сборник. Collectanea Borisiglebiana. Вып. 1. Paris: ACHCbyz. C. 57-116.

Шемаханская М.С., 2000. Результаты химико-технологического анализа комплекса меднолитых энколпионов и крестов могильника в урочище «Погост» на Афанасовом поле в Радонеже // РА. № 1. С. 82-89.

Шемаханская М. С., Дубровин А. Ф., Дубровин М.Ф., Равич И.Г., 1996. Исследование металла древнерусской меднолитой мелкой пластики как основа ее атрибуции // Консервация и реставрация памятников истории и культуры. Экспресс-информация. Вып. 5-6. М.: Информкультура.

Щапова Ю.Л., 1972. Стекло Киевской Руси. М.: МГУ. $216 \mathrm{c.}$

Spinei Victor, 2011. Principii martiri Boris si Gle. Iconografie si canonizare. Braila. 
Вл. В. Седов

Институт археологии РАН, г. Москва

\section{Скульптурный фрагмент с мордой зверя из Боголюбова}

Во время разведывательных раскопок в 2015 г. в пос. Боголюбово Владимирской обл., известном тем, что здесь находится комплекс древнерусских белокаменных построек середины XII в., времени князя Андрея Боголюбского, состоящий из храма, лестничной башни и арочного перехода к храму (Воронин, 1939а; 1939б; 1945; 1961. С. 201-261; Седов, 2015; 2017a; 2017б; 2017в), внутри и с внешней стороны собора Рождества Богородицы было заложено три шурфа: шурф 1 внутри собора, шурф 2 у северного портала и шурф 3 - у юго-западного угла знаменитой лестничной башни, примыкающей к собору с севера (рис. 1). В шурфе 3 на уровне VI пласта, то есть на глубине более 1 м, найден фрагмент белокаменной скульптуры, чертеж которой был выполнен Ю. С. Фомичевой (рис. 2).
Перед нами окончание морды животного, вряд ли быка или барана, скорее одного из представителей семейства кошачьих. Фрагмент обломан со стороны расширения морды к глазам, внизу и сверху он уплощен, но в целом представляет собой обобщенное цилиндрическое тело, сужающееся к пасти и обрубленное несколько по косой линии вниз (рис. $3 ; 4 ; 5)$. Общие размеры фрагмента: диаметр - 7,5 см, высота - 6,5 см, сохранившаяся длина - примерно 10 см. Скульптор наметил по бокам и с торца очертания пасти, зубы не показаны, но кажется, что это пасть хищника: нижняя челюсть чуть короче и скошена, верхняя нависает над нижней (это место «усов» у кошачьих). Вверху по сторонам уплощенной поверхности показаны две воронкообразные ноздри, обращенные вверх.

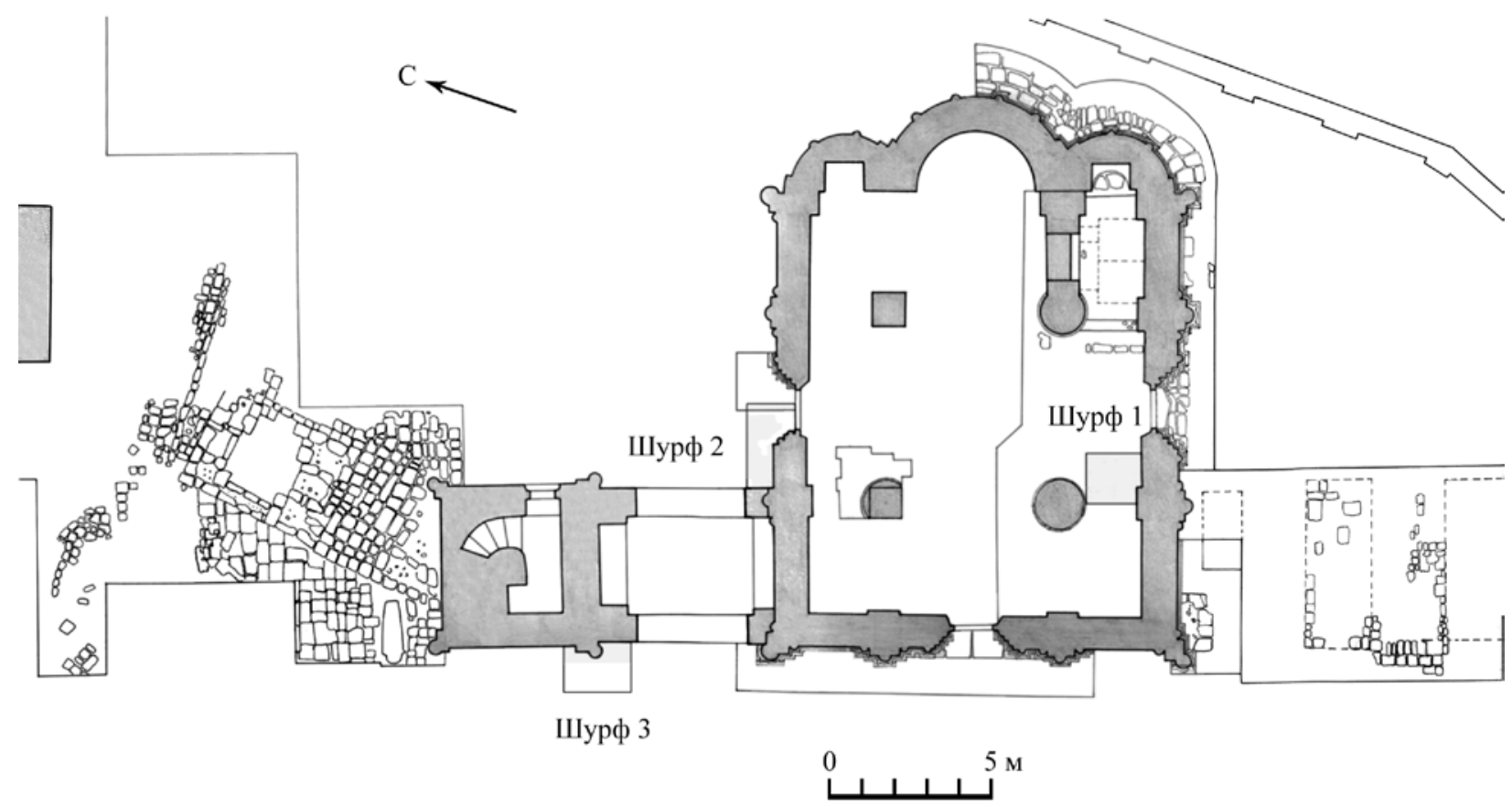

Рис. 1. План Боголюбовского комплекса по Н.Н. Воронину с указанием расположения шурфов 1, 2 и 32015 г. 


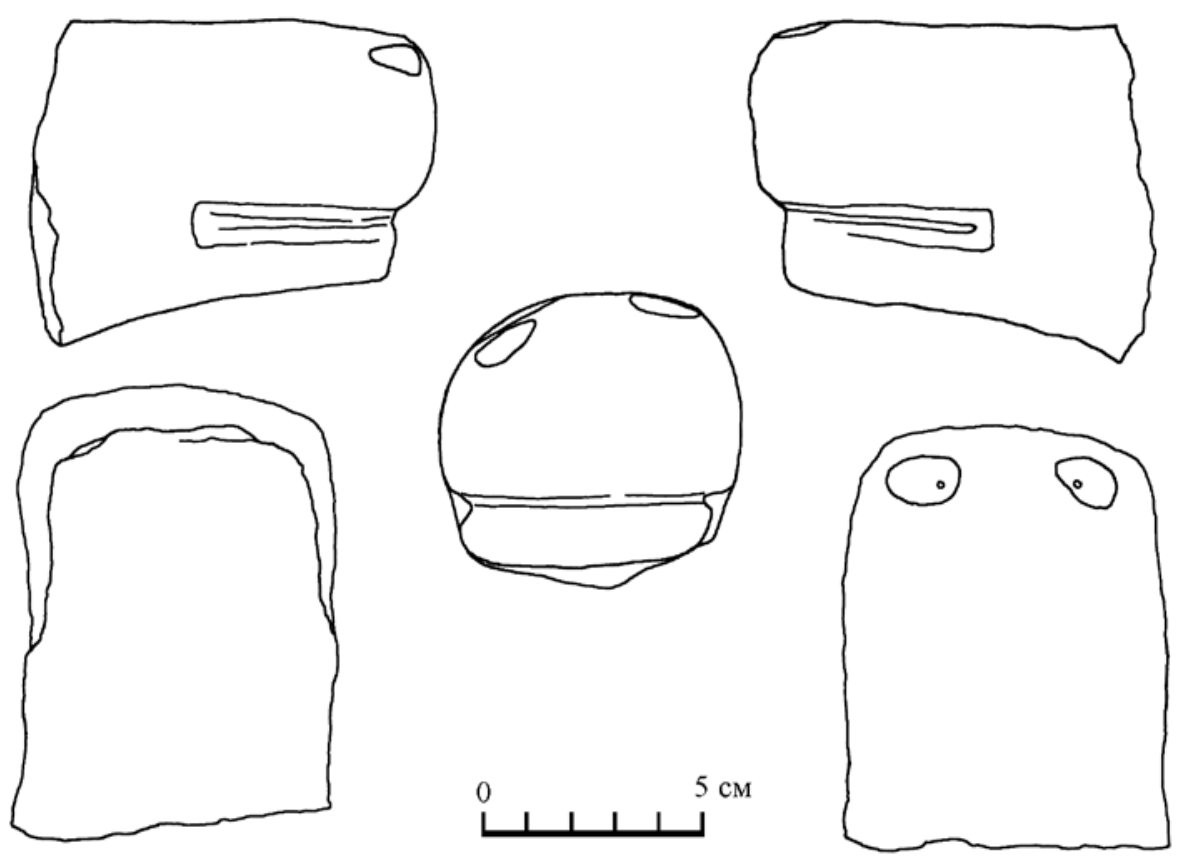

Рис. 2. Голова зверя - фрагмент 2015 г. Виды с боков, снизу, с торца и сверху.

Чертеж Ю.С. Фомичевой

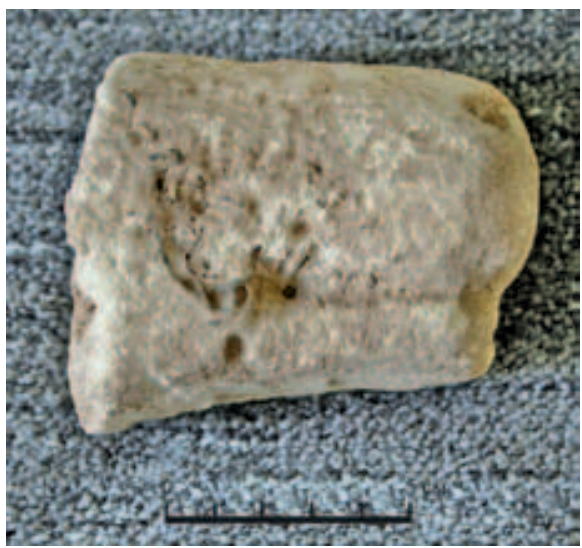

Рис. 3. Голова зверя - фрагмент 2015 г. Вид сбоку

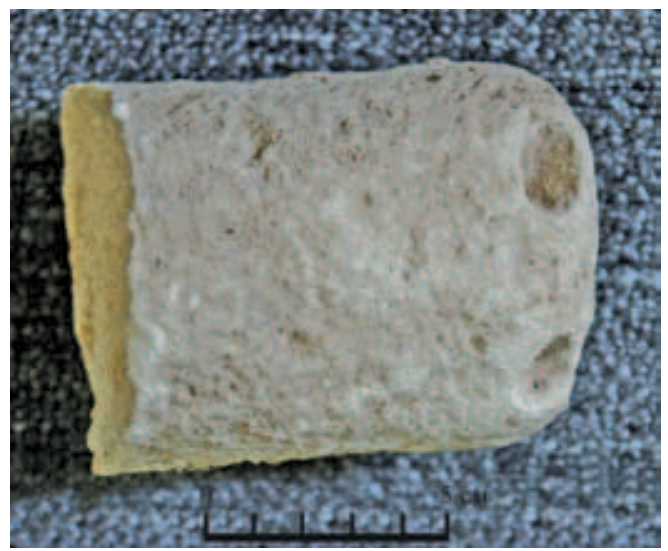

Рис. 5. Голова зверя - фрагмент 2015 г. Вид сверху

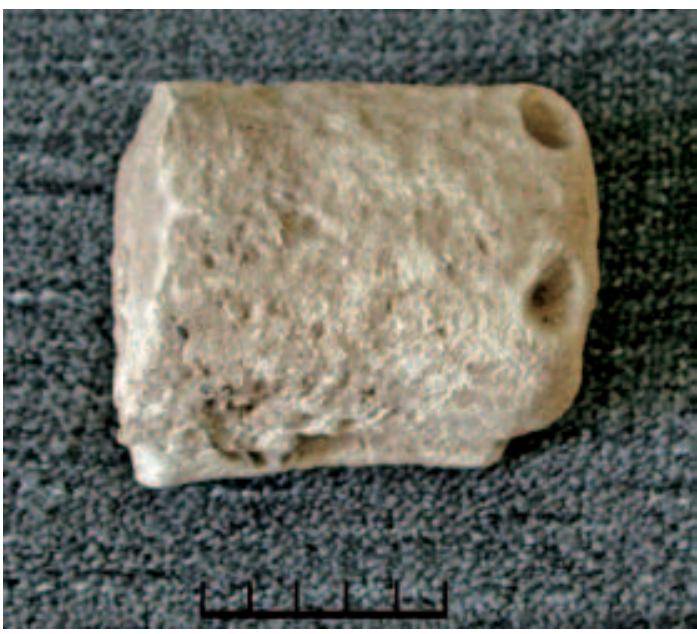

Рис. 4. Голова зверя - фрагмент 2015 г. Вид сверху и сбоку

Этот фрагмент из Боголюбова, найденный в 2015 г., показывает, что в церкви Рождества Богородицы, сооруженной князем Андреем Боголюбским в конце 1150-х или в 1160-е, была круглая или почти круглая скульптура изобразительного характера.

Впервые об объемной резьбе Боголюбова написал Н.Н. Воронин, который опубликовал похожую морду (рис. 6), найденную в раскопках у перехода от лестничной башни к собору, то есть в том же месте, в котором в 2015 г. был обнаружен публикуемый фрагмент морды. В опубликованном в 1939 г. Н.Н. Ворониным фрагменте сохранились 


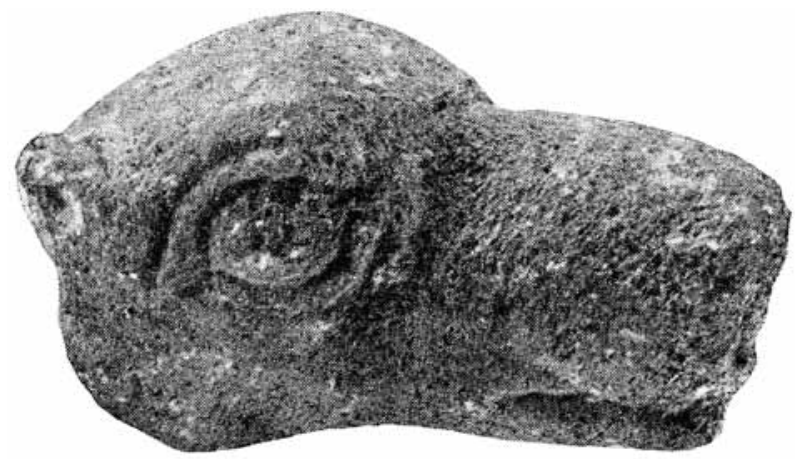

Рис. 6. Голова зверя из раскопок Н.Н. Воронина

не только морда, но и голова с крупными миндалевидными глазами и небольшие треугольные уши; фрагмент опубликован с подписью: «Голова собаки. Фрагмент круглой скульптуры дворцового перехода» (Воронин, 1939а. С. 68). Исследователь писал об этой скульптуре: «Наиболее интересен фрагмент круглой скульптуры, относящийся к переходу, - голова собаки (или дракона, вырезанная из пористого известняка и позволяющая с большей уверенностью говорить о развитии круглой скульптуры в искусстве Владимиро-Суздальской земли периода его расцвета при Боголюбском» (Воронин, 1939. С. 67).

В своей книге о зодчестве Владимиро-Суздальской земли Н.Н. Воронин еще раз написал об этом фрагменте из Боголюбова (Воронин, 1961. C. 214-217): «Над капителями в ендовах между закомарами выступали резные белокаменные водометы. Житие Андрея упоминает бывшие на соборе «каменные трубы для стечения воды». От фигуры зверя, оседлавшего верхний камень желоба, найдены голова и часть ноги. Водомет в целом подобен водомету Успенского собора, о котором говорилось выше». На рисунке 98 под литерой «в» дана фотография головы зверя, которая очень близка описанному выше фрагменту 2015 г.

Итак, в Боголюбове известны уже два фрагмента с изображением головы зверя. Но были ли это верхние части водометов? Н.Н. Воронин говорил об этом с большой определенностью, опираясь также на фрагменты водометов с растительной резьбой и с изображением ноги зверя, связываемые с Успенским собором во Владимире, построенном князем Андреем Боголюбским, и хранящиеся в ГИМ. На основании изображения ноги зверя ученый говорит о том, что лоток водомета, «несомненно, имел покрывавшую лоток верхнюю часть, представлявшую, видимо, трехмерную фигуру самого зверя. Полной уверенности в принадлежности данного фрагмента андреевскому собору у нас нет, тем более что водомет со звериной лапой очень похож на изданный Н.А. Артлебеном водомет, происходящий якобы из собора Рождественского монастыря... Голову подобного зверя, оседлавшего водомет, мы увидим ниже в Боголюбовском замке. В этом виде водометы напоминали гаргульи средневековой архитектуры Запада» (Воронин, 1961. С. 182). Исследователь опубликовал также графическую реконструкцию водомета (рис. 7), сделанную архитектором-реставратором Б. А. Огневым (Воронин, 1961. С. 182, рис. 72).

Н.Н. Воронин только указал на авторство Б.А. Огнева, создавшего реконструкцию водомета, судя по всему, безусловно принятую первым. Однако существует более ранняя по отношению к книге 1961 г. статья Б.А. Огнева, в которой он разбирает вид и устройство водометов, а также дает реконструкцию верха того водомета, в которой помещает не только знакомый нам рисунок, правда, с наклоном водомета и несколько иным положением фигуры зверя, а также сечение реконструируемой трубы (рис. 8). Этот рису-

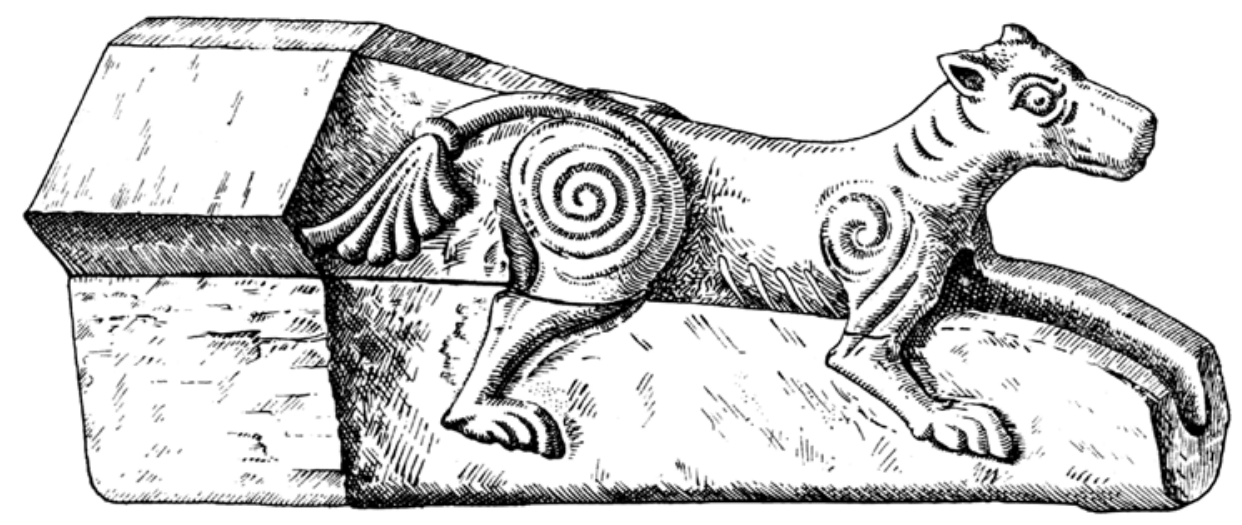

Рис. 7. Реконструкция водомета по Б. А. Огневу из публикации Н.Н. Воронина 


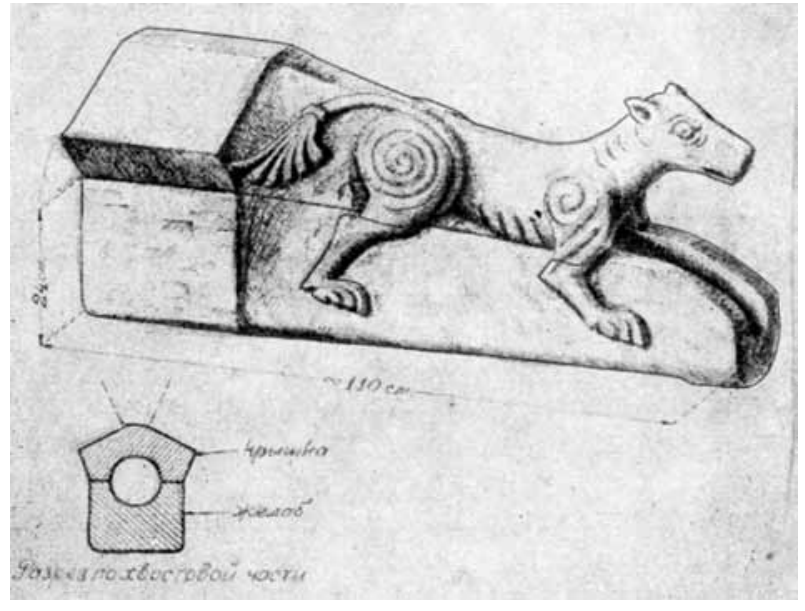

Рис. 8. Реконструкция водомета. Чертеж Б. А. Огнева

нок был найден при разборке одного из контрфорсов владимирского Успенского собора, и на нем изображена нога зверя. Б.А. Огнев писал: «Один из этих фрагментов имеет на своих боковых сторонах рельефные изображения звериных лап, обрывающихся у верхнего среза гладко обтесанного желоба. Очевидно, само тело зверя должно было располагаться выше обреза желоба, откуда следует, что сверху желоб был покрыт крышкой, которая вместе с нижней частью образовывала трубу... Судя по реконструированному нами общему виду такого крытого водомета, голова зверя была сделана круглой скульптурой (на основании находки Н.Н. Ворониным скульптурной звериной головы в Боголюбове в 1937 г.) (Огнев, 1958. С. 51-52)».

Другой упомянутый Н.Н. Ворониным водомет, из собора Рождественского монастыря во Владимире, был опубликован Н.А. Артлебеном (рис. 9), который писал: «Во Владимире найдены были, при вырытии рвов для постройки, в Рождествене монастыре каменные, украшенные изваяниями желобья, представленные на прилагаемых рисунках, и другие гладкие - на сводах под крышею церкви Девичьего монастыря. На этой церкви, между настенных полукружий, над пилястрами, приметны заделанные в стену корневые части этих обломанных впоследствии желобьев. В романских и потом готических церквах были в употреблении подобные желобья, изваянные в виде разных чудовищ, человеческих фигур, птиц, зверей и пр.; они состояли из двух желобчатых камней, наложенных один на другой, наружность которых представляла какую-нибудь фигуру. На рисунке представлен желоб церкви в Лане, во Франции, XIII века. По фигуре этого желоба видно, что в наших недостает верхней части с той фигурой, которой при- надлежали вырезанные на нижнем камне руки и ноги» (Артлебен, 1871. С. 293-294). Отметим сразу, что желоба, опубликованные Н.А. Артлебеном, разные: один имеет полукруглое сечение, а другой - прямоугольное. Кроме того, это именно он высказал догадку о завершении владимирских водометов верхним желобом, хотя ни одного фрагмента такого верха пока не найдено.

Мы видим целую цепочку статей, содержащую целый ряд предположений, которые к концу цепочки превращаются в уверенность. Сначала Н. А. Артлебен опубликовал несколько фрагментов нижних частей водометов и предположил, что они были накрыты своеобразной крышкой, а также привел в качестве аналогов гаргульи западных водометов (впрочем, очень отличающиеся - уже и вода в них проходит сквозь рот фигуры, и никто сверху на желобе не сидит).

Затем Б.А. Огнев реконструировал другие, хотя и похожие, водометы с крышкой и водруженным на крышу зверем, причем зверя он взял из публикации Н.Н. Воронина 1939 г., в которой

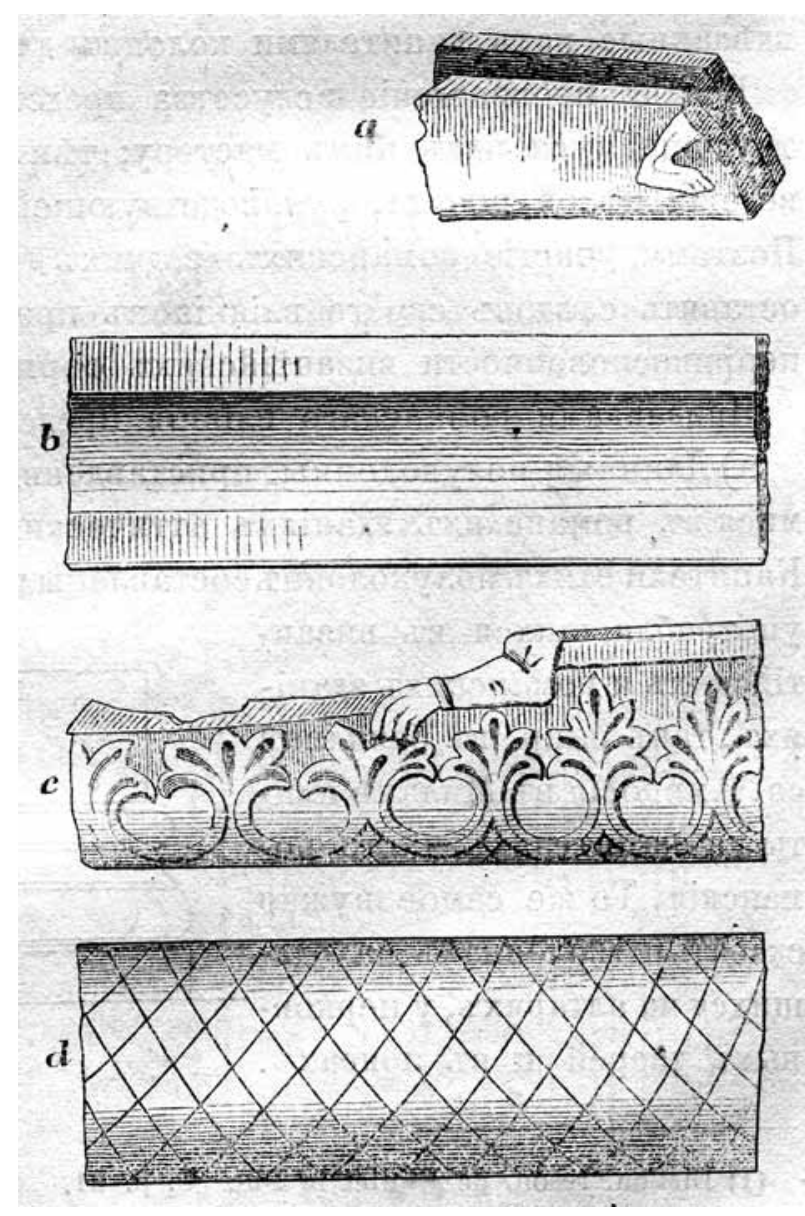

Рис. 9. Фрагменты водометов. Чертеж Н. А. Артлебена 
исследователь о водометах еще не думал. Н. Н. Воронин принял версию Б. А. Огнева и опубликовал в своей книге его реконструкцию, упомянув голову зверя из Боголюбова уже как водомет.

Г.К. Вагнер уже не сомневался, что «голова зверя» из Боголюбова являлась частью водомета: «Дошедшая до нас небольшая (в длину 18 см) голова неизвестного зверя представляет уже круглую скульптуру, сильно выступающую из плоскости стены. Н.Н. Воронин считает, что это был водомет, украшенный сверху фигурой зверя, голова которого, таким образом, выступала вперед от плоскости стены и рисовалась на фоне неба. В связи с этим понятна лапидарная и отвлеченная трактовка зверя. Он не входил в какую-либо тематическую композицию или серию, где требовалась семантическая конкретизация образа. Но голове нельзя отказать в пластичности... В решительно вырубленной, продолговатой и тупоносой, как у терьера, морде зверя сказывается не примитив, а развитое чувство объема, его материальности». Относительно происхождения мастеров Г.К. Вагнер высказывается довольно определенно: «Видимо, инициаторами зооморфных водометов тоже были приглашенные Андреем Боголюбским иноземные мастера. Как увидим ниже, водометы более поздних владимирских храмов (даже зооморфные) будут иметь другой характер» (Вагнер, 1969. С. 76; Рис. 39 на с. 73).

Последняя фраза, в которой констатируется разница известных водометов и водомета реконструированного, на котором была помещена найденная в Боголюбове голова зверя, эта фраза могла бы насторожить ее автора, но Г.К. Вагнер в главе, посвященной более поздней владимирской резьбе, привел куски тех «других», плоскостных по резьбе водометов, а рядом поместил и реконструкцию Б. А. Огнева «в виде похожего на волка или собаку зверя» и выделил три типа водометов, первый из которых, «с зооморфной скульптурой, но без орнамента» представлен уже много раз упомянутой реконструкцией Б. А. Огнева (Вагнер, 1969. С. 224-225). В дальнейшем предположение, реконструкция стали фактом. И в недавней «Истории русского искусства» найденная в раскопках Н.Н. Воронина голова зверя уже традиционно интерпретируется как фрагмент резного белокаменного водомета (Лифиии, 2015. С. 358).

Мы имеем две скульптурные головы из Боголюбова, причем сохранившую только конец морды голову, найденную в 2015 г., как будто дополняет голова, обнаруженная в раскопках Н.Н. Воронина 1937 г. Скажем прямо, интерпретация этой головы в качестве головы скульптурного зверя кажется натяжкой. Б.А. Огнев не имел никаких оснований для соединения этой головы и нижней части водомета, а дальше Н.Н. Воронин своим принятием этой реконструкции буквально водворил этот хорошо нарисованный, но трудно объяснимый образ в качестве бесспорной истины. Между тем мы видели, что такой вид водомета (реконструированный, со скульптурой), во-первых, не имеет аналогий в русском материале, а во-вторых, не очень похож и на гаргульи Лана и других соборов, в которых никакой восседающей фигуры на крышке водомета нет, а фигура встраивается в сам водомет, составляет его тело.

Мы не касаемся сейчас вопроса о реконструкции водометов: у нас мало данных и прежде всего нет сведений о «верхних» камнях, которых просто не найдено. Ноги животных и рука человека могли заканчиваться не фигурами на крышке, а фигурами по бокам, возвышавшимися над открытым лотком водомета. Но все эти соображения пока отдают гаданием. Надо ждать нового материала.

Для нашей статьи важнее, что голова зверя не обязательно связана с водометом и полной фигурой, даже более того, скорее всего, вовсе не связана. Мы имеем дело с двумя головами, то есть их использование в декоре храма Боголюбова было связано с неким множеством. Нам кажется, что здесь мы имеем дело со скульптурой, в которой представлена только голова зверя, без туловища. То есть это не была в полной мере круглая скульптура, это была скульптура с выступающими частями, с выступающей головой.

В пользу этого предположения говорит как раз отсутствие круглой скульптуры в зодчестве Владимиро-Суздальской Руси. Голова зверя из-за своей уникальности потому и вызвала такой интерес ученых, что она казалась частью развитого туловища. Если мы представим себе, что из плоскости или из какой-то конструктивной части выступала только голова, то нам такая композиция представится более логичной, более схожей с тем кругом рельефов той или иной проработанности и того или иного выступа, каким представляется резьба Владимира и Боголюбова.

Следует исключить только ситуацию, в которой эта голова выступает перпендикулярно из плоскости стены: в этом случае во владимирских белокаменных памятниках всегда делали довольно плоскостные или уплощенно-скругленные рельефы. Не может эта голова быть обращенной и вбок - по тем же основаниям и в связи с отсутствием каких-либо прецедентов. 

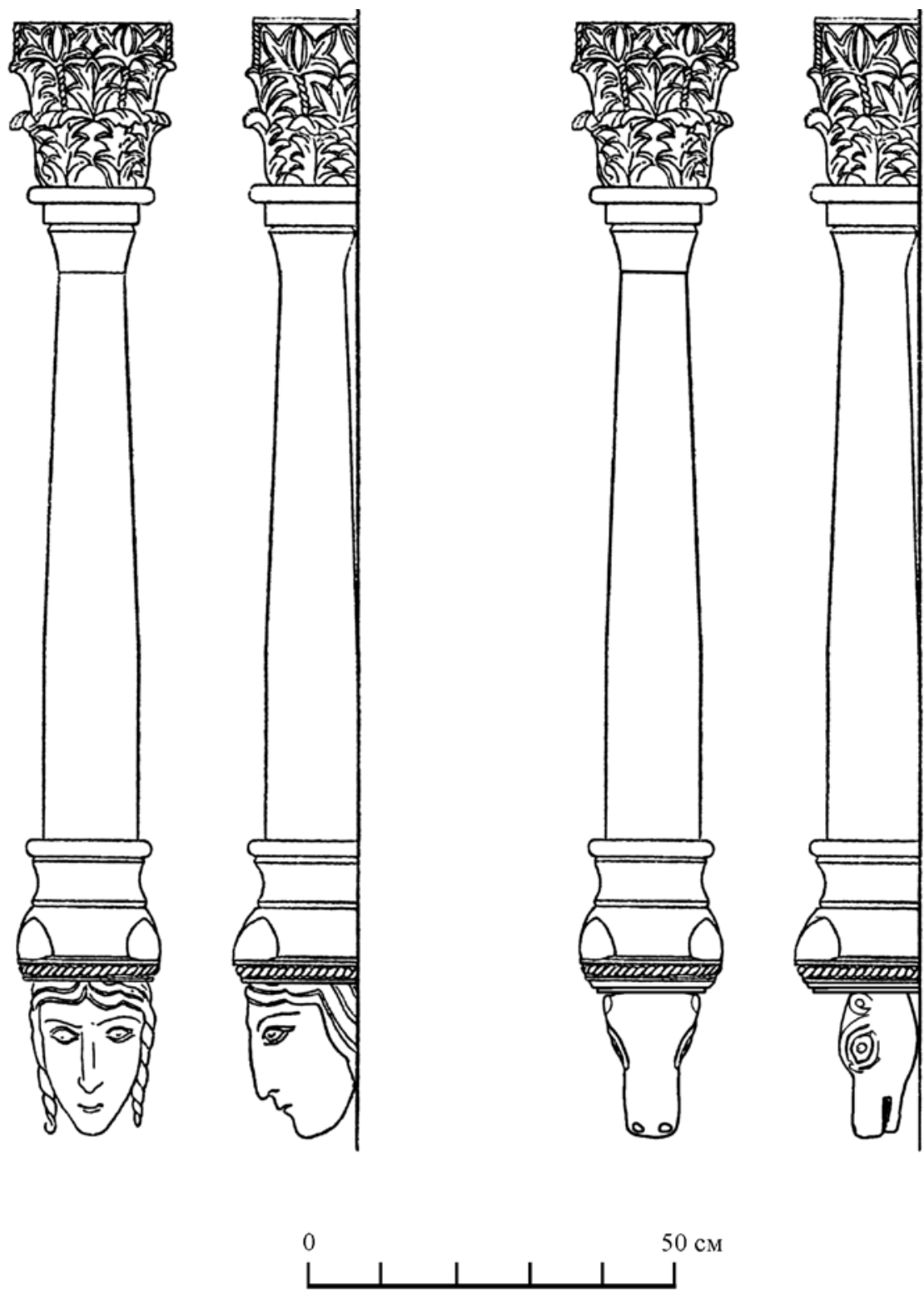

Рис. 10. Церковь Покрова на Нерли. Колонна на антропоморфной консоли (слева). Церковь Рождества Богородицы в Боголюбове. Реконструкция колонны на зооморфной консоли (справа). Чертеж Ю. С. Фомичевой

В настоящий момент понятно, что резьбе или, лучше сказать, скульптуре Владимиро-Суздальской Руси аналогии нужно искать в романской скульптуре Италии, точно так же, как для архитектурных форм следует искать итальянские прообразы (Гордин, 2013; Иоаннисян, 2005; Седов, 2017а; 2017б). Но формы ранней скульптуры Суздальского княжества времени князя Андрея Боголюбского хотя и обладают большой выразительностью и принадлежат незаурядным мастерам, однако по сравнению с высшими образцами скульптуры Италии начала XII в., особенно с работами мастера
Вильгельма, участвовавшего в постройке собора в Модене и впитавшего в своем творчестве влияние античной скульптуры (Quintavalle, 1967; Rotili, 1968), резьба Владимира и Боголюбова не столько проигрывает, сколько отступает в сторону.

Мастера скульптуры, работавшие во Владимире, проще по своей манере, они связаны с искусством, находившимся уровнем ниже, в области той культуры, которую можно было бы назвать «коренной» романикой. Это искусство, эта область или слой были наполнены странным смешением натурализма и фантазии, тогда как собственно 


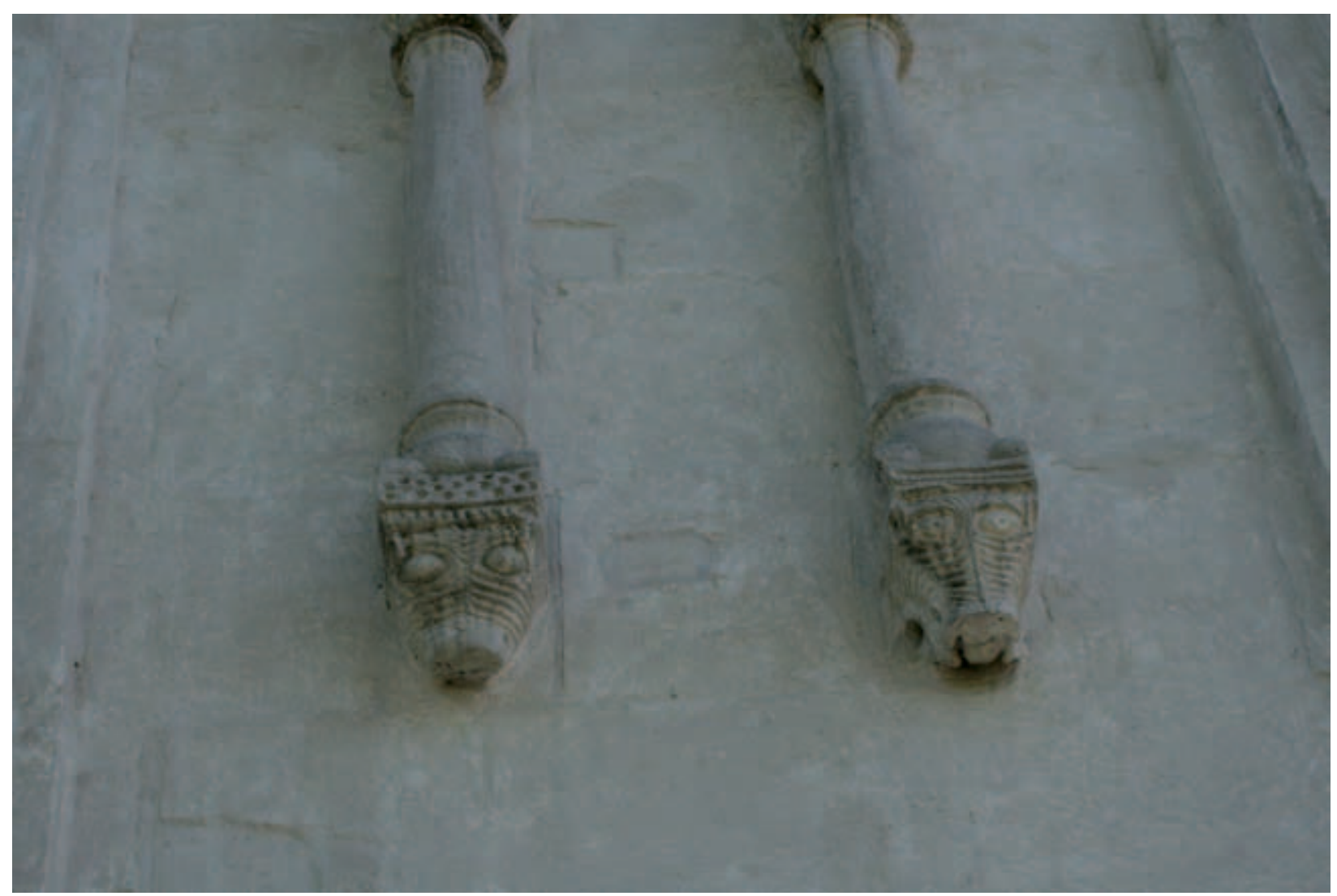

Рис. 11. Зооморфные консоли на южном фасаде церкви Покрова на Нерли

реалистическая или античная (что, на наш взгляд, почти то же самое) линия оставалась в их творчестве только фоном, лишь иногда выдвигавшимся на первый план (заметим, что во Владимире так и не выдвинувшимся). И в этой области наблюдательности и фантазии те итальянские мастера, которые прибыли на Северо-Восток Руси около 1158 г., когда начал строиться Успенский собор во Владимире, были не только носителями большой и развитой традиции, перемещенной в область, лишенную своей скульптурной жизни, они были еще и очень искусными мастерами, великолепно справлявшимися со сложнейшими задачами. Со временем, перебирая памятники Эмилии или Ломбардии, мы найдем похожее искусство, сможем определить родину (или несколько родных городов) этих мастеров. Но уже сейчас можем ощутить сложность их искусства, их свободный и изобретательный дух.

Помимо поиска стилевых прообразов надо хотя бы попытаться указать на то возможное место, которые головы зверей могли занимать в скульптурном декоре Боголюбова. Поначалу нам показалось возможным поместить такую голову в качестве свисающей части консоли под колонкой аркатурно-колончатого фриза. Аркатурно-колончатый фриз был в церкви Рождества Богородицы в Боголюбове, части его есть на лестничной башне, а часть, самое основание, сохранилась на северном фасаде храма, под переходом, где были найдены скульптурные головы. Однако колонки в указанных поясах Боголюбова опираются на призматические, закругленные внизу консоли.

Консоли в виде человеческих (ангельских) голов существуют в церкви Покрова на Нерли, формы которой имеют большое сходство с формами церкви в Боголюбове. Эти консоли под колонками были сначала выбраны нами в качестве аналогов расположения морды зверя: слева мы разместили консоль с головой из церкви Покрова на Нерли (фас и профиль консоли и колонки), а справа - предположительное расположение найденной нами и Н.Н. Ворониным головы зверя (рис. 10). Сравнение показывает, что голова зверя еще неплохо смотрится в фас, а в профиль она слишком субтильна, а к тому же не имеет точки соприкосновения со стеной, которую мы видим в антропоморфной консоли церкви Покрова. Кроме того, на южном 


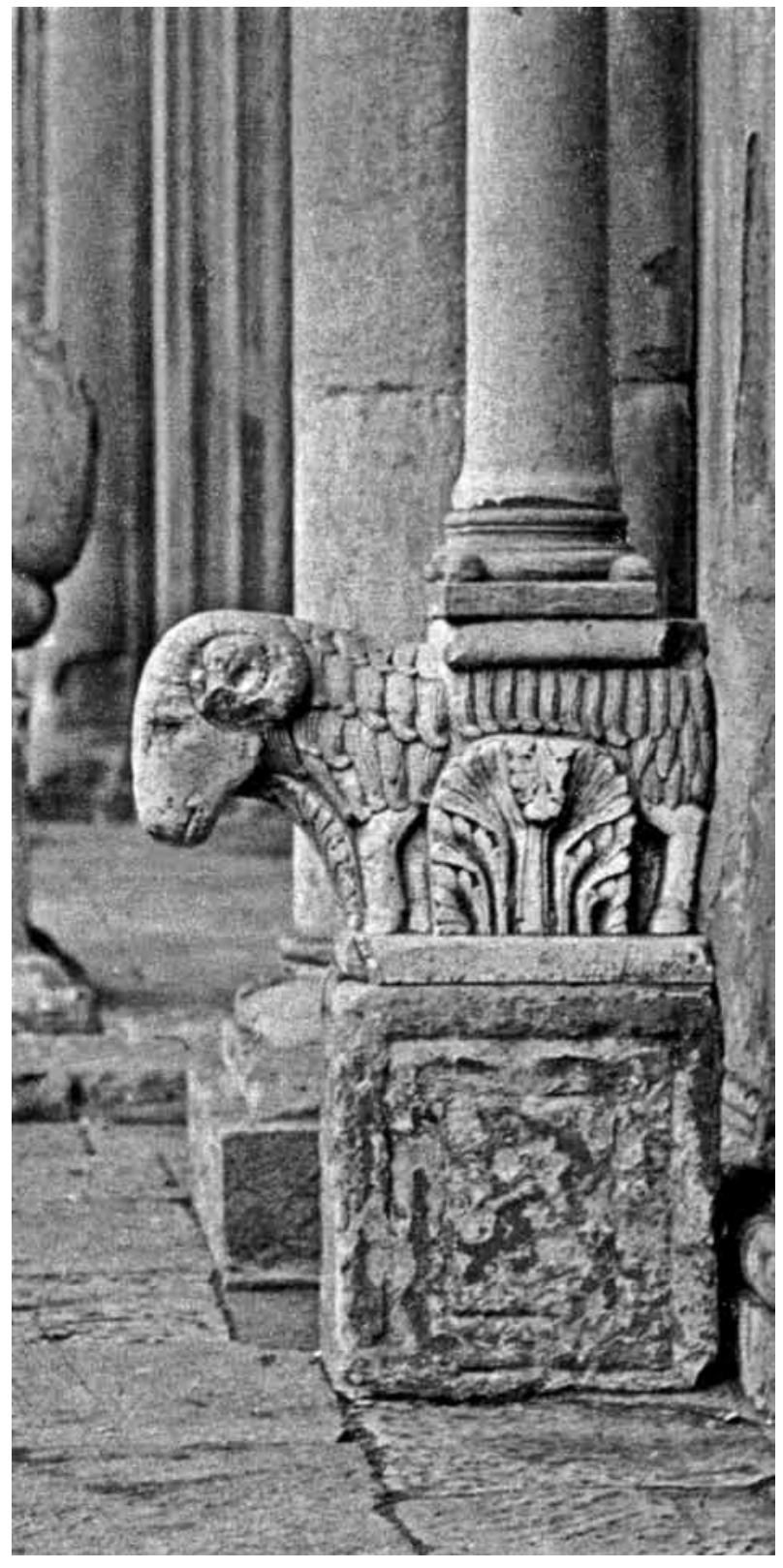

Рис. 12. Основание колонны бокового портала собора в Фиденце

и северном фасадах в восточных пряслах колонки пояса опираются на консоли в виде голов вепря (?) с обращенными вниз мордами. Но эти головы не столь объемны, как в Боголюбове, они примыкают к стене, составляя с ней единое целое, и только несколько выдаются вовне и вниз (рис. 11). Мы видим, что предположение о том, что найденные головы из Боголюбова могут быть частями консолей, основывается на очень шатких основаниях и, скорее всего, должно быть отброшено.

Но где же все же могли располагаться объемные - не рельефные, а трехмерные головы зверей?
Для того чтобы предположить хотя бы несколько решений, следует обратиться к романской скульптуре итальянской области Эмилия, к скульптурам соборов в Модене и Фиденце. В соборе города Фиденца, созданном в XII в., на западном фасаде колонны трех порталов опираются на фигуры зверей. В главном портале это львы, а в боковых - бараны, морды которых странным образом похожи на морду, найденную в 2015 г. (рис. 12). Это первый возможный вариант. Однако отметим, что основания колонок порталов в Боголюбове сохранились, и места там для таких зверей просто нет.

Еще одно предположение о месте расположения голов из Боголюбова (или скорее только головы, найденной в 2015 г.) можно сделать, разглядывая западный фасад собора в Модене, созданного в конце XI - начале XII в. Здесь в капителях колонн, членящих фасад, имеются далеко выдвинутые головы, среди которых следует указать на головы баранов с похожей трактовкой окончания морд (рис. 13). В Боголюбове и Владимиро-Суздальской земле нам такие капители с фигурами людей и зверей неизвестны, но они могли быть, о чем и свидетельствуют найденные скульптурные морды.

Предположение о том, что эти морды были частью капителей, их угловых частей, нам кажется вероятным. Более того, мы думаем, что голова из раскопок 2015 г. могла быть головой и хищника, и барана, тогда как голова из раскопок Н.Н. Воронина достоверно принадлежит хищнику, ско-

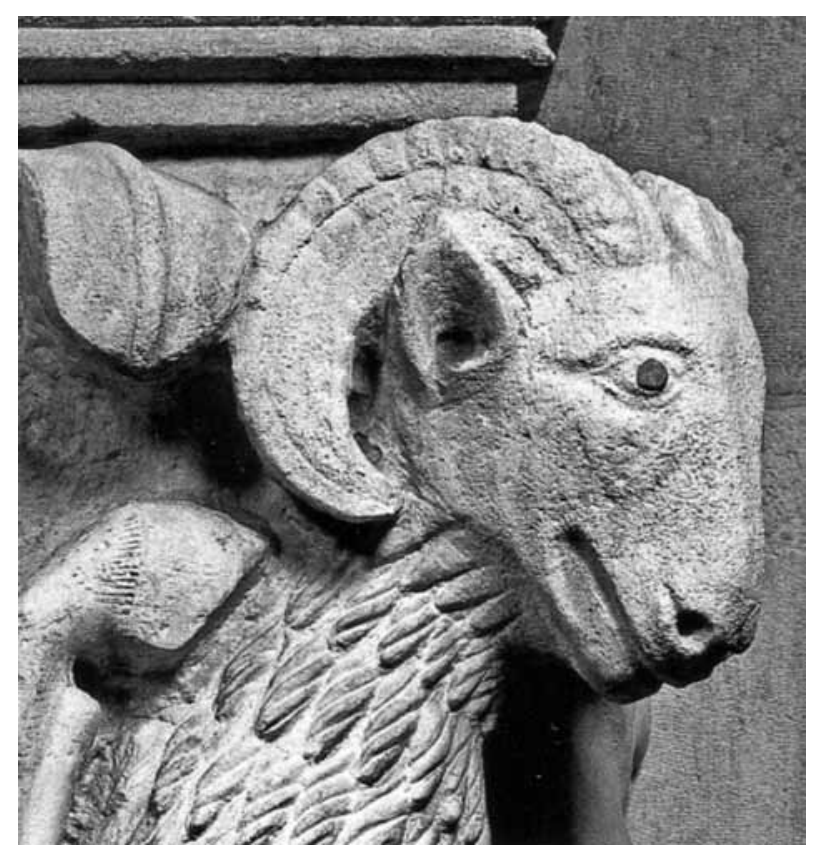

Рис. 13. Угловая часть капители собора в Модене 


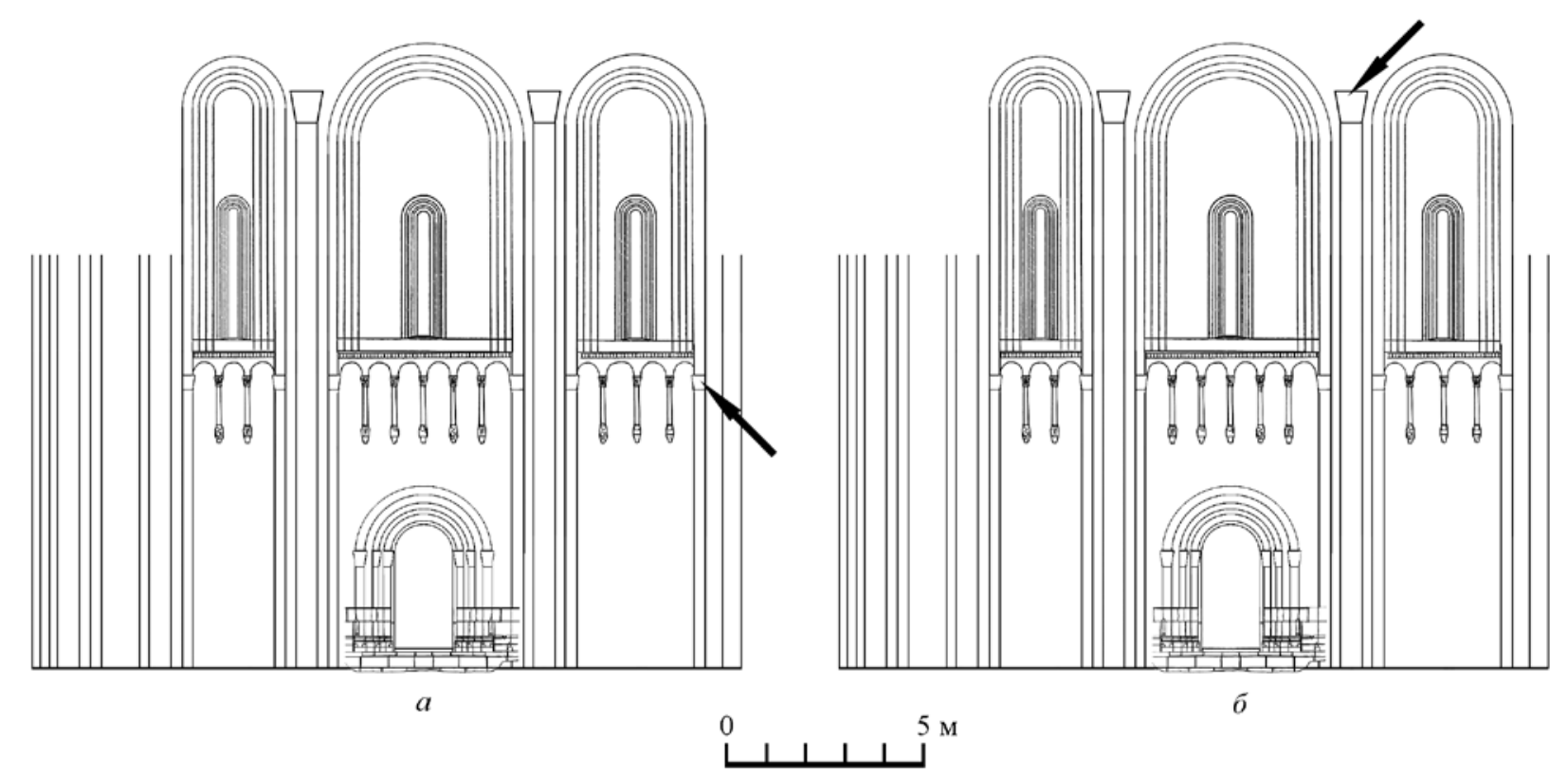

Рис. 14. Предположения о возможном размещении скульптурных капителей на северном фасаде церкви Рождества Богородицы в Боголюбове. Слева - капители боковых колонок у лопаток, справа - капители больших колонн, разделяющих прясла. Чертеж Ю.С. Фомичевой по материалам автора

рее львице, чем собаке. Возможное расположение капителей с фигурами зверей на фасаде церкви Рождества в Боголюбове мы показываем на отдельном чертеже (рис. 14), где видно, что такие капители могли увенчивать как боковые колонки прясел (на чертеже слева), так и высокие колонны, наложенные на лопатки и заканчивающиеся в основании закомар (на чертеже справа).

Мы понимаем, что пока интерпретация скульптурных морд из Боголюбова очень гипотетична.
Но этой статьей хотели бы начать работу по дальнейшей атрибуции и интерпретации скульптурных фрагментов из храма в Боголюбове, а также из церкви Покрова на Нерли. Эту работу можно осуществлять при постоянном сравнении фрагментов и композиций названных владимирских памятников со скульптурой Эмилии и, возможно, Ломбардии. Сейчас мы стоим только в самом начале пути, когда еще далеко до развернутых сопоставлений, когда можно только нащупывать отдельные черты сходства.

\section{Литература}

Артлебен Н.А., 1871. По вопросу об архитектуре XII века// Труды Первого археологического съезда в Москве. 1869. Т. І. М. С. 288-299.

Воронин Н. Н., 1939а. Замок Андрея Боголюбского // Архитектура СССР. № 11. С. 66-69.

Воронин Н. Н., 1939б. О дворце Андрея Боголюбского в Боголюбове // КСИИМК. Вып. II. С. 29-30.

Воронин Н.Н., 1945. Основные вопросы реконструкции Боголюбовского дворца // КСИИМК. Вып. XI. C. 78-86.

Воронин Н.Н., 1961. Зодчество Северо-Восточной Руси XII-XV веков. Т.I. ХІІ столетие. М.: Изд-во АН СССР. 583 с.
Гордин А.М., 2013. К вопросу об истоках владимирской белокаменной резьбы // «Хвалам достойный». Андрей Боголюбский в русской истории и культуре. Владимир. С. 168-183.

Иоаннисян О. М., 2005. Романские истоки зодчества Владимиро-Суздальской Руси времени Андрея Боголюбского (Германия или Италия?) // Византийский мир: Искусство Константинополя и национальные традиции. К 2000-летию христианства. Памяти О.И. Подобедовой. М.: Северный паломник. С. 31-70.

Лифиии Л. И., 2015. Белокаменная резьба СевероВосточной Руси // История русского искусства. 
Т. 2/2. Искусство второй половины XII века. М.: Гос. ин-т искусствознания. С. 354-431.

Огнев Б., 1958. О позакомарных покрытиях (К вопросу реставрации позакомарных покрытий храмов Северо-Восточной Руси XII-XV веков) // Архитектурное наследство. Вып. 10. М.: Гос. изд-во литературы по строительству, архитектуре и строительных наук. С. 43-58.

Седов Вл. В., 2015. Каменные стены Боголюбова. Исследования 2015 года // КСИА. Вып. 241. С. 191-202.

Седов Вл. В., 2017а. Боголюбовский киворий: фиал и проблема интерпретации комплекса // Святая вода в иеротопии и иконографии христианского мира / Ред.-сост. А.М. Лидов. М.: Феория. C. 397-414.

Седов Вл. В., 2017б. Северный портал собора Рождества Богородицы в Боголюбове // КСИА. Вып. 246. С. 56-69.

Седов Вл. В., 2017в. Лестничная башня в Боголюбове (по материалам раскопок 2015 года) // КСИА. Вып. 249. Ч. II. С. 131-150.

Quintavalle A.C. Wiligelmo. Firenze: Sadea/Sansoni Editori. 121 p.

Rotili M., 1968. Wiligelmo e il Romanico. Milano: Fratelli Fabri Editori. 88 p. 


\section{Л. А. Беляев ${ }^{*}$ В. П. Глазов, П.Л. Зыков ${ }^{* *}$, О. М. Иоаннисян ${ }^{* *}$ \\ * Институт археологии РАН, г. Москва, \\ ** Государственный Эрмитаж, г. Санкт-Петербург}

\section{Погребальные сооружения XII-XV веков на месте собора Рождества Богородицы во Владимире (по материалам работ 1997-2000 годов)}

Среди проблем, связанных с рождением культуры Московской Руси, существенное место занимают вопросы появления характерных только для нее типов предметов. Они, несомненно, существовали, причем выделяли московскую культуру в кругу других современных ей культурных вариантов удельных княжеств и земель. Особое место занимают важные для духовной самоидентификации объекты, связанные с христианской погребальной обрядностью. Так, в Москве закрепился и распространился обычай пролития на покойного елея; для нее же с XV в. стали типичны гробы с выраженным оглавием (антропоморфные, антропоидные) из белого камня (саркофаги) или дерева; в XV-начале XVI в. сложился местный тип надгробной плиты с характерной, также антропоморфной схемой орнамента и выработалась (XVI в.) устойчивая формулярная эпитафия.

Определить истоки и раннюю хронологию этих категорий-значит, многое прояснить в генезисе Московского государства, ведь обычный вопрос, задаваемый историку культуры, - это вопрос об импульсе, об исходной точке для развития (не пишем «заимствование»: то, что не в состоянии усвоить, не заимствуют, в противном случае возникает версия «культа карго», чего мы в московской культуре отнюдь не наблюдаем). Известную роль эти исследования могут внести и в просопографию. Ее понятный интерес к погребальным объектам в последние годы явно усилился, причем именно в отношении семей владимирских Рюриковичей (см., например, работы А.В. Сиренова: 2010. С. 25-59; 2011; и др.).

Обычно при описании Московского княжества удельного этапа указывают на такие истоки его культуры, как: 1) древнерусская традиция; 2) опосредованные контакты с Европой через Псков, Новгород, генуэзские колонии в Крыму и в Тане;
3) привычные связи с восточнохристианским миром через тот же Крым, его армянские колонии и такой византийский город, как Херсонес; 4) восточный вектор, усилившийся включенностью Северо-Восточной Руси в состав Орды. Направления определены правильно, но слишком широкими мазками, что не позволяет решать вопросы на конкретно-историческом уровне, с точной хронологией и деталями. Этого можно добиться только углубленным источниковедческим анализом.

Так, проблема владимиро-суздальского наследия в послемонгольское время немного прояснилась после раскопок Спасо-Преображенского собора в Твери в 2010-х гг. (Беляев, Сафарова, Хохлов, 2018). В то же время связь с этим наследием первых каменных соборов Москвы 1226-1240-х гг. после критики имеющихся источников оказалась под сомнением (Баталов, Беляев, 2018). Анализ путей проникновения в Москву арабеска позволил конкретизировать его связь, указав на районы Центральной Анатолии и сельджукскую резьбу Крыма (Беляев, 2016; Баталов, 2018). И так далее.

Аналогично звучит вопрос о взаимной зависимости погребальных сооружений. Н.Н. Воронину и его современникам генезис антропоморфного саркофага казался очевидным, их выводили из романской традиции. Позже была предложена восточнохристианская версия. Сейчас доказано, что такой саркофаг известен в Европе со времен Крестовых походов, а это возвращает нас к вопросу о конкретном импульсе (Беляев, 2015). Однако саркофаг не появляется ранее конца XIV, а скоpee начала XV в. Два экземпляра антропоморфных гробов, известных в Боголюбове и в Суздале, вероятно, попали туда не ранее XVI в. Это можно понять хотя бы потому, что и домонгольская, и послемонгольская погребальные традиции этих 
городов используют в массовом порядке саркофаги прямоугольные и трапециевидные, причем исключительно их, на что указал Л.А. Беляев, затем А.Е. Леонтьев; в недавнее время повторный обзор предпринял Вл.В. Седов, придя к тому же выводу (см.: Беляев, 1996. С. 108, 110 и др.; 2018 (библиография); Леонтьев, Иоаннисян, 2008; Седов, 2017).

Так обстоят дела с формой. А что же с орнаментом могильных плит? Мы привыкли писать о нем как о московском, учитывая близость техники и отчасти композиций XV-XVI вв. к орнаменту самых ранних (XII-XIV вв.) плит из «старших» городов Владимиро-Суздальского княжества (Ростов Великий, Переславль-Залесский, Владимир).

С этим вопросом, несомненно, стоит разобраться детальнее, для чего требуется свести воедино погребальные сооружения домонгольского и удельного времени. Они умножаются (хотя и медленно), но по большой части не введены в оборот, не сопоставлены друг с другом и с контекстом обнаружения. Это потребует значительной предварительной работы, и данная статья - только заявка на большой проект, который заполнит лакуну в истории ранних погребальных комплексов Владимиро-Суздальских земель, включая, разумеется, и Москву. А. Е. Леонтьев уже принял в заполнении пробела определенное участие как исследователь Успенского собора и соборной площади в Ростове, и мы надеемся продолжить сотрудничество с ним.

Как вообще образовалась эта лакуна? Дело в том, что центр исследования археологии удельного периода остается в Москве, где материалов с XII по первую половину XV в. мало, и датированы они неточно. Стратиграфический контекст часто смутный, а серии короткие, обычно однодва изделия (лишь изредка, с учетом фрагментов, до десятка: Успенский собор Московского Кремля, собор Богоявленского монастыря за Торгом; кладбище церкви Троицы в Полях).

Материалы раскопок 1990-2000-х гг. в Рождественском монастыре Владимира (руководите- ли О.М. Иоаннисян, В. П. Глазов, П. Л. Зыков $\left.{ }^{1}\right)$ и в зоне Успенского собора Ростова (руководители А.Е. Леонтьев, О.М. Иоаннисян и др.) в этом смысле выигрышнее. Они включены в архитектурно-археологическую систему и позволяют наблюдать историческую последовательность развития плит и саркофагов на раннем этапе в сравнительно крупных сериях с твердой нижней датой. А это создает почву для сравнения московской традиции с владимирской в собственно владимирских, ростовских и переславских образцах ${ }^{2}$.

Об этом писалось еще в книге 1996 г. (Беляев, 1996. С. 12-14), но за истекшие после работ три десятилетия о ключевом для истории древнерусской мемориальной традиции XII-XIV вв. материале, отчасти обработанном для публикации еще на уровне отчетов, подзабыли. В сравнении c архитектурно-археологическими сюжетами погребальные древности представлялись менее интересными. Свою роль сыграла передача объектов Церкви. Печально сложились и обстоятельства жизни сотрудников, занимавшихся некрополем: в 2007 г. ушел из жизни маститый полевой исследователь В.П. Глазов, за ним, в 2009 г., молодой ученый А.В. Повелихин. Мы продолжим и разовьем начатый ими труд, тем самым поздравив Андрея Евгеньевича Леонтьева не только от себя, но и от лица коллег, не доживших до праздничного дня.

В первой статье задуманного нами цикла будут в общих чертах представлены ранние погребальные сооружения церкви Рождества Богородицы во Владимире. Храм, согласно Лаврентьевской летописи, построен в 1192-1196 гг. (ПСРЛ. Т.І. Стб. 409, 413), вероятно, ех поvо и на новом месте (слой строительства перекрывает яму жилой постройки не ранее середины XII в. уничтоженной при возведении храма), возможно, сразу как собор монастыря, служившего также резиденцией епископа (сам монастырь впервые упомянут в 1206 г.) ${ }^{3}$. Его обширный некрополь сформировался в четверике, нартексе и трехсторонней галерее, а также

1 Работы велись объединенной экспедицией Государственного Эрмитажа и Гос. центра по учету, использованию и реставрации памятников истории и культуры Владимирской области (руководители экспедиции О. М. Иоаннисян и В. П. Глазов).

2 В стороне пока остается Суздаль, где известны каменные четырехгранные саркофаги, но не плиты или крышки с трехгранно-выемчатой резьбой - возможно, со временем они будут там обнаружены.

${ }^{3}$ Не повторяя историю собора, подробно реконструированную Н.Н. Ворониным и О.М. Иоаннисяном, укажем значимые этапы: в XVII в. собор перестроили, в 1859 г. полностью разобрали и заменили реконструкцией храма XII в. по проекту Н.А. Артлебена (в 1930-х разобрали и этот храм), сделав перед разборкой весьма точные обмеры древних частей. Обмеры и результаты раскопок показали, что первоначально Рождественский собор окружала галерея, разобранная до цоколя еще в XVII в. Реконструкцию XVII в. Н. А. Артлебен принял за достройку 1678 г. и не стал восстанавливать, реконструировав наос без галерей. Тем самым цокольная часть галерей домонгольского времени, включая полы, сохранилась до нашего времени. При полном сносе собора в 1930-х гг. цокольные части оставались в земле и не были выбраны, в отличие от основного объема собора (см. литературу и изложение дискуссий: Иоаннисян, 2018). 


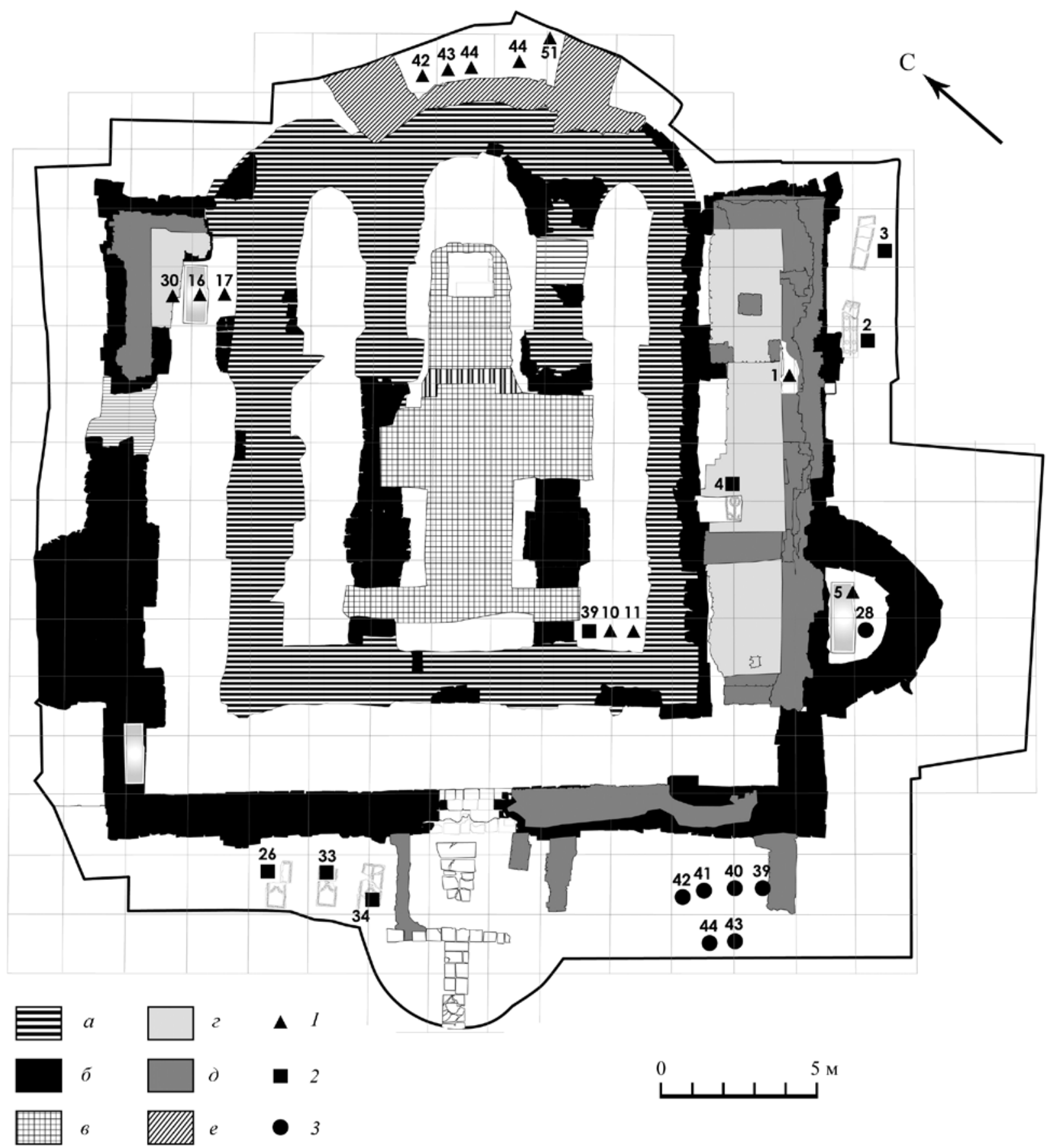

Рис. 1. Обобщенный план работ 1999 г. на месте собора Рождества Богородицы во Владимире. Рис. П. Л. Зыкова $a$ - фундаментные рвы собора XII в.; $\sigma$ - сохранившиеся участки кладки XII в.; 6 - пол собора XII в.; 2 - пол XVII в.; $\partial$ - кладка галерей XVII в.; $e$ - кладка XIX в. 1 - саркофаг; 2 - надгробная плита; 3 - погребение

снаружи у стен. На нем довольно ясно выделяются группы погребений конца XII - XIV в. и более поздние (часто использующие саркофаги вторично, как костницы). В то же время нужно учесть, что памятник сохранился не целиком и вскрыт не полностью, что затрудняет оценку планиметрической последовательности погребений (рис. 1).
Ранние могилы разбросаны довольно свободно вдоль боковых стен в галерее и снаружи от нее, а также в нартексе и в наосе. Южнее и западнее юго-западного столба (в традиционной точке начала погребений в храме) встречена группа из трех погребений, включающая два саркофага и каменную надгробную плиту над деревянной 


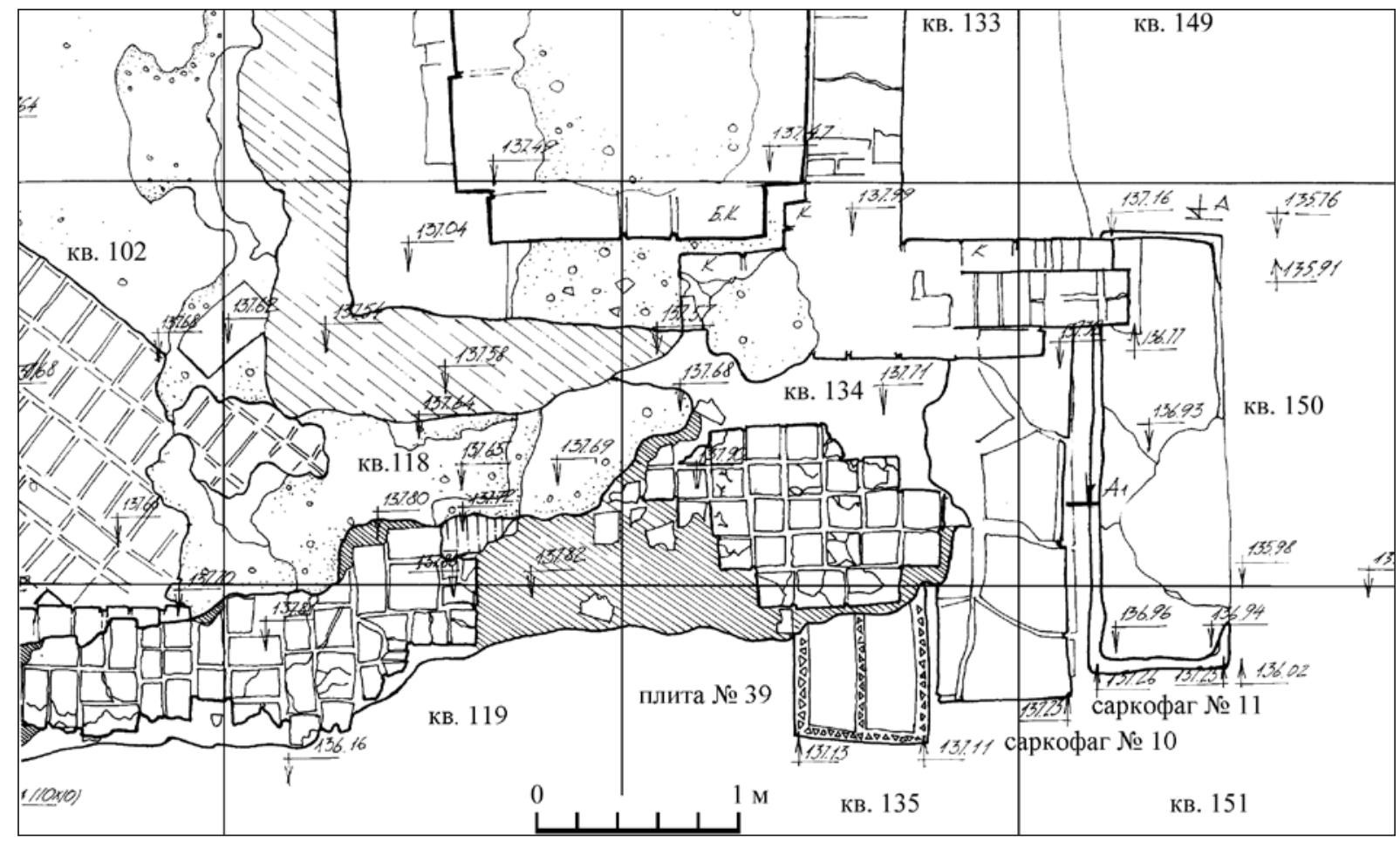

Рис. 2. Собор Рождества Богородицы во Владимире. Плита № 39 и саркофаги № 10-11 на плане раскопа

домовиной (на них сразу было обращено внимание и сделаны первые заключения; см.: Беляев, 2006. С. 12-13. Рис. 1). Эти погребения совершены через определенный промежуток времени после строительства собора. Их перекрыл плитчатый пол, в слоях подсыпки под который, в том числе ниже погребений, содержатся фрагменты фресок, вероятно, попавшие в слой уже при ремонте интерьера (рис. 2; 3; 4).

Всего в первый же сезон работ (1997) было учтено 38 погребений, с которыми связаны 36 белокаменных сооружений, плит и/или саркофагов ${ }^{4}$. Вскрыты были только три саркофага и одна мо- гила под плитой. В описание А.В. Повелихина при этом вошли: условный саркофаг № 1 (часть днища, укрепленного на растворе XVII в., в приделе Александра Невского $\left.{ }^{6}\right)$; саркофаги с плоскими крышками без орнамента: № 17 (в восточной части северной галереи, с погребением № 11; скелет мужчины, погибшего в бою от множества ран; с подголовником из куска плинфы), № 16 (севернее № 17, с погребением № 10) и № 5 (в апсидиоле южной галереи, с довольно странным погребением № 27 и добавленными к нему скелетными остатками), а также плиты: № 2 (в восточном конце южной галереи) и «от саркофага № 3» (в восточном

\footnotetext{
4 При проведении исследований Рождественского собора установлено, что значительная часть надгробных плит находится в переотложенном состоянии в результате работ XIX-XX вв. или была перемещена еще в древности, и плиты не соответствуют каким-либо погребениям. Кроме того, в некоторых саркофагах фиксировалось более одного погребения. Эти факты вынудили ввести раздельную нумерацию для погребений, надгробных плит и саркофагов.

5 К сожалению, не без некоторой путаницы, которую придется устранять путем сопоставления документации разных лет.

${ }^{6}$ Контекст, в котором обнаружен саркофаг № 1, необычен. В южной стене восточной части южной галереи, при входе в выделенный в ней (в XVII в.?) придел св. Александра Невского, часть днища каменного гроба была намеренно уложена на раствор поверх кирпичной кладки XVII в. Возможно, над ним имелся аркосолий или простая ниша, открывавшая доступ к камню. Письменные источники не фиксируют традиции почитания князя, но предполагать связь объекта с прославлением князя естественно. Важный аргумент в пользу этого - сам размер ниши, в плане точно отвечающий именно сохранившемуся фрагменту, а не целому гробу. Авторы отчета 1997 г. предположили, что дно саркофага сохраняли и почитали как вторичную реликвию, соприкасавшуюся с мощами князя. Вероятно, этот контекст для почитания был сконструирован в XVII в., когда мощи перенесли из нартекса, где они были погребены, в специально построенный придел, устроив архитектурный «ковчег» для части старого саркофага тут же, вблизи придела. В каком виде был саркофаг в момент открытия мощей, мы не знаем. Останки князя переложили в новый гроб, из которого вновь извлекли в начале XVIII в. для перенесения в Санкт-Петербург.
} 


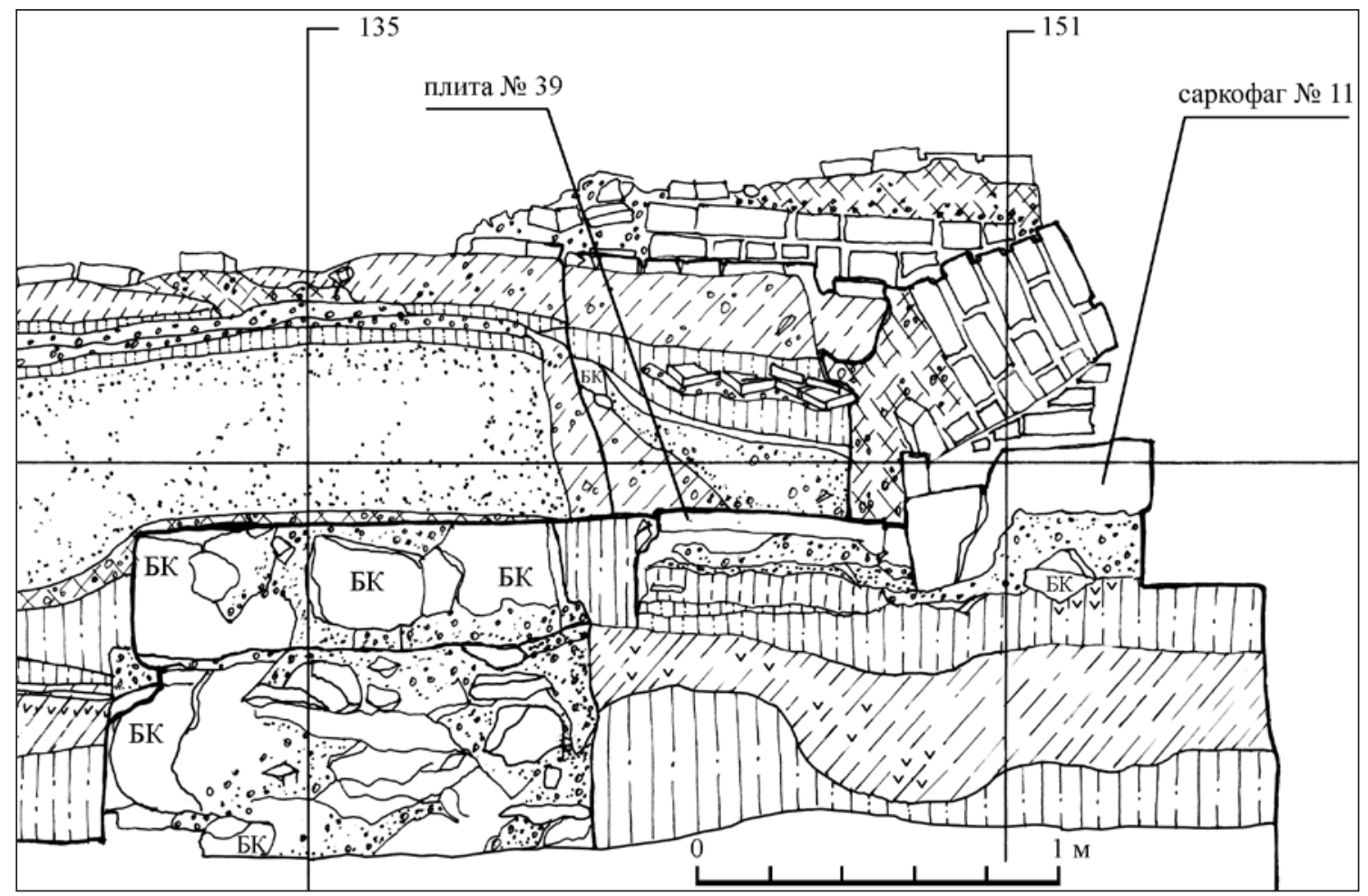

Рис. 3. Собор Рождества Богородицы во Владимире. Плита № 39 и саркофаг № 11 в профиле раскопа

конце южной галереи, отношения к саркофагам она не имеет). В ходе раскопок сложилось мнение, что под плитами № 2 и 3 не было погребений, возможно, они были уложены наподобие отмостки (рис. 5; 6).

Был отмечен ряд погребений в могилах без саркофагов или плит: № 1 (кв. 201), № 204 (кв. 158-159), № 28 (рядом с саркофагом № 5 в южной апсидиоле). По сути дела, следует в самой апсидиоле-«певнице» видеть отдельное погребальное сооружение, род небольшой боковой капеллы (или очень крупного аркосолия оригинальной конструкции), выступавшей из внешней стены галереи в ее юго-западной части. Традиция погребальных капелл известна и западному Средневековью, и Византии, и Руси (правда, не в форме боковых экседр) (рис. 7).

При продолжении работ (1998 г.) исследовали еще четыре погребения: № 7 (в белокаменном саркофаге № 11, XII-XIII вв.) 7 ; № 24 (в белокаменном саркофаге № 30, XIII-XIV вв., в восточной части северной галереи собора), № 37 (со стеклянным сосудом XVII в.?) и № 16 (в кирпичном склепе № 24, с двумя костяками).

Несколько отмеченных ранее гробниц изучили в 1999 г. Внутри собора это погребение № 38 (в деревянной домовине, но под каменной плитой № $39^{8}$ ), южнее которого стояли два белокаменных саркофага: № 11 (погребение № 7) и не пронумерованный в отчете саркофаг (№ 10). Снаружи от галереи собора отмечены более поздние комплексы погребений: от № 39 (рядом с кирпичным склепом № 40) до № 45 и от № 46 до № 50 (в зоне южной экседры). Против центральной апсиды (группа саркофагов № 42-45) вскрыты № 44 (с одним погребением), а также № 51 (к югу от саркофага 45), использованный как оссуарий ${ }^{9}$.

В 2000 г. на небольшом участке (40 кв. м) у южной экседры расчистили 68 погребений в несколько уровней. Их восточный ряд образовали три

\footnotetext{
${ }^{7}$ В отчетах отдельно пронумерованы погребения, саркофаги, кирпичные склепы и намогильные плиты. Чтобы не создавать путаницы, мы сохраняем этот порядок.

8 Размеры плиты: $197 \times 66-65 \times 10$ см.

9 Вскрытый саркофаг № 44 стоял против центральной апсиды, примыкая к ней изголовьем (между северным контрфорсом и основанием наружной пилястры), его северная стенка соприкасалась со стенкой саркофага № 43. Саркофаг длинный (222,5 см), ширина в изголовье 65 см, в ногах 57 см, высота стенок уменьшается к ногам (41 и 39 см от дна, 47 и 45 см снаружи). Вскрытый саркофаг № 51 содержал в заполнении фрагменты керамики XIII-XVI (?) вв. В саркофаге - три скелета (все кости перемещены, частично утрачены).
} 


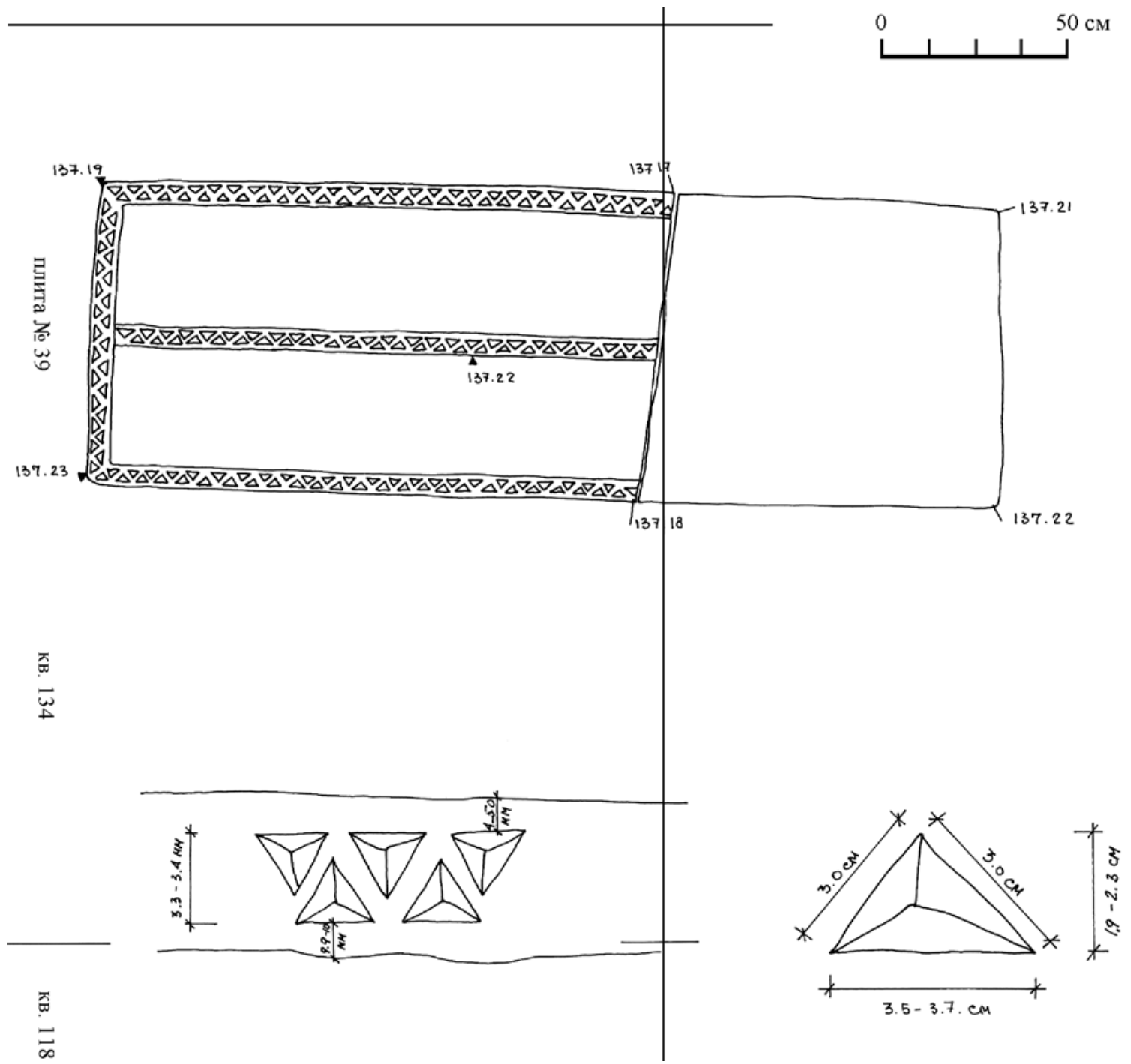

Рис. 4. Собор Рождества Богородицы во Владимире. Плита № 39
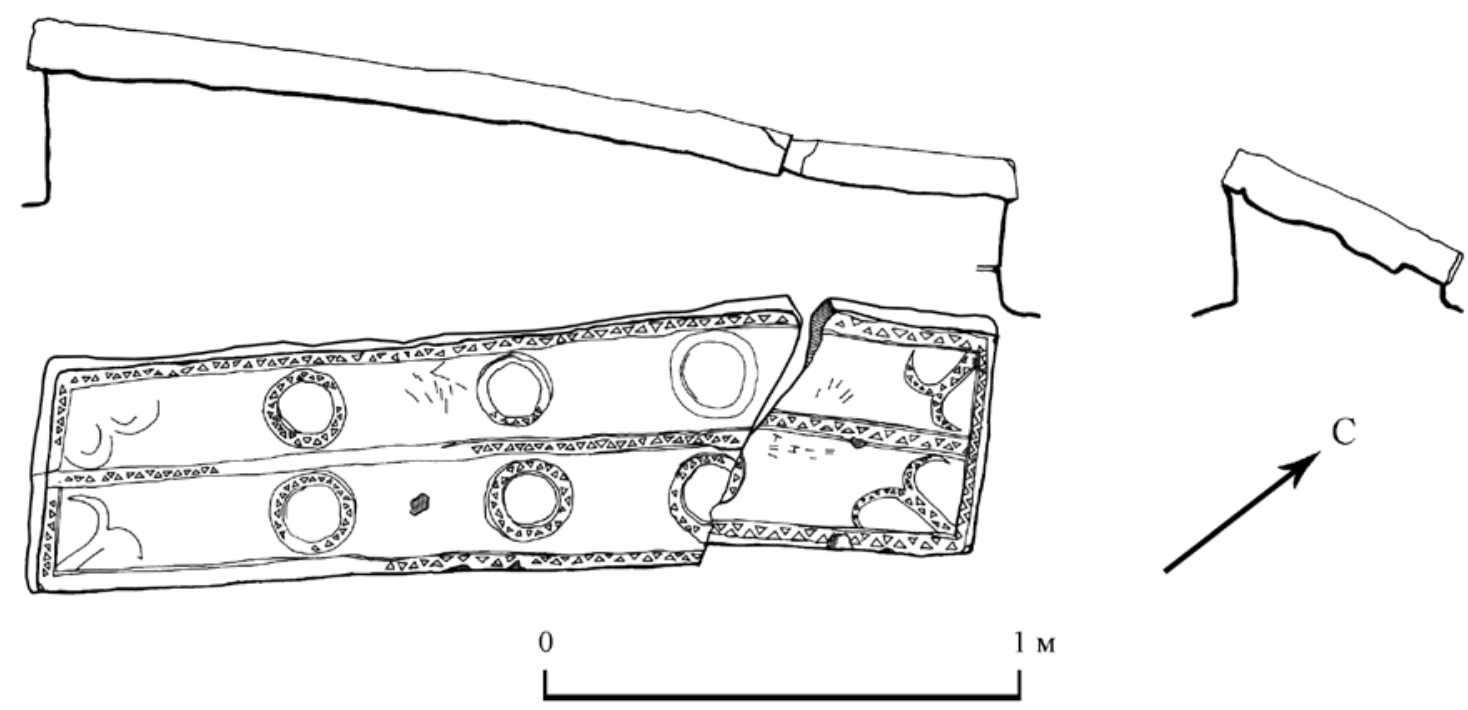

Рис. 5. Собор Рождества Богородицы во Владимире. Плита № 2a 


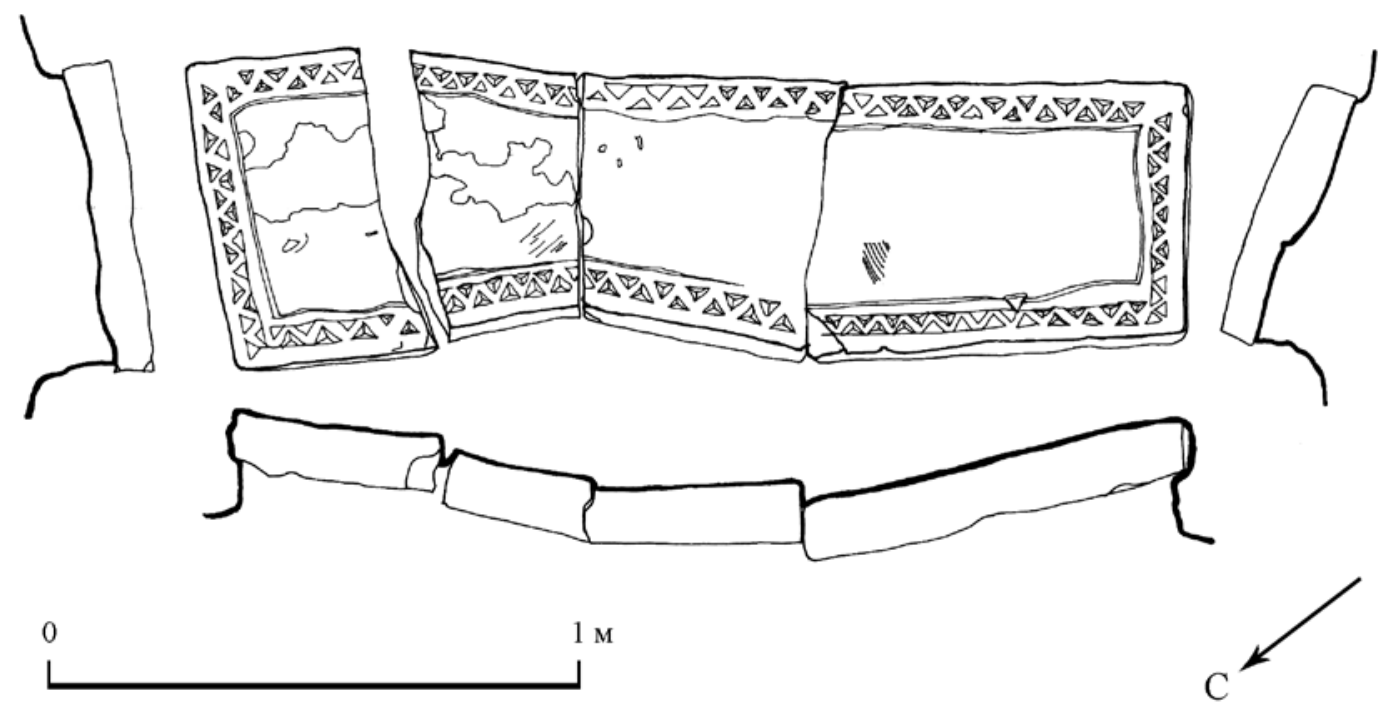

Рис. 6. Собор Рождества Богородицы во Владимире. Плита № 3

белокаменных саркофага ${ }^{10}$. Авторы работ отнесли их суммарно к XIII-XV вв., хотя отметили, что на одном из погребенных в могиле рядом с саркофагами сохранилась грибовидная пуговка, датируемая домонгольским временем. Поздние погребения совершались в кирпичных склепах, с кирпичными «подушками» в изголовье и вещами XV-XVII вв. ${ }^{11}$ В числе надгробий отмечено пять плит (№ 26, 33, 34, 39 и 40) с надписями XVI-XVII вв. ${ }^{12}$

Таким образом, в обширном погребальном комплексе изучено более 100 погребений, которые можно стратиграфически и типо-хронологически разделить на группы. Часть домонгольских и, возможно, удельного времени погребений совершены в белокаменных (туда обычно ставили деревянный гроб) саркофагах и деревянных колодах. Погребения XV-XVI вв. - в дощатых гробах. Погребения XVII-XVIII вв.-в кирпичных склепах ${ }^{13}$. Само кладбище носит упорядоченный характер, погребения располагались довольно строгими рядами. Оно, несомненно, привлечет интерес как монастырский некрополь, развивавшийся без помех более 500 лет, но здесь мы анализируем только раннюю часть - конца XII - XIV в.

Для истории оформления надгробных сооружений интересны ранние части кладбища, лежащие в югозападной части наоса, в обеих галереях и снаружи, за апсидами собора и с южной стороны от галереи, в том числе вблизи экседры (апсидиолы, «певницы»). Все эти погребения, как уже сказано, совершены в каменных саркофагах или под каменными плитами (но не то и другое сразу). Все саркофаги - ящичной формы, в плане прямоугольные или трапецоидные, цельнотесаные (в одном случае прослежено повреждение стенок, тщательно стянутых и затем замазанных). Крышки плоские, в ряде случаев со слабовыраженным гребнем по продольной оси или с низкими скатами. Орнаментов и надписей на них нет.

Судя по наблюдениям (см. вышеуказанные работы Л.А. Беляева и А.Е. Леонтьева), саркофаги с ребром могут уходить во вторую половину XII в., а каменные гробы с плоскими крышками, вероятно, появились несколько позднее - даты их вряд ли старше позднего XIII - XIV в.

10 Размеры саркофагов близки 1,90-2,05×55-60×60 см.

11 В том числе каменный крестик с бронзовыми накладками на концах, сцепленными друг с другом проволокой, образующей ромб; костяной крест-тельник с изображением св. Николая (с благовествующей правой рукой и Евангелием в левой) на одной стороне и Голгофой с орудиями страстей на другой (первая половина - середина XV в.).

12 Эти плиты прочел и включил в отчет сотрудник экспедиции Е.Э. Слива. Их тексты указывают на погребения XVI-XVII вв. В слое имеются фрагменты плит с характерным каннелированным орнаментом боковых граней, типичного во второй половине XVI - середине XVII в.

13 В конце XX в. мы полагали, что кирпичные склепы - признак XVIII-XIX вв. После работ в суздальском Спасо-Евфимиевом и московском Новоспасском монастырях можно считать установленным, что такие склепы ведут происхождение от XVII в., если не ранее (см.: Беляев, 2013). 


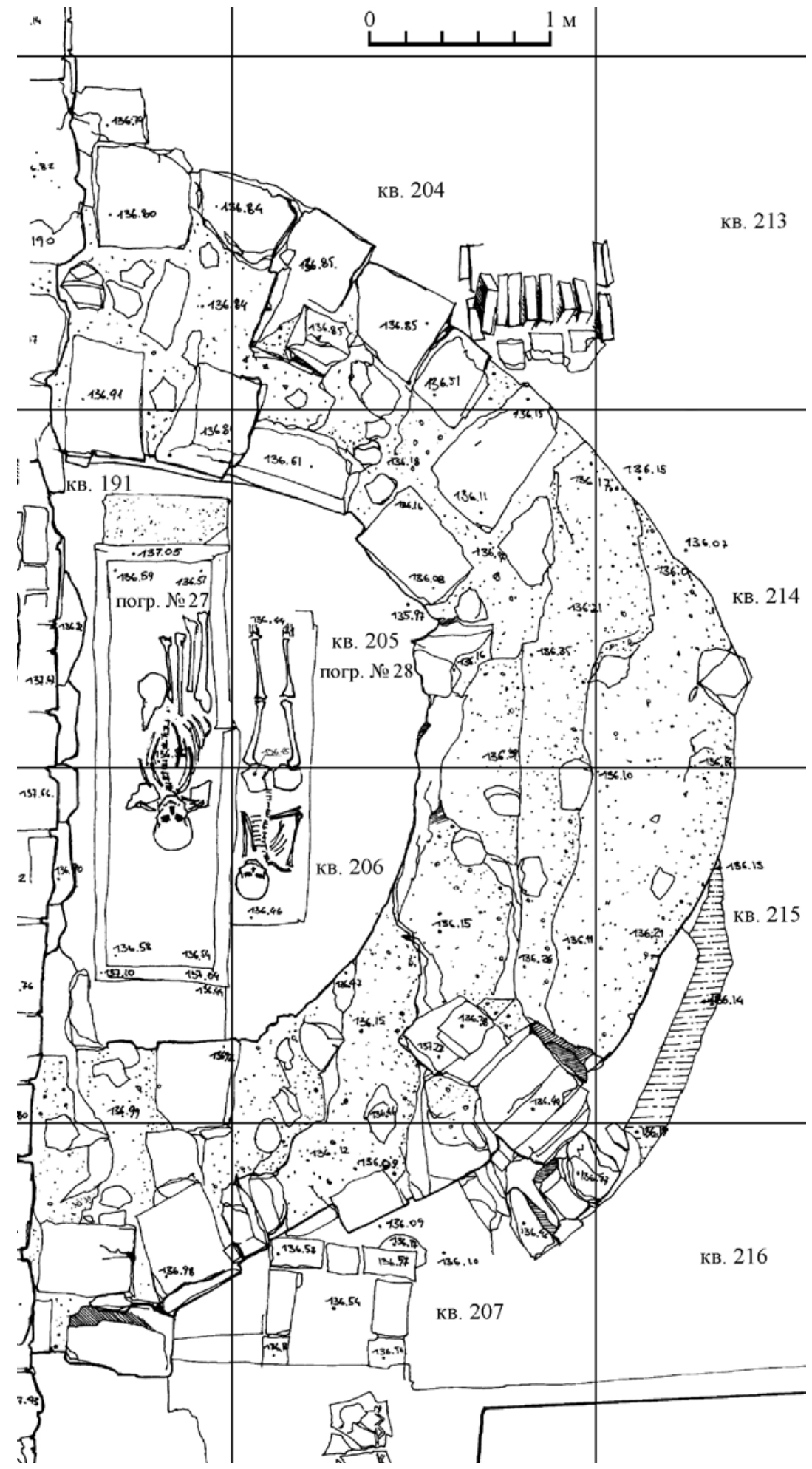




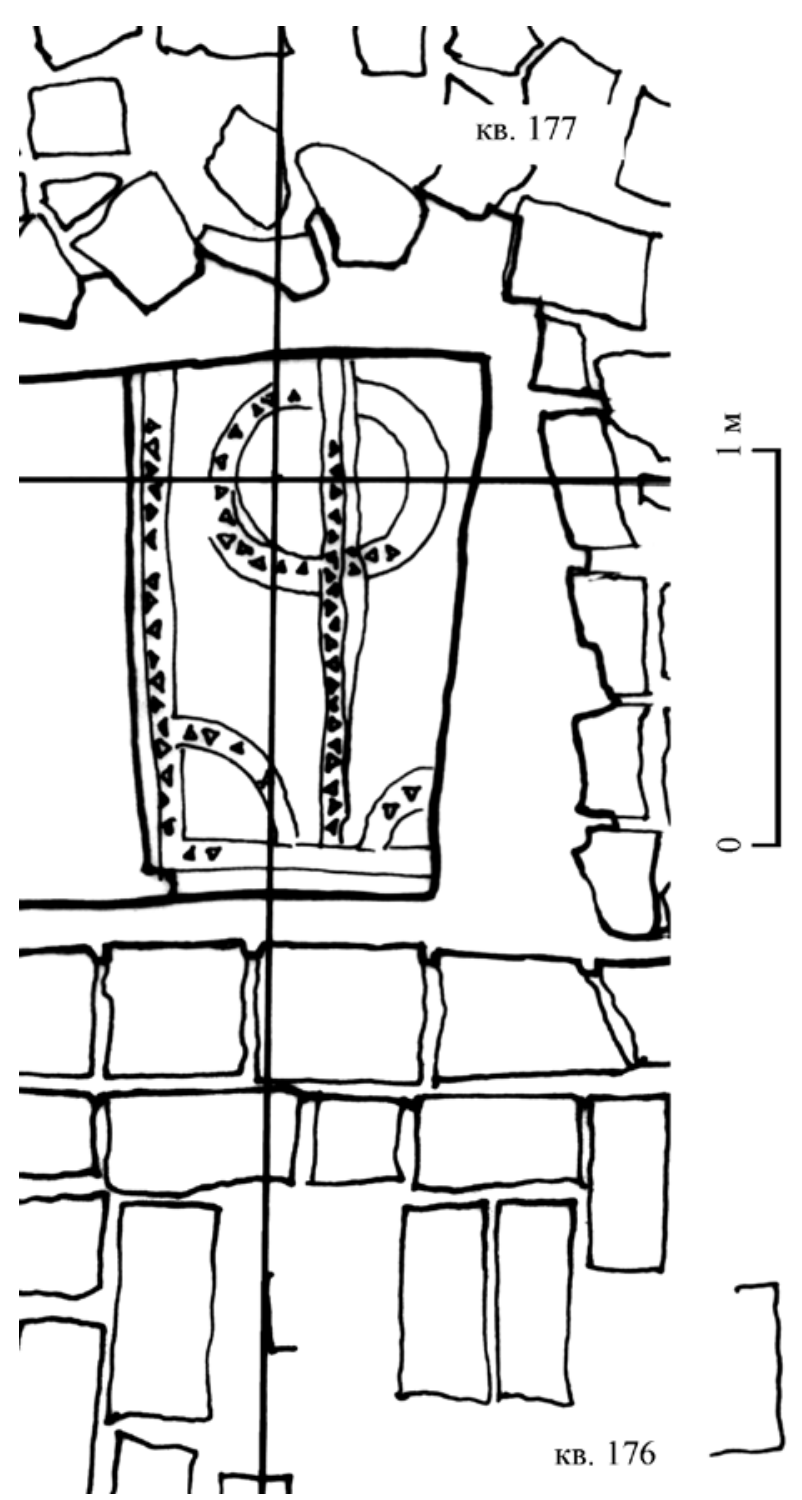

Рис. 8. Собор Рождества Богородицы во Владимире. Плита № 4 на плане раскопа

Ранние плиты сравнительно тонкие (7-9 см), слегка выпуклые по центру, иногда с намеком на ребро или скаты ${ }^{14}$. По-видимому, их делали, стремясь вытесать прямоугольник, а не трапецию, но получалось не всегда: в плане плиты достаточно неровные. Элемент декора единственный и однотипный - это волчий зуб из сравнительно крупных равносторонних противопоставленных вершинами треугольников, тщательно и глубоко нарезанных и образующих змейку. На всех плитах использована графья. Линии бордюров применяются к неровностям плит. Композиция орнамента полностью симметричная, что указывает на связь намогильных плит, прямоугольных в плане ящичных саркофагов и их крышек. Всего орнаментированных плит раннего типа отмечено не менее пяти: две в восточной части южной галереи, восточная, № 3 (кв. 199), и западная, № 2 (кв. 200-201); одна, № 4, под полом южной галереи (кв. 175-176); одна, № 39, у юго-западного столба (кв. 134-135). Эти четыре плиты явно лежали на своих местах, в то время как пятая служила порогом двери из нартекса в наос и была уложена поперек, в направлении север - юг (кв. 106).

В композиционном отношении плиты делятся так: одна (кв. 199) имеет только простейший бордюр из волчьего зуба; на двух других добавлена осевая лента (кв. 200-201 и106); на четвертой плите имеется бордюр, осевая, шесть парных пустых кругов-«венков» в два ряда и угловые скаты, обозначенные расходящимися ростками ${ }^{15}$; наконец, плита № 4 (кв. 175-176) несет в центре большой круг («венок»), пересеченный осью, а углы отсечены четвертными сегментами (схематические «актротерии») (рис. 8). Все композиции симметричные и прямоугольные.

Композиции орнамента имеют аналоги в комплексах Переславля-Залесского и Москвы. Близкая схема (круги в две линии, без угловых скатов) отмечена в соборе Никитского монастыря Переславля-Залесского (предложенная в свое время дата - начало XV в. - привязана к попытке обретения мощей св. Никиты Столпника и ненадежна, см.: Станюкович, 2001). В том же соборе найден кусок крышки саркофага с вытесанными на тыльной стороне четвертями для крепления на ящик, тоже с бордюром и кругами (из них сохранилось два). Добавим крышку с орнаментом на цельнокаменном прямоугольном саркофаге в Преображенском собоpe, ассоциируемом с князем Иваном Дмитриевичем (ум. в 1302 г.; см.: Воронин, 1949. Рис. 7).

В Московском Кремле осевая линия с тремя кругами встречена на плитах середины - второй половины XIV в. с кладбищ Успенского собора (Шеляпина,

\footnotetext{
14 Вопрос о толщине ранних плит не так однозначен. По-видимому, тонкие плиты восходят к крышкам саркофагов, но на некрополях встречаются, причем в несомненно ранних контекстах, и плиты значительной (15-30 см) толщины. Обычно они без декора, часто грубо околоты, но в редких случаях несут традиционный трехгранно-выемчатый орнамент наиболее архаического типа. Этот вопрос нуждается в дополнительной проработке, которая со временем, возможно, позволит выявить две линии развития ранних плит.

15 Плита крупная, $198 \times 55,5 \times 56$ см, но тонкая, $8-9$ см.
} 
1971а. Табл.; 1971б. Рис. 11 и 26; Беленькая, 1971) и церкви Козьмы и Дамиана (Панова, 2006).

Вообще, на кладбищах Кремля, как и на кладбище владимирского Рождественского собора, обнаруживается вся цепочка развития орнамента от практически пустых полей, ограниченных треугольчатым бордюром, до насыщенных деталями композиций. Аналог, целиком тождественный плите № 2, встречен на кладбище церкви Троицы в Полях ${ }^{16}$, а частичные - в монастыре Богоявления за Торгом (часть крышки саркофага с большим кругом и осью, от которой отходят подобные «скатам» «ростки») ${ }^{17}$. Интересны параллели композиции «крупный круг по центру плиты», представленной небольшой частью плиты или крышки саркофага, найденной при раскопках под руководством Л.А. Беляева в 2015 г. в Зарядье, и хорошо известной крышкой саркофага из Старой Рязани (возможно, XIII в.). Все они сохраняют четырехстороннюю симметричность композиции.

Ситуация изменится, видимо, ближе к концу XIV - началу XV в., когда на кладбищах появятся трапециевидные плиты и асимметричные композиции орнамента, предвестники эпохи антропо- морфных саркофагов и надгробий ${ }^{18}$. В монастыре Рождества Богородицы таких нет, но трапециевидные ящичные саркофаги с такими же крышками встречаются.

Все саркофаги и плиты, согласно дате самой церкви, не ранее 1192-1196 гг. ${ }^{19}$. С учетом существующей сегодня хронологии, основанной на московском материале, эти погребальные сооружения можно относить к периоду с рубежа XII-XIII по конец XIV в., но вряд ли позже. Вероятно, можно считать установленным хронологически выраженный дрейф формы цельнотесаного саркофага от прямоугольного к трапециевидному в плане, что облегчит принятие в XV в. принципиально новой антропоморфной схемы. Наконец, встает ряд вопросов, касающихся появления плит раннего типа в Москве и их распространения там. Более полную картину этого раннего, все еще скрытого от нас (чтобы не сказать загадочного) процесса мы надеемся получить по мере развития проекта, который предварительно заявлен здесь как «Погребальные белокаменные сооружения Северо-Восточной Руси XII-XIV вв.: хронология, семантика, биографика».

\section{Литература}

Баталов А. Л., 2018. «Арабский цветок»: к вопросу о генезисе декоративных мотивов в московской архитектуре XIV-XV вв. // РА. № 3. (В печати.)

Баталов А.Л., Беляев Л.А., 2018. Зодчество Москвы и Твери второй половины XIII - первой половины XIV века // История русского искусства. Т. III. М.: Северный Паломник. С. 159-207.

Беленькая Д. А., 1971. Археологические наблюдения в Успенском соборе в 1966 г. // Древности Московского Кремля. М.: Наука. С. 158-163.

Беляев Л. А., 1996. Русское средневековое надгробие. Белокаменные плиты Москвы и Северо-Восточной Руси XIII-XVII вв. М.: ИА РАН. 568 с.

Беляев Л.А., 2006. Новое в изучении надгробных памятников Средневековья // Русское средневековое надгробие XIII-XVII вв. Материалы к своду. Вып. 1 / авт.-сост. Л.А. Беляев. М.: Наука. С. 7-30.

Беляев Л.А., 2013. Родовая усыпальница князей Пожарских и Хованских в Спасо-Евфимиевом монастыре Суздаля: 150 лет изучения. М.: ИА РАН; Нестор-История.

Беляев Л.А., 2015. Заметки по истории антропоморфных саркофагов в Европе и России // Города и веси средневековой Руси: археология, история, культура: к 60-летию академика Н.А. Макарова / ИА РАН; отв. ред. П. Г. Гайдуков. М. Вологда: Древности Севера. С. 365-374.

Беляев Л.А., 2016. Исламский восток и формирование материальной культуры Московской Руси: о методических подходах к оценке // Поволжская археология. № 2 (16). С. 18-43.

16 См.: Векслер, 2000. На том же кладбище встречено около дюжины фрагментов от ранних плит, но их археологический контекст в отчете представлен недостаточно ясно и нуждается в проработке.

17 Беляев, 1996. С. 286-298. Фото 21-23, 159. Табл. I.

18 На кладбище кремлевского Чудова монастыря такая плита с угловыми сегментами - «отсечками» и пущенными от них в изголовье, к центру, тончайшими линиями была даже использована как крышка антропоморфного саркофага (ее собственная дата, вероятно, вторая половина XIV - начало XV в.).

19 Одно погребение на кладбище снаружи от собора перекрыто саркофагом, то есть совершено ранее, но дата того и другого точно не установлена, вероятно, оба появились после 1190-х гг. 
Беляев Л.А., 2018. К хронологии антропоморфных саркофагов Руси XV-XVII вв.// КСИА. (В печати.)

Беляев Л.А., Сафарова И.А., Х Хохлов А.Н., 2018. Спасо-Преображенский собор в Тверском кремле: итоги раскопок 2012-2014 гг.// РА. № 2. C. 148-160.

Векслер А.Г., 2000. Исследования в Китай-городе в 1999 г. в г. Москве. Отчет об охранных археологических раскопках церкви Св. Троицы в Старых Полях (Третьяковский проезд, д. 1, 2) / Архив ИА РАН, Ф. 1. Р. 1. № 22456-22461.

Воронин Н.Н., 1949. Раскопки в Переславле-Залесском // Материалы и исследования по археологии древнерусских городов. Т. 1. М. - Л.: Изд. АН СССР. С. 193-202. (МИА; т. 11).

Иоаннисян О. М., 2018. Зодчество конца XII - первой половины XIII века // История русского искусства. Т. II. Ч. 3. М. (В печати.)

Иоаннисян О.М., Глазов В.П., Зыков П.Л., 1998. Исследования во Владимире в 1997 году / Архив ИА РАН. Р-1. № 20918-20921.

Леонтьев А.Е., Иоаннисян О.М., 2008. Погребения XI в., церковь Иоанна Предтечи в Ростове и история саркофага св. Леонтия Ростовского // Московская Русь. Проблемы археологии и истории архитектуры: к 60-летию Л.А. Беляева. М.: ИА РАН. С. 43-51.

Панова Т.Д., 2006. Ранний этап развития московского надгробия. Материалы XIV-XVI вв.
Из собрания музея-заповедника «Московский Кремль»// Русское средневековое надгробие XIII-XVII вв. Материалы к своду. Вып. 1/ авт.-сост. Л. А. Беляев. М.: Наука. С. 31-36.

ПСРЛ. Т. І. Лаврентьевская летопись. Рязань: Александрия. 2001. 586 стр. (Серия «Русские летописи»; т. 12).

Русское средневековое надгробие XIII-XVII вв. Материалы к своду. Вып. 1 / авт.-сост. Л. А. Беляев. М.: Наука, 2006. 359 с.

Седов Вл. В., 2017. Саркофаг князя Всеволода Большое гнездо в Успенском соборе (по данным Н. Н. Воронина) // КСИА. Вып. 248. С. 278-289.

Сиренов A.B., 2010. Степенная книга и русская историческая мысль XVI-XVIII вв. М. - СПб.: Альянс-Архео. 552 с.

Сиренов А.В.,2011.Описаниедревнерусскихнекрополей в рукописях XVI-XVII вв.// PA. № 1. C. 106-110.

Станюкович A. K., 2001. Гробница преподобного Никиты Столпника, переславского чудотворца: Церков.-археол. очерк. Звенигород: Изд. авт. $48 \mathrm{c.}$

Шеляпина Н. С., 1971а. Надгробия XIII-XIV вв. из раскопок в Московском Кремле // СА. № 3. С. 284-289.

Шеляпина Н. С., 1971б. Археологические наблюдения в Московском Кремле в 1963-1965 гг. // Древности Московского Кремля. М.: Наука. С. 117-157. (МИА. № 167). 


\section{Об одном погребении могильника Шекшово в Суздальском Ополье}

В 20 км к северо-западу от Суздаля по обоим берегам p. Ирмез (приток р. Нерль) располагается Шекшовский археологический комплекс, включающий в себя 16 средневековых поселений и могильник Шекшово 9 (Федорина, Красникова, 2015). В 2011-2018 гг. могильник, занимающий участок не менее 7 га и в настоящее время оказавшийся на пахотном поле, исследовался Суздальской археологической экспедицией Института археологии РАН под руководством академика Н.А. Макарова. Раскопанная площадь составляет 2030 кв.м. На некрополе открыты остатки снивелированных курганов, содержащие погребения по обрядам кремации на стороне и ингумации, исследованы в пахотном слое переотложенные погребения по обряду поверхностного рассыпания кремированных на стороне костей, а также бескурганные ингумации в материковых ямах (Макаров, Зайцева, Красникова, 2013; Макаров, Красникова, Зайчева, 2013; Макаров, Зайцева, Красникова, 2015; Макаров, Зайцева, Угулава, 2016а; 2016б; Макаров и др., 2017). Всего изучено 21 непотревоженное погребение по обряду ингумации в ямах, большая часть которых уже введена в научный оборот (Макаров, Зайцева, 2016). Среди новых комплексов-расчищенное в 2017 г. погребение, получившее номер 6 (раскоп 2), которое заслуживает, на наш взгляд, специального рассмотрения (рис. $1-5)^{1}$.

Пятно ямы грунтового бескурганного погребения, заполненное слоями коричневого и серокоричневого гумусированного суглинков, было обнаружено после снятия пахотного слоя. Оно имело подпрямоугольную форму размерами $266 \times 118-125$ см и было вытянуто в направлении запад- восток с небольшим отклонением к югу. В заполнении ямы фиксировались мелкие угольки², а также редкие одиночные кальцинированные кости, собраны небольшие обломки лепной керамики, фрагмент стеклянной желтой лимоновидной бусины (№ 1; рис. $4^{3}$ ), бронзовая обувная подвеска с двумя волютами (№ 2; рис. 5), оплавленный бронзовый предмет (№ 3) и серебростеклянная бусина (№ 4; рис. 4).

На глубине 15-20 см от уровня поверхности материка или 45-48 см от уровня современной дневной поверхности в яме расчищено погребение по обряду ингумации. Остатков гроба не найдено. Костяк средней сохранности лежал на спине головой на запад с отклонением к югу $15^{\circ}$. Череп был немного склонен к югу, частично сохранились ключицы и позвонки нижнего отдела позвоночника. Руки были широко раскинуты и чуть согнуты в локтях, кости кистей рук не сохранились (рис. 1). Ноги лежали прямо параллельно друг другу. Длина костяка равна 158 см.

Определение костей скелета произведено М.В. Добровольской. Она указывает, что все швы черепа открыты, корни третьих моляров верхней челюсти сформированы не полностью, на нижней челюсти зубы мудрости отсутствуют. Все эпифизы крупных трубчатых костей приросли полностью. Возраст индивида составляет около 20 лет. Миниатюрность черепа и посткраниального скелета, строение лобной кости однозначно указывают на женский пол индивида.

Биологические особенности: фрагмент лобной кости в области назиона и глабеллы позволяет предполагать слабое выступание носовых костей.

\footnotetext{
1 Авторы признательны Н. А. Макарову за возможность публикации материала и благодарны всем участникам Суздальской экспедиции, участвовавшим в разборке и обработке погребения.

${ }^{2}$ Определение собранных по площади ямы угольков по ${ }^{14} \mathrm{C}$ дало дату 675-782 гг. (ГИН-15679).

3 В статье даны полевые номера находок.
} 


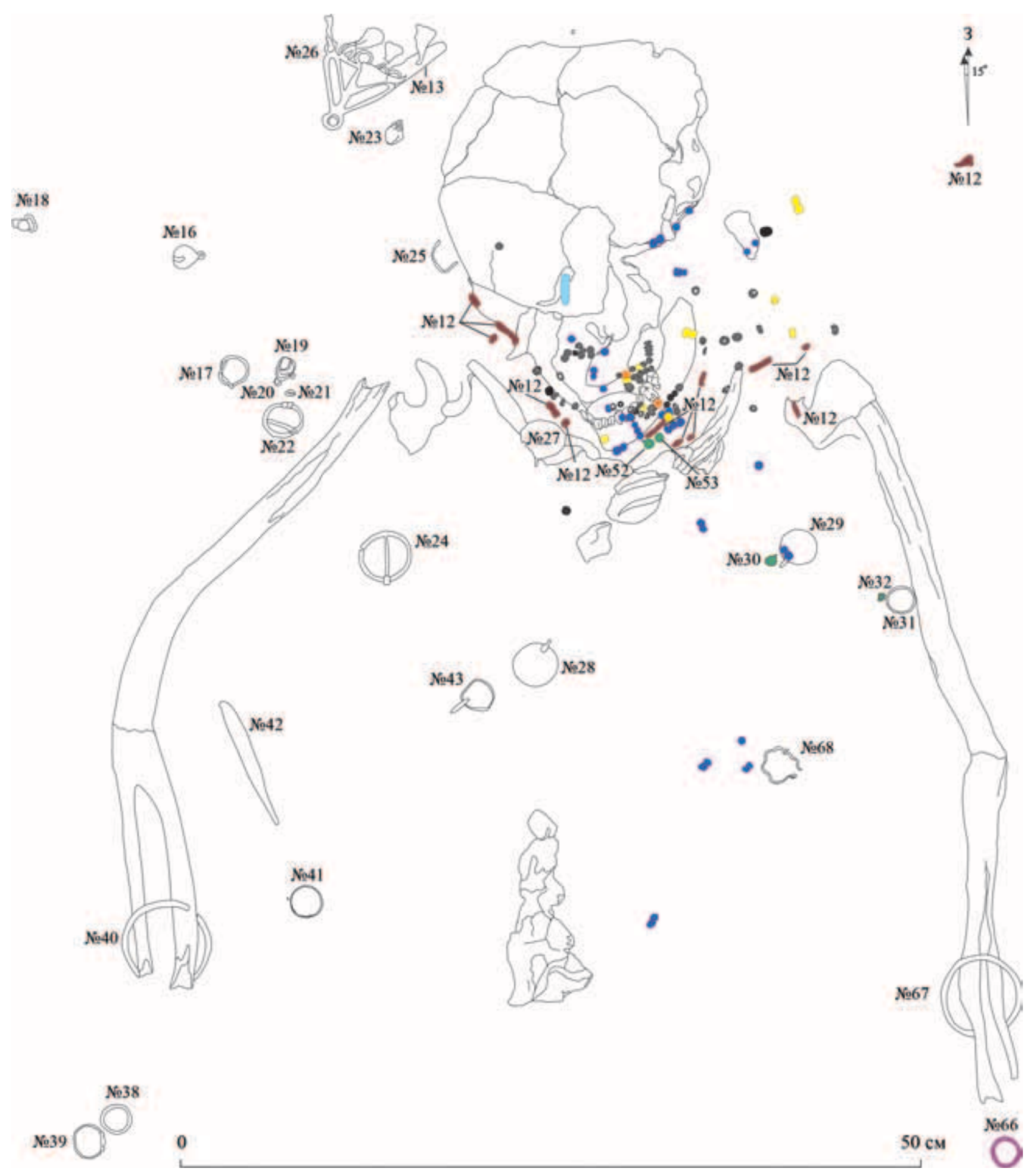

Рис. 1. Шекшово 9. Погребение 6. План верхней части

Фрагмент верхней челюсти в области грушевидного отверстия указывает на то, что череп характеризовался прогнатизмом. Обе черты характерны для типичного образа финской внешности. Однако пользоваться этой информацией нужно крайне осторожно, так как индивидуальные морфологические признаки не могут являться расово диагностическими.
В могилу за ногами погребенной был поставлен лепной гладкий приземистый подлощенный горшок (№ 10; рис. 2), свойственный для мерянских форм керамики (Макаров, 2012. С. 200), рядом с которым лежало железное шило с остатками деревянной рукояти (№ 8; рис. 2). Положение орудий труда в головах или ногах погребенных 

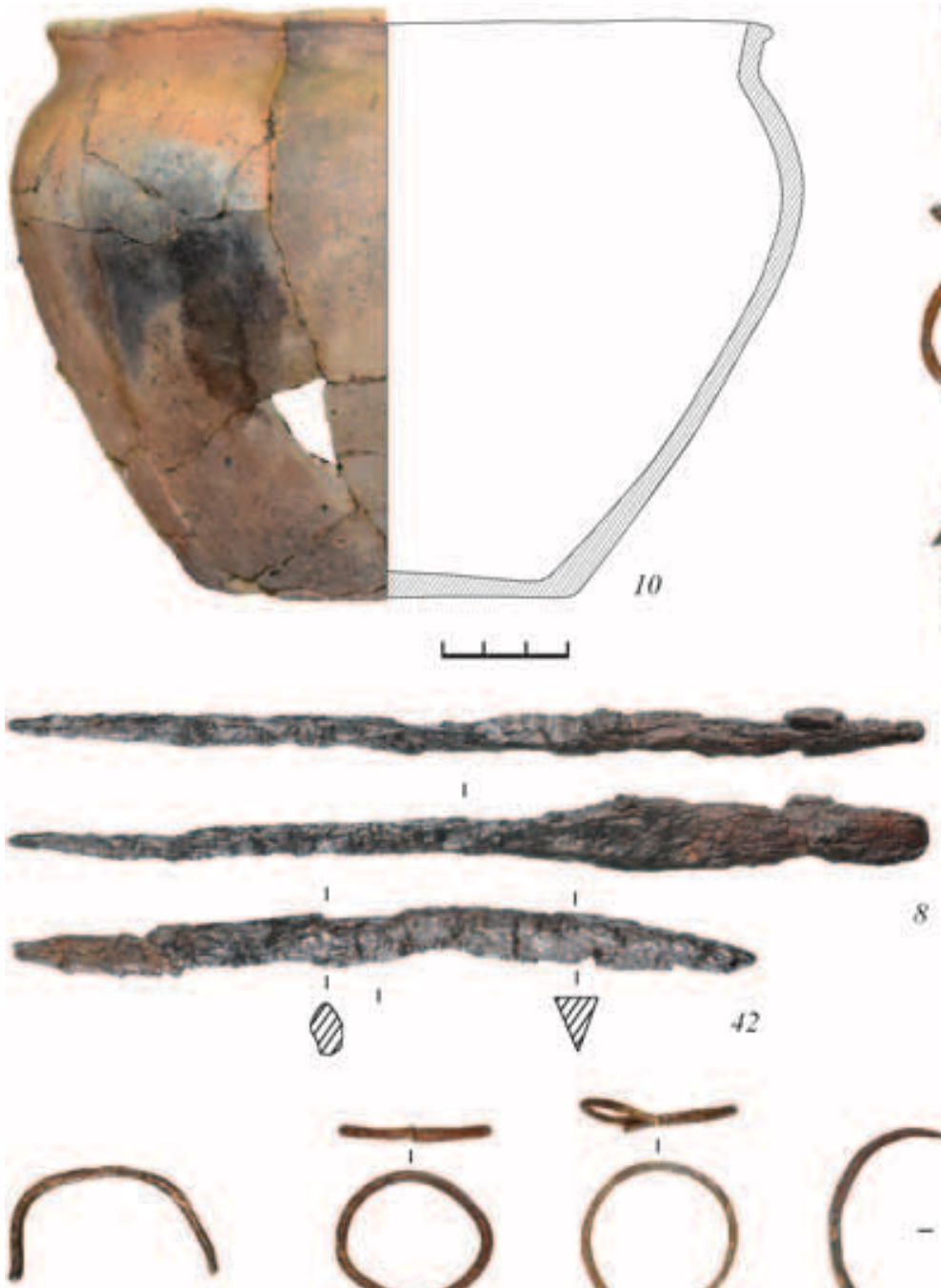

25
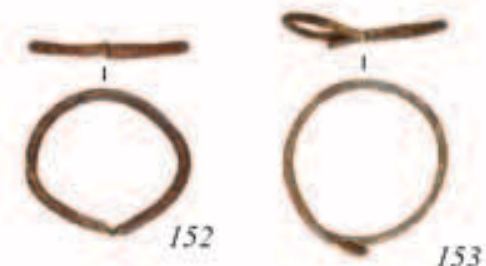

153
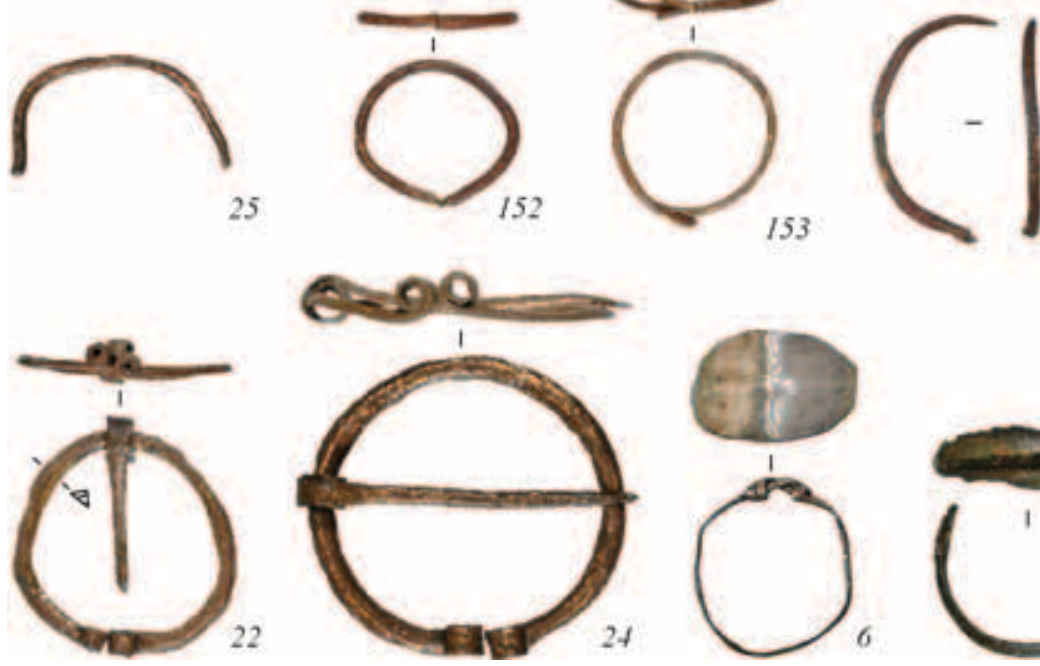

154
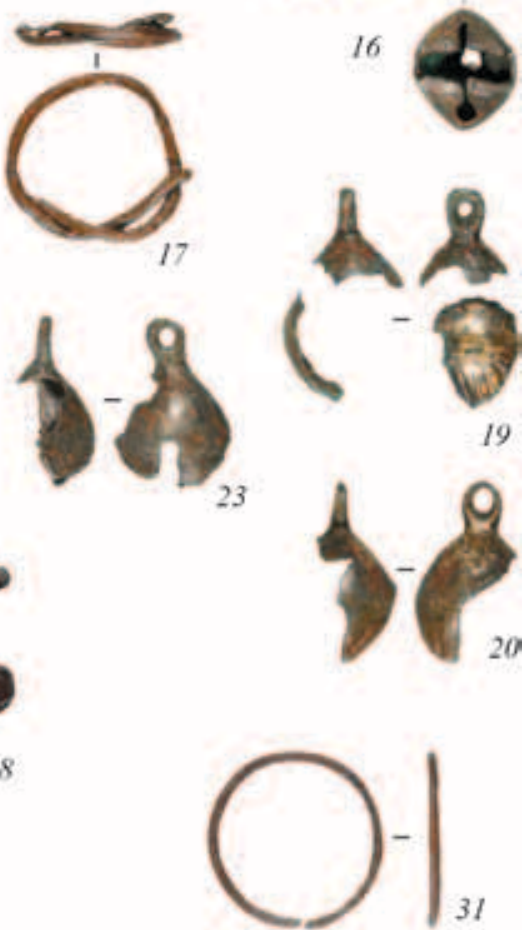

23

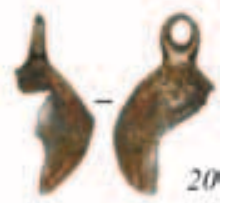

8

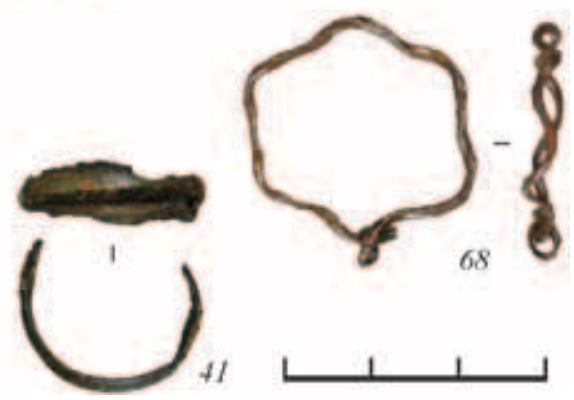

Рис. 2. Шекшово 9. Погребение 6. Находки

10 - лепной сосуд (реконструкция и рисунок Н.Д. Угулавы); 18 - пряжка; 16, 19, 20, 23 - бубенчики; 17 - кольцо; 8 - шило; 42 - нож; 25, 31, 43, 68, 152-154 - височные кольца; 22, 24 - фибулы; 6, 41 - перстни. 10 - глина; 8,42 - железо; 6 - серебро; остальное - цветной металл. Номера на рисунке соответствуют полевым номерам 
женщин - одна из характерных черт восточнофинского погребального обряда, берущая свое начало в культуре рязано-окских могильников (Белоцерковская, 2003.). В Шекшове еще в шести комплекcax обнаружены специально положенные в могилу предметы (кроме сосудов), при этом только в двух погребениях девочек первой половины XI в. это были орудия труда-игольник и пряслице (погр. 16), нож (погр. 4). Около локтевой кости правой руки располагался небольшой железный нож с горбатой спинкой, сделанный в технике трехслойного пакета, с остатками деревянной рукояти, который лежал острием к голове (№ 42; рис. 2).

Остальные находки, обнаруженные в погребении, были деталями костюма. Возможно, некоторые вещи были смещены со своих первоначальных мест, поэтому точная реконструкция костюма затруднительна.

Под черепом найдены четыре бронзовых проволочных перстнеобразных височных кольца диаметром около 2,5 см, которые служили для крепления прически (№ 25, 152-154; рис. 2). Находки нескольких перстнеобразных колец под черепом известны и в других погребениях Шекшова, например в погребении 12 (Зайцุева, 2017. С. 193-194).

Вероятно, на погребенной был головной убор на жесткой основе, поскольку справа от головы лежали фрагменты луба (№ 13). Около них располагалась бронзовая треугольная подвеска размерами $8,4 \times 5,2$ см с рядом из пяти колечек по низу, в которых висели привески-лапки (№ 26; рис. 3$)^{4}$.

Большие треугольные подвески с шумящими привесками рассматриваются исследователями как характерный этноопределяющий «мерянский» тип украшения. Впервые об этом написал еще А. С. Уваров (1872. С. 90). Его точка зрения была развита Е.И. Горюновой (1961. С. 101), Л. А. Голубевой (1982), Е.А. Рябининым, А.Е. Леонтьевым (Леонтьев, 1996. С. 173). Л. А. Голубева посвятила треугольным подвескам специальную работу, указав, что экземпляры, аналогичные нашему (выделенный ею тип III, вариант 2), многочисленны (более 100 экз.) и происходят из не менее 32 могильников (Голубева, 1982. С. 117).

В большинстве захоронений, где удалось проследить положение этих украшений, они найдены на плечах. Если в погребении имелось более одной подвески, они лежали на обоих плечах, если одна, то чаще на правом плече (19 случаев из 35), как и в нашем случае (Голубева, 1982. С. 117-118). Мож- но предположить, что треугольные подвески все же не нашивались на одежду в районе плеч, а относились к головному убору: были накосными или крепились на ленты. Подвески этого типа датируются Л. А. Голубевой преимущественно X-XI вв. А. Е. Рябинин уточняет, что, несмотря на то что треугольные подвески общепризнаны в качестве индикатора центральной группы мери, большинство их находок происходит из курганов (80 из 100 экз.), то есть из памятников, оставленных уже смешанным населением (Рябинин, 1997. С. 176).

А.А.Спицын указывал, что в погребениях во владимирских курганах изредка встречаются также в районе плеч кисти из бубенчиков (Cnuџын, 1905. С. 104. Рис. 401). Вероятно, такая кисть была и в рассматриваемом нами комплексе: на участке справа от черепа найдены лежащие в беспорядке четыре бронзовых грушевидных крестопрорезных бубенчика (№ 16, 19, 20, 23; рис. 2), обрывок бронзовой согнутой проволоки (№ 21) и проволочное перстнеобразное височное колечко диаметром 2 см с заходящими друг за друга концами, на которое они могли крепиться (№ 17; рис. 2). Возможно, шумящая кисть также относилась к головному убору. По наблюдениям Ю.В. Степановой, бубенчики зафиксированы в 20\% женских костюмных комплексах погребенных в курганах Верхневолжья, однако находки кистей из бубенчиков очень редки. Такие кисти на колечках встречены в районе плеч и пояса (Степанова, 2009. С. 45-46). Справа от головы найден обломок лировидной пряжки (№ 18; рис. 2), по-видимому служившей для пристегивания к шапочке свисающих деталей украшения головы.

Одежда женщины была многослойной, о чем свидетельствуют две бронзовые застежки-фибулы. Обе они лежали в районе правого плеча и правой стороны груди. Фибулы, или сюльгамы, одинаковы по типу: это подковообразные застежки с дугой треугольного (диаметр 2,6 см - № 22; рис. 2) или трапециевидного (диаметр 3,7 см - № 24; рис. 2) сечений и раскованными и завернутыми в спираль концами. Иглы фибул также бронзовые.

Кости грудной клетки и позвоночника практически не сохранились, однако на участке, занимаемом туловищем, расчищены многочисленные мелкие предметы, располагающиеся бессистемно по всей площади. Это бронзовые перстнеобразные височные кольца из волоченой проволоки диаметром 2 см (№ 31,43 ; рис. 2) и кольцо диаметром 2,9 см, сделанное из проволоки, бывшей до этого в витом браслете

${ }^{4}$ Возможно, подвеска была положена в лубяном футляре отдельно. 
(№ 68; рис. 2), бронзовый и серебряный завязанный пластинчатые широкосрединные с выпуклыми продольными валиками перстни (№ 41, 6; рис. 2), стеклянные сине-фиолетовые бусы (№ 69-72; рис. 4) и нашивки (?) из легкоплавкого сплава. Последние практически полностью разложились и были зафиксированы в виде выпуклых скорлупок диаметром около 5 мм без системы крепления. Всего отмечено 15 таких скорлупок на левой стороне груди и справа в районе пояса. Все эти вещи могли или нашиваться на одежду, или украшать крепившиеся к шапочке наспинную лопасть или ленты. Не исключено, что стеклянные бусины могли быть и в ожерелье. Видимые остатки деятельности землероев на этом участке не отмечены, поэтому определенно интерпретировать хаотичность расположения находок в области грудной клетки возможности не предоставляется. Еще один бронзовый пластинчатый разомкнутый перстень (?) с суживающимися концами без орнамента лежал около голени правой ноги (№ 5; рис. 5; см. ниже).

В районе шеи погребенной находились железная дротовая гривна и ожерелье из стеклянных и гагатовых бусин и металлических подвесок. И гривна, и ожерелье плотно охватывали шею.

Гривна из кованого неперекрученного дрота квадратного неравномерного сечения размерами от 2,3×2,3 до $4 \times 4$ мм была сильно фрагментирована (№ 12; рис. 3). В погребении найден железный наконечник гривны ромбической формы, украшенный геометрическим орнаментом, сделанным колесиком. Его размеры без отломанного конца с крючком составляют $11 \times 2$ см. Пластина наконечника была приварена к обручу. Второй наконечник отсутствует. Это первая находка гривны в ингумации в Шекшове. Железные гривны встречены на широкой территории от Швеции на западе до восточнофинских могильников на востоке. По мнению М.В. Фехнер, большая часть найденных на Руси железных дротовых гривен была привозной из Скандинавии (Швеция, Финляндия), однако она не исключала и их местное производство (Фехнер, 1967. С. 62, 63). Г. Л. Новикова, составившая каталог железных гривен с территории Восточной Европы (70 экз.), также склоняется к скандинавскому происхождению этих украшений (Новикова, 1991. С. 197). Необычен железный наконечник, приделанный к обручу. При анализе серебряных гривен из клада в устье р. Варзуги В.М. Горюнова и О.В. Овсянников указывают на скандинавское происхождение наконечников гривен ромбической формы на основе многочисленных аналогий предметов из кладов (Горюнова, Овсянников, 2002. С. 219-220). Необходимо отметить, что бронзовые гривны с ромбическими наконечниками с крючком найдены в могильнике Минино в погребении XI в. и в марийском Русенихинском могильнике (Зайцева, 2008. С. 106-107; Никитина, Пузаткина, 2017. С. 198). Железные экземпляры гривен с ромбическими наконечниками нам пока неизвестны. По наблюдениям В.В. Бейлекчи, железные дротовые гривны периодически встречаются у мордвы (Бейлекчи, 2005. С. 44). Возможно, это изделие местного ремесла, выполненное в подражание серебряным гривнам.

Ожерелье состояло из 103 бус (96 стеклянных и семи гагатовых; рис. 4), трех серебряных подвесок, сделанных из монет, и четырех маленьких бронзовых выпуклых подвесочек-скорлупок с петельчатыми ушками (№ 30, 32, 52, 53; рис. 3). Бусы были частично перемещены по сторонам, а частично при разложении мягких тканей оказались во рту у женщины, тем не менее фиксируется не менее трех рядов бус. Под черепом найден небольшой фрагмент согнутой в кольцо бронзовой проволоки, возможно, служившей застежкой ожерелья (№ 151; рис. 3).

Из трех монет, находившихся в ожерелье, две восточные - подражания саманидским дирхемам Насра б. Ахмада 5 , получившие распространение, по наблюдениям А.А. Гомзина, во второй половине X в. (№ 27, 28; рис. 3), одна византийская, милиарисий императоров Константина VII и Романа II 945-959 гг. (№ 29; рис. 3). Монеты были подвешены за серебряные ушки: восточные за петельчатые, византийская за пластинчатое рифленое.

Редкость находок византийских серебряных монет на древнерусских памятниках, и особенно в погребениях, неоднократно отмечалась археологами (Равдина, 1988, С. 145; Шевциов, 2017; Макаров, Гайдуков, Гомзин, 2016. С. 65). По наблюдениям А. О. Шевцова, на территории Древней Руси известны пять кладов с монетами Константина VII и Романа II. Все они зарыты в пределах 970-990 гг. (Шевцุов, 2017. С. 303). Основная масса кладов и погребений с милиарисиями тяготеет к бассейну Днепра и Северо-Западу, маркируя путь «из варяг в греки» (Шевцуов, 2017. С. 302). По данным Н.А. Макарова, в Суздальском Ополье ранее были известны лишь четыре находки милиарисиев: две из них были сделаны А.С. Уваровым при

5 Определение А. А. Гомзина. 

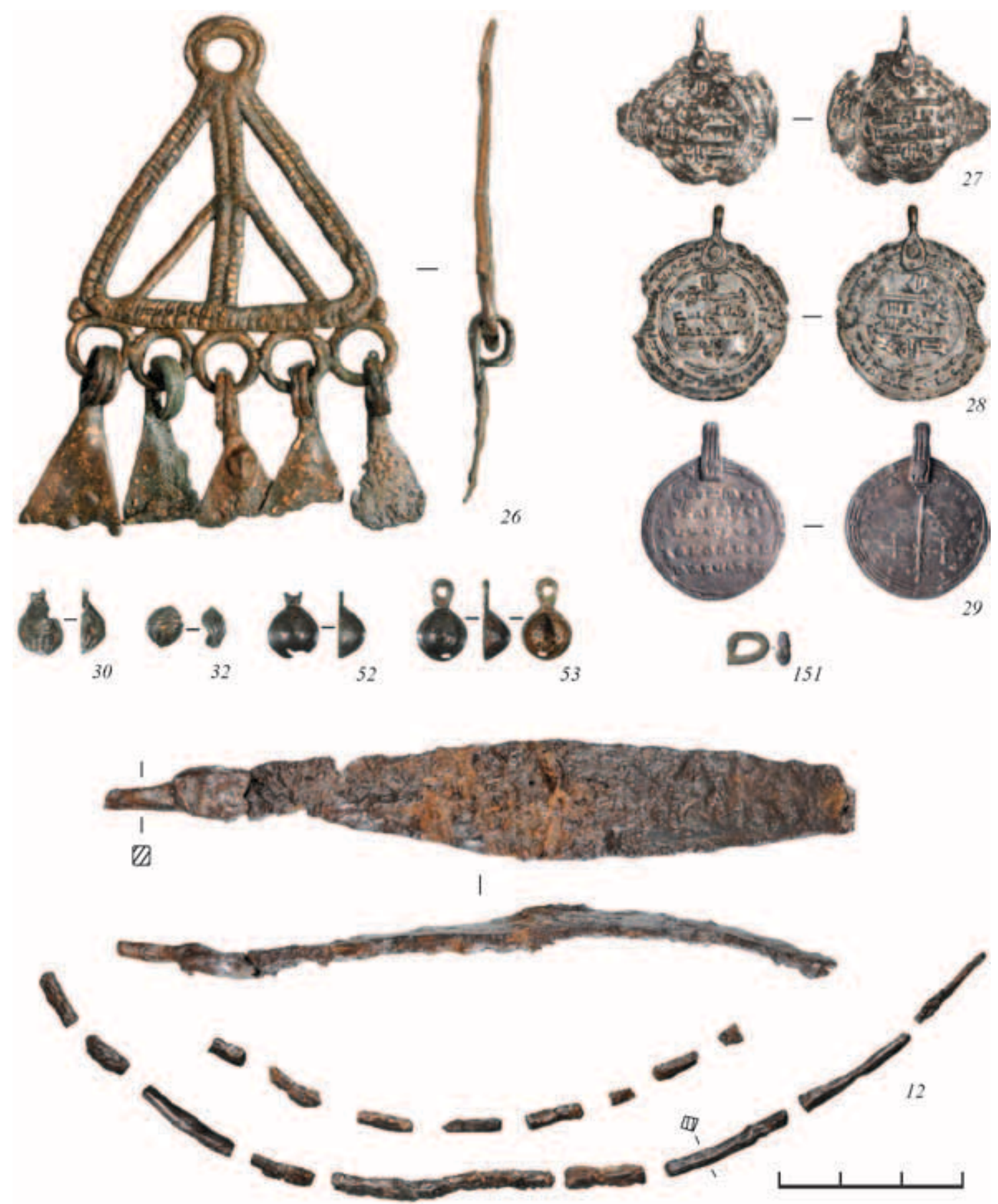

Рис. 3. Шекшово 9. Погребение 6. Находки

26 - подвеска; 27-29 - подвески из монет; 30, 32, 52, 53 - скорлупообразные подвески; 151 - застежка ожерелья; 12 - гривна. 26, 30, 32, 52, 53, 151 - цветной металл; 27-29- серебро; 12 - железо. Номера на рисунке соответствуют полевым номерам 
Таблица 1. Форма тулова стеклянных бус из погребения 6.

\begin{tabular}{|c|c|c|c|c|c|}
\hline \multicolumn{4}{|c|}{ Форма тулова } & \multirow{3}{*}{$\begin{array}{c}\text { Кол-во } \\
51 \\
\end{array}$} & \multirow{3}{*}{\begin{tabular}{|l|}
$\%$ \\
51 \\
\end{tabular}} \\
\hline Форма поперечного сечения & \multicolumn{3}{|c|}{ Форма продольного сечения } & & \\
\hline \multirow[t]{12}{*}{ округлое } & \multirow{7}{*}{$\begin{array}{l}\text { шаровидное } \\
\text { усеченное дважды }\end{array}$} & \multirow[t]{3}{*}{ с шейками } & одночастные & & \\
\hline & & & двухчастные & 1 & 1 \\
\hline & & & четырехчастные & 1 & 1 \\
\hline & & \multirow[t]{4}{*}{ без шеек } & одночастные & 17 & 17 \\
\hline & & & двухчастные & 11 & 11 \\
\hline & & & трехчастные & 3 & 3 \\
\hline & & & четырехчастные & 1 & 1 \\
\hline & цилиндрическое & без шеек & одночастные & 7 & 7 \\
\hline & \multirow[t]{2}{*}{ эллипсоидное } & с шейками & двухчастные & 1 & 1 \\
\hline & & без шеек & одночастные & 1 & 1 \\
\hline & кольцевидное & без шеек & одночастные & 1 & 1 \\
\hline & \multicolumn{3}{|l|}{ нельзя установить } & 1 & 1 \\
\hline винтообразное & $\begin{array}{l}\text { шаровидное } \\
\text { усеченное дважды }\end{array}$ & без шеек & одночастные & 3 & 3 \\
\hline граненое & призматическое & 8-гранное & & 1 & 1 \\
\hline \multicolumn{4}{|l|}{ Итого } & 100 & 100 \\
\hline
\end{tabular}

раскопках курганов в Василькове, еще две - находки последнего десятилетия из Шекшова и Тарбаева (Макаров, Гайдуков, Гомзин, 2016б. С. 65$)^{6}$.

Гладкие выпуклые литые подвески-скорлупки (две с рифлением по низу) имеют диаметр 8 мм. Подобные изделия производились в Волжской Болгарии (Казаков, 2007. С. 203. Рис. XV; Музей... 2016. С. 117). Вероятно, они использовались и как пуговицы, и как подвески. В качестве подвесок они обнаружены в могильниках Пермского Предуралья и марийцев (Белавин, 2000. С. 109; Никитина, Пузаткина, 2017. С. 198).

Большинство стеклянных бус имеют округлое поперечное сечение (96 экз.). Среди них преобладают шаровидные усеченные дважды одночастные (68 экз.) с шейками (лимоновидные) и без них (зонные), двухчастных значительно меньше (12 экз.), трехчастных - всего три, четырехчастных - два экземпляра. В этой же группе присутствуют семь цилиндрических одночастных, две эллипсоидные, одночастная и двухчастная, а также одна кольцевидная одночастная. Еще у одной бусины форма продольного сечения не устанавливается.

Три бусины отнесены к винтообразным шаровидным усеченным дважды, все они одночастные. Одна бусина граненая призматическая с восемью гранями (табл. 1).

Практически все бусы (95 экз.) по диаметру/ширине тулова входят в группу микробусин по Ю. Кальмеру (до 0,8 см) и всего две - в группу средних (от 0,9 до 1,7 см) (Callmer, 1977. Р. 35). У трех этот параметр не установлен (табл. 2).

Высота бус колеблется от 0,2 до 1,9 см. Больше всего экземпляров с высотой 0,4 см (20 экз.) и $0,5 \mathrm{~cm}$ (18 экз.), меньше с высотой $0,35 \mathrm{~cm}$ (10 экз.), 0,45 см (9 экз.), и 0,3 см (8 экз.). Остальные размеры единичны. У двух бус этот показатель не установлен (табл. 3).

Цветовая палитра бусин представлена семью тонами: желтым, синим, сине-фиолетовым, бирю-

Таблица 2. Диаметр/ширина тулова стеклянных бус из погребения 6.

\begin{tabular}{|l|c|c|c|}
\hline \multicolumn{2}{|c|}{ Диаметр/ширина тулова, см } & Кол-во & \% \\
\hline \multirow{4}{*}{ малые } & 0,30 & 1 & 1 \\
\cline { 2 - 4 } & 0,50 & 5 & 5 \\
\cline { 2 - 4 } & 0,55 & 16 & 16 \\
\cline { 2 - 4 } & 0,60 & 25 & 25 \\
\cline { 2 - 4 } & 0,65 & 23 & 23 \\
\cline { 2 - 4 } & 0,70 & 20 & 20 \\
\cline { 2 - 4 } & 0,75 & 2 & 2 \\
\cline { 2 - 4 } & 0,80 & 3 & 3 \\
\hline средние & 0,90 & 1 & 1 \\
\cline { 2 - 4 } & 1,0 & 1 & 1 \\
\hline нельзя установить & & 3 & 3 \\
\hline Итого & 100 & 100 \\
\hline
\end{tabular}

${ }^{6}$ Еще один милиарисий обнаружен на могильнике Шекшово 9 в поверхностных сборах весной 2018 г. 
Таблица 3. Высота тулова стеклянных бус из погребения 6.

\begin{tabular}{|c|c|c|}
\hline Высота тулова, см & Кол-во & $\%$ \\
\hline 0,20 & 1 & 1 \\
\hline 0,25 & 1 & 1 \\
\hline 0,30 & 8 & 8 \\
\hline 0,35 & 10 & 10 \\
\hline 0,40 & 20 & 20 \\
\hline 0,45 & 9 & 9 \\
\hline 0,50 & 18 & 18 \\
\hline 0,55 & 4 & 4 \\
\hline 0,60 & 4 & 4 \\
\hline 0,65 & 2 & 2 \\
\hline 0,70 & 2 & 2 \\
\hline 0,75 & 1 & 1 \\
\hline 0,80 & 2 & 2 \\
\hline 0,85 & 2 & 2 \\
\hline 0,90 & 1 & 1 \\
\hline 1,00 & 5 & 5 \\
\hline 1,05 & 1 & 1 \\
\hline 1,10 & 1 & 1 \\
\hline 1,40 & 2 & 2 \\
\hline 1,45 & 2 & 2 \\
\hline 1,55 & 1 & 1 \\
\hline 1,90 & 1 & 1 \\
\hline Нельзя установить & 2 & 2 \\
\hline Итого & 100 & 100 \\
\hline
\end{tabular}

зовым, серо-голубым, черным, бесцветным. Половина бусин двухслойные. В большинстве случаев (47 экз.) между слоями стекла проложена еще и серебряная фольга. За исключением двух, у которых для имитации золотой фольги внешний слой сделан из прозрачного стекла желтого цвета (ложнозолотостеклянные), остальные имеют и внутренний, и внешний слои из бесцветного стекла (серебростеклянные). Три бусины состоят из двух слоев стекла без фольги: полупрозрачного желтого (внешнего) и бесцветного (внутреннего). Другая половина бус - однослойные из стекла всех названных цветов, за исключением бесцветного. Среди них большинство из полупрозрачного стекла сине-фиолетового цвета, значительно меньше из непрозрачного желтого и черного. По одной бусине - из полупрозрачного синего, бирюзового и непрозрачного сероголубого стекла (табл. 4).

Декорированы только пять черных округлых бусин - четыре зонные и одна цилиндрическая. Они украшены плоскими продольными многократными полосами из белого стекла.

По технологии изготовления стеклянные бусины можно разделить на две группы: из тянутой трубочки и выполненные навивкой. Бусин из трубочки - две трети (68 экз.), навитых - треть (32 экз.).

Среди бус из трубочки большая часть (47 экз.) двуслойные с прокладкой из серебряной фольги (рис. 4 , а). Большинство серебростеклянных (рис. 4 , a, 4, 37, 46, 48, 55-59, 63, 74-76, 80, 86, 91, 92, 94, 98, $100-102,106,108,109,110,114,115,117,119,120$, $122-126,129,133,134,136-138,140,141)$ и только две ложнозолотостеклянные (рис. 4, a, 45, 112). Их форма - лимоновидная (рис. 4, а, 4, 37, 45, 46, 55-59, 63, 74-76, 80, 86, 91, 92, 94, 98, 100-102, 106, $108-110,112,114,115,117,119,120,122-126,129$, $133,134,136-138,140,141)$, кроме одной зонной (рис. 4, a, 48). Бусы одночастные и одна четырехчастная с неглубокими перехватами между дольками (рис. 4, а, 129). Следует заметить, что большая часть бус этого типа имеет очень небольшую высоту тулова без учета шеек - 2-3 мм, что делает их похожими на колесики (41 экз.) (рис. 4, а, 4, 45, 46, 48, 55-57, 63, 74-76, 80, 86, 91, 92, 94, 98, 100-102, 106, $108-110,112,114,115,117,119,120,122-124,126$, 133, 134, 136-138, 140, 141).

Таблица 4. Цвета стеклянных бус из погребения 6.

\begin{tabular}{|c|c|c|c|c|}
\hline \multicolumn{2}{|r|}{ Цветовая гамма } & & Кол-во & $\%$ \\
\hline \multirow[t]{6}{*}{ однослойные } & сине-фиолетовый & & 30 & 30 \\
\hline & желтый & & 10 & 10 \\
\hline & черный & & 7 & 7 \\
\hline & серо-голубой & & 1 & 1 \\
\hline & бирюзовый & & 1 & 1 \\
\hline & синий & & 1 & 1 \\
\hline \multirow[t]{3}{*}{ двухслойные } & \multirow[t]{2}{*}{ желтый + бесцветный } & без фольги & 3 & 3 \\
\hline & & с фольгой & 2 & 2 \\
\hline & бесцветный + бесцветный & с фольгой & 45 & 45 \\
\hline \multicolumn{2}{|l|}{ Итого } & & 100 & 100 \\
\hline
\end{tabular}



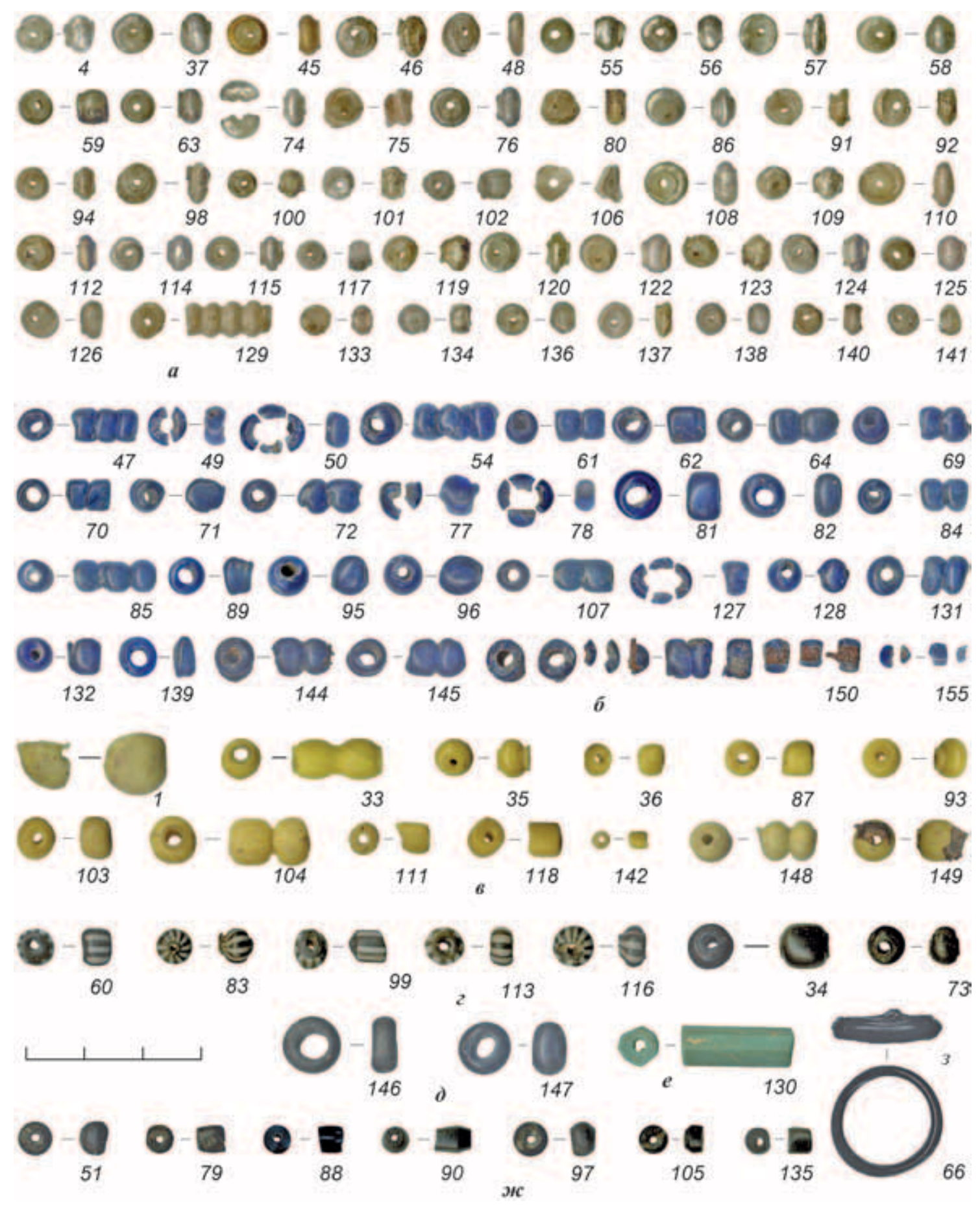

Рис. 4. Шекшово 9. Погребение 6. Стеклянные и гагатовые украшения

$a$-стеклянные бусины из трубочки с прокладкой из серебряной фольги; $\sigma$ - стеклянные навитые бусины из сине-фиолетового полупрозрачного стекла; 8 - стеклянные бусины из трубочки из желтого стекла (однослойные и двуслойные); 2 - стеклянные бусины из трубочки из черного непрозрачного стекла и с полосатым декором; $\partial$ - стеклянные навитые бусины из бирюзового и синего стекла; $e$ - стеклянная бусина из трубочки из серо-голубого непрозрачного стекла; ж-гагатовые бусины; з - стеклянный перстень. Номера на рисунке соответствуют полевым номерам 
В Старой Ладоге бусы с серебряной фольгой из трубочки (группа VIII, подгруппа 1) обнаруживаются в нижних слоях городища, начиная от горизонта $\mathrm{E}_{3}$ (VIII - первая половина IX в.) до уровня построек горизонта Д (Х в.) включительно, но основная их масса находится в горизонтах $\mathrm{E}_{1}$ и $\mathrm{E}_{2}$, датируемых IX в. Это самый ранний тип бус из трубочек на городище (Львова, 1968. С. 82, 84). 3. А. Львова выделяет ранние и поздние бусы этого типа ${ }^{7}$. К периоду VIII - начала IX в. относятся многочастные экземпляры с неглубоким перехватом. Грубым раскалыванием без полирования краев их делили на отдельные лимоновидные дольки. Но делали это, как считает 3. А. Львова, не мастера, а приобретавшие их коробейники. Покрытие таких бус могло быть желтым, цвета морской волны или бесцветным. Среди экземпляров второй половины IX - X в. преобладают украшения с желтым покрытием и глубокими перехватами. Вместо многочастных превалируют трех-, двух- и одночастные лимонообразные бусы с профессионально полированными краями. Судя по этим признакам, шекшовские бусы должны относиться к ранней группе.

В Мининском археологическом комплексе одночастные бусы происходят из погребений второй половины Х в. могильника Минино II (Захаров, Кyзина, 2008. С. 186. Табл. 86. Тип I-3: 11) и из комплекса середины XI - начала XII в. селища Минино VI (Захаров, Кузина, 2008. С. 189. Табл. 87. Тип I-3: 11). Этот тип бус отнесен исследователями к третьей хронологической группе (X-XI вв.), при этом основной период их бытования ограничен серединой XI в., а в комплексах второй половины столетия они могут встречаться лишь изредка (Захаров, Кузина, 2008. С. 196). Аналогичные бусы происходят с поселений центрального Белозерья - Крутик и Никольское V. Верхняя дата последнего не выходит за пределы начала XI в. Такая же верхняя хронологическая граница была принята в литературе для Крутика до недавнего времени. Однако в ходе работ последних лет на одном из принадлежавших поселению могильников Кладовка II и на северной и восточной окраинах самого поселения были выявлены слои, относящиеся к концу $\mathrm{X}$ - первой половине XI в. (Захаров, 2012. С. 216, 221, 223, 235, 238. Рис. 7; 2015. Рис. II-IV; Захаров и др., 2016. С. 176).

Похожие экземпляры присутствуют в нескольких поздних комплексах первого периода существования селища Весь 5 (вторая половина IX -
Х в.; Макаров, Захаров, Шполянский, 2010. С. 119, $125,132)$. В Ростове бусы с серебряной фольгой не выходят за рамки Х в. (Самойлович, 2006. С. 381, 384. Табл. 3). Серебростеклянные и ложнозолотостеклянные бусины, как одночастные, так и многочастные, обнаружены при раскопках Рюрикова городища (Носов, Плохов, Хвощинская, 2017. Ил. 1, 36). Судя по выводам авторов, называющих слой ХІ в. «пустым» (Носов, Плохов, Хвощзинская, 2017. С. 241), они должны быть отнесены к предшествующему времени. Следует отметить, что на Рюриковом городище, как и на белозерских поселениях, бусин с небольшой высотой тулова (2-3 мм), как в нашем случае, не отмечено. В Новгороде одно-, двух- и трехчастные бусины с серебряной фольгой (золоченые и серебреные, по Щаповой) распространены непрерывно с 22-го до 28го яруса, что соответствует середине X - XI в. (Щапова, 1956. С. 174. Табл. 11; Колчин, 1963. С. 90).

Серебростеклянные и ложнозолотостеклянные бусы, как одночастные, так и двух- и трехчастные, присутствуют в ингумациях Гнёздова (Оль30, Дн-3, Л-124, 179, 192, Ц-84, 171, 198, 212, 276, 301 - Доброва, 2017. С. 241-243. Табл. 2. Рис. 1, В, С. Рис. 2, А, N). Часть этих комплексов (Оль-30, Дн-3, Л-124, Ц-84, 171, 276) датирована серединой X - началом XI в., другие (Ц-212, 301) не выходят за пределы Х в. (Доброва, 2017. С. 253).

Таким образом, основной период бытования бус с серебряной фольгой - IX - начало XI в. На протяжении остальной части XI в., особенно во второй половине столетия, их становится значительно меньше.

Вторая по количеству группа бус включает навитые бусы, сделанные из сине-фиолетового полупрозрачного стекла, по-видимому, окрашенного кобальтом (30 экз.) (рис. 4, б). Среди них больше всего зонных (28 экз.), из которых три бусины винтообразные (рис. 4, б, 71, 89, 139), остальные округлые (рис. 4, $6,47,49,50,54,61,64,69,70,72,77,78,81,82,84$, $85,95,96,107,127,128,131,132,144,145,150)$. Больше всего одночастных - 14 экземпляров, двухчастных - 10, трехчастных - 3 экземпляра, четырехчастных - 1 (рис. 4, б, 150). Одна бусина округлая цилиндрическая одночастная (рис. $4,6,62$ ). У одной форма не устанавливается (рис. 4, б, 155).

Большая часть бус этой группы как одночастные, так и многочастные (27 экз.) (рис. 4, б, 47, 49, 50, 54, 61, 62, 64, 69-72, 77, 78, 84, 85, 89, 95, 96, $107,127,128,131,132,139,144,145,150)$, диа-

7 Электронный ресурс: http://chernov-trezin.narod.ru/ZLATA_LVOVA.htm_ 
метр тулова которых не превышает 0,7 см, имеет неправильную, асимметричную форму, на краях канала-выступы и сколы, что главным образом обусловлено применением серийных приемов изготовления. Особняком от них стоят две одночастные бусы, более крупные по размеру (диаметр тулова 0,75 и 0,8 см) правильной зонной формы, приближающейся к кольцевидной, выполненные индивидуальной навивкой (рис. 4, б, 81, 82).

Следует отметить, что стекло, использованное для изготовления этих бусин, неоднородное, оно имеет пороки: большое количество пузырей внутри стекломассы и каверн (лопнувших пузырей) на поверхности. Это может быть связано с недостаточной температурой варки стекла. Особенно много каверн находится по краям канала. В ряде случаев это вело к откалыванию кусочков стекла у краев канала при снятии бусин с металлической основы, а в дальнейшем и к полному их разрушению, поскольку пузыри уменьшают физическую стойкость стекла. В одной, разрушившейся бусине (рис. 4, б, 150) часть железного стержня-основы так и осталась внутри канала.

В Старой Ладоге такие бусины (группа IV, подгруппа 3, зонные бусы «а») происходят из слоев от $\mathrm{E}_{3}$ (VIII в.) до Д (X в.) и выше, но преобладают в последних. Здесь этот тип относится к одним из наиболее ранних из навитых бусин из сине-фиолетового стекла (Львова, 1968. С. 78).

Исследователи мининских бус отнесли в целом этот тип, как и бусы с фольгой, к хронологической группе X-XI вв., но в отличие от них навитые сине-фиолетовые бусы могут бытовать на протяжении всего XI в. (Захаров, Кузина, 2008. С. 196). Бусы, соответствующие асимметричным сине-фиолетовым навитым, есть в культурном слое селища Минино I, в могильнике Минино II они отсутствуют (Захаров, Кузина, 2008. С. 150. Рис. 131). Есть подобные экземпляры в могильнике Владышнево II (вторая половина X - начало XI в.), где они найдены в пахотном слое, основная часть находок которого предположительно составляла инвентарь одного захоронения (Макаров, Меснянкина, 2004. С. 212. Рис. 3). Такие бусы составляют большинство в кремациях могильника Кладовка II (конец X - первая половина XI в.), в заметном количестве встречены они и в позднейших отложениях Крутика (в более ранних напластованиях представлены единичными находками) (Захаров, Кашинцев, Меснянкина, 2013. C. 241). Некоторые из бус имеют характерные пу- зыри внутри стекломассы. Единичные экземпляры подобных бус происходят с селища Никольское V (Захаров, 2015. Рис. I).

Похожие бусы, правда, в небольшом количестве и только одночастные, присутствуют в слоях селища Весь 5, датируемых второй половиной IX - X в. Авторы также отмечают многочисленные пузыри внутри стекла и каверны по краям их каналов (Макаров, Захаров, Шполянский, 2010. С. 120, 132). В Гнёздове немногочисленные находки сине-фиолетовых одно-, двух- и трехчастных бус есть на городище и на селище, при этом в ингумациях они отсутствуют ${ }^{8}$.

Таким образом, основной период бытования сине-фиолетовых навитых асимметричных бус - вторая половина $\mathrm{X}$ - первая половина XI в. Однако их отсутствие на Рюриковом городище, где слой XI в. «пустой», наличие единичных находок в первом периоде существования селища Весь 5 (вторая половина IX - X в.), присутствие немногочисленных экземпляров на Гнёздовском поселении и на селище Никольское V, преобладание их в могильнике Кладовка II, возникшем в конце X в., и заметное присутствие в синхронных могильнику отложениях на Крутике, вероятно, указывают, что главный период их бытования относится к концу X-началу XI в. Такая датировка согласуется с мнением Ю. Кальмера, что византийские бусы, к которым, по нашему мнению, и относится рассматриваемый тип (Щапова, 1991. С. 156), появляются в Скандинавии около 1000 г. (Callmer, 2003. Р. 45).

Что касается двух крупных индивидуально выполненных правильной формы бусин, то в могильнике Минино II такие встречены в погребениях по обряду кремации второй половины X-начала XI в. (Зайцева, Макаров, 2007. С. 260, 325, 330. Рис. 226, 315, 321), отдельные экземпляры имеются в ингумациях второй четверти XI в. (Зайцева, Макаров, 2007. С. 260, 262, 270. Рис. 230) и конца XI - pубежа XI-XII вв. (Зайцева, Макаров, 2007. С. 238. Рис. 203; Захаров, Кузина, 2008. С. 186. Табл. 86. Тип III-2: 40). Есть они и в напластованиях селища Минино I (Захаров, Кузина, 2008. С. 150. Рис. 131). Подобные же находки (3 экз.) присутствуют в захоронениях могильника Никольское III в центральном Белозерье, функционировавшего в 1030-1070-е годы (Кузина, 2015. С. 243).

В Новгороде подобные бусины найдены в 21-28-м ярусах (середина X-конец XI в.), из яруса середины XII в. известно только два

8 Любезное сообщение О.П. Добровой. 
экземпляра (Щапова, 1956. С. 166-168). В Ростове аналогичные бусины обнаружены в слоях X-XI вв. Этот тип является там, как и в Новгороде, самым многочисленным и самым ранним среди навитых (Самойлович, 2006. С. 372, 383. Табл. 1). Такие же экземпляры, датированные серединой $\mathrm{X}$ - первой половиной XI в., обнаружены в пойменной части гнёздовского поселения (Френкель, 2007. С. 80. I-3-А. Рис. 12, 20).

Таким образом, основной хронологический период бытования сине-фиолетовых бус правильной формы более длительный - вторая половина X - XI в. Возможно, эти две группы бус отличались друг от друга не только хронологией, но и местом производства.

В погребении 6 имеется 10 округлых бусин из тянутых трубочек из желтого непрозрачного стекла (рис. 4, в). Среди них пять цилиндрических (рис. 4, в, 87, 103, 111, 118, 142) (одну по диаметру тулова можно отнести к бисеру ${ }^{9}$ (рис. 4, в, 142)), три лимоновидные (рис. 4, в, 35, 93, 148), из них одна сдвоенная, и две зонные (рис. 4, в, 1, 36).

Им близки три округлые двуслойные бусины: бесцветное стекло основы покрыто сверху желтым полупрозрачным стеклом. Из них одна - одинарная лимоновидная (рис. 4, в, 149), две сдвоенные, из которых одна зонная (рис. 4, в, 104), другая эллипсоидная (рис. 4, в, 33). Видимо, этот тип имитирует бусы из однослойного желтого непрозрачного стекла, по наблюдениям С.Д. Захарова и И.Н. Кузиной, появляющиеся раньше (Захаров, Кузина, 2008. С. 196).

М.В. Фехнер относит желтые бусы из трубочек к X-началу ХІ в. (Фехнер, 1959. С. 171). В Старой Ладоге одно- и двухчастные желтые бусины из трубочек (группа VIII, подгруппа 4) фиксируются на уровне построек горизонта Д (Х в.) (Львова, 1968. С. 88). В Новгороде основная масса таких бусин (132 экз. из 146) встречается в ярусах Х в. Начало XI в. - время доживания этих форм (Щапова, 1956. С. 174. Табл. 10). Такие же бусины найдены при раскопках Рюрикова городища, в том числе на месте древнего рва, в черном культурном слое, сброшенном в него при нивелировке участка, в перемешанном слое раскопа на месте установки «Княжьего камня», а также в южной части городища (Носов, Плохов, Хвошинская, 2017. С. 87, 96, 126, 130, 167).

В Минино основная масса желтых бусин из однослойной и двуслойной трубочки обнаружена в погребениях по обряду кремации второй половины X - начала XI в. могильников Минино II и Владышнево II и в комплексах того же времени селища Минино I. Только несколько находок датированы более поздним временем: два экземпляра отмечены в погребениях по обряду ингумации второй и третьей четверти XI в. могильника Минино II и один в комплексе середины XI - начала XII в. селища Минино VI (Захаров, Кузина, 2008. С. 186, 189, 196. Табл. 86, 87. Тип I-5). Верхняя граница бытования желтых бус из трубочки, как и бус с металлической фольгой, ограничена исследователями серединой XI в. (Захаров, Кузина, 2008. С. 196). Аналогичные бусы происходят с поселений Крутик и Никольское V (Захаров, 2012. С. 216, 221, 223, 235. Рис. 7; 2015. Рис. II-IV).

В Ростове большинство таких бус найдено в слоях X в., в первой половине XI в. их значительно меньше (Самойлович, 2006. С. 380, 384. Табл. 3). На селище Весь 5 желтые одночастные и двухчастные бусы из трубочек обнаружены в нескольких поздних комплексах первого периода существования селища (Макаров, Захаров, Шполянский, 2010. C. 124-126).

Такие же бусы, но только однослойные, присутствуют в ингумациях Гнёздова (Поль- $5,7,52$, 76, Дн-17, 40, Л-124, Ц-212, 276, 301, 306; Доброва, 2017. С. 241-243. Табл. 2. Рис. 1, А, В. Рис. 2, В, С, H, J, N). Часть этих комплексов (Поль-52, 76, Дн40, Л-124, Ц-276) датирована серединой Х - началом XI в., другие (Ц-212, 301, 306) не выходят за пределы Х в. (Доброва, 2017. С. 253).

Что касается единственной находки желтой рубленой бисерины (рис. 4, в, 142), то это самый многочисленный тип бисера на памятниках, исследованных по традиционной методике: Старая Ладога, Ростов, Новгород ${ }^{10}$. В Старой Ладоге (группа VIII, подгруппа 3) он встречен в ранних слоях городища $\mathrm{E}_{3}, \mathrm{E}_{2}, \mathrm{E}_{1}$ и в слое под постройками горизонта Д (VIII-IX вв.), но основная его масса обнаружена на уровне построек горизонта Д (X в.) (Львова, 1968. С. 86-87). В Ростове он отмечен в доярусных отложениях, но большинство находок приходится на слой X в., в XI в. эти бисерины единичны (Самойлович, 2006. С. 379-380, 383. Табл. 2). В Новгороде большинство желтого бисера найдено на уровне 23-28-го ярусов (середина X-середина XI в.; Щапова, 1956. С. 172; Колчин, 1963. С. 90). В могильнике Минино II этот

\footnotetext{
9 Под бисером мы понимаем бусы различных форм диаметром не более 3,5 мм.

10 Подробнее о причинах несоответствия соотношений бисера одного цвета в различных памятниках см.: Захаров, 2015.
} 
тип бисера происходит из погребений по обряду кремации второй половины X-начала XI в. (3aхаров, Кузина, 2008. С. 186. Табл. 86. Тип I-7: 25). Он отнесен исследователями к третьей хронологической группе (X-XI вв.), но верхняя граница его бытования ограничена серединой XI в. (Захаров, Кузина, 2008. С. 196). Желтый бисер обнаружен в нескольких поздних комплексах первого периода существования селища Весь 5 (Макаров, Захаров, Шполянский, 2010. С. 124-126), на Рюриковом городище (Носов, Плохов, Хвошиисккая, 2017. Ил. 1, 36), на Крутике и на Никольском V (Захаров, 2012. С. 216, 221, 223, 235. Рис. 7; 2015. Рис. II-IV).

Таким образом, основной период бытования бус и бисера из трубочек желтого стекла можно отнести к X-началу XI в. Время их доживания - первая половина XI в.

Еще одна группа - семь округлых бусин из черного непрозрачного стекла, сделанных из трубочек (рис. 4, г). Из них пять украшены продольными полосками из белого непрозрачного стекла. Их форма: две зонные (рис. 4, г, 60, 113), две лимоновидные (рис. 4, г, 83, 116), одна цилиндрическая (рис. 4, г, 99). Среди черных бусин без деко$\mathrm{pa}$ - одна лимоновидная (рис. 4, г, 73) и одна эллипсоидная (рис. 4, г, 34).

М.В. Фехнер датирует бусины с продольными полосками X-началом XI в. (Фехнер, 1959. С. 171). Две полосатые черно-белые бусины найдены в ингумации Гнёздова (Ц-212), датированной третьей четвертью X в. (Доброва, 2017. С. 253. Табл. 2. Рис. 1, 15, 18). Такие же бусины обнаружены на Рюриковом городище: одна в центральной части, другая - в сооружении 2 раскопа на месте установки «Княжьего камня», датированном не позднее третьей четверти Х в. (Hoсов, Плохов, Хвощинская, 2017. С. 38. Ил. 1, 72. С. 155,159 . Ил. 2,35$)$. Аналогичные экземпляры происходят с поселения Крутик (Захаров, 2012. С. 216, 221, 223. Рис. 7), а также из слоев первой половины IX - 30-60-х гг. Х в. Саркела (Львова, 1959. С. 325). Похожая двухчастная бусина найдена в погребении 81 конца $\mathrm{X}$ - первой половины XI в. мордовского Елизавет-Михайловского могильника (Вихляев и др., 2008. С. 146-147; Tерехова, 2014. С. 59, 202, 283. Группа I. Подгруппа А. Тип 2. Вид 1а. Рис. 7, 2011). Черные бусины с белыми полосками обнаружены и на памятниках более раннего времени: в Верх-Саинском могильнике Верхнего Прикамья в нескольких погребениях конца VII - IX в. есть такие бусины эллипсоидной формы (Голдина, 2010. С. 28, 122. Рис. 19, 20, 37. Тип ІБ1а). В целом черные бусины с белыми полосками наиболее характерны для X - начала XI в.

В погребении найдены округлая кольцевидная бусина из бирюзового полупрозрачного стекла (рис. 4, д, 146) и зонная из синего полупрозрачного стекла (рис. 4, д, 147). Обе выполнены навивкой, первая - индивидуальной, вторая - серийной. Похожие бусы есть в материалах центральной части Рюрикова городища, в том числе и в черном культурном слое древнего рва (Носов, Плохов, Хвощинская, 2017. С. 38,96 . Ил. $1,45-47,52)$, а также в заполнениях сооружений третьей четверти Х в., открытых в раскопе на месте установки «Княжьего камня» (Носов, Плохов, Хвощинская, 2017. С. 146, 153, 155, 159). Зонные и кольцевидные бусины из синего стекла присутствуют на поселении Никольское V (Захаров, 2015. Рис. II), а из синего и бирюзового - в ингумациях Гнёздова (Доброва, 2017. С. 240. Рис. 3, 25). Бусины подобного типа Ю. Кальмер относит к скандинавскому производству и датирует серединой $\mathrm{X}-\mathrm{XI}$ в. (Callmer, 2003. P. 43. Fig. 4.4, A4, B5, C1).

Одна бусина граненой призматической восьмигранной формы (высота 1,9 см) выполнена из серо-голубого непрозрачного стекла при помощи вытягивания трубочки и прессования (рис. $4, \mathrm{e}, 130$ ). Бусина, очень похожая по цвету, но шеститигранная, происходит из ингумации середины X - начала XI в. Гнёздовского могильника (Ц-292) (Доброва, 2017. С. 239, 253. Рис. 3, 27). Такая же бусина, но зеленая, есть в другом комплексе этого же времени (Ц-290; Доброва, 2017. С. 239, 253). Восьмигранная бусина лилового цвета найдена в Новгороде в 13-м ярусе (1220-1240-е) Неревского раскопа, что, по-видимому, демонстрирует исключительно долгое доживание бус этого типа (Доброва, 2018. С. 38. Рис. 1, 2). Призматические зеленые бусины обнаружены в Старой Ладоге, но там они имеют необработанные края и меньшую высоту. Появляются такие бусины (группа VIII, подгруппа 5) в горизонтах $\mathrm{E}_{2}, \mathrm{E}_{1}$ и Д нижний (IX в.), но наибольшее их количество встречено на уровне построек горизонта Д (Х в.; Львова, 1968. С. 90). Шеститигранные зеленые бусины с необработанными краями есть и на селище Весь 5 (Макаров, Захаров, Шполянский, 2010. С. 119. Цв. ил. VI, 111). Один зеленый четырехгранный экземпляр происходит с селища Минино I (Захаров, Кузина, 2008. С. 174, 175. Рис. 164, 4. Табл. 70). Длинные призматиче-

11 Благодарим Н.В. Терехову, любезно предоставившую рукопись диссертации. 
ские многогранные бусины синего стекла отмечены в материалах Рюрикова городища (Медведева, 1999. С. 264).

Бусин из гагата найдено семь экземпляров. Все округлые, из них две зонные (рис. 4, ж, 51, 97), две цилиндрические (рис. 4, ж, 88, 135), две биконические (рис. 4 , ж, 90, 105) и одна эллипсоидная (рис. 4, ж, 79).

Гагатовые бусы-достаточно редкая находка на древнерусских памятниках конца I - начала II тыс. Больше они известны в Крыму и на Кавказе и в чуть более раннее время - в VIII-IX вв. (Ковалевская, 1998. С. 36). Можно лишь отметить две гагатовые бусины (четырехгранные со срезанными углами) из женского погребения 3 в Шекшове (первая половина XI в.) (Макаров, Зайцева, 2016). Остальные известные нам аналогии найдены на сопредельных территориях. Две граненые призматические со срезанными углами бусины с циркульным орнаментом есть в мордовском Пановском могильнике (Терехова, 2013. С. 58. Рис. III, 10). Несколько гагатовых бусин происходит из Болгара и Селитренного городища. Рассмотревшая эти находки М.Д. Полубояринова отмечает, что гагатовые бусины «в виде сплющенного шара» есть в Танкеевском могильнике. Много гагатовых бусин встречено на средневековых памятниках Средней Азии, откуда они, возможно, и привозились (Полубояринова, 1991. С. 46). Месторождения гагата известны в Ирландии, Англии, Франции, Испании, Закавказье, около Кутаиси, на Северном Кавказе, в районе Геленджика и Новороссийска, в юго-западном Крыму. Считается, что изделия из гагата производили там же, где и добывали, поскольку необходимо было постоянно поддерживать гагат во влажном состоянии, что исключает перевозку сырья (Алексеева, 1978. С. 6).

Таким образом, две трети бус погребения составляют украшения разных типов и цветов, сделанные из трубочек, являющихся ближневосточной продукцией. В целом они характерны для IX, X и начала XI в. Время до середины XI в. и позднее - период доживания этих типов. Треть бусин погребения представляют навитые бусины, основную массу которых (из сине-фиолетового стекла) можно относить к византийской продукции. Появление таких бус относится ко второй половине - концу $\mathrm{X}$ в., а главный период их существования - к концу X - началу XI в.

На каждой руке погребенной чуть выше запястий было надето по одному бронзовому гладкому пластинчатому браслету диаметром около 6 см с разомкнутыми расширяющимися прямо обре- занными концами (№ 40, 67; рис. 5). Браслеты вырезаны из кованых пластин одинаковой толщины. Ширина пластин в серединах обручей составляет 4,9 мм, у концов 7 мм. Находки браслетов в шекшовских погребениях достаточно редки. Гладкий пластинчатый браслет с расширяющимися концами найден в погребении подростка (р. 2, погр. 1), датирующемся концом X-началом XI в. Витой, завязанный на две стороны браслет происходит из погребения 3 (первая половина - середина XI в.; Макаров, Зайцуева, 2016. С. 342).

По наблюдениям всех исследователей, обращавшихся к материалам могильников Суздальского Ополья и сопредельных территорий, пластинчатые браслеты с расширяющимися концами являются характерными для Ополья, Тверского, Угличского и Ярославского Поволжья (Левашева, 1967. С. 237; Горюнова, 1961. С. 137; Леонтьев, 1996. С. 178). В Ополье такие браслеты численно преобладают в коллекциях. В. П. Левашева отнесла этот тип к XI-XII вв. (Левашева, 1967. С. 237). Находки оплавленных фрагментов пластинчатых ширококонечных браслетов из разрушенных поверхностных кремаций в Шекшове позволяют говорить о более раннем их появлении в регионе.

Пластинчатые браслеты с расширяющимися прямо обрезанными концами известны в рязано-окских могильниках начиная с IV в., в погребениях ранних стадий Безводнинского могильника (Воронина, Энговатова, Зеленцюва, 2005. С. 72). Мода на такие украшения сохраняется в восточнофинской среде и позднее: они есть и в комплексах X-XI вв. среднецнинских мордовских (Вихляев и др., 2008. С. 39), муромских (Бейлекчи, 2005. С. 42), марийских (Нuкитина, 2012. С. 121, 166). Популярность пластинчатых ширококонечных браслетов в Суздальском Ополье, вероятно, имеет восточнофинские истоки.

В районе пальцев правой руки найдены два стоящих на ребре перстня: бронзовый круглодротовый замкнутый диаметром 22 мм (№ 38; рис. 5) и серебряный круглодротовый со щитком в виде так называемой улитки, размерами 24×25 мм (№ 39; рис. 5). Таким образом, в погребении находилось пять металлических перстней: два круглодротовых и три пластинчатых широкосрединных. Все они относятся к типам, широко распространенным в севернорусских землях во второй половине $\mathrm{X}$ - первой половине XII в. (см., напр.: Зайцева, 2008. С. 121).

Возле пальцев левой руки найден стеклянный перстень без щитка (№ 66). Он сделан навивкой из красно-коричневого полупрозрачного стекла (рис. 4, 3, 66). Обруч перстня имеет ребристое полукруглое сечение. Внутренний диаметр перстня равен 

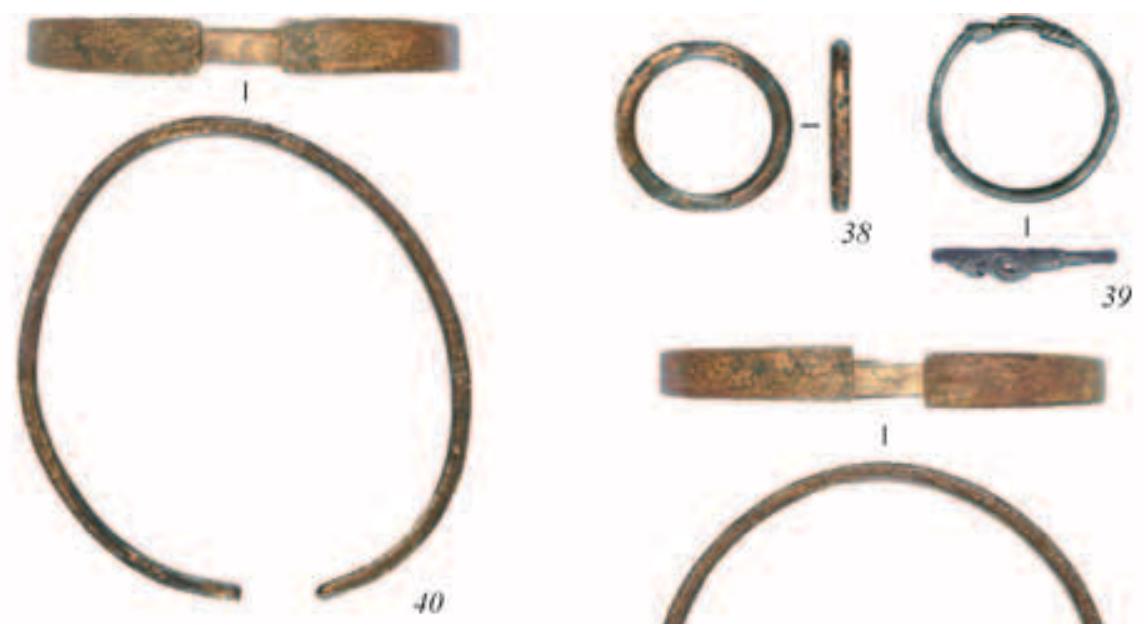

10
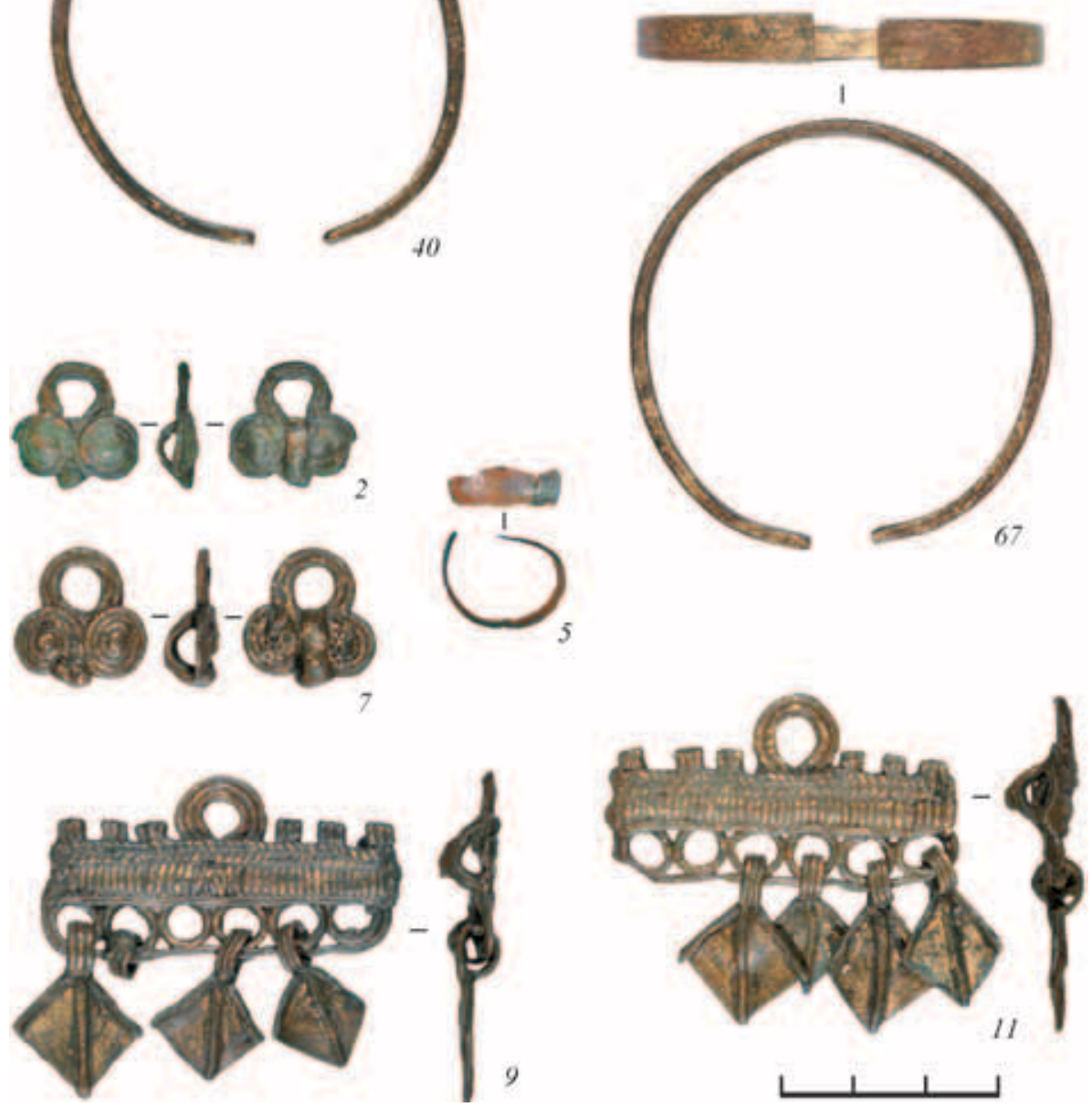

Рис. 5. Шекшово 9. Погребение 6. Украшения рук и обуви

38, 39 - перстни; 40, 67 - браслеты; 2, 5, 7, 9, 11 - украшения обуви. 39 - серебро; остальное - цветной металл. Номера на рисунке соответствуют полевым номерам

1,5 см. Стеклянные перстни редко встречаются в погребениях. Можно назвать только находки зеленых, синих и лиловых перстней из кургана 69 у с. Весь и кургана у с. Веселково из раскопок А.С. Уварова (Спищьын, 1905. С. 120, 149. Рис. 270, 272).

На костях стоп на правой и левой ногах лежали прямоугольные подвески длиной 5 см с верхней петлей, двумя ушками на обороте и шестью колечками по низу, к которым крепились привески в виде широких утиных лапок (№ 9, 11; рис. 5). У левого колена найдена бронзовая обувная подвеска в виде двух волют с петлей (№ 7; рис. 5). Вторая такая подвеска была в заполнении ямы.
Это первая ингумация в Шекшове, где обнаружены украшения обуви. Положение подвески с волютами в районе колена позволяет полагать, что обувь была высокой (скорее всего, онучи и кожаные туфли). Металлические украшения обуви - одна из характерных черт восточнофинского костюма, не получившая распространения в древнерусской среде. Множество подвесок обоих типов имеется в материалах из раскопок курганов А.С. Уваровым (Спицын, 1905. Рис. 453). Подвески с волютами найдены in situ во многих восточнофинских погребениях, опубликованы реконструкции обуви с их использованием (Никитина, 2014. С. 121, 128, 198). 
Как правило, это невысокая обувь типа туфель. Прямоугольные подвески с привесками причислены исследователями к этноопределяющим центральной группы мери (Горюнова, 1961. С. 100; Рябинин, 1997. С. 159). Наши находки позволяют определенно идентифицировать их как обувные. Подобные подвески расчищены в погребении 234 из раскопок В.А. Городцова в Подболотье (Бейлекчи, 2005. С. 185). В.В. Бейлекчи пишет, что они могли скреплять ремешки туфель (Бейлекчи, 2005. С. 61). По наблюдениям Л.А. Голубевой, в мерянских погребениях находили браслеты и перстни в районе колен. Исследовательница считает, что они пришивались к онучам (Голубева, 1987. С. 90). Такой же случай зафиксирован и в нашем погребении: перстень в районе правой голени (№ 5; рис. 5).

Узкая датировка обувных подвесок затруднена отсутствием разработанной хронологической шкалы финно-угорских шумящих украшений последней четверти I тыс. Тем не менее оба типа подвесок представлены в материалах, относимых к раннему горизонту селища Весь 5, верхняя дата которого определена как конец Х в. (Макаров, 2012. С. 207).

Заключение. Детально рассмотренное нами женское погребение 6 выделяется из всех исследованных в Шекшове ингумаций как по количеству погребального инвентаря, так и по его облику. Костюмы остальных 12 женщин и девочек, погребения которых расчищены в этом некрополе (конец X - вторая половина XI в.), имеют «древнерусский облик» и выглядят более скромными: ожерелья из бусин, перстни, височные кольца, из сопровождающего инвентаря сосуды и ножи. Только в одном погребении 3 середины XI в. есть шумящая накосная подвеска (Макаров, Зайцева, 2016. С. 192). Богатство украшений костюма женщины из погребения 6, вероятно, следует рассматривать не с точки зрения ее особого социального статуса, а в контексте этнической ситуации в шекшовской популяции: погребальный обряд (положение в ногах орудий труда), многослойный костюм со сложным головным убором и специфической обувью, обилие украшений рук, лощеный мерянский сосуд, индивидуальные морфологические признаки лицевой части скелета свидетельствуют в пользу восточнофинской принадлежности погребенной.

Подробный анализ комплекта бусин из ожерелья позволяет сузить дату погребения: соотноше- ние типов бус из трубочек и навитых дает основание для датировки погребения концом X-началом XI в. В это время бусы из трубочки еще популярны, но уже входят в обиход навитые византийские бусы. «Бусинная» дата хорошо согласуется с датировкой подвесок-монет из ожерелья: середина - вторая половина Х в.

Проблемы истории и археологии мери и еe ассимиляции славянским населением имеют обширную историографию, начиная с работы А.С. Уварова 1872 г. Последние крупные обобщающие исследования по этой проблематике, рассматривающие весь комплекс поселенческих и погребальных памятников региона, созданы в 1980-1990-х гг. (Леонтьев, Рябинин, 1980; Голубева, 1987; Леонтьев, 1996; Рябинин, 1997) ${ }^{12}$. В них определены хронологические рубежи и показана динамика ассимиляции мерянского населения славянским. По подсчетам А.Е. Леонтьева и А.Е. Рябинина, мерянские элементы в обряде (меридиональная ориентировка, орудия труда в женских погребениях) и инвентаре (этноопределяющие мерянские украшения) представлены в 500 из более чем 7000 раскопанных курганов (Леонтьев, Рябинин, 1980. С. 74-75). Важными представляются выводы исследователей, что чисто мерянские курганные группы отсутствуют, можно говорить только об отдельных комплексах, вкрапленных среди курганов с древнерусскими погребениями, и что корреляции между меридианальной ориентировкой погребенных и наличием в погребениях шумящих украшений не наблюдается (Леонтьев, Рябинин, 1980. С. 74-75) ${ }^{13}$. Мерянским в Суздальском Ополье считается только грунтовый могильник Сунгирь с северо-западной и юго-восточной ориентировкой погребенных, хотя большинство комплексов на нем имеет «древнерусский облик» (Мошенина, 1973; Леонтьев, Рябинин, 1980. С. 78).

Работы Суздальской экспедиции в Шекшове позволили по-новому взглянуть на Владимирские курганы: если ранее считалось, что курганные могильники содержат только подкурганные погребения (Леонтьев, Рябинин, 1980. С. 74), то теперь стало ясно, что в межкурганном пространстве и на свободных участках совершались грунтовые захоронения по обряду ингумации. Курганы и грунтовые могилы синхронны, костюм погребенных по обряду ингумации единообразен ${ }^{14}$

\footnotetext{
12 В них же приведена подробная историография проблемы.

13 Л.А. Голубева обращает внимание, что в кургане 76 в Шекшове женщина с набором мерянских украшений была погребена с конем (Голубева, 1987. С. 75).

14 Вопрос о хронологическом соотношении подкурганных и поверхностных кремаций находится в стадии разработки.
} 
(Макаров, Зайцеева, 2016; Макаров и др., 2017). Пока мы фиксируем такую ситуацию только в Шекшове, но, вполне вероятно, она характерна и для других памятников региона.

Погребение 6 наряду с 9-м и 14-м относится к самым ранним исследованным в Шекшове ингумациям (Макаров, Зайцуева, 2016), но сильно отличается от них по обряду и инвентарю: в погребениях 9 и 14 обнаружены девочки, лежащие головами на восток, с наборами бус и сосудами.

Многочисленные обломки оплавленных шумящих украшений найдены в Шекшово в верхнем пахотном слое и интерпретируются как остатки погребений по обряду кремации, значительная часть которых принадлежит, вероятно, представителям восточнофинского населения. Интересно, что разрушенная, но локализуемая поверхностная кремация открыта на участке, примыкающем к яме погребения 6 с запада: среди кальцинированных костей здесь найдены оплавленные обломки серебряного втульчатого височного кольца, подвескиконька владимирского типа, подвески из дирхема, синие и желтые бисерины. Погребение датируется второй половиной X в. Это второй комплекс с мерянскими украшениями, открытый экспедицией в Шекшове.

Достаточно точная хронологическая позиция погребения 6 позволяет достоверно утверждать, что в конце X-начале XI в. в Шекшове проживали «носители финских культурных традиций», они не были обособлены и хоронили умерших на общем кладбище поселка. Таким образом, отдельные археологические комплексы и находки дают возможность четче представить этнокультурную ситуацию на конкретном памятнике и в регионе в целом, маркируя процессы культурной интеграции в их хронологической динамике (Макаров, 2012. С. 211).

\section{Литература}

Алексеева Е.М., 1978. Античные бусы Северного Причерноморья. М.: Наука. 104 с. (САИ. Г1-12).

Бейлекчи В. В., 2005. Древности летописной муромы (погребальный обряд и поселения). Уч. пособ. М.- Муром: Изд-во МПСИ. 275 с.

Белавин А. М.,2000. Камский торговый путь. Средневековое Предуралье в его экономических и этнокультурных связях. Пермь: Пермский гос. пед. ун-т. $200 \mathrm{c.}$

Белоиерковская И. В., 2003. Некоторые черты погребального обряда рязано-окских могильников // Проблемы древней и средневековой археологии Окского бассейна. Рязань. С. 150-153.

Вихляев В.И., Беговаткин А.А., Зеленцуова О.В., Шитов В.Н., 2008. Хронология могильников населения I-XIV вв. западной части Среднего Поволжья. Саранск: [б. и.], 2008. 352 с.

Воронина Р. Ф., Энговатова А.В., Зеленщова О. В., 2005. Никининский могильник. Публикация материалов раскопок 1977-1978 гг. М.: ИА РАН. 178 с.

Голдина Е.В.,2010. Бусы могильников неволинской культуры (конец IV-IX в.). Ижевск: Удмуртский гос. ун-т. 264 с.

Голубева Л.А., 1982. К истории треугольной подвески // Средневековые памятники бассейна р. Чепцы / Отв. ред. М.Г. Иванова. Ижевск: НИИ при Сов. мин. Удм. АССР. С. 110-124.

Голубева Л.А., 1987. Меря // Финно-угры и балты в эпоху средневековья / Отв. ред. В.В.Седов. М.: Наука. С. 61-80. (Археология СССР).
Горюнова Е.И., 1961. Этническая история ВолгоОкского междуречья. М.: АН СССР. 264 с. (МИА. № 94).

Горюнова, Овсянников, 2002. Клад конца X - начала XIII в. в устье р. Варзуги (Терский берег Кольского п-ова) // Ладога и ее соседи в эпоху средневековья. СПб.: ИИМК. С. 211-220.

Доброва О.П., 2017. Бусы из погребений по обряду ингумации Гнёздовского могильника // Поволжская археология. № 4 (22). С. 236-257.

Доброва О.П., 2018. О некоторых типах бус по материалам Неревского раскопа Новгорода Великого // Нескончаемое лето. Сб. ст. в честь Елены Александровны Рыбиной / Отв. ред.-сост. В.К. Сингх. М.- Великий Новгород: МГУ, 2018. С. 36-40.

Зайцева И. Е., 2008. Изделия из цветных металлов и серебра // Археология севернорусской деревни X-XIII веков: средневековые поселения и могильники на Кубенском озере. Т.2. Материальная культура и хронология /Отв. ред. Н. А. Макаров. М.: Наука. С. 57-142.

Зайцеева И.Е., 2017. Височные кольца из Шекшово в Суздальском Ополье // Памятники средневековой археологии Восточной Европы. К юбилею М. Д. Полубояриновой / Отв. ред. А.В. Чернецов. М.: ИА РАН. С. 187-195.

Зайцева И. Е., Макаров Н. А., 2007. Могильник Минино II. Описание погребальных комплексов // Археология севернорусской деревни X-XIII 
веков: средневековые поселения и могильники на Кубенском озере. Т. 1. Поселения и могильники / Отв. ред. Н. А. Макаров. М.: Наука. С. 233-338.

Захаров С.Д., 2012. Белоозеро // Русь в IX-XI вв.: археологическая панорама / Отв. ред. Н.А. Макаров. М.- Вологда: Древности Севера. С. 213-239.

Захаров С.Д., 2015. Стеклянные бусы в археологических коллекциях: новые методы полевых исследований и проблемы интерпретации результатов // Стекло Восточной Европы с древности до начала XX века. СПб.: Нестор-История. С. 344-352.

Захаров С. Д., Кашиниеев А. Ю., Меснянкина С.В., 2013. Необычные сооружения из раскопок Крутика 2010-2012 гг. // КСИА. Вып. 230. C. 234-244.

Захаров С. Д., Кузина И. Н., 2008. Вещевой материал Мининского археологического комплекса. Изделия из стекла и каменные бусы // Археология севернорусской деревни X-XIII веков.: средневековые поселения и могильники на Кубенском озере / Отв. ред. Н. А. Макаров. М.: Наука. Т.2. Материальная культура и хронология. C. 142-215.

Захаров С.Д., Меснянкина С.В., Кузина И.Н., Зозуля С. С., 2016. Крутик и Тимерёво: археологические исследования 2011-2015 годов// Вестник РГНФ. № 3-4. С. 169-181.

Казаков Е.П., 2007. Волжские болгары, угры и финны в IX-XIV вв.: проблемы взаимодействия. Казань: ИИ АН РТ. 208 с.

Ковалевская В.Б., 1998. Хронология восточноевропейских древностей V-IX веков. Вып. 1. Каменные бусы Кавказа и Крыма. М.: ИА РАН. 78 с.

Колчин Б. А., 1963. Дендрохронология Новгорода // Новые методы в археологии. Тр. НАЭ. Т. 3. М.: АН СССР. С. 5-103. (МИА. № 117).

Кузина И.Н., 2015. Стеклянные бусы из могильника Никольское III в центральном Белозерье // Города и веси средневековой Руси: археология, история, культура. К 60-летию Николая Андреевича Макарова. М. - Вологда: Древности Севера. С. 240-246.

Левашева В.П., 1967. Браслеты // Очерки по истории русской деревни / ред. Б. А. Рыбаков. М.: Советская Россия. С. 207-252. (Тр. ГИМ; вып. 43).

Леонтьев A.E., 1996. Археология мери. К предыстории Северо-Восточной Руси. М.: ИА РАН. 342 c.

Леонтьев А.Е., Рябинин Е.А., 1980. Этапы и формы ассимиляции летописной мери (к постановке вопроса) // РА. № 2. С. 67-79.
Львова 3.А. Стеклянные бусы Старой Ладоги как исторический источник / Электронный ресурс: http://chernov-trezin.narod.ru/ZLATA_LVOVA. $\mathrm{htm}$.

Львова 3.А., 1959. Стеклянные браслеты и бусы Саркела - Белой Вежи // Тр. Волго-Донской археологической экспедиции. Т. 2. М. - Л.: АН СССР. С. 307-332. (МИА. № 75).

Львова 3.А., 1968. Стеклянные бусы Старой. Ладоги. Ч. 1. Способы изготовления, ареал и время распространения // АСГЭ. Л.: Советский художник. Вып. 10. С. 64-94.

Макаров Н. А., 2012. Суздальское Ополье // Русь в IX-X веках: археологическая панорама / Отв. ред. Н.А. Макаров. М. - Вологда: Древности Севера. С. 194-211.

Макаров Н.А., Гайдуков П.Г., Гомзин А.А., 2016. Серебро на селищах: монеты и торговый инвентарь IX-XI вв. в Суздальском Ополье // РА. № 1. С. 48-74.

Макаров Н.А., Зайщева И.Е., 2016. Бескурганные ингумации в могильнике Шекшово: новые материалы к изучению древнерусского погребального обряда XI в. // Археология Владимиро-Суздальской земли. Материалы научного семинара. Вып. 6. М.- СПб.: Нестор-История. С. 185-198.

Макаров Н.А., Зайцева И.Е., Красникова А. М., 2013. Парадный топорик с княжескими знаками из Суздальского Ополья // Фундаментальные проблемы археологии, антропологии и этнографии Евразии. К 70-летию академика А. П. Деревянко. Новосибирск: ИАЭ СО РАН. С. 435-444.

Макаров Н.А., Зайцева И.Е., Красникова А. М., 2015. Могильник Шекшово в Суздальском Ополье // Институт археологии: новые экспедиции и проекты / Отв. ред. Н. А. Макаров. М.: ИА РАН. С. 101-103.

Макаров Н.А., З Зайцева И.Е., К Красникова А. М., Угулава Н.Д., 2017. Исследование могильника Шекшово в Суздальском Ополье // АВС3. М.: ИА РАН. Вып. 7. С. 7-18.

Макаров Н.А., Зайцева И.Е., Угулава Н.Д., $2016 а$. Исследование средневекового могильника Шекшово // АО 2015. М.: ИА РАН. С. 149-153.

Макаров Н.А., Зайчева И.Е., Угулава Н.Д., $2016 б$. Исследование средневекового могильника Шекшово в Суздальском Ополье // АО 2014. М.: ИА РАН. С. 129-131.

Макаров Н.А., З Захаров С.Д., В Шполянский С. В., 2010. О датировке средневекового поселения Весь 5 под Суздалем // Диалог культур и народов средневековой Европы. К 60-летию со дня рождения Евгения Николаевича Носова / Отв. 
ред. А.Е. Мусин (ред.-сост.), Н. В. Хвощинская. СПб.: Дмитрий Буланин. С. 113-164.

Макаров Н.А., Красникова А.М., З Зайцуева И.Е., 2013. Средневековый могильник Шекшово в Суздальском Ополье: спустя 160 лет после раскопок А.С. Уварова // КСИА. Вып. 230. C. 219-233.

Макаров Н.А., Меснянкина С.В., 2004. К изучению средневековых могильников с кремациями на Русском Севере // Восточная Европа в Средневековье. К 80-летию Валентина Васильевича Седова. М.: Наука. С. 207-217.

Медведева М.В., 1999. Стеклянные бусы Рюрикова городища конца I тыс.н. э. (предварительный анализ) // ННЗ. Новгород: НГМЗ. Вып. 13. C. 261-265.

Мошенина Н.Н., 1973. Отчет об археологических раскопках могильника Сунгирь и в г. Владимире в 1972-1973 гг. / Архив ИА РАН. Р-1. № 5193.

Музей Болгарской цивилизации. Т. 1. Древний Болгар: жизнь города. Казань, 2016.

Никитина Т.Б., 2012. Погребальные памятники IX-XI вв. Ветлужско-Вятского междуречья. Казань: ИИ АН РТ. 408 с.

Никитина Т.Б., Пузаткина Е.А., 2017. Русенихинский могильник: междисциплинарный подход к изучению памятника // Поволжская археология. № 2. С. 187-203.

Носов Е.Н., Плохов А.В., Хвошинская Н.В., 2017. Рюриково городище. Новые этапы исследований. СПб.: Дмитрий Буланин. 288 с. (Тр. ИИМК РАН; т. 49).

Полубояринова М.Д., 1991. Украшения из цветных камней Болгара и Золотой Орды. М.: ИА РАН. $112 \mathrm{c}$

Равдина Т.В., 1988. Погребения Х-ХІ вв. с монетами на территории Древней Руси: каталог. М.: Наука. $151 \mathrm{c.}$

Рябинин Е. А., 1997. Финно-угорские племена в составе Древней Руси. СПб.: СПбГУ. 260 с.

Самойлович Н.Г., 2006. Стеклянные бусы Ростова Великого // Археология Верхнего Поволжья. К 80-летию К.И. Комарова / Под ред. А. В. Кашкина. М.: ИА РАН. С. 371-386.

Спицьын А. A., 1905. Владимирские курганы // ИАК. Вып. 15. СПб. С. 84-172.
Степанова Ю.В., 2009. Древнерусский погребальный костюм Верхневолжья. Тверь: Изд-во ТвГУ. 364 с.

Терехова Н.В., 2013. Каменные бусы из цнинских могильников средневековой мордвы // КСИА. Вып. 228. С. 57-63.

Терехова Н.В., 2014. Бусы среднецнинской мордвы как исторический источник. Дисс. ... канд. истор. наук. М.: ИА РАН. 327 с.

Уваров А. С., 1872. Меряне и их быт по курганным раскопкам. М.: Синодальная тип. 230 с.

Фехнер M.B., 1959. К вопросу об экономических связях древнерусской деревни // Очерки по истории русской деревни. М.: Советская Россия. С. 149-224. (Тр. ГИМ; вып. 33).

Френкель Я.В., 2007. Опыт датирования пойменной части гнёздовского поселения на основании анализа коллекции стеклянных и каменных бус (по материалам раскопок 1999-2003 гг.) // Гнездово. Результаты комплексных исследований памятника. М.: Альфарет. С. 79-117.

Шевизов А.О., 2017. Пути поступления византийских серебряных монет на территорию Древней Руси // АИППЗ. Вып. 32. М.: ИА РАН. C. 296-308.

Щапова Ю.Л., 1956. Стеклянные бусы древнего Новгорода // Тр. НАЭ. Т. 1. М.- Л.: АН СССР. С. 164-179. (МИА. № 55).

Щапова Ю.Л., 1991. Византия и Восточная Европа. Направление и характер связей в IX-XII вв. (по находкам из стекла) // Византия. Средиземноморье. Славянский мир. К XVIII Междун. конгрессу византинистов. М.: МГУ, 1991. C. $155-177$.

Callmer J., 1977. Trade Beads and Bead Trade in Scandinavia, ca 800-1000 A.D. Bonn; Lund: Habelt. 229 p. (Acta Archaeologia Lundensia. Series in $4^{\circ}$. Nr. 11).

Callmer J., 2003. Beads in Scandinavia in the early and high medieval periods, ca. A. D. 400-1200// Ornaments from the past, beads studies after Beck. A book on glass and semiprecious stone beads in history and archaeology for archaeologists, jewellery historians and collectors / Ed. by I. C. Glover, H.H. Brock, J. Henderson.L.: The Bead Study Trust. P. 38-46. 


\section{К.И. Комаров \\ Институт археологии РАН, г. Москва}

\section{Расселение славян в Верхнем Поволжье}

«Повесть временных лет» начинает рассказ о начале русской истории с 862 г. До того времени осевшие на Русской равнине племена «свою волость имели», и каждое из них «своимъ родомъ владяше». В 862 г. словене ильменские, кривичи и их соседи чудь, меря, весь пригласили на княжение Рюрика с дружиной (ПВЛ, 1996. С. 13). Личность Рюрика кажется вполне реальной. В западных хрониках имеются сведения о похождениях Рюрика-Рёрика в Ютландии и Фризии примерно в это же время. Можно представить исторического Рёрика Ютландского и Рюрика летописного одним и тем же историческим персонажем, но для этого нет иных оснований, кроме совпадения имени. При попытке представить их одним и тем же лицом выявляется явное хронологическое противоречие: по западным хроникам деятельность Рёрика как вассала франкских королей отмечена в 863, 867 и 873 гг; Рюрик княжил в Новгороде в 862-879 гг. Сказание о Рюрике записано в летописи не менее 250 лет спустя после события и представляет собой не более чем легенду. Княжение Рюрика никакими заметными деяниями не отмечено, кроме одного: приняв власть, он стал раздавать города мужам своим. В действительности названные городами пункты в IX в. городами в полном смысле этого слова еще не были. Как совершенно справедливо заметил А. В. Куза, «до объединения Руси под властью киевских князей мы нигде (за исключением, вероятно, Киева) не обнаруживаем раннегородских образований» (Куза, 1989. С. 154). Запись о раздаче городов мужам отражает более поздние реалии в истории Киевской Руси.

Первым реальным актом нарождающегося государства был победоносный поход утвердившегося в Киеве конунга Олега на Константинополь в 907 г. Равноправный договор 911 г. Руси с Византией утвердил появление на международной арене государства, получившего название Киевская Русь. Образование княжества Киевского как первой формы русского государства сопрово- ждалось обустройством собственной территории и установлением властных структур на местах. Внутренняя политика главным образом выражалась в обязанности подвластных областей платить дань. Сбор дани осуществлялся в форме денежных взносов («по чернее куне», «по щьлягу») и в форме полюдья, преимущественно в натуральном виде. Взыскание дани производились как военный поход князя или его мужей с дружиной, часто превращаясь в прямой грабеж. «Примученные» общинники принуждались к уплате силой.

«Въ лето 6391. Поча Олегъ воевати деревляны, и примучивъ а, имаше на них дань по чернее куне». «Въ лето 6392. Иде Олегъ на северяне, и победи северяны, и възложи на нь дань легъку».

«Въ лето 6393. Посла къ радимичемъ, река: «Кому дань даете?» Они же реша: «Козаромъ». И рече имъ Олегъ: «Не дайте козаромъ, но мне дайте». И въдаша Ольгови по щьлягу, яко же и козаромъ даяху» (ПВЛ, 1996. С. 14).

Политику Олега неизменно продолжают его последователи, что нередко вызывает сопротивление «примученных».

«В лето 6453. Игорь... иде в Дерева в дань, и промышлявше къ первой дани, и насиляше имъ и мужи его». Поразмыслив, Игорь возвращается, «желая больша именья» (ПВЛ, 1996. С. 26, 27). Возмущенные древляне убивают нарушителя «права».

Ольга жестоко мстит непокорным, но обстоятельства вынуждают ее ограничить произвол, регламентировать сбор и размер дани и в то же время утвердить порядок на одном из проблемных участков пути «из варяг в греки», связующем Киев с Новгородом. «В лето 6455. Иде Вольга Новугороду, и устави по Мьсте повосты и дани и по Лузе оброки и дани» (ПВЛ, 1996. С. 29). Ольга устанавливала свойственный государству порядок на подвластной территории. Походы Святослава на Оку и Волгу расширяют волость Киева. В 966 г. он 
побеждает вятичей и принуждает их к выплате дани (ПВЛ, 1996. С. 31). Решающие события в становлении русской государственности происходят в Киеве и Новгороде в последней четверти $\mathrm{X}$ в. В 980 г. единовластным князем на столе в Киеве стал Владимир. Вначале ему приходится вновь усмирять «заратившихся» вятичей и радимичей. Следующей мерой по централизации государственного управления стало направление своих сыновей наместниками в крупные волостные центры. Начинается процесс политико-административного освоения Киевом подвластных территорий. На местах формируются подчиненные Киеву административные, экономические, военно-оборонительные центры. Союз племенных княжений перерастает в единое государственное управление. Активная политика христианизации, проводимая с принятием христианства в 988 г., также стала весомым фактором в процессе укрепления государства и консолидации населения.

Систематическое увеличение поборов и даней, сопровождаемых «насилием», провоцировало отток населения на свободные земли. На заре становления древнерусского государства это была слабо заселенная территория Верхнего Поволжья и вся обширная область Волго-Клязьминского междуречья, где располагалось финно-угорское племя меря. Самой очевидной исходной территорией славянской колонизации Верхнего Поволжья в российской исторической науке рассматривалась область обитания племени ильменских словен. Последователь этой точки зрения И.В. Дубов утверждал: «Начиная с IX в. Волжская система становится торной дорогой новгородских словен и северо-западных финно-угров в их движении в Залескую землю» (Дубов, 1982. С. 44). П.Н. Третьяков допускал участие в процессе колонизации смоленских кривичей (Третьяков, 1966. С. 297-299). Археологические памятники Верхнего Поволжья показывают сложный характер этнических процессов в эпоху Средневековья.

На верхней Волге от Твери до Ярославля нет славянских поселений VII-VIII вв. На конечном участке этого отрезка реки известны только три археологических памятника, ярославские могильники, ранние погребения в которых датируются концом IX - началом X в. Самый значительный из этих памятников, Тимерёвский могильник с примыкающим селищем, совершенно справедливо охарактеризован А.Е Леонтьевым в качестве погоста, пункта сбора дани с местной округи, характерного для ранней административной системы нарождающегося государства (Леонтьев,
1989). Топографическое положение этих комплексов непригодно для устройства регулярных торжищ. С волжской водной системой они напрямую не связаны. Существование прямого пути с верхней Волги в Булгар не находит подтверждения, монетных кладов на берегах Волги от устья Которосли до устья Камы нет. Клады на поселении у д. Тимерёво и под Угличем свидетельствуют о включении Верхнего Поволжья в сферу балтийской торговли. В IX-X вв. активно функционировал только северный отрезок торговли по Волге, главным образом по Селигерскому пути (Носов, 1976).

Новые исследования показали, что славянская колонизация происходила не по крупным водным артериям, а по малым рекам. В первую очередь осваивались обжитые аборигенами угодья. Об этом свидетельствуют многочисленные славянские поселения и курганные могильники, которые появляются в Ростовской области около середины Х в. Они концентрируются вокруг коренных мерянских земель в округе озер Неро, Клещино (Плещеево) и в районе древнего Суздаля (Комаров, 1995; Лапшин, 1981; Леонтьев, 1996).

Славянская колонизация Волго-Клязьминского междуречья по времени совпадает и даже несколько предшествует исходящим из центра мерам по укреплению местных властных структур. В 988 г. наместником в Ростов был направлен Ярослав. Вскоре после смерти Вышеслава он переводится в Новгород, но продолжает наблюдать и за Ростовской землей. В результате драматической борьбы за власть с отцом и братьями в 1015-1026 гг. Ярослав закрепил за собой обладание Киевом. В ходе этой борьбы Ярославу пришлось улаживать противоречия в структурах княжеской военно-административной системы и самой системы с горожанами Новгорода. В 1019 г. в Новгороде был принят в письменном виде кодекс «Русская Правда». Его принятие было вызвано развитием новых социальных отношений, не охваченных нормами обычного права. В 1024 г. Ярослав усмиряет волнения в Суздальской земле и издает новый «Устав»- «устави землю ту» (ПСРЛ. Т. ХХV. С. 375). Несомненно, это был письменный «Устав», подобный дошедшим до нас уставам позднейшего времени: «Устав о церковных судах» Владимира Святославича XII в. (Щапов, 1976. С. 12-139) или «Устав о мостех» Ярослава Ярославича от ХІІІ в. (НПЛ, 2000. С. 507). Только с этого времени, с первой половины XI в., на берегах Волги от Твери до Ярославля появляются славянские поселения. Появление славянских памятников на верхней Волге совпадает по времени с мерами Ярослава по установлению 
порядка в крае в 1024 г. По волжскому пути создавались сторожевые пункты, погосты, существование которых засвидетельствовано в описании восстания волхвов в Ярославле в 1071 г. Одним из таких предприятий князя стало основание города в свое имя при устье р. Которосль, на пересечении пути с Волги в Ростово-Суздальскую землю. Первоначально небольшой городок должен был нести охрану этого участка пути. В 1152 г. «мал городок» обеспечил успешное отражение внезапного нападения булгарской рати на Ростов.

В настоящее время на Волге от Твери до Ярославля известно 10 городищ, в том числе летописных - 4; селищ - 79; курганных могильников - 65 . По времени возникновения они начинают функционировать от первой четверти до середины XI в. В курганных могильниках повсеместно соблюдается ритуал ингумации. Только в двух курганах могильника Загорье 1 Ю.Г. Гендуне (1906) отметила обряд кремации, но достоверность ее вывода сомнительна. Остатки «кремаций» помещались в ямах размеров $1,1 \times 0,6$ и 2,0×0,8 м и более похожи на обычные захоронения по обряду ингумации. Неясен вопрос о наличии в них кальцинированных костей. Сведения о «длинных курганах» у с. Охотино сомнительны и неопределенны. Славянские памятники отличаются содержанием керамического материала. На памятниках археологии северной территории Руси в XI в. преобладает лепная керамика. Только во второй половине XI в. она начинает уступать место гончарной и почти до конца века оба типа керамики встречаются вместе. В XII в. гончарная керамика полностью сменяет лепную. В Верхнем Поволжье около половины учтенных поселений содержат смешанный состав керамики, в другой половине отмечена только гончарная.

Колонизация Поволжья являлась аграрной, и основным занятием населения было земледелие. Сельскохозяйственные орудия (косы, серпы, наральники) найдены на пяти памятниках. Рыболовство (крючки, острога, керамические грузила) было дополнительным промыслом. Очевидно, для контроля волжского пути жители некоторых поселений были обязаны нести охранные функции или повинности, о чем свидетельствуют находки предметов вооружения, снаряжения коня и всадника. Наконечники копий и сулиц найдены в двух курганных могильниках, наконечники стрел - в шести селищах и семи курганных могильниках, топоры боевые и рабочие - в 12 курганных могильниках. Железное стремя и бронзовый затыльник плети представлены единичными находками (рис. 1, 1). На наличие одного из возможных сторожевых пун- ктов указывает полностью раскопанный курганный могильник Плешково 1 из 60 курганов, в котором открыто 16 погребений с оружием (Комаров, 2002. C. 161-162). Наконечники копий обнаружены в семи погребениях. Они принадлежат к типу втульчатых с ромбовидным пером. По классификации А.Н. Кирпичникова, подобные наконечники датируются концом X - XI в., один наконечник с пером удлиненных пропорций $-\mathrm{X}$ - началом XII в. В двух погребениях зафиксированы черешковые наконечники дротиков или сулиц. Топоры найдены в 18 погребениях. В общей массе они принадлежат к наиболее распространенному в X-XII вв. типу рабочих топоров. Не исключено их использование и в качестве боевых. В двух погребениях вместе с такими топорами лежали наконечник копья и дротика. Несомненно боевыми являются только два топора в парном погребении. Покойники лежали на основании кургана рядом, вероятно, в одинаковой одежде, застегнутой на уровне пояса большими однотипными фибулами с маковидными головками. У одного из них на фибуле сохранились фрагменты одежды из грубой шерстяной ткани типа кафтана. Под фибулой находилась бронзовая лировидная пряжка. Это парное погребение можно рассматривать как захоронение стражников в службе обеспечения безопасности пути по Волге.

Осевшее на Волге население вовлекалось в торговые операции, осуществлявшиеся на этом пути. Это обстоятельство нашло отражение в составе инвентаря поселений и могильников, в первую очередь в находках монет. Монеты и монетные подражания-брактеаты найдены в 19 курганных могильниках, а также в Усть-Шексне и Ярославле. В восьми могильниках обнаружены только арабские монеты и их подражания, в трех могильниках вместе с арабскими были монеты западноевропейские, в восьми могильниках - только западноевропейские. В могильнике Плешково 1 найдена редкая в Поволжье византийская монета. Большая часть монет использовалась в качестве нагрудных украшений с приклепанным ушком или отверстием для подвешивания. В могильнике Пекуново 2 монету положили в рот покойницы в качестве обола, в погребении могильника Плешково 1 монета как заупокойный дар находилась в заполнении могилы над погребением. По материалам могильника Плешково 1 можно заметить последствия «серебряного» кризиса, наступившего на рубеже X-XI вв., когда приток восточного серебра прекратился. Нехватка монет восполнялась подделками. Имитация монет производилась путем односторонних оттисков подлинника на тонком серебряном кружочке 


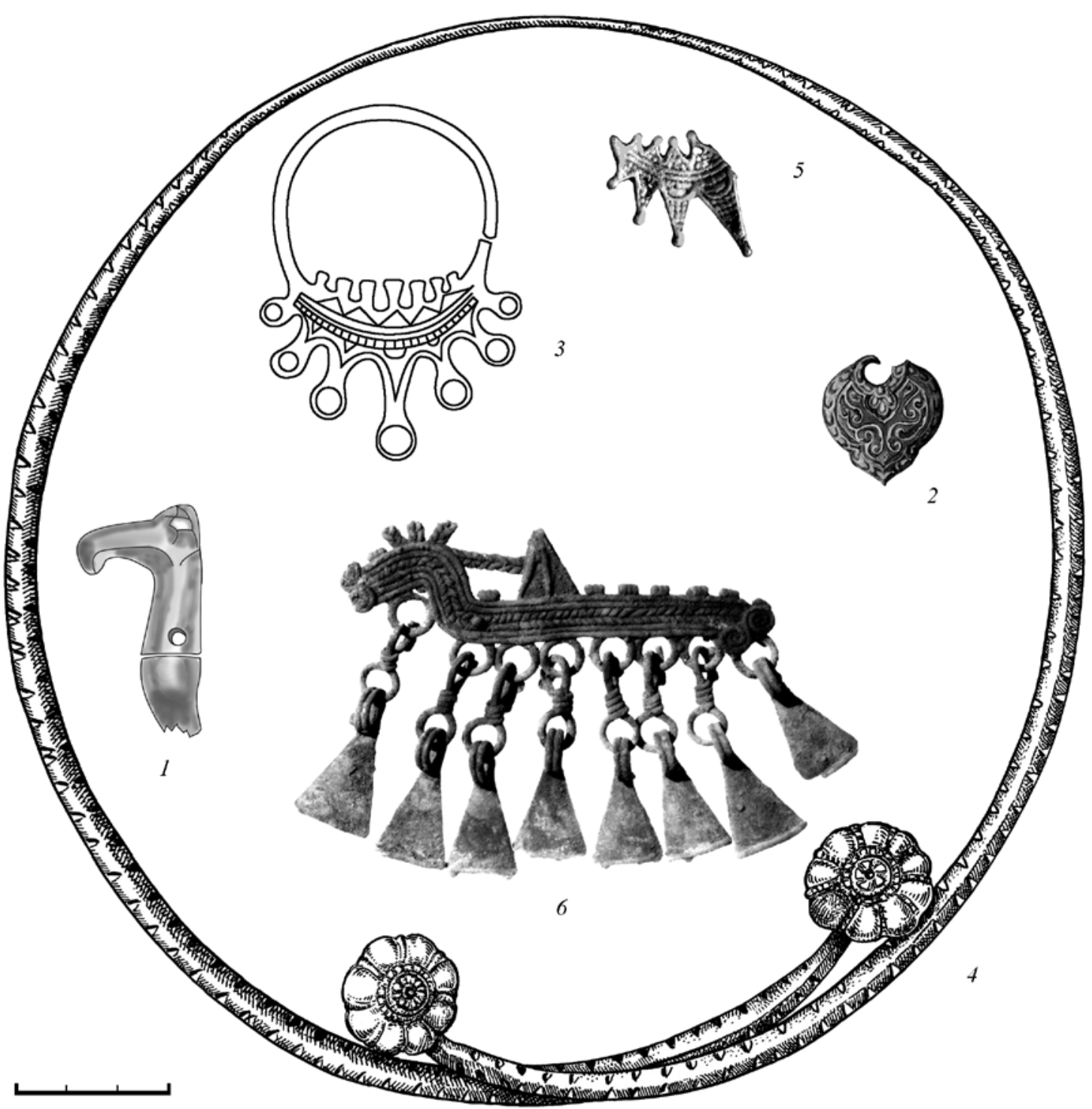

Рис. 1. Находки со средневековых памятников Верхнего Поволжья

1 - бронзовый затыльник плети; 2 - позолоченная ременная бляшка, могильник Пекуново 2; 3 - височное кольцо, могильник у д. Рыпы; 4 - шейная гривна, могильник Пекуново 2; 5 - височное кольцо, могильник Пекуново 2; 6 - шумящая подвеска-конек, могильник Плешково 1

либо отливкой в формочках по оттискам подлинников. Некоторая часть найденных здесь украшений была изготовлена из оловянистых сплавов. В первую очередь это подделки монет, отлитые по форме популярных арабских дирхемов. Наряду с серебряными монистами фиксируются мониста из оловянной проволоки с нанизанными на стержень бусами. Олово употреблялось также для имитации некоторых украшений под серебро. Полудой был покрыт головной венчик из бронзовой ленты, найденный в кургане № 44 могильника Плешково 1. Здесь же отмечены и другие погребения с признаками некоторых украшений на черепе
(Комаров, 2002. С. 144.). К сожалению, изделия из олова сохранились плохо и рассыпались в порошок при выемке. Не исключено, что в некоторых случаях изделия подобного рода могли быть не замечены из-за плохой сохранности.

Кроме монет среди населения Поволжья оседали и другие изделия заморского импорта. Наряду с византийской монетой в кургане № 26 могильника Плешково 1 найдена керамическая византийская чашечка, единственная аналогия которой зафиксирована в кургане № 42 могильника у с. Весь на Владимирщине (Уваров, 1871. С. 821). Высокохудожественная позолоченная ременная бляшка иранской 
работы входила в состав нагрудного украшения в женском погребении могильника Пекуново 2 (рис. 1,2$)$. Среди других изделий, свидетельствующих об участии местного населения в торговых операциях, можно отметить находки бронзовой стрелки от чашечных весов и железного писала на поселении Золоторучье 2. Находка писала на сельском поселении представляется уникальной.

Набор инвентаря свидетельствует о разноэтничном составе погребенных в курганных могильниках Верхнего Поволжья. Большая часть височных украшений принадлежит к типу браслетообразных незавязанных. Начало их распространения в Волго-Клязьминском междуречье В.В. Седов связывал с инфильтрацией части населения из областей центральной и придунайской Европы в V-VII вв. (Седов, 1999. С. 150-154) и формированием местной культуры раннего железного века. В одном кургане могильника Пекуново 2 найдены семилучевые височные кольца. Они несколько отличаются от классических радимичских, но, несомненно, относятся к тому же типу и находились в комплексе с гривной радимичского типа (рис. 1, 4). В другом кургане найден фрагмент орнаментированного ложной зернью височного кольца радимичского типа с отверстием для подвешивания (рис. 1,5$)$. Гривна радимичского типа, найденная в кургане соседнего могильника Пекуново 1, была в сочетании с подвесками мерянского стиля (Успенская, 1971. С. 254, 256, 257). Семилопастные височные кольца раннего вятичского типа найдены в могильнике Глинники и при обследовании площади размытого могильника у д. Рыпы (рис. 1, 3). Ромбощитковое и овальнощитковое височные кольца словен новгородских найдены в единичных экземплярах в курганах Плешково 1 и Оленино. Завязанные проволочные браслеты из серебряной проволоки из могильника Плешково 1, по мнению Ю.М. Лесмана, появились в верхнем Поволжье в результате варяжского проникновения еще в конце IX в. (Комаров, 2002. С. 156; Лесман, 1996).

Вероятно, западное влияние из области смоленских кривичей отмечают коньки смоленского типа, найденные в семи курганных могильниках и поселениях. В некоторых погребениях они были привешены на цепочке вместе с небольшими ножами, бубенчиками и колокольчиками. В одном погребении вместе с бубенчиками гирляндой висело шесть коньков. Бубенчики составляли заметную категорию в инвентаре женских украшений. Они обнаружены в 15 курганных могильниках и по большей части находились в составе подвесок вместе с другими типами амулетов. Бубенчики-подвески встречаются на широкой территории, в том числе во владимирских курганах. В двух погребениях найдено 11 и 16 бубенчиков, вплетенных в косы в несколько ярусов. Здесь сохранились фрагменты льняного (?) шнура, сохранившиеся в медных обоймицах. Подобный тип убора находит ближайшие аналогии в Шатрищенском (Кравченко, 1974. С. 134-136) и Безводнинском могильниках (Краснов, 1980. С. 48, 49). В этом же могильнике наряду с обычными браслетообразными височными кольцами находились втульчатые височные кольца (мерянские, по определению Е.И. Горюновой). В могильнике Пекуново 1 фрагмент конька мерянского стиля вместе с ажурным треугольником оказался нанизанным на гривну радимичского типа. В числе многочисленных шумящих подвесок в могильнике Плешково 1 найден характерный конек мерянского типа (рис. 1, б). Здесь же отмечен случай подвески к гривне ажурного треугольника на шнурке из шерстяной нити. Уникальной находкой в могильнике Плешково 1 можно считать подвеску, которая находит аналогии в древностях муромы (Комаров, 2002. Рис. 4. 15; см. также: Финноугры и балты... 1987. Таб. XXXV, 2). Случаи находок мерянского стиля отмечены на магистральном пути из Ростовской земли на Белоозеро по р. Шексне (Горюнова, 1954. С. 153-156; Кудряшов, 2007. Рис. 3,2$)$ и в культурном слое Усть-Шексны (Рькунов, Рыкунова, Иванов, 2011. С. 57, 58).

В некоторых пунктах на общем фоне выделяются компактные группы памятников с инвентарем определенного этнического стиля. На Волге у г. Мышкина в близком соседстве расположено три курганных могильника с находками в инвентаре зооморфных подвесок в виде плоских прорезных и полых фигурок уточек и петушков с шумящими привесками. В культурном слое Усть-Шексны наряду с украшениями мерянского стиля найдено значительное количество объемных и пластинчатых зооморфных фигурок. Подобные украшения могли появиться здесь в результате оседания славянизированного чудского населения Новгородской земли. В могильнике Плешково 1 выделяется значительное количество погребений с инвентарем меряно-муромского типа виде треугольных, перстневидных и некоторых других подвесок с привесками из лапок, трапеций и бубенчиков. Несомненно, это население было переведено сюда с юга из Ростово-Суздальской земли. В инвентаре могильников Пекуново 1 и 2 проявляется радимичское влияние. Присутствие вятичского этнического элемента в среде насельников Верхневолжья отмечается находками семилопастных височных колец 
раннего вятичского типа. Очевидно, «уставляя землю ту», Ярослав следовал политике отца, набиравшего для создания обороны южных рубежей своей земли «муже лучьшие от словенъ, и от кривичь, и от чюди, и от вятичь» (ПВЛ, 1996. С. 54). Ярослав, тесно связанный с Новгородом и Ростовом, выводил на Волгу поселенцев из подвластных земель компактными группами. Эта политика отмечается и впоследствии. В одной из войн с Рязанью в 1208 г. Всеволод Большое Гнездо выводит побежденных в свою землю: «и повеле великый князь всем людем изити из града и с товаром, и яко изидоша вси, повеле зажещи град... и възвратися... поимъ по собе все Рязанцы» (ПСРЛ.Т.І. Стб. 434). Очевидно, с переводом рязанцев на угличском участке Волги вплоть до Дубны появляется гончарная керамика с накольчатым штампом по тулову, впервые отмеченная на городище Старая Рязань в слое XI в. (Фехнер, 1957. С. 190).

Успехи аграрной колонизации Волго-Клязьминского междуречья вместе с ростом народонаселения обусловили подъем экономического потенциала области. На этой основе оформляется Ростово-Суздальское княжество. Киевская Русь вступала в фазу феодальной раздробленности, характеризуемую междоусобными войнами и переделом владений. На северо-востоке Руси первая феодальная война разразилась в 1096 г., в ходе нее погиб сын Владимира Мономаха Изяслав. Другой его сын, Мстислав, дал отпор незаконному претенденту Олегу Святославичу Черниговскому. Обстоятельства вынудили Владимира Мономаха в период 1001-1008 гг. трижды наезжать в Ростов для обустройства своей волости (ПВЛ, 1996. С. 104, 119, 120). Результатом его деятельности стало основание городов Владимира на Клязьме, Переславля Старого на оз. Клещино и укрепление Суздаля обширными валами. Его младший сын Юрий Долгорукий около 1152 г. перенес Переславль старый на новое место, построил Юрьев Польской, в 1154 г. Дмитров, возвел новые укрепления в Суздале и Владимире. Города становятся центрами определенной, тесно связанной с ними аграрной округи. Они эксплуатируют аграрную периферию и обеспечивают ее поставками ремесленных изделий, услугами торговли и другими экономическими потребностями. В городах строятся церкви - очаги распространения православной культуры. Развивается и совершенствуется административная система управления на местах.

На Волге возникает цепочка городов. В войне с Юрием Долгоруким Изяслав Мстиславич, пройдя по Волге до Ярославля, разорил шесть городов. В их числе называются Дубна, Кснятин, Углич, Молога, Ярославль. На роль неназванного города может претендовать только Усть-Шексна. Возможно, располагаясь в междуречье двух мощных водных систем, он не нуждался во внешних укреплениях. Тем не менее здесь находилось обширное поселение с богатой материальной культурой $(P b l-$ кунова, Рыкунов, Иванов, 2004; Рыкунов, Рыкунова, Иванов, 2011). Ключевое положение на перекрестке путей сообщения по Волге, Шексне и Мологе придавало Усть-Шексне исключительно важное стратегическое значение. Растет бывший «мал городок» Ярославль. Бывший Ростовский удел наряду с другими землями Руси становится княжеством.

\section{Литература}

Гендуне Ю.Г., 1906. Отчет о раскопках в 19051906 гг. / Архив ЛОИА. Ф. 1. № 30.

Горюнова Е.И., 1954. Мерянский могильник на Рыбинском море // КСИИМК. Вып. 54. С. 153-163.

Дубов И. В., 1982. Северо-Восточная Русь в эпоху раннего средневековья. Л.: ЛГУ. 248 с.

Комаров К.И., 1995. К истории населения побережья Плещеева озера в X-XIII вв. // Сообщения Ростовского музея. Вып. VIII. Ярославль: ФГИ «Содействие». С. 137-172.

Комаров К.И., 2002. Раскопки курганного могильника у д. Плешково Тверской области // Археологические статьи и материалы: Сб. участников Великой Отечественной войны. Тула: Гриф и $\mathrm{K}^{\circ}$. C. 141-189.
Кравченко Т.А., 1974. Шатрищенский могильник (по раскопкам 1966-1969 гг.) // Археология Рязанской земли. М.: Наука. С. 116-184.

Краснов Ю.А., 1980. Безводнинский могильник. М.: Наука. 224 с.

Кудряшов A.В., 2007. Поселение Черный ручей-2 на речке Андоге (некоторые итоги исследований в 2003-2006 годах) // Археология: история и перспектива. Третья межрегиональная конференция. Ярославль. С. 114-123.

Куза А.В., 1989. Малые города древней Руси. М.: Наука, 168 c.

Лапшин В.А., 1981. Ранняя дата Владимирских курганов // КСИА. № 166. С. 45-48. 
Леонтьев А.Е., 1989. Тимерево. Проблема исторической интерпретации археологического памятника // СА. № 3. С. 79-86.

Леонтьев А.Е., 1996. Археология мери. К предыстории Северо-Восточной Руси. М.: Геоэко. 340 с.

Лесман Ю.М., 1996. Двойной узел в средневековых ювелирных изделиях Восточной Европы // Ювелирное искусство и материальная культура. Тез. докл. 2-го коллоквиума. СПб.: ГЭ. С. 35-37.

Носов Е.Н., 1976. Нумизматические данные о северной части балтийско-волжского пути конца VIII-X в. // ВИД. Вып. VIII. C. 96-110.

НПЛ. ПСРЛ. Т. 3. М.: ЯРК, 2000. 723 с. (репр. изд. под ред. А. Н. Насонова: М.-Л.: Изд. АН СССР, 1950).

ПВЛ. СПб.: Наука, 1996. 667 с. (Литературные памятники).

ПСРЛ. Т. І. Лаврентьевская летопись. Рязань: Александрия. 2001. 586 стр. (Русские летописи; т. 12).

ПСРЛ. Т. IX. Никоновская летопись. СПб: Тип. Эдуарда Праца, 1862. 256 с.

ПСРЛ. Т. XXV. Московский летописный свод конца XV века. М.-Л., 1949. 464 с.
Рькунов А.Н., Рькунова И. И., Иванов Л. М., 2011. Рыбинск: путешествие сквозь века. Археология земли Рыбинской. Рыбинск: Медиарост. 168 с.

Рыкунова И.И., Рыкунов А. Н., Иванов Л. М., 2004. Тысячелетия вокруг устья Шексны. Рыбинск: Рыбинский дом печати. 272 с.

Седов В. В., 1999. Древнерусская народность. М.: ЯРК. 317 c.

Третьяков П.Н., 1966. Финно-угры, балты и славяне на Днепре и Волге. М.-Л.: Наука. 308 с.

Уваров А. С., 1871. Меряне и их быт по курганным раскопкам // Труды I AC. Т. II. М. С. 633- 847.

Успенская А.В., 1971. Пекуновское селище и курганы // СА. № 1. С. 254-257.

Фехнер М.В., 1957. Селиша Ярославского Поволжья XI-XIII вв. // Краеведческие записки. Вып. II. Ярославль: Ярославский областной краеведческий музей.

Финно-угры и балты в эпоху средневековья. М.: Наука, 1987. 512 с. (Археология СССР).

Щапов Я.Н., 1976. Древнерусские княжеские уставы. XI-XV вв. М.: Наука. 240 с.

Послесловие

\section{О статье Константина Ивановича Комарова}

Несмотря на уже плохое здоровье, Константин Иванович в основном написал эту статью в 2017 г. и закончил ее в начале 2018 г., незадолго до своей кончины на 92-м году жизни.

Константин Иванович стал археологом в сорокалетнем возрасте, но успел сделать в науке очень много. Его первая публикация посвящена раннеславянским древностям на одном из поселений в бассейне Верхнего Дона под Липецком (Комаров, 1972), что было связано с тематикой дипломной работы, защищенной в 1966 г. на кафедре археологии МГУ. Однако в конце 1960-х гг. К. И. Комаров раз и навсегда связал свою научную деятельность с древнерусской археологией Верхнего Поволжья, будучи сотрудником сначала Верхневолжской, затем Волго-Окской экспедиций ИА РАН.

Одновременно с ежегодными разведками и раскопками в Верхневолжском регионе Константин Иванович во второй половине 1970-х гг. занялся проблемой славянского (древнерусского) расселения на Плещеевом озере и в его окрестностях. Работая над этой темой, он одним из первых тщательно изучил дневники раскопок А.С. Уварова и П.С. Савельева, хранящиеся в отделе письменных источников ГИМ, и частично восстановил вещевые комплексы из раскопанных курганов по коллекциям отдела археологических памятников ГИМ. В результате была создана обширная картотека, каждая карточка которой содержит краткое и емкое описание отдельного погребения по единой системе, что впервые сделало материалы раскопок 1851-1854 гг. полноценным археологическим источником. Эта рукописная база данных по погребальным комплексам района Плещеева озера до сих пор сохраняет важное научное значение и, надеемся, будет и дальше использоваться археологами. Изучение архивных источников и музейных коллекций дополнялось полевыми изысканиями, в ходе которых он локализовал на местности остатки раскопанных могильников и обнаружил связанные с ними синхронные селища. К сожалению, К. И. Комаров не смог по независящим от него причинам защитить почти законченную работу как кандидатскую диссертацию, однако в дальнейшем опубликовал основные результаты своего исследования (Комаров, 1993; 1995; 2006б; 2010; 2014). 
Еще одним крупным вкладом К.И. Комарова в археологию Верхнего Поволжья и Северо-Восточной Руси стало создание монографических выпусков серии «Археологическая карта России» по трем областям Верхневолжского региона - Ивановской, Костромской и Ярославской (Комаров, 1994; 1999; 2005). Первый из них Константин Иванович защитил в качестве кандидатской диссертации. Важно подчеркнуть, что при подготовке этих научно-справочных томов К.И. Комаров опирался не только на архивные и литературные данные, но и на собственные многолетние полевые исследования в Верхневолжье, особенно разведки. За 30 лет им были открыты или заново обследованы на современном научном уровне сотни памятников археологии, устранены многочисленные противоречия и неточности в работах предшественников. Нельзя не упомянуть о проведенных им раскопках многих памятников, в первую очередь курганного могильника XI - первой половины XII в. у д. Плешково в Тверской области, насчитывавшего около 60 насыпей и полностью исследованного в 1980-1986 гг. Публикация материалов этих раскопок (Комаров, 2002) является одной из лучших для древнерусских сельских некрополей.

В последние годы Константин Иванович закономерно обратился к широким научным обобщениям. В их числе - публикуемая ниже статья. Другой тщательно разработанный сюжет - это вопрос о ходе, условиях и обстоятельствах татаро-монгольского нашествия на Северо-Восточную Русь в 1237-1238 гг. (Комаров, 2006а; 2012). Казалось бы, такое крупнейшее в древнерусской истории событие изучено практически досконально. Однако К.И. Комарову удалось найти новые подходы, аргументированно опровергнуть некоторые ошибочные трактовки и распространенные заблуждения. В основе его исследования лежит не только глубокое знание археологических и письменных источников по истории Северо-Восточной Руси, но и непосредственное знакомство с тем историко-географическим регионом, по которому проходило нашествие монголов, особенно с такими ключевыми территориями, как район битвы на р. Сить в марте 1238 г. (Комаров, 1978). Здесь Константин Иванович использовал свои знания и опыт не только ученого, полевого археолога, но и бывшего военного, в том числе военного топографа. Мы уверены, что эти новаторские исследования получат высокую оценку историков Древней Руси. Что же касается вклада К. И. Комарова в славяно-русскую археологию Верхнего Поволжья, то его большое значение понятно уже сейчас и, несомненно, будет в полной мере осознано в будущем.

Комаров К. И., 1972. Находка раннеславянской керамики на Верхнем Дону // КСИА. Вып. 129. С. 47-49.

Комаров К.И., 1978. К вопросу о месте битвы 1238 г. на Сити // Проблемы советской археологии. М.: Наука. C. 209-218.

Комаров К. И., 1993. Импортные ткани во Владимирских курганах // КСИА. Вып. 210. С. 77-85.

Комаров К. И., 1994. АКР. Ивановская область. М.: ИА РАН. 224 с.

Комаров К. И., 1995. К истории населения побережья Плещеева озера в X-XIII вв. // Сообщения Ростовского музея. Вып. VIII. Ярославль: ФГИ «Содействие». С. 137-172.

Комаров К. И., 1999. АКР. Костромская область. М.: Восточная литература РАН. 368 с.

Комаров К.И., 2005. АКР. Ярославская область. М.: ИА РАН. 408 с.

Комаров К. И., 2006а. Нашествие Батыя на Северо-Восточную Русь (1237-1238 гг.) // Археология Верхнего Поволжья (к 80-летию К. И. Комарова). М.: ИА РАН. С. 16-39.

Комаров К.И., 2006б. Славянские поселения на Плещеевом озере в Х-XIII вв. // Археология: история и перспективы. Вторая межрегиональная конференция. Ярославль. С. 424-438.

Комаров К.И., 2010. Курганы ростовской округи по раскопкам П.С. Савельева // Археология: история и перспективы. Четвертая межрегиональная конференция. Вып. 4. Ярославль. С. 129-143.

Комаров К. И., 2012. О нашествии Батыя на Северо-Восточную Русь в 1237-1238 гг. // ВИ. № 10. С. 87-96.

Комаров К. И., 2014. Городище Александрова гора - памятник археологии V в. до н. э. - XVII в. н. э. // PA. № 3. C. 140-146. 


\section{Ю. Ю. Моргунов \\ Институт археологии РАН, г. Москва}

\section{Еще раз о «полезной площади» городищ}

На современный уровень изучение социальноисторической типологии древнерусских укрепленных поселений были поднято А.В. Кузой. Автор той исследовательской волны не увидел полной публикации своих наработок (Куза, 1983; 1985; 1989. С. 40-70; 1996. С. 28-37). Тем не менее его научный вклад по заслугам оценили современники и последователи.

Ныне не остается сомнений в том, что, за исключением крупнейших городов, наделенных полнотой «городских» признаков, письменные и археологические источники указывают на существование иерархического каскада укрепленных поселений «младших» рангов. К их числу относят частновладельческие города, сторожевые крепости, усадьбы-замки, крепости-убежища и некоторые другие. Было бы заманчиво с опорой на эту классификацию еще до раскопок хотя бы приблизительно представлять, городище какой категории предстоит исследовать. Но это невозможно: в летописных источниках городами именовались даже незначительные защитные укрепления и даже ограждения. Бессильны и археологические наработки: атрибутика меньших укреплений пока довольно условна, поскольку объективные критерии и признаки этих памятников еще ожидают детализации.

В связи с этим любопытно проведенное В.Ю. Ковалем на довольно обширном материале уточнение городской атрибутики. По его мнению, одним из ведущих признаков по-прежнему остаются размеры детинцев, посадов и селищ. Этот анализ показал, что классические признаки города не столь жестко связаны с привычной иерархической колонкой. Частью они встречаются и на небольших городищах, селищах, феодальных усадьбах, а полным набором городских атрибутов обладали не только крупнейшие летописные города XII-XIII вв., но и средние по величине. Для подавляющего большинства укрепленных поселений нормой являлись лишь несколько призна- ков, но отсутствие других не является основанием для отрицания городского характера поселения. По мнению исследователя, для оценки социальной иерархии наиболее значимым для реальных городов было наличие развитой усадебно-дворовой планировки и уличной системы застройки. Второе по значению место занимают экономический и религиозный признаки, хотя в подавляющем большинстве церкви малых городов были бревенчатыми (Коваль, 2014).

Довольно однородной была и материальная культура древнерусских городов, разница заключается лишь в ассортименте дорогих вещей. Но количественная оценка предметов дальнего импорта, изделий из драгоценных металлов, символов власти и кладов скорее определяется наличием на памятниках усадеб аристократии и попаданием их частей в зону раскопок. Таким образом, обобщенное выделение малых городов в отдельную категорию В. Ю. Ковалю представляется несколько искусственным: малые города возникали в определенных исторических условиях. Они появились в XI в. с расширением городской сети, а в XII-XV вв. к числу малых относилось подавляющее большинство укрепленных поселений Руси. Это самый многочисленный субъект цивилизации, основной структурообразующий компонент любого государства (Коваль, 2017. С. 246-250).

С выводами исследователя трудно не согласиться. Нельзя забывать, что жесткие рамки городских признаков были для А. В. Кузы лишь первой фазой обобщения материалов, подлежавшие дальнейшей разработке. В частности, его беспокоили слишком дробные интервалы размеров привлеченных им городищ (до 0,2, 0,2-0,5, 0,5-1,0, 1,0-1,5, 1,5-2,0, 2,0-2,5 га и т. д.): они заставляли привлекать иные, порой второстепенные возможности оценки памятников, что вновь возвращает нас к необходимости первичной оценки укреплений по размерам детинцев. Несомненно, это вынужденная мера: 
она обусловлена слабой изученностью большинства городищ.

Мой первый статистический опыт в этом направлении был применен к посульским городищам округлой конфигурации (Моргунов, 1986. Рис. 4; 1990. Рис. 2). Оказалось, что памятники этого типа распределялись компактными группами размерами 0,16-0,37, 0,7-1,0 и 1,6-1,8 га, а далее следовало более рассеянное расположение крупнейших памятников. Соответственно, лакуны между группами имели протяженность 0,37-0,70, $1,0-1,6$ и 1,8-2,1 га. Интересно, что в интервал 0,7-1,0 га попали и небольшие летописные города, а в размерной группе более 1,6 га содержались исключительно летописные памятники. С одной стороны, это отсылает нас к выводам В.Ю. Коваля, a с другой - напоминает о давних предположениях о существовании древнерусских «градостроительных стандартов» (Моргунов, 1986. С. 113-118; 1990. С. 99-108; Лебедев, 1995. С. 94, 95). Таблица подтвердила реальность этих ожиданий и вероятность строительства крепостей по заранее намеченному плану с заданным комплексом оборонительных требований и определенной социальной и оборонительной нагрузкой.

Распространение опыта на мысовые городища того же региона вновь указало на стандартизацию крепостных сооружений и прямую связь размеров детинцев с упоминаниями крепостей в письменных источниках (Моргунов, 2012. Рис. 129) (табл. 1). Высказывалось даже предположение об уникальности посульской фортификации, связанной с ведущей ролью княжеской власти в создании этого рубежа (Куза, 1996. С. 40). Попытка оценки подобным образом всех детинцев Переяславской земли оказалась неудачной из-за разной методики замеров исследователями их площадей. Чаще подсчеты велись по гребням валов, но нередко в размеры детинцев включали всю ширину валов и рвов. Подобный разнобой не отражает сути «полезной» площади укрытий, которая ограничивалась величиной площадок городищ. Очевидно, именно методические погрешности стали причиной множественности лишь немногим отличавшихся групп городищ, зафиксированных А. В. Кузой (1989. С. 41) и М. П. Кучерой (1984. С. 70).

Следующим шагом стало создание таблицы размеров летописных городов Переяславской земли с указанием величин детинцев и сопровождав- ших их поселений в гектарах: несмотря на разницу в замерах, городищенская картина вновь приблизилась к размерной группировке (табл. 2). Верхняя часть таблицы показывает, что реальными городами были далеко выходящие за ее пределы центры земель-княжений ${ }^{1}$. Ниже нашли свое место городища площадью 2,0-3,5 га, с окрестными поселениями площадью 20-23 га. Их неодинаковые размеры отражают индивидуальное развитие городов: городскими центрами их считал М.П. Кучера (1984. С. 72). А. В. Куза за городские принимал городища размером не менее 2,5 га; он собирался снизить эту цифру до 2,0 га, но не решился или не успел это осуществить, хотя для них характерна максимальная доля городских атрибутов (Куза, 1985. С. 47; 1989. С. 43). Любопытна картография размещения крепостей этой группы, красной нитью пометивших степной рубеж от Курска до Воиня: это были ключевые центры переяславской окраины, вероятно, наделенные городским статусом.

Компактная группа детинцев размерами 1,5-1,8 га с посадами площадью 10-50 га приближается к предшествующему, более рассеянному скоплению значительных укреплений: их разделяет промежуток всего в 0,2 га. Социальная идентификация этих укреплений пока однозначно не определяется, но хотелось бы видеть в них малые княжеские города с полномочиями, зафиксированными на многих из них актовыми печатями.

Столь же компактна группа укреплений с детинцами площадью 0,7-1,0 га и посадами размерами от 8 до 30 га. Разрастание их политической значимости и поселенческой базы к середине XII в. сделало Путивль и Остерский Городец центрами обширных волостей, что указывает на определенную гибкость структурных изменений. Стационарными раскопками городища летописного г. Снепорода изучены его мощные укрепления со сложной конструкцией въезда, но на исследованной трети площадки обнаружилась лишь рассеянная кольцевая застройка. В каждый период существования крепости на ней размещалось всего от двух до четырех жилых построек без хозяйственных служб; по сравнению с посадом напластования детинца отличались и низкой насыщенностью.

Среди находок детинца и посада Снепорода нередки предметы вооружения, снаряжения коня и всадника, предметы импорта, ювелирные изделия с позолотой и перегородчатой эмалью; неоднократны

\footnotetext{
${ }^{1}$ Оговорюсь: в связи с плотной застройкой Курска и Рыльска площади их древнерусских городищ нуждаются в дальнейшем уточнении. Оба памятника были крупными центрами и в позднесредневековое время, но остатки домонгольской фортификации достоверно не выделены.
} 
Таблица 1. Распределение городищ Посулья по размерам их площадок.

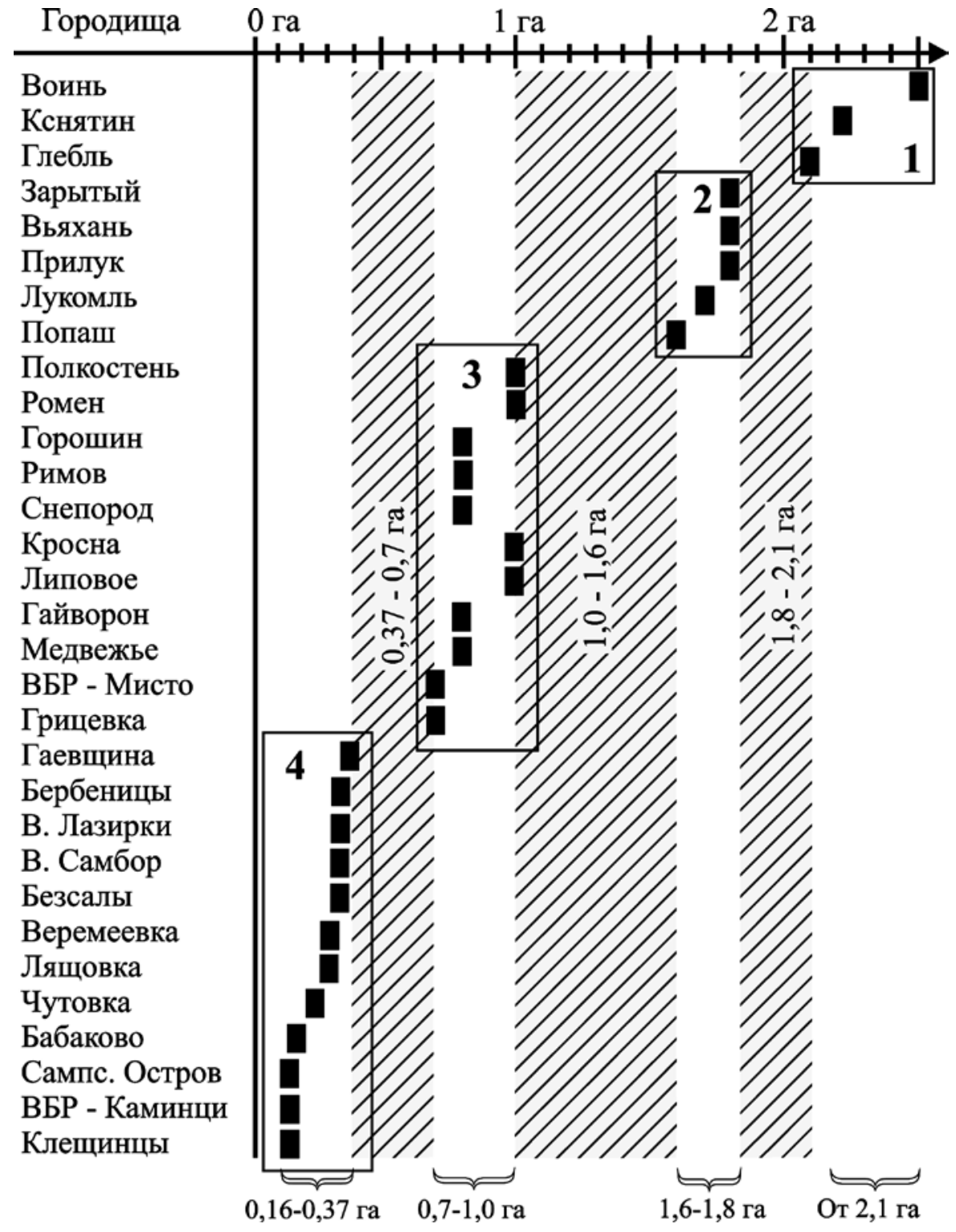

и предметы с граффити. В конце XII в. на детинце появилась небольшая бревенчатая церковь. Но следов резкого социального неравенства не обнаружено: это объясняет, почему Снепород принимают за сторожевую княжескую крепость с проживавшими на посаде «переяславскими торками» и обширной сельскохозяйственной округой (Моргунов, 2012. С. 100-109, 116-120). Вероятно, такими могли быть и другие укрепления подобных размеров.

Группа наименьших крепостей «полезной» площадью 0,3-0,5 га представляет собой остатки универсальных, экономичных при возведении укреплений: их можно было построить в любом месте и приспособить к несению множества функций. Ярким представителем этой группы является княжеский замок Любеч. Размеры его детинца - 0,3 га, двух плохо изученных укрепленных посадов-5 га, существовало также окружение из могильников и селищ. Даже в разграбленном виде его клады и богатство других находок живо напоминают опустошенное разгромом Игорево сельцо - «добрый двор», упомянутый в Ипатьевской летописи под 1146 г. «...Бち же тоу готовизни много в бретьяничахъ [бретяницех] и въ погребех вина и медовђ; и что тяжкого товара всякого до жельза и до мъди не тягли бяхоуть от множества всякого того вывозити. Давыдовича же повельста имати на возы собъ и воемъ, и потом повельста зажечи 
Таблица 2. Размерные характеристики летописных городов лесостепного Левобережья Днепра.

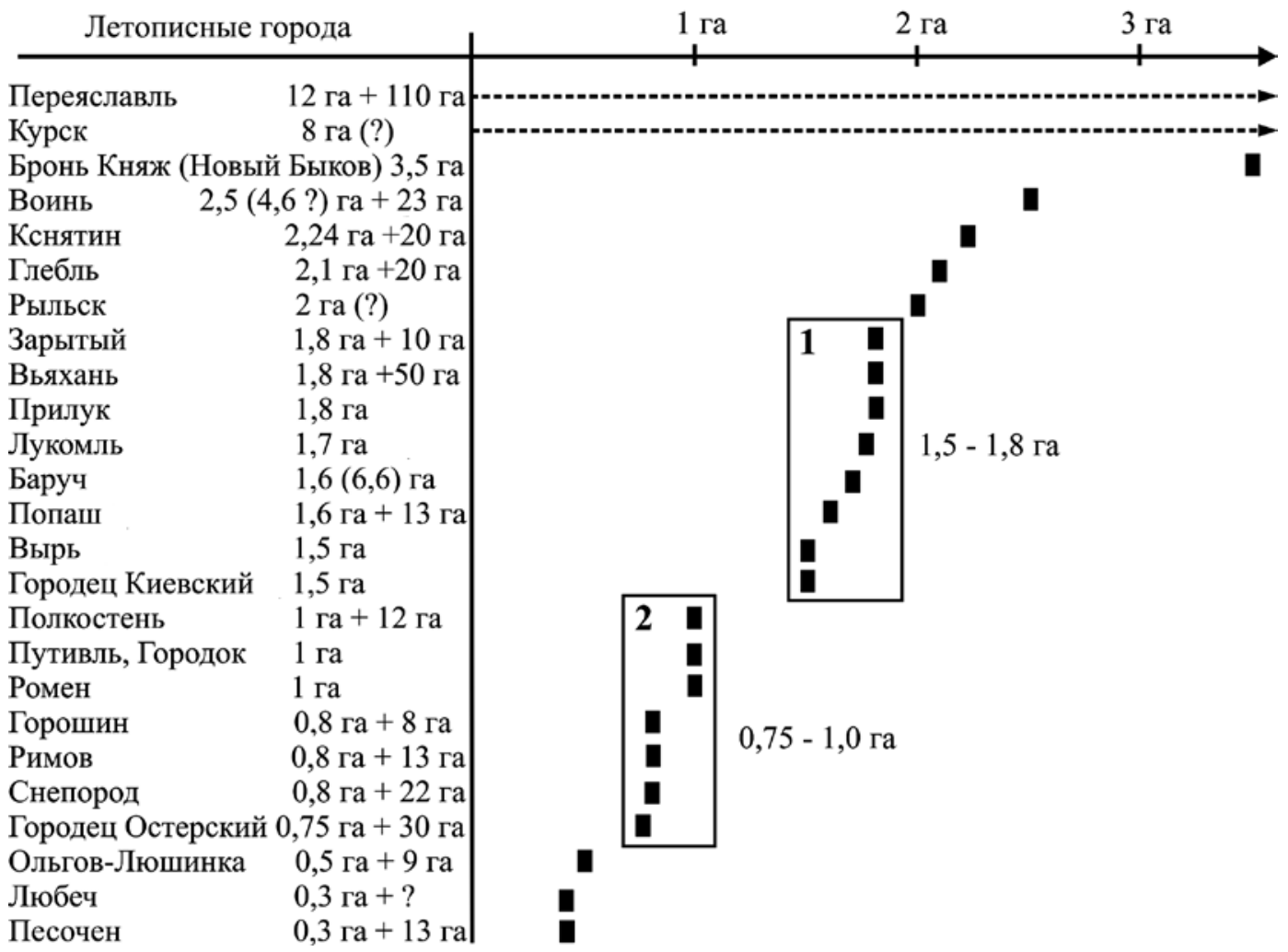

дворъ и церковь святаго Георгия, и гоумно его: в немже бъ стогов 9 сот...» (ПСРЛ.Т. 2. С. 333).

Подобным центром мог быть среди прочих летописный Ольгов на Сейме, отождествленный с городищем Люшинка: размеры его детинца - 0,5 га, посада - 9 га (Стародубиев, 2008; Стародубиев, Зорин, Остроухов, 2008). Вероятно, сходным памятником является летописный Песочен (с. Песчаное на р. Супой). Размеры его детинца сопоставимы с Любечем, а площадь окружающих селищ составляет 16 га. Значимость раннего расселения увеличивают находки анонимных византийских фолисов Х в., сребреников и вислой печати переяславского князя Ярополка Владимировича (Прядко, 2015). Судя по спутниковым снимкам, там вероятно существование укрепленного посада площадью не менее 13 га $^{2}$. Конструктивно сходно и плохо изученное городище XII-XIII вв. Светильня на Трубеже с детинцем размерами 0,45 га (Кучера, 1978. C. 22-26) и полукольцом разрушенных укреплений посада площадью около 20 га. По размерам к ним близки торческие укрепления Бербеницы и Высокие Лазирки (Лохвица-2). Все эти укрепления можно условно отнести к усадьбам-замкам.

Резюмируя приведенные выше материалы, можно заметить, что размеры детинцев могли определяться целью их строительства, заключавшейся в необходимости защитить стандартную или ключевую географическую точку с достаточным количеством окрестного населения, способного обеспечить его оборону и снабдить его обитателей продукцией сельскохозяйственного производства. Серьезным основанием для определения дальнейшей функциональной нагрузки крепости являлась возраставшая или уменьшавшаяся со временем политическая и оборонительная значимость региона.

Из категории наименьших укреплений (табл. 1) в современной исследовательской базе интересны раскопки остатков небольшого форпоста Сампсониев Остров на Средней Суле, охранявшего речной переход на выходе из степей к летописному городу Синцу. На его «полезной» площади (всего 0,18 га) изучено три четверти площадки детинца с инструментальной фиксацией всех датирующих

${ }^{2} \mathrm{http} / /$ wikimapia.org/\#lang=ru\&lat=50.481541\&lon=32.849121\&z=10\&m=yh. 
носителей. Анализ показал, что на площадке существовали две разновременные жилые зоны площадью по 180-200 кв. м, что близко к размерам рядовых городских усадеб рубежа XI-XII-XIV вв.: те также состояли из одного дома и трех-четырех хозяйственных построек (Кутовой, 1984. С. 66; Хорошев, 1997. С. 420). За пределами жилых зон ожидались множественные находки инвентаря, потерянного при скоплении укрывавшегося за стенами населения. Но его не было: окрестное население уходило от опасности под защиту соседних надпойменных лесов.

Для демографических подсчетов наиболее пригоден произведенный В.К. Козюбой комплексный статистический анализ, основанный на антропологических материалах, свидетельствах письменных источников и историко-демографических наработках. Настаивая на условности выводов, применимых лишь для значительных поселенческих агломераций, исследователь вывел среднестатистический показатель численности малой семьи, равный 6,31 человека (Козюба, 2001).

Подсчеты В.К. Козюбы позволяют с известной осторожностью прикинуть заселенность прилегавшего к укреплению открытого поселения в конце XII в. Его хорошо фиксирующаяся площадь исчисляется цифрой, близкой к 4 га, из которых сплошными раскопками охвачено 3,5 тыс. кв. м с остатками восьми жилых построек того времени. Поскольку в песчаном материке следы усадебного ограждения не сохранились, можно предположить, что в среднем за каждой семьей закреплялся участок площадью 445 кв. м, или 4,5 сотки. Исходя из размеров селища, допустимо предположение об одновременном существовании там во второй половине XII в. до 90 усадеб. Если учесть, что каждая семья располагала не менее чем двумя взрослыми мужчинами (к примеру, отец и старший сын), то вооруженный костяк, состоящий из 180 защитников, приводил сельскую крепостицу из минимальных размеров в разряд существенной по оборонительным возможностям боевой единицы.

В случае экстремальной необходимости, например дальнего похода в степи, такое поселение могло выставить в княжеское войско не менее сотни взрослых ополченцев. И даже в этом случае контингент защитников крепости не истощался: при нужде они могли бы занять все 150 м периметра заборол. Конечно, такой форпост рассчитан на отражение лишь небольших набегов, но количественно их было неизмеримо больше, чем рейдов, известных по летописным источникам. При появлении серьезной угрозы на помощь могла прийти поддержка из расположенного совсем рядом летописного Синца (Моргунов, 2003. С. 161-167).

Судя по поздним источникам, пожары нередко уничтожали значительные участки городов с их плотной бревенчатой застройкой. Применительно к домонгольскому времени раскопки также обнаруживают следы мощных возгораний, разрушавших стены крепостей. Их отличает толстый слой пепелища с развалами обгоревших бревен и прокаленными суглинистыми забутовками городней. Следы подобных катастроф распространялись и на прилегавшую часть площадки с уничтоженным жильем, сохранявшим следы неожиданной гибели. Раскопки же Сампсониева Острова показали, что за столетие его существования один пожар случился при въезде, а более мощным было охвачено всего 15-20 м протяженности обращенной к дороге части крепостной стены, где прослежены следы трех последовательных реконструкций. Эти локальные возгорания нельзя отнести к следствиям победных осад или полного сожжения крепости (Моргунов, 2003. С. 50). Очевидно, защитники не занимали всего периметра заборол, а скапливались лишь на опасном участке (Моргунов, 2003. С. 72-79, 164). Эта картина сходна с осадой Кончаком летописного Римова в 1185 г., когда часть стены рухнула как раз из-за скопления защитников на ратной стороне стены.

В свое время широкие разведки с обильной шурфовкой городищ и селищ Посулья не обнаружили в их культурных напластованиях следов обширных пожаров второй половины - конца XII в. Пожары не прослеживались и в разрезах городищенских валов, т.е. поселения не подвергались губительными разорениями этого времени на всем протяжении сульского рубежа. Это подтверждает ложность летописных сведений о том, что в 1185 г. «половци... взяша всђ городы по Сулњ», или что Кончак «снесе Сулу» (ПСРЛ. Т. 1. С. 399; Т. 2. С. 716). Скорее всего, эти сведения действительно легендарны или заимствованы из половецких эпических песен (Присёлков, 1996. С. 289; Pblбаков, 1971. С. 101). Напротив, после отдельных локальных пожаров горелые слои участков стен без стерильных прослоек или погребенной почвы перекрывались новыми строительными горизонтами, дожившими до середины XIII в. Возможно, это явление присуще только приграничным крепостям, разрушение которых открывало брешь в обороне Руси. Тем не менее захватчикам не пришлось разрушать крепости и в период татарской катастрофы: население заблаговременно покидало места обитания (Корінний, Моргунов, 1984). 


\section{Литература}

Коваль В.Ю., 2014. Малые города средневековой Руси: основные отличительные особенности // Tp. IV (20) ВАС в Казани. Т. 1. Казань: Отечество. С. 76-79.

Коваль В. Ю., 2017. «Малые города» средневековой Руси: особенности материальной культуры // Tp. V (21) ВАС в Барнауле. Т. 2. Барнаул: изд-во Алтайского ГУ. С. 246-251.

Козюба В.К., 2001. Історико-демографічна характеристика давньо-руської сім’і (за матеріалами історичних та археологічних джерел) // Археологія. № 1. С. 29-41.

Корінний М.М., Моргунов Ю.Ю., 1984. До питания про руйнування Кончаком переяславського Посулля в 1185 р. // УІЖ. № 7. С. 118-122.

Куза А.В., 1983. Социально-историческая типология древнерусских укрепленных поселений IX - середины XIII вв. // Археологические памятники лесостепного Подонья и Поднепровья I тысячелетия н.э.: межвузовский сборник научных трудов. Воронеж: изд-во Воронежского ГУ. С. 38-41.

Куза А.В., 1985. Укрепленные поселения // Древняя Русь. Город. Замок. Село. М.: Наука. С. 39-51. (Археология СССР).

Куза А. В., 1989. Малые города Древней Руси. М.: Наука. 168 c.

Куза А.В., 1996. Древнерусские городища XXIII вв. Свод археологических памятников. М.: Христианское изд-во. 256 с.

Кутовой А.И., 1984. Усадьбы как основной элемент градостроительной структуры древнерусского города // Древнерусский город (матер. Всесоюзной археологической конф., посвященной 1500-летию города Киева). Киев: Наукова думка. С. 65-66.

Кучера М.П., 1978. Давньоруські городища взахідній частиніПереяславщини // Археологія, № 25. C. 21-31.

Кучера М. П., 1984. Размеры древнерусского города по данным городищ на территории Украинской ССР // Древнерусский город (матер. Всесоюзной археологической конф., посвященной 1500-летию города Киева). Киев: Наукова думка. С. 69-72.

Лебедев Г.С., 1995. «Градки» на пути из варяг в греки (к проблеме фортификации как фактора древнерусской урбанизации IX-XIвв.) // Фортификация в древности и средневековье (матер. методологического семинара ИИМК). СПб.: ИИМК. С. 94-97.
Моргунов Ю. Ю., 1986. Круглые городища Левобережья Днепра // СА. № 2. С. 110-120.

Моргунов Ю.Ю., 1990. Функциональное назначение пограничных городищ Юго-Восточной Руси // Археологические исследования на Полтавщине / Под ред. А.Б. Супруненко. Полтава: Полтавське обласне управління культури. C. 95-108.

Моргунов Ю. Ю., 2003. Сампсониев Остров: пограничная крепость на посульской окраине Южной Руси в XI-XIII вв. М.: Наука. 186 с.

Моргунов Ю.Ю., 2012. Летописный город Снепород и его округа. X-XIII вв. СПб.: изд-во филологического факультета СПбГУ. 252 с. (Archaeologica Varia).

Присёлков М.Д., 1996. Летописание Западной Украины и Белоруссии // История русского летописания XI-XV вв. Приложение. СПб.: Дмитрий Буланин. 325 с.

Прядко О., 2015. Давньоруське городище Піщане на р. Супій // Археологія і фортифікація України. Зб. Матер. V Всеукраїнської науково-практичної конференції. Кам'янецьПодільський. С. 124-128.

ПСРЛ. Т. 1. Лаврентьевская летопись и Суздальская летопись по Академическому списку. М.: Языки славянской культуры, 2001. 496 с.

ПСРЛ. Т. 2. Ипатьевская летопись. 2-е изд. М.: Языки славянской культуры, 2001. 938 с.

Рыббаков Б. А., 1971. «Слово о полку Игореве» и его современники. М.: Наука. 293 с.

Самоквасов Д.Я., 1873. Древние города России. СПб. $190 \mathrm{c.}$

Стародубиев Г.Ю., 2008. Предметы вооружения, снаряжения и конской упряжи из раскопок люшинского археологического комплекса // Восточнославянский мир Днепро-Донского междуречья и кочевники южнорусских степей в эпоху раннего средневековья. Матер. науч. конф. Воронеж. С. 102-104.

Стародубиев Г.Ю., Зорин А.В., Остроухов С.А., 2008. Люшинский археологический комплекс и летописный Ольгов // Русский сборник. Вып. 4. Брянск: РИО БГУ. С. 60-64. (Тр. кафедры отечественной истории древности и средневековья Брянского ГУ им. И.Г. Петровского; вып. 9).

Хорошев А.С., 1997. Новгородские усадьбы Х$\mathrm{XV}$ вв. // Славянский средневековый город. М.: Наука. C. 411-425. (Тр. VI Международного Конгресса славянской археологии; т. 2). 


\section{П. Д. Малыгин \\ Институт археологии РАН, г. Москва}

\section{O «парах» и «переносах» городов древней Руси}

Основные вехи магистрального направления разработки теории происхождения древнерусского города с начала XX в. представляются нам следующим образом. В.О. Ключевский в рамках своей «торговой» теории усматривал два этапа древнейшей урбанизации на Руси. В VIII в. города возникали как сборные места торговли, в IX в. они окружаются укреплениями, и в них сосредотачивается военная сила общества. Так возникает «вооруженный торговый город» (Ключевский, 1902. С. 22-23).

С.В. Юшков выделил три типа древнерусских городов:

1) «племенные» города;

2) собственно княжеские (города-замки);

3) «находившиеся в общей административной системе земли-княжения».

Таким образом, город - это прежде всего феодальный центр (Юшков, 1939. С. 23, 46-47, 131-137, 172).

М.Н. Тихомиров считал, что ведущей функцией древнерусских городов была торгово-ремесленная. И о городах можно говорить лишь после появления у стен детинцев торгово-ремесленных посадов (Тихомиров, 1956. С. 44, 51). Позднее «посадом-общиной» как главным индикатором древнерусского города занимался Б. А. Тимощук (1988; 1995. С. 104-122).

По концепции Б. Д. Грекова, в основе процесса градообразования лежало отделение ремесла от сельского хозяйства и постепенное превращение поселения, где сосредотачивались торговцы и ремесленники, в опорные пункты феодального властвования (Греков, 1959. С. 78-90).

По Б. А. Рыбакову, древнерусское государство наделяло поселенческие центры функциями (элементами, признаками), которые накапливались и достигали обязательного сочетания в виде крепости, дворов феодалов, ремесленно-торгового посада, аппарата административного управления и церквей (История СССР... 1966. С. 536). Таким образом, поселение приобретало черты феодального города, выступавшего «узлом прочности» сельской округи (Рыбаков, 1982. С. 94-96).

В работе 1976 г. В.В. Карлов сделал важные замечания о том, что «раннегородское поселение имело лишь некоторые городообразующие признаки», а «в целом настоящий город характеризуется только совокупностью этих черт». Город с неполным набором признаков В.В. Карлов вслед за рядом археологов называет городом-«эмбрионом» и противопоставляет его «подлинному» городу с полным набором функций (Карлов, 1976. С. 37).

В концепции А.В. Кузы ключевыми выступают семь «городских» археологических признаков. Экономический, представленный производственными комплексами, торговым инвентарем и привозными вещами; административный, маркируемый находками печатей; военныци, включающий остатки укреплений и находки оружия, доспехов и снаряжения коня; архитектурно-монументальный, иначе - каменные культовые и гражданские сооружения и их остатки; культурный (памятники эпиграфики и орудия письма); топографический, которому соответствует усадебно-дворовая застройка и, наконец, характеризующие присутствие на поселении феодальной элиты предметы парадного убора и дорогой утвари (Куза, 1989. С. 51). А.В. Куза также предложил четыре основных варианта образования городов древней Руси (Куза, 1989. С. 161):

- из племенного центра;

- из укрепленного стана или погоста;

- из порубежной крепости;

- как единовременное основание (как правило, князем) города.

В.В. Седов поставил вопрос о перерастании протогорода в город. По мнению ученого, ранними городами стали протогорода, имевшие наряду с ремесленными и торговыми функциями еще 
и административную, политическую и культурную нагрузку (Седов, 1989. С. 45-46).

Во второй половине XX в. советские историки высказывали различные точки зрения по вопросу возникновения города в Восточной Европе. Среди них теория возникновения Новгорода из трех поселков-концов (Янин, Алешковский, 1971). И.Я. Фроянов, которого можно назвать реставратором теории древнерусского города-государства, выдвинутой еще Н.И. Костомаровым и М.Д. Затыркевичем, назвал механизм формирования города путем слияния нескольких поселений синойкизмом (Фроянов, 1980. С. 228-229).

В середине 1990-х гг. В.П. Даркевич обрушился с жесткой критикой на присутствующий в определении понятия «древнерусский город» свойственный марксизму экономический детерминизм (Даркевич, 1994a; 1994б; 1995). Исследователь показал, как глубоко и долго заблуждались отечественные историки, переоценивая воздействие экономических факторов в урбанизации древней Руси. Соглашаясь в целом с полифункциональностью средневекового города (Даркевич, 1995. С. 127, 137), он постулировал, что «урбанизация - прежде всего культурный процесс. Политико-административные и культурные функции города явно важнее, чем ремесло и торговля» (Даркевич, 1994a. С. 51-52). Исследователь обвинил в «непонимании средневековой экономики и социологии» (Даркевич, 1994б. С. 10) авторов определения средневекового города («постоянный населенный пункт, в котором с обширной сельской округи-волости концентрировалась, перерабатывалась и перераспределялась большая часть произведенного там прибавочного продукта» (Древняя Русь... 1985. С. 52), резонно заметив: «О каком прибавочном продукте, отчуждаемом из сельского хозяйства, может идти речь, например, в Старой Рязани, когда, судя по археологическим данным, она возникла веком раньше окруживших ее потом деревень?» (Даркевич, 1994а. С. 44). Для В.П. Даркевича древнерусский город - это центр, в котором «усваивались, сплавлялись, по-своему перерабатывались и осмысливались разнородные культурные элементы» (Даркевич, 1994а. С. 59). Не согласился В.П. Даркевич и с попытками сравнения древнерусского города с западноевропейским. Во-первых, «советским историкам не удалось доказать наличие в городах домонгольской Руси объединений ремесленников, подобных западным цехам» (Даркевич, 1994a. С. 44). Во-вторых, при отсутствии крупного боярского землевладения (развитой ленной системы), классовой борьбы и коммунального движения за городские вольности против феодальных сеньо- ров, замки типа западноевропейских на территории Руси получить распространение не могли (Даркевич, 1994а. С. 48; Даркевич, 1994б. С. 12). Наконец, совершенно необоснованно выглядит «подтягивание» древнерусского города к средневековому европейскому с помощью «непомерного удревнения времени градообразования» на Руси (Даркевич, 1994a. С. 46). Подробно остановился В.П. Даркевич и на направлениях в историографии, которые обозначены в названии нашей статьи. Но все по порядку.

Одновременно с рассмотренным магистральным направлением изучения градообразования древней Руси с начала XX в. появляются новые подходы к этой проблеме, основанные прежде всего на данных археологии и связанные с именем А.А. Спицына. Именно он выдвинул теорию «переноса» городов, предполагавшую обязательное наличие первоначального (первого) и нового, существующего вплоть до современности, места городского центра, то есть своеобразной пары поселений. Эта теория основывалась, во-первых, на изучении материалов археологических раскопок широко известного Гнёздовского могильника близ Смоленска. По мнению А. А. Спицына, Гнёздово было древним Смоленском, а на новое, современное место он был перенесен в XI в. (Спицьын, 1905a. С. 7-8). Во-вторых, по поводу Сарского городища под Ростовом он предполагал, что «это первоначальное место Ростова» (Спицььн, 1905 . С. 94). Это мнение А. А. Спицына получило широкое распространение и было поддержано С. А. Таракановой, Н.Н. Ворониным, А.Н. Насоновым (Леонтьев, 1996. С. 72). В неопубликованном до сих пор «Археологическом очерке Тверской губернии» 1921 г. А.А. Спицын предположительно указывает первоначальные (первые) места, а следовательно, «переносы» Ржева, Бежецка и Торжка, основываясь на мнениях краеведов и народных преданиях (Спицььн, 1921. С. 44-45).

В 1928 г. белорусский археолог А.Н. Лявданский открыл в черте города Полоцка городище в излучине старицы р. Полоты, в 0,8 км от места впадения ее в Западную Двину, где расположен детинец с Софийским собором. В 1930 г. этот исследователь высказал мысль о существовании на обнаруженном городище первоначального Полоцка (Штыххов, 1978. С. 19, 146). Так теория «переноса» городов А.А. Спицына расширила свои географические рамки.

В. И. Равдоникас в 1934 г. поддержал точку зрения А.А. Спицына о предшественниках Смоленска и Ростова. Кроме того, исследователь привел, 
как ему представлялось, аналогичные примеры для Белозерска, Старой Рязани и Новгорода, подчеркнув, что «перемещение города на новое место в известный момент его развития наблюдается повсеместно» (цит. по: Дубов, 1983. С. 70).

В работе 1941 г. П.Н. Третьяков также согласился с мнением А.А. Спицына и полагал, что Сарское городище IX в. - это древнейший (862 г.) летописный Ростов, «эмбрион города» (Третьяков, 1941. С. 93, 95).

Дальнейшая разработка теории «переноса» городов связана с именем В.В. Мавродина. В двух его монографиях (1945 и 1946 гг.) даются краткие характеристики «переносов» шести древнерусских городов. В Полоцке «старое городище превращается в «Детинец», но когда он перестал удовлетворять потребности горожан, в XI в. выстраивается новый «Детинец», в пять раз больше первого, но уже в устье реки Полоты» (Мавродин, 1945. С. 144-145; 1946. С. 121). Древнейший Смоленск располагался у д. Гнёздово. «В Х в. здесь возникают два новые, укрепленные валами городища - одно в устье реки Свинки, другое - в устье реки Ольшанки, окруженное обширными селищами и огромным курганным некрополем, насчитывающим несколько тысяч курганов. В XI в., когда городища перестали удовлетворять потребности древних смольнян, город был перенесен на теперешнее его место» (Мавродин, 1945. С. 144-145; 1946. С. 121). «Перенос» Новгорода с Рюрикова Городища и Белозерска от р. Шексны - это аналогичная «эволюция» (Мавродин, 1945. С. 144-145; 1946. С. 121). «Эмбрионом» Ростова было древнее Сарское городище (Мавродин, 1945. С. 144-145; 1946. С. 121). Наконец, это Ярославль, выросший рядом с древним «городищем Медвежий угол» (Мавродин, 1945. С. 144-145; 1946. С. 121). А в учебном пособии 1971 г. В.В. Мавродин, предполагая «переносы» для многих древнерусских поселений, особо подчеркнул: «... часто «город» переносили со старого места и основывали где-то рядом» (Мавродин, 1971. С. 51). К списку из шести «парных» поселений исследователь добавил Седнев (Сновск) - Чернигов (Мавродин, 1971. С. 51).

В конце 1960-х гг. к археологическому изучению Гнёздовского комплекса приступил И.И. Ляпушкин. В результате исследований он пришел к выводу, что гипотеза А. А. Спицына о Гнёздове как древнейшем Смоленске имеет все основания. «И так будет до тех пор, пока в самом Смоленске не обнаружен слой ранее ХІ в.» (Ляпушкин, 1971. С. 37).

В статье 1974 г. ленинградские археологи В. А. Булкин и Г. С. Лебедев сравнили археологичес- кие комплексы типа Гнёздова со скандинавскими средневековыми «виками» и отметили, что те и другие начинают функционировать в IX в., достигают расцвета в X в. и приходят в упадок к концу $\mathrm{X}$ - началу ХІ в. (Булкин, Лебедев, 1974. С. 15, 17).

По мнению И.Я. Фроянова и И. В. Дубова, существовало два типа раннегородских поселений Руси VIII-IX вв.: племенные центры и протогорода. Оба типа в конце X - начале XI в. теряют свое значение и сменяются городами, часть из которых вырастает на месте старого центра, а другие на новом месте «путем вытеснения старого центра новым». Именно этот второй путь определяется как «перенос» города (Фроянов, Дубов, 1977).

В 1978 г. вышла в свет знаменитая работа В. А. Булкина, И. В. Дубова и Г. С. Лебедева, в которой выдвигалась теория развития древнерусских городов не из «племенных», а из «надплеменных» центров. Последние в силу своего расположения на трансъевропейских водно-торговых путях получили наименование «открытых торгово-ремесленных поселений» (ОТРП). Это прежде всего Рюриково городище под Новгородом, Тимерёво под Ярославлем, Гнёздово под Смоленском и Ладога, в которых присутствует скандинавский элемент (Булкин, Дубов, Лебедев, 1978. С. 139). Протогорода типа ОТРП не перерастают в средневековые города, они либо вообще перестают существовать, либо преобразуются в городские посады (Булкин, Дубов, Лебедев, 1978. С. 140). По мнению В.А. Булкина, «возрождение на новом месте» Полоцка и Смоленска происходит в результате «разрушения» предшественника Полоцка и «упадка Гнездова» (Булкин, 1987. С. 42). Непосредственно о «переносе» городов отмечается в работе 1978 г. в разделе, посвященном Северо-Восточной Руси. Явление «переноса» называется феноменом; однако оказывается, что «на Северо-Востоке это происходит повсеместно-переносится Белоозеро. Ярославль сменяет Тимерёво, Ростов-Сарское городище, Переславль-Залесский - Клещин. Старые племенные центры, протогорода переходной эпохи, теряют свое значение и не в состоянии конкурировать с раннефеодальными княжескими крепостями и городами, которые основываются в начале XI в.» (Булкин, Дубов, Лебедев, 1978. С. 136). Как видим, в сравнении со списками перенесенных городов В. В. Мавродина предшественником Ярославля называется не Медвежий угол, а Тимерёво и прибавляется «перенос» Переславля-Залесского.

В том же 1978 г. была издана монография белорусского археолога Г.В. Штыхова, посвященная древним городам Полоцкой земли. Небольшой 
раздел в ней называется «К вопросу перенесения городов». Именно термином «перенесение» автор обозначил «перенос» городов. Впервые в советской историографии Г.В. Штыхов дал определение данному явлению: «Под перенесением города мы будем понимать такое изменение его исторической топографии, когда город оказался на новом месте, вне первоначального своего местоположения, где поселения городского типа прекращают свое существование... Смещение городов связано с оставлением людьми населенного пункта, вследствие чего жизнь в нем замирала, и возникновением в другом месте нового пункта, к которому переходили функции старого города» (Штыхов, 1978. С. 20). Особо остановился автор на переносе Полоцка, о чем впервые, как уже отмечалось, высказался А.Н. Лявданский. Причину «перенесения детинца» Г.В. Штыхов усматривает в невозможности старого центра, расположенного на острове, расширяться, и в преимуществах нового города, расположившегося на берегу важной водной артерии - Западной Двины (Штыхов, 1978. С. 19).

В своих работах, посвященных «переносу» городов, И. В. Дубов назвал это явление «одним из путей возникновения древнерусского города» (Дубов, 1985. С. 25). «Перенос» городов - это «массовое», «общее явление, но не обязательное для всех районов и центров» (Дубов, 1983. С. 82, 80; 1985. С. 31). Новые города-крепости возникают «в противовес старым центрам племен», в результате чего между ними начинается «противоборство» или «противостояние» (Дубов, 1983. С. 80-81). Таким образом, старый и новый центры «какое-то время могли сосуществовать» (Дубов, 1983. С. 78). Механизм «переноса» рассматривается на примере Гнёздова-Смоленска: «Постепенно происходит отток жителей из Гнёздова, и Смоленск расширяется» (Дубов, 1983. С. 74; 1985. С. 28). И. В. Дубов особо подчеркивает, что «"перенос" этот происходил не по волевому усилию какой-либо личности или социальной группы, а явился объективным следствием процесса разрушения старых родовых связей и становления раннефеодального общества» (Дубов, 1983. С. 74; 1985. С. 28). Кроме того, И.В. Дубов вносит коррективы в список «классических» «переносов»,, считая, что предшественником Ярославля было не поселение Медвежий угол, а сразу два протогородских центра - Михайловское и Тимерёво. Ярославль как город-крепость на Волге стал своеобразным преемником Михайловского, а торгово-ремесленные функции перешли к нему от Тимерёва. В результате происходит «затухание» Михайловского и Тимерёва и образо- вание города Ярославля (Дубов, 1983. С. 79; 1985. С. 98; 1996. С. 182).

Категорически не принял теорию «переноса» городов, и особенно по отношению к Гнёздову - Смоленску, Д.А. Авдусин. В своих работах 1960-1990-х гг. этот ученый буквально воспринимает достаточно условный термин «перенос», который большинство исследователей понимает как затухание первоначального центра и начало интенсивного развития расположенного рядом нового центра, составляющих в археологическом плане «пару» поселений. Для Д.А. Авдусина «переносы» городов «мнимы» и «невероятны», а реально «соперничество», «возобладание одного города над другим». При этом «победивший город переманивал к себе население побежденного, становясь более крупным и мощным», где «переплелись функции как административного, так и военного центра» (Авдусин, 1980. С. 39, 30). Точке зрения Д.А. Авдусина созвучно мнение П.П. Толочко, который пишет не о «переносе», а «затухании жизни» протогородских центров, «возвышении нового города» и периоде их «парного существования» (Толочко, 1989. С. 161-162). По его мнению, «теория “переноса" городов... упрощает... проблему существования торгово-ремесленных центров, которые будто бы и не исчезали, а лишь сменили местоположение» (Толочко, 1997. С. 13).

Точку зрения на существование «пар» городов, а не их «перенос» сформулировали ученики Д.А. Авдусина. При этом кардинальным образом изменилась характеристика центров, составляющих «пары». В кандидатской диссертации, посвященной итогам изучения Сарского городища, А.Е. Леонтьев к «парам» (параллельно развивающимся двум поселениям) отнес «Смоленск и Гнёздово, Киев и Вышгород, Изборск и Псков», особо отметив, что «первые - это старые племенные центры, вторые - новообразования». Однако ситуация с «парой» Ростов - Сарское городище, по мнению исследователя, выглядит иначе. «Сарское городище - оплот мери, Ростов - опорный пункт древнерусской княжеской власти» (Леонтьев, 1975. С. 22). В монографии 1996 г. А.Е. Леонтьев вновь подчеркнул, что Сарское городище «до конца своего существования оставалось именно мерянским центром, что, собственно, предопределило его исчезновение в соперничестве с возникшим поблизости древнерусским городом Ростовом» (Леонтьев, 1996. С. 192).

Для В.Я. Петрухина и Т.А. Пушкиной то, что считалось со времен А.А. Спицына центрами предшественниками городов, -это «новые цен- 
тры, ориентированные на обслуживание внешних связей Руси, феодализирующейся дружины, на сбор дани и т. д. Таковы Гнёздово под Смоленском, Рюриково городище под Новгородом, Сарское городище под Ростовом, Шестовицкое поселение под Черниговом, возможно, Тимерёвское селище под Ярославлем» (Петрухин, Пушкина, 1979. С. 108). Эти «новые центры», по мнению авторов, не что иное, как «княжеские погосты»-пункты для сбора дани (полюдья) дружинниками (Петрухин, Пушкина, 1979. С. 105-106, 109; Петрухин, 1987. С. 29). То, что считалось новыми «перенесенными» центрами, стало «племенными центрами», поскольку «Новгород, Ростов, Смоленск упоминаются летописью как племенные центры c IX в. Не вполне правомерно, ссылаясь на отсутствие археологических данных, отрицать достоверность летописных известий» (Петрухин, Пушкина, 1979. С. 109). По поводу этих неожиданных метаморфоз с «парными» поселениями резонно заметил П.П. Толочко: «Утверждение В.Я. Петрухина и Т.А. Пушкиной о том, что на смену “опорным пунктам великокняжеской власти" приходят города, развивающиеся из племенных центров, невозможно обосновать конкретными материалами. В действительности последовательность здесь была обратной. Княжеские феодальные города сменили старые племенные центры» (Толочко, 1997. С. 22, прим. 20). Таким образом, В.Я. Петрухин и Т.А. Пушкина не согласились с весьма, на наш взгляд, обоснованной точкой зрения А.Е. Леонтьева о том, что не Ростов, а Сарское городище - племенной центр; а также добавили в список «парных» поселений Чернигов - Шестовицы. В.Я. Петрухин и Т.А. Пушкина отрицают возможность «переноса» городов, рассматривая соотношение «парных» центров не с точки зрения их генетической преемственности, а с их частичного сосуществования, различного статуса и соперничества. По их мнению, «в связи с упадком Гнёздова можно предполагать перенос (здесь и далее курсив мой. -П. М.) некоторых административных функций погоста в Смоленск и переход туда части населения в XI в., но это не перенос города» (Петрухин, Пушкина, 1979. С. 106). На наш взгляд, это чистая казуистика, поскольку сторонники «переноса» городов и берут этот термин в кавычки, предполагая на определенном этапе сосуществование старого и нового центров и их противостояния. По нашему мнению, наличие «парных» ияентров и есть индикатор явления «переноса» городов.

В дальнейшем В.Я. Петрухин, обосновывая, какой из «парных» центров был старым «племен- ным» городом, коснулся хронологической особенности культурного слоя этих городов: Новгорода, где не обнаружены слои IX - начала X в.; Ростова, где древнейшие напластования датируются концом Х в.; Смоленска и Чернигова, не имеющих слоев $\mathrm{X}$ в. Объясняется такое несоответствие, по его мнению, тем, что «ранние маломощные слои разрушались наиболее интенсивно, и во многих городах, о существовании которых в IX-X вв. известно из сообщений летописи, слои этого времени пока не прослежены. Это дало повод для создания теории “переноса городов" в Древней Руси» (Мельникова, Петрухин, 1986. С. 73, прим. 66). С другой стороны, В.Я. Петрухин присоединился к мнению сторонников теории «переноса» городов в том, что поселения типа Гнёздова (по его мнению, «княжеские погосты») исчезают или приходят в упадок в одно и то же время - в конце X - первой половине XI в. (Мельникова, Петрухин, 1986. С. 76-77). В.Я. Петрухин дополнил список «княжеских погостов» Городком на верхней Луге и Городком на Ловати (Петрухин, 1995. С. 159), хотя это и противоречило его же мнению, что «крупнейшие погосты располагались, как правило, вблизи древнейших племенных центров» (Мельникова, Петрухин, 1986. С. 73). В конечном итоге точка зрения В.Я. Петрухина сводится к тому, что в древней Руси существовала целая система «“дуальных” комплексов поселений» - «княжеских погостов» (центров формирующегося государства) и «племенных городов» (центров местной округи). В конце X-XI в. «княжеские погосты» переживают глубокий кризис, поскольку княжеская власть утверждается в соседних старых племенных центрах, превращающихся в полноценные древнерусские города (Петрухин, 1995. С. 165-167). Нам совершенно очевидно, что этот предполагаемый процесс можно назвать и «переносом» княжеской власти из погоста в племенной центр.

Е.Н.Носов выделил две географические зоны градообразования на Руси. «Возникновению первых городов в Среднем Поднепровье предшествовал определенный период в стабильности развития славянского общества... Уже для VI-VII вв. можно говорить о появлении славянских “градов” как прежде всего административно-политических центров племен. Часть этих “градов” в дальнейшем переросла в города. Однако широкий процесс образования городов как нового типа поселений, противостоявших сельской стихии, начался позже - в VIII-X вв. Города вырастали в плотно освоенных земледельческим населением районах, в местах концентрации сельских поселений как центры обширных 
округ, приобретая шаг за шагом административные, ремесленные и торговые функции» (Носов, 1992. C. 31). На севере Руси Е.Н. Носов усматривает иную картину, нежели на юге. «Время становления здесь городов оказалось чрезвычайно близким началу самого славянского расселения, и даже порой города основывались непосредственно в процессе освоения новых территорий. Тем самым они рождались преимущественно не постепенно, как главные поселения сельских районов, а изначально росли в ключевых местах основных торговых путей, как торгово-ремесленные и военно-административные пункты... Так начиналась история Ладоги, Новгорода, Нового Торга, Волока Ламского, Городка на Ловати (Великих Лук)» (Носов, 1992. С. 31-32). Абсолютно реальным для Е.Н. Носова является «существование «парных» центров, подобных Городищу и Новгороду, один из которых более древний, ориентированный на внешние связи и торгово-ремесленную деятельность, а другой опирается на местную экономическую основу и является центром тянущих к нему сельских территорий». Помимо Городища (Рюрикова городища) и Новгорода называются «подобные “пары”»: «Гнёздово и Смоленск, Шестовицы и Чернигов, Сарское городище и Ростов, Тимерёво и Ярославль, Городок на Ловати и Великие Луки, возможно, городище на р. Дорогоще и Новый Торг и другие» (Носов, 1992. С. 32). В новейшей работе Е.Н. Носов на примере Городища и Новгорода отмечает не «перенос» города, а «перенос резиденции князя» (Ярослава Мудрого) в начале XI в. с Рюрикова городища вниз по течению Волхова к торгу, что явилось крупным политическим актом государственного значения. Последним шагом в процессе формирования нового центра Приильменья было строительство князем Владимиром Ярославичем в 1044 г. новой крепости на месте епископского двора и возведения каменного Софийского собора, сменившего одноименный дубовый храм. Интересно, что в последней трети XI в., с появлением в Новгороде выборных посадников, князья были вынуждены вернуться на Рюриково городище, в свою основную резиденцию, сохранив за собой право и на Ярославово дворище как на городскую усадьбу (Носов, Плохов, Хвощинская, 2017. С. 28).

Исследователи древнерусских городских центров, разумеется, ставили и вопрос о причинах «переноса» городов или затухания жизни на «парных» им поселениях. По мысли В.В. Мавродина, «город переносили в том случае, если изменялся этнический состав населения, или когда подвергалась разгрому древняя родоплеменная знать, или тогда, когда перенос диктовался нуждами торговли и военных предприятий князей» (Мавродин, 1971. С. 51). Главную причину «переносов» городов И. В. Дубов видит в ситуации, при которой «новый нарождающийся класс феодалов не в состоянии был полностью оттеснить родоплеменную знать, отчаянно цепляющуюся за свою власть, основанную на родовых устоях и порядках». В результате «возникают новые раннефеодальные города как бы в противовес старым центрам племен» (Дубов, 1983. С. 80-81). Причину затухания жизни на Сарском городище и в Гнёздове В.Я. Петрухин объясняет так: «После учреждения в городе княжеского стола Ростов аккумулирует все функции центра округи и связи с международными путями, Сарское становится феодальной усадьбой... Не нужен стал и погост в Гнёздове - княжеский стол появился в старом «племенном» центре (то есть Смоленске)... Княжеская власть утвердилась собственно в русских городах. Туда, а не на погосты должны были поступать государственные доходы, там княжеская администрация должна была распределять их» (Петрухин, 1995. С. 166-167).

Однако главная причина «переноса» городов или кризиса и исчезновения центров, составляющих с городами «пары», на наш взгляд, лежит на поверхности. Достаточно обратиться к хронологии и вспомнить, что как сторонники, так и противники теории «переноса» городов единодушны в вопросе, когда поселения типа Гнёздова, Сарского городища, Шестовиц, Тимерёва утратили свое значение и уступили место находящимся поблизости городам. Это конец X - первая половина XI в. (Булкин, Лебедев, 1974. С. 14; Алексеев, 1977. С. 88; Петрухин, Пушкина, 1979. С. 103, 109-110; Дубов, 1983. С. 82; 1985. С. 25; Мельникова, Петрухин, 1986. С. 76; Петрухин, 1987. С. 26; Толочко, 1989. С. 160-161; Носов, 1992. С. 33). Этот период совпадает с общеисторической хронологией формирования древнерусских городов, предложенной рядом известных ученых. Н.Н. Воронин считал, что подлинные города на Руси были основаны в конце X - начале ХІ в. (Воронин, 1951. С. 9, 13). Н. Ф. Котляр начало перерастания «зародышей городов» в раннефеодальные города датирует второй половиной $\mathrm{X}$ - первой половиной XI в. (Котляр, 1980. С. 132). А. Поппэ переломный момент в развитии городской жизни Руси видит опять-таки в конце X - начале ХІ в. (Котляр, 1980. С. 120). Очевидно, что это время принятия и начала распространения христианства в качестве государственной религии древней Руси. Недаром один из древнейших источников, Новгородская первая летопись, крещение Руси и основание городов 
ставит в прямую зависимость. В вводной части НПЛ, составленной в середине XIII в., сообщается: «... како избра Бог страну нашу на последнее время, и грады почаша бывати по местом» (НПЛ, 1950. С. 103). А под 988 г. в той же летописи находим: «... приняли суть крещение... нови людие, крестияне, избрании богомъ. Володимиръ же просвещенъ самъ и сынове... и нача ставити городы по Десне и по Въстри и по Трубежю и по Суле и по Стугне...» (НПЛ, 1950. С. 159).

Пожалуй, первыми, кто решился особо отметить эту явную зависимость и связать ее с проблемой «переноса» городов, были С. В. Белецкий и Ю. М. Лесман. В рецензии 1979 г. на публикации белорусских археологов они писали: «Процесс активного градообразования XI в. совпадает по времени с прекращением функционирования языческих городов, что фиксируется археологически переносом замков в городах X в. на новое место... Процесс топографических изменений сопровождался изменениями социального и идеологического плана» (Белеикий, Лесман, 1979. С. 312-313). Однако в рецензии 1982 г. эти же авторы полностью отказались признать идеологический фактор в процессе смены одного центра другим, отметив лишь социальные изменения: «“перенос города” - лишь один из вариантов общего изменения топографической структуры поселения, отражающего происшедшие изменения в социальной структуре» (Белецкий, Лесман, 1982. С. 245).

В 1980 г. упомянул о значении христианизации города Д.А. Авдусин: «Крещение Руси, крах языческой религии привели к переоценке роли тех или иных населенных пунктов и их частей» (Авдусин, 1980. С. 37). Однако это справедливое и важное замечание не получило дальнейшего развития в работах ученого. И.В. Дубов в статье, посвященной проблеме «переноса» городов, обмолвился о сопутствующих этому явлению «процессе христианизации» и компромиссе между «язычеством и православием» (Дубов, 1996. С. 181). Но буквально через страницу в связи с «переносом» городов исследователь писал только лишь о «новых социально-политических отношениях в древнерусском обществе» (Дубов, 1996. С. 183).

В.П. Даркевич обоснованно отметил, вопервых, что приметой переходного времени в урбанизации Руси является «сосуществование» протогородских поселений с древнейшими городами (Даркевич, 1994а. С. 50). Во-вторых, «образование первых городов синхронно принятию христианства» (Даркевич, 1995. С. 129). В-третьих, «возникновение древнерусских городов во всем многооб- разии их функций - это скачок, взрыв» («Процесс урбанизации... скорее революционен, чем эволюционен») (Даркевич, 1994а. С. 53; 1994б. С. 13). В-четвертых, «в мире современников Ярослава Мудрого основание городов воспринималось как покорение враждебного [языческого] пространства» (Даркевич, 1994а. С. 52). И наконец, что «советские историки зациклились на идее “вторичности” религии» (Даркевич, 1994а. С. 55). Важным представляется тезис, согласно которому «особенно после принятия христианства происходит не перенос поселения на другое место, то есть трансурбанизация, а создание вблизи него... развитого города нового типа» (Даркевич, 1994а. С. 51). Однако даже этот ученый, высказавший столько новаторских идей, среди причин возникновения новых городов на первое место ставит не принятие новой веры, а мало понятные читателю «усиление Древнерусского государства» (Даркевич, 1994б. С. 13) или «культурный процесс» и «усложнения аппарата управления» (Даркевич, 1995. С. 127, 136).

Трудно согласиться и с заявлением В.П. Даркевича, что «город перемещается на новое, лучше защищенное место» (Даркевич, 1995. С. 131-132). Дело в том, что исследователи отмечали некую неясность в явлении «переноса» городов и связанные с ним начало кризиса и затухание центров-предшественников, составлявших вместе «пары» поселений. В.И. Равдоникас в «переносе» (перемещении) городов видел «какую-то общую закономерность» (цит. по: Дубов, 1983. С. 70). Спад активной жизни Гнёздовского комплекса приходится на рубеж X-XI вв. или на первую половину XI в., но для В.А. Булкина и Г. С. Лебедева «неясныли остаются его причины и характер» (Булкин, Лебедев, 1974. С. 14). Еще более загадочными выглядят «переносы» Ростова и Переславля-Залесского с господствующих над окружающей местностью сухих мест на низкие и даже болотистые озерные берега. «Если возникновение Ростова именно на озере Неро было явлением закономерным, - пишет А. Е. Леонтьев, - то его расположение на низкой береговой террасе объяснить сложно. Древнерусский город всегда не в последнюю очередь был крепостью, но в данном случае оказались не реализованными возможности для основания укрепленного центра в других более благоприятных местах побережья. Не получил дальнейшего развития идеально подходящий по топографическим условиям для подобной роли прежний мерянский центр-Сарское городище. Очевидно, существовали какие-то субъективные причины, повлиявшие на выбор места для города, 
понять которые спустя тысячу лет, невозможно» (Леонтьев, 1991. С. 5-6; 1996. С. 281).

Судя по схеме развития территории Ростова в X-XIV вв., составленной А.Е. Леонтьевым, город основывается на необжитом месте в районе Успенского собора, вне приозерного мерянского поселка (АКР, 2005. С. 69. Рис. 37) и идола бога Велеса на месте Богоявленского монастыря (Щапов, 1989. С. 47). Предшественником ПереславляЗалесского, как убедительно показал И. В. Дубов, являлся Клещинский комплекс IX-XIII вв. с крепостью на Александровой горе, сменившим ее укреплением у с. Городище, селищем и языческим курганным могильником (Дубов, 1985. С. 111, 173. Рис. 10). Справедливо замечание этого же исследователя, что местоположение названного комплекса «на возвышенных и сухих местах» не идет ни в какое сравнение с Переславлем, заложенным в 1152 г. «на болоте в сырой низине, там, где впадает р. Трубеж в оз. Плещеево (Клещино)» (Дубов, 1985. С. 112). Таким образом, ландшафтная ситуация с Переславлем-Залесским и Клещином аналогична рассмотренной выше ситуации с Ростовом и Сарским городищем. Как для А.Е. Леонтьева появление Ростова, так и для И. В. Дубова появление нового города в низине Плещеева озера представляются труднообъяснимыми. «Неясно, что руководило действиями князя Юрия» при основании Переславля-Залесского, «тем более что Клещин занимал более выгодное стратегическое положение на важнейших путях» (Дубов, 1985. С. 111-112). Доказательством тому, что новый город закладывался на совершенно неосвоенном ранее месте, служат раскопки Н.Н. Воронина у стен СпасоПреображенского собора 1152 г. Переславля-Залесского: «... город стал на совершенно чистом песчаном берегу озера, - ему не предшествовало никакое более раннее поселение» (Воронин, 1949. С. 196; 1974. С. 142). Похожая ситуация со строительством города наблюдается в Устюге, где в результате «переноса города на новое место... городище... представляет собой укрепление, поставленное в низине и окруженное болотом и долиной небольшой речки, впадающей в Сухону» (Тихомиров, 1956. С. 421). Итак, достаточно уверенно можно говорить о том, что возникают новые города вблизи своих предшественников на незаселенном, свободном месте.

Еще на рубеже 1980-1990-х гг. в поисках причин вероятного «переноса» Торжка мы обратились к литературным памятникам XVI-XVIII вв., которые можно расценивать и как поздние исторические источники, и как ранние историографические свидетельства по проблеме возникновения древнерусских городов. В итоге был сделан следующий вывод: «Возможный «перенос» поселения на Нижнее городище Торжка, как и перемещение на новые места других известных поселений лесной зоны Восточной Европы, мог быть связан со строительством первого христианского храма в стороне от древних центров с языческими святилищами» (Мальгин, 1992. С. 8). Эта наша точка зрения была замечена лишь Е.Н. Носовым, который возникновение Новгорода рассматривал как формирование центра, «где располагались христианский комплекс (владычный двор, общегородской храм), торг, княжеский двор»; а для «возможной» «пары» городище на р. Дорогоща - Новый Торг (Торжок), в последнем предполагал сосредоточение «новых органов административного и церковного управления» (Носов, 1992. С. 32).

Интереснейшим памятником, содержащим описание четкого механизма возникновения древнейшего поволжского города, является «Сказание о построении града Ярославля» (1960), что мы неоднократно отмечали (Мальгин, 2001. С. 40; 2002. С. 42). «Сказание...» как исторический источник использовалось Н.Н. Ворониным, убедительно доказавшим, что в его основе лежит народное предание, уходящее корнями в глубокую древность (Воронин, 1960). М.Г. Мейерович показал, что «Сказание...» дошло до нас в записи Самуила Миславского, бывшего в 1776-1788 гг. ростовским архиепископом (Мейерович, 1978). И.В. Дубов и В. Н. Седых обращались к «Сказанию...», считая, что этот источник «признан в науке как вполне достоверный» (Дубов, Ceдblx, 2004). Однако как памятник, описывающий механизм основания древнерусского города, «Сказание...» не привлекалось. Этот механизм включает несколько важнейших условий и конкретных действий, к рассмотрению которых мы и приступаем.

Итак, в «Сказании...» указаны следующие обстоятельства основания города Ярославля:

1. Близ места, где ныне стоит город Ярославль, «бысть селище, рекомое Медвежий угол, в нем же насельницы человецы, поганыя вере - языцы, зли сущее... мнози и грабления и кровопролития верным твориша...» (Сказание... 1960. С. 90 (6)).

2. Тут же стоял «Идол, ему же кланястася сии, бысть Волос, сиречь скотий бог. И сей Волос... стояше среди логовины, нарицаемой Волосовой... Сему многокозненному идолу и кереметь створена бысть и волхв вдан, а сей неугасимый огнь Волосу держа и жертвенная ему кури... Тако исконный враг рода человеческаго омрачи сердце сих 
человеков, и тако сии человецы жиша мнози леты» (Сказание... 1960. С. 90 (6-7)).

3. Далее рассказывается о посещении этих мест князем Ярославом Мудрым: «... в некоем лете прилучися Благоверному Князю Ярославу плыти на ладиях с сильною и великою ратью по реце Волге, у праваго брега оной, идеже стоя то селище, зовомое Медвежий угол» (Сказание... 1960. С. 91 (7)).

4. «Князь узре, яко некии люди жестоци наноси гибель судом, шествовавшим с товары по Волге... Согляда вся творимая, Благоверный Князь Ярослав повеле дружине своей устрашити и разгнати шатание сих беззаконных... молитвами пречистыя Богородицы и святых угодников... княже воинство победи врагов» (Сказание... 1960. С. 91 (7)).

5. Князь облагает жителей Медвежьего угла оброками и «моли их креститися». Язычники «обеща Князю житии в согласии и оброцы ему даяти, но точию не хотяху креститися» (Сказание... 1960. C. $91(7))$.

6. После чего «Благоверный Князь отыде в престольный град свой Ростов» (Сказание... 1960. C. $91(8))$.

7. Вскоре князь организует новый, явно антиязыческий, поход в Медвежий угол. Теперь с ним направляются не только «воины», князь пребывает на Волгу «со епископы, со пресвитеры, диаконы и церковники, мастеры». На эту делегацию во главе с князем язычники Медвежьего угла «испусти от клети некоего люта зверя и псов». Далее происходит событие, отраженное в изображении медведя с секирою на гербе города Ярославля: князь «секирою своею победи зверя, а пси, яко агнцы, не прикоснуся никомуждо от них» (Сказание... 1960. С. $91(8))$.

8. Разгневанный князь покидает жителей Медвежьего угла, пораженных его храбростью в схватке с «лютым зверем». Здесь уместно сделать отступление от «Сказания...» и отметить, что в памятнике XVI в. «Повести о водворении христианства в Муроме» описывается похожая ситуация, но с князем Глебом Владимировичем: «И егда прииде святый Глебъ ко граду Мурому, и еще тогда неверни быша людие и жестоцы, и не прияша его к себе на княжение, и не крестишася, но и сопротивляхуся ему. Онъ же отееха от града 12 поприщъ на реку Ишню и тамо пребываше...» (Памятники... 1860. С. 229).

9. После ухода из Медвежьего угла князь выбирает неподалеку «место пусто, на утри же из шатра своего изнесе икону Богоматери... и со епископом, и со пресвитеры, и со всем духовным чином, и с мастеры и с воины приде на брег Волги».
Освятив место будущего города, «Благоверный Князь водрузи на земле сей древян крест и ту положи основу святому храму Божия Илии». Посвящение храма «Сказание...» связывает с Ильиным днем, когда князь «хищнаго и лютаго зверя победи» (Сказание... 1960. С. 91 (8)). Однако это посвящение пророку могло быть связано и с именем сына Ярослава Владимировича, упомянутого в перечне князей в Новгородской первой летописи: «Ярослав... идя къ Киеву, посади в Новегороде Коснятина Добрыница. И родися у Ярослава сынъ Илья, и посади в Новегороде, и умре. И потом разгневася Ярославъ на Коснятина, и заточи и; а сына своего Володимира посади в Новегороде...» (НПЛ, 1950. С. 161). Описанные события происходили в период 1016-1036 гг.

10. Следующее действие отмечено в «Сказании...» так: «христолюбивый Князь повеле народу рубити древеса и чистити место, идеже умысли и град создати» (Сказание... 1960. С. 91 (8)).

11. Далее лаконично описывается процесс закладки будущего города: «И тако делатели нача строити церковь святаго Илии и град созидати» (Сказание... 1960. С. 91-92 (8)), то есть укрепления (непосредственно «град») выглядят здесь вторичными по сравнению с сооружением христианского храма. Подчеркнем особо, из «Сказания...» становится совершенно ясно, что храм и город закладываются на незаселенном месте («князь опасно согляда все место пусто», где «высокая древеса растуша, да травяны пажити точию обретахуся»), предварительно освященном: «... постави на месте уготованном икону Богоматери и повеле епископу сотворити пред нею молебное пение и святити воду и сею кропити землю» (Сказание... 1960. С. 91 (8), 90 (6)).

12. Настает черед наименованию города: «Град сей Благоверный Князь Ярослав назва во свое имя Ярославлем...» (Сказание... 1960. С. 92 (8)).

13. Завершающий этап основания города - это наполнение его жителями и представителями государственной христианской идеологии: «... насели его христианами, а в церкви постави пресвитеры, диаконы и клирики» (Сказание... 1960. С. 92 (8)). Этот фрагмент «Сказания...» вполне созвучен, вопервых, с летописными известиями о деятельности отца основателя Ярославля - Владимира Святого: «... нача ставити по градом церкви и попы, и людие на крещение приводити по всем градам и селам» (ПВЛ, 1950. С. 53; НПЛ, 1950. С. 157), а во-вторых, с известием летописи, но уже непосредственно о Ярославе Владимировиче, который после подавления восстания волхвов в Суздале 
в 1024 г. «устави землю ту» (ПСРЛ.Т. 25, 1949. С. 375$)$, то есть утвердил княжескую власть.

После основания города образуется «пара» поселений. Старое-языческий Медвежий угол, новое - христианский Ярославль: «Но егда же и построися град Ярославль, насельницы Медвежияго угла не приобщашеся граду, живяше особь и кланяшеся Волосу» (Сказание... 1960. С. 92 (9)). Как было отмечено в историографическом обзоре, именно эту «пару» называл В.В. Мавродин, а Тимерёво и Михайловское, как предшественники Ярославля, появляются на страницах археологических статей только в 1970-х гг. Противостояние Медвежьего угла и Ярославля завершается в пользу последнего. Заключительная часть «Сказания...» повествует об активной христианской пропаганде, которую среди язычников Медвежьего угла ведет «пресвитер церкви Божия Илии». Когда изнывающие от засухи язычники, приглашенные на молитву «пресвитера» на послание дождя, увидели, что «пролияся дождь велии», они «изшед из града, много пакости сотвори Волосу... и растеса его на части и кереметь сокруши, и предаде огненну запалению» (Сказание... 1960. С. 92 (10)). В итоге бывшие язычники испросили князя и епископа «на месте, идеже стоя кереметь, построити ту храм во имя святого Власия, епископа Севастийского» (Сказание... 1960. С. 93 (11)).

Д.А. Авдусин отмечал, что «славянский город возникал на необжитом месте» (Авдусин, 1991. С. 8), а В.П. Даркевич констатировал: «города Средневековья... рождаются, как правило, на "неподготовленной” почве - иногда поблизости, но не на месте предгородских поселений» (Даркевич, 1995. С. 130). Как видим, «Сказание о построении града Ярославля» раскрывает «секрет» «переноса» города на необжитое, иногда даже неудобное для крепости место. Основание новых христианских городов в стороне от их предшественников - результат первоначального мощного противодействия со стороны языческой родовой власти новой вере, носителями которой выступают, как правило, князья, уже принявшие христианство. В свою очередь для постройки первого центрального храма, своеобразного символа нового города и нового государства, выббиралось место, нередко проигрывающее старому центру по топографическим данным, но не оскверненное языческим капищем и поселением. Процесс противостояния христианского храма и языческого святилища завершается в более поздний период сооружением новых церквей непосредственно на местах утративших постепенно свою идеологическую роль ка- пищ (Мальгин, 2001. С. 40-41; 2002. С. 42). Уместно, как нам представляется, в связи с этим отметить, что «стержневая идея древнерусской литературы домонгольского времени - это христианская «Русская земля" в ее противостоянии “поганым" (язычникам), ее политическое единство в целях такого противостояния» (Назаренко, 2009. С. 319).

Если князь Ярослав на стрелке Волги и Которосли сооружает в первую очередь храм, а затем укрепления («город»), то, судя по «Волоколамскому Патерику» Досифея Топоркова первой половины XVI в., чью информацию А.А. Зимин считал достоверной (Зимин, 1961. С. 99-100), при основании Волока Ламского тем же Ярославом сначала сооружается крепость, а внутри ее возводится собор. «Тако древни бяше град тои, бе же первие на брезе Ламы реки и тои ныне нарицаетьца старыи Волок... велики Ярослав... проязду творя по градом руськым, прииде на старыи Волок и прошед его два поприща и ста шатры на горе, близ речкы, иже впаде в Ламу. В полудни починути и явися ему во сне муж стар и показа ему перстом на другои стране рекы, глаголя: “на сем месте заложи град Волок, и люди приведи оттулева”. И близ показа гору и глаголя ему: “а на сеи горе постави церковь Воздвижение Честнаго Креста Христова, и сотвори монастырь, а на неи, же почиваеши горе, сотвори церковь во имя святого пророка Ильи и такоже сотвори монастырь”. Вопроси же его: “господине, ты кто еси”. Он же рече: “аз есмь Боговидец пророк Илья” и си рек, невидим бысть. Возбнув же благочестивыи велики князь Ярослав и сотвори вся, елика повеле ему святыи пророк Илья. И град сотвори Волок идеже и до ныне стоить и оба монастыря на показанных ему горах, $u$ внутрь града соборную ичерковь Воскресение Господа нашего Исуса Христа. И дасть свещеником и обоим монастырем, во окормление тамгу со всего и померное и явку с животины и пятно и даст им грамоты вечныя и печати златыя приложи, их же мы самовидцы быхом и прочтохом» (Волоколамский Патерик... 1973. С. 177 (Л. 3-4)). Важно отметить, что этот фрагмент из «Патерика» созвучен со «Сказанием о построении града Ярославля» в той части, когда князь «приде на старыи Волок и прошед его два поприща». Нетрудно догадаться, что «проходит» Ярослав языческое поселение и останавливается на необжитом, чистом месте, где и основывает новый город. Кроме того, по «Сказанию...» на месте будущего города сооружается первый храм в честь Ильи, а в «Патерике» фигурирует даже сам пророк Илья, в культе которого постепенно «растворились» Перун и Ярило (Введение христианства... 
1987. С. 268). Заслуживает внимания и тот факт, что старый Волок (с. Староволоцкое) находился на р. Ламе, а новый город был основан на небольшой речке, получившей название Городенки.

Описанный в «Сказании о построении града Ярославля» и «Волоколамском Патерике» механизм «переноса» города, очевидно, применим и к другим городам, у которых имелись предшественники. Существование «парных» центров, расположенных в непосредственной близости друг от друга, один из которых мог являться первоначальным (первым), отмечается на огромных пространствах древней Руси - как на юге, так и в лесной зоне Восточной Европы. К «классическим» «парам» Гнёздово - Смоленск, Сарское городище - Ростов, Рюриково городище - Новгород, Медвежий угол (Тимерёво и Михайловское) - Ярославль, Клещин - Переславль-Залесский Е.Н. Носов, как отмечалось выше, добавляет Городок на Ловати - Великие Луки и, возможно, городище на Дорогоще - Торжок. Вполне вероятен «перенос» Торопца (Лесман, 1988). Также в научной литературе отмечаются «перенос» Устюга (Tuхомиров, 1956. С. 421; Куза, 1996. С. 131), возможны «пары» для Воротынска (Куза, 1996. С. 131) и Пскова (Плоткин, 1989. С. 165). О «переносе» Волока Ламского отмечается в «Патерике» XVI в. В «Повести о водворении христианства в Муроме» также XVI в. прямо говорится, что «многим летом прешедшим пренесен бысть градъ ныне во ином месте, идеже и ныне стоит» (Памятники... 1860. С. 229), а в «Повести о рязанском епископе Василии» опять-таки XVI в. находим: «Слышах... древняя сказаниа о граде Мураме... бяше... во дни древняя. Многим же летом прешедшим разорися некако и запусте, и потом по многих летех перенесен бысть на ино место... и ту поставлен бысть, идеже и ныне есть» (ПЛДР. 1984. С. 648). Достаточно посмотреть дореволюционную краеведческую литературу, чтобы убедиться, что почти в каждом старинном русском городе были популярны народные легенды и предания о переносе города и его первоначальном месте. Выше отмечались в связи с этим Ржев и Бежецк, добавим к ним Белый (Редков, 1915. С. 8-9). Существовали легенда о переносе Белоозера с северного берега оз. Белое в районе Киснемского погоста (Шахматов, 1904. С. 53); древнее предание о переносе Москвы с устья Яузы в устье Неглинной (Тихомиров, 1975. C. 392, 394, 400); легенда о поселении - предшественнике Дмитрова, основанного в 1154 г. (Tuхомиров, 1973. С. 172). Костромские краеведы писали о перенесении Костромы с правого берега
Волги на левый (Фехнер, 1952. С. 101). П. И. Мельников (Печерский) упоминал о первоначальном месте Нижнего Новгорода (Тихомиров, 1956. С. 417-418; Куза, 1996. С. 122). На территории Белоруссии археологами отмечаются «переносы» Полоцка, Волковыска и Турова (Белецкий, Лесман, 1979. С. 312; Куза, 1996. С. 93-94), Усвята (Шmыхов, 1978. С. 53, 55), Минска (Белецкий, Лесман, 1982. С. 248; Загорульский, 1982. С. 30-31, 62-63; Алексеев, 1998. С. 380-388). Вполне возможно, что поселения-предшественники были у Витебска (Белеикий, Лесман, 1982. С. 244, прим. 2) и Кричева (Куза, 1996. С. 87). На территории Украины помимо «классической» «пары» Шестовицы - Чернигов П.П. Толочко называет поселение в урочище Лесковое в 2 км от летописного Листвена (Толочко, 1997. С. 13). «Пары» укрепленных поселений в непосредственной близости друг от друга выявлены в Галиче (Тимощук, 1988. С. 81, 88), Теребовле (Тимомук, 1988. С. 81-82, 89), Ревне на Пруте (Тимощук, 1988. С. 87), Василеве на Днестре (Tuмошук, 1995. С. 113-114), Судовой Вишне в Львовской обл. (Куза, 1996. С. 150), Всеволоже и, возможно, Любомле на Волыни (Куза, 1996. С. 152, 156). Первоначальные места, откуда могли быть «перенесены» города, отмечаются для Белгорода, Переяславля Южного, Канева, Пересопницы (Tuхомиров, 1956. С. 299, 310, 302, 323).

Представляется, что выявленные археологически «пары» городов и легенды о «переносах» древних центров связаны со временем противостояния язычества и христианства. Может показаться, что ошибочно связывать с этим противостоянием города, основанные в XII-XIII вв. В этом отношении будет небесполезно сравнить процессы христианизации, имевшие место на берегах озер Неро и Плещеево. Утверждение о «переносе» Переславля-Залесского в 1152 г. как о «совершенно иной ситуации» по сравнению с «переносами» Ростова и Ярославля (Дубов, 1983. С. 82; 1996. С. 183) следует считать ошибочным. На Плещееве озере, как и на оз. Неро и Волге, за «переносом» города стоят одни и те же процессы, связанные с распространением христианства. В том, что комплекс у с. Городище (Клещин) был языческим, не приходится сомневаться. У подножия городища Клещин располагался курганный могильник из 237 насыпей с ингумациями, раскопанный в 1853 г. П.С. Савельевым (АКР. 2005. С. 165, 309-310; Дубов, 1996. С. 185). Следовательно, вопреки мнению И. В. Дубова (1996. С. 184), крепость Клещин не могла быть основана Юрием Долгоруким. Сомнительной выглядит и точка зрения К.И. Комарова об основании 
Клещина (Переславля старого) Владимиром Мономахом в начале XII в. (АКР, 2005. С. 71). В работе 1934 г. переславский краевед М.И. Смирнов подсчитал количество языческих курганов, приуроченных к берегам оз. Неро (Ростовское) и оз. Плещеево (Клещино). В первом случае оказалось 353 кургана, а во втором в семь раз больше - свыше 2500 насыпей (Смирнов, 1995. С. 43, 53-54). В этих курганах, почти полностью раскопанных в XIX в., обнаружены кремации (от 20 до 60\% от всей погребенных), появившиеся с середины X в., и ингумации XI-XII вв. (АКР, 2005. С. 65, 67). Столь разительное несоответствие в количестве курганов в окрестностях Ростова и Переславля-Залесского, на наш взгляд, объясняется следующим образом. Из Ростова, где уже в 992 г. была построена дубовая церковь (Щапов, 1989. С. 46), очевидно на месте нынешнего Успенского собоpa, то есть вне мерянского поселка IX-X вв. (АКР, 2005. С. 69. Рис. 37. С. 202), а в 1073-1076 гг. учреждена епископия (Поппэ, 1996. С. 444), христианство активно распространилось на густонаселенные (АКР, 2005. С. 201. Рис. 96) берега оз. Неро, почти не оставив места для языческих курганных могильников, несмотря на сопротивление волхвов в 1024 и 1071 гг. Плодородные берега Плещеева озера в это время были плотно освоены кривичско-словенско-мерянским населением (АКР, 2005. С. 62-64). Христианизация этого региона началась, судя по всему, лишь с середины XII в., когда Юрий Долгорукий «заложи... градъ и церк (о)вь... в нем доспе (вариант - «постави»)» (ПСРЛ.Т. 24, 2000. С. 77). Именно это основание христианского Переславля-Залесского в Типографской и Новгородской четвертой летописях было названо «переводом» города. Подобная Ростовской и Переяславской округам ситуация была нами рассмотрена на примере христианизированного в XI в. Торжка с округой и еще языческого в это время Торопца (Мальгин, 2014. С. 416-418).

Но, разумеется, в процессе урбанизации средневековой Руси перемещения ряда городских центров были связаны не с христианизацией, а с правительственными указами и разорениями. Так, из рукописей XVII-XVIII вв., рассказывающих о г. Белозерске, узнаем: «В лето 6907-го (1399) года, при великом князе... по его государеву указу, гражданы белозерцы переселишася с Шексны-реки в Карголом-град, и церкви, и посады поставиша. Тогда соборную церковь Великаго Василия перенесли и поставиша на посаде» (Прохоров, 1994. С. 204). В 1536 г. «замысли государь наш князь велики Иван Васильевичь новыи город поставити от литовского рубежа на Заволочье... и церкви постави Покров Святеи Богородица... и присуд з Дворец и наместников дву, и посажан свел на Заволочье, и повеле им там дворы ставити» (Псковские летописи, 1941. С. 108). Мы предполагаем перенос после Батыева нашествия Твери с Глинного городища, располагавшегося напротив устья Тверцы, в устье р. Тьмаки (Мальгин, 1994. С. 124,$125 ; 2003$. С. 94, 95).

К сожалению, и в новейших работах очень важное и верное, на наш взгляд, замечание, что «только после принятия христианства впервые обнаруживается такое ранее неслыханное на Руси явление, как закладка новых городов князем», практически полностью исчезает из окончательного и главного вывода, формулирующегося следующим образом: «Само появление городов происходило в основном по инициативе властных структур (князей), а их дальнейшая судьба находилась в прямой зависимости от того, что они служили административными центрами, т.е. обеспечивали структуру государственной власти и управления» (Коваль, 2017. С. 26, 31). Мы же пытаемся показать, что возникновение древнерусских городов связано прежде всего с возведением в них князьями одновременно с крепостными сооружениями храма, олицетворяющего государственную идеологию и новое христианское мировоззрение.

Процесс урбанизации древней Руси, начавшийся с конца $X$ в., не был разнообразным. Археологически он маркируется наличием «nарныхх» изентров как индикаторов явления, традиционно называемого «переносом» городов ${ }^{1}$. Временное сосуществование христианского центра и «парного» с ним старого языческого поселения неизбежно приводило к кризису и запустению последнего.

Возникновение христианских городов ознаменовало новую эпоху в истории древней Руси. Первые храмы в них, ставшие затем, как правило, центральными городскими соборами соответствующего посвящения, были идеологическими, религиозными, культурными, просветительскими и даже административно-хозяйственными центрами. Внутри и у стен храмов возникали христианские некрополи, в которых хоронили по новому погребальному обряду, постепенно распространившемуся и в сельской среде.

\footnotetext{
1 А.Е. Мусин пишет о «явлении “переноса городов“ в форме существования “парных поселений”» (Мусин, 2010. С. 318), что представляется нам весьма туманной формулировкой.
} 


\section{Литература}

Авдусин Д. А., 1980. Происхождение древнерусских городов (по археологическим данным) // ВИ. № 12. C. 24-42.

Авдусин Д. А., 1991. Актуальные вопросы изучения древностей Смоленска и его ближайшей округи // Смоленск и Гнёздово (к истории древнерусского города). М.: Изд. МГУ. С. 3-20.

АКР: Ярославская область. М.: ИА РАН, 2005. 408 с.

Алексеев Л. В., 1977. О древнем Смоленске (к проблеме происхождения, начальной истории и топографии) // СА. № 1. С. 83-103.

Алексеев Л. В., 1998. «Меньск» и Минск (к начальной истории белорусской столицы) // Культура славян и Руси. М.: Наука. С. 375-391.

Белецикий С. В., Лесман Ю. М., 1979. Новые публикации материалов раскопок средневековых городов Белоруссии // СА. № 1. С. 303-313.

Белеикий С. В., Лесман Ю.М., 1982. Рец.: Штыхов Г.В. Города Полоцкой земли (IX-XIII вв.). Мн., 1978 // СА. № 3. С. 243-248.

Булкин В.А., 1987. Историко-географические данные к проблеме возникновения городов Днепро-Двинского междуречья // Труды V Международного конгресса славянской археологии. T. I. Вып. 2а. Секция II. М.: Международная уния славянской археологии, ИА АН СССР. ИА АН УССР. С. 34-42.

Булкин В. А, Дубов И. В., Лебедев Г. С., 1978. Археологические памятники Древней Руси IX-XI веков / Под ред. В.В. Мавродина. Л.: Изд. ЛГУ. $150 \mathrm{c}$.

Булкин В. А., Лебедев Г. С., 1974. Гнездово и Бирка (к проблеме становления городов) // Культура средневековой Руси. Л.: Наука. С. 11-17.

Введение христианства на Руси. М.: Мысль, 1987. $302 \mathrm{c}$.

Волоколамский Патерик // Богословские труды. Сб. 10. М.: Изд. Московской Патриархии, 1973. C. 175-222.

Воронин Н. Н., 1949. Раскопки в Переславле-Залесском // Материалы и исследования по археологии древнерусских городов. Т. І.М.-Л.: Изд. АН СССР. С. 193-202. (МИА. № 11).

Воронин Н.Н., 1951. К итогам и задачам археологического изучения древнерусского города // КСИИМК. Вып. 61. С. 5-29.

Воронин Н.Н., 1960. Медвежий куль в Верхнем Поволжье // Краеведческие записки. Вып. 4. Ярославль. С. 25-93.

Воронин Н. Н., 1974. «Переяславль новый» // Летописи и хроники. 1973 г. М.: Наука. С. 137-142.
Греков Б. Д., 1959. Киевская Русь // Греков Б. Д. Избранные труды. Т. II. М.: Изд. АН СССР. C. $11-410$.

Даркевич В. П., 1994а. Происхождение и развитие городов древней Руси (X-XIII вв.) // ВИ. № 10. С. 43-60.

Даркевич В.П., 1994б. К проблеме происхождения древнерусских городов // Восточная Европа в древности и средневековье. Тез. докл. М.: ИА РАН. С. 10-13.

Даркевич В.П., 1995. О некоторых спорных проблемах происхождения и развития древнерусских городов (X-XIII вв.) // Город как социокультурное явление исторического процесса. М.: ИА РАН. С. 126-137.

Древняя Русь: город, замок, село. М.: Наука, 1985. 431 с. (Археология СССР).

Дубов И. В., 1983. К проблеме «переноса» городов в Древней Руси // Генезис и развитие феодализма в России. Проблемы историографии. Межвуз. сб. К 75-летию В.В. Мавродина. Л.: Изд. ЛГУ. С. 70-82. (Проблемы отечественной и всеобщей истории. Вып. 7).

Дубов И.В., 1985. Города, величеством сияющие. Л.: Изд. ЛГУ. 182 с.

Дубов И. В., 1996. Проблема образования городов в Древней Руси // Средневековая и новая Россия. Сб. науч. ст. К 60-летию И.Я. Фроянова. СПб.: Изд. СПбГУ. С. 168-188.

Дубов И.В., Седых В.Н., 2004. К 1000-летнему юбилею города Ярославля // Археология, история, нумизматика, этнография Восточной Европы. Сб. ст. памяти И. В. Дубова. СПб: Изд. СПбГУ. С. 52-54.

Загорульский Э. М., 1982. Возникновение Минска. Минск: Изд. БГУ. 358 с.

Зимин А.A., 1961. Новгород и Волоколамск в XI-XV веках // НИС. Вып. 10. Новгород. C. 97-116.

История СССР с древнейших времен до наших дней. В 12 тт. Т. I/ Под ред. С.А. Плетневой и Б. А. Рыбакова. М.: Наука, 1966. 720 с.

Карлов В.В., 1976. О факторах экономического и политического развития русского города в эпоху Средневековья (к постановке вопроса) // Русский город (историко-методологический сборник). М.: Изд. МГУ. С. 32-69.

Ключевский В. О., 1902. Боярская Дума Древней Руси. Изд. 3-е. М.: Синодальная типография. 547 с.

Коваль В.Ю., 2017. Малые города средневековой Руси: исторические этапы формирования // Го- 
роховец и земли Окско-Клязьминского междуречья в XII-XVII вв.: история и археология. Матер. науч. конф. М.: ИА РАН. С. 25-32.

Котляр Н.Ф., 1980. К вопросу о генезисе восточнославянских городов (на материалах Галичины и Волыни) // Славянские древности. Этногенез. Материальная культура Древней Руси. Сб. науч. тр. К.: Изд. АН УССР. С. 117-133.

Куза А. В., 1989. Малые города Древней Руси. М.: Наука. 168 с.

Куза А.В., 1996. Древнерусские городища XXIII вв. Свод археологических памятников. М.: РГНФ. 256 c.

Леонтьев А.Е., 1975. Сарское городище в истории Ростовской земли (VIII-XI вв.). Автореф. дис. ... канд. истор. наук. М.: МГУ. 25 с.

Леонтьев А.Е., 1991. Заметки о ранней истории Ростова // Сообщения Ростовского музея. Вып. I. Ростов: Ростово-Ярославский архитектурно-художественный музей-заповедник. С. 3-7.

Леонтьев А.E., 1996. Археология мери: К предыстории Северо-Восточной Руси. М.: ИА РАН. $340 \mathrm{c}$

Лесман Ю.М., 1988. Торопец и Луки. (Сравнение исторических судеб) // АИППЗ. Псков. С. 71-75.

Ляпушкин И. И., 1971. Гнездово и Смоленск // Проблемы истории феодальной России. Л.: Изд. ЛГУ. С. 33-37.

Мавродин В.В., 1945. Образование Древнерусского государства. Л.: Изд. ЛГУ. 432 с.

Мавродин B.B., 1946. Древняя Русь (происхождение русского народа и образование Киевского государства). Л.: ОГИЗ. Госполитиздат. 311 с.

Мавродин В.В., 1971. Образование Древнерусского государства и формирование древнерусской народности. М.: Высшая школа. 192 с.

Мальгин П.Д., 1992. Торжок в составе новгородских земель (конец I тыс. н. э. - конец XV в.). Автореф. дис. ... канд. истор. наук. М.: МГУ. 19 с.

Мальгин П.Д., 1994. Некоторые итоги и проблемы изучения средневековых древностей территории Тверской области // ТАС. Вып. 1. Тверь. С. 116-128.

Мальгин П.Д., 2001. Возникновение Торжка и некоторые замечания по теории «переноса городов» // Управление городами: история и современность. Матер. науч. конф. Тверь: ТвГУ. С. $36-45$.

Мальгин П.Д., 2002. Проблемы ранней истории Торжка в свете теории «переноса городов» // «И свет во тьме светит...» Сб. науч. тр. ВИЭМ, посвящ. 2000-летию Рождества Христова. Торжок: ВИЭМ. С. 38-47.
Мальгин П.Д., 2003. Судьбы Торжка и Твери в XIII веке // Русь в XIII веке: Древности темного времени. М.: Наука. С. 92-96.

Мальгин П.Д., 2014. О времени основания Новоторжского Борисоглебского монастыря // Русь в IX-XII веках: общество, государство, культуpa. М.-Вологда: Древности Севера. С. 413-420.

Мейерович М.Г., 1978. Так начинался Ярославль... // ВИ. № 3. С. 208-213.

Мельникова Е.А., Петрухин В.Я., 1986. Формирование сети раннегородских центров и становление государства (Древняя Русь и Скандинавия) // История СССР. № 5. С. 64-78.

Мусин A.E., 2010. Церковь и горожане средневекового Пскова. Историко-археологическое исследование. СПб.: Факультет филологии и искусств СПбГУ. 364 с.

Назаренко А.В., 2009. Древняя Русь и славяне (историко-филологические исследования. М.: Русский фонд содействия образованию и науке. 528 с.

Носов Е.Н., 1992. Новгородская земля IX-XI вв. (Историко-археологические очерки). Автореф. дис. ... док. истор. наук. СПб.: ИИМК РАН. $40 \mathrm{c}$.

Носов Е.Н., Плохов А.В., Хвошчинская Н.В., 2017. Рюриково городище: Новые этапы исследований. СПб.: ИИМК РАН. 288 с.

НПЛ. М.-Л.: Изд. АН СССР, 1950.

Памятники старинной русской литературы. Т.I. СПб., 1860. С. 229-238.

ПВЛ. М.-Л.: Изд. Акад. наук СССР, 1950. Т. 1: Текст и перевод. 405 с. (Литературные памятники).

Петрухин В.Я., 1987. О функциях раннегородской сети в становлении Древнерусского государства // Тр. V Междунар. конгресса славянской археологии. Т. І. Вып. 2б. М.: Международная уния славянской археологии, ИА АН СССР, ИА АН УСССР. С. 24-29.

Петрухин В.Я., 1995. Начало этнокультурной истории Руси IX-XI веков. Смоленск: Русич; М.: Гнозис. 320 с.

Петрухин В.Я., Пушкина Т.А., 1979. К предыстории древнерусского города // История СССР. № 4. С. 100-112.

ПЛДР. Конец XV - первая половина XVI века. М.: Художественная литература, 1984. 768 с.

Плоткин К.М., 1989. Округа Пскова накануне и в период становления города // Становление европейского средневекового города. М.: Наука. С. 159-186.

Попnэ A., 1996. Митрополиты и князья Киевской Руси // Подскальски Г. Христианство и бого- 
словская литература в Киевской Руси (9881237 гг.). Изд. 2-е. СПб.: Византинороссика. C. 441-498. (Subsidia Byzantinorossica. T. 1).

Прохоров Г.М., 1994. Повесть об Устьшехонском Троицком монастыре и рассказы о городе Белозерске // Книжные центры Древней Руси. XVII век. Разные аспекты исследования. СПб.: Наука. С. 163-206.

Псковские летописи. Вып. 1. М.-Л.: Изд. АН СССР, 1941. $147 \mathrm{c.}$

ПСРЛ.Т. 24. Типографская летопись. М.: ЯРК, 2000. 272 c.

ПСРЛ. Т. 25. Московский летописный свод конца XV века. М.-Л.: Изд. АН СССР, 1949. 429 с.

Редков Н. Н., 1915. Историко-статистическое описание церквей и приходов Смоленской епархии. Вып. 1. Бельский уезд. Смоленск. 399 с.

Рыбаков Б. А., 1982. Киевская Русь и русские княжества XII-XIII вв. М.: Наука. 589 с.

Седов В.В., 1989. Становление европейского раннесредневекового города // Становление европейского средневекового города. М.: Наука. С. 6-55.

Сказание о построении града Ярославля. (По А. Лебедеву. Храмы Власьевского прихода г. Ярославля. Ярославль, 1877. С. 6-11) // Краеведческие записки. Вып. 4. Ярославль: Ярославская областная тип., 1960. С. 90-93.

Смирнов М. И., 1995. Переславль-Залесский. Исторический очерк 1934 г. Переславль-Залесский: Плещеево озеро. 368 с.

Спищыл А.A., 1905а. Гнездовские курганы в раскопках С.И. Сергеева // ИАК. СПб. Вып. 15. C. 6-70.

Спицыын А.A., 1905б. Владимирские курганы // ИАК. Вып. 15. С. 84-172.

Спицыьн А.А., 1921. Археологический очерк Тверской губ. 1921 г. Рукопись / Архив ТГОМ. Оп. 1. Ед. хр. 233. 51 с.

Тимошук Б. А., 1988. Об археологических признаках древнерусского города // Археологические источники об общественных отношениях эпохи средневековья. М.: ИА РАН. С. 69-89.
Тимошук Б.А., 1995. Восточные славяне: от общины к городам. М.: Изд. МГУ. 261 с.

Тихомиров М.Н., 1956. Древнерусские города. Изд. 2. М.: Госполитиздат. 478 с.

Тихомиров М.Н., 1973. Российское государство XV-XVII веков. М.: Наука. 424 с.

Тихомиров М.Н., 1975. Древняя Русь. М.: Наука. $429 \mathrm{c}$.

Толочко П. П., 1989. О торгово-ремесленном пути становления древнерусских городов // История и культура древнерусского города. М.: Изд. МГУ. С. 159-167.

Толочко П.П., 1997. Пути становления древнерусских городов // Тр. VI Междунар. конгресса славянской археологии. Т. 1. М.: ИА РАН. C. 11-22.

Третьяков П. Н., 1941. К истории племен Верхнего Поволжья в первом тысячелетии н. э. М.-Л.: Изд. АН СССР. 156 с. (МИА. № 5).

Фехнер М.В., 1952. Раскопки в Костроме. (К вопросу о времени возникновения Костромы и ее первоначальном местоположении) // КСИИМК. Вып. 47. С. 101-108.

Фроянов И.Я., 1980. Киевская Русь: Очерки социально-политической истории. Л.: Изд. ЛГУ. $256 \mathrm{c.}$

Фроянов И. Я., Дубов И. В., 1977. Основные этапы социального развития древнерусского города (IX-XII вв.) // Древние города. Матер. к Всесоюз. конф. «Культура Средней Азии и Казахстана в эпоху средневековья». Л.: Изд. ЛГУ. С. 69-71.

Шахматов A. A., 1904. Сказание о призвании варягов. СПб. $85 \mathrm{c.}$

Штыхов Г.В., 1978. Города Полоцкой земли (IXXIII вв.). Минск: Наука и техника. 159 с.

Щапов Я. Н., 1989. Государство и церковь Древней Руси X-XIII вв. М.: Наука. 232 с.

Юшков С. В., 1939. Очерки по истории феодализма в Киевской Руси. М.-Л.: Изд. АН СССР. 254 с.

Янин В.Л., Алешковский М.Х., 1971. Происхождение Новгорода (к постановке проблемы) // История СССР. № 2. С. 32-61. 


\section{В.Я. Петрухин \\ Институт славяноведения РАН, \\ НИУ Высшая школа экономики, г. Москва}

\section{«Начаша владђти сами собђ и городы ставити»: археология и источники варяжской легенды}

Одной из общих для Восточной Европы и вечных проблем славяно-русской археологии и начальной русской истории остается проблема историчности первых летописных известий: насколько реальным можно себе представить участие поволжско-финского племени меря наряду с летописными кривичами и словенами в призвании варяжских князей и общем развитии древнерусской Ростово-Суздальской земли. Этой проблемой в контексте славянской колонизации Ростовской земли и проникновения на эту землю скандинавов успешно занимается А.Е. Леонтьев (1996). Его исследования значительно расширили представления о присутствии там скандинавов и, стало быть, об участии населения Ростовской земли в этнокультурных процессах, объединявших Восточную и Северную Европу в IX-X вв.

Уникальное свидетельство существования отдельного сезонного лагеря скандинавских «гостей» (ср. др.-pус. погост как обозначение стана для дружины, собирающей дань) обнаружено А.Е. Леонтьевым возле Сарского городища (и Ростова): лагерь, возможно, и просуществовал один летний сезон в начале $\mathrm{X}$ в.; его инвентарь - предметы вооружения (в том числе скандинавского происхождения), весовые гирьки, серебряные восточные монеты-свидетельствует о занятиях «гостей» (Леонтьев, 1996. С. 99-103). Сеть подобных пунктов на международных речных магистралях расширяется благодаря новым раскопкам: более ранние (первая половина IX в.) свидетельства связей со Скандинавией содержит клад городища Выжегша (Леонтьев, 1988), торжище исследуется А.Е. Леонтьевым на городище Еськи (Леонтьев, 2017). Принципиально важным стало открытие скандинавских древностей Х в. собственно в Ростове (Леонтьев, Пуикина, 2017).

Эта тенденция характеризует археологию всех древнерусских городов, упомянутых в летописи в связи с участием варягов в начальной русской истории. Скандинавские древности обнаружены в самом Смоленске (при давно очевидной ранней концентрации их в Гнёздове в X в.), в Полоцке (при малой исследованности ранних слоев в том и другом городе; ср.: Дук, 2012). Естественно, скандинавские древности обнаружены и на ранних (X в.) усадьбах Новгорода (Рыбина, Хвощиинская, 2010), при особой концентрации этих древностей на новгородском Городище (Носов, Плохов, Хвощинская, 2017. С. 27). Предшествующие этим открытиям представления о соотношении и значении «парных» предгородских центров - Городища и Новгорода, Гнёздова и Смоленска, Сарского и Ростова (Петрухин, Пушкина, 1979) - нуждается в корректировке. Скандинавы более широко участвовали в формировании древнерусской городской сети, не ограничиваясь контролем над «станами» возле славянских городов (ср.: Рыбаков, 1966. С. 489-490). Сходную позицию занимал В. Л. Янин, предполагавший, что призванный в Новгород князь с дружиной обосновался на обособленном урочище - Городище, которое, впрочем, привлекало заинтересованных в упрочении с князем договорных отношений (летописного ряда) новгородцев: те основали в непосредственной близости свои «города», предшественники новгородских концов: так возник «Новый» город (ср.: Янин, 2007; Носов, Плохов, Хвошинская, 2017. С. 18-33).

Давно поставленные археологические проблемы касаются также летописной текстологии и достоверности летописного предания начала XII в. Трудно представить историческую ситуацию, изображаемую легендой о призвании варягов, когда славянские и финские племена на общем вече должны были формулировать требования ряда - договора с призванными князьями. В.О. Ключевский считал легенду конструкцией 


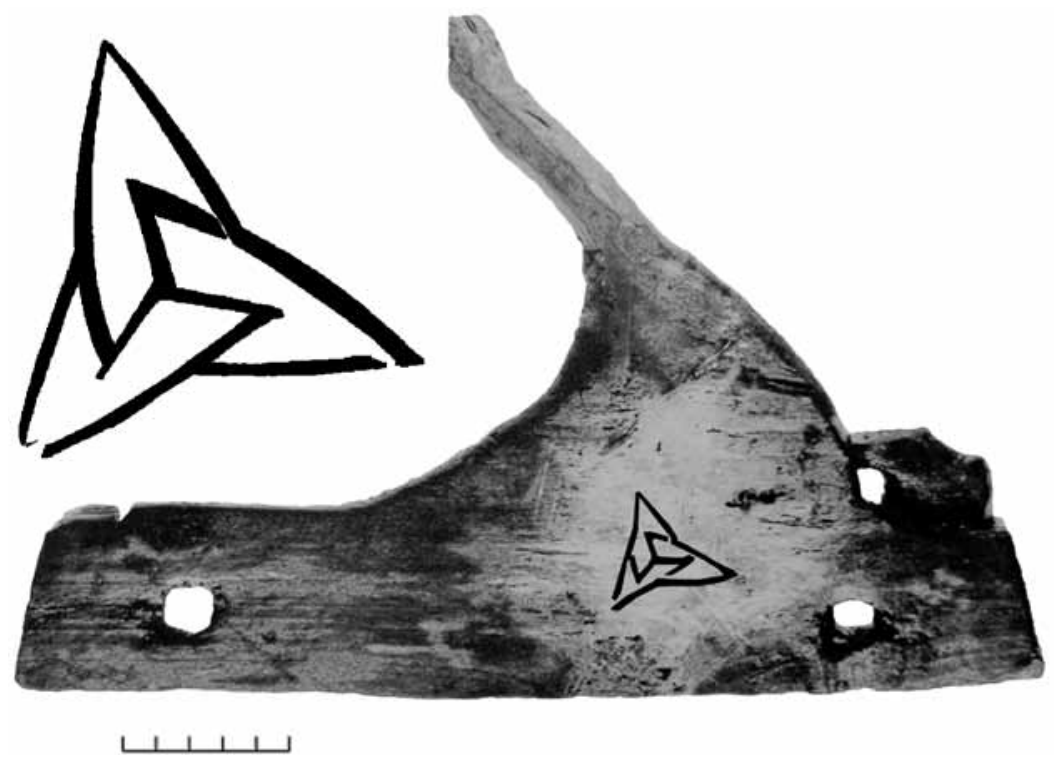

Рис. 1. Уключина из Новгорода (по: Мусин и др., 2016. С. 163. Рис. 6, 2)

летописца, камуфлирующей норманские завоевания в Восточной Европе, которые упрочивались тем, что варяги «нарубали» для себя города (Ключевский, 1987. С. 155). Археология демонстрирует мирную включенность скандинавов в жизнь древнерусских городов, в том числе на усадьбах древнерусского облика (Рыбина, Хвощчнская, 2010). Конфликты имели место в периоды кризисов - в эпоху крещения Руси, когда язычники разорили двор варягов-христиан в Киеве (ПВЛ под 983 г.), или в момент династического кризиса после смерти Владимира Святославича в Новгороде, когда новгородцы перебили варягов - наемников Ярослава (НПЛ под 1016 г.).

Специфику жизнедеятельности варягов в мирное время характеризуют замечательные находки на территории известных памятников: в Новгороде обнаружены деревянные части ладей, в том числе уключина со скандинавским знаком (триквестр - рис. 1; Мусин и др., 2016. С. 163. Рис. 6, 2), близкие изделия обнаружены в «портовой части» Гнёздова (рис. 2; Ениосова, Пушкина, 2016. С. 269); А.Е. Леонтьев исследовал обнаруженные в Ростове шпангоуты, свидетельствующие о развитии судостроения на рубеже X и ХІ вв. в эпоху ростовского княжения Ярослава Мудрого (Леонтьев,
1994). Коммуникации на речных магистралях были основой развития древнерусской городской сети и даже государственности (об этом свидетельствовал Константин Багрянородный), скандинавская этимология самого имени русь («гребцы», дружина на речных судах) отражает эту систему коммуникаций (см.: Мельникова, Петрухин, 1989).

Археологические данные о начале Руси в целом соответствуют летописной традиции (ср. изданные в одном томе Трудов ОИФН статьи: Макаров, Носов, Янин, 2014; Петрухин, 2014). Однако достоверность конкретных летописных известий и формулировок вызывает сомнения уже на уровне летописной текстологии. Лаврентьевская редакция ПВЛ (1996. С. 13) не знает города, который стал резиденцией призванного Рюрика, упоминание Новгорода восстанавливается по более поздним спискам (см.: ПВЛ, 1996. С. 404; ср.: Вилкул, 2008; Алешковский, 2015. С. 32-34). Древнейшей версией варяжской легенды остается ипатьевская, согласно которой три князя «придоша къ словђномъ първъе ${ }^{1}$ и срубиша город Ладогу. и съде старђишии в Ладозъ Рюрикъ», и лишь затем, по смерти братьев, Рюрик «пришед къ Ильмерю и сруби город надъ Волховом и прозваша и Новгород и сьде ту княжа» (ПСРЛ. Т. II, 1998. Стб. 14).

${ }^{1}$ Полемика о древности летописных текстов продолжается: М.Х. Алешковский указывал на то, что текст лаврентьевского варианта испорчен; действительно, там говорится, что призванные князья «изъбрашася и придоша»... неизвестно куда. Ипатьевский вариант уточняет: «...и придоша к словђномъ първђе». НПЛ настаивает: «приидоша к Новугороду»; М.X. Алешковский вслед за А.А. Шахматовым считал этот текст древнейшим, но НПЛ начиная с позднего введения тенденциозно проводила идею первенства Новгорода. 


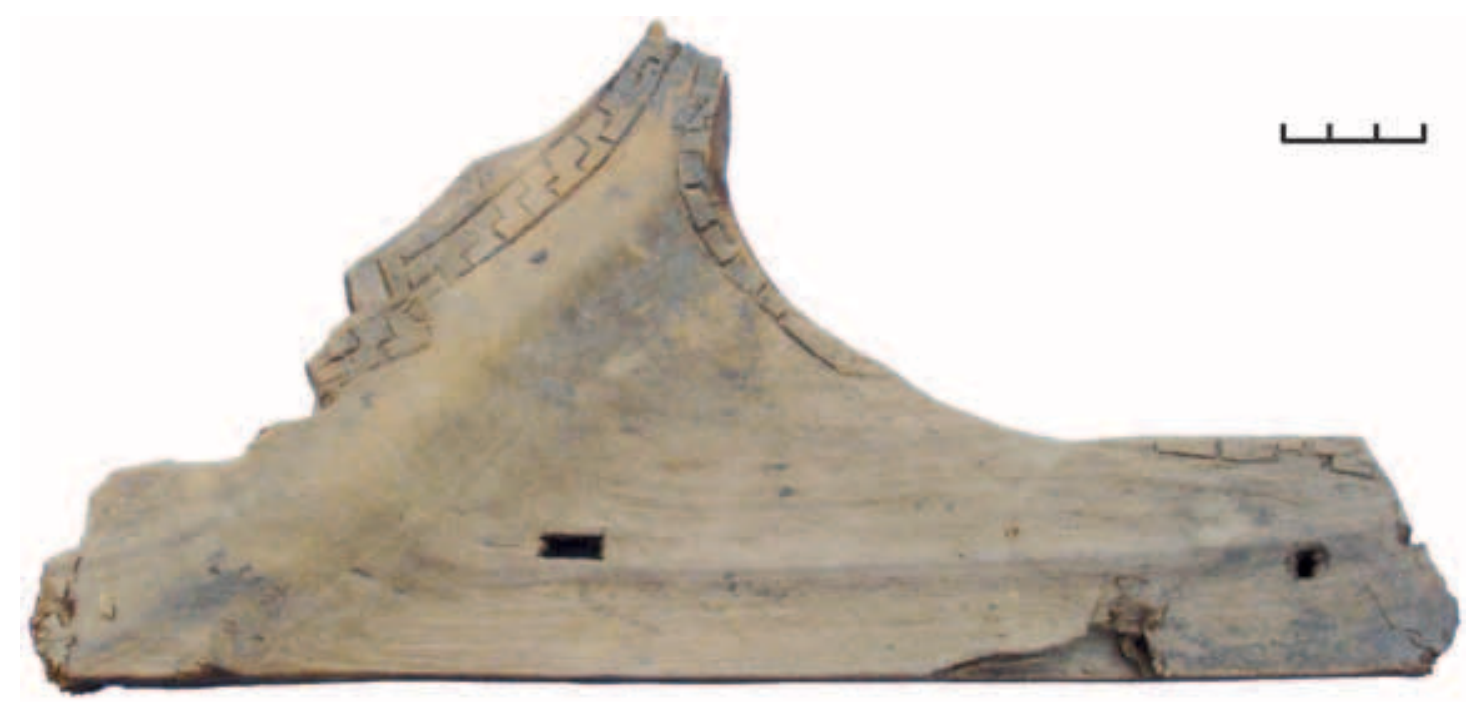

Рис. 2. Уключина из Гнёздова из раскопок В. В. Мурашевой (по: Петрухин, 2017. С. 194)

Исследователи Ладоги отстаивают ее приоритет как древней столицы (Кирпичников, Сарабьянов, 2013): ранние городские напластования Ладоги относятся к середине VIII в., все этнические компоненты, участвующие в призвании варягов, обнаруживаются в ладожских древностях. В. Л. Янин (2007. С. 208) допускает «кратковременную остановку» Рюрика в Ладоге на волховском пути к Новгороду (для смены морских судов на плоскодонные гребные), настаивая на мифичности мотива основания Рюриком Новгорода²; напомню, что и Ладога существовала задолго до летописного призвания. Проблема в том, что понимать под летописным «сруби»-если речь идет просто об укреплении существующих поселений, то города не были основаны Рюриком, а укрепление или даже поселение на Городище (топоним и означал укрепленное поселение) могло восприниматься как основание Новгорода.

Можно догадываться, почему исторический приоритет Ладоги вызывал сомнения у редактора Начальной летописи в начале XII в. (и порчу текста), ведь тогда было известно, что Ладога - «пригород» Новгорода.

Понимание древнейшей истории этих городов, инициаторов «ряда», во многом зависит от дальнейших раскопок (Носов, Плохов, Хвощиинская, 2017) и исследования источников летописной легенды. При этом существенно, что вполне очевидная ориентация летописного изложения на биб- лейскую традицию относится и ко всем редакциям варяжской легенды. Существен в этом отношении сюжет, связанный с правлением праведного библейского царя Асы: пророк Азария предупреждает царя, что в правление живущего «без закона» «народ будет сражаться с народом, и город с городом» (Паралипоменон, 2.15.6); разные племена собрались тогда в Иерусалиме, и весь народ вступил в завет с Всевышним, скрепив договор клятвой.

Вторая книга Паралипоменон неизвестна в ранних славянских переводах, но близкий мотив неурядиц, предшествующих Всемирному потопу, повторяется в широко распространенном (с X в.?) апокрифе - славянской книге Еноха, известной, судя по упоминанию сюжетов, и ПВЛ. Во сне Господь является сыну Еноха Мефусалому и предвещает, что «языкъ на языкъ възмутить ся рать, наполнит ся вся земля крови и нестроениа зла», что приведет к потопу; Мефусалом «призва вся старца людскиа ${ }^{3}$, и повьда все... и (по смерти Мефусалома.- В.П.) бысть миръ и устроение по всей земли», но в следующем поколении стали «людие на люди възмущаху ся, и языкъ на языкъ въста бранью, и бысть мятеж великъ», что привело к потопу (см.: БЛДР. Т. 3. С. 232-236).

Повторю, что специфика варяжской легенды Новгородской первой летописи заключается в особой роли городов в распрях между изгнавшими насильников-варягов «людьми, рекомии Словени и Кривици и Меря», которые «начаша владђти

\footnotetext{
2 В более ранней работе В. Л. Янин (2004. С. 74-75) усматривал в Новгороде исконный вечевой центр, где представители трех летописных племен решили призвать варяжских князей: с мерей у Янина ассоциируется прибалтийско-финская норова/нерева, чье имя сохранилось в названии Неревского конца.

3 Замечу, что и фигура старцев («старцев градских» и т. п.) - характерный для начального летописания библеизм.
} 
сами собъ и городы ставити», затем «въсташа сами на ся воевать, и бысть межи ими рать велика и усобица, и въсташа град на град (везде курсив мой. - В. П.), и не бъша в нихъ правды» (НПЛ, 2000. C. 106). Как уже говорилось, так понимал историю В.О. Ключевский: «Туземцы, собравшись с силами, прогнали пришельцев и для обороны от их дальнейших нападений наняли партию других варягов, которых звали русью. Укрепившись в обороняемой стране, нарубив себе «городов», укрепленных стоянок, наемные сторожа повели себя завоевателями» (Ключевский, 1987. С. 155). Сходную позицию занимал Б.А. Рыбаков, усматривавший в Новгородском городище, Гнёздове под Смоленском, летописном Угорском под Киевом станы, где обосновались варяги, которые не могли захватить русские города. Как уже говорилось, археология демонстрирует более продуктивные отношения между автохтонными племенами и «находниками», чем предполагавшееся норманское завоевание (ср.: Макаров, Носов, Янин, 2014).

Кроме того, летописный мотив создания городов, предваряющий распри, характерен для друго- го апокрифического источника начального летописания, исследованного С. Франклином (Franklin, 1982) вслед за любителем древнерусской словесности Г. М. Барацем - «Малого Бытия»: архетипическим началом этого процесса, естественно, оказывается строительство Вавилона с его башней, затем следует сюжет вторжения Ханаана в жребий Сима, который в рассказе ПВЛ о распре между Ярославичами благочестиво заменен на общего предка праведных народов Сифа (ПВЛ, 1996. С. 79). После этого «начали сыновья Ноевы воевать друг с другом... и возводить мощные города, и стены, и башни, и люди возвысились над племенами, и обрели начала царств, и пошли войной народ на народ, и племя на племя, и город на город» и т.д. до рождения Авраама, оказавшегося от идолослужения и заключившего завет с Богом (и здесь «Малое Бытие» следует цитированному выше Паралипоменону; см.: Книга Юбилеев. Х).

Ориентация ПВЛ, главного источника по истории начальной Руси на библейскую традицию, требует учета при попытках соотнесения данных археологии с летописными известиями.

\section{Литература}

Алешковский М.Х., 2015. Повесть временных лет: Из истории создания и редакционной переработки. М.: Весь Мир. 320 с.

БЛДР. Т. 3: ХІ-ХІІ века / Под ред. Д. С. Лихачева, Л. А. Дмитриева, А. А. Алексеева, Н. В. Понырко. СПб.: Наука, 1999. 413 с.

Вилкул T., 2008. Ладога или Новгород? // Palaeoslavica, 2008. XVI/2. Р. 272-280.

Дук Д., 2012. Полоцк 1150 // Родина. № 9. С. 66-69.

Ениосова Н.В., Пушикина Т.А., 2016. Гнёздово раннегородской центр эпохи формирования древнерусского государства // ДГ 2014. М.: РФСОН. С. 258-303.

Кирпичников А.Н., Сарабьянов В.Д., 2013. Старая Ладога: Первая столица Руси. СПб.: Славия. 216 c.

Ключевский В. О., 1987. Сочинения в 9-ти тт. Т. 1. Курс русской истории. Ч. 1 / Под ред. В. Л. Янина. М.: Мысль. 430 с.

Книга Юбилеев, или Малое Бытие // Ветхозаветные апокрифы / Пер. Е.В. Витковского. М.: АСТ; Фолио, 2001. С. 15-116.

Леонтьев А.Е., 1988. Городище Выжегша и происхождение выжегшского клада // Проблемы изучения древнерусской культуры: расселение и этно- культурные процессы на Северо-Востоке Руси. Сб. науч. трудов / отв. ред. М.В. Седова. М.: Изд. ИА АН СССР. С. 94-102.

Леонтьев A.E., 1994. Ладейные шпангоуты Х в. из Ростова // История и культура Ростовской земли. Ростов: Ростово-Ярославский архитектурно-художественный музей-заповедник. C. 177-178.

Леонтьев А.Е., 1996. Археология мери: к предыстории Северо-Восточной Руси. М.: Геоэко. $340 \mathrm{c.}$

Леонтьев А.E., 2017. Городище-торжище Еськи на Верхней Мологе // Памятники средневековой археологии Восточной Европы: К юбилею Марины Дмитриевны Полубояриновой // отв. ред. А. В. Чернецов. М.: ИА РАН. С. 196-200.

Леонтьев А.Е., Пушкина Т.А., 2017. Ростовские находки скандинавских вещей) // Культурний шар. Статті на пошану Гліба Юрійовича Івакіна / Відпов. ред. О.П. Толочко. Київ: Laurus. C. 297-304.

Макаров Н.А., Носов Е.Н., Янин В.Л., 2014. Начало Руси глазами современной археологии // Тр. ОИФН. 2008-2013 / отв. ред. В.А. Тишков. М.: Наука. С. 17-36. 
Мельникова Е.А., Петрухин В.Я., 1989. Название «Русь» в этнокультурной истории Древнерусского государства // ВИ. № 8. С. 24-38.

Мусин А.Е., Тарабардина О.А., Кокуиза Л.В., Кубло Э. К., 2016. Деревянные предметы с христианской и языческой символикой из раскопок в Новгороде и Старой Руссе // РАЕ. № 5-6. С. 157-170.

НПЛ. ПСРЛ. Т. 3. М.: ЯРК, 2000. 723 с. (репр. изд. под ред. А. Н. Насонова: М.-Л.: Изд. АН СССР, 1950).

Носов Е.Н., Плохов А.В., Хвошинская Н.В., 2017. Рюриково городище: новые этапы исследования. СПб.: Дмитрий Буланин. 288 с. (Тр. ИИМК PAH; т. XLIX).

Петрухин В.Я., 2014. Призвание варягов: традиция и исторические реалии // Тр. ОИФН. 2008-2013 / отв. ред. В. А. Тишков. М.: Наука. C. 289-299.

Петрухин В.Я., 2017. Русь в IX-X вв.: от призвания варягов до выбора веры. М.: Форум; Неолит. 464 с.

Петрухин В.Я., Пушкина Т.А., 1979. К предыстории древнерусского города // История СССР. № 4. C. 100-112.

ПВЛ. СПб.: Наука, 1996. 667 с. (Литературные памятники).
ПСРЛ. Т. ІІ. Ипатьевская летопись. М.: ЯРК. М., 1998. 648 стр.

Рыгбаков Б.А., 1966. Киевская Русь // История СССР с древнейших времен до наших дней. Т. 1. Первобытнообщинный строй. Древнейшие государства Закавказья и Средней Азии. Древняя Русь (до начала ХІІІ в.) / Ред. тома С. А. Плетнева, Б. А. Рыбаков. М.: Наука. С. 476-571.

Рьбина Е.А., Хвощчинская Н.В., 2010. Еще раз о скандинавских находках из раскопок Новгорода // Диалог культур и народов средневековой Европы. Сб. статей в честь 60-летия Е. Н. Носова / Ред. Хвощинская Н.В., Мусин А.Е. СПб.: Дмитрий Буланин. С. 66-78.

Янин В.Л., 2004. Средневековый Новгород. М.: Наука. 416 с.

Янин В.Л., 2007. О начале Новгорода // У истоков русской государственности: Мат. междунар. науч. конф. (4-7 октября 2005 г., Великий Новгород) / отв. ред. Е. Н. Носов, А. Е. Мусин. СПб.: Дмитрий Буланин. С. 205-212.

Franklin S., 1982. Some apocryphal sources of Kievan Russian Historiography // Oxford Slavonic papers. Vol. 15. P. 1-27. 


\section{В. С. Курмановский \\ Институт археологии РАН, г. Москва}

\section{Территориальные структуры центральных районов Смоленской земли в XI-XV веках. К постановке проблемы}

Изучение формирования территорий различных земель средневековой Руси на основе метода комплексного источниковедения, включающего в себя анализ письменных, археологических и иных источников, является одним из перспективных и развивающихся направлений отечественной медиевистики. При этом различные регионы средневековой Руси в этом отношении изучены неравномерно. Смоленскую землю, несмотря на то что ей были посвящены весьма крупные и блестящие для своего времени работы П.В. Голубовского (2011), В.В. Седова (1960) и Л. В. Алексеева (1976; 1980), вряд ли можно отнести к досконально изученным в этом отношении территориям.

История Смоленской земли эпохи Средневековья - раннего Нового времени благодаря как определенным историческим вехам, так и специфике источниковой базы может быть разделена на три крупнейших периода, изучение территориальных структур в течение каждого из которых требует своих методических подходов и имеет собственную историографию.

Первый из них, хронологически наиболее поздний, датируется временем с первой половины - середины XVI в. до екатерининской губернской реформы 1775 г. Историческая география и административно-территориальное деление данного периода истории Смоленщины рассматривались исследователями как самостоятельно (карта В.П. Мальцева (1940. После с. 346); работы Е. Б. Французовой (1980а; 1980б), новейшие работы и публикации В.А. Прохорова (2017; Смоленщина... 2017)), так и в совокупности с предшествующим периодом XV - начала XVI в. (Кашпровский, 1899; Шеламанова, 1970)). Данный период характеризуется в целом более или менее массовой сохранностью документальных источников. Вплотную к этому периоду примыкает формирование крупнейшего и информативнейшего фонда картографических источников - материалов Генерального межевания. Следует, однако, оговориться, что массовая сохранность документальных источников для Смоленской земли, как и для других регионов России, фактически характерна лишь для периода начиная с 20-х годов XVII в. Однако административно-территориальная структура смоленских земель, отраженная в документах XVII-XVIII вв., в целом, несомненно, сформировалась в предшествующем XVI в. Актуальность привлечения источников данного периода при изучении более отдаленных эпох Средневековья видится в наличии прослеживаемой преемственности между элементами территориальной структуры XVI-XVIII вв. (станы, волости и их центры, локализация храмов и др.) с территориальными составляющими Смоленской земли XV - начала XVI в., а в некоторых случаях и более раннего времени. Кроме того, следует отметить, что определенные реалии территориальных структур, зафиксированные в источниках XVII-XVIII вв., вряд ли могли возникнуть в ходе административной деятельности московских, польско-литовских или российских имперских властей и предположительно могут являться реликтами более раннего территориального устройства (погосты, десятки и др.).

Особенность периода XVI-XVIII вв. состоит в первую очередь в том, что наши знания о территориальных структурах этого времени, по крайней мере для отдельных его этапов, достаточно полные. Известны границы территориальных образований, полные списки селений, чего мы не имеем для более отдаленных периодов (рис. 1).

Второй период развития территориальных структур Смоленщины отражен преимущественно в документах XV - начала XVI в., однако есть основания экстраполировать его как минимум на XIV в. Для этого времени имеется довольно большой по объему фонд документальных источников, в первую очередь принадлежащих к корпусу Литовской 


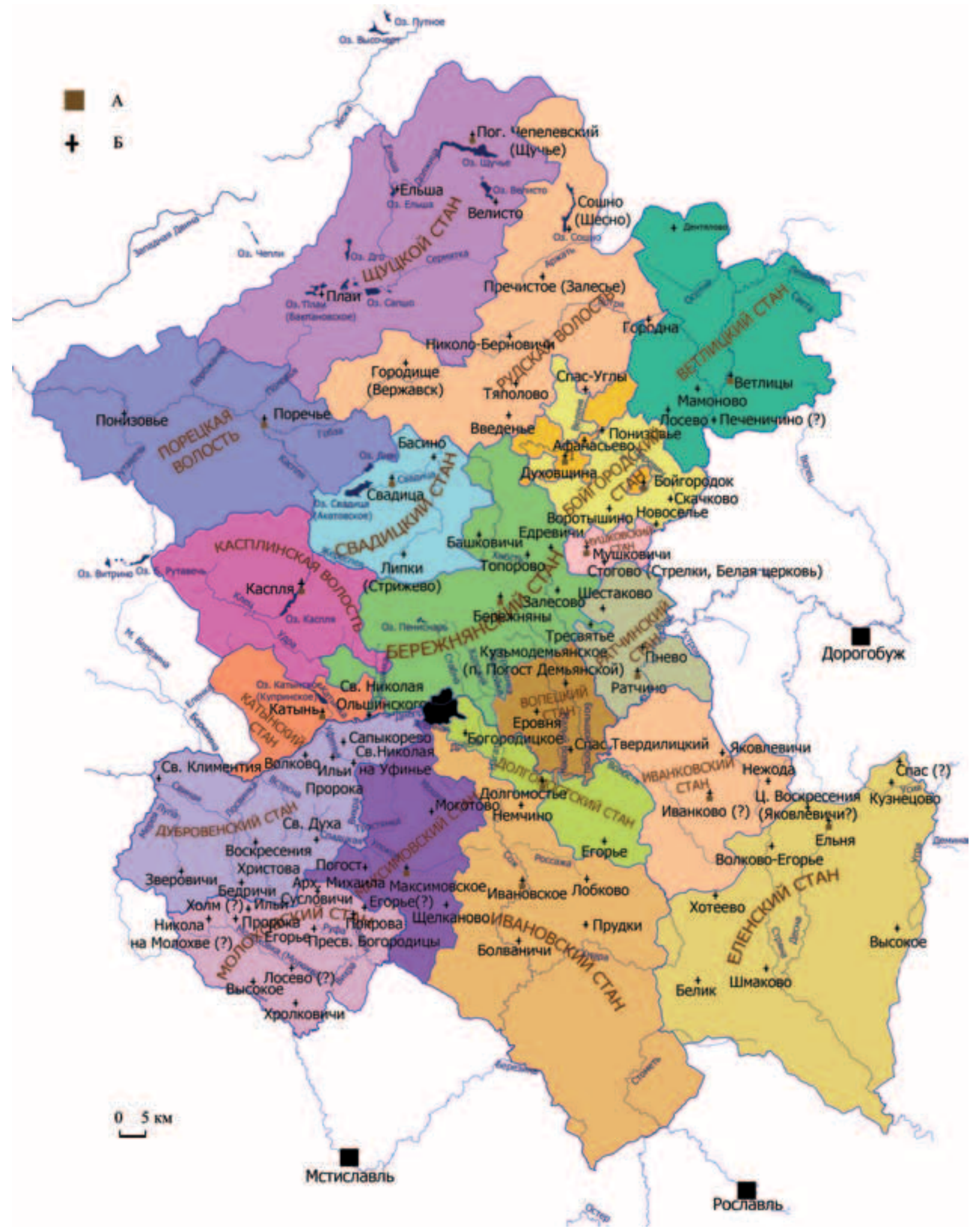

Рис. 1. Смоленский уезд в XVI-XVIII вв. (до губернской реформы 1775 г.). Показанные границы станов и волостей в основном отражают ситуацию второй половины XVII в. Граница Свадицкого стана и Порецкой волости показана по ситуации на 1665 г., граница Катынского, Бережнянского станов и Касплинской волости - по ситуации на 1670-е годы

А - центры станов и волостей Смоленского уезда; Б - локализация основных храмов, существовавших до 1611 г. (показана с учетом данных комментариев В. А. Прохорова к привилею смоленскому архиепископу 1633 г.); I - Духовская волость Бойгородского стана 
Метрики, в том числе уникальный «Список смоленских князей, бояр и слуг» конца XV в., однако данные этих источников в сравнении с источниками позднейшего периода более отрывочны. Выше уже отмечалась возможность ретроспективного привлечения для данного периода источников XVII-XVIII вв., требующая, однако, определенной осторожности. Для изучения территориальных структур Смоленской земли данного периода, как показывает анализ документальных источников, важное значение обретают данные топонимики. Именно в XV-начале XVI в. в целом, похоже, сложился основной фонд названий сельских поселений Смоленской земли. Та же ситуация прослеживается и для Московской Руси, что блестяще продемонстрировал в своих работах С.Б. Веселовский (1969). Как показывает, например, анализ текста «Списка смоленских князей, бояр и слуг», названия селений в этот период были достаточно неустойчивыми и образовывались от имен и прозвищ фактических владельцев либо жителей. Благодаря этому анализ топонимики, отраженной как на современной, так и на исторических картах и в иных источниках, позволяет получить большой объем информации, касающейся структур землевладения XV - начала XVI в. (рис. 2). В связи с ограниченностью фонда письменных источников для данного периода существенное значение обретают данные археологии. Однако следует отметить, что памятники археологии XIV-XV вв. на Смоленщине исследованы весьма незначительно. Более того, само выделение археологических памятников данного периода в историографии представляет собой определенную проблему ${ }^{1}$.

Третий период может быть в целом соотнесен с домонгольским временем. Основным письменным источником для данного периода оказывается комплекс грамот смоленской епископии, датируемый различными исследователями XII-XIII либо только XII в. ${ }^{2}$ Определенную информацию о территориальных структурах Смоленской земли этого периода можно извлечь также из летописей и договорных грамот Смоленска с Готским берегом XIII в. В целом информация письменных источников для данного периода крайне отрывочна, поэтому важнейшую роль играют археологические данные (рис. 3). Кроме того, с определенными ого- ворками могут быть использованы ретроспективные данные позднейших источников, а также данные топонимики.

Первый из описанных выше периодов выходит за поставленные хронологические рамки работы, однако обретает значение как источник ретроспективной информации. Для второго выделенного периода основным источником, как уже отмечалось, являются материалы Литовской Метрики XV - начала XVI в. Декларируемое стремление литовских властей к приверженности «старине», а также упоминание отдельных волостей, в частности Молохвы ${ }^{3}$, в контексте событий присоединения Смоленска к Литве в начале XV в. позволяет говорить о том, что зафиксированная структура сложилась еще в период существования самостоятельного Смоленского княжества. Среди прямого наследия долитовского периода фигурирует также церковное владение Прость ${ }^{4}$, в позднейший период упоминаемое как одна из смоленских волостей (СИРИО, 1885. № 75. С. 395). Не исключена связь данного топонима с «прощениками» Уставной грамоты Ростислава Мстиславича (ДКУ, 1976. С. 141).

Реконструируемая Н.Г. Бережковым наиболее ранняя из содержащих информацию о Смоленской земле «книга данин» великого князя Казимира, датируемая 1440-ми - 1455 гг. (Бережков, 1946. С. 57), сохранившаяся в составе третьей Книги записей Литовской Метрики, содержит данные о примерно 200 пожалованиях в Смоленской земле (точное количество подсчитать затруднительно, поскольку в некоторых случаях не представляется возможным определить, идет ли речь о Смоленской земле или других территориях). Выделяются несколько разновидностей пожалований. Среди них пожалования людей («чоловеков», «семей», «селец с людьми»), пожалования угодий либо дохода с них («земель», «бережков», «кадей меду»), а также «пустых» сел или земель, пожалования волостей либо иных географических объектов, не названных каким-либо термином. Эти различные виды пожалований в источнике отражены в формуле «аж не будет никакова жалования, людей, ани волости». В единичных случаях встречены пожалования «отраслевого» характера: «данничое чорное» (вероятно, понятие, близкое

\footnotetext{
1 О проблемах выявления смоленской керамики XIV-XV вв. см.: Курмановский, 2014.

2 О проблемах датировки комплекса грамот Смоленской епископии см.: Янин, 1998

3 «...и што великий князь Витовт обернул был ко Мстиславлю Смоленскођ волости Молоховскии люди, и тые люди его милость опять привернул к Молохве...» (АЗР, 1846. С. 361).

${ }^{4}$ « ...издавна тые прощане церковные, в старых записех записаны, а отнял был дей князь великий Витовт, розгневався на первого владыку...» (РИБ, 1910. Стб. 63).
} 
к «чернокунству» Новгородской земли) (РИБ, 1910. Стб. 39), «у Смоленску ключ медовый» (РИБ, 1910. Стб. 40), «ловчее» (РИБ, 1910. Стб. 67), «конюшое» (РИБ, 1910. Стб. 39). Подобные формы доходных статей находят аналогии в отраслевых «путях» Московского княжества. В соседнем Брянске в конце XV в. «ловчае», «конюшое», «редничое» и «поездничое» фигурируют как «волости» (АЗР, 2012. № 599. С. 401). В Берестейской земле в этот же период существовали «одна чотыри волостки: данничое, а житщина, а бобровщина, а ловчое» (АЗР, 2012. № 320. С. 224).

В целом в этот период в источниках фигурируют такие элементы территориальной структуры Смоленской земли, как волости, пути и господарские дворы. Волости в документах Литовской Метрики XV-начала XVI в. упоминаются как особая разновидность объектов пожалования различным лицам из числа местной либо литовской знати. Эти пожалования могли быть временными («на три годы», «на пять год», «до воли») или же наследственными («у вотчину»). Встречаются также аналогичные пожалования географических объектов, не названных напрямую волостями. Другая разновидность пожалований - пожалование «людей», «сел» или угодий, в документах часто также привязывается к волости либо некой округе, не названной каким-либо термином. Чаще всего в основе названия волости либо иной округи лежит гидроним. Кроме того, в ряде случаев название волости связывается с существовавшим городом, в том числе утратившим свой статус к моменту упоминания (Вержавск, Рославль, Ельна). Статус населения, образующего волость, и характер получаемых с нее доходов может быть различным. Так, князь Дмитрий Всеволодович Мезецкий получил от великого князя Казимира «Шюе а Демены у хлебокормленье» (РИБ, 1910. Стб. 40). Основу «волостейских доходов» с волости Щучье, в 1496 г. делившихся между смоленскими боярами Иваном и Григорием Павловичами и Иваном и Григорием Федоровичами, а ранее между их отцами Павлом и Федором Плюсковыми, составляла «серебреная дань» (АЗР, 2012. № 175. С. 127). Повинности волостки Белик в 1498 г. складывались из «посощины» «подлуг земли Смоленское обычая», «дани грошовое» и трех кадей и двух пудов меда (АЗР, 2012. № 272. С. 187). В волостях имелись должностные лица - «прыказники».

Другой термин, относящийся к элементам территориальной структуры,-«пути». В Смоленской земле встречены упоминания шести путей: Дубровенского, Молоховского, Максимовского,
Юрьевского, Радшинского и Вержавского. Названия смоленских путей, в отличие от, скажем, путей Московского княжества, носят не «отраслевой», а территориальный характер. При этом названия, по крайней мере, Дубровенского и Вержавского путей, вероятно, образованы не от их центров, а от пунктов, в направлении от Смоленска к которым эти пути лежали. Так, Дубровенский путь, очевидно, охватывал земли, расположенные вдоль дороги из Смоленска к г. Дубровно. Первые упоминания смоленского Дубровенского пути относятся к 1440-м гг. (Полехов, 2014. С. 166-167), по археологическим данным, поселение на месте г. Дубровно возникает в XIV в. (Археалогія Беларусі, 2009. С. 326-327). Таким образом, формирование территориальной единицы Дубровенский путь, вероятнее всего, можно датировать временем не ранее XIV в. Вержавский путь, судя по локализации его селений, лежал по дороге из Смоленска в волость Вержавск. В путях, как показывают документы, как и в волостях, проживало население различного статуса, однако «Список смоленских князей, бояр и слуг» демонстрирует определенную концентрацию здесь различных категорий «слуг». Предположительно «слуги» Литовской Руси могут быть сопоставлены со «слугами вольными» Восточной Руси и восходить к «молодшей дружине» домонгольского времени (Любавский, 1915. С. 112). Некоторые категории «слуг», такие как «слуги щитные» и «доспешные», известны только в Смоленской земле (Любавский, 1893. С. 45). Обращает на себя внимание также созвучие наименования путей с общелитовской категорией «путных слуг». Однако вряд ли можно говорить о том, что помещение здесь военно-служилого населения являлось отличительной особенностью путей. Как показывает «Список...», таковые имелись и в таких волостях, как Рославль, Пацынь, Ельня, Светславль, Мащин и Опаков (РИБ, 1910. Стб. 490-491, 493-498). В отличие от волостей, пути в документах Литовской Метрики не фигурируют как пожалования в целом. Как и в волостях, в путях имелись «прыказники». Географически пути локализовались к западу и югу от Смоленска (Дубровенский, Молоховский, Максимовский и Юрьевский), а также к северу и востоку от него (Вержавский, Радчинский). Юрьевский путь Смоленского повета не был локализован Н.Б. Шеламановой, однако локализация селений, созвучных с фамилиями слуг Юрьевского пути в «Списке...» (Молоково, Самотыгино, Мотовилово), а также упоминание здесь же р. Охморы (Хмары) позволяет определить его местонахождение в бассейне р. Сож в пределах 


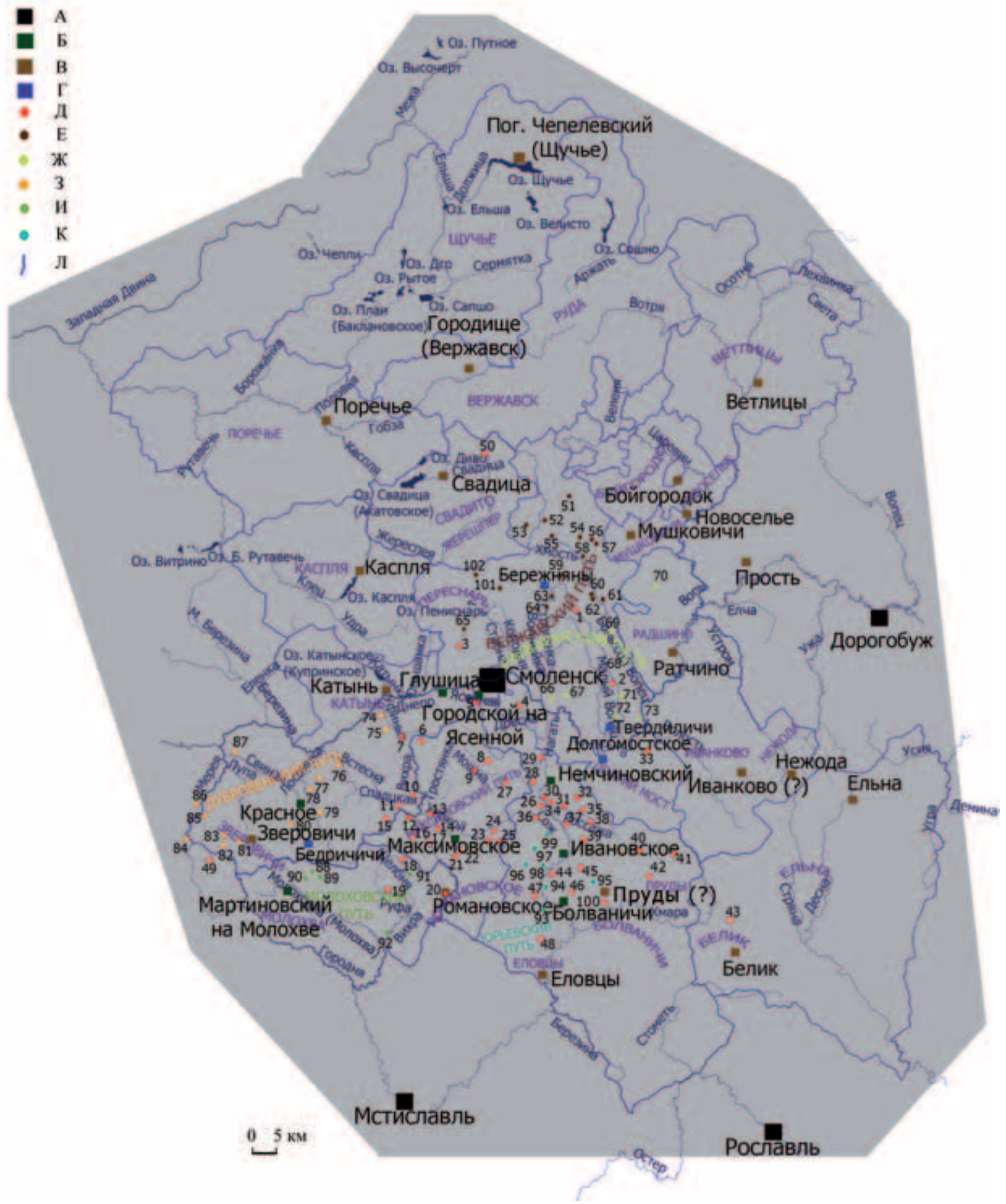

Рис. 2. Центральная часть Смоленского повета ВКЛ (в пределах Смоленского уезда до 1775 г.) в XV - начале XVI в.

А - города; Б - господарские дворы; В - центры волостей; Г - центры территориальных образований, не названных в источниках каким-либо термином; Д-топонимы, образованные от фамилий смоленских князей и бояр, известных по источникам XV - начала XVI в.; E - селения бояр и слуг Вержавского пути; Ж - селения бояр и слуг Радщинского пути; 3 - селения слуг Дубровенского пути; И - селения слуг Молоховского пути; К - селения слуг Юрьевского пути;

Л - границы станов и волостей Смоленского уезда в XVII в. 1 - Верещакино; 2 - Лаптево; 3 - Скрипорово; 4 - Алтуховская; 5 - Александровское; 6 - Бердебяки; 7 - Мирослав (показано гипотетически); 8 - Басино; 9 - Русилово; 10 - Гольцово; 11 - Мончино; 12 - Чальцево; 13 - Голосово; 14 - Юрово; 15 - Зибрики; 16 - Окортево; 17 - Бритово; 18 - Нагишкино; 19 - Досугово; 20 - Романовское; 21 - Стегримово; 22 - Сумароково; 23 - Богатищево; 24 - Герчиково; 25 - Беликово; 26 - Лаптево; 27 - Моготово; 28 - Дудино; 29 - Сумароково; 30 - Кощино; 31 - Кривцово; 32 - Сверчково; 33 - Мончино; 
позднейшего Ивановского стана Смоленского уезда (рис. 2). Следует отметить, что в перемирной грамоте Василия III с Сигизмундом I 1522 г. Дубровенский путь упомянут в числе смоленских волостей (СИРИО, 1885. № 93. С. 639).

Еще одним сегментом территориальной структуры оказываются великокняжеские усадьбы«господарские дворы» с принадлежащими к ним селениями. Всего в актовом материале XV-начала XVI в. встречены упоминания девяти господарских дворов (Городской на Ясенной, городской двор в Красном, Мартиновский на Молохве, Немчиновский, Глушица, Ивановский, Вопецкий, Максимовский, Болваничи), расположенных в Левобережье и в юго-восточной части Заднепровья (Вопецкий двор в точности не локализуется) (рис. 2). Сеть господарских дворов, таким образом, охватывала фактически всю центральную и западную часть левобережья Днепра в пределах позднейшего Смоленского уезда, на северо-востоке распространяясь и на противоположный правый берег. Расположение господарских дворов, таким образом, в значительной мере накладывалось на территорию смоленских путей, с которыми господарские дворы обнаруживают определенную взаимосвязь. Так, Мартиновский двор на Молохве и Максимовский двор предположительно оказываются центрами Молоховского и Максимовского путей соответственно. В Дубровенском пути какой-либо центр не выделяется, однако отмечается тяготение людей данного пути (в том числе его территориально отдаленных западных районов) ко двору Глушица. Кроме того, на территории Дубровенского пути, очевидно, должен был находиться господарский двор в Красном. Есть основания полагать, что территории, подведомственные господарским дворам, назывались поветами. Упоминаются, в частности, повет Мартиновского двора (РИБ, 1910. Стб. 571-572; 592- 593), Максимовский повет (АЗР, 2012. № 142. С. 108), Ивановский повет (РИБ, 1910. Стб. 678). Подобно волостям, господарские дворы могли быть переданы в кормление либо вот- чину. Администрацию господарских дворов представлял тиун («тивун»). Так, в спорном деле дворянина Михаила Данильевича с людьми Дубровенского пути Митрохановыми 1508 г. в качестве свидетеля выступал «тивун глушыцкий» (Lietuvos Metrika, 1995. № 412. S. 310). В описании двора Болваничи и принадлежащих к нему селений, предоставляемых князю Константину Крошинскому, 1498 г. отмечено «сел (ь)це Яковлево, что был тивуном за пана Ивана Вяжевича» (АЗР, 2012. № 272. С. 187). Господарские дворы известны и в других землях Великого княжества Литовского, являясь специфическим элементом его государственного устройства (Любавский, 1893. С. 301). Кроме того, господарские дворы, судя по их довольно частым упоминаниям в документах, являлись реально действующим средоточием власти на местах, центрами поступления повинностей с подведомственного населения. В связи с этим есть основание считать их инновацией, связанной с включением Смоленской земли в состав Великого княжества Литовского. В то же время нельзя исключать существования некоторой преемственности между ними и некими административными центрами, существовавшими в период самостоятельности Смоленского княжества.

Отдельный вопрос составляет характер вотчинного землевладения смоленских бояр. Анализ источников позволяет говорить о том, что в значительной мере смоленские бояре получали доход от кормления с держания волостей и временных держаний «сел с людьми». Вместе с тем у них имелись и собственные вотчинные владения, масштаб которых, однако, вероятно, был не столь велик. В «Списке смоленских князей, бояр и слуг» отдельно упомянуты бояре в Вержавском и Радщинском путях, мащинские, еленские бояре, очевидно, владевшие селами в этих территориальных единицах. Эти бояре по своему статусу, вероятно, стояли ниже основной части смоленских бояр, упомянутых в начале списка. В актовом материале упоминаются также бояре молоховские

34 - Коркодиново; 35 - Свиридоново; 36 - Александровское; 37 - Татарово; 38 - Кинборово; 39 - Колычево; 40 - Лобково; 41 - Бердебяки; 42 - Бесищево; 43 - Докудово; 44 - Александровское; 45 - Белейкотлово; 46 - Кошкино; 47 - Сверщково; 48 - Пантюховка; 49 - Ботвиньево; 50 - Басино; 51 - Рыково; 52 - Кубарово; 53 - Башковичи; 54 - Едревичи; 55 - Усово; 56 - Колентеево; 57 - Смогири; 58 - Медведево; 59 - Веено; 60 - Бородино; 61 - Мартьяново; 62 - Варваровщина; 63 - Сущево; 64 - Дягилево; 65 - Близнаки; 66 - Онохово; 67 - Рогачево; 68 - Любково; 69 - Прокшиничи; 70 - Шестаково; 71 - Кочекорово; 72 - Шишкино; 73 - Бельчевицы; 74 - Давыдково; 75 - Сковородино; 76 - Железково; 77 - Литвиново; 78 - Маньково; 79 - Сорхатино; 80 - Буяново; 81 - Скороходово; 82 - Шеино; 83 - Василевичи; 84 - Баево; 85 - Тугощичи (Туговищи); 86 - Золотовичи; 87 - Бежали; 88 - Ледыще; 89 - Гвоздово; 90 - Шиловичи (Шилково?); 91 - Капустино; 92 - Ходнево; 93 - Мотовилово; 94 - Самотыгино; 95 - Холопищево; 96 - Молоково; 97 - Клемятино; 98 - Захарово; 99 - Ледничи; 100 - Пивовка; 101 - Островкино; 102 - Захарино 


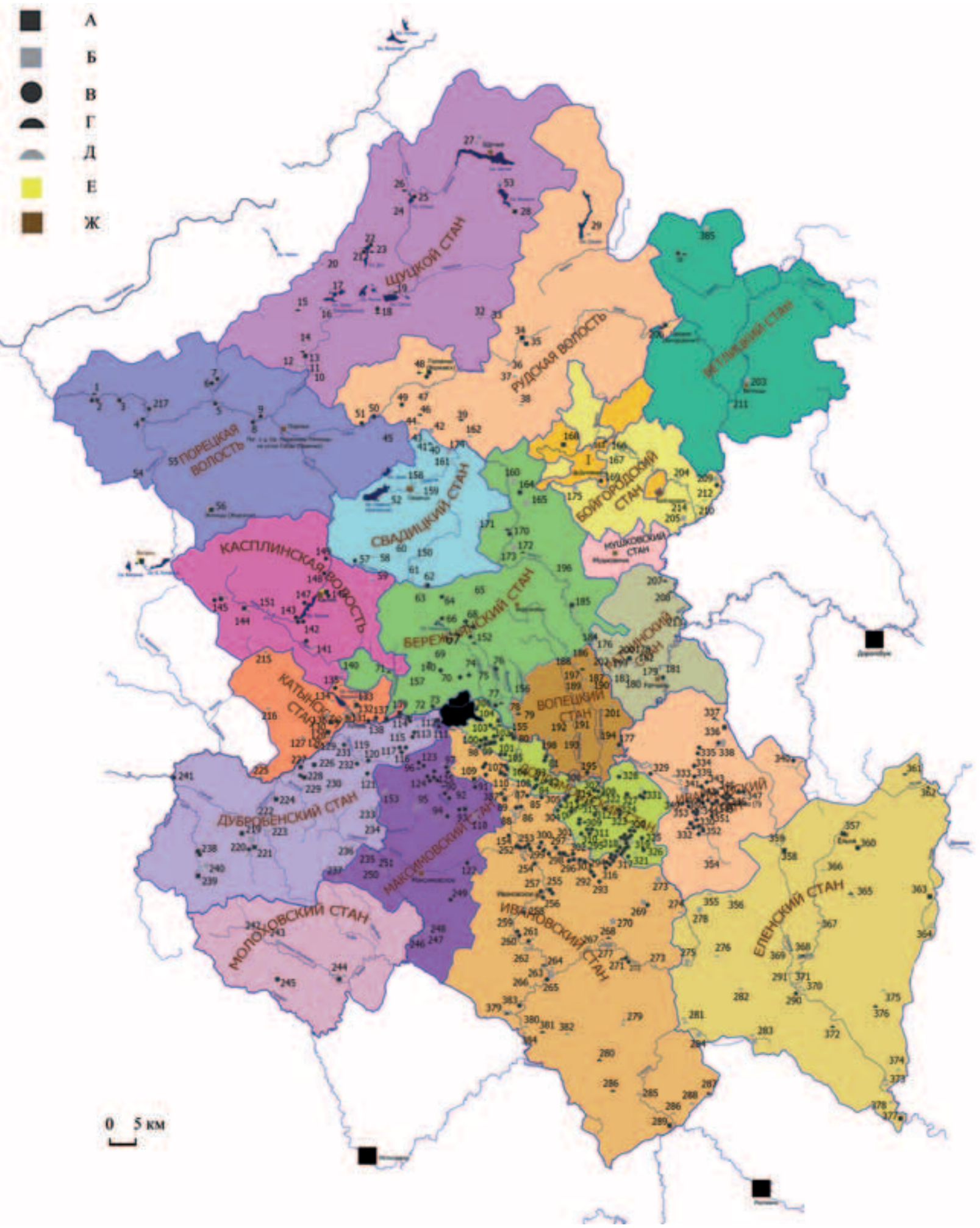

Рис. 3. Древнерусские (и потенциально древнерусские) археологические памятники XI-XIII вв. в пределах Смоленского уезда до губернской реформы 1775 г.

А - городища с культурным слоем древнерусского времени; Б - городища неизвестной культурной принадлежности (не считая городищ без культурного слоя); В - древнерусские селища XI-XIII вв.; Г - курганы XI-XIII вв.; Д - курганные могильники, содержащие полусферические курганы, и единичные полусферические курганы неизвестной культурной и временной принадлежности (потенциально древнерусские); Е - локализация центров податных объектов Уставной Грамоты Ростислава Мстиславича; Ж - центры станов и волостей Смоленского уезда догубернского деления. 1 - Клименки; 
2 - Верхние Кошевичи; 3 - Нов. Мышково; 4 - Понизовье; 5 - Борода, селище 1; 6 - Борода, селище 2; 7 - Борода, селище 3;

8 - Минаки; 9 - Лобаново; 10 - Хомяки; 11 - Никасицы; 12 - Великая; 13 - Заборье; 14 - Баталово; 15 - Саки; 16 - Побоище; 17 - Бакланово; 18 - Лужок; 19 - Пржевальское; 20 - Черная Грязь; 21 - Заозерье; 22 - Ерилово, селище; 23 - Ерилово, курганный могильник; 24 - Горки; 25 - Ельша; 26 - Подосинки; 27 - Горы; 28 - Велисто; 29 - Добрино; 30 - Девятое;

31 - Городна; 32 - Рибшево, курганный могильник 3; 33 - Тарасово; 34 - Загоскино (Городище); 35 - Николо-Берновичи; 36 - Буризи; 37 - Малое Старыгино; 38 - Колошино; 39 - Елисеевичи; 40 - Преображенск, курганный могильник 2;

41 - Преображенск, курганный могильник 1; 42 - Нескучное; 43 - Городная, курган; 44 - Городная, курганный могильник; 45 - Котовщина (Тарасово); 46 - Варнавино; 47 - Брод; 48 - Городище (Вержавск); 49 - Свистовичи; 50 - Няньковичи, селище 2; 51 - Няньковичи, селище 1; 52 - Акатово, курганный могильник 1; 53 - Никольское; 54 - Боярщина; 55 - Бор; 56 - Жичицы; 57 - Язвище, селище 1 и курган; 58 - Дубровка; 59 - Кислые; 60 - Аполье; 61 - Самолюбово; 62 - Абрамково; 63 - Плаи; 64 - Захарино (селище и курганный могильник); 65 - Иловка, курганный могильник; 66 - Дуброво; 67 - Жуково; 68 - Зыколино; 69 - Близнаки; 70 - Печерск; 71 - Ольша; 72 - Верх. Ясенная, курган; 73 - Дубровенка; 74 - Корохоткино;

75 - Буховка; 76 - Рогачево; 77 - Валутино; 78 - Колодня; 79 - Митино; 80 - Высокое; 81 - Боровики; 82 - Березинка; 83 - Березинка, городище Шапырево; 84 - Муравщина; 85 - Яново (селище и курганный могильник); 86 - Горяны;

87 - Борешино; 88 - Гевино; 89 - Бобыри; 90 - Теличино; 91 - Сож; 92 - Басино (Босино); 93 - Лахтеево; 94 - Червонное; 95 - Беленки; 96 - Кушлянщина; 97 - Рай; 98 - Малая Дресна; 99 - Ройновка; 100 - Успенская; 101 - Богородицкое (городище и селища 1-4); 102 - Козино (селища 1 и 2); 103 - Туринщина; 104 - Маркатушино; 105 - Корюзино;

106 - Барщевщина (Крицковщина); 107 - Знаменка (Воищина); 108 - Талашкино; 109 - Вербовка (Нагать), селища 1-3; 110 - Сумароково; 111 - Александровка; 112 - В. Ясенная, городище; 113 - Дроветчино; 114 - Глушица; 115 - Демидовка; 116 - Лубня; 117 - Шпаки; 118 - Софьино; 119 - Гороховка; 120 - Цурковка; 121 - Корытня; 122 - Герчики; 123 - Жаковка; 124 - Сушковщина; 125 - Селезневщина; 126 - Коробино; 127 - Загусинье; 128 - Красная Горка; 129 - Шафорово; 130 - Вонлярово; 131 - Катынь; 132 - Борок; 133 - Ладыжицы; 134 - Будково; 135 - Старое Куприно; 136 - Сметанино; 137 - Гнёздово, Нивлянское поселение; 138 - Гнёздово, Ольшанское городище; 139 - Гнёздово, Центральное городище и Левобережные курганы; 140 - Ермаки; 141 - Волоковая; 142 - Пилички; 143 - Горбуны, селища 1 и 2; 144 - Иньково;

145 - Рокот; 146 - Каспля; 147 - Прудники; 148 - Семеново; 149 - Шилы; 150 - Сыр-Липки; 151 - Заборье; 152 - Ивахово;

153 - Новоселье; 154 - Лучинка; 155 - Соколья Гора; 156 - Волчейка; 157 - Яцынино; 158 - Боровики; 159 - Мироново; 160 - Алферово; 161 - Басино; 162 - Головицы (Бродки); 163 - Жатомля; 164 - Стратилатово; 165 - Бельково;

166 - Буянцево; 167 - Троицкое; 168 - Еськово; 169 - Третьяково; 170 - Турье; 171 - Редня; 172 - Топорово; 173 - Новоселки; 174 - Озерецкое (Могилка); 175 - Сельцо; 176 - Кардымово; 177 - Бельчевицы; 178 - Богатырево; 179 - Бураково;

180 - Городок; 181 - Заборье; 182 - Кунцево; 183 - Морево; 184 - Курдимово; 185 - Городок; 186 - Сопачево; 187 - Кривцы; 188 - Ермачки; 189 - Заполье; 190 - Любково; 191 - Вяльково; 192 - Гололобово; 193 - Федорово; 194 - Кочкорово;

195 - Козичино; 196 - Велюжино; 197 - Мольково; 198 - Наумово (Рубцово); 199 - Некисово (Слотово); 200 - Пищулино;

201 - Холм (Вуймоново); 202 - Цурьково; 203 - Ветлицы; 204 - Шишкино (Наволок); 205 - Дуброво; 206 - Новоселки;

207 - Сельцо; 208 - Хатуни; 209 - Рядыни; 210 - Скачихино; 211 - Устье; 212 - Приселье; 213 - Соловьево (Пищиково); 214 - Скачково; 215 - Надва; 216 - Анциферово; 217 - Селечки; 218 - Шарки; 219 - Красный; 220 - Павлово

(Волохово-Доброе); 221 - Буяново; 222 - Маньково; 223 - Новоселки; 224 - Смилово; 225 - Алексеевка; 226 - Волково; 227 - Горбачи (Прудники); 228 - Городец; 229 - Даниловка; 230 - Лукиничи; 231 - Романовка; 232 - Кончинка;

233 - Григорьево; 234 - Рогайлово; 235 - Чальцево; 236 - Мончино; 237 - Доморацкое; 238 - Зверовичи; 239 - Городище;

240 - Скороходово (Сорокино); 241 - Козлы; 242 - Горбово; 243 - Викторово (Коровино); 244 - Перепечино (Тригубово); 245 - Высокое; 246 - Макарово; 247 - Дмыничи; 248 - Соболево; 249 - Каблуково; 250 - Васильево; 251 - Левково;

252 - Покровка (Ковшаровское городище и селище); 253 - Обухово; 254 - Бакланово; 255 - Колычево; 256 - Ивановское;

257 - Потемкино; 258 - Вердихово; 259 - Кошелево; 260 - Матвеево; 261 - Слобода-Глушица; 262 - Светлое; 263 - Мошевая

(курганы и городище); 264 - Казаринка; 265 - Прилепово; 266 - Федорово; 267 - Молуки; 268 - Починок; 269 - Бабыново;

270 - Белое; 271 - Рудня; 272 - Демешки; 273 - Анеково; 273 - Мачулы; 274 - Сергеево; 275 - Хмара; 276 - Климщина;

277 - Цыгановка; 278 - Городок; 279 - Гапоново; 280 - Ефремовка; 281 - Семиново; 282 - Белик; 283 - Заборье; 284 - Рудня; 285 - Тростино; 286 - Печкуры; 287 - Кубарки; 288 - Борщевка; 289 - Деребуж 1-й; 290 - Стряна; 291 - Шмаково; 292 - Пересна; 293 - Денисово; 294 - Дементьево; 295 - Рожново; 296 - Васильево (Вошкино); 297 - Лазарево;

298 - Ямполье; 299 - Быково; 300 - Крокодиново; 301 - Сверчково; 302 - Свиридоново; 303 - Россаж; 304 - Кучино;

305 - Авдотьино; 306 - Рябцево; 307 - Верхние Немыкари, курганы; 308 - Верхние Немыкари, селища 1-2; 309 - Путятинки;

310 - Панское 1-е; 311 - Акулы; 312 - Шестаково; 313 - Белоручье; 314 - Долгомостье; 315 - Яцково; 316 - Юкавщина, селища 1-7; 317 - Птахино; 318 - Станьково, селища 1-6; 319 - Плескачи, селища 2-7, курганные могильники

1-3, одиночный курган; 320 - Васильево, селища 1-2; 321 - Огарково, курганный могильник 3; 322 - Воскресенск;

323 - Арефьино 1-е; 324 - Арефьино 2-е; 325 - Николино; 326 - Круглово; 327 - Боровая; 328 - Мончино; 329 - Шилово;

330 - Галашино; 331 - Белый Холм; 332 - Бородино; 333 - Марьино; 334 - Василево; 335 - Вишняки; 336 - Клемятино;

337 - Милеево; 338 - Левыкино; 339 - Тимошево; 340 - Николаевское; 341 - Дубосище; 342 - Болотово (Рудлово);

343 - Бортеново; 344 - Воротнино; 345 - Рокачево; 346 - Иваники; 347 - Васильково; 348 - Ганино; 349 - Конщино; 350 - Орлово; 351 - Княжье Село; 352 - Матвеево; 353 - Пашино; 354 - Розовка; 355 - Ханино; 356 - Хотеево; 357 - Ельня; 358 - Волково-Егорье; 359 - Волково-Егорье (Озеренск); 360 - Данино; 361 - Добрушино; 362 - Савостьяново; 363 - Уварово (Лазаревское); 364 - Бабичи; 365 - Болоновец; 366 - Филатки; 367 - Лапино; 368 - Дуброво; 369 - Малышевка; 370 - Стряна

(Литвиновка); 371 - Замошье (Литвиновка); 372 - Богданово; 373 - Зимницы; 374 - Старое Сырокоренье; 375 - Заболотье;

376 - Ведерники (Старые Словени); 377 - Караковичи; 378 - Конята; 379 - Еловцы; 380 - Суборовка; 381 - Новая Рудня; 382 - Комаровка; 383 - Коханово; 384 - Новое Воробьево; 385 - Батурино; 386 - Новосельцы; 387 - Шершуны 
(РИБ, 1910. Стб. 622-623) и болваницкие (РИБ, 1910. Стб. 652). Информация о локализации сел смоленских бояр может быть почерпнута из данных топонимики. Наибольшая концентрация топонимов, связанных с фамилиями смоленских бояр, известных по данным Литовской Метрики, фиксируется в центральной части левобережья, к югу, отчасти юго-востоку и юго-западу от Смоленска (территория позднейших Ивановского, Максимовского, частично Долгомостского и Дубровенского станов) (рис. 2).

Для Смоленской земли «литовского» периода, как и ряда других русских земель XIV-XV вв., как показывают материалы Литовской Метрики, была характерна определенная неустойчивость топонимики, когда селения назывались по именам фактических владельцев или же жителей, при смене которых названия менялись. При этом на Смоленщине сохранился обширный пласт топонимики, восходящий к именам, фамилиям и прозвищам лиц, упоминаемых в документах Литовской Метрики (боярам, слугам и др.). Наличие такой топонимики позволяет, например, достаточно надежно локализовать пути Смоленского повета. В то же время среди топонимики Смоленской земли, находящейся в процессе формирования в XV - начале XVI в., как показывают документы Литовской Метрики, весьма редко встречаются названия-патронимы с формантом -ичи/-ицы. Таковые в документах Литовской Метрики фигурируют как уже существующие, являясь при этом названиями сел: Бабиничи (РИБ., 1910. Стб. 713), Погоновичи (РИБ, 1910. Стб. 442); господарских дворов (Болваничи), волостей (Ветличи/Ветлицы, Мушковичи), употребляясь как топоним без какого-либо определения (Едревичи (РИБ, 1910. Стб. 490), Ратиславичи (РИБ, 1910. Стб. 483)) либо как название некой округи без обозначения какимлибо термином: Бедричичи (РИБ, 1910. Стб. 40), Чепиничи (АЗР, 2012. № 238. С. 164), Озариничи (АЗР, 2012. № 119. С. 95), Твердиличи (РИБ, 1910. Стб. 747). Последний вариант упоминания таких топонимов перекликается с упоминанием Погонович в Уставной грамоте Ростислава Мстиславича (ДКУ, 1976. С. 143). При этом селения, находящиеся в «округах-патронимиях» Зверовичи и Бедричи/Бедричичи, находились на территории и в юрисдикции Дубровенского пути. Аналогичным территориальным объединением на территории Вержавского пути, однако с иным, но также характерным лингвистическим формантом, оказываются Бережняны (ср. Вержавляне, Дешняне в Уставной грамоте Ростислава Мстиславича)
(ДКУ, 1976 С. 141, 142). Впоследствии, в XVI в., село Бережняны становится центром Бережнянского стана Смоленского уезда, включившего в себя территорию прежнего Вержавского пути. Совокупность данных обстоятельств позволяет предположить, что формирование подобных топонимов и связанных с ними «округов-патронимий» (или псевдопатронимий) относится к более раннему, вероятно, древнерусскому периоду. При этом следует отметить, что на Смоленщине известны также аналогичные по форме названия заведомо позднего формирования, образованные от фамилий землевладельцев XVII-XVIII вв. Подобным примером может служить деревня Дурасовичи, существовавшая в окрестностях д. Дроветчино Смоленского р-на, в так называемых казачьих грунтах. Ее название было образовано от фамилии землевладельцев Дурасовичей, появившихся здесь в XVII в. Следует также отметить, что подобные названия-патронимы в позднейших источниках часто коррелируют с местонахождением храмов, волостными центрами (Зверовичи, Мушковичи, Болваничи, Берновичи, Бабиничи, Ветлицы/Ветличи, Сусловичи, Бедричи и др.) (Смоленщина... 2017. С. 302-304), а также с находящимися в селении либо в его ближайшей округе городищами с древнерусским материалом (Жидчичи/Жичицы, Ладыжицы/Ладыжичи, Берновичи, Зверовичи, Кошевичи). В качестве своеобразных потенциально датирующих признаков можно проследить, что некоторые из этих названий образованы от христианских крестильных имен (Антоновичи, Василевичи, Елисеевичи), некоторые - от имен дохристианского происхождения (Хотесловичи, Твердиличи, Ратиславичи).

Одним из элементов территориальной структуры Смоленской земли в «литовский» период являлись также погосты. Фактически их упоминание в этот период встречно лишь единожды, в грамоте от короля и великого князя Александра великому князю Ивану III от 12 августа 1503 г.: «И как уж послы твои от тебе к нам пришли, тогды ж за ними прислали к нам князи и бояре наши смоленские, жалуючи нам на твои украинники, штож они волостей наших толко погосты оставили, а села и люди наши, и теж бояр наших села, дворы, люди, земли, воды и всякие вгодья поотрубали и в них ся поввязали...» (СИРИО, 1885. № 76. С. 436). Однако из данного фрагмента следует особый статус погостов в составе смоленских волостей, центрами которых они, очевидно, являлись. При том, что погосты - волостные центры в этот период, очевидно, не являлись крупными поселениями, представляя 
собой, как и погосты центральных районов Московского государства XVI-XVII в., отдельно стоящие церкви с кладбищами и дворами причта. В Экономических примечаниях к планам Генерального межевания некоторые центры существовавших ранее волостей и станов (такие, в частности, как Свадица (РГАДА. Ф. 1355. Оп. 1. Ед. хр. 1508. Л. 65) и Ратчино (РГАДА. Ф. 1355. Оп. 1. Ед. хр. 1487. Л. 40) обозначены именно как погосты. С этим также перекликается отсутствие описаний большинства центров станов и волостей Смоленского уезда в переписных книгах второй половины XVII в., могущие свидетельствовать об отсутствии там интересовавших переписчиков облагаемых земель и податного населения (РГАДА. Ф. 1209. Оп. 1. Ед. хр. 15152; 15154; 15167a).

Анализом географии и территориальных структур важнейшего из документальных источников, связанных с домонгольской Смоленской землей, Уставной грамоты князя Ростислава Мстиславича подробно занимались П. В. Голубовский, И. М. Красноперов (1894. С. 64-111; 1903. С. 23-39), В.В. Седов, Л.В. Алексеев. Важное значение в изучении данного источника обретают наблюдения Б.Н. Флори, проследившего в тексте Уставной грамоты признаки существования так называемой служебной организации - совокупности групп людей определенных профессий, несших государственную службу и освобожденных от других обязанностей. «Служебная организация» известна в странах Центральной Европы с XI в. и связывается с существованием в обществе системы централизованной эксплуатации при слабом развитии частного феодализма. К таковым исследователь относит названия поселений, а точнее, податных объектов, связанные с профессиональной деятельностью - Бортники, Бобровники и Солодовники, а также пожалованный епископу тетеревник (Флоря, 1992. С. 56-74). Сделанное Б.Н. Флорей фактическое открытие «служебной организации» в средневековой Руси получило значительное развитие в работах С.З. Чернова на материале земель Московского княжества XIII - начала XVI в. (Чернов, 2005. С. 339-351). Однако применительно к Смоленской земле изучение «служебной организации» фактически не получило какого-либо продолжения.

Традиционно все упомянутые в Уставной грамоте Ростислава Мстиславича податные объекты понимаются как волости или же отдельные поселения. Основы их локализации были в целом заложены исследованием П.В. Голубовского, причем значительная часть объектов была ло- кализована весьма гипотетически (Голубовский, 2011. С. 56-77, 362-388). Некоторые уточнения в локализации отдельных пунктов были внесены И.М. Красноперовым (1903. С. 31-38) и В.В. Седовым (1961. С. 318-323). Однако в свете исследования Б.Н. Флори среди них можно видеть как минимум две разновидности: различные категории «служебного» населения и даннические «волости-провинции». К первым помимо упомянутых Б.Н. Флорей бортников, солодовников и бобровников, очевидно, могут быть отнесены также позиции Уставной грамоты «во врочницех» (ДКУ, 1976. С. 141) и «в лодейницех» (ДКУ, 1976. С. 143). Исследователями Уставной грамоты отмечалось созвучие названия «врочницы» со словом «врок»/«урок» (Голубовский, 2011 С. 367; Алексеев, 1980. С. 95). Отметим, что термин «врок»/«урок» в реалиях Литовской Руси XV-XVI вв. соответствовал термину «оброк» Северо-Восточной Руси (Любавский, 1893. С. 415-416). Поэтому представляется возможным сопоставить слово «врочницы» с термином «оброчники», фигурирующим в духовных и договорных грамотах московских князей XIV-XV вв. (ДДГ, 1950. № 1а. С. 8; № 16. С. 10; № 4а. С. 15. № 46. С. 17. № 5. С. 20 и др.). Отдельный вопрос, следует ли пытаться отождествить каждую из названных позиций с конкретным географическим объектом или же речь здесь идет именно о категориях населения как таковых. В этом отношении интересна пометка о бортниках «на оной стороне», то есть, очевидно, на правом берегу Днепра. Такая формулировка вряд ли может свидетельствовать о том, что речь здесь идет об одном конкретном пункте. Скорее здесь имеется в виду совокупность бортников правого берега. П.В. Голубовский отождествил местонахождение податного центра Бортницы с селом Бортники Духовщинского уезда (ныне Ярцевский р-н Смоленской обл.) (Голубовский, 2011. С. 366). Однако примерно в 15 км северо-восточнее в том же районе, согласно планам Генерального межевания, располагалась деревня Бортники (РГАДА. Ф. 1356. Оп. 1. Ед. хр. 5458. Лл. 29, 33 об. - 34), название которой к XIX в. приобрело форму Борники (Исторический атлас... 2011. Л. 71), почему, видимо, и выпало из внимания П. В. Голубовского. Оба селения находились в окрестностях бассейна р. Лойни, левого притока р. Царевич, правого притока p. Вопь, правого притока Днепра: Бортники, отмеченные П. В. Голубовским, - на правом притоке p. Царевич Клюшне (Клишне), приблизительно в 3 км к юго-западу от впадения Лойни в Царевич; другие Бортники - в верховьях левого притока 
Лойни р. Касицкая ${ }^{5}$. Таким образом, в позднейшей топонимике, очевидно, отразились следы сети поселений бортников, располагавшихся сравнительно компактно в восточной части Днепровского Правобережья. Отметим, однако, что в последующие периоды (XV-XVIII вв.) эти два селения принадлежали к различным территориальным образованиям (Буйгородскому и Ветлицкому станам Смоленского уезда соответственно). Аналогичным образом под другими объектами подобного рода можно предполагать не конкретные географические пункты, а совокупность людей соответствующей специальности как таковых, хотя, возможно, и сосредоточенных в одном или нескольких соседних поселениях. Поселения «служебников» особых специальностей - «конюхов опецких пять» (РИБ, 1910. Стб. 69), «сельцо на реце на Нагати, где жывуть псарцы наши» (РИБ., 1910. Стб. 385) фиксируются и в материалах Литовской Метрики XV в. В 1495 г. городничий смоленский Федор Полтевич просил у великого князя «землицы в Смоленску на имя Колупаевщины а брата его Ивановы стрименников уво Озариничох», дававших по 10 стремян в год (АЗР, 2012. № 119. С. 95). С «человека на имя Зенька» с детьми и племянниками «ув Опецком повете в Твердиличох за Днепром», в 1499 г. пожалованного смоленскому епископу Иосифу, великому князю шла «служба одна плотницъкая а посощына» (РИБ, 1910. Стб. 747). Следы поселений «служебников», хотя и недатируемые, можно видеть и в ряде иных топонимов, связанных с населением, обладающим некой специализацией (Псарцы, Бочарники, Щитники, Санники, Колесники и др.).

Исследователями Уставной грамоты обращалось внимание на различное языковое оформление названий податных объектов (волостей) Смоленской земли (Алексеев, 1980. С. 93-94). Помимо описанных выше названий, связанных со «служебным» населением, можно выделить такие категории, как названия-гидронимы (Каспля, Жижец, Искона), названия территориальных общностей, также восходящие к гидронимам (Вержавляне, Дешняне) и названия-патронимы (или псевдопатронимы) (Жидчичи, Мирятичи, Вото (р)овичи, Дедогостичи) (Алексеев, 1980. С. 94-95), а также названия, очевидно образованные от имен с суффиксом принадлежности (Добрятино, Доброчков). Нельзя исключать того, что различный способ наименования податных объектов может быть связан с определенными различиями в их социальной характеристике. Так, например, названия-патронимы могут быть связаны с некими коллективами, связываемыми реальным или легендарным родством, в то время как «территориальные» объединения таковых связей не предполагали.

Часть податных объектов из второй категории в той или иной степени может быть соотнесена с территориальными единицами, существовавшими в позднейшее время (Торопец, Жижец (Голубовский, 2011. С. 365), Каспля (СИРИО, 1885. № 93. С. 639), Путтино-Путынь (Голубовский, 2011. С. 376), Пацинь (РИБ, 1910. Стб. 68 и др.), Басея (Вялікі гістарычны... 2009. С. 119, 195)). Объекты, поддающиеся более или менее надежной локализации, оказываются размещены преимущественно в правобережной части позднейшего Смоленского уезда (Вержавляне, Каспля, Жидчичи, Вото[р]овичи) либо в более отдаленных северных и северозападных (Торопец, Жижец), юго-западных (Кречют, Прупой, Копысь), южных (Пацинь), юго-восточных (Дешняне, Оболвь, Путтино) и восточных (Искона) районах.

Кроме того, можно говорить о выделении третьей категории географических объектов Уставной грамоты. Они надежно локализуются преимущественно в центральных районах днепровского Левобережья. Здесь фиксируются села («село Ясеньское» и «село Дросенское»), земли («земля Моишиньская в Погоновичех») и угодья (озера и «сеножати» с «княжими уездами») (ДКУ, 1976. С. 143), являющиеся предметами не обложения, а пожалования. Среди населения жалуемых сел отмечены «изгои» в Дросенском и бортник в Ясенском селе. Упоминание жалуемого ясенского бортника в известной мере противопоставляет его бортникам «оной стороны», вносившим дань в княжескую казну. Жалуемыми епископу представителями «служебного» населения оказываются также находящийся «за рекою», то есть, очевидно, на правом берегу Днепра, тетеревник и капустник на горе с их женами и детьми (ДКУ, 1976. С. 144). Упомянутые в разделе о пожаловании Погоновичи также продолжают ряд названий-патронимов, причем жалование земли «в Погоновичах» позволяет считать их центром некой округи.

Таким образом, в тексте Уставной грамоты можно видеть намеки на существование некоторого районирования территории Смоленского княжества.

\footnotetext{
5 Окрестности обоих этих селений были обследованы В. В. Седовым на предмет поиска здесь древнерусского городища центра волости Бортницы, не увенчавшегося, однако, успехом.
} 
Так, мы можем видеть начало формирования основного фонда владельческих земель с зависимым населением в центральной части левобережья Днепра. Отметим также, что эта территория вообще представлена в тексте Уставной грамоты весьма фрагментарно, что может говорить о существовании здесь на момент создания документа каких-то групп населения, не платящих дани. Л.В. Алексеев объяснял этот факт тем, что земли вокруг Смоленска на момент возникновения Смоленского княжения (1054 г.) были захвачены местной родовой знатью (Алексеев, 1980. С. 124; 1976. С. 53-54). По современным представлениям, для столь раннего периода трудно предполагать существование крупных земельных вотчин (Флоря, 1992. С. 59; Чернов, 2005. C. 350-351), однако в позднейшее время (в XV - начале XVI в.), как отмечалось выше, именно здесь оказываются сконцентрированы как села смоленских бояр, так и великокняжеские «господарские дворы». На правобережье в центральной части Смоленской земли фиксируется существование «служебного» населения (бортники, тетеревник). Прочие податные объекты, условно обозначаемые как «волости-провинции», тяготеют к более отдаленным от центра районам.

О размерах и численности населения податных единиц Уставной грамоты позволяет судить сопоставление данных о размере поступавшей с них дани с существующими сведениями о раскладке обложения данью в средневековой Руси. Ордынская дань XIII-XIV вв., как правило, составляла рубль (около 200 г) серебра с двух сох, что составляло примерно 50 г серебра с одного хозяйства, однако в реальности эта сумма могла быть меньше (Фетищев, 2012. С. 270-279). Дань, взимавшаяся ранее с восьми запустевших «тяглей», тянувших к смоленскому господарскому двору Болваничи, согласно документу 1498 г., составляла 3 копы и 10 грошей, то есть приблизительно 100 г серебра с одного тягла (АЗР, 2012. С. 187). При этом тягло могло включать в себя более одного двора. В 1660-х гг. денежный оброк с дворцовых крестьян Смоленского уезда составлял в среднем около рубля (44 г серебра) с двора (РГАДА. Ф. 1209. Оп. 1. Ед. хр. 15152). Гривна как расчетная денежная единица на Руси XII в. известна в двух вариантах - как гривна серебра и гривна кун, соотносящихся между собой как 1:4. В северных областях Руси гривна кун составляла 51,9 г; в южных, включая Смоленск, - 40,92 г (Янин, 1985. С. 365).
Из текста Уставной грамоты не вполне ясно, идет здесь речь о гривнах серебра или гривнах кун ${ }^{6}$. В то же время в документе наряду с прочими видами княжеского дохода упоминаются виры, взимавшиеся гривнами серебра. Таким образом, принимая за условно усредненные данные размер дани в гривну кун с одного двора, можно получить диапазон значений приблизительного количества дворов от минимума, равного числу гривен выплачиваемой дани, принимая гривну за гривну кун, до количества гривен, умноженного на 4 (рассматривая гривну Уставной грамоты как гривну серебра).

Не вполне ясным остается также расположение и соотношение с другими известными территориальными единицами фактически единственного объекта территориальной структуры Смоленской земли, упоминаемого в договорных грамотах Смоленска с Готским берегом XIII в. - волока с обслуживающими его «волочанами» и ведающим ими тиуном (Смоленские грамоты... 1963. С. 12, 22-24, 27-29, 33-34, 37-38, 42, 44 и др.). Несомненно, местонахождение его - между Смоленском, а скорее всего, между течением Днепра в районе от Гнёздова до Катыни и Касплей, однако конкретный маршрут в этом районе и граница принадлежащей к нему территории остается неясной и разными исследователями определялась по-разному (Лявданский, 2002. С. 186; Алексеев, 1980. С. 64-65; Нефедов, 2012. С. 93-94). Ориентиром оказывается топоним Волоковая в нижним течении р. Удры у впадения в нее р. Лелеквы. Вблизи д. Волоковая расположен комплекс археологических памятников: городище с материалом тушемлинской культуры и культуры смоленскополоцких длинных курганов, селище с древнерусской гончарной керамикой, курганный могильник, в одном из насыпей которого Е.А. Шмидтом были прослежены остатки трупосожжения, и одиночный курган (АКР, 1997. С. 80). Таким образом, трасса участка древнего пути из варяг в греки от Днепра до озера Каспля выстраивается следующим образом: Катынь - р. Катынка - оз. Купринское (в документах XVII в. - Катынское) - устье р. Лелеква - оз. Каспля. В таком случае маршрут волока, скорее всего, пролегал либо от Днепра у устья Катынки до оз. Каспля и занимал центральную часть позднейших Катынской и южную оконечность Касплинской волости Смоленского уезда. Вместе с тем обращает на себя внимание конфигурация границ позднейших территориальных образований правобережья Днепра. Если границы ближайших к городу станов

${ }^{6}$ О проблеме трактовки гривны Уставной грамоты см.: Алексеев, 1980. С. 79. 
и волостей левобережья Днепра (Дубровенского, Максимовского, Ивановского, Долгомостского) и прилежащего к ним в восточной части правобережья Вопецкого стана образуют веерообразную структуру, сходящуюся к Смоленску, то на правобережье границы трех территориальных образований - Бережнянского стана (восходящего к Вержавскому пути XV в.), Катынской и Касплинской волостей сходятся не к Смоленску, а к району Гнёздова и р. Ольшанки. При этом граница Касплинской волости образует выступ в юго-восточном направлении, захватывая в районе д. Шеломец верхнее течение впадающей в Днепр р. Ольшанки. Весьма вероятно, что такая конфигурация границ свидетельствует о функционировании некогда еще одного транспортного пути, шедшего вдоль р. Ольшанки и далее на северо-запад к Каспле, и подходящего вплотную к памятникам Гнёздовского комплекса. Не исключено, что этот путь и границы могут восходить к эпохе основного периода функционирования Гнёздовского поселения. Несомненно, волок представлял собой особую территориальную единицу со своей администрацией. Вряд ли это территориальное образование могло сосуществовать с волостью Катынь, первые документальные упоминания которой относятся к 80-м годам XV в. (РИБ, 1910. Стб. 324). Очевидно, волость возникла в более позднее время, включив в себя южную часть прежнего территориального округа Волок.

Еще одна категория топонимов, вероятно имеющих древнерусское происхождение и отражающих определенные социальные реалии, - названия наподобие Княжое, Княжное, Княгинино, Княжье Село. Заслуживает интереса расположение топонима Княжное в непосредственной близости от господарского двора Болваничи. К таким же названиям примыкает встреченное в привилее 1625 г. название починка Ярополков (РГАДА. Ф. 389. Оп. 1. Кн. 101. Л. 293 об. - 295). Название починка может быть связано с единственным смоленским князем, носившим такое имя, Ярополком Романовичем, правившим в Смоленске в 1172-1174 и 1175-1177 гг. Согласно документу, починок находился в бассейне р. Волость (Owość) в Иванковском стане Смоленского уезда. Таким образом, древнерусское поселение, давшее название позднейшему починку, с большой долей вероятности было исследовано работами В.В. Седова. На карте ХІХ в. из поселений данного владения сохранился топоним Губино на правом берегу верхней Волости (Исторический атлас... 2011. Л. 122). Юго-западнее, на противоположном берегу р. Волость, расположено обследованное В.В. Седовым Бородинское городище, трактуемое исследователем как феодальная усадьба; восточнее, в бассейне р. Мошны, - селище у д. Малое Княжье Село (на планах XVIII-XIX вв. - Княжое Село), северо-восточнее - Воротнинское городище, также интерпретируемое как феодальная усадьба (Седов, 1960. С. 42. Рис. 16. С. 151). В непосредственной близости от последнего на планах Генерального межевания обозначен погост Докукин. Собственно, на территорию дачи, в состав которой, по планам Генерального межевания, входило селение Губино (РГАДА. Ф. 1356. Оп. 1. Ед. хр. 5458. Л. 98 об. - 99), попадает лишь один археологический памятник, исследованный В.В. Седовым, - Галашинское селище, датированное автором XI-XV вв. и отнесенное к селениям, подвластным бородинскому феодалу (Седов, 1960. С. 39. Рис. 13. С. 149).

В.В. Седову принадлежит, пожалуй, наиболее весомый вклад в археологическое изучение древнерусских памятников Смоленской земли и их историческую интерпретацию. Им, в частности, были сплошь обследованы славяно-русские памятники значительного участка левобережья Днепра к востоку от Смоленска, идентифицирован археологически ряд центров податных округов Смоленского княжества, упомянутых в Уставной грамоте и других письменных источниках. Нужно отметить, что в некоторых случаях эти атрибуции представляются не вполне обоснованными. Так, в частности, В.В.Седов вслед за другими исследователями возводил топонимы Уставной грамоты Мирятичи и Воторовичи, имеющие ярко выраженный патронимический облик, к гидронимам Мерея и Вотря соответственно, с чем едва ли можно согласиться. Первое название, как представляется, скорее может быть образовано от имени Мирята, встреченного, в частности, в новгородской берестяной грамоте № 631, датируемой серединой 10-х - началом 40-х гг. XII в. (Зализняк, 1995. С. 286). Известны также топонимы Большое и Малое Мирятино в исторической Новгородской земле, в черте современного г. Кириши Ленинградской обл., а также Мирятино в Мышкинском р-не Ярославской обл. Второй топоним, прочтение которого в принципе достаточно спорно (существует вариант чтения Вотоловичи - Голубовский, 2011. С. 57-58), отождествлен В.В. Седовым с открытым городищем у д. Городна в бассейне р. Вотри (Седов, 1963. С. 326-327). Центр волости Мирятичи отождествлен автором с городищем у с. Ляды на р. Мерее в Дубровенском р-не Витебской обл. (Седов, 1963. С. 336-337). Ошибочным видится также заимствованное у П. В. Голубовского отождествление топонима (или термина) Уставной грамоты Лодейницы 
(очевидно, связанного со «служебниками»-изготовителями ладей) с современным топонимом Ладыжицы (в более ранних источниках - Лодыжичи), явно представляющим собой патроним, образованный от прозвища Лодыга, и соответственно, с городищем близ данной деревни (Седов, 1963. С. 333). При поиске древнего смоленского города Красн В.В. Седов сразу отверг поиски его в районе современного поселка (бывшего уездного города) Красный, расположенного в нехарактерном для древнерусского города низменном ландшафте, и отождествил его с крупным городищем у с. Зверовичи, близ которого протекает ручей Красный. При этом автор отмечает, что название Красный, связываемое с современным поселком, вновь возникает в источниках лишь в начале XVII в. (Седов, 1963. С. 334-335). Не ставя вопросы археологической идентификации древнерусского г. Красн, можно отметить, что первые упоминания в позднесредневековых источниках Красного (как господарского двора) относятся уже к концу XV в. (1499 г.) (АЗР, 2012. № 597. С. 399), а Зверович - к началу XVI в. (1511 г. как центр некой округи в Дубровенском пути, затем в качестве одной из смоленских волостей - в перемирной грамоте 1522 г.; СИРИО, 1885. Т. 35. № 93. С. 639), при этом облик названия может свидетельствовать о его более раннем происхождении.

Основой для датировки обследуемых памятников послужил керамический материал, типология и хронология которого была разработана А.А. Бобринским (Седов, 1960. С. 15). При этом нужно отметить, что дендрохронологическая шкала, давшая абсолютную хронологию культурного слоя Смоленска, на тот момент еще не была разработана, и полученные впоследствии представления о хронологии смоленской керамики, нашедшие отражение в работах Е.В. Каменецкой (1976; 1977) и Т. В. Сергиной (2004), во многом расходятся с датировками керамики, предложенными А.А. Бобринским. Поэтому хронологические атрибуции исследованных В.В. Седовым памятников нуждаются в существенном пересмотре.

Применительно к реконструкции заселения Смоленской земли по археологическим данным следует остановиться на том, что археологическая обследованность различных ее районов неравномерна, и отсутствие известных археологических памятников в ряде случаев может говорить скорее не о незаселенности, а о недостаточной исследованности того или иного района (рис. 3). Прослеживается также определенная корреляция местонахождения храмов в селах и погостах XVI-XIX вв. и, соответствен- но, центров административных образований эпохи позднего Средневековья с древнерусскими археологическими памятниками, в том числе городищами с древнерусским материалом: Каспля (АКР, 1997. С. 101), Зверовичи - древнерусский Красн по В.В. Седову, Вержавск (Седов, 1963. С. 324), Волково (АКР, 1997. С. 211), Городна-Воторовичи по В.В. Седову, Ельня, Понизовье (АКР, 1997. С. 238), Николо-Берновичи (АКР, 1997. С. 197), Ольшанское городище и др., либо крупными селищами (Белоручье). В то же время нельзя однозначно утверждать, во всех ли случаях прослеживается преемственность в размещении центра какой-либо округи, либо имеют место проявления традиции размещения церкви и кладбища на древнем городище.

Следует также отдельно остановиться на такой категории памятников, как довольно многочисленные на Смоленщине небольшие по площади городища со средневековым материалом, на которых часто находятся предметы вооружения, конского снаряжения, а также вещи, связанные с бытом представителей высших слоев общества. Традиционно такие памятники трактуются как феодальные усадьбы замкового типа. Ряд таких памятников на левобережье Днепра выше Смоленска был исследован В. В. Седовым. Из них наиболее изучены и опубликованы городища Воищина и Бородинское (Седов, 1960. С. 51-122). Подобного рода памятники рассмотрены также в небольшой статье П.Н. Третьякова, отметившего, что район, обследованный В.В. Седовым, в силу заболоченного характера местности представляет собой периферию их распространения. Основным же районом концентрации городищ-замчищ, по словам автора, оказываются юго-западные районы левобережья Днепра ниже Смоленска и верховьев Сожа. Ниже по Сожу, на верхней Десне и в бассейне Остра, на древних городищах, как правило, нет средневекового материала, а средневековые городища в этом районе имеют большие размеры и представляют собой остатки не феодальных усадеб, а древнерусских городов (Третьяков, 1962. С. 237-242). Закономерности, прослеженные П.Н. Третьяковым, в целом соответствуют отмеченному в тексте Уставной грамоты противопоставлению районов левобережья Днепра недалеко от города более отдаленным данническим «волостям», а также концентрации владений смоленских бояр XV - начала XVI в. в центральном Левобережье, включая бассейн верхнего Сожа. Однако в XV - начале XVI в. в западной части Левобережья, где, согласно П.Н. Третьякову, особенно концентрируются феодальные городища-замчища, преимущественно 
сосредоточены селения мелких военно-служилых землевладельцев - слуг Дубровенского пути (рис. 2). Возможно, подобные изменения связаны с кризисным состоянием, переживаемым Смоленской землей в XIII-XIV вв. Кроме того, похожие городища, трактуемые как феодальные усадьбы, присутствуют также в отдаленных районах Правобережья, в бассейне Западной Двины, где скорее можно предполагать проживание даннического населения (Понизовье, Николо-Берновичи - АКР, 1997. С. 238, 197). Вероятно, социально-историческая характеристика подобных городищ (боярские или княжеские усадьбы, военно-административные пункты - погосты раннего типа и др.), в том числе каждого конкретного памятника, требует более тщательного и осторожного изучения.

Таким образом, анализ данных источников о территориальных структурах центральной части Смоленской земли в XIV - начале XVI и XI-XIII вв. позволяет выделить некоторые общие особенности, прослеживающиеся на протяжении обоих периодов, а также по позднейшим письменным и картографическим источникам. Это определенное противопоставление ближней округи города (в первую очередь ее левобережной части), где были сосредоточены княжеские резиденции - дворы с принадлежащими к ним угодьями и обслуживающими их людьми, селения княжеских служебников, перемежающиеся с боярскими вотчинными селами и церковными землями, более отдаленным территориям, преимущественно населенным лично свободными общинниками, платящими в княжескую казну денежную дань и иные подати. Среди ближайших к городу районов последние охватывали западную часть правобережья, расположенную на древнем пути из варяг в греки (будущие Катынскую, Касплинскую, Порецкую, Щуцкую и Рудскую волости), где и в позднейший период преобладали дворцовые земли. Другая особенность-наличие сети небольших территориальных округов (погостов, волостей, приходов), более мелких, чем станы и волости «московского» времени с названиями часто патронимического характера, центры которых могут быть отмечены городищами с древнерусским слоем, а в период позднего Средневековья, как правило, имели храмы. В ряде случаев существование этих центров может быть прослежено документально с домонгольского времени. Вопрос о степени преемственности между подобными образованиями домонгольского и последующего времени вряд ли можно решить определенно без масштабных полевых исследований, однако предварительно могут быть высказаны определенные аргументы как за, так и против подобной преем- ственности. С одной стороны, совокупность данных письменных и археологических источников говорит в целом о более благоприятных условиях жизни населения Смоленской земли и ее общем высоком развитии в домонгольское время, что свидетельствует в пользу большего количества в домонгольский период таких округов и их центров, а сохранившиеся в позднейший период с большой вероятностью были основаны в домонгольское время. С другой стороны, период середины XIII - XIV в. отмечен совокупностью кризисных явлений, способствующих разрыву преемственности. Фиксируется определенный разрыв керамической традиции, вероятно, связанный со сменой населения. В частности, доминирующая форма керамики XIV-XVI вв., тип 5 по типологии Т.В. Сергиной, своим происхождением связана с южными областями Руси (Сергина, 2004. С. 23-24). Возможно, пришедшее новое население создало новые территориальные структуры, лишь частично повторяющие более ранние. При этом следует также отметить, что археологические исследования средневековых административных центров осложнены тем, что они весьма часто заняты действующими кладбищами. Кроме того, исследование вопросов преемственности (при том, что шансы столкнуться с надежно стратифицированным слоем на памятнике не столь велики) требует очень тщательной проработки хронологии археологического материала, прежде всего керамики, что на данном этапе развития наших представлений труднодостижимо. Так, исследование поселения Глушица 1, связываемого с господарским двором Глушица XV - начала XVI в., выявило наличие здесь археологического материала XII - начала XIII, XIII и XV вв. Выявление материала XIV в. в чистом виде, который мог бы непосредственно указать на преемственность в существовании поселения, остается проблематичным. На входящем в состав Гнёздовского археологического комплекса Ольшанском городище, где в начале XVII в. существовала церковь св. Николы Ольшинского, прослежен археологический материал X-XII и XV - начала XVII в., материал, уверенно датируемый XIII-XIV вв., не выявлен. Связано ли это с разрывом в существовании поселения или же материал данного периода, характеризуемого кризисными явлениями, на памятнике присутствует, но трудноуловим, утверждать на данный момент не представляется возможным. В то же время решение подобных задач видится в перспективе при дальнейшем проведении полевых работ, изучении существующих коллекций и новых памятников, привлечении естественнонаучных методов и методов комплексного источниковедения. 


\section{Литература и источники}

АЗР. Т. 1. СПб.: Тип. ІІ Отдел. собств. Е.И.В. канцелярии, $1846.419 \mathrm{c}$.

АЗР. Т. 1 (6). Сборник документов канцелярии великого князя литовского Александра Ягеллончика 1494-1506 гг. М. - СПб.: Нестор-История, 2012. $664 \mathrm{c}$.

АКР. Смоленская область. Т. 1. М.: ИА РАН, 1997. $304 \mathrm{c}$.

Алексеев Л. В., 1976. Домен Ростислава Смоленского // Средневековая Русь. М.: Наука. С. 53-59

Алексеев Л. В., 1980. Смоленская земля в IX-XIII вв. М.: Наука. 262 с.

Археалогія Беларусі. Энцыклапедыя. Т. 1. Мн.: Беларуская энцыклапедыя імя Петруся Броўкі, 2009. $496 \mathrm{c}$.

Бережкков Н.Г., 1946. Литовская Метрика как исторический источник. Ч. 1. О первоначальном составе книг Литовской Метрики по 1522 г. М.- Л.: AH CCCP. 180 c.

Веселовский С.Б., 1969. Исследования по истории класса служилых землевладельцев. М.: Наука. $584 \mathrm{C}$.

Вялікі гістарычны атлас Беларусі. Т. 1. Мн.: Белкартаграфія, 2009. 248 с.

Голубовский П. В., 2011. История Смоленской земли до начала XV столетия. М.: Кучково поле. $464 \mathrm{c}$.

ДДГ. Подг. Л.В. Черепнин. М-Л.: АН СССР, 1950. $594 \mathrm{c}$.

ДКУ. Подг. Я.Н. Щапов. М.: Наука, 1976. 240 с.

Зализняк А.А., 1995. Древненовгородский диалект. М.: Школа «ЯРК».720 c.

Исторический атлас Смоленской губернии. Репринтное издание военно-топографической карты 1863 г. СПб.: www.remaps.ru, 2011. 176 c.

Каменеикая Е.В., 1976. Керамика Смоленска XII-XIII вв.// Проблемы истории СССР. Вып. 5. М.: МГУ. С. 40-55.

Каменеикая E.В., 1977. Керамика IX-XIII вв. как источник по истории Смоленского Поднепровья. Дисс. ... канд. истор. наук. М. 140 с.

Кашпровский Е.И., 1899. Борьба Василия III Ивановича с Сигизмундом I Казимировичем из-за обладания Смоленском (1507-1522) // Сб. историко-филологического общества при институте князя Безбородко в Нежине. Т. 2. Нежин. C. $172-344$.

Красноперов И.М., 1894. Очерк промышленности и торговли Смоленского княжества с древнейших времен до XV в. // Историческое обозрение. Т. 7. СПб.: Тип. М.М. Стасюлевича. С. 64-111.
Красноперов И.М., 1903. Некоторые данные по географии Смоленского и Тверского края в XII в. // Сб. Тверского общества любителей истории, археологии и естествознания. Вып. 1. Тверь: Тип. губ. правления. С. 23-39.

Курмановский В. С., 2014. Керамика поселений Глушицкого комплекса (Смоленская область): проблемы хронологии и классификации // АП. Вып. 10. М.: ИА РАН. С. 405-418.

Любавский М. К., 1893. Областное деление и местное управление Литовско-Русского государства ко времени издания Первого Литовского Статута. М.: Унив. тип. 998 с.

Любавский М. К., 1915. Очерк истории ЛитовскоРусского государства до Люблинской унии включительно. М.: Московская художественная печатня. $414 \mathrm{c.}$

Лявданский А.Н., 2002. Материалы для археологической карты Смоленской губернии // Смоленские древности. Вып. 2. Смоленск: Центр по охране и использованию памятников истории и культуры. С. 185-256.

Мальиев В.П., 1940. Борьба за Смоленск (XVIXVII вв.). Смоленск: Смолгиз. 346 с.

Нефёдов В.С., 2012. Ранние этапы политогенеза на территории Смоленской земли (конец IX - первая половина XIв.) // Северная Русь и проблемы формирования Древнерусского государства. Сб. матер. междун. науч. конф. Вологда: Древности Севера. С. 89-113.

Полехов С. В., 2014. Смоленское восстание 1440 г. // Исторический вестник. М.: Руниверс. Т. 7 [154]. C. $166-167$.

Прохоров В.А., 2017. Заметки о топографии Смоленска (1-я половина XVII века): Русские храмы и монастыри до осады 1609-1611 гг. Конфессии, ордена, монастыри и приходы в польский период // Край Смоленский. Смоленск. № 6. С. 3-17.

РГАДА. Ф. 389. Литовская Метрика. Оп. 1. Кн. 101. 370 Л.

РГАДА. Ф. 1209. Оп. 1. Ед. хр. 15152. 1665г. Переписная книга дворцовых земель Смоленского у. переписи Кирилла Яковлева. 235 л.

РГАДА. Ф. 1209. Оп. 1. Ед. хр. 15154. 1668 г. Переписная книга дворцовых, монастырских и архиерейских земель Смоленского у. переписи Данила Чернцова. 951 л.

РГАДА. Ф. 1209. Оп. 1 Ед. хр. 15167а. 1677/1678 г. Переписная книга Смоленского у. 748 л.

РГАДА. Ф. 1355. Оп. 1. Ед. хр. 1487. Смоленская губерния. Духовщинский уезд. Экономические 
примечания на 626 дач и алфавиты дач и владельцев. 50 л.

РГАДА. Ф. 1355. ОП. 1. Ед. хр. 1508. Смоленская губерния. Экономические примечания на 348 дач Поречского у. и на 657 дач Смоленского у. и алфавиты дач и владельцев. 90 л.

РГАДА. Ф. 1356. Оп. 1. Ед. хр. 5458. Атласы Смоленской губернии, содержащие в себе уездные карты (масштаб 5 верст в 1 дюйме). Ч. 1. 101 л.

РИБ. Т. 27. СПб.: Сенат. тип., 1910. 660 с.

СИРИО. Т. 35. СПб.: Тип.Ф. Елеонского, 1885. $952 \mathrm{c}$.

Седов В. В., 1961. К исторической географии Смоленской земли // МИСО. Вып. IV. Смоленск: Смолгиз. С. 318-323.

Седов В.В., 1960. Сельские поселения центральных районов Смоленской земли (VIII-XV вв.). М.: АН СССР. 160 с. (МИА № 92).

Сергина T.B., 2004. Керамика Смоленска середины XIII-XVII вв.// Смоленские древности. Вып. 3. Смоленск. С. 5-194.

Смоленские грамоты XIII-XIV вв./Подг. Т. А. Сумникова и В. В. Лопатин. М.: АН СССР, 1963. $140 \mathrm{c}$.

Смоленщина в документах Литовской Метрики первой половины XVII в. Владельцы и их маетности / Подг. В.А. Прохоров. Смоленск: Край Смоленский, 2017. 544 с.

Третьяков П.Н., 1962. Средневековые замчища Смоленщины // Историко-археологический сборник. М.: МГУ. С. 237-242.
Фетищчев С. А., 2012. «Дань великая тяжкая...»// Русское средневековье. Сб. ст. в честь проф. Юрия Георгиевича Алексеева. М.: Древлехранилище. С. 270-279.

Флоря Б.Н., 1992. «Служебная организация» и ее роль в развитии феодального общества у восточных и западных славян // ОИ. № 2. С. 56-74.

Французова Е.Б., 1980. Из истории русско-польских отношений в последней трети XVII в. (по материалам межевых комиссий) // ИЗ. № 105. С. 280-293.

Французова Е.Б., 1980. Переписные книги Смоленской земли второй половины XVII - начала XVIII вв. как источник по истории народонаселения // Проблемы исторической демографии СССР. Томск: Изд. ТГУ. С. 251-258.

Чернов С. 3., 2005. Культура средневековой Москвы: исторические ландшафты. Т. 2. Домен московских князей в городских станах 1271-1505 гг. М.: Наука. 651 с.

Шеламанова Н.Б., 1970. Образование западной части территории России в XVI в. в связи с ее отношениями с Великим княжеством Литовским и Речью Посполитой. Дисс. ... канд. истор. наук. М. 699 с.

Янин В.Л., 1985. Русские денежные системы IXXV вв. // Древняя Русь. Город. Замок. Село. М.: Наука. С. 364-375. (Археология СССР).

Янин В.Л., 1998. Новгород и Литва: пограничные ситуации XIII-XV вв. М.: МГУ. 216 с.

Lietuvos Metrika (1499-1514). Knyga Nr. 8. Vilnius: Lietuvos istorijos institutas, 1995. $708 \mathrm{~s}$. 


\section{Н. В. Ениосова", Т.А. Пушкина", Е. К. Столярова **}

"Московский государственный университет им. М. В. Ломоносова, г. Москва;

** Институт археологии РАН, г. Москва

\section{Стеклянные игральные фишки из раскопок в Гнёздове}

Среди археологических находок, характеризующих культуру эпохи образования Древнерусского государства, есть группа предметов, относящихся к настольным играм: это фишки из органических и неорганических материалов; доски, расчерченные на квадраты, а также игральные кости. Они происходят из памятников Верхнего и Среднего Поднепровья, Ярославского Поволжья и Северо-Запада Руси.

В эпоху Средневековья настольные игры были широко распространены в Византии, Западной Европе и на исламском Востоке (Eales, 2007. Р. 162168; Riddler, 2007. P. 256-263; Semenov, 2007. P. 169-177; Witte, 2010. S. 387-394). Однако наиболее близкие параллели древнерусским находкам обнаруживаются в материалах Скандинавии.

Игральные принадлежности из стекла, янтаря и слоновой кости известны в Северной Европе с позднеримской эпохи. Так, на территории Дании в 23 богатых погребальных комплексах обнаружено более 450 стеклянных фишек. Как полагают, их производили в европейских провинциальноримских мастерских (Fonnesbech-Sandberg, 2002. S. 211-215). В культурном слое поселений находки этой категории встречаются исключительно редко. Например, из комплекса первых веков нашей эры в Сурте Мульд на о. Борнхольм происходит невысокая выпуклая фишка, выполненная в технике миллифиори, отличающаяся от стандартных монохромных изделий этой эпохи (Lund Hansen, 2009. P. 91). Единичные экземпляры стеклянных фишек римского времени встречены также в комплексах построек и мастерских эпохи викингов на поселениях в Швеции (Бирка, Хельго), Норвегии (Каупанг) и Северной Германии (Хедебю). Вероятно, их использовали в качестве сырья для производства бус (Gaut, 2011. Р. 229).
В эпоху Великого переселения народов, вендельский период и эпоху викингов число погребений с фишками резко возрастает: принадлежности для игры из кости и рога встречаются в курганах не самого высокого статуса, атрибутами элитарных погребений являются стеклянные и янтарные экземпляры, а также изделия из китовой кости, моржового клыка или лошадиного зуба - на фишках из органических материалов иногда сохраняются следы красочной росписи. До VI в. доминируют низкие, слегка выпуклые экземпляры. В эпоху Венделя появляются сферические фишки с плоским основанием, их форма и размеры во многом зависели от материала изготовления (Gustavsson et al., 2015. P. 51-54; Rundkvist, Williams, 2008. P. 85, 93).

Считается, что кости, доски и фишки предназначались для игры под названием Hnefatafl («Королевская доска»): одна из играющих сторон передвигала фигурку короля от центра доски к краю, а фишки разных цветов помогали или мешали его перемещению в соответствии с выпавшими случайно глазками игральной кости. Сохранившиеся полностью наборы для игры известны исключительно из богатых погребений Скандинавии, Древней Руси, Прибалтики, Северной Германии, Британских островов и Франции. Они состоят из расчерченных на квадраты досок, сделанных из китовой кости, камня (сланец) или дерева, окантованного металлическими или роговыми полосками с помощью заклепок. Второй обязательный элемент игры - кубики или прямоугольники с глазками из рога, кости или янтаря. Наибольшим разнообразием материалов для изготовления отличаются фишки. Они выполнены из стекла, янтаря, мела, известняка, гематита, глины или выточены на токарном станке из различных видов костной ткани или дерева. В некоторых наборах 
обнаружены «короли»- условные и антропоморфные. К первым относятся фишки, отличающиеся от остальных по цвету и форме, а также плоские камешки. Ко вторым принадлежат антропоморфные фигурки из стекла, камня, кости, моржового клыка, янтаря и металла (Хамайко, 2012. С. 284-288).

Изображения людей, играющих в настольные игры, встречены на золотом роге V в. из Галлехуса (Южная Ютландия), руническом камне рубежа Х-ХІ вв. из Уклебу (Гестрикланд, Швеция). Резные головы двух игроков помещены на противоположных сторонах целиком сохранившейся знаменитой деревянной доски конца IX в. из Балиндерри (Ирландия) (Murray, 1978. Р. 59). Сведения об игре Hnefatafl упоминаются 31 раз в 28 древнеисландских источниках, включая песни «Эдды», саги и судебники (Gogosz, 2016. Р. 181).

Учитывая письменные, изобразительные и археологические свидетельства длительной непрерывной истории развития игры в Северной Европе на протяжении почти тысячи лет, следует признать, что до сих пор остаются актуальными выводы, сделанные Г.Ф. Корзухиной более 50 лет назад: «Игра в шашки была занесена к нам с севера», а находки как дорогих стеклянных, так и простых, выточенных из рога или кости, экземпляров связаны с пунктами сосредоточения «русских и наемных княжеских дружин» (Корзухина, 1963. С. 190).

Список и география находок за время, прошедшее со дня публикации работы Г.Ф. Корзухиной, немного изменились. Наиболее полные обзоры по этой теме, включающие новые материалы с территории Древней Руси и Скандинавии, содержатся в статьях украинских коллег (Сагайдак, Хамайко, Вергун, 2008. С. 284-288; Хамайко, 2016. С. 69-78). Однако многие находки до сих пор не введены в научный оборот. К настоящему времени нам удалось собрать сведения о костяных, роговых, каменных, янтарных и стеклянных фишках из коллекций 11 памятников, расширив список Г.Ф. Корзухиной на четыре пункта. Подавляющее число находок происходит из погребений и поселений, расположенных на Пути из варяг в греки: это Старая Ладога, Рюриково Городище, Новгород, Городок на Ловати, Гнёздово, Седнев, Шестовица, Чернигов и Киев. С Волжским путем связаны находки из двух пунктов - Тимерёва и Ростова Великого.

Стеклянные фишки найдены в трупосожжении второй половины Х в. (курган 277), а также в богатом парном камерном погребении (курган 100) последней четверти Х в. Тимерёвского могильника в Верхнем Поволжье. В первом случае две фишки зеленого и темно-вишневого прозрачного стекла находились вместе с железной оковкой от игральной доски. Во втором случае фишка из голубоватозеленого прозрачного стекла оказалась единственной находкой, связанной с игрой (Фехнер, Недошивина, 1987. С. 85). Из раскопок городского слоя Ростова Великого происходит фишка темно-вишневого полупрозрачного стекла, обнаруженная в развале постройки 60-х годов XI в. Она имеет форму перевернутого усеченного конуса с полусферическим верхом (Леонтьев, 1989. С. 42)1․

Северная часть Пути из варяг в греки или его волховско-ловатский отрезок представлен немногочисленными находками, происходящими только с территории поселений.

В Старой Ладоге на Земляном городище в слоях IX-X вв. обнаружены янтарные фишка и игральная кость, а также приблизительно 10 роговых или костяных полусферических фишек и один конусовидный экземпляр с округлой головкой (Davidan, 1992. № 146-148, 151-154; 1984. С. 122-123. Рис. 2, $22,23)$. Наиболее экзотической находкой является окаменелый морской еж, использовавшийся в качестве шашки (Старая Ладога, 2003. С. 99. № 275).

Глиняная, стеклянная и каменная фишки, а также деревянная доска ${ }^{2}$ найдены в слоях X в. на Рюриковом Городище близ Новгорода (Носов, 1990. С. 80,95 . Рис. 33,$1 ; 37,15)$. Игральные фишки Х в. известны и в Новгороде: роговой экземпляр встречен в ярусе 27 (70-80 гг. Х в.) Неревского раскопа ${ }^{3}$; на усадьбе Ж Троицкого раскопа обнаружено две фишки - конусовидная из моржового клыка в слое середины X в. и полусферическая известняковая в слое начала XI в. ${ }^{4}$ Из Городка на Ловати происходят конусовидная и полусферическая роговые фишки, обнаруженные в постройках, датированных второй - третьей четвертью X в. (Горюнова, 2016. С. 65. Рис. 56, 1; 60, 2).

\footnotetext{
1 Фишка не опубликована, она выставлена в археологической экспозиции Государственного музея-заповедника «Ростовский кремль», зал 3. Выражаем искреннюю благодарность Н.Г. Самойлович и А.Е. Леонтьеву за предоставленную информацию.

2 Фишка темного стекла и фрагмент деревянной игральной доски из раскопок Рюрикова Городища выставлены в археологической экспозиции НГМЗ.

${ }^{3}$ Благодарим А.М. Гринева за информацию об этой находке.

4 Благодарим В.К. Сингха за предоставленные сведения.
} 
Южный отрезок Пути из варяг в греки, то есть его днепровская часть, представлен как отдельными находками, так и практически полными игральными наборами, происходящими из поселений, погребений и кладов.

В Среднем Поднепровье и Днепро-Деснинском междуречье зафиксирована самая высокая концентрация стеклянных игральных принадлежностей. Шесть фишек из стекла обнаружены в черниговском кургане Черная Могила вместе с десятью костяными экземплярами и двумя игральными костями ${ }^{5}$. В курганах Шестовицкого могильника 11 стеклянных фишек найдено в богатой кремации XIX (24); игральная кость, 10 фишек и две фигурки королей происходят из кургана XXI (33); еще 24 (26) шашек и два короля - из комплекса VI (98) (Бліфельд, 1977. С. 123-124, 127, 170; Станкевич, 1962. С. 23-27). Среди шестовицких находок преобладают изделия из голубого и коричневого стекла, голубовато-зеленый цвет встречается реже (Хамайко, 2016. С. 69-74). Единственная крупная глиняная фишка почти цилиндрической формы происходит с территории Шестовицкого поселения (Корзухина, 1963. С. 89. Рис. 1, 11).

Находки из Седневских курганов обнаружены в погребениях по обряду сожжения: в двух курганах, раскопанных в конце XIX в., найдены слитки стекла, которые по цвету и массивности Г. Ф. Корзухина предположительно определила как шашки (Корзухина, 1963. С. 86-87). Достоверная находка четырех стеклянных шашек из голубого и коричневого стекла в седневском кургане № 2 второй половины $\mathrm{X}$ в., раскопанном С.С. Ширинским в 1967 г., подтверждает гипотезу исследовательницы (Ширинский, 1968. С. 240).

Из Киевского некрополя происходит набор шашек (более 10 штук), обнаруженный в 1900 г. в разрушенном погребении недалеко от Золотых ворот; из них сохранилось четыре экземпляра черного (темного?) и голубовато-зеленого цвета. По мнению М. К. Каргера, из этого же погребения происходили шесть дирхамов, четыре из которых выпущены во времена Насра бен Ахмада, правившего с 914 по 943 г. (Корзухина, 1963. С. 85).
Отдельные стеклянные фишки обнаружены во время раскопок в Киеве в 70-90-е годы прошлого столетия: зеленая происходит из сруба первой половины $\mathrm{X}$ в., исследованного на Контрактовой площади Подола; фиолетовая - в Верхнем городе в переотложенном слое разрушенного могильника Х в. (Хамайко, 2016. С. 74).

На верхнеднепровском участке Пути из варяг в греки все находки игральных принадлежностей происходят из Гнёздова: они обнаружены в 11 погребальных комплексах; 12 экземпляров найдены на различных участках поселения в культурном слое; одна фишка зафиксирована в составе клада.

Несколько фишек из плотного рога, костей крупного рогатого скота и трубчатой кости крупного копытного животного ${ }^{6}$ найдены в культурном слое Центрального городища, содержавшего преимущественно раннекруговую керамику и половинку саманидского дирхама, выпущенного не ранее первой четверти X в. В этом же слое обнаружены крупные сферические фишки из известняка и гематита, обломок янтарной шашки, украшенной концентрическими резными поясками, а также экземпляр в форме шарового сегмента, вырезанный из эпифиза кости животного. Из перемешанного слоя площадки городища происходит практически целая фишка из темно-зеленого стекла (Авдусин, Пушикина, 1988. С. 23, 35, 43). Еще две стеклянные фишки темного и бирюзового цвета найдены на склоне городища и в восточной части площадки. Первая происходит из прослойки, насыщенной лепной керамикой, которая, видимо, связана с остатками каких-то деревянных конструкций, укреплявших склон (Авдусин, 1972. С. 134). Сильно оббитый фрагмент стеклянной фишки бирюзового цвета найден в слое, содержавшем примерно равное количество лепной и круговой керамики и несколько обломков аббасидских дирхамов VIII-IX вв. ${ }^{7}$, то есть может быть датирован временем не ранее середины Х в. (Авдусин, Пуикина, 1987. С. 158). С территории пойменной части селища из слоя второй половины X - начала XI в. происходит фишка из стекла темного, почти черного цвета (Мурашева и др., 2010. С. 525. Рис. 1, 5).

\footnotetext{
${ }^{5}$ Г.Ф. Корзухина очень осторожно предположила наличие в этом кургане стеклянных шашек, ссылаясь на упоминание «округлых стеклянных слитков» в публикации Д. Я. Самоквасова (Корзухина, 1963. С. 87). Оказалось, что это оплавленные шашки из темного стекла (ГИМ. Инв. 76990. Оп. 1539/57-61). Благодарим В.В. Мурашеву за предоставленную информацию.

${ }^{6}$ Определение костной ткани проведено О.С. Лебедевой и Л.В. Яворской, которым мы выражаем глубокую признательность.

7 Монеты были определены в 1986-1987 гг. кандидатом исторических наук А.В. Фоминым, научным сотрудником отдела нумизматики ГИМ.
} 
Среди материалов террасной части селища находок шашек не зафиксировано, но с западной окраиной связан один из наиболее крупных гнёздовских кладов, найденный в 1909 г. В его составе оказалась оббитая фишка зеленоватого стекла. Самая младшая монета клада среди 781, образующих его основную часть дирхамов, относится к 953-954 гг.н.э. Формальной дате сокрытия клада, определяемой этой монетой, не противоречит дата бытования круглых скандинавских фибул типа 117 ЯП, одна из которых также входила в состав сокровища (Корзухина, 1954. С. 89. № 26). Клад, к сожалению, утрачен, но, судя по фотографии из архива Археологической комиссии, форма и размер шашки совпадают с характеристиками экземпляра темно-зеленого стекла, найденного на городище.

Рассматривая курганные находки Гнёздовского могильника, Г.Ф. Корзухина уверенно говорила о стеклянных фишках из кургана 23, раскопанного И.С. Абрамовым в Ольшанской группе, и предполагала наличие игральных принадлежностей еще в трех насыпях, исследованных С.И. Сергеевым в Днепровской и Центральной группах. Это курганы 65, 74, и 12 (Корзухина, 1963. С. 87-88) ${ }^{8}$. Особенно сильно пострадали стеклянные изделия из курганов, раскопанных Сергеевым: в фондах археологического отдела ГИМ хранится около 20 слитков разного цвета, среди которых можно различить два-три комка сплавленных бус бесцветного или темно-синего стекла 9 . Не исключено, что оплавленные слитки черного, синего, бирюзового, вишневого и зеленого цвета из больших курганов высшего слоя гнёздовской элиты до воздействия высокой температуры погребального костра были фишками. Однако восстановить первоначальную форму этих предметов невозможно, и принадлежность их к интересующей нас категории является спорной. В кургане 12 присутствие в погребении фрагментов игральной доски дает дополнительный аргумент в пользу атрибуции Г.Ф. Корзухиной. 25 слитков бирюзового цвета из кургана 23 (раскопки И.С. Абрамова) более плотные и массивные. По цвету они совпадают с находками фишек (17 экз.) из камерного погребения 750 в Бирке (Arbman, 1943. S. 271. Abb. 218, 48).

Каменные фишки в курганах Гнёздова не обнаружены ${ }^{10}$. Выточенные из рога (или кости) игральные фишки происходят из пяти курганов Лесной, Центральной и Ольшанской групп: они найдены в трех богатых трупосожжениях (учтены Г. Ф. Корзухиной) и двух трупоположениях (Ц-160 и Л-205), раскопанных Смоленской экспедицией МГУ в 1990 и 2005 гг.

Единственный на сегодняшний день достоверный набор стеклянных фишек входил в состав инвентаря самой большой камеры Гнёздова (Оль-30), раскопанной в 1988 г. в Ольшанской группе (размер камеры столбовой конструкции - $670 \times 480$ см, высота деревянной конструкции - до 200 см). Камера содержала погребение четырех человек и двух лошадей, расположенных в ногах у людей. В состав погребального инвентаря входили перстнеобразные височные кольца, перстень, серебростеклянные пронизки и янтарная бусина, железная подковообразная фибула, конская уздечка венгерского происхождения, ледоходные шипы, прикамское кресало и другие предметы (Жарнов, 1992. С. 107-108). На полу камеры кургана Оль-30 расчищены 13 стеклянных фишек, различающихся по цвету, размерам, декору и технологическим признакам (рис. 1). Рядом с ними лежали две довольно крупные цветные гальки - овальная желтая (кремневая порода) без следов обработки и халцедоновая пурпурная круглая со следами шлифовки ${ }^{11}$, видимо, дополняющие набор фигурок ${ }^{12}$.

8 В статье Мурашевой В.В., Довгалюк Н.П. и Фетисова А.А. допущена досадная неточность или опечатка. Раскопанные С.И. Сергеевым курганы обозначены буквой Л, то есть отнесены к Лесной группе, что не соответствует действительности (Мурашева и др., 2010. С. 523).

9 ГИМ, отдел археологических памятников. Оп. 1537, № 150, 162-164, 1397-1406, 512. Все осмотренные нами слитки имеют аморфную форму, они легкие и относительно тонкие, некоторые из них состоят из светлого зеленовато-голубого стекла, в котором различаются неровные полоски-нити красновато-фиолетового цвета.

10 Фишки из раскопанных В. И. Сизовым и И.С. Абрамовым курганов с трупосожжениями, которые Г. Ф. Корзухина посчитала каменными, на самом деле вырезаны из рога. Кроме того, курганы Ольшанской группы № 24 (раскопки И.С. Абрамова, 1905) и № 1 (раскопки Д.А. Авдусина, 1950) - это один и тот же комплекс (Корзухина, 1963. С. 88). В 2018 году не менее 10 вырезанных из рога шашек были найдены в кургане Л-210 (богатое трупосожжение). Благодарим С. Ю. Каинова за предоставленную информацию.

11 Авторы признательны кандидату геолого-минералогических наук А. В. Окулову за определение пород камня и следов их обработки.

12 Четыре кварцевые гальки вместе с 12 фишками из моржового клыка входили в набор, обнаруженный вместе со сланцевой игральной доской на поселении Ярлсхоф (Шетландские о-ва). Они выставлены в экспозиции Национального музея Шотландии в Эдинбурге. 


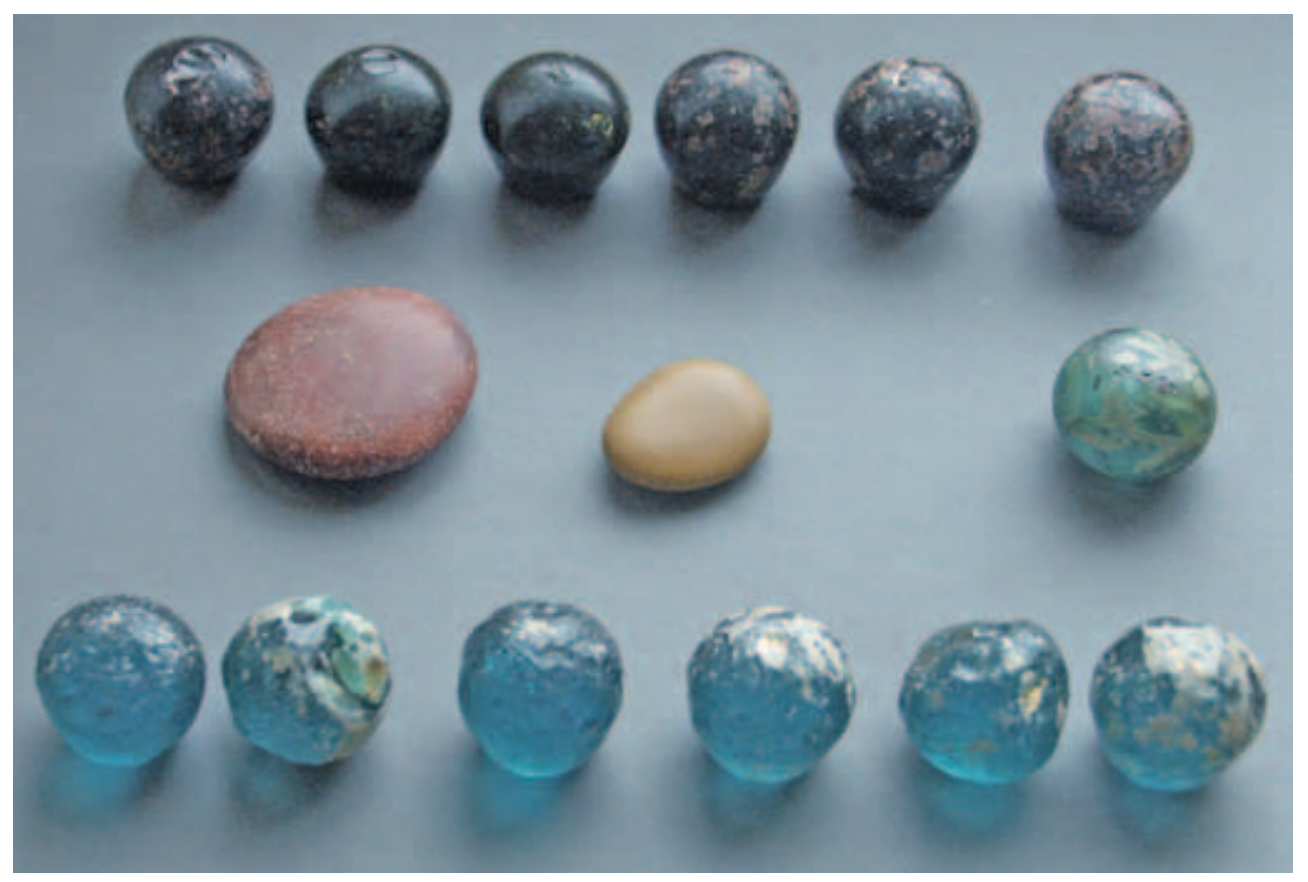

Рис. 1. Набор игральных фишек из кургана 30 Ольшанской курганной группы в Гнёздове (Гн-88, Оль-30, № п/о 354-366) ${ }^{13}$

К набору для игры относятся также обломки деревянной доски с оковками из тонких железных пластин. В камере сохранились ручки двух сундучков, фрагменты застежки и ключей. Не исключено, что игральные принадлежности были помещены в погребение в сундучке.

Особенность этого кургана-ощутимая концентрация предметов роскоши. Помимо набора стеклянных фишек к ним относятся фрагменты пряденых золотных нитей, украшавших шелковую тесьму, обломки белоглиняной византийской полихромной кружки и миниатюрные разноцветные стеклянные пластины (около 100 экземпляров) квадратной, прямоугольной и листовидной формы, вырезанные из обломков сосудов и оконного стекла. Судя по компактному расположению пластин в погребальной камере, они украшали несохранившиеся изделие из органики, сложенное в несколько слоев: парадное облачение, изготовленное, вероятно, в императорских мастерских Константинополя (Ениосова, Пушкина, 2012. С. 55, 58-61).

В погребении Оль-30 обнаружены обломки трех саманидских дирхамов (1/2 монеты, выпущенной
Исмаилом бен Ахмадом в Шаше в 906 г.; 1/4 монеты, выпущенной Насром бен Ахмадом в Нисабуре в 935 г., и 1/4 монеты, вышедшей с монетного двора в Шаше в первой половине X в.). С ними вместе найдена целая монета - подражание саманидскому чекану двора аш-Шаша (895 г.). На основании монетных находок и инвентаря комплекс отнесен ко второй половине Х в. (Авдусин, Пушкина, 1989. C. 3). Эту датировку подтверждают три радиоуглеродные даты, полученные для органических образцов из погребения ${ }^{14}$.

Фишки из кургана Оль-30 (№ п/о 354-366) вместе с тремя образцами из раскопок городища (№ п/о 4, 12, 281) подверглись подробному изучению. Разбитая городищенская фишка из прозрачного бирюзового стекла (№ п/о 281 - рис. 2) не позволяет точно восстановить ее форму. Остальные сохранились практически полностью. Четырнадцать ${ }^{15}$ из них можно разделить на две неравные группы. В первую вошли 13 фишек, имеющих форму расходящегося или перевернутого конуса, усеченного снизу и завершающегося сверху полусферой. В большинстве случаев основания у этих

${ }_{13}$ Все фотографии для статьи выполнены Н. В. Ениосовой.

14 Радиоуглеродные даты получены для образцов дерева (AD 924-946; AD 921-951), шерсти или волос (AD 887-989). Анализ выполнен А. Черкинским в Центре прикладных изотопных исследований Университета штата Джорджия, CША (UGAMS 30174-30176) методом ускорительной масс-спектрометрии.

15 Морфо-технологическое изучение для фишки № 4 не проводилось. 


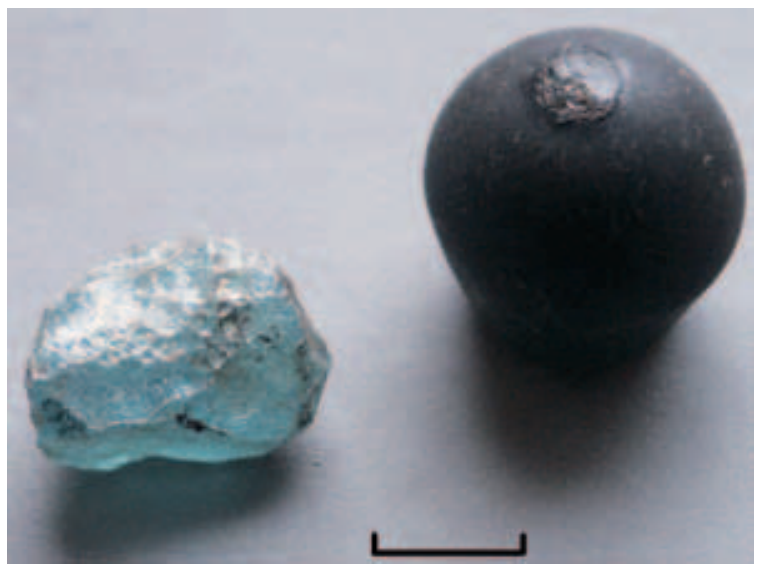

Рис. 2. Стеклянные фишки из раскопок гнёздовского городища из бирюзового (Гн-86, ЦГ-ХІХ, № п/о 281)

и зеленого стекла (Гн-87, ЦГ-ХХ, № п/о 12)

фишек вогнутые или плоские с углублением (10 экз.: № п/о 355, 357-360, 362-366), в остальных случаях - плоские (3 экз.: № п/о 12, 356, 361).

Все находки этой группы одноцветные. Они выполнены из стекла четырех цветов: бирюзового (7 экз.: № п/о 281, 355, 357, 360, 363, 364, 366), фиолетового (4 экз.: № п/о 358, 359, 362, 365 - рис. 3 ), оливкового (2 экз.: № п/о 356, 361), зеленого (№ п/о 12 - рис. 2). Заметим, что только у фиолетовых и бирюзовых фишек отмечены вогнутые или

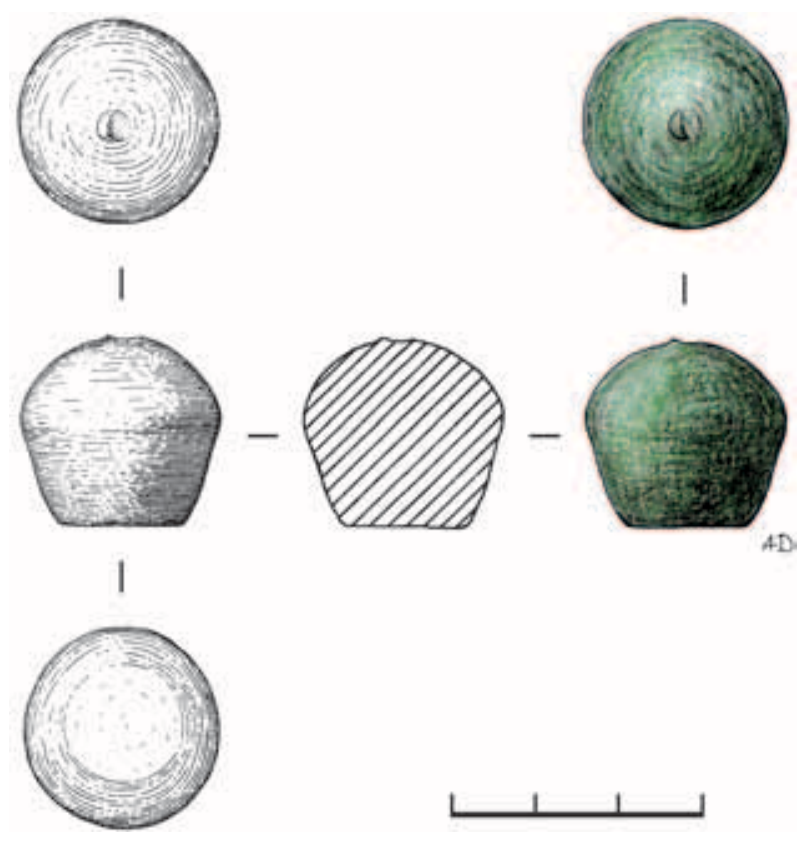

Рис. 4. Стеклянная фишка из оливкового стекла (Гн-88, Оль-30, № п/о 361) ${ }^{16}$

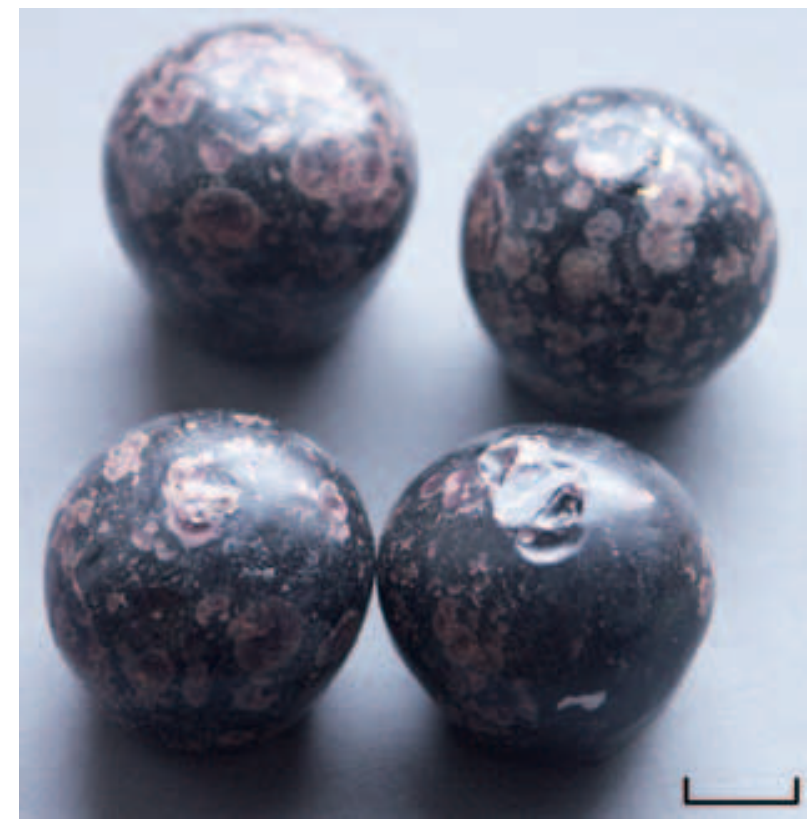

Рис. 3. Стеклянные фишки из фиолетового стекла (Гн-88, Оль-30, № п/о 358, 359, 362, 365)

плоские с углублением основания, а у оливковых и зеленой они всегда плоские (рис. 4; 5).

Размеры фишек этой группы довольно стандартны. Высота - от 2,2 до 2,4 см, максимальный диаметр-от 2,25 до 2,45 см, диаметр основа-
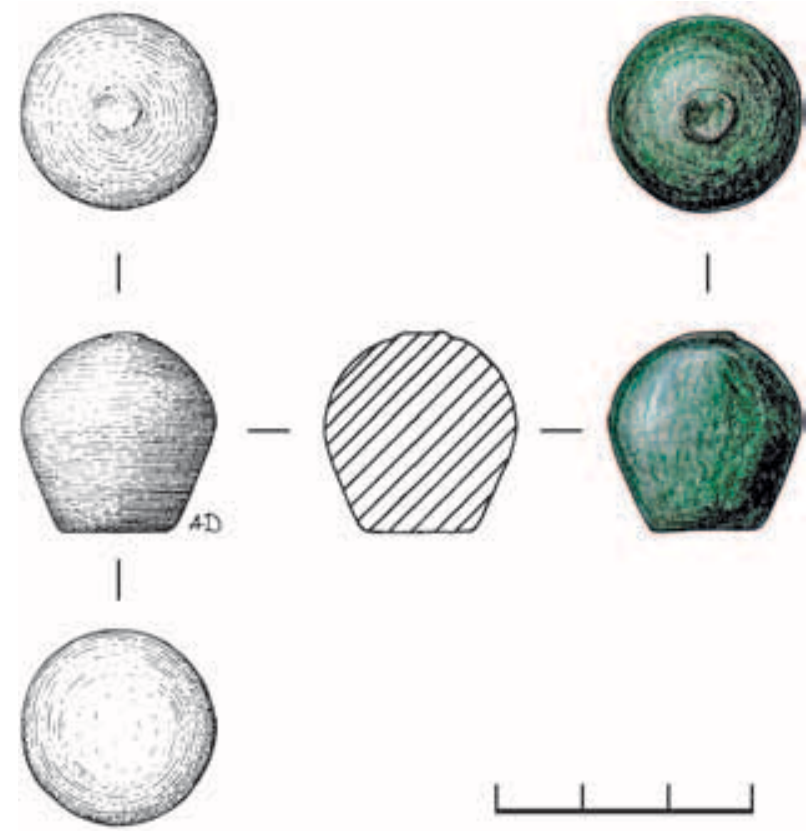

Рис. 5. Стеклянная фишка из зеленого стекла (Гн-87, ЦГ-ХХ, п/о № 12)

$\overline{16}$ Все рисунки выполнены А. С. Дементьевой. 
ния - от 1,4 до 1,6 см, высота конической части фишек - от 1,25 до 1,60 см. Интересно, что самая маленькая фишка - из зеленого стекла с городища (№ п/о 12). У нее зафиксированы самый маленький максимальный диаметр (2,25 мм) и самая маленькая высота конической части (1,25 см) (рис. 4).

Бирюзовые и фиолетовые фишки имеют следы золотого декора (рис. 6). По-видимому, он имел вид пятиконечной звезды, лучи которой расходились из центра полусферы вниз до места перехода полусферы в конус, где их объединяет горизонтальная лента, идущая вдоль всего периметра фишки (рис. 7). Заметим, что несколько шашек из кости, обнаруженных в погребении по обряду кремации № 917 в Бирке, имеют схожий декор, нанесенный резьбой (Arbman, 1943. S. 357-358, 1940. Taf. 150: 2). Аналогичный мотив пятилучевой звезды имеют некоторые стеклянные предметы, например, пуговицы, обнаруженные на Белоозере и на поселении XII-XV вв. Мякинино 1 в Подмосковье (Захаров, 2004. С. 156. Рис. 331, 38, 39; Столярова, 2006. Л. 341).

Фишки в виде расходящегося конуса изготовлены при помощи литья в открытую коническую форму (рис. 8,1 ). На этот способ указывают сферические беспорядочные пузыри внутри стекла и такие же каверны на его поверхности (рис. 9). Возможно, была использована неразогретая каменная форма, о чем говорит матовый и неровный характер поверхности оснований и нижних, конических частей фишек (рис. 10). Постоянство высоты фишек (2,2-2,4 см) указывает на тщательное отмеривание объема порции стекла, помещаемой в форму. Под действием сил поверхностного
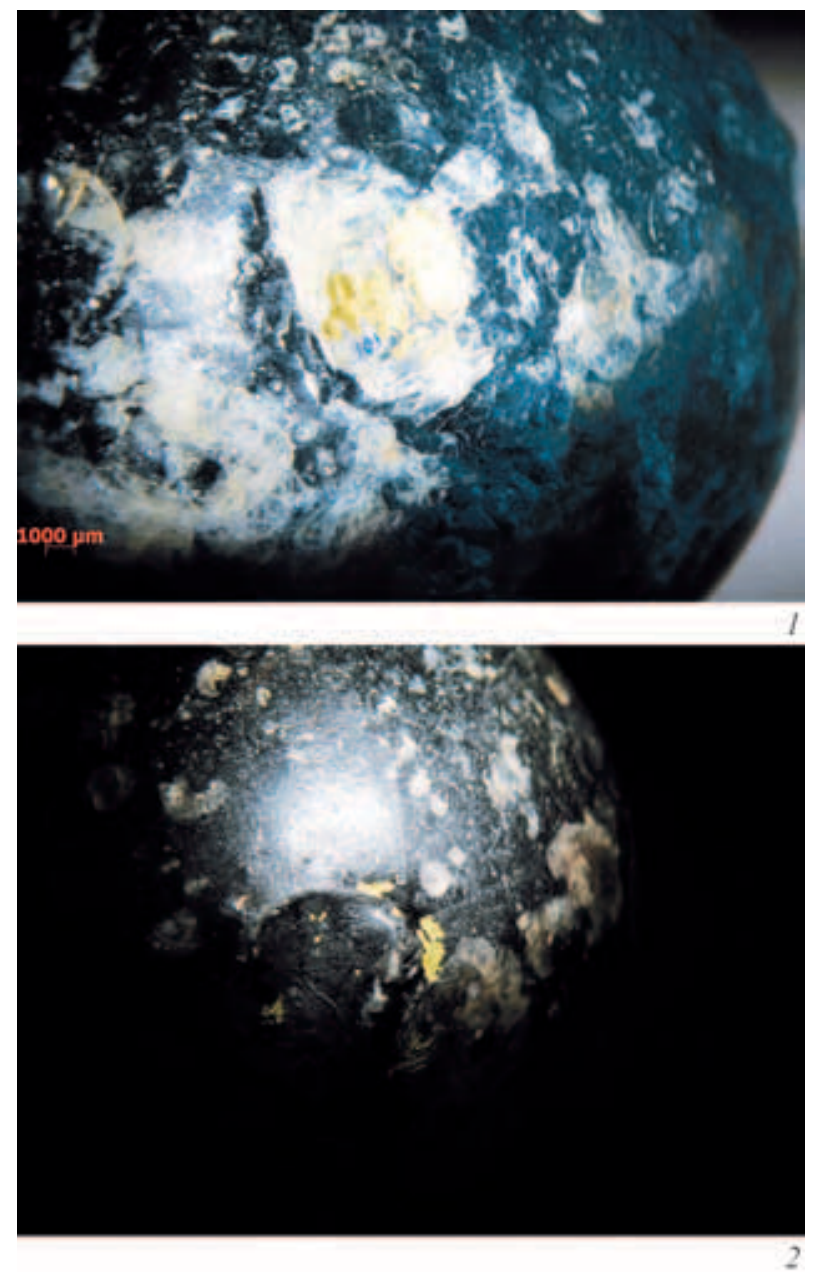

Рис. 6. Остатки золотого декора на бирюзовой (1) и фиолетовой (2) фишках из кургана Оль-30. Увеличение $\times 20$

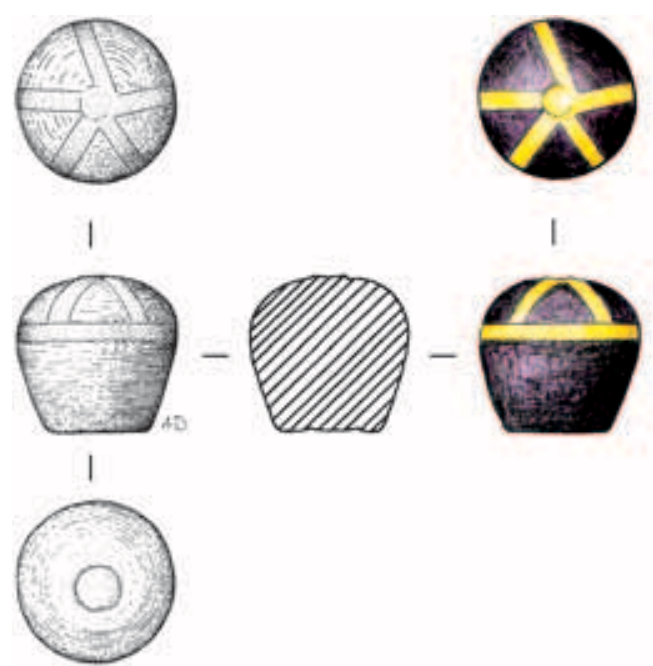

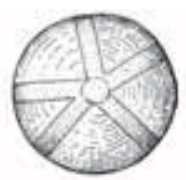

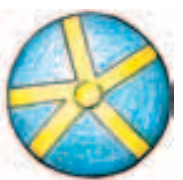

।

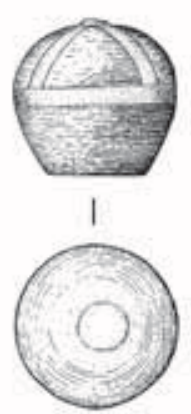

Рис. 7. Фишки из бирюзового и фиолетового стекла с золотым декором (реконструкция Е.К. Столяровой) 


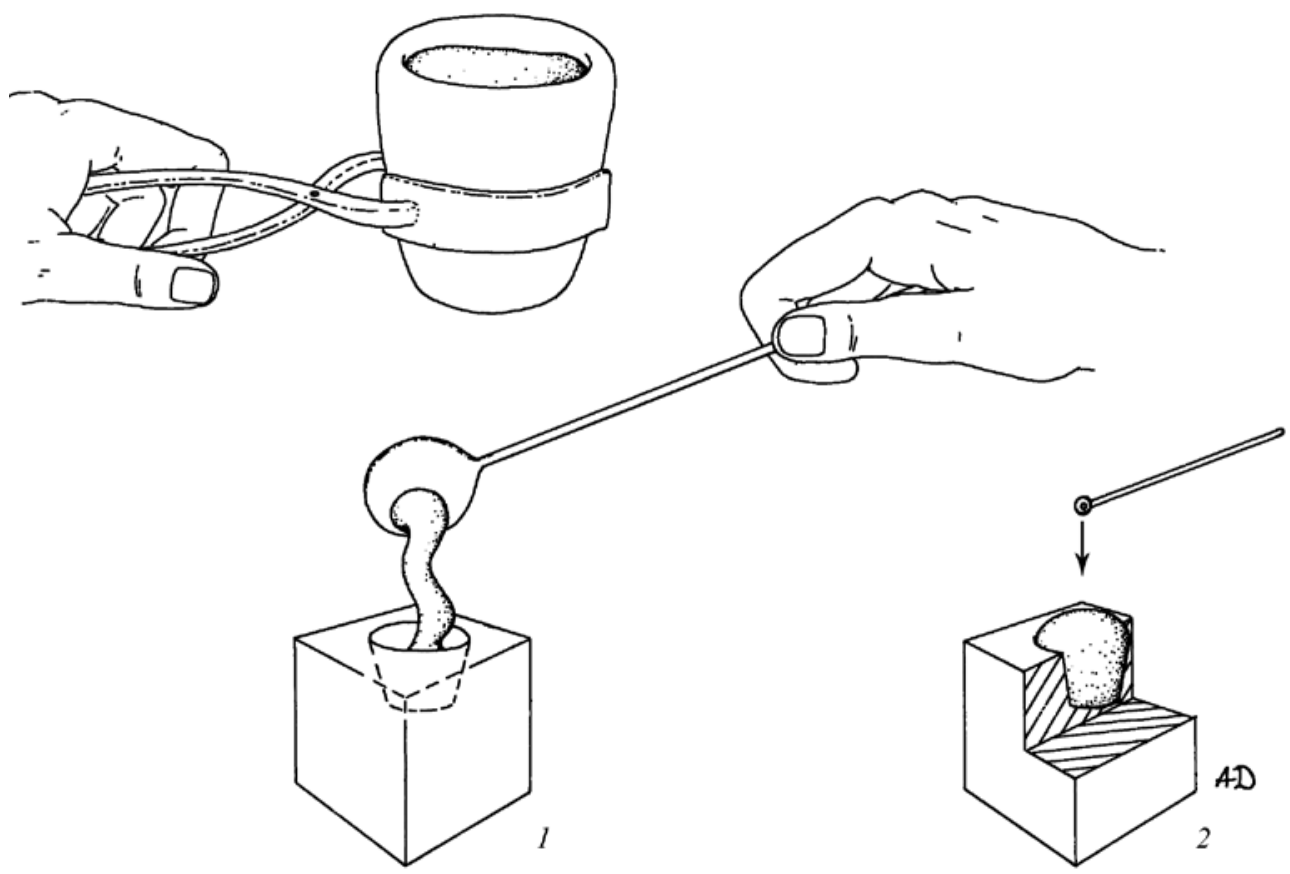

Рис. 8. Процесс изготовления фишек в форме перевернутого конуса (реконструкция Е.К. Столяровой)

1 - литье в открытую форму; 2 - прикрепление понтии для извлечения фишки из формы

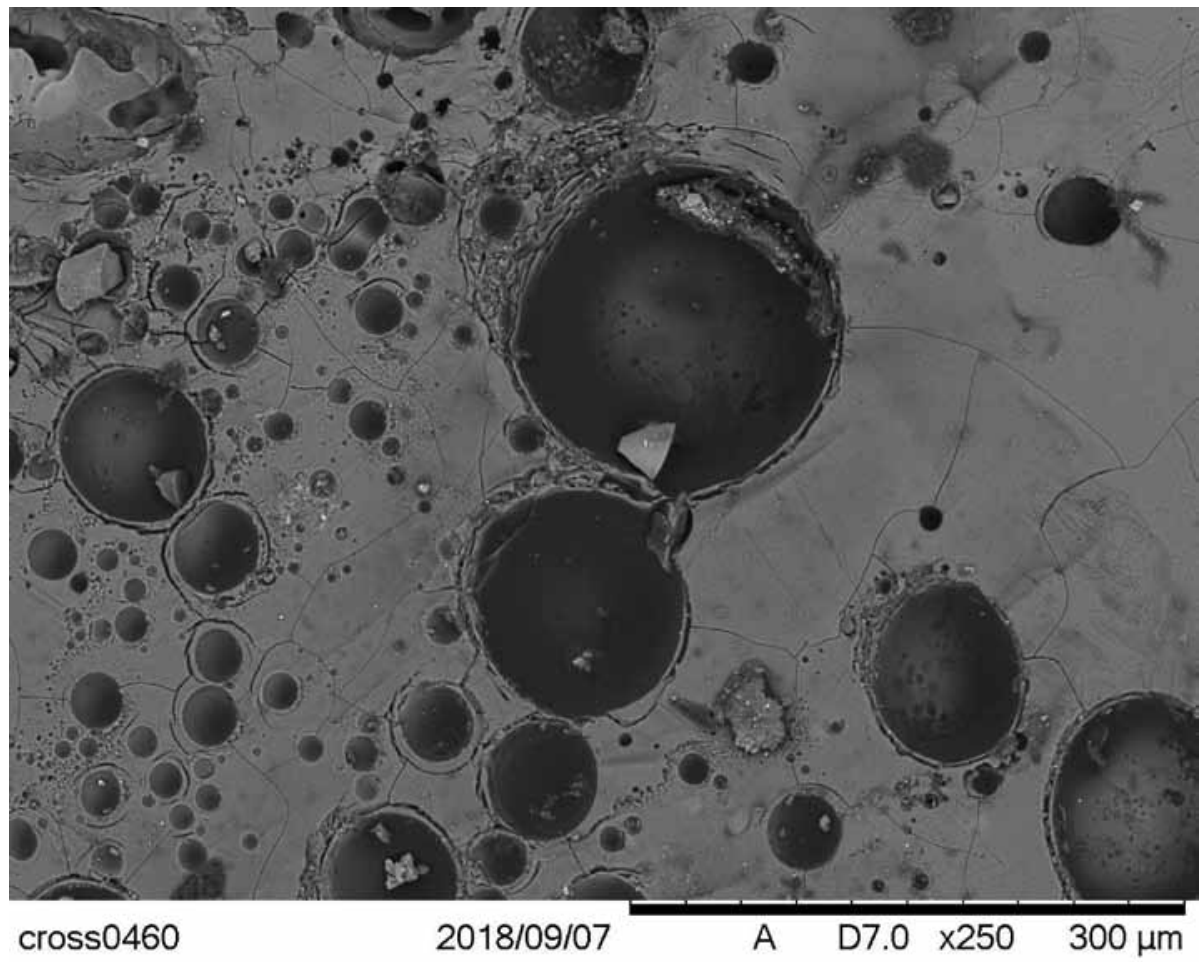

Рис. 9. Сферические беспорядочные пузыри внутри стекла, зафиксированные с помощью сканирующего электронного микроскопа. Увеличение $\times 250$ 


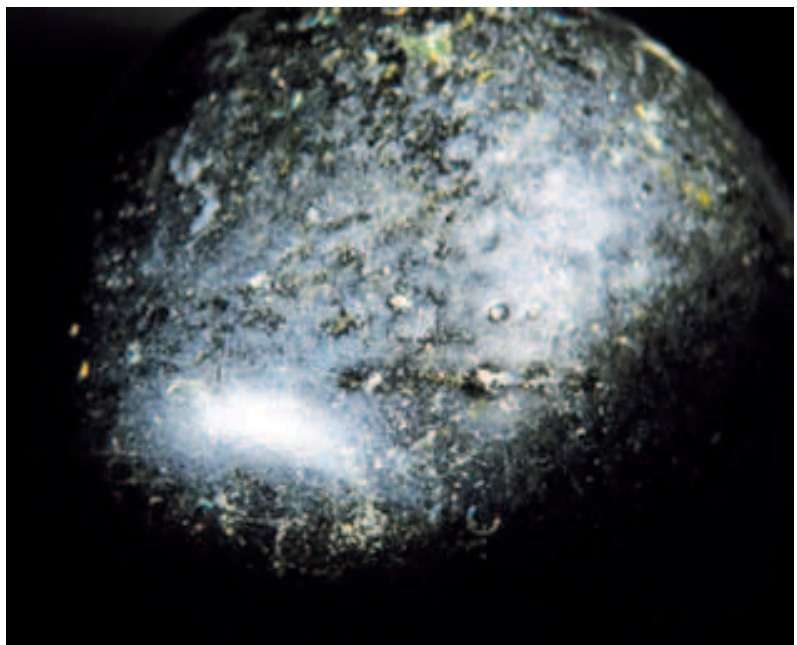

Рис. 10. Матовая и неровная поверхность основания и нижней конической части фишки из оливкового стекла из кургана Оль-30

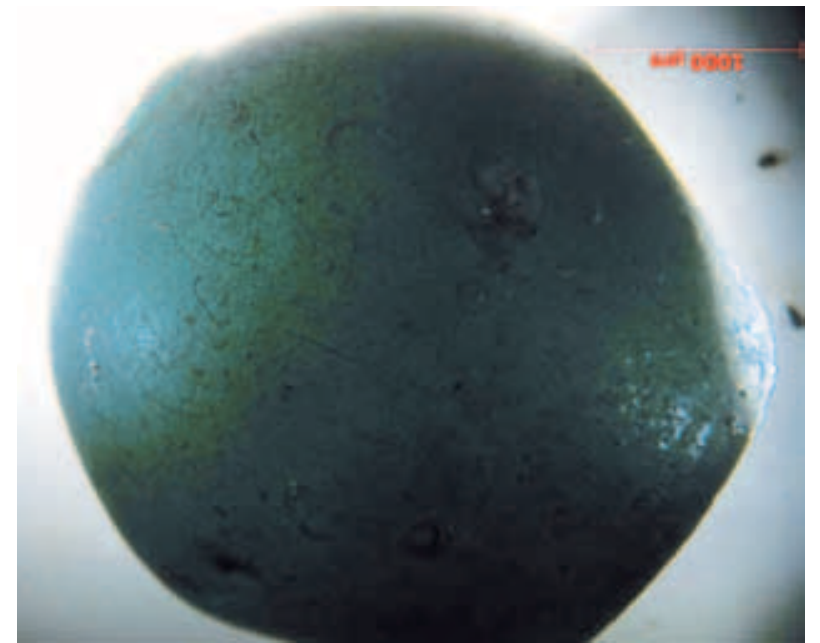

Рис. 11. Стеклянная фишка из зеленого стекла (Гн-87, ЦГ-ХХ, № п/о 12)
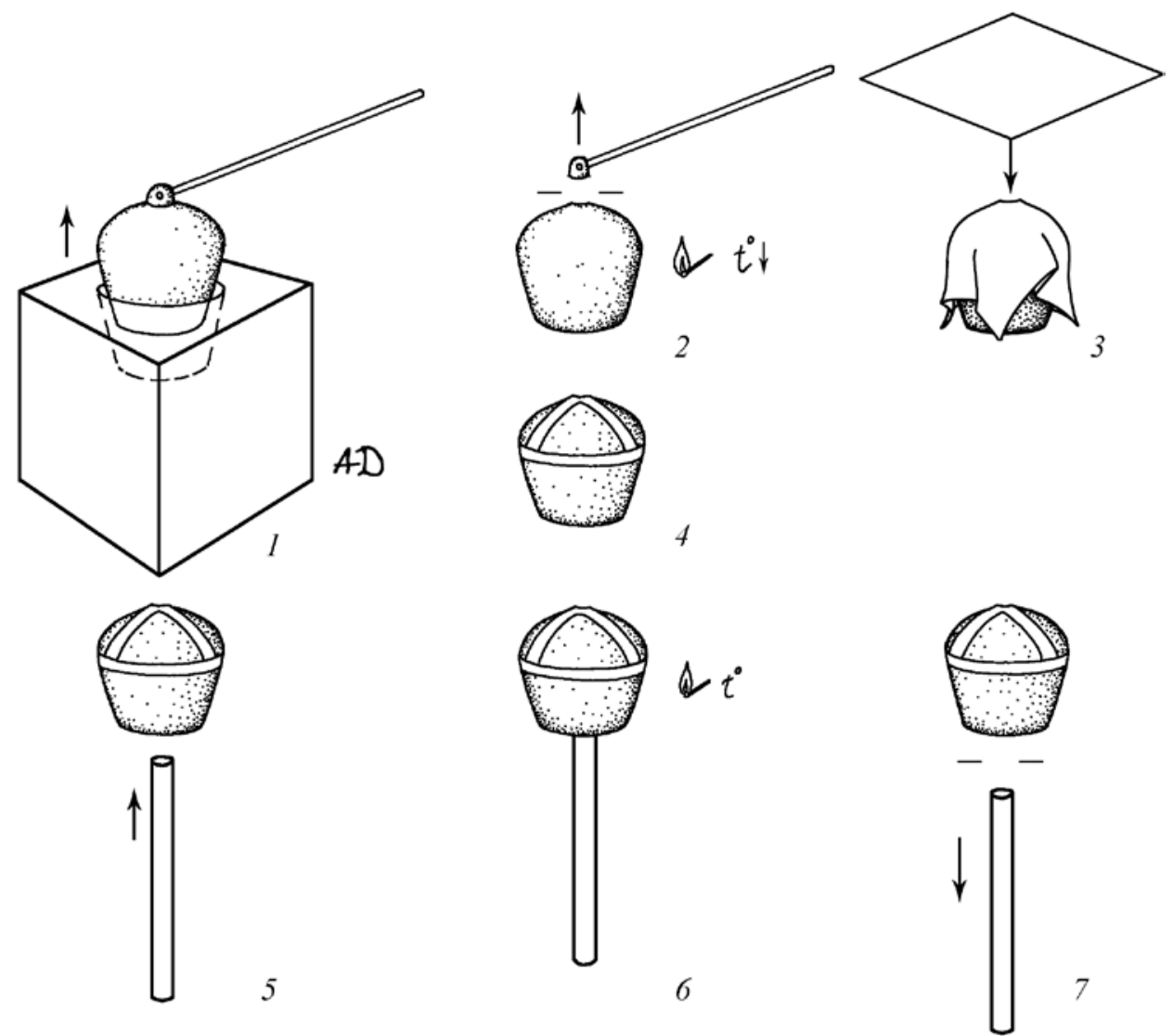

Рис. 12. Процесс изготовления и декорирования фишек в форме перевернутого конуса (реконструкция Е.К. Столяровой)

1 - извлечение фишки из формы; 2 - отделение понтии; 3 - покрытие золотой фольгой; 4 - готовая фишка с золотым декором; 5 - прикрепление трубки к основанию фишки; 6 - обжиг в печи для закрепления золота; 7 - отделение трубки 

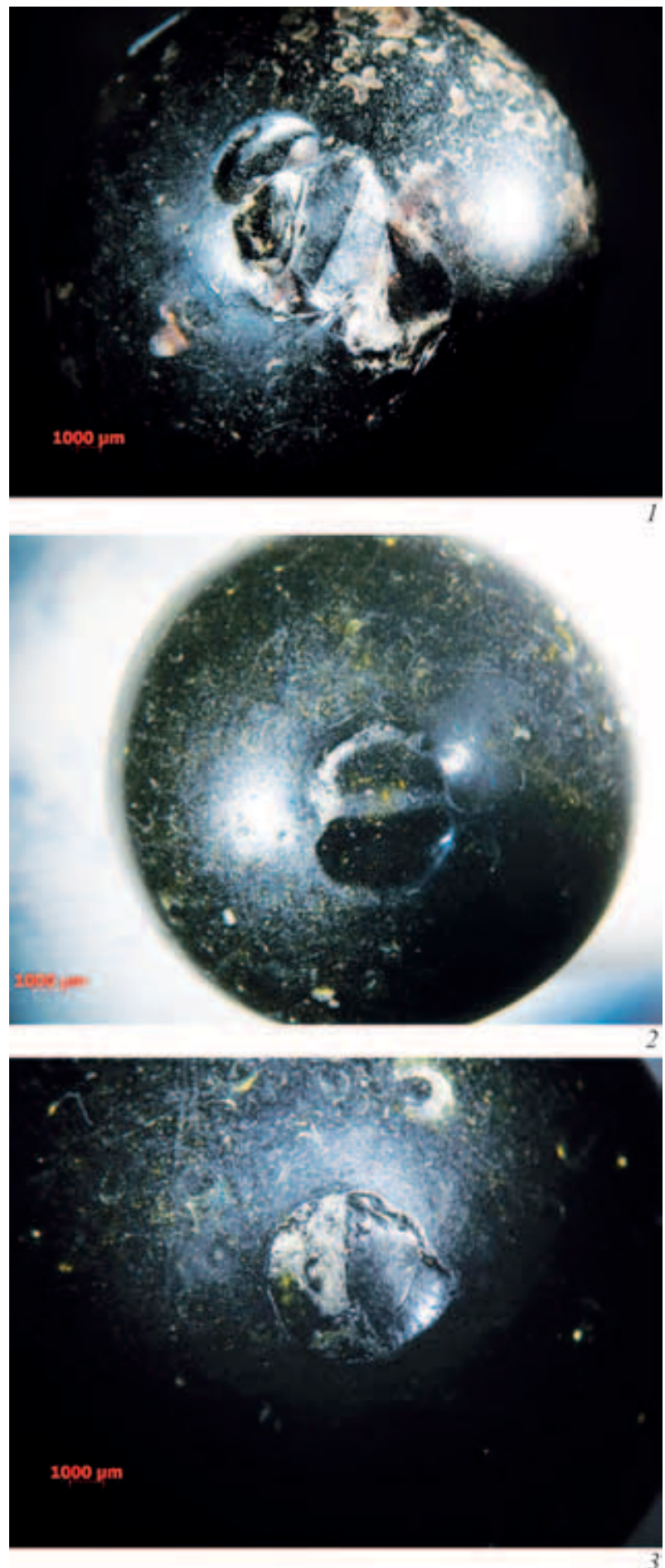

Рис. 13. Следы отделения понтии от верхней части фишек фиолетового (1) и оливкового (2) стекла из кургана Оль-30 и зеленого (3) с Центрального городища. Увеличение $\times 20$

натяжения стекло, помещенное в открытую форму, принимало вид полусферы (рис. 11). Об этом свидетельствует ровная поверхность этой части фишек. Для того чтобы вынуть фишку из формы,
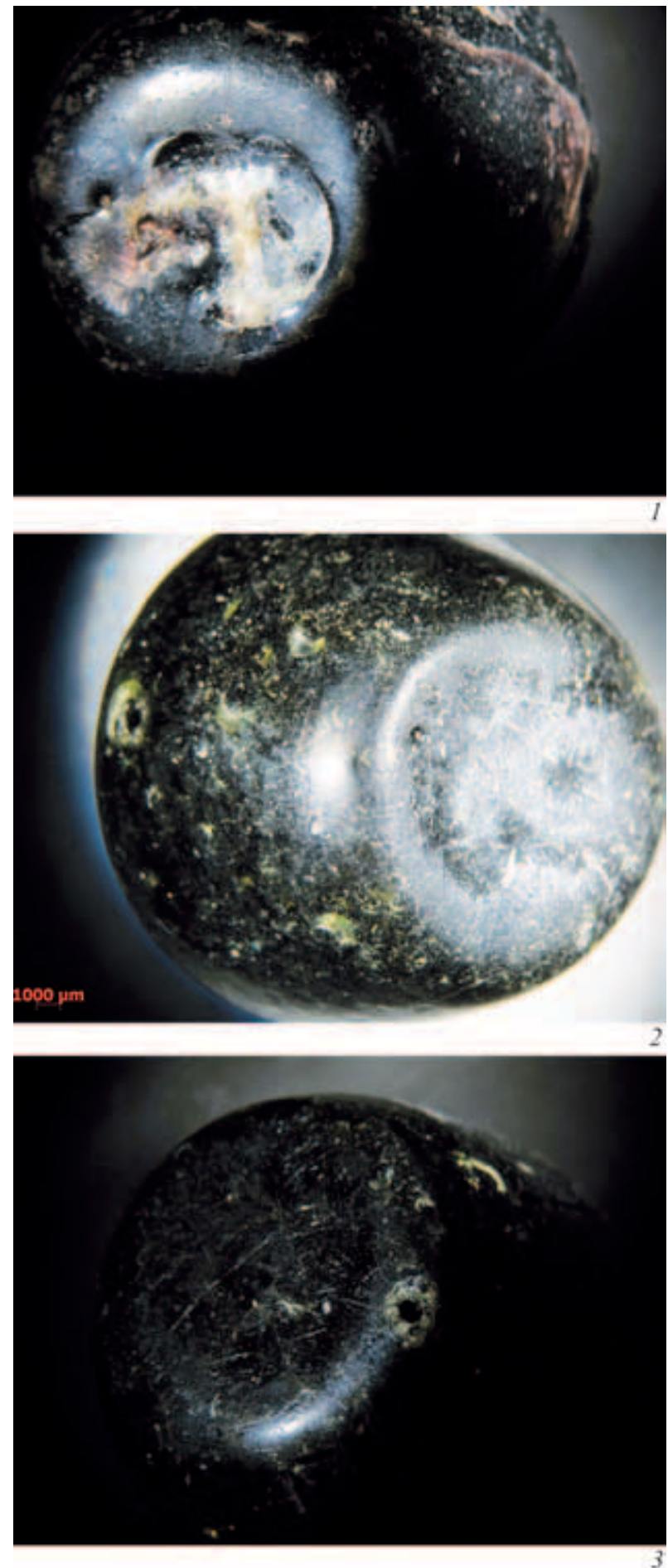

Рис. 14. Основания фишек фиолетового стекла со следами трубки (1); оливкового (2) стекла из кургана Оль-30 и зеленого (3) с Центрального городища без следов трубки

мастер прикасался к самой верхней точке полусферы разогретым металлическим прутом - понтией со стеклянной каплей на конце (рис. 8, 2; 12, 1). Для ее отделения еще вязкую каплю оттягивали 
и отрезали ножницами либо отшибали в случае остывания (рис. 12, 2). В результате все фишки конической формы имеют в своей верхней части следы такой операции в виде углублений с выступами или сколами (рис. 13). Возможно, после этого фишки помещали в печь для отжига.

На основании фишек бирюзового и фиолетового цветов обнаружены тонкие концентрические складки и раковистые изломы (рис. 14,1$)$. По-видимому, это следы еще одного металлического инструмента, предположительно трубки, которую присоединяли к основаниям фишек, в результате чего последние стали вогнутыми или получили углубление. Заметим, что именно эти фишки имеют следы золотого декора, в то время как ни оливковые, ни зеленая фишки не имеют ни декора, ни следов инструмента на основании (рис. 14, 2, 3). Декор на бирюзовых и фиолетовых фишках выполнен с помощью покрытия золотой фольгой. Это хорошо видно на макрофотографиях электронного микроскопа (рис. 15). Вероятно, первоначально верхнюю часть фишки целиком покрывали очень тонким золотым листиком (листиками) (рис. 12, 3). Затем мастер убирал лишние участки листа, оставляя золотое покрытие только на вершине, отходящих от нее лучах и на линии соединения конической и полусферической частей фишки (рис. 12, 4). Затем для вплавления фольги в поверхность стекла, что хорошо видно на макрофотографии (рис. 15, 2), изделие нужно было поместить в печь при невысокой температуpe $-550^{\circ}$. Такая температура ниже температуры размягчения стекла, но достаточна для соединения металла со стеклом. Именно для внесения фишки в печь и применяли трубку, присоединенную к основанию фишки (рис. 12, 5-7).

Вторая группа представлена единственной фишкой, имеющей форму усеченного шара с плоским основанием (№п/о 354), изготовленной из прозрачного сине-зеленого стекла (рис. 16). Вся поверхность фишки снаружи, а также внутри стеклянной массы покрыта беспорядочными пятнами и линиями красно-коричневого и серо-голубого цвета. Сверху фишка украшена цветком, состоящим из семи лепестков такого же серо-голубого цвета. Высота фишки - 1,9 см, максимальный диаметр - 2,5 см, диаметр основания - 1,8 см. Можно предположить, что особая форма и декор фишки облегчали ее восприятие в качестве короля на игральной доске.

Эта фишка изготовлена при помощи литья в открытую, вероятно, каменную форму (рис. 17, 1). На это указывают сферические беспорядочные пузыри внутри стекломассы и такие же каверны на матовой поверхности фишки. По-видимому,
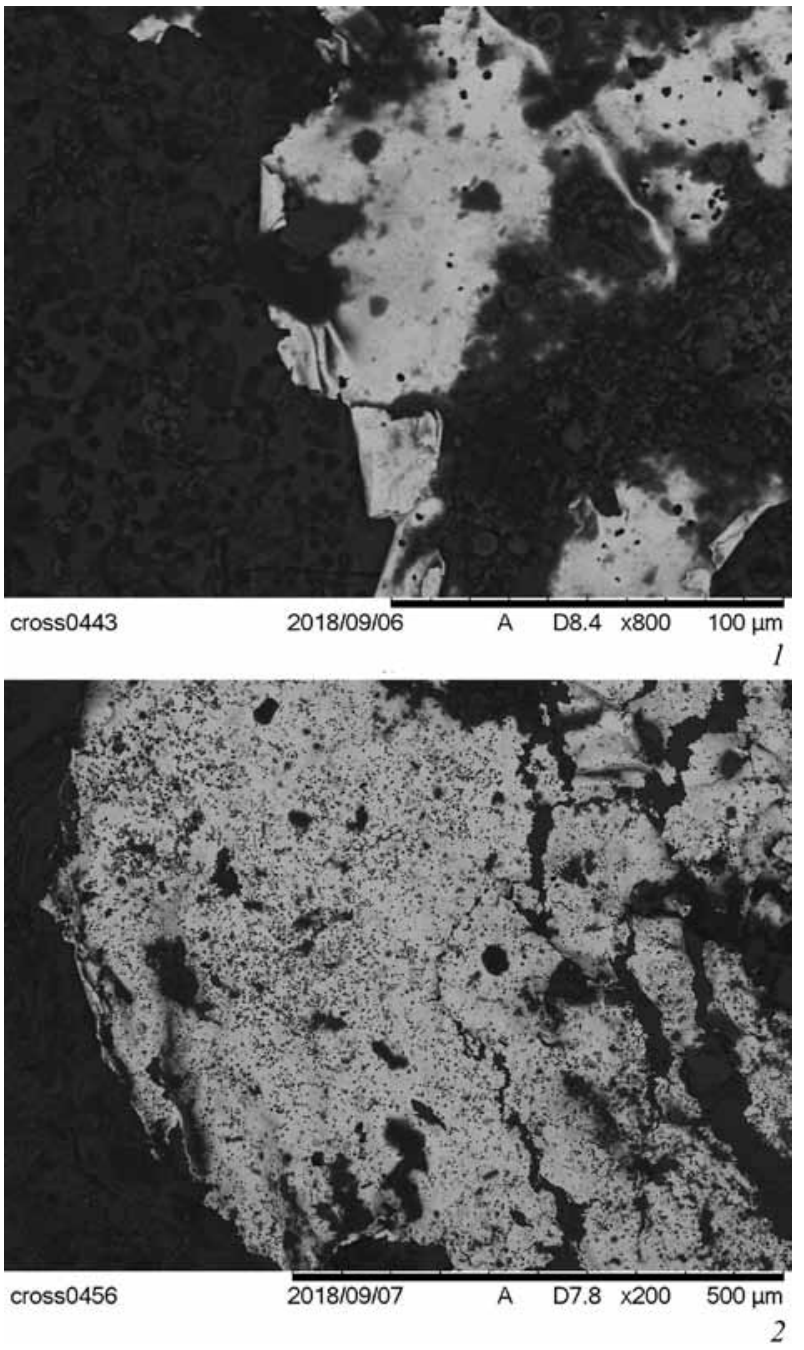

Рис. 15. Остатки золотой фольги на фишках бирюзового цвета из кургана Оль-30. Фотографии получены с помощью электронного микроскопа. Увеличение $\times 200$ и $\times 800$

стекло распределялось в форме по спирали. Из формы фишка была извлечена при помощи понтии еще в неостывшем состоянии. В момент присоединения понтии фишка была слегка приплюснута (рис. 17, 2-4). Затем инструмент отделили от основы, о чем свидетельствует круглый выступ на ее основании (рис. 17, 5, б). После этого предмет, вероятно, подвергли высокотемпературной наводке, что привело к появлению пятен и линий красно-коричневого и серо-голубого цветов. Предварительно на поверхности фишки с помощью плоского инструмента были проведены линии, образовавшие семиконечную звезду или цветок, которые в результате наводки приобрели серо-голубой цвет.

Подводя итог рассмотрению технологии, можно утверждать, что изученные нами фишки произведе- 

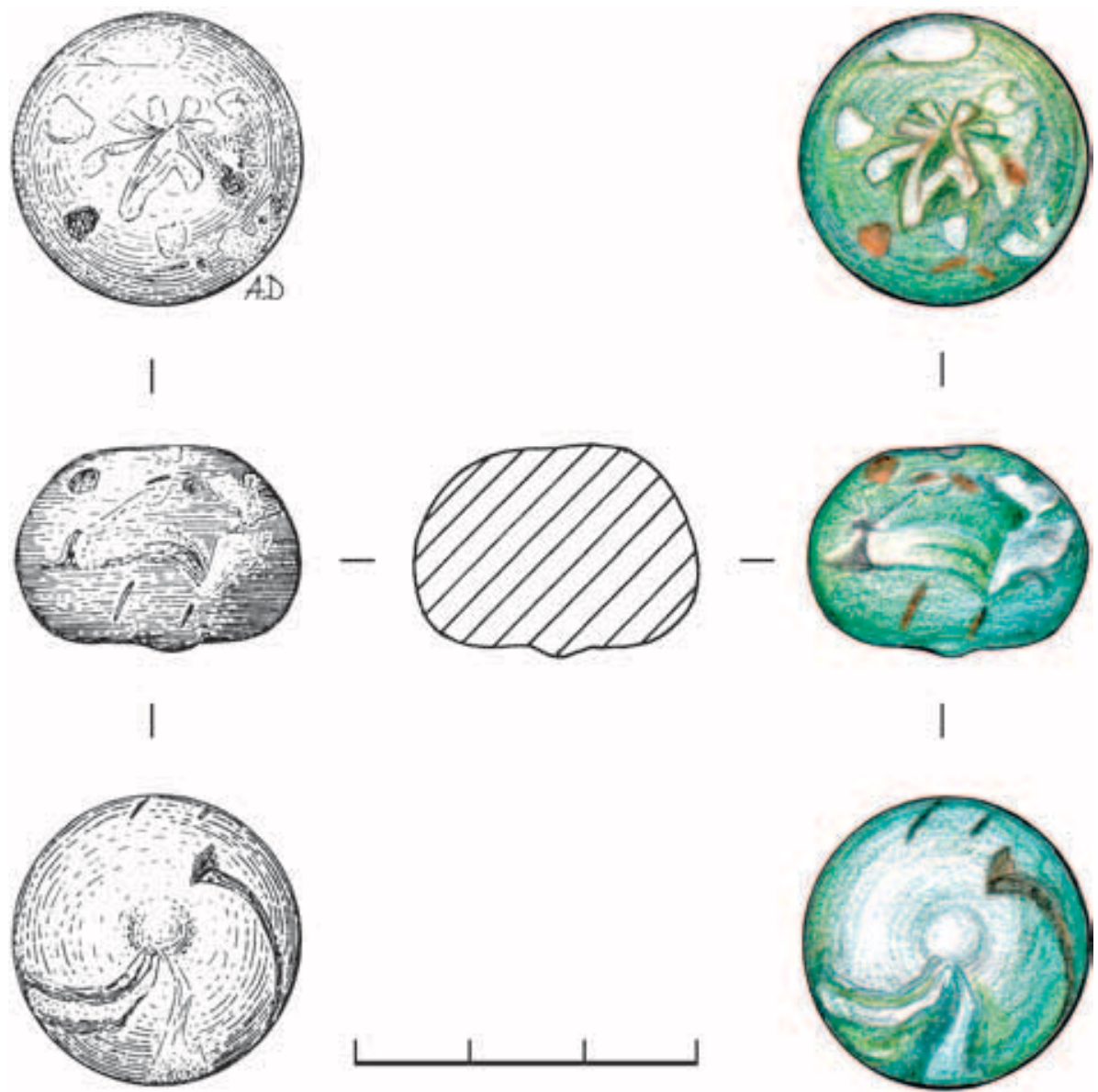

Рис. 16. Стеклянная фишка из сине-зеленого стекла (Гн-88, Оль-30, № п/о 354)

ны в мастерских полного цикла с помощью сложных многоступенчатых технологических приемов и схем мастерами высокого уровня, владеющими секретами стекольного дела. Подобная организация производства, разделенная на множество этапов, одним из которых было использование золотой фольги, возможна в мастерских, производивших предметы роскоши и существовавших под патронажем правителей (Щапова, 1998. С. 198-199).

Стекло всех исследованных фишек, кроме одной (п/о № 358), результат анализа которой требует проверки ${ }^{17}$, сварено на золе галофитов-растений пустынной зоны (табл. 1) ${ }^{18}$. На это указывает соотношение окисей натрия и калия - во всех случаях оно находится в пределах от 1 до 13 (Щапова, 1983. С. 29-30). Такое сырье в рассматриваемый период в равной степени использовалось стеклоделами Византии и стран Переднего и Ближнего Востока. Интересно, что обе фишки из Шестовицкого могильника показали иной состав: они сварены на минеральной соде (Безбородов, 1956. С. 208. Табл. 26). По содержанию щелочных земель $(\mathrm{RO}=\mathrm{CaO}+\mathrm{MgO})$ и по их

17 Анализ показал преобладание $\mathrm{K}_{2} \mathrm{O}$ над $\mathrm{Na}_{2} \mathrm{O}$, что могло бы указывать на применение золы растений умеренной зоны, если бы не полное морфо-технологическое сходство этой фишки с остальными, выполненными на золе растений пустынной зоны. Вероятно, такой результат связан с анализом неровной поверхности фишки и неравномерным выщелачиванием натрия и калия из поверхностного слоя стекла.

${ }_{18}$ Неразрушающий поверхностный анализ выполнен на кафедре археологии исторического факультета МГУ Н. В. Ениосовой при помощи настольного электронного микроскопа TM3030 Hitachi. Прибор работает по принципу низковакуумного наблюдения, где узко сфокусированный электронный луч направляется на образец. Образующиеся обратно отраженные электроны улавливаются полупроводниковым детектором, что позволяет получить трехмерное изображение с большим увеличением и высоким разрешением. Микроскоп снабжен РФА микроанализатором-спектрометром Quantax 70EDX, обеспечивающим идентификацию элементов в составе стекла и определение их концентрации на основе безэталонного метода фундаментальных параметров. 


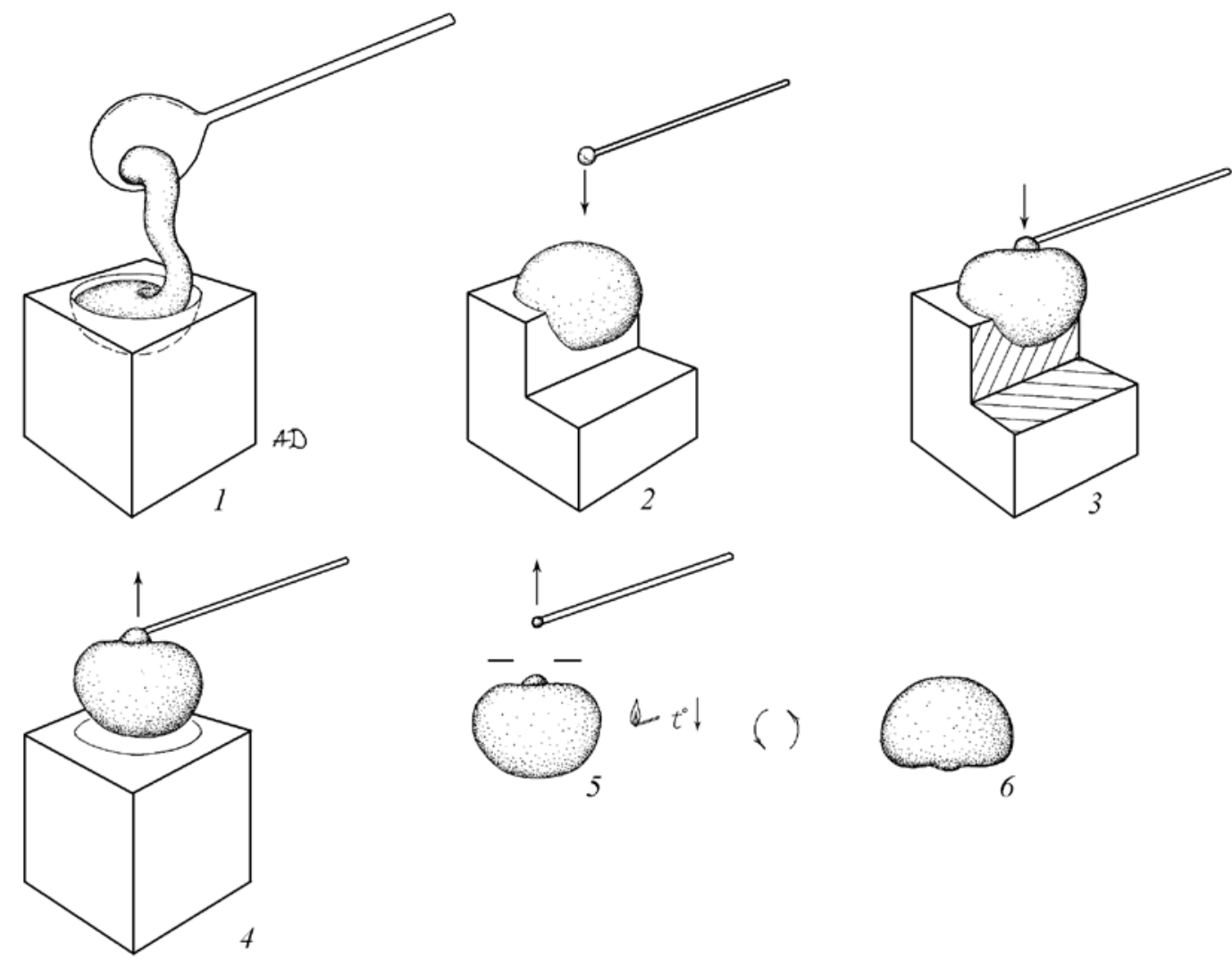

Рис. 17. Процесс изготовления фишки из сине-зеленого стекла (реконструкция Е. К. Столяровой) 1 - литье в открытую форму; 2 - прикрепление понтии для извлечения фишки из формы; 3,4 - извлечение фишки из формы; 5 - отделение понтии от фишки и отжиг

соотношению с щелочами $\left(\mathrm{R}_{2} \mathrm{O}=\mathrm{Na}_{2} \mathrm{O}+\mathrm{K}_{2} \mathrm{O}\right)$ изученные гнёздовские стекла можно разделить на две группы. К первой можно отнести стекла с высоким содержанием щелочных земель и равным или превышающим их в полтора-два раза содержанием щелочей (класс $\mathrm{Na}_{2} \mathrm{O}-\mathrm{CaO}-\mathrm{SiO}_{2}$ ). Сюда относятся стекла девяти фишек, среди которых обе оливковые, три бирюзовые (№ п/о 281, 357, 366), одна фиолетовая (№ п/о 365), единственные зеленая, темная и синезеленая (многоцветная). Ко второй группе с низким содержанием щелочных земель и превышающим их в 3-4,5 раза содержанием щелочей (класс $\mathrm{Na}_{2} \mathrm{O}$ $\mathrm{SiO}_{2}$ ) относятся стекла шести фишек, среди которых остальные бирюзовые (№ п/о 355, 360, 363, 364) и фиолетовые (№ п/о 359, 362).

Красителями бирюзовых (№ п/о 281, 355, 357, $360,363,364,366)$, оливковых (№ п/о 356, 361) и зеленой (№ п/о 12) фишек, вероятно, являлась окись железа. Бирюзовые и зеленая фишки были окрашены двухвалентным железом, которое обычно образуется в восстановительных условиях варки (Ланцетти, Нестеренко, 1987. С. 37; Галибин, 2001. С. 36).
Полученная разница в цвете - бирюзовое и зеленое стекло - при одинаковом красителе, возможно, объясняется разным числом ионов, находящихся в непосредственной близости от окрашивающего иона, так называемым координационным числом, либо разной температурой варки (Ланцеетти, Нестеренко, 1987. С. 32). Оливковые фишки (№ п/о 356, 361) окрашены с помощью трехвалентного железа. В этом случае варка стекла велась в окислительной среде (Ланцеетти, Нестеренко, 1987. С. 37; Галибин, 2001. С. 36). У темной фишки (№ п/о 4) содержание оксида железа чрезвычайно низкое $(0,13 \%)$, что не позволяет считать его красителем. При этом в стекле присутствует значительное количество окиси марганца $(1,04 \%)$, которая, вероятно, и привела к получению стекла почти черного цвета. Для двух фиолетовых фишек (№п/о 358,359 ) окись марганца как краситель определяется более уверенно. Обратная ситуация с двумя другими фиолетовыми фишками (№ п/о 362, 365), у которых содержание окиси марганца не превышает 0,26\%, что недостаточно для окрашивания. Одна фишка (№ п/о 354) окрашена окисью меди в сине-зеленый 


\begin{tabular}{|c|c|c|c|c|c|c|c|c|c|c|c|c|c|c|c|c|}
\hline U & $\begin{array}{l}\sigma_{\alpha} \\
\sigma^{2}\end{array}$ & $\overrightarrow{0}$ & 8 & iे & $\because$ & 8 & $\begin{array}{l}\infty \\
0 \\
0\end{array}$ & $\begin{array}{l}8 \\
8 \\
0\end{array}$ & $\begin{array}{l}8 \\
8 \\
0\end{array}$ & 8 & $\begin{array}{l}\hat{j} \\
\hat{i}\end{array}$ & $\begin{array}{l}8 \\
0 \\
0\end{array}$ & $\begin{array}{l}\hat{2} \\
\hat{\sigma}\end{array}$ & $\begin{array}{l}\tilde{\omega} \\
\infty \\
i\end{array}$ & $\begin{array}{l}8 \\
0\end{array}$ & 8 \\
\hline os & $\begin{array}{l}8 \\
0 \\
0\end{array}$ & 8 & $\stackrel{8}{8}$ & 8 & त̃ & 8 & $\begin{array}{l}8 \\
0 \\
0\end{array}$ & $\begin{array}{l}8 \\
0 \\
0\end{array}$ & $\begin{array}{l}8 \\
0 \\
0\end{array}$ & $\begin{array}{l}8 \\
: \\
0\end{array}$ & $\begin{array}{l}8 \\
: \\
0\end{array}$ & $\begin{array}{l}0 \\
0 \\
0 \\
0\end{array}$ & $\begin{array}{c}\hat{\infty} \\
0 \\
0\end{array}$ & $\stackrel{\tilde{n}}{\tilde{0}}$ & స్ & $\stackrel{8}{8}$ \\
\hline 2 & $\stackrel{8}{0}$ & त̂ & 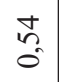 & 8 & 导 & 8 & $\frac{0}{0}$ & $\frac{0}{0}$ & $\begin{array}{l}n \\
n \\
0 \\
0\end{array}$ & $\stackrel{0}{0}$ & $\underset{-}{\tilde{-}}$ & $\left|\begin{array}{c}0 \\
3 \\
3 \\
0\end{array}\right|$ & $\begin{array}{l}\dot{H} \\
m_{0}\end{array}$ & $\hat{n}$ & $\stackrel{0}{0}$ & 8 \\
\hline $\begin{array}{l}0^{N} \\
\frac{8}{2}\end{array}$ & 8 & $\begin{array}{c}0 \\
\text { m. } \\
0\end{array}$ & 8 & 8 & $\begin{array}{l}2 \\
\infty \\
0\end{array}$ & $\begin{array}{l}\text { to } \\
0\end{array}$ & $\begin{array}{l}8 \\
0 \\
0\end{array}$ & $\begin{array}{l}2 \\
0\end{array}$ & $\begin{array}{l}0 \\
0\end{array}$ & \begin{tabular}{l}
0 \\
\multirow{2}{1}{} \\
0
\end{tabular} & $\begin{array}{l}8 \\
8\end{array}$ & $\begin{array}{l}\tilde{n} \\
\tilde{0}\end{array} \mid$ & $\begin{array}{l}n \\
n \\
0 \\
0\end{array}$ & Әे & ક̊ & $\vec{\delta}$ \\
\hline U & $\begin{array}{l}8 \\
0 \\
0\end{array}$ & ${ }_{0}^{t}$ & 8 & $\hat{m}$ & $\overline{0}$ & $\stackrel{2}{0}$ & $\frac{\Delta}{0}$ & $\begin{array}{l}\tilde{1} \\
\tilde{0}\end{array}$ & $\begin{array}{l}0 \\
0\end{array}$ & $\begin{array}{l}8 \\
0\end{array}$ & $\begin{array}{l}8 \\
0 \\
0\end{array}$ & $\mid \begin{array}{l}n \\
0 \\
0\end{array}$ & $\begin{array}{l}\infty \\
0 \\
0 \\
0\end{array}$ & 8 & 8 & 8 \\
\hline $0^{m}$ & $\frac{m}{0}$ & $\underset{i}{\stackrel{f}{i}}$ & $\underset{\sim}{\stackrel{f}{\sigma}}$ & $\stackrel{m}{\rightarrow}$ & $\stackrel{f}{\sim}$ & 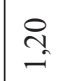 & $\stackrel{\circ}{\sim}$ & $\hat{\sigma}$ & $\tilde{\sigma}$ & مे & $\begin{array}{l}\infty \\
0 \\
i \\
i\end{array}$ & $\begin{array}{l}\infty \\
\infty \\
-\end{array}$ & $\exists$ & $\begin{array}{l}\infty \\
\infty \\
i \\
i\end{array}$ & $\begin{array}{l}\infty \\
\infty \\
0 \\
0\end{array}$ & i \\
\hline$\stackrel{O}{E}$ & $\underset{-}{0}$ & 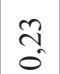 & $\underset{0}{+}$ & $\stackrel{8}{0}$ & $\hat{\sigma}_{0}$ & $\begin{array}{l}n \\
\text { in } \\
\text { in }\end{array}$ & $\stackrel{n}{0}$ & $\hat{n}$ & $\cong$ & $\begin{array}{l}0 \\
n \\
0 \\
0\end{array}$ & $\begin{array}{l} \pm \\
0\end{array}$ & 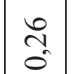 & ते & $\stackrel{0}{2}$ & $\overrightarrow{\vec{N}}$ & i \\
\hline$\overbrace{}^{\sim}$ & 8 & m. & 8 & $\begin{array}{l}n \\
n \\
0 \\
0\end{array}$ & 8 & 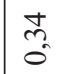 & $\vec{m}$ & $\begin{array}{l}0 \\
2 \\
0\end{array}$ & $\begin{array}{l}0 \\
n \\
0\end{array}$ & $\frac{n}{0}$ & $\begin{array}{l}\frac{n}{0} \\
0\end{array}$ & $\left|\begin{array}{l}n \\
n \\
0\end{array}\right|$ & $\begin{array}{c}0 \\
\text { âd } \\
0\end{array}$ & $\begin{array}{c}\text { त̃ } \\
\text { ô }\end{array}$ & ñ & $\begin{array}{l}\tilde{\hat{\sigma}} \\
\text { os }\end{array}$ \\
\hline Uే & $\begin{array}{l}\infty \\
0 \\
i n\end{array}$ & ڤ̆ & $\underset{\sim}{8}$ & $\begin{array}{l}\tilde{n} \\
\tilde{a}^{2}\end{array}$ & $\overrightarrow{\vec{i}}$ & 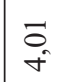 & $\begin{array}{l}\circ \\
\circ\end{array}$ & $\begin{array}{l}\infty \\
\infty \\
\infty\end{array}$ & $\underset{-}{0}$ & $\frac{0}{i}$ & \begin{tabular}{l}
2 \\
\multirow{+}{*}{}
\end{tabular} \mid & $\begin{array}{c} \pm \\
\dot{m}\end{array}$ & $\begin{array}{l}\hat{n} \\
m\end{array}$ & $\begin{array}{r}\tilde{~} \\
\text { ले }\end{array}$ & $\begin{array}{l}\tilde{f} \\
\stackrel{0}{0}\end{array}$ & $\stackrel{0}{0}$ \\
\hline $\begin{array}{l}0 \\
-1\end{array}$ & $\hat{a}$ & $\begin{array}{l}\hat{z} \\
i \\
i\end{array}$ & ने & $\stackrel{t}{\sim}$ & $\stackrel{8}{\sim}$ & $\begin{array}{l}2 \\
\sim \\
f\end{array}$ & ले & ले & $\overrightarrow{F_{-}}$ & $\stackrel{\infty}{\stackrel{\infty}{-}}$ & $\stackrel{n}{n}$ & $\mid \begin{array}{l}0 \\
i \\
\text { in }\end{array}$ & $\vec{m}$ & $\stackrel{\leftrightarrow}{m}$ & $\begin{array}{l}n \\
\tilde{i} \\
i\end{array}$ & ते \\
\hline $\begin{array}{l}0 \\
\tilde{\sigma}^{N}\end{array}$ & $\begin{array}{l}2 \\
0 \\
0\end{array}$ & $\begin{array}{l}0 \\
+ \\
\infty \\
\infty\end{array}$ & $\stackrel{0}{\stackrel{i}{i}}$ & $\begin{array}{l}i n \\
=\end{array}$ & $\begin{array}{l}0 \\
\infty \\
\infty \\
\infty\end{array}$ & $\begin{array}{l}n \\
n \\
n\end{array}$ & $\begin{array}{l}\infty \\
\stackrel{\infty}{ \pm} \\
\stackrel{ \pm}{=}\end{array}$ & 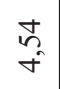 & $\begin{array}{l}\dot{m} \\
\sigma^{2}\end{array}$ & $\begin{array}{l}\infty \\
\stackrel{1}{1} \\
\stackrel{0}{=}\end{array}$ & $\stackrel{\circ}{\circ}$ & $\left|\begin{array}{l}0 \\
\vec{i} \\
\simeq\end{array}\right|$ & $\begin{array}{l}\infty \\
\infty \\
\Omega^{2}\end{array}$ & \begin{tabular}{l}
\multirow{n}{*}{} \\
\multirow{J}{*}{}
\end{tabular} & $\begin{array}{c}\text { న్ } \\
\infty \\
\infty\end{array}$ & fó \\
\hline$\stackrel{O}{n}^{N}$ & $\begin{array}{l}\text { ले } \\
\stackrel{2}{n}\end{array}$ & $\begin{array}{l}8 \\
8 \\
2\end{array}$ & $\begin{array}{l}8 \\
\frac{1}{n}\end{array}$ & $\vec{\Im}$ & \begin{tabular}{l}
$\infty$ \\
\multirow{1}{*}{} \\
$\infty$ \\
$\infty$
\end{tabular} & $\begin{array}{c}n \\
m \\
i\end{array}$ & $\begin{array}{l}\hat{\sigma} \\
\infty_{0}\end{array}$ & $\begin{array}{l}\vec{\sigma} \\
\dot{\nabla}\end{array}$ & $\begin{array}{l}\hat{n} \\
\hat{\Sigma}\end{array}$ & $\begin{array}{l}\infty \\
i \\
i \\
i \\
i\end{array}$ & $\begin{array}{l}\hat{\circ} \\
\hat{\sigma}\end{array}$ & $\begin{array}{l}\vec{i} \\
i\end{array}$ & $\begin{array}{l}0 \\
6 \\
0 \\
0 \\
0\end{array}$ & ڤે & $\begin{array}{l}\infty \\
\hat{\sigma}\end{array}$ & $\underset{\infty}{\infty}$ \\
\hline$\frac{0^{m}}{\mathbb{e}^{n}}$ & $\begin{array}{l}n \\
\therefore \\
r\end{array}$ & శ్ & $\underset{f}{\stackrel{f}{*}}$ & $\begin{array}{l}\infty \\
\infty \\
i\end{array}$ & $\frac{\infty}{m}$ & $\begin{array}{l}\text { q } \\
\infty\end{array}$ & $\begin{array}{l}\infty \\
\infty \\
-\end{array}$ & $\begin{array}{l}n \\
2 \\
\sigma\end{array}$ & 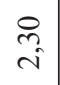 & $\underset{\stackrel{f}{\sim}}{\stackrel{f}{\sigma}}$ & $\begin{array}{l}0 \\
\infty \\
\infty\end{array} \mid$ & $\begin{array}{l}\hat{\gamma} \\
\tilde{f}\end{array}$ & $\underset{r}{\stackrel{f}{f}}$ & $\begin{array}{c}\text { ले } \\
\text { n) }\end{array}$ & $\hat{\widetilde{N}}$ & $\frac{0}{m}$ \\
\hline$\sum_{i}^{\circ}$ & $\begin{array}{l}\infty \\
\dot{0} \\
0\end{array}$ & $\begin{array}{l}n \\
\infty \\
\infty \\
\infty\end{array}$ & $\begin{array}{c}\text { ô } \\
\text { r. }\end{array}$ & $\begin{array}{l}0 \\
\infty \\
0\end{array}$ & $\begin{array}{l}0 \\
\stackrel{0}{0}\end{array}$ & $\underset{\sim}{\stackrel{\Xi}{\sim}}$ & $\begin{array}{l}\stackrel{2}{0} \\
\stackrel{0}{0}\end{array}$ & $\begin{array}{l}0 \\
\vdots \\
0\end{array}$ & $\stackrel{2}{\approx}$ & $\stackrel{g}{g}$ & $\begin{array}{l} \pm \\
0 \\
0\end{array}$ & 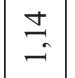 & aे & $\stackrel{\Rightarrow}{\Rightarrow}$ & $\stackrel{ }{=}$ & $\stackrel{\circ}{-}$ \\
\hline 总 & 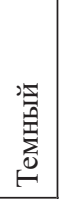 & 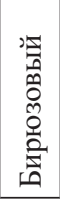 & 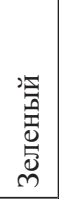 & 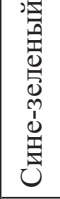 & 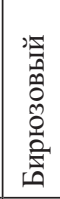 & 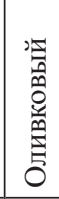 & 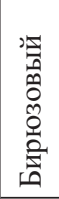 & 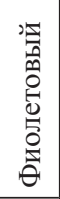 & 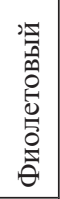 & 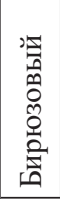 & 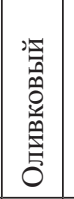 & 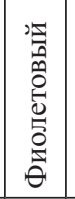 & 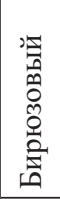 & 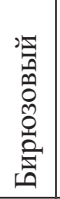 & 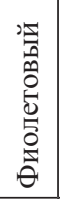 & 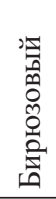 \\
\hline $\begin{array}{l}\stackrel{0}{\Xi} \\
\stackrel{01}{2}\end{array}$ & $\nabla$ & $\vec{\infty}$ & $\simeq$ & 点 & in & $\stackrel{0}{n}$ & in & $\stackrel{\infty}{n}$ & के & 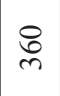 & $\vec{D}$ & $\begin{array}{l}\tilde{O} \\
\text { r }\end{array}$ & $\vec{b}$ & $\underset{ల}{\mathbb{N}}$ & 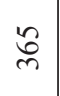 & $\underset{ల}{0}$ \\
\hline 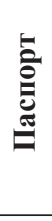 & 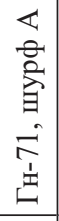 & 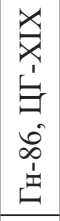 & 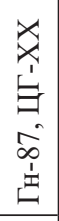 & 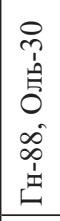 & 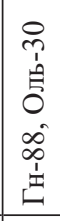 & 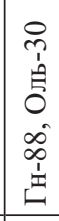 & 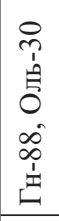 & 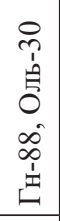 & 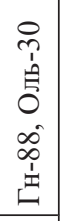 & 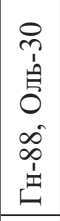 & 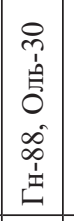 & 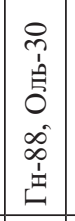 & 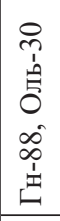 & 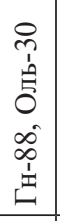 & 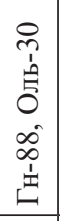 & 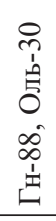 \\
\hline 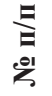 & - & $\sim$ & $m$ & $\sigma$ & $n$ & 0 & $r$ & $\infty$ & $a$ & 으 & $=$ & $\simeq$ & 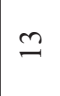 & \pm & $\cong$ & 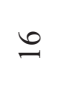 \\
\hline
\end{tabular}


цвет. Оксид меди, оказавшись в восстановительной газовой среде, восстановился до металлической меди, в результате чего на поверхности и внутри фишки мы наблюдаем непрозрачные пятна и полосы красно-коричневого цвета (Галибин, 2001. С. 33). Этот процесс носит название наводки, то есть выдерживания при определенной температуре и среде для выращивания частиц красителя. Наводку обычно совмещают с отжигом или с выработкой изделий (Ланщетти, Нестеренко, 1987. С. 39). Наличие на поверхности и внутри фишки непрозрачных пятен и линий серо-голубого цвета можно объяснить высокотемпературной многократной наводкой, в результате чего в стеклах, содержащих медь, возникают серые и зеленовато-серые оттенки (Ланцетти, Нестеренко, 1987. С. 41). Пока нельзя точно сказать, был ли процесс наводки сознательным или нет.

Применение обесцвечивателя в виде оксида марганца можно предположить для четырех бирюзовых фишек (№ п/о 355, 360, 364, 366) и одной оливковой (№ п/о 356). В остальных случаях содержание окиси марганца ниже нижнего предела концентрации, определяемого в $0,5 \%$, что делает маловероятным ее использование в этих целях (Щапова, 1989. С. 107. Табл. 6).

Химический состав стекла свидетельствует против одной из наиболее распространенных версий о происхождении стеклянных фишек эпохи викингов, существующих в археологической литературе. Эта версия - западноевропейская - была высказана Хольгером Арбманом (Arbman, 1937. S. 65-66). Находки каких-либо стеклянных фишек из стекла, сваренного на золе растений умеренной зоны, в западноевропейских материалах, синхронных скандинавским и древнерусским, неизвестны. Об этом писала и Г.Ф. Корзухина, подчеркивая, что появление и распространение шашек из любого материала на территории Древней Руси непосредственно связаны с появлением здесь скандинавов (Корзухина, 1963. С. 100).

Полностью соглашаясь с выводами Г. Ф. Корзухиной о времени и контексте находок, некоторые авторы считают, что стеклянные фишки имеют византийское происхождение, и распространение их шло по днепровскому пути с юга на север (Хамайко, 2012. С. 128). С учетом находок стеклянных фишек в Тимерёве, Ростове Великом и на Рюриковом городище картина распределения находок на территории Руси - только вдоль днепровского отрезка Пути из варяг в греки, нуждается в пересмотре.

Версию о том, что стеклянные фишки были произведены в византийских мастерских, впервые выдвинула Ю. Л. Щапова (1991. С. 166). Она была поддержана в статье, посвященной византийским импортам с территории пойменной части Гнёздовского поселения (Мурашева и др., 2010. С. 523-525). Византийскую версию происхождения стеклянных гнёздовских фишек кроме использования золы растений пустынной зоны как будто подтверждает примечательная концентрация вещей византийского круга в кургане Оль-30, свидетельствующая, что погребенный там представитель высшего слоя древнерусской аристократии был вовлечен в дипломатические и торговые контакты с Византийской империей. Однако византийской версии противоречат некоторые факты.

Нельзя отрицать, что в Византии были распространены игры в кости, карты и шахматы. Моральная оценка азартных игр христианской церковью была негативной, но отдельные люди продолжали играть, надеясь на неожиданную перемену судьбы (Games. Boards, 1991. Р. 820-821). Игральные доски, фишки, кости и астрагалы встречены во время раскопок таких памятников, как Амориум и Коринф, а также на территории Константинополя в районах Сарачхане и Еникапи (Davidson, 1952. Р. 219-220. P1. 99, 1695-1698). Однако все известные на настоящий момент фишки средневизантийского периода похожи на аналогичные изделия римской эпохи из кости, рога или слоновой кости и сильно отличаются от синхронных им принадлежностей для игры из Скандинавии, Британских островов или Древней Руси. Они имеют форму слегка выпуклого диска диаметром от 2 до 3 см, украшенного геометрическим орнаментом. В юго-западной части гнёздовского городища на участке с необычайно плотной концентрацией обломков амфор обнаружена единственная фишка византийского облика из рога (Енuосова, Пушкина, 2016. С. 290).

Второй аргумент касается датировки находок полусферических и конических фишек из стекла, янтаря, кости, рога и камня. Нет сомнений, что характерные морфологические признаки этих изделий являются результатом их долгого и непрерывного развития на территории Скандинавии и Британских островов. Сложившиеся формы игральных фишек из янтаря и костной ткани существуют уже в вендельскую эпоху. Фишки из рога, кости и даже более редкого вида сырья - китовой кости, без сомнения, стали массовой категорией, о чем свидетельствуют находки из коллективных захоронений в двух кораблях на о. Саарема в Эстонии. По данным изотопного анализа, люди, погребенные на берегу моря неподалеку от деревни Салме в 650-750 гг., были выходцами из Средней Швеции. Отправляясь в дальний морской поход, они захватили с собой 
принадлежности для игры: в одном из кораблей обнаружено 250 полусферических шашек из китовой кости и семь - из моржового клыка. Во втором захоронении найдено 72 фишки из китовой кости и костей быка. Добыча китов была сосредоточена на Атлантическом побережье Скандинавии, межрегиональная торговля этим сырьем в Северной Европе приобрела значительный масштаб уже в вендельскую эпоху (Gustavsson et al., 2015. Р. 51-54; Price et al., 2016. Р. 1022-1037).

Стеклянные фишки характерных для эпохи викингов форм появляются в Северной Европе значительно раньше, чем на Пути из варяг в греки. Самым ранним игральным набором с коническими стеклянными фигурками в настоящий момент является набор из Гуннарсхауг (Рогаланд, Норвегия). Он содержит 16 фишек из глухого стекла: 11 голубых, четыре желтых с коричневым ободком на вершине и экземпляр из синего стекла с коричневой верхушкой, оканчивающейся желтым ободком. Погребение датируют началом IX в. (Från Vikinger till Korsfarare... 1992. S. 123, № 143). Из 18 погребений Бирки с игральными принадлежностями стеклянные фишки обнаружены в одном трупосожжении и четырех камерных погребениях. Все они относятся к позднему периоду Бирки, ограниченному последними десятилетиями IX - 70-ми годами X столетия. X в. в целом датируются стеклянные фишки, найденные и на других скандинавских памятниках, сосредоточенных в основном в Средней Швеции: Вальсерде 3, Лонгтора и Туна (Lindquist, 1984. S. 215-218; Arbman, 1940. Taf. 147, 2; 148, 1, 2). По морфологическим признакам они ничем не отличаются от экземпляров с территории Древней Руси, во многом совпадает и цветовая гамма: в обеих выборках есть монохромные бирюзовые, лиловые, темно-зеленые, оливковые и янтарно-коричневые фишки. Однако среди скандинавских находок пока не зафиксировано случаев использования золотой фольги в декоре, а на территории Древней Руси нет фишек, украшенных накладной спиральной нитью темно-вишневого цвета. Исключение составляют только антропоморфные фигурки «королей» из Шестовицы.

Несмотря на локальные различия в декоре, фишки из Средней Швеции и Древней Руси выполнены по единой технологии и, возможно, в одной мастерской ремесленниками, владевшими сложной и редкой для Руси и Скандинавии техникой производства литых изделий в форме. Локализация этой мастерской (мастерских) невозможна до обнаружения производственных свидетельств. Однако, учитывая факт практически полного отсутствия следов изготовления изделий из стекла в раннегородских центрах Древней Руси (за исключением Старой Ладоги), можно с осторожностью предположить, что стеклянные игральные принадлежности IX - начала XI в. производились в Северной Европе. Не исключено, что благодаря контактам с Ближним Востоком и Ираном, начавшимся уже в VIII в., скандинавы узнали о стеклянных фигурках для игры и стали изготавливать фишки привычной им полусферической формы из красивого и престижного материала, поступавшего на Север Европы в результате дальней торговли.

Настольные игры-нарды и трик-трак на 12 или 24 полях с 30 камешками (фишками) и двумя игральными костями были популярными азартными играми в Центральной Азии и Иране. Играли на деньги; известно, что можно было выиграть огромную сумму - 20 динаров. Религиозные люди подвергали игроков и игры осуждению, называя их порождением сатаны наряду с бегами ослов, псовой охотой, бараньими и петушиными боями. Несмотря на осуждение, запретить азартные игры было невозможно: случайный характер выигрыша символизировал непредсказуемость жизни людей Средневековья (Мец, 1973. С. 324-325). В археологических коллекциях из Музея исламского искусства в Берлине, Метрополитен-музея и других собраний есть игральные фишки из горного хрусталя, гагата, фаянса, кости и рога. Находки стеклянных игральных фишек IX-XI вв. преимущественно конической формы, происходят с территории Ирана, Ирака (Ктесифон, Нишапур, Самарра и Суса), Афганистана и Египта. Есть экземпляры и с округлым верхом, встречаются предметы из мозаичного стекла; в каирском музее хранятся фигурки со следами позолоты (Kröger, 1995. Р. 113, 162; Carboni, 2001. Р. 45. Cat. 1, 13a). Стеклянные фишки из мозаичного стекла обнаружены также в Армении в средневековых Двине и Гарни ${ }^{19}$. Р.М. Джанполадян датировала находки IX-X вв. и предположила, что это импорт из стран Халифата (Джсанполадян, 1974. С. 70, 131).

На сегодняшний день у авторов статьи не сложилось окончательного общего мнения относительно происхождения гнёздовских шашек. Очевидна необходимость дальнейших исследований этой редкой категории находок и расширение аналитической базы по химическому составу стекла игральных фишек из памятников Древней Руси, Скандинавии и Ближнего Востока.

19 Благодарим С.И. Валиулину, указавшую нам на эти находки. 


\section{Литература}

Авдусин Д. А., 1972. Отчет Смоленской экспедиции за 1971 год / Архив ИА РАН. Р-1. № 4629. 211 л.

Авдусин Д.А., Пушкина Т.А., 1987. Отчет Смоленской археологической экспедиции МГУ за 1986 год / Архив ИА РАН. Р-1. № 11966. 175 л.

Авдусин Д.А., Пушкина Т.А., 1988. Отчет о работе Смоленской археологической экспедиции МГУ в 1987 году / Архив ИА РАН. Р-1. № 12251. 174 л.

Авдусин Д.А., Пушкина Т.А., 1989. Отчет о работах Смоленской археологической экспедиции в 1988 году / Архив ИА РАН. Р-1. № 14423. 198 л.

Безбородов М.А., 1956. Стеклоделие в древней Руси. Минск: АН БССР. 306 с.

Бліфельд Д.І., 1977. Давньоруські пам'ятки Шестовиці. Київ: Наукова думка. 235 с.

Галибин В.А., 2001. Состав стекла как археологический источник. СПб.: Петербургское востоковедение. 216 с.

Горюнова В. М., 2016. Городок на Ловати (К проблеме становления города Северной Руси). СПб.: Дмитрий Буланин. 352 с.

Давидан О.И., 1984. Янтарь Старой Ладоги // АСГЭ. Вып. 25. С. 118-126.

Джанполадян Р.М., 1974. Средневековое стекло Двина IX-XIII вв. Ереван: Изд-во АН Армянской ССР. 77 с. (Археологические памятники Армении. Вып. 7).

Ениосова Н. В. Пушкина Т.А., 2012. Находки византийского происхождения из раннегородского центра Гнездова в свете контактов между Русью и Константинополем в X в. // Сугдейский сборник. Вып. 5. Матер. V Судацкой междунар. науч. конф. «Причерноморье, Крым, Русь в истории и культуре» (г. Судак, 23-24 сентября 2010 г.). Киев - Судак: «Горобец» С. 34-85.

Ениосова Н.В., Пушкина Т.А., 2016. Гнёздово как раннегородской центр эпохи формирования Древнерусского государства и некоторые вопросы его интерпретации // ДГВЕ. 2014. Древняя Русь и средневековая Европа: возникновение государств. М. С. 258-303.

Жарнов Ю. Э., 1992. Погребальный обряд в Древней Руси по материалам Гнёздовского некрополя. А-1992. Дисс. ... канд. истор. наук. М.

Захаров С.Д., 2004. Древнерусский город Белоозеро. М.: Индрик. 592 с.

Корзухина Г.Ф., 1954. Русские клады Х-XIII вв. М. - Л.: АН СССР. 226 c.

Корзухина Г. Ф., 1963. Из истории игр на Руси // СА. № 4. C. $85-102$
Ланцетти А.Г., Нестеренко М. Л., 1987. Изготовление художественного стекла. М.: Высшая школа. $304 \mathrm{c}$.

Леонтьев А.Е., 1989. Отчет о работе Волго-Окской экспедиции в 1988 г. / Архив ИА РАН. Р-1. № 12858.55 л.

Мец A., 1973. Мусульманский Ренессанс. М.: Наука. $473 \mathrm{c}$.

Мурашева В.В., Довгалюк Н. П., Фетисов А.А., 2010. Византийские импорты с территории пойменной части Гнёздовского поселения // Краеугольный камень. Археология, история, искусство, культура России и сопредельных стран. Т. 1. М.: Ломоносовъ. С. 512-536.

Носов Е. Н., 1990. Новгородское (Рюриково) Городище. Л.: Наука. 216 с.

Сагайдак М.А., Хамайко Н.В., Вергун О.И., 2008. Новые находки древнерусских игральных фигурок из Киева // Стародавній Іскоростень i слов'янскі гради. 3б. наукових праць. Т. 2. Коростень. С. 137-145.

Станкевич Я.В., 1962. Шестовицкое поселение и могильник по материалам раскопок 1946 года // КСИИМК. Вып. 87. С. 18-35.

Старая Ладога. Древняя столица Руси. Каталог выставки. СПб.: ГЭ, 2003. 183 с.

Столярова Е. К., 2006. Приложение 3. Стеклянные предметы поселения Мякинино I (раскопки 2005 года) // Энговатова А. В., Коваль В. Ю. Отчет об охранных археологических раскопках в Красногорском и Дмитровском районах Московской области в 2005 году. Т. 1 / Архив ИА РАН. Р-1. № 26681. Л. 338-343.

Хамайко Н. В., 2012. Тавлейные короли Х в. // Славяне восточной Европы накануне образования Древнерусского государства. Сб. матер. междун. конф., посвященной 110 годовщине со дня рождения И. И. Ляпушкина (1902-1968). СПб.: Соло. С. 284-288.

Хамайко Н.B., 2012. Гральний набір із заплавного кургану Шестовиці// Архелогия и давняя история Украини. Вип. 8. Коллекціі науковых фондів Институту археології НАН Україны. Джерела та дослїдження. Київ. С. 121-128.

Хамайко Н.В. 2016. Гральні набори 3 розкопок П.І. Смолічева із заплавного могильника Шестовиці // Археологія. № 1. С. 69-78.

Фехнер М.В., Недошивина Н.Г., 1987. Этнокультурная характеристика Тимеревского могильника по материалам погребального инвентаря // СА. № 2. С. 70-89. 
Ширинский С. С., 1968. Курганы полян у с. Седнев // АО 1967. М. С. 239-240.

Щапова Ю.Л., 1983. Очерки истории древнего стеклоделия (по материалам долины Нила, Ближнего Востока и Европы). М.: МГУ. 200 с.

Щапова Ю.Л., 1989. Древнее стекло. Морфология, технология, химический состав. М.: МГУ. 120 с.

Щапова Ю.Л., 1991. Византия и Восточная Европа. Направление и характер связей в IX-XII вв. (по находкам из стекла) // Византия. Средиземноморье. Славянский мир (к XVIII Международному конгрессу византинистов). М.: МГУ. C. $155-177$.

Щапова Ю.Л., 1998. Византийское стекло. Очерки истории. М.: Эдиториал УРСС. 288 с.

Arbman H., 1937. Schweden und das karolingische Reich. Studien zu den Handelsverbindungen des 9. Jahrhunderts. Stockholm. $272 \mathrm{~S}$.

Arbman H., 1940. Birka. Die Gräber. I. Tafeln 1-282. Stockholm.

Arbman H., 1943. Birka. Die Gräber. II. Text. Stockholm. S. I-XXVIII + 529.

Carboni S., 2001. Glass from Islamic lands. NY.: Thames \& Hudson. 416 p.

Davidan O., 1992. Kunsthandwerkliche Gegenstände des 8. bis 10. Jahrhunderts aus Alt-Ladoga // Die Sammlung der stadtlichen Ermitage in St. Petersburg. Köln. S. 5-61.

Davidson G.R., 1952. Corinth XII. The Minor Objects. NY; Princenton. $366 \mathrm{p}$.

Eales R., 2007. Changing Cultures. The Reception of Chess into Western Europe in the Middle Ages // Ancient Board Games in Perspective.L.: British Museum Press. P. 162-167.

Fonnesbech-Sandberg E., 2002. Romerske spillerbrikker og anden import I en sjællandsk fyrstegrav// Dirk - og du vil leve skønt. Festskift til Ulla Lund Hansen på 60-årsdagen. Copenhagen. P. 211-215. (Publications from The National Museum Studies in Archaeology \& History. Vol. 7).

Från Vikinger till Korsfarare Norden och Europa 8001200. Stockholm: Föreningen Norden, 1992. 430 S.

Games. Boards // The Oxford Dictionary of Byzantium. Vol. 2. Oxford: Oxford University Press, 1991. P. 820-821.
Gaut B., 2011. Vessel Glass and Evidence of Glassworking // Things from the town. Artefacts and Inhabitants in Viking-age Kaupang. Oslo: Aarhus University Press \& the Kaupang Excavatijn Project. P. 169-274. (Kaupang Excavation Project Publication Series. Vol. 3. Norske Oldfunn XXIV).

Gogosz R., 2016. «Hver er sterkastr?» The Sports and Games of the Northmen in the Middle Ages. Role, Rules and Aspects: Study with the Special focus on Saga-Age Iceland/Dissertation. Uniwersytet Rzeszowski. Rzeszow.

Gustavsson R., Hennius A., Ljungkvist J., 2015. Are many Vendel and Viking Period gaming pieces made of whalebone? // Fornvännen. 110. P. 51-54.

Kröger J., 1995. Nishapur. Glass of the Early Islamic Period. NY: The Metropolitan Museum of Art. $256 \mathrm{p}$.

Lindquist M., 1984. Spielsteine, Würfel und Spielbretter// Birka II. 1 Systematische Analysen der Gräberfunde. Stockholm. S. 215-218.

Lund Hansen U., 2009. Glass and beads // Sorte Muld. Wealth, power and religion at an Iron Age Central Settlement on Bornholm. Rønne: Bornholms Museum. P. 91-95.

Murray H.J. R., 1978. History of board games other than chess. NY: Hacker. 267 p.

Price D. T., Peets J., Allmäe R., Maldre L., Oras E., 2016. Isotopic provenancing of the Salme ship burials in Pre-Viking Age Estonia // Antiquity. 90. P. 1022-1037.

Riddler J., 2007. The Pursuit of Hnefatafl// Ancient Board Games in Perspective. L.: British Museum Press. P. 256-261.

Rundkvist M., Williams H., 2008. A Viking Boat Grave with Amber Gaming Pieces Excavated at Skamby, Östergötland, Sweden // Medieval Archaeology. 52. P. 69-101.

Semenov G.L., 2007. Board Games in Central Asia and Iran//Ancient Board Games in Perspective. L.: British Museum Press. P. 169-175.

Witte J., 2010. Freizeitbeswchäftingung in Amorium: die Spiele // Byzanz - das Römerreich im Mittelalter. Teil 2, 1 Schauplätze. Mainz. S. 327-392. (Monographien des Römisch-Germanischen Zentralmuseums. Band 84, 2, 1). 


\section{А. А. Гомзин \\ Институт археологии РАН, г. Москва}

\section{Вторая часть Мшагского клада куфических монет}

В 2016 г. в окрестностях деревень Мшага Воскресенская и Мшага Ямская Шимского р-на Новгородской обл. найден клад серебряных куфических монет. Общие размеры находки остались невыясненными, известно лишь, что речь может идти о двух-трех десятках экземпляров. В Новгородский государственный объединенный музей-заповедник поступило 17 дирхамов.

Состав выборки: Умайады-2, Аббасиды-12, Аглабиды - 1, Идрисиды-1, неопределенные 1 экземпляр. Старшим являлся один из двух мелких фрагментов умайадских дирхамов, чьи выпускные сведения однозначно не восстанавливаются. Младшим - Аббасиды, ал-Ма'мун, Ма'дан Баджунайс, 210 г. х. (825/826 г.) (Гомзин, 2017. С. 95-104).

После сдачи статьи о кладе в печать нам удалось ознакомиться еще с девятью монетами, входившими в его состав (рис. 1). Характерная сохранность и насечки (царапины) на большинстве экземпляров подтверждают, что они действительно могут относиться к указанной находке.

В этой части, как и в первой, большинство (семь дирхамов) принадлежит чекану Аббасидов, а в качестве «примеси»-по одной монете Идрисидов и современников Идрисидов. Целыми являются три дирхама (Список монет, № 1, 5, 8). Остальные представлены фрагментами, из которых три обломка (Список монет, № 2, 4, 9), один обрезок (Список монет, № 3), еще два получены в результате сочетания обрезывания и обламывания монетной пластины (Список монет, № 6, 7). В первой части клада выявлены аналогичные способы фрагментации при доминировании обломков (Гомзин, 2017. С. 96).

Старшая монета выборки - Аббасиды, алМансур, ар-Райй, 147 г.х. (764/765 г.) (Список монет, № 1). Младшая - Аббасиды, ал-Му“тасим биллах, ал-Мухаммадийа, 226 или 227 г. х. (840/841 или 841/842 г.) (Список монет, № 7). Ее же следует считать и младшим дирхамом всего клада. Несмотря на временной разрыв с младшим экземпляром пер- вой части, такое возможно, учитывая выявленные особенности в виде небольшого размера, преобладания фрагментов над целыми дирхамами и размытый хронологический состав. И это нисколько не противоречит определенной ранее датировке клада, распространявшейся на 840-е годы включительно (Гомзин, 2017. С. 96, 98). Теперь же она может быть ограничена именно этим десятилетием.

Из аббасидских монет второй части одна выпущена в правление халифа ал-Мансура, две - при ал-Махди, три - в правление Харуна ар-Рашида и одна - при ал-Му“тасиме. Номенклатура мест выпуска пополнилась не отмеченными ранее дирхамами Шаша и Заранджа (Список монет, № 4, 5; табл. 1). Появились и два экземпляра столичной чеканки (Список монет, № 2, 6; табл. 1). При этом выявленная особенность, заключавшаяся в преобладании дирхамов ал-'Аббасийи, сохраняется (табл. 1) (Гомзин, 2017. С. 98).

Отдельно стоит отметить две монеты, в связи с чем в списке приведено их описание, более подробное по сравнению с остальными. Первая - аббасидский дирхам Мадинат Заранджа 190 г.х. (805/806 г.) (Список монет, № 5). Монетный двор в Зарандже, главном городе области Сиджистан (Систан), достаточно интенсивно работал при Харуне ар-Рашиде и выпускал серебряную монету (Lowick, 1996. Р. XXVII). В то же время в восточноевропейских кладах его дирхамы встречаются нечасто.

В материалах бассейнов Ильменя и Волхова четыре монеты Заранджа входили в состав клада 1920 г. из окрестностей Кирилловского (Кириллова) монастыря (младшие дирхамы 250 г.х. (864/865 г.)) (Бауер, 2014. С. 108, № 13; Кропоткин, 1971. С. 82, № 50; Пахомов, 1926. С. 79, № 264, место указано неверно; Фасмер, 1925. С. 242-276; 1926. С. 291, № 28). Девять дирхамов содержатся в крупном (1257 экз.) Шумиловском кладе 1927 г. (младшие монеты 257 г. х. (870/871 г.)) (Бауер, 2014. С. 109, 

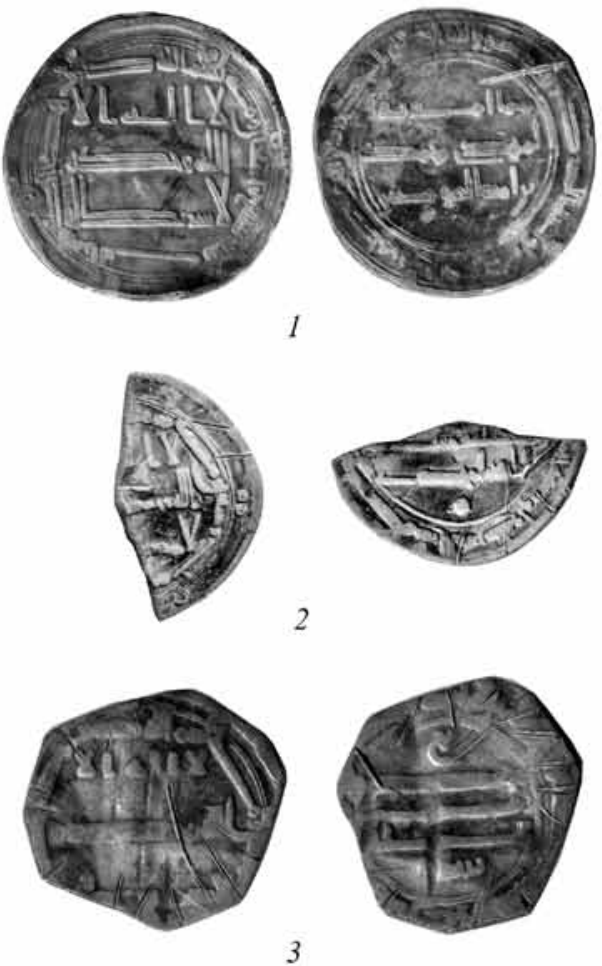

3
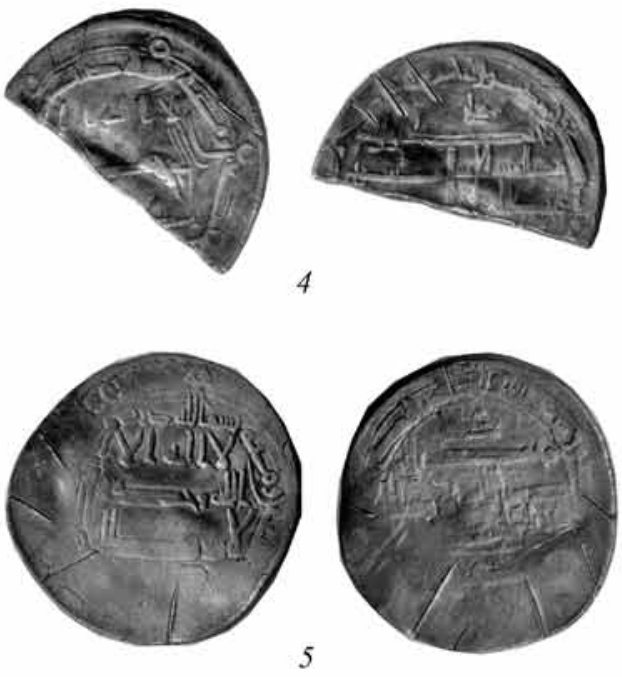
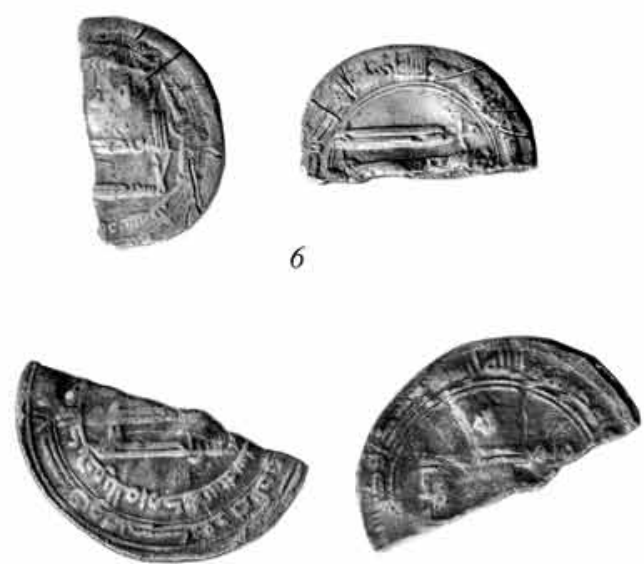

7
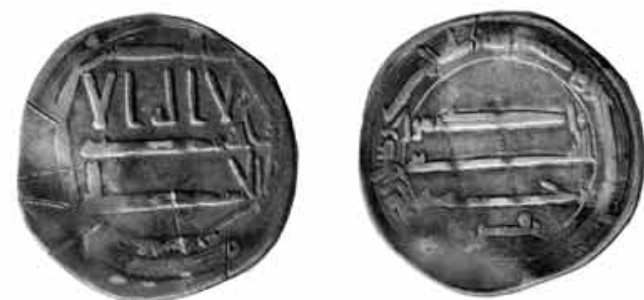

8
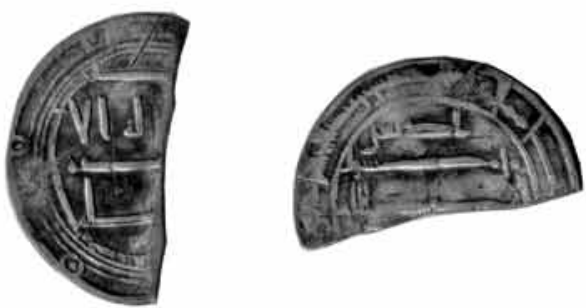

9

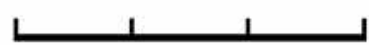

Рис. 1. Монеты второй части Мшагского клада

№ 21; Кропоткин, 1971. С. 83, № 56; Кулешов, 2011. С. 191-231; Пахомов, 1949. С. 94, № 1305; 1966. С. 110-112, № 2159; Янин, 1960. С. 142, № 1). Еще один экземпляр попал в Новгородский клад 1903 г. (младшая монета 341 г.х. (952/953 г.)) (Бауер, 2014. С. 120, № 34; Быков, 1925. С. 133-139; Кропоткин, 1971. С. 82, № 49; Фасмер, 1926. С. 290, № 25). Возможно, какое-то количество обнаружится в кладах, чей помонетный состав остается не введенным в научный оборот. Пока же стоит отметить, что среди перечисленных совсем нет заранджских дирхамов 190 г.х., и Мшагский клад оказывается первым содержащим монету этого года выпуска и одновременно наиболее ранним из комплексов указанного региона, где присутствует продукция данного места чеканки.

Второй дирхам выпущен в Тудге в 179 г.х. (795/796 г.) и на оборотной стороне несет имя Зуфара (Список монет, № 8). Тудга располагалась в южной части Дальнего ал-Магриба, недалеко 
от серебряных месторождений Тамдалта, и являлась оплотом суфритов, умеренного течения хариджитов, пока не попала под контроль Идрисидов (Cressier, García-Arenal, 1998. Р. 382). В правление Идриса б. 'Абдаллаха и Идриса б. Идриса в Южном Марокко имела место эпизодическая чеканка серебряной монеты от имени локальных правителей хариджитского, суфритского и ибадитского течений. Примером этому является рассматриваемый дирхам, хотя кем именно был Зуфар, неизвестно (Album, 2011. Р. 75, А433).

Если дирхамы Идрисидов периодически встречаются в восточноевропейских кладах IX в., то монеты местных владетелей южной части Дальнего ал-Магриба значительно более редки. В Приильменье и Поволховье только два самых крупных клада, Шумиловский 1927 г. и Любыньский 1972 г. (2361 экз., младшая монета 260 г. х. (873/874 г.)), содержали по одному подобному экземпляру с именами Мусы и Халафа соответственно (Кулешов, 2011. С. 194; Фомин, 2003. С. 70; Noonan, Kovalev, 2002. С. 152-153). Дирхам же Зуфара встречается в кладовом комплексе региона впервые.

Вторая часть Мшагского клада по-прежнему позволяет усматривать сходные черты и коррелировать его с Демянским кладом 1833 г. (младшая монета 209 г.х. (824/825 г.)), аналогично относящимся к периоду второй четверти IX в. (Бауер, 2014. С. 101, № 11; Гомзин, 2017. С. 98; Григорьев, 1844. С. 140, № 78; Марков, 1910. С. 28, № 154; Френ, 1842. С. 70, № 9). Кроме указанных двух в Поволховье к этому же периоду принадлежит Староладожский клад 1938 г. с младшей монетой 232 г.х. (846/847 г.). Его подробный состав остается неизвестным, но обращают на себя внимание аналогично небольшие размеры и преобладание фрагментов над целыми дирхамами, 18 и 5 экземпляров соответственно (Бауер, 2014. С. 107, № 8а; Кропоткин, 1971. С. 82, № 44; Носов, 1976. С. 100-102, прим. 23; Пахомов, 1949. С. 93, № 1302).

Как и в первой, во второй части Мшагского клада не зафиксировано ни одной монеты аббасидского халифа ал-Мутаваккила 'ала-ллаха (232-247 гг. х./847-861 гг.), чье присутствие в восточноевропейских комплексах второй половины IX в. достаточно представительно. Учитывая это и время чеканки младшего дирхама, датировка рассматриваемой находки может быть теперь ограничена 840-ми гг. Хронологическое и географическое распределение подтверждает сделанный ранее вывод о том, что клад относится к комплексам без целенаправленного накопления, а фрагментированность основной массы монет и наличие насечек (царапин) позволяют предполагать его значимость для владельца в первую очередь как источника драгоценного металла.

\section{Список монет второй части Мшагского клада}

\section{Аббасиды}

1. Ал-Мансур, ар-Райй, 147 г.х. (764/765 г.) (Тизенгаузен, 1873. С. 76, № 764; Lowick, 1996. Р. 228-229, № 2002). Вес 2,85 г; размер 25,32× 24,54 мм. Целый. Край погнут и немного искрошен. С о.с. по краю одна насечка (царапина) ${ }^{1}$.

2. Ал-Махди, место чеканки отломлено, по типу Мадинат ас-Салам, 163 г.х. (779/780 г.) (Тизенгаузен, 1873. С. 101, № 934; Lowick, 1996. Р. 158-159, № 1231). Вес 1,24 г; размер 21,68×12,54 мм. Обломок около $1 / 2$. Немного погнут. С л. с. по краю две насечки (царапины). С о.с. по краю четыре насечки (царапины) и еще одна у линии слома.

3. Ал-Махди, место чеканки и единицы года обрезаны, по типу и палеографии - ал-“Аббасийа, 16x г.х., в поле о.с. под символом - Йазид. Вес 1,48 г; размер 22,12×21,08 мм. Обрезан по периметру в форме многоугольника примерно до 2/3 целой монеты. Немного деформирован. С л.с. по краю 11 насечек (царапин) и еще одна раздваивающаяся у одного из концов в поле. В поле также множество мелких царапин разной глубины и размеров, образующих сложный взаимопересекающийся конгломерат линий, которые могут восприниматься как граффити. С о.с. по краю 14 насечек (царапин) и еще одна в поле. В поле также множество мелких царапин разной глубины и размеров, образующих сложный взаимопересекающийся конгломерат линий, которые могут восприниматься как граффити.

4. Харун ар-Рашид, место чеканки отломлено, по типу - Ма'дан аш-Шаш, 190 г.х. (805/806 г.) (Тизенгаузен, 1873. С. 165, № 1478; Lowick, 1996. Р. 296-297, № 2733-2735, но число ободков на л.с. три + один внешний). Вес 2,06 г; размер

\footnotetext{
${ }^{1}$ В описании монет приведены династическая принадлежность, эмитент, место и год чеканки, вес, размеры и степень сохранности. Когда возможно, указан тип экземпляра по литературе. Утраченные выпускные сведения восстанавливались, ориентируясь на содержание легенд, взаимное расположение их элементов, дифференты в поле л.с. и о.с., особенности палеографии надписей и сверяясь с однотипными и одноштемпельными экземплярами лучшей сохранности. Номера монет на иллюстрации соответствуют порядковым номерам в списке.
} 
Таблица 1. Географическое распределение монет Мшагского клада

\begin{tabular}{|l|c|c|c|}
\hline \multirow{2}{*}{ Место чеканки } & \multicolumn{2}{|c|}{ Количество, экз. } & \multirow{2}{*}{ Общее количество, экз. } \\
\cline { 2 - 4 } & 1-я часть & 1 & 5 \\
\hline Ал-'Аббасийа & 4 & - & 1 \\
\hline Ифрикийа & 1 & - & 1 \\
\hline Ма'дан Баджунайс & 1 & 1 & 1 \\
\hline Ма'дан аш-Шаш & - & - & 2 \\
\hline Мадинат Балх & 2 & - & 1 \\
\hline Мадинат Джайй & 1 & 1 & 1 \\
\hline Мадинат Зарандж & - & - & 1 \\
\hline Мадинат Исбахан & 1 & - & 2 \\
\hline Мадинат Марв & 1 & 2 & 3 \\
\hline Мадинат ас-Салам & - & 2 & 3 \\
\hline $\begin{array}{l}\text { Ал-Мухаммадийа } \\
\text { (ар-Райй) }\end{array}$ & 1 & 2 & \\
\hline Тудга & 1 & & \\
\hline
\end{tabular}

$22,94 \times 22,2$ мм. Обломок около 2/3. Немного деформирован. С л.с. по краю три насечки (царапины) и еще две у линии слома. С о.с. по краю четыре насечки (царапины).

5. Харун ар-Рашид, место не прочеканено, по типу - Мадинат Зарандж, 190 г.х. (805/806 г.) (Тизенгаузен, 1873. С. 166, № 1488; Lowick, 1996. P. 272-273, № 2460). Вес 3,34 г; размер 25,34× 24,92 мм. Целый. О. с. с двойным ударом. Небрежно отчеканен. Немного погнут. С л. с. по краю четыре насечки (царапины). С о. с. по краю семь насечек (царапин) и еще одна в поле.

Дифференты: о-оо-[о-оо-о]-оо, отделены от круговой легенды л.с. двойным ободком.

Поле л.с.: первая часть символа веры в три строки. Выпускные сведения круговой легенды: تسعين و مئة

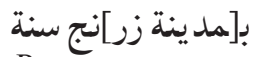

Верх поля о.с.: علئي

Поле о.с.: الله / صلى الله عليه و سلم / [الخليفة الرّشيد

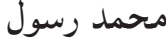

Низ поля о.с.: [الق]وحمي]

Круговая легенда о.с.: Коран, IX, 33 (фрагменты), отделена от поля ободком.

6. Харун ар-Рашид, Мадинат ас-Салам, 193 г.х. (808/809 г.) (Тизенгаузен, 1873. С. 170-171, № 1530; Lowick, 1996. Р. 170-171, № 1383). Вec 1,51 г; размер 20,34×11,66 мм. Фрагмент (обрезок-обломок) около $1 / 2$. Край немного искрошен. С л. с. по краю шесть насечек (царапин) и еще одна у линии слома. C о.с. по краю шесть насечек (царапин) и еще одна у линии слома.
7. Имя эмитента, сотни и десятки года отломлены, ал-Мухаммадийа, хx6 или хx7 г.х., по типу и палеографии - ал-Му'тасим биллах, 226 или 227 г.х. (840/841 или 841/842 г.) (Марков, 1896. C. 100, № 69 или № 72, указаны как тахиридские выпуски). Вес 1,51 г; размер 25,04×18,32 мм. Фрагмент (обрезок-обломок) около 1/2. Немного деформирован.

Идрисиды и их современники

8. Зуфар, Тудга, 179 г. х. (795/796 г.) (Album, 2011. P. 75, А433). Вес 3,12 г; размер 24,68×24 мм. Целый. Край немного деформирован. С л.с. по краю пять насечек (царапин). С о. с. по краю одна насечка (царапина) и еще одна в поле.

Дифференты: из-за сдвига штемпеля и повреждений видны только о ... о, отделены от круговой легенды л.с. двойным ободком.

Поле л.с.: первая часть символа веры в три строки. Выпускные сведения круговой легенды: سبعين و مئة بتدغة سنة تسع و

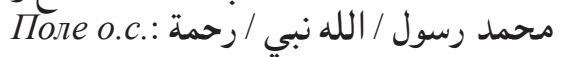

Низ поля о.с.: زبة

Круговая легенда о.с.: Коран, IX, 33 (фрагменты), отделена от поля ободком.

9. Идрис б. Идрис, Тудга, год чеканки отломлен, по типу - 176-178 гг. х. (792-795 гг.), с именем Идриса б. 'Абдаллаха в круговой легенде о.с. Вес 1,3 г; размер $24,92 \times 15,66$ мм. Обломок около $1 / 2$. Немного деформирован. Трещина у линии слома. С л. с. по краю три насечки (царапины). C о.с. по краю две насечки (царапины). 


\section{Литература}

Бауер Н. П., 2014. История древнерусских денежных систем IX в. - 1535 г. / Под ред. П. Г. Гайдукова. М.: ООО «Русское слово-учебник». CXXIV + 692 с.: ил.

Быков A.A., 1925. Клад серебряных куфических монет, найденный в Новгороде в 1903 г.// ИРАИМК. Т. ІV. Л. С. 133-139.

Гомзин А.А., 2017. Клад куфических монет 2016 года из Новгородской области // Памятники средневековой археологии Восточной Европы. К юбилею М.Д. Полубояриновой. М.: ИА РАН, 2017. С. 95-104.

Григорьев В.В., 1844. О куфических монетах VIII, IX, X и отчасти VII и XI века, находимых в России и прибалтийских странах, как источник для древнейшей отечественной истории // ЗООИД. Т. І. Одесса. С. 115-166.

Кропоткин В.В., 1971. Новые находки сасанидских и куфических монет в Восточной Европе // НЭ. Т. IX. М.: Наука. С. 76-97.

Кулешов Вяч.С., 2011. Шумиловский клад // НЭ. Вып. XVIII. М.: Памятники исторической мысли. С. 191-231.

Марков А. К., 1896. Инвентарный каталог мусульманских монет Императорского Эрмитажа. СПб. 872 с.

Марков А. К., 1910. Топография кладов восточных монет (сасанидских и куфических). СПб. 148 с.

Носов Е. Н., 1976. Нумизматические данные о северной части Балтийско-Волжского пути конца VIII-X в. // ВИД. Т. VIII. Л.: Наука, Ленингр. отд-ние. С. 93-110.

Пахомов Е.А., 1926. Монетные клады Азербайджана и Закавказья. Вып. І. Баку. 100 с.

Пахомов Е. А., 1949. Монетные клады Азербайджана и других республик, краев и областей Кавказа. Вып. IV. Баку: Изд-во АН АзССР. 116 с.
Пахомов Е. А., 1966. Монетные клады Азербайджана и других республик, краев и областей Кавказа. Вып. IX. Баку: Изд-во АН АзССР. 124 с.

Тизенгаузен В.Г., 1873. Монеты Восточного халифата. СПб. 428 с.

Фасмер Р.P., 1925. Клад куфических монет, найденный в Новгороде в 1920 г. // ИРАИМК. T. IV. Л. С. 242-276.

Фасмер Р.Р., 1926. Список монетных находок, зарегистрированных секцией нумизматики и глиптики Академии истории материальной культуры в 1920-1925 гг. // СГАИМК. Т. І.Л. С. 287-308.

Фомин А.В., 2003. Новгородские клады куфических монет IX в. // Одиннадцатая ВНК. Тез. докладов и сообщений. СПб.: Изд-во Гос. Эрмитажа. С. 69-70.

Френ Х.M., 1842. О восточных монетах, находимых в России // Сын Отечества. Журнал истории, политики, словесности, наук и художеств. Кн. 7 (июль). С. 51-100.

Янин В.Л., 1960. Монетные клады Новгородского музея // НЭ. Т. II. М.: Изд-во АН СССР. C. 141-154.

Album S., 2011. Checklist of Islamic Coins. Third Edition. Santa Rosa. 324 p.

Cressier P., García-Arenal M., 1998. Genèse de la ville islamique en al-Andalus et au Maghreb occidental. Madrid: Casa de Velázquez. 403 p.

Lowick N., 1996. Early 'Abbāsid Coinage. A Type Corpus. 132-218 H/AD 750-833. London [stopped in press]. 521 p., 29 pl.

Noonan T.S., Kovalev R.K., 2002. Клад 873/74 гг. из Любыни: войны и захоронение кладов в эпоху Рюрика // Клады: состав, хронология, интерпретация. Материалы тематической научной конференции. СПб. С. 152-156. 


\section{А.А. Медынцева \\ Институт археологии РАН, г. Москва}

\section{Еще раз о Воймерицком кресте}

Древнерусский крест с надписью, названный так по месту обнаружения у д. Воймерицы на р. Мсте Боровичского уезда Новгородской губернии, известен в литературе с начала XIX в. Впервые цинкографическое изображение креста с надписью было опубликовано в 1903 г. А.А. Спицыным. Но стал он известен специалистам несколько ранее, когда во время подготовки задуманного И.А. Шляпкиным свода древнерусской эпиграфики были разосланы по губерниям письма-запросы об имеющихся древностях. Вероятно, тогда им и были получены сведения о трех каменных крестах (один из них с надписью), находящихся на погосте часовни свв. Петра и Павла и Рождества Богородицы, возле с. Воймерицы. И.А. Шляпкин изучил кресты и произвел раскопки некоторых погребений в окрестностях Воймериц. Тогда же были сделаны первые фотографии креста, зарисовки надписи и планы-схемы места обнаружения. Уже в это время И. А. Шляпкин правильно прочитал надпись (за исключением первых двух букв имени), датированную им не позднее XIII в. Это же прочтение с цинкографическим изображением помещено в упомянутом труде А.А. Спицына (1903. С. 205, 208. Рис. 322). Таким образом, первое издание креста осуществил А.А. Спицын, хотя обследование, прочтение и фотофиксация впервые сделаны И. А. Шляпкиным. Он посчитал, что кресты (с надписью и два маленьких без надписей, хранившиеся там же, на галерее у часовни), несомненно, надгробные, и даже раскопал одну из сопок, находившихся поблизости, более разрушенную, но погребений не обнаружил (см.: Михеев, 2012. С. 11).

Оба исследователя читали надпись следующим образом: «... роуславоу и Лазареви братьл и м(а)ти Мирослава поставили хрсть. Славоне дылале».

И. А. Шляпкин в 1906 г., уже после публикации А.А. Спицына, воспроизвел это же изображение в своем труде «Древние русские кресты» (Шляпкин, 1906. С. 9. Табл. ХІ. [Рис.] 322). Однако бо- лее широкую известность Воймерицкий крест получил позднее в результате включения сведений о нем А.С. Орловым в «Библиографию русских надписей», впервые вышедшую в 1936 г. и переизданную в 1952 г. с дополнениями М.А. Сотниковой (Орлов, 1936. С. 64. № СІІ; 1952. С. 76-77. № 102). В прочтении А.С. Орлова надпись выглядит следующим образом: «(м)ироуславоу и лазареви | братья и мти миро|слава поставили хрст | славоне | дълале». Надпись на Воймерицком кресте А.С. Орлов датировал XIII в. без палеографического и исторического комментария. Вместе с тем он тоже предположил, что крест, вероятно, надгробный. Это же прочтение и датировку принял Б.А. Рыбаков в капитальном труде «Ремесло Древней Руси» (Рыбаков, 1948а. С. 418-419; 19486. С. 159-160).

Таким образом, опубликованный вариант креста и надписи, кажется, прочно вошел в фонд изданных каменных крестов с древнерусскими надписями. Некоторые разногласия вызывало лишь сочетание и интерпретация имен, как и объяснение родственных взаимоотношений упомянутых в них лиц. В тексте названо четыре имени - три мужских и одно женское: Богуслав, Лазарь, Мирослава, Славоне. Особенно непонятным являлось последнее - Славоне, в котором некоторые исследователи допускали упоминание жителей новгородской Славоней (Славней) улицы, коллективно поставивших памятный крест лицам, перечисленным в первых строках надписи. Если изданный вариант надписи прочно вошел в научную литературу, то сам оригинал претерпел немало перемещений и испытаний до тех пор, пока в начале 1970-х гг. прошлого века заботами Л.И. Петровой его не перевезли с места обнаружения в фонды Новгородского исторического музея. Однако даже в музее он какое-то время был труднодоступен для изучения, так как находился в скверике возле Грановитой палаты в лежачем положении, обернутый надписью вверх. 
В настоящее время крест представлен в экспозиции музея (КП № 31397 - по: Михеев, 2012. С. 7). Но еще долгое время надпись на нем не привлекала внимания исследователей, хотя, вероятно, обрабатывалась сотрудниками новгородского музея для учета и регистрации. Лишь в 1995 г. А.А. Зализняк, обратившийся непосредственно к подлиннику, включил небольшой, но необычайно содержательный параграф «Надпись на Воймерицком кресте» в монографию «Древненовгородский диалект» (1995. С. 374; 2004. С. 457-458). Следуя надписи на музейной этикетке 1970-х гг., авторство которой не установлено (Михеев, 2012. Прим. 40 на с. 18), он прочел первое имя как Б(о)гоуславоу.

Это прочтение неизвестного автора принял А.А. Зализняк, допустив, что первое имя написано с сокращением, хотя титло над ним отсутствует. Но главным было не столько прочтение имени, сколько убедительное объяснение слова «славоне», что позволило прочесть последние две строки надписи как имя изготовителя-Славоне дылале (Славон делал). Окончание -е в Им. пад. ед. числа

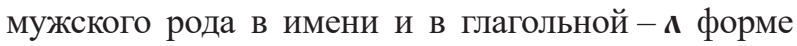
(дtлале) он привел как пример отражения древненовгородского диалекта, что не оставляет сомнения в новгородском происхождении мастера. Время появления этой надписи он отнес к более раннему времени и предложил дату XII в., основываясь на графико-орфографических особенностях. Одновременно прояснилось назначение креста как памятного, так как для надгробной надписи текст весьма необычен и более всего, по мнению исследователя, напоминает тексты на скандинавских рунических камнях, поставленных в память родственников, нередко людям, погибшим вдалеке от дома.

В 2010-2011 гг. крест, к тому времени уже врытый вертикально, обследовали и сфотографировали А.А. Гиппиус и С.М. Михеев, после чего почти одновременно вышли две статьи, ему посвященные: Т.В. Рождественской (2011) и С. М. Михеева (2012). Оба автора принимают прочтение А.А. Зализняка, (Б)гоускавоу и $\mathbf{\Lambda а - ~}$ зоревн Братья н мтн Мнрослава поставнин Хрст Gкавоне А тья и мать Мирослава поставили крест. Славон делал), но в датировке и объяснении формуляра надписи и историко-культурных традиций, отраженных в этом памятнике, наблюдаются значительные расхождения. Т.В. Рождественская при датировке надписи, опираясь на широкий круг эпиграфических источников, включающий и южнославянские лапидарные памятники, приходит к мнению, что, хотя в почерке мастера Славона отражаются традиционные начертания X-XII вв., сам крест датируется приблизительно второй половиной XI-XII в., так как мастер ориентировался на более древние надписи. По ее мнению, традиция нанесения памятных надписей находится на пересечении двух меморативных традиций: древнерусской летописной и традиции скандинавского кенотафа-мемориального памятника, ставившегося обычно погибшим на чужбине воинам (Рождественская, 2011. С. 390).

Обширная статья С. М. Михеева (2012) интересна прежде всего подробным и тщательным описанием истории обнаружения креста, его изучения и длительного процесса перемещения памятника с места находки в фонды Новгородского музея, где он далеко не сразу нашел свое законное место в экспозиции. Эта история, продлившаяся в общей сложности немногим меньше ста лет, изложена со всей тщательностью и обращением к архивным материалам, с публикацией архивных данных и ссылками на все имеющиеся публикации по истории вопроса, включая заметки в местной прессе. В статье приведены и данные петрографического анализа камня, послужившего материалом для изготовления памятника, происходящего из местного минералогического комплекса Валдайской возвышенности. Но изучением истории обнаружения и изучения креста С. М. Михеев не ограничивается. Излагая версии прочтения и датировки надписи и следуя прочтению А.А. Зализняка, он отмечает новые детали в вырезанном тексте: в частности, то, что буква ь во 2-й строке была первоначально задумана как ъ, на что указывает наличие небольших выемок слева от ь (рис. 1). Таким образом, С. М. Михеев предполагает, что мастер имел намерение использовать одноеровую графику, но затем резчик изменил намерение и вырезал, также им отмечено, что в конце 2-й строки, вероятно, резчиком была намечена буква $\mathbf{6}$.

Он отмечает и более неглубокую резьбу крестика, вырезанного над надписью. Кроме того, в надписи есть два места, где, вероятно, резчиком при разметке были тонко намечены штрихи, позднее не вырезанные. Эти штрихи обозначены им на прориси тонкими пунктирными линиями. Предполагаемая первичная одноеровость, как известно, свойственная некоторым древнейшим новгородским письменным памятникам, вероятно, по мысли С. М. Михеева, должна подкрепить архаичность надписи. Но в данном случае это наблюдение, скорее всего, свидетельствует о первичной черновой разметке надписи. Далее С.М. Михеев подробно рассматривает все палеографические особенности 

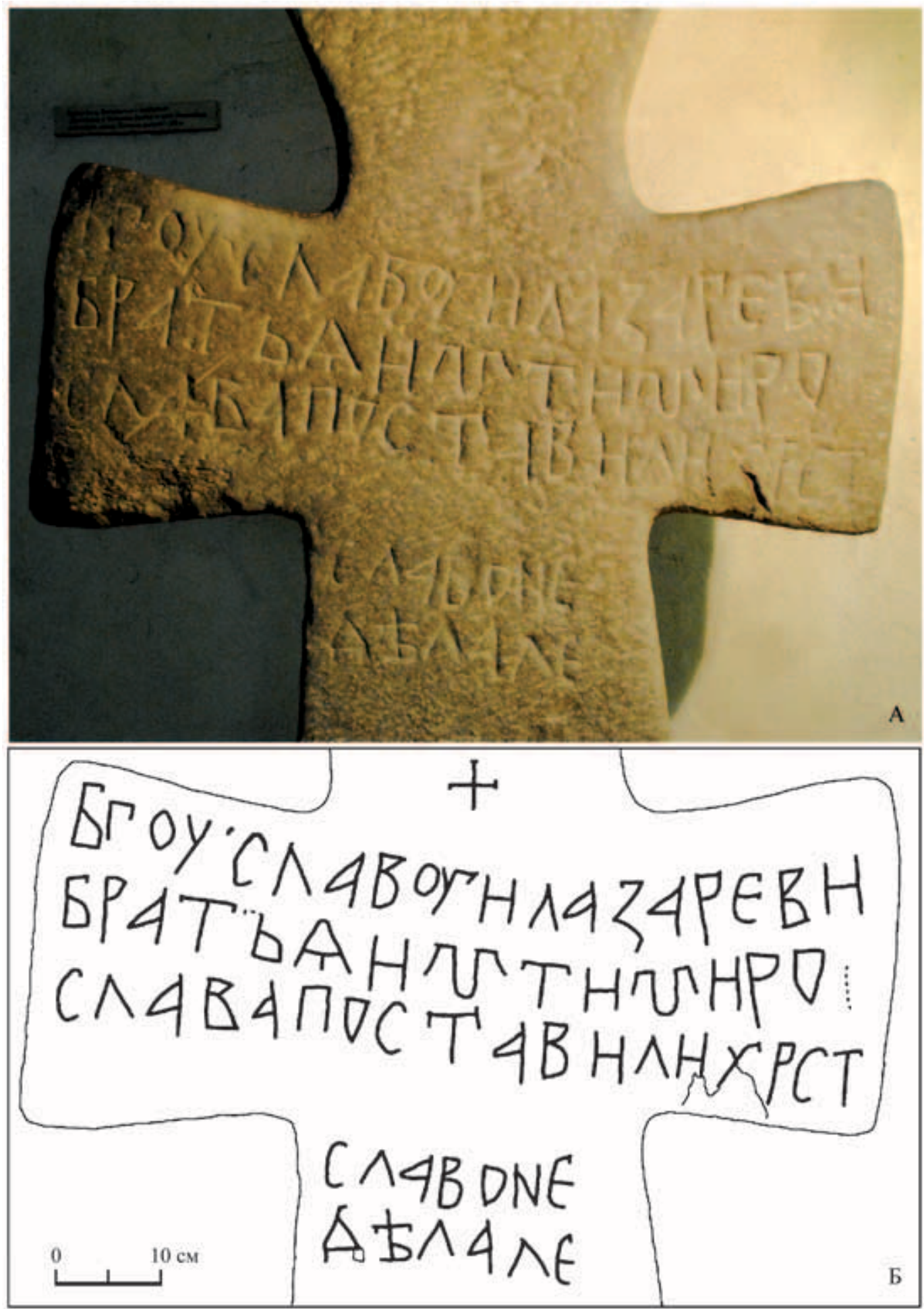

Рис. 1. Надпись на Воймерицком кресте

А - надпись на Воймерицком кресте (фото А. А. Гиппиуса и С. М. Михеева);

Б - надпись на Воймерицком кресте (прорись С. М. Михеева) 
надписи, сравнивая их в основном с материалом новгородских берестяных грамот по методике, разработанной А.А. Зализняком, но обращаясь к материалу и других письменных памятников. Нет смысла в короткой заметке повторять все аргументы, подробно рассмотренные в статье. Достаточно привести вывод, к которому он приходит: надпись должна датироваться временем до 1120 г. по материалу берестяных грамот. Но так как фонд берестяных грамот XI в. невелик, исследователь обращается к другим памятникам эпиграфики, находя аналоги в надписях на русских монетах конца X - начала XI в.: подписи Анны Ярославны 1063 г.; некоторым ранним граффити Софии Киевской; граффито Софии Новгородской; надписи XI в; надписи на кресте из с. Преградного на Северном Кавказе; пергаменной рукописи Жития Кондрата конца X-XI в. С. М. Михеев справедливо полагает, что основными датирующими моментами в надписи на кресте обладают буквы $\boldsymbol{A}$ и $\boldsymbol{\boldsymbol { R }}$. Он отмечает, что подобные начертания букв а и в регулярно встречаются в болгарских надписях IX-XI вв. и в русских памятниках конца $\mathrm{X}$ - первой половины XI в., хотя таких памятников немного; изредка встречаются в третьей четверти XI в. (в работе представлены таблицы начертаний этих букв в упомянутых памятниках). Исходя из комплекса наблюдений над палеографией надписи, С.М. Михеев приходит к выводу, что надпись на Воймерицком кресте выполнена примерно в первой половине XI в., а резчик надписи на Воймерицком кресте Славон учился грамоте не позже первой трети XI в. (Михеев, 2012. С. 25-27).

Таким образом, две последние по времени работы о Воймерицком кресте значительно удревняют его появление. Вместо принятой ранее датировки XII (И.А. Шляпкин, А.А. Спицын) или XIII в. (А.С. Орлов) он принадлежит к XII в., по мнению Т.В. Рождественской, или к концу X-первой половине XI в. по датировке С. М. Михеева. Оба исследователя считают возможным видеть в создании памятного креста с надписью отражение скандинавской традиции создания памятных камней-кенотафов.

Кажется, после прочтения надписи А. А. Зализняком и двух последовательно вышедших статей упомянутых выше исследователей этот памятник наконец получил должное исследование с исчерпывающими комментариями и качественное воспроизведение, теперь уже нечего добавить к его изучению. Но некоторые вопросы все же остаются. Во-первых, неясно прочтение первого имени как Бгуслав (Богуслав), предполагающее написание первого имени (вероятно, главного ктитора) под титлом, в то время как все остальные имена написаны полностью, развернуто. Т.В. Рождественская объясняет это необычное сокращение главного имени тем, что «первая основа имени Богуслав ассоциировалась со словом Бог и поэтому резчик привычно использовал титло» (Рождественская, 2011. С. 385). Как и А.А. Зализняк, она замечает, что титла, вероятно, были и над словами мти и хрсть (Рождественская, 2011. С. 384). С. М. Михеев также читает первое имя как «Бгуслав», но при этом отмечает, что титла во всей надписи отсутствуют (Михеев, 2012. С. 20). Между тем существует еще одно прочтение первого имени, которое не было (и не могло быть) известно исследователям, так как не нашло отражения в публикациях и архивных материалах. Речь идет о прочтении Т.В. Николаевой, которое было оглашено в отзыве на мою работу в начале 1980 -х на заседании сектора славяно-русской археологии Института археологии РАН. В свое время я не обратила на него должного внимания и лишь недавно, после выхода статей Т.В. Рождественской и С.М. Михеева, обнаружила рукописный вариант отзыва в своем личном архиве и предлагаю сейчас вниманию научной общественности часть его, касающуюся прочтения надписи на Воймерицком кресте (рис. 2). В нем говорится, что в 1967 г. Т. В. Николаева обследовала этот крест, лежащий в то время в скверике возле Грановитой палаты, и прочла надпись иначе, чем было принято ранее:

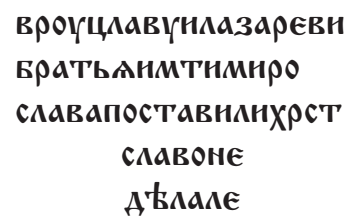

В этой наскоро сделанной карандашной прориси привлекает новое прочтение первого имени - Вруиялаву, на которое я не обратила в то время должного внимания в основном из-за чтения пятой буквы первого имени как Ц довольно позднего облика, в то время как надпись на кресте вполне очевидно относилась к более раннему времени. В настоящее время ясно, что эта буква - результат зрительного объединения написания предыдущей буквы \ с длинным горизонтальным отворотом справа вверху и засечкой на конце этого отворота (см. отчетливо читаемую У в конце этого имени - так называемую с крючочком) и присоединения следующей буквы $\mathbf{G}$. Но прочтение имени в целом заслуживает внимания, хотя и с небольшой поправкой, а именно Вроуславу. В древнерусских именословах 


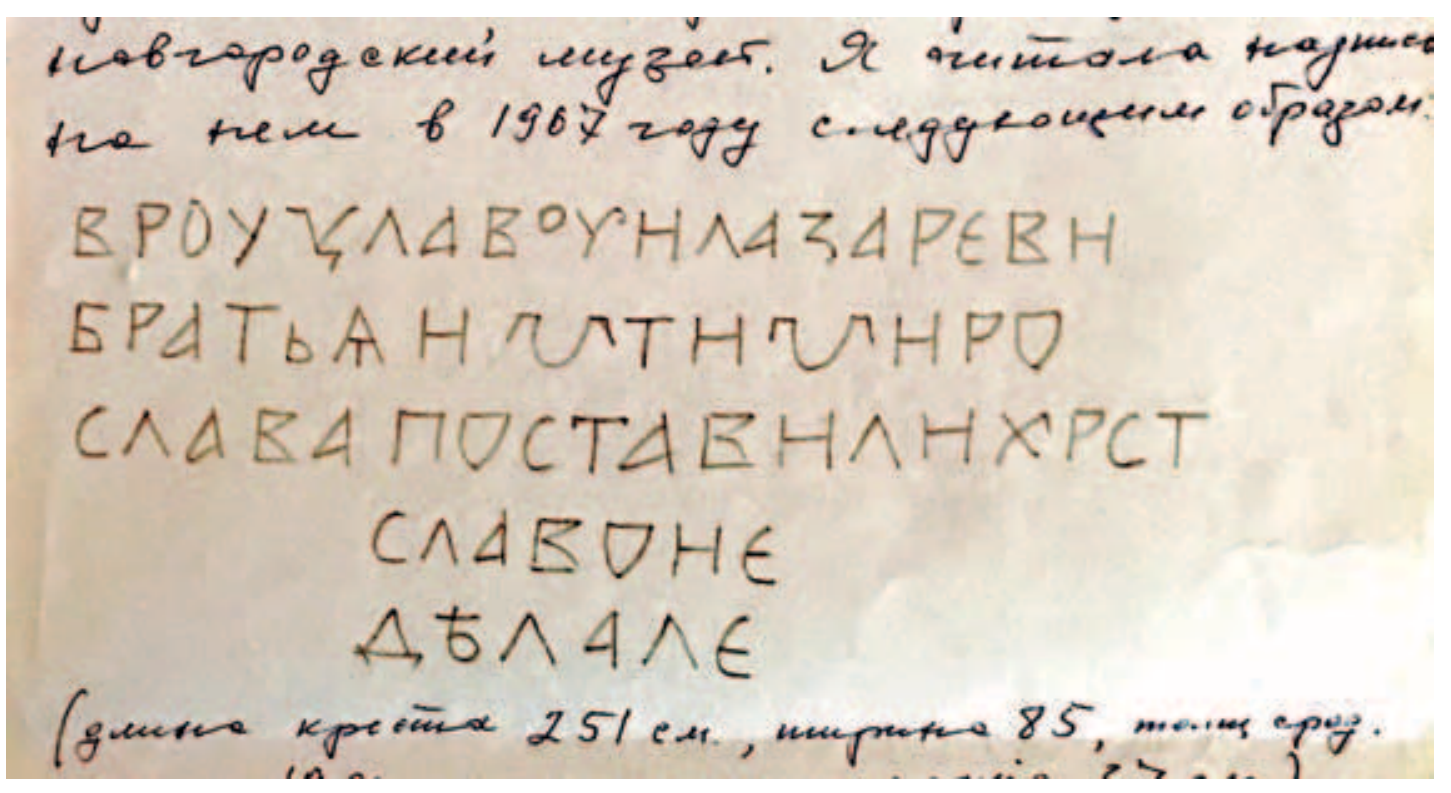

Рис. 2. Прочтение надписи на Воймерицком кресте Т.В. Николаевой

оно не отмечено. Но в словарях отмечается старославянский глагол вьрtmu, вьрю и др/p вьрети, вьрж в значении «кипеть» (Фасмер, 1986. С. 362). Производные от этого слова сохранились в ряде славянских языков, том числе в болг. извор в значении «источник». В древнерусских летописях засвидетельствован топоним - город Вручий (современный г. Овруч). Впервые упомянут в «Повести временных лет» под 977 г. как древлянский город Вручий в связи с гибелью под его стенами князя Олега Святославича - сына Святослава Игоревича (ПСРЛ. Т. І. 1962. Стб. 75). Имя Вьруслав вполне отвечает образованию, обычному для древнерусских двухсоставных имен. При этом следует признать утрату слабого $\mathbf{~}$. Обратившись к цифровой фотографии (рис. $3, a)^{1}$, мы можем убедиться в правомерности прочтения имени как Вруслав, хотя нужно отметить, что первые буквы имени несколько худшей сохранности вследствие выщербленности поверхности камня у края левого рукава креста (рис. 3, б). Кроме того, первые две буквы очень близко расположены одна к другой, что отмечается и при предыдущих прочтениях. Первая буква $\boldsymbol{\beta}$ несколько большего размера, но по форме (прямоугольный угол верхней петли и овальная петля несколько меньшего размера по сравнению с нижней, почти примыкающая к мачте несколько выше ее середины) ничем не отличается от начертаний этой же буквы в других словах (см. например, предпоследнюю букву в имени Лазореви). Больше проблем с чтением следующей буквы $\mathbf{P}$, очень близко написанной к предыдущей, к тому же несколько поврежденной утратами поверхности камня, что и повлекло к прочтению вместо нее $\boldsymbol{\Gamma}$. Но все же отчетливо прослеживается закругленная петля $\mathbf{P}$, видимо, не примыкающая вплотную к мачте, целиком умещающейся в строке. Такие начертания $\mathbf{P}$ с незамкнутой петлей - явление обычное в тех же берестяных грамотах, хотя нужно сказать, что остальные буквы $\boldsymbol{P}$ этой надписи имеют замкнутую петлю. Заметим также, что как $\mathbf{P}$ ее читали и первые исследователи надписи в 1898 г. (см.: Михеев, 2012. С. 10. Рис. 1. С. 13. Рис. 3). Прочтение имени как Вруслав снимает необходимость прочтения имени под титлом, труднообъяснимое при том, что остальные имена написаны без сокращения, и не противоречит засвидетельствованной летописью древнейшей топонимике.

Второй не выясненный до конца вопрос - датировка надписи. Как говорилось, существует несколько вариантов датировки. А.А. Спицын предположительно относил Воймерицкий крест к XII в.; И. А. Шляпкин считал, что крест «не позже XIII в. или, вероятно XIII века»; XIII в. датировал его А.С. Орлов; А.А. Зализняк отнес почерк Славона к XII в.; Т.В. Рождественская датировала

\footnotetext{
${ }^{1}$ Выражаю искреннюю благодарность С. М. Михееву за представленные фото, сделанные им совместно с А. А. Гиппиусом во время обследования креста.
} 

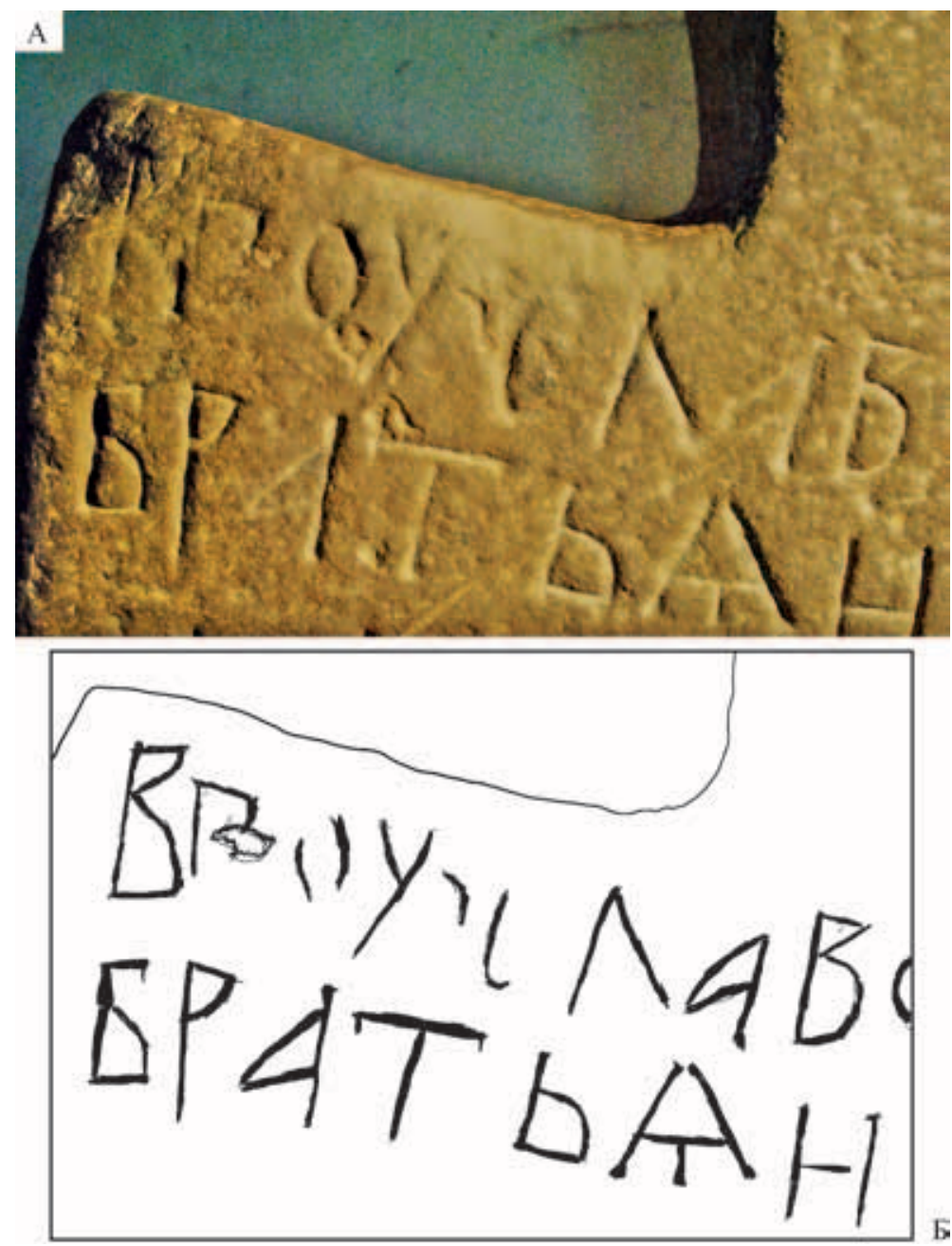

Рис. 3. Надпись на Воймерицком кресте

А - фрагмент начала надписи (фото А. А. Гиппиуса и С. М. Михеева); Б - фрагмент надписи (прорись А. А. Медынцевой)

почерк X-XII вв., но отнесла крест, примерно, ко второй половине XI-XII в., и, наконец, С. М. Михеев утверждает, что надпись на Воймерицком кресте была выполнена примерно в первой половине XI в., а ее резчик Славон, судя по всему, учился письму в Новгороде в конце $\mathrm{X}$ - первой трети XI в. Таким образом, существует значительное разнообразие в датировке памятника. Сразу нужно отметить, что исследователи, считающие, что надпись значительно древнее, чем было принято считать ранее, безусловно, правы, на что указывают буквально почти все начертания надписи. Нет смысла снова разбирать все начертания букв надписи, подробно рассмотренные в статьях Т. В. Рождественской и С. М. Михеева. При этом последний из указанных авторов предостерегает об опасности использования метода подбора аналогий, но сам это делает, так как фонд древнейших берестяных грамот невелик, и он вынужден обращаться к более широкому кругу памятников, что дает и более широкую датировку. По этому поводу можно сказать следующее: указанный метод работает тем точнее, чем ближе сравниваемые письменные памятники по месту происхождения, материалу, способу исполнения и назначению. Именно этим обстоятельством, привлечением памятников географически и исторически отдаленных, объясняется, что надпись на Воймерицком кресте находит соответствие в слишком широком хронологически круге южнославянских и древнерусских письменных памятников. Между тем В.Н. Щепкин предупреждал, что особенности письма древнеболгарских памятников, так называемый малый масштаб некоторых букв, наблюдаемый и в рукописях, и в лапидарном 
письме, суть отражение более древней письменной византийской традиции IX в., получившей развитие в славянских древнейших памятниках с «опозданием» приблизительно на сто лет (Щепкин, 1967). Точно так же можно заметить, что и в древнерусской эпиграфике наблюдается подобное запаздывание относительно памятников южнославянских - архаические начертания в древнерусских памятниках, и рукописных, и эпиграфических, встречаются уже как «пережиток» более древних южнославянских образцов. Особенно это наблюдение относится к древнейшим новгородским письменным памятникам (и некоторым рукописям, и памятникам эпиграфики). Не случайно весь массив глаголических надписей, почти неизвестных в других регионах Руси, сосредоточен в Новгороде. Поэтому наиболее показательным являются поиски аналогий среди новгородских памятников письменности, так как новгородское происхождение исполнителя надписи мастера Славона и местонахождение самого Воймерицкого креста несомненны. Можно согласиться с С. М. Михеевым, что верхней хронологической границей воймерицкой надписи является 1120 г. (около этого времени, так как берестяные грамоты не дают абсолютно точной даты.- A. M.). В поисках нижней границы важно наблюдение над почерком сохранившихся фрагментов Преградненского креста, найденного в Ставрополье (Кузнецов, Медьниеева, 1975). Надпись, несмотря на значительные утраты текста, уверенно палеографически датируется XI в., но стоит учесть сведения специалистов, видевших надпись до разрушения, что некогда в ней читалась дата 1046 г. Верхнюю границу дает надпись на каменном Стерженском кресте, поставленном новгородским посадником Иванко Павловичем в память об углублении русла реки при впадении Волги в озеро Стерж в 1134 г., за два года до гибели посадника в битве на Жданой горе (Рыбаков, 1964. С. 27-28). В обеих надписях встречаются особенности почерка, встречающиеся в надписи на Воймерицком кресте, в частности, такие выразительные, как «малый масштаб» букв А, Р, Д, на Стерженском к ним добавляется Ц, то есть особенности, сохраняющиеся как пережиток старославянского письма в древнерусских письменных памятниках второй половины XI - начала XII в. Как и Воймерицкий крест, крест Иванко Павловича вытесан новгородцем, о чем говорит и содержание (упоминание имени новгородского посадника), и такая характерная диалектная черта, как «цоканье». Поэтому при обилии архаических начертаний в надписи на Воймерицком кресте следует ориентироваться на эти два памятника, особенно на Стерженский крест, наиболее близкий по назначению, материалу и технике исполнения и происхождению (исполнитель надписи - житель новгородской земли), сохранившему ясно читаемую дату - 14 июля 6641 (1133) года. Таким образом, из двух датировок, удревняющих появление Воймерицкого креста, следует предпочесть, на мой взгляд, как наиболее вероятную дату, промежуточную между датами, предложенными двумя исследователями (С. М. Михеевым и Т.В. Рождественской): вторая половина XI-первые десятилетия XII в.

Оба упомянутых выше исследователя вслед за А.А. Зализняком склонны видеть в появлении памятной надписи на Воймерицком кресте отражение скандинавской традиции вырезания надписи на камнях в память об умерших родственниках на основе сходства формуляра надписи Славона с руническими надписями на скандинавских памятных стелах. К этому С. М. Михеев добавляет следующее соображение: «...очертания Воймерицкого креста довольно необычны: лопасти его короткие, все они расширяются от средокрестия, верхняя лопасть завершается треугольным зубцом. Весьма близкими аналогиями этому типу креста являются скандинавские нательные кресты X-XI вв.» (Михеев, 2012. С. 23). При этом он ссылается на работу В.И. Молодина (2005. С. 95, 108. Рис. 34-35). Но нужно учесть, что «скандинавскими» в археологической литературе принято называть несколько типов тельников: крестовидные привески, а иногда крестики с так называемым грубым изображением распятого Христа в длинном хитоне (коллобии), крестовидной перевязи на груди и с раскинутыми крупными кистями рук или кресты с примитивными изображениями Распятия, найденные на территории Скандинавии. Обычно это название носит условный характер и всегда помещается в кавычки. Термин подразумевает, что аналогии этим типам древнейших крестов имеются в археологических материалах скандинавского региона, но это совсем не обозначает место их производства и происхождения, которое до сих пор не выяснено. На мой взгляд, правомерно предположение В.В. Седова, который ведет происхождение одного из типов (с «грубым» изображением Распятия) из Центральной Европы - Великой Моравии и Чехии, где они найдены в хорошо датированных археологических комплексах IX в. (Седов, 2002. С. 547). Таким образом, ссылка на якобы «скандинавский» облик Воймерицкого креста ничего не добавляет к аргументам 
о скандинавской традиции, отразившейся в его изготовлении. Более сдержанно высказывается Т.В. Рождественская, которая и в древнерусском, и в руническом формуляре подобных памятных надписей скорее видит одинаковый стереотип: «Общим для них служит указание на производителя и/или заказчика и на адресата, кому или чему поставлен памятный знак (камень, крест), что, вообще говоря, является простейшей стереотипной схемой» (Рождественская, 2011. С. 387). В Скандинавии подобные камни с памятными и намогильными надписями чрезвычайно распространены. На Руси, как отмечает В. Б. Яшкина (Панченко), самые ранние каменные кресты, намогильные, и обетные, с кириллическими надписями на них, немногочисленны и имеют в основном новгородское происхождение. Девять таких памятников датируются XII-XIII вв. Они связаны с лицами довольно высокого социального статуса (Ящкина, 1998. С. 76, 82). Вполне может быть, что традиция установки памятных крестов пришла на Русь вместе со скандинавами. Но не нужно забывать, что Скандинавия официально получила крещение значительно позже (за исключением Дании) - приблизительно на сто лет позднее, чем Русь, хотя знакомство скандинавов с христианством состоялось задолго до официального принятия новой веры. Вполне вероятно, что эта традиция пришла на Русь вместе с крещеными скандинавами, хотя преобладание памятных и намогильных крестов в Новгороде по сравнению с остальной территорией Древней Руси может быть объяснено и просто ландшафтными условиями, так как, несомненно, должны были существовать и деревянные кресты, не сохранившиеся по естественным причинам. Кресты на пересечении торговых путей и в памятных местах, на околицах сел до недавнего времени являлись особенностью пейзажа ВосточноЕвропейской равнины. Один из них, Игначь крест, даже попал в летописные тексты (НПЛ, 1950. С. 289), обозначая место, откуда круто повернуло вспять монголо-татарское войско, намеревавшееся первоначально идти на Новгород. Возможно, что обычай установки памятных крестов имеет и другой источник. Если говорить о напоминающем по форме Воймерицкий крест Преградненском кресте, тоже с расширяющимися лопастями и пропорциями «латинского» креста, то наиболее вероятна в данном примере версия об отражении другой традиции, связанной с христианством Армении. Как известно, хачкары (крест-камень), каменные плиты с изображением крестов, иногда богато орнаментированные, известны в Армении с древнейшего времени. По форме и пропорциям они напоминают Преградненский крест. Вероятно, не имеют большого смысла поиски аналогий Воймерицкому кресту, основываясь на его форме, но если говорить о ней, то наиболее близкой аналогией так называемым скандинавским крестамтельникам, происходящим с территории Скандинавии, является Стерженский, за исключением подтреугольного завершения верхней лопасти и пропорций. Он близок к Воймерицкому и по палеографическим особенностям. Особенно важно, что Стерженский крест имеет точную дату в тексте - 1133 г., на которую, как на верхнюю границу, и следует ориентироваться при датировке Воймерицкого креста.

\section{Литература}

Зализняк А.А., 1995. Древненовгородский диалект. М.: ЯРК. $720 \mathrm{c}$.

Зализняк А. А., 2004. Новгородский диалект. Изд. 2. М.: ЯСК. $872 \mathrm{c}$.

Кузнецов В.А., Медьнцева А.А., 1975. Славянорусская надпись XI в. из с. Преградного на Северном Кавказе // КСИА. Вып. 144. С. 11-17.

Михеев С.M., 2012. Надпись на каменном кресте из Воймериц на реке Мсте - памятник начальной истории древнерусской письменности // Вопросы эпиграфики. Вып. VI. Ч. І. С. 7-30.

Молодин В.И., 2005. Европейские кресты-тельники // Ставрографический сборник. Кн. III: Крест как личная святыня. С. 83-133.
НПЛ / [Под ред. и с предисл. А.Н. Насонова]. М. - Л.: Изд-во АН СССР, 1950. 642 с.; 5 л.

Орлов А. С., 1936. Библиография русских надписей XI-XV вв. М.-Л.: Изд-во АН СССР. 180 с.

Орлов A.C., 1952. Библиография русских надписей XI-XV вв. М.-Л.: Изд-во АН СССР. 239 с.

ПСРЛ. Т. І. М. Издательство восточной литературы, $1962.580 \mathrm{c.}$

Рождественская T.B., 2011. О надписи на Воймерицком кресте // Висы дружбы. Сб. в честь Татьяны Николаевны Джаксон. М.: РФСОН. C. 382-390.

Рыбаков Б.А., 1948а. Ремесло древней Руси. М.: Изд-во АН СССР. 803 с. 
Рыбаков Б. А., 1948б. Ремесло // История культуры древней Руси. Домонгольский период. Т. I: Материальная культура. М.-Л.: АН СССР. C. $78-181$.

Рыбаков Б.А., 1964. Русские датированные надписи XI-XIV веков. М.: Наука. 48 с., 46 илл. (САИ. Вып. Е1-44).

$C$ [пицыны A. A., 1903. Заметка о каменных крестах, преимущественно новгородских // ЗОРСА. T. V. Вып. 1. С. 203-234.

Седов В. В., 1988. Об одной группе древнерусских крестов // Древности славян и Руси. М.: Наука. C. 63-67.

Седов В. В., 2002. Славяне. Историко-археологическое исследование. М.: ЯСК. 622 с.
Фасмер М., 1986. Этимологический словарь русского языка. Т. 1. М.: Прогресс. 576 с.

Шляпкин И.А., 1906. Древние русские кресты. [T.] I. Кресты новгородские, до XV века, неподвижные и не церковной службы. СПб.: Тип. И. Н. Скороходова. 63 с.

Щепкин В.Н., 1967. Русская палеография. М.: Наука. 224 с. (Репринт.)

Яшкина (Панченко) В.Б., 1998. К вопросу о распространении каменных крестов Древней Руси // Староладожский сборник: Матер. I-V конфер. «Северо-Западная Русь в эпоху средневековья: междисциплинарные исследования». Старая Ладога, 1994-1998. СПб. - Старая Ладога: [б. и.]. С. 78-86. 
О.М. Олейников

Институт археологии РАН, г. Москва

\section{К вопросу о письменной культуре средневекового Новгорода}

Высокий уровень письменной культуры новгородцев в эпоху Средневековья наряду с письменными источниками характеризуют разнообразные археологические материалы. В первую очередь это памятники древнерусской эпиграфики и специальные инструменты для письма на бересте, навощенных дощечках (церах), свинцовых пластинках, штукатурке или ином достаточно твердом и податливом материале путем прочерчивания или выдавливания букв и знаков - писала-стили. Типологически и функционально они являются полной аналогией древнеримским стилям.

На Руси самые ранние упоминания инструментов для письма под названием «писала» связаны с Новгородом и относятся к середине XI в. (Будилович, 1875. С. 64; Медведев, 1960. С. 80-81). Развитие массовой грамотности среди всех слоев населения в Новгороде начинается с XI в. В летописях под 1030 г. есть прямые указания на массовое обучение грамоте новгородских детей (ПСРЛ, 2000. C. 176).

Грамотность - один из главных показателей высокого уровня средневековой культуры, которая, в свою очередь, связана с распространением и укоренением христианства. Именно многочисленные монастыри являлись центрами, где происходило развитие христианской культуры, неотъемлемой частью которой являлась богатая письменная традиция. Вместе с тем развитие ремесла и особенно торговли обусловило распространение грамотности среди торговцев, ремесленников и простых горожан, чему способствовала доступность дешевого материала, особенно при обучении письму (Тимомук, 1956. С. 157).

Раскопки хоздоговорного отряда Новгородской экспедиции Института археологии РАН в 2008-2017 гг. пополнили представительную коллекцию писал Новгорода 23 новыми находками, обнаруженными в слоях XI-XV вв. (табл. 1).
Преобладают инструменты, изготовленные из железа (14 экз.), семь писал бронзовые, два - костяные. Сохранность находок высокая, что позволяет уверенно их классифицировать. Практически все находки, за исключением одной (Досл-1/1-149), представленной фрагментом, сохранили полную форму.

Большинство писал (21 экз.) вписываются в общую эволюцию типов этой категории находок и укладывается в классификацию, разработанную А. Ф. Медведевым (1960) и дополненную А. А. Медынцевой (1997) и Б. Б. Овчинниковой (2000).

Исключение составляют два бронзовых писала с фигурным завершением в виде сомкнутых пальцев левой руки, образующих небольшое отверстие для привешивания (рис. 1). Они относятся к западноевропейскому кругу древностей и представляют новый тип письменных принадлежностей (писала-шильца), впервые зафиксированный не только в Новгороде, но и на памятниках средневековой Руси. Им посвящено отдельное исследование (Олейников, 2016. С. 191-198), что позволяет в рамках данной статьи ограничиться кратким сообщением. Эти писала обнаружены в 2014 г. в Плотницком конце средневекового Новгорода на Рогатицком-2 раскопе (ул.Б. Московская, 30) в слое второй половины XII в. Значение этих находок в том, что они свидетельствуют о сложившейся торговой деятельности Новгорода с западными странами и показывают культурный уровень общества, в котором предметы для письма были востребованы.

Остальные писала представляют хорошо известные типы и находят аналогии на различных памятниках древней Руси.

Описание новых находок дается в соответствии с принятой типологией (Медведев, 1960; Овчинникова, 2000).

Тип 1, вариант «б». Писало (Ник. пер., 7/3-166) обнаружено на Торговой стороне в Плотницком 


\begin{tabular}{|c|c|c|c|c|c|c|c|c|c|c|c|c|c|c|c|c|c|c|c|c|c|c|c|}
\hline ஜ & $\vec{i}$ & $\begin{array}{c}n \\
i \\
i\end{array}$ & $\begin{array}{l}m \\
i \\
i\end{array}$ & $\begin{array}{l}y \\
i\end{array}$ & $\begin{array}{l}n \\
i \\
\end{array}$ & $\begin{array}{l}0 \\
i \\
i\end{array}$ & $\begin{array}{l}\hat{i} \\
\mathrm{i}\end{array}$ & $\begin{array}{l}\infty \\
i \\
i\end{array}$ & aे & $\begin{array}{l}2 \\
i\end{array}$ & $\begin{array}{l}z \\
i\end{array}$ & $\vec{m}$ & $\begin{array}{c}\sim \\
m\end{array}$ & $\begin{array}{l}m \\
m\end{array}$ & $\begin{array}{c}\forall \\
\dot{m}\end{array}$ & in & $\begin{array}{c}6 \\
m^{2} \\
\end{array}$ & $\begin{array}{c}n \\
m^{\prime}\end{array}$ & $\begin{array}{l}\infty \\
m^{n}\end{array}$ & $\begin{array}{l}a \\
\text { mi }\end{array}$ & $\begin{array}{l}\stackrel{2}{m} \\
m\end{array}$ & $\cong$ & $\stackrel{\sim}{\cong}$ \\
\hline 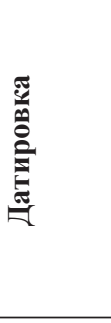 & $\sum^{\infty}$ & 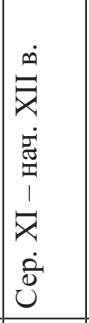 & 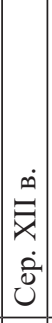 & 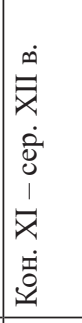 & 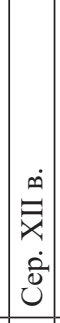 & 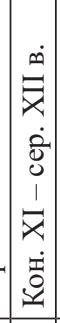 & $\begin{array}{c}\dot{\infty} \\
\vec{x} \\
\hat{0} \\
0 \\
\hat{0} \\
\dot{\vec{j}} \\
0 \\
\dot{0} \\
\end{array}$ & 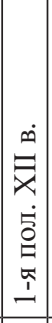 & 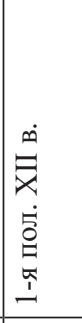 & 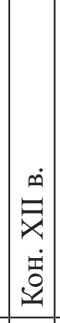 & $\begin{array}{l}\dot{\infty} \\
\dot{x} \\
\dot{x}\end{array}$ & 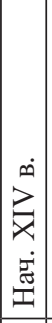 & $\sum_{x}^{\infty}$ & 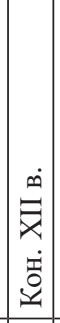 & 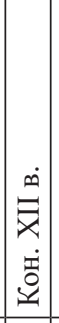 & $\begin{array}{l}\dot{\infty} \\
\ddot{\nabla} \\
\dot{0} \\
\dot{0}\end{array}$ & 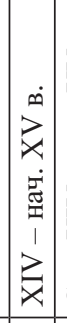 & 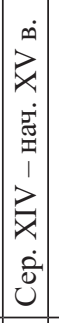 & $\dot{\infty}$ & 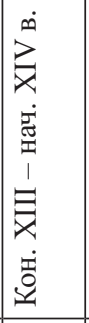 & 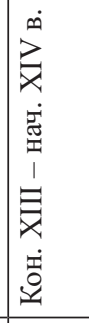 & 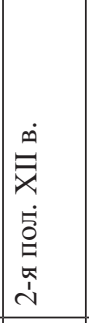 & 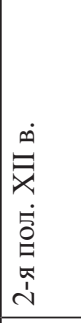 \\
\hline 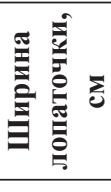 & $\stackrel{-}{-}$ & $\stackrel{\sim}{\sim}$ & $\stackrel{m}{-}$ & $\approx$ & $\vec{i}$ & $\stackrel{+}{-}$ & 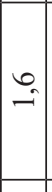 & $\Rightarrow$ & $\stackrel{?}{-}$ & $\vec{i}$ & 年 & $\because$ & $\frac{0}{i}$ & $\therefore$ & $\Rightarrow$ & $\stackrel{2}{\Rightarrow}$ & $\stackrel{\oplus}{-}$ & $\mid \begin{array}{l}0 \\
-\end{array}$ & $\stackrel{m}{\rightarrow}$ & $\stackrel{\sim}{=}$ & $\stackrel{\infty}{\rightarrow}$ & 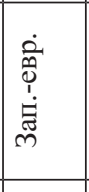 & 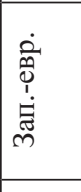 \\
\hline 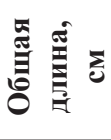 & $\vec{a}$ & $\vec{\infty}$ & $\vec{\infty}$ & $\stackrel{?}{\mathfrak{f}}$ & $\stackrel{\infty}{=}$ & $\vec{\infty}$ & $\stackrel{0}{=}$ & 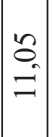 & $\begin{array}{l}n \\
2 \\
\infty \\
\infty\end{array}$ & $\stackrel{0}{=}$ & $\stackrel{+}{=}$ & $\because$ & $\begin{array}{l}\tilde{j} \\
\hat{i} \\
\hat{i}\end{array}$ & $\begin{array}{l}n \\
0 \\
0\end{array}$ & $\hat{\infty}^{\circ}$ & $\begin{array}{l}1 \\
\infty \\
\infty\end{array}$ & $\left|\begin{array}{l}2 \\
0 \\
0 \\
0\end{array}\right|$ & $\mid \begin{array}{c}\hat{1} \\
\hat{\theta}\end{array}$ & $\begin{array}{l}0 \\
=\end{array}$ & $\begin{array}{l}\infty \\
\text { in }\end{array}$ & $\because$ & $\vec{\infty}$ & $\hat{\tilde{\theta}}$ \\
\hline 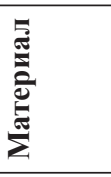 & 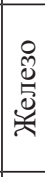 & 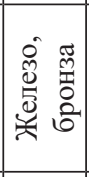 & 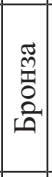 & 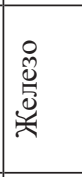 & 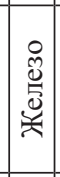 & 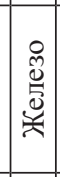 & 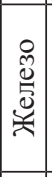 & 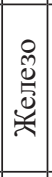 & 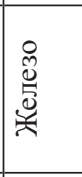 & 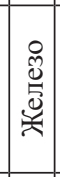 & 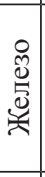 & 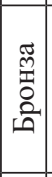 & 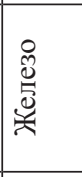 & 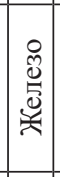 & 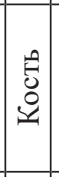 & 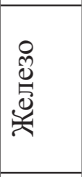 & 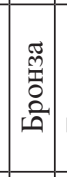 & 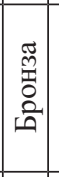 & $\begin{array}{l}\hat{E} \\
0 \\
0\end{array}$ & 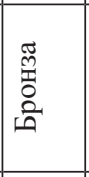 & 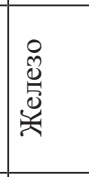 & 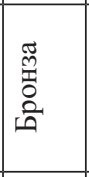 & 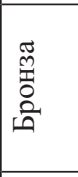 \\
\hline 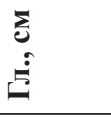 & $\frac{8}{1}$ & $\frac{n}{2}$ & 菅 & के & 通 & $\hat{\imath}$ & $\underset{⿱}{\stackrel{7}{二}}$ & $\frac{\infty}{\infty}$ & ণे & $\begin{array}{l}\infty \\
\stackrel{\alpha}{\gamma} \\
\dot{\gamma}\end{array}$ & $\begin{array}{l}0 \\
\stackrel{2}{?} \\
1\end{array}$ & $\stackrel{\sim}{\stackrel{r}{r}}$ & & 竎 & 旁 & $\frac{0}{1}$ & 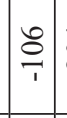 & 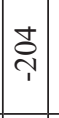 & $\stackrel{?}{\frac{1}{1}}$ & $\underset{\overbrace{}}{\stackrel{9}{1}}$ & $\stackrel{\overbrace{}}{7}$ & $\begin{array}{l}0 \\
i \\
i \\
i\end{array}$ & $\tilde{n}$ \\
\hline$\dot{\hat{\theta}}$ & $\hat{d}$ & $\underset{\infty}{\infty}$ & $\frac{m}{ \pm}$ & $\hat{b}$ & $\hat{\sim}$ & $\begin{array}{l}n \\
\dot{m}\end{array}$ & $\begin{array}{c}\hat{y} \\
\dot{1}\end{array}$ & $\hat{q}$ & 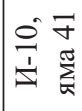 & $\hat{\imath}$ & $\begin{array}{l}n \\
\dot{1}\end{array}$ & $\stackrel{\sim}{\sim}$ & 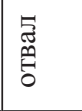 & $\left|\begin{array}{l}n \\
n \\
1\end{array}\right|$ & $\stackrel{n}{\sim}$ & $\overrightarrow{\dot{1}}$ & $\frac{m}{\dot{m}}$ & $\stackrel{\tilde{L}}{\tilde{L}}$ & $\hat{n}$ & $\overline{\dot{k}}$ & $\frac{0}{\frac{1}{4}}$ & $\tilde{n}$ & $?$ \\
\hline$\grave{2}_{2}^{\circ}$ & $\stackrel{\circ}{\circ}$ & $\stackrel{\infty}{\varrho}$ & $\stackrel{\infty}{2}$ & 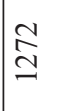 & $\frac{\pi}{m}$ & 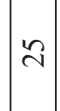 & $\mid \begin{array}{c}\stackrel{t}{f} \\
f\end{array}$ & gे & Ұ & $\begin{array}{l}0 \\
\infty \\
0\end{array}$ & 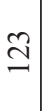 & 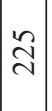 & సे & $\left|\begin{array}{c}\sigma \\
\infty\end{array}\right|$ & $\vec{\sigma}$ & $\stackrel{0}{0}$ & $\approx$ & 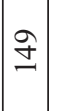 & $\begin{array}{l}\infty \\
\stackrel{2}{n}\end{array}$ & to & $\tilde{q}$ & 等 & $\overrightarrow{\widetilde{d}}$ \\
\hline$\dot{\nabla}$ & $m$ & $m$ & $a$ & - & - & $m$ & - & $=$ & 0 & $m$ & $\nabla$ & - & $r$ & - & $\sim$ & $\sim$ & in & -1 & $=$ & - & $\sim$ & - & - \\
\hline$\stackrel{5}{6}$ & 올 & $\stackrel{\vec{\sim}}{\stackrel{\sim}{\sim}}$ & 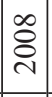 & 离 & $\stackrel{r}{\vec{n}}$ & $\frac{n}{2}$ & $\begin{array}{l}0 \\
0 \\
0 \\
\text { in }\end{array}$ & $\begin{array}{l}\infty \\
0 \\
0 \\
\text { i }\end{array}$ & 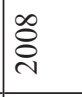 & $\stackrel{\Delta}{\stackrel{\Delta}{\sim}}$ & 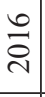 & $\begin{array}{l}\Delta \\
\stackrel{\sim}{\sim}\end{array}$ & 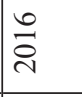 & 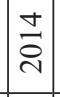 & 㐫 & $\stackrel{n}{\stackrel{2}{\sim}}$ & $\vec{\Xi}$ & $\begin{array}{l}\vec{\Xi} \\
\stackrel{\sim}{2}\end{array}$ & 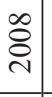 & $\stackrel{n}{\stackrel{i}{d}}$ & $\stackrel{n}{\stackrel{\sim}{n}}$ & $\vec{\sim}$ & $\vec{\sim}$ \\
\hline 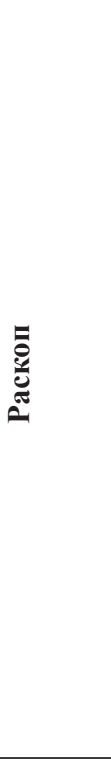 & 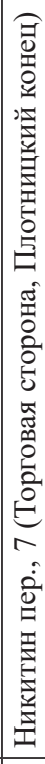 & 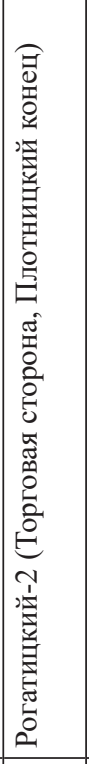 & 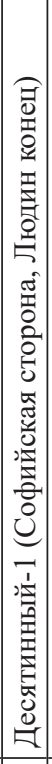 & 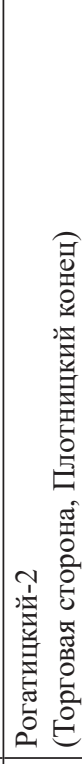 & 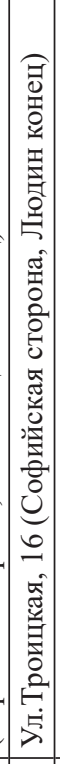 & 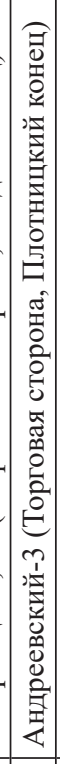 & 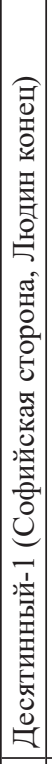 & 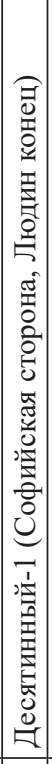 & 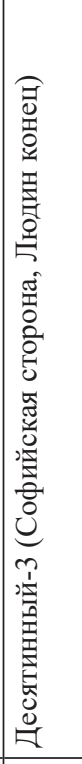 & 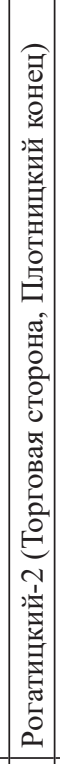 & 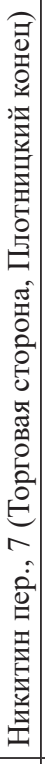 & 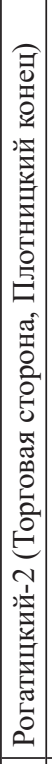 & 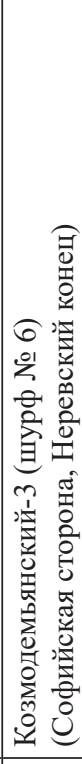 & 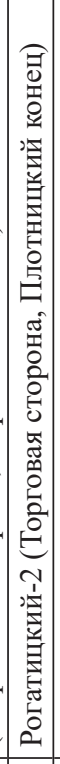 & 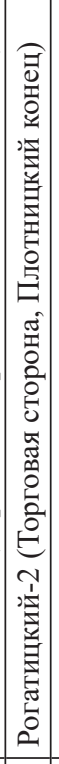 & 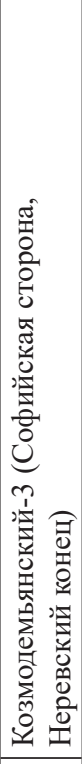 & 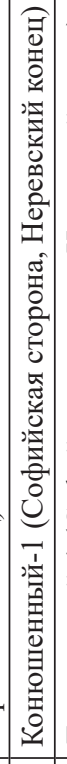 & 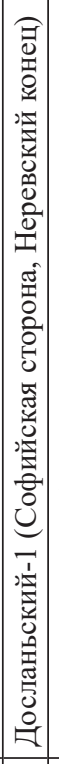 & 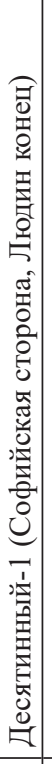 & 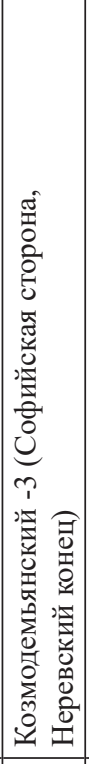 & 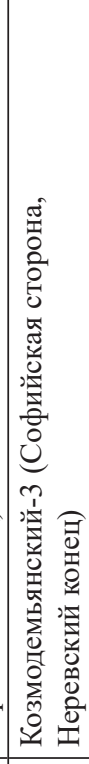 & 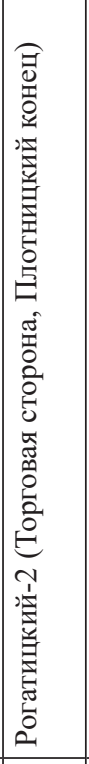 & 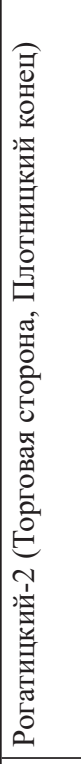 \\
\hline$E$ & 10 & $\sim$ & $\sim$ & 疋 & f & \& & $\therefore$ & 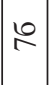 & 20 & $\infty$ & 7 & $\widetilde{\pi}$ & 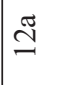 & $\stackrel{\sim}{\simeq}$ & $\stackrel{\sim}{\simeq}$ & 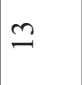 & $\stackrel{0}{ \pm}$ & $\stackrel{\mathbb{0}}{ \pm}$ & $\begin{array}{l}0 \\
\cong\end{array}$ & $\stackrel{10}{2}$ & 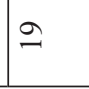 & 空 & लि \\
\hline
\end{tabular}


конце на раскопе по адресу: Никитин пер., 7, в слое XIV в. Лопаточка имеет форму четырехугольника, слегка суженного к витому в верхней части стержню (рис. 2, 1). Изготовлено из железа.

Тип 2 представлен двумя находками хорошей сохранности.

Писало железное (Рог-2/3-1068 1 ). Обнаружено в Плотницком конце (Торговая сторона) на раскопе Рогатицкий-2 в слое середины XI-начала XII в. Небольшие утраты не позволяют судить о наличии орнамента лопатки. Переход к стержню подчеркнут дисковидным упором - валиком. Стержень украшен инкрустацией из прекрасно сохранившейся тонкой бронзовой проволоки (рис. 2, 2).

Писало бронзовое (Дес-1/9-158). Оно происходит с раскопа Десятинный-1 (Софийская сторона, Людин конец) из слоя середины XII в. (рис. 2, 3). Лопаточка имеет форму слегка вытянутого бокальчика с плавными контурами, трапециевидным завершением и острым лезвием; украшена двусторонним орнаментом и небольшими симметричными завитками в нижней части корпуса, заостренная в верхней части. В месте перехода от лопаточки к стержню - небольшая узкая шейка и шарообразный упор. Стержень гладкий круглого сечения.

Аналогичные писала обнаружены в слоях конца X - середины XII в. на Неревском, Ильинском, Буяном и Троицком раскопах Великого Новгорода, а также в Старой Рязани, Галиче, Новогрудке, Друцке, Минске, на Белоозере (Медведев, 1946. С. 67; Хорочев, 1978. С. 183; Овчинникова, 2000. С. 48, 64; Захаров, 2004. С. 210-211).

К типу 4 относятся три железных писала, у которых боковые грани лопаточек имеют сглаженные зубчики (рис. 2, 4-б). Стержень гладкий. Переход от лопаточки к стержню оформлен небольшой шейкой и шарообразным упором.

Два писала по форме лопаточки (боковые грани прямые параллельные) близки варианту «а»: писало (Рог-2/1-1272) найдено на Торговой стороне в Плотницком конце на Рогатицком-2 раскопе в слое конца XI - середины XII в. (рис. 2, 4); писало (Тp, 16/1-312) обнаружено на Софийской стороне (Людин конец) на раскопе по адресу: ул. Троицая, д. 16, в слое середины ХІІ в. (рис. 2, 5).

Писало (Андр-3/3-25) с треугольной формой лопаточки относится к варианту «б». Эта находка происходит с Андреевского-3 раскопа (Торговая сторона, Плотницкий конец) из слоя первой половины XII в. (рис. 2, б).

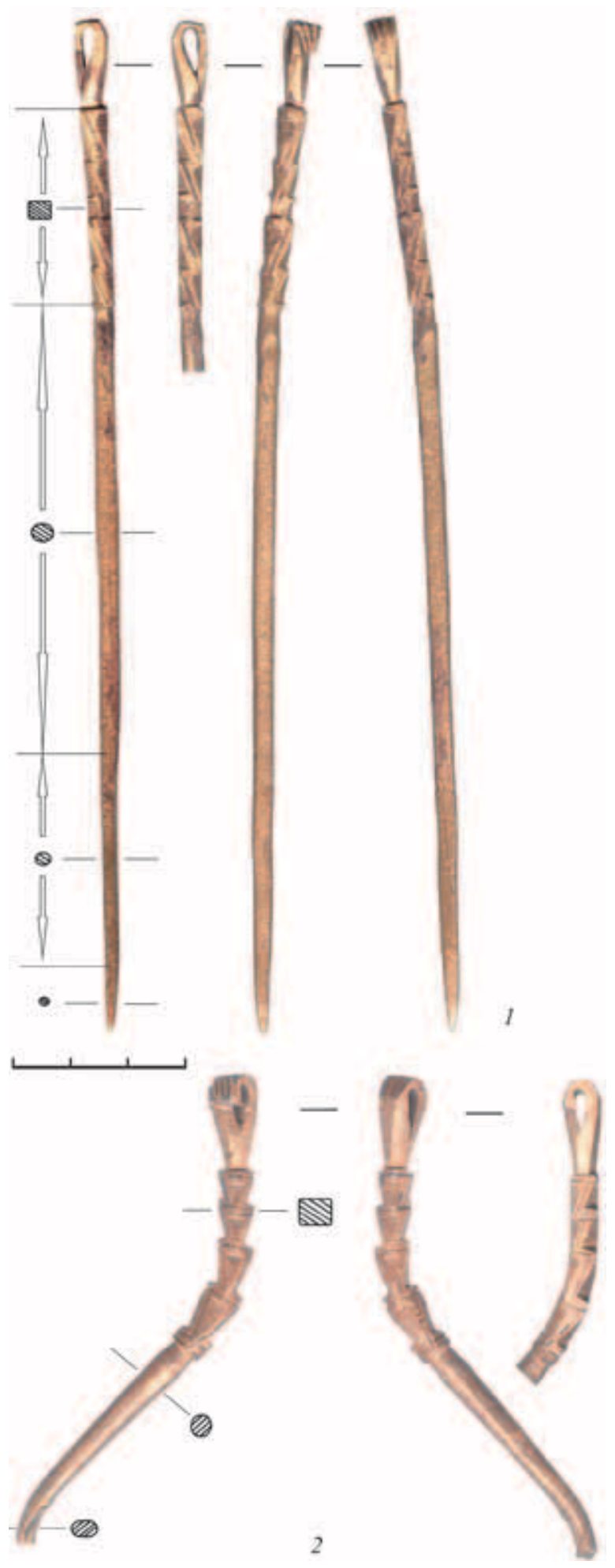

Рис. 1. Бронзовые писала-шильца с завершением в виде сомкнутых пальцев кисти руки, обнаруженные в Великом Новгороде, 2-я пол. XII в. Раскоп Рогатицкий-2. Фото автора

1 - полная форма (Б. Мос-30/1-1445); 2 - фрагмент (Б. Мос-30/1-2021)

${ }^{1}$ Шифр находки означает: раскоп/участок-номер полевой описи. 

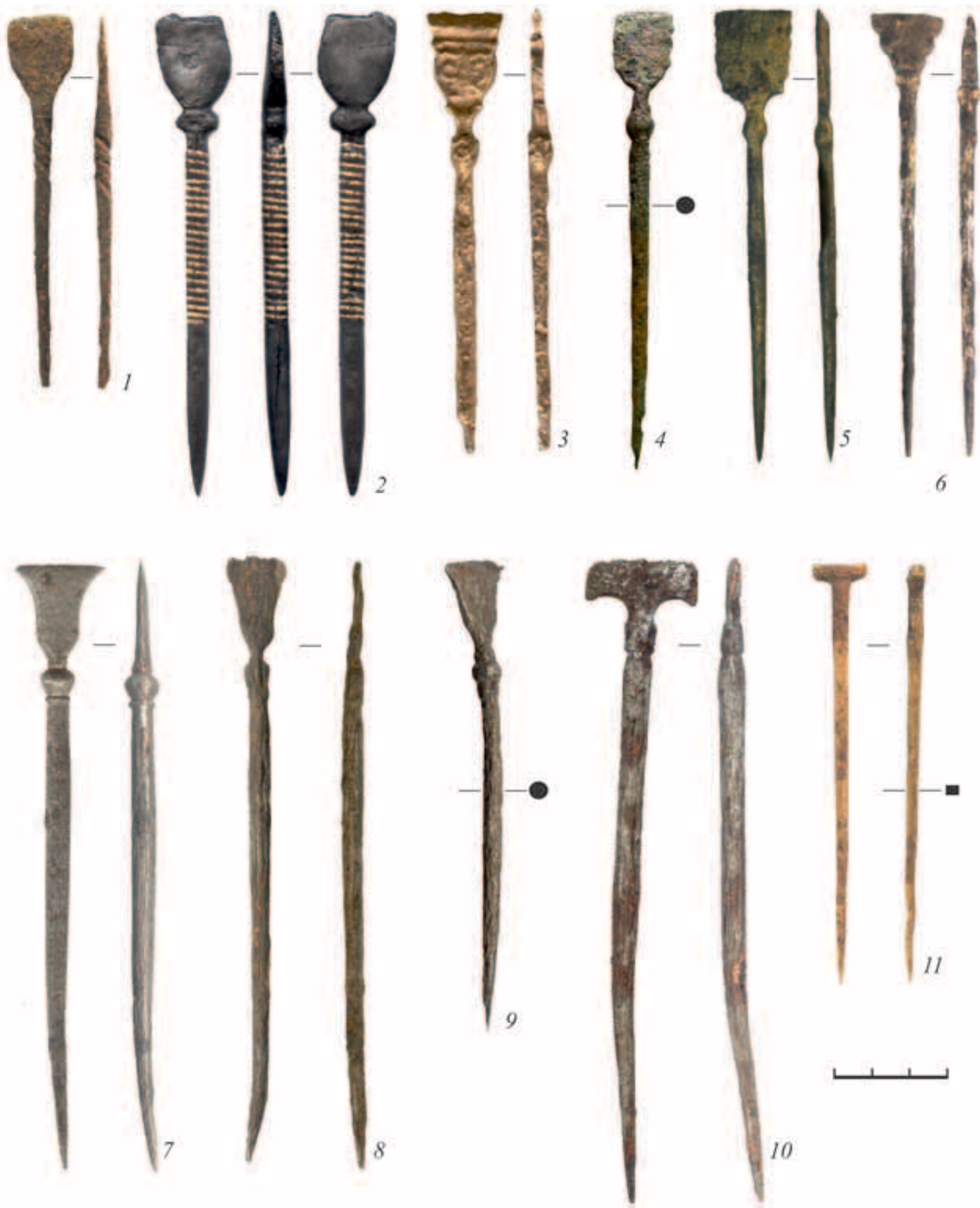

Рис. 2. Писала, обнаруженные в Великом Новгороде. Фото автора

1 - тип 16 (Ник. пер., 7/3-166); 2 - тип 2а (Рог-2/3-1068); 3 - тип 26 (Дес-1/9-158); 4 - тип 4а (Рог-2/1-1274); 5 - тип 4а (Тр, 16/1-312); 6 - тип 4б (Андр-3/3-25); 7 - тип 7а (Дес-1/1-474); 8 - тип 7б (Дес-1/11-49); 9 - тип $7 б$ (Дес-3/6-44); 10 - тип 8в (Рог-2/3-686); 11 - тип 8д (Ник. пер., 7/4-123).

$$
\text { 1, 4-11 - железо; } 2 \text { - железо, бронза; } 3 \text { - бронза }
$$


Тип 7 -один из самых распространенных в Новгороде и на территории древней Руси типов писал, определенный Ф.Д. Гуревич как общерусский тип (Гуревич, 1973. С. 31), представлен тремя находками (рис. 2, 7-9). Это железные писала, лопаточка которых напоминает «форму изящного бокальчика». Все они были найдены на Софийской стороне в северо-западной части Людина конца, недалеко от Рождественского Десятинного монастыря (Десятинные раскопы).

Писало (Дес-1/1-474), тип 7, вариант «а» (края рабочей части лопаточки оттянуты горизонтально) обнаружено на Десятинном-1 раскопе в слое последней трети XII в. (рис. 2, 7).

Писало (Дес-1/11-49), тип 7, вариант «б» (без оттянутых краев рабочей части лопаточки), найдено также на Десятинном-1 раскопе в слое первой половины XII в. Оно сохранилось несколько хуже (рис. 2, 8).

Писало (Дес-3/6-44) тип 7, вариант «б» найдено также в слое первой половины XII в. в границах Десятинного-3 раскопа (рис. 2, 9).

Тип 8, один из самых многочисленных в Новгороде, представлен двумя экземплярами. Железное писало (Рог-2/3-686), имеющее Т-образную лопаточку, рабочая (горизонтальная) поверхность которой ровная, а боковые стороны оттянуты вниз, образуя углы (рис. 2, 10), относится к варианту «в». Оно было найдено на Рогатицком-2 раскопе в слое конца XII в., что хорошо укладывается в хронологический период наибольшего распространения (вторая половина XII - вторая половина XIII в.) этого варианта в Новгороде (Овчинникова, 2000. С. 53).

Т-образное писало с лопаточкой прямоугольной формы без оттянутых углов (Ник. пер., 7/4-123) стало вторым экземпляром варианта «д». До нашей находки к типу 8д было отнесено только одно писало, происходящее с Троицкого раскопа из слоя второй половины XIII в. (Овчинникова, 2000. С. 54). Писало нашей выборки обнаружено на Торговой стороне в Плотницком конце на раскопе по адресу Никитин переулок, 7, в слое XIV в. Особенностью писал типа 8д является стержень прямоугольного сечения (рис. 2, 11).

Тип 12 представлен тремя очень простыми по форме писалами с лопаточкой треугольной формы, которая переходит к стержню без упора (рис. 3, 2-4).

Железное писало (Козм-3/7-207), имеющее витой стержень, представляет вариант «а» (рис. 3, 2). Оно обнаружено на раскопе на Coфийской стороне в Неревском конце на раскопе Козмодемьянский-3 в слое XIV в.
Два других инструмента, имеющие гладкий стержень, можно отнести к варианту «в». Оба происходят с Рогатицкого-2 раскопа (Торговая сторона, Плотницкий конец). Одно из них (Рог-2/1-892) железное, хорошей сохранности, найдено в слое конца XII в. (рис. 3, 3). Другое - костяное (Рог-2/2-914), с отверстием на лопаточке, обнаружено также в слое конца XII в. (рис. 3, 4). В Новгороде писала этого типа бытовали в течение очень долгого времени - с XI до середины XIV в. Они обнаружены на Троицком, Неревском и Славенском раскопах. Аналогичные писала известны на территории Болгарии, где датируются IX - серединой XI в. (Овчинникова, 2000. С. 57, 76).

Тип 13. Простое железное писало (Козм-3/2-686), как и предыдущие инструменты, имеет треугольную лопаточку и стержень круглого сечения. Но, в отличие от предыдущего типа, переход к стержню оформлен небольшим упором (рис. 3, 5). Обнаружено на раскопе Козмодемьянский-3 (Неревский конец, Софийская сторона) в слое середины XII в.

Тип 14. Представлен двумя писалами, найденными в Неревском конце (Софийская сторона).

Одно писало (Кон-1/5-25) происходит с Конюшенного раскопа из слоя XIV - начала XV в., его можно отнести к варианту «б»-рабочий край лопаточки завершается валиком (рис. 3, б). Другое (Досл-1/1-149), сохранившееся фрагментарно, представляет вариант «в»- по краям лопаточки этого экземпляра размещены небольшие завитки (рис. 3,7$)$. Писало найдено на Досланьском раскопе в слое середины XIV- начала XV в.

Это отличие единственное. В целом инструменты очень похожи. Оба писала отлиты из бронзы и представляют орудия письма по воску. Рабочая часть лопаточки завершается валиком длиной 1,4 см и диаметром 0,45 см, который служил для заглаживания воска. На лопаточке три круглых сквозных отверстия, расположенных симметрично в два яруса. Диаметр верхних отверстий составляет 0,39 см, нижнее отверстие немного больше $-0,48$ см. Переход от лопаточки к стержню имеет двухъярусный упор, оформленный тонкими парными валиками.

Бронзовое писало (Рог-2/1-225) обнаружено на раскопе Рогатицкий-2 в слое, имеющем стратиграфическую дату начало XIV в. (рис. 3, 1). Рабочая часть лопаточки завершается валиком, который опирается на два выгнутых отростка. Верхняя часть стержня имеет продольные насечки. Аналогичные инструменты найдены на Неревском и Ильинском раскопах в слоях конца XIII - начала XIV в. 

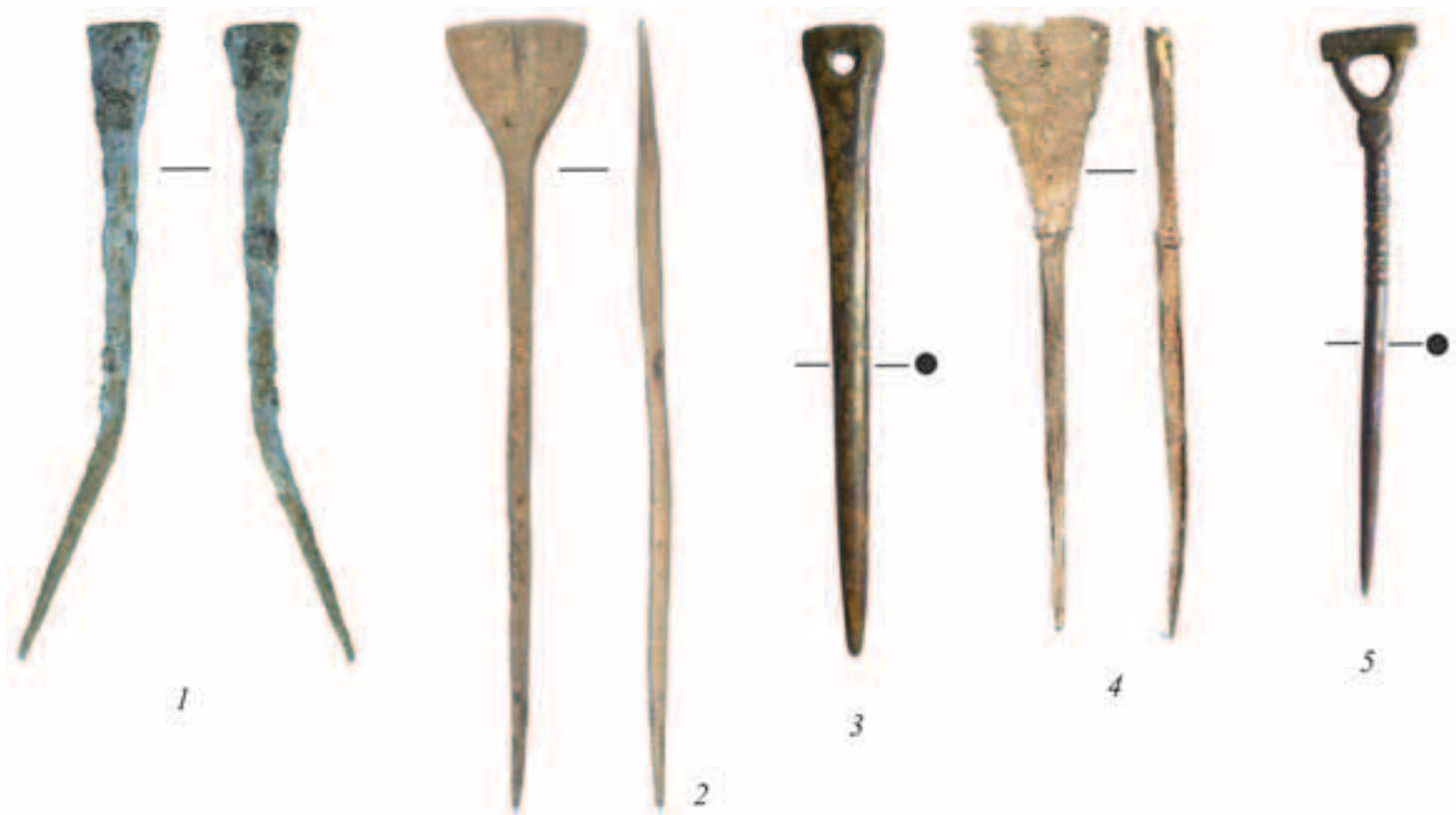

3
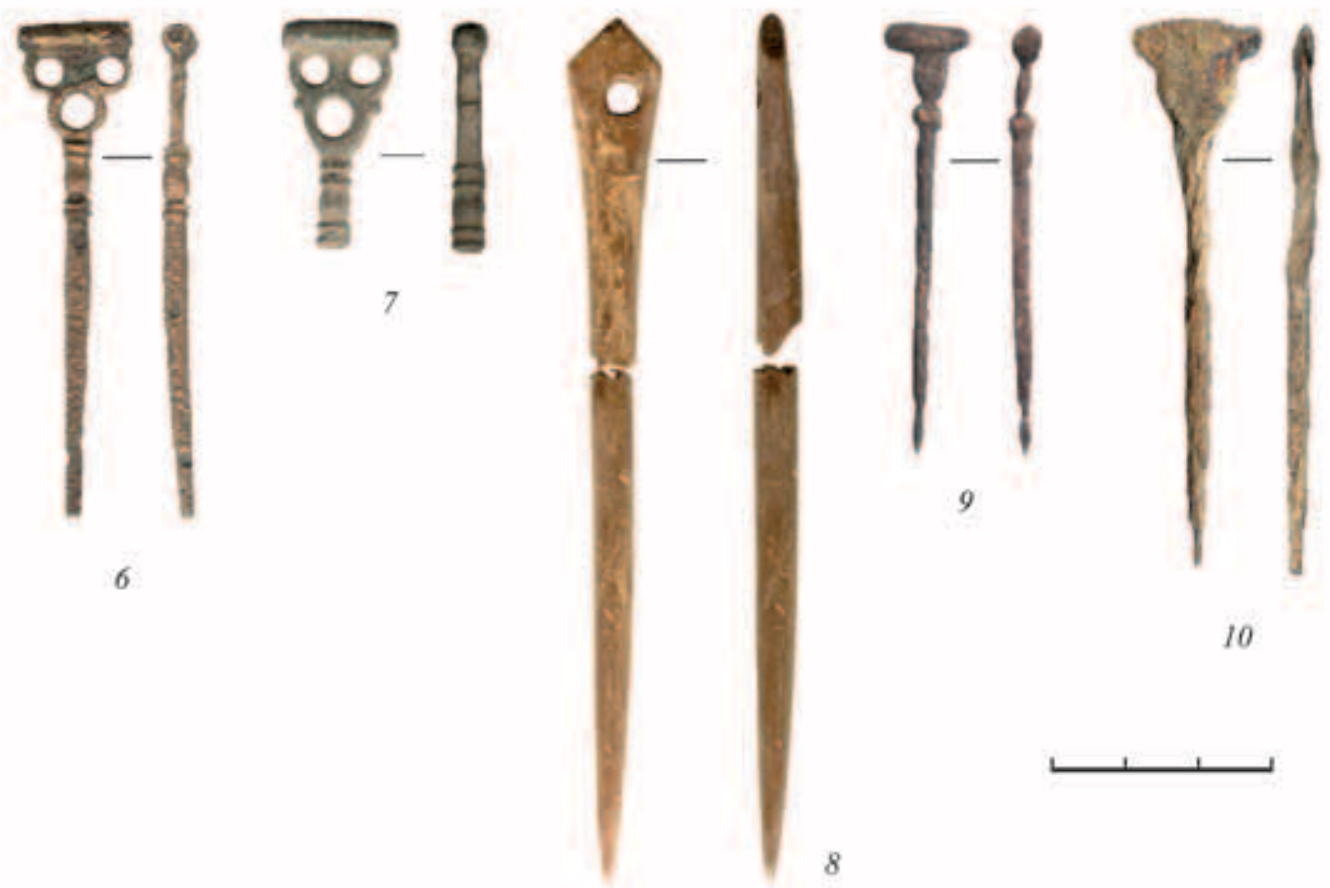

10

Рис. 3. Писала, обнаруженные в Великом Новгороде. Фото автора

1 - тип 10а (Рог-2/1-225); 2 - тип 12а (Козм-3/7-207); 3 - тип 12в (Рог-2/1-892); 4 - тип 12в (Рог-2/2-914);

5 - тип 13 (Козм-3/2-686); 6 - тип 14б (Кон-1/5-25); 7 - тип 14в (Досл-1/1-149); 8 - тип 17б (Дес-1/11-158);

9 - тип 196 (Козм-3/1-164); 10 - тип 19г (Козм-3/2-453). 1-3, 5, 9, 10 - железо; 4, 8 - кость; 6, 7 - бронза

Тип 17. Костяное писало (Дес-1/11-158) стало самым ранним в представленной коллекции. Оно обнаружено в слое XI в. в Людином конце (Софийская сторона) на Десятинном-1 раскопе (рис. 3, 8). Писало относится к дискуссионному типу 176 (писала-проколки). Заостренный круглый стержень переходит в геометрическое остроугольное завершение, в центре которого расположено сквозное круглое отверстие диаметром 0,45 см. Писало было сломано в древности и, видимо, по этой причине выброшено. Этот факт представляет особое значение, поскольку в данном случае выпадение 

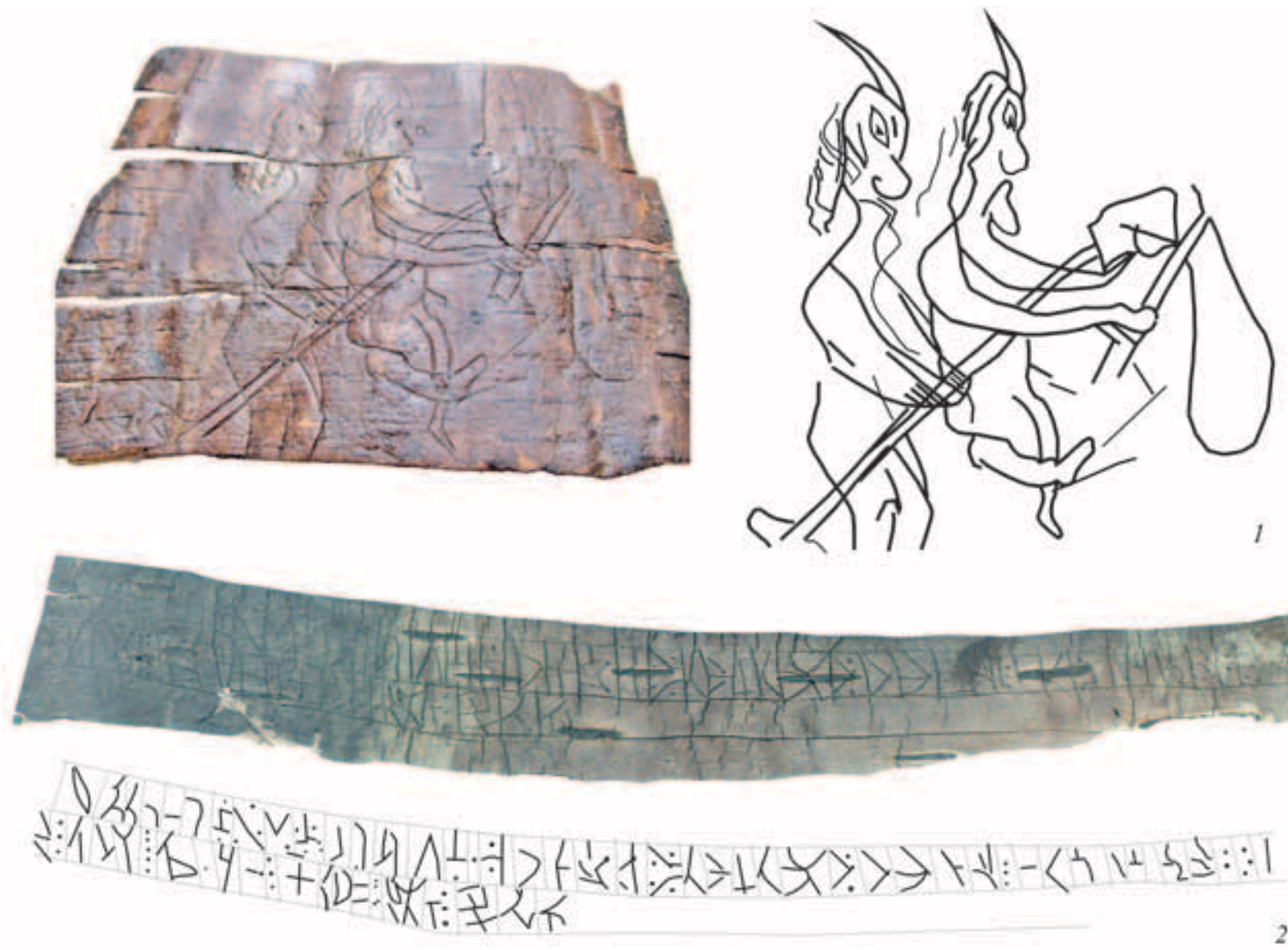

Рис. 4. Рисунки и знаки на бересте из слоя XII в. Великий Новгород, раскоп Рогатицкий-2 (ул. Б. Московская, 30). Фото и прорисовки автора

1 - «танцующие чертики» (Рог-2/1-1472); 2 - тайнопись (?) (Рог-2/1-1467)

вещи в культурный слой точно маркирует период бытования артефакта. В Новгороде все известные писала типа 17 встречены на Троицком и Неревском раскопах в слоях XI-XIII вв. Наиболее близкая находка - на раскопе Троицкий IX (усадьба Л, пл. 14, кв. 862) в слое второй половины ХІ в. (рис. 2,7; Овчинникова, 2000. С. 70, 82).

Тип 19. Представлен двумя писалами по воску (рис. 3, 9, 10). Лопаточка имеет треугольную форму, рабочий край которой завершается валиком.

Оба писала обнаружены на Козмодемьянском-3 раскопе (Неревский конец, Софийская сторона) в слое конца XIII - начала XIV в. Писало (Козм-3/1-164) имеет упор в виде валика (вариант «б»-рис. 3, 9; Овчинникова, 2000. С. 61), писало (Козм-3/2-453) такого упора не имеет и представляет, видимо, новый вариант (рис. 3,10 ).

Писала, являясь специальным инструментом для письма, были, безусловно, предметом многофункциональным: им могли выводиться и буквы, и изображения.
Новгородской экспедицией ИА РАН с 2008 г. по настоящее время собраны разнообразные предметы с различными надписями и граффити, выполненные на камне, свинце, керамике, дереве, кости и, конечно, бересте.

Береста, как самый доступный материал, использовалась в Новгороде широко и повсеместно. Среди изображений на бересте можно выделить рисунок, изображающий двух веселых «чертиков» (рис. 4,1$)$, и бересту с тайнописью, которая пока не расшифрована (рис. 4,2 ). Обе находки происходят с Рогатицкого-2 раскопа из слоя XII в.

Орнаменты и рисунки, выполненные на этом податливом материале, также могли сделать любым заостренным предметом, в том числе и деревянным. На Рогатицком-2 раскопе было обнаружено восемь деревянных заостренных стержней, происходящих из слоя второй половины XII в. (табл. 2; рис. 5), один из которых (Рог-2/1-1627) имеет резное завершение (рис. 5, 1). Длина стержней составляет примерно 13-15 см. Учитывая 
Таблица. 2. Паспортные данные деревянных заостренных стержней. Раскоп Рогатицкий-2, Великий Новгород.

\begin{tabular}{|c|c|c|c|c|c|c|}
\hline № п/п & Уч. & № п/о & Кв. & Гл., см & Примечание & № рис. \\
\hline 1 & 1 & 1625 & A-5 & -546 & & \\
\hline 2 & 1 & 1626 & A-5 & -547 & Резное завершение & 5,1 \\
\hline 3 & 1 & 1627 & A-5 & -547 & & 5,2 \\
\hline 4 & 1 & 1632 & A-5 & -548 & & \\
\hline 5 & 1 & 2016 & B-4 & -648 & & \\
\hline 6 & 2 & 1060 & E-1 & -532 & & 5,3 \\
\hline 7 & 2 & 1067 & Д-3 & -532 & & \\
\hline 8 & 3 & 763 & B-8 & -520 & & \\
\hline
\end{tabular}

многофункциональность подобных предметов, они вполне могли использоваться для нанесения букв, рисунков и знаков на бересте или воске.

Надписи на предметах быта говорят не только о грамотности ремесленников, но и о грамотности тех, для кого надписи предназначались. В связи с этим особый интерес представляют шиферные

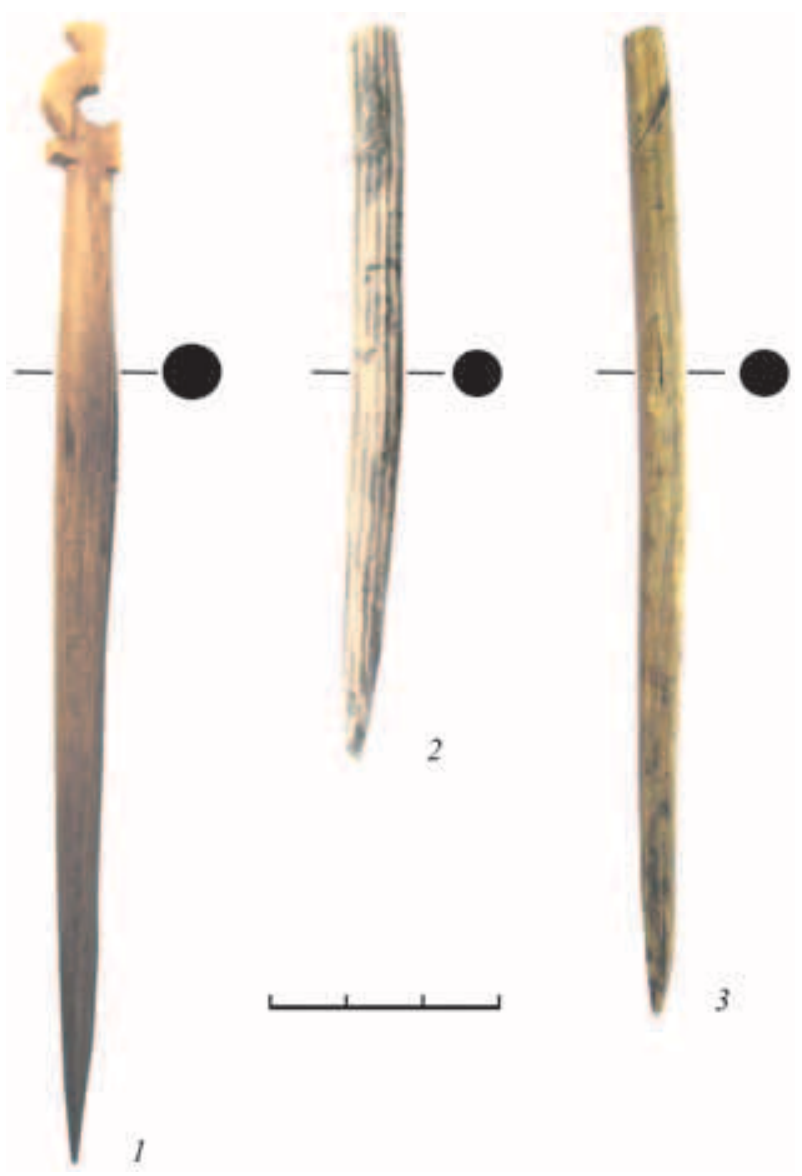

Рис. 5. Деревянные заостренные стержни. Великий Новгород. Раскоп Рогатицкий-2

1 - стержень с резным навершием (Рог-2/1-1627); 2 - Рог-2/1-1632; 3 - Рог-2/3-763 пряслица, использовавшиеся при прядении. Очень часто они несут на себе владельческие надписи или знаки, которые могли сделать любым заостренным железным предметом ремесленники или сами владелицы (рис. 6).

Шифер (пирофиллитовый сланец) представляет собой натуральный природный камень, отвечающий по составу гидросиликату алюминия. В природе встречается в двух разновидностях - фиолетовой (более твердой) и розовой. Слоистая структуpa, небольшая твердость (1-2 по шкале Мооса) и высокие декоративные качества обеспечили широкое использование этого природного камня в быту.

Но если для начертания знаков и прорисей на пряслицах, керамике и прочих поверхностях могли использоваться любые предметы в форме заостренного стержня, то написание букв представляло собой куда более сложный процесс. Воспроизведение букв на различном материале было довольно сложным (Медведев, 1960: Овчинникова, 2000. С. 65). Поэтому мастеру-писцу помимо материала и приспособлений для подчисток и соскабливания ошибок в тексте (Чаев, Черепнин, 1946. С. 118) требовался некий набор письменных инструментов, включающий различные типы писал и шильца для разлиновки.

Есть все основания утверждать, что описанные выше писала представляют собой набор специальных инструментов для письма. Они выполнены из кости, бронзы и железа, что позволяло использовать их при работе с поверхностями различной твердости. Конструктивные особенности навершия писала (лопаточки) позволяли править и убирать текст, заглаживать и соскабливать воск в цеpax, убирать залитый в формочках воск, сохраняя надписи. М.Н. Тихомиров высказал предположение, что многочисленные граффити новгородских церквей XI-XII вв. сделаны писцами или горожанами, постоянно носившими эти орудия при себе (Аричиховский, Тихомиров, 1953. С. 14). 

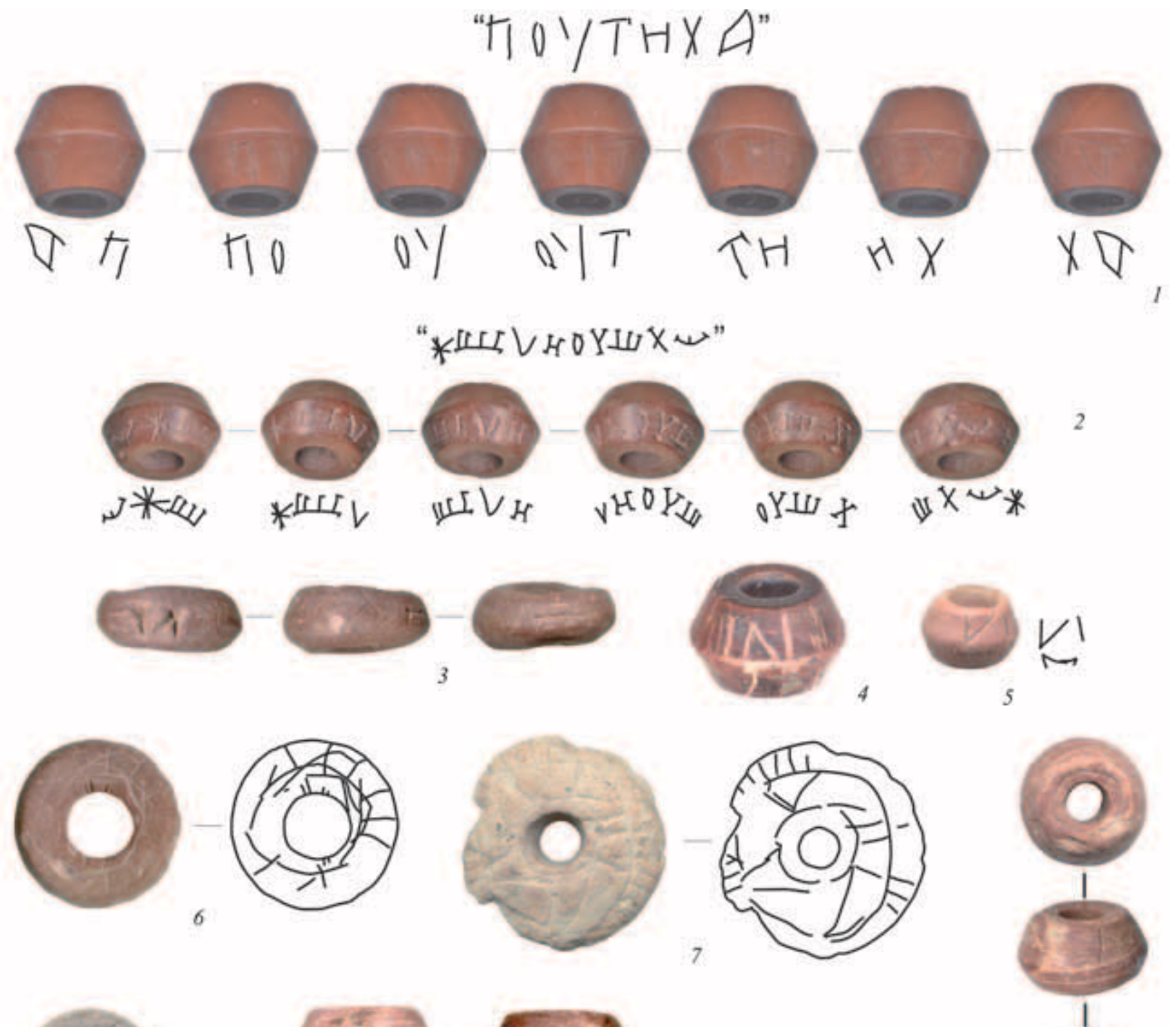

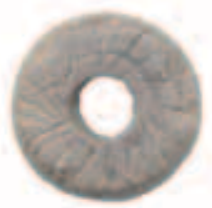

8

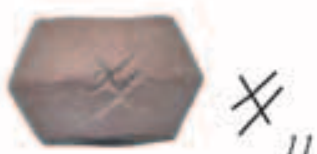

11
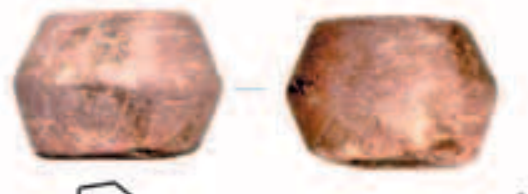

$\sqrt{1}$ $\sim \sim \sim$

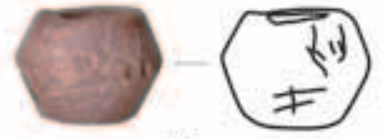

12
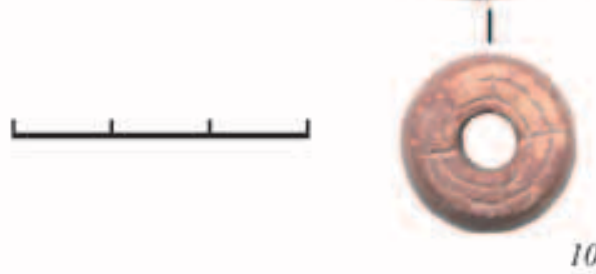

13

Рис. 6. Шиферные пряслица с процарапанными надписями и знаками. Великий Новгород.

Раскопы Власьевский-2, Досланьский-1, Десятинный-1. Фото и прорисовки автора

1 - владельческая надпись «ПУТИХА» (Влас-2/2-23); 2 - подражание письму (?) (Влас-2/3-236); 3 - буквенный знак «И» (Досл-1/13-5); 4 - знаки и черточки (Влас-2/2-72); 5 - знаки и черточки (Дес-1/2-712); 6 - черточки (Дес-1/7-61);

7 - черточки (Дес-3/2-3); 8 - черточки (Влас-2/6-38); 9 - черточки (Дес-1/1-75); 10 - крест в круге и зигзагообразная линия (Дес-1/7-182); 11 - черточки (Дес-1/3-428); 12 - черточки (Дес-1/9-124); 13 - крест (Дес-1/11-41) 


\section{Литература}

Арииховский А. В., Тихомиров М.Н., 1953. Новгородские грамоты на бересте (из раскопок 1951 года). М.: АН СССР. 68 с.

Будилович А.С., 1875. XIII слов Григория Богослова в древнеславянском переводе по рукописи Императорской Публичной библиотеки XI века: Критико-палеографический труд А. Будиловича. СПб.: Отд. рус. яз. и словестности Имп. Акад. наук. 285 с.

Гуревич Ф.Д., 1973. Грамотность горожан древнерусского Понеманья // КСИА. Вып. 135. C. $28-34$.

Захаров С. Д., 2004. Древнерусский город Белоозеро. М.: Индрик. $592 \mathrm{c}$.

Медведев А. Ф., 1960. Древнерусские писала $\mathrm{X}-$ XV вв. // СA. № 2. С. 63-88.

Медынщева А. А., 1997. Эпиграфика, писала (стили) и церы//Древняя Русь. Быт и культура. М.: Наука. С. 140-152. (Археология).
Овчинникова Б.Б., 2000. Писала-стилосы древнего Новгорода $\mathrm{X}-\mathrm{XV}$ вв. (свод исторического источника) // Новгородская Русь: историческое пространство и культурное наследие. Екатеринбург. С. 45-105. (Проблемы истории России; вып. 3).

Олейников О.М., 2016. Новый тип письменных принадлежностей из Великого Новгорода // КСИА. Вып. 242. С. 191-198.

ПСРЛ.Т. 6. Вып. 1. Софийская первая летопись старшего извода. М.: ЯСК, 2000. 312 с.

Тимощук Б.А., 1956. Об инструментах для письма («стилях») // КСИИМК. Вып. 62. С. 155-158.

Чаев Н. С., Черепнин Л. В., 1946. Русская палеография. М.: Главное архивное управление МВД СССР. Историко-архивный институт. 213 с.

Хорошев А.С., 1978. Раскопы южной части Плотницкого конца // Археологическое изучение Новгорода / Под общ. ред. Б. А. Колчина и В. Л. Янина. М.: Наука. С. 174-196. 


\section{Музыкальные инструменты с Фёдоровского раскопа в Новгороде ${ }^{1}$}

Федоровский раскоп является одним из крупнейших новгородских раскопов. Он располагался на южном берегу ныне засыпанного Федоровского ручья в Плотницком конце средневекового города.

Археологические исследования на раскопе, общая площадь которого составила 2470 кв. м, проводились в течение четырех полевых сезонов (1991-1993; 1997 гг.). В процессе работ изучены остатки уличных настилов двух средневековых улиц - Коржевой и Славковой, а также застроечные комплексы восьми усадеб (А-3) с более чем 160 жилыми и хозяйственными сооружениями XI-XVI вв. (рис. 1).

На раскопе обнаружено более 6600 индивидуальных находок, среди которых берестяные грамоты XI-XIV вв., вислые свинцовые актовые печати и пломбы, комплекс находок византийского происхождения XI-XII вв. и т. Д. (Дубровин, Тарабардина, 2004).

Среди вещевого материала Федоровского раскопа представлены три основные группы музыкальных инструментов: самозвучащие, духовые и струнные ${ }^{2}$.

\section{Самозвучащие музыкальные инструменты}

\section{Бубенчики бронзовые}

К самозвучащим музыкальным инструментам В. И. Поветкин предлагал относить бубенчики. Обычно они изготавливались из бронзы и использовались как привески к одежде, пуговицы (?) или входили в комплект музыкальных погремушек (Поветкин, 1994а. С. 68). На Федоровском раскопе в слоях второй половины XI - начала XIII в. ${ }^{3}$ найдено 14 литых и тисненых бронзовых бубенчиков (табл. 1). Среди них представлены как ранние грушевидные крестопрорезные экземпляры (рис. 2, 1), так и более поздние - шаровидные линейнопрорезные (рис. 2, 2). Все федоровские бубенчики вписываются в разработанную М.В. Седовой и дополненную Ю.М. Лесманом типологию с соответствующими хронологическими границами (Седова, 1981. С. 156. Рис. 62; Лесман, 1990. С. 60-61, Рис. 6, 3.2-3.7).

Шумящие привески, по мнению В.И. Поветкина, следует рассматривать не только как украшения женского костюма, но и как самозвучащие музыкальные инструменты, призванные своим позвякиванием отгонять злые силы от их владельцев (Поветкин, 1997а. С. 185). На Федоровском раскопе обнаружено четыре бронзовые шумящие привески (перекоп-балласт-382/701/, перекоп-15-351/40/, $\left.2_{1-4}-16-61 / 2 /, 6 / 7{ }_{6}-19-518 / 44 /{ }^{4}\right)$. К сожалению, все они, кроме одной, сохранились в крайне фрагментированном виде, что затрудняет их типологическое определение, однако две привески (перекоп-балласт-382 (701) и перекоп-15-351 (40) - рис. 3, 2) все-таки условно можно отнести к полым конькам, распространенным в Новгороде в XIII-XIV вв. (Седова, 1981. С. 31) Единственная привеска, сохранившаяся целиком (рис. 3,1 ; 6/7-19-518 (44) - конец 70-х гг. ХІ в. - середина 30-х гг. XII в.), имеет аналоги в средневековом материале прикамских финнов, в частности, в вымской культуре коми-зырян IX-XI вв. ${ }^{5}$

\footnotetext{
${ }^{1}$ Владимир Иванович Поветкин в свое время ознакомился с представленными в статье материалами и высказал ряд ценных замечаний.

2 Здесь используется классификация музыкальных инструментов по В. И. Поветкину (1994а. С. 67-74).

3 Датировку ярусов Федоровского раскопа см.: Дубровин, Тарабардина, Тихонов, 2000.

4 Паспорта находок: ярус-пласт-квадрат (полевой номер).

5 См.: Финно-угры ... 1987. Табл. LVII, 6. Благодарю Л.В. Покровскую за консультацию по этому вопросу.
} 


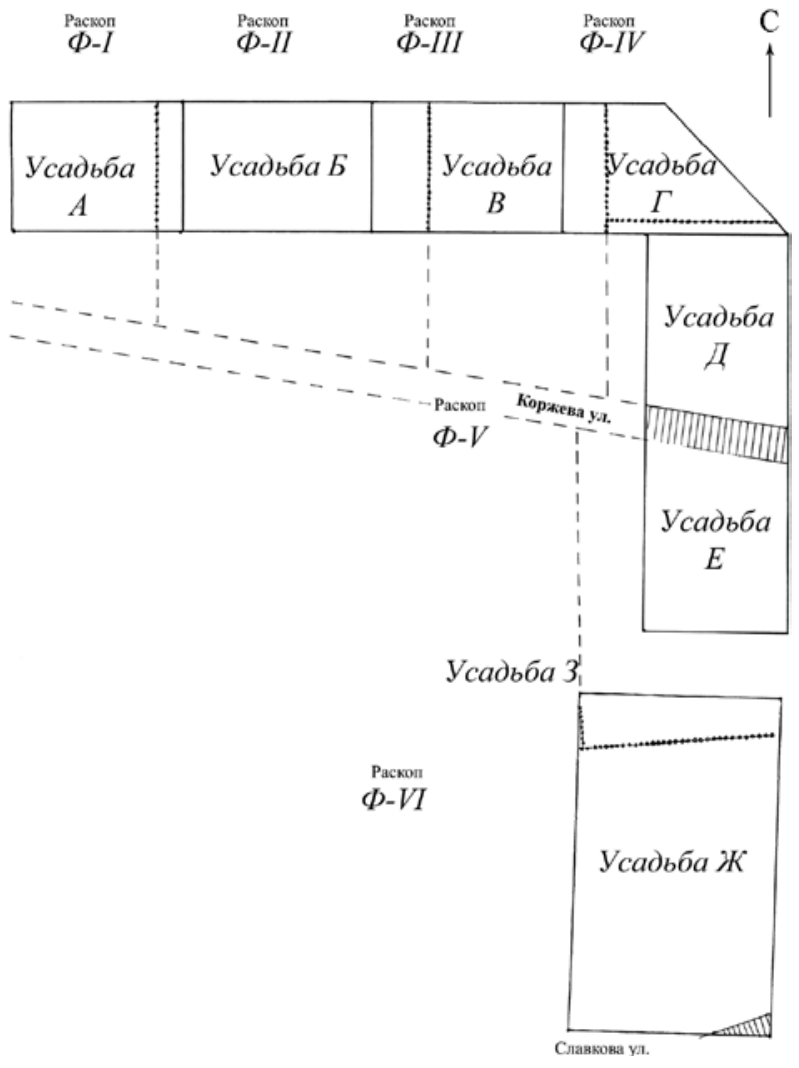

Рис. 1. Усадьбы Федоровского раскопа
Погремушки керамические 6 представлены в материалах Федоровского раскопа двумя находками. Крайне невыразительный фрагмент шарообразной погремушки происходит из перемешанных напластований: перекоп-14-546 (16). Еще одна, на этот раз целая, погремушка в форме яйца размерами $45 \times 33$ мм (рис. 2, 3; 2/3 $1-4$-16-114/46/) датируется началом - серединой XIII в. В корпусах обеих прослежены отверстия, а внутри у целой погремушки находился небольшой камешек, обеспечивающий звучание игрушки, которое, по мнению В.И. Поветкина, выполняло и сакральные охранительные функции (Поветкин, 1994а. С. 68).

Шаркунки (иаркуны), или берестяные погремушки, делались из берестяной ленты, сворачиваемой таким образом, чтобы получить объемную фигуру. Во внутреннюю полость шаркунка помещали небольшие камешки или сушеный горох, в результате чего получалась погремушка (Хорошев, 1998. С. 90. Рис. 3, 3). На Федоровском раскопе найдено 24 предмета, предположительно интерпретированные как шаркунки (рис. 2, 4; Дубровин, 2016. Табл. 3). Все они пирамидальной формы, и хотя внутри них не обнаружено ни камешков, ни горошин ${ }^{7}$, тем не менее изначально они представляли собой объемные фигуры, которые вполне могли использоваться в качестве

Таблица 1. Распределение бронзовых бубенчиков по пластам и ярусам Федоровского раскопа.

\begin{tabular}{|l|c|c|c|c|}
\hline \multicolumn{1}{|c|}{ Тип } & Пласт & Ярус & Квадрат & № полевой \\
\hline Грушевидный крестопрорезной & 13 & $13_{5}$ & 400 & 3 \\
\hline Неопределимый фр-т & 14 & Перекоп & 406 & 108 \\
\hline $\begin{array}{l}\text { Шаровидный линейнопрорезной с двойным, } \\
\text { а не тройным рельефным пояском }\end{array}$ & 16 & Перекоп & 40 & 26 \\
\hline $\begin{array}{l}\text { Шаровидный линейнопрорезной с одинарным } \\
\text { рельефным валиком }\end{array}$ & 18 & Перекоп & 109 & 15 \\
\hline Шаровидный линейнопрорезной гладкий & 18 & $4 / 5_{1-4}$ & 10 & 15 \\
\hline Неопределимый фр-т & 18 & Перекоп & 138 & 56 \\
\hline $\begin{array}{l}\text { Шаровидный линейнопрорезной с двойным } \\
\text { рельефным пояском }\end{array}$ & 18 & Перекоп & 161 & 86 \\
\hline Шаровидный лиейнопрорезной Гладкий & 18 & $4 / 5_{1-4}$ & 254 & 30 \\
\hline Грушевидный крестопрорезной с колечком & 18 & $6 / 7_{6}$ & 569 & 8 \\
\hline Шаровидный линейнопрорезной гладкий & 19 & $5 / 6_{1-4}$ & 106 & 7 \\
\hline Грушевидный крестопрорезной & 19 & Перекоп & 413 & 15 \\
\hline Грушевидный крестопрорезной & 20 & $7 / 8_{1-4}$ & 172 & 22 \\
\hline Неопределимый фр-т & 21 & $8_{1-4}$ & 101 & 44 \\
\hline Грушевидный крестопрорезной & 21 & $7 / 8_{1-4}$ & 53 & 50 \\
\hline
\end{tabular}

${ }^{6}$ По мнению Р.Л. Розенфельдта и В.И. Поветкина, к погремушкам можно отнести и глиняные писанки (см: Розенфельдт, 1997. С. 117; Поветкин, 2004). Эта категория находок представлена в статье Г.Е. Дубровина, посвященной детским игрушкам с Федоровского раскопа (Дубровин, 2016. Табл. 4).

7 Горошины вряд ли могли сохраниться в культурном слое. 

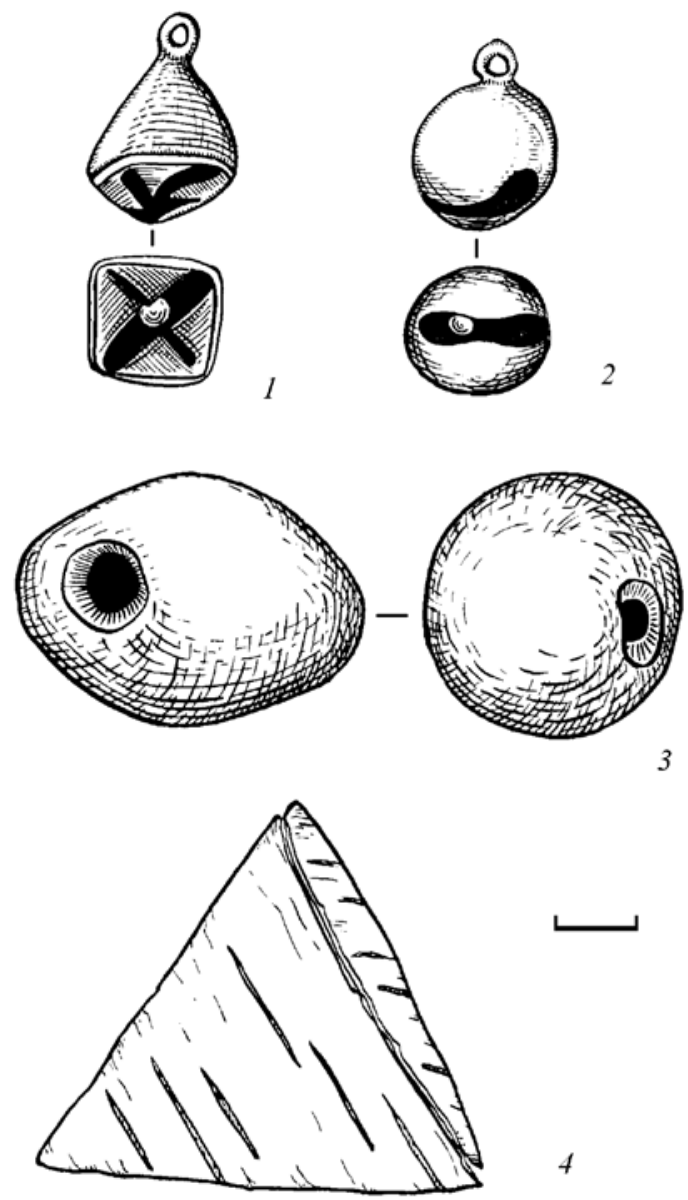

Рис. 2. Самозвучащие музыкальные инструменты 1 - бубенчик (шарок) - 7/8 1 -20-172(22); 2 - бубенчик (шарок) - 4/5 $1-4-18-10(15) ; 3$ - погремушка - $2 / 3_{1-4}-16-$ $114(46) ; 4$ - шаркунок (?) - 6/7 $1-4$-19-111(58). 1-2 - бронза; 3 - глина; 4 - береста

погремушек. Довольно интересным является распределение федоровских шаркунков (?) в культурном слое 8 : один $\left(12 / 13_{5}-18-362 / 119 /-\right.$ второй половины XI в.- середины 30-х гг. XII в.) найден на усадьбе $\mathrm{E}$, скопление из пяти штук (5/6 $1-4$-18-111/40/- середины 30 -х - второй половины 70-х гг. XII в.) и еще один экземпляр $\left(6 / 7_{1-4}{ }^{-}\right.$ 19-111/58/ - начала 80-х ХІ- середины 40-х гг. XII в.) - на усадьбе Б, остальные 17 предметов обнаружены на соседней с Б усадьбе А, преимущественно на уровне ярусов $6_{1-4}-4_{1-4}$ что соответствует середине 30-х гг. XII - началу XIII в. Не исключено, что это обстоятельство связано с какими-то традициями, существовавшими у жителей усадеб А и Б во второй трети XII - начале XIII в. (рис. 1).

\section{Духовые музыкальные инструменты}

Брунчалки (гудалки) представляли собой небольшие трубчатые косточки животных или птиц с одним или двумя просверленными отверстиями, в которые продевались тонкие ремешки (или нитки). Вращаемая взад-вперед посредством периодического натяжения ремешка брунчалка издавала угрожающий гул (Поветкин, 1994а. С. 68). На Федоровском раскопе найдено пять брунчалок (рис. 4, 1-3; Дубровин, 2016. Табл. 5) (конец 90-х гг. XI - середина XIII в.). Только у одной федоровской брунчалки (2/3 $1-4$-17-38/80/) (начало - середина XIII в.) отмечено два отверстия (рис. 4, 3), у всех же остальных - по одному.

Две близкие друг к другу по конструкции зооморфные глиняные свистульки (рис. 4, 4, 5) обнаружены в перемешанных напластованиях (перекоп-19-90/14/; перекоп-колодец 1, Фед. I, В. 12/б/н/). Это обстоятельство, к сожалению, не позволяет датировать указанные находки, которые, судя по этнографическим аналогам, могут оказаться слишком поздними для соотнесения их со средневековыми археологическими материалами раскопа. Разве что первая из свистулек, по мнению В. И. Поветкина, может датироваться XV-XVI вв.
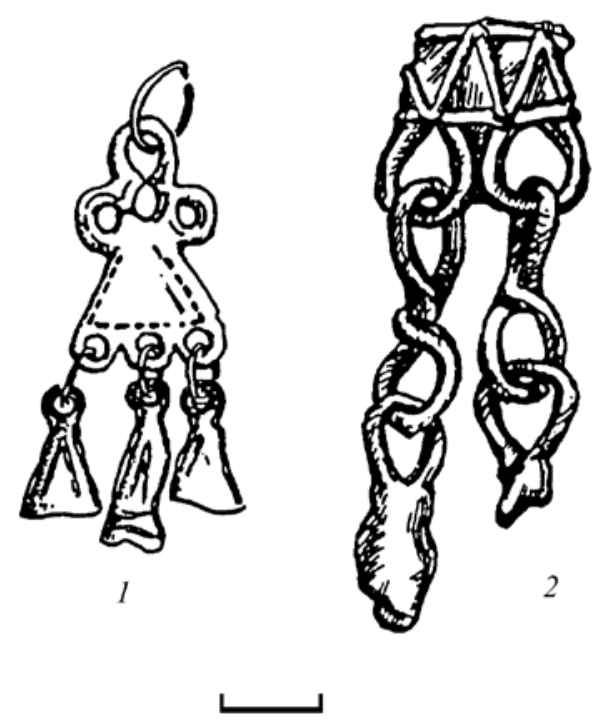

Рис. 3. Самозвучащие музыкальные инструменты. Бронзовые шумящие привески 1 - 6/76-19-518(44); 2 - перекоп-15-351 (40)

${ }^{8}$ Все они обнаружены на усадьбах Коржевой ул. 

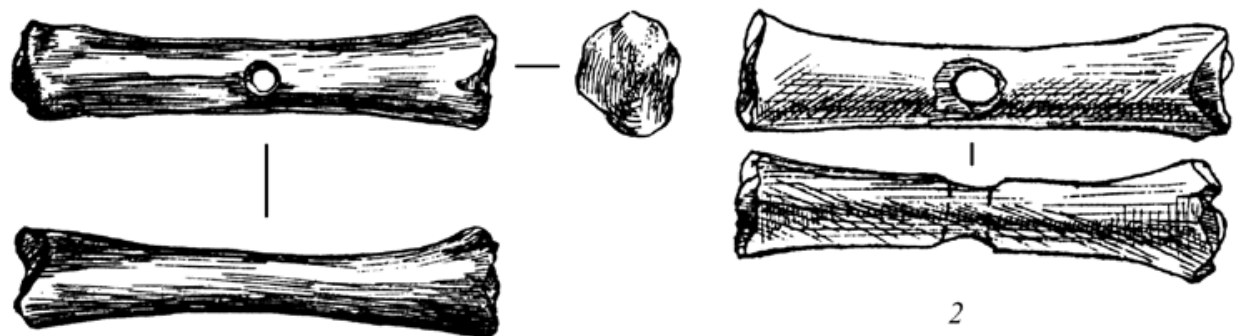

1

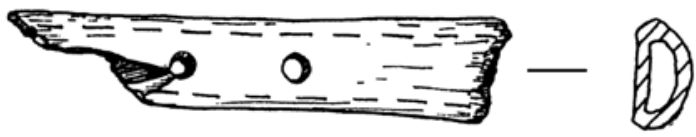

3
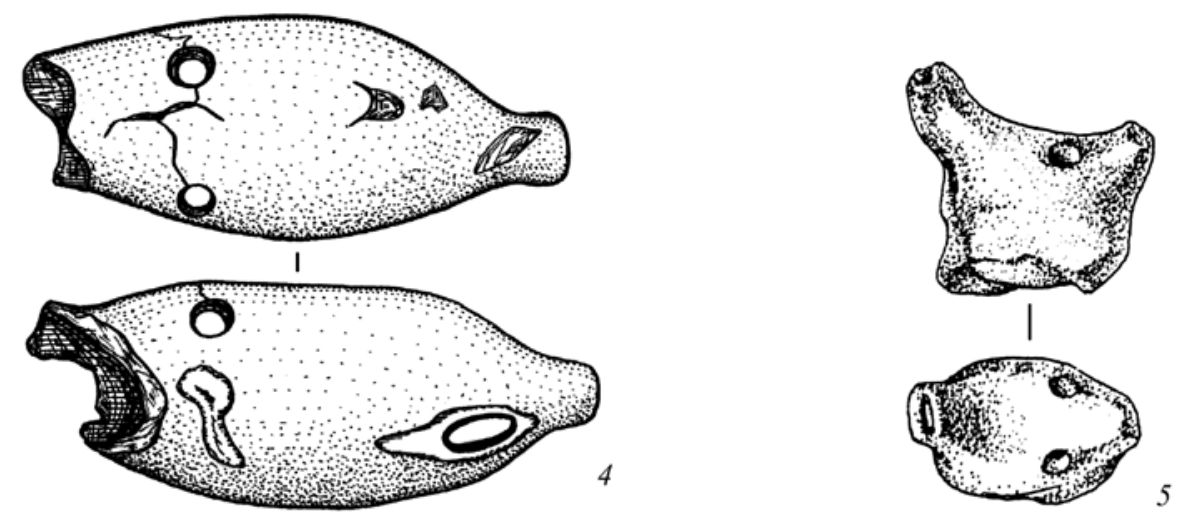

Рис. 4. Духовые музыкальные инструменты: брунчалки (1-3) и свистульки (4-5) 1 - 2-4-16-210(5); 2 - 10/11 5 -16-360(53); 3-2/3 1-4-17-38(80, фрагмент); 4 - перекоп-19-90(14); 5 - перекоп-колодец 1, Фед. I, кв. 12 (б/н). 1-3 - кость; 4-5 - глина

\section{Струнные музыкальные инструменты}

Данная разновидность музыкальных инструментов представлена на Федоровском раскопе фрагментами гуслей и гудка, а также двумя колками (шпеньками).

Колки (шпеньки). Оба федоровских колка обнаружены в перекопах (перекоп-22-43/48/ - рис. 5, 2; перекоп-балласт-334/465 - рис. 5, 3), однако первый из них с определенной долей вероятности все-таки может быть соотнесен с ярусами 8/9 $1-4$, соответствующими второй половине XI в. (до начала 80-х гг.). Оба колка, к сожалению, обломаны. Они сохранились на длину 28 и 47 мм соответственно. Диаметр рабочей части, которой колки вставлялись в колковое отверстие гуслей или гудка, -7 и 6 мм. Оба колка (шпенька) уже упоминались в публикациях В.И. Поветкина (1993. С. 145 , табл. 1,4 ; 1994б. С. 135 , табл. 1, б).

Фрагмент лирообразных гуслей (12/13-18304/1/) найден в напластованиях второй половины XI - середины 30-х гг. XII в. на территории усадь- бы Д (рис. 5, 1). Вот как описывает В.И. Поветкин эту находку: «Он представляет собой верхнюю правую часть инструмента на ширину двух шпеньковых отверстий с остатками игрового окна и следами излома в том месте, где начиналось корытце, иначе, полый сосуд гуслей. По остаткам игрового окна, по расстоянию между шпеньковыми отверстиями и их нисходящей влево линии расположения можно определить, что этот инструмент был пятиструнным. От большинства других лирообразных гуслей он отличался простыми, лишенными художественных украшений формами. Материалом для его изготовления послужило бревно диаметром 160 мм сосновой породы» (Поветкин, 1994б. С. 137). Собственно, добавить здесь нечего, разве что можно отметить, что размеры указанного фрагмента - $145 \times 72 \times 23$ мм, диаметр шпеньковых отверстий - около 6 мм, размеры игрового окна-около $60 \times 90$ мм. По графической реконструкции В.И. Поветкина данные гусли имели длину около 420 мм (Поветкин, 1994б. С. 137).

Обломок трехструнного гудка (8/9 ${ }_{1-4}-21-121 /$ $23 /$ - рис. 6) найден на усадьбе Б в напластованиях, 
соответствующих ярусам 8/9, ${ }_{1-4}$, соотносимым со второй половиной ХІ в. (до начала 80-х гг.). Показательно, что из четырех находок Федоровского раскопа, связанных со струнными музыкальными инструментами, две (обломки гуслей и гудка) относятся к этому раннему периоду, а еще одна (колок: перекоп-22-43/48/) с большой долей вероятности может быть им синхронна.

Фрагмент длиной 146 мм представлял собой обломок верхней части корпуса гудка, головки, с четырьмя отверстиями. Три из них, диаметром 6-7 мм, судя по всему, предназначались для шпеньков-колков. Четвертое отверстие меньшего диаметра (2,5-3,0 мм), вероятно, имело какое-то вспомогательное назначение. Например, в него мог вдеваться шнурок для подвешивания инструмента (Поветкин, 1997а. С. 182, Табл. 107, 3). Головка гудка была тщательно вырезана и имела красивую изогнутую форму. На ее внешней поверхности сохранились остатки резного геометрического орнамента 9 .

Находки с Федоровского раскопа пополнили коллекцию музыкальных инструментов средневекового Новгорода предметами трех разных типов.

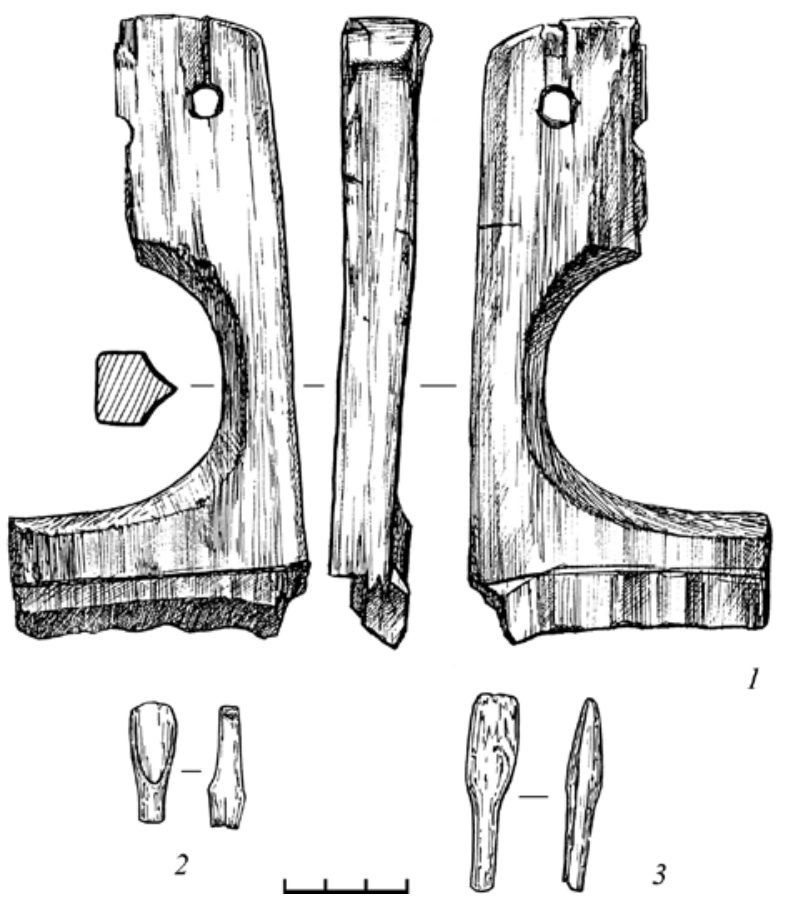

Рис. 5. Струнные музыкальные инструменты 1 - фрагмент гуслей - 12/13 5 -18-304(1); 2 - колок (шпенек) перекоп (8/9 $1-4$ ?)-22-43 (48); 3 - колок (шпенек) перекоп-балласт-334 (465)
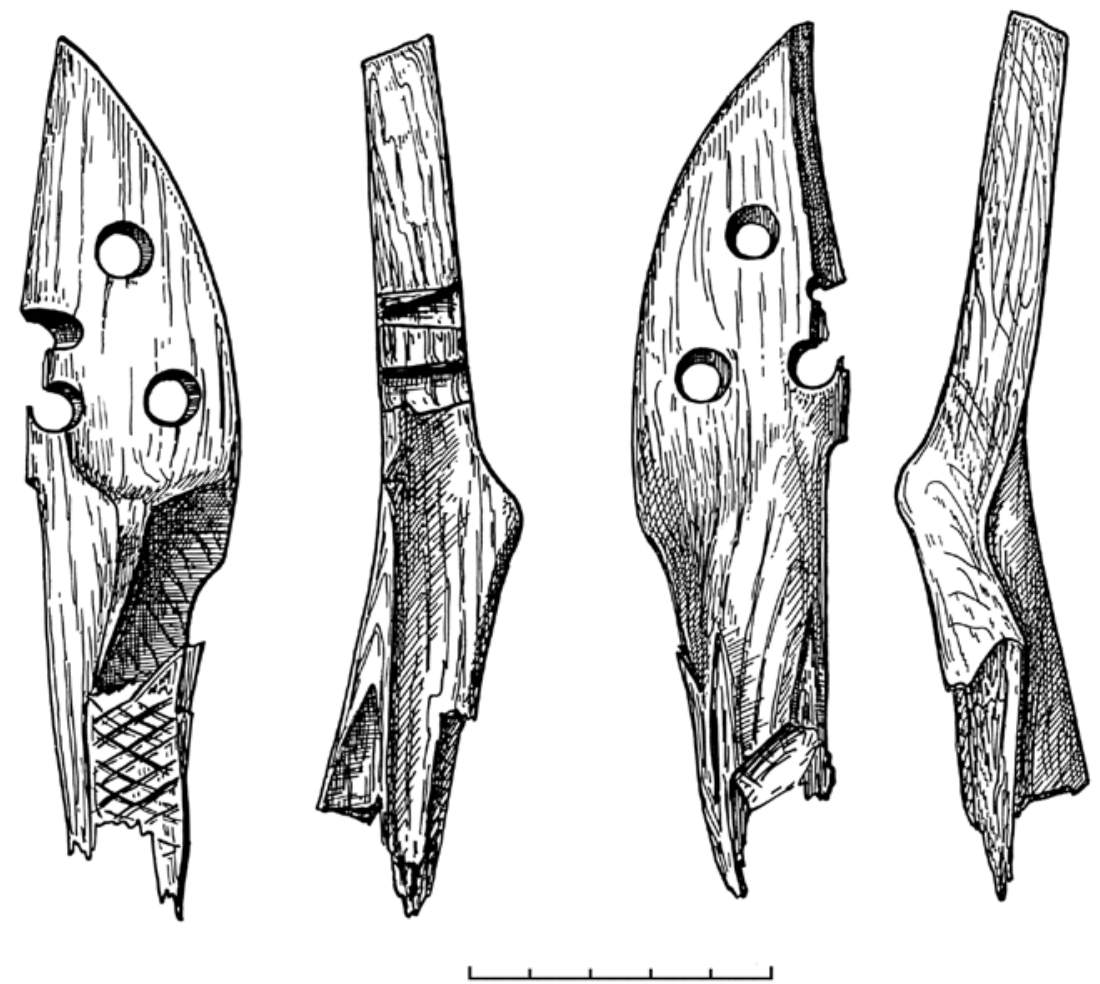

Рис. 6. Фрагмент гудка, 8/9 $1-4-21-121$ (23)

\footnotetext{
9 Кроме приведенных в данном разделе находок, по мнению В.И. Поветкина, к музыкальным древностям могут быть также отнесены костяные наконечники стрел с боковыми отверстиями - так называемые свисты (Поветкин, 1997б. С. 69-75. Рис. 2,3$)$. Однако эту категорию находок целесообразно рассматривать отдельно, вместе с другими предметами вооружения.
} 


\section{Литература}

Дубровин Г.Е., 2016. Детские игрушки с Федоровского раскопа в Новгороде // КСИА. Вып. 245. Ч. II. C. $75-89$.

Дубровин Г.Е., Тарабардина О.А., Тихонов П.И., 2000. Хронология Федоровского раскопа // ННЗ. Вып. 14. Новгород: НГМЗ. С. 183-194.

Дубровин Г.Е., Тарабардина О.А.,2004. Федоровский раскоп в Новгороде. Некоторые итоги // Новгородские археологические чтения - 2. Матер. науч. конфер., посвященные 70-летию археологического изучения Новгорода и $100-л е-$ тию со дня рождения основателя Новгородской археологической экспедиции А. В. Арциховского. Великий Новгород: НГМЗ. С. 224-233.

Лесман Ю.М., 1990. Хронология ювелирных изделий Новгорода (X-XIV вв.) // Материалы по археологии Новгорода 1988. М.: НАЭ МГУ, ИА АН СССР и НГОМЗ. С. 29-98.

Поветкин В.И., 1993. Новгород музыкальный по материалам археологических исследований. Раскопки 1992 г. // ННЗ. Вып. 7. Новгород: НГМЗ. С. 144-152.

Поветкин В.И., 1994а. Музыкальные древности Новгорода // Новгородские археологические чтения: Матер. науч. конф., посвященной 60-летию археологического изучения Новгорода и 90-летию со дня рождения основателя Новгородской археологической экспедиции А.В. Арциховского. 28 сентября - 2 октября 1992 г. Новгород: НГМЗ. С. 67-74.
Поветкин В.И., 1994б. Новгород музыкальный по материалам археологических исследований. Открытия 1993 г. // ННЗ. Вып. 8. Новгород: НГМЗ. С. 134-143.

Поветкин В. И., 1997а. Музыкальные инструменты // Древняя Русь. Быт и культура. М.: Наука. С. 179-185. (Археология).

Поветкин В. И., 1997б. Слово о музыкальной археологии России // ННЗ. Вып. 11. Новгород: НГМЗ. C. $166-176$.

Поветкин В.И., 2004. Начало источниковой базы музыкальной археологии в Великом Новгороде (музыкальные древности из раскопок А.В.Арциховского) // Новгородские археологические чтения - 2. Матер. науч. конфер., посвященной 70-летию археологического изучения Новгорода и 100-летию со дня рождения основателя Новгородской археологической экспедиции А. В. Арциховского. г. Великий Новгород, 21-24 сентября 2002 г. Великий Новгород: НГМЗ. С. 114-123.

Розенфельдт Р.Л., 1997. Игры взрослых и детей // Древняя Русь. Быт и культура. М.: Наука. С. 110-119. (Археология).

Седова М.В., 1981. Ювелирные изделия древнего Новгорода (X-XV вв.) М.: Наука. 194 с.

Финно-угры и балты в эпоху средневековья. М.: Наука, 1987. 509 с. (Археология СССР).

Хорошев А.С., 1998. Детские игрушки из Новгорода (классификационный обзор археологических находок) // ННЗ. Вып. 12. Новгород: НГМЗ. С. 82-94. 


\section{В. Ю. Коваль \\ Институт археологии РАН, г. Москва}

\section{Импортная поливная керамика Житного раскопа в кремле Переяславля Рязанского}

В ходе исследований на Житном раскопе, проводившихся под руководством В.И. Завьялова в 2004-2015 гг, была получена небольшая, но чрезвычайно интересная коллекция поливной керамики, происходившей из слоев XIII-XVII вв. Наиболее выразительную ее часть составляли образцы дальнего импорта, наряду с которыми имелись изделия местного русского производства, привезенные, вероятно, из других городов средневековой Руси.

Импортная поливная керамика Рязани уже становилась предметом исследований (Коваль, Судаков, 1995; Коваль, 2005), большая серия находок была включена в общерусский свод импортной восточной керамики (Коваль, 2010), однако целиком комплекс находок с Житного раскопа рассматривается впервые. Наиболее целесообразным представляется начать изучение этого комплекса с группировки материала, проводимой по принципам, принятым для классификации восточной керамики (Коваль, 2010. С. 18-24).

Импортная поливная керамика на Житном раскопе представлена 54 находками, относившимися к 40-45 изделиям. Почти все они являлись обломками различных сосудов, но наряду с ними встречены также привеска и обломок декоративной облицовочной плитки. Среди всех этих находок чуть более половины (29 экз.) составляла керамика из кашина, 19 находок принадлежали изделиям из различных глин (майолике и полумайолике), а шесть обломков - китайским селадонам.

Керамика из кашина (силикатной массы) представлена исключительно изделиями, покрытыми прозрачной глазурью (полуфаянсами по принятой условной терминологии).

\section{Полуфаянсы}

К этому классу принадлежали изделия трех серий - без дополнительного декора, с надглазурным и подглазурным декором.

Полуфаянсы без дополнительного декора включали две разновидности:

1) с бирюзовой глазурью - два небольших обломка сосудов (рис. 1,1 ) из слоев XIV в. ${ }^{1}$;

2) с ультрамариновой глазурью - мелкий обломок сосуда, найденный в слое второй половины XV в. ${ }^{2}$, то есть в переотложенном состоянии.

Все сосуды изготовлены из белого (или розоватого) рыхлого кашина, идентичного по своим характеристикам изделиям нижневолжских центров Золотой Орды, функционировавшим в середине XIV - начале XV в. Соотнесение перечисленных образцов с керамикой без дополнительного декора условно, поскольку они невелики по размерам, а на целых сосудах вполне мог размещаться какой-то декор, не попавший на эти осколки.

Вторая серия полуфаянсов - с надглазурным декором - также невелика по объему и включает только две группы.

$A$. Керамика с росписью люстром по ультрамариновой прозрачной глазури - два обломка ${ }^{3}$, принадлежавших, вероятно, одному и тому же сосуду (предположительно кувшину с рельефно моделированным туловом), изготовленному из твердого белого кашина. Люстровая роспись фиксируется на внешней поверхности сосуда, покрытой ультрамариновой глазурью, тогда как внутренняя не декорирована и облицована бесцветной прозрачной глазурью, на которой видны мелкие синие точки

\footnotetext{
2012-53, 503. Здесь и далее шифры находок состоят из года раскопок и номеров по коллекционным описям, приложенным к отчетам о раскопках.

2 2010-22.

3 2013-739, 2015-141.
} 
от кобальтового красителя, применявшегося для окраски ультрамариновой глазури (рис. 1, 2). Обломки столь малы, что не позволяют составить представление о внешнем виде и декоре целого сосуда. Однако все признаки этого изделия (облицовка внутренней поверхности бесцветной глазурью, твердый кашин, рельефная моделировка тулова) более характерны для продукции Ирана второй половины XII - первой трети XIII в. Такая керамика известна как в музейных коллекциях иранских художественных изделий, так и среди археологических находок на территории Руси: в Великом Новгороде, Твери, Владимире, Дмитрове, Киеве, Чернигове (Коваль, 2010. С. 58-60). Одна находка подобного сосуда в прошлом была сделана и в Рязанском кремле - в раскопках 1988 г. (Коваль, Судаков, 1995. С. 127). Однако наиболее полные аналогии происходят из Старой Рязани, где найдены четыре обломка от двух кувшинов с рельефной моделировкой тулова, у которых внутренняя поверхность также была покрыта бесцветной глазурью (Даркевич, Стародуб, 1983. Рис. 1Б, 19, 22).

Обе новые рязанские находки происходили из одного и того же контекста (пласта 28), однозначно датируемого в пределах конца XII - первой половины XIII в. (Завьялов, Судаков, 2017. Табл. 1), что позволяет уверенно относить остатки иранского кувшина к домонгольскому периоду.

Б. Второй образец полуфаянса с надглазурной росписью не менее интересен, поскольку относится к чрезвычайно редкой разновидности - это кашинная подвеска ${ }^{4}$ с декором из бирюзовой и коричневой (марганцевой) глазури (рис. 1, 4). Подвеска изготовлена из твердого белого кашина, ее лицевая сторона имеет рельефный подглазурный декор. После того как изделие было облицовано бирюзовой глазурью, углубления на ее лицевой поверхности заполнялись марганцевой глазурью, толстый слой которой давал интенсивный черный цвет. Трудно сказать, наносилась ли марганцевая глазурь до первого обжига или после него (для ее закрепления в этом случае требовался второй обжиг), однако в результате глазури сплавлялись столь прочно, что ни малейших отслоений черного декора не наблюдается.

На территории Руси до сих пор были известны только две находки кашинных подвесок (из Нижнего Новгорода и селища Новинки близ Ельца), только одна из которых (вторая) была близка рязанской по размерам, хотя имела иную, прямоугольную форму и иной декор - рельефный «шахматный», но также подцвеченный марганцевой глазурью (Коваль, 2010. С. 180. Ил. 75, 10). Последняя происходила из контекста XIII в. Максимальное же сходство с рязанской находкой имеет кашинная подвеска, найденная при раскопках остатков города Болгара (в Татарстане) в комплексе, датированном второй половиной XIII - началом XIV в. (рис. 1, 5).

Подвеска из Рязанского кремля происходит из слоев, вскрывавшихся пластом 25 , и датируемых первой половиной XIV в., ее контекст почти полностью совпадает с датировками наиболее близких ей по технологии изготовления подвесок из-под Ельца и из Болгара ${ }^{5}$. К сожалению, место производства таких подвесок не установлено. На импортный характер изделий указывают использование твердого кашина и сложная технология нанесения декора. В раннезолотоордынский период изготовление кашинной керамики на территории Джучидского государства еще не было налажено, но такие производства имелись в Иране, Египте и Сирии.

Самой массовой серией полуфаянсов является керамика с подглазурныл декором. Такой декор наносился на кашинную основу до облицовки сосуда глазурью и обжига. В коллекции Житного раскопа присутствуют изделия двух групп, каждая из которых объединяет образцы нескольких типов.

Группа 1. Полуфаянсы с росписью красками.

Подгруппа $A$ - с бесцветной глазурью.

Тип 1. Полуфаянсы с полихромной (черной/зеленой, синей и бирюзовой) росписью.

Вид 1. Изделия из твердого кашина.

Единственная находка была сделана в слое XVII в. Это обломок плеча тонкостенного (3 мм) кувшина, изготовленного из твердого белого кашина, из которого было сделано пряслице диаметром 2,3 см, также впоследствии разбитое 6 . Роспись внешней поверхности выполнена буровато-зеленоватой и синей красками (рис. 1, 5). Подобный декор в сочетании с высококачественным кашином - признаки дальнего импорта, вероятно, из Ирана или Турции, где подобные изделия могли производиться в XVI-XVII вв. Довольно примитивный декор не позволяет предложить конкретные аналогии, поэтому для уточнения происхождения этого сосуда потребуется химический анализ кашина и глазури. Однако для периода XVI-XVII вв.

4 2012-701 (КП-29301; А 902; № 195). Благодарю Д. А. Иванова (РГИАМЗ) за предоставленные фото артефакта.

52015 - раскоп CLXXIX - № 1118.

$62005-221$. 

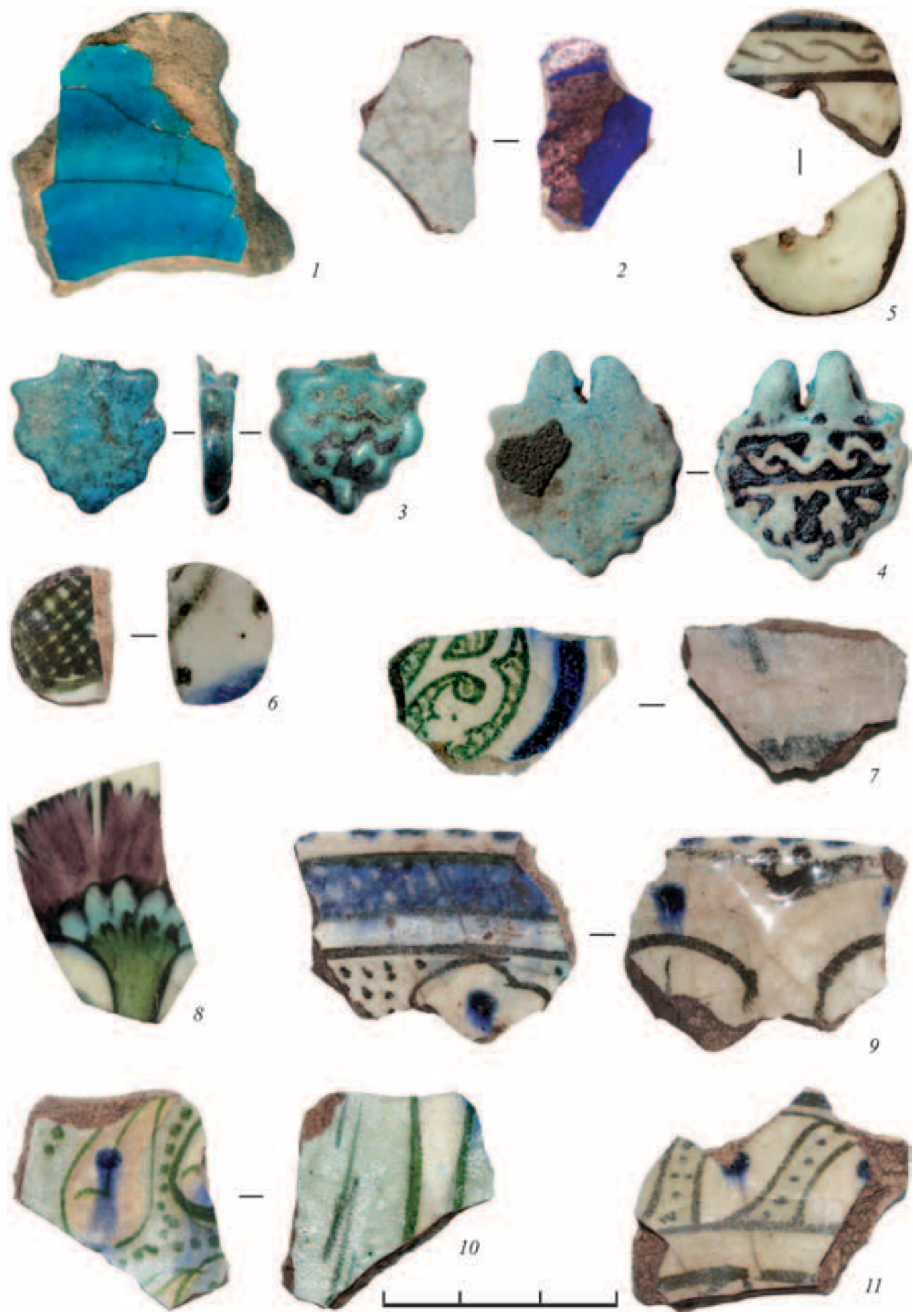

Рис. 1. Полуфаянсовые (кашинные) изделия из Переяславля Рязанского и Болгара

1 - бирюзовый полуфаянс (2012-53); 2 - люстровый полуфаянс (2013-739); 3, 4 - кашинные подвески из Рязани (2012-701) и Болгара; 5-8 - полуфаянсы с полихромной росписью (2005-223; 2010-152; 2012-94; 2005-221); 9-11 - полуфаянсы с росписью красками и белым ангобом (9: 2011-257, 10-11: 2012-229) 
эта конкретизация не столь актуальна, поскольку связи Руси с Ираном и Турцией были в это время одинаково ограниченными.

Вид 2. Изделия из рыхлого кашина.

К этому виду относятся в основном чаши, изготовленные в мастерских нижневолжских центров Золотой Орды в середине - второй половине XIV в. Обломки таких сосудов найдены практически во всех городах Руси этого времени, более или менее изученных. В рассматриваемой коллекции к этому виду керамики относились пять находок ${ }^{7}$, принадлежавших четырем чашам, в росписи которых использованы темно-зеленый и синий красители (рис. 1, 6, 7). Из одного обломка пытались изготовить пряслице диаметром 1,8 см, но еще до просверливания отверстия оно, вероятно, раскололось (рис. 1,6$)$. Подобная цветовая гамма особенно характерна для изделий второй половины XIV в. Почти все находки происходят из контекстов середины XIV в. (пласты 24, 25), и только заготовка пряслица найдена в пласте 20 -в отложениях первой половины XV в. (Завьялов, Судаков, 2017. Рис. 12).

Тип 2. Полуфаянсы с полихромной (зеленой, бирюзовой и коричневой) росписью в черных контурах.

К числу изделий этого типа, изготовленных из мягкого кашина и покрытых бесцветной глазурью, относился единственный обломок кувшина ${ }^{8}$ с изображением цветка гвоздики (рис. 1, 8). Этот образец уже публиковался (Коваль, 2010. Ил. 25, 2) и был атрибутирован производству Османской Турции XVI-XVII вв. Контекст находки (пласт 8) соответствует слою начала XVII в., так что дату сосуда можно уточнить в сторону некоторого удревнения. Уже отмечалось, что мотив цветка гвоздики был одним из излюбленных на турецких полуфаянсах, производившихся в городе Изник, но эти цветки изображались при помощи красного ангоба, тогда как в данном случае применен марганцевый краситель. Учитывая тот факт, что марганцевая подцветка рисунка начала использоваться мастерами Изника уже в первой половине XVI в., а цветочные композиции с позитивным рисунком на белом фоне распространяются с середины XVI в. вместе с применением красного ангоба (Коваль, 2010. С. 80), можно думать, что кувшин с пурпурно-коричневым цветком гвоздики мог быть создан в первой половине - середине XVI в., до обретения нового стиля раскраски рисунков.

Тип 3. Полуфаянсы с монохромной синей росписью.

Вид 1. Изделия из твердого кашина.

Целое пряслице (диаметром 1,7 см) и обломок другого пряслица диаметром 1,9 см9 найдены в контекстах начала XVII в. (пласт 8). Несмотря на то что образцы очень невелики, на каждом из них сохранились остатки декора в виде параллельных синих линий. Реконструировать такой декор невозможно, но если на целых сосудах он был монхромным, то перед нами, вероятно, части одного или двух сосудов, произведенных в Иране в XV-XVI вв. и попавших в Рязань по путям волжской торговли. Такие изделия встречаются на Руси очень редко и до сих пор были известны только в трех городах - Москве, Коломне и Нижнем Новгороде. Присутствие редких импортов в Рязани позволяет думать, что они доставлялись сюда из Москвы, монополизировавшей внешнюю торговлю, а владельцами сосудов (до того, как они были разбиты) могли быть чиновники самого высокого ранга.

Вид 2. Изделия из рыхлого кашина.

Небольшой обломок стенки чаши, украшенной вертикальными синими полосами ${ }^{10}$. Контекст находки (пласт 21), соответствующий слою первой половины XV в., полностью соответствует дате распространения подобной керамики. Несмотря на то что чаша сделана из рыхлого белого кашина, она отличается тонкими стенками (3 мм), поэтому более вероятно ее происхождение не из Золотой Орды (где подобная посуда производилась в конце XIV - первой половине XV в.), а из Ирана.

Подгруппа Б. Полуфаянсы с бирюзовой глазурью.

Включает три образца, относившихся к одному типу изделий с монохромной черной (или темнозеленой) росписью, изготовленных из рыхлого белого кашина. Из них одна находка - это маленький обломок края чаши ${ }^{11}$, а две других - обломки стенок вазы «гюльабдан» ${ }^{12}$. Такая керамика производилась в нижневолжских центрах Золотой Орды и поступала в середине - второй половине XIV в. во все крупные города Руси. Контексты находок (пласты 22 и 24) относятся ко второй

\footnotetext{
2010-152; 2012-36, 42, 94, 438.

2005-223.

2005-181, б/№.

2010-315

1 2012-79.

12 2011-65, 158 .
} 
половине XIV в. (Завьялов, Судаков, 2017. Рис. 12), то есть точно соответствуют времени бытования таких сосудов в Орде и на Руси.

Группа 2. Полуфаянсы с росписью красками и белым ангобом.

На Житном раскопе встречено 10 находок подобной керамики ${ }^{13}$ (включавшие 12 обломков от 8-10 чаш), изготовленной из белого рыхлого кашина, то есть идентичной изделиям нижневолжских городов Золотой Орды. Красочная роспись таких сосудов включала набор из черной (или зеленой разных оттенков), синей и бирюзовой красок, причем последняя использовалась очень скупо, лишь для отдельных деталей, поэтому на фрагментарном материале обычно можно наблюдать только две краски. Из 12 обломков на 7 вместо черной краски использована зеленая (рис. 1, 10, 11), а в случае применения черной краски (рис. 1,9) она могла иметь оттенки от темно-серого до коричневого. Внешняя поверхность всех чаш орнаментирована одинаково - в виде стилизованных лепестков лотоса (рис. 1, 9, 10), тогда как декор внутренней поверхности был более разнообразным: не менее двух чаш украшены рядами стилизованных ныряющих рыбок (рис. 1, 10, 11), на двух чашах этот декор состоял из трилистников и на одной - из стилизованных надписей, повторявших начертание арабского слова «икбаль» («успех»). К сожалению, все найденные обломки столь невелики по размеру, что этот декор лишь угадывается по фрагментам рисунков. Однако все перечисленные мотивы росписи относятся к серии декоративных схем, наиболее распространенных в производящих центрах Золотой Орды.

Интересны контексты находок. За исключением одного крошечного обломка, встреченного в слое XVI в., все остальные происходили из пластов 22-24 - из контекстов второй половины XIV в., что полностью соответствует встречаемости такой керамики как в других городах Руси, так и времени ее массового производства на Нижней Волге.

\section{Майолика}

К классу майолики, то есть керамики, покрытой непрозрачной поливой, принадлежат два изделия.

Одно из них - тарелка, два обломка от которой найдены с разрывом в четыре года в разных контекстах - в пластах 8 (в слое начала XVII в.) и 16 (первой половины XVI в.) ${ }^{14}$. Тарелка диаме- тром около 26 см изготовлена из белой глины без видимых примесей, с кольцевым поддоном, в котором еще до обжига проделали отверстие диаметром 2-3 мм, предназначенное для подвешивания на стену. Внешнюю поверхность тарелки покрыли бесцветной прозрачной глазурью и оставили недекорированной, но глазурь внутри поддона окрашена в нежно-зеленый цвет. Внутренняя поверхность облицована белой непрозрачной поливой, по которой проведена внутриглазурная (совершенная по сырой глазури до обжига изделия) роспись, выполненная в основном синей краской (кобальт) с добавлением оранжевого, желтого и нежно-зеленого красителей. Орнаментация довольно проста и состояла из центральной розетки и концентрических поясов, заполненных линейным орнаментом, а также мотивами лепестков и мелких цветков (?) в крайне геометризированном стиле (рис. 2, 1). Подобная керамика ранее не встречалась на территории Руси.

Майолика с подобным декором была широко распространена в Западной Европе в XVI-XVII вв. Она производилась в Италии (на родине майолики) и в других странах, в частности, в Нидерландах и Фландрии. Причем именно североевропейские изделия имеют с исследуемым образцом максимальное сходство по сочетанию следующих признаков:

1) покрытие внешней поверхности бесцветной глазурью;

2) применение беложгущейся глины;

3) набор красок росписи (синей, оранжевой, желтой и зеленой);

4) стилистика декора (центральная розетка и концентрические пояса вокруг нее);

5) отверстия для подвешивания тарелок в кольцевых поддонах.

По отдельности каждый из перечисленных признаков можно встретить на майолике разных стран, однако взаимное их сочетание присутствует именно на продукции Нидерландов и Фландрии, датируемых преимущественно в интервале 1550-1625 гг. (Amsterdam ceramics, 2012. Р. 202, 203. № 500, 502-505; Tietzel, 1980. P. 9, 118, 119. № 11-13; Pauwels, Houtekier, 1994. Р. 77-82. № 74-81; Biesboer, 1997; Korf, 1991), среди них можно привести целый ряд почти полных аналогий рязанской тарелке, например, по изображению центральной розетки (Hurst, Neal, van Beuningen,

\footnotetext{
13 2008-83; 2011-126, 136, 257; 2012-51, 104, 167, 194, 201, 229.

14 2005-242, 2009-6.
} 

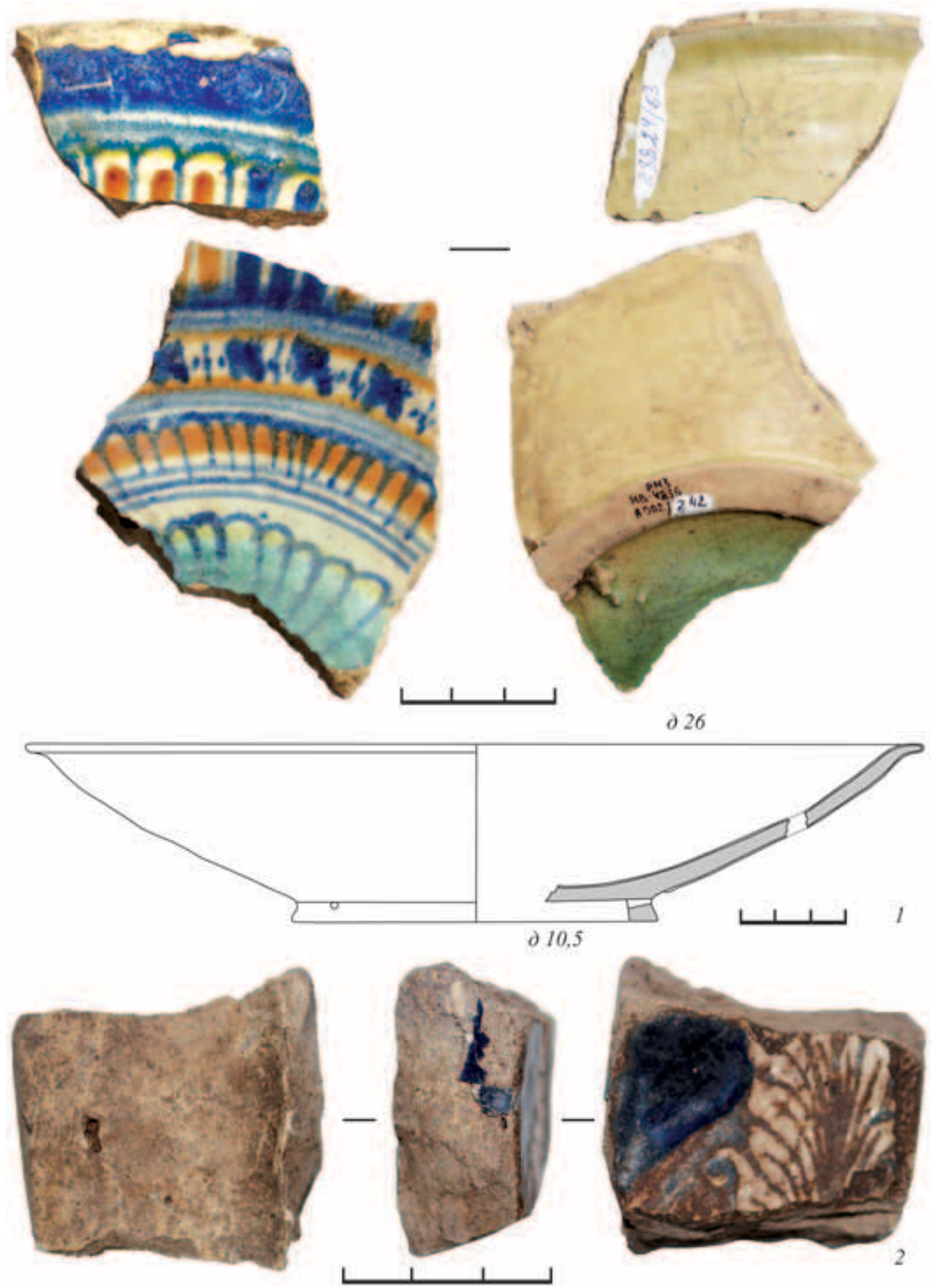

Рис. 2. Изделия из майолики

1 - обломки майоликовой тарелки (2005-242, 2009-6), графическая реконструкция профиля тарелки; 2 - обломок майоликовой декоративной облицовочной плитки (2013-53)

1986. Fig. 55. № 169; Pauwels, Houtekier, 1994. № 74, 81; Biesboer, 1997. Katnr. 21) (рис. 3). Подобные розетки серийно встречаются исключительно на керамике Нидерландов и Фландрии. Однако более точно назвать место производства в рамках очерченного региона сложно, поскольку существовало несколько подобных мест, а их продукция имела большое сходство.

Атрибуция и датировка находок позволяет также выразить уверенность в том, что только один 


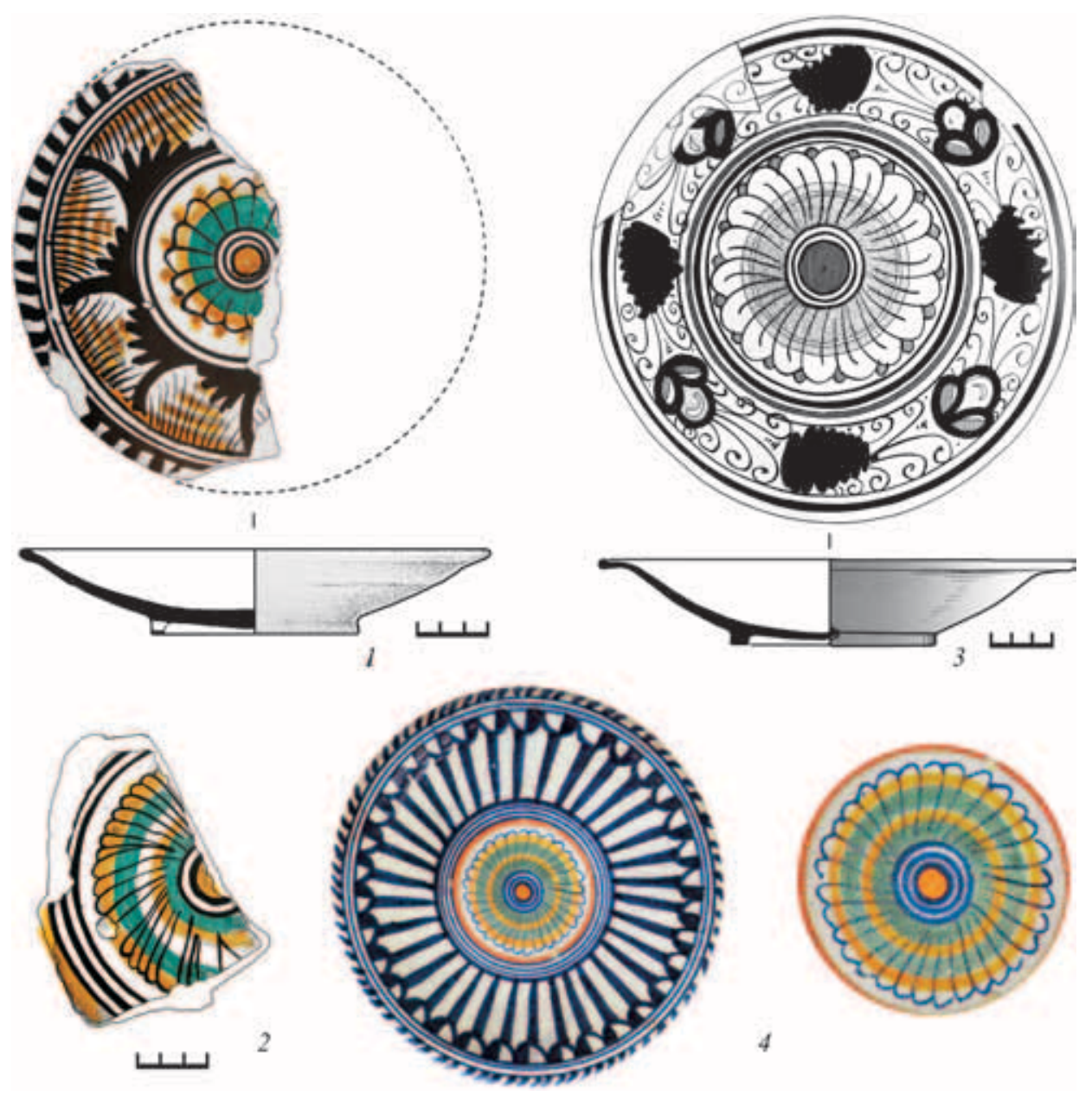

Рис. 3. Нидерландская майолика кон. XVI - 1-й пол. XVII в. с центральными розетками на дне 1, 2 - по: Pauwels, Houtekier, 1994. № 74, 81; 3 - по: Hurst, Neal, van Beuningen, 1986. Fig. 55. № 169; 4 - по: Biesboer, 1997. Katnr. 21

из обломков тарелки был найден в синхронном контексте (которым следует считать пласт 8), тогда как второй попал в более древние отложения в результате перекопа. Хотя к середине XVI в. майолика в Северо-Западной Европе уже производилась, однако она еще не получила известности и распространения, поэтому сложно предполагать ее импорт в Россию. Появление же этой керамики в Рязани надо связывать, по-видимому, со Смутным временем, когда на Русь вместе с польско-литовскими интервентами попадали самые разные вещи европейского производства. И хотя Рязань не становилась объектом разорения, контакты с приходившими с Запада людьми были весьма обширными. Конечно, вряд ли нидерландская тарелка попала в Рязань в результате торговых опе- раций, скорее она входила в состав личного имущества одного из руководителей интервенции, разграбленного после одного из многочисленных боевых столкновений того времени.

Второй образец майолики с Житного раскопа менее понятен для атрибуции. Это маленький обломок декоративной облицовочной плитки, изготовленной из беложгущейся глины без видимых грубых примесей, лицевая поверхность покрыта белой непрозрачной поливой, поверх которой выполнена роспись синей глазурью (рис. 2, 2) ${ }^{15}$. К сожалению, находка не имеет контекста, поскольку сделана в осыпи борта раскопа. Орнаментика росписи не может быть восстановлена, но, судя по сохранившей части, она включала растительные мотивы. Глазурь, которой выполнена роспись, недостаточно

15 2013-53. 
качественная, и ее поверхность начала разрушаться прежде всего там, где слой ее был тонок. В результате пучок растительности на поверхности плитки приобрел бурый оттенок. Тем не менее хорошо видно, что там, где слой глазури был толще, ее синий цвет частично сохранился.

Низкое качество синей глазури не позволяет видеть в этой плитке предмет импорта, хотя такой вариант нельзя полностью исключить. В Нидерландах XVI-XVII вв. белоглиняные облицовочные плитки с монохромной и полихромной (с преобладанием синего цвета) росписью были весьма распространены, а находка тарелки, привезенной из тех же мест, как будто подталкивает к аналогичной атрибуции. Однако голландские изделия не имеют таких элементов декора, как на рассматриваемом образце, и гораздо выше качеством. Поэтому предлагать какую-то конкретную атрибуцию для этого загадочного образца было бы преждевременно.

\section{Полумайолика}

К классу полумайолики относятся глиняные изделия, покрытые прозрачной глазурью. На Житном раскопе сделано 15 подобных находок, представленных довольно мелкими обломками. Основную их долю (10 экз.) составляли сосуды, отнесенные к серии без дополнительного декора, все они до глазурования облицовывались белым ангобом.

Подгруппа $A$ - с желтой глазурью.

К этой подгруппе принадлежал только один обломок чаши из светло-красной глины без видимых примесей, с двусторонней глазурью, причем на внешней стороне ангоб нанесен не сплошь, а небрежно, пятнами ${ }^{16}$. Формовочная масса этой чаши более характерна для византийских изделий. Контекст находки (пласт 25) соответствует отложениям первой половины XIV в.

Подгруппа $Б$ - с зеленой глазурью.

Bce сосуды этой подгруппы изготовлены из красножгущейся глины с примесями мелкого шамота, то есть обладали признаками изделий городов юго-восточного Крыма (Каффы, Солдайи и Эски-Крыма). Обломки принадлежали крупному чашевидному сосуду ${ }^{17}$, тарному сосуду типа «аптечная амфора» ${ }^{18}$, чаше ${ }^{19}$ и двум кувшинам. Один из них был без глазурного покрытия внутри ${ }^{20}$, другой имел внутреннее покрытие бесцветной глазурью по основе ${ }^{21}$. Одному из перечисленных кувшинов мог принадлежать обломок ручки (рис. 4,1$)^{22}$. Кроме того, найден кольцевой поддон от чаши, изготовленной из аналогичного керамического теста, на котором не сохранилось следов глазури ${ }^{23}$.

Интересны контексты этих находок. Одна половина их происходила из пластов 23-24, то есть контекстов второй половины XIV в., полностью соответствовавших времени производства такой керамики, другая половина - из пластов 26-27, которыми вскрывались слои второй половины XIII - первой половины XIV в. Производство поливной посуды в юго-восточном Крыму только начало налаживаться в конце XIII в., поэтому можно связывать наши находки с более поздней частью этого стратиграфического горизонта. Ручка кувшина найдена в пласте 14 (контекст второй половины XVI в.), но ее единичность заставляет думать, что она оказалась там в результате перекопа, происходя в действительности из слоев XIV в. В этом убеждает и плохая сохранность образца, глазурь на котором обколота.

Полумайолика с подглазурным декором весьма разнообразна и относится к трем группам.

Группа 1. Изделия с рельефным тисненым декором.

Единственный обломок сосуда этой группы не нес на себе глазурного покрытия, но на его поверхности сохранилось пятно зеленой глазури, которое позволяет предполагать, что целый сосуд все же относился именно к этой группе. Дело в том, что подобные сосуды имели ангобно-глазурное покрытие только по верхней части тулова, тогда как нижняя часть его оставалась неангобированной и неглазурованной (Бочаров, Масловский, 2015. С. 192). Рассматриваемый обломок изготовлен из красножгущейся глины с примесью мелкого шамота, то есть относится к группе изделий юговосточного Крыма (рис. 4, 3$)^{24}$.

$162012-692$.

17 2010-277.

18 2012-644. Обоснование этого названия см.: Бочаров, Масловский, 2015. С. 190.

$192014-424$.

$202013-170,356,588$.

${ }^{21} 2011-309,2013-55$.

22 2008-137.

${ }^{23} 2012-324$

${ }^{24} 2012-17$. 

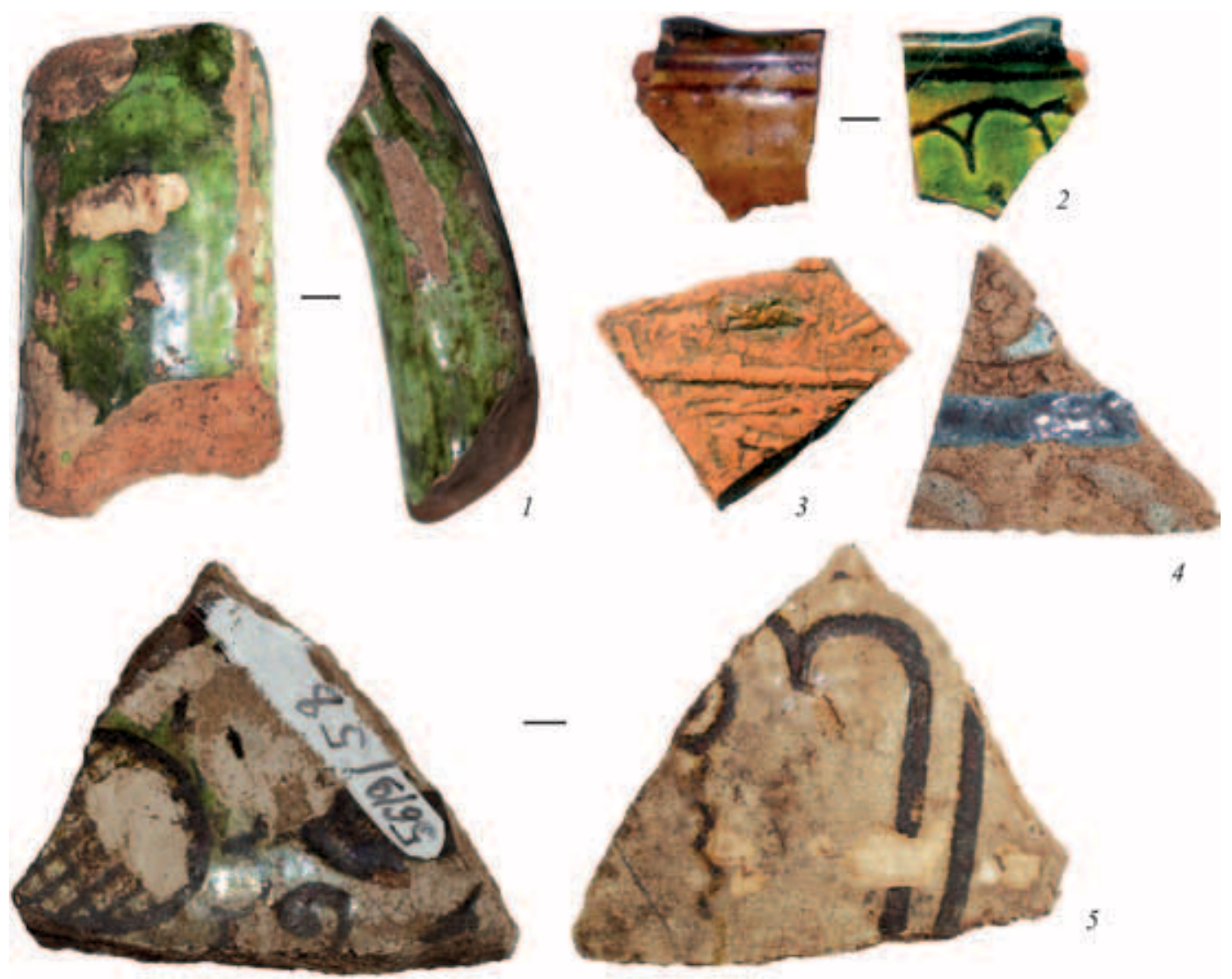

4

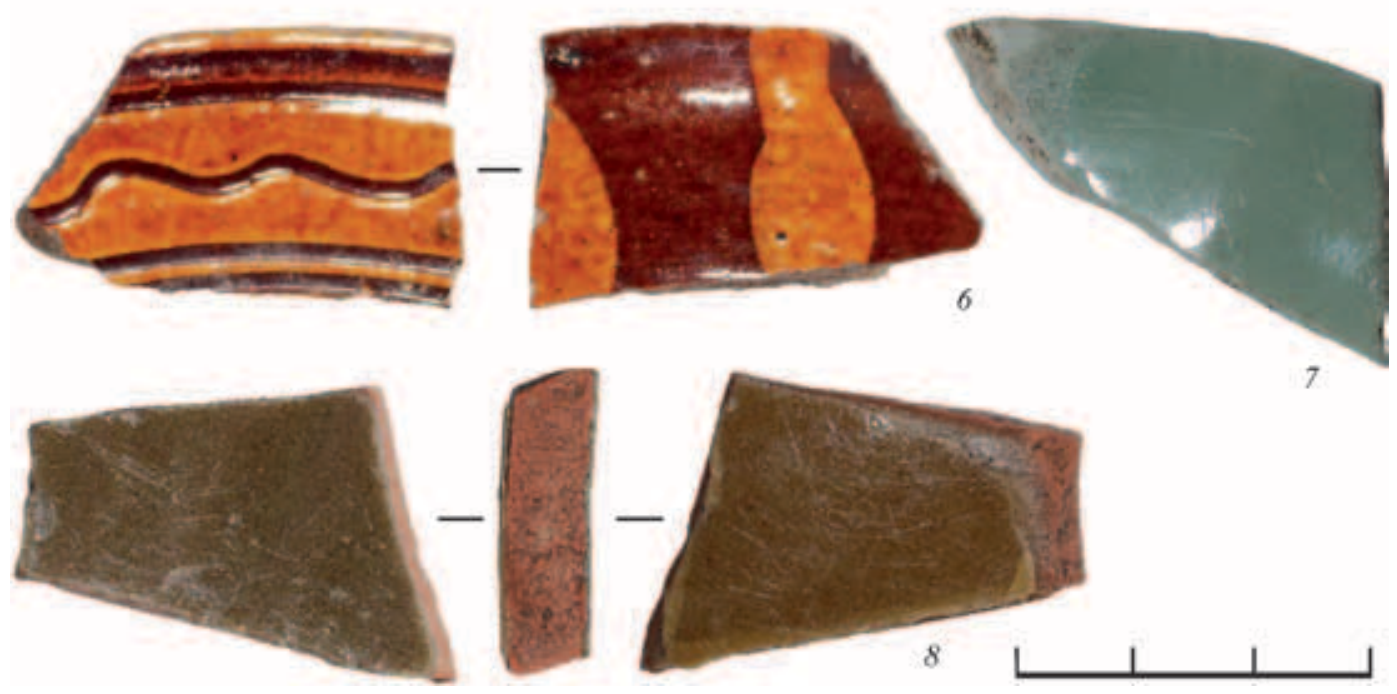

Рис. 4. Изделия из полумайолики, тисненой керамики и селадона

1-3, 5, 6 - полумайолика (2010-277, 2012-377, 2012-17, 2010-265, 2014-626); 4 - тисненая керамика с росписью глазурями (2012-400); 7-8- селадоны (2009-2, 2010-65)

Контекст находки (пласт 24), соответствующий горизонту второй половины XIV в., полностью соответствует времени производства такой керамики в Крыму. Рассматриваемый экземпляр является первым образцом крымской тисненой поливной керамики, встреченным в Рязани. Это в некотором смысле удивительно, поскольку она была довольно широко распространена и известна во многих городах Руси, в том числе близлежащих - Коломне и Ростиславле. 
Группа 2. Полумайолика с росписью красками.

В этой группе имеются два образца, относящихся к разным типам посуды. Первый - это крошечный обломок чаши с пятнами марганца под бесцветной глазурью ${ }^{25}$. Размеры обломка не позволили достоверно установить его происхождение, между тем подобная керамика в больших количествах импортировалась из Византии в конце XIII - первой половине XIV в., а также производилась в городах юго-восточного Крыма и тоже могла быть привезена на Русь (Бочаров, Масловский, 2012. С. 29, 30). Как правило, пятна марганца дополняли орнамент в технике сграффито.

Находка связана с контекстом первой половины XIV в. (пласт 25), но мелкие размеры обломка позволяют допускать, что чашу разбили несколько ранее, после чего отдельные ее обломки были разбросаны по большой площади. Если же поступление ее в Рязань и разрушение приходилось на начало XIV в., то единственным местом ее происхождения могла быть Византия.

Второй образец керамики этой группы принадлежал чаше, изготовленной из неожелезненной глины (светло-кремового оттенка) с примесью мелкого песка ${ }^{26}$. При этом обе поверхности чаши были все же покрыты белым ангобом, по которому провели роспись черной (темно-коричневой) краской. На внутренней поверхности эта роспись включала растительные побеги и крупный цветок с короткими фестончатыми лепестками и сетчатой серединой, здесь видны также слабые пятна от зеленого красителя, которым, видимо, подкрасили рисунок (рис. 4, 5). Внешняя поверхность украшена стилизованными лепестками лотоса, причем использовалась поздняя разновидность стилизации с завершением лепестков в виде «фигурной скобки», получившей распространение на Востоке лишь с конца XIV в. в результате копирования китайского сине-белого фарфора - на нем такие стилизации и появились впервые.

Аналогичные цветки с сетчатым заполнением середины соцветия можно видеть на сосудах тимуридского стиля (с монохромной синей росписью), то есть произведенных в конце XIV-XV в. в Золотой Орде и Средней Азии (Самашев, Кузнецуова, Плахов, 2008. Рис. на с. 58), а лепестки лотоса со специфической стилизацией того же времени - на тимуридской кашинной керамике
(Шляхова, 1980. Рис. 3; 4, 4) и синхронной среднеазиатской полумайолике (Коваль, 2010. Ил. 44, 3). Таким образом, декоративные элементы нашей чаши указывают на ее датировку не ранее конца XIV в. Контекст находки полностью соответствует этой дате, она зафиксирована в пласте 21, то есть в слое первой половины XV в. (Завьялов, Судаков, 2017. Рис. 12).

Происхождение светлоглиняной керамики с росписью в общем для всего Среднего Востока стиле в целом не вызывает сомнений - единственным регионом, где такая керамика производилась в массовом количестве, были города долины Сыр-Дарьи, прежде всего Отрар (Акишев, Байпаков, Ерзакович, 1975. С. 39; Тепловодская, 1977. С. 136; Байпаков, Алдабергенов, 2005. С. 168-176, 196, 197).

Керамика Отрара (или соседних с ним городов) известна по материалам раскопок в Болгаре, на Торецком поселении и даже в Москве (Коваль, 2010. C. $120 ; 2014$. С. 57-58; 2017. 58-59, 63-64).

Группа 3. Полумайолика с декором в технике сграффито.

К этой группе принадлежали два обломка сосудов, отнесенных к одной подгруппе изделий с желтой глазурью.

Первая находка представляла собой край чаши из светло-красной глины без видимых примесей, внутренняя (лицевая) поверхность которой покрыта желтой глазурью, а внешняя - зеленой (рис. 4,2$)^{27}$. Обломок столь мал, что атрибуция его сложна. Однако можно заметить, что тесто сосуда нехарактерно для крымских изделий (наиболее массовых на территории Руси). Не находит прямых аналогий среди них и декор внешней поверхности, в котором были использованы, вероятно, какие-то довольно сложные растительные мотивы. Все это заставляет осторожно предполагать, что чашу привезли из более отдаленных стран, вероятно, из Византии. Контекст находки (пласт 25) соответствует слою первой половины XIV в.

Вторую находку можно определить более точно. Это край тарелки, изготовленной из красножгущейся глины без видимых примесей, обе стороны которой покрыты ярко-желтой глазурью. Декор внутренней поверхности выполнен в технике сграффитто, с волнистой линией, ограниченной двумя концентрическими линиями, а на внешней - вертикальные потеки белого ангоба (рис. 4,6$)^{28}$. 
Керамика подобного облика не была широко распространена в Причерноморье, но хорошо известна в Средиземноморском бассейне под различными наименованиями (Imitation Zeuxippus Ware, Zeuxippus Derivative, Orange-Brown Glazed Ware и др.). В России некоторые разновидности такой керамики (поименованные группой 1) впервые были выделены И. В. Волковым на материалах раскопок Семеновской крепости на северном побережье Азовского моря, при этом была выдвинута гипотеза о ее производстве в окрестностях Трапезунта (Волков, 2005. С. 136). Однако наиболее полно она была представлена в публикации кораблекрушения в бухте Новый Свет близ Судака в Крыму, исследованного С. М. Зеленко. Именно там имеются прямые аналогии рязанскому образцу (Зеленко, Тесленко, Ваксман, 2012. С. 130, 131. Рис. 5, 1; 6, 1-3; 15, BYZ912). По мнению авторов исследования, керамика с перечисленными выше морфологическими и декоративными особенностями происходит с территории Византии, но центр ее производства пока не может быть установлен, поскольку проведенная серия химических анализов образцов показала отличия от эталонов, связанных с рядом византийских центров (при этом эталоны из Трапезунта у исследователей отсутствовали и вариант происхождения керамики из этого города не рассматривался). Предложено ее условное наименование - «группа Новый Свет» (на английском оно сформулировано несколько иначе: Zeuxippus Ware Family De Type 'Novy Svet'.

Датировка комплекса из кораблекрушения в Новом Свете последней третью XIII в., опирающаяся как на археологический материал, так и на письменные источники, позволяет уверенно датировать рязанский образец тем же временем. Стратиграфическая датировка контекста (пласт 26) второй половиной XIII - началом XIV в. как нельзя более полно соответствует имеющимся аналогиям. Таким образом, византийская миска была разбита и выпала в культурный слой очень скоро после того, как была привезена в Рязань.

\section{Селадоны}

Китайским селадонам на Руси посвящена уже довольно обширная литература, и они продолжают вызывать пристальный интерес исследователей (обзор некоторых мнений см.: Коваль, 2017б). Появились они в Восточной Европе только в XIV в., то есть после включения Китая в состав Монгольской империи, а в XV в. их импорт из Китая в целом закончился. В Рязанском кремле обломок селадона впервые нашли при раскопках в 1990 г., еще два обломка происходят с площади Острога (Коваль, Судаков, 1995. С. 132).

На Житном раскопе встречено шесть обломков таких сосудов ${ }^{29}$, большинство которых были мелкими и невыразительными. Пять находок из шести отличаются голубоватым цветом глазури и, вероятно, принадлежат одной чаше (или блюду) с рельефной моделировкой внешней поверхности и гравированным орнаментом на внутренней (рис. 4, 7). Наибольший интерес представляет маленький обломок блюда, черепок которого на изломе не светло-серого (а это обязательный признак селадонов), а темно-красного цвета (рис. 4, 8). Глазурь на блюде также имела совершенно необычный для селадонов зеленовато-коричневый цвет. Аналогии этому образцу неизвестны, хотя все остальные внешние признаки (фактура и качество черепка и глазури) не оставляют никакого сомнения, что это именно часть селадона. Можно предположить, что это обломок сосуда, в составе фарфоровой массы которого по какой-то ошибке количество оксида железа оказалось чрезмерным, что и привело после обжига к появлению красного цвета у черепка и изменению обычного цвета глазури. Фактически это блюдо являлось браком, однако оно, вероятно, не имело деформаций или иных деструктивных внешних изменений, а потому было признано годным для экспорта за пределы Китая.

Все находки селадонов встречены в контекстах первой половины XVI в. (пласты 15 и 16), что, безусловно, вызывает удивление. И пусть речь идет о частях только двух сосудов, отсутствие такой керамики в более ранних слоях заставляет считать их импортом конца XV или даже начала XVI в., то есть того периода, когда Рязань уже находилась в сильной зависимости от Москвы, накануне присоединения к ее землям. Сложно сказать, были ли эти китайские сосуды получены через торговлю рязанских купцов или же привезены из Москвы, имевшей прямые и разносторонние связи со странами Востока.

Последним образцом импорта, требующим упоминания, является небольшой обломок стенки кувшина с тисненым рельефным декором ${ }^{30}$ (рис. 4, 4). Сосуд изготовлен из слабоожелезненной глины без

29 2009-2; 2008-290, 368, 501, 530; 2010-65.

30 2012-400. 
Таблица 1. Количество импортной керамики XIII-XIV вв. из раскопок в городах Руси и Золотой Орды (\%).

\begin{tabular}{|l|c|c|c|}
\hline \multicolumn{1}{|c|}{ Памятники } & Кашинная керамика & Керамика из глин & Китайский фарфор \\
\hline Переяславль Рязанский & 46 & 46 & 8 \\
\hline Москва $^{31}$ & 63 & 20 & 2 \\
\hline Тверь $^{32}$ & 94 & 4 & 1 \\
\hline Нижний Новгород $^{33}$ & 90 & 9 & 5 \\
\hline Болгар $^{34}$ & 62 & 33 & Нет данных \\
\hline Селитренное городище $^{35}$ & 38 & 62 & \\
\hline
\end{tabular}

видимых примесей, поверхность и излом имеют серовато-желтоватый цвет. Декор состоял из оттиснутого в калыпе (форме) рельефного рисунка, поверх которого отдельные детали были украшены полосами и пятнами ультрамариновой и голубой непрозрачных глазурей. Поскольку глазурь использована столь локально, называть такой сосуд глазурованным невозможно, как и включать его в классификационную схему, изложенную выше.

Тисненая керамика с росписью разноцветными поливами производилась в середине - второй половине XIV в. на территории Золотой Орды. Достоверно места ее изготовления не установлены, но существуют аргументы за то, что ее производство могло существовать в Маджаре (Волков, 2007. C. 35). На территории Руси ранее единичные находки мелких обломков такой керамики были известны только в Твери и Коломне (Коваль, 2010. C. 114). Даже на территории Орды такие сосуды редко встречаются целыми (Байпаков и др., 2011. Рис. на с. 197).

Рязанский образец найден в контексте первой половины XIV в. (пласт 25).

Исследованная выборка невелика, она несколько уступает числу рязанских керамических импортов из раскопок 1955-2003 гг. - 78 экз. (Коваль, 2005). Если же рассмотреть суммарную структуру таких импортов, то есть прибавить к ранее опубликованным данным сведения об импортах Житного раскопа, то общее количество составит 132 экз., а такая выборка уже гораздо представительнее. Попробуем сравнить эти цифры с известными по другим городам Руси XIII-XIV вв. и Золотой Орды (табл. 1).

Разумеется, выборки из разных городов имеют разные размеры, причем выборка из Переяславля примерно вдвое меньше, чем московская, нижегородская и болгарская, однако эти различия не столь существенны, чтобы не доверять полученным результатам. Из таблицы видно, что Переяславль отличался от других городов СевероВосточной Руси повышенной долей поливной керамики из глин, которая происходила из Византии и Крыма. Более высокими показателями обладает только Селитренное городище, где существовало собственное производство красноглиняной поливной керамики. Трудно сказать, почему импорт восточной поливной посуды в русские города золотоордынской эпохи формировался именно таким образом. Разумеется, поволжские города Руси (Тверь и Нижний Новгород) имели самые широкие возможности для ввоза продукции из столичных центров Нижней Волги, однако там производилась не только кашинная керамика. Почему же ввозилась туда почти исключительно она одна? Ответ может состоять в том, что привозились только самые яркие, пышно оформленные сосуды, а такими были именно кашинные изделия, но никак не красноглиняные чаши с одноцветным глазурным покрытием (полихромная полумайолика в нижневолжских центрах, как известно, не получила распространения).

Более высокая доля майоликовой керамики в Москве связана, вероятно, с более широкими связями этого города, приобретшего в XIV в. столичный статус, постоянно богатевшего и притягивавшего к себе аристократию из Золотой Орды (со сложившейся привычкой пользоваться разнообразными импортами). Структура же импортной керамики в Переяславле Рязанском, как представляется, определялась размещением Рязанского княжества на торговых путях, ведших в Причерноморье (прежде всего Донской путь и степные шляхи),

31 Суммарные данные по двум публикациям (Коваль, 1997б; 2015).

32 Суммарные данные по двум публикациям (Коваль, 1997a; 2009).

33 Благодарю В.А. Лапшина за возможность ознакомиться с неопубликованными материалами.

34 По: Коваль, 2014.

35 По: Булатов, 1968. 
откуда и поступала разнообразная поливная посуда. Конечно, связи с Поволжьем, где размещались центры власти Орды и мощные производственные центры, были столь же важны для Рязани, но южное направление связей было географически неизбежным для этого региона.

Важно подчеркнуть, что, хотя количество находок импортной поливной керамики в Переяславле существенно уступает массам аналогичных импортов, известных в Москве и многих других городах
Руси, это «отставание» объясняется не меньшей насыщенностью культурного слоя такими находками, а меньшим объемом проведенных исследований. По концентрации же находок керамических импортов Переяславль ничуть не уступает другим городам - столицам княжеств ордынского периода. Нельзя также не отметить, что Переяславль является вторым (после Москвы) городом Руси ${ }^{36}$, где обнаружена западноевропейская поливная керамика XVI-XVII вв.

\section{Литература}

Акишев К.А., Байпаков К.М., Ерзакович Л. Б., 1975. Отрар XVI-XVIII веков по итогам раскопок 1971-1973 гг.// Древности Казахстана. АлмаАта: Наука. С. 3-48.

Байпаков К.М., Алдабергенов Н.О., 2005. Отрар Алкабы. Алматы: Баур. 253 с.

[K. Байпаков и др.], 2011. Художественная культура Центральной Азии и Азербайджана IX-XV веков. Т. 1. Самарканд - Ташкент: МИЦАИ. 255 с.

Бочаров С.Г., Масловский А.Н., 2012. Византийская поливная керамика в городах Северного Причерноморья золотоордынского периода (вторая половина XIII - конец XIVв.) // Поволжская археология. № 1. С. 20-36.

Бочаров С.Г., Масловский А.Н., 2015. Наиболее массовые типы поливных импортов крымского производства и некоторые вопросы торговли в Восточной Европе в XIV в. // Поволжская археология. № 4. С. 189-200.

Булатов Н.М., 1968. Классификация кашинной поливной керамики золотоордынских городов // СА. № 4. С. 95-109.

Волков И. В., 2005. Поливная керамика комплекса Кабарди (1240-1260) // Поливная керамика Средиземноморья и Причерноморья X-XVIII вв. Киев: Стилос. С. 122-159.

Волков И.В., 2007. Поливная керамика Маджара // Поливная керамика Восточной Европы, Причерноморья и Средиземноморья в $\mathrm{X}-$ XVIII вв. II Междунар. науч. конф. Ялта: Крымский филиал ИА РАН. С. 33-42.

Даркевич В. П., Стародуб Т. Х., 1983. Иранская керамика из раскопок Старой Рязани // СА. № 2. C. 183-195.
Завьялов В.И., Судаков В.В., 2017. Стратиграфия и хронология Житного раскопа в кремле Переяславля Рязанского // АП. Вып. 13. М.: ИА РАН. С. $68-87$.

Зеленко С.М., Тесленко И.Б., Ваксман С.Й., 2012. Несколько групп поливной керамики с кораблекрушения конца XIII в. вблизи Судака (Крым) // 1000 років візантійскої торгівлі (V-XV століття). Київ: Київський Національний університет. С. 129-148.

Коваль В.Ю., 1997а. Восточная поливная керамика в средневековой Твери // ТТЗ. Вып. 2. Тверь. C. 179-187.

Коваль В.Ю., 1997б. Керамика Востока в средневековой Москве (опыт систематизации). Полумайолика, фарфор, неполивная посудная, техническая, декоративная и архитектурная керамика // РА. № 3. С. 94-113.

Коваль В.Ю., 2005. Восточные связи Рязанской земли по материалам импортной керамики // Великое княжество Рязанское. М.: Памятники исторической мысли. С. 480-520.

Коваль В.Ю., 2009. Керамика Востока в Тверском кремле // Лапшин В.А. Тверь в XIII-XIV вв. (по материалам раскопок 1993-1997 гг.). СПб.: СПбГУ, 2009. С. 273-296.

Коваль В.Ю., 2010. Керамика Востока на Руси. IX-XVII вв. М.: Наука. 269 с.

Коваль В.Ю., 2014. Импортная поливная керамика из раскопок в Болгаре // Поливная керамика Причерноморья - Средиземноморья как источник по изучению византийской цивилизации. Тез. докл. Севастополь: Заповедник «Херсонес Таврический». С. 56-60.

\footnotetext{
36 Речь идет о Руси вне границ Великого княжества Литовского, в города которого европейская керамика ввозилась в более заметных количествах. Правда, большинство находок такой керамики остаются неопубликованными.
} 
Коваль В. Ю., 2015. Импортная керамика Московского Кремля по материалам раскопок на Подоле в 2007 г.// АП. Вып. 11. М.: ИА РАН. C. $254-286$

Коваль В. Ю., 2017а. Импортная поливная керамика Торецкого поселения // От Руси до Китая. Из новых археологических исследований. М.: ИА РАН. С. 42-73.

Коваль В.Ю., 2017б. Привозились ли в Европу корейские селадоны? // От Руси до Китая. Из новых археологических исследований.М.: ИА РАН. С. 93-100.

Коваль В.Ю., Судаков В.В., 1995. Средневековая восточная керамика из Переяславля Рязанского // Археологические памятники Среднего Поочья. Вып. 4. Рязань: НПЦ по охране и использованию памятников истории и культуры. C. 120-139.

Самашев 3., Кузнецова О., Плахов В., 2008. Керамика Сарайчика. Алматы: ZUR. 263 с.

Тепловодская T.M., 1977. Некоторые данные о технологии изготовления керамики в позднесред- невековом Отраре // Археологические исследования в Отраре. Алма-Ата. С. 131-138.

Шляхова В.И., 1980. Керамика с кобальтовой росписью в Золотой Орде // СА. № 4. С. 75-86.

Biesboer P., 1997. Nederlandse Majolica 1550-1650. Schotels en tegels vor de sier. Amsterdam: Museum Haarlem. 188 p.

Amsterdam ceramics. A city's history and archaeological ceramics catalogue 1175-2011 / Ed. Gawronski J. Amsterdam: Uitgeverij Bas Lubberhuizen, 2012. 334 p.

Hurst G., Neal D.S., van Beuningen H.J.E., 1986. Pottery produced and traded in north-west Europe 1350-1650// Rotterdam Papers VI. Rotterdam: Het Nederlandse Gebruiksvoorwerp. 281 p.

Korf D., 1991. Nederlandse Majolica. Haarlem: De Haan.122 s.

Pauwels A. G., Houtekier M., 1994. Majolica. Kortruk: Stedelijke musea Kortruk. 212 p.

Tietzel B., 1980. Fayence I. Niederlande, Frankreich, England. Köln: Kunstgewerbemuseum der stadt Köln. 408 p. 


\author{
Д. Ю. Бадеев \\ Институт археологии РАН, г. Москва
}

\title{
Христианские древности с территории ремесленно-торгового района золотоордынского Болгара
}

Взаимоотношения христианского и мусульманского населения в рамках средневекового городского сообщества остаются актуальной темой при исследовании городской культуры Древней Руси, Волжской Болгарии и Золотой Орды. Исследователи формируют набор признаков материальной культуры, позволяющих говорить о проживании населения указанных религиозных конфессий на иноверных территориях. Подробное исследование на основе археологических источников христианского, в первую очередь русского, населения на территории древнего Болгара, одного из центров средневекового ислама, было представлено в монографии М.Д. Полубояриновой «Русь и Волжская Болгария в X-XV вв.» (1993). Одним из явных маркеров христианского населения выступают предметы личного благочестия, прежде всего нательные кресты. На территории Болгарского городища к концу XX в. в ходе археологических раскопок и в качестве случайных находок было известно 29 крестов: 12 экз. каменных, 6 крестов-энколпионов, 11 небольших нательных крестов медного сплава различных типов (Полубояринова, 1993. С. 14-18). Кроме того, с территории Болгарского городища происходило шесть иконок: три каменные, по одной - из медного сплава, стекла и кости; также встречена бронзовая христианская утварь: две детали хороса, держатель и цепочки от лампады, кадильница (Полубояринова, 1993. С. 19-22, 31-33). К вещам, содержащим христианскую символику, можно отнести клад серебряных с позолотой медальонов, которые вместе с тремя бусинами составляли оплечье. Место и обстоятельства обнаружения этого клада неизвестны. На восьми из девяти медальонов имелись «процветшие кресты различного рисунка», а «их принадлежность к русскому художественному ремеслу не вызывает никаких сомнений» (Полубояринова, 1993. С. 23, рис. 4-5). При этом большинство исследователей склонны датировать медальоны из этого клада второй половиной XII - XIII в. (Корзухина, 1954. C. 43). В ходе работ 2013 г. на раскопе CLXXXV в заполнении хозяйственной ямы золотоордынского периода было обнаружено пять разбитых литейных форм для изготовления аналогичных медальонов с изображениями процветших крестов (Ситдиков, Сивицкий, 2014. С. 12-13). Эта находка дает возможность предполагать, что медальоны с орнаментом в виде процветшего креста могли изготавливаться русскими мастерами на территории Болгара и в золотоордынский период.

В результате масштабных археологических работ 2011-2017 гг. коллекция предметов христианского культа, прежде всего нательных крестов, пополнилась еще рядом предметов, найденных к западу от Соборной мечети (рис. 1). Так, в раскопе CLXXXV (2013 г.) в составе клада из серебряных монет XIV в., стеклянных и янтарных бус, бронзового зеркала, серьги в виде знака вопроса и копоушки обнаружено два нательных крестика из янтаря (Ситдиков, Сивицкий, 2014. С. 14). Из раскопа СС (2014 г.), располагавшегося напротив современного здания Музея болгарской цивилизации, происходил крест-энколпион XII-XIII вв. (Сивицкий, Губайдуллин, Худяков, 2015. С. 21). В уникальном для Болгарского городища (рис. 1, в) погребении на раскопе CXLIX (2010 г.), «усопший находился в сидячем положении со скрещенными руками в области живота», «между рук находился процессионный крест с каменными вставками» (Археологические исследования... 2011. С. 16).

Планиграфия христианских древностей (без учета армянских надгробий) на территории Болгарского городища на данный момент выглядит следующим образом: поселение Ага-Базар (торговая пристань средневекового Болгара)-4 экземпляра; с площади Греческой палаты, трактуемой исследователями как христианский (армянский) 


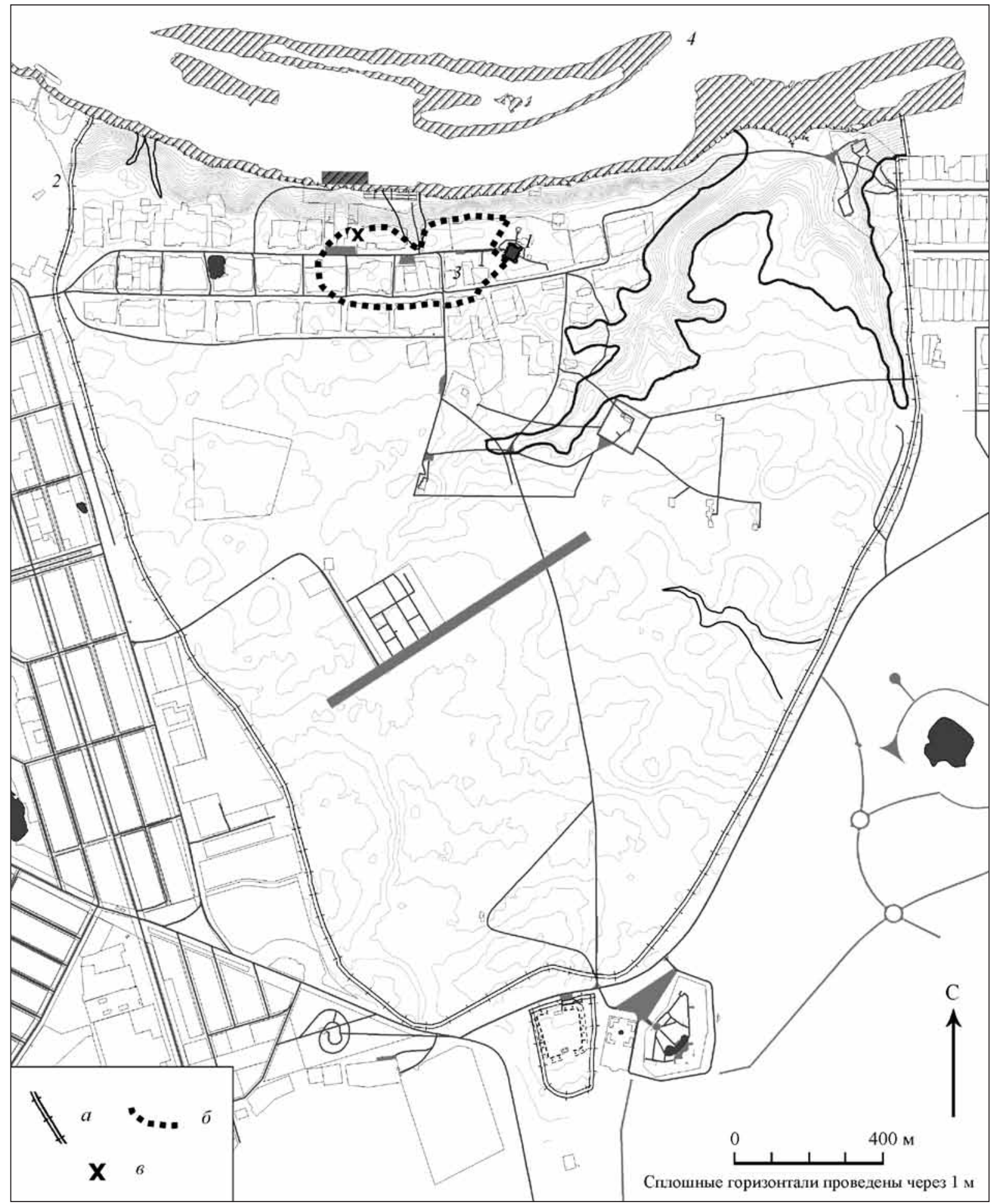

Рис. 1. План Болгарского городища с указанием участка максимальной концентрации христианских древностей $a$ - оборонительные укрепления (сер. XIV в.); $\sigma$ - участок максимальной концентрации предметов, связанных с христианским культом; $в$ - погребение с процессионным крестом. 1 - Соборная мечеть (1260-1270-е); 2 - Греческая палата - христианский храм с могильником (2-я пол. XIV в.); 3 - ремесленно-торговый район (2-я пол. XIII-XIV в.); 4 - «русский ремесленный поселок» на северо-восточной окраине золотоордынского Болгара 


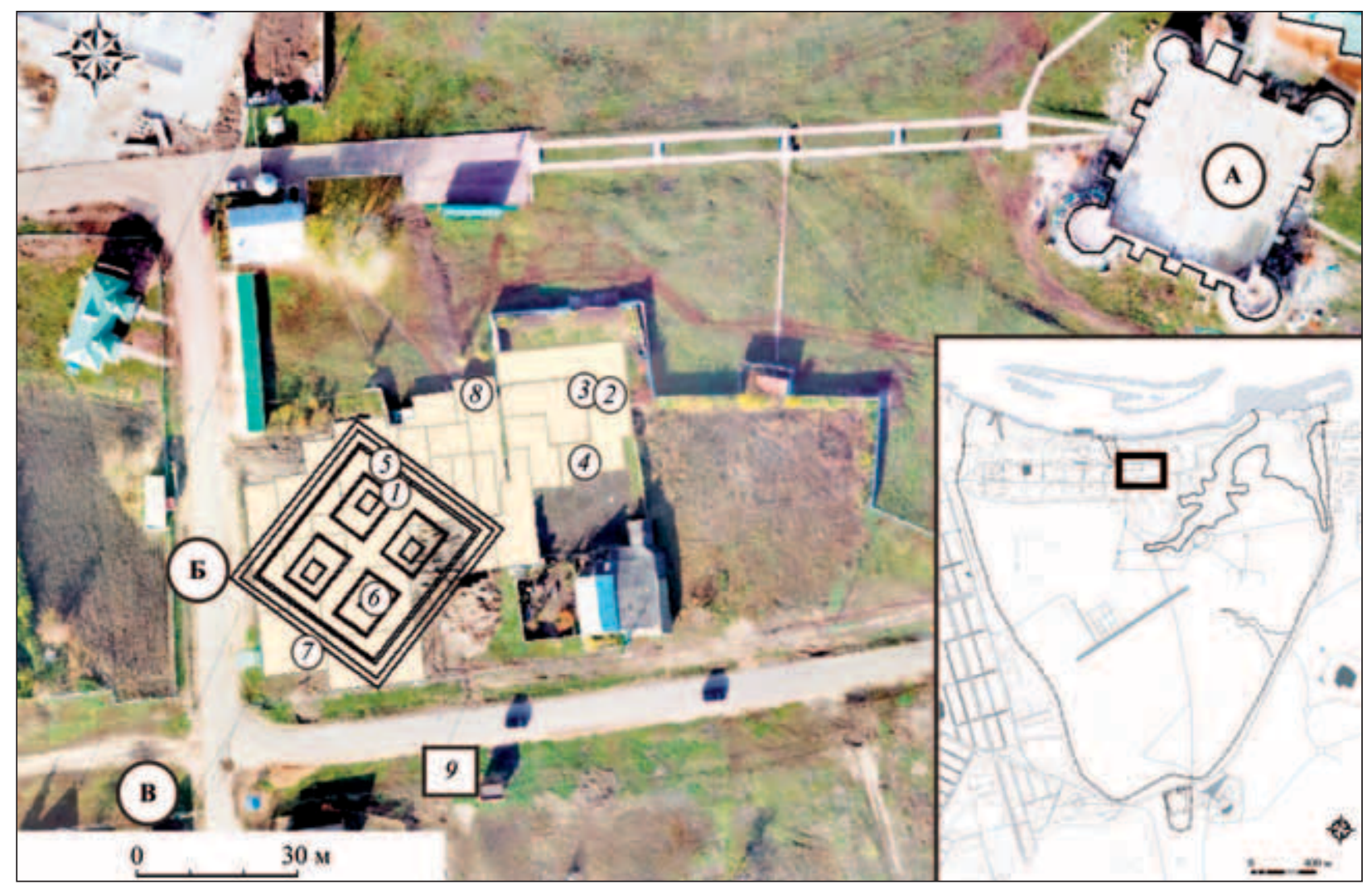

Рис. 2. Планиграфия находок в ремесленно-торговом районе золотоордынского Болгара

A - Соборная мечеть (1260-1270-е); Б - городской базар (сер. XIV в.); В - участок максимальной концентрации русской керамики XIV группы в золотоордынском слое Болгарского городища (по М.Д. Полубояриновой). 1-3 - каменные нательные кресты; 4 - плоский нательный крест из медного сплава с зеленоватой глазурью; 5 - объемный нательный крест из медного сплава с шаровидными окончаниями лопастей; 6 - энколпион из медного сплава; 7 - энколпион-квадрифолий из медного сплава; 8 - литейная форма для отливки миниатюрного нательного креста; 9 - комплекс «русских» вещей в раскопе 15 (1948, 1949 гг.): каменный нательный крест, бронзовые цепочки и шестилопастный держатель от лампады

храм с прилегающим могильником второй половины XIV в. (Хлебникова, 1987. С. 38), - 3 экземпляра; в Заречной части города, так называемом русском ремесленном поселке на северо-восточной окраине города, - 2 экземпляра; к западу и юго-западу от Соборной мечети - 17 экземпляров. Общая датировка христианских древностей с Болгарского городища вписывается в рамки XII-XIV вв. Таким образом, к западу от Соборной мечети выделяется участок максимальной концентрации предметов, связанных с христианским культом (рис. 1, б). В состав выделяемой области входит и ремесленно-торговый район золотоордынского Болгара.

В последние годы на Болгарском городище одним из интереснейших участков археологических исследований оказалась площадка в 120-180 м к юго-западу от Соборной мечети. Уже после первых лет археологических работ (40-е годы XX в.) за этим участком закрепилась характеристика ремесленного района, сформированного на начальной стадии развития го- рода и просуществовавшего вплоть до его угасания в XV в. (Смирнов, 1974. С. 13). Здесь зафиксированы усадьбы с металлургическим, ювелирным, косторезным, стеклообрабатывающим ремесленными производствами, а в середине XIV в. появляется здание городского базара, простоявшего недолгое время (Коваль, Бадеев, 2015; Бадеев, Коваль, 2018). Максимальная концентрация древнерусской керамики с этого участка происходит из напластований раннего золотоордынского слоя, в некоторых выборках (раскоп CXCII, 2017 г.) она достигает 3,4\% от всей керамики. Эта цифра сопоставима с максимальной концентрацией древнерусской керамики в золотоордынском слое на Болгарском городище, отмеченной М.Д. Полубояриновой в непосредственной близости от места исследования, на перекрестке Школьного переулка и улицы Назаровых (рис. 2, В). Там процент русской керамики достигал 4,3\% (Полубояринова, 1993. С. 57). Кроме того, в раскопе CXVIII (1993 г.) (рис. 2, 8) в золотоордынских напластовани- 
ях обнаружена створка каменной литейной формы для отливки нательного креста с прямым средокрестием и прямоугольными концами (Кокорина, 1994. С. 17; 2012. Рис. 1, 2). Кресты подобной формы служили подражанием каменным нательным крестам. Литейные формы для отливки аналогичных крестов, как и сами кресты, найдены в Новгороде, Старой Рязани, Белоозере и Серенске. Предполагаемое время бытования данного типа крестов - XIII-XV вв. (Беленькая, 1993. С. 13).

С площадки исследования ремесленно-торгового района золотоордынского Болгара происходят три каменных нательных креста - так называемые корсунчики, два небольших нательных креста медного сплава и два креста-энколпиона других типов. Так как кресты публикуются впервые, рассмотрим каждый из них.

1. Каменный нательный крест найден в раскопе CLXII (2011 г.) (рис. 2, 1; 3, 1). Порода камня не определялась, цвет камня белый. Одна сторона креста приобрела черный окрас из-за того, что находка лежала в слое пожара. Верхняя часть изделия, где, вероятно, располагалось отверстие для подвешивания, сколота. Зафиксированные размеры креста составили 2,0×1,6×0,6 см.

Крест происходил из контактной зоны бытования и разрушения городского базара с подстилающими его прослойками первой половины XIV в. На территории древнерусских городов каменные кресты встречаются в напластованиях и объектах XII-XIV вв. Имеются находки каменных крестов и на территории нижневолжских золотоордынских городов (Полубояринова, 1978. С. 60).

2. Каменный нательный крест (рис. 2, 2; 3, 2). Порода камня не определялась, цвет камня белый. В верхней лопасти сбоку размещалось отверстие для подвешивания диаметром не более 0,2 см. Размеры креста 2,5×2,0×0,8 $(0,9)$ см. Крест найден в раскопе CXCII (2017 г.), в прослойках раннего золотоордынского слоя, относившихся к верхней части заполнения ямы второй половины XIII в. Среди керамики этнокультурных групп из данного объекта преобладала XIV группа (59 экз., т. е. 21\%). Остеологический материал из объекта, в верхней части которого был найден крест, отличается высоким процентом (по сравнению с другими объектами Болгарского городища) костей свиньи - 3,8\%.

3. Каменный нательный крест (рис. 2, 3; 3, 3). Порода камня - серый сланец. В верхней лопасти сбоку размещалось отверстие для подвешивания диаметром не более 0,2 см. На трех концах крестазаметны окислы металла (серебра), возможно, крест украшали серебряные обоймицы. Средокрестие по отношению к концам креста имеет некоторое углубление. Размеры креста - 2,7×2,5×0,4 см. Он обнаружен в раскопе СXCII (2016 г.), в заполнении ямы 140 - подвала второй половины XIII в., откуда происходил медный пул Менгу-хана. Среди керамики этнокультурных групп 36\% там составляла керамика группы XIX, 29\% - группы XIV, также заметно присутствие групп XVI и XVIII.

Кресты № 2 и 3 располагались в непосредственной близости друг от друга. Скорее всего, они относились к одному комплексу раннего золотоордынского периода.

4. Нательный крестик из медного сплава, с массивным ушком и треугольным завершением лопастей (рис. 2, 4; 3, 4). Внешняя сторона изделия с крестообразным углубленным ковчежцем покрыта глазурью желтоватого цвета, внутренняя гладкая. На верхней лопасти креста располагалось кольцевидное ушко с отверстием для подвешивания. Размеры креста - 2,2×1,5 см (без учета петли для подвешивания). Происходил крест из объекта (хозяйственной ямы), по монетному материалу датируемого первой половиной XIV в. На Болгарском городище это второй крест подобной формы. О месте находки первого известно только, что он был найден в кладе с джучидскими монетами XIV в. (Полубояринова, 1993. С. 18, 69. Рис. 2, 2). Основная масса крестов данного типа с территории древнерусских городов датируется XIV-XV вв., а в качестве центра их производства рассматривается Тверь (Беленькая, 1993. С. 17).

5. Объемный нательный крест из медного сплава с шаровидными окончаниями прямых лопастей и цилиндрической формы ушком для подвешивания (рис. 2, 5; 3, 5). Крест обнаружен в раскопе CLXII (2011 г.) и связан с прослойкой серой супеси, соотносимой с нижней частью позднеордынского слоя (20-40-е гг. XIV в.). Размеры изделия составили 2,3×1,6 см. Диаметр отверстия для подвешивания - не более 0,2 см.

Схожий по форме крест имеется в старых коллекциях с Болгарского городища (Полубояринова, 1993. Рис. 2, 14). Крест относится к широко распространенному типу древнерусских нательных крестов с утолщенными профилированными концами. Датируются подобные изделия на территории Древней Руси XI-XIII вв.

6. Круглоконечный энколпион из медного сплава с выступающими дугами в средокрестии (рис. 2, 6; 3, б) происходит из раскопа CLXXIX (2013 г.). Крест выявлен в нижней части напластований позднего золотоордынского слоя, датируемого по монетному материалу 20-40-х гг. XIV в. Размеры креста 

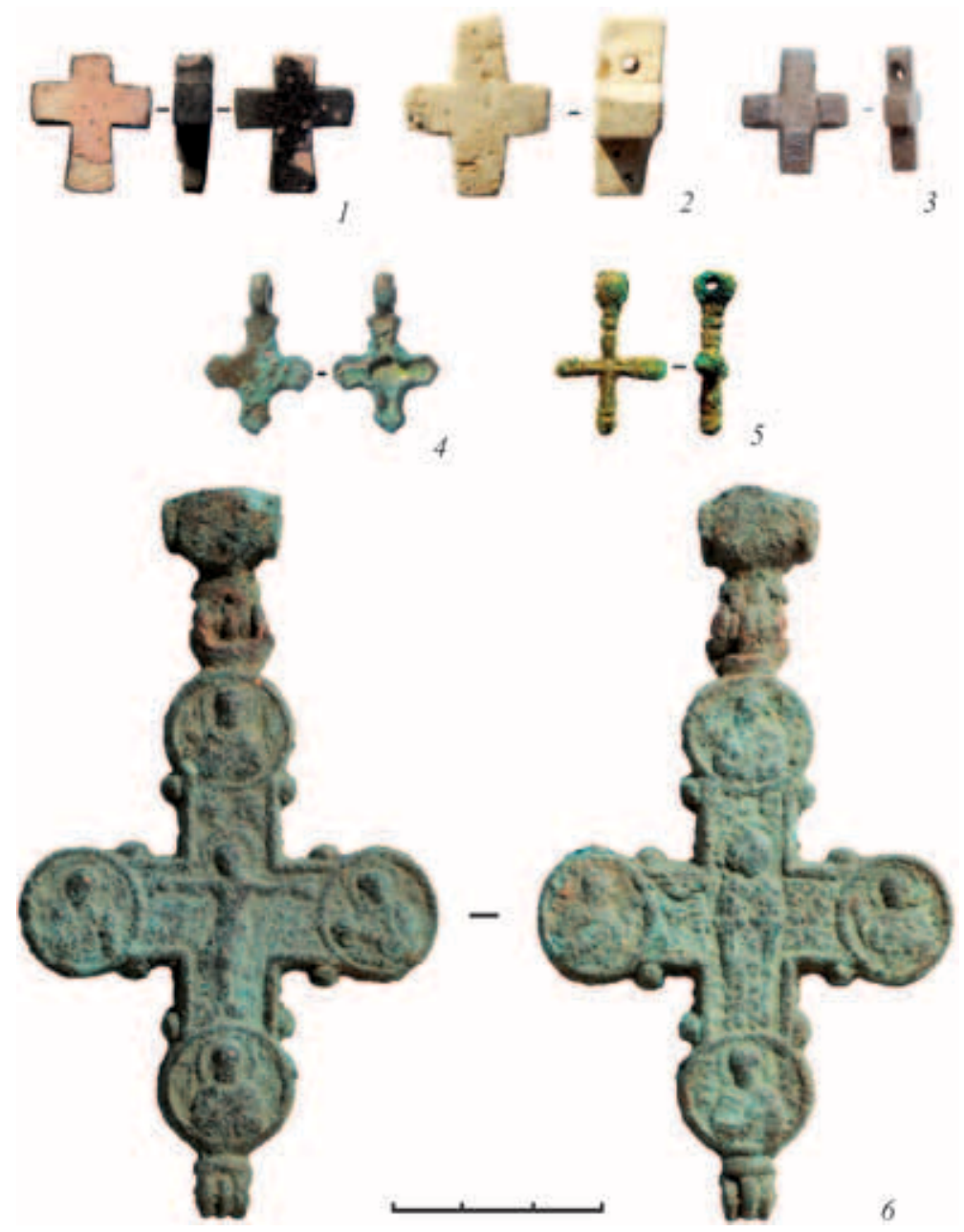

Рис. 3. Кресты с площадки исследований (раскопы 2011-2017 гг.) в торгово-ремесленном районе золотоордынского Болгара

1-3 - каменные нательные кресты; 4, 5 - миниатюрные нательные кресты из медного сплава; 6 - крест-энколпион из медного сплава

без оглавия составили $8,0 \times 6,0 \times 1,3 \mathrm{~cm}$. Оглавие с отверстием для подвешивания выполнено в форме бусины. Крест имеет хорошую сохранность: вероятно, он был утерян, после чего практически не перемещался в рамках слоя. На одной из сторон креста имеется рельефное изображение Богоматери Ассунта (Успения) и избранных святых в клеймах на лопастях креста, с другой - распятие также с избранными святыми в клеймах на лопастях (Распятие с предстоящими). Данный тип энколпионов относится к домонгольским крестам киевского типа. Датировки по аналогиям возможны в рамках XII - начала XIII в. Известен аналогичный крест с территории золотоордынского поселения у с. Березовка второй половины XIII-XIV в. (Полубояринова, 1978. С. 110-111. Рис. 37). В целом бытование домонгольских христианских предметов во второй половине XIII - первой половине XIV в. характерно для территорий, вошедших в состав Золотой Орды.

7. Энколпион-квадрифолий из медного сплава (рис. 2, 7; 4) найден в раскопе CLXXIX (2015 г.) непосредственно в рыжем суглинке, уложенном здесь для выравнивания поверхности перед строительством здания городского базара в середине XIV в. Размеры креста составили $8,5 \times 6,2 \times 1,5$ см. С обеих сторон в клеймах на его лопастях различимы рельефные изображения святых, неопределимых изза плохой сохранности. Центральное место в средокрестии с одной стороны занимало изображение Богоматери с младенцем, вписанное в квадратное клеймо (рис. $4, A$ ), на обороте - погрудное изображение Спасителя в круглом клейме (рис. 4,5 ). Скорее всего, крест был завернут в ткань, о чем свидетельствует сохранившийся на двух сторонах 


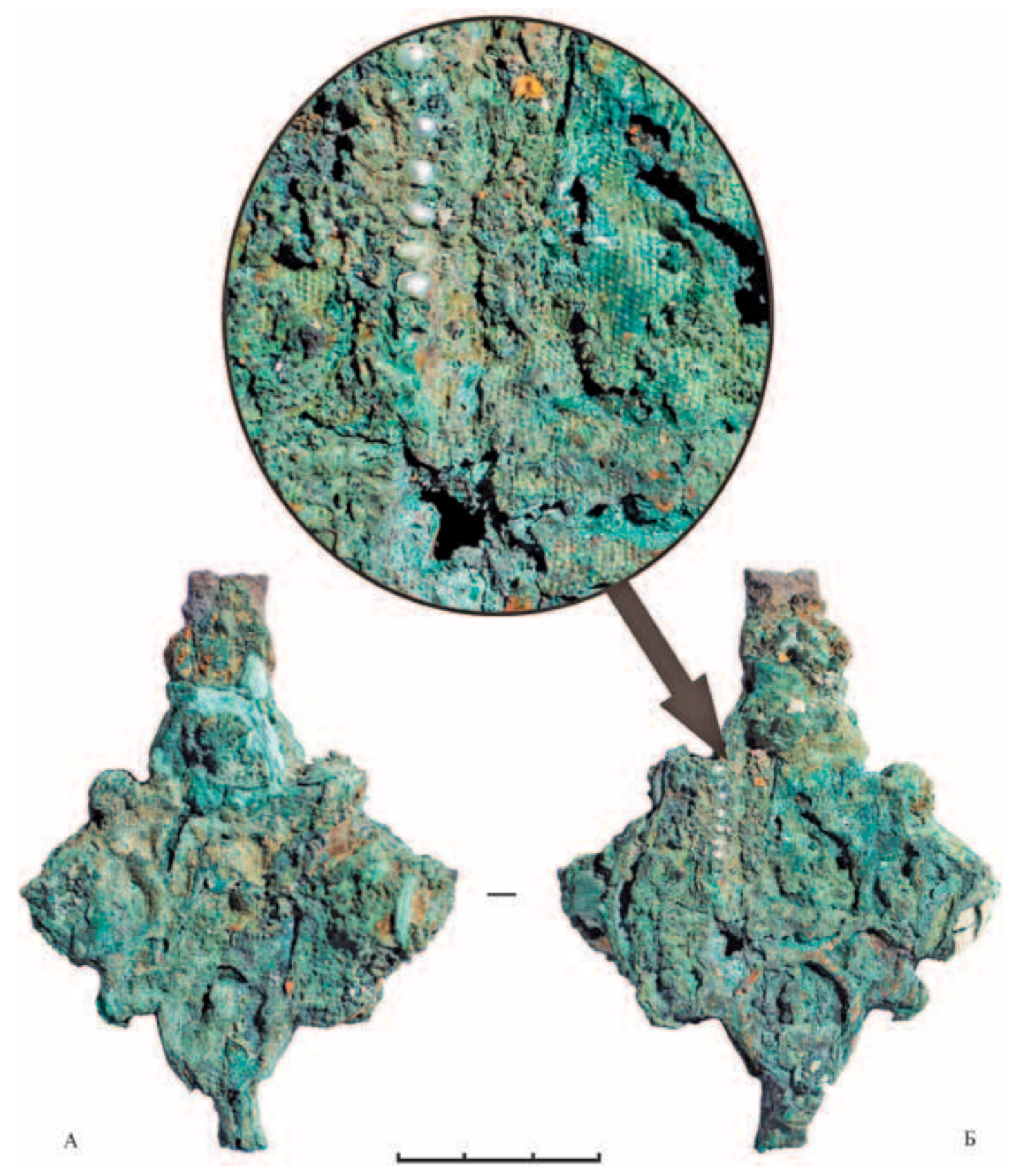

Рис. 4. Энколпион-квадрифолий с отпечатком фрагмента шелковой ткани, расшитой речным бисером

креста отпечаток расшитого речным жемчугом шелка ${ }^{1}$. Аналогичный крест происходит из слоев XIII-XIV вв. Старой Руссы ${ }^{2}$.

Исходя из представленных материалов, можно отметить несколько важных моментов. На основной площади золотоордынского Болгара христи- анские древности в большинстве своем происходят из объектов и прослоек, датируемых в рамках второй половины XIII - первой половины XIV в. В пределах границ золотоордынского города концентрация христианских древностей отмечена к западу от Соборной мечети и в Заречной части го-

\footnotetext{
1 Определение ткани провела И.И. Ёлкина, научный сотрудник ИА РАН.

2 Древности Новгородской земли: электронная база данных археологических находок [Электронный ресурс] // Новгородский государственный университет имени Ярослава Мудрого: сайт. Режим доступа: http://www.novsu.ru/archeology. Дата обращения: 10.05.2018.
} 
рода, где некоторыми исследователями на основании нескольких признаков (характерные для Северо-Восточной Руси каркасно-столбовые заглубленные постройки и сыродутные металлургические горны, древнерусская керамика и наличие в кухонных останках костей свиньи) выделяется «русский ремесленный поселок» (Хлебникова, 1956). Представленные в обзоре предметы личного благочестия могли принадлежать широкому социальному кругу. Зафиксированы как простые в исполнении изделия (например, каменные и небольшие нательные крестики из медного сплава), так и кресты-энколпионы, свидетельствующие о высоком социальном статусе владельца. Вероятно, во второй половине XIII - XIV в. на участке к западу от Соборной мечети в ремесленно-торговом районе золото- ордынского Болгара христианское население проживало совместно с мусульманскими торговцами и ремесленниками. При этом одни христиане могли быть свободными, другие - рабами. О конфликтах, возникавших на религиозной почве между христианским и мусульманским населением, свидетельствует запись в Никоновской летописи от 1323 г., когда в результате религиозного спора с местными мусульманами был убит некий купец Феодор Иерусалимлянин (ПСРЛ, 1885. С. 188-189). Возможно, именно это происшествие послужило поводом к переносу основной части христианской общины Болгара на северо-западную окраину города, на место, где во второй половине XIV в. возникают христианский храм, так называемая Греческая палата, и армянская колония.

\section{Литература}

Археологические исследования 2010 г.: Болгар и Свияжск / сост.: Р. Р. Валиев, А.Г. Ситдиков, 3.Г. Шакиров. Казань: ИД «Казанская недвижимость», 2011. 36 с.

Бадеев Д. Ю., Коваль В.Ю., 2018. Исследования ремесленно-торгового района средневекового Болгара // Поволжская археология. № 2 (24). С. 270-289.

Беленькая Д.А., 1993. Медная пластика городов Московской Руси (XIII-XV вв.) // КСИА. Вып. 208. C. 11-19.

Коваль В. Ю., Бадеев Д. Ю., $2015 . \quad$ Исследования центрального базара Болгара в 20122013 гг. // КСИА. Вып. 237. С. 188-199.

Кокорина Н.А., 1994. Отчет об археологических раскопках в 1993 году на Болгарском городище в Куйбышевском районе Республики Татарстан (раскоп CXVIII) / Архив БГИАМЗ. КП-672. Док.ф. 105.

Кокорина Н. А., 2012. Знаки ремесленников на булгарских литейных формах // Поволжская археология. № 1. С. 129-143.

Корзухина Г.Ф., 1954. Русские клады IX-XIII вв. М.: Изд-во АН СССР. 226 с.

Полное собрание русских летописей. Т.Х. Летописный сборник, именуемый Патриаршей или Никоновской летописью. СПб.: Тип. МВД. 1885. 244 c.
Полубояринова М.Д., 1978. Русские люди в Золотой Орде. М.: Наука. 134 с.

Полубояринова М.Д., 1993. Русь и Волжская Болгария в X-XV вв. М.: Наука. 123 с.

Сивицикий М.В., Губайдуллин Т.Р., Худяков А. В., 2015. Предварительные итоги работ на раскопе СС на Болгарском городище // Археологические исследования 2014 г.: Болгар и Свияжск / Авт.-сост.: Ситдиков А.Г., Валиев Р.Р., Старков А.С. Казань: ИД «Казанская недвижимость». С. 19-21.

Ситдиков А.Г., Сивиикий М.В., 2014. Раскопы CLXXXIII, CLXXXV, CLXXXVII, CLXXXVIII // Археологические исследования 2013 г: Болгар и Свияжск / Авт.-сост.: Ситдиков А.Г., Валиев Р.Р., Старков А.С. Казань: ИД «Казанская недвижимость». С. 12-14.

Смирнов А.П., 1974. Новые данные об исторической и социальной топографии города Великие Болгары // Города Поволжья в средние века/ Отв. ред. А.П. Смирнов, Г.А. Федоров-Давыдов. М.: Наука. С. 4-13.

Хлебникова Т.А., 1956. Древнерусское поселение в Болгарах // КСИИМК. Вып. 62. С. 141-147.

Хлебникова Т.А., 1987. История археологического изучения Болгарского городища. Стратиграфия. Топография // Город Болгар: Очерки истории и культуры / Отв. ред. Г. А. Федоров-Давыдов. М.: Наука. С. 32-88. 
Н.В. Жилина

Институт археологии РАН, г. Москва

\section{Орнаментальный мир древнерусских тканей X-XI веков}

В начальный период государственности Русь знакомится с различными зрелыми художественными традициями, сложившимися в Византии, Скандинавии и на Востоке.

Древнерусские текстильные изделия довольно много изучались, выявлена их технология ( $\mathrm{Ha}$ хлик, 1963; Савенкова, 1997; Клочко, Бредіс, 1996; Барвенава, 2008. С. 79-92; Климова, 1971; Орфинская, 2009), составлены каталоги и списки находок (Новиикая, 1972; Фехнер, $1993^{1}$; Михайлов, 2007). Ткани изучались как предметы импорта и показатели торговых связей с другими странами (Фехнер, $1971 ; 1973$, и др.), как фрагменты и части предметов одежды для реконструкции (Сабурова, 1997; 2012; Михайлов, 2016; Зубкова, Орфинская, 2016; и др.).

Авторы многих публикаций отмечают общее сходство орнаментики тканей и произведений других видов русского декоративного искусства. М. А. Новицкая выделила на вышивках геометрический, растительный и зооморфный орнамент, причем завитковая и плетеная орнаментация отнесены к геометрическому. Основные мотивы этих орнаментов представлены вне хронологии. Указано два типа композиций, которые четко не определены: 1) «с элементами, расположенными на некотором расстоянии»; 2) складывающийся из трех вариантов, строящихся волнистой линией, ломаными линиями и бесконечной плетенкой (Новиџкая, 1972. С. 45-47. Табл. II, III, VI). По-видимому, здесь можно видеть попытку выделить орнаментальные бордюры различной структуры. Р.С. Орлов при анализе одной из вышивок выделяет геральдическую композицию $(O p$ лов, 1973. С. 45). А. Барвенова подчеркнула роль геометрического орнамента и сеточного строения композиций, коснулась примеров растительного (виноградной лозы и крина) и зооморфного орнаментов, а также их символического значения, сопоставила орнаментацию древнерусских тканей и их художественных изображений (Барвенава, 2008. C. 36-48).

Но в целом специального анализа орнаментики тканей из Древней Руси не проделано, не обращается внимание на стилистическую характеристику произведений. Сами ткани и многочисленные хронологически широкие аналогии их орнаментации (от X до XIV в.) требуется систематизировать хронологически и композиционно-стилистически. Такая работа начата, систематизирован орнаментальный материал конца XI - начала XIII в., в рамках которого выделены основные периоды развития орнаментики (Жилина, 2010; 2014; 2016). Цель этой работы - характеристика орнаментики древнерусских тканей предшествующего этапа - X-XI вв., анализ взаимодействия художественных традиций этого времени на примере текстильного материала.

В рассматриваемое время Русь обладала развитой технологической базой для создания и оформления тканей.

В IX-X вв. известен способ ткачества на дощечках: в Старой Ладоге и Новгороде найдены деревянные и костяные дощечки для изготовления шнуров, поясов и ленты (Нахлик, 1963. С. 279; Савенкова, 2012). По тканям Новгорода X-XII вв. и Старой Ладоги реконструируется использование вертикального ткацкого станка (Нахлик, 1963. С. 275, 276, 280). Детали горизонтального станка также известны с Х в. (Савенкова, 2011а. С. 172-176, 182, 183). Вязаные изделия выполнялись в игольной технике, традиция вязания в Новгороде прослеживается с Х в. (Нахлик, 1963. С. 264; Савенкова, 2011б. С. 100-104). По XI в.

\footnotetext{
${ }^{1}$ В данную статью включены те материалы из данного каталога, дату которых можно связывать с ХІ-ХІІ вв. (Фехнер, 1993. C. 13-16. № 1-20).
} 
включительно большое значение сохраняло местное шерстяное сырье (Нахлик, 1963. С. 286).

Текстильные изделия обладают декором, возникающим в самом процессе их изготовления от технологии плетения, ткачества и вязания, а также от окраски материалов. Такой декор иногда называют технологическим орнаментом, противопоставляя изобразительному (Савенкова, 1997. С. 13; Клочко, Бредіс, 1996. С. 106).

Декор, на наш взгляд, более широкое понятие, включающее все виды художественного оформления, а также все зоны его размещения: общая форма предмета; поверхность: свободная композиция, сплошное покрытие, орнамент, то есть ритмизованные изображения в композициях сетки, розетки, бордюра и геральдической. Большинство композиций на тканях и вышивках относится к виду бордюрных. Основные виды орнаментов традиционно выделяются по характеру основных мотивов: геометрический, завитковый, плетеный, растительный, зооморфный. Виды существуют не изолированно, а в комбинациях между собой, какой-либо вид преобладает. Группировка произведений в данной работе осуществляется с учетом этого. Орнаментальным элементом является наименьшая, практически неделимая единица (лист), мотив состоит из нескольких элементов (трилистник).

Грань, за которой после технического изготовления вещи начинается декоративное оформление, почти всегда условна, но наметить ее все же полезно. Простое полотняное переплетение ткани из нитей одного цвета, вероятно, не следует считать декором. Это скорее технологическая основа для его возникновения. Добавление цветной нити создает декор в виде клетки или полосы. Более сложные виды переплетений, начинающиеся с саржевого, когда нити идут по косой линии, производят эстетический эффект.

Крашеные ткани, образцы с саржевым переплетением и выделкой «в елочку» известны в Новгороде с X в. К X-XI вв. относятся фрагменты плетения, тесьма, обработка кромки, в том числе и с бахромой. Округлые кромки есть и в нижних слоях Старой Ладоги (Нахлик, 1963. С. 230, 255, 256, 265. Рис. 18; Савенкова, 2011а. С. 209). Двухосновные ткани из смешанного сырья, клетчатые поневы, ткались из разноцветных нитей (Савенкова, 2015. С. 151). Есть примеры ажурного ткачества из конского волоса Х в., шерстяной ворсовой ткани власяницы с саржевым переплетением (Савенкова, 1997. С. 14, 15). Образец с выделкой в клетку из 23 ярусов, вероятно, является импортной английской тканью (Нахлик, 1963. С. 230, 255, 256. Рис. 24).
Анализируя плетеный и тканый декор, М.М. Савенкова ставит во главу угла магическое содержание мотивов или элементов. Орнамент, по ее мнению, это изображение в виде эстетических образов ритуального содержания текстиля. Ткацкие и плетеные орнаменты рассматриваются в «генетическом родстве» между собой. С одной стороны, указывается, что технологический орнамент ткани перешел в плетеный (Савенкова, 1997. С. 10, 11, 17). С другой стороны, поскольку утверждается изначальная сакральность плетения, возникает трактовка, что при переносе плетеных или веревочных орнаментов на ткань они упрощаются (Савенкова, 2009. С. 91-93).

На наш взгляд, декор, рождаемый технологией, изначально не имеет семантического содержания. Рациональность и правильность построения ткани обладают красотой и эстетически воздействуют на человека. Правильность построения и ритмичность орнамента человек сопоставляет со строением предметов, жилищ, мира, и это наиболее общее философское осмысление орнамента. Конкретное содержание вносится при восприятии орнамента человеком с теми или иными взглядами, то есть вторично. Кроме того, орнамент развивается и независимо от каких-либо техник и ремесел как художественная ритмическая абстракция. Поэтому вряд ли стоит устанавливать генетическую связь между различными текстильными техниками в том или другом направлении, каждая создавала свои варианты технического декора. Развитие орнамента, не вытекающего из технологии, - peзультат общего развития искусства эпохи.

В рассматриваемый период Русь была знакома с яркими произведениями мирового текстильного искусства - импортными тканями. Они оказывали воздействие на формирование стилей и вкусов декоративного оформления древнерусских тканей. Это был тот материал, из комбинации декоративных принципов которого Русь складывала свои традиции. Несмотря на то что нельзя точно сказать, где выполнена та или иная вышивка, для изучения древнерусской орнаментации она в любом случае важна, поскольку характерна для времени и становилась образцом для творческого восприятия.

Наибольшее количество шелковых тканей поступало на Русь из Византии. М.В. Фехнер в основном на основании технологии выделила среди тканей, встреченных на Руси, также иранские, среднеазиатские и испанские (Фехнер, 1977. С. 132-136; 1982. С. 57-69; Клочко, Бредіс, 1996. С. 107). Другие исследователи отмечают, что в различных странах были известны сходные 


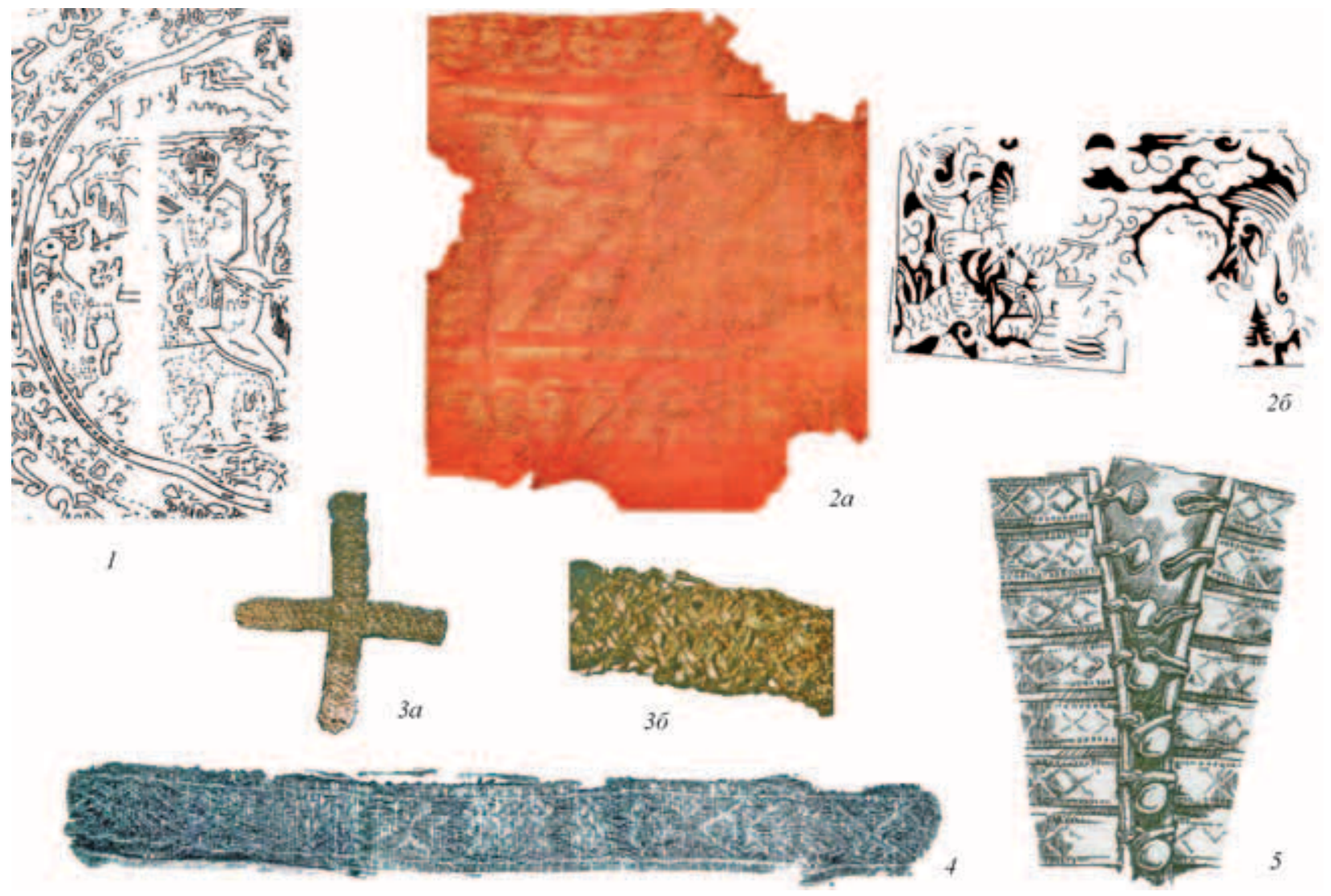

Рис. 1. Иностранные ткани X в. на Руси (шелк, золотная нить)

1 - реконструкция орнамента византийской ткани хитона, Псков, камерное погребение № 3 (по: Зубкова, Орфинская, 2016. Рис. 12, Б); 2 - ткань распашного платья-халата, Китай, Гнёздово, погребение Ц-301, реконструкция орнамента О.В. Орфинской (по: Меч и златник... 2012. № 239; Пушкина, Орфинская, 2011. Рис. 4); 3 - нашивной крест, плетение из золотной нити, Псков, камерное погребение № 8, 2-я пол. Х в. (по: Ениосова, 2016. Рис. 15); 4 - тесьма женской головной повязки, Гнёздово, курган Ц-198, 3-я четв. Х в. (по: Путь ... 1996. № 292. Рис. на с. 54); 5 - реконструкция К. А. Михайлова расположения тесьмы на застежке кафтана, погребальная камера кургана Поль-62, Х в. (рис. О. В. Федорова, по: Михайлов, 2016. Рис. 3).

технологии ткачества (Михайлов, 2007. С. 192). Во многом сходной была и орнаментация, к XI в. сложился интернациональный стиль шелкоткачества (Орлова, 2012. С. 352). По-видимому, основным его создателем для европейского средневекового мира была Византия. Для того чтобы различить ткани по месту производства, необходима публикация и сравнение анализов технологии ткани и нитей, чего пока не проделано.

Для Х в. известно немало находок золотной нити в виде вышивки или аппликации плетеных деталей на одежду (рис. 1, 3). Эту традицию связывают с античностью и Византией, она широко известна в Скандинавии (Михайлов, 2007. С. 196-198). Вышивка могла выполняться также на Руси, причем можно допустить, что и в Х в. Не стоит исключать такую возможность лишь на основании того, что письменные сведения о золотошвейных мастерских на Руси есть только для XI в.
Фрагментов ткани, дающих представление об орнаментации, для X в. известно немного. Характерны геометрический, плетеный и завитковый орнаменты. Растительный ярко не представлен, он, видимо, встречен на более поздних примерах, переходных к XI в., и тесно связан с завитковым.

Два полюса культурного воздействия на орнаментику тканей X в. обозначены находками богато орнаментированных тканей. Византийская ткань из камерного погребения № 3 второй половины - конца X в. с сюжетом «охота Бахрам Гура» (Древнерусский некрополь... 2016. С. 136, 160. Рис. Кат. 28; Зубкова, Орфинская, 2016. С. 389.) демонстрирует восточное воздействие, приходившее на Русь «в византийской передаче» (рис. 1, 1). Китайская шелковая ткань с изображением драконов из Гнездовского кургана Ц-301 (Меч и златник, 2012. № 239; Пушкина, Орфинская, 2011. С. 92-96) свидетельствует о непосредственном интересе 


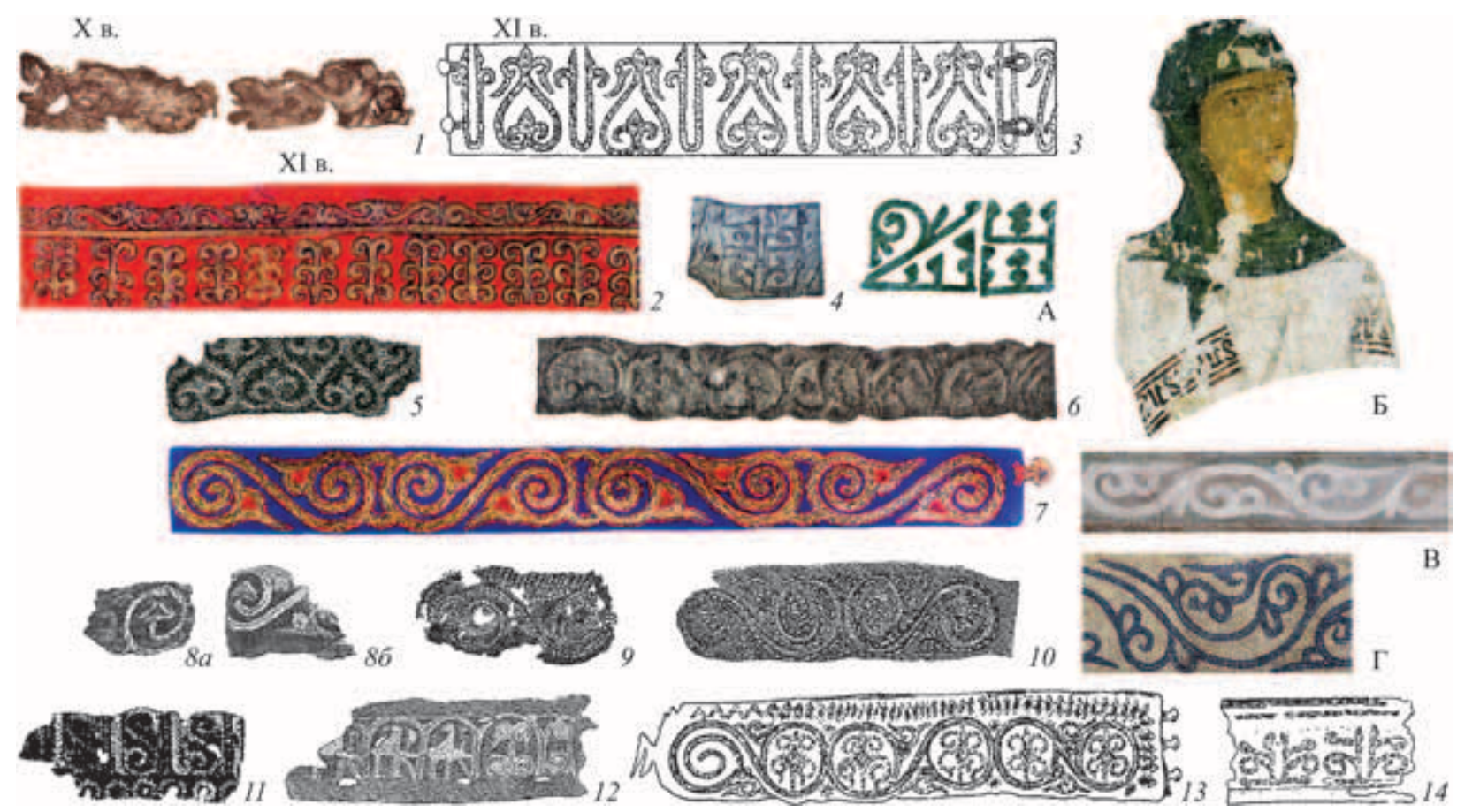

Рис. 2. Завитковая орнаментация тканей и вышивок из памятников XI и XI-XII вв. (шелк и золотная вышивка)

1 - остатки вышивки или ткани, Киев, погребение у Десятинной церкви № 123, посл. четв. Х в. (по: Каргер, 1958.

Табл. XXVII); 2 - Суздальский некрополь, погребение № 73, раскопки 1979 г., кон. X - XI в. (?), стоячий воротник с разрезом слева из цельной ленты (по: Сабурова, 2012. Рис. 2, 1, 2, ив. вкл.); 3 - обшлаг из гробницы Владимира Ярославича, Новгород,

1-я пол. ХІ в. (по: Сабурова, 1997. Табл. 67, 3); 4 - погребения близ с. Шарки (Шаргород), из материалов В. В. Хвойко (по: Новищька, 1965. Табл. II, 4); 5, 10 - Кубаево, Владимирская губ., курган, фр-ты воротников, XI-XII вв. (по: Фехнер, 1993.

С. 15. № 8, 11; рис. 2, 2; 1976. Рис. на с. 223); 6 - Белгород, из материалов В.В. Хвойко, ориентировочно XI-XII вв. (по: Новищька, 1965. Табл. 1, 4); 7 - Суздальский некрополь, погребение № 74, ожерелье, ХІ в. - ? (по: Сабурова, 2012. Рис. 1, 3, изв. вкл.); 8 - Киев, Десятинная церковь (по: Новиџкая, 1972. Табл. 1, 3, 4); 9 - Кирьянова, Ярославская обл., фр-т воротника,

XI в. (по: Фехнер, 1993. С. 14. № 6. Рис. 1, 3); 11 - Троицкая группа на Болдиной Горе, курган IX, фр-т очелья, XI в.

(по: Фехнер, 1993. С. 14, № 5. Рис. 1, 2); 12 - курган Кургино 2 на р. Оять, воротник (по: Фехнер, 1985. С. 199, 200. Рис. 2); 13, 14 - фр-ты воротников, Суздальский некрополь, курган № 11 (по: Сабурова, 2012. Рис. 2, 5, б). Аналогии: А - фрески собора Рождества Богородицы Антониева монастрыря, Новгород, 1-я тр. ХІІ в. (по: Орлова, 2012. Ил. 414); Б - куфический декор на одежде, фрески Спасо-Преображенского собора Мирожского монастыря, Псков (по: Орлова, 2012. Ил. 481); В, Г - роспись и мозаика Софийского собора в Киеве, ХІ в. (по: Орлова, 2007а. Ил. 285, 314).

к восточной культуре (рис. 1, 2). Подражаний таким высоким образцам на Руси в X-XI вв. пока не наблюдается.

Византийская тесьма с золотной нитью из Гнездова представляет целый ряд более простых аналогичных изделий, бытовавших и позже, вытканных с геометрическим узором, продиктованным технологией ткачества, состоящим из треугольных, крестообразных и ромбических фигур (рис. 1, 4). Тесьма использовалась в декоре мужского и женского костюма (Седова, 1978. С. 94. Табл. 4, 23). Геометрический орнамент хорошо представлен и среди деревянных изделий, где также связан с технологией резьбы (см.: Колчин, 1971. Табл. 3, 36. № 42).

Налобный венок из погребения в Киеве у Десятинной церкви позволяет прочитать фрагмент завиткового орнамента, возможно, завитково-рас- тительного (рис. 2, 2). Это один из традиционных византийских орнаментов (рис. 2, $B$ ).

Вышивка из Черной Могилы дает фрагмент плетеного орнамента, сохраняющего узловатость и нерегулярность, характерные для скандинавского плетеного орнамента (рис. 3, 1) (Jansson, 1985. P. 18, 33, 36, 44. Fig. 3, 19, 23, 32; Смирницкая, 2012. C. 153. Рис. 2, 14). Аналогии дают плетеные орнаменты новгородских деревянных изделий того же времени (Колчин, 1971. Табл. 1, 10; 26, 3) (рис. 3, A).

Для тканей, связываемых с XI в., характерно обилие завиткового орнамента. Датированным образцом является орнамент шелковых обшлагов с золотной вышивкой князя Владимира Ярославича из гробницы в Софийском соборе Новгорода, где он был захоронен в 1052 г. (рис. 2, 3). Это произведение позволяет выделить характерные 


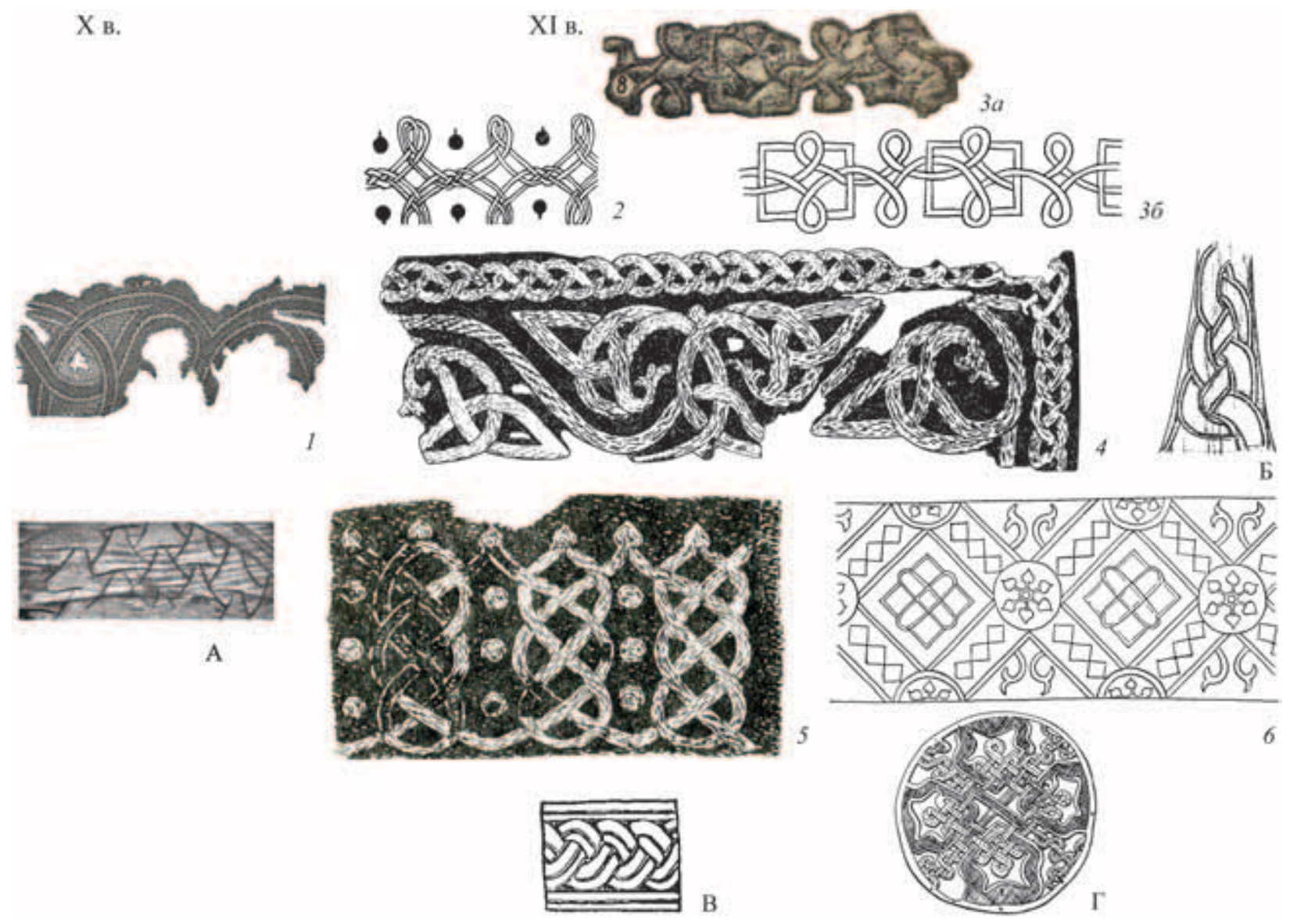

Рис. 3. Плетеная орнаментация тканей и золотных вышивок по шелку X и XI-XII вв.

1 - фр-т из кургана Черная Могила, Чернигов, 2-я пол. Х в. (по: Фехнер, 1979. Рис. на с. 402); 2 - вышивка полы, Белгородский могильник (по: Мезенцева, Прилипко, 1976. Рис. 3); 3 - погребения близ с. Шарки (Шаргород), из материалов В. В. Хвойко (по: Новищька, 1965. Табл. II, 8; 1972. Табл. VIII, 3); 4 - курган у д. Караш Ярославской губ., фр-ты воротника (по: Фехнер, 1993. С. 15. № 17. Рис. 2, 4); 5 - Васильки, Владимирская губ., курган № 206, фр-т воротника (по: Фехнер, 1993. С. 14. № 7. Рис. 2, 1); 6 - Жижава Тернопольской обл. (?), X-XI вв. - ? (по: Новицкая, 1972. Табл. VII: 3). Аналогии, дерево, Новгород: А - крышка кадки, 972-989 гг. (по: Колчин, 1971. Табл. 2, 3. № 13); Б - копыл, сер. ХІ в. (по: Колчин, 1971. Табл. 1, 19. № 62); В - ложка, 1-я пол. ХІ в. (по: Колчин, 1971. Табл. 3, 32. № 17); Г - туес, береста, 1096-1116 гг. (по: Колчин, 1971. Табл. 43, 7. № 291).

для того времени черты. Во-первых, завитковая структура раппортов бордюра дополняется растительно-кринообразным орнаментом. Мотив трехили пятилистного крина-лилии используется в византийском искусстве с V-VIII вв., а к X-XI вв. преобладает, заменяя собой другие растительные мотивы - виноградного листа, пальметты, аканта (Кондаков, 1896. С. 206-208). Во-вторых, используются вертикальные куфические знаки арабской письменности (рис. 2, 3). Так называемый шрифтовой орнамент в искусстве христианского мира известен с X в., к середине XI в. относится фреска собора Св. Софии в Охриде с его использованием. С XI в. развивается так называемый лиственный куфи. Орнамент часто встречается при изображении тканей и предметов одежды (рис. 2, Б).
В монументальном искусстве Руси орнамент представлен с начала XII в. Наиболее ранний пример геометризованного варианта (рис. 2, A)-фрески собора Рождества Богоматери Антониева монастыря в Новгороде (Орлова, 2012. С. 347-349, 390; ил. 413, 414; 481; 2015. С. 441. Ил. 644).

На новгородском обшлаге наблюдается вариант лиственного, или кринообразного, куфи. В орнаменте новгородского обшлага параллельные вертикальные стержни петлевидных мотивов, расположенных между сердцевидными, дополнены половиной геометризованного листа. Аналогичный мотив завиткового орнамента с элементами геометризованного куфи представлен на вышивке из погребения близ с. Шарки (рис. 2, 4). Этот вариант наиболее близок орнаментации фресок собора 
Антониева монастыря. Более свободную комбинацию элементов куфи и завиткового геральдического раппорта дает вышивка из Суздальского некрополя, петлевидные мотивы сходны с орнаментацией обшлага (рис. 2,14$)^{2}$.

Завитки образуют в бордюрах вышивок XI в. сердцевидные, S-видные, волютообразные и геральдические парные раппорты. В некоторых случаях завитки не дополняются другими элементами или дополняются незначительно. Это характерно для волютообразных (рис. 2, б) и S-видных раппортов, расположенных вертикально или горизонтально (рис. 2, 9-11; Фехнер, 1993. С. 14. № 4). Фрагменты вышивок из Десятинной церкви не датируются точно, входя в обширный комплекс материала разного времени (Каргер, 1950. С. 123-128. Рис. 95-98; Жилина, 2014. № 248). По орнаментации некоторые из них сближаются с вышивками XI в. из владимирских и ярославских погребений, S-видные завитки дополнены треугольными элементами (рис. 2, 8a, б). Сердцевидный завитковый раппорт дополняется листом, при этом образуется схематичная форма крина (рис. 2, 5). Вертикальные раппорты из трех пар завитков наблюдаются на воротнике из Суздальского некрополя (рис. 2, 2). Иногда такие мотивы сближают с растительными, характеризуют как «древа» (Сабурова, 2012. С. 155), но для этого оснований нет, мотивы абстрактны. Аналогичная орнаментация из двух пар завитков внутри арок, дополненная растительными элементами, представлена на воротнике из могильника Кургино, здесь они чередуются с зооморфными раппортами с изображениями грифонов (рис. 2, 12) ${ }^{3}$. Данный пример, вероятно, является наиболее поздним, его дата может переходить в XII в.

Наиболее сложный бордюр из S-видных раппортов представлен на суздальском воротнике. Внутри завитков расположены геральдические композиции из двух пар завитков. Основной бордюр дополнен кринообразными элементами, а по периметру - геометрическими (рис. 2, 13).

На примерах из Суздаля представлен кринообразно-завитковый орнамент, построенный на основе S-видных раппортов простого и спирального завитка. Лиственные дополнения делают этот орнамент более плавным и мягким, тем не менее основную роль в нем играет именно завиток (рис. 2, $2,7)$. Аналогичный орнамент представлен на фресках Софийского собора в Киеве (рис. 2, $B, \Gamma$ ). При- водятся также аналогии с византийскими тканями (Фехнер, 1976. С. 224, 225).

В целом завитковые элементы придают композициям с преобладанием этого вида орнамента четкую геометрическую структуру, геометризованную стилистику и абстрактность. Это впечатление усиливают сочетающиеся с завитками геометрические элементы, а дополняющие орнамент растительные и зооморфные элементы и мотивы также имеют геометризованный характер.

Некоторые примеры плетеного орнамента отталкиваются от технологии плетения, сохраняя реальное переплетение золотных нитей. Такие примеры наблюдаются в тканом орнаменте (Opфинская, 2009. С. 167. Рис. 95). Аппликацией или вышивкой «вприкреп», видимо, следует считать украшение полы одежды из Белгородского могильника (рис 3, 2). Имитацию плетения дает и вышивка из погребения в Шарках (рис. 3, 3). Для таких примеров большее значение имеют технологические, а не чисто орнаментальные аналогии, в частности, плетеная тесьма (рис. 1, 3б).

Но плетеный орнамент развивается и независимо от технологии. Орнамент воротника из кургана в Караше Ярославской губернии дает пример сложных плетеных мотивов с подтреугольными узлами, общая композиция характеризуется регулярностью (рис. 3, 4). Это продолжение традиции скандинавского орнаментального плетения, пример которого происходит из кургана Черная Могила в Чернигове, структура треугольных переплетений совпадает (рис. 3,1$)$. Аналогии дают и резные изделия Новгорода (рис. 3, Б).

Этот и другие примеры плетеного вышитого орнамента показывают его устанавливающуюся регулярность, что характерно для византийской традиции (Архипова, 2007. Ил. 625, 628; Жилина, 2016. Рис. 1, 10). В композициях доминируют крупные плетеные мотивы, характерны геометрические или небольшие растительные дополнения (рис. 3, 5, б). Регулярная структура плетеного орнамента способствует выработке сложной геометрической композиции, а также геометризованной стилистики дополнительных растительных мотивов и их абстрактности. Сходные примеры представлены на деревянной ложке и берестяном туесе из Новгорода XI - начала XII в. (рис. $3, B$, $Г$ ).

Отдельную группу составляют вышивки с христианскими сюжетами. Примеры происходят из

2 В работе использованы материалы тканей из Суздальского некрополя, связываемые согласно датировкам курганов с XI-XII вв. (Сабурова, Седова, 1984. С. 104, 105. Табл. 2).

3 Данное погребение связывается с XI-XII вв. (Кочкуркина, Линевский, 1985. С. 108. № 175). 

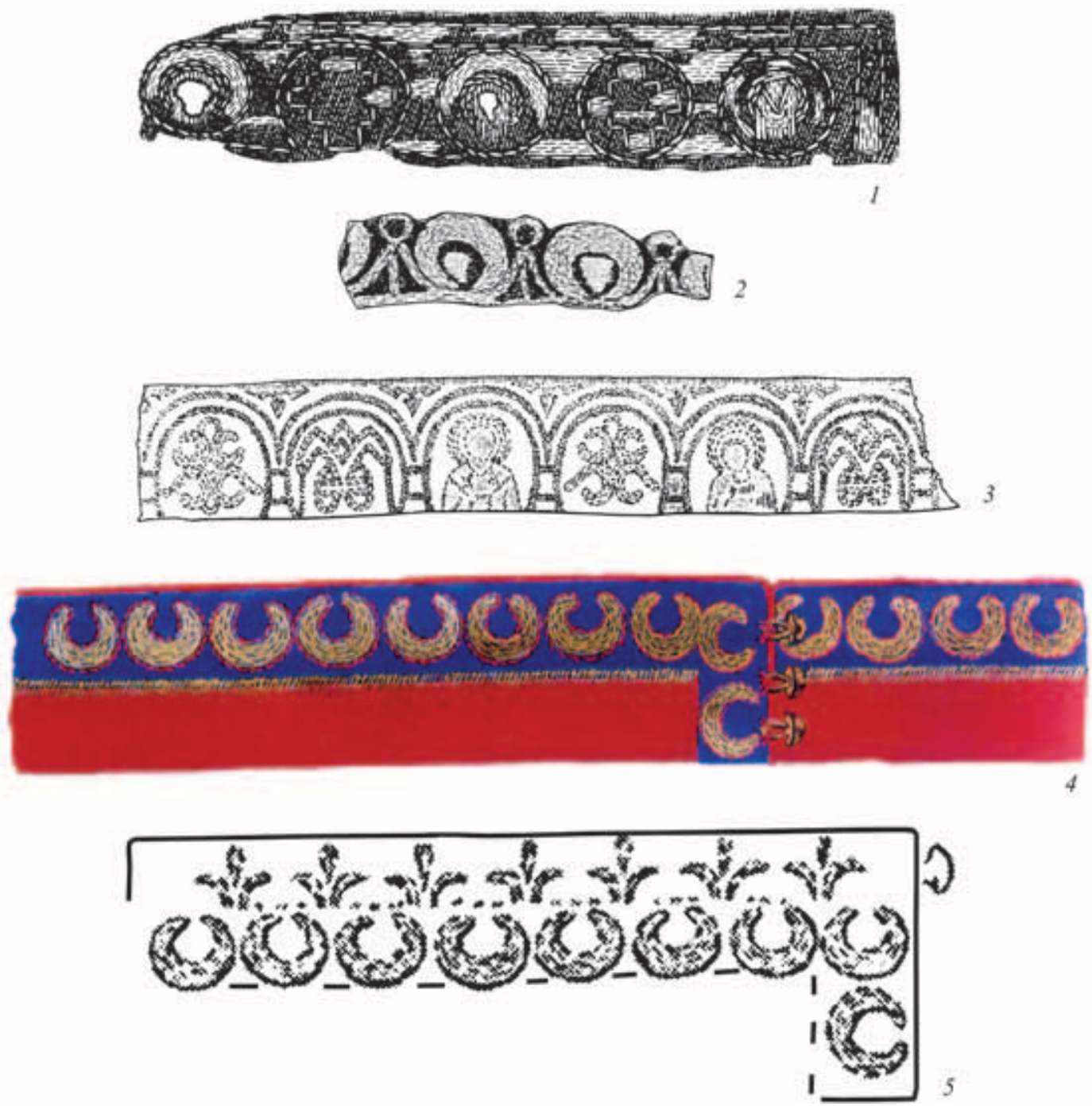

Рис. 4. Христианские мотивы в орнаментации тканей и золотных вышивок по шелку XI-XII вв.

1 - Кубаево, Владимирская губ., курган, фр-т воротника (по: Фехнер, 1993. С. 15. № 10. Рис. 2, 3); 2 - Осиповцы, Владимирская губ., курган, фр-т воротника (по: Фехнер, 1993. С. 15. № 14; 1985. Рис. на с. 223); 3 - Караш Ярославской губ., курган, очелье (по: Фехнер, 1993. С. 15, 16. № 19; ИАК. Вып. 15, 1905. С. 148. Рис. 257); 4, 5 - Суздальский некрополь, бескурганный могильник, погр. № 3 и курган № 50 (по: Сабурова, 2012. Рис 1, 1, цъ. вкл.; 2, 8).

комплексов XI-XII вв., но начало такой традиции оформления вполне может связываться с XI в. Очелье или венок, использующийся при христианском обряде погребения, имел на себе композицию Деисуса. Такой пример происходит из курганов в Ярославской губернии. Внутри арок чередуются изображения персонажей Деисуса и растительные кринообразные мотивы либо геометризованной стилистики, либо завитковой структуры (рис. 4, 3). На воротниках из других погребений есть примеры орнаментов с христианской семантикой, выполненных в схематичной геометрической манере (рис. 4, 1, 2). М.В. Фехнер охарактеризовала этот орнамент как состоящий из лунниц и крестовидных фигур (Фехнер, 1993. С. 15, № 10, 14). Но в упрощенном геометризованном варианте здесь отразились нимбы, лики и мотив христианского креста. Вероятно, в процессе дальнейшей орнаментализации такие композиции упрощаются и действительно превращаются в бордюр из лунниц (рис. 4, 4, 5). Такой орнамент вышит на нескольких воротниках из Суздальского некрополя XI-XII вв., в одном случае он дополнен кринообразным бордюром, в другом - геометрическим орнаментом (Сабурова, 2012. Рис. 2, 7-9).

Растительный орнамент на тканях XI в. представлен яркими, но пока немногочисленными примерами. Есть образцы, демонстрирующие 

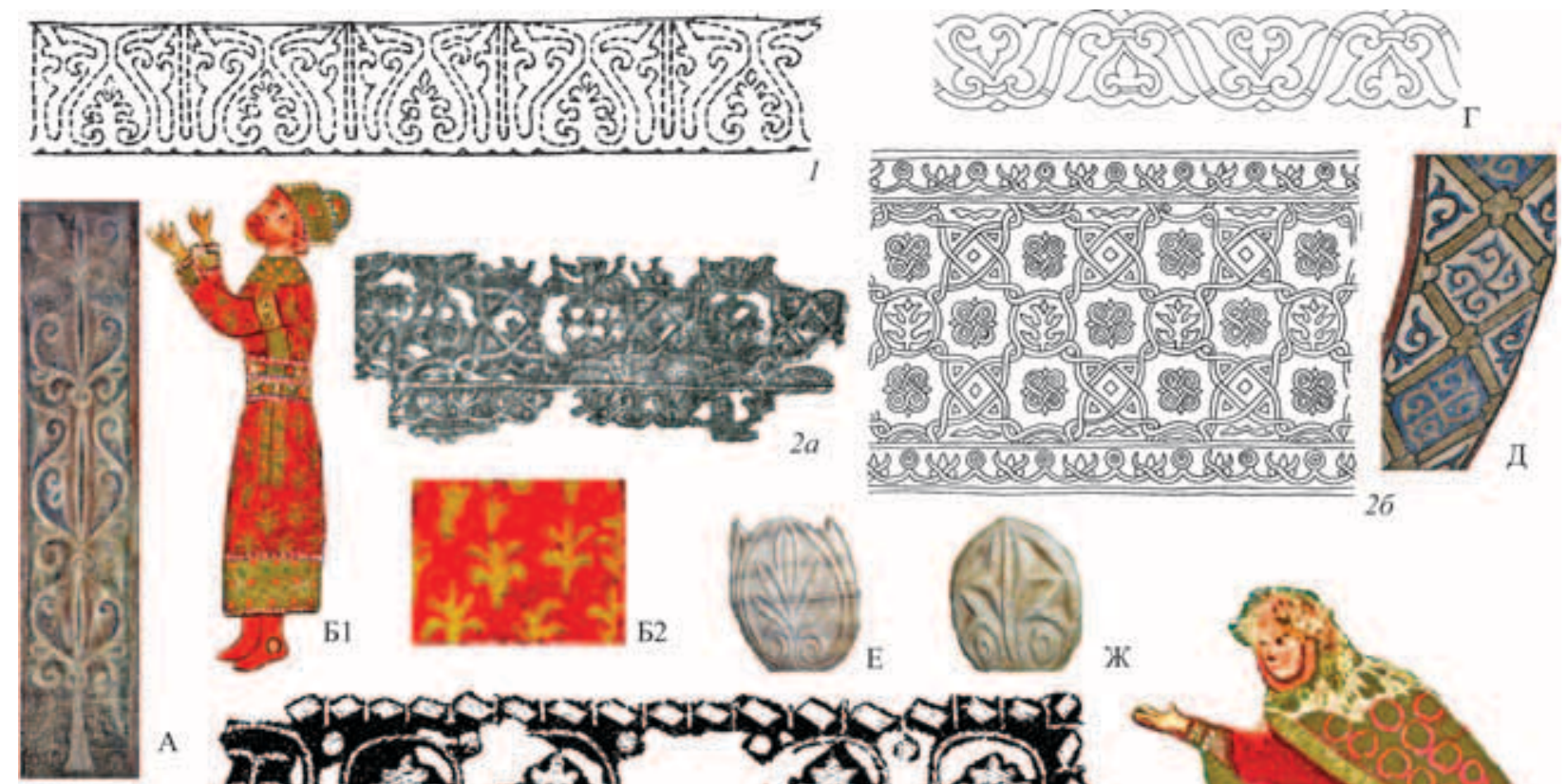

A
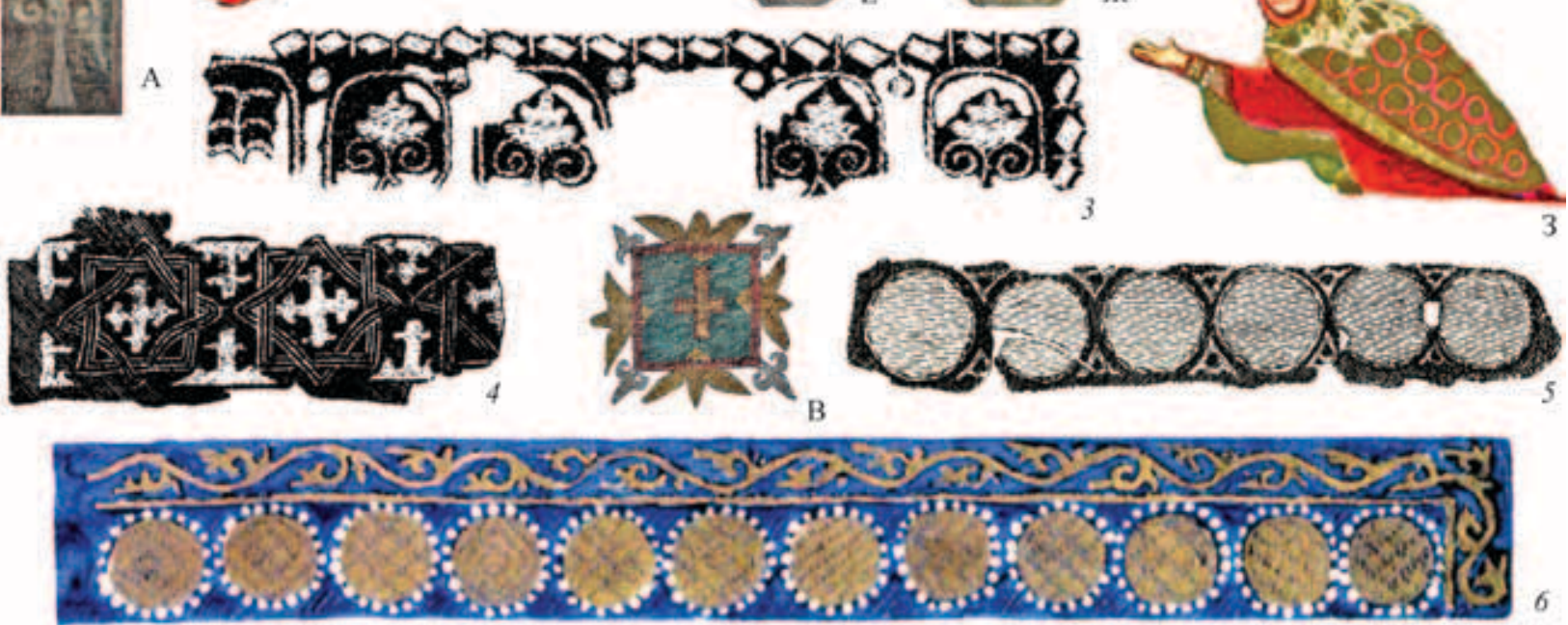

Рис. 5. Растительная и геометрическая орнаментация XI-XII вв.

1 - пояс, византийская ткань, гробница Владимира Ярославича, Новгород, 1-я пол. ХІ в. (по: Сабурова, 1997. Табл. 67, 2); 2 - Херсонес, погребение, раскопки К. К. Косцюшко-Валюжинича, золотная вышивка и реконструкция орнамента М. А. Новицкой (по: Новиикая, 1967. Рис. 2; 1972. Табл. IX); 3 - Шелебово, Владимирская губ., курган № 187, воротник стоячий, XI в. (по: Фехнер, 1993. С. 14. № 3. Рис. 1, 1); 4, 5 - курган у д. Караш Ярославской губ., фр-ты воротников (по: Фехнер, 1993. С. 15, 16. № 18, 20. Рис. 2, 5, б); 6- воротник, Суздальский некрополь, курган № 71 (по: Сабурова, 2012. Рис. 2, 3, цв. вкл.). Аналогии: А - фреска, Софийский собор в Киеве, ХІ в. (по: Орлова, 2007а. Ил. 332); Б, 3 - орнаментация княжеского костюма Ярополка и Гертруды, миниатюра Трирской псалтыри, 1-я пол. XI в. (Кондаков, 1906. Табл. VI); В - мозаика, Софийский собор в Киеве, XI в. (по: Орлова, 2007а. Ил. 322); Г - фрески, Софийский собор в Новгороде, нач. XII в. (по: Орлова, 2007б. Ил. 575); Д - мозаика монастыря Осиос Лукас в Фокиде (по: Орлова, 2007а. Ил. 305); Е, Ж - мраморные капители Софийского собора в Киеве, ХІ в. (по: Архипова, 2007. Ил. 604, a, в).

стилистическую и иконографическую стадию развития растительного орнамента в данное время. Таким является пояс с тканым узором из византийской ткани первой половины ХІ в. из погребения Владимира Ярославича в Новгороде. Полагают, что вышитый узор обшлага из этой же гробницы заимствован именно с этого пояса (Фехнер, 1982. С. 59). Но при общем сходстве сердцевидного раппорта орнаментов все же очевидно, что они относятся к разным видам. На поясе представлен растительный орнамент, мотив завитка не выделен, хотя и дополняет растительный. Основным растительным мотивом является высокий многолистник, который можно сопоставить с акантом, мотивом в виде высокого разветвленного листа одноименного растения, перешедшим от античности в Византию, где он приобрел геометризованную стилистику (Буткевич, 2008. С. 123, 124). Мотивы аканта обрамлены кринообразными ветвями. Здесь наблюдается и мотив куфического шрифтового орнамента (рис. 5, 1). 

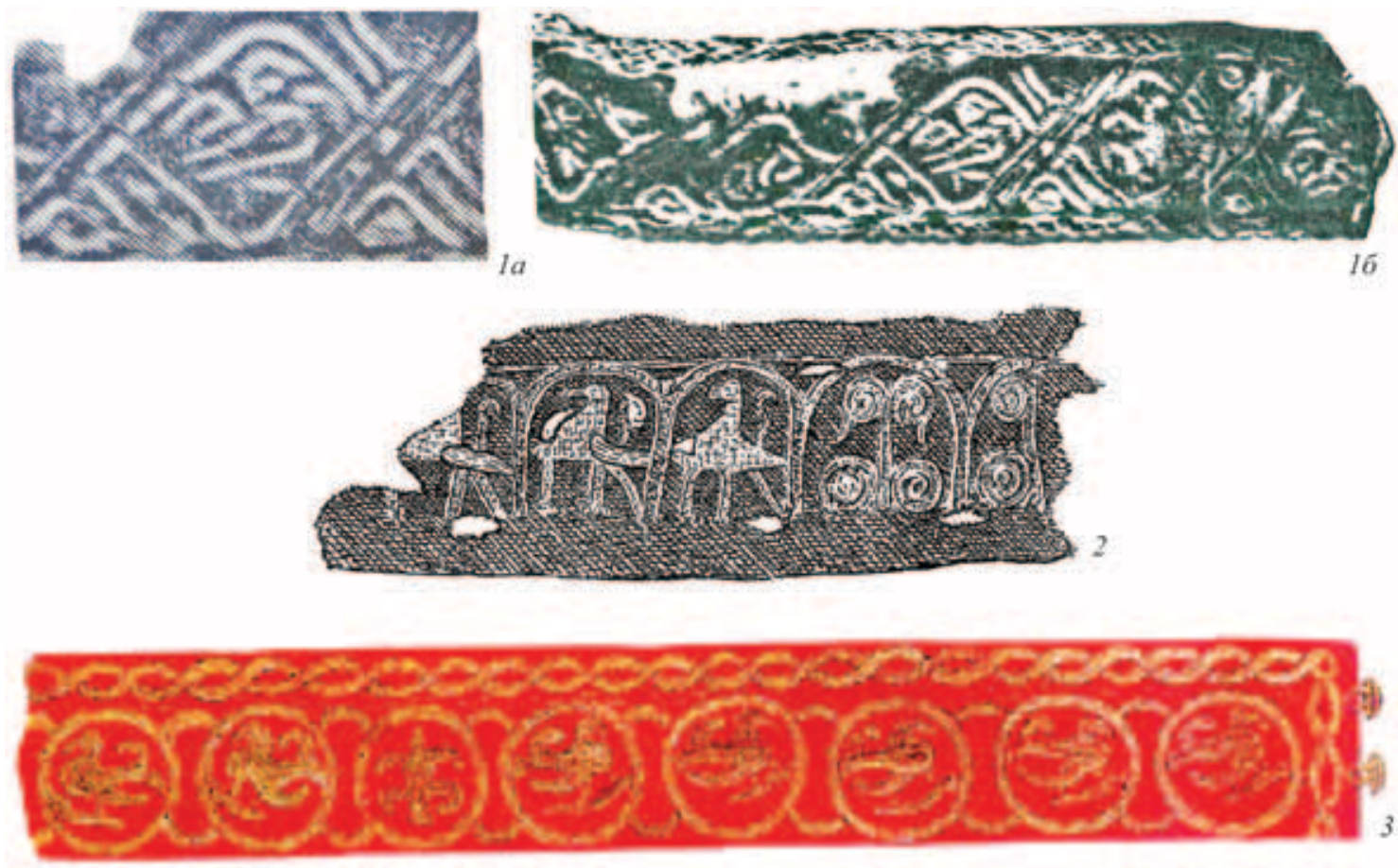

Рис. 6. Зооморфная орнаментация вышивок XI-XII вв.

1 - погребения близ с. Шарки (Шаргород), из материалов В. В. Хвойко (по: Новищька, 1965. Табл. I, 3; 1972. Табл. VIII, 3 ; 1972. Табл. IV, 1); 2 - курган Кургино 2, на р. Оять, воротник (по: Фехнер, 1985. С. 199, 200. Рис. 2); 3 - воротник, Суздальский некрополь, бескурганный могильник, погребение 2 (по: Сабурова, 2012. Рис 1, 2, ив. вкл.)

Другой пример вышивки, но без точной даты, происходит из погребения в Херсонесе, он может быть связан со средневизантийским периодом, ориентировочно - с XI-XII вв. (ОАК за 1904 г., 1907. С. 49). Реконструкция орнамента вышивки, проделанная М.А. Новицкой, показывает, что в центральной зоне в композиции сетки чередуются плетеные и спиральные мотивы в виде четырехчастных регулярных розеток, а также мотивы аканта. Мотивы крина составляют здесь отдельные бордюры и незначительно дополняют завитковые розетки (рис. 5,2 ).

Геометризованный мотив аканта с завитковыми нижними отростками в арках составляет раппорт центрального бордюра на вышивке воротника одного из курганов в Шелебово Владимирской губернии. По периметру расположены бордюры из геометрических элементов (рис. 5, 3).

Аналогии использования мотива аканта есть в орнаменте монументальной живописи и каменной резьбы XI - начала XII в.: на фресках, мозаиках и мраморных капителях Софийского собора в Киеве, фресках Софийского собора в Новгороде (рис. $5, A, \Gamma, E, \mathcal{W}$ ). В XI в. мотив аканта не полностью подавлен мотивом крина, сохраняется высота листа, но его отростки оформляются в виде раппортов растительно-кринообразного орнамента (рис. 5, A). Интересно привести пример такого мотива именно на княжеской одежде этого времени - орнаментация туники Ярополка на миниатюре Трирской псалтыри (рис. 5, Б).

Примеры чисто кринообразного орнамента в геометризованной манере дают вышивки из курганов Ярославской губернии. В одном случае крестообразно-кринообразные композиции включены в плетеные розетки и разделены встречными кринами сверху и снизу (рис. 5,4 ). Четырехчастная розетка из трилистников могла осмысливаться как христианский крест, но в орнаменте такой мотив имел скорее декоративное значение. Композиционные и стилистические аналогии розеткам из кринообразных мотивов и элементов в композиции бордюра и сетки дают мозаики XI в. Софийского собора в Киеве и монастыря Осиос Лукас в Фокиде (рис. 5, В, Д).

В другом случае орнамент почти неотличим от геометрического, бордюр составлен из кругов, между которыми сверху и снизу встречно направлены подтреугольные мотивы со слабо выраженными кринообразными завершениями (рис. 5, 5). М.В. Фехнер трактует круги как солярные знаки (Фехнер, 1993. С. 16. № 20). М. А. Сабурова объясняет его более правильно - как подражание круг- 
лому раппорту византийских тканей и парчовых лент (Сабурова, 2012. С. 154. Рис. 2, 2). Орнаментальной аналогией является изображение круговой орнаментации ткани плаща Гертруды на миниатюpe Трирской псалтыри XI в. (рис. 5, 3). Аналогичный круговой орнамент, дополненный развитым кринообразным бордюром, в основе композиции которого лежит волнистый стебель, вышит на воротнике из Суздальского некрополя (рис. 5, 6).

Растительно-кринообразному орнаменту суждено было стать в дальнейшем основным. В рассматриваемое время в текстильном искусстве он складывается и характеризуется геометризованной стилистикой и связью с геометрическим орнаментом.

Примеры зооморфного орнамента, которые можно было бы ориентировочно связать с XI-XII вв., немногочисленны. Зооморфные мотивы используются, как правило, в комбинации с геометрическими, витыми и завитковыми, кринообразными мотивами. Стилистика мотивов птиц и грифонов геометризованная. Мотив птицы включается в ромбическую сетку бордюра (рис. 6, 1), в круг (рис. 6, 3), мотив грифона - в арку (рис. 6, 2).

В результате можно выделить основные черты декоративного оформления древнерусских тканей X-XI вв. Наиболее распространен завитковый орнамент, развивается его связь с рас- тительно-кринообразным. Плетеный орнамент в начале периода характеризуется скандинавской узловатой структурой, но постепенно в нем нарастает регулярность, источником которой является как технологическая структура плетения и ткачества, так и византийская орнаментальная традиция. В XI в. создаются вышивки с христианскими мотивами, закладываются основы традиций русского лицевого шитья. В растительном орнаменте XI в. сохраняются мотивы аканта, куфического шрифтового орнамента, но есть и чистые примеры развитого растительно-кринообразного орнамента. Зооморфный орнамент используется в комбинации с завитковым и кринообразным. Для стилистики всех орнаментов рассматриваемого периода характерна геометризованность, дополнение геометрическими элементами. Используются преимущественно геометрические композиции ритмизованного бордюра и сетки. Для растительного орнамента характерно построение бордюра с помощью раппортов из плавной завитковой линии.

Основную художественную традицию начинает закладывать византийское орнаментальное искусство, передающее адаптированные элементы арабского куфического орнамента, вбирающего в свою систему и элементы скандинавского плетеного орнамента.

\section{Литература}

Архипова Е.И., 2007. Архитектурный декор и монументальная пластика Киевской Руси. Конец X - первая четверть XII века // История русского искусства. В 22 т. Т. 1. Искусство Киевской Руси IX - первая четверть XII века / Отв. ред. А.И. Комеч. М.: Северный паломник. 2007. С. 569-617.

Барвенава Г.А, 2008. Тэкстыль сярэднявечча на землях Беларусі. Мінск: Беларускі дзяржауны універсітэт культуры і мастацтвау. 246 с.

Буткевич Л. М., 2008. История орнамента. М.: Гуманитарный издательский центр ВЛАДОС. 267 с., 8 с. с ил.

Древнерусский некрополь Пскова X-начала XI века. Т. 2 / Отв. ред. И. К. Лабутина. СПб.: НесторИстория. 2016. 624 с.

Ениосова Н.В., 2016. Исследование химического состава металла и техники изготовления украшений и бытовых предметов из камерных погребений Старовознесенского некрополя // Древнерусский некрополь Пскова X-начала XI века.
Т. 2 / Отв. ред. И.К. Лабутина. СПб.: НесторИстория. С. 518-559.

Жилина Н.В., 2010. Тисненый убор по древнерусским кладам X-XIII вв. (от орнаментального рифления до эмблемы княжеской власти) // Stratum plus. № 5. СПб. - Кишинев Одесса - Бухарест. С. 23-144.

Жилина Н.В., 2014. Древнерусские клады IXXIII вв. Классификация, стилистика и хронология украшений. M.: URSS; Книжный дом «Либроком». $400 \mathrm{c}$.

Жилина Н.В., 2016. Стилистические параллели: ювелирные украшения, архитектурная резьба и живопись Древней Руси // Древняя Русь. Вопросы медиевистики. № 4 (66). С. 129-142.

Зубкова Е.С., Орфинская О.В., 2016. Текстиль из камерных погребений Старовознесенского некрополя Пскова // Древнерусский некрополь Пскова X-начала XI века. Т. 2 / Отв. ред. И.К. Лабутина. СПб.: Нестор-История. С. 373-394. 
ИАК. Вып. 15. СПб: Типография Главного Управления Уделов, 1905.

Каргер М.К., 1950. Археологические исследования древнего Киева. Отчеты и материалы (19381947 гг.). К.: Изд-во АН УССР. 252 с.

Каргер М.К., 1958. Древний Киев. М. - Л.: Изд-во АН CCCP. T. I. 580 c.

Колчин Б.А., 1971. Новгородские древности. Резное дерево. М.: Наука. 62 с. 48 табл. (САИ. Е1-55).

Кондаков Н.П., 1896. Русские клады. Исследование древностей великокняжеского периода. T. I. СПб.: Тип. Главного Управления Уделов. 214 с. Табл.

Кондаков Н.П., 1906. Изображения русской княжеской семьи в миниатюрах XI века. СПб.: изд. Императорской Академии наук. 123 с. VI таб.

Климова Н.Т., 1971. Технология шелковых тканей из коллекции Государственного исторического музея // История и культура Восточной Европы по археологическим данным/под ред. С. М. Орешникова и др. М.: Советская Россия. C. 228-243.

Клочко Л., Бредіс Н., 1996. Дослідження текстилю// Церква Богородиці Десятинна в Киеві. Київ: АртЕк. С. 105-109.

Кочкуркина С.И., Линевский А.М., 1985. Курганы летописной веси X-начала XIII в. Петрозаводск: Карелия. 224 с.

Мезенцеева Г. Г., Прилипко Я. П., 1976. Открытие Белгородского могильника // СА. № 2. С. 245-248.

Меч и златник. К 1150-летию зарождения Древнерусского государства. Каталог выставки. М.: Кучково поле, 2012. 320 с.

Михайлов К.А., 2007. Ранние образцы древнерусского золотного шитья // ННЗ. Вып. 21. Великий Новгород. С. 191-208.

Михайлов К. А., 2016. Костюм из псковских камерных погребений 2-й пол. Х в. на фоне раннесредневековых европейских аналогий // Древнерусский некрополь Пскова X - начала XI века. Т. 2 / Отв. ред. И.К. Лабутина. СПб.: НесторИстория. 2016. С. 415-427.

Нахлик A., 1963. Ткани Новгорода. Опыт технологического анализа // Жилища Древнего Новгорода. М.: Изд-во АН СССР. С. 228-313. (Тр. НАЭ. Т. IV; МИА. № 123).

Новицька М.О., 1965. Гаптування в Київскій Русі (За матеріалами розкопок на території УРСР // Археологія. № XVIII. Київ. С. 24-38.

Новицкая М.А., 1967. Орнаментальная вышивка средневекового Крыма // Одесское археологическое общество. Записки. Т. 2. Одесса. C. 284-288.
Новиикая М.А., 1972. Золотная вышивка Кивской Руси // Byzantinislavica. 33. Prague. С. 42-50. Табл. I-IX.

Орлов Р. С., 1973. Давньоруська вишивка XII ст. // Археологія. № 12. Київ. С. 41-50.

Орлова М.А., 2007а. Орнамент в живописи конца $\mathrm{X}$-середины XI века// История русского искусства. В 22 т. Т. 1: Искусство Киевской Руси IX-первая четверть XII века/Отв. ред. А.И. Комеч. М.: Северный паломник. С. 325-358.

Орлова М.А., 2007б. Орнамент в живописи второй половины XI-первой четверти XII века // История русского искусства. В 22 т. T. 1: Искусство Киевской Руси IX - первая четверть XII века / Отв. ред. А.И. Комеч. М.: Северный паломник. С. 537-567.

Орлова М.А., 2012. Орнамент и другие элементы декоративного убранства в живописи середины 1120-х - начала 1160-х годов // История русского искусства. В 22 т. Т. 2/1. Искусство 20-60х годов XII века / Отв. ред. Л.И. Лившиц. М.: Гос. ин-т искусствознания. С. 336-411.

Орлова М.А., 2015. Орнамент и другие виды декоративного убранства в живописи второй половины XII в.// История русского искусства. В 22 т. Т. 2/2. Искусство второй половины XII века / Отв. ред. Л.И. Лившиц. М.: Гос. ин-т искусствознания. С. 432-525.

Орфинская О.В., 2009. Текстиль из могильника Минино II // Археология севернорусской деревни X-XIII веков. Средневековые поселения и могильники на Кубенском озере. В 3-х тт. 2007 / Науч. рук. и отв. ред. Н. А. Макаров. Т. 3. Палеоэкологические условия, общество и культура. М.: Наука. С. 167-174.

ОАК за 1904 г. СПб.: Тип. Главного Управления Уделов, 1907. 185 с.

Путь из варяг в греки и из грек... Каталог выставки / Ред. В. Л. Егоров. М: ГИМ, Калиникин и Ко, 1996. $104 \mathrm{c}$.

Пушкина Т.А., Орфинская О.В., 2011. Текстиль из женского камерного погребения Ц-301 в Гнёздове // АИППЗ. Матер. 57-го засед. М. - Псков: ИА РАН. С. 92-99.

Сабурова М.А., 1997. Древнерусский костюм // Древняя Русь. Быт и культура / Отв. ред.: Б.А. Колчин, Т.И. Макарова. М.: Наука. С. 93-109. Табл. 66-78. (Археология).

Сабурова М.A., 2012. Находки деталей одежды в Суздальской земле и их значение для изучения русского национального костюма // Древняя Русь. Быт и культура / Отв. ред.: Б.А. Колчин, 
Т.И. Макарова. М.: Наука. С. 150-158. Цв. вкл. Рис. 1-4. (Археология).

Сабурова М.А., Седова М.В., 1984. Некрополь Суздаля // Культура и искусство средневекового города / Отв. ред. И. П. Русанова. М.: Наука. С. 91-130.

Савенкова М.М., 1997. Художественный текстиль Древнего Новгорода $\mathrm{X}-\mathrm{XV}$ вв. (истоки, эволюция, художественная природа). Автореферат дисс. ... канд. истор. наук. М.

Савенкова М.М., 2009. «Веревочный» орнамент на Волхове: по материалам Новгородской экспедиции // Родина. № 9. С. 91-93.

Савенкова М.М., 2011а. Реконструкция процесса ткачества на горизонтальном станке в средневековом Новгороде (по материалам Новгородской археологической экспедиции) // Археологические вести. Вып. 17. С. 169-184.

Савенкова М. М., 2011б. Вязаный текстиль средневекового Новгорода // АИППЗ. Матер. 57-го засед. М. - Псков: ИА РАН. С. 99-110.

Савенкова М.М., 2012. Историческая реконструкция древнерусского текстиля, выработанного в технике ткачества на дощечках // Актуальные проблемы современной науки: информационно-аналитический журнал. М.: Спутник. № 5. С. 16-22.

Савенкова М. М., 2015. Поневы из средневекового Новгорода (по материалам археологических раскопок) // Исторические, философские, политические и юридические науки, культурология и искусствоведение. Вопросы теории и практики. № 9 (59). Ч. І. Тамбов: Грамота. С. 150-155.

Седова М. В., 1978. Ярополч Залесский. М.: Наука. $160 \mathrm{c}$.
Смирницкая Е.B., 2012. Германский звериный стиль как орнаментальное искусство // Атлантика. Вып. Х. М.: МАКС Пресс. С. 131-182.

Фехнер М.В., 1971. Шелковые ткани как источник для изучения экономических связей Древней Руси // История и культура Восточной Европы по археологическим данным/под ред. С.М. Орешникова и др. М.: Советская Россия. C. 207-227.

Фехнер М.В., 1976. Золотное шитье ВладимироСуздальской Руси // Средневековая Русь / пред. ред. Д. С. Лихачев. М.: Наука. С. 222-225.

Фехнер М.В., 1977. Изделия шелкоткацких мастерских Византии в Древней Руси // СА. № 3. C. $130-142$.

Фехнер М.В., 1979. Золотное шитье Древней Руси // Памятники культуры. Новые открытия. Письменность. Искусство. Археология. Ежегодник 1978 / пред. ред. Д. С. Лихачев. Л.: Наука. С. 401-405.

Фехнер М.В., 1982. Шелковые ткани в средневековой Восточной Европе // СА. № 2. С. 57-70.

Фехнер М. В., 1993. Древнерусское золотное шитье $\mathrm{X}$-XIII вв. в собрании Государственного исторического музея// Средневековые древности Восточной Европы / Отв. ред. Н. Г. Недошивина. М.: ГИМ. С. 3-21. (Тр. ГИМ; вып. 82).

Jansson I., 1985. Ovala spännbucklor. En studie av vikingatida standardsmycken med utgångspunkt från Björkö-fynden. Uppsala: Uppsala University Institute of North European Archaeology. 238 p. (Archaeological Studies. Aun 7). 


\section{Славянская технологическая традиция в формировании модели древнерусского кузнечного ремесла}

Построение и исследование технологических моделей позволяет получить наиболее адекватное представление о производственной культуре древних обществ. Под моделью технологического развития мы понимаем совокупность трех взаимозависимых составляющих, таких как техникотехнологический стереотип, производственные традиции и инокультурные воздействия. Техникотехнологический стереотип включает определенный набор и соотношение признаков, характеризующих материал, категориальный состав, приемы и способы изготовления изделий в конкретной археологической культуре. Технико-технологический стереотип в кузнечном производстве представляет устойчивый элемент культуры. Его закрепление и передача из поколения в поколение на протяжении длительного времени составляют суть производственных традиций. Модель производственной культуры подразумевает две составные части: производственный процесс и взаимодействие участников этого процесса.

Сама возможность конструирования технологических моделей непосредственно связана с внедрением в археологию метода археометаллографии. Перспективность этого метода была продемонстрирована Б. А. Колчиным именно на материалах древнерусских памятников (Колчин, 1953). На основании изучения массовых серий кузнечных артефактов Б. А. Колчин пришел к выводу о высоком уровне развития древнерусского кузнечного ремесла, в основе которого лежали сложные приемы технологической сварки - соединения железной основы с твердым стальным лезвием (Колчин, 1953. C. 207).

В дальнейшем на материалах Великого Новгорода Б.А. Колчиным была прослежена динамика технологических изменений в кузнечном ремесле, увязанная с определенными хронологическими этапами (Колчин, 1959). Основные выводы
Б.А. Колчина подтверждаются аналитическими материалами из других древнерусских памятников (Терехова и др., 1997; Завьялов, Розанова, Терехова, 2012; Завьялов, Терехова, 2013).

На основании имеющихся на сегодняшний день аналитических данных можно констатировать, что характерной особенностью древнерусской технологической модели является неоднократная смена технико-технологических стереотипов и последовательное динамичное развитие производства.

Как свидетельствуют археометаллографические данные, основу формирующегося древнерусского городского ремесла в X-XI вв. составлял такой технологический стереотип, как трехслойный пакет. Например, среди ножей Великого Новгорода в X в. трехслойные изделия составляли более $90 \%$, в Ростове Великом - 55\%. Суть этой технологии заключается в сварке трех полос металла: двух железных и стальной между ними с выходом последней на режущую кромку. Учитывая накопленные археологические и археометаллографические данные, мы можем уверенно утверждать, что своими корнями технология трехслойного пакета восходит к скандинавским производственным традициям (Завьялов, Розанова, Терехова, 2012. С. 53). На это указывают наиболее ранние изделия, выполненные в трехслойной технологии, из таких памятников, как Хельгё (VII в.), а также Бирка и Хедебю (Arrhenius, 1989; Modin, Pleiner, 1978. P. 102-103; Pleiner, 2006. Р. 205; Tomtlund, 1973). Появление и распространение в Восточной Европе вещей, изготовленных по технологии трехслойного пакета, напрямую связано с функционированием балтийско-волжского пути, активизировавшего торговые связи скандинавов и местного населения.

Смена технологических стереотипов происходит в XII в., когда основной технологией в кузнечном производстве Древней Руси становится технология наварки стального лезвия на железную осно- 
ву. Эта технология демонстрирует принципиально иную конструктивную схему: наложение и сварка стального лезвия с железной основой, а не вставка стального лезвия между железными полосами, как это имело место в схеме трехслойного пакета. Наварка обладала рядом преимуществ по сравнению с технологией трехслойного пакета: экономия стали и универсальность (то есть возможности использования на разнообразных категориях орудий труда и оружия).

Есть все основания утверждать, что производственная традиция, основанная на технологии наварки, формировалась в славянском мире, в частности, в западнославянских областях. Наиболее ранние предметы с наварными лезвиями известны в материалах памятников VII-VIII вв. междуречья Вислы и Одера и Великой Моравии (Piaskowski, 1974. S. 83-94; Pleiner, 1967. S. 93, 138). По данным Р. Плейнера, ножи с наварным лезвием составляли более трети кузнечных изделий из моравских памятников (Pleiner, 1967. S. 136).

Как свидетельствуют накопленные к настоящему времени археометаллографические данные по материалам из восточнославянских памятников (Вознесенська, Недопако, Паньков, 1996; Вознесенская, 1979; Гопак, 1976. С. 55), к концу I тысячелетия н.э. в местном кузнечном ремесле уже сформировалась определенная технологическая модель. В основе этой модели лежит технико-технологический стереотип, характеризующийся использованием простых технологий (ковка изделий целиком из железа либо из сырцовой стали) в сочетании с таким высокотехнологичным приемом, как наварка стального лезвия на железную основу.

При этом характерной чертой распространения наварки на восточноевропейских памятниках является определенная позитивная динамика. Так, если на памятниках третьей четверти I тыс.н.э. такие орудия составляют менее $5 \%$, то на поселениях боршевской культуры (VIII-X вв.) - 18\% (Teрехова и др., 1997. С. 207).

В настоящее время мы располагаем дополнительными материалами, позволяющими проследить особенности технологической модели у различных восточнославянских племен: роменских (городище Супруты), боршевских (Животинное городище) и словен новгородских (городище Любша).

Городище Супруты (Тульская обл.) в VIII-X вв. являлось крупным торговым центром между Поднепровской Русью и Хазарским каганатом. Раскопками исследовано более $40 \%$ площади памятника. Вещевой комплекс свидетельствует о полиэтничности местного населения: наряду со славянски- ми вещами представлены предметы салтовского, финно-угорского, балтского и скандинавского типов (Григорьев, 2005. С. 185). При этом, по словам В. В. Мурашевой, «наблюдается утрата этнической самоидентификации - в составе одного женского убора могли сочетаться скандинавские амулеты, салтовские серьги и славянские височные кольца» (Мурашева, 2011. С. 72).

Животинное городище расположено в Воронежской обл. у с. Староживотинного. Раннеславянское поселение датируется второй половиной VIII - началом XIв. Особенностью этого памятника, как и других памятников Верхнего Дона, исследователи считают удаленность от магистральных торговых путей, на что указывает практически полное отсутствие монетных находок и торгового инвентаря (весы, гирьки) (Винников, 2014. С. 223). По мнению А. 3. Винникова, огромное количество шлаков в слое позволяет говорить о развитии на Животинном городище металлургического производства (Винников, 2011. С. 13).

Городище Любша расположено на мысу, образованном впадением р. Любши в Волхов, в 2 км к северо-востоку от Земляного городища Старой Ладоги. По предварительным данным, памятник датируется первой половиной VIII - второй половиной IX в.

Как показал металлографический анализ, при изготовлении ножей из указанных памятников основными технологическими схемами были ковка изделий из цельнометаллических заготовок, трехслойный пакет и наварка. Соотношение технологических схем на всех трех памятниках очень близко, что подтверждает тезис о единых производственных традициях в восточнославянском мире. Это тем более показательно, что указанные памятники расположены на значительном расстоянии друг от друга.

Судя по приведенным данным, особенностью восточнославянской производственной модели является присутствие наряду с традиционно славянскими инновационной скандинавской технологии трехслойного пакета. В то же время на западнославянских землях, как свидетельствуют археометаллографические данные (Hošek, Meduna, 2011; Piaskowski, 1997. S. 266; Pleiner, 1979), она не получила сколько-нибудь широкого распространения.

В связи с этим большой интерес представляет вопрос взаимодействия славянской и скандинавской производственных традиций.

Характер культурно-исторических взаимодействий в производственной сфере мы можем определить исходя из разработанной нами методики 
(Завьялов, Розанова, Терехова, 2009. С. 9). Обращаясь к трехслойным изделиям, мы выделяем два варианта: классический, или североевропейский, и восточноевропейский (Завьялов, Розанова, Тере-

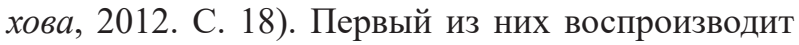
наиболее ранние образцы, известные по материалам из Скандинавии, сочетающие форму (североевропейские ножи - группа IV, по Р. С. Минасяну), материал (фосфористое железо и высокоуглеродистая сталь) и технологию (сварка в пакет). Во втором случае могут выявляться отступления от классического образца.

Североевропейский вариант характеризует продукцию носителей скандинавских производственных традиций. Восточноевропейский - попытку местных мастеров подражать инновационной технологии.

Исходя из приведенных дефиниций, обратимся к конкретным материалам перечисленных памятников.

Изделия, выполненные в обоих вариантах технологии трехслойного пакета, зафиксированы на всех упомянутых памятниках. Однако соотношение их различно, что отражает взаимодействие инновационной и традиционных технологий. Так, в Супрутах среди шести трехслойных ножей только один изготовлен по классической схеме, что является свидетельством непосредственных контактов местных мастеров с носителями новационных технологий. И как результат воспроизведение новой технологии в местном, восточноевропейском варианте.

Другую форму взаимодействий демонстрируют материалы из Животинного городища. Все трехслойные ножи из этого памятника представлены восточноевропейским технологическим вариантом. Этот факт можно увязывать с появлением на поселении славянского населения из центров, где местными мастерами уже была освоена новая технология. По данным А. З. Винникова, на Животинном городище прослежено несколько волн переселения славянского населения из ареала роменской культуры (Винников, 2014. С. 224). Известно, что на роменских памятниках трехслойные ножи были распространены достаточно широко (Вознесенская, 1979. С. 73; Вознесенська, Недопако, Паньков, 1996. С. 53, 57).

В материалах из городища Любша оба варианта трехслойной технологии представлены поровну (по два экземпляра). Это, вероятно, свидетельствует о поступлении на поселение как продукции непосредственно носителей скандинавских производственных традиций, так и изделий мастеров, осваивавших инновационную технологию. В этом случае речь может идти как о торговых контактах, так и привнесении артефактов в местную среду самими владельцами.

Подчеркнем, что наряду с изделиями в трехслойной технологии на всех памятниках присутствуют и артефакты с наварными лезвиями. Это свидетельствует о том, что, несмотря на активное освоение восточными славянами трехслойной технологии (в восточноевропейском варианте), славянская производственная традиция в виде технологии наварки продолжает существовать.

Таким образом, распространение на восточнославянских памятниках изделий, выполненных в инновационных технологиях, существенно не изменило характера местной славянской производственной традиции. Можно утверждать, что появление и распространение технологии трехслойного пакета на славянских памятниках не вытесняет традиционную технологию наварки. Объяснить это можно не только устойчивостью местных традиций, но и определенными преимуществами наварки перед трехслойным пакетом: экономия стали и универсальность (то есть возможность использования на разнообразных категориях орудий труда и оружия).

Итак, археометаллографическое исследование кузнечной продукции из восточнославянских памятников позволило прийти к следующим выводам.

1. Восточнославянские технологические традиции являются составной частью общеславянской производственной модели, которая начала формироваться в VII-VIII вв. в западнославянских землях.

2. Особенностью восточнославянского кузнечного ремесла является использование начиная с IX в. инновационной (скандинавской) технологии трехслойного пакета.

3. Взаимодействие двух традиций (славянской и скандинавской) демонстрирует устойчивость славянского технико-технологического стереотипа, который в XII в. становится основой модели древнерусского кузнечного ремесла. 


\section{Литература}

Винников А.3., 2011. Животинное городище конца VIII - начала XI в. на р. Воронеж // Tp. III (ХІХ) ВАС. СПб. - М. - Великий Новгород: ИИМК РАН. С. 12-13.

Винников А. 3., 2014. Юго-восточная окраина славянского мира в VIII - нач. XIII в. (Животинное городище на р. Воронеж). Воронеж: Кварта. $396 \mathrm{c}$.

Вознесенская Г.А., 1979. Техника кузнечного производства у восточных славян в VIII-X вв. // CA. № 2. С. 70-76.

Вознесенська Г.О., Недопако Д.П., Паньков С.В., 1996. Чорна металургія та металообробка населення східноєвропейського лісостепу за доби ранніх слов'ян і Київської Русі. Київ: ІА НАНУ. 192 c.

Гопак В.Д., 1976. Техника кузнечного ремесла у восточных славян во второй половине I тысячелетия н. э. // СА. № 2. С. 46-56.

Григорьев А.В., 2005. Славянское население водораздела Оки и Дона в конце I - начале II тыс.н. э. Тула: Гос. музей-заповедник «Куликово поле». $207 \mathrm{c}$.

Завьялов В.И., Розанова Л.С., Терехова Н.Н., 2009. История кузнечного ремесла финно-угорских народов Поволжья и Предуралья. К проблеме этнокультурных взаимодействий. М.: Знак. 264 с.

Завьялов В.И., Р РозановаЛ.С., Терехова Н.Н., 2012. Традиции и инновации в производственной культуре Северной Руси. М.: Анкил. 376 с.

Завьялов В.И., Терехова Н.Н., 2013. Кузнечное ремесло Великого княжества Рязанского. М.: ИА PAH. 272 c.

Колчин Б.А., 1953. Черная металлургия и металлообработка в Древней Руси. М.: АН СССР. 280 с. (МИА № 32).

Колчин Б.А., 1959. Железообрабатывающее ремесло Новгорода Великого // Тр. НАЭ. Т. II. М.: АН СССР. С. 7-120. (МИА № 65).
Мурашева B. В., 2011. Городище у с. Супруты (IX - начало X в.) в системе этнокультурных связей // Тр. III (XIX) ВАС. СПб. - М. - Великий Новгород: ИИМК РАН. Т. ІІ. С. 72.

Терехова Н.Н., Розанова Л. С., Завьялов В.И., Толмачёва М.M., 1997. Очерки по истории древней железообработки в Восточной Европе. М.: Металлургия. 318 с.

Arrhenius B., 1989. Arbeitsmesser aus den Grabern von Birka // Birka II:3. Sistematische Analisen der Gräbefunde. Stokholm. S. 65-81.

Hošek J., Meduna P., 2011. Metallography of knives from the medieval village of Hrdlovka and the burial ground of Zlončice, Bohemia // The archaeometallurgy of iron. Praha: Archeologický ústav AV ČR. P. 137-152.

Modin S., Pleiner R., 1978. The metallographic examinations of lock, keys and tools // Excavations at Helgö V: 1. Stockholm.

Piaskowski J., 1974. Untersuchungen der Fruh-Mittelalterlichen Eisen- und Stahltechnologie der Slaven in der Gebieten zwischen Weichsel und der Oder // Archeologia Polona. XV. S. 67-96.

Piaskowski J., 1997. Badania metaloznawcze przedmiotów żelaznych z wczesnośredniowecxnego grodziska w Stradowie, woj. Kielce // Sprawozdania Archeologiczne. T. 49. S. 265-272.

Pleiner R., 1967. Die Technologie des Schmiedes in der Gross marischen Kultur // Slovenska archeologia XV-1. Bratislava. S. 77-188.

Pleiner R., 1979. K vývoji slovanské nožířské techniky v Čechách // Archeologické rozhledy. N 31. S. 354-360.

Pleiner R., 2006. Iron in Archaeology. Earle European Blacksmiths. Praha: Archeologický Ústav AVČR. $384 \mathrm{p}$.

Tomtlund J.-E., 1973. Metallographic investigation of 13 knives from Helgö // Early Medieval Studies. 5. Stockholm. P. 42-63. 
И.Л. Кызласов

Институт археологии РАН, г. Москва

\title{
Новое в жизни Восточной Европы в XI-XII веках. (Влияние Великого Сибирского пути, открытое археологией)
}

\author{
Андрею Евгеньевичу Леонтьеву - \\ знатоку археологии древней Руси, \\ соседящих с нею и субстратных культур, \\ с высоким профессиональным уважением \\ и давними дружескими чувствами.
}

Некогда Г.Ф. Миллер, участник Сухопутного отряда Второй Камчатской экспедиции $1733-$ 1743 гг., опираясь на летописи, коротко и точно указал «первую возможность Российскому государству познакомиться с обширной и известной, но для древних совершенно незнакомой областью, называемой нами Сибирью». «Я имею в виду, - писал далее один из первых академических историков Отечества, - пермяков, вогулов и самоедов, которые с давних времен поддерживали сношения между собой. Следовательно, русским поселенцам в этих местностях было нетрудно получить через них некоторые, хотя и неточные, сведения о соседней Сибири» (Миллер, 1937. С. 202; 2005. С. 197). Подтверждающие это ранние летописные свидетельства не раз использовались в трудах по истории Приуралья и Западной Сибири.

Будем помнить, что государственная политика освоения новых земель никогда не велась на ощупь, а первопроходцы не были вольными авантюристами на пути незнаемом. Наложение русской дани требовало овладения аборигенными административными центрами: сдача пушнины была у сибирских народов извечной формой подчинения. Кто владел властными пунктами, тот имел право сбора дани. Поэтому изучение истории зауральских поселений привело к своду письменных русских источников о Сибири начиная с XII по XVII в. и анализу данных обо всем этом в трудах народившегося в XVIII и развернувшегося в XIX в. научного сибиреведения (Кызласов Л.Р., 1986; 1992. С. 35-73, 101-123; 1995; 1997; 2006.
C. 39-72, 85-101; Kyzlasov L.R., 2010. P. 53-89, 103-120).

Отметим также, что «первым из русских историков обратился Миллер и к археологии $<\ldots$.. >, первый оценил важность изучения археологических древностей, “из которых о древних временах и приключениях хотя не совершенное, однако же не совсем отметное свидетельство получить можно"» (Бахрушин, 1937. С. 28; 2005. С. 38). Именно археология, изучая следы повседневной жизни, утверждает ныне: еще в домонгольское время русские люди не просто познакомились с жителями земель за Югорским каменем, но взаимодействовали и даже смешивались с ними. Славяне действительно продвигались на восток благодаря сведениям, получаемым от уже хорошо известной им приуральской югры, однако этого мало. Оказывается, русские проникали в Западную Сибирь чуть ли не внутри этой самой югорской среды, которая, наращивая предшествующие внешние связи VI-IX вв., в X-XIII вв. активно продвигалась за Урал с Камы и Вычегды.

Подлинным знатоком западносибирских древностей, вековечных процессов сложения и развития угро-самодийских культур огромного края, многочисленных конкретных материалов, раскрывающих особенности проникновения в тайгу и лесостепь как приуральского, так и волжскобулгарского и северорусского населения домонгольского времени, был В.А. Могильников (1987a; 1990в; 1991). С.Г. Пархимович (1991. С. 145) указанием на наблюдения Г.Ф. Миллера предварил 
обстоятельный обзор археологических и лингвистических свидетельств о связях с хантами и манси, существовавших в начале II тысячелетия у предков коми, первых проводников в Восточную страну древнерусских отрядов. Далеко за Уралом изучены памятники как коми-зырян (вымская культура, см: Розенфельдт, 1987a), так и коми-пермяков (родановская культура, см.: Розенфельдт, 1987б).

Археологическая наука, по словам Г.Ф. Миллера, «как получает свет из истории, так и взаимно ей самой сообщает» (Бахрушин, 1937. С. 28; 2005. C. 38). В последние десятилетия она также показала нам, что не только жители западных и восточных отрогов Урала оказались знатоками проезжих дорог, ведущих в сибирские земли. Далекие пути на Иртыш требовали познания тех сведений, которые принесли на Русь саяно-алтайские торговые караваны и их конвои в XI-XII вв. Значение Великого Сибирского пути в формировании России, в исторической судьбе как русского народа, так и всех народов Сибири стало проясняться для медиевистов-археологов с выделением в землях Восточной Европы многочисленных аскизских древностей домонгольского времени (рис. 1-3) (Кьзлласов И. Л., 2007).

В начале этим пришлось заниматься сибиреведу (Кьзласов И.Л., 1978. С. 139; 1980, С. 80-87; 1983. С. 41, 53, 65, 66, 68; 1996; 1997; 1998; 2000; 2001; 2003а. С. 5; 2003б; 2008. С. 91-95), затем подключились исследователи Восточной Европы: Руси (Никольская, 1987. С. 133, 134, рис. 68, 16; Русанова, Тимощук, 1993. С. 46, 56, 59, рис. 45, 20, 60, 8, 13, 14; Гоняный, 2005; Кызласов И. Л., Гайдуков, 2006) и ее восточных соседей (Гришаков, 1992. C. 109, табл. IV, 1-4, 6, 7, 10; Казаков, 1997. С. 66, рис. 7; 2000. С. 39, рис. 5; Иванов, 1998. С. 135 , рис. $57,13-22,64,13$; Белорыбкин, 2000; 2001; 2003. Рис. 1, 6, 8-16; Винничек, 2000. С. 152; 2003. С. 372; Винничек, Губанов, 2003. С. 342-344, 347, рис. 1-3; Погорелов, 2003; Белавин, 2003).

Особенно много и цельно представил и осмыслил материалы Среднего Поволжья и Прикамья К.А. Руденко, выявивший среди них не только изделия, принадлежавшие к собственно аскизской культуре, но и выполненные по сибирским образцам многочисленные местные подражания, орга- нично, но по-разному вошедшие в раннесредневековые культуры волжских булгар и, во многом в отработанных ими модификациях, древней мордвы, муромы, марийцев, удмуртов и коми. Труды этого исследователя отличает прочное археологическое источниковедение, ясное осознание профессиональных задач, встающих при анализе материала, и целенаправленность в их разрешении (Руденко, 2000а; 2000б; 2000в. С. 25, 33, 54, рис. 1, 1, 14, $15,18-22,6,1-7,13-15 ; 2001 ; 2003 \mathrm{a} ; 20036 ; 2005$; $2007 \mathrm{a} ; 20076$. С. $25,28,50,51,58-62$, рис. 54-60, 66, 5, 6, 72-74, 124; 2008a. С. 42; 2008б. С. 245, 246; 2011; 2014. С. 541-549, библиография). На названных землях аскизские вещи и их дериваты стали хронологическим показателем, отмечая период XI и XII вв. ${ }^{1}$

Причины продвижения средневековых хакасов на запад и полноценное овладение ими трассами Великого Сибирского пути все еще остаются недопонятыми. Здесь и установленные письменными и археологическими источниками давние для южносибирского общества традиции караванной внешней торговли с Востоком (Китаем, Маньчжурией, Кореей и даже Японией), с Югом (Восточным Туркестаном и Индией) и Западом (странами Средней Азии, Казахстана, Афганистана, Ирана) - того занятия, которое веками пребывало в сфере государственной политики, обеспечивалось официальными договорами (определявшими даже периодичность и объем поставляемых товаров), а также военными конвоями (Кьзласов И.Л., 2007; библиогр. там же); купец на Востоке всегда был не только торговцем, но и доверенным лицом государя, выполняя посольскую миссию. Здесь и серебряный кризис, охвативший в то время запад Евразии, но неведомый Саяно-Алтаю, покрывавшему серебром конскую сбрую как всадников, так и всадниц; вероятно, и торговля оловом (Винничек, 2000). Здесь, надо думать, и духовные основы - наступившее в то время слияние державной идеологии Восточной Европы и Средней Азии с западноазиатскими по корням мировыми религиями, в зону которых Южная Сибирь с официальным принятием манихейства вошла еще во второй половине VIII в. Быть может, географическая

\footnotetext{
${ }^{1}$ Следующим шагом стало выделение аскизских изделий XIII-XIV вв., востребованных монгольской имперской культурой и потому распространившихся вне коренной территории без участия самих их создателей - средневековых хакасов (Кызласов И.Л., 2007. С. 64, 65, 69; 2010). К середине II тысячелетия, подобно прежним векам, сложились и широко распространились формы, подражавшие аскизским предметам, более всего - всаднической и воинской амуниции. Эти новые, происходящие от южносибирских, но не тождественные им по облику изделия, отличали уже кыпчакскую среду. Такие находки нередки в памятниках Восточной Европы (Двуреченский, 2004. С. 44-47, рис. 75, 28, 79, 24, 25, 80, 5, 13; Шиолянский, 2007. С. 105; Зайцева, 2014. С. 365).
} 

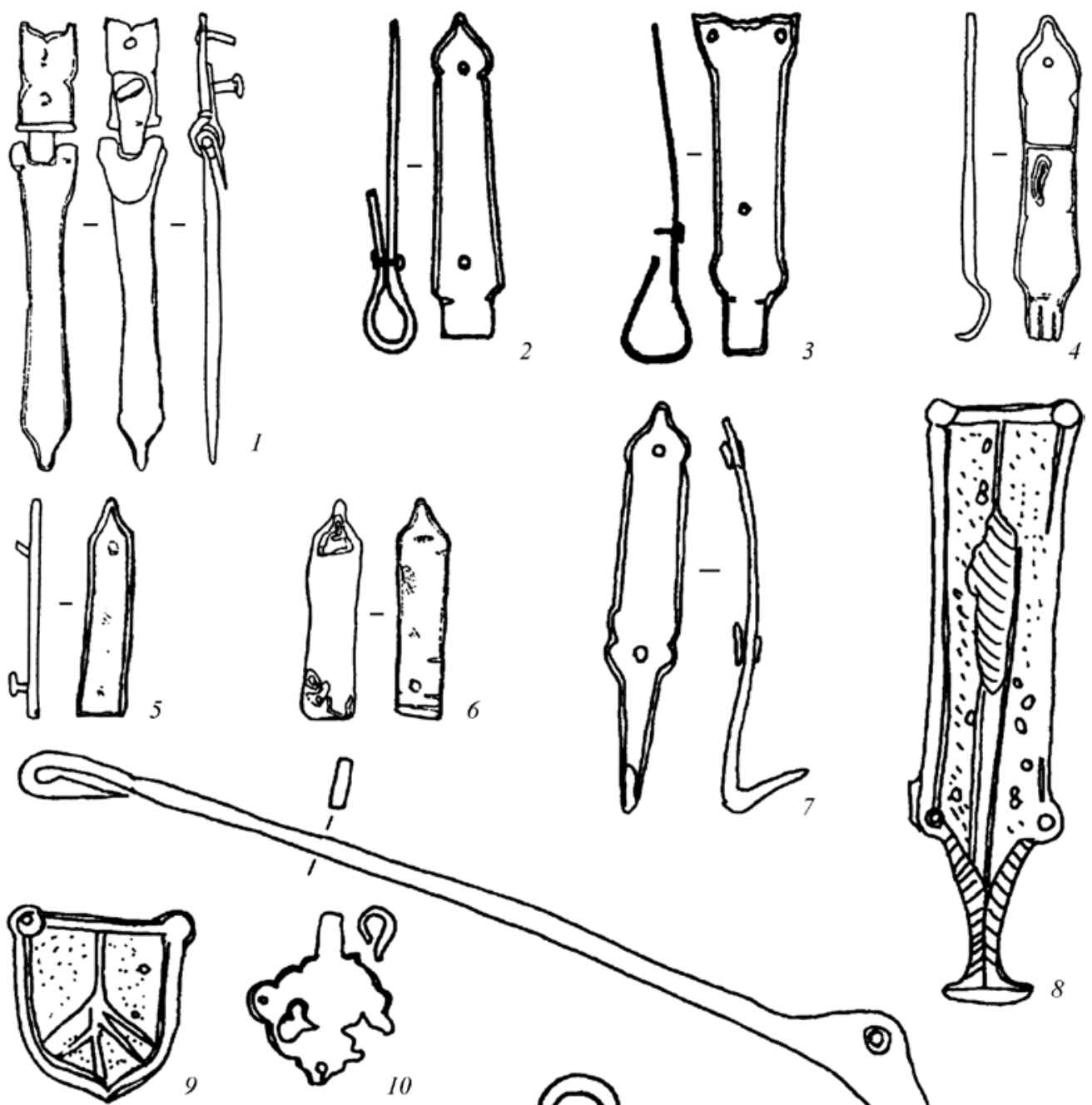

6
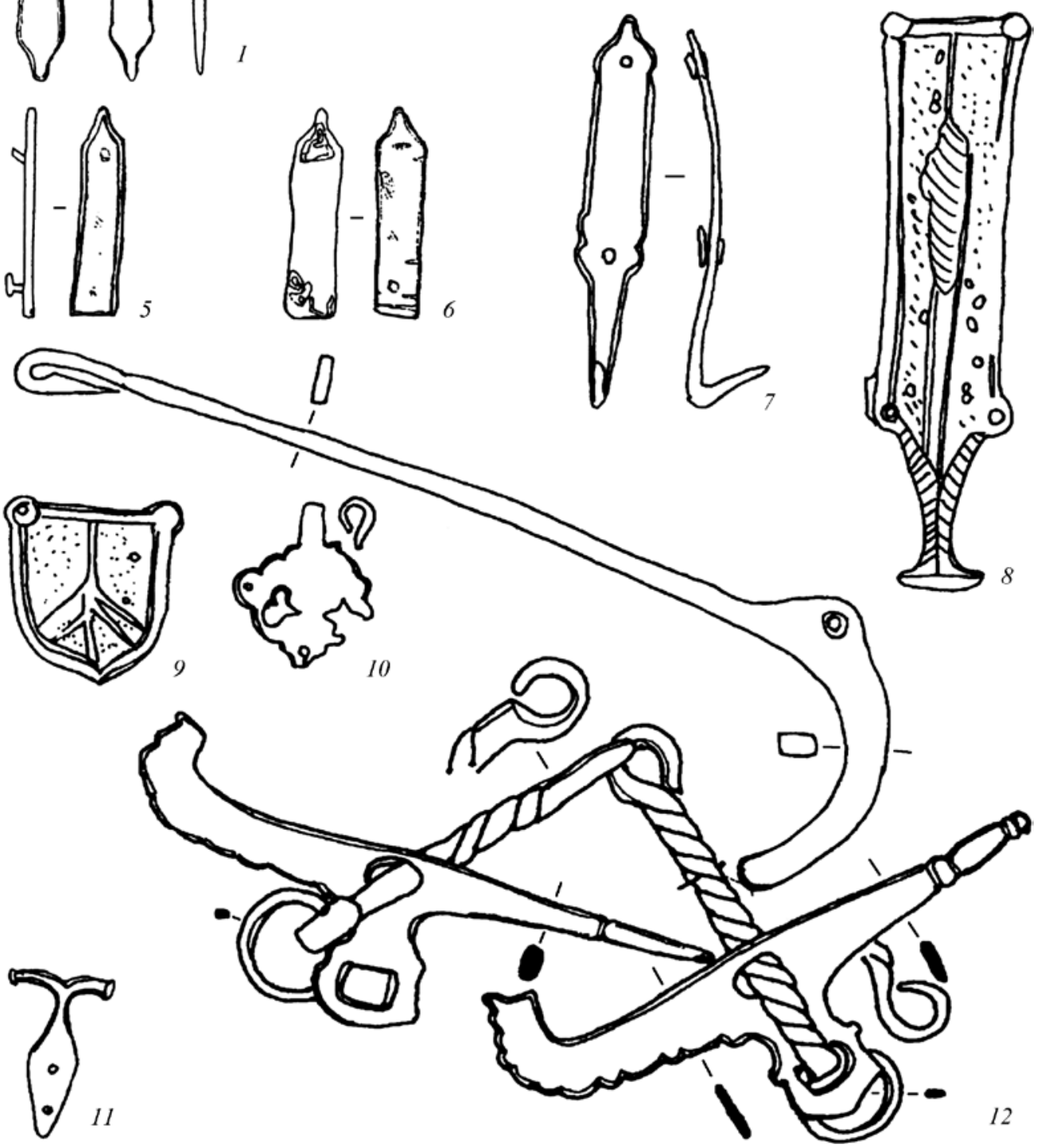

Рис. 1. Образцы аскизских изделий XI-XII вв., найденных в Волго-Камье (по: Руденко, 2001)

событийная широта, присущая произведениям манихейской житийной литературы, также подвигла средневековых хакасов к дальним странствиям.

Не приходится сомневаться, что в перечень привозимого в Европу надо включить пушнину, a также продукцию металлообработки. Архео- логически доказан, например, не только завоз сбруйно-портупейной гарнитуры, но и стремян (Кызласов И.Л., 2007. С. 64), вероятно, и клинкового оружия. Представить в общих чертах товары, которые средневековые хакасы доставляли на запад, все же можно, куда как сложнее понять, ради 

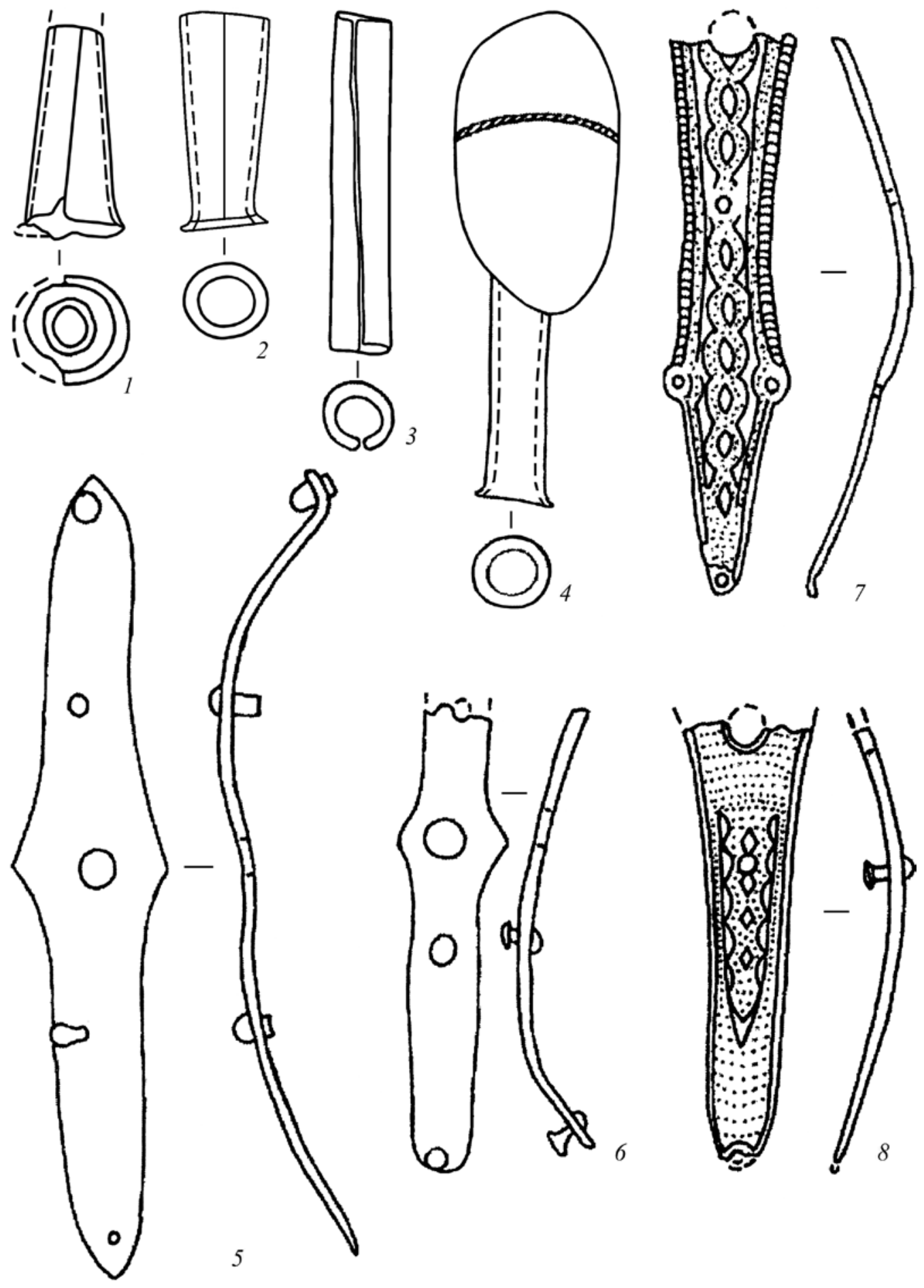

Рис. 2. Уздечные наносные султаны аскизской культуры, найденные на Золотарёвском селище (по: Белорыбкин, 2000) 1-4 - султанные трубки; 5-8- пластины для крепления трубок. 1-3, 5, 6-железо; 4- бронза с позолотой; 7-8 - железо с золотой аппликацией

чего они туда ездили. Что за Уралом было такого, чего недоставало в Южной Сибири? С какой целью преодолевалась по суше дорога в несколько тысяч километров? На эти вопросы ответа нет. Перечень пунктов Восточной Европы, отмеченных находками художественной металлической, поливной и стеклянной посуды Востока X-XIII вв. (Даркевич, 1976. Табл. 53, 54), что на Днепровском, что на Волжском пути на север, что на дороге, связавшей Болгар и Киев, во многом и, разумеется, 

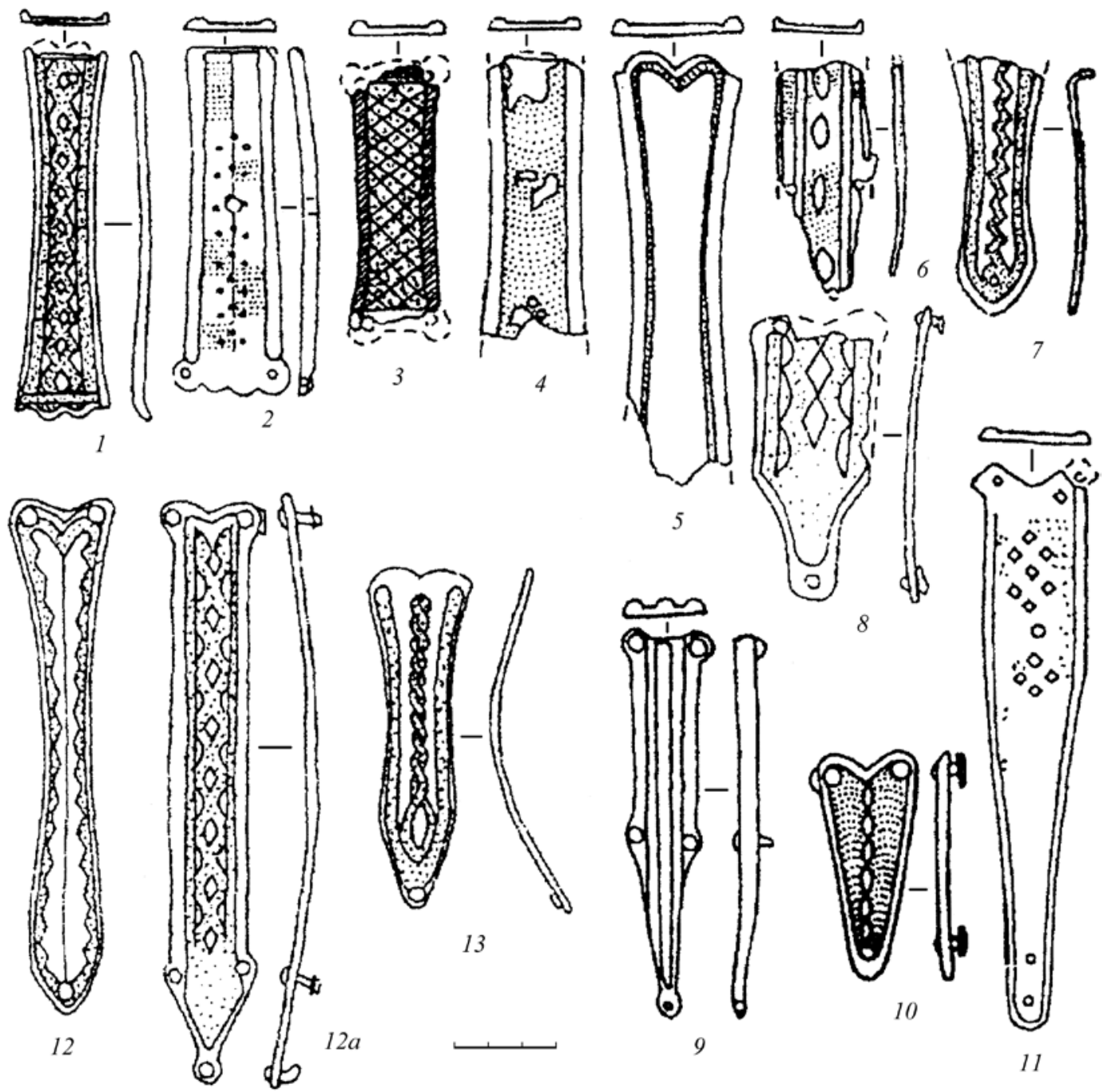

Рис. 3. Наременные накладки аскизской культуры, найденные на Золотарёвском селище (по: Руденко, 2001)

9 - железо, остальное - железо с золотой аппликацией

не случайно совпадает с городами и поселениями, в которых найдены древнехакасские предметы XI - начала XIII в. (Болгар, Биляр, Новгород, Смоленск, Новогрудок и т.д.). Однако, ограничиваясь международной торговлей, поднятая проблема все же не затрагивает целиком такое историческое явление, как аскизский феномен.

Между тем археология свидетельствует: изменяясь, облик аскизских изделий в Европе последова- тельно отражал поэтапное развитие культуры в самой саяно-алтайской метрополии ${ }^{2}$ (рис. 1-3). Выходит, около двух веков прямые экспедиции из Сибири приходили беспрестанно. Более того, в Среднем Поволжье и в Прикамье в то время постоянно существовали сибирские торгово-ремесленные фактории ${ }^{3}$, породившие устойчивый спрос на изделия средневековых хакасов. Мастерами Волжской Булгарии из первых рук была получена и освоена

\footnotetext{
2 При обновлении систематики инвентаря найденные в Восточной Европе предметы не составят локального варианта, они прямо войдут в общую типологию изделий аскизской культуры. Речь не идет о подражаниях и выросших на их почве местных формах.

3 Археологические памятники побережья Среднего Иртыша, Верхней и Средней Оби позволяют полагать, что торгово-ремесленные фактории существовали в международной деятельности средневековых хакасов еще на стадии тюхтятской культуры в IX-Х вв. (Кызласов Л. Р., 1981б. С. 54, 143, рис. 32; 1984б. С. 111, 112; 1987. С. 79, 80). Крупные и долговременные поселения существовали на Среднем Чулыме на малиновском и каменском этапах аскизской культуры, оставив могильники из большого числа курганов (Беликова, 1996).
} 
пришлая передовая технология художественной обработки железа, возникло массовое изготовление подражаний южносибирским образцам (Руденко, 2007a; 2008б. С. 248; 2014. С. 547 и библиография). Таковы были последствия прямого и долговременного контакта на месте с носителями ремесленных традиций Древнехакасского государства.

Ныне появляется возможность объяснить пребывание древних хакасов в Восточной Европе не только их торгово-ремесленной деятельностью, но и присущим им привилегированным общественным статусом.

Сначала свидетельства проживания древних хакасов были обнаружены на булгарском Лаишевское селище (Чакме) - ремесленном, прежде всего кузнечно-металлургическом поселении, с XI в. испытавшем сильное воздействие аскизской производственной традиции (Руденко, 2007б. С. 15, 24, $25,46,47$, прим. 234, рис. 2, II). Усадьбы сибирских пришельцев выделялись по размещению в культурном слое железной воинской и всаднической гарнитуры, составлявшей явные наборы, хотя и оформленные в характерном аскизском стиле, но в каждом отдельном случае объединенные своим узором ${ }^{4}$.

Затем то же явление для более позднего времени было прослежено на древнерусском поселении близ д. Усолье в районе Куликова поля. Аскизские накладки и наконечники сбруйных ремней, крытые как серебряной, так и золотой аппликацией, вероятно, относились к одной усадьбе, так как были «обнаружены недалеко друг от друга на участке площадью около 2 га» (Гоняный, 2005. С. 90). Благодаря разработанной М.И. Гоняным строгой методике планшетной металлодетекторной съемки средневековых поселений на Верхнем Дону стало понятно, что даже те единичные аскизские предметы, которые найдены во многих крупных городах Руси (Кьззласов И.Л., 1997; 2001; Кызласов И. Л., Гайдуков, 2006), недостаточно расценивать лишь как свидетельства периодических наездов древних хакасов.

На значительной площади в центральной части селища Устье 3, которое автор работ считает посадом летописного Дубка, встречено необычно много аскизских, булгарских, половецких и иных степных древностей второй четверти XIII - конца XIV в. Всаднический воинский контингент появляется здесь еще в конце XII - первой половине XIII в., что М.И. Гоняный объясняет откатом на Русь населения при первой волне монгольского нашествия, увязывая концентрацию его на поселении с существованием там древнерусского наместничества (выявлены остатки усадьбы, церкви, прилегающего грунтового могильника) $)^{5}$.

Исследователь считает, что разноплеменные воины-всадники, включая военно-административную знать - носителей аскизской культуры (Гоняный, 2007. С. 91), находились здесь на русской службе, в дальнейшем оставшись в той же роли у местной ордынской администрации. Историко-археологические факты, как известно, подтверждают существование с конца XI в. на пограничье Руси подобных неоднородных по этническому составу, но спаянных общей службой степных воинских объединений. Достаточно назвать черных клобуков, собравших в XII в. в Поросье в одно целое вассальных киевским князьям представителей торков, печенегов, берендеев и других тюркских народов того времени. Разумеется, в отношения почетной зависимости вступала крупная знать, приводя под знамена нового сюзерена подвластные ей воинские отряды.

Богато украшенные серебром и золотом аскизские сбруйные наборы, найденные археологами Восточной Европы только на селищах и городищах, свидетельствуют, что среди приходивших туда сибиряков была древнехакасская аристократия. Подолгу проживая на землях Волжской Булгарии и Руси, обычно в центральных, плотно заселенных районах и в крупных городах (Руденко, 2011. С. 156), она по законам эпохи сознательно вливалась в местную политическую структуру, на протяжении нескольких поколений вступая в связь с тамошними властителями и, сохраняя свой рыцарский статус и достоинство, была обязана им воинской службой ${ }^{6}$.

Археологические материалы показывают явное сословное единство, существовавшее в Поволжье: собственно аскизские изделия соседствуют

${ }^{4}$ Благодарю К. А. Руденко, рассказавшего мне об этом.

5 Опираюсь на доклад М.И. Гоняного «Археологические свидетельства ордынского военно-административного присутствия на посаде древнерусского городка Дубок в верховьях Дона во второй четверти XIII - конце XIV в.», прочитанный в ИА РАН 23.03.2018 на XV Ежегодной московской конференции «Восточные древности в истории России. Эпоха средневековья и ее археологическое окружение».

6 У древнехакасской знати был собственный предшествующий опыт расселения и использования в своих владениях воинских групп иноплеменных союзников. После гибели II Восточнотюркского каганата (745 г.) таковыми во второй половине VIII, в IX и X вв. стали, например, отступившие на север из Тувы, Монголии и Алтая тюрки, пришедшие в Хакасско-Минусинскую котловину с семьями и оставившие там свои могильники (Кызласов Л. Р., 1981а. С. 51, 100, рис. 28, Ж, 68-79; 1981б. С. 57, 58, 101, рис. 33, Г, 33, справа; 1984а. С. 137). 
на одних памятниках и даже в одних комплексах с булгарскими их подражаниями. Зная закономерности средневекового вассалитета, распространявшиеся в Европе на степных всадников, будь то черные клобуки на Руси или половцы (куны/куманы) в Венгрии, следует думать, что и привлекаемую к воинской службе древнехакасскую аристократию местные правители осознанно поселяли в своих владениях, предоставляя ей определенные земли ${ }^{7}$. Быть может, стоит обратить особое внимание на то, что в Прикамье (Лаишевское селище и др.), на Суре (Золотаревское городище) и на Верхнем Дону (селище Устье 3) скопление аскизских находок обнаружено в поселениях, не только стоявших на значимых торговых путях, но и располагавшихся близ значимых в то время речных переправ.

Ныне важно понять, что носители аскизской культуры не были в Восточной Европе только пришельцами, на каждом этапе своего прибытия они становились переселенцами. Последующее археологическое изучение вопроса, надо надеяться, очертит на Русской равнине места, а то и зоны сибирского расселения.

Воинское предназначение проживавшего там древнехакасского контингента отчетливо проступает в составе археологических находок не только на селище Устье 3, но и на иных памятниках. Так, на Золотаревском комплексе, сочетавшем городище и три прилегавших поселения, погибшем в результате крупного сражения, археологи собрали более 1000 наконечников стрел, характерных для аскизской культуры. На Мурзихинском селище не было обнаружено следов нападения, но подъемный и раскопочный материал дал 92 наконечника стрел. Исследователи отмечают пик в изменении ассортимента наконечников стрел в Волжской Булгарии, пришедшийся на начало XI в. и вызванный массовым появлением аскизских форм (Руденко, 2003а. С. 142, 143).

Благодаря изложенному пониманию археологических данных аскизские находки могут получить новое объяснение.

Обосновавшиеся в Восточной Европе южносибирские федераты местных волжскобулгарских владык во второй половине XII в., вероятно, участвовали в их походах и нападениях на подвластные поселения - таких, как погибшее в пожаре Сосновское II городище (Руденко, 2005, С. 122, 123,125 , рис. 9, 1-10), Лаишевское селище (Чакма) со сгоревшими постройками (Руденко, 2003a.
С. 41) в Татарстане. Но те же воинские отряды участвовали и в обороне входивших в Волжскую Булгарию крепостей и поселений в годы монгольского нашествия - таких, как Золотаревский комплекс на Суре. Вероятно, подобную роль играли древнехакасские всадники и на Руси. Вопрос этот малоисследован, но необходимо сказать, что при раскопках летописного Снепорода (городища Мацковцы), одной из южнорусских крепостей черных клобуков, обнаружены железные части узды аскизской археологической культуры (Моргунов, 1996. С. 98 , 99, рис. 31 , 1; 2009. С. 180; 2010. С. 70; Кызласов И.Л., 1997. С. 383, рис. 1, 6, 2, 3, 4).

Не только высокое искусство художественной обработки металла, но и породивший это мастерство и отразившийся в нем запрос аристократической всаднической культуры, тот изначальный высокий социальный статус, который имели ставшие в Восточной Европе своими сибирские воины-профессионалы, привели к заимствованию присущего им ратного убора, аскизского стиля амуниции. Лишь облачение социальных верхов всегда влияло на изменение костюма широких кругов людей, вызывая подражание. Всюду витязи и их дружины принадлежали к привилегированной части общества. В условиях формирования государственной материальной культуры Волжской Булгарии, в социально значимых сферах вытеснявшей самобытные формы разноязыких культур страны, особо значимыми оказались пришлые проявления аристократизма, изначально лишенные местных связей (Руденко, 2011. С. 160). Стремление войти во властное, привилегированное сословие отражают, вероятно, некоторые памятники разноплеменного населения Волжской Булгарии.

Таково, например, мужское погребение 60 Мордовско-Паркинского могильника, среди прочего сопровождаемое и несвойственным для средневековой мордвы воинским инвентарем: палашом южносибирского типа, включая особенности подвески ножен, аскизско-булгарскими железными бляшками, пряжкой пояса и серебряными кольчатыми серьгами, распространенными на Саяно-Алтае (Гришаков, 1992. С. 108, 109, рис. IV). Можно думать, что это воин булгарского отряда, снаряженного в аскизском стиле. Древнехакасские клинки, части их перекрестий и ножен, характерные южносибирские козырьковые ножи («уникальные ножи с продольным желобком, прорубленном вдоль верхней кромки»)

\footnotetext{
7 Закономерностям расселения степных федератов на Руси и специфике возводимых ими укреплений посвящены вышедшие в последние годы труды Ю. Ю. Моргунова (2009. С. 163-198; 2010), обобщающие многолетние исследования.
} 
(ср.: Кызласов И.Л., 1983. С. 39, табл. XVIII, 9, 13, 16) и оригинальные части или булгарские дериваты железной поясной и портупейной гарнитуры встречены и на мордовском могильнике Татарская Лака II (Винничек, Губанов, 2003. С. 242, 243, 344, 347 , рис. 1, 42-49, 2, 24-28, 3, 19-21).

Итак, пребывание древних хакасов не было в Восточной Европе отражением одних лишь торгово-посольских контактов и отношений. Сибирские князья, их дружины и ремесленники вошли в социально-политическую жизнь Волжской Булгарии, Руси, сопредельного населения и долгие десятилетия активно воздействовали на нее. Нет сомнения, что получаемые социальные привилегии, иные благоприятные для жизни условия оказались настолько значимыми для военной аристократии СаяноАлтая, что длительность пути от Енисея до Волги, а затем и до Немана не являлась для нее препятствием. Не позднее XI в. в лесостепной части Евразии сложились прочные, на протяжении шести-семи поколений не прекращавшиеся связи древнехакасской воинской знати и владык Волжской Булгарии и Руси. Эти прямые контакты прервало лишь монгольское нашествие. Не случайно местное производство изделий характерного вида, с XI в. порождаемое воздействием аскизской всаднической гарнитуры и древнехакасской технологии металлообработки, просуществовало в Волго-Камье только до конца ХІІ в. (Руденко, 2011. С. 159, 160).

Осознание этих позиций, выявленных анализом археологических данных и ставших в нашей науке крупным открытием последних десятилетий, способно изменить имеющиеся научные представления не только о Древнехакасском государстве, но и о действительном уровне общественной жизни Волжской Булгарии (прежде всего), Руси и Восточной Европы в целом. Степень экономического, социального и политического развития всех этих стран раннего средневековья, бывших, как и любое иное государство, многоплеменными, оказывается более высокой.

Предстоит отыскать загадочную ныне причину, вызывавшую с начала XI и до начала XIII в. движение южносибирской военно-родовой знати, ее дружин, ремесленников и купцов на запад. Огромная, экономически мощная сибирская страна в те времена пребывала в расцвете и не испытывала ни удельной тесноты, ни внешнего давления. Движение каев и кунов, вытеснившее в Европу кыпчаков-половцев, прошло стороной. С возникшей в начале $\mathrm{X}$ и существовавшей в Центральной Азии по первую четверть XII в. киданьской империей Ляо у древних хакасов сложились мирные отношения (Кызласов Л.Р., 1969. С. 96, 120, 127; 1984а. С. 76-78; ср.: Кызласов И. Л., 2007. С. 65, 69, прим. 28). Движущие мотивы, связавшие саяно-алтайское общество с восточноевропейскими державами, должны были иметь иную природу.

Она заключена в широкой известности Древнехакасского государства в тогдашнем мире, сделавшей древний династийный род страны, кыргызов, символом степной аристократии (см.: Кызласов И.Л., 2010. С. 158-161; 2018). В той громкой славе, которую создала для первично лишь енисейской, а затем уже огромной, общей для всей Южной Сибири державы одержанная ею победа в 20-летней войне, сокрушившей в 840 г. могучий Уйгурский каганат.

Именно в IX-X вв. появляются первые археологические свидетельства знакомства Европы со средневековыми хакасами и их аристократическими всадническими атрибутами - сбруйные серебряные и бронзовые бляхи тюхтятской культуры обнаружены на Днепре (рис. 4) и в низовьях Дона ${ }^{8}$ (рис. 5) ${ }^{9}$, а подвески смешанного скандинаво-сибирского облика - на Северо-Западе (Михайлов,

\footnotetext{
${ }^{8}$ К сожалению, при издании находок, сделанных близ Таганрогского залива, рассмотрение их как изолированных категорий декорированных предметов и абсолютизация морфологического подхода к материалу привели к отказу от восприятия археологических культур, к которым эти вещи принадлежат (Король, Конькова, 2004; 2007; Король, 2008. С. 164, рис. 39). (Иной подход, проявленный при сложном сопоставлении, см.: Михайлов, 1997.) Лишь конвейерное производство создает стереотипную продукцию. Традиционная русская вышивка, неповторимая в каждом образце, при цветовой и орнаментально-композиционной близости не растворяет себя ни в финно-угорском, ни в индоевропейском субстрате. Стилевое и техническое сходство не уводит художественные металлические изделия средневековья в безбрежье окружавшего мира, основательное рассмотрение детальных признаков не отдельно взятых категорий, а совокупности предметов ремесленного искусства, включая разные его виды, объединяет их во вполне конкретные группы, свойственные определенным археологическим культурам. В торевтике примером такого исследования служат классические работы Б. И. Маршака (1971, и др.).

9 Расположение этих находок может указывать на попытку средневековых хакасов воспользоваться южным торговым путем, по данным IX в. связывавшим Испанию и Францию с Китаем через Хазарию и Среднюю Азию (Ибн Хордадбех, 1986. С. 124 (§ 73 г); Заходер, 1967. С. 85; Велиханова, 1986. С. 42; см.: Кызласов Л. Р., 1984а. С. 116, 117; 1984б. С. 111; 1987. С. 79). Предположение нуждается в специальном внимании археологов. На карте «основных торговых путей, соединяющих Южную Сибирь со странами всех сторон света» (Кызласов Л. Р., 1987. С. 80), дорога в Восточную Европу помечена цифрой 2 и, согласно археологическим данным, намечена севернее Средней Азии.
} 


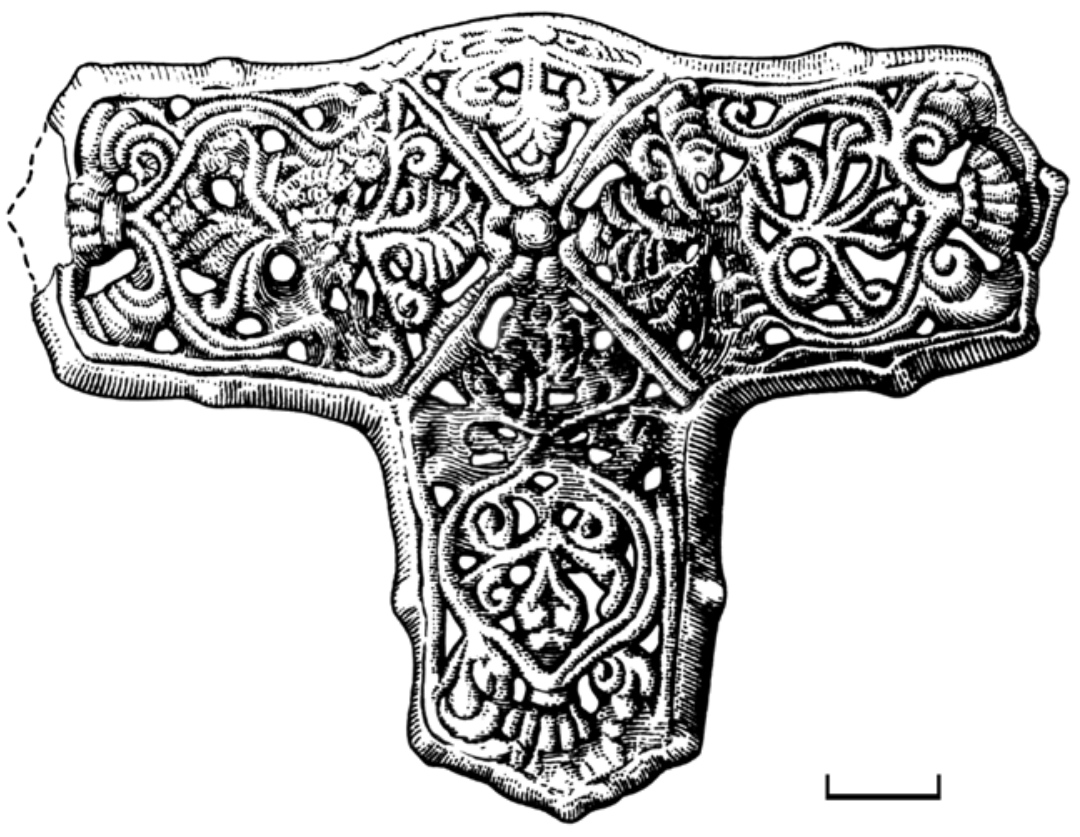

Рис. 4. Серебряная бляха конской сбруи. Тюхтятская культура, IX-X вв. Найдена в Чигирском уезде Киевской губ. Коллекция Б. Н. и В.Н. Ханенко (по: Кызласов Л. Р., Король, 1990)
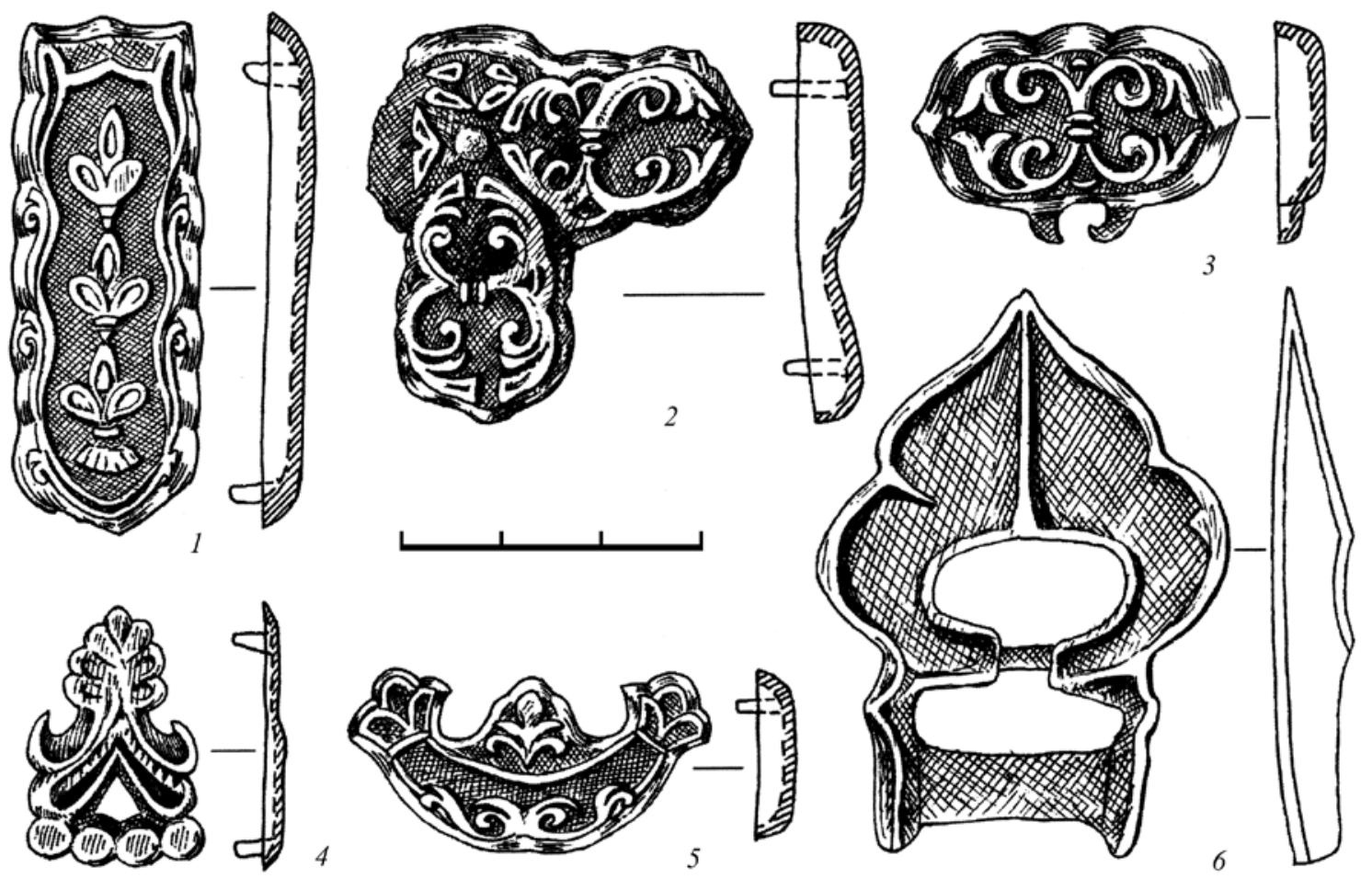

Рис. 5. Бронзовые изделия тюхтятской $(1-3$ и, возможно, 4$)$ и сросткинской $(5,6)$ культур, IX-X вв. Случайно найдены в Донской губернии меж Таганрогом и Ростовом. Коллекция Г.Д. Филимонова и И.Д. Беляева (по: Король, 2008) 
1997). Одновременно характерные позолоченные украшения достигают тунгусского по языку населения Приамурья и Приморья, а в Северном Китае железные изделия Древнехакасского государства вызывают подражания в художественной металлообработке империи Ляо (Кьзласов, Король, 1990. С. 172-174, рис. 64, 65; Кьзласов И. Л., 2007. С. 63, 65. 67, прим. 4-6, 69, прим. 28).

Тогда же была нарушена и древняя дальневосточная монополия на письменные свидетельства о южносибирской земле и ее народах. С этого времени они привлекли пристальное внимание западноазиатской и западноевропейской мусульманской - арабской и персидской - географической литературы. О древнехакасском династийном роде кыргыз (хирхиз, хырхыз), называя по его имени страну и народ, пишет уже Ибн Мукаффа (VIII в., Басра) и Ибн Хордадбех (IX в., Багдад), a c X в., когда жанр переживает пору своего расцвета, число ученых авторов возрастает многократно. В их трудах содержится множество важных для историков сведений (Кьзласов Л.Р., 1984а), из числа которых изберем здесь лишь особо показательные для нашего исследования примеры.

Таково описание Волги (Ра, Атил, Исил, Итил и пр.; Коновалова, 2006. С. 308-310, 316). АлИстахри, Ибн Хаукаль (оба сочинения - середина Х в.), неизвестный автор «Худуд ал-Алам» (982 г.), вслед за ними и более поздние авторы (Заходер, 1967. С. 164) считали верхним течением этой реки Каму и утверждали, что Волга «берет начало близ (земли) хырхызов» или «вытекает от границы хырхызов» ${ }^{10}$, и ее приток Рас (?), «вытекает из области Хирхиз» (Minorsky, 1970. Р. 75, note 41, 283) ${ }^{11}$, вероятно, принимая за таковой р. Урал (Кызласов Л. Р., 1984a. С. 118 и библиография). Вряд ли арабоперсидские географы искали истоки Волги далеко на востоке потому, что путали их с верховьями Иртыша (Коновалова, 2000. С. 130; 2006. С. 145). Поскольку древнехакасские караваны, постоянно прибывавшие в Поволжье, перевалив Урал, спускались туда по Каме, а затем сибиряки и обжива- лись на ее берегах, у посторонних наблюдателей могло сложиться впечатление о начале этой реки в пределах Древнехакасской державы (Кызласов И. Л., 2007. С. 64).

Характерны два других примера известности и далеко идущей славы южносибирской страны в мусульманском мире домонгольского времени. В 1154 г. араб ал-Идриси написал свой географический трактат в Палермо. Он не бывал восточнее Сицилии, но в его описаниях и на картах мира есть страна Хирхиз на Енисее и стоявшие там города. Великий персоязычный азербайджанский поэт Низами, родившийся и живший в Гяндже, между 1198 и 1203 гг. завершил «Искандер-намэ». Неожиданным в «Книге об Александре» был не традиционный для Востока легендарный сюжет о подвигах и странствиях Искандера (прообразом которого был Александр Македонский) и даже не выдающаяся художественная сила произведения, а воспевание в ней «страны Хирхиз»-идеально устроенного мира, к которому стремился и который обрел на далеком севере герой поэмы (Кьзласов Л. Р., 1968).

Недаром в середине ХІ в. перс Гардизи не только описал три дороги, что ведут в «лагерь киргизского хакана» с востока, запада и юга, но также, хотя и в форме легенды, зато с полным перечнем проезжаемых стран, указал путь от славян до Енисея, связывая происхождение правившего там рода кыргыз с бежавшим славянским вельможей (Бартольд, 1973. С. 46, 47; Кьзласов Л. Р., 1984а. С. 119,$120 ; 19846$. С. 114,$115 ; 1987$. C. 82,83 ; Kbl3ласов И. Л., 2007. С. 63) ${ }^{12}$.

С официальным принятием ислама в первой четверти Х в. в города Волжской Булгарии вошла арабская и персидская наука, принеся накопленные ею обширные географические познания. Они пополнили многими книжными и новыми устными свидетельствами уже имевшиеся у булгар и их соседей сведения о Древнехакасском государстве и славе его правящего рода кыргыз, возбуждали интерес к ним. Не случайно аскизские древности появляются

10 Согласно второй версии, уживавшейся с первой, верховья Атила определялись ближе к современным представлениям, и река именовалась ар-Рус, то есть Река русов, хотя иногда в источниках она выглядела притоком Волги (Кызласов Л. Р., 1984a. С. 118; Коновалова, 2006. С. 137-139; ср.: С. 145, 244). Полагают также, что Ибн Хаукаль ошибся и Рекой русов арабские географы называли Дон (Большаков, 2006. С. 745, прим. 452).

11 Перевод О.Г. Большакова (2006. С. 749), считающего, что речь идет о Каме и Белой: «А у реки Итиль с восточной стороны есть ветвь, которая вытекает из области хирхизов...»

12 Широкий анализ исторической ситуации, отраженной в письменных и археологических памятниках, привел Л.Р. Кызласова (1984а. С. 120, прим. 59; 19846. С. 115; 1987. С. 83) к следующему допущению: «Весьма вероятно, что именно к IX-X вв. относится проникновение в землю Башджурт тех родоплеменных групп, которые сохранились в составе современных башкир: кахас и киргиз (из состава древних хакасов; ун (унгар) и сарыглар (из древних уйгуров), а также ас (из азов)». 
в Среднем Поволжье и Камском Приуралье с XI в., закономерно и то, что в Волжской Булгарии концентрируются основные древнехакасские изделия домонгольского времени, находимые на Русской равнине. Именно в эту страну Восточной Европы стремились посланцы Южной Сибири. Именно там особо высоко ценилась саяно-алтайская всадническая аристократия, облику которой старалась подражать местная воинская знать.

Уяснив эти позиции, сформированные на археологических и исторических источниках, остается заключить: державная власть Волжской Булгарии сама приглашала в свои владения прославленную княжескую верхушку и конные отряды Древнехакасского государства, беря их на ратную службу и окружая почетом ${ }^{13}$. В этих условиях произошло дальнейшее распространение на запад высокородных сибирских всадников - аскизский инвентарь в домонгольской Руси (в Новгороде, Смоленске, Новогрудке и др.) в основном принадлежит к XII - первой трети XIII в. ${ }^{14}$

Проведенные разыскания показали, что носители аскизской культуры за 200 лет до монголов и за 500 лет до Ермака Тимофеевича принесли с собой на Русскую равнину знания о Сибири, особенностях ее политической и культурной жизни, сведения о трассах Великого Сибирского пути и практические навыки продвижения по нему.

Широтная, проторенная по суше в лесостепи дорога, открывавшая странам Европы огромное международное пространство на Востоке, дополнила традиционные меридиональные водные трассы. Движение на ней быстро стало двухсторонним. Уже 35 лет назад находки дорогих западноевропейских изделий домонгольского времени, сделанные не в таежной, а в лесостепной Западной Сибири, были объяснены деятельностью Великого Сибирского пути в специальных изданиях, адресованных как в целом всесоюзным исследователям и университетским аудиториям, так и отдельно сибирским и среднеазиатским ученым (Кызласов Л. Р., 1984а. С. 120,$121 ; 19846$. С. $115 ; 1987$. С. 83$)$.

Таковы находки известного со времен Г.Ф. Миллера (1937. Рис. 19, 20; 2005. Рис. 19, 20), ныне хранимого в Государственном Эрмитаже бронзового водолея, отлитого в Лотарингии в начале ХІІІ в. (Кызласов Л.Р., 1984б. С. 115; 1987. С. 83) и изображавшего схватку дракона и драконоборца ${ }^{15}$, точное место обнаружения этого изделия осталось неизвестным (рис. 6; 7), а также обнаруженного как случайная находка в 1975 г. на памятнике Преображенка III в Барабинской степи, в 270 км к восток-северо-востоку от Омска, западноевропейского меча (Молодин, 1976) с трехчастным навершием (рис. 8, 1, 2), украшенного позолоченной серебряной насечкой и изготовленного, согласно палеографии латинской надписи на клинке (рис. 8, 3), в конце XII - начале XIII в. (Дрбоглав, Кирпичников, 1981), точнее, в «последние годы XII в. <..> [-] первую четверть XIII в.» (Дрбоглав, 1984. С. 64-66, VI-5, 123, табл. VI, 5B, табл. XIII, 6. VI гр.). Оружиеведы полагают, что выкованный на Рейне клинок, характер орнаментики и клейм которого восходит к XI в., мог получить рукоять в Швеции (включая о. Готланд) (Дрбоглав, Кирпичников, 1981; Дрбоглав, 1987. С. 62).

Оба обсуждаемых памятника, получив верную датировку и широкое историко-культурное объяснение, вошли в обобщающие работы (меч-Moгильников, 1987a. С. 215, 245, табл. XСII, 25, карта 41, 1; водолей и меч - Кызласов Л.Р., $1984 \mathrm{a}$. С. 120, 121; 1993. С. 88; Кызласов И.Л., 2007.

13 Представления о военной службе как о единственном достойном аристократа деле сохранялись на Енисее все средневековье. В начале XVII в. хакасские князья не раз выражали готовность принять подданство Белого царя, привести под его высокую руку своих подданных и присоединить свои земли, если бы «государь... пожаловал, велел бы нам свою государеву службу служить». Московская администрация, не понимая природу династийного рода тюркских народов, дававшую многовековую устойчивость власти и уровень ее сословного самосознания, приравнивала местную знать к прочему населению. В итоге вооруженная борьба велась более столетия (1596-1718 гг.), но сами князья-кыргызы фактически так никогда и не платили ясак (Кьзласов Л. Р., 1996. С. 10, 39-42).

14 Давняя связь аристократической культуры южносибирского общества с древнехакасским династийным родом кыргыз давно показана в исторической литературе. Распространение этого этнонима, ставшего символом степной аристократии от Якутии до Молдавии, было сопоставлено с выходом характерного археологического материала за первоначальные пределы аскизской культуры (Кызласов, 2010. С. 158-161). Обсуждаемые ныне древности Восточной Европы показывают, что аскизский всаднический убор стал в степной и лесостепной Евразии символом воинской аристократии, и позволяют полагать, что этноним кыргыз получил широкое распространение уже в домонгольское время. Эти наблюдения побуждают внимательнее отнестись к приведенному выше (см. прим. 11) предположению Л. Р. Кызласова.

15 На сайте РАН в юбилейном альбоме «Кунсткамера (1714-1836): К 300-летию первого академического музея» (С. 123) воспроизведен оригинал одного из рисунков со следующей подписью: «И.В. Люрсениус. Акваманил в виде схватки дракона и драконоборца. Вид слева: “Рисунок медного идола наподобие змея”. XII-XIII вв. Бумага. Акварель. $45 \times 28$ см. 1735 г. В правом нижнем углу подпись художника: “ad vivum del[ineavit] J. W. Lürsenius” (с натуры зарисовал И. В. Люрсениус). СПФ АРАН. Ф. 21. Оп. 5. Д. 39/51. Л. 1». http://www.ras.ru/kunstkamera/7c5d7948-06bc-4fcd-96cc-7ad0423de5ad.aspx?hidetoc=0. 


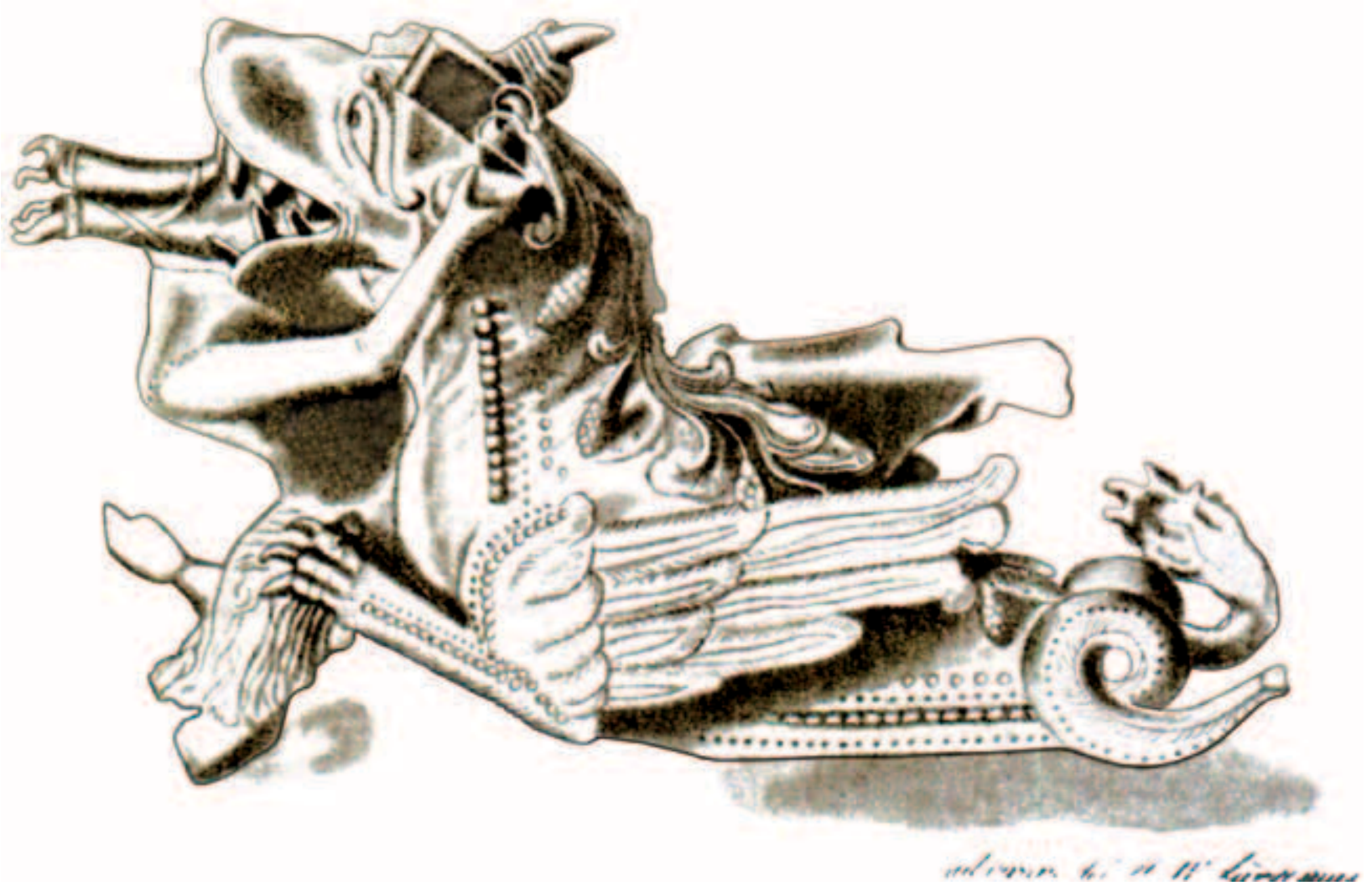

Рис. 6. Вид бронзового водолея. Лотарингия, нач. XIII в. Найден в Сибири.

Рис. И. В. Люрсениуса, Вторая Камчатская экспедиция, 1733-1743 гг. (по Г. Ф. Миллеру)

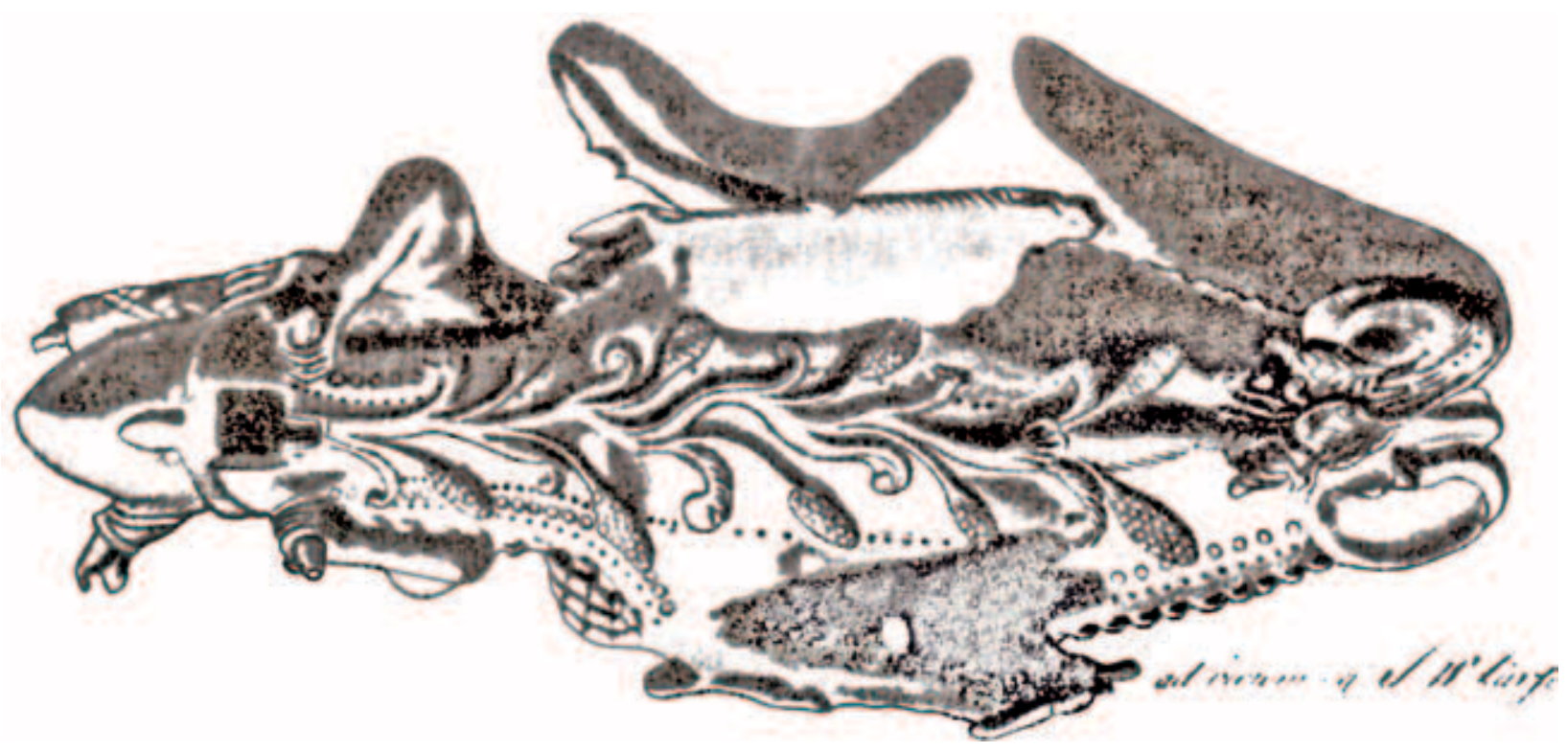

Рис. 7. Иной вид бронзового водолея (по Г.Ф. Миллеру) 

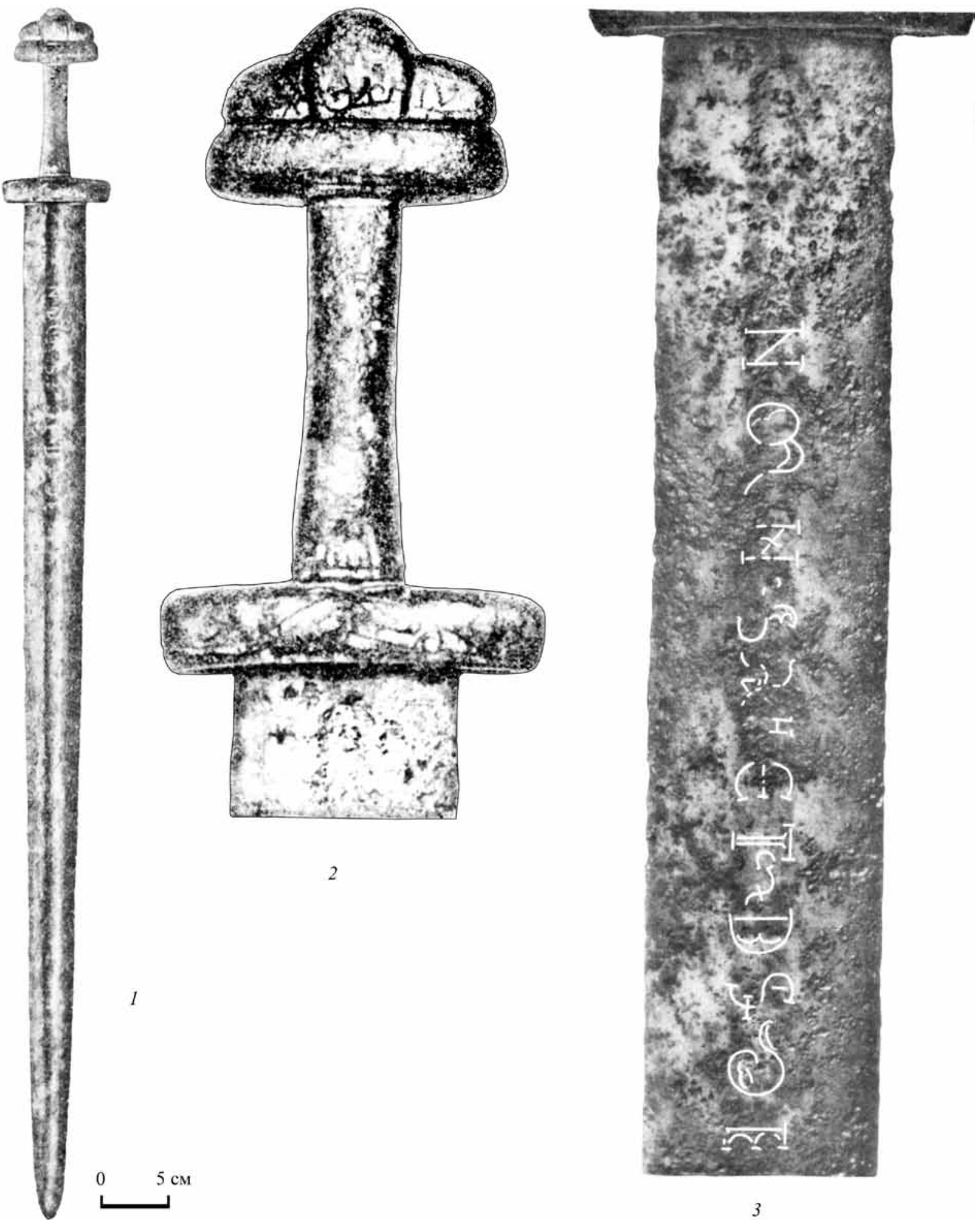

Рис. 8. Западноевропейский меч, кон. XII - нач. XIII в. Сталь, серебряная позолоченная насечка. Найден на р. Омь, Барабинская степь, случайная находка на объекте Преображенка III 1 - общий вид; 2 - орнаментированная рукоять; 3 - латинская надпись, клеймо на клинке (по: Дрбоглав, Кирпичников, 1981) 
C. 65). Разумеется, нельзя точно сказать, как эти уникальные предметы достигли глубин Западной Сибири - при древнерусском посредничестве (Молодин, 1976. С. 127; Дрбоглав, Кирпичников, 1981. С. 532, 533; Могильников, 1987а. С. 215; 1991. С. 80) или при кыпчакском (Зыков, 2011. С. 133, 134) ${ }^{16}$, как думают о преображенском мече ${ }^{17}$. Более нет надобности связывать попадание восточно- и западноевропейских изделий только с известной северной торговлей, приводившей в тайгу Приобья, как и увязывать их появление за Уралом лишь с новгородцами (Дрбоглав, Кирпичников, 1981. С. 532, $533)^{18}$. Важно, что не только обсуждаемые здесь уникумы, но и иные подобные находки обнаружены на трассе лесостепного Великого Сибирского пути. Ныне преображенский меч уже не является единственным экземпляром европейского раннесредневекового клинкового оружия в Азии - другой меч второй половины X-начала XI в. общеевропейского облика, но изготовленный на Руси, случайно найден на Южном Урале у степного с. Бородиновка в 140 км к востоку от Магнитогорска и в 40 км от границ Казахстана (рис. 9, 1). Морфологическая характеристика этого изделия была подкреплена металлографическим анализом (3blков, 2011. С. 131, 132,134. Рис. 1, 1).
Продвижение восточноевропейского населения в Западную Сибирь в раннем средневековье осуществлялось людьми разных языковых групп. В юдинской культуре X-XIII вв. известен комплекс железных изделий финно-угорских родановской и вымской культур (топоры, ножи, кресала), бронзовых и серебряных украшений (бубенчики, браслеты, перстни, серьги), стеклянных и металлических бус древнерусской и волжскобулгарской работы, попавших туда при посредстве прикамского населения, распространившего также свойственные ему наконечники копий, серьги, височные шумящие подвески, пронизки. Много вещей западного происхождения (славянского, приуральского, пермского и волжскобулгарского) содержат памятники и восточнее расположенной усть-ишимской культуры Омского Прииртышья конца IX-XIII вв. (Могильников, 1987а. С. 171-175, 198, 200-202).

Вещевой комплекс всех западных для Сибири культур был собран Владиславом Александровичем не только в известной работе, изданной в 1987 г., но и в значительно пополненном виде в последующей докторской диссертации (Могильников, 1990а. С. 281-324; 1990б. Табл. 40-46, карты 16-18; 1990в. С. 27-33), имевшей специальный раздел «Русско-угорские связи». В приложенных

16 Обнаруживший и издавший меч В.И. Молодин допускал, что тот случайно попал в лесостепь с севера, где проходил путь из Руси в Приобье (Молодин, 1976. С. 127), «в результате обмена (или военного трофея?) между степным тюркоязычным и таежным угорским населением» (Молодин, 2005. С. 112; 2007. С. 72). Объяснение случайных находок - не гадания, как это стремится представить А. В. Жук (2014. С. 43), намеренно доводя вопрос до абсурда: меч-де «мог быть привезенным к новому месту службы романтически настроенным русским офицером XVIII-XIX вв. как “прадедовский” клинок». Александр Владиленович иначе бы расценил уникальную находку, если бы учел давно указанный археологами Великий Сибирский путь, действовавший в раннем средневековье между Азией и Европой. Однако об этом пути часто все еще не знают даже те специалисты, которые специально занимаются степными караванными связями (Таиров, 2013).

17 В 1970-е годы не было известно о существовании в раннем средневековье Великого Сибирского пути, как и связанного с ним аскизского феномена. Однако через много лет, после заключений ряда медиевистов и накопления нового относящегося к проблеме материала, для весьма искушенного археолога-сибиреведа оказалось непросто расстаться с возникшей в те годы романтической идеей о принадлежности меча отряду Ермака (Молодин, 1976. С. 127; 2005. С. 112, 113; 2006; 2007. С. 73). Иллюзорные представления отразились в научно-популярных работах других новосибирских археологов (Соловьев, 2003. С. 193, рис. 33). Красивой легендой остается и величание находки мечом Каролингов. Автору названной так популярной книги (Молодин, 2006) и очерка в ней известно, что каролингская эпоха в Европе окончилась в Х в., последующий период именуют романским, соответственно, «в оружиеведческой литературе мечи XI-XIII вв. получили название романских», об иноземных мечах того времени, к которым и принадлежит преображенский клинок, говорят как «об импорте романского оружия на Русь» и т. п. (Кирпичников, 1966. С. 49, 52, 53, 57; ср.: Дрбоглав, 1984. С. 21, прим. 11). В изданиях, предназначенных для массового читателя, огорчают также допущенные искажения личных имен средневековых и современных ученых: ал-Гарнати, единственный мусульманский автор XII в. побывавший на Руси, стал в тексте ал-Гарани, а специалист по средневековой латыни Донат Александрович Дрбоглав (1924-2005 гг., МГУ), благодаря знаниям которого были расшифрованы надписи на мече, дважды назван Дубоглавом (неверна и приведенная в тексте дата выхода труда Д.А. Дрбоглава и А.Н. Кирпичникова) (Молодин, 2005. С. 111, 112; 2007. С. 72, 73).

${ }^{18}$ Нет необходимости рассматривать археологические подтверждения торговых отношений с таежным севером Западной Сибири в домонгольское время, материалы широко известны. Вероятно, следует обратить внимание лишь на доказательства специальной организации такой торговли со стороны древней Руси. Показателен обломок меча общеевропейского типа конца X-XII в., найденного в 1966 г. в слое юдинской культуры на Туманском укрепленном жилище на Лозьве, текущей с восточного склона Северного Урала (Зылков, 1987. С. 143, 144, рис. 1, 11; 2011. Рис. 1, 2; Могильников, 1990а. С. 331; 1990б. Табл. 44, 5; 1990в. С. 30, 31; 1991. С. 80, рис. 7, 2). Этот внешне безупречный клинок оказался непригодным для боя, поскольку был сделан из чистого железа низкого качества (потому и найден лишь его обломок - рис. 5,2 ) и оказался третьим подобным мечем древнерусской работы. Кому попадали эти изготовленные ради продажи клинки, не имело значения: два других найдены в Гнёздове и на Северском Донце (Зыков, 2011. С. 135-140). 


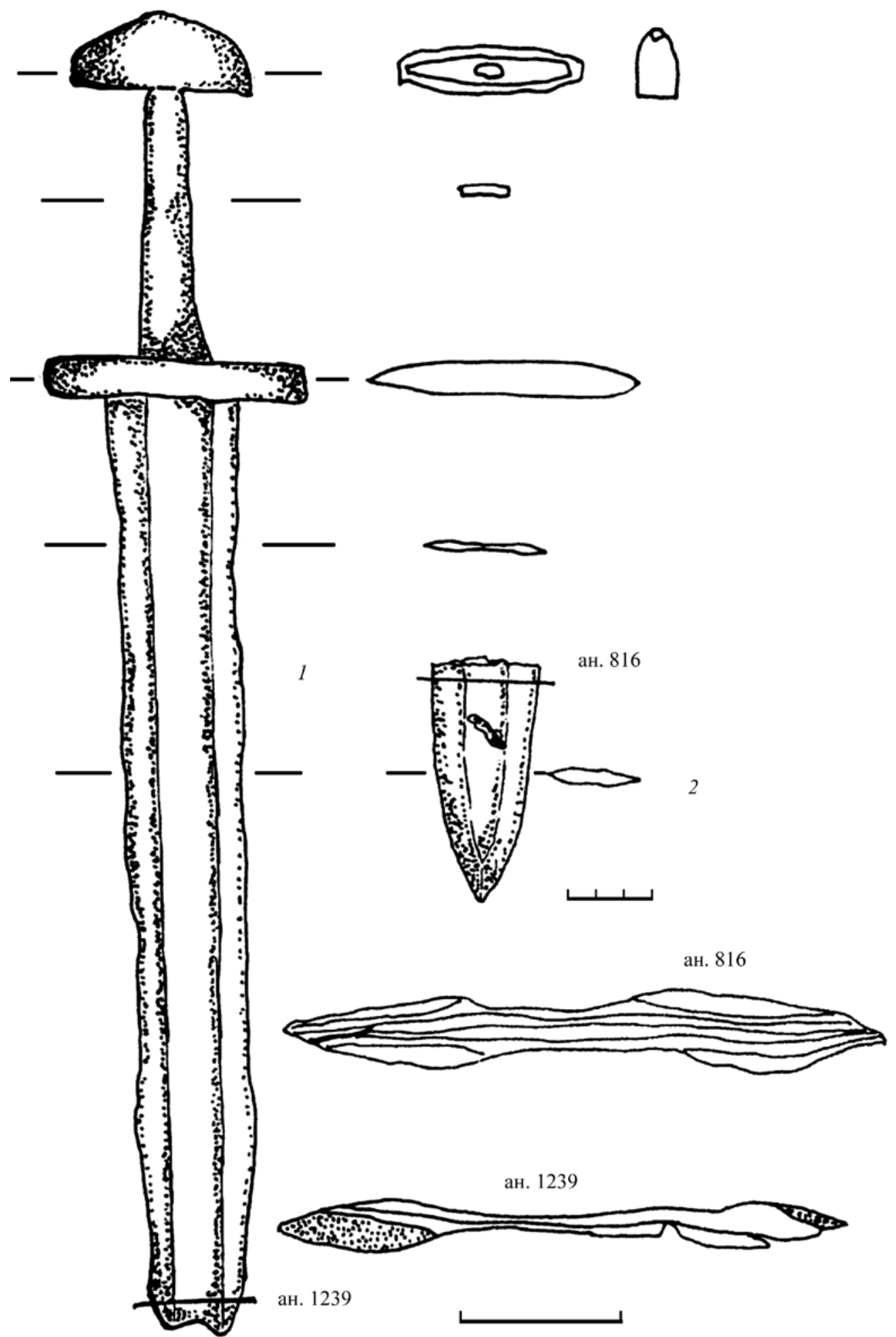

Рис. 9. Мечи, найденные восточнее Урала, и технологические схемы их изготовления 1 - близ с. Бородиновка Варненского р-на Челябинской обл. 2-я пол. X - нач. XI в.; 2 - Туманское укрепление на р. Лозьве, кон. X - XII в. (по: Зыюков, 2011) 
к рукописи графических таблицах были листы, представлявшие типичные формы: «Вещи финноугров Приуралья из Западной Сибири» (табл. 40), «Предметы болгарского происхождения с памятников Зауралья и Западной Сибири X-XIII вв.» (табл. 41), а также вещи древнерусских типов из Западной Сибири и отдельно - с памятников лесного Зауралья и Нижнего Обь-Иртышья XI-XIV вв. (табл. 42-45), византийская чаша с древнерусской надписью, найденная близ г. Березова (табл. 46). На карте 18 («Распространение вещей древнерусского производства и их местных копий в лесном Обь-Иртышье») оговорены 17 категорий изделий и их разновидностей, указано 30 пунктов восьми культурно-хозяйственных типов.

Анализ археологической картины внедрения западных культурных элементов был опубликован в близком к диссертации изложении, но насыщенность и построение сводных таблиц заметно изменились: две из них были посвящены предметам приуральских типов (включая погребальный комплекс Окунево VI) и булгарским вещам лесного Обь-Иртышья, две других - древнерусским находкам в южнотаежной зоне; воспроизведены три соответствующие карты находок (Могильников, 1991).

Особенно значимы те памятники, которые содержат специфическую категорию инвентаря - древнерусскую керамику. Из трех таких городищ два лежат за пределами нашего поиска: либо находясь далеко в северной тайге (Мань-Няслантур на р. Ляпин; три фрагмента), либо принадлежа к позднему времени (Старый Погост, XIV-XV вв., кусок венчика) (Могильников, 1991. С. 86, рис. 7, № 10, 21).

Материал третьего памятника, городища Уки II, лежавшего на Великом Сибирском пути и раскопанного самим В.А. Могильниковым в 1985 г. на Нижнем Иртыше в 100 км северо-восточнее Тобольска, требует серьезного рассмотрения, но все еще остается вне внимания наших русистов ${ }^{19}$.

Причина, вероятно, что редактура заметки в «Археологических открытиях» сделала сжатый информационный текст недостаточно внятным (Могильников, 1987б), а позднее вышедшее краткое описание находок хотя и сопровождалось рисунками показательного материала и было издано в Москве, но не являлось полноценной публи- кацией. Древнерусский материал вошел в работу, характеризующую общий поток перешедших Урал западных культур раннего средневековья. Соответственно этому статья имела широкое, непривлекательное для славяноведов название (Могильников, 1991. С. 86, 87, 96, рис. 3).

Раскопки были проведены близ вала в северозападной части городища на двух разных, хотя и близко лежащих раскопах (Могильников, 1986, рис. 17). Работы выявили принадлежность основного вещевого комплекса и четырех из раскопанных жилищ к позднеоронтуровскому и кинтусовскому этапам нижнеобской культуры древних хантов (о культуре см.: Могильников, 1987а. C. 202-216). Отмечаются также контакты с западными соседями: финно-уграми Приуралья, Восточного Урала и таежного Зауралья (Могильников, 1986. С. 23, 25; 1990б. Рис. 40, 10; 1991. С. 70, 96, рис. 1,11$)$. Вместе с тем были встречены фрагменты волжскобулгарской посуды XII - начала XIII в. (Могильников, 1986. С. 24, рис. 41, 1; 1991. С. 76, 96 , рис. 2,10$)$ и древнерусской керамики.

Дальнейшее описание построено на тексте и иллюстрациях полевого отчета (Могильников, 1986). Толщина культурного слоя на обоих раскопах достигала 1,3 м, по цвету и составу супесчаных отложений разделяясь на две не имеющие четкой границы части мощностью 0,5 (верхний слой 2) и 0,8 см (нижний слой 3). «Судя по стратиграфии, на городище Уки II выделяются 2 последовательных периода обитания в эпоху средневековья» (Могильников, 1986. С. 16) - в ряде мест раскопа I слои разделяются очажными прокалами, углисто-сажистыми прослойками и супесчаными линзами. «В узких хронологических пределах вещи из слоев 2 и 3 не различаются» (Могильников, 1986. С. 15).

На участке Ж-4 на границе слоев 2 и 3 на глубине 0,6 м от поверхности находился развал каменного очага $(0,6 \times 0,7$ м, первоначально очаг был больше, часть развала лежала на уч. Ж/5-6) (Могильников, 1986. Рис. 21), перекрывая неглубокие котлованы жилищ 1 и 2 нижнего слоя (Могильников, 1986. Рис. 22). «С этим очагом связана находка фрагментов русского станкового сосуда из глины темно-серого цвета [см. здесь: рис. 10.- И. К.] с хорошо промешанным тестом и хорошим обжигом (рис. 38) <..>. На участке Ж-5, на 4 штыке

\footnotetext{
19 В Омске вышла первая историографическая статья, посвященная исследованию В.А. Могильниковым древнерусского проникновения в Западную Сибирь в X-XIII вв. Основное внимание в ней уделено летописным и поздним литературным источникам, связанным с восприятием той эпохи и некоторых древностей, относящихся к ней. В таком подходе к проблематике автор, вероятно, и видит «дальнейшее и более глубокое развитие заглавной темы, нежели это сделал В. А. Могильников», завершая текст, однако, призывом вести раскопки (Жук, 2014).
} 


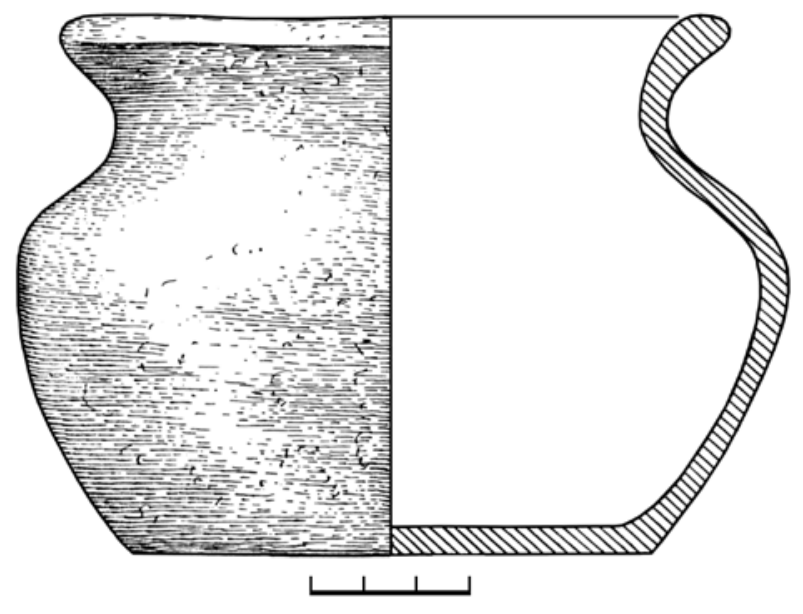

Рис. 10. Древнерусский круговой сосуд, глина. Найден в низовьях Иртыша в Уватском р-не Тюменской обл. Городище Уки II, кинтусовский этап нижнеобской культуры (по полевому отчету В.А. Могильникова)
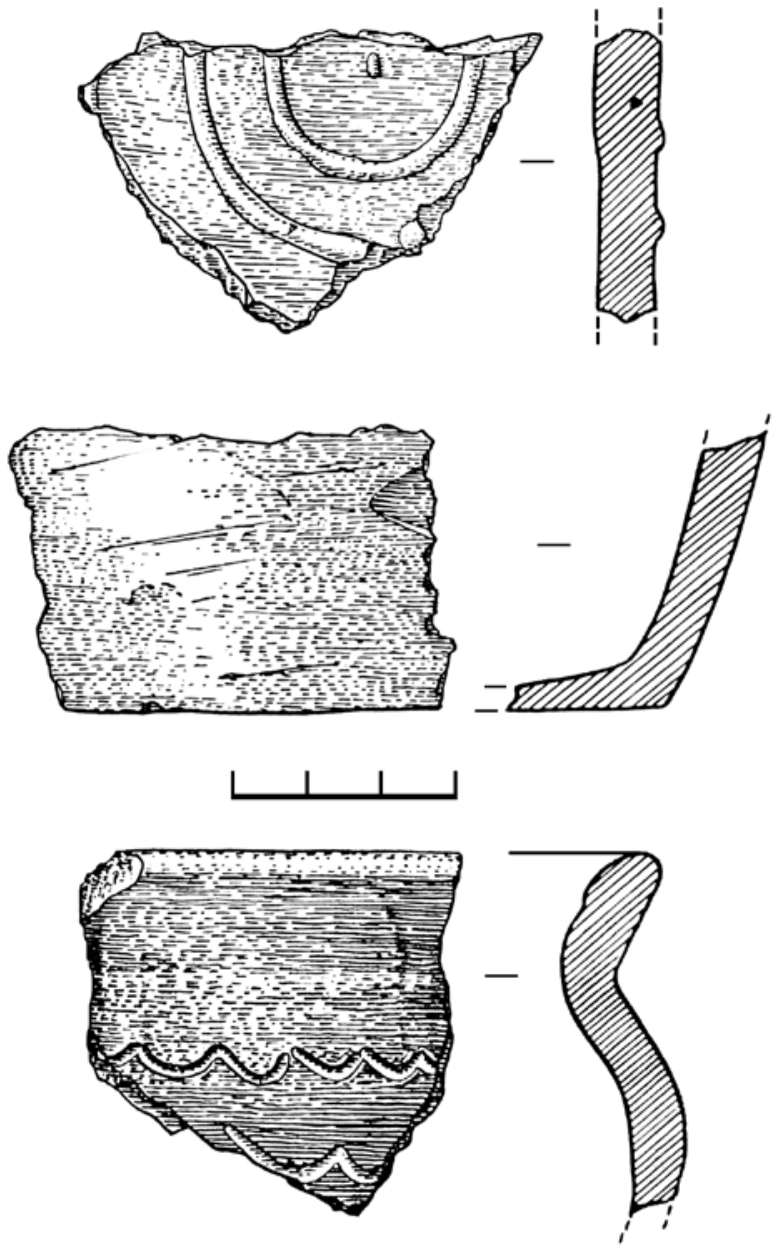

Рис. 11. Фрагменты станковых древнерусских горшков, глина. Найдены на городище Уки II (по полевому отчету В.А. Могильникова) [каждый штык проходил по 20 см.- И. К.] найден обломок дна другого славянского станкового сосуда с концентрическим клеймом (рис. 39,1$)$ [см. здесь: рис. 11, 1.-И.К.], а также фрагмент венчика славянского сосуда с волнистым орнаментом по плечикам [см. здесь: рис. 11, 3.- И.К.] <..>. Указанный очаг был сложен из камней на нижележащем культурном слое 3 и находился, вероятно, внутри наземного срубного жилища, остатки которого почти не сохранились. Вероятно, с ним связаны остатки бревна длиной около 1,5 м, толщиной 0,15 м, выявленные на уч. Ж/4-5 (рис. 21)» (Могильников, 1986. С. 16). В тексте отчета мне не удалось отыскать описания условий находки, а на плане не удалось рассмотреть условного обозначения обломка плоского донца станкового древнерусского горшка (рис. 11, 2), воспроизведенного в альбоме (Могильников, 1990б. Рис. 39, 3) с указанием полевого шифра Л-12/2 № 44, то есть найденного на участке раскопа II (Могильников, 1986. Рис. 23).

Таким образом, «на городище Уки II встречены фрагменты четырех древнерусских сосудов, формованных на гончарном круге из плотного теста, хорошо обожженных, темно-серо-коричневого цвета (рис. 6, 7) (табл. 42, 11, 14-16)» (Могильников, 1990а. С. 319).

Итожа результаты работ, В.А. Могильников вновь подчеркивает, что «основной средневековый комплекс материала в хронологическом и культурном планах в раскопах I и II не различаются» (Moгильников, 1986. С. 22), «представленный инвентарь датирует городище в основном XI-XIII вв.» (Могильников, 1986. С. 25). Ко времени написания отчета автор работ получил консультации о древнерусской керамике у Г.П. Смирновой. Согласно eе определениям, аналогии сосуду, найденному у очага (рис. 10), «представлены в новгородской керамике XII-XIV вв. (раскопы XXV-XXX на Козьмодемьянской ул., 9-й ярус $<\ldots>$ )», фрагменту венчика с волною по плечикам (рис. 11, 3) «также в новгородской керамике второй половины XI - начала XII в.» (Могильников, 1986. С. 16). Уверенность в датировке укрепляет в исследователе сравнение определений керамики и металлических древнерусских изделий, в лаконичном тексте полевого отчета он приводит этот довод дважды: в обоих раскопах слой 2 «датируется также двулезвийными кресалами (рис. $45,1,2$ ), аналогичными новгородским XII-XIII вв.», «среди вещей, представленных в этом комплексе, наиболее узко датирующиеся XII-XIII вв. двулезвийные кресала новгородских типов» (Могильников, 1986. С. 16, 22). 
Однако в основной сводной работе, написанной практически одновременно с полевым отчетом (Moгильников, 1987a. С. 215), в тексте диссертации, соответственно и автореферата (Могильников, 1990в. С. 31), и опубликованной статьи (Могильников, 1991. С. 77) находки керамики и иных древнерусских предметов, встреченных на городище Уки II, получили иную датировку. Они отнесены уже к XIII-XIV вв., и «найденный около очага приземистый горшок (табл. 42, 14) по профилировке сближается с керамикой Новгорода XIV в. <...>. Фрагмент венчика небольшого сосуда, орнаментированный двумя рядами прочерченной волны (табл. 42, 15), подобен новгородской посуде типа II-B XIII-XIV вв. $<$...> и посуде XVI группы керамики Волжской Болгарии, которая появляется в конце домонгольского периода и существовала до XIV в. <...>. Клеймо в виде концентрических окружностей на дне сосуда (табл. 42,11$)$ аналогично новгородским клеймам, распространенным преимущественно до XIV в. $<\ldots>$. От четвертого сосуда сохранился фрагмент плоского дна с частью стенки (табл. 42, 16). В целом славянскую керамику с городища Уки II можно датировать XIII-XIV вв.», а двулезвийные кресала связываются со второй половиной XIII-XV в. (Moгильников, 1990а. С. 308, 311, 319).

Вполне понятно, что с течением времени в археологической науке уточняются и заменяются прежние представления. Надо надеяться, что изложенные материалы ныне привлекут внимание специалистов по древнерусским древностям и приведут к проверке высказанных взглядов. Ради полноты восприятия ситуации следует ее дополнить иными данными, указывающими на более раннюю дату находок ${ }^{20}$.

С согласия В.А. Могильникова древнерусская керамика, полученная им при раскопках на Иртыше срубного жилища с печью-каменкой, была в те же годы показана автором этих строк Р. Л. Розенфельдту. Ростислав Леонидович отнес ее к XII в. и посчитал не новгородской, а владимиро-суздальской. Как выяснилось в последующие годы, схожие с развалами древнерусских печей-каменок разрушившиеся очаги, сложенные из крупного камня на глинобитных основаниях, были характерны для вымской и родановской культур Приуралья, оставленных предками коми, в своем продвижении в Западную Сибирь достигшими в домонгольское время таежного Прииртышья. Жилища приуральских переселенцев также были в основном наземными срубами (Пархимович, 1991. С. 148; Могильников, 1987a. C. 124, 155, 209, 214, 235).

По аналогиям славянское височное кольцо, согласно статье, встреченное на городище Уки II, относится к XI-началу XII в. (Могильников, 1991. С. 82,96 , рис. 3 , б). Фрагмент ручки волжскобулгарского сосуда, найденный на уч. 3-6 (полевой № 131), имеет аналогии в посуде XII - начала ХІІІ в. (Могильников, 1986. Рис. 41, 1; $1990 б$. Табл. 41, 14; 1991. С. 76, 96. Рис. 2, 10).

На раскопе I Владислав Александрович обнаружил среди железных изделий того же слоя 2 на участке Ж-7, то есть метрах в четырех от фрагментов керамики, «щиток пряжки» (Могильников, 1986. С. 24 , рис. 44 , 2), полевой № 62 , который отнес к комплексу вещей древнерусского типа (Могильников, 1990б. С. 489 , рис. 42, 1 , подпись) и определил в тексте диссертации и статье уже как шарнир-накладку от шкатулки либо накладку от запора шкатулки или пояса (Могильников, 1990а. С. 310; 1990б. Рис. 42,1 ; 1991. С. 78, 96. Рис. 3, 1). На деле это часть шарнирного наконечника - типичной сбруйной детали аскизской археологической культуры (рис. 12,1), по форме характерная для ее древностей ХІ в. (Кызласов И. Л., 1983, С. 34, 35. Рис. 16, 2. Табл. X, 1, 20, 22, 23, XXVIII, 14, и др.). К этому же времени принадлежит и характерный аскизский наконечник стрелы (полевой № 3 ) (рис. 12, 2), найденный на городище в тех же условиях (Могильников, 1986. С. 24 , рис. 48,1$)$.

Таким образом, городище Уки II в низовьях Иртыша оказалось очень показательным памятником. На нем фактически одновременно отложились раннесредневековые древности местного угорского и пришлого финно-угорского приуральского, тюркоязычного волжскобулгарского и древнехакасского, а также славянского древнерусского населения. Исследовавший этот памятник В.А. Могильников обнаружил на нем следы активного железоделательного производства, справедливо допустив возможность проживания в хантыйской среде новгородцев «на началах торговой фактории» (для таежного Нижнего Приобья существование таких купеческих станов допускалось и ранее) (Могильников, 1986. С. $25 ; 1987$ a. С. 213,$215 ; 1990$ a. С. 321 ; 1991. С. 87). Думается, что археологический материал указывает на былое существование на этом

${ }^{20}$ К уточнению датировки не могут привлекаться встреченные на городище долго бытовавшие предметы: круглая вставка перстня середины XII - конца XIV в., лунница рубежа XII/XIII-XIV вв., игольник с орнаментом X-XIV вв., круглая бляха с тиснением, тип которой известен у обских угров в X-XIII вв., на этот раз оказывается связан с изображением креста и т. п. (Могильников, 1991. С. 81-87, 96, рис. 3, 3, 4, 6). 

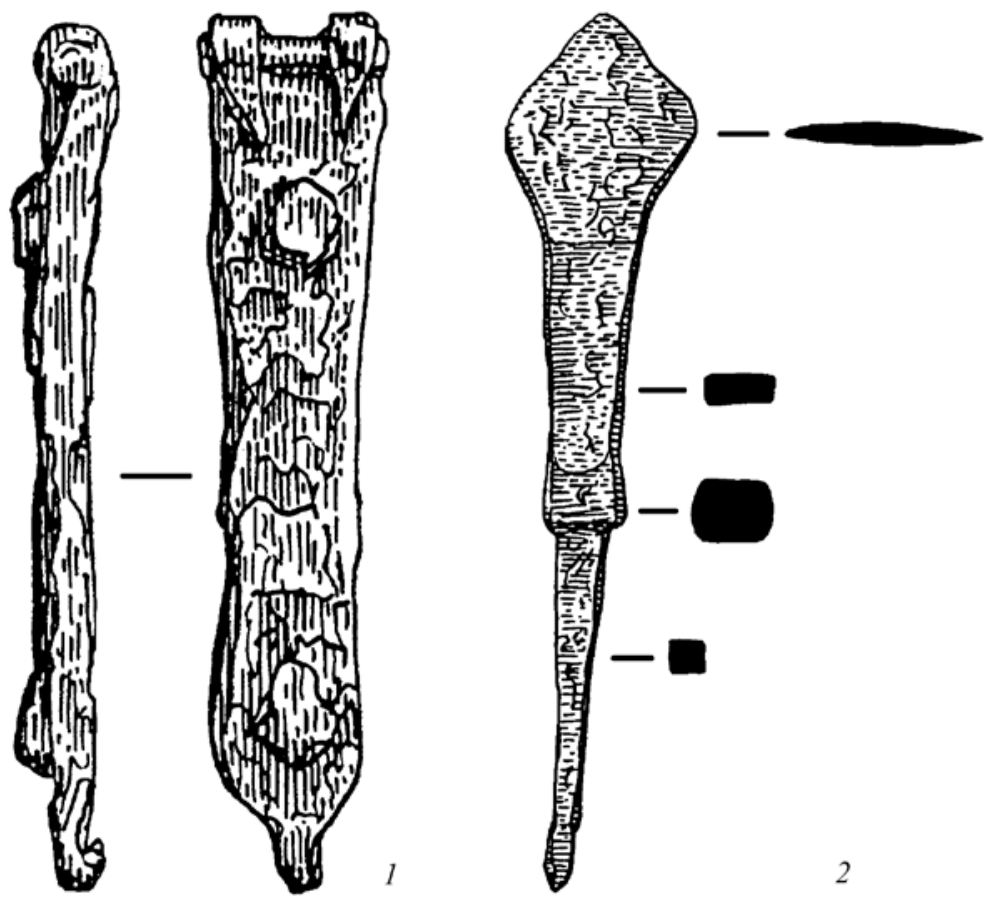

Рис. 12. Шарнирный наконечник (1) и наконечник стрелы (2). Железо. Аскизская культура, XI в. Найдены на городище Уки II (по полевому отчету В.А. Могильникова)

месте нескольких торгово-ремесленных факторий разноязыкого населения, в том числе и выходцев из Верхнего Прикамья и с Вычегды, в 70 км южнее устья которой стоит на Северной Двине Великий Устюг - в то время не новгородский, а владимиросуздальский город. Возможно также, что Владимирская Русь использовала дорогу, проходившую южнее. Как бы там ни было, но в целом именно так, как Уки II, и может выглядеть при раскопках поселение, существовавшее на Великом Сибирском пути в домонгольское и более позднее время.

Судя по составу находок, средневековые хакасы встречались с русскими людьми, живя одновремен- но с ними в полиэтничных булгарских поселках, таких как VI Алексеевское и Мурзихинское селища в низовьях Камы (Руденко, 2015, С. 65, 66, 68, 71, $72,82,138,139,144,145$. Рис. 1, 5, 6 и др.). Такие долговременные контакты, как видим, происходили в домонгольское время и на западносибирских землях, весьма далеких от Уральского хребта. Проникновение происходило не только по давно известным науке северным лесным дорогам. Зона южной тайги и лесостепи входила в трассу международного Великого Сибирского пути. Безошибочным показателем его трасс для археолога служат железные изделия древнехакасской аскизской культуры.

\section{Литература}

Бартольд В. В., 1973. <Извлечение из сочинения Гардизи Зайн ал-ахбар>. Приложение к «Отчету о поездке в Среднюю Азию с научной целью. 1893-1894 гг. »// Бартольд В.В. Сочинения. T. VIII. Работы по источниковедению. М.: Наука; Глав. ред. вост. литературы. С. 23-62.

Бахрушин С.В., 1937. Г.Ф. Миллер как историк Сибири // Миллер Г.Ф. История Сибири. Т. І. М.-Л.: Изд-во АН СССР. С. 3-55.

Бахрушин С.В., 2005. Г.Ф. Миллер как историк Сибири // Миллер Г.Ф. История Сибири. Изд. 3-е. T. I. М.: Восточная литература. С. 17-65.
Белавин А. М., 2003. Аскизские предметы в Пермском Предуралье // Междунар. (XVI Уральское) археологическое совещание. Матер. междунар. науч. конф. 6-10 октября 20003 г. Пермь. С. 138-139.

Беликова О.Б., 1996. Среднее Причулымье в ХХІІІ вв. Томск: Изд-во ТГУ. 272 с.

Белорыбкин Г. Н., 2000. Аскизские следы в СурскоОкском междуречие // Аскизские древности в средневековой истории Евразии. Казань: Гос. объединенный музей РТ. С. 128-149.

Белорыбкин Г.Н., 2001. Золотарёвское поселениие. СПб. - Пенза: Изд-во ПГПУ. 198 с. 
Белорыбкин Г.Н., 2003. Новые материалы Золотарёвского поселения // Археология Восточноевропейской лесостепи. Пенза: Пензенский ин-т развития образования. С. 410-432.

Большаков О.Г., 2006. Ал-Истахри-Ибн Хаукаль // История татар с древнейших времен в 7 тт. Т. II. Волжская Булгария и Великая Степь. Казань: РухИЛ. С. 745-752.

Велиханова Н.М., 1986. Введение в изучение памятника // Ибн Хордадбех. Книга путей и стран / Пер., комм., иссл. Н. Велихановой. Баку: Элм. С. 8-52.

Винничек В.А., 2000. Свинцово-оловянные грузики и слитки на поселениях с коричнево-красной гончарной посудой булгарского типа X-XIII веков // Аскизские древности в средневековой истории Евразии. Казань. С. 150-154.

Винничек В. А., 2003. Ременные накладки из цветных металлов с верхнесурских средневековых поселений // Археология восточноевропейской лесостепи. Пенза: Пензенский ин-т развития образования. С. 352-375.

Винничек В.А., Губанов А.А., 2003. Могильник Татарская Лака II в системе средневековых памятников мордвы // Археология Восточноевропейской лесостепи. Пенза: Пензенский ин-т развития образования. С. 339-352.

Гоняный М.И., 2005. Тюркские элементы в материальной культуре древнерусских поселений конца XII - третьей четверти XIV в. района Куликова поля (на примере украшений ременной гарнитуры) // Русь в IX-XIV веках. Взаимодействие Севера и Юга. М.: Наука. С. 85-100, цв. вкл.

Гришаков В.В., 1992. Два погребения с саблями из Мордовско-Паркинского могильника // Археологические исследования в Окско-Сурском междуречье. Саранск: Мордов. кн. изд-во. С. 105-115. (Тр. НИИЯЛИЭ. Вып. 107).

Даркевич В.П.,1976. Художественный металл Востока VIII-XIII вв. Произведения восточной торевтики на территории Европейской части СССР и Зауралья. М.: Наука. 199 с.

Двуреченский О.В., 2004. Изделия из черного металла // Средневековое поселение Настасьино. М.: ИА РАН. С. 41-51. (Тр. ПЭ ИА РАН. Т. 2).

Дрбоглав Д.А., 1984. Загадки латинских клейм на мечах IX-XIV веков. Классификация, датировка и чтение надписей. М.: Изд-во МГУ. 152 с.

Дрбоглав Д.А., Кирпичников А.Н., 1981. Европейский средневековый меч, найденный в Западной Сибири // Памятники культуры. Новые открытия. Письменность. Искусство. Археология. Ежегодник. 1980. Л.: Наука. С. 528-533.
Жук А. В., 2014. Русские на севере Западной Сибири в Х-ХІІІ вв. (в свете изысканий В. А. Могильникова) // Вопросы истории Сибири. Вып. 9. Сб. науч. ст. памяти В.А. Могильникова. Омск: Изд-во ОмГПУ. С. 43-61.

Зайцева И.Е., 2014. Детали поясной и уздечной гарнитуры из материалов обследований сельских поселений Суздальского Ополья // Русь в IX-XII веках: общество, государство, культура. М.; Вологда: Древности Севера. С. 363-376. Заходер Б.Н., 1967. Каспийский свод сведений о Восточной Европе. М.: Наука. Глав. ред. восточной литературы. Т. II. 212 с.

Зыков А.П., 1987. Вооружение обских угров в X-XIII вв. // Ранний железный век и средневековье Урало-Иртышского междуречья. Челябинск: ЧГУ. С. 143-154.

Зыков А. П., 2011. Находки европейских средневековых мечей восточнее Уральских гор // Уральский исторический вестник. № 1. С. 131-140.

Иванов А.Г., 1998. Этнокультурные и экономические связи населения бассейна р. Чепцы в эпоху средневековья (конец V-первая половина XIII в.). Ижевск: Удмуртский НИИЯЛИ; Уро РАН, 1998. $309 \mathrm{c}$.

Ибн Хордадбех, 1986. Книга путей и стран / Пер., комм., исслед. Н. Велихановой. Баку: Элм. $428 \mathrm{c}$.

Казаков Е. П., 1997. Об этнокультурных компонентах народов Юго-Восточной Европы в Волжской Болгарии (по археологическим материалам) // Татарская археология. № 1. С. 61-77.

Казаков Е.П., 2000. О тюркских инновациях в культуре волжских болгар (по археологическим материалам) // Аскизские древности в средневековой истории Евразии. Казань: Гос. объединенный музей РТ. С. 30-40.

Кирпичников А.Н., 1966. Древнерусское оружие. Вып. 1. Мечи и сабли IX-XIII вв. М.-Л.: Наука. 179 с. (САИ, Вып. Е1-36).

Коновалова И.Г., 2000. Пути сообщения в Восточной Европе по данным средневековых арабо-персидских авторов // ДГВЕ. 1998. М.: Вост. литература. С. 126-133.

Коновалова И.Г., 2006. Ал-Идриси о странах и народах Восточной Европы: текст, перевод, комментарий. М.: Восточная литература. 328 с.

Король Г.Г., 2008. Искусство средневековых кочевников Евразии. Очерки. / Тр. Сибирской ассоциации исследователей первобытного искусства. Вып. V. М.; Кемерово: Кузбассвузиздат. 332 с.

Король Г.Г., Конькова Л.В., 2004. Средневековые ременные украшения из коллекции ГИМ 
(проблемы атрибуции, датировки, интерпретации) // РА. № 4. С. 126-134.

Король Г.Г., Конькова Л. В., 2007. Южносибирские импорты в Восточной Европе и проблемы этнокультурного и регионального взаимодействия в X-XIII веках // Археологические вести. Вып. 14. СПб. С. 145-154.

Кызласов И.Л., 1978. Курганы средневековых хакасов XIII-XIV вв. (аскизская культура в монгольское время) // СА. № 1. С. 122-140.

Кызласов И.Л., 1980. Кыпчаки и восстания енисейских племен в ХІІІ в. // СА. № 2. С. 80-93.

Кызласов И.Л., 1983. Аскизская культура Южной Сибири. X-XIV вв. М.: Наука. 128 с. (САИ. Вып. Е3-18).

Кызласов И.Л., 1996. Сибирские землепроходцы на Руси // Горный Алтай и Россия: 240 лет. Горно-Алтайск. С. 60-64 и 3-й форзац (карта).

Кызласов И.Л., 1997. Следы пребывания древних хакасов в городах Руси XI-XIII вв.// Памятники старины. Концепции. Открытия. Версии. СПб. - Псков. Т. І. С. 380-386.

Кызласов И.Л., 1998. Пребывание древних хакасов в Восточной Европе (конец X-начало XIII в.) // Славяне и их соседи. Славяне и кочевой мир. Средние века - раннее новое время. Сб. тез. докл. 17-й конф. М. С. 72-74, 74a.

Кызласов И.Л., 2000. Успехи в изучении древнехакасских изделий, найденных на Руси и в Поволжье // Аскизские древности в средневековой истории Евразии. Казань: Гос. объединенный музей РТ. С. 3-7.

Кызласов И.Л., 2001. Аскизская культура Южной Сибири и её древности в Восточной Европе // К.А. Руденко. Тюркский мир и Волго-Камье в XI-XIV вв. Изделия аскизского круга в Среднем Поволжье. Исследования и каталог. Казань: Заман. С. 6-10.

Кызласов И.Л., 2003а. Средневековая Евразия в свете новых открытий // КСИА. Вып. 215. C. 3-6.

Кызласов И.Л., 2003б. Связи Южной Сибири с Восточной Европой. Мечи домонгольской поры // Археология Восточноевропейской лесостепи. Пенза: Пензенский ин-т развития образования. С. 456-473.

Кызласов И.Л., 2007. Великий Сибирский путь в судьбе России // Средневековая археология евразийских степей. Матер. Учредительного съезда Международного конгресса. Казань: ИИ АН РТ. Т. II. С. 63-70.

Кызласов И.Л., 2008. Меч из Прииртышья на фоне рубящего оружия степной Евразии //
Древности эпохи средневековья евразийской лесостепи. Воронеж: Изд-во ВГУ. С. 72-99.

Кызласов И.Л., 2010. Особенности появления аскизских изделий в Европе в XIII-XIV вв.// Русь и Восток в IX-XVI веках. Новые археологические исследования. М.: Наука. С. 139-162.

Кызласов И.Л., 2018. Имя кыргызов-символ аристократии (К историческим особенностям тюркских этнонимов) // Вопросы тюркской филологии. Вып. XII. Матер. Дмитриевских чтений, посвященных памяти Дмитрия Михайловича Насилова. М.: Изд-во МБА. С. 190-202.

Кызласов И.Л., Гайдуков П.Г., 2006. О дальности восточных связей Великого Новгорода в древнерусскую эпоху // Средневековая археология евразийских степей. Сб. ст. к юбилею профессора С. А. Плетневой. М. - Йошкар-Ола: Издво МарГУ. С. 217-223. (Матер. и иссл. по археологии Поволжья. Вып. 3).

Кьзласов Л.Р., 1968. Низами о древнехакасском государстве // СА. № 4. С. 69-76.

Кьзласов Л. Р., 1969. История Тувы в средние века. М.: МГУ. 212 с.

Кьзласов Л.Р., 1981а. Древнехакасская культура чаатас VI-IX вв. // Степи Евразии в эпоху средневековья. М.: Наука. С. 46-52, 100, 136-139, рис. 28, 29, 32. (Археология СССР).

Кьзласов Л.Р., 1981б. Тюхтятская культура древних хакасов (IX-X вв.) // Степи Евразии в эпоху средневековья. М.: Наука. С. 54-59, 101, 143-146, рис. 32-34. (Археология СССР).

Кьзласов Л.Р., 1984а. История Южной Сибири в средние века. М.: Высшая школа. 168 с.

Кызласов Л. Р., 1984б. Торговые пути и связи древнехакасского государства с Западной Сибирью и Восточной Европой // Западная Сибирь в эпоху средневековья. Томск: ТГУ. С. 111-118.

Кьзласов Л.Р., 1986. Сообщения русских источников о древних и средневековых городах Сибири // Русский город. М.: МГУ. Вып. 8. С. 31-42.

Кызласов Л.Р., 1987. Торговые пути и связи древнехакасского государства с Западной Сибирью и Восточной Европой // Прошлое Средней Азии. Душанбе: Дониш. С. 79-86.

Кызласов Л.Р., 1992. Письменные известия о древних городах Сибири. Спецкурс. М.: МГУ. 135 с.

Кызласов Л.Р., 1993. Экономика и общественный строй государства древних хакасов // История Хакасии с древнейших времен до 1917 г. М.: Наука. Восточная литература. С. 73-98.

Кызласов Л.Р., 1995. Загадка Грустины и Серпонова - торговых городов средневековой Сибири (по «Запискам о Московии» Сигизмунда 
Герберштейна) // ВМУ. Сер. 8. История. № 1. C. 63-69.

Кызласов Л.Р., 1996. О присоединении Хакасии к России / Страницы истории и современность. Вып. 2. Абакан - М.: Изд-во ХГУ. 64 с.

Кызласов Л.Р., 1997. Загадка Грустины и Серпонова, торговых городов средневековой Сибири // Journal de la Société Finno-Ougrienne. Helsinki. Vol. 87. P. 131-138.

Кызласов Л.Р., 2006. Городская цивилизация Срединной и Северной Азии. Исторические и археологические исследования. М.: Восточная литература. 360 с

Кызласов Л.Р., Король Г.Г., 1990. Декоративное искусство средневековых хакасов как исторический источник. М.: Наука. Глав. ред. вост. Литературы. 216 с.

Маршак Б. И., 1971. Согдийское серебро. Очерки по восточной торевтике. М.: Глав. ред. вост. лит-ры. $191 \mathrm{c.}$

Миллер Г.Ф., 1937. История Сибири. Т. І. М.-Л.: Изд-во АН СССР. 607 с.

Миллер Г. Ф., 2005. История Сибири. Изд. 3-е. Т. I. М.: Восточная литература. 630 с.

Михайлов К. А., 1997. Центральноазиатские ременные украшения в материалах древнерусских памятников X века // ННЗ. Новгород. Вып. 11. C. 251-260.

Могильников В.А., 1986. Отчет о полевых исследованиях в Тюменской области и Алтайском крае в 1985 году / Архив ИА РАН. Р-1. № 10695.

Могильников В.А., 1987а. Угры и самодийцы Урала и Западной Сибири // Финно-угры и балты в эпоху средневековья. М.: Наука. С. 163-235, 245-248, 315-351. (Археология СССР).

Могильников В.А., 1987б. Работы Алтайской экспедиции // АО 1985 года. М.: Наука. С. 269-270.

Могильников В.А., 1990а. Этнокультурная история Западной Сибири в средние века. Диссертация доктора истор. наук / Архив ИА РАН. Р-2. № 2470.

Могильников В. А., 1990б. Этнокультурная история Западной Сибири в средние века. Диссертация доктора истор. наук. Приложения / Архив ИА РАН. Р-2. № 2471.

Могильников В.А., 1990в. Этнокультурная история Западной Сибири в средние века. Автореф. дисс. ... докт. истор. наук. М. 47 с.

Могильников В. А., 1991. Контакты населения лесной полосы Приуралья и Западной Сибири в конце I - начале II тысячелетия н. э. // Проблемы археологии Евразии. [Сб. к 90-летию со дня рождения А. П. Смирнова]. М.: Вост. литератуpa. C. 57-105.
Молодин В.И., 1976. Находка меча из Западной Сибири (предварительное сообщение) // Изв. CO АН CССР. Сер. общ. наук. № 11. Вып. 3. C. $125-127$.

Молодин В.И., 2005. Меч Каролингов // Наука из первых рук. № 1. С. 100-113.

Молодин В.И., 2006. Меч Каролингов. Новосибирск: Инфолио-пресс. 144 с.

Молодин В.И., 2007. Меч Каролингов // Достояние поколений. № 1. С. 68-73.

Моргунов Ю.Ю., 1996. Древнерусские памятники поречья Сулы. Курск: Курский гос. обл. музей археологии. 160 с. (Матер. и исслед. по археологии Днепровского Левобережья. Вып. 2).

Моргунов Ю.Ю., 2009. Древо-земляные укрепления Южной Руси X-XIII веков. М.: Наука. 303 с.

Моргунов Ю.Ю., 2010. Древняя Русь и кочевники Причерноморья // Русь и Восток в IX-XVI веках. Новые археологические исследования. М.: Наука. С. 62-75.

Никольская Т.Н., 1987. Городище Слободка XIIXIII вв. К истории древнерусского градостроительства в Земле вятичей. М.: Наука. 185 с.

Пархимович С.Г., 1991. О контактах населения Нижнего Приобья и Северного Приуралья в начале II тысячелетия н.э. // Вопросы археологии Урала. [Вып. 20]. Екатеринбург: УрГУ. С. 145-153.

Погорелов E. В., 2003. Находка сабли конца XIIXIII веков в окрестностях города Пензы // Археология Восточноевропейской лесостепи. Пенза. С. 473-476.

Розенфельдт Р.Л., 1987а. Вымская культура // Финно-угры и балты в эпоху средневековья. М.: Наука. С. 122-130, 244, 305, 306. (Археология СССР).

Розенфельдт Р. Л., 1987б. Родановская культура // Финно-угры и балты в эпоху средневековья. М.: Наука. С. 153-162, 245, 313, 314. (Археология СССР).

Руденко К. А., 2000а. Тюркский мир и Волго-Камье в XI-XII вв. (археологические аспекты проблемы) // Татарская археология. № 1-2. С. 42-102.

Руденко К.А., 2000б. Датировка находок «аскизского круга» из Волжской Булгарии // Аскизские древности в средневековой истории Евразии. Казань: Гос. объединенный музей РТ. С. 47-127.

Руденко К. А., 2000в. VI Алексеевское селище. Казань: Репер. 107 с.

Руденко К.А., 2001. Тюркский мир и Волго-Камье в XI-XIV вв. Изделия аскизского круга в Среднем Поволжье. Исследование и каталог. Казань: Заман. 256 с. 
Руденко К. А., 2003а. Железные наконечники стрел VIII-XV вв. из Волжской Булгарии. Исследование и каталог. Казань: Заман. 512 с.

Руденко К.А., 2003б. Происхождение и развитие элементов аскизской культуры в Поволжье и Прикамье в XI-XIV вв. // Археология восточноевропейской лесостепи. Пенза. С. 476-488.

Руденко К.А., 2005. Исследования Сосновского II городища и I селища в 2004 г.// Археология и компьютерные технологии: представление и анализ археологических материалов. Ижевск. С. 120-133.

Руденко К. А., 2007а. Восточные элементы в материальной культуре населения Среднего Поволжья и Нижнего Прикамья в XI-XII вв. // Средневековая археология евразийских степей. Матер. Учредительного съезда Междунар. конгресса. Казань: ИИ АН РТ. Т. І. С. 132-135.

Pуденко К. А., 2007б. Волжская Булгария в XI - начале XIII в.: поселения и материальная культура. Казань: Школа. 244 с.

Руденко К.А., 2008а. Этнокультурное взаимодействие кочевого и оседлого населения в Казанском Поволжье в XI-XIV вв. (по археологическим данным) // Finno-Ugrica. № 11. С. 40-53.

Руденко К.А., 2008б. Археология Волжской Булгарии. Историография и история изучения (X-XX вв.). Уч. пособ. Казань: Школа. 264 с.

Руденко К.А., 2011. Аскизские древности в материальной культуре домонгольской Волжской Булгарии и сопредельных территорий // Форум «Идель - Алтай». Мат-лы науч.-практич. конф. «Идель - Алтай: истоки евразийской цивилизации», I Междунар. конгресса средневековой археологии евразийских степей/Археология евразийских степей. Вып. 13. Казань: Фолиант, ИИ АН РТ. С. 156-162.

Руденко К.А., 2014. История археологического изучения Волжской Булгарии (X - начало XIII в.). Казань: Школа. 768 с.

Руденко К.А., 2015. Исследования VI Алексеевского и Мурзихинского селищ в Татарстане в 1992-1996 гг. Казань: Казанская недвижимость. 400 с.

Русанова И.П., Тимощук Б.А., 1993. Языческие святилища древних славян. М.: Науч.-исслед. археол. центр «Архэ». 217 с.

Соловьев А.И., 2003. Оружие и доспехи. Сибирское вооружение от каменного века до средневековья. Новосибирск: Инфолио-пресс. 219 с.

Тачров А.Д., 2013. Источники реконструкции древних караванных путей в степях Центральной Евразии // Вестник Челябинского гос. унта. № 12. История. Вып. 55. С. 68-73.

Шиолянский С. В., 2007. Вещевой комплекс селища Кленово 2 из окрестностей Перемышля Московского (К вопросу об изучении материальной культуры русской деревни после монгольского нашествия) // КСИА. Вып. 221 С. 99-111.

[Minorsky], 1970. Hudud al-Alam «The Regions of the Wold» a Persian Geography 372 A.H. 982 A.D. / Translated and explained by V. Minorsky. $2^{\text {nd }} \mathrm{Ed}$. L.

Kyzlasov L.R., 2010. The Urban Civilization of Northern and Innermost Asia. Historical and Archeological Research. Bucureşti - Brăila: Editura Academiei Române, Editura Istros a Muzeului Brăilei. 426 p. 


\section{Б. Е. Янишевский \\ Институт археологии РАН, г. Москва}

\section{Раскопки на месте церкви св. Анастасии в Переславле-Залесском}

В 2015 г. в Переславле-Залесском экспедицией Института археологии РАН под общим руководством И.В. Ислановой были проведены раскопки на правом берегу р. Трубеж (впадает в оз. Плещеево). Раскоп размерами $8 \times 8$ м был расположен на склоне надпойменной правобережной террасы p. Трубеж, в 15 м от русла реки и в 2,7 м над ее уровнем, в 104 м к западу от д. 1 по ул. Плещеевской, в 120 м к западу от моста через р. Трубеж (Исланова, 2016).

Город Переяславль основан Владимиро-Суздальским князем Юрием Владимировичем (Долгоруким) в 1159 г. на восточном краю Суздальского Ополья, в 120 км к югу от Ярославля и на таком же расстоянии к западу от Владимира. Дерево-земляная крепость была построена в километре выше устья p. Трубеж, на ее левом берегу. Место для этого было выбрано низменное, грунтовые воды сейчас находятся на глубине не более метра от современной поверхности, при этом весь этот метр составляет культурный слой, отложившийся с XII в. Возможно, что крепость возводилась в противовес существовавшему укрепленному поселению Клещин на высоком берегу оз. Плещеевское. Так или иначе, Клещин с его значительным посадом постепенно захирел, а город, основанный на менее удачном в геоморфологическом отношении месте, существует до сих пор и далеко вышел за пределы крепости XII в.

К великому Московскому княжеству Переяславское княжество отошло в 1303 г. и с тех пор всегда входило в домен московских князей. В XVIII в. город стал называться ПереславлемЗалесским и вошел с того времени в состав Владимирской губернии вплоть до 1920-х гг. Сейчас город относится к Ярославской обл. Центральная часть Переславля-Залесского является объектом культурного наследия регионального значения под названием «Культурный слой города Переславля-Залесского XII-XVII вв.».
Археологические раскопки в Переславле-Залесском начал П.С. Савельев в 1853 г., в XX столетии их продолжил Н.Н. Воронин (1939), затем в 1970-е И.Б. Пуришев и Е.В. Каменецкая, а в начале $2000-\mathrm{x}-$ В.И. Вишневский (2006б; 2007). Исследованная площадь не превышала в целом 200 кв. м, причем это были в основном траншеи и шурфы. С началом работ Переславль-Залесской экспедиции ИА РАН в 2011 г. в городе исследован культурный слой на площади, превышающей 4000 кв. м. Раскопки проводились под руководством автора статьи, археологами К. И. Комаровым и В.А. Зейфером. При этом исследования осуществлялись большими площадями, большинство раскопов превышают площадь 200 кв. м. Работы велись как внутри валового кольца (на ул. Садовой, д. 10 и 12 - в 150 м от Спасского собора и на ул. Советской, д. 33 и 37, в 200 м от южных ворот), так и на посадах. Посады исследованы в большей степени на правобережье $\mathrm{p}$. Трубеж (на ул. Кузнецова, д. 9 и в Красном переулке; общая площадь - 1800 кв. м), а также на левом берегу реки - на ул. Кардовского. у д. 3 и 7 - снаружи вала у южных ворот города, вблизи Борисоглебского монастыря, у озера в Ветеринарном пер., 3 (Воронин, 1949. С. 193-202; Каменеикая, Пуришев, 1974. С. 234-237; Вишневский, 2006а. С. 216-226; 2010. С. 5-14; Зейфер, Янишевский, 2014. С. 290-304; Зейфер, 2016. С. 188-192).

На месте раскопок 2015 г. перед началом работ никаких зданий и сооружений не фиксировалось, поверхность была задернована. Однако на плане 1960-1970-х гг. около раскопа значилось здание пивной с подходящей к нему канализацией (рис. 1). Один заброшенный канализационный колодец попал в границы раскопа. Понижение высот с севера на юг на площади раскопа составляло 25 см, с запада на восток - 8-15 см. Исследованная мощность культурного слоя составила 1,8 м (в ямах - до 2,5 м). 


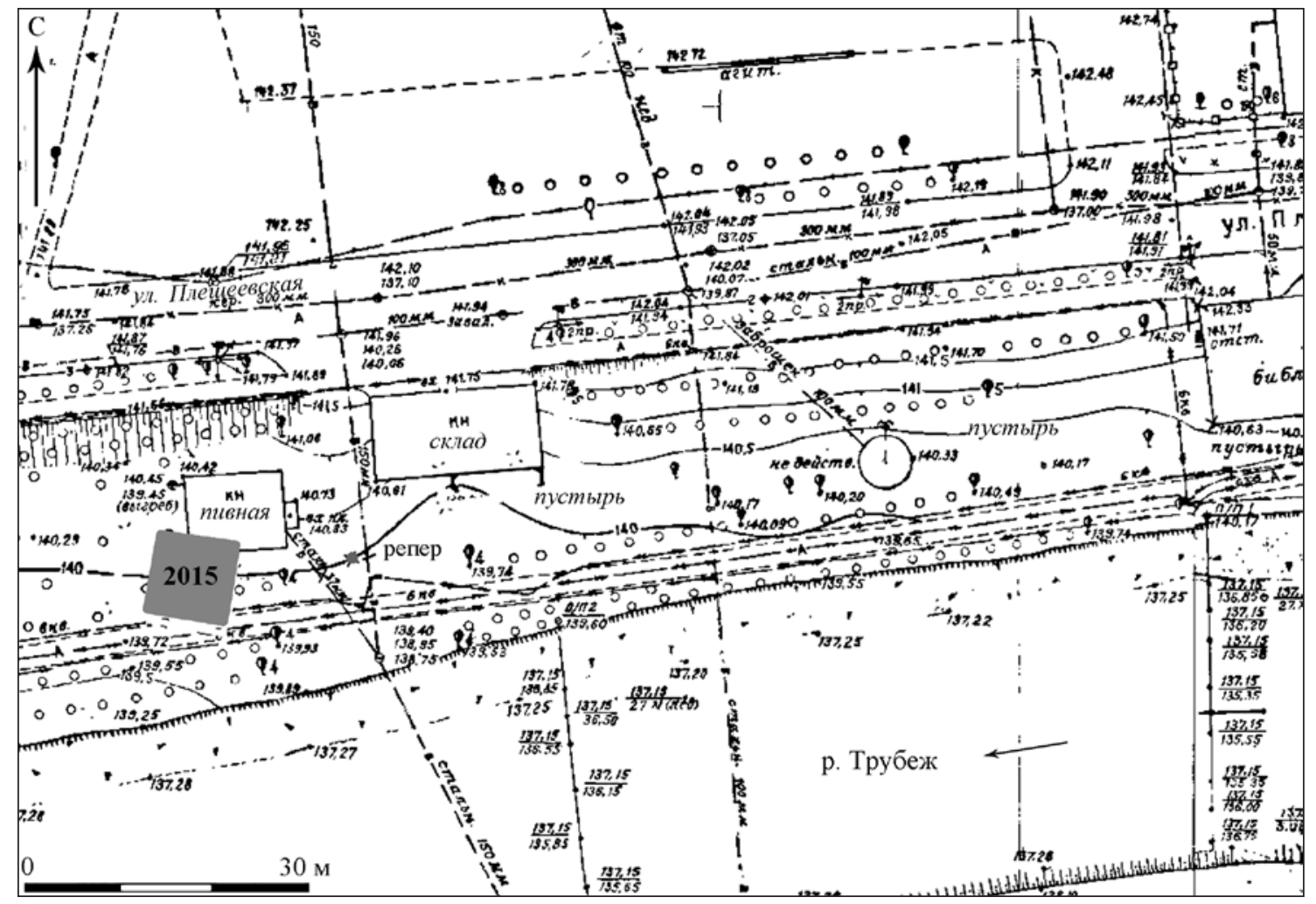

Рис. 1. Раскоп 2015 г. на плане части города Переславля-Залесского 1970-х годов

На глубине -79/-85 см выявилось сооружение 1, длиной около 4 м и в ширину около метра. Сооружение представляло собой тлен от досок пола, с деревянными лагами под ним. На уровне пола и под ним найдены 15 медных монет XVIII-XIX вв., младшая из которых чеканена в 1884 г. Кроме того, обнаружены предметы из медного сплава: крест нательный, пряжка, а также железные нож и обувная подковка. Датировка находок не выходит за пределы датировки монет. Пласт датирован по младшей находке - последней четвертью XIX в. С северной стороны к сооружению примыкала постройка $1^{1}$, зафиксированная в одном пласте с сооружением 1. Она представляла собой подквадратный сруб (от бревен остался только древесный тлен) размерами около $2 \times 2$ м (рис. 2). В постройке 1 найдено 10 монет, восемь из них - чеканки императрицы Екатерины Второй, а две - 1853 и 1876 гг. Дно сруба постройки 1 было выложено досками на глубине -92/ -104 см, то есть на 10-20 см ниже досок сооружения 1. Единственный сохранившийся венец зафиксирован на уровне -85/ -92 см. Можно предположить, что постройка 1 и сооружение 1 располагались на одной высоте, а доски пола в постройке 1 просто провалились (рис. 3). С севера к уже описанному срубу постройки 1 примыкал в этом же пласте еще один сруб, длиннее первого в направлении восток - запад и уходящий в западную и северную стенки раскопа. Северное бревно первого сруба оказалось одновременно южным бревном второго сруба, оно прослежено в этом пласте на длину 2,94 м (часть бревна разрушена при установке бетонного кольца канализации). Пол второго сруба постройки 1 также был дощатым, его тлен расчищен на уровне -93/-100 см. Пол в срубе 2 был выложен досками, лежащими на 20-25 см ниже досок пола сруба 1. Возможно, этот сруб и был основным объемом постройки.

После разборки досок пола и бревен стен срубов постройки 1 выявилось пятно постройки 2, а также пятно постройки 3 , находившееся в метре к западу от юго-западного угла постройки 2. Верхние венцы построек 2 и 3 находились в пласте, нижняя отметка которого составляла $-140 \mathrm{~cm}$.

Постройка 2 представляла собой углубленную в материк часть (погреб) несохранившегося

${ }^{1}$ В отчете сооружение 1 и постройка 1 получили название «сооружение 1 ». 


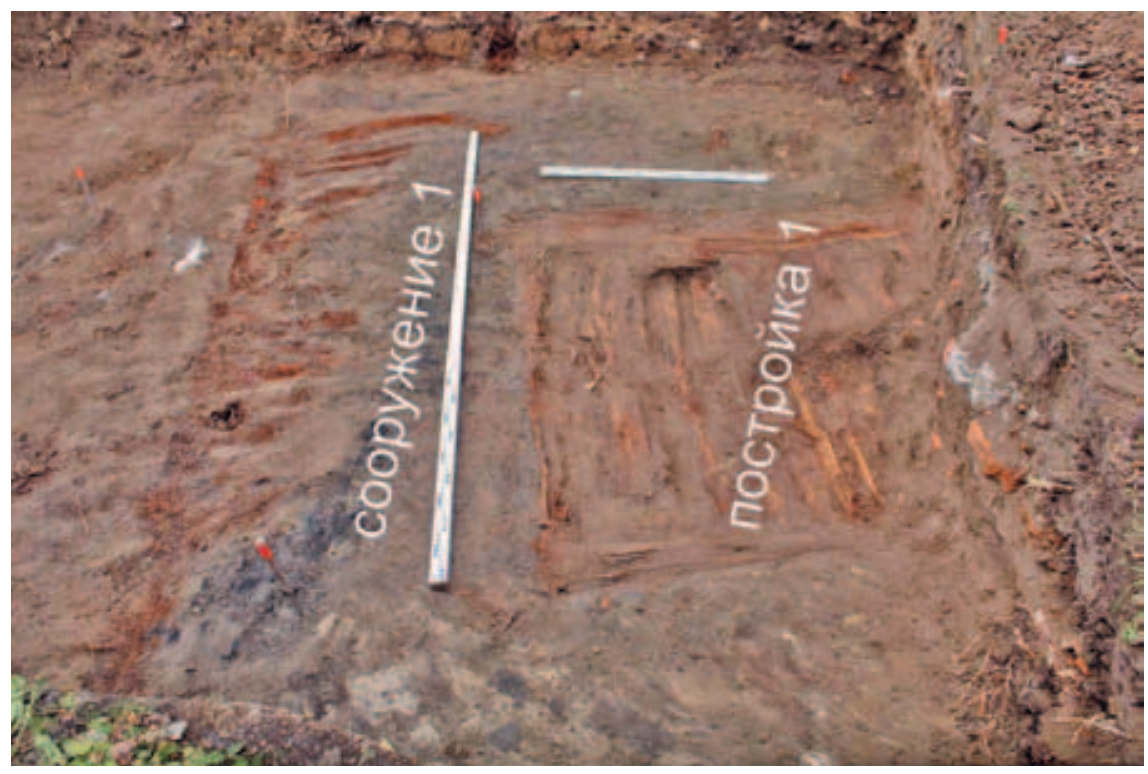

Рис. 2. Сооружение 1 и постройка 1 на уровне -82 / -104 см. Вид с востока

дома, разрушенного постройкой 1. Общая длина постройки 2 составила 5,2 м, ширина неизвестна (но не менее 2,6 м), так как постройка 2 уходила в северную стенку раскопа. По углам ямы в плане хорошо видны характерные округлые ямки для помещения концов бревен сруба крепления стенок погреба (рис. 4). Сохранились четыре венца сруба крепления погреба постройки 2 (рис. 5). Общая глубина ямы погреба от уровня материка $-65 /-80 \mathrm{~cm}$.

На уровне -120 см выявлены отдельные погребения по христианскому обряду, в следующих трех пластах превратившиеся в целое кладбище. Всего в раскоп попали полностью или частично 27 погребений. Кладбище по глубинам располагалось в пластах -120/ -220 см (23 погребения располагались в пластах -140/ -180 см) без учета падения материка. Два погребения (№ 17 и 18), кости которых располагались на глубинах -160/-172 см, рядом и параллельно друг другу с западной стороны постройки 2 , у северной стенки раскопа, были наполовину разрушены этой постройкой. Сохранились верхние части скелетов, а в северном погребении (№ 17) три черепа. Возможно, что устроители котлована для погреба постройки 2 обнаружили еще два погребения, черепа которых они по обычаю положили в другую могилу, а остальные кости вместе с тазовыми костями и костями ног погребе- ний 17 и 18 выбросили. Таким образом, очевидно, что постройку 2 поставили позже совершения погребений 17 и 18 (рис. 6). Раскопками в постройке найдены 39 монет, из них 38 - медных второй половины XVIII в. и одна серебряная XVII в. Это можно считать кладом, сокрытым в конце царствования Екатерины Второй (ни одной монеты Павла Первого не встречено). По этому кладу постройку 2 можно датировать временем сокрытия клада. Всего в постройке собрано 228 фрагментов керамики (рис. 7).

Ранние типы керамики (XIII-XV вв.), а именно серая, красноглиняная грубая и красноглиняная гладкая ${ }^{2}$ составляют не более $1,5 \%$ каждый, керамика красноглиняная переславского типа составляет $51 \%$, чернолощеная сплошь $-31 \%$, серая с коротким венчиком $-9,6 \%$, мореная $-3,6 \%$. Датировке этих типов керамики посвящена специальная работа (Янишевский, Андреева, 2016. С. 206-215), наглядно показывающая, что такие типы керамики, как чернолощеная сплошь, красноглиняная переславского типа и серая с коротким венчиком в XVIII в. сосуществуют. Данные распределения типов керамики в керамическом наборе из комплекса постройки 2 позволяют подтвердить ранее сделанный вывод³. Датировка постройки 2 по керамике не противоречит данным нумизматического материала.

2 Описание этих хорошо известных и изученных типов московской керамики см.: Московская керамика. Новые данные по хронологии, 1991.

3 Определение типов керамики выполнено Т. А. Васиной, к огромному сожалению, недавно ушедшей из жизни. 


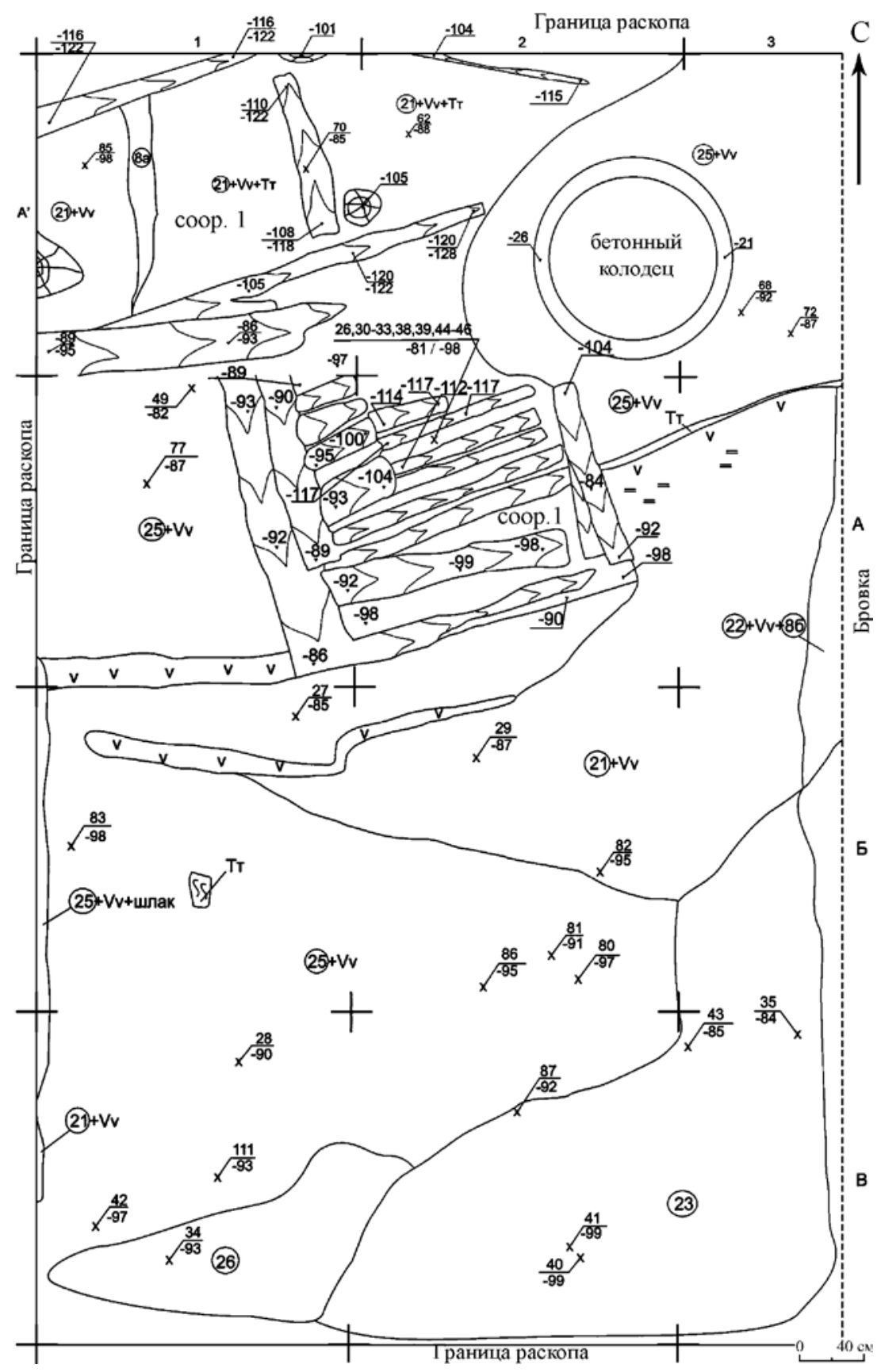

Рис. 3. Постройка 1 после полной расчистки и прирезки раскопа (уровень -100 см).

Индивидуальные находки на плане раскопа

№ 26 - кольцо железное; № 27 - монета медная; № 28 - монета медная; № 29 - монета медная; № 30 - монета медная, coop. 1; № 31 - монета медная, соор. 1; № 32 - монета медная, соор. 1; № 33 - монета медная, соор. 1; № 34 - монета медная; № 35 - монета медная; № 38 - монета медная, соор. 1; № 39 - монета медная, соор. 1; № 40 - монета медная; № 41 - монета медная; № 42 - монета медная; № 43 - монета медная; № 44 - монета медная, соор. 1; № 45 - монета медная, соор. 1; № 46 - монета медная, соор. 1; № 49 - нож железный; № 62 - накладка медная; № 68 - монета медная;

№ 70 - монета медная, соор. 1; № 72 - монета серебряная; № 77 - пешня железная; № 80 - грузила рыболовного керамического фр-ты; № 81 - грузило рыболовное керамическое; № 82 - нож железный; № 83 - конской упряжи деталь; № 85 - молоток железный; № 86 - грузило рыболовное керамическое; № 87 - грузила рыболовного керамического фрагмент; № 111 - монета медная 


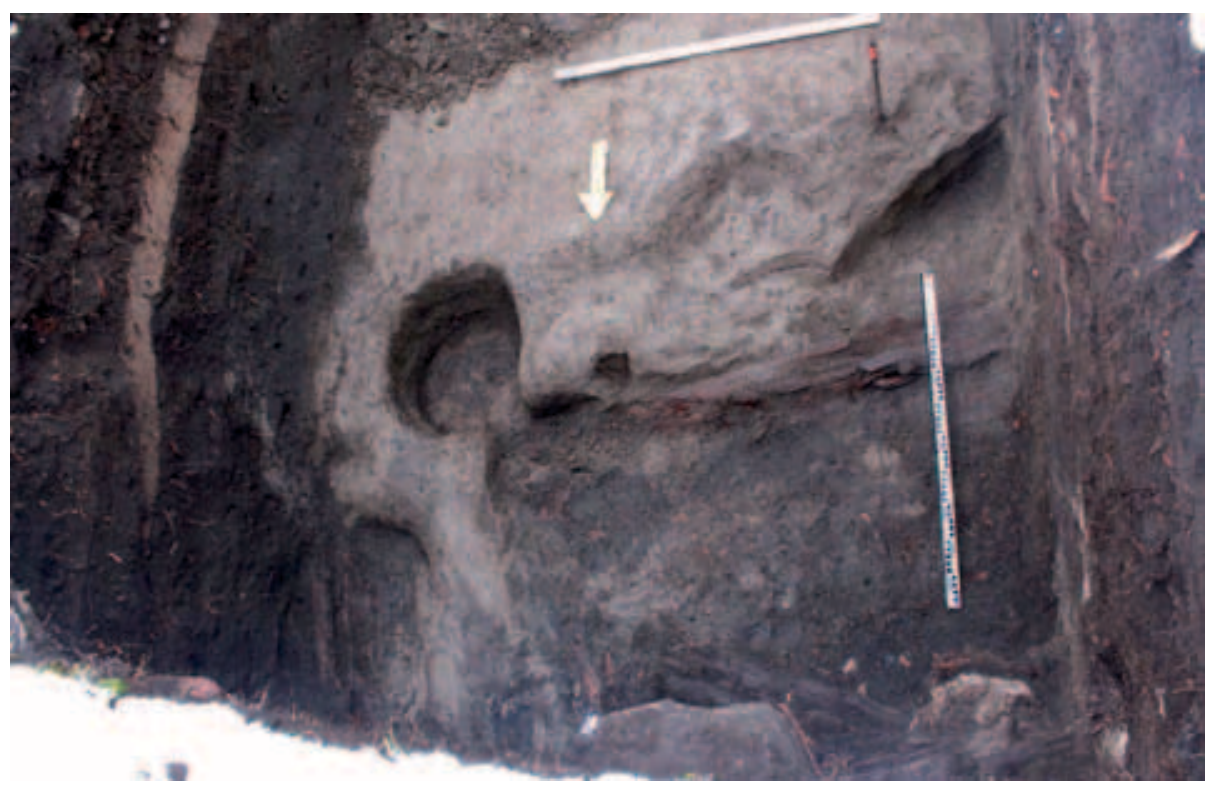

Рис. 4. Постройка 2. Начало выборки заполнения. В углах углубленной части постройки видны ямки для помещения концов бревен сруба. Вид с севера

Постройка $3^{4}$ располагалась у западного борта раскопа, как уже говорилось, юго-западный угол постройки 2 находился в метре к западу от северовосточного угла постройки 3 , хотя их котлованы находятся даже ближе. Постройка представляет собой такой же, как у постройки 2, сруб, опущенный в материковую яму (погреб) глубиной 70 см. Длина одной (восточной) стороны постройки 3 , целиком вошедшей в раскоп, 3 м, поперечная сторона вошла в раскоп на 2 м. Ниже основного сруба на два венца был помещен еще меньший сруб $(2,0 \times 1,5$ м), вошедший в раскоп целиком; в западном борту раскопа прослежена его четвертая стенка. Этот последний, меньший сруб имел пять венцов и стоял на материке. На дне его фиксировался древесный тлен от пола. Внизу на материке прослежены четыре ямы от столбов толщиной до 25 см по сторонам маленького сруба (рис. 8). Стены постройки 3 параллельны стенам постройки 2, то есть эти два сооружения построены в едином архитектурном пространстве (рис. 6).

Датирующими индивидуальными находками из постройки 3 являются только две: фрагмент светло-зеленого стеклянного браслета и медная монета 1731 г. Стеклянный браслет датируется XIII-XIV вв. и попал в комплекс из культурного слоя города при засыпке погреба. Монета найдена всего одна и не может являться прочным основа- нием для датировки. Керамика из постройки 3 собрана в количестве 169 фрагментов (рис. 9).

Как и в рассмотренном выше керамическом комплексе из постройки 2 , наибольший процент

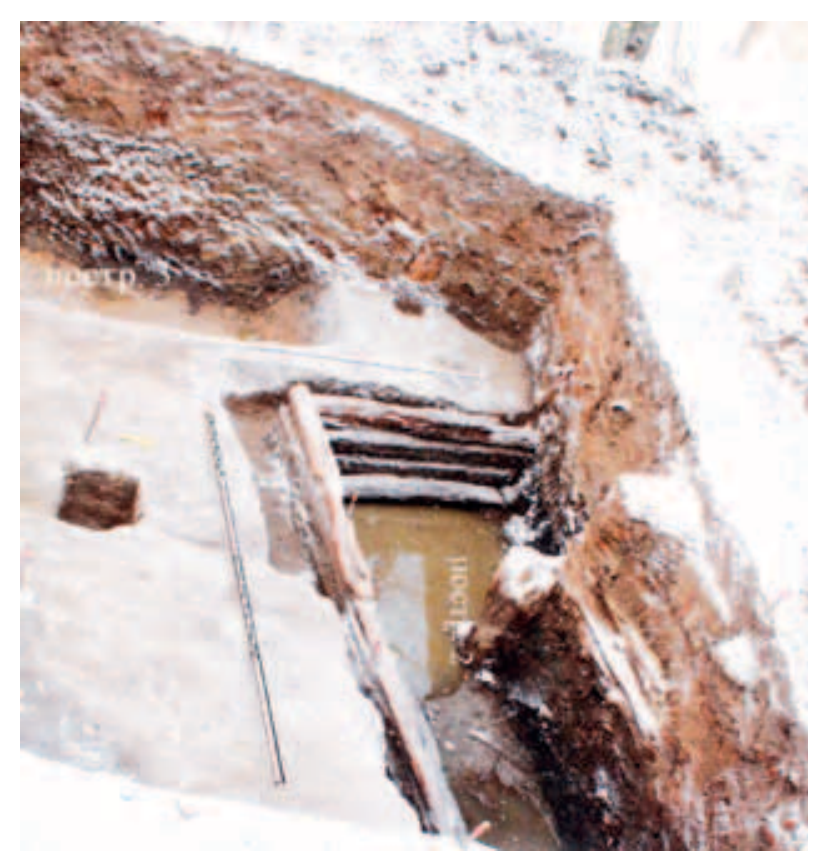

Рис. 5. Постройка 2 после выборки заполнения. Вид с юго-востока

${ }^{4}$ В отчете названа «сооружение $3 »$. 


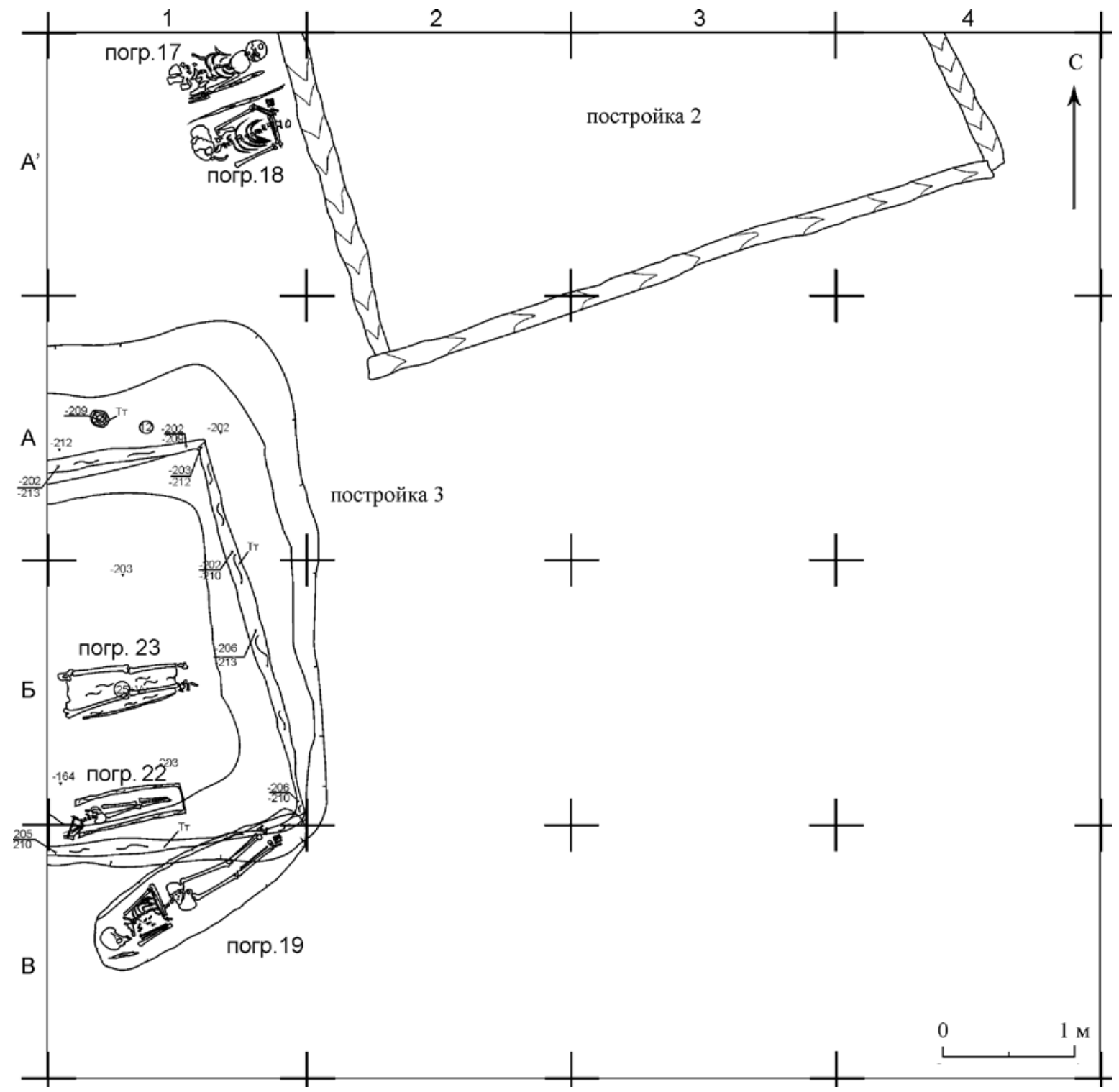

Рис. 6. Совмещенный план построек 2,3 и связанных с ними погребений на нижнем уровне -180 (погребения), -203 / -210 (бревна сруба)

составляет керамика красноглиняная гладкая переславского типа. Этот тип керамики был распространен в Переславле, как и чернолощеная сплошь керамика, в XVIII в. (Янишевский, Андреева, 2016. C. 206-215). В постройке 2 эти два типа доминируют. Однако в данном керамическом комплексе чернолощеной керамики в разы меньше, чем в постройке 2. Значителен процент ранних типов керамики (XII-XVI вв.), вместе они составляют более $25 \%$. Привлекает внимание присутствие единственного фрагмента керамики серой с коротким венчиком, распространенной в Переславле в конце XVIII - начале XIX в. (Янишевский, Андреева, 2016. С. 206-215), а главное - это отсут- ствие других поздних типов керамики, например, поливной XIX в., что указывает на более раннюю датировку комплекса, чем датировка комплекса керамики из постройки 2.

Интересна стратиграфия погребений кладбища в районе постройки 3 (рис. 6). Два погребения (№ 22 и 23) попали внутрь постройки. Погребение 22 (кости на уровне -167/ -172 см) находилось на 40 см выше погребения 23 (кости на уровне -206/-212 см), но оба погребения располагаются выше дна постройки (-231/ -249), то есть сделаны уже после начала засыпки подвала или в процессе разрушения постройки над подвалом. Погребение 19 располагается в том же уров- 
не, что и погребение 22, но южнее постройки 3 , северный край могильной ямы слегка пересекает юго-восточный угол постройки 3. Сохранившийся тлен от бревна постройки 3 находится на отметке -206 см, что глубже уровня костей погребения 19 (-160/ -170 см). Таким образом, нижний ярус погребений возник уже после засыпки подвала постройки 3 не менее чем на 40 см. Однако засыпка продолжалась и после совершения погребений 22 и 23, пятна от которых не видны ни в одном пласте. То есть вполне вероятно, что погребения 22 и 23 совершены практически сразу после разрушения постройки 3. Засыпка была произведена как внутри подвала, так и выше уровня подвала почти на всей поверхности, выше верхнего уровня ямы подвала на 50 см. Судя по цвету засыпки, коричневому, это слой разрушения деревянных построек, истлевших за прошедшее время; кстати, слой засыпки по консистенции и цвету аналогичен нижнему слою засыпки подвала постройки 3. Пятно от погребения 19 видно в пласте -160 см, оно частично пересекает пятно от ямы постройки 3. С уровня пласта -125/ -130 см были сделаны погребения 8, 10 и 14 (в последнем было два черепа), кости этих погребений находились на уровне -140/-160 см, то есть закопаны очень неглубоко. Погребения этого, верхнего, яруса перерезают стены подвала постройки 3 , то есть располагаются уже вне всякой связи с этим сооружением (рис. 10).

Подводя итоги, скажем, что сооружение 1 (доски, лежавшие на лагах вне срубов), вероятнее всего, является отмосткой у крыльца (постройка 1, сруб 1) дома, которым является постройка 1, сруб 2. По монетным находкам сооружение 1 и по-

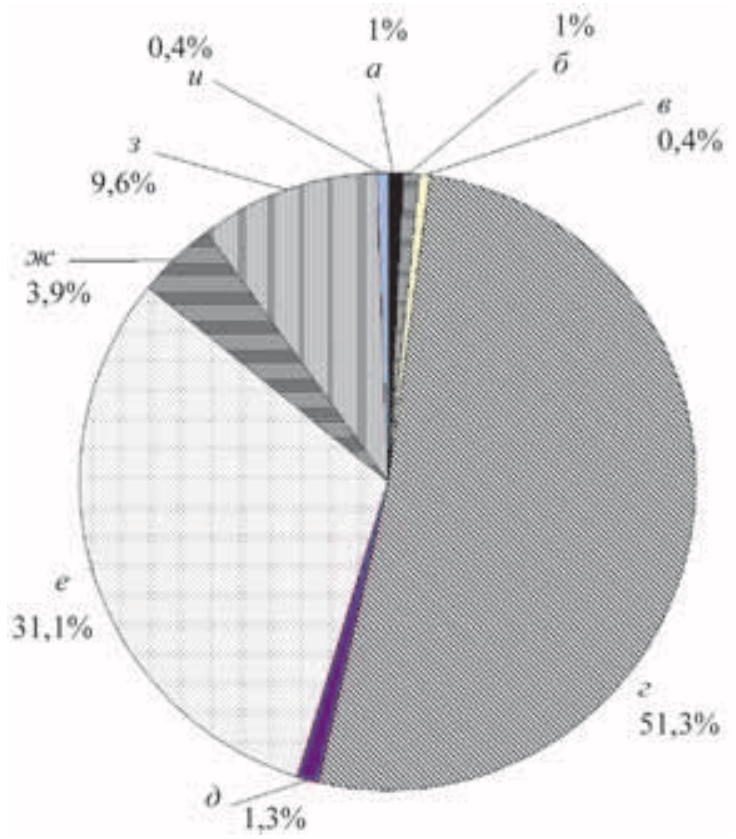

Рис. 7. Распределение керамики по типам. Постройка 2. Всего 228 фр-тов

$a$ - серая; $\sigma$ - красноглиняная грубая; $в$ - красноглиняная гладкая; г - красноглиняная гладкая переславского типа; $\partial$ - белоглиняная грубая; $e$ - чернолощеная сплошь; $ж-$ белоглиняная мореная; 3 - серая с коротким венчиком; $u-$ поливная XVIII-XIX вв.

стройка 1 (срубы 1 и 2) датируются концом XIX в. Постройка 2, которая имела углубленный в землю погреб, датирована по большому количеству монет концом XVIII - началом XIX в. Керамический материал из этой постройки не противоречит нумизматическому. Постройка 2 возведена на уже су-
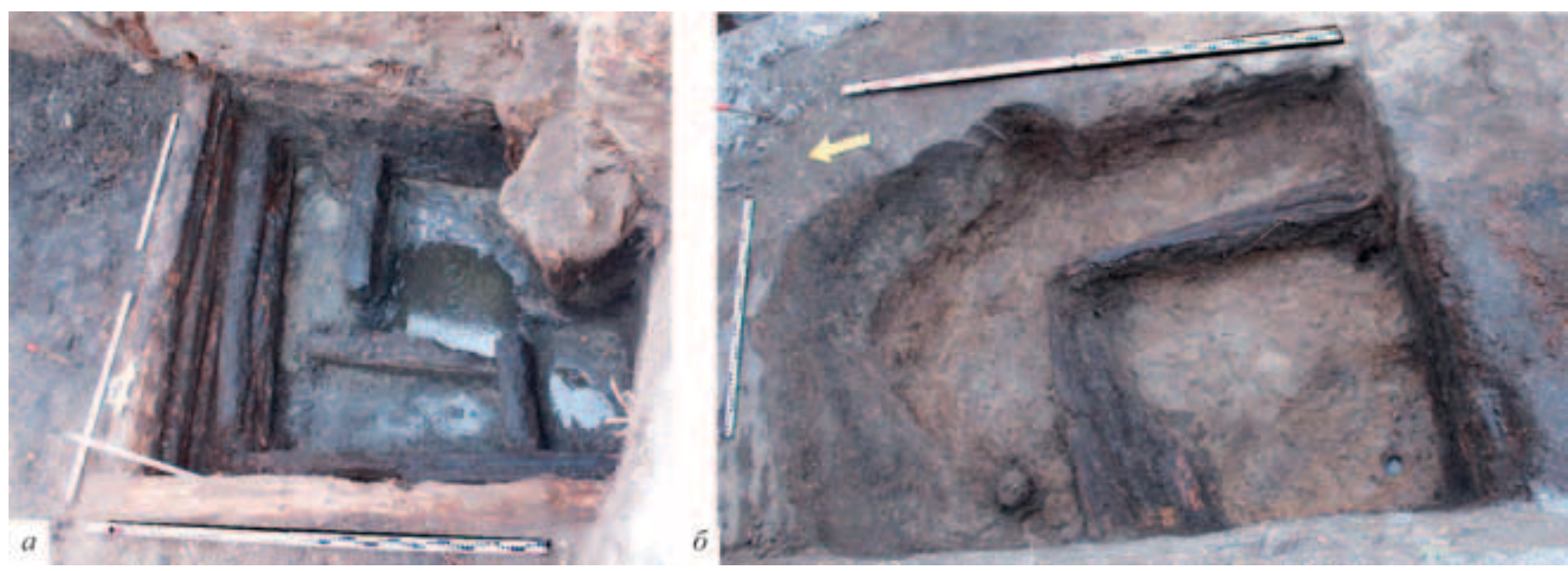

Рис. 8. Постройка 3

$a$ - после выборки заполнения на четыре венца внешнего сруба, вид с юга; $\sigma$ - после выборки всего заполнения. Видны нижние венцы внутреннего сруба (опечка?). Вид с запада 


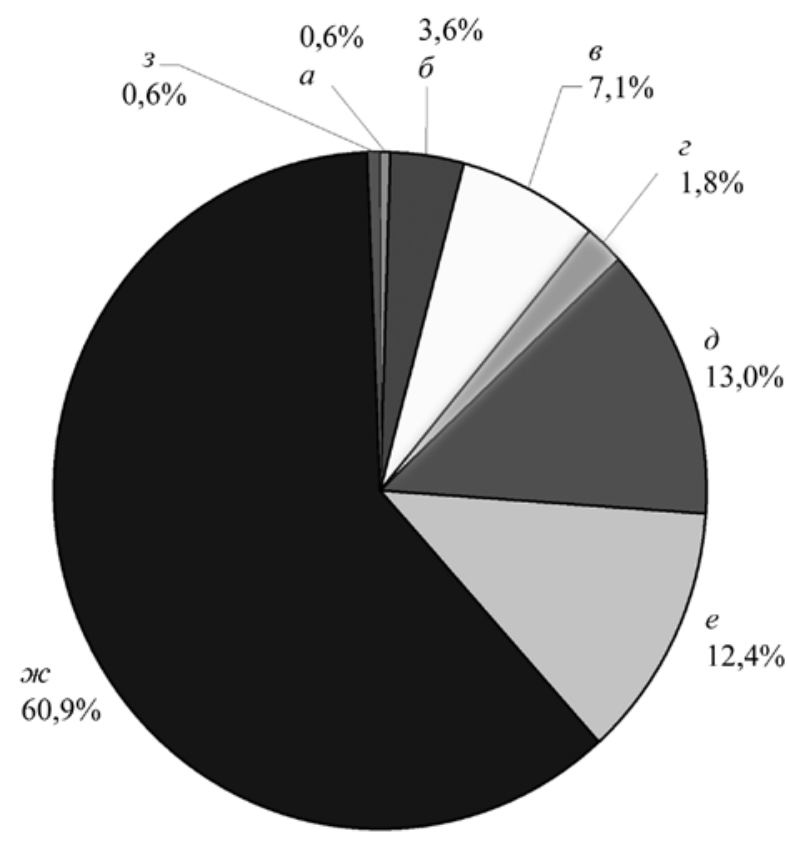

Рис. 9. Распределение керамики по типам. Постройка 3. Всего 169 фр-тов

$a$ - курганная; $\sigma$ - серая; 8 - красноглиняная грубая;

2 - красноглиняная гладкая; $\partial$ - белоглинянаная грубая; $e$ - чернолощеная; ж - красноглиняная гладкая переславльского типа; з - серая с коротким венчиком

ществовавшем кладбище, она перерубает два погребения верхнего яруса кладбища. Постройка 3 , расположенная в 1 м западнее постройки 2, датирована по керамическому материалу временем более ранним, чем постройка 2, примерно на 50 лет. Кладбище возникло тогда, когда постройка 3 уже разрушалась. Два погребения нижнего яруса кладбища сделаны в еще не до конца засыпанном котловане подвала постройки 3. Еще четыре погребения сделаны уже после засыпки котлована и пересекают границы постройки. Таким образом, датировка по керамическому материалу не противоречит наблюдениям за стратиграфией раскопа.

\section{Исторические материалы}

Наличие на месте раскопок кладбища наводит на мысль, что где-то недалеко располагалась церковь. Ближайшей церковью являлась церковь св. Анастасии Великомученицы, обозначенной на картах города Переславля второй половины конца XVIII в. ${ }^{5}$ (рис. 11-13; Шадуни, 2014. С. 245. Рис. 1. № 5). Древнейшее письменное упоминание о ней в окладных книгах Патриаршего приказа под 137-м годом (1629) записано: «церковь святые великомученицы Анастасии, на площади, на берегу реки Трубежа, дани нет, пуста» (Малицкий, 1913. C. 605-609). Когда была построена эта церковь впервые, неизвестно. Под 138-м (1630) годом помечена тоже «пустою». Возможно, что все-таки священник в церкви появился, поскольку в 1653 г. при церкви приходских дворов не было, но был двор попа, поп же получал «на прокормление» руги 8 рублей в год. В 1687 г. церковь эта сгорела «без остатку».

30 сентября 1726 г. церковными властями было разрешено на том же месте построить новую. 15 января 1728 г. новая церковь была освящена. Собственно, освящен главный престол был во имя св. Николая Чудотворца, а теплый придел был во имя святой великомученицы Анастасии. В ноябре 1754 г. священник церкви Илья Иванов обратился в консисторию с прошением о том, что «при Анастасиинской церкви не имеется ни одного двора, при прочих же разных градских церквах имеется приходских дворов довольное число», просил с прочими градскими церквами дворами церковь уравнять. В 1755 г. в городе Переславле к каждой приходской церкви расписано было по 30 приходских дворов; церковь св. Анастасии и некоторые другие получили по 20 дворов. В облегчение содержания церкви она была освобождена от платы данных денег; ее священно- и церковнослужители обязаны были только платить на содержание семинарии и консистории по 40 копеек в год. Но неожиданно Переславский магистрат с 1756 г. прекратил выдачу в церковь ладана, свечей, вина и руги по 8 рублей в год. Последовала жалоба в консисторию. Пока шла переписка, в 1761 г. церковь сгорела со всей утварью, а прихожане восстанавливать церковь не спешили.

Священник просил консисторию о разрешении собирать подаяние на восстановление церкви. При обсуждении этого выяснилось, что в церкви уже давно нет причетников, и каким образом священник служит один, неизвестно. Кроме того, выяснилось, что священнику уже 77 лет. Консистория в 1762 г. определила: «оная сгоравшая церковь была в непристойном месте, близ самых купецких лавок, где всегдашний в торгу происходит шум, и когда только лавки загорались, то по самой близости и оная церковь вместе с ними сгорала», и «на том месте церковь строить никогда не дозволять, только на месте оной, где тоя сгоревшия церкви престолу

\footnotetext{
${ }^{5}$ Автор благодарит Е. К. Шадунц за предоставленные материалы XVIII в.
} 


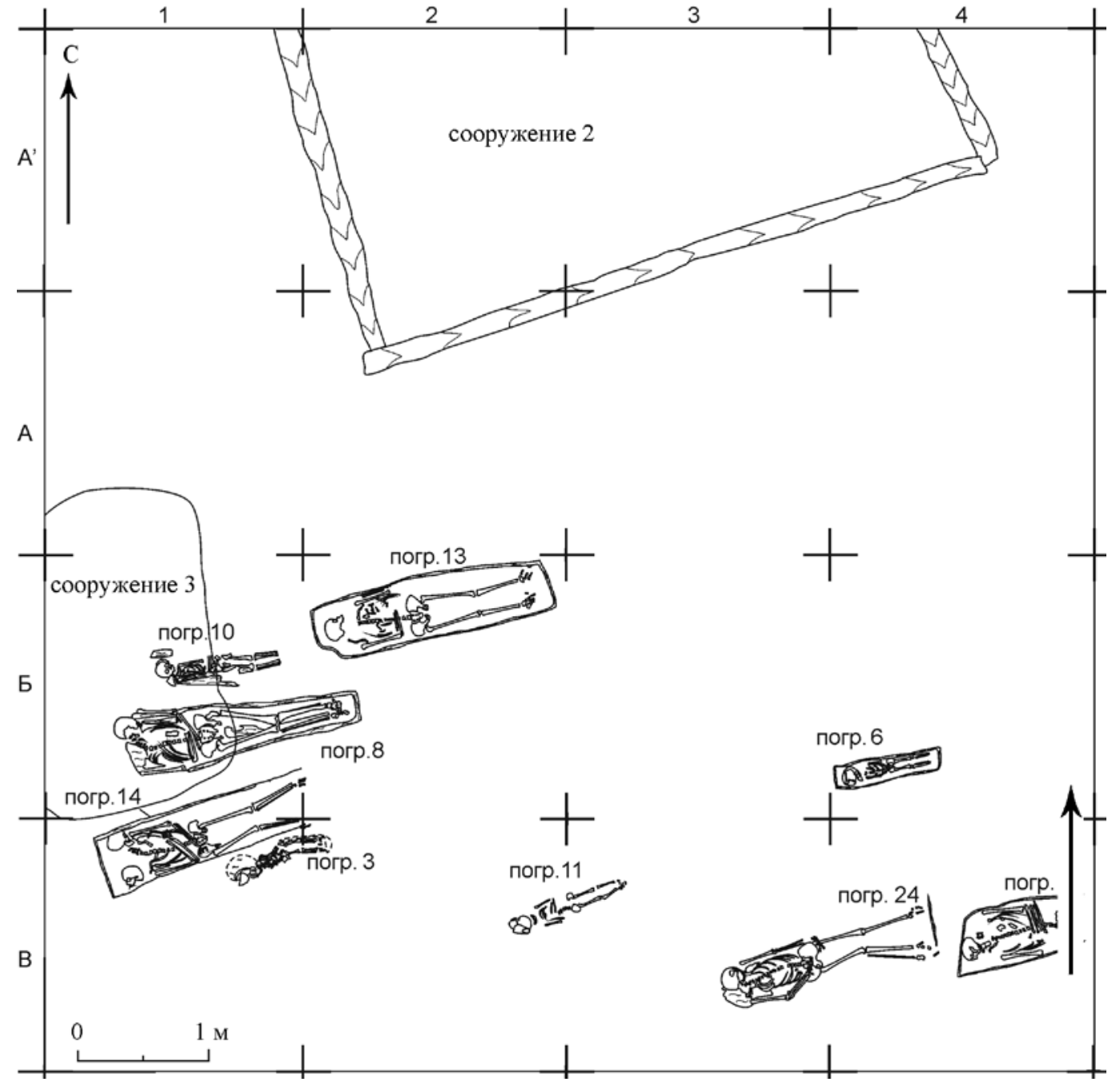

Рис. 10. Совмещенный план построек 2 и 3 и погребений на уровне -140 / -160 см

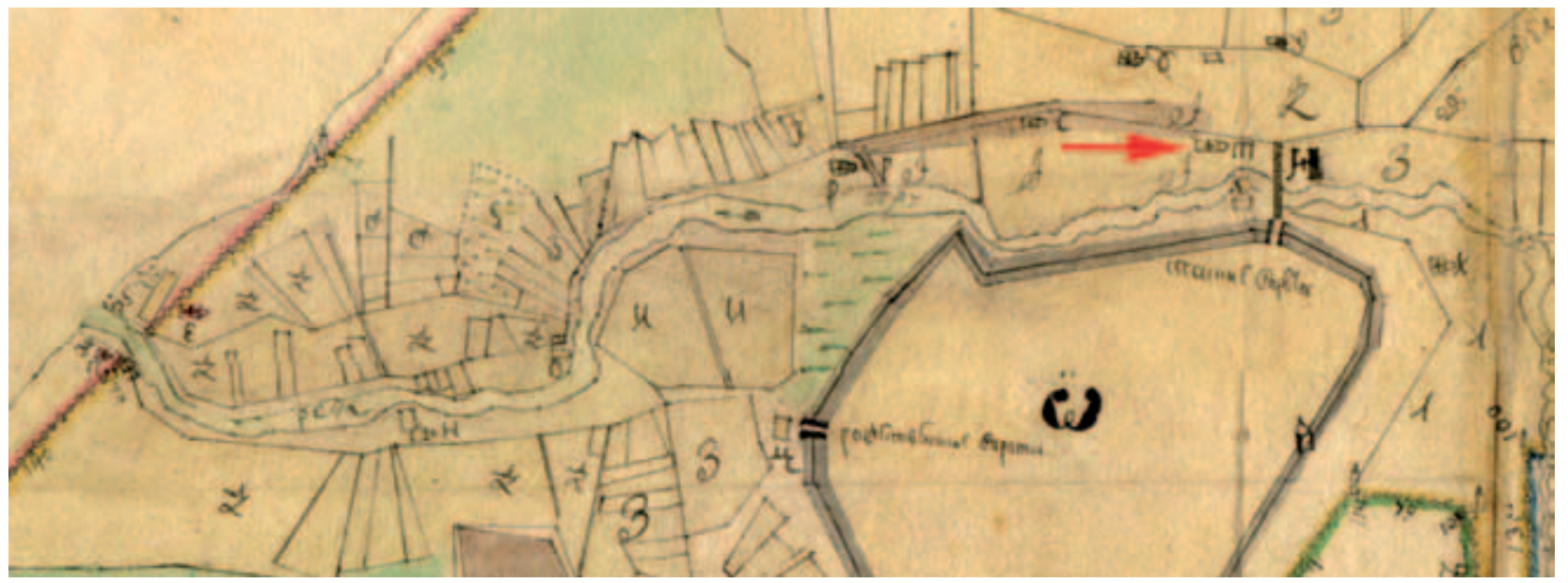

Рис. 11. Церковь св. Анастасии (отмечена красной стрелкой и литерой Т) на плане г. Переславля-Залесского 1756 г. 


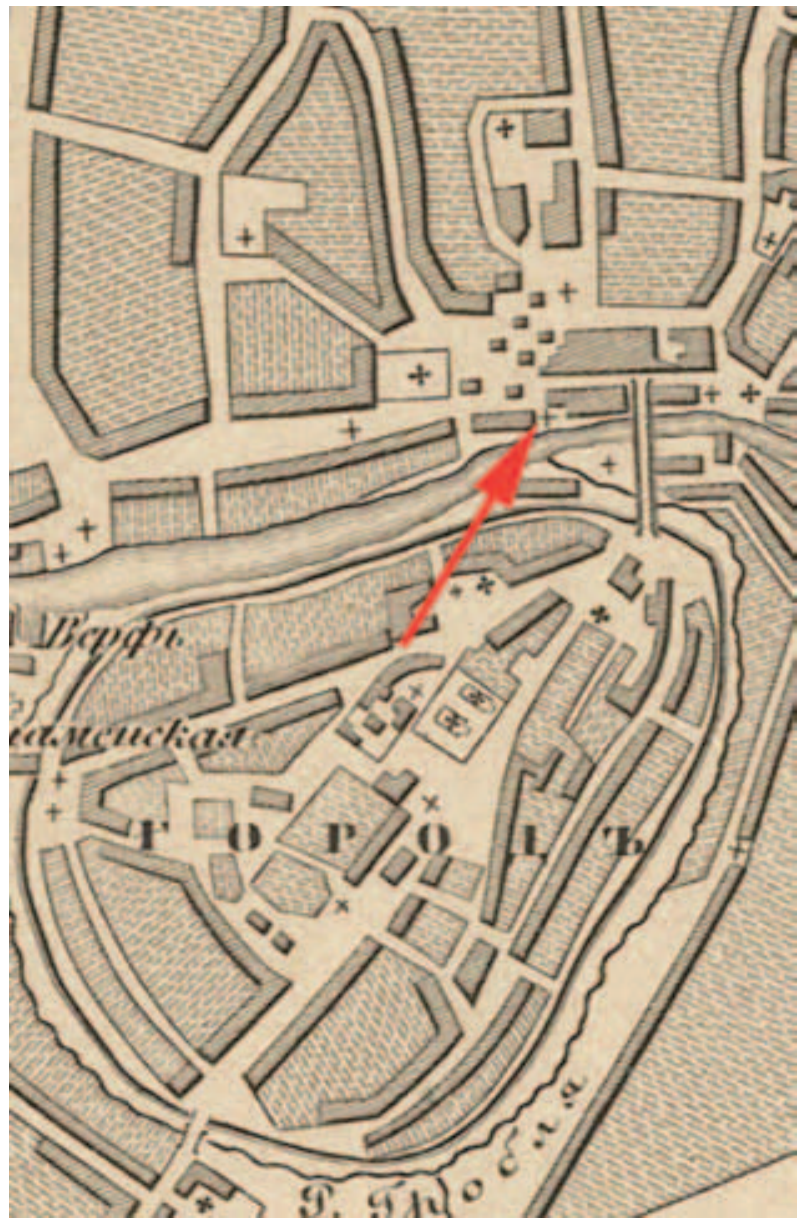

Рис. 12. Церковь св. Анастасии (отмечена красной стрелкой) на плане г. Переславля-Залесского около 1772 г.

быть, построить по обычаю везде содержимому каменную или деревянную часовню», а священника отправить в монастырь, который он сам выберет. Кирпичную шатровую часовню-столб поставили не на месте церкви, а на площади, в ряд с лавками. Однако история церкви на этом не кончилась. Хотя храм и сгорел, но в нем еще в 1766 г. продолжал числиться пономарь ${ }^{6}$, которого ранее в действовавшей церкви не было. По решению городового магистрата церковное место оставили незастроенным, так как по нему проходила дорога из торговых рядов к р. Трубеж. В межевых книгах 1772 г. упомянут «пустовой погост бывшей церкви Анастасии ... мерой 115 кв. саженей». В 1779 г. на месте ее престола стоял деревянный крест, «а где церковь и трапеза и погост, были места, занимаемые... поставлением лошадей с телегами» (Шадуни, 2014. С. 250).

Можно ли соотнести какое-либо сооружение или постройку из нашего раскопа с церковью? Если и можно, то только постройку 3 , которая предшествовала погребениям. Маленький сруб, впущенный в подвал постройки 3 , может быть опечком. Наблюдения за стратиграфией и планиграфией постройки 3 показывают, что погребения на месте постройки начались только после ее разрушения. Керамический материал показывает, что керамика в яму постройки 3 попала примерно на 50 лет раньше, чем в яму от постройки 2 , которая была разрушена не позднее начала XIX в. Причем постройку 2 поставили уже на несуществующем кладбище, поскольку она перерезает погребения. Церковь св. Анастасии сгорела последний раз в 1761 г. После пожара на месте церкви могли еще недолго продолжаться погребения. Небольшое количество редко расположенных могил ${ }^{7}$ объединенных в несколько групп (семейные захоронения?), часто расположенных друг над другом, вполне соотносится с небольшим приходом. Против сопоставления постройки 3 и церкви говорит то, что постройка 3 не сгорела, а была разобрана за ветхостью: в яме от подвала и над ним не слой углей, а сгнившее

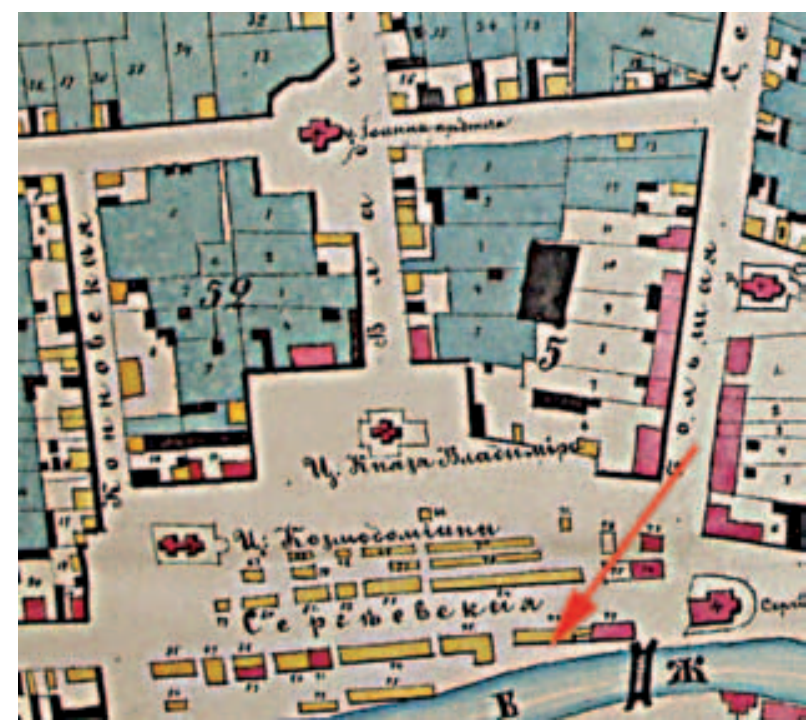

Рис. 13. Примерное место церкви св. Анастасии (отмечено красной стрелкой) на плане ПереславляЗалесского 1858 г. Кармином отмечены каменные здания

6 «Дело о наказании плетьми пономаря церкви Св. Вмч. Анастасии г. Переславля Залесского Якова Ефимова за озорство» (9 янв. -4 июля 1766 г. / ГАЯО. Ф. 1200. Оп. 1-4. ПДК. Д. № 530, 37 л.

Понятно, что раскопом захвачено не все кладбище, однако небольшая плотность погребений необычна для городских кладбищ. Тем более что история церкви охватывает период не менее 130 лет. 
дерево. Возможно и то, что церковь св. Анастасии не попала в раскоп, а осталась за его пределами, но недалеко от кладбища. Тем более что на месте церкви и погоста в 1779 г. числилось пустое место, где располагались телеги, а не постройки. Сооружение 1 и постройка 1, датированные по самой поздней монете из провалившихся между досок пола последней четвертью XIX в., перекрыли кладбище и разрушенные постройки 2 и 3 . То есть в XIX в. про кладбище уже никто не помнил. То же мы видим и на картографическом материале: на плане 1756 г. (рис. 11) и на плане, составленном около 1772 г., церковь нанесена (рис. 12), а на плане 1858 г. ее уже нет (рис. 13).

\section{Литература}

Вишневский В. И. 2002. Отчет об охранных археологических работах в Переславле-Залесском в 2002 году / Архив ИА РАН. Р-1. № 26807.

Вишневский В. И., 2006а. Культурный слой Переславля-Залесского (по данным археологических разведок 2002-2003 гг.) // Археология: история и перспективы. Вторая межрегиональная конференция: сб. статей. Ярославль.

Вишневский В.И., 2006б. Отчет об охранных археологических работах в г. Переславль-Залесский Ярославской области в 2006 году / Архив ИА РАН. Р-1. № 28619, 28620.

Вишневский В.И., 2007. Отчет об охранных и разведочных археологических работах в г. Переславль-Залесский Ярославской области в 2007 году / Архив ИА РАН. Р-1. № 28622.

Вишневский В.И., 2010 . Домонгольский слой Переславля-Залесского (открытия 2002-2008 гг.) // Археология: история и перспективы. Четвертая межрегиональная конференция. Сб. статей. Ярославль, 2010.

Воронин Н.Н., 1939. Раскопки в Переславле-Залесском / Архив ИИМК РАН. Ф. 8. Д. 4.

Воронин Н.Н., 1949. Раскопки в Переславле-Залесском // МИА № 11.

Добронравов В.Г., 2014. Историко-статистическое описание церквей и приходов Владимирской епархии (Переславский уезд). М.

Добронравов В.Г., Березин В.Д., 1895. Историкостатистическое описание церквей и приходов Владимирской епархии. Ч. 2: Переславский и Александровский уезды. Владимир.

Ермакова Н.Н., 2004. Храмы Переславля: существующие и утраченные. М.

Зейфер В. А., 2013. Отчет об археологических раскопках в городе Переславль-Залесский Ярославской области по адресу: ул. Советская, 37 в 2013 году / Архив ИА РАН. Р-1. № 39901.

Зейфер В.А., 2015. Предварительный анализ жилых и хозяйственных построек из раскопок южной части кремля Переславля-Залесского (по результатам исследований 2013 года) // АП. Вып. 11. М.
Зейфер В. А., 2016. Ордынский след в истории Переславля (Переяславля) - Залесского XIII-XV вв. (по материалам археологических раскопок 2011-2013 годов на территории кремля и посада) // Наука, образование, культура. Материалы Международной научно-практической конференции, посвященной 25-й годовщине Комратского государственного университета 4 февраля 2016. Т. II. Лингвистика, история и культура.

Зейфер В. А., Янишевский Б. Е., 2014. Раскопки в Переславле-Залесском в 2011-2012 гг.// Археология: история и перспективы. Шестая межрегиональная конференция: сб. статей. Ярославль.

Исланова И.В., 2016. Отчет об археологических раскопках в г. Переславле-Залесском Ярославской области на участке по адресу: Плещеевская ул., у д. 1 в 2015 году / Архив ИА РАН. Р-1. № 49596.

Каменецүкая Е. В., Пуришев И.Б., 1974. Деревянные конструкции вала Переславля-Залесского // СА. № 1

Комаров К.И., 2013. Отчет об археологических раскопках в г. Переславле-Залесском Ярославской области по адресу: ул. Кардовского, д. 3 в 2012 году / Архив ИА РАН. Р-1. № 47459.

Малицүкий Н. В., 1913 Церковь Святой Великомученицы Анастасии в городе Переславле/Н.В. Малицкий // Владимирские епархиальные ведомости (часть неофициальная). 1913. 27 июля (№ 30). (Совр. издание: Переславская краеведческая инициатива. Код. 1575: http://pki.botik. ru/articles/c-anastasia1913mal.pdf)

Московская керамика. Новые данные по хронологии. М.: ИА РАН, 1991. 198 с.

Смирнов М.И., 1926. По забытым путям Залесья (Историко-этнографический очерк) // Доклады ПЕЗАНПРОБ. Переславль-Залесский. Вып. 15.

Смирнов М. И., 1996. Переславль-Залесский. Исторический очерк. 1934 г. Переславль-Залесский.

Шадуни Е.К., 2014. Иллюстрация к «Истории царствования Петра Великого» как исторический источник для археологии // Археология: 
история и перспективы: Шестая межрегиональная конференция: Сборник статей. Ярославль, Рыбинск.

Янишевский Б. Е., 2012. Отчет об охранных археологических раскопках на территории объекта археологического наследия «Культурный слой города Переславля-Залесского 12-17 вв.» по адресу: ул. Садовая, 10 в 2011 году / Архив ИА РАН. Р-1. № 30905.

Янишевский Б. Е., 2013. Отчет о раскопках на территории г. Переславля-Залесского по адресу: ул. Кузнецова, 9 в 2012 году / Архив ИА РАН. P-1. № 36541 .
Янишевский Б.Е., 2014. Отчет об охранных археологических раскопках на территории объекта культурного наследия «Культурный слой г. Переславль-Залесский, XII-XVII вв.» по адресу: Ярославская обл., г. Переславль-Залесский, пер. Красный, кадастровый номер участка 76:18:10937:29 в 2014 году/Архив ИА РАН. P-1. № 39409.

Янишевский Б.Е., Андреева А.Ю., 2016. Поздние типы керамики из Переславля-Залесского // Археология: история и перспективы: Седьмая межрегиональная конференция: Сб. статей. Ярославль. 
B. А. Буров

Институт археологии РАН, г. Москва

\section{К реконструкции монашеских лавок Соловецкого монастыря}

В 1982 г. в Святительском корпусе Соловецкого монастыря после завершения реставрации одной из братских келий ${ }^{1}$ была открыта постоянная выставка «Интерьер монастырской кельи XVII в.», которая действует до сих пор и входит в состав экскурсионного маршрута. По нашим расчетам, данная экспозиция была развернута в передней келье № 51 в соответствии с нумерацией описи келий 1641-1674 гг. (Книга переписная... 1641-1674 гг. Л. 165 об.- 169; Буров В. А., 2011. С. 196. Рис. 58).
При воссоздании интерьера авторы экспозиции, сотрудники Государственного историко-архитектурного и природного музея-заповедника Ю.М. Критский и А.Г. Мельник, руководствовались в основном сведениями письменных источников XVII - начала XVIII в. (Критский Ю.М., Мельник А.Г., 1983). Для этой выставки специально сделали реконструкции монашеских спальных лавок, располагавшихся вдоль стен. Ножки лавок фигурные. В их центре размещается диск, вверх и вниз от которого отходят трапеции (рис. 1).

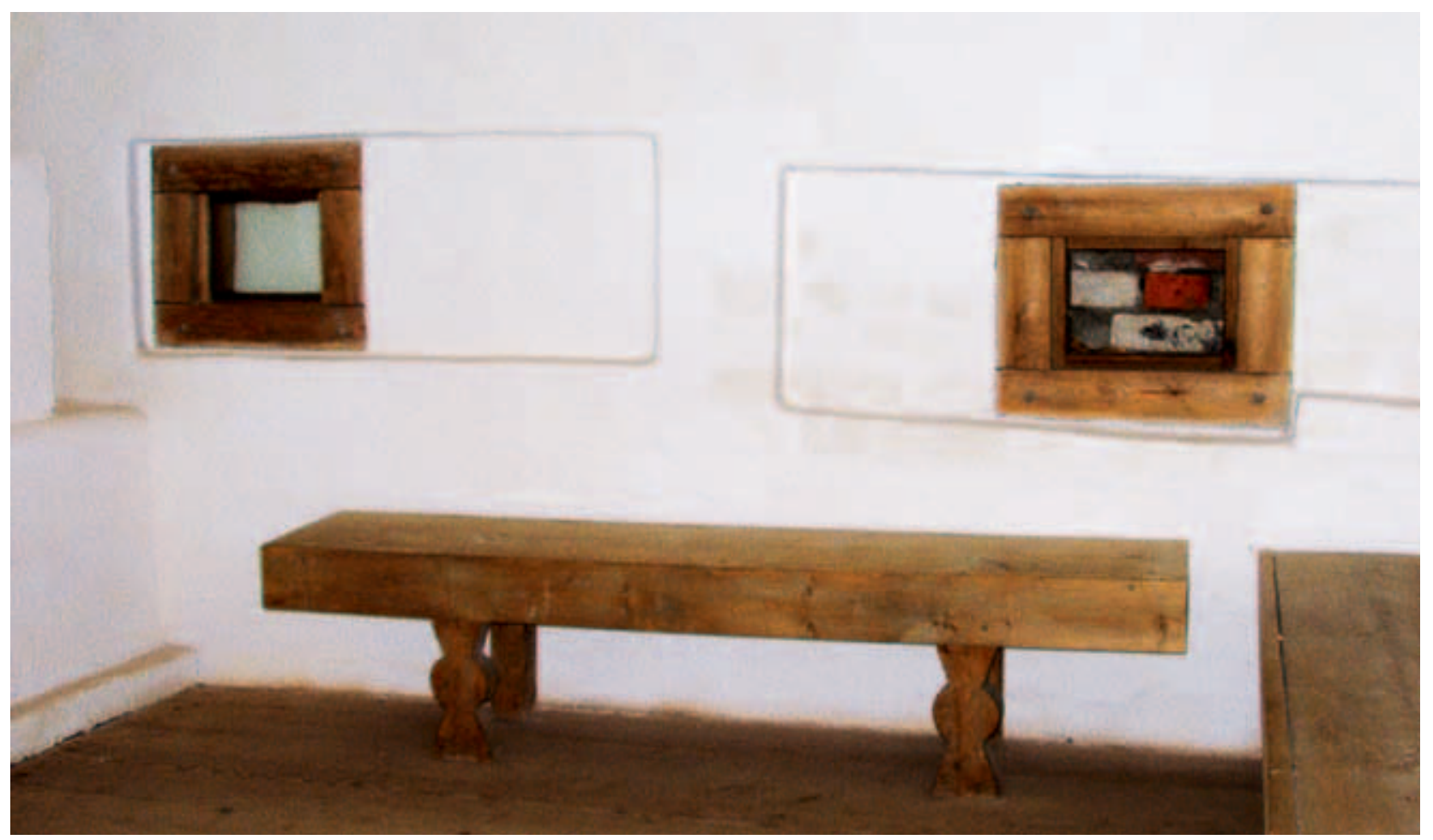

Рис. 1. Монашеская лавка на выставке «Интерьер монастырской кельи XVII в.». Реконструкция, 1983 г. Соловецкий музей-заповедник

1 Авторы проекта реставрации - архитекторы О. Д. Савицкая и В.В. Сошин. 

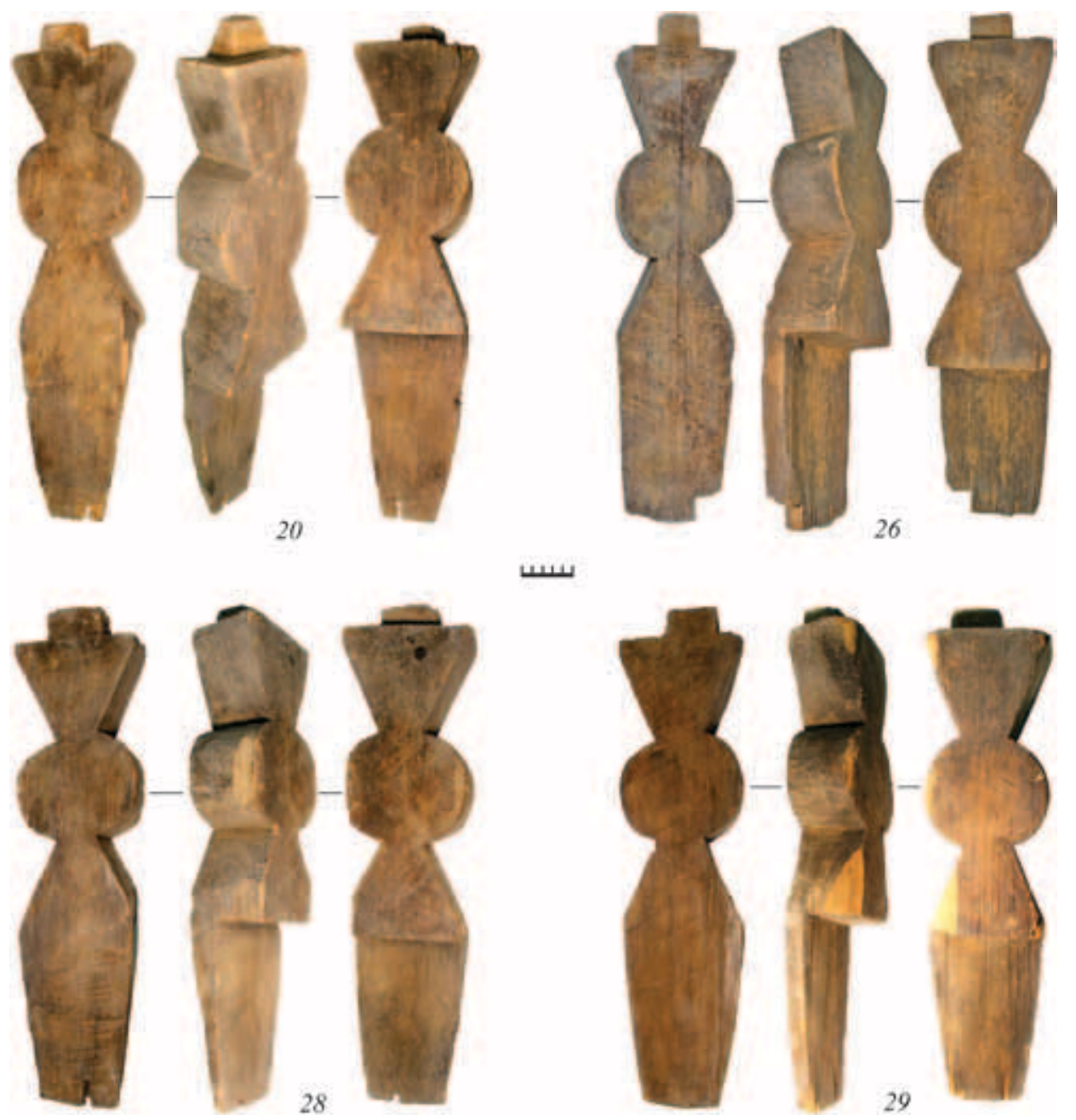

Рис. 2. Деревянные балясины от монашеских лавок. Археологические находки из Святительского корпуса Соловецкого монастыря, келья № 49 (1-я пол. XVIIв.). Слой 3 времени реконструкции кельи в 1801 г. (Номера на рисунке приведены по полевой описи)

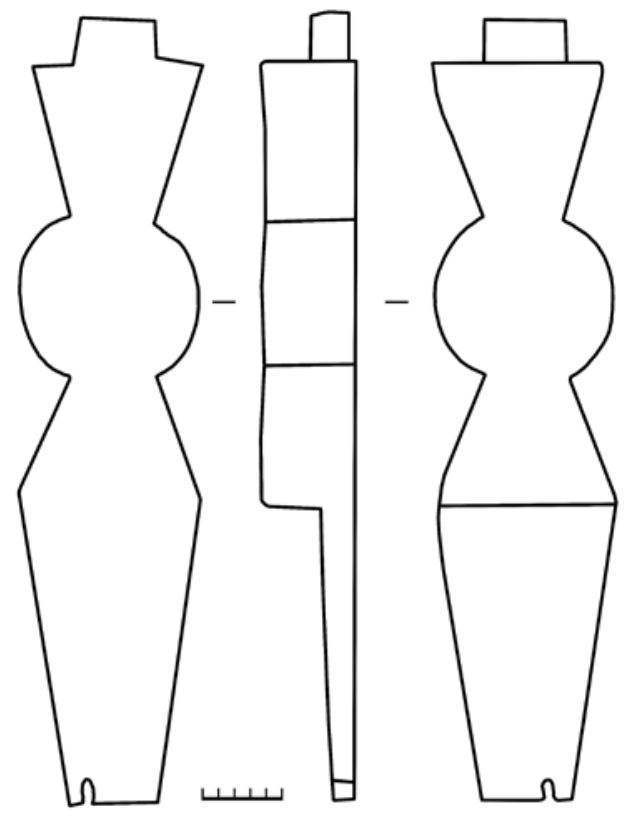

Однако в 2011 г. в ходе раскопок подпольного пространства в соседней келье № 49 были найдены не ножки от спальных лавок, а пять деревянных балясин с аналогичными фигурами (рис. 2; 3). Это указывает на совершенно иную конструкцию спальных мест в братских кельях Соловецкого монастыря. Высота балясин - в пределах 46,5-49,5 см, толщина - 5,5-7,0 см, ширина минимальная - 5,2-9,5 см, ширина максимальная 10,5-11,6 см (табл. 1). Дерево хорошо сохранилось, очень плотное, очевидно дуб.

Основные параметры фигурных балясин от спальных монашеских лавок из кельи № 49 Соловецкого монастыря из р. 4 Святительского 2011 г. приведены в таблице 1.

Рис. 3. Балясина № 27 из раскопок в Святительском корпусе Соловецкого монастыря 
Таблица 1. Основные параметры фигурных балясин от спальных монашеских лавок из кельи № 49 Соловецкого монастыря. Раскоп-4 Святительский. 2011 г. (Буров В. А., 2012. С. 39-46)

\begin{tabular}{|c|c|c|c|c|c|}
\hline \multirow{2}{*}{$\begin{array}{c}\text { № по } \\
\text { порядку }\end{array}$} & \multicolumn{4}{|c|}{ Размеры, см } & \multirow{2}{*}{$\begin{array}{c}\text { № по полевой } \\
\text { описи }\end{array}$} \\
\cline { 2 - 5 } & общая высота & ширина & толщина & диаметр круга & 20 \\
\hline 1 & 49,5 & $5,2-11,6$ & $6,0-6,5$ & 11,7 & 26 \\
\hline 2 & 46,5 & $9,5-11,4$ & 7,0 & 11,4 & 27 \\
\hline 3 & 47,2 & $5,7-11,0$ & 5,5 & 11,0 & 28 \\
\hline 4 & 47,2 & $7,5-10,5$ & 7,0 & $9,0 \times 11,5$ & 29 \\
\hline 5 & 47,6 & $7,2-10,8$ & $5,5-6,0$ & $9,2 \times 11,0$ & \\
\hline
\end{tabular}

Балясины залегали в сухом слое 3 серо-желтого песка, который стратиграфически относился к первой крупной перестройке кельи 1801 г. О ней известно следующее: «Переправлены в монастыре с полуденной стороны по одной линии с новою больницею на старом фундаменте каменныя двухэтажныя пространныя келии на обе стороны с окнами: верхния для ризничаго, и при них портная, а нижния для пребывания братии; внутри оштукатурены и снаружи выбелены» (Паисий, 1821. С. 81, 82; Досифей, 1833. С. $129 ; 1836$. С. 245). Это позволяет уверенно датировать балясины по крайней мере XVIII столетием.
Как и на реконструированных лавочных ножках, в центре балясины расположен диск, от которого в противоположные стороны отходят фигуры коротких равнобедренных трапеций. Широкое основание нижней трапеции переходит в зауженный шип толщиной в половину доски, который предназначен для вставки в паз. Противоположную, верхнюю трапецию венчает короткий шип, также конструктивно предназначенный для паза. Данные находки меняют наше представление о внешнем облике и конструкции монашеских лавок в Соловецком монастыре. Не было никаких фигурных

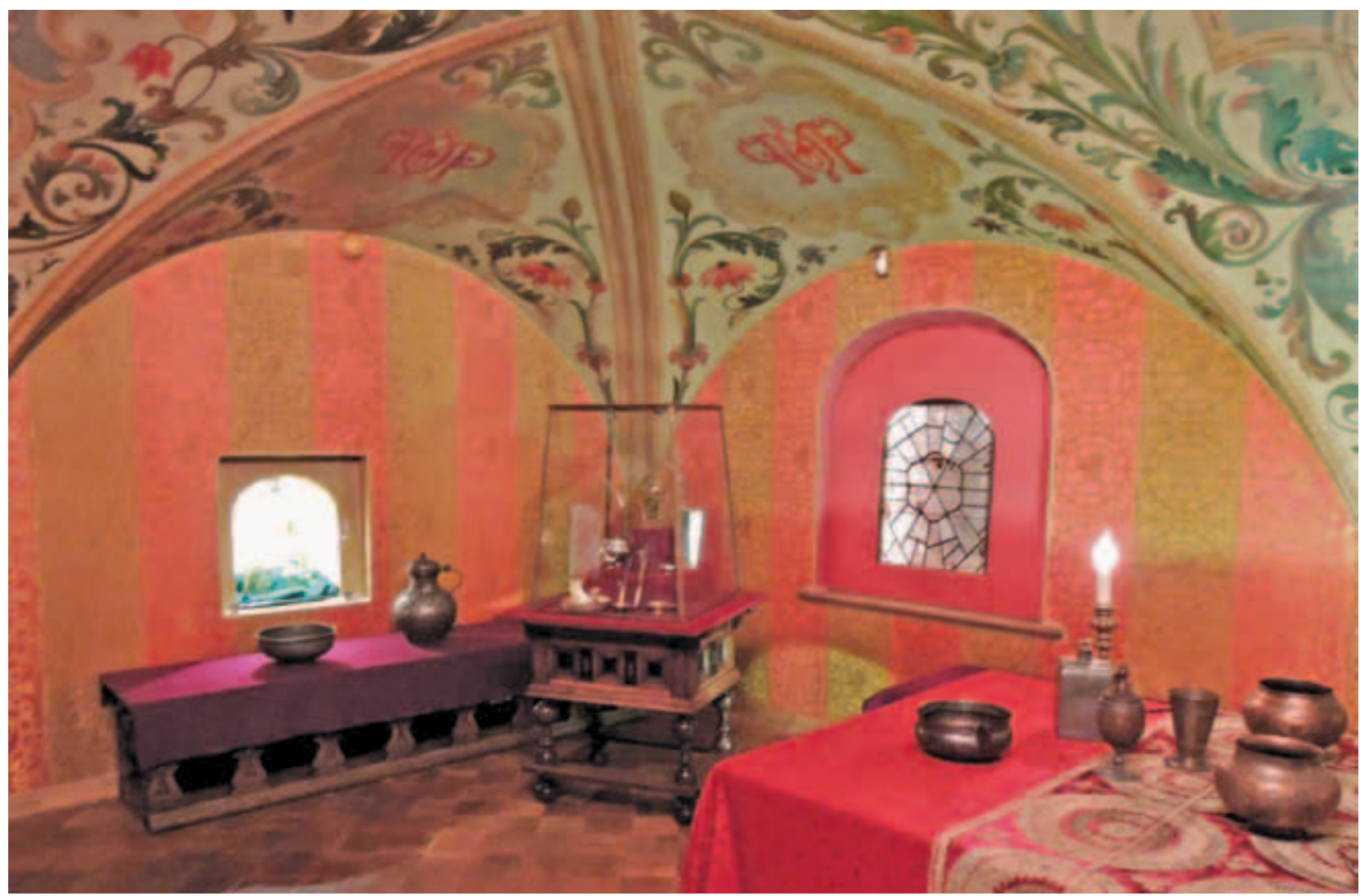

Рис. 4. Свечной ларь 2-й пол. XVII в. с фигурными балясинами.

Экспозиция музея-заповедника «Ростовский кремль». Фото 2018 г. 


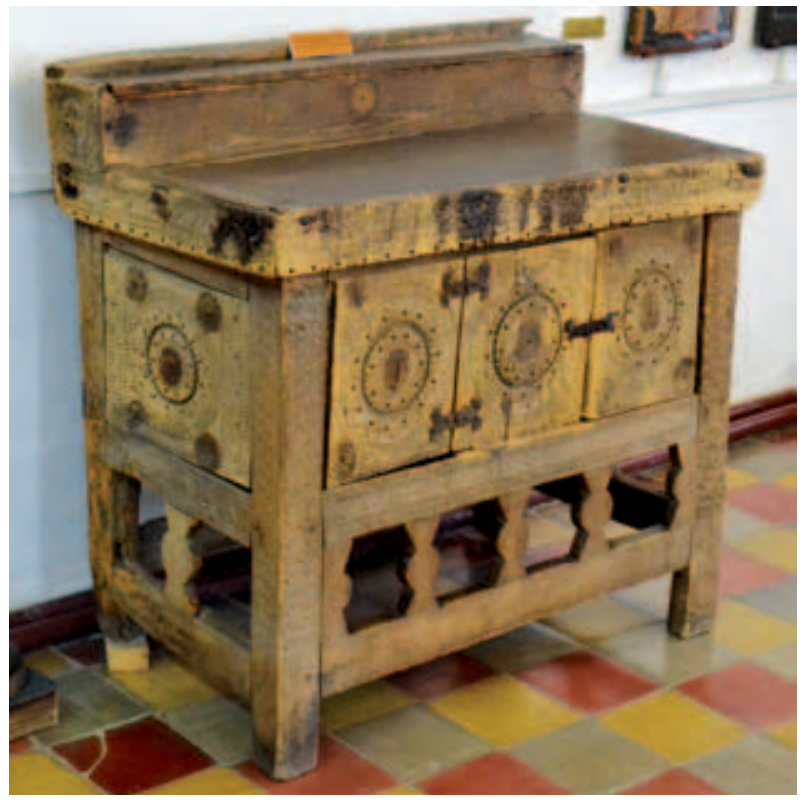

Рис. 5. Лавка с фигурными балясинами в экспозиции музея «Палаты бояр Романовых» (ГИМ, Москва). Музейная реконструкция ножек, к тому же достаточно неустойчивых. Здесь была применена конструкция из рам со вставленными в них вертикально балясинами. Сама рама крепилась по бокам к мощным ножкам. При этом рама могла стоять на полу или быть приподнятой на некотором расстоянии от него. Конструкция из рамы со вставленными аналогичными по форме балясинами широко применялась не только в лавках, скамьях, но и в столах, аналоях, ткацких станках, кониках (Бобринский А. А., 1911. Табл. 6, 2,$3 ; 8,3 ; 13,7 ; 32,1 ; 23,1-3 ; 26,1-4 ; 96,1,2 ; 109$, 4; 117, 5). В качестве показательного примера приведем свечной ларь второй половины XVII в., представленный в экспозиции музея-заповедника «Ростовский кремль» (рис. 4). А в музее «Палаты бояр Романовых» на Варварке в Москве можно ознакомиться с иной конструкцией лавки. Балясины соединяли верхнюю и нижнюю горизонтальные рамы из бруса. Поверх верхней рамы крепились доски спального ложа (рис. 5). Но это уже поздняя музейная реконструкция.

\section{Литература}

Бобринский А. А., 2011. Народные русские деревянные изделия. Предметы домашнего, хозяйственного и отчасти церковного быта. М.: Издательство В. Шевчук. $264 \mathrm{c}$.

Буров В.А., 2011. История келейной застройки Соловецкого монастыря XV-XIX веков. Архангельск: б/изд. 490 с.

Буров В.А., 2012. Отчет об археологических раскопках на территории Соловецкого монастыря Приморского района Архангельской области в 2011 году / Архив ИА РАН. Р-1.

Досифей, 1833. Летописец Соловецкий на четыре столетия от основания Соловецкого монастыря до настоящего времени, то есть с 1429 по 1833 год. Изд. 3. М.: В Университетской Типографии. 175 с.

Досифей, 1836. Географическое, историческое и статистическое описание Ставропигиального первоклассного Соловецкого монастыря и других подведомых сей обители монастырей, скитов, приход- ских церквей и подворьев, с присовокуплением многих царских, патриарших и других, знаменитых гражданских и духовных лиц граммат, относящихся к истории сего монастыря, составленное трудами Соловецкого монастыря архимандрита Досифея. Ч. 1. М.: В Университетской Типографии. 444 с.

Книга переписная келий старцев казначея Саввы и будильщика Боголепа при игумене Маркелле. 1641-1674 гг. / РГАДА. Ф. 1201. Оп. 1. Д. 455.

Критский Ю.М., Мельник А.Г., 1983. Из опыта изучения и музеефикации интерьера кельи XVII в. Соловецкого монастыря // Актуальные проблемы развития историко-архитектурных и природных музеев-заповедников. (Тез. докл. II Межреспубликанской школы-семинара молодых ученых по проблемам современного музееведения.) Архангельск. C. 71-73.

Паисий, 1821. Летописец Соловецкий. Изд. 2-е. М.: В типографии Пономарева, 1821. 87, [1] с. 


\section{Деревянные изделия из раскопок храма у села Веселое под Адлером}

Раскопки в 2010-2011 гг. христианского храма X-XI вв. у с. Веселое под Адлером, памятника византийского круга, построенного в традициях абхазской школы ${ }^{1}$, принесли две неожиданные для Северо-Восточного Причерноморья находки, которые заслуживают пристального внимания. Это два деревянных изделия - точеная чаша и резная доска, поднятые из каменного колодца, обнаруженного у юго-западного угла храма и полностью исследованного в 2011 г. $^{2}$ Предметы из дерева в культурном слое здешних археологических памятников практически отсутствуют, что говорит о неординарности данных находок.

Колодец расположен в непосредственной близости к храму, примыкая с юга к вымощенной камнем площадке перед южным входом в нартекс. В дошедшем до нас руинированном виде он представляет собой каменное сооружение, образующее в плане неправильную трапецию с прямыми северо- и юго-западными, тупым юго-восточным и острым северо-восточным углами. Длина его северной стороны по верху равна 4,52 м; длина других сторон колеблется от 4,85 до 4,15 м по фундаменту. Внутри сооружения ближе к его северной стенке находится вертикальная, аккуратно сложенная из камня круглая в поперечном сечении колодезная шахта. Размеры ее округлого устья $-45 \times 48$ см. По мере заглубления шахта постепенно расширяется до 155 см в 3 м от верха, а затем резко сужается в придонной части до $80 \mathrm{~cm}$. Таким образом, она имеет асимметричное биконическое вертикальное сечение, ее максимальный диаметр приходится на нижнюю часть. Пространство между аккуратно выложенными стенками шахты и внешними фасами сооружения забутовано известковым раствором с включением мелких камней и горизонтально, но бессистемно уложенных подтесанных каменных плит. Первоначальный вид и высота сооружения не ясны, возможно, оно было ступенчатым наподобие стилобата.

Сооружение перекрывал слой разрушения в виде серовато-коричневой супеси с крупными песчаниковыми плитами из развала стен. В глубину колодец был раскопан на 3,3 м до появления грунтовых вод. Его заполняла темно-коричневая супесь с включениями черепков бытовой керамики - неполивных круговых красноглиняных кувшинов (в том числе одного расписного), венчика пифоса и осколка поливного белоглиняного сосуда с желтой росписью. Кроме того, туда попали единичные обломки черепицы, железные кованый гвоздь и обрывок цепи из трех S-видных звеньев, а также фрагмент неопределенного изделия из гипсового раствора, осколки разноцветных оконных дисков и донце стеклянного сосуда. Оба деревянных предмета происходят из мокрого нижнего слоя заполнения колодца, благодаря чему без доступа воздуха они сохранились, как и подобные артефакты в культурном слое древнего Новгорода. Таков археологический контекст этих деревянных изделий из Веселого. В целом, исходя из стратиграфических условий, все находки из колодца у храма можно отнести к закрытому комплексу.

Первое изделие - это выточенная на токарном станке круглая чаша на плоском низком дисковидном поддоне (рис. 1; 2). Ее стенки плавно расходятся,

\footnotetext{
${ }^{1}$ О храме см.: Армарчук, Мимоход, Седов, 2012. С. 78-90; Армарчук, Мимоход, Седов, 2015. С. 318-319.

2 Считаю своим долгом выразить благодарность реставраторам обеих находок - Л.В. Кокуце (мастерская по консервации мокрой археологической древесины Новгородского государственного музея-заповедника) и Н.П. Синицыной (ВХНРЦ им. ак. И.Э. Грабаря). В настоящее время находки переданы в Музей истории города-курорта Сочи (главный хранитель - Е. В. Галищева).
} 

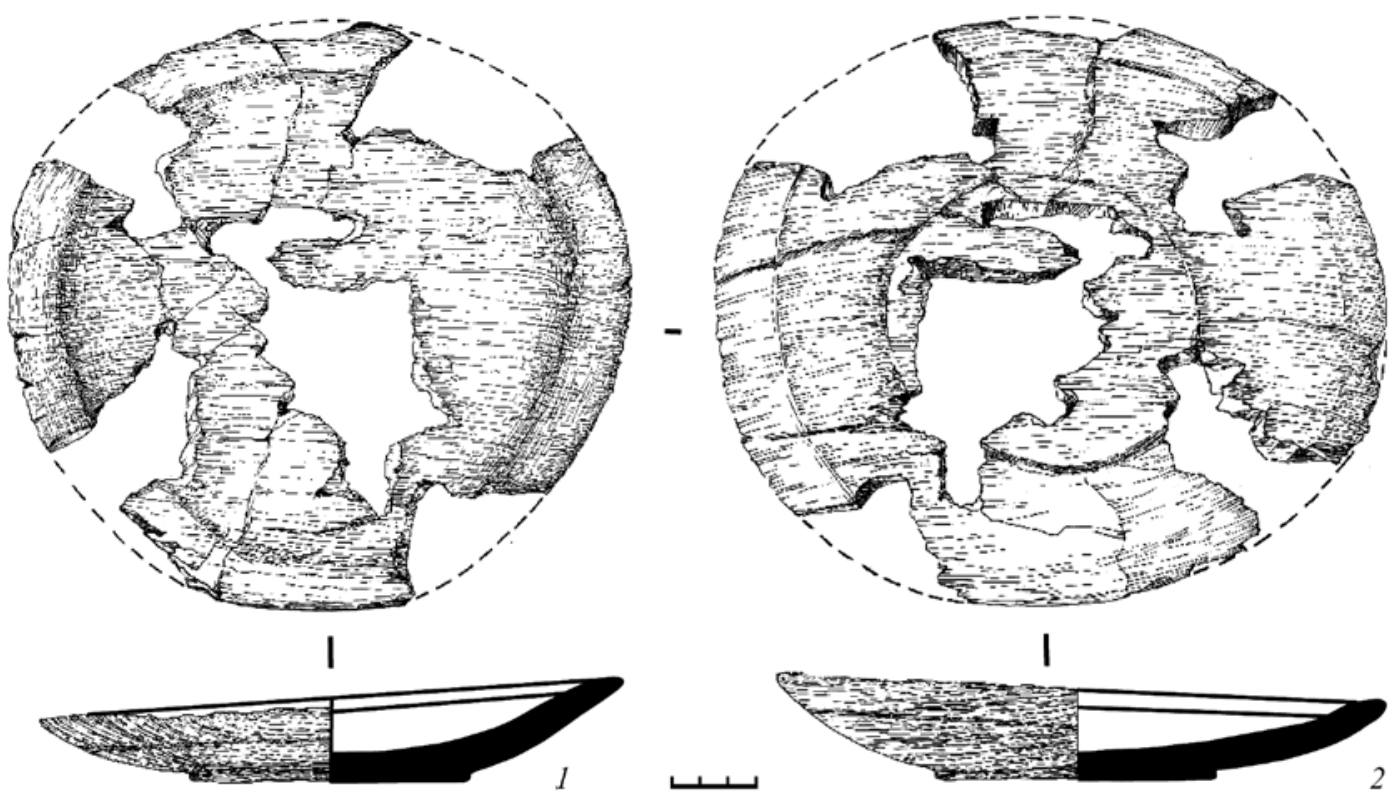

Рис. 1. Точеная чаша из колодца в Веселом. Рис. А.Н. Лехницкой 1 - вид внутри; 2 - вид снаружи

образуя сегментовидный профиль сосуда. Диаметр чаши составляет от 20,7 до 22,0 см; диаметр поддона равен 10 см при его высоте 0,3 см. Общая высота чаши -3 см. Ее край имеет уплощенный, чуть наклонный внутрь бережок шириной 1,8-2,0 см (рис. 1,$1 ; 2,1)$. Снаружи на стенках в 2 см от края наблюдается врезная неглубокая бороздка по всей окружности (рис. 1; 2, 2). Другой отделки, кроме этого простого линейного декора, у чаши нет.

Врезная контурная орнаментация нередко украшала обычную бытовую деревянную посуду в отличие, например, от профилирования (фигурного формообразования), применявшегося для парадных сосудов (Сергеева, 2010. С. 398). Такой внешний врезной «поясок» наблюдается под венчиком чаши из Киева домонгольского времени (Сергеева, 1998а. Рис. 3, 1). Этим линейным орнаментом издавна украшались токарные сосуды, особенно широко - в Центральной и Западной Европе в период Средневековья (Сергеева, 1998б. С. 87). Об изготовлении данной чаши на токарном станке говорят два характерных признака,

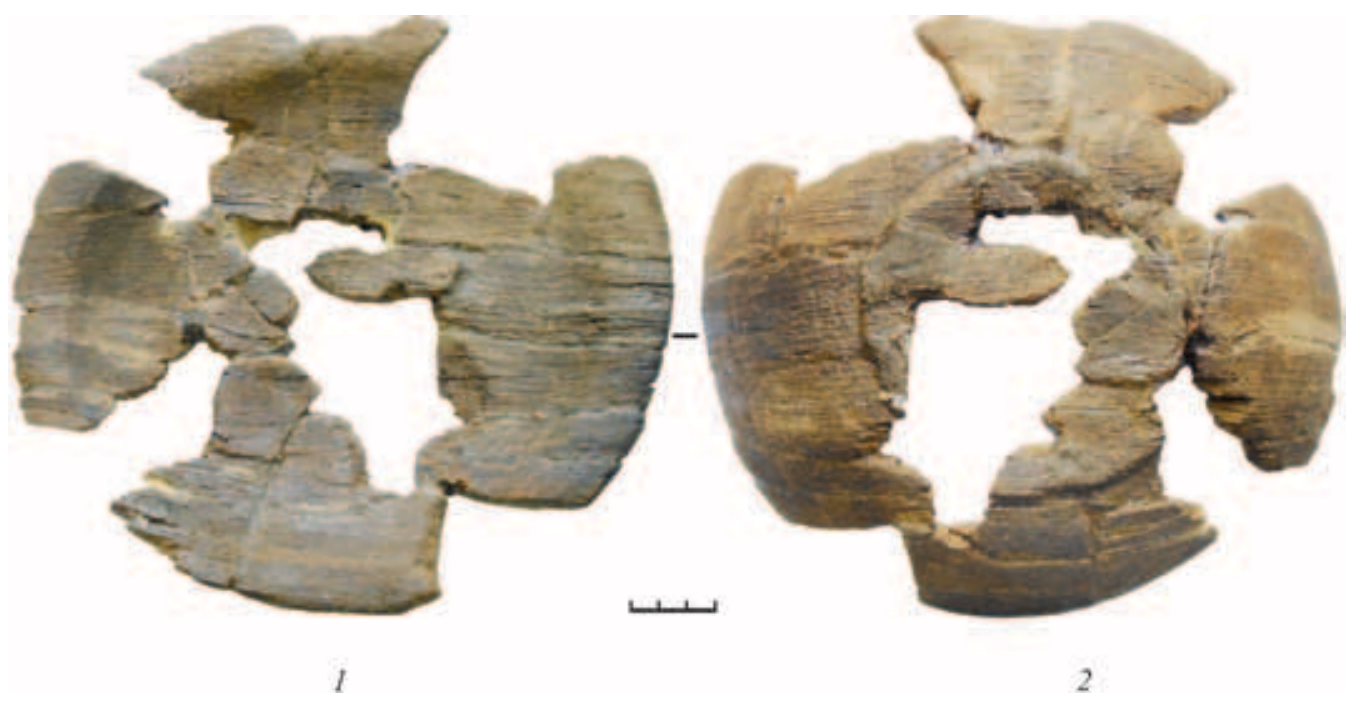

Рис. 2. Чаша из колодца в Веселом. Фото автора 1 - вид внутри; 2 - вид снаружи 


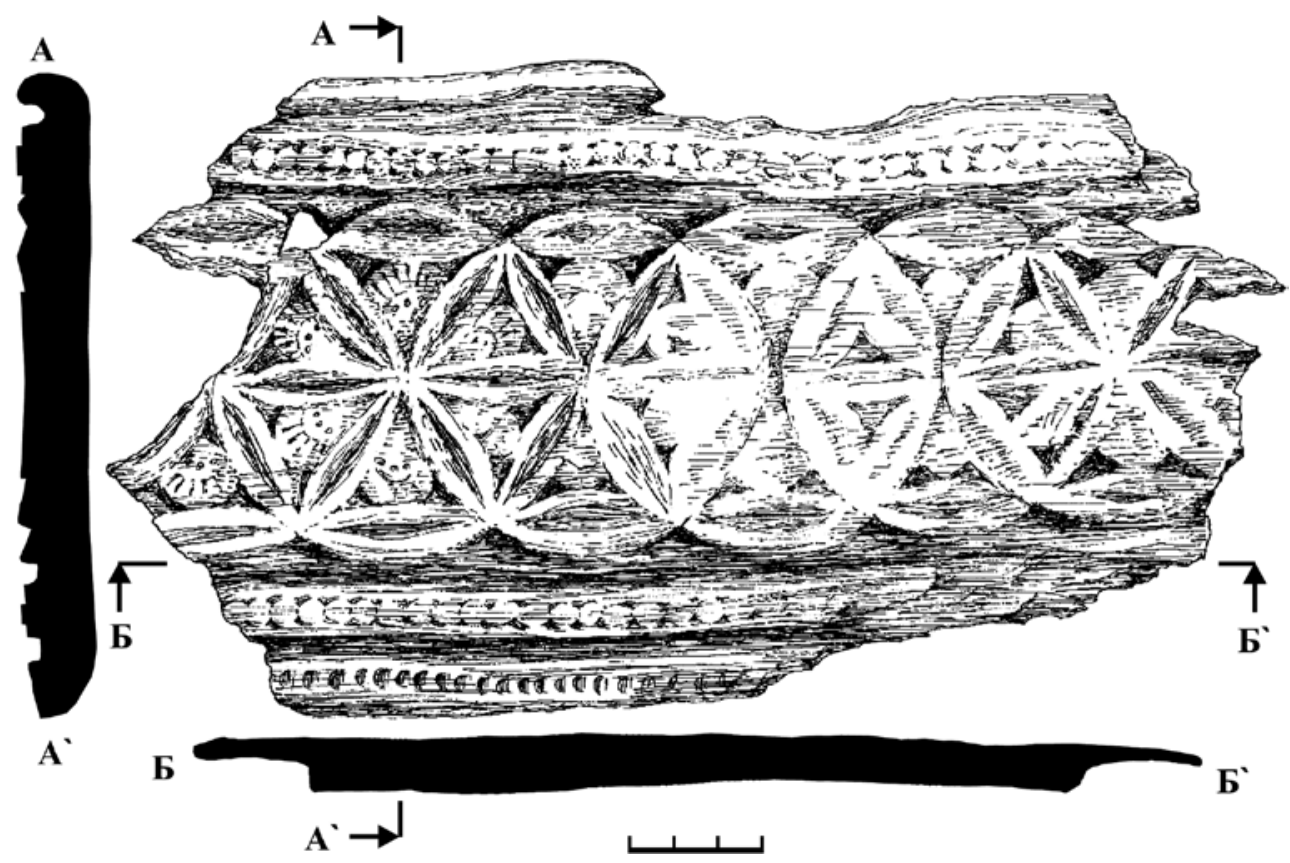

Рис. 3. Резная доска из колодца в Веселом. Рис. А.Н. Лехницкой

на которые указал Б. А. Колчин при исследовании родственных новгородских материалов: концентричность всех линий на поверхности сосуда и повторение по кругу его формы и профиля (Колчин, 1968. С. 31). В связи с этим полагаю, что наблюдаемая небольшая асимметричность этой чаши объяснима ее деформацией из-за длительного пребывания в сыром слое.

Сравнение с новгородской средневековой деревянной посудой показывает отсутствие прямых морфологических совпадений: чаша из Веселого в отличие от новгородских блюд не имеет широких бортиков с отогнутым плоским краем, но близка к ним по высоте, а приближаясь по профилю к чашам, она не имеет их доминирующих пропорций 1:4 и 1:3 (отношения $h$ к d). Однако в целом эта чаша соотносима с мелкими новгородскими чашами, бытовавшими, как минимум, с XI в., для которых характерна большая приплюснутость, плоский низкий поддон и почти прямой венчик (Колчин, 1968. С. 32. Табл. 16, 16). Она также сопоставима с мисками второго вида, которые появляются в Новгороде в конце XI в. и используются затем в XII-XIII вв. (Розенфельдт, 1997. С. 45. Табл. 32, 14).

Чаша из Веселого отличается от токарной столовой посуды из древнерусских памятников Среднего Поднепровья отсутствием кольцевидного поддона, который является характерным признаком последней и имеет заметную высоту около сантиметра (Сергеева, 1998а. С. 123). Среди этой посуды нет морфологических совпадений с данной чашей.
В мастерской по консервации археологической древесины при Новгородском государственном музее-заповеднике микроскопическим методом по признакам анатомического строения была определена таксономическая принадлежность древесины, из которой выточена чаша. В итоге сделано следующее заключение: порода данного предмета - ольха (Alnus sp.), перфорации сосудов лестничные, сосудистая поровость точечная и переходная, сосуды малые, группирующиеся, рассеянные, лучи гомогенные однорядные и агрегатные.

Второе изделие из Веселого представляет собой фрагментированную резную доску с неровно обломанными концами (рис. 3 ; 4). Она имеет подпрямоугольную форму; ее ширина равна $15 \mathrm{~cm}$, длина достигает 26 см, но изначально была большей. Средняя часть доски на протяжении $18 \mathrm{~cm}$ более толстая. С тыльной стороны хорошо видны ограничивающие ее уступы во всю ширину, из-за чего изделие имеет неровный продольный профиль (рис. 4). Максимальная толщина доски - от 1,2 до 1,7 см; за пределами выступа она уменьшается от 0,5 до 0,2-0,4 см.

На лицевой стороне доски сохранился вырезанный на всей ее поверхности растительно-геометрический орнамент (рис. 4). Он представляет собой непрерывную полосу смыкающихся, расположенных в один ряд кругов диаметром от 8,0 до 8,5 см со вписанными в них шестилепестковыми розетками. При этом сами окружности образованы не одинарной линией, а шестью 

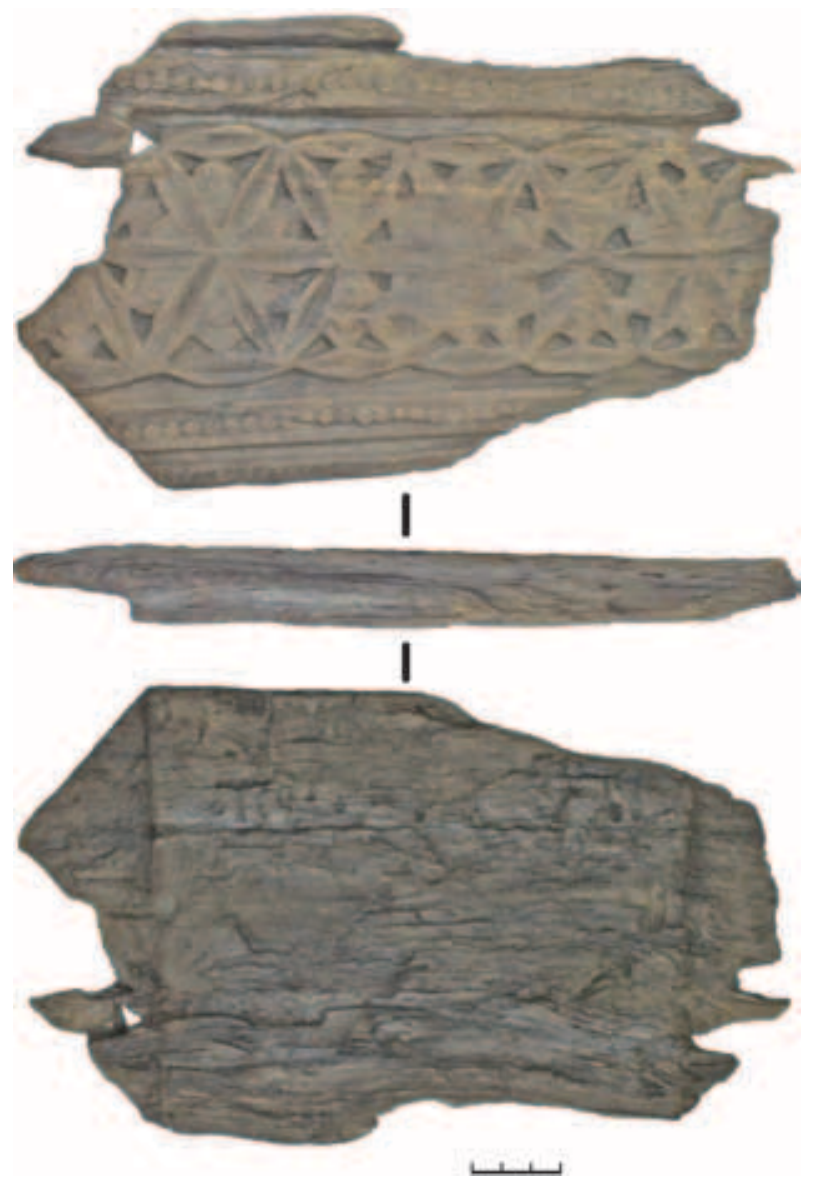

Рис. 4. Резная доска из колодца. Фото автора

такими же удлиненными, узкими и заостренными лепестками, из каких состоят розетки. Внутри розеток промежутки между их узкими лепестками заполняют шесть округлых, коротких и более широких лепестков. Они украшены контурной резьбой в виде мелких циркульных кружочков и радиально направленных линейных штрихов (рис. 5). По одному такому широкому лепестку вырезано также вверху и внизу между кругами.

Полосу кругов с розетками окаймляют бордюры в виде ленты с цепочкой мелких дисков, по одному вдоль длинных сторон доски. Ширина «лент» равна сантиметру, диаметр дисков - не более 0,5 см. Вдоль одной продольной стороны доски между ее краем и «лентой» с дисками вырезан второй бордюр в виде цепочки дуговидных выемок, в длину не превышающих 0,5 см. Кроме того, на лицевой стороне примерно посреди утолщенной части доски наблюдается поперечная потертость, где узор несколько стерт, сглажен.

В соответствии с наблюдениями Б. А. Колчина, сделанными при изучении им находок из раскопок древнего Новгорода, обработку данной доски следует отнести к плоскорельефному виду плоскостной резьбы по дереву, известному в Новгороде с середины Х в. (Колчин, 1971. С. 9). Такая резьба отличается небольшой рельефностью и направлена как бы вглубь материала, что хорошо показывает и наша доска, у которой эта резьба сочетается с контурной. В отличие от вида резьбы, узор на доске не имеет параллелей среди каких-либо новгородских средневековых деревянных изделий (Wood... 2007).

Прямые аналогии орнаменту доски из Веселого пока не найдены, чего нельзя сказать о его составных элементах. Главный из них, розетки, являются распространенным мотивом в прикладном искусстве Византии и стран Закавказья (с произведениями которых в первую очередь надо сопоставить эту резную доску), но их изображения и число лучей-лепестков весьма разнообразны. Так, мелкие рельефные восьмилучевые розетки - показательный элемент на резных костяных пластинах-обкладках деревянных, так называемых розеточных, византийских ларцов X-XI вв. (рис. 6), найденных

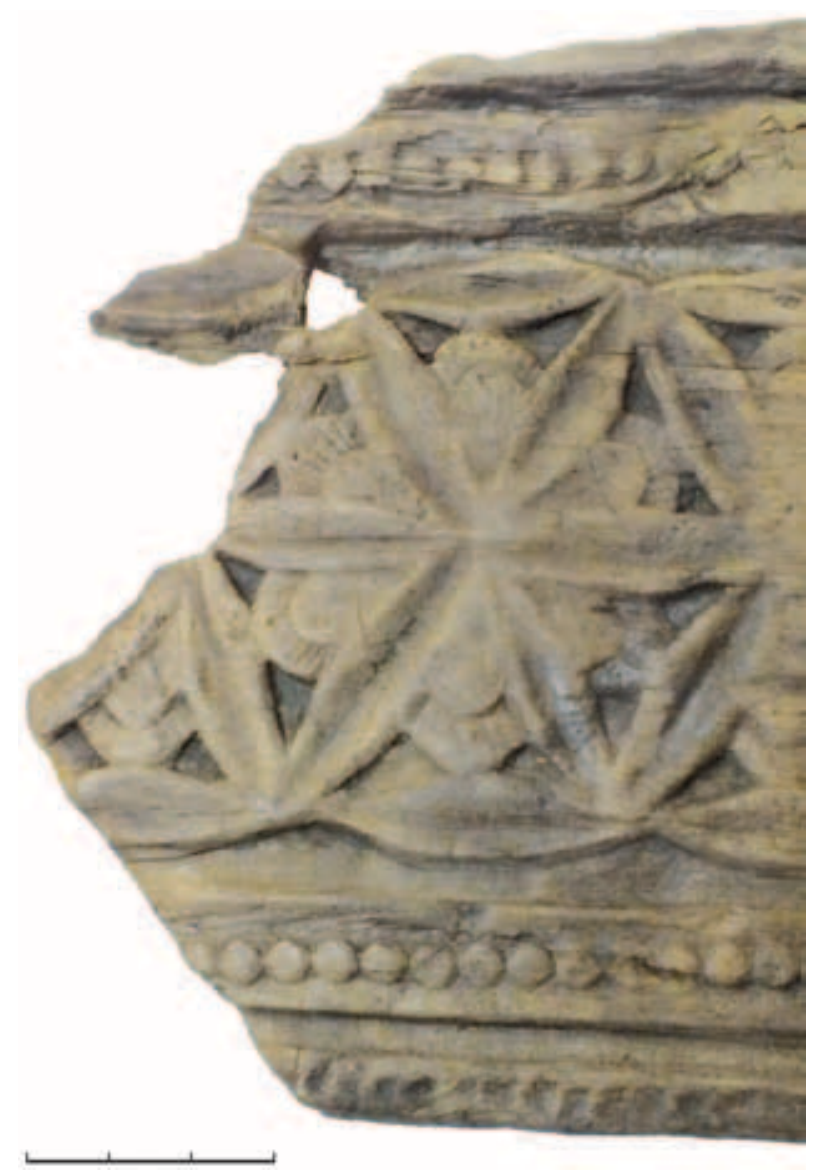

Рис. 5. Фрагмент резной доски со следами контурной резьбы 

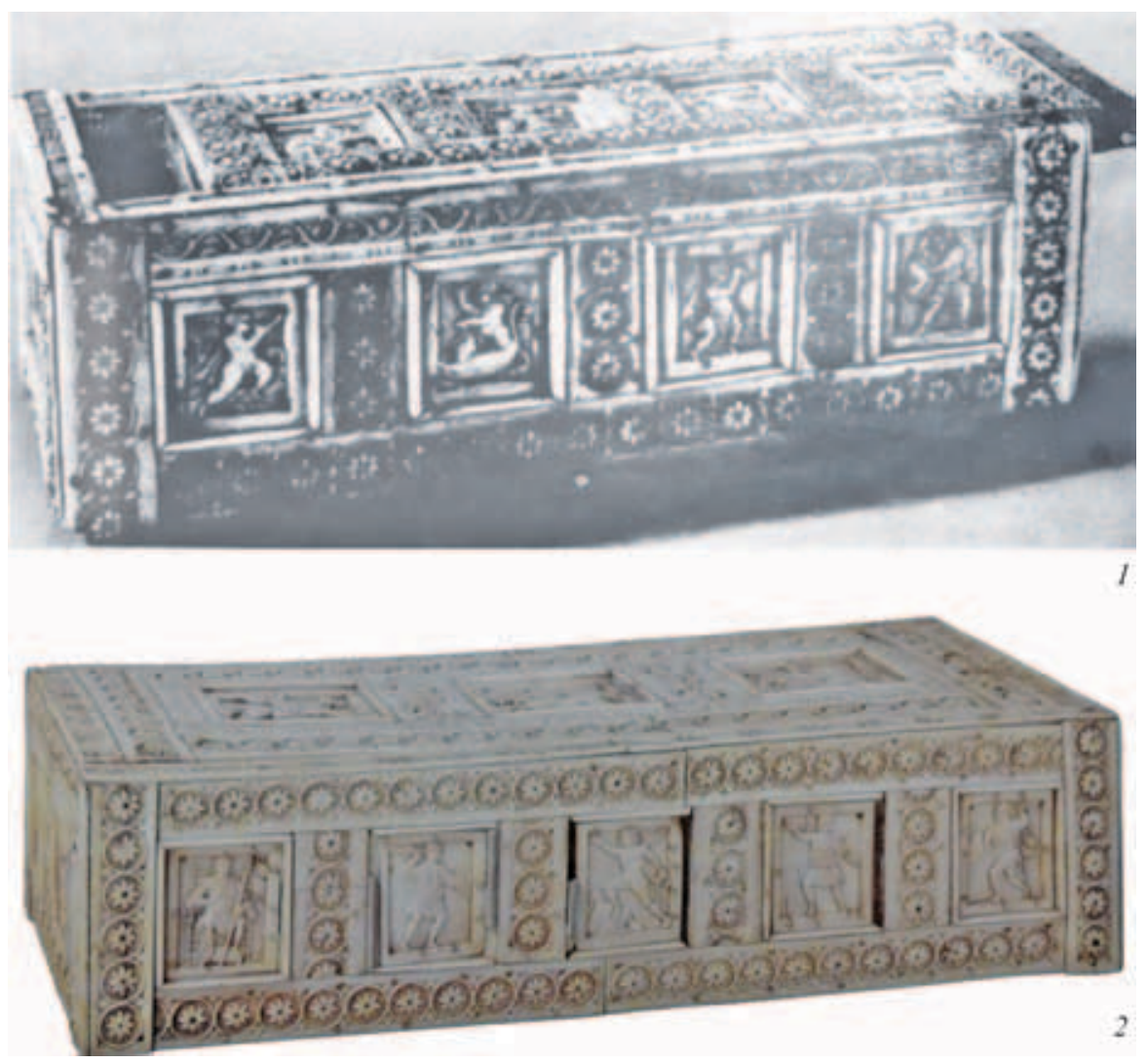

Рис. 6. Византийские ларцы с костяными накладками

1 - ларец с выдвинутой крышкой ХІ в., ГЭ (по: Искусство Византии... 1977. С. 108. № 603);

2 - ларец X-XI вв., Metropolitan Museum of Art (по: The Glory of Byzantine, 1997. Р. 232-233. № 155)
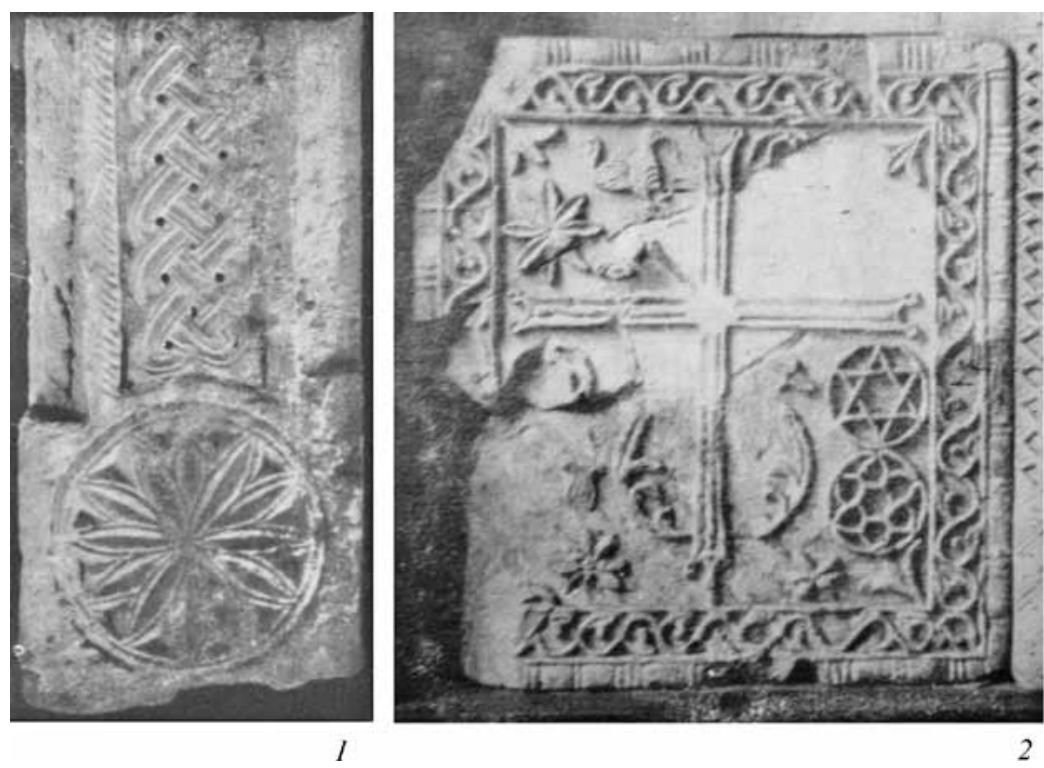

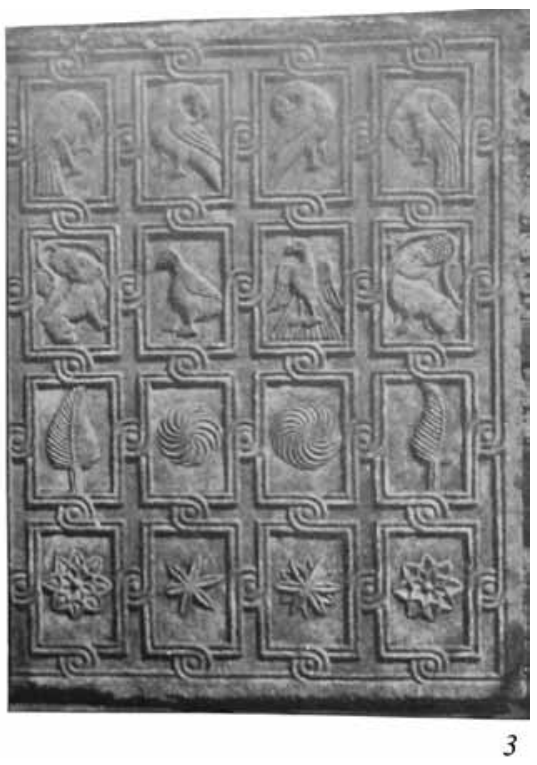

Рис. 7. Розетки в каменной резьбе

1 - столбик алтарной преграды Х в. из Салхино; 2 - плита алтарной преграды Х в. из Потолети (по: Шмерлинг, 1962. Табл. 16, 22); 3 - мраморная плита из храма в Нерезе 2-й пол. ХІІ в. (по: Окунев, 1929. Табл. II) 

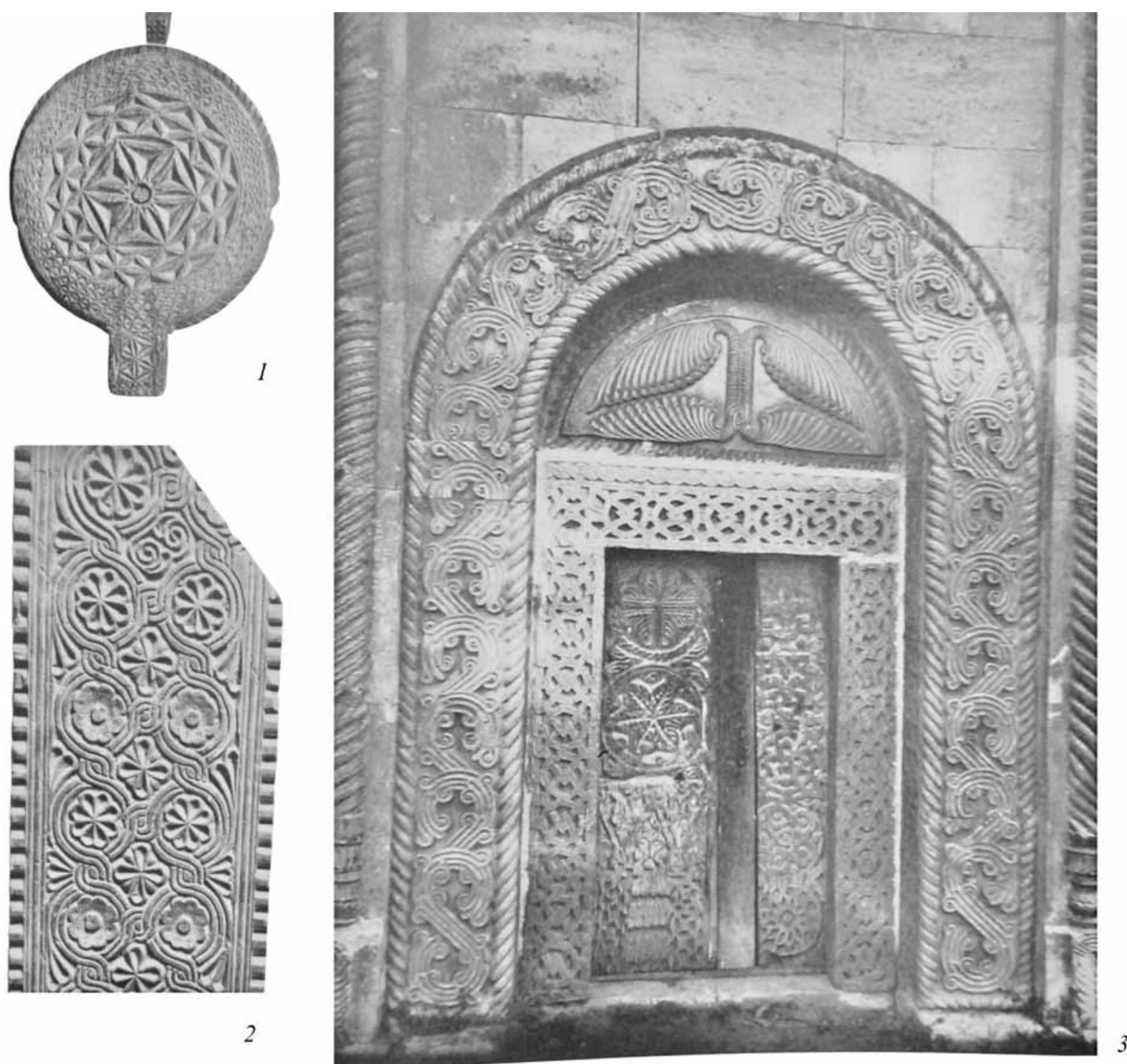

Рис. 8. Розетки в грузинской резьбе X-XI вв. по дереву

1 - на табакорезке; 2 - на фрагменте дверной рамы из Ркони; 3 - на двери из Саване (по: Чубинашвили, 1958. Табл. 6, 71, 63)

на территории империи и за ее пределами и занявших видное место в мировых музеях (Diehl, 1910. Fig. 172, 303; Банк, 1978. С. 82-83; Искусство Византии... 1977. № 598, 600, 601, 603; The Glory of Byzantium, 1997. P. 228-233. № 152, 153, 155, 157; Rom und Byzanz, 1998. S. 192-194. № 55).

Этот мотив был весьма востребован в архитектурной каменной резьбе периода IX-XII вв. на территории Абхазского царства, Закавказья и Византии (Ендольцеева, 2011. С. 184). Приведу лишь некоторые примеры: шестилучевая розетка в круге на капители приапсидной пилястры средневекового храма Кзыл Килиса в окрестностях городища Дманиси в Грузии (Джапаридзе, 1976. Табл. LXI-1); многолучевые розетки на плитах преград - парапетов из Торчелло и Лавры эпохи IX-XII вв. (Diehl, 1910. Fig. 205, 206); заключенная в круг розетка со множеством узких лучей на столбике алтарной преграды Х в. из Салхино (рис. 7, 1) и восьмилучевые разнотипные розетки на плите алтарной преграды из храма Х в. в Потолети (рис. 7, 2) (Шмерлинг, 1962. С. 53, 99-101. Табл. 16, 23). Розетка с шестью длинными узкими лепестками, аналогичная розетке на доске из Веселого, вырезана на большой мраморной плите из сербской церкви Св. Пантелеймона в Нерезе второй половины XII в. (рис. 7, 3), где она сочетается с иными вариантами этого мотива (Окунев, 1929. С. 10-11, 15. Табл. II). 


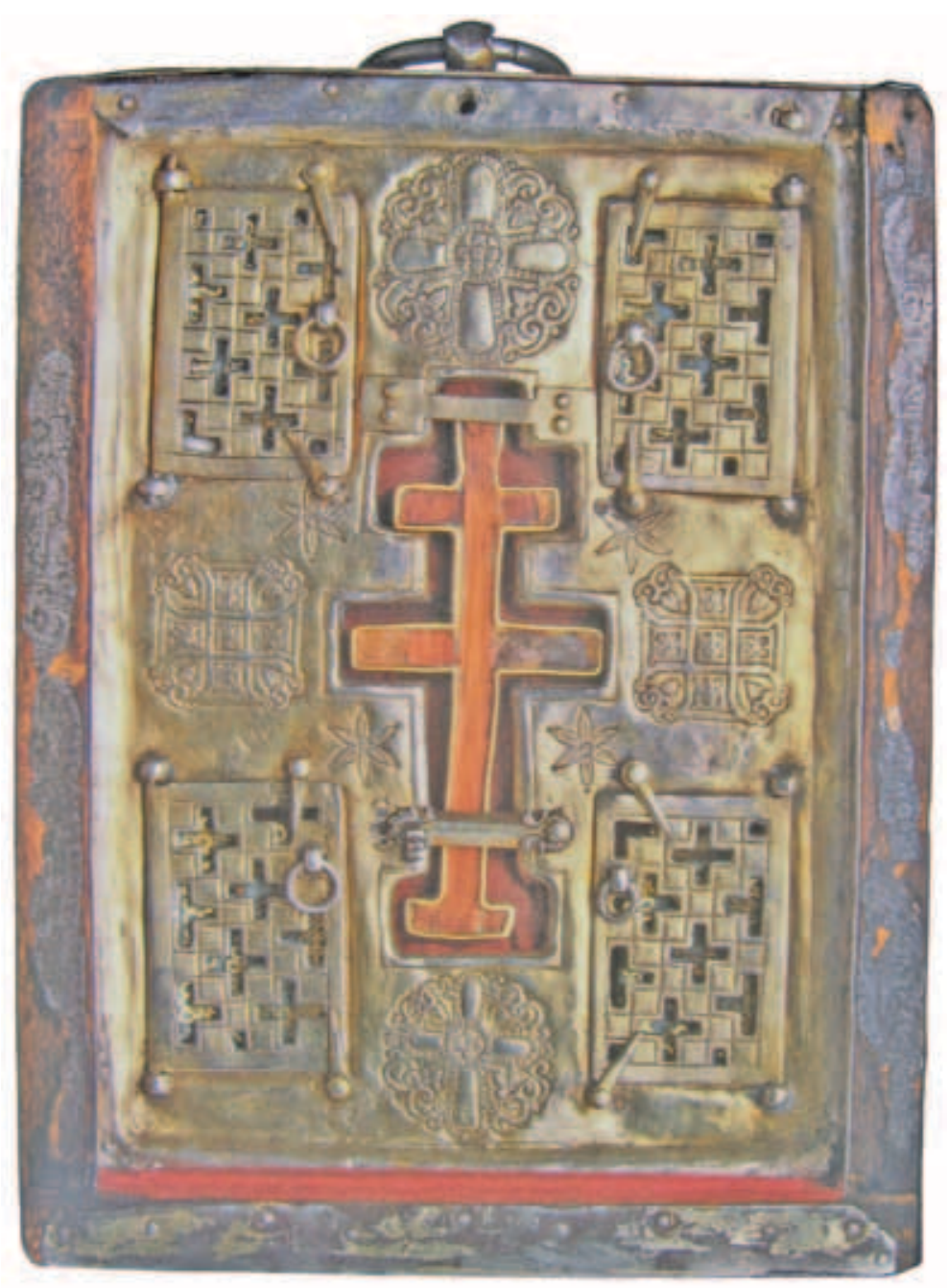

Рис. 9. Ставротека из Баварского Национального музея в Мюнхене (по: Rom und Byzanz, 1998. S. 153. № 27)

Шести- и многолучевые розетки встречаются на грузинских изделиях из дерева, будь то бытовые предметы, например доска-табакорезка (рис. 8, 1), или такие детали построек, как балки, двери и их коробки (рис. 8, 2, 3), датируемые в рамках X-XI вв. (Чубинашвили, 1958. Табл. 6, 17, 63, 70, 134).

Обращают на себя внимание четыре розетки с шестью узкими лепестками, выгравированные на металлической обкладке ларца-ставротеки, изготовленного в Константинополе на рубеже XI-XII вв. (Rom und Byzanz, 1998. P. 133. № 27). По иконографии они весьма близки розетке на доске из Веселого (рис. 9).

Другой элемент композиции, то есть «лента с дисками-пуговками», обычно играет в декоре не основную, а второстепенную роль и используется для бордюров и рамок орнаментальных медальонов, что показывает и находка из Веселого. Она стабильно встречается в средневековой резьбе по камню и дереву в Закавказье и Византии, а также на синхронном византийском текстиле. Эти «ленты» являются достаточно показательными в нашем случае и помогают датировать доску благодаря их аналогиям. Перечислю следующие: такая же кайма обрамляет прямоугольные панно на полотнищах двухстворчатой деревянной двери из пещерного храма Спаса Гвимского монастыря в Грузии, отнесенного в давней публикации к XIII в. (Церетели, 1898. С. 92-93. Табл. Х). Аналогичные «пуговки» можно видеть в орнаментальной ленте плетения и рамках на створках храмовых дверей из горных селений Оциндале (рис. 10), Джахундери (рис. 11) и Чукули (рис. 12) в Сванетии (Чубинашвили, 1958. С. 18-19, 20-22, 35. Табл. 32-35, 43-56). Важно, что эти три двери датируются первой четвертью XI в. на основе разностороннего анализа резьбы, орнаментации и их совпадения с другими средневековыми памятниками грузинского 


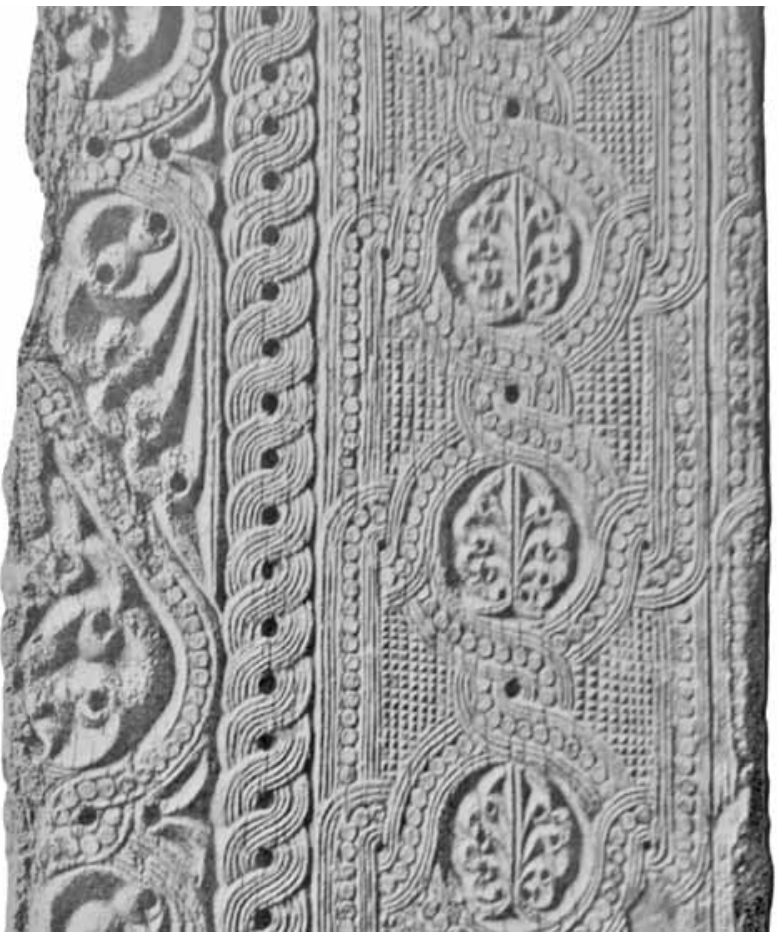

Рис. 10. Фрагмент резной двери из Оциндали (по: Чубинашвили, 1958. Табл. 32)

искусства (Чубинашвили, 1958. С. 17, 20, 22, 37). К этому перечню добавлю дверь из селения Аци с аналогичными бордюрами (Чубинашвили, 1958. С. 72-74. Табл. 58, 58a). В качестве рамки-абриса «с перлами» этот элемент можно часто видеть на византийских шелках X-XII вв. (напр., см.: Rom und Byzanz, 1998. P. 230, 232. № 66, 73, 74).

Второй вид обработки изделия из Веселого - контурная резьба, очень мелкая и локальная, так как ею украшены только широкие лепестки внутри розеток (см. выше). Большая ее часть стерта в результате использования предмета, в результате чего ее можно разглядеть лишь на отдельных лепестках. Эта резьба включает расположенные по дуге циркульные окружности диаметром 2 мм и короткие радиальные линейные штрихи над ними, что в совокупности, вероятно, имитирует тычинки цветка (рис. 5). Такой мелкий узор предполагает рассматривать его с близкого расстояния.

По наблюдениям М.С. Сергеевой, циркульные кружки вместе с простыми линиями являются наиболее распространенным орнаментальным мотивом на предметах из дерева и кости. Ею замечено, что на изделиях X-XI вв. из лесостепного Поднепровья циркульный орнамент чаще сочетается с линейным, а в XII-XIII вв. он становится более самостоятельным (Сергеева, 1998б. С. 89-90).
Это как бы подтверждает и единичная находка из Веселого.

В завершение скажу, что функциональная трактовка данной находки затруднительна, а отсутствие прямых или полных аналогий пока мешает уверенно ее атрибутировать. Использование этой доски как декоративного элемента интерьера (например, настенного фриза) или архитектурной детали приходится отвергнуть, во-первых, изза небольшой ее толщины, специфического выступа на тыльной стороне и мелкой контурной резьбы в ее орнаментации, не рассчитанной на дистанционное восприятие. Во-вторых, из-за своеобразной потертости на лицевой поверхности. Также трудно принять эту доску за фрагмент какой-то рамы.

Bce перечисленные признаки подтолкнули меня к следующей гипотезе: не служило ли изделие из Веселого выдвижной крышкой какогото ларца или ящичка наподобие тех, какие имели упоминавшиеся византийские «розеточные» ларцы X-XI вв.? О возможном таком использовании говорит, во-первых, заметная потертость на лицевой стороне, которая могла возникнуть

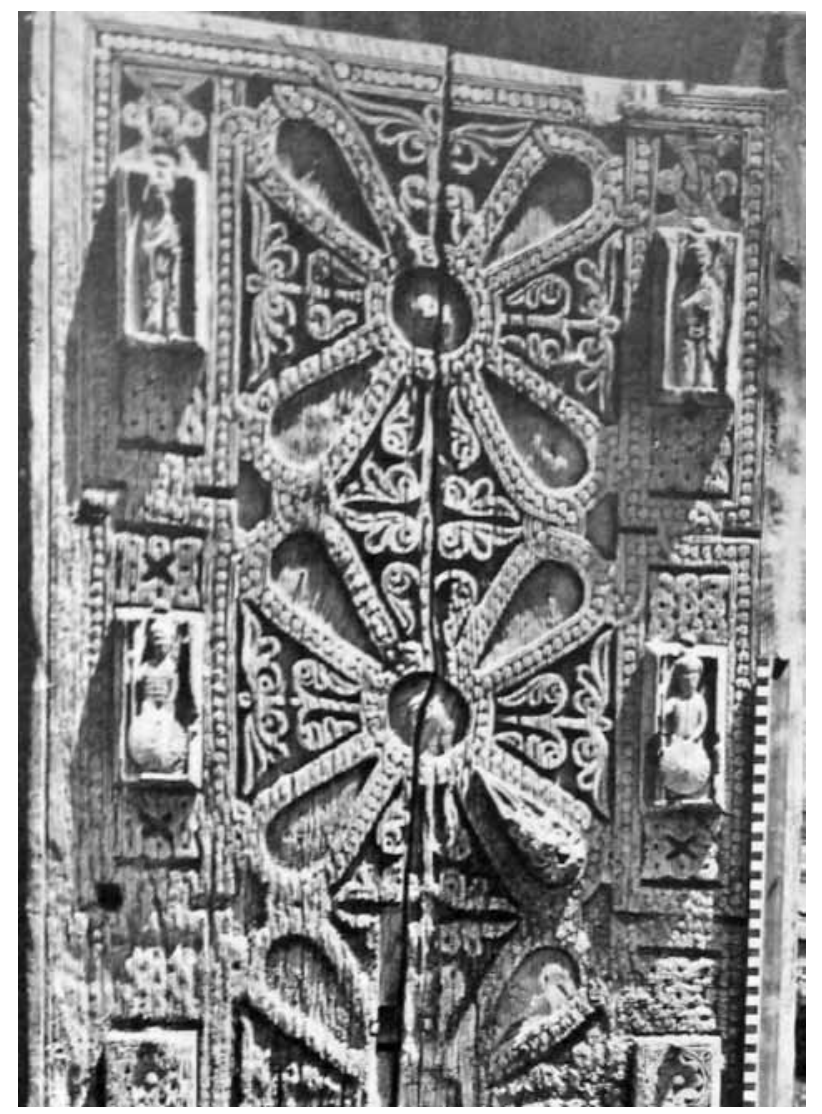

Рис. 11. Фрагмент резной двери из Джахундери (по: Чубинашвили, 1958. Табл. 34) 
от неоднократно прикладываемой ладони, чтобы сдвинуть крышку в определенном направлении.

Во-вторых, выступ на тыльной стороне. Правда, в таком случае этот выступ показывает, что крышка выдвигалась не с торца, как у византийских ларцов (см. рис. 6,1 ), а с продольной стороны ящичка. К сожалению, мне осталась непонятной конструкция крышек этих ларцов, в частности, их профиль или сечение, что затрудняет детальное сопоставление и точную атрибуцию нашей находки.

В-третьих, размеры изделия из Веселого, на мой взгляд, приближаются к размерам «розеточных» ларцов, длина большинства которых в среднем составляет $40 \mathrm{~cm}$, а ширина - $12 \mathrm{~cm}$. С учетом обломанных концов и краев изделия из Веселого надо иметь в виду, что его габариты изначально были другими: как минимум, его длина явно превышала 26 см, ширина была чуть большей.

Обе рассмотренные находки из колодца возле храма в Веселом хронологически вписываются в X-XI вв. Строительство храма относится ко второй трети Х в. (Армарчук, Мимоход, Седов, 2012. С. 89), что показывает нижнюю дату находок. Верхнюю дату помогают определить два факта. Первый: присутствие в комплексе артефактов из колодца расписного кувшина, показательного для материальной культуры Абхазского царства и в хронологическом плане не выходящего за пределы Х в. (Армарчук, 2012. С. 18). Второй факт: наличие аналогий элементам орнамента доски в деревянной резьбе средневековой Квемо Сванети (Грузия) первой четверти XI в. и преобладание среди других аналогий тех, которые в большей степени относятся к X в. Следовательно, верхней датой находок выступает начало XI в. В итоге я полагаю, что датировку деревянных изделий

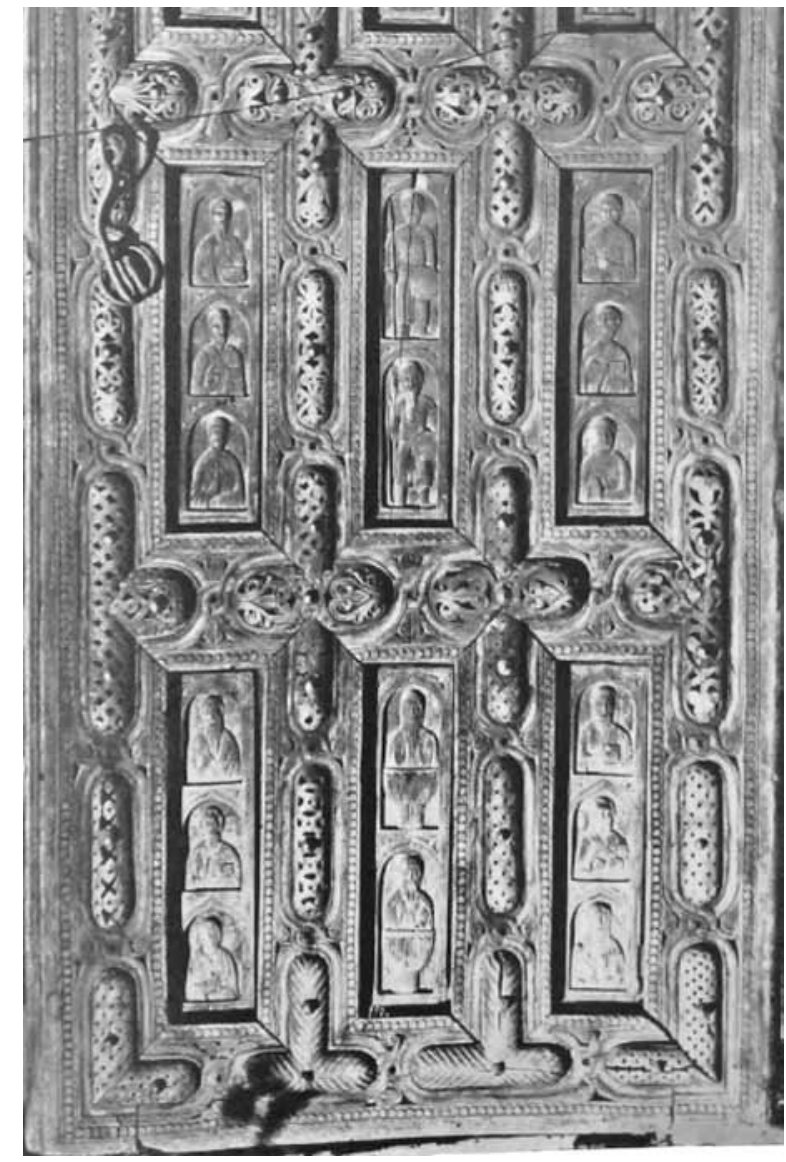

Рис. 12. Резная дверь из Чукули (по: Чубинашвили, 1958. Табл. 43)

из Веселого следует ограничить второй половиной X - началом XI в., а сами их отнести к разряду уникальных для данного региона, где такие изделия обнаружены впервые и при этом одно из них имеет художественную ценность.

\section{Литература}

Армарчук E.A., 2012. Новые находки расписной керамики эпохи Абхазского царства // Поволжская археология. № 1. С. 8-19.

Армарчук Е.А., Мимоход Р.А., Седов Вл.В., 2012. Христианский храм у пос. Веселое: предварительная публикация результатов раскопок 2010 года // РА. № 3. С. 78-90.

Армарчук Е.А., Мимоход Р.А., Седов Вл.В., 2015. Раскопки христианского храма у с. Веселое под Адлером в 2010-2011 гг. // АО 2010-2013 годов. М.: Наука. С. 318-319.

Банк A. B., 1978. Прикладное искусство Византии IX-XII веков. Очерки. М.: Наука. 203 с.
Джапаридзе В., 1976. Археологические разведки окрестностей городища Дманиси // Полевые археологические исследования в 1974 г. (краткие сообщения). Тбилиси: Мецниереба. C. 89-95.

Ендольцеева Е.Ю., 2011. Каменные рельефы Анакопии // Искусство Абхазского царства VIII-XI веков. Христианские памятники Анакопийской крепости. СПб.: Изд-во РХГА. С. 89-208.

Искусство Византии в собраниях СССР. Каталог выставки в 3 ч. [Ч.] 2: Искусство эпохи иконоборчества. Искусство IX-XII веков. М.: Советский художник, 1977. 156 с. 
Колчин Б. А., 1968. Новгородские древности. Деревянные изделия. М.: Наука. 182 с. (САИ. Е1-55).

Колчин Б. А., 1971. Новгородские древности. Резное дерево. М.: Наука. 63 с. (САИ. Е1-55).

Окунев Н.Л., 1929. Алтарная преграда XII века в Нерезе// Сб. статей по археологии и византиноведению, издаваемый семинарием имени Н.П. Кондакова. III. Прага: Seminarium Kondakovianum. C. 5-23.

Розенфельдт Р.Л., 1997. Бытовые изделия: деревянная тара и посуда // Древняя Русь. Быт и культура. М.: Наука. С. 43-45. (Археология).

Сергеева М.С., 1998а. Дерев'яний посуд 3 давньоруських міст Середнього Подніпров'я // Археологія. № 1. С. 118-128.

Сергеева М.С., 1998б. Орнаментация изделий из дерева и кости в лесостепном Поднепровье в $\mathrm{X}$ XIII веках // Вопросы истории славян. Археология и этнография. Воронеж: Изд-во ВГУ. С. 83-95.

Сергеева М.С., 2010. К вопросу о художественной резьбе по дереву X-XIII веков на территории Среднего Поднепровья // Археологический альманах. № 21. Донецк. С. 396-403.
Церетели Г., 1898. Археологическая прогулка по Квирильскому ущелью // МАК. Вып. VII. М.: Тов-во тип. А.И. Мамонтова. С. 81-114.

Чубинашвили Н., 1958. Грузинская средневековая художественная резьба по дереву (перелома X-XI вв.). Тбилиси: Гос. Изд-во Сабчота Сакартвело. $117 \mathrm{c}$.

Шмерлинг P., 1962. Малые формы в архитектуре средневековой Грузии. Тбилиси: Изд-во АН Груз. ССР. 293 с.

Diehl Ch., 1910. Manuel d'art byzantin. Paris. 837 p.

Rom und Byzanz: Schatzkammerstücke aus bayerischen Sammlungen/Katalog zur Ausstellung des Bayerischen Nationalmuseums München, 20. Oktober 1998 bis 14. Februar 1999. Bayerisches Nationalmuseum. München: Hirmer Verlag. 280 s.

The Glory of Byzantium: Art and Culture of the Middle Byzantine Era, A.D. 843-1261 / Ed. by Helen C. Evans and William D. Wixom. NY: The Metropolitan Museum of Art, 1997. 574 p.

Wood Use in Medieval Novgorod / Ed. by Mark Brisbane and Jon Hather. Oxford, UK: Oxbow Books, 2007. $470 \mathrm{p}$. 


\section{Цинкосодержащие сплавы в цветной металлообработке лесной и лесостепной зон конца I тысячелетия до н.э. - первой половины І тысячелетия н.э.: «индекс романизации»"}

Момент перехода от конца I тысячелетия до н. э. к первым векам нашей эры в цветной металлообработке знаменуется определенными изменениями, захватившими также широкое пространство степи, лесостепи и леса; своеобразным последствием этих изменений стало повсеместное использование цинкосодержащих сплавов, на производство которых была установлена монополия Римской империи (Bayley, 1998. Р. 7; Craddock, Ekstein, 2003. P. 217-218; Weisgerber et al., 2007; и др.). Для конца I тысячелетия до н. э. - начала I тысячелетия н. э. цинкосодержащие сплавы, их близость к эталонным римским образцам, степень распространения служат маркером своеобразного «индекса романизации» культур (Dungworth, 1997), определяющего степень включенности изучаемых территорий в зону римского политического влияния, торговли, иных видов взаимодействий. Наряду с римскими импортами наличие в выборках предметов из сплавов с высоким содержанием цинка может, таким образом, свидетельствовать о существовании определенных процессов интеграции материальной культуры, определяемых уровнем контактов между империей и ее периферией и более отдаленными регионами (Braund, 1984).

Территории, граничащие с восточными рубежами Римской империи, в том числе западные регионы европейской части России, характеризуются интенсивностью и яркостью протекания исторических процессов на территории «широкой контактной зоны» лесостепи и леса от Верхнего Поднепровья до верховьев Волги (Шукин, 1994. С. 232, 236-237, 278). Считается, что именно на восточных рубежах Римской империи в I в. до н.э. было начато регулярное производство двухкомпонентной латуни, которая уже в начале II в н.э. из-за высокой интенсивности использования уступила место тройным латуням или многокомпонентным сплавам (Rehren, 1999b; и др.).

Накопленные в настоящее время данные по химическому составу цветного металла Европейской России I тысячелетия до н. э. - I тысячелетия н. э., особенно для ее западных регионов (Черныхх, Хоферте, Бариева, 1969; Бариева, Вознесенская, Черных, 1972; Бариева, 1981b; Сапрыкина, 2007; и др.), позволяют проследить смену основных рецептур, отметить момент появления цинкосодержащих сплавов в цветной металлообработке лесостепных и лесных культур и динамику изменений рецептур сплавов. Все это позволяет рассмотреть цветную металлообработку Европейской России в раннем железном веке через призму своеобразного «индекса романизации» - наличия цинкосодержащих сплавов в выборках, доминирующих типов сплавов и процентного содержания цинка на каждом из хронологических этапов.

Химический состав цветного металла из привлекаемых в этой публикации выборок исследовался разными методами; значительная часть анализов выполнена в 1960-80-е методом ОЭСА в Лаборатории естественнонаучных методов Института археологии АН СССР (Е.Н. Черных, Т. Б. Барцева и др.); другая часть анализов выполнена в 2000-х гг. методами безэталонного РФА в МГУ (аналитик - кандидат геолого-минералогических наук Р.А. Митоян) или $S E M-E D X$ (ИОНХ РАН, аналитик - доктор технических наук Г.Ю. Юрков). В настоящее время аналитическая выборка раннего железного века и раннего средневековья продолжает пополняться анализами по методу безэталонного РФА; часть полученных результатов уже опубликована.

\footnotetext{
* Статья подготовлена при поддержке РНФ, проект № 18-18-00193 «Начальный период истории денег: переход от полновесной монеты к знаку условной стоимости».
} 
Для лучшего понимания изменений, произошедших в цветной металлообработке на рубеже эр, необходимо рассмотреть ее основные характеристики в предшествующий период на территории широкой «контактной зоны» от Верхнего Поднепровья до верховьев Волги.

Так, Т. Б. Барцевой был получен большой корпус данных по химическому составу цветного металла из комплексов VI-III вв. до н.э. из лесостепного Днепровского Левобережья, степного Поднепровья и других регионов (Бариеева, 1980, 1981a; и др.). Благодаря этому мы с большой долей уверенности можем говорить о преимущественном использовании во второй половине I тысячелетия до н.э. оловянной $(\mathrm{CuSn})$ и оловянно-свинцовой $(\mathrm{CuSnPb})$ бронз, с доминированием с IV в. до н.э. тройной бронзы со средним процентным содержанием олова в 4-12\% и свинца в 2-6\% (max содержание олова фиксируется в 33\%; Бариева, 1980. С. 78-83, табл. 1, 2; Бариеева, 1981а. С. 90-92, табл. 1; Бариеева, 1981b. С. 104-105, табл. 1). Данные по Подонью показывают повышенные по сравнению со средними значениями концентрации олова, но также демонстрируют преобладание в выборке тройных бронз (Богданова-Березовская, 1973. С. 46-51; Меркулов, 2018. С. 101-102, табл. 1). Аналогичные данные видим и в небольших выборках по цветному металлу с балтских, юхновских и милоградских памятников (Изюмова, 1967. С. 135-136; Бариеева, Лошенков, 1995. С. 99, табл. II; Разумов и др. $\left.{ }^{1}\right)$. Сопоставление с результатами, полученными для цветного металла дьяковской археологической культуры (своеобразной буферной зоны рассматриваемой территории по М. Ю. Щукину - 1994. С. 243), только подтверждает это наблюдение: в выборках второй половины I тысячелетия до н. э. преобладают оловянные и оловянно-свинцовые сплавы, где содержание олова в среднем укладывается в границы до 8-12\% ( $\mathrm{Ca}$ прыкина, 2007. С. 110; 2008. С. 263-265; Сапрыкина, Сыроватко, 2011. С. 73, табл. 1). Максимальные (единичные) концентрации олова в исследованных дьяковских выборках достигают 25 или 50-59\% (Сапрыкина, Энговатова, 2002. С. 488, табл. 3; Сапрыкина, 2008. С. 263); а в процентном соотношении, как и в других (лесостепных и степных) выборках этого периода, основное количество проб относится к тройному сплаву $\mathrm{CuSnPb}$. Эти данные отличаются от известных на данный момент резуль- татов исследований химического состава цветного металла в Западной Европе, где для раннего железного века классическими типами сплавов являлись высоколегированные свинцовые бронзы (Hamilton, 1996; Danielisova, Bursak, 2018²; и др.).

Если для второй половины I тысячелетия до н.э. использование и доминирование в разных регионах определенных типов сплавов определялось, как нам представляется, больше прагматическими соображениями (к примеру, доступными источниками сырья, основными торговыми направлениями, экономической стоимостью сырья и др.), то для более позднего периода, в частности рубежа эр, рассматриваются и иные причины. Внедрение цинка, известного еще с эпохи бронзы, в массовое производство в I в. до н.э., точное следование рецептуре сплава и выбора латуни в качестве некоторой демонстрации отношений империи и периферии, говорит о том, что металлообработка в этот период могла подчиняться определенному набору критериев при выборе и производстве медных сплавов, отражающих не только их механические свойства, но прежде всего моду, предвзятость и требования времени и культуры (Ponting, 2002. Р. 559). В связи с этим неудивителен взрывной рост количества предметов, изготовленных из сплава с цинком (двухкомпонентной латуни), который, судя по результатам исследований, проведенных в Британии, приходится на І в. н. э. (рубеж І в. до н. э. - І в. н. э.) (Pollard et al., 2015. Р. 701, tab. 3). На этот же период приходится и резкое увеличение количества сплавов, которые зарубежные исследователи относят к категории gunmetal (сплав с повышенным процентным содержанием олова и/или свинца), где содержание цинка сохраняется на уровне до 10 и 15-20\% (Dungworth, 1997. P. 905-906, fig. 4-5). Этот же рост фиксируется и для других регионов Европы, в частности северной Германии, где найдены остатки мастерских по получению цинка методом цементации (Rehren, 1999b. Р. 252).

Bo II в.н.э. количество латунных предметов так же резко, как увеличивалось, уменьшается; в противоположность этому использование многокомпонентного сплава, высоколегированного оловом, а особенно свинцом, увеличивается в геометрической прогрессии и практически полностью вытесняет двухкомпонентную латунь уже к III в. (Dungworth, 1997. Р. 907, fig. 6; Pollard et al., 2015. P. 703, Fig. 1). По данным Д. Данворта, содержание

\footnotetext{
${ }^{1}$ Выражаю искреннюю признательность авторам находок за возможность использовать полученные данные в настоящей публикации.

2 Danielisova A., Bursak D., 2018. Life cycles of metals and people in the Iron Age - sourcing and recycling of copper based alloys. Доклад, прочитанный 6 сентября 2018 г. на международной конференции ЕAA 2018, Barcelona (секция 520).
} 
цинка в металле предметов в этот период падает до 3-8\% (Dungworth, 1997. Р. 907, tab. 3). Все это свидетельствует прежде всего о широко распространившейся практике переплавки (перемешивания) сплавов и о резком сокращении (возможно, прекращении как результат коллапса Римской империи) производства цинка методом цементации в III-IV вв. (Rehren, 1999а. Р. 252). Новый пик использования латуней, уже с большими присадками олова и особенно свинца, относится к V-VI вв. н. э. (Pollard et al., 2015. P. 705, fig. 3-4).

Довольно сложно рассматривать процесс появления и внедрения цинкосодержащих сплавов на небольших выборках рубежа эр - первой половины I тысячелетия н.э. из памятников европейской части России; основная часть выборок этого времени пока приходится на памятники дьяковской археологической культуры, по остроумному замечанию М.Б. Щукина, культуры «четвертого» мира, хотя она обладает даже большим количеством бронзовых изделий, чем памятники мира «третьего» (Щукин, 1994. С. 22). В любом случае на данный момент самые ранние для лесной зоны цинкосодержащие сплавы зафиксированы в материалах из раскопок дьяковского городища Настасьино, существование которого прекратилось в I-II вв. Н. э. (Canpblкина, Энговатова, 2002; Энговатова, Сапрыкина, 2005. С. 128, 136). Относительно хорошо датированными среди таких находок из дьяковского слоя городища Настасьино могут быть только накладки, которые по аналогиям относятся к периоду рубежа эр - I-II вв. В металле этих украшений содержится 4-5\% цинка в составе многокомпонентного сплава. Вообще, сплавы с цинком в Настасьино составляют 1/12 часть всей выборки, содержание цинка в них колеблется от 1,1 до 13\% (Сапрыкина, Энговатова, 2002. С. 490-491, табл. 7). Все остальные предметы из цинкосодержащих сплавов можно отнести к так называемым транскультурным типам, датировка которых крайне широка, и среди них присутствуют предметы с высоким содержанием цинка. Примечательно, что двухкомпонентной латуни в ранней выборке из городища Настасьино нет.

Совершенно иная картина предстает по материалам Троицкого городища, металл которого исследовался в 1960-е годы (Черных, Бариева, 1970. С. 200-206, табл. 1) и доисследовался позднее ( $\mathrm{Ca}$ прыкина, 2005. С. 522-523, табл. 1). Помимо находки в слое городища «солдатской» фибулы типа Aucissa (развитый тип с надписью, 6/19-50/70 гг. н. э./начало последней четверти I в. н. э.; Gugl, 1995), как правило, изготовлявшихся из латуни (CuZn) (Bayley, 1998. P. 14, fig. 3), в выборке из Троицкого городища более 50\% из 118 проб относятся к латуням и многокомпонентному сплаву (Сапрыкина, 2005. С. 522-523, табл. 1). По замечанию К.А. Смирнова, стратиграфическое положение основного количества изделий из цветного металла, происходящих из верхних слоев городища, позволяет совокупно датировать их II-V вв. (Смирнов, 1970. С. 191). Отметим, что статистически в выборке первой половины I тысячелетия н.э. доля многокомпонентного сплава примерно равна доле тройной и двухкомпонентной латуни; в общих чертах выборка из Троицкого городища оказывается близкой выборкам из римских провинций, для которых характерно пропорциональное использование латуней и многокомпонентных сплавов (Craddock et al., 2010. Р. 61).

Если более детально разложить сплавы с цинком из выборки Троицкого городища, сузив временные интервалы, то можно говорить о следующем. Большая проанализированная выборка умбоновидных подвесок Троицкого городища (9 ед.), отнесенная к типу 4 по Н. А. Кренке (2011. С. 80) и датированная К.А. Смирновым в пределах II-III/IV вв. (Смирнов, 1970. С. 233), Н.А. Кренке - I-II вв. (Кренке, 2011. C. 80), а мной - в более широком диапазоне I-V вв., как «классическая» форма украшений ${ }^{3}$ (Сапрыкина, 2006. С. 37), изготовлена из всех имеющихся в выборке сплавов с цинком. Характерной чертой этих сплавов является низкое процентное содержание цинка (1-4\%, max 10\%); только в двух случаях отмечается высокое процентное содержание или олова, или свинца в многокомпонентном сплаве, в основном их значения не превышают 4-5\%.

При этом украшения, дата которых может быть определена позднее, чем дата умбоновидных подвесок типа 4 по Н. А. Кренке (это пронизи, сюльгамы, ажурные застежки, разнообразные подвески, накладки разных типов, по аналогиям датируемые III-IV/V вв.н.э.), были изготовлены преимущественно из сплавов с высоким содержанием цинка (разброс в пределах от 3 до 24,49\%; среднее значение в пределах 10-13, 22-23\%). Интересной чертой этой более поздней по времени выборки наряду с высоким содержанием цинка в сплавах является доминирование латуни и тройной латуни (в основном легированной оловом; $\min / \mathrm{max}$

\footnotetext{
3 Здесь мы не уделяем внимания вопросам хронологии украшений дьяковской археологической культуры, однако ясно, что этот момент становится принципиальным для понимания хронологии появления цинкосодержащих сплавов в лесной полосе европейской части России и изменения рецептуры сплавов с цинком.
} 
$1-6,96 \%$, среднее значение $2-4 \%$ ); а многокомпонентный сплав, характеризующийся пониженным содержанием цинка, показывает низкие концентрации свинца и повышенное значение олова (до 39,8\%; среднее значение в пределах 3-8\%). Но парадоксальным образом данные по цинку коррелируют с данными, полученными при анализе римских монет I-II вв. н.э. из кладов № 1-2, найденных в районе Копорья, где содержание цинка фиксируется в среднем в пределах 5-15\% (Шаров и др., 2011. С. 352, рис. 10; С. 359, прил. $3,4)$, и с опубликованными данными из латвийских памятников II-IV вв., демонстрирующими повышенные значения содержания цинка в латунях и многокомпонентных сплавах (Черных и др., 1969. С. 114-119, табл. 1).

Отметим, что выборка III-IV/V вв. н. э. из Троицкого городища по высокому процентному содержанию цинка близка известным и опубликованным ранее выборкам из памятников черняховской культуры (Черных и др., 1972. С. 84-105); конечно, она наиболее хорошо сопоставима с данными по памятникам из северо-восточного ареала черняховской культуры, где содержание цинка несколько ниже, чем в металле ее западных и центральных областей (Черных и дp., 1972. C. 98-103). К этой же группе цинкосодержащих сплавов примыкает и выборка металла Мощинского клада и предметов мощинских типов (Черных и др., 1969. С. 112, рис. 54; Черных, Бариева, 1972. С. 61 , рис. 4 ; с. 62 , табл. 2). Результаты анализа металла украшений из Мощинского клада и из слоя Мощинского городища, выполненные в 1960-х гг. Т.Б. Барцевой (табл. 1), показывают доминирование многокомпонентного сплава, который характеризуется низкими концентрациями как олова, так и свинца. Содержание цинка в сплавах варьируется в пределах 2,3-15,0\% для многокомпонентного сплава, 10-20\% для двухкомпонентной латуни, $1,6-20 \%$ для тройных латуней (значения $\min / \max$ ). Довольно большое количество предметов из выборки мощинского круга древностей, таким образом, изготовлено из сплавов с содержанием цинка в средних значениях 4-10\% и стабильно низкими концентрациями как олова, так и свинца.

Такие же значения по содержанию цинка характерны и для выборок, датированных IV-VII вв. (выборка из городища Боршева Московская - табл. 2; выборка из городища Орлов Городок - табл. 3$)^{4}$.
Для этих выборок характерно присутствие тройных латуней или многокомпонентных сплавов со средним содержанием цинка в сплавах от 6 до $8 \%$ (min/max: 2,05-17,5\% для выборки из раскопок на Боршеве Московской, 1,88-18,41\% для выборки из раскопок на Орлове Городке). Их отличительной чертой является более высокое, чем ранее, содержание либо олова, либо свинца (табл. 2; 3). Известно, что в IV в. широкое распространение получили свинцовые бронзы, их доля в общем объеме увеличилась (Dungworth, 1997. P. 907, fig. 6), а для периода с 430 по 650 г. характерно использование многокомпонентных сплавов, высоколегированных свинцом (Pollard et al., 2015. P. 704, fig. 2). Bce это свидетельствует, по мнению исследователей, о массовой переработке цинкосодержащего лома цветных металлов, который в процессе переплавок постоянно освежался новыми порциями металла (в частности, со свинцом); интересно, что для британских выборок после IV в. н.э. отмечается увеличение количества предметов, изготовленных из цинкосодержащих сплавов с крайне низкими значениями по содержанию самого цинка, по сравнению с позднеримским периодом (Pollard et al., 2015. P. 705, fig. 4). Имеющиеся аналитические выборки материала из нашей лесной зоны тоже демонстрируют присутствие сплавов с пониженным содержанием цинка в металле изделий, что естественно в связи с многочисленными переплавками, хотя в отношении количества предметов, изготовленных из таких сплавов, мы пока ничего сказать не можем (к примеру, предметы из Велегожского клада: Сапрыкина, 2015. С. 103-106).

Несколько иная картина - в материалах из лесостепной зоны: так, металл Куриловского клада раннего Средневековья демонстрирует высокие значения содержания цинка (4-10\% или $14,79-28 \%$ в многокомпонентном сплаве, 5-11\% в тройных латунях) при повышенных значениях по содержанию олова или свинца в сплавах (олова - до $28 \%$, свинца - до 44\%) (Сапрыкина, 2014. С. 178-186).

В этом контексте крайне важными представляются пока редкие находки предметов, которые мы могли бы связать с плавкой и литьем цинкосодержащих сплавов непосредственно на поселениях лесной и лесостепной зон в рассматриваемый период. В частности, в материалах из раскопок на городище Отмичи лесной зоны присутствует некоторое количество тиглей-льячек с короткой

\footnotetext{
${ }^{4}$ Анализировался материал из раскопок 1970-х гг. под руководством Х.И. Крис (раскопки на городище Боршева Московская, Московская обл.) и материал из раскопок 1980-х гг. под руководством А. Д. Максимова (раскопки на городище Орлов Городок, Тверская обл.).
} 


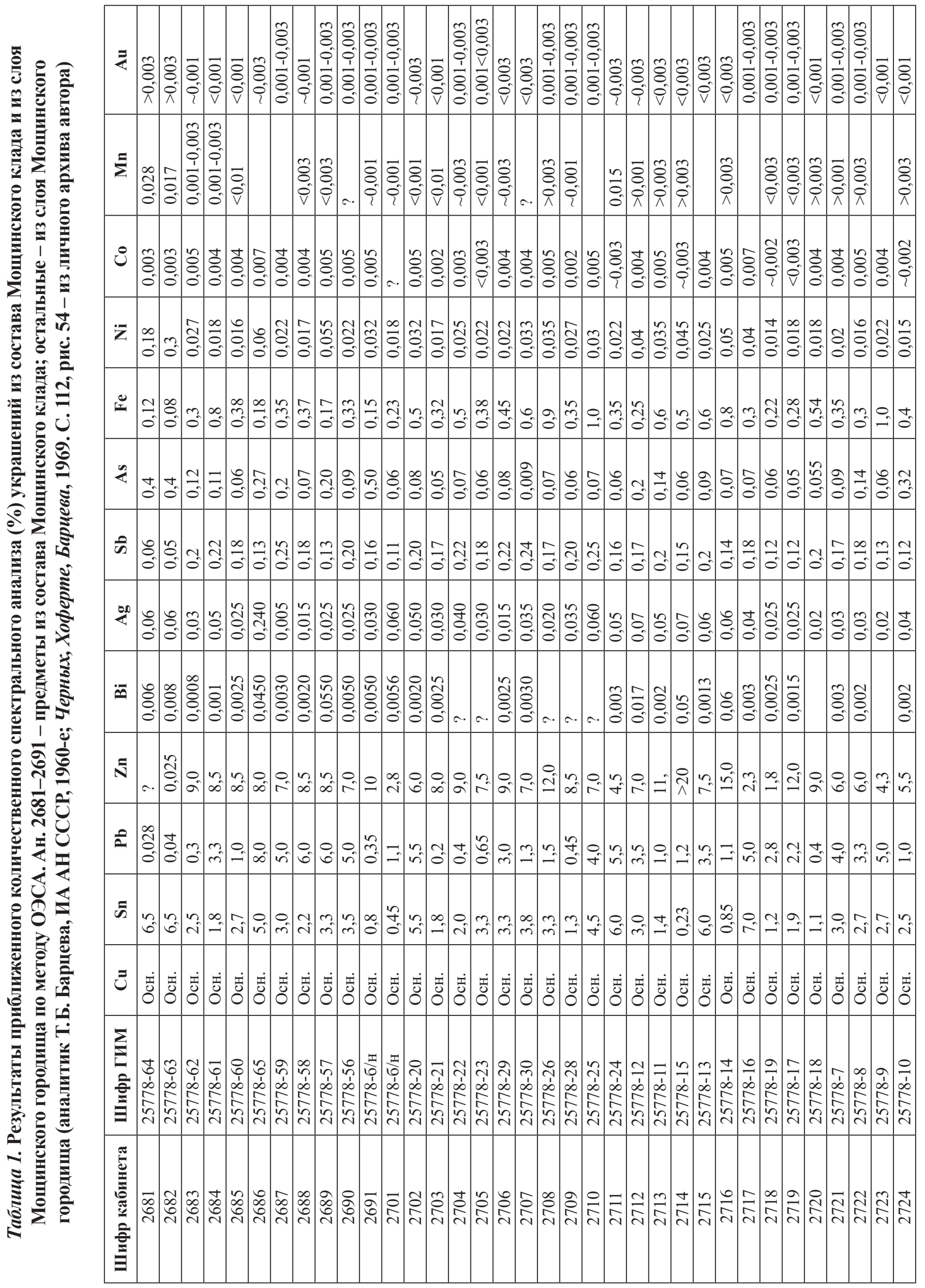




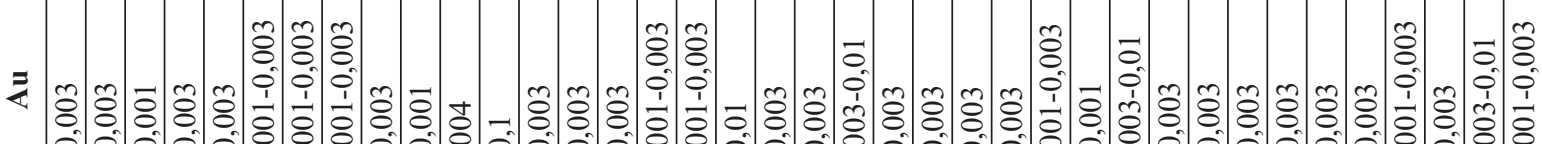

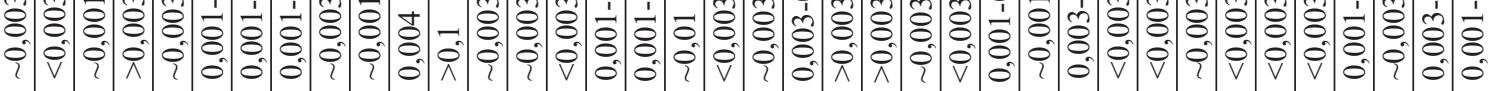

zิ

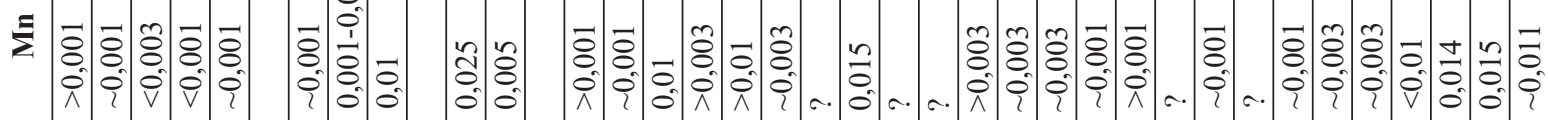

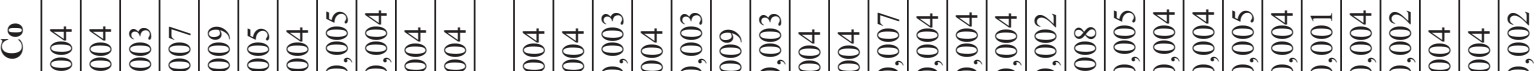

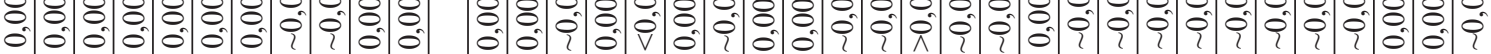

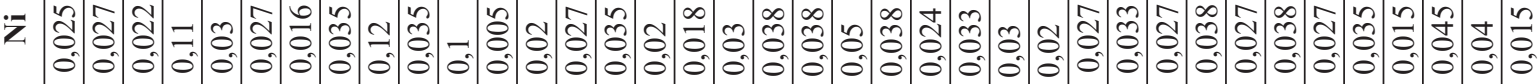

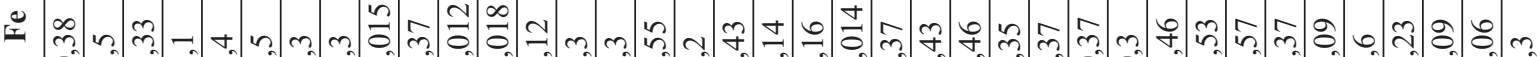

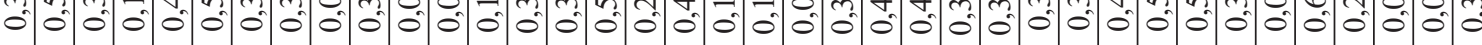

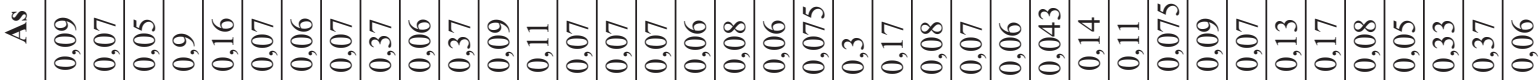

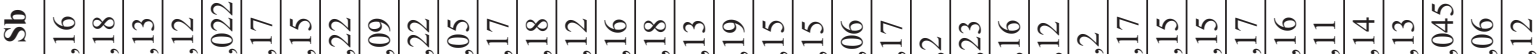

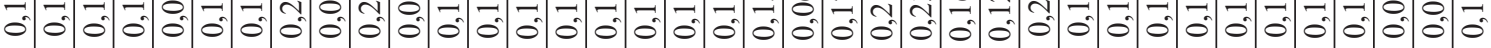

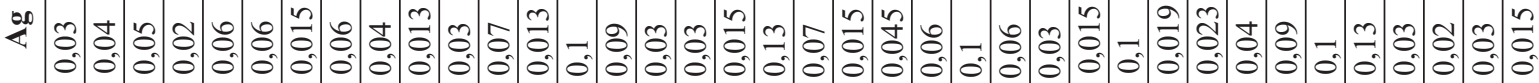

-

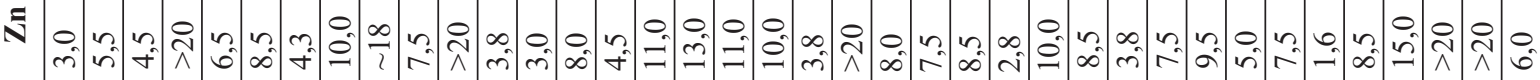

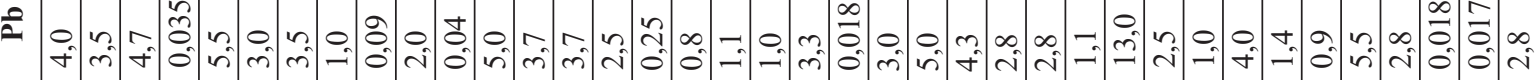

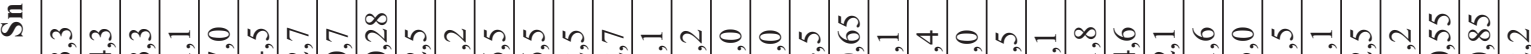

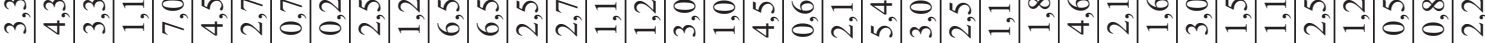

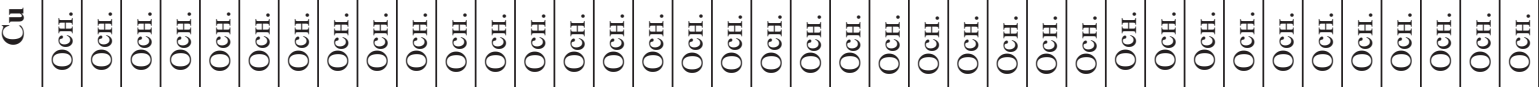

(1)

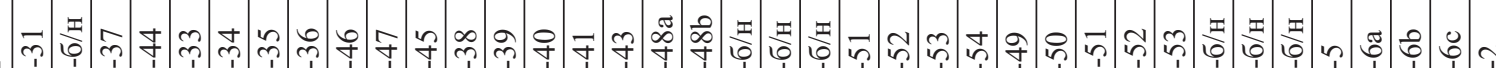

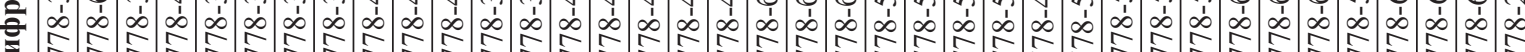

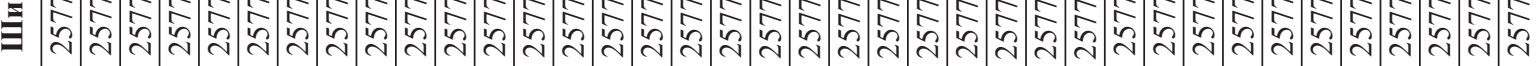



:

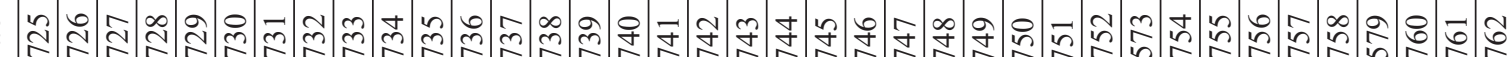

产 
Таблица 2. Результаты исследования предметов из цветного металла из городища Боршева Московская методом безэталонного РФА (аналитик - Р.А. Митоян; МГУ им. М.В. Ломоносова, геологический факультет, кафедра геохимии).

\begin{tabular}{|c|l|l|l|l|l|l|l|l|l|l|l|l|l|}
\hline $\begin{array}{c}\text { Номер } \\
\text { по описи }\end{array}$ & $\mathbf{C u}$ & $\mathbf{S n}$ & $\mathbf{P b}$ & $\mathbf{Z n}$ & $\mathbf{B i}$ & $\mathbf{A g}$ & $\mathbf{S b}$ & $\mathbf{A s}$ & $\mathbf{F e}$ & $\mathbf{N i}$ & $\mathbf{C o}$ & $\mathbf{M n}$ & $\mathbf{A u}$ \\
\hline 360 & 67,6 & 12,71 & 11,48 & 8,02 & 0,001 & 0,19 & 0,001 & 0,001 & 0,001 & 0,001 & 0,001 & 0,001 & 0,001 \\
\hline 331 & 61,75 & 24,54 & 13,72 & 0,001 & 0,001 & 0,001 & 0,001 & 0,001 & 0,001 & 0,001 & 0,001 & 0,001 & 0,001 \\
\hline 503 & 64,09 & 35,91 & 0,001 & 0,001 & 0,001 & 0,001 & 0,001 & 0,001 & 0,001 & 0,001 & 0,001 & 0,001 & 0,001 \\
\hline 497 & 76,51 & 15,91 & 7,57 & 0,001 & 0,001 & 0,001 & 0,001 & 0,001 & 0,001 & 0,001 & 0,001 & 0,001 & 0,001 \\
\hline 498 & 69,05 & 22,76 & 8,19 & 0,001 & 0,001 & 0,001 & 0,001 & 0,001 & 0,001 & 0,001 & 0,001 & 0,001 & 0,001 \\
\hline 532 & 83,22 & 2,81 & 4,16 & 9,64 & 0,001 & 0,18 & 0,001 & 0,001 & 0,001 & 0,001 & 0,001 & 0,001 & 0,001 \\
\hline 125 & 78,25 & 4,71 & 3,45 & 13,15 & 0,001 & 0,42 & 0,11 & 0,001 & 0,001 & 0,001 & 0,001 & 0,001 & 0,001 \\
\hline 268 & 88,99 & 7,73 & 3,72 & 0,001 & 0,001 & 0,001 & 0,001 & 0,001 & 0,001 & 0,001 & 0,001 & 0,001 & 0,001 \\
\hline 45 & 81,84 & 6,97 & 4,35 & 6,18 & 0,001 & 0,21 & 0,001 & 0,45 & 0,001 & 0,001 & 0,001 & 0,001 & 0,001 \\
\hline 45 & 70,47 & 7,03 & 15,99 & 5,54 & 0,001 & 0,001 & 0,001 & 0,96 & 0,001 & 0,001 & 0,001 & 0,001 & 0,001 \\
\hline 36 & 79,63 & 4,7 & 1,48 & 13,69 & 0,001 & 0,16 & 0,001 & 0,34 & 0,001 & 0,001 & 0,001 & 0,001 & 0,001 \\
\hline 47 & 94,8 & 0,11 & 4,28 & 0,27 & 0,001 & 0,1 & 0,13 & 0,31 & 0,001 & 0,001 & 0,001 & 0,001 & 0,001 \\
\hline 44 & 55,62 & 0,5 & 34,08 & 7,22 & 0,001 & 0,18 & 1,07 & 1,34 & 0,001 & 0,001 & 0,001 & 0,001 & 0,001 \\
\hline 48 & 79,71 & 14,42 & 0,001 & 5,87 & 0,001 & 0,001 & 0,001 & 0,001 & 0,001 & 0,001 & 0,001 & 0,001 & 0,001 \\
\hline 196 & 79,3 & 6,75 & 5,56 & 8,39 & 0,001 & 0,001 & 0,001 & 0,001 & 0,001 & 0,001 & 0,001 & 0,001 & 0,001 \\
\hline 153 & 71,43 & 23,65 & 3,99 & 0,93 & 0,001 & 0,001 & 0,001 & 0,001 & 0,001 & 0,001 & 0,001 & 0,001 & 0,001 \\
\hline 533 & 77,9 & 15,2 & 2,61 & 4,29 & 0,001 & 0,001 & 0,001 & 0,001 & 0,001 & 0,001 & 0,001 & 0,001 & 0,001 \\
\hline 132 & 78,54 & 16,98 & 2,13 & 2,05 & 0,001 & 0,001 & 0,001 & 0,29 & 0,001 & 0,001 & 0,001 & 0,001 & 0,001 \\
\hline 93 & 66,04 & 3,14 & 18,25 & 11,26 & 0,001 & 0,13 & 0,001 & 1,18 & 0,001 & 0,001 & 0,001 & 0,001 & 0,001 \\
\hline 26 & 72,91 & 6,61 & 1,73 & 17,5 & 0,001 & 0,16 & 0,21 & 0,87 & 0,001 & 0,001 & 0,001 & 0,001 & 0,001 \\
\hline
\end{tabular}

ручкой, анализ ошлакованной поверхности которых показал наличие (помимо элементов, относящихся к химическому составу самой глины) цинка в высоких процентных содержаниях: 7,3-73,58\% (Сапрыкина, 2008. С. 264-265, № 38-51). По своему стратиграфическому положению эти льячки могут датироваться серединой I тысячеления н.э. (Исланова, 2008. С. 44). Такие высокие процентные содержания из-за летучести цинка маркируют скорее процесс плавки в открытых тиглях при температуре ниже 950-1100 ${ }^{\circ} \mathrm{C}$ (Bourgarit, Thomas, 2015. Р. 260). Используя гистограмму, предложенную Д. Данвортом (Dungworth, 1996. Р. 232, fig. 3), мы гипотетически можем представить, насколько падает каждый раз содержание цинка при переплавках; в сплавах, которые уже были переплавлены несколько раз, содержание цинка стремится к нулю, но, по замечанию этого же исследователя, никогда его не достигает. В настоящее время исследователи приходят к выводу, что цинк в сплавах позднеримского времени падал не из-за постоянных переплавок, а из-за целенаправленной политики разбавления латуни высоколегированными бронзами, что особенно ярко прослеживается на выборках позднеримских монет или предметов позднеримского времени, в частности, выполненных из многокомпонентного сплава: здесь содержание цинка варьируется в пределах 5\%, с хвостами до 12\% (Pollard et al., 2015. Р. 706). Похоже, что для более позднего времени, начиная c IV в.н.э., сплавы с цинком уже переплавлялись как лом цветных металлов и мешались со всеми типами сплавов, циркулировавшими на конкретных территориях.

Завершая наш краткий обзор по цинкосодержащим сплавам на территории лесной и лесостепной зон в конце I тысячелетия до н. э. - первой половине I тысячелетия н.э., отметим следующее. На данный момент у нас есть данные о появлении цинкосодержащих сплавов на территории лесной зоны европейской части России в I-II вв.н. э.; пока мы можем говорить лишь о многокомпонентных сплавах с низким процентным содержанием цинка, что свидетельствует в пользу использования переплавленного металла. Несомненно, цинкосодержащий сплав в этот период попал в лесную зону 
Таблица 3. Результаты исследования предметов из цветного металла из городища Орлов Городок методом безэталонного РФА (аналитик - Р. А. Митоян; МГУ им. М.В. Ломоносова, геологический факультет, кафедра геохимии).

\begin{tabular}{|c|c|c|c|c|c|c|c|c|c|c|c|c|c|}
\hline $\begin{array}{c}\text { Номер } \\
\text { по описи }\end{array}$ & $\mathrm{Cu}$ & Sn & $\mathbf{P b}$ & $\mathbf{Z n}$ & Ag & $\mathbf{S b}$ & As & $\mathbf{B i}$ & $\mathrm{Fe}$ & $\mathbf{N i}$ & Co & Mn & $\mathbf{A u}$ \\
\hline $32-160$ & 54,29 & 12,75 & 29,55 & 2,14 & 0,14 & 0,49 & 0,64 & 0,001 & 0,001 & 0,001 & 0,001 & 0,001 & 0,001 \\
\hline $53-272$ & 87,21 & 1,57 & 1,36 & 9,72 & 0,02 & 0,001 & 0,06 & 0,001 & 0,001 & 0,001 & 0,001 & 0,001 & 0,001 \\
\hline $38-164$ & 76,89 & 7,35 & 8,6 & 6,04 & 0,1 & 0,14 & 0,88 & 0,001 & 0,001 & 0,001 & 0,001 & 0,001 & 0,001 \\
\hline $40-171$ & 53,77 & 18,34 & 26,91 & 0,46 & 0,09 & 0,21 & 0,22 & 0,001 & 0,001 & 0,001 & 0,001 & 0,001 & 0,001 \\
\hline $51-266$ & 70,36 & 1,02 & 23,72 & 4,12 & 0,001 & 0,001 & 0,78 & 0,001 & 0,001 & 0,001 & 0,001 & 0,001 & 0,001 \\
\hline $45-260$ & 67,93 & 21,49 & 2,62 & 7,16 & 0,16 & 0,001 & 0,64 & 0,001 & 0,001 & 0,001 & 0,001 & 0,001 & 0,001 \\
\hline $42-172$ & 89,97 & 1,93 & 0,001 & 7,69 & 0,42 & 0,001 & 0,001 & 0,001 & 0,001 & 0,001 & 0,001 & 0,001 & 0,001 \\
\hline $71-379$ & 74,90 & 23,49 & 1,58 & 0,001 & 0,001 & 0,001 & 0,03 & 0,001 & 0,001 & 0,001 & 0,001 & 0,001 & 0,001 \\
\hline $52-204$ & 28,90 & 7,39 & 58,12 & 3,75 & 0,001 & 0,26 & 1,58 & 0,001 & 0,001 & 0,001 & 0,001 & 0,001 & 0,001 \\
\hline $67-393$ & 66,92 & 26,28 & 6,58 & 0,001 & 0,001 & 0,001 & 0,22 & 0,001 & 0,001 & 0,001 & 0,001 & 0,001 & 0,001 \\
\hline $48-189$ & 81,44 & 11,57 & 0,74 & 5,72 & 0,001 & 0,001 & 0,53 & 0,001 & 0,001 & 0,001 & 0,001 & 0,001 & 0,001 \\
\hline $65-157$ & 93,62 & 0,001 & 2,02 & 3,97 & 0,18 & 0,001 & 0,2 & 0,001 & 0,001 & 0,001 & 0,001 & 0,001 & 0,001 \\
\hline 57 & 76,27 & 17,15 & 6,56 & 0,001 & 0,001 & 0,001 & 0,02 & 0,001 & 0,001 & 0,001 & 0,001 & 0,001 & 0,001 \\
\hline $62-413$ & 75,14 & 4,58 & 15,58 & 4,15 & 0,23 & 0,001 & 0,31 & 0,001 & 0,001 & 0,001 & 0,001 & 0,001 & 0,001 \\
\hline $52-271$ & 59,69 & 18,37 & 21,14 & 0,001 & 0,21 & 0,31 & 0,27 & 0,001 & 0,001 & 0,001 & 0,001 & 0,001 & 0,001 \\
\hline $52-268$ & 79,41 & 9,19 & 3,96 & 6,88 & 0,14 & 0,001 & 0,42 & 0,001 & 0,001 & 0,001 & 0,001 & 0,001 & 0,001 \\
\hline $52-270$ & 94,68 & 1,36 & 1,08 & 2,23 & 0,001 & 0,001 & 0,65 & 0,001 & 0,001 & 0,001 & 0,001 & 0,001 & 0,001 \\
\hline $40-299$ & 76,16 & 8,32 & 7,37 & 7,56 & 0,12 & 0,001 & 0,47 & 0,001 & 0,001 & 0,001 & 0,001 & 0,001 & 0,001 \\
\hline $55-326$ & 82,48 & 4,09 & 1,9 & 11,24 & 0,04 & 0,12 & 0,12 & 0,001 & 0,001 & 0,001 & 0,001 & 0,001 & 0,001 \\
\hline $54-411$ & 90,73 & 1,26 & 0,001 & 6,63 & 0,11 & 0,22 & 1,05 & 0,001 & 0,001 & 0,001 & 0,001 & 0,001 & 0,001 \\
\hline $69-348$ & 72,18 & 8,6 & 13,39 & 4,78 & 0,18 & 0,001 & 0,87 & 0,001 & 0,001 & 0,001 & 0,001 & 0,001 & 0,001 \\
\hline $56-275$ & 75,47 & 6 & 0,001 & 18,41 & 0,001 & 0,001 & 0,12 & 0,001 & 0,001 & 0,001 & 0,001 & 0,001 & 0,001 \\
\hline $46-184$ & 42,61 & 27,73 & 27,06 & 1,88 & 0,001 & 0,001 & 0,73 & 0,001 & 0,001 & 0,001 & 0,001 & 0,001 & 0,001 \\
\hline $47-310$ & 85,15 & 5,69 & 1,98 & 6,32 & 0,07 & 0,2 & 0,59 & 0,001 & 0,001 & 0,001 & 0,001 & 0,001 & 0,001 \\
\hline
\end{tabular}

случайным образом, скорее всего, в виде предметов римского происхождения, как, например, фибула типа Aucissa из раскопок Троицкого городища. Предметы римского производства, в том числе римские провинциальные фибулы, находят в погребениях первых веков из Андреевского, Кошибеевского и других могильников (Ставииякий, 2013. С. 127-130). Вполне вероятно, что источник поступления цинкосодержащих сплавов в лесную зону для этого периода находился не на западе, а на востоке. Картина существенным образом меняется в III-V вв., когда в металлообработке лесной и лесостепной зон цинкосодержащие сплавы (латунь, оловянная или свинцовая латунь, многокомпонентный сплав) занимают большую долю в имеющихся выборках, процентное содержание цинка в сплавах значительно повышается, а соотношение типов цинкосодержащих сплавов в выборках приближается к римским пропорциям. Скорее всего, это связано с увеличением потока цинкосодержащих сплавов (в частности, римских монет) на территории лесной и лесостепной зон, появления контакта с традициями римской цветной металлообработки через, к примеру, черняховскую культуру или балтские племена (Бейдин и др., 2006; Сорокин, Шаров, 2008; и др.). Здесь нужно сказать о существовании значительного, более столетия, временного лага между появлением классических для римской металлообработки сплавов с цинком на территории лесной и лесостепной зон и временем активного производства и использования этих же типов сплавов (с подобными же характеристиками) на территории самой Римской империи (см. также: Хаврин и др., 2011). Такой же временной лаг мы можем зафиксировать и для более позднего периода - середины I тысячелетия н. э., когда в выборках из лесной зоны содержание цинка падает до значений 6-8\%, в выборках из лесостепной зоны - до 4-11\% при повышенных 
значениях олова или свинца, тогда как такие сплавы на других территориях, в том числе периферийных, появляются не позднее III-IV вв. Характерной особенностью цинкосодержащих сплавов лесной и лесостепной зон является их легирование преимущественно оловом, тогда как для периферийных территорий Римской империи характерно легирование цинкосодержащих сплавов преимущественно свинцом; на территории лесной и лесостепной зон такие сплавы существенную долю в выборках занимают только к середине I тысячелетия н. э. Наиболее вероятно, что доминирование в выборках лесной и лесостепной зон цинкосодержащих сплавов, высоколегированных оловом, можно объяснить географической близостью с Карпатским металлургическим центром, металл которого характеризуется повышенным содержанием олова до $25 \%$ и цинка (до 15-30\%), часто дополнительно легированных свинцом (Craddock et al., 2010. Р. 61).

Таким образом, если говорить о цинкосодержащих сплавах как о своеобразном «индексе романизации», принятом в европейской археологии, то для лесной и лесостепной зон этот индекс работает очень своеобразно: он скорее указывает на суще- ствование различных для каждого из хронологических этапов условий поступления таких сплавов на территорию европейской части России. Если посмотреть на результат сопоставления данных по нашим выборкам с синхронными выборками из других регионов, в том числе с территорией Римской империи, то для наших материалов на первый план выходят совершенно иные вопросы: каким образом на территории лесной и лесостепной зон была организована плавка цинкосодержащих сплавов с сохранением высоких значений по содержанию цинка; в каких центрах это производство велось, к примеру, после III в.н.э.; и означает ли находка в слое городища Отмичи середины I тысячелетия н.э. тиглей-льячек с содержанием цинка 50-70\% на ошлакованных стенках, что на территории лесной зоны в этот период продолжалось производство таких сплавов. Естественным образом эти вопросы подразумевают необходимость решения проблемы источников поступления цинкосодержащих сплавов на территорию лесной и лесостепной зон в период после III-IV вв. и определение масштабов циркуляции таких сплавов после прекращения их производства Римской империей.

\section{Литература}

Бариева Т.Б., Вознесенская Г.А., Черных Е.Н., 1972. Металл черняховской культуры. М.: Наука. 106 с., ил.

Баризева Т.Б., 1980. О химическом составе металла наверший скифского времени // СА. № 3. C. 77-91.

Баризева Т.Б., 1981а. Цветная металлообработка скифского времени. Лесостепное днепровское левобережье. М.: Наука. 127 с.

Барияева Т.Б., 1981б. О химико-металлургическом исследовании бронзовых вещей Марицкого городища // Пузикова А. И. Марицкое городище в Посеймье VI-V вв. до н.э. М.: Наука. C. 102-106.

Бейдин Г.В., 2006. Находки монет римского времени на территории Харьковской области // Древности римского времени на Слобожанщине. Харьков: Курсор. С. 110-143.

Богданова-Березовская И.В., 1973. Металлические изделия из Мастюгинских курганов. Химический состав // Материалы по археологии европейской части СССР от эпохи р.ж. в. до средневековья. Л.: Аврора. С. 46-51. (АСГЭ. Вып. № 15).
Изюмова С.А., 1967. О бронзолитейном производстве Сатинского городища // СА. № 1. С. $122-138$.

Исланова И. В. Городище Отмичи. М.: ИА РАН. 2008. 284 с., ил. (Раннеславянский мир. Вып. 11).

Кренке Н. А. Дьяково городище: культура населения бассейна Москвы-реки в I тыс. до н.э. - I тыс. н. э. 2011. М.: ИА РАН. 548 с., ил.

Лотенков М.И., Баричева Т.Б., 1995. К вопросу о бронзолитейном ремесле населения милоградской культуры // ГАЗ. № 6. Мінск. С. 78-104.

Меркулов А.Н., 2018. Результаты рентгеноспектральных исследований бронзовых изделий скифского времени из Лесостепного Подонья // Изв. ВПГУ. Гуманитарные науки. Сер.: Истор. науки, археология. № 1 (278). С. 100-103.

Разумов И.Н., Миненко В.В., Бишутин М.А., Федонин Р. А. Археологические разведки на территории Жуковского и Жирятинского районов Брянской области // АО 2017. (В печати.)

Сапрыкина И. А., Энговатова А. В., 2002. Химический состав цветного металла дьяковского времени из раскопок городища Настасьино // TAC. Вып. 5. Тверь. С. 477-493. 
Сапрыкина И.А., 2005. Производственный ювелирный комплекс Троицкого городища дьяковской культуры // Древности Евразии. От ранней бронзы до раннего средневековья. Памяти В.С. Ольховского / Гл. ред. В. И. Гуляев. М.: ИА РАН. С. 204-211.

Сапрыкина И.А., 2006. К вопросу об умбоновидных подвесках дьяковской культуры // РА. № 4. C. $36-40$.

Сапрыкина И.А., 2007. Ювелирные украшения дьяковской культуры по материалам памятников бассейна Москвы-реки. Дисс. ... канд. истор. наук. М.

Сапрыкина И.А., 2008. Каталог исследованных изделий из цветного металла городища Отмичи // И. В. Исланова: Городище Отмичи. М.: ИА РАН. С. 245-265. (Раннеславянский мир. Археология славян и их соседей. Вып. 11).

Сапрыкина И.А., 2014. Состав металла изделий из Куриловского клада раннесредневекового времени (по результатам рентгенофлуоресцентного анализа) // КСИА. Вып. 233. С. 178-186.

Сапрыкина И.А., 2015. Результаты исследования химического состава металла Велегожского клада // Лесная и лесостепная зоны Восточной Европы в эпохи римских влияний и Великого переселения народов. Конфер. 4. Ч. 1/ред. И. О. Гавритухин, А.М. Воронцов. Тула: ГМЗ «Куликово поле». С. 103-106.

Смирнов К. А., 1970. Части костюма и украшения, найденные на Троицком городище // Древнее поселение в Подмосковье. МИА СССР, № 156. Отв. ред. К. Ф. Смирнов. М.: Наука. С. 179-181. Сорокин П.Е., Шаров О.В., 2008. О новых находках римской эпохи на Северо-Западе // Древности Ижорской земли. Археологическое наследие Санкт-Петербурга. Вып. 2. СПб.: ИИМК РАН, Северо-Западный институт наследия. С. 167-201.

Ставицкий B.B., 2013. Западный компонент в материалах Андреевского кургана // Вестник НИИ гуманитарных наук при Правительстве Республики Мордовия. Сер.: Археология. № 3 (27). С. 126-141.

Сыроватко А. С., Сапрыкина И. А., 2011. Клад рубчатых браслетов на реке Оке // АП. Вып. 7. М.: ИА РАН. С. 72-76.

Хаврин С.В., Юшкова М.А., Кулешов Вяч.С., 2011. Металл эпохи римских влияний на Ижорской возвышенности // Европейская Сарматия. XIV чтения памяти Анны Мачинской. СПб. С. 208-224.

Черных Е.Н., Барцеева Т.Б., 1970. Химический состав цветного металла Троицкого городища // Древнее поселение в Подмосковье / Отв. ред. К.Ф. Смирнов. М.: Наука. С. 200-206. (МИА СССР. № 156).
Черных Е.Н., Хоферте Д. Б., Бариева Т.Б., 1969. Металлургические группы цветного металла I тысячелетия н.э. из Прибалтики // КСИА. Вып. 119. C. 109-120.

Черных Е. Н., Бариеева Т.Б., 1972. Сплавы цветных металлов // Барцева Т. Б., В Вознесенская Г. А., Черных Е.Н. Металл черняховской культуры. М.: Наука. С. 50-117. (МИА. № 187).

Шаров О.В., Палагута И.В., Хаврин С.В., 2011. Находки кладов римских монет в районе Копорья // Российский археологический ежегодник, № 1. С. 336-360.

Щукин М.Б., 1994. На рубеже эр. Опыт историкоархеологической реконструкции политических событий III в. до н.э. - I в.н.э. в Восточной и Центральной Европе. СПб.: Фарн. 323 с., ил. (Российская археологическая библиотека. № 2).

Энговатова А.В., Сапрыкина И.А., 2005. Хронология раннего периода москворецкой группы памятников дьяковской культуры по данным радиоуглеродного анализа // Древности Евразии. От ранней бронзы до раннего средневековья. Памяти В.С. Ольховского / Гл. ред. В.И. Гуляев. М.: ИА РАН. С. 127-137.

Bayley J., 1998. The production of brass in antiquity with particular reference to roman Britain // 2000 Years of Zinc and Brass / Ed. by P.T. Craddock. British Museum Occassional Papers, № 50. P. 7-26.

Bourgarit D., Thomas N., 2015. Ancient brass: misconceptions and new insights // Archaeometallurgy in Europe III. Proceedings of the $3^{\text {rd }}$ International Conference / Ed. by A. Hauptmann, D. Modaressi-Tehrani. Bochum. P. 225-262.

Braund D. Rome and the Friendly King. The Character of the Client Kingship. L. and Canberra: Croom Helm, and NY.: St Martin's Press, 1984. 226 p., ii.

Craddock P. T., Eckstein K., 2003. Production of brass in Antiquity by direct reduction// Mining and Metal Production Through the Ages/Ed. by P.T. Craddock and J. Lang. L.: Archetype.P. 216-230.

Craddock P.T., Cowell M., Hook D., Hughes M., La Niece S., Meeks N., 2010. Change and statis: the technology of Dark Age metalwork from the Carpathian Basin // Technical Research Bulletin. British Museum / Ed.D. Saunders. Vol. 4. Archetype Publications Ltd. P. 55-65.

Dungworth D., 1996. Caley`s zinc decline reconsidered // Numismatic Chronicle, 156. P. 228-234.

Dungworth D., 1997. Roman Copper Alloys: Analysis of Artefacts from Northern Britain // Journal of Archaeological Science, 24. P. 910-910.

Gugl Ch. Die römischen Fibeln aus Virunum. Klagenfurt. 1995. 
Hamilton E. G., 1996. Technology and Social Change in Belgic Gaul: Copper Working at the Titelberg, Luxembourg, 125 B.C. - A.D. 300. Michigan: University of Pennsylvania Museum of Archaeology and Anthropology, MASCA Research Papers in Science and Archaeology. $96 \mathrm{p}$.

Pollard A.M., Bray P., Gosden C., Wilson A., Hamerow H., 2015. Characterising copper-based metals in Britain in the first millennium AD: a preliminary quantification on metal flow and recycling // Antiquity, 89. P. 697-713.

Ponting M.J., 2002. Roman military copper-alloy artefacts from Israel: questions of organization and ethnicity // Archaeometry, 44. P. 555-571.
Rehren Th., 1999a. «The same... but different»: a juxtaposition of Roman and Medieval brass making in Central Europe // Metals in Antiquity / Ed. by S.M.M. Young, A.M. Pollard, P. Budd and R.A. Ixer. Archaeopress. P. 252-257. (BAR International Series, 792).

Rehren Th., 1999b. Small Size, Large Scale. Roman Brass Production in German Inferior // Journal of Archaeological Science, 26 (8). P. 1083-1087.

Weisgerber G., CraddockP., Meeks N., Baumer U., Koller J., 2007. Roman brass and lead ingots from the western Mediterranean // Metals and Mines. Studies in archaeometallurgy / Ed. S. La Niece, D. Hook, P. Craddock. Archetype Publications Ltd. P. 148-158. 


\section{И.В. Исланова \\ Институт археологии РАН, г. Москва}

\section{Ермоловское городище (материалы раннего железного века)}

Для Верхнего Поволжья наименее изученными являются древности I тысячелетия до н.э. участка так называемого ржевского течения реки. На карте К.А. Смирнова эта территория входит в ареал дьяковской культуры (Смирнов, 1974. Табл. Х). Верховья Волги были отнесены мною к контактной зоне днепродвинских и дьяковских древностей (Исланова, 2012. Рис. 23). Но не исключено, что культурная картина была многограннее, но малочисленная источниковая база не позволяет определенно говорить о культурных приоритетах населения раннего железного века.

Одним из основных памятников для выяснения культурной ситуации в середине - второй половине I тысячелетия до н.э. является Ермоловское городище. Городище было обнаружено в 1923 г. учениками школы-коммуны д. Шопорово и получило наименование по расположенной поблизости бывш. усадьбе Ермоловых в сельце Иваньково, лежащем между д. Шопорово и Строево (рис. 1). В 1924 г. городище было обследовано «Верхне-Волжской археологической экскурсией», организованной сотрудником Государственного Эрмитажа П.Н. Шульцем и директором Ржевского историко-археологического музея С.Л. Бычинским. Помимо древностей эпохи бронзы и раннего железного века «экскурсией» выявлялись и обследовались древнерусские курганные могильники и средневековые поселения. Результаты их работ были опубликованы в 1926 г. в Ржевском краеведческом сборнике (Бычинский, 1926. С. 150-157; Шульи, 1926. С. 172-194). Описание исследований также содержатся в отчете П.Н. Шульца за 1925 г, хранящимся в архиве ИИМК (Шульи, 1925а). Однако иллюстрации и в публикации, и в отчете отсутствуют, хотя в последнем был список рисунков и ссылки на них. Коллекция находок, поступившая на хранение в Ржевский историко-археологический музей, была утрачена во время Великой Отечественной войны.
После работ, проведенных в 20-е годы ХХ в., и само городище фактически было утеряно археологами. На карте распространения балтских булавок, составленной В.В. Седовым, Ермоловское городище обозначено на правом берегу Волги (Седов, 1970. Рис. 4). В 1977 г. при разведочных работах историко-археологической экспедиции Калининского (ныне Тверского) государственного университета, которые велись с целью постановки на учет археологических памятников и составления на них паспортов, городище у д. Редькино, лежащее на правом берегу р. Волги, было ошибочно идентифицировано с Ермоловским. Сведения из паспорта «городище у д. Редькино (Ермоловское)» вошли в свод памятников Ржевского района Тверской области 2007 г. (АКР, 2007. С. 274).

В 2004 и 2005 гг. сотрудник Тверского государственного объединенного музея (ТГОМ) Р.А. Оруджев, опираясь на первые публикации материалов Ермоловского городища, обследует участок местности на окраине г. Ржева на левом берегу р. Волги. Предполагаемое Ермоловское городище именуется в его отчете городищем Ржев 3 (Оруджев, 2004; 2005). В 2009 г. этот же объект обследуется В. А. Шестаковым (2009), а в 2010 г. - автором настоящей статьи во время инвентаризации памятников на территории г. Ржева (Исланова, 2010).

Обнаруженные при исследованиях начала XXI в. фрагменты лепной керамики и описания начала $\mathrm{XX}$ в. местоположения, характера и формы площадки памятника позволили поселение Ржев 3 отождествить с Ермоловским городищем. Но окончательную точку в вопросе локализации ставит сохранившаяся в архиве ТГОМ вместе с машинописным отчетом и списком рисунков карта археологических памятников, обследованных П.Н. Шульцем в 1924 1925 гг. (Шульц, 1925б), ранее не привлекавшаяся исследователями ${ }^{1}$. Ермоловское городище на карте

1 Дело в том, что и карта, и машинописная копия полевого отчета 1925 г. П. Н. Шульца были подшиты к делам за 1933-1938 гг. 


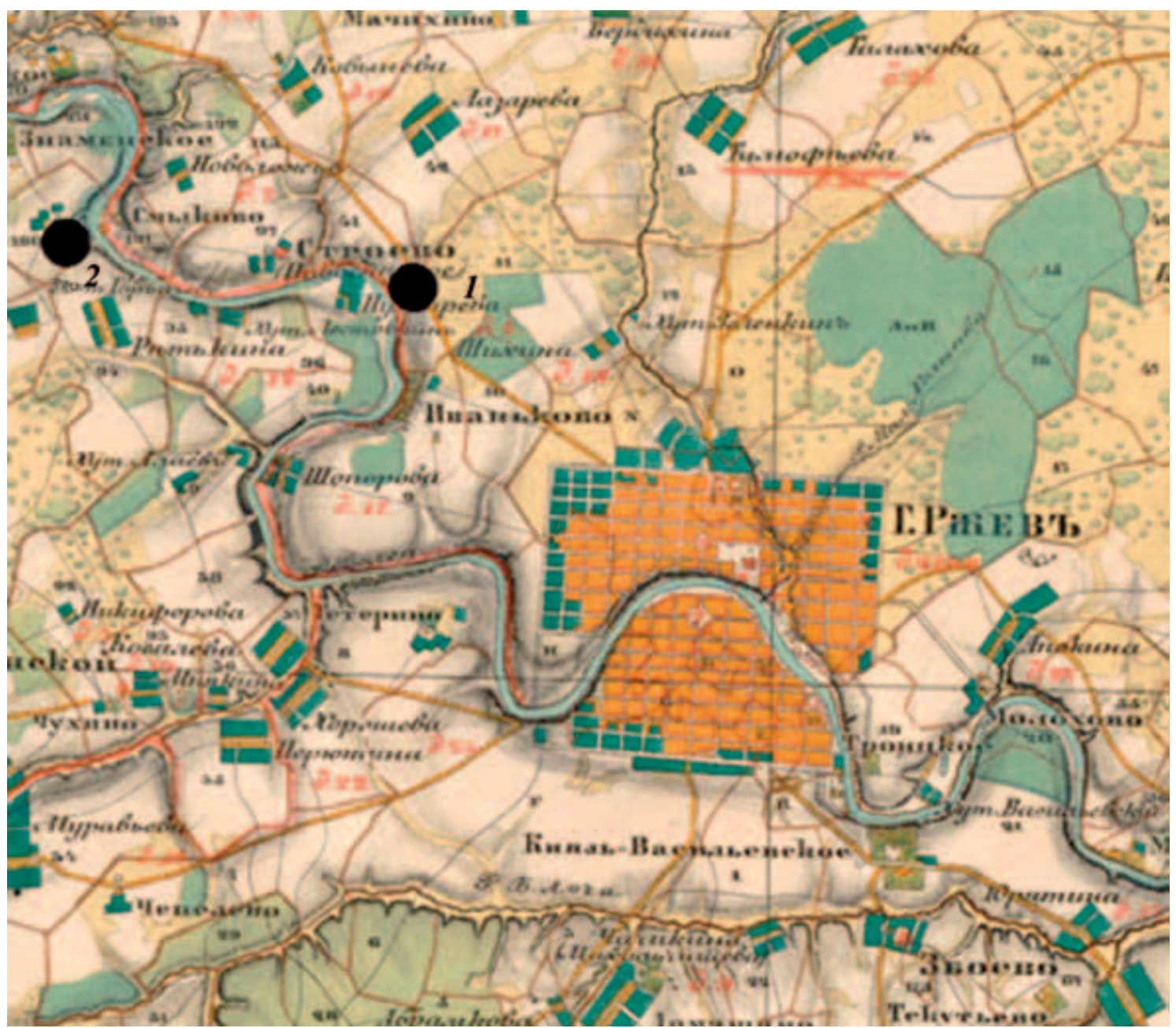

Рис. 1. Местоположение двух городищ на топографической межевой карте 1853 г. А.И. Менде 1 - Ермоловское городище (Ржев 3); 2 - городище Редькино

обозначено на левом берегу р. Волги выше по течению от г. Ржева (рис. 2).

В настоящее время можно с уверенностью говорить, что Ермоловское городище (городище Ржев 3) находится на северо-западной окраине современного г. Ржева, в 110 м к западу от шоссе Ржев - Осташков, в 160 м к юго-западу от кирпичного завода. От шоссе городище отделено современными постройками водозабора г. Ржева. Поселение расположено на мысу левого коренного берега р. Волги при впадении в нее оврага (правый берег). Высота над летним уровнем воды в реке -25-26 м (рис. 3). По сведениям С. Л. Бычинского и П.Н. Шульца, площадка имела треугольную форму размерами соответственно $50 \times 30$ или $60 \times 40$ м. При инвентаризации памятника в 2010 г. в его территорию были включены склоны к реке и к руслу оврага (Исланова, 2018. С. 251). Поэтому общая территория памятника получила трапециевидную форму и протяженность с юго-запада на северо-восток от 85 до $175 \mathrm{M}$ и с юго-востока на северо-запад до $110 \mathrm{M}$.

С напольной стороны в 20-е годы XX в. находился вал, идущий от оврага до середины площадки. В настоящее время следы вала не прослеживаются. Видимо, при интенсивной пахоте во второй половине XX в. он был снивелирован. Еще в начале XX в. П.Н. Шульц указывал, что помимо интенсивного размыва культурного слоя во время весенних половодий берега «не менее разрушительная работа произведена здесь любительскими раскопками» (Шульи, 1926. С. 180). В настоящее время склон к р. Волге слабо задернован и происходит дальнейшее сползание слоя. Площадка памятника задернована.

В 1924 г. было изучено несколько квадратных метров (заложены «ряд пробных кессонов») по склону оврага. Культурные напластования здесь достигали 0,75-1,50 м. Отсюда происходили 


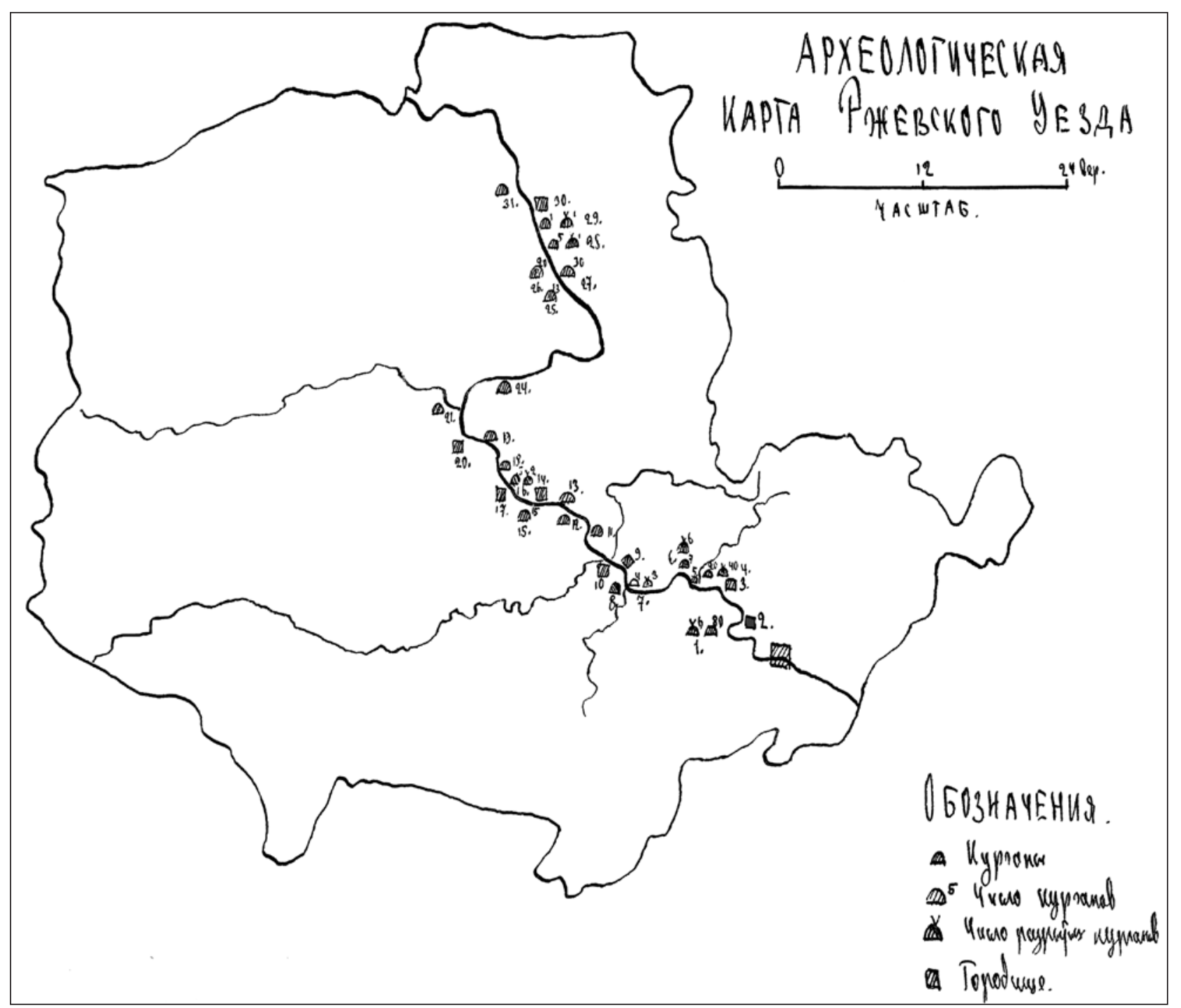

Рис. 2. Карта П.Н. Шульца из отчета 1925 г. (Шульц, 1925б. Л. 44-46). Публикуется впервые, легенда приводится по тексту в отчете

«Указатель к археологической карте... 1. На правом берегу Волги, напротив д. Шопорово - группа из 90 курганов. 2. На левом берегу Волги близъ б. им. Ермоловых - городище. 3. На левом берегу Волги близ б. им. Петровского - городище. 4. На левом берегу Волги в парке б. им. Петровского - группа в 60 курганов. Свыше 40 копаны. 5. На левом берегу Волги при впадении р. Доброй - 1 курган рытый. 6. На левом берегу Волги ниже б. им. Коромлино - группа в 13 курганов, 6 рытых. 7. На левом берегу Волги против впадения р. Дуньки - группа в 7 курганов, 3 рытых. 8. На правом берегу Волги близ впадения р. Дуньки - курган. 9. На левом берегу Волги близ впадения р. Кокши - городище. 10. На правом берегу Волги б. погоста Николо-Сишки - городище. 11. На левом берегу

Волги б. имения Клепинино - курганы. 12. На правом б. Волги б. деревни Веклина - курганы. 13. На левом б. Волги против д. Веклина - курганы (запахиваются). 14. На левом б. Волги выше д. Веклина - городище. 15. На правом б. Волги у д. Струйская - группа в 15 курганов не копанных. 16. На правом б. Волги близъ д. Гульцово - группа из 7 курганов, 2 раскопано. 17. На правом б. Волги выше д. Фролово - городище. 18. На левом б. Волги против б. им. Пупово - курганы. 19. На левом б. Волги выше погоста Подборовья - курганы. 20. На правом б. Волги в погосте Троицо-Сковоротыни - городище. 21. На правом б. Молодого Туда около 1 версты выше устья - курганы. 22. На левом

б. Волги в б. им. Горки - группа в 10 курганов. 7 раскопано. 23. На левом б. Волги выше б. им. Горки - 13 курганов, 4 разрытых. 24. На левом б. Волги против деревни Горки - 1 курган, не рытый. 25. На правом б. Волги против

с. Сытьково - 13 курганов не рытых. 26. На правом б. Волги близъ д. Холмово - около 20 курганов. 27. На левом б. Волги близ д. Сосуново - около 30 курганов. 28. На левом б. Волги близ д. Шолохово - 6 курганов, 1 - копан. 29. На левом б. Волги против п. Тихвинского - 2 кургана, 1 - копан. 30. На левом б. Волги близ д. Рождествено - городище. 31. На правом б. Волги против с. Лукома - курганы, не рытые» 


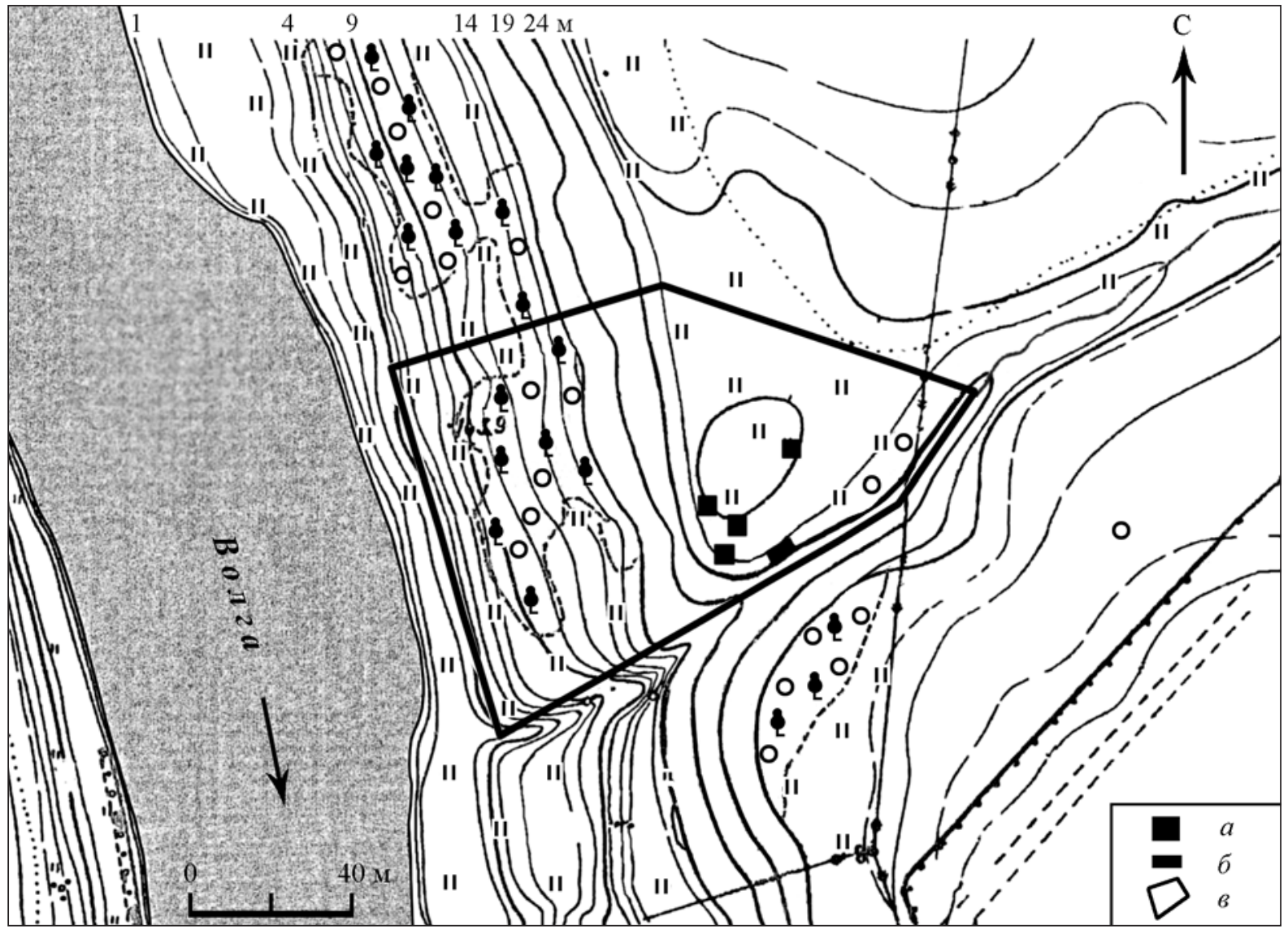

Рис. 3. Инструментальный план Ермоловского городища

$a$ - шурф; $\sigma$ - зачистка; в - примерные границы городища

основные вещевые и керамические находки, относящиеся к раннему железному веку. В начале XXI в. на склоне к р. Волге собирался подъемный материал, а на площадке заложены четыре шурфа и сделана зачистка ямы на склоне оврага (рис. 3). При этих исследованиях выяснилось, что памятник представляет собой многослойное поселение и имеет разной степени сохранности напластования эпохи камня (мезолит - неолит), раннего железного века (вторая половина I тысячелетия до н. э. - начало I тысячелетия н. э.) и Средневековья (XIII-XVI вв.) (Исланова, 2018. С. 251).

На площадке городища зафиксирован культурный слой, поврежденный распашкой, общей мощностью от 0,10 до 0,23 м. Это черная гумусированная супесь с углями и мелкими обожженными камнями. Помимо вещей и керамики в начале XX в. был собран остеологический материал: кости домашних (лошади, коровы, овцы) и диких (куницы, бобра, лося, медведя) животных, кости рыб и птиц (Бычинский, 1926. С. 152; Шульи, 1926. С. 179).

Кералика. При исследованиях начала ХХ в., судя по описаниям в публикациях, обнаружены фрагмен- ты лепной посуды (рис. 4, 1, 2) - как гладкостенные, так и орнаментированные крупнозубчатым штампом, ямками, нарезками, ногтевыми вдавлениями и оттисками, сделанными краем кости (Бычинский, 1926. С. 153; Шульи, 1926. С. 179). Фрагменты днищ имели или не имели закраин. При разведочных работах начала XXI в. найдены мелкие фрагменты венчиков и стенок лепных сосудов с примесью небольших зерен дресвы в глиняном тесте. Встречены фрагмент стенки сосуда с орнаментом в виде защипов (рис. 4, 5) и фрагмент венчика с нарезками по его краю. В 2009 г. найдена миниатюрная лепная чашечка (рис. 4,8 ). Встреченная на лепной керамике орнаментация известна на дьяковской посуде конца I тысячелетия до н.э. - первых веков н.э. (Розенфельдт, 1971. С. 53-54) и на керамике верхнеокской культуры (Столяров, 2012. Рис. 26, 29, 30).

Следует отметить, что на городище найдено всего два фрагмента стенок сетчатых сосудов: один при раскопках П.Н. Шульца и Л.С. Бычинского, другой - в 2005 г. Известно, что единичные находки сетчатой керамики происходят с днепродвинских и верхнеокских поселений (Шадыро, 

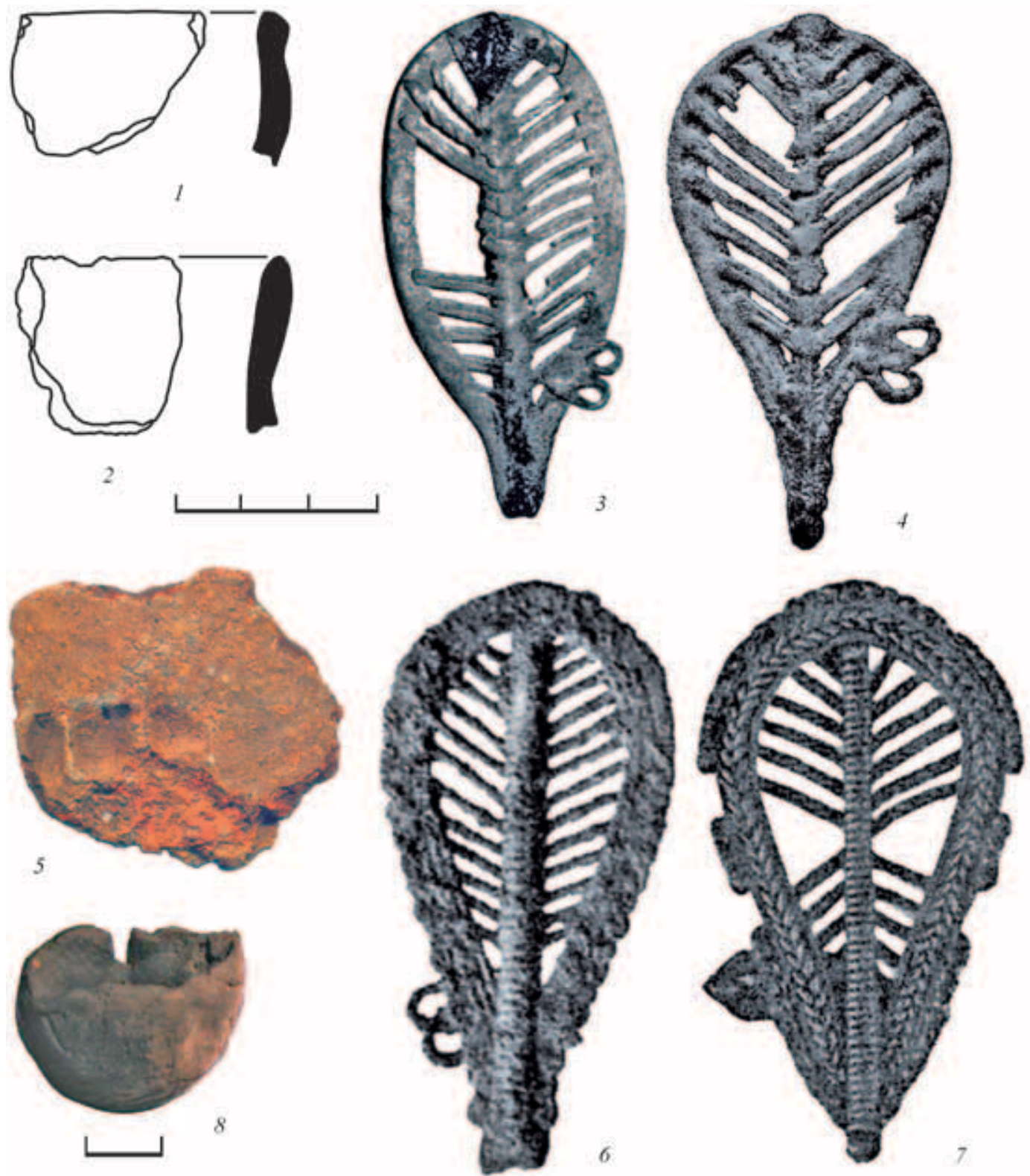

Рис. 4. Лепная керамика с Ермоловского городища и схожие навершия подгорцевского стиля

1, 2 - подъемный материал 2010 г.; 3 - городище Козлово; 4 - городище Николо-Ленивец; 5 - подъемный материал 2004 г.; 6 - городище Гремячево; 7 - городище Свинухово; 8 - находка из шурфа 2009 г.

1985. С. 81, 82; Столяров, 2012. С. 75). В целом датировать лепную керамику Ермоловского городища можно второй половиной I тысячелетия до н. э. - началом I тысячелетия н. э.

Вещевой материал. Вещевые находки, о которых можно судить только по описаниям, происходят из шурфов и, видимо, сборов 1923 и 1924 гг. Костяные изделия преобладали над остальными предметами. Это гарпуны «с прямым продолговатым насадом» и «с выступом у основания», рукояти, острия, проколки, «небольшой цилиндрик... полый внутри, с тремя отверстиями по бокам», «предмет наподобие гребня, с двумя крупными зубьями и выступами по обеим сторонам», «подвеска продолговатой формы, полая внутри с отверстием у основания» (Бычинский, 1926. С. 152-153; Шульи, 1926. С. 179). Костяные предметы - весьма характерные и наиболее частые находки в древностях лесной зоны I тысячелетия до н. э.

На городище также были обнаружены «железная круглая бляха в виде конуса с широким основанием» и обломок железного ножа, бронзовый 
пластинчатый браслет «с нисходящими концами», каменный клин, точильные и шлифовальные камни (Шульц, 1926. С. 180).

Особого внимания, конечно, заслуживает находка бронзового ажурного листовидного навершия подгорцевского стиля. Исследователи Ермоловского городища указали на аналог обнаруженного предмета - это навершие с городища Гремячее на р. Оке (Бblчинский, 1926. С. 155; Шульи, 1926. С. 180). Поэтому утраченный ныне предмет мы примерно можем представить (рис. 4, б). Близкие по форме изделия происходят также с других памятников верхнеокской культуры, расположенных на р. Оке и на ее левом притоке p. Угре: с городищ Козлово, Николо-Ленивец, Свинухово (рис. 4, 3, 4, 7). Подобные навершия датируются IV-III вв. до н. э. (Столяров, 2013. С. 427-438.). При этом изделие, происходящее с Ермоловского городища, является самым северным по месту находки.
Таким образом, нет никаких особых материалов, позволяющих причислить Ермоловское городище к раннедьяковским: отсутствуют грузики дьякова типа, единична сетчатая керамика. Керамический материал близок лепной посуде верхнеокской и днепро-двинской культур. Однако для того, чтобы отнести Ермоловское городище к верхнеокской культуре, артефактов недостаточно. Имеющиеся небольшие вещевые и керамические материалы позволяют говорить об имевшихся так называемых культурных импульсах из Верхнеокского региона. Если учитывать находки керамики на городище Осечен (Исланова, Миреццкий, Олейников, 2007. С. 134), расположенного в 40 км выше по течению реки от анализируемого памятника, участок ржевского течения p. Волги во второй половине I тысячелетия до н.э. мог являться своеобразной контактной зоной двух культур - верхнеокской и днепро-двинской.

\section{Литература}

АКР. Тверская область. Ч. 2. Андреапольский, Бельский, Жарковский, Западнодвинский, Нелидовский, Оленинский, Ржевский, Торопецкий районы / Авт.-сост. В.С. Нефёдов.. М.: ИА РАН, 2007. $440 \mathrm{c}$

Бычинский С.Л., 1926. Ермоловское городище // Ржевский край. Сборник Ржевского краеведческого общества. № 1. Ржев. С. 150-156.

Исланова И.В., 2010. Отчет об инвентаризации археологических памятников в г. Ржеве / Архив ИА РАН. Р-1. № 39799.

Исланова И. В., 2012. Древности в верховьях Волги (ранний железный век и раннее средневековье). М.: ИА РАН. 219 с. (РСМ; вып. 14).

Исланова И.В., 2018. Объекты археологического наследия на территории современного г. Ржева (по материалам инвентаризации 2010 г. // ТАС. Вып. 11. Тверь: ООО «Изд-во «Триада». C. 244-263.

Исланова И.В., Мирецкий А.В., Олейников О.М., 2007. Городище Осечен (ранний железный век и раннее средневековье) // ТАС. Вып. 6. Т. II. Тверь: ООО «Изд-во «Триада». С. 132-146.

Оруджев Р.А., 2004. Отчет о разведочных работах на территории современного г. Ржева в 2004 г. / Архив ИА РАН. Р-1. № 31562.

Оруджев Р. А., 2005. Отчет о разведочных работах на территории современного г. Ржева в Тверской области. 2005 г. / Архив ИА РАН. Р-1. № 28027.

Розенфельдт И.Г., 1971. Керамика Троицкого городища // Древнее поселение в Подмосковье. М.: Наука. С. 6-79. (МИА; № 184).
Седов В.В., 1970. Славяне Верхнего Поднепровья и Подвинья. М.: Наука. 200 с.

Смирнов К.А., 1974. Дьяковская культура (материальная культура городищ междуречья Оки и Волги) // Дьяковская культура. М.: Наука. 1974. С. 7-89.

Столяров E. B., 2012. Культурные традиции населения бассейна Верхней Оки в эпоху раннего железного века: VI в. до н. э. - I в. н. э. Дисс... канд. истор. наук. / Архив ИА РАН. Р-2. № 22818.

Столяров E.B., 2013. Украшения подгорцевского типа в бассейне Верхней Оки (ажурные навершия булавок) // ТАС. Вып. 9. Тверь: ООО «Издво «Триада». С. 427-435.

Шадыро В.И., 1985. Ранний железный век Северной Белоруссии. Минск: Наука и техника. 126 с.

Шестаков В.A., 2009. Отчет об археологической разведке в Тверской области в 2009 году / Архив ИА РАН. Р-1. № 38221.

Шульи П.Н., $\quad$ 1925a. Раскопки П.Н. Шульца в Ржевском уезде Тверской губ. Отчет об археологической экскурсии и переписка / Архив ИИМК. Ф. 2. Оп. 1. 1925. № 142.

Шульи П.Н., 1925б. Отчет об археологической экскурсии на Верхнюю Волгу (Ржевский уезд) с 15 июля по 1 августа 1925 г. // Отчеты и описания раскопок и находок археологических экспедиций музея за 1933-1938 гг. / Архив ТГОМ. Ф. Р-1. Оп. 1. Ед. хр. 273. Св. 32.

Шульи П.Н., 1926. Разведки во Ржевском уезде в 1924-25 гг. // Ржевский край. Сб. Ржевского краеведческого общ-ва. № 1. Ржев. С. 172-194. 


\author{
А. В. Кашкин, К.И. Комаров \\ Институт археологии РАН, г. Москва
}

\title{
Итоги мониторинга памятников археологии Ростовского района
}

В последние годы к традиционным археологическим задачам (раскопки и разведки) прибавилось еще одно направление профессиональной деятельности - мониторинг памятников археологии. Это связано в первую очередь с составлением единого реестра памятников истории и культуры, куда, естественно, входят и все археологические объекты, выявленные и поставленные на учет в предыдущие годы. Следует заметить, что активная паспортизация памятников археологии в СССР проводилась в основном в 1970-1980-х гг., в том числе и в интересующем нас Ростовском p-не Ярославской обл. Надо отметить, что большая часть памятников этого региона (92 из 135 , или $68 \%$ ) была открыта А.Е. Леонтьевым. Всего же им обследовано 112 памятников Ростовского р-на. Именно Ростовский р-н является на сегодняшний день самым исследованным в регионе, что нашло отражение в книге серии «Археологическая карта России» по Ярославской обл. (Комаров, 2005).

Однако с того времени прошел значительный срок. К тому же большинство памятников не посещалось археологами именно с тех лет, поэтому возникла насущная необходимость вновь обследовать эти памятники, перепроверить и уточнить их характеристики, привязать к системе географических координат. Решение именно этих и иных задач и было предпринято в процессе мониторинга состояния и использования объектов культурного наследия (памятников археологии) в рамках федеральной целевой программы «Культура России» в 2005-2012 гг. Волго-Окской экспедицией ИА РАН под руководством А. В. Кашкина и при непосредственном участии К.И. Комарова и А.Е. Ле- онтьева (рис. 1). Всего нами в Ростовском р-не обследовано 117 памятников (85\%). В процессе работ по мониторингу проведены следующие процедуры: обнаружение памятника, его точная привязка с использованием GPS-навигатора, повторное описание памятника с уточнением его характеристик (привязка к населенным пунктам, размеры, высоты), определение современного технического состояния (повреждения, утраты), фотофиксация, выявление владельца (арендатора) территории, на которой расположен памятник.

Далее мы публикуем каталог памятников Ростовского р-на с изменениями и дополнениями по результатам мониторинга, которые в основном касались позиций, обозначенных выше ${ }^{1}$. Цифры в скобках означают номера памятников на карте (рис. 2; 3).

1 (26). Алевайцино. Селище, XI-XIII вв. Расположено в 0,5 км к востоку от д. Алевайцино, на правобережной террасе р. Кось (левый приток р. Сары). Обследовано в 1979 г. А.Е. Леонтьевым, в 2007 г. А.В. Кашкиным. Уточненные размеры памятника $-120 \times 110$ м, высота от реки -3-5 м. Поверхность задернована, ранее распахивалась. Культурный слой толщиной 0,35 м. Состояние памятника хорошее.

2(27). Алешково. Селище, X-XIII, XIV-XVII вв. По данным 2007 г., расположено в 0,4 км к северо-западу от д. Алешково, на мысу левобережной террасы р. Кось (левый приток р. Сары). Обследовано в 1979 г. А.Е. Леонтьевым, в 2007 г. А. В. Кашкиным. Уточненные размеры - 80×30-40 м, высота от реки $-2-5$ м. Культурный слой, по данным 1979 г., толщиной до 1 м. Состояние памятника

\footnotetext{
${ }^{1}$ Полная библиография по всем памятникам содержится в книге серии АКР по Ярославской области (Комаров, 2005. С. 324-333). Новая библиография приводится в отдельных случаях, когда на памятниках проводились исследования.

${ }^{2}$ Слова «по данным...» и «уточненные размеры» здесь и далее указывают на изменение технических характеристик памятника.
} 


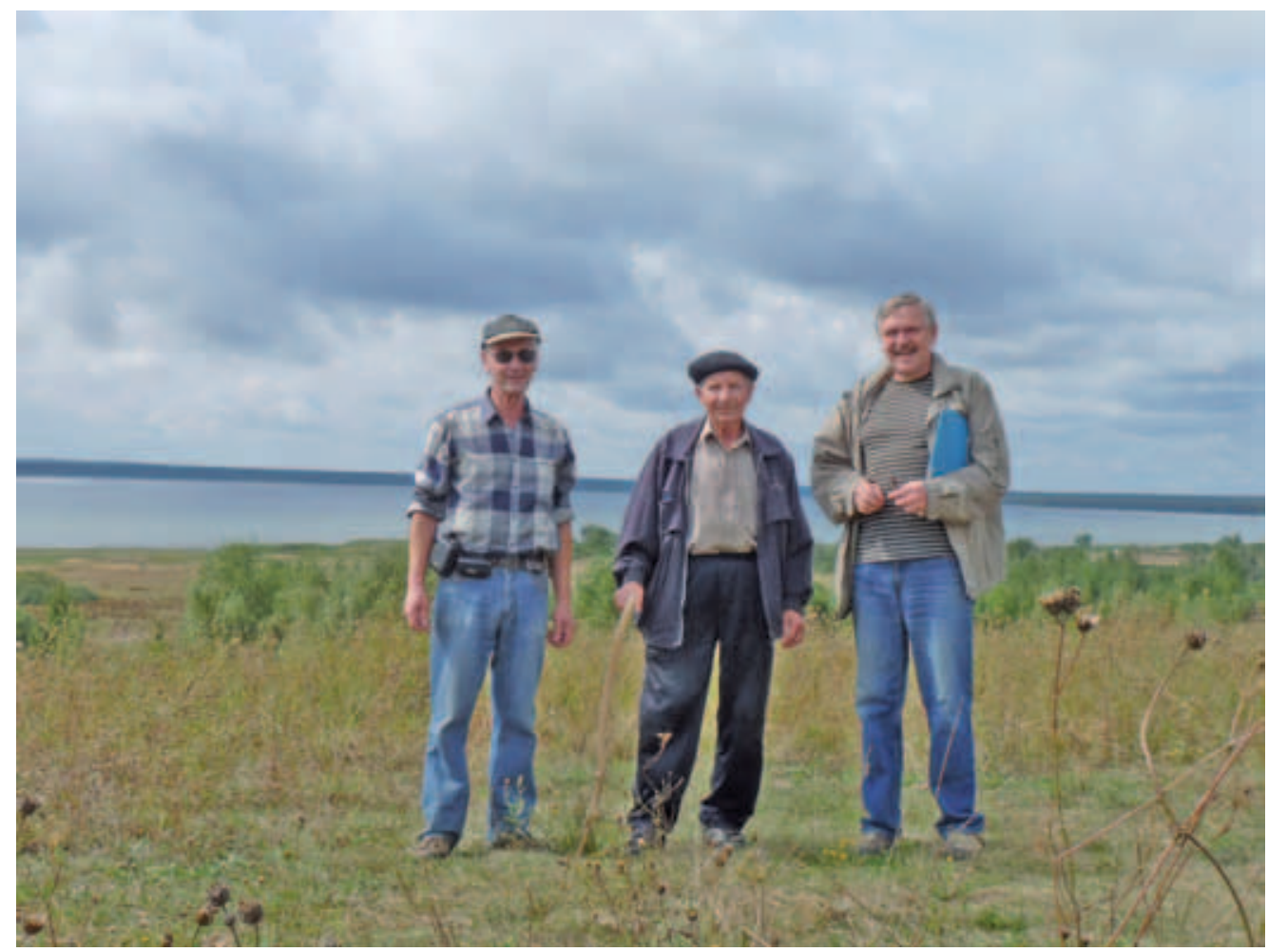

Рис. 1. Участники работ по мониторингу на берегу оз. Неро, 2010 г.

Слева направо: А. Е. Леонтьев, К. И. Комаров, А. В. Кашкин

хорошее, поверхность, которая ранее распахивалась, задернована.

3 (34). Бабки. Селище, X-XIII, XIV-XVII вв. Расположено на северо-западной окраине д. Бабки, на мысу первой надпойменной террасы левого берега р. Ишни. Обследовано в 1981 г. А.Е. Леонтьевым, в 2006 г. А. В. Кашкиным. Уточненные размеры - 140×50 м, высота от реки - 3-4 м. Культурный слой толщиной до 0,3 м. Состояние памятника хорошее. Поверхность задернована.

4 (19). Бакланово. Поселение 1, неолит, эпоха бронзы. По данным 2007 г., расположено в 1,5 км к востоко-юго-востоку от д. Бакланово, на мысу левобережной террасы р. Которосли (правый приток р. Волги). Обследовано в 1980 г. В.В. Сидоровым, в 2007 г. А.В. Кашкиным. Уточненные размеры - 150-180×80-100 м, высота от реки - 2-5 м. Культурный слой, по данным 1980 г., толщиной 0,3 м. Состояние памятника хорошее, поверхность, которая ранее распахивалась, задернована.

5 (18). Бакланово. Поселение 2, эпоха бронзы. По данным 2007 г., расположено в 1,3 км к востоко-юго-востоку от д. Бакланово, на левобережной террасе р. Которосли (правый приток р. Волги). Обследовано в 1980 г. В.В. Сидоровым, в 2007 г. А. В. Кашкиным. Уточненные размеры $-45 \times 35$ м, высота от реки - 4-5 м. Культурный слой, по данным 1980 г., толщиной 0,3 м. Состояние памятника хорошее, поверхность, которая ранее распахивалась, задернована.

6 (17). Бакланово. Селище, XIV-XVII вв. По данным 2007 г., расположено в 40-50 м к востоку от д. Бакланово, на левобережной террасе р. Которосли (правый приток р. Волги). Обследовано в 1977 г. А.Е. Леонтьевым, в 2007 г. А. В. Кашкиным. Уточненные размеры - 390×100 м, высота от реки - 6-8 м. Культурный слой, по данным 1977 г., толщиной до 0,25 м. Состояние памятника хорошее, поверхность, которая ранее распахивалась, задернована.

7 (7). Бахматово. Селище, XIV-XVII вв. Расположено в 0,85 км к юго-востоку от д. Бахматово, возвышенность на правобережной террасе p. Устье (левый приток р. Которосли). Обследовано в 1981 г. А.Е. Леонтьевым, в 2007 г. А. В. Кашкиным. Уточненные размеры - $120 \times 50$ м, высота от поймы - 1-2 м. Культурный слой толщиной до 0,3 м. Состояние памятника удовлетворительное, поверхность занята лесопосадками.

8 (128). Бикань. Курганный могильник 1, XI-XIII вв. Расположен в 0,4 км к северо-северо-западу от д. Бикань, на левобережном плато 


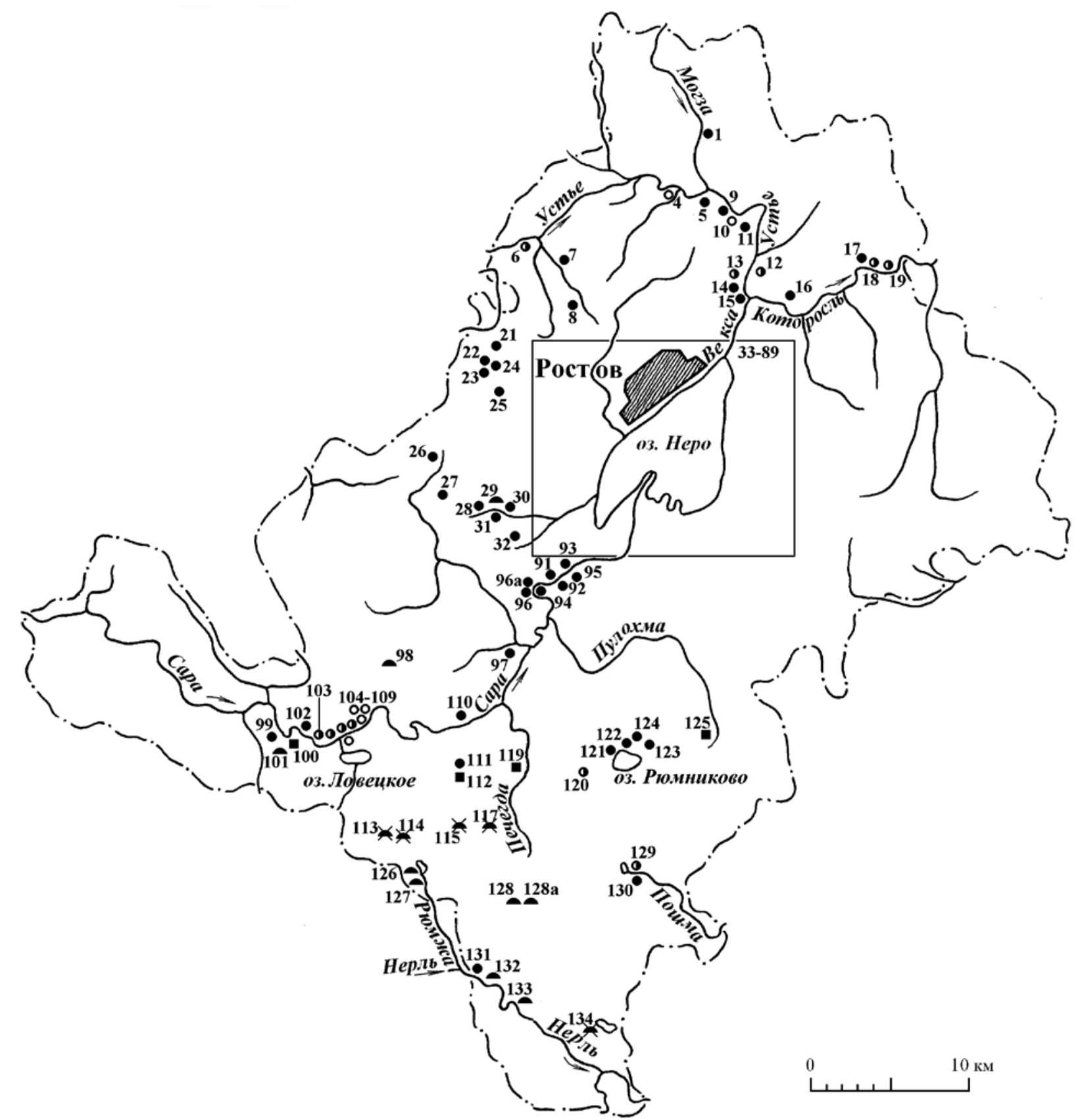

Рис. 2. Археологические памятники Ростовского района, обследованные по программе мониторинга (перечеркнутые значки - утраченные памятники)

р. Нерли (левый приток р. Клязьмы, левый приток р. Оки, правый приток р. Волги), в лесу. Исследовался в 1854 г. П. С. Савельевым (раскопано 10 курганов), обследован в 1990 г. К.И. Комаровым, в 2009 г. А.В. Кашкиным. Сохранилось восемь насыпей высотой 0,7-1,2 м, диаметром 5-8 м. Все они повреждены ямами, вероятно, от раскопок XIX в. Состояние памятника удовлетворительное, насыпи задернованы, поросли деревьями.
9 (128а). Бикань. Курганный могильник 2, XI-XIII вв. Расположен в 0,7 км к западо-северозападу от д. Бикань, на равнинном левобережном плато р. Нерли, в лесу. Исследовался в 1854 г. П. С. Савельевым (раскопано 12 курганов), обследован в 1990 г. К.И. Комаровым (могильник им не был найден, информация о памятнике помещена в АКР в разделе несохранившихся памятников), в 2009 г. А. Н. Каретниковым, в 2009 г. А. В. Кашкиным. Сохранилось 16 насыпей высотой 0,6-1,4 м, 


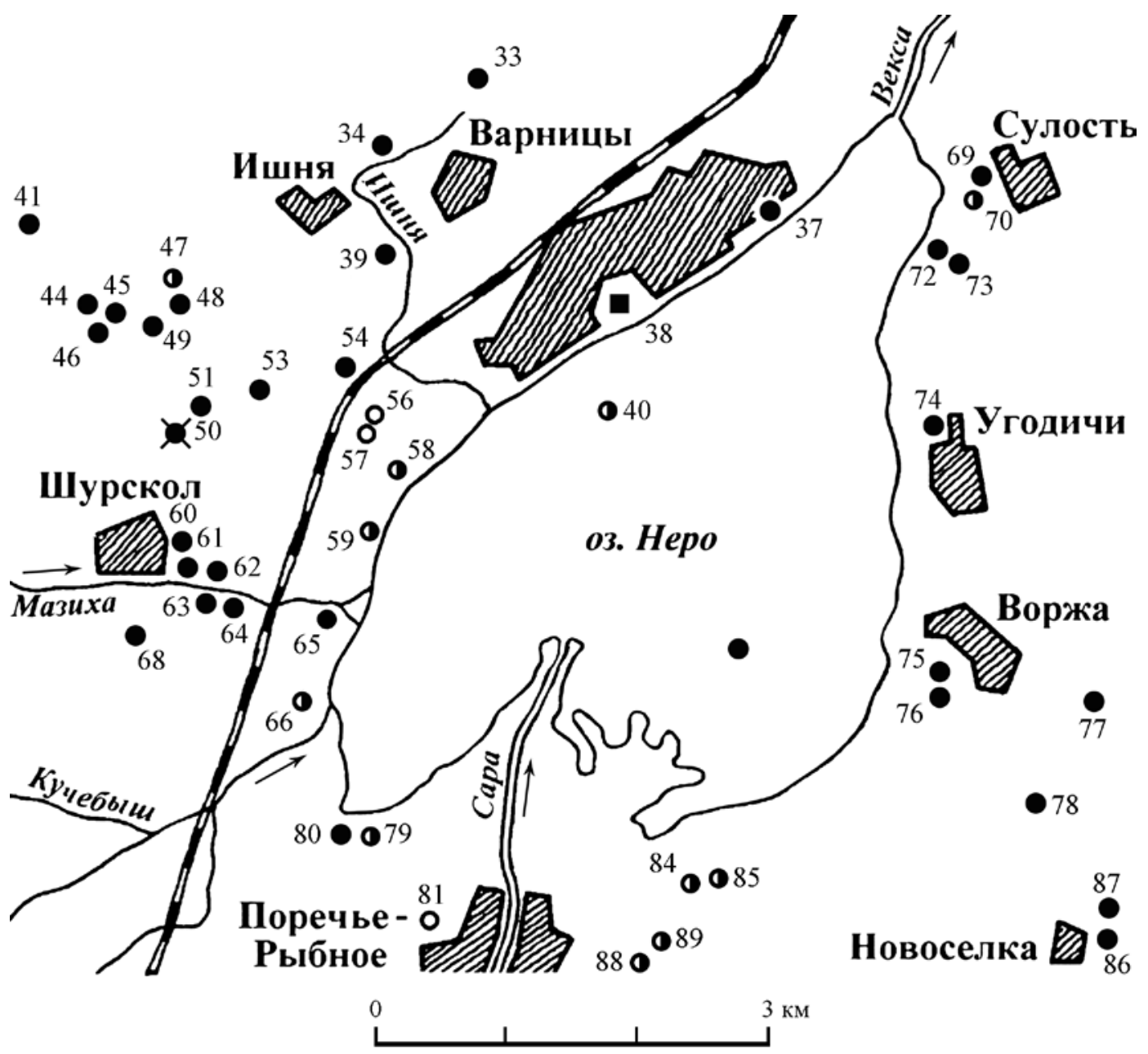

Рис. 3. Археологические памятники г. Ростова и его округи (врезка к карте на рис. 2)

диаметром 5-10 м. Десять курганов повреждены ямами, вероятно, от раскопок XIX в. Состояние памятника удовлетворительное, насыпи задернованы, поросли деревьями.

10 (87). Благовещенская Гора. Селище, VII-X вв. Расположено в 0,3 км к западу от с. Благовещенская Гора, на склоне правобережной террасы р. Чучерки (впадает в оз. Неро). Обследовано в 1988 г. А.Е. Леонтьевым, в 1993 г. К. И. Комаровым, в 2007 г. А. В. Кашкиным. Размеры - 220×120 м, высота от реки - 8-12 м. Культурный слой толщиной до 0,3 м. Состояние памятника хорошее, поверхность, которая ранее распахивалась, задернована.

11 (54). Богослов. Селище, X-XIII вв. Расположено в 0,3 км к юго-западу от с. Богослов, на правобережной террасе руч. Гороховка (правый приток р. Ишни). Обследовано в 1969 и 1977 гг. А.Е. Леонтьевым, в 2006 г. А. В. Кашкиным. Уточненные размеры - 100-110×40 м, высота от ручья - до 3 м.
Культурный слой толщиной 0,2-0,3 м. Состояние памятника плохое. Поверхность занята огородами, распахивается.

12 (120). Булатово. Селище, РЖВ, Х-XIII вв. Расположено в 0,9 км к юго-востоку от д. Булатово, на возвышенности водораздельного плато бассейнов оз. Неро и р. Нерли. Обследовано в 1969 г. А.Е. Леонтьевым, в 1993 г. К.И. Комаровым, в 2009 г. А. В. Кашкиным. Уточненные размеры памятника - 100×40 м, высота от подножия - 8-10 м. Поверхность ранее распахивалась, в настоящее время задернована. Культурный слой толщиной 0,10-0,15 м. Состояние памятника удовлетворительное, поверхность ранее распахивалась, в настоящее время задернована.

13 (127). Вепрева Пустынь. Курганный могильник 1, XI-XIII вв. По данным 2009 г., расположен в 2 км к востоко-северо-востоку от с. Вепрева Пустынь, на плато левого берега р. Рюмжа (левый приток р. Нерли, левый притока р. Клязьмы, 
левый приток р. Оки, правый приток р. Волги), 38 квартал лесного массива. Обследован в 1973 г. А.Е. Леонтьевым, в 2009 г. А.В. Кашкиным. Сохранилось пять насыпей высотой 0,4-1,2 м, диаметром 6-8 м. Состояние памятника плохое. Две насыпи значительно повреждены дорогой, на одной установлена опора ЛЭП.

14 (126). Вепрева Пустынь. Курганный могильник 2, XI-XIII вв. По данным 2009 г., расположен в 0,5 км на восток от с. Вепрева Пустынь, на плато левого берега р. Рюмжи, в 14 квартале лесного массива. Исследовался в 1854 г. П.С. Савельевым (раскопано 52 кургана), обследован в 1975 г. А.Е. Леонтьевым, в 2009 г. А. В. Кашкиным. Насчитывает 36 насыпей диаметром 5-10 м, высотой $0,5-1,2$ м, с ровиками у основания. Сохранность курганов плохая, все они раскопаны колодцем в XIX в.

15 (75). Воржа. Селище 1, 2-я пол. I тыс. н.э. Расположено в 1,2 км к югу от с. Воржа, на останце эродированной первой террасы оз. Неро. Обследовано в 1981 г. А.Е. Леонтьевым, в 1982 г. В. В. Сидоровым, в 2005 г. А. В. Кашкиным. Уточненные размеры - 230×80-100 м, высота от заболоченной поймы -4 м. Культурный слой, темно-серая супесь толщиной до 0,42 м. Состояние памятника хорошее, поверхность задернована.

16 (76). Воржа. Селище 2, XII-XIV вв. По данным 2005 г., расположено в 1,6 км к юго-западу от с. Воржа, на первой террасе оз. Неро. Обследовано в 1981 г. А.Е. Леонтьевым, в 1982 г. В. В. Сидоровым, в 2005 г. А.В. Кашкиным. Размеры - 220×60-80 м, высота от заболоченной поймы - 2-3 м. Культурный слой толщиной до 0,5 м. Состояние памятника хорошее, поверхность задернована.

17 (125). Годеново. Городище (Лихининское), РЖВ. По данным 2008 г., расположено в 2,7 км к северо-северо-востоку от с. Годеново, на моренном холме у западного края болота Чистое (исток p. Пулохмы, правого притока р. Сары, впадающей в оз. Неро). Обследовано в 1969 г. А.Е. Леонтьевым, в 1992 г. К.И. Комаровым, в 2009 г. А.В. Кашкиным. Площадка городища овальной в плане формы размерами $70 \times 25$ м, высотой от подошвы 6 м. Склоны эскарпированы. Площадка укреплена кольцевым рвом глубиной $0,50-1,09$ м, шириной $0,5-0,7$ м с перемычками шириной 3,5-4 м на востоке и западе. Поверхность задернована, поросла деревьями, незначительно повреждена несколькими кладоискательскими ямами. Культурный слой толщиной 0,2-0,7 м содержит материалы дьяковской культуры. Состояние памятника в целом хорошее.
18 (110). Горки. Селище, XI-XIII вв. Расположено на юго-западной окраине д. Горки, на территории кладбища и к востоку от него, на склоне левобережной террасы р. Сары (впадает в оз. Неро). Обследовано в 1986 г. А.Е. Леонтьевым, в 2007 г. А. В. Кашкиным. Размеры $-210 \times 75$ м, высота от реки - 12-15 м. Культурный слой толщиной до 0,4 м. Состояние памятника плохое, западная половина повреждена могилами современного кладбища.

19 (119). Гусарниково. Городище Городец, РЖВ. Расположено в 0,7 км к югу от д. Гусарниково, в 1,3 км от д. Демьянское, на северной оконечности моренной гряды на правом берегу р. Печегды (правый приток р. Сары). Обследовано в 1854 г. П.С. Савельевым, в 1969 г. А. Е. Леонтьевым, в 1990 г. К.И. Комаровым, в 2005 г. А. В. Кашкиным. Исследовалось в 1976 г. И.Л. Станкевич шурфами площадью 16 кв.м. Площадка овальной в плане формы размерами $60 \times 37$ м понижается к западному краю с падением высоты более 1,5 м. Высота от подошвы - 12 м, от реки -25 м. По периметру на уровне 4 м ниже площадки прослежен кольцевой ров глубиной $0,5-0,8$ м, шириной 2,5-3 м. С южной стороны гряда сужается до перемычки шириной 5 м и понижается в виде седловины на 3-4 м ниже площадки. Перемычка наполовину уничтожена карьером, частично нарушившим южный фас укреплений. Культурный слой толщиной $0,15-0,7$ м содержит материалы дьяковской культуры. Состояние памятника хорошее. Площадка задернована, склоны поросли лесом. Карьер более не разрабатывается и не угрожает сохранности памятника.

20 (91). Деболовское. Селище 1, VIII-X, XI-XIII, XIV-XVII вв. Расположено на юго-восточной окраине с. Деболовское, на левобережной террасе р. Сары (впадает в оз. Неро). Обследовано в 1958 г. М.Е. Фехнер, в 1979-1980 гг. А.Е. Леонтьевым, в 2007 г. А. В. Кашкиным. Уточненные размеры - 150×70-90 м, высота от реки - 5-10 м. Культурный слой толщиной $0,5-0,8$ м. Состояние памятника удовлетворительное, поверхность распахивается под огороды.

21 (92). Деболовское. Селище 2, РЖВ. По данным 2007 г., расположено в 0,4 км к востоку от с. Деболовское, на мысу правобережной террасы р. Сары (впадает в оз. Неро). Обследовано в 1976 г. К. И. Комаровым, в 1979-1980 гг. А.Е. Леонтьевым, в 2007 г. А.В. Кашкиным. Уточненные размеры - 230×45 м, высота от реки -4-5 м. Культурный слой толщиной до 0,3 м. Состояние памятника хорошее, поверхность задернована. 
22 (93). Деболовское. Селище 3, РЖВ, 2-я пол. 1 тыс.н.э. По данным 2007 г., расположено в 0,7 км к востоку от с. Деболовское, на левобережной террасе р. Сары (впадает в оз. Неро). Обследовано в 1977 г. А.Е. Леонтьевым, в 2007 г. А. В. Кашкиным. Уточненные размеры $-60 \times 35$ м, высота от реки - 5 м. Культурный слой, по данным 1977 г., толщиной 0,55 м. Состояние памятника удовлетворительное, поверхность, которая ранее распахивалась, задернована.

23 (94). Деболовское. Сарское городище (Посад), X-XI вв. По данным 2013 г., расположено в 2,1 км к юго-западу от с. Деболовское, на второй надпойменной террасе правого берега р. Сары (впадает в оз. Неро), к востоко-юго-востоку от края Сарского городища. Исследовался в 1972, 1973, 1975, 1978, 1980, 1981 гг. А. Е. Леонтьевым (раскопано ок. 800 кв. м), обследовано в 2013 г. А. В. Кашкиным. Уточненные размеры - 220×15-35 м. Культурный слой толщиной до 0,55 м. Состояние памятника удовлетворительное, на задернованной поверхности видны следы раскопов.

24 (97). Деревни. Селище, XI-XIII вв. Расположено в 0,6 км к западу от с. Деревни, на правобережной террасер. Иринки (правый притокр. Кось). Обследовано в 1965 г. Д.А. Крайновым, в 1981 г. А.Е. Леонтьевым, в 1991 г. К.И. Комаровым, в 2007 г. А. В. Кашкиным. Размеры - 170×90 м, высота от реки 5-13 м. Культурный слой, по данным 1991 г., толщиной 0,4-0,5 м. Состояние памятника плохое, центральная его часть уничтожена карьером, который ныне не используется.

25 (114). Дертники. Курганный могильник 1, X-XIII вв. Был расположен в 1,8 км к северо-западу от д. Дертники, на плато правого берега р. Сары (впадает в оз. Неро), по дороге в д. Галахово, в лесу. Исследовался в 1878 г. Н.Г. Керцелли (раскопано четыре кургана), обследован в 1878 г. А.И. Кельсиевым, в 1975 г. А. Е. Леонтьевым, в 2009 г. А. В. Кашкиным. Памятник уничтожен карьером.

26 (113). Дертники. Курганный могильник 2, XI-XII вв. Был расположен в 2,7 км к северо-западу от д. Дертники, на плато правого берега р. Сары (впадает в оз. Неро), по дороге в д. Галахово, в лесу. Обследован в 1975 г. А.Е. Леонтьевым, в 2009 г. А. В. Кашкиным. Памятник уничтожен карьером.

27 (68). Дубник. Селище, VIII-X вв. Расположено в 1 км к северо-востоку от д. Дубник, на террасе западного коренного берега оз. Неро. Обследовано в 1979 г. А.Е. Леонтьевым, в 2006 г. А. В. Кашкиным. Уточненные размеры $-140 \times 120$ м, высота от озера - 31-33 м. Культурный слой толщиной 0,3 м. Состояние памятника удовлетворитель- ное, поверхность распахивается, восточный край задернован.

28 (6). Дуброво. Поселение, эпоха бронзы, РЖВ. По данным 2007 г., расположено в 1 км к западу от д. Дуброво, на останце правобережной террасы р. Устье (левый приток р. Которосли). Обследовано в 1977 г. А.Е. Леонтьевым, в 1994 г. К.И. Комаровым, в 2007 г. А.В. Кашкиным. Уточненные размеры - 55×35 м, высота от поймы - 2-3 м. Культурный слой, по данным 1994 г., толщиной до 0,4 м. Состояние памятника хорошее, поверхность задернована.

29 (25). Ивакино. Селище, XIV-XVI вв. Расположено в 0,9 км к северо-северо-западу от с. Ивакино, на мысу, образованном двумя ручьями (правые притоки р. Шулы, правый приток р. Устье, левый приток р. Которосли, правый приток р. Волги). Обследовано в 1986 г. А.Е. Леонтьевым, в 2009 г. А.В. Кашкиным. Уточненные размеры памятника $-280 \times 210$ м, высота от ручьев - 2-6 м. Культурный слой толщиной до 0,35 м. Состояние памятника хорошее. Поверхность ранее распахивалась, в настоящее время задернована.

30 (49). Ивановское. Селище, XII-XVI вв. По данным 2005 г., расположено в 0,36 км к северу от д. Ивановское, на правом берегу безымянного ручья (правый приток р. Ишни, притока оз. Неро). Обследовано в 1987 г. А.Е. Леонтьевым, в 1994 г. К.И. Комаровым, в 2005 г. А. В. Кашкиным. Размеры - 150×150 м, высота от ручья - 3-7 м. Культурный слой толщиной 0,15-0,40 м. Состояние памятника удовлетворительное, поверхность раннее распахивалась, в настоящее время задернована.

31 (32). Казарка. Селище, VII-X вв. По данным 2005 г., расположено в 0,45 км к северо-западу от д. Казарка, на склоне коренного берега оз. Неро, на правом берегу руч. Кучебыш. Исследовалось в 1982 г. А.Е. Леонтьевым, раскопано 100 кв. м, обследовано в 2005 г. А.В. Кашкиным. Уточненные размеры памятника - 300×150-220 м, высота от ручья - 2-11 м. Культурный слой толщиной до 0,3 м. Состояние памятника удовлетворительное, поверхность распахивается.

32 (129). Караш. Поселение, неолит, эпоха бронзы. По данным 2013 г., расположено в 1,3 км к северо-западу от церкви в с. Караш, в озерной котловине оз. Караш, на правом берегу р. Пошмы (левый приток р. Нерли, левый приток р. Клязьмы, левый приток р. Оки, правый приток р. Волги). Исследовалось в 1954-1955, 1958 и 1972 гг. Д.А. Крайновым (раскопано 416 кв. м). Обследовано в 1991 г. К. И. Комаровым, в 2013 г. А. В. Кашкиным. Размеры сохранившейся части $-75 \times 40$ м, 
высота от озера - 1 м. Культурный слой толщиной до 0,65 м перекрыт озерными отложениями и содержит материалы эпохи неолита и бронзы. Состояние памятника удовлетворительное, поверхность задернована, частично заболочена.

33 (130). Караш. Селище, XI-XIII вв. По данным 2013 г., расположено в 0,4 км к северу от церкви в с. Караш, в озерной котловине оз. Караш, на первой террасе правого и левого берегов р. Пошмы (левый приток р. Нерли, левый приток р. Клязьмы, левый приток р. Оки, правый приток р. Волги). Обследовано в 1991 г. К.И. Комаровым, в 2013 г. А.В. Кашкиным. Уточненные размеры - 80×70 м, высота от реки - 2-5 м. Культурный слой толщиной до 0,4 м содержит древнерусские материалы XI-XIII вв. Состояние памятника плохое, его западная часть застроена жилыми и хозяйственными постройками, распахивается под огороды.

34 (12). Кладовицы. Поселение, эпоха бронзы, РЖВ. По данным 2007 г., расположено в 0,1 км к западу от д. Кладовицы, на левобережной террасе p. Устье (левый приток р. Которосли). Обследовано в 1976 г. И. Л. Станкевич, в 1977 г. А.Е. Леонтьевым, в 2007 г. А. В. Кашкиным. Уточненные размеры - 260×80 м, высота от реки - 3 м. Культурный слой толщиной до 0,5 м. Состояние памятника хорошее, поверхность, которая ранее распахивалась, задернована.

35 (11). Козлово. Селище, XI-XIII вв. По данным 2007 г., расположено в 20-40 м к юго-западу от юго-восточной окраины д. Козлово, на левобережной террасе р. Устье (левый приток р. Которосли). Обследовано в 1969 и 1977 гг. А.Е. Леонтьевым, в 2007 г. А. В. Кашкиным. Уточненные размеры - 200×75 м, высота от реки - 5-6 м. Культурный слой толщиной до 0,4 м. Состояние памятника удовлетворительное, поверхность распахивается под огороды.

36 (117). Коленово. Курганный могильник 1, XI-XII вв. Был расположен в 1,5 км к юго-юго-западу от д. Коленово, на правобережном плато р. Сары (впадает в оз. Неро). В 1882 г. А. А. Титовым раскопан один курган (по сведениям Д.Н. Эдинга, было раскопано три кургана), в 1922 г. исследовался Д.Н. Эдингом (раскопано четыре кургана), обследован в 1969 г. А.Е. Леонтьевым, в 2009 г. А. В. Кашкиным. Памятник уничтожен карьером.

37 (115). Коленово. Курганный могильник $4^{3}$, XI-XII вв. Был расположен в 2 км к западу от д. Коленово, на правобережном плато р. Сары (впадает в оз. Неро), в уроч. Мироновский лес. Обследован в 1973 г. А.Е. Леонтьевым, в 2009 г. А.В. Кашкиным. Насчитывал 10 курганных насыпей. Памятник уничтожен карьером.

38 (30). Кустерь. Селище 1, X-XIII вв. Расположено на южной окраине д. Кустерь, на западном берегу котловины оз. Неро, на левобережном мысу руч. Кучебыш (впадает в оз. Неро). Исследовалось в 1977, 1978, и 1982 гг. А. Е. Леонтьевым. Раскопано 108 кв. м, обследовано в 2005 г. А. В. Кашкиным. Уточненные размеры памятника - 200×100 м, высота от ручья - 3-7 м. Культурный слой толщиной 0,3 м. Состояние памятника удовлетворительное, поверхность распахивается под огороды.

39 (31). Кустерь. Селище 2, X-XI, XVII вв. По данным 2006 г., расположено в 0,3 км к югу и юго-западу от д. Кустерь, на правобережной террасе безымянного ручья, у места слияния трех ручьев (ниже основное русло преобразуется в руч. Кучебыш, впадает в оз. Неро). Обследовано в 1977 и 1978 гг. А.Е. Леонтьевым, в 2006 г. А. В. Кашкиным. Уточненные размеры 400×130 м, высота от ручья - 2-6 м. Культурный слой толщиной $0,15-0,70$ м. Состояние памятника удовлетворительное, поверхность распахивается.

40 (28). Кустерь. Селище 3, X-XIII вв. Расположено в 0,2 км к юго-западу от д. Кустерь, у места слияния двух ручьев и образования руч. Кучебеш, впадающего в оз. Неро. Обследовано в 1977 и 1978 гг. А.Е. Леонтьевым, в 2006 г. А.В. Кашкиным. Уточненные размеры $-220 \times 160$ м, высота от ручья4-6 м. Культурный слой толщиной 0,25-0,35 м. Состояние памятника удовлетворительное, поверхность распахивается.

41 (29). Кустерь. Курганный могильник, X-XII вв. Расположено в 0,8 км к западу от д. Кустерь, к югу от грунтовой дороги в д. Алешково, в урочище Святье, в небольшом перелеске на краю поля. Это один из могильников у деревни, исследованный в 1854 г. П. С. Савельевым. Раскопано 110 курганов. В 1973 и 1977 гг. могильник обследован А. Е. Леонтьевым, в 2005 г. А. В. Кашкиным. Сохранилась 51 насыпь высотой 0,3-1,0, диаметром 4-8 м, раскопанных колодцем. Состояние памятника удовлетворительное.

42 (96). Левина Гора. Селище, XI-XIII вв. По данным 2007 г, расположено в 0,18 км к западу от д. Левина Гора, на левобережной терpace p. Сара (впадает в оз. Неро). Обследовано в 1972 и 1977 гг. А.Е. Леонтьевым, в 2007 г.

3 Курганные могильники 2 и 3 нами пока не найдены. 
А. В. Кашкиным. Уточненные размеры - 80×60 м, высота от реки - 7-8 м. Культурный слой толщиной до 0,3 м. Состояние памятника хорошее, поверхность, которая ранее распахивалась, задернована.

43 (85). Липовка. Поселение 1, эпоха бронзы. Расположено в 1,2 км к северу от д. Липовка, на мысу правобережной террасы безымянного ручья (впадает в оз. Неро). Обследовано в 1980 г. В.В. Сидоровым, в 2007 г. А. В. Кашкиным. Уточненные размеры $-70 \times 55$ м, высота от ручья - 2-4 м. Культурный слой толщиной 0,2 м. Состояние памятника хорошее, поверхность поросла деревьями и кустарником.

44 (84). Липовка. Поселение 2, неолит, эпоха бронзы. Расположено в 1,3 км к северу от д. Липовка, на мысу левобережной террасы безымянного ручья (впадает в оз. Неро). Обследовано в 1980 г. В.В. Сидоровым, в 2007 г. А.В. Кашкиным. Уточненные размеры $-65 \times 50$ м, высота от ручья - 2-3 м. Культурный слой толщиной 0,12 м. Состояние памятника хорошее, поверхность задернована, повреждена одной ямой.

45 (106). Ловцы. Стоянка 1 (Ловцы 3), неолит. Расположена на западной окраине д. Ловцы, на мысу первой надпойменной террасы правого берега р. Сары (впадает в оз. Неро). Обследована в 1977 г. А.Е. Леонтьевым, в 2009 г. А.В. Кашкиным. Уточненные размеры памятника $-30 \times 25$ м, высота от реки - 1-2 м. Культурный слой толщиной 0,03-0,14 м перекрыт слоем аллювиального наноса толщиной до 0,2 м. Состояние памятника хорошее.

46 (107). Ловцы. Стоянка 2 (Ловцы 5), неолит. По данным 2009 г., расположена в 0,6 км к северо-востоку от д. Ловцы, мыс первой террасы левого берега р. Сары (впадает в о3. Неро), в 0,4 км к юго-востоку от устья р. Корости. Обследована в 1980 г. В. В. Сидоровым, в 2009 г. А. В. Кашкиным. Уточненные размеры памятника $-25 \times 20$ м, высота от реки - 2-4 м. Культурный слой толщиной 0,20-0,22 м. Состояние памятника удовлетворительное, поверхность задернована, поросла лесом. Центральный участок поврежден песчаным карьером размерами $20 \times 15$ м.

47 (105). Ловцы. Стоянка 3 (Ловцы 6), неолит. По данным 2009 г., расположена в 0,4 км к северо-востоку от д. Ловцы, на первой надпойменной террасе левого берега р. Сары (впадает в оз. Неро), в 0,16 км к юго-западу от устья р. Корости. Обследована в 1980 г. В.В. Сидоровым, в 2009 г. А.В. Кашкиным. Уточненные размеры памятника - 22×20 м, высота от реки - 2-3 м. Культурный слой толщиной 0,2-0,3 м перекрыт слоем почвы толщиной 0,28 м. Состояние памятника хорошее, поверхность задернована, поросла лесом.

48 (104). Ловцы. Поселение 1 (Ловцы 1), неолит, XII-XIII вв. По данным 2009 г., расположено в 0,12 км к северу от восточной части д. Ловцы, на мысу первой надпойменной террасы левого берега р. Сары (впадает в оз. Неро). Обследовано в 1979 г. А.Е. Леонтьевым, в 2009 г. А. В. Кашкиным, исследовалось в 1988 г. В.В. Сидоровым. Уточненные размеры памятника - 120×60 м, высота от реки - 1-2 м. Поверхность задернована. Культурный слой толщиной до 0,15 м. Состояние памятника хорошее.

49 (109). Ловцы. Поселение 2 (Ловцы 2), неолит, эпоха бронзы. По данным 2009 г., расположено в 0,1 км к северу от центральной части д. Ловцы, на мысу первой надпойменной террасы левого берега р. Сары (впадает в оз. Неро). Обследовано в 1977 г. А. Е. Леонтьевым, в 2009 г. А. В. Кашкиным. Уточненные размеры памятника $-145 \times 70$ м, высота от реки - 1-3 м. Культурный слой толщиной до 0,35 м. Состояние памятника хорошее.

50 (108). Ловцы. Поселение 3 (Ловцы 4), эпоха бронзы. Расположено в 0,25 км к северо-северовостоку от восточной окраины д. Ловцы, на останце первой надпойменной террасы левого берега р. Сары (впадает в оз. Неро). Обследовано А. Е. Леонтьевым в 1977 г., в 2009 г. А.В. Кашкиным. Уточненные размеры памятника $-65 \times 55$ м, высота от реки - 0,6-1,0 м. Состояние памятника удовлетворительное. Поверхность задернована, северный край поврежден дренажной траншеей и песчаным карьером.

51 (66). Львы. Поселение Кучебыш, неолит, эпоха бронзы. Расположено в 2 км к югу от с. Львы, занимает северо-восточную часть обширного останца первой террасе юго-западного берега оз. Неро, среди заболоченной низины. Исследовалось в 1979-1980 гг. В.В. Сидоровым раскопом площадью 24 кв. м, обследовано в 2005 г. А. В. Кашкиным. Уточненные размеры - 480-380×200 м, высота от заболоченной поймы - 0,5-2,0 м. Культурный слой толщиной 0,12-0,30 м перекрыт слоем торфянистого дерна и торфа толщиной $0,2-0,3$ м. Состояние памятника в целом хорошее. Центральная часть памятника незначительно повреждена дренажной траншеей. Поверхность задернована, прибрежный край порос отдельными деревьями и кустарником.

52 (65). Львы. Селище, X-XI, XVII вв. Расположено на южной окраине с. Львы, к югу от крайних домов, мыс левобережной террасы древнего русла руч. Мазиха (новое искусственное русло 
ручья проложено севернее). Обследовано в 1979 г. А. Е. Леонтьевым, в 2006 г. А. В. Кашкиным. Уточненные размеры памятника - 145×70-100 м, высота от поймы - 1-4 м. Культурный слой толщиной до 0,3-0,6 м. Состояние памятника удовлетворительное. Северная половина памятника занята огородами, южная задернована.

53 (131). Любильцево. Селище, XI-XIII вв. Расположено в 1,3 км к 3 от д. Любильцево, на левобережной террасе р. Рюмжа (левый приток p. Нерль, левый приток р. Клязьма, левый приток p. Ока, правый приток р. Волга), в лесу. Обследовано в 1991 г. К.И. Комаровым, в 2009 г. А. В. Кашкиным. Уточненные размеры памятника $145 \times 95$ м, высота от реки 22-24 м. Культурный слой толщиной 0,2-0,4 м. Состояние памятника хорошее, поверхность поросла лесом.

54 (132). Любильцево. Курганный могильник, XI-XIII вв. Расположен в 1,3 км к западу от д. Любильцево, на левобережной террасе р. Рюмжи, в лесу. Обследован в 1991 г. К. И. Комаровым, в 2009 г. А. В. Кашкиным. Состоит из 11 насыпей высотой 0,3-1,0 м, диаметром 4-7 м, расположенных по краю террасы на протяжении 70 м, на высоте 23-24 м от реки. Курганы поросли лесом, три насыпи раскопаны колодцем. Состояние памятника удовлетворительное.

55 (44). Максимовицы. Селище 1, XI-XII, XIV-XVI вв. Расположено в 0,3 км к юго-востоку от д. Максимовицы, на склоне левобережной террасы безымянного ручья (правый приток р. Ишни, притока оз. Неро). Обследовано в 1988 г. А.Е. Леонтьевым, в 1994 г. К. И. Комаровым, в 2005 г. А. В. Кашкиным. Уточненные размеры - 330×75-115 м, высота от ручья -4-8 м. Культурный слой толщиной $0,2-0,4$ м. Состояние памятника хорошее. Поверхность ранее распахивалась, в настоящее время задернована, восточный участок прорезан оврагом.

56 (45). Максимовицы. Селище 2, XI-XII, XIV-XVII вв. По данным 2006 г., расположено в 0,15 км к юго-юго-востоку от д. Максимовицы, на склоне правобережной террасы безымянного ручья (правый приток р. Ишни). Обследовано в 1988 г. А.Е. Леонтьевым, в 1994 г. К. И. Комаровым, в 2006 г. А. В. Кашкиным. Размеры памятника - 300×200 м, высота от ручья - 2-10 м. Культурный слой толщиной 0,25 м. Состояние памятника удовлетворительное. Большая часть поверхности поросла деревьями и кустарником.

57 (46). Максимовицы. Селище 3, VIII-X вв. По данным 2006 г., расположено в 0,5 км к юго-востоку от д. Максимовицы, на склоне правобережной террасы безымянного ручья (правый приток p. Ишни). Обследовано в 1988 г. А. Е. Леонтьевым, в 1994 г. К.И. Комаровым, в 2006 г. А.В. Кашкиным. Уточненные размеры памятника $-350 \times 280$ м, высота от ручья - 2-28 м. Культурный слой толщиной 0,3-0,4 м. Состояние памятника хорошее.

58 (41). Малая Шугорь. Селище, XI-XIII, XIV-XVII вв. Расположено на юго-западной окраине с. Малая Шугорь и к западу от нее, на левобережной террасе безымянного ручья (правый приток р. Ишни). Обследовано в 1986 г. А. Е. Леонтьевым, в 2006 г. А.В. Кашкиным. Уточненные размеры памятника - 550×140 м, высота от ручья - 5-15 м. Культурный слой толщиной 0,2-0,7 м. Состояние памятника плохое. Поверхность распахивается, западная часть селища занята усадьбами села.

59 (13). Меленки. Поселение, эпоха бронзы. Расположено в 0,8 км к северу от д. Меленки, на мысу правобережной террасы р. Устье (левый приток р. Которосли), у старицы. Обследовано в 1981 г. А.Е. Леонтьевым, в 2006 г. А. В. Кашкиным. Размеры памятника $-80 \times 70$ м, высота от поймы - 6 м. Культурный слой толщиной 0,3 м. Состояние памятника хорошее. Поверхность ранее распахивалась, ныне задернована, прибрежный край порос деревьями и кустарником.

60 (14). Николо-Перевоз. Селище 1, XI-XIII, XIV-XVII вв. По данным 2007 г., расположено на северо-восточной окраине с. Николо-Перевоз, на правобережной террасе р. Устье (левый приток р. Которосли). Обследовано в 1977 г. А.Е. Леонтьевым, в 2007 г. А. В. Кашкиным. Уточненные размеры - 230×70 м, высота от реки - 4-7 м. Культурный слой толщиной до 0,4 м. Состояние памятника плохое, поверхность занята церковью, кладбищем, домами и приусадебными участками села.

61 (15). Николо-Перевоз. Селище 2, РЖВ. По данным 2007 г., расположено в 0,3 км к северу от с. Николо-Перевоз, на останце правобережной террасы р. Устье (левый приток р. Которосли). Обследовано в 1977 г. А.Е. Леонтьевым, в 2007 г. А.В. Кашкиным. Уточненные размеры $-65 \times 40$ м, высота от реки - 2-3 м. Культурный слой, по данным 1977 г., толщиной до 0,5 м. Состояние памятника хорошее, поверхность задернована.

62 (10). Новосёлка (Новоникольская сел. адм.). Стоянка, неолит. По данным 2007 г., расположено в 0,5 км к юго-востоку от д. Новосёлка, на останце правобережной террасы р. Устье (левый приток р. Которосли). Обследовано в 1977 г. А. Е. Леонтьевым, в 2007 г. А. В. Кашкиным. Уточненные размеры $-45 \times 35$ м, высота от реки - 1-4 м. Культурный слой толщиной 0,3 м. Состояние 
памятника удовлетворительное, центральная часть повреждена ныне заброшенным песчаным карьером, поверхность задернована.

63 (9). Новосёлка (Новоникольская сел. адм.). Селище, XIV-XVII вв. По данным 2007 г., pacположено в 30 м к юго-востоку от д. Новосёлка, на первой надпойменной террасе правого берега p. Устье (левый приток р. Которосли). Обследовано в 1977 г. А.Е. Леонтьевым, в 2007 г. А.В. Кашкиным. Уточненные размеры $-140 \times 50$ м, высота от реки - 1-2 м. Культурный слой толщиной 0,2 м. Состояние памятника хорошее, поверхность, которая ранее распахивалась, задернована.

64 (86). Новосёлка (Угодичская сел. адм.). Селище, XIV-XVII вв. По данным 2007 г., расположено в 20 м к востоку от д. Новосёлка, на левобережной террасе р. Чучерки (впадает в оз. Неро). Обследовано в 1977 г. А.Е. Леонтьевым, в 2007 г. А. В. Кашкиным. Уточненные размеры - 70×50 м, высота от реки - 4-7 м. Культурный слой толщиной до 0,4 м. Состояние памятника хорошее, поверхность, которая ранее распахивалась, задернована.

65 (78). Новосёлка (Угодичская сел. адм.). Селище Чучеры, VII-X, XI-XIII вв. По данным 2007 г., расположено в 1,2 км к северо-западу от д. Новосёлка, в уроч. Чучеры, на правобережной терpace p. Чучерки (впадает в оз. Неро). Обследовано в 1988 г. А.Е. Леонтьевым, в 1993 г. К.И. Комаровым, в 2007 г. А.В. Кашкиным. Уточненные размеры - 300×40-75 м, высота от реки -2-7 м. Культурный слой толщиной до 0,3 м. Состояние памятника хорошее, поверхность, которая ранее распахивалась, задернована.

66 (103). Новотроицкое. Поселение, эпоха бронзы. Расположено в 1,2 км к юго-юго-западу от с. Новотроицкое, на мысу левобережной террасы р. Сары (впадает в оз. Неро). Обследовано в 1980 г. В. В. Сидоровым, в 2007 г. А. В. Кашкиным. Размеры - 70×40 м, высота от реки - 1-3 м. Культурный слой толщиной до 0,33 м. Состояние памятника хорошее, поверхность, которая ранее распахивалась, задернована, частично поросла деревьями.

67 (102). Новотроицкое. Селище, VII-X вв. Расположено в 1 км к юго-юго-западу от с. Новотроицкое, на склоне левобережной террасы р. Сары (впадает в оз. Неро). Обследовано в 1980 г. В. В. Сидоровым, в 1988 г. А.Е. Леонтьевым, в 2007 г. А. В. Кашкиным. Уточненные размеры 500×230-250 м, высота от реки - 2-14 м. Культурный слой толщиной до 0,5 м. Состояние памятника хорошее, поверхность, которая ранее распахивалась, задернована, северо-западный край порос деревьями.
68 (4). Осиновцы. Селище, РЖВ. По данным 2007 г., расположено в 90 м к западу от д. Осиновцы, на останце эродированной правобережной террасы p. Устье (левый приток р. Которосли). Обследовано в 1977 г. А.Е. Леонтьевым, в 2007 г. А. В. Кашкиным. Уточненные размеры $-150 \times 130$ м, высота от реки - 5-7 м. Культурный слой, по данным 1977 г., толщиной до 0,25 м. Состояние памятника удовлетворительное, поверхность задернована, местами эродирована, поросла лесом.

69 (124). Осоево. Селище, XI-XIII вв. По данным 2009 г., расположено на территории бывшей д. Осоево, в 2 км к северо-востоку от д. Рюмниково, в центральной части моренной возвышенности на левобережье р. Пулохмы (правый приток р. Сары, впадающей в оз. Неро). Обследовано в 1969 г. А.Е. Леонтьевым, в 2009 г. А. В. Кашкиным. Уточненные размеры памятника $-110 \times 80$ м, высота от подошвы - 26-30 м. Культурный слой толщиной 0,3 м. Состояние памятника плохое, юго-восточная половина памятника уничтожена кладбищем.

70 (112). Осокино. Городище, РЖВ. По данным 2007 г., расположено в 10 м к северо-западу от д. Осокино, на моренной возвышенности на правобережье р. Сары (впадает в оз. Неро). Обследовано в 1969 г. А.Е. Леонтьевым, в 2007 г. А.В. Кашкиным. Уточненные размеры (по основанию) - $140 \times 100$ м, сохранившейся части площадки - 40×20 м, высота от подошвы - 10-12 м. Культурный слой толщиной до 0,35 м. Состояние памятника плохое, большая часть возвышенности, в т. ч. площадки, уничтожена карьером, который в настоящее время не эксплуатируется. Сохранившаяся часть площадки и склоны задернованы, поросли отдельными деревьями.

71 (111). Осокино. Селище, XI-XIII вв. По данным 2007 г., расположено в 0,6 км к северо-северо-востоку от д. Осокино, на вершине моренной возвышенности на правобережье р. Сары (впадает в оз. Неро). Обследовано в 1969 г. А. Е. Леонтьевым, в 2007 г. А.В. Кашкиным. Уточненные размеры - 85×40 м, высота от подошвы-11-12 м. Культурный слой толщиной до 0,15 м. Состояние памятника хорошее, поверхность задернована, поросла деревьями.

72 (57). Песочное. Стоянка 1 (Песочное 2), мезолит, неолит. По данным 2005 г., расположена в 1,2 км к северо-северо-востоку от д. Песочное, в 0,2 км к востоку от шоссе Москва - Архангельск, северо-западная оконечность мыса первой террасы западного берега оз. Неро, к северу от территории садового товарищества «Неро». Обследована 
в 1928 г. М.В. Талицким, в 1979 г. А.Е. Леонтьевым, в 2005 г. А.В. Кашкиным. Размеры $-70 \times 50$ м, высота над заболоченной поймой $-1-2$ м. Культурный слой толщиной до 0,34 м. Состояние памятника хорошее. Поверхность задернована, ранее распахивалась.

73 (56). Песочное. Стоянка 2 (Песочное 3), неолит. Расположена в 1,8 км к северо-северовостоку от д. Песочное, в 0,3 км к юго-востоку от моста через р. Ишню на шоссе Москва - Архангельск, на мысу первой террасы правого берега р. Ишни (впадает в оз. Неро). Обследована в 1979 г. А.Е. Леонтьевым, в 2005 г. А.В. Кашкиным. Уточненные размеры $-100 \times 60$ м, высота от заболоченной поймы - 1-2 м. Культурный слой толщиной до 0,32 м. Состояние памятника хорошее. Поверхность задернована, ранее распахивалась, западная половина памятника поросла деревьями и кустарником.

74 (58). Песочное. Поселение 1 (Песочное 1), неолит, эпоха бронзы. Расположено в 1 км к северо-востоку от д. Песочное, на мысу первой террасы западного берега оз. Неро, к западу от территории садового товарищества «Неро». Обследовано в 1928 г. М.В. Талицким, в 1958 г. А. Л. Никитиным, в 1977 и 1979 гг. А.Е. Леонтьевым, в 2005 г. А. В. Кашкиным. Уточненные размеры $-130 \times 50$ м, высота над заболоченной поймой - 1-2 м. Культурный слой толщиной до 0,6 м делится на два горизонта. Состояние памятника плохое. Его западная часть (не менее трети) уничтожена. Поверхность задернована, но местами повреждена выемкой дерна и культурного слоя на садовые участки.

75 (59). Песочное. Поселение 2 (Песочное 4), эпоха бронзы. Расположено в 0,2 км к северо-востоку от домов южной части д. Песочное, на мысу первой террасы западного берега оз. Неро, в 40 м к западу и юго-западу от пруда. Обследовано в 1979 г. А.Е. Леонтьевым, в 2006 г. А. В. Кашкиным. Уточненные размеры - $150 \times 70$ м, высота над заболоченной поймой - 1 м. Культурный слой толщиной до 0,48 м. Состояние памятника хорошее, поверхность задернована.

76 (47). Поддыбъе. Поселение (Поддыбье 3), эпоха бронзы, РЖВ, XI-XIII вв. По данным 2006 г., расположено в 0,75 км к югу от д. Поддыбье, на левобережной террасе руч. Подрощенка (правый приток р. Ишни). Обследовано в 1988 г. А.Е. Леонтьевым, в 1994 г. К.И. Комаровым, в 2006 г. А.В. Кашкиным. Уточненные размеры памятника $-100 \times 50$ м, высота от ручья -6-7 м. Культурный слой толщиной до 0,5 м. Состояние памятника удовлетворительное, поверхность распахивается.
77 (48). Поддыбъе. Селище (Поддыбье 1), XI-XIII вв. По данным 2006 г., расположено в 0,9 км к югу от д. Поддыбье, на правобережной террасе руч. Подрощенка (правый приток р. Ишни). Обследовано в 1982 г. А.Е. Леонтьевым, в 2006 г. А.В. Кашкиным. Уточненные размеры памятника $-100 \times 60$ м, высота от ручья - 5-8 м. Культурный слой толщиной $0,3-0,5$ м. Состояние памятника удовлетворительное, поверхность распахивается.

78 (134). Покров. Курганный могильник, XI-XIII вв. Был расположен на северо-западной окраине деревни, на склоне северо-западного берега оз. Покровское. Обследован в 1990 г. К. И. Комаровым, в 2009 г. А. В. Кашкиным. Насчитывал три насыпи высотой 0,4-0,6 м, диаметром 4,5-6,5 м. Памятник уничтожен распашкой под огороды.

79 (16). Полежаево. Селище, XIV-XVII вв. По данным 2007 г., расположено в 50 м к юговостоку от д. Полежаево, на правобережной террасе безымянного ручья (правый приток р. Которосли). Обследовано в 1977 г. А.Е. Леонтьевым, в 2007 г. А.В. Кашкиным. Уточненные размеры - 180×150 м, высота от ручья -2 м. Культурный слой толщиной до 0,2 м. Состояние памятника удовлетворительное, поверхность распахивается.

80 (81). Поречье-Рыбное. Стоянка 1, мезолит. По данным 2007 г., расположено в 0,5 км к северо-западу от пос. Поречье-Рыбное, к юго-западу от шоссе Ростов-Поречье-Рыбное, на первой надпойменной террасе южного берега оз. Неро. Обследовано в 1979 г. А.Е. Леонтьевым, в 2007 г. A. В. Кашкиным. Размеры $-60 \times 50 \quad$ м, высота от уровня озера $-2-3$ м. Толщина культурного слоя не установлена. Состояние памятника удовлетворительное, поверхность, которая ранее распахивалась, задернована.

81 (79). Поречье-Рыбное. Поселение (Варос 1), неолит, эпоха бронзы. По данным 2005 г., расположено в 2,5 км к северо-западу от пос. Поречье-Рыбное, в 0,25 км к северу от шоссе, на мысе первой террасы южного берега оз. Неро, правом берегу дренированного руч. Варос-древнего устья р. Сары. Обследовано в 1979 г. А.Е. Леонтьевым, в 2005 г. А.В. Кашкиным, исследовалось в 1980 и 1982 гг. В.В. Сидоровым. Вскрыта площадь 72 кв.м. Уточненные размеры памятника $-580 \times 70-150$ м, высота от заболоченной поймы - 1-3 м. Культурный слой толщиной 0,4-0,6 м перекрыт торфом толщиной $0,20-0,35$ м. Состояние памятника удовлетворительное. Прибрежная полоса и склон террасы задернованы, южная половина памятника распахивается, центральная часть повреждена дренажным каналом шириной 2 м. 
82 (80). Поречье-Рыбное. Селище (Варос 2), IX-X, XVI-XVII вв. По данным 2005 г., расположено в 2,7 км к западо-северо-западу от пос. Поречье-Рыбное, к северу от шоссе, на первой террасе оз. Неро и правом берегу руч. Варос, при его устье. Северный край селища частично перекрывает культурный слой поселения Варос 1. Обследовано в 1979 г. А.Е. Леонтьевым, в 1980 г. В.В. Сидоровым, в 2005 г. А. В. Кашкиным. Уточненные размеры памятника $-290 \times 150$ м, высота от заболоченной поймы $-2-3,5$ м. Культурный слой толщиной 0,35 м. Состояние памятника удовлетворительное. Прибрежная часть селища задернована, остальная распахивается.

83 (50). Пужбол. Селище 1. Было расположено в 0,8 км к северо-западу от с. Пужбол, на склоне правого берега руч. Подрощенка (правый приток р. Ишни, притока оз. Неро). Обследовано в 1973 г. А.Е. Леонтьевым. Уже тогда памятник был значительно разрушен карьером. В настоящее время памятник не существует, он полностью уничтожен карьером.

84 (51). Пужбол. Селище 2, XI-XIII, XIVXVII вв. По данным 2006 г., расположено на северо-западной окраине с. Пужбол, в 0,12 км к северо-западу от церкви, на левобережной террасе безымянного ручья (бассейн оз. Неро). Обследовано в 1986 г. А.Е. Леонтьевым, в 2006 г. А. В. Кашкиным. Уточненные размеры памятника - 170×100 м, высота от ручья - 16-24 м. Культурный слой толщиной до 0,5 м. Состояние памятника удовлетворительное. Поверхность распахивается, юго-западный участок застроен.

85 (53). Пужбол. Селище 3, VIII-X, XI-XIII вв. По данным 2013 г., расположено в 1,2 км к северу от с. Пужбол, на левобережной террасе безымянного ручья, на выходе его в приозерную низину оз. Неро. Обследовано в 1987 г. А.Е. Леонтьевым, в 1994 г. К. И. Комаровым, в 2013 г. А. В. Кашкиным.. Размеры - 160×120 м, высота от ручья - 4-10 м. Культурный слой толщиной до 0,25 м. Состояние памятника хорошее, поверхность задернована.

86 (40). Ростов. Поселение Рождественский Остров, эпоха бронзы. По данным 2007 г., расположено в 1,1 км к югу от г. Ростов, на восточном берегу северной оконечности о. Рождественский на оз. Неро. Обследовано в 1958 г. А.Л. Никитиным， в 1961 г. Д.А. Крайновым， в 2007 г. А.В. Кашкиным. Уточненные размеры $-70 \times 40$ м, высота от озера - до 1 м. Культурный слой тол- щиной до 0,2 м перекрыт илистыми отложениями мощностью $0,7-0,9$ м. Состояние памятника удовлетворительное, поверхность задернована, поросла кустарником, периодически заливается.

87 (38). Ростов. Исторический культурный слой ${ }^{4}$, IX-XIII, XIV-XVII вв. Зафиксирован в центральной и юго-восточной частях г. Ростова, на северо-западном берегу оз. Неро. Границы распространения культурного слоя установлены в результате многолетних исследований (наблюдения, шурфовка, данные бурения) Волго-Окской экспедиции ИА РАН (А.Е. Леонтьев, Н.Г. Самойлович). Протяженность вдоль берега озера - до 6 км, в глубину городской застройки - от 0,5 до 1,8 км. Практически вся площадь находится под городской застройкой, на отдельных участках занята приусадебными садами и огородами. Культурный слой толщиной от 0,5 м (на периферии) до 5,0 м (в центральной, древней части города). Состояние памятника удовлетворительное. Культурный слой регулярно исследуется Волго-Окской экспедицией в рамках проведения охранных раскопок и наблюдений.

88 (37). Ростов. Селище Петровская Слобода, VIII-X вв. По данным 2006 г., расположено в 0,2 км к северо-северо-востоку от западной окраины г. Ростова (Петровская слобода), на террасе северо-западного берега оз. Неро. Обследовано в 1979 г. А.Е. Леонтьевым, в 2006 г. А. В. Кашкиным. Уточненные размеры памятника $-130 \times 90$ м, высота от озера $-0,5-1,0$ м. Культурный слой толщиной $0,3-0,4$ м. Состояние памятника удовлетворительное, поверхность задернована.

89 (122). Рюмниково. Селище 1, XIV в. По данным 2009 г., расположено на южной окраине д. Рюмниково, на озерной террасе северного берега оз. Рюмниково. Обследовано в 1969 г. А.Е. Леонтьевым, в 2009 г. А. В. Кашкиным. Уточненные размеры памятника $-280 \times 85$ м, высота от озера -6-10 м. Состояние памятника плохое, северная его половина значительно повреждена (частично уничтожена) современными постройками и распашкой под огороды.

90 (121). Рюмниково. Селище 2, XIII-XVII вв. Расположено в 0,6 км к северу от д. Рюмниково, на левобережном плато р. Пулохмы (правый приток р. Сары, впадающей в оз. Неро). Обследовано в 1969 г. А. Е. Леонтьевым, в 2009 г. А.В. Кашкиным. Уточненные размеры памятника $-160 \times 70 \mathrm{M}$, высота - 2-9 м. Состояние памятника удовлетворительное, поверхность распахивается.

${ }^{4}$ Полное описание см. в АКР. 
91 (123). Рюмниково. Селище 3, XIII-XV вв. По данным 2009 г., расположено в 0,6 км к востоку от д. Рюмниково, на склоне озерной террасы северного берега оз. Рюмниково. Обследовано в 1969 г. А.Е. Леонтьевым, в 2009 г. А. В. Кашкиным. Уточненные размеры памятника $-45 \times 20$ м, высота от озера - 2 м. Состояние памятника удовлетворительное, поверхность распахивается.

92 (8). Сажино. Селище, XIV-XVII вв. По данным 2007 г., расположено в 1,8 км к северо-западу от д. Сажино, на останце на правобережье p. Устье (левый приток р. Которосли). Обследовано в 1977 г. А.Е. Леонтьевым, в 2007 г. А. В. Кашкиным. Уточненные размеры $-170 \times 90$ м, высота от основания останца $-1-2$ м. Культурный слой толщиной до 0,35 м. Состояние памятника удовлетворительное, поверхность поросла лесом, незначительно повреждена грунтовой дорогой.

93 (70). Сельцо. Поселение 1 (Сельцо 1), неолит, эпоха бронзы. Расположено в 0,5 км к северозападу от д. Сельцо, на западном краю мыса первой террасы восточного берега оз. Неро. Обследовано в 1929 г. Д.Н. Эдингом, в 1961 г. Д. А. Крайновым, в 1979 г. А.Е. Леонтьевым, в 2005 г. А. В. Кашкиным. Размеры - 120×80-90 м, высота над озером - до 2 м. Культурный слой толщиной до 0,42 м. Состояние памятника плохое. Юго-восточный край поселения распахивается, северо-восточный край поврежден сапропелевым отстойником, центральная и прибрежная части повреждены дренажными каналами.

94 (72). Сельцо. Селище 1 (Сельцо 3) ${ }^{5}$, РЖВ, XII-XIII вв. Расположено в 0,7 км к юго-западу от д. Сельцо, на первой террасе восточного берега о3. Неро, к северо-востоку от русла дренированного ручья. Обследовано в 1994 г. К.И. Комаровым, в 2005 г. А.В. Кашкиным. Уточненные размеры памятника - 120-170×80 м, высота от озеpa - 1-3,5 м. Культурный слой толщиной от 0,18 м до 0,4 м. Состояние памятника удовлетворительное. Поверхность распахивается, прибрежная полоса шириной 5-6 м задернована.

95 (95). Скнятиново. Селище, XIV-XVII вв. По данным 2007 г., расположено в 1 км к северу от с. Скнятиново, на правобережной террасе р. Сары (впадает в оз. Неро). Обследовано в 1979 г. А.Е. Леонтьевым, в 2007 г. А. В. Кашкиным. Уточненные размеры - 75×20-40 м, высота от реки - 5 м. Культурный слой толщиной 0,2 м. Состояние памятника удовлетворительное, поверхность распахивается.
96 (23). Согило. Селище 1, X-XIII вв. Расположено в 0,35 км к западо-юго-западу от д. Согило, в 0,1 км к востоку от д. Хаурово, на плато правого берега безымянного ручья (правый приток р. Шулы, правый приток р. Устье, левый приток р. Которосли, правый приток р. Волги). Обследовано в 1986 г. А.Е. Леонтьевым, в 2009 г. А.В. Кашкиным. Уточненные размеры памятника - 480×250-300 м, высота от реки - 15-40 м. Культурный слой толщиной 0,2-0,5 м. Состояние памятника хорошее; поверхность, ранее распахивавшаяся, задернована.

97 (22). Согило. Селище 2, X в. Расположено в 0,7 км к юго-западу от д. Согило, на мысу левого берега безымянного ручья (правый приток р. Шулы, правый приток р. Устье, левый приток p. Которосли, правый приток р. Волги), ограниченный с юга оврагом. Обследовано в 1986 г. А. Е. Леонтьевым, в 2009 г. А.В. Кашкиным. Уточненные размеры памятника - 270×110-180 м, высота от ручья -33-42 м. Культурный слой толщиной до 0,4 м. Состояние памятника хорошее; поверхность, ранее распахивавшаяся, задернована.

98 (24). Согило. Селище 3, XI-XIII вв. Расположено в 0,2 км к югу от д. Согило, на правобережной террасе безымянного ручья (правый приток р. Шулы, правый приток р. Устье, левый приток р. Которосли, правый приток р. Волга). Обследовано в 1986 г. А.Е. Леонтьевым, в 2009 г. А.В. Кашкиным. Уточненные размеры памятника - 220×140 м, высота - 32-36 м от ручья. Культурный слой толщиной до 0,35 м. Состояние памятника удовлетворительное. Поверхность задернована, ранее распахивалась. Северный край частично поврежден котлованом (до 0,5 м) от какогото несохранившегося строения.

99 (133). Старово. Курганный могильник 2, XI-XIII вв. Расположен в 0,4 км к югу от д. Старово, на левобережной террасе р. Нерли (левый приток р. Клязьмы, левый приток р. Оки, правый приток р. Волги), в лесу. Исследовался в 1854 г. П.С. Савельевым (раскопано 109 курганов), обследован в 1982 г. А.Е. Леонтьевым, в 2009 г. А.В. Кашкиным. Сохранилась 81 насыпь высотой 0,4-0,6 м, диаметром 5-7 м, а некоторые из них - высотой до 1,2 м, диаметром до 10 м. У крупных курганов прослеживаются ровики. Все они раскопаны колодцем, поросли деревьями. Состояние памятника плохое, все курганы носят следы раскопок XIX в.

5 Памятники Сельцо 2 и Сельцо 4 нами пока не обследованы. 
100 (69). Сулость. Поселение, неолит, VII-X вв. По данным 2007 г., расположено в 30 м к западоюго-западу от с. Сулость, на правобережной терpace р. Сулы (впадает в оз. Неро). Обследовано в 1979 г. А.Е. Леонтьевым, в 2007 г. А. В. Кашкиным. Размеры $-125 \times 75$ м, высота от реки - 1-2 м. Культурный слой толщиной до 0,2 м. Состояние памятника хорошее, поверхность задернована.

101 (98). Талицы. Курганный могильник, XI-XIII вв. Расположено в 1 км к югу от с. Талицы, на левобережном плато р. Сары (впадает в о3. Неро). Обследован в 1973 г. А. Е. Леонтьевым, в 2007 г. А.В. Кашкиным. Размеры могильника (по крайним курганам) $-50 \times 50$ м. Насчитывает 23 курганные насыпи высотой 0,3-2,0 м и диаметром до 7 м. Состояние памятника плохое, 9 насыпей повреждены кладоискательскими ямами, 4 - грунтовой дорогой, все поросли деревьями.

102 (1). Татищев-Погост. Селище, VIII-X, XII-XIII вв. По данным 2005 г,, расположено на юго-западной окраине с. Татищев Погост, на склоне левобережной террасы р. Луть (левый приток р. Устье, левый приток р. Которосли, правый приток р. Волги). Основная территория селища расположена к юго-западу от заброшенного карьера и к западу от шоссе, ведущего в село. Обследовано А.Е. Леонтьевым в 1987 г. и К.И. Комаровым в 1993 г., в 2005 г. А. В. Кашкиным. Уточненные размеры памятника (основная территория) - 150-200×120-190 м, к северу продолжается вдоль русла р. Луть еще на 100 м. Культурный слой толщиной 0,35-0,50 м. Состояние памятника плохое. Большая часть поверхности задернована, северо-восточный край уничтожен карьером (ныне не разрабатывается), южный край частично застроен, по территории селища проходят грунтовая и шоссейная дороги.

103 (96а). Теханово. Селище 6 , X-XI вв. По данным 2013 г., расположено в 1,4 км к северо-северо-западу от д. Теханово, на мысу левобережной террасы р. Сары (впадает в оз. Неро). Обследовано А. Е. Леонтьевым в 1981 г., в 2013 г. А. В. Кашкиным. Уточненные размеры $-65 \times 30$ м. Культурный слой толщиной до 0,4 м. Состояние памятника удовлетворительное, поверхность поросла лесом.

104 (33). Уваиха. Селище, XIV-XVII вв. По данным 2006 г., расположено в 0,5 км к югоюго-западу от д. Уваиха, на мысу первой надпойменной террасы левого берега р. Ишни (впадает в оз. Неро). Обследовано в 1981 г. А.Е. Леонтье- вым, в 2006 г. А. В. Кашкиным. Размеры памятника - 240×60 м, высота от поймы - 2-3 м. Культурный слой толщиной $0,35-0,45$ м. Состояние памятника удовлетворительное. Поверхность поросла деревьями и кустарником.

105 (74). Угодичи. Селище, VIII-X, XI-XIII вв. Расположено в северной части с. Угодичи, в 0,4 км к северу от церкви, на мысовидном выступе первой террасы восточного берега оз. Неро. Обследовано в 1981 г. А.Е. Леонтьевым, в 2005 г. А. В. Кашкиным. В 1914 г. на селище был найден клад восточных монет и серебряных вещей, датируемый началом IX в. Размеры памятника $-520 \times 350$ м, высота от заболоченной поймы - 2-6 м. Культурный слой толщиной 0,25-0,40 м (в низинах до 0,6 м) сверху местами перекрыт слоем торфа толщиной до 0,15 м. Состояние памятника плохое. Западная половина задернована, по краю частично повреждена ямами и карьерными выемками, восточный и юго-восточный участки заняты пашней, огородами и строениями.

106 (88). Филимоново (Пореченская пос. адм.). Поселение 1, эпоха бронзы. Расположено в 1 км к северу от д. Филимоново, на возвышенности в пойме восточного берега оз. Неро. Обследовано в 1980 г. В. В. Сидоровым, в 2007 г. А. В. Кашкиным. Уточненные размеры - 170×120 м, высота от поймы - 1-2 м. Культурный слой толщиной до 0,3 м. Состояние памятника хорошее, поверхность задернована.

107 (89). Филимоново (Пореченская пос. адм.). Поселение 2, эпоха бронзы. Расположено в 0,9 км к северу от д. Филимоново, на мысу первой надпойменной террасы восточного берега оз. Неро. Обследовано в 1980 г. В.В.Сидоровым, в 2007 г. А.В. Кашкиным. Уточненные размеры - 110×60 м, высота от поймы - 1-4 м. Культурный слой толщиной до 0,3 м. Состояние памятника хорошее, поверхность задернована.

108 (101). Филимоново (Фатьяновская сел. адм.). Курганный могильник, XI-XIII вв. Расположено в 1 км к юго-юго-востоку от с. Филимоново, в 0,23 км к юго-юго-западу от городища, на правобережной террасе р. Сары (впадает в оз. Неро). Обследован в 1990 г. К.И. Комаровым, в 1991 г. А. Е. Леонтьевым, в 2006, 2010 и 2011 гг. И. В. Купцовым, в 2007 г. А. В. Кашкиным, в 2015 г. А. Е. Леонтьевым. Площадь могильника-около 1 га. По уточненным данным (по И. В. Купцову), насчитывает 196 курганных насыпей высотой 0,2-1,5 м

${ }^{6}$ Было пропущено в АКР. 
и диаметром 0,2-7,5 м. В 1991 г. А.Е. Леонтьевым было раскопано пять курганов. Одиночные трупоположения, ориентированные на запад с отклонениями, находились в ямах глубиной $0,2-1,0$ м. Инвентарь найден в двух погребениях. В женском погребении были бронзовые перстнеобразные височные кольца, четыре бронзовые полые бусины, рубчатый и гладкий бронзовые перстни. В погребении девочки находились небольшое ожерелье из стеклянных цветных бус, две бронзовые грибовидные пуговки, браслет. Отдельно близ локтя левой руки в круглой лубяной коробочке вместе с поясным кольцом лежали бронзовые подвески: пластинчатая уточка, круглая с ушком и тремя петельками для шумящих привесок и необычная в виде двух соприкасающихся клювиками птичек. Состояние памятника в целом удовлетворительное, 28 насыпей разрушены кладоискателями, еще 12 имеют повреждения, все поросли деревьями.

Леонтьев, Кашкин, Самойлович, 2017. C. $126-128$.

109 (100). Филимоново (Фатьяновская сел. адм.). Городище Святая Мария, XI-XIII, XIV-XVII вв. По данным 2015 г., расположено в 0,8 км к югу от с. Филимоново (Фатьяновская сел. адм.), на мысу правобережной террасы p. Сары (впадает в оз. Неро). Обследовано в 1991 г. К. И. Комаровым, в 2007 г. А. В. Кашкиным, в 2015 г. А.Е. Леонтьевым. Исследовано в 1991 г. А.Е. Леонтьевым (вскрыто 102 кв.м), в 2006 г. И. В. Купцовым (вскрыто 24 кв. м). Площадка подтреугольной в плане формы размерами $120 \times 80$ м, высота от реки до 40 м. Оборонительные сооружения не сохранились. Исследованы развалы печейкаменок, развал камней в виде вымостки. Найдены обломок тигля, нож, кованые гвозди, кости животных. Гончарная керамика датируется XII-XIII вв., в большей части XIV-XVI вв. У восточного края площадки в раскопе 1991 г. обнаружено 11 безынвентарных погребений. Еще 23 погребения были найдены в 2006 г. Это остатки грунтового могильника XV-XVII вв. Состояние памятника удовлетворительное, отмечены повреждения культурного слоя кладоискательскими ямами, площадка и склоны задернованы, поросли лесом.

Купиов, Бобрецов, 2014. С. 102-115; Леонтьев, Кашкин, Самойлович, 2017. С. 126-128.

110 (77). Шестаково. Селище, VII-X вв. Расположено в 0,12 км к югу и юго-западу от южной окраины с. Шестаково, на мысу правобережной террасы р. Княжни (впадает в оз. Неро). Обследовано в 1988 г. А.Е. Леонтьевым, в 1993 г. К. И. Комаровым, в 2005 г. А. В. Кашкиным. Уточ- ненные размеры памятника $-300 \times 50-200$ м, высота от реки -3-8 м. Культурный слой толщиной $0,2-0,3$ м. Состояние памятника удовлетворительное, поверхность распахивается.

111 (21). Шулец. Селище, X-XIII вв. Расположено в 1 км к северу от д. Шулец, на правобережной террасе р. Шулы (правый приток р. Устье, левый приток р. Которосли, правый приток р. Волги). Обследовано А.Е. Леонтьевым в 1973 и 1977 гг., в 2009 г. А. В. Кашкиным. Размеры сохранившейся части $-75 \times 20-40$ м, высота от реки -2-4 м. Поверхность задернована, частично поросла деревьями. Культурный слой толщиной до 0,45 м. Со времени обследования 1977 г. памятник претерпел серьезные нарушения. Значительная его часть разрушена при сооружении автодороги Ростов - Борисоглебский с ответвлением на с. Шулец. Состояние памятника плохое. Сохранилось около четверти площади селища в северной его части.

112 (62). Шурскол. Селище 1, РЖВ. По данным 2006 г., расположено в 0,2 км к востоко-юговостоку от с. Шурскол, в 10 м к юго-востоку от территории электроподстанции, на левобережной терpace p. Мазиха (впадает в оз. Неро). Обследовано в 1975 г. А.Е. Леонтьевым (как селище 2 у с. Львы), в 2006 г. А. В. Кашкиным. А.Е Леонтьев определил территорию селища к югу от дороги и до края обрыва к реке. Нами зафиксирован культурный слой и к северу от дороги. Уточненные размеры памятника - 115×40 м, высота от реки - 9-18 м. Поверхность распахивается, частично повреждена дорогой. Культурный слой толщиной $0,3-0,4$ м. Состояние памятника удовлетворительное. Южная часть памятника уничтожена при строительстве дороги.

113 (63). Шурскол. Селище 2, X-ХІІ вв. По данным 2005 г., расположено в 0,5 км к востоко-юговостоку от с. Шурскол, в 10 м к юго-западу от моста, на правобережной террасе р. Мазихи (впадает в оз. Неро). Обследовано в 1973, 1975 и 1977 гг. А.Е. Леонтьевым (по отчетам 1973 и 1975 гг. обозначено селище 1 у с. Львы). В 1978 г. исследовалось И.В. Ислановой, раскопано 204 кв.м, в 2005 г. обследовано А.В. Кашкиным. Уточненные размеры памятника - 165-240×110-155 м, высота от реки - 4-10 м. Культурный слой толщиной от $0,14-0,24$ до $0,4-0,5$ м. Состояние памятника хорошее. Поверхность задернована, ранее распахивалась.

114 (64). Шурскол. Селище 3, VIII-X вв. По данным 2005 г., расположено в 0,3 км к юговостоку от с. Шурскол, на правобережной терpace p. Мазихи (впадает в оз. Неро). Обследовано в 1979 г., исследовалось в 1980 и 1983 гг. 
А.Е. Леонтьевым, раскопано 504 кв.м, обследовано в 2005 г. А.В. Кашкиным. Уточненные размеры - 480×150-220 м, высота от реки - 24-34 м. Культурный слой толщиной $0,3-0,5$ м. Состояние памятника удовлетворительное, поверхность распахивается.

115 (61). Шурскол. Селище 4, VIII-X, XIV-XVII вв. Расположено в 0,6 км к востоку от с. Шурскол, на мысу коренного плато западного берега оз. Неро. Обследовано в 1986 г. А.Е. Леонтьевым, в 2006 г. А. В. Кашкиным. Размеры памятника $-140 \times 70$ м, высота от озера -32 м. Культурный слой толщиной $0,15-0,40$ м. Состояние памятника хорошее. Поверхность частично поросла деревьями и кустарником.

116 (60). Шурскол. Селище 5, XI-XIII, XIV-XVII вв. По данным 2006 г., расположено в 0,6кмксеверо-востоку отс. Шурскол, на склоне коренного плато западного берега оз. Неро. Обследовано в 1986 г. А. Е. Леонтьевым, в 2006 г. А.В. Кашкиным. Размеры памятника $-140 \times 70$ м, высота от озера $-37-40$ м. Культурный слой толщиной 0,25-0,30 м. Состояние памятника удовлетворительное, поверхность распахивается.
117 (39). Юрьевская Слобода. Селище, IX-XIII, XIV-XVII вв. Расположено на северозападной окраине д. Юрьевская Слобода, к северу от шоссе Ростов - Борисоглебский, к северо-западу от моста, на правобережной террасе р. Ишни (впадает в оз. Неро). Обследовано в 1981 г. А. Е. Леонтьевым, в 2006 г. А. В. Кашкиным. Размеры памятника $-200 \times 80$ м, высота от реки $-5-7$ м. Культурный слой толщиной $0,25-0,30$ м. Состояние памятника удовлетворительное. Поверхность распахивается, северный и частично восточный края памятника застроены.

В результате мониторинга были уточнены характеристики 60 памятников по расстоянию и направлению от населенных пунктов, 85 памятников по размерам и высоте расположения. Техническое состояние 46 памятников Ростовского р-на следует считать хорошим, 55 памятников - удовлетворительным, а 16 памятников - плохим. Значительная часть ранее распахиваемых памятников в настоящее время задернована, а некоторые из них заросли деревьями и кустарником. В результате хозяйственной деятельности (разработка карьеров) исчезли 6 памятников (одно селище и пять курганных могильников).

\section{Литература}

Комаров К. И., 2005. Археологическая карта России. Ярославская область. М.: ИА РАН. 408 с.

Леонтьев А. Е., Кашкин А. В., Самойлович Н. Г., 2017. Работы в Ростове и Ростовском районе // АО 2015. C. $126-128$.
Купщов И. В., Бобрецов И. В., 2014. Исторический некрополь городища Филимоново: опыт археологического и антропологического исследования // Археология: история и перспективы. VI межрег. конф. Сб. ст. Ярославль. С. 102-115. 
Н.А. Кренке

Институт археологии РАН, г. Москва

\section{Керамика Подболотьевского могильника из раскопок В.А. Городцова}

Сорок лет назад, в 1978 г., в конце обучения на третьем курсе кафедры археологии МГУ, побывав в экспедиции А.Е. Леонтьева в Костромской области, я спросил у него совета: на какую тему готовить курсовую? Андрей Евгеньевич практически сразу предложил обработать коллекцию керамики из Подболотьевского могильника конца I тысячелетия н. э. возле Мурома, раскопанного В.А. Городцовым в 1910 г. (Городияов, 1914), которая хранится в ГИМ. По его словам, ситуация очень удачная, так как есть хороший задел, но есть и простор для работы. Я приступил к этому исследованию, отрисовал все горшки, начал думать над подходами к классификации, но затем моя тема изменилась кардинально: стал заниматься Сибирью под руководством профессора Л. Р. Кызласова.
В этой статье делается попытка выполнить старое задание. Работа актуальна сегодня, так как обследование могильника было проведено вновь в 1991 г. А.Е. Леонтьевым (1992), отмечена перспективность его дальнейшего исследования, а широкие раскопки возобновлены в 2012 г. О.В. Зеленцовой и С.И. Миловановым (Зеленцова, 2014).

Андрей Евгеньевич известен своим редким качеством - объективностью. Видимо, общение с ним повлияло на студента. Мне захотелось представить керамику могильника максимально объективно. Решил воспользоваться методом антропологов по составлению объединенного фотопортрета. Эта методика разрабатывалась в 1970-х гг. доктором биологических наук И.В. Перевозчиковым

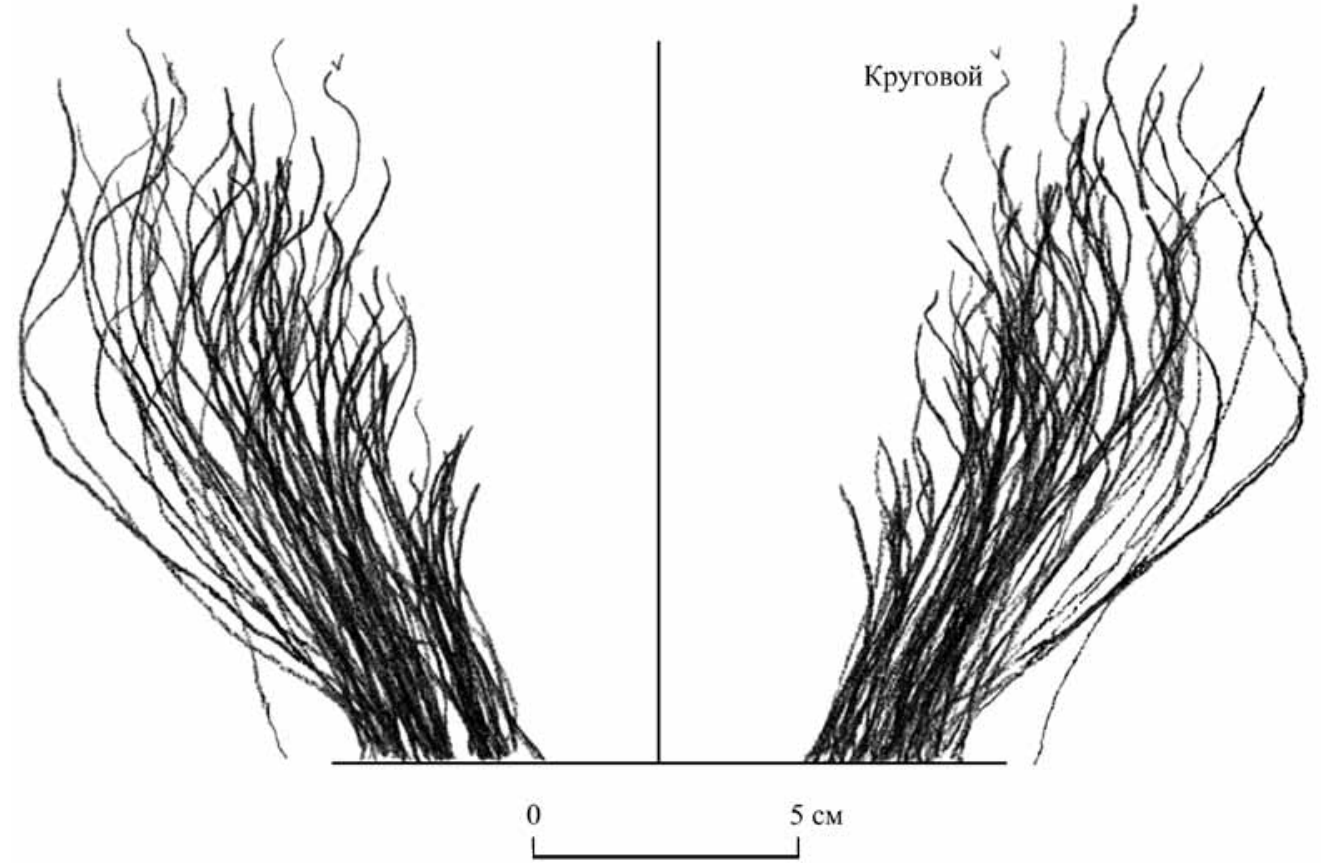

Рис. 1. Совмещенные профили сосудов из Подболотьевского могильника (раскопки В.А. Городцова) 
ก. 125

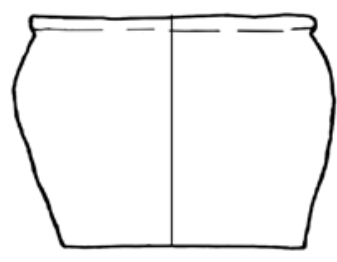

п. 84

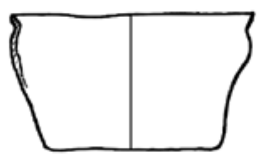

ก. 86
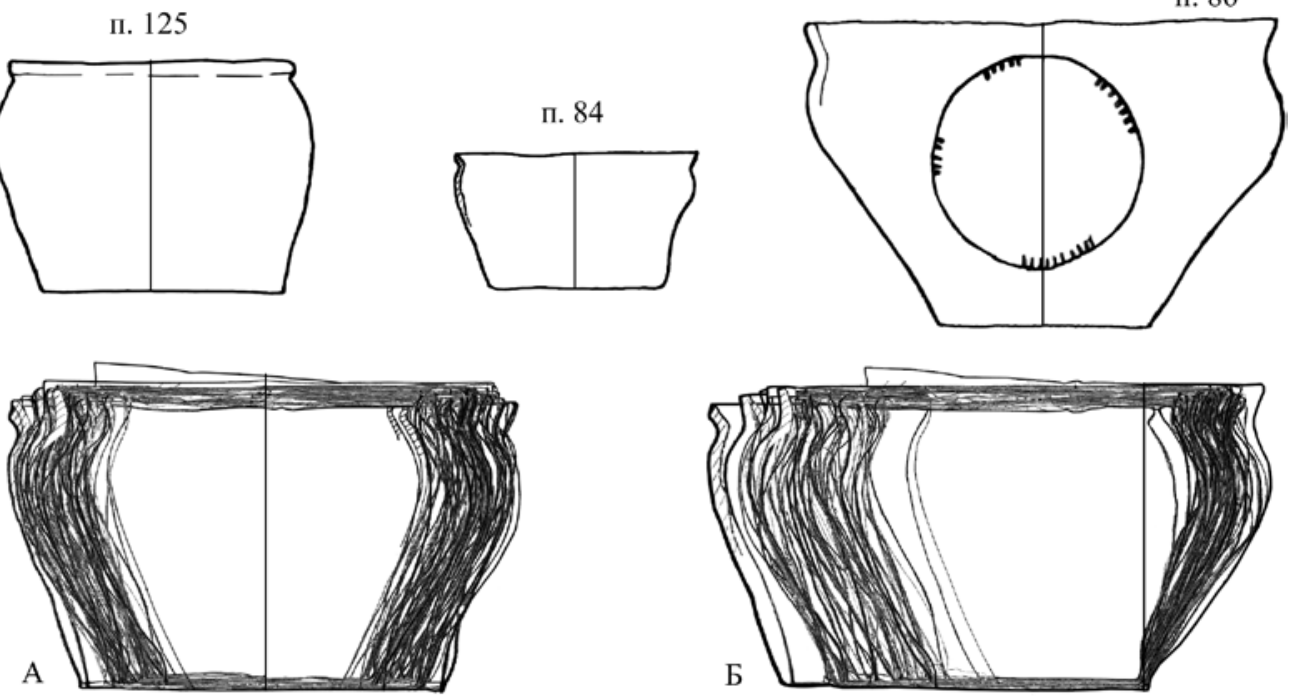

п. 284
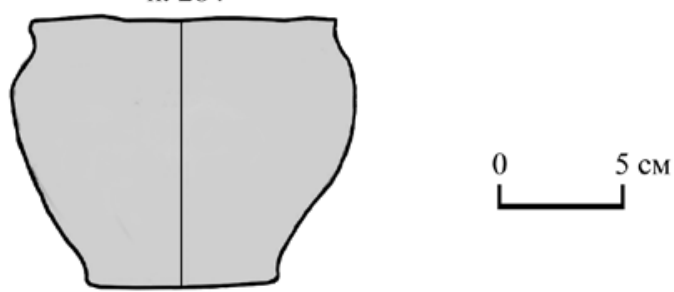

Рис. 2. Совмещенные профили горшков из Подболотьевского могильника. Типичная (отмечена серым) и редкие формы

А - совмещение по оси симметрии; Б - совмещение по правому краю донца
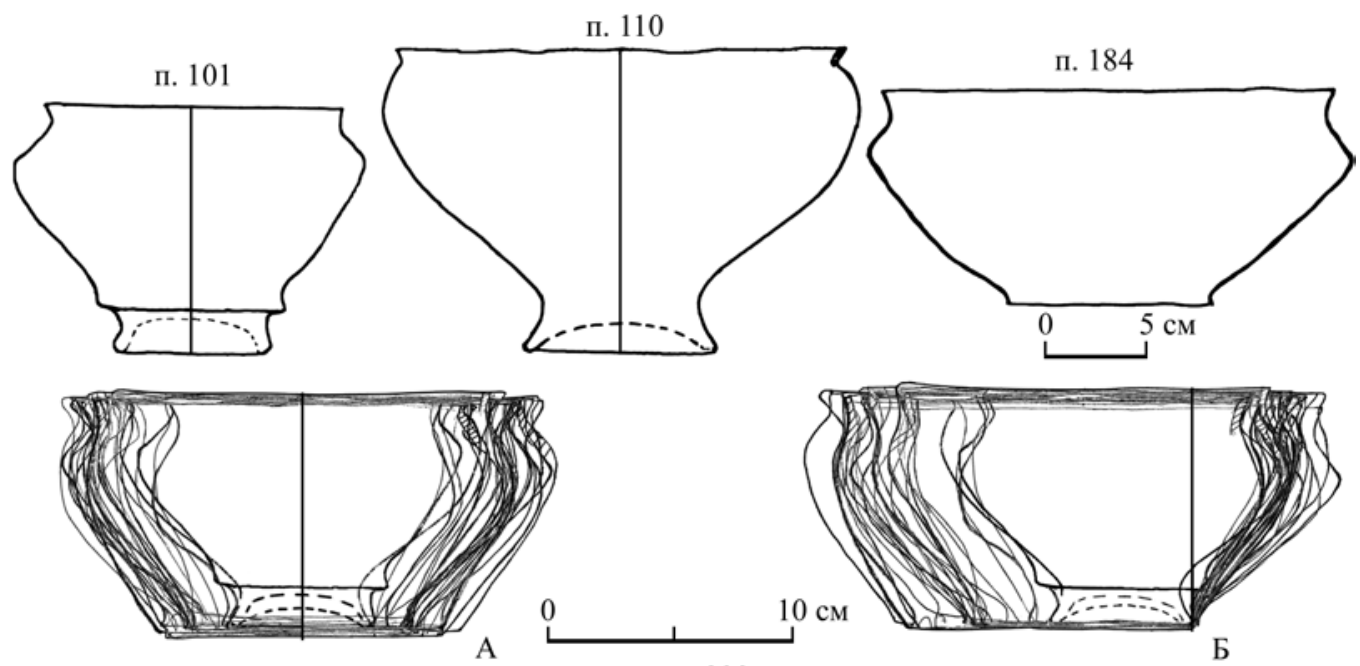

п. 233
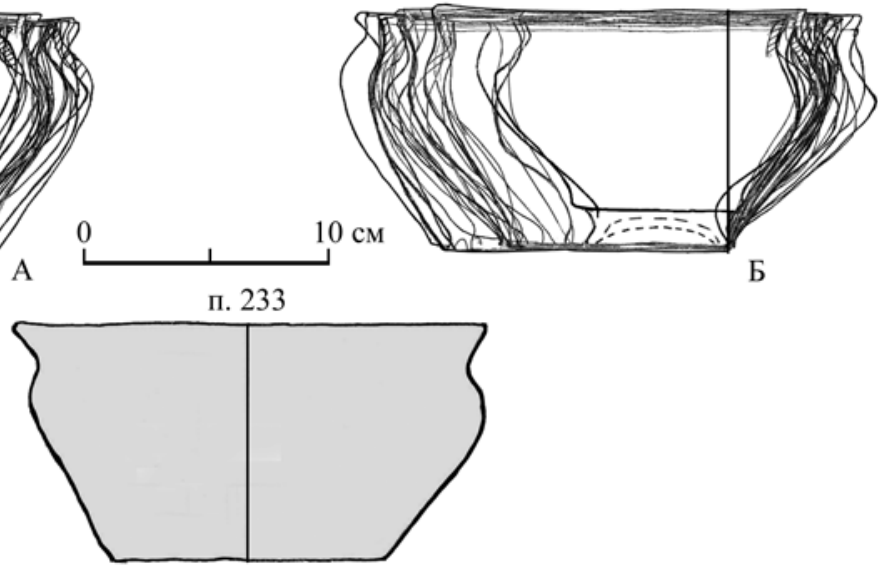

Рис. 3. Совмещенные профили мисок из Подболотьевского могильника. Типичная (отмечена серым) и редкие формы 

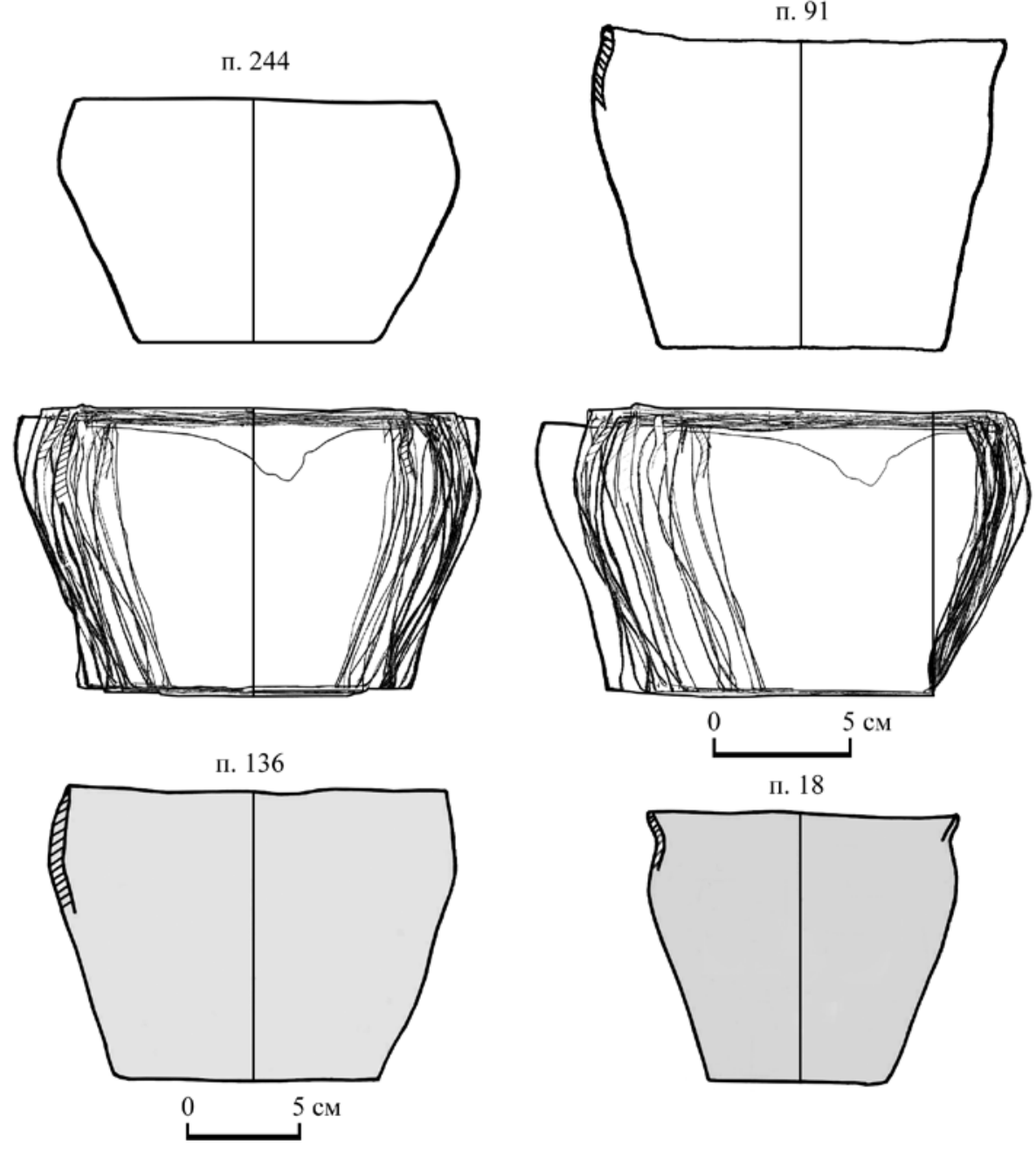

п. 18

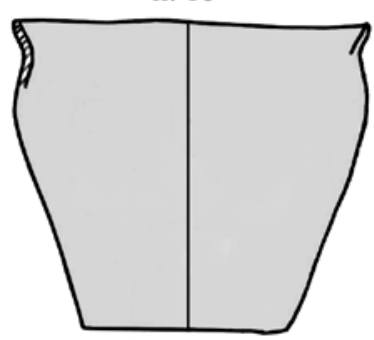

Рис. 4. Совмещенные профили «кубков» из Подболотьевского могильника. Типичные (отмечены серым) и редкие формы

в НИИ и Музее антропологии МГУ. Антропологи совмещают портреты людей, соединяя их по точкам зрачков.

Всего было нарисовано 106 сосудов, практически вся коллекция. 105 сосудов лепные (возможно, подправленные на вращающейся подставке) местного производства муромы конца I тысячелетия н. э. Один горшок - привозной, славянский раннекруговой с горизонтальным рифлением тулова, вероятно, Х в. (погр. 176).

Первый полученный результат совмещения профилей горшков представлен на рис. 1. Горшки совмещались двумя способами: по вертикальной оси симметрии и по точке перегиба, где стенка соединяется с донцем (рис. 2, А, Б). Таким образом можно увидеть на одной иллюстрации всю коллекцию в несколько разных ракурсах.

Темные области характеризуют наиболее типичные формы, редкие единичные формы оказы- ваются по краям основного скопления. Рис. 1 дает представление о размерах горшков, но в то же время наложение многочисленных линий друг на друга затемняет картину, так как оказывают влияние различия в размерах сходных по форме горшков. Чтобы избежать этого влияния, была предпринята попытка «нормализации»: сосуды приводились к одной высоте с сохранением их пропорций. При этом оказалось, что предварительно целесообразно разделить их на крупные морфологическо-размерные группы. В данном случае такими явились:

1) горшки;

2) миски (вазы, урны);

3) кубки (высокие горшки);

4) чашечки (малые формы).

В процессе работы осуществлялась корректировка первоначального разделения, произведенного на глаз. Некоторые экземпляры переносились из одной группы в другую - туда, где они больше 
подходили. Работа производилась в программе Photoshop Adobe.

В группе горшков из 61 сосуда (рис. 2) уверенно выделилась одна темная область, характеризующая наиболее распространенные формы. Горшок из погребения 284 может рассматриваться как типичный образец, он взят из середины темной области на рис. 2. По краям ареала находятся горшки из погребений $84,86,125$. Это единичные редкие вариации форм. Уникальность их подчеркивает горшок из погребения 86, у него на донце есть насечки. Таким образом, рисунок 2 дает представление обо всем диапазоне изменчивости форм горшков, о наиболее типичной и редких формах.

На рис. 3 представлены миски - открытые формы горшков с широким устьем и небольшой высотой. Общее количество этой группы сосудов - 29 . Здесь мы видим картину, примерно сходную с вышеописанной. Темная область одна, но менее ярко выражена. Значительное количество единичных, не похожих друг на друга форм. Миска из погребения 233 может рассматриваться как типичная. Формы на поддонах с резко выделенными плечиками из погребений 101, 110, 184 являются уникальными. Кстати, эти миски выделяются не только морфологически, но и по технологии изготовления. Так, сосуд из погребения 110 имеет лощение.

Группа «кубков», или высоких горшков, насчитывает 21 сосуд (рис. 4). Здесь, видимо, можно выделить два характерных подтипа: а) с вогнутой

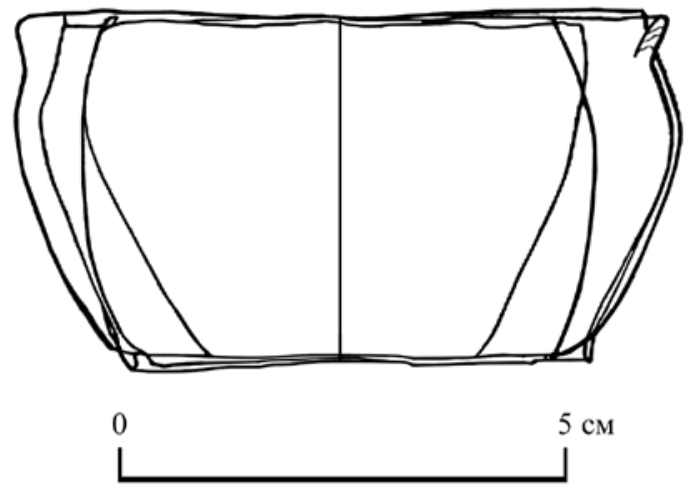

Рис. 5. Совмещенные профили чашечек из Подболотьевского могильника

внутрь горловиной (погр. 136); б) с венчиком, край которого немного отогнут наружу (погр. 18). Редкие формы не столь сильно отличаются от типичных, образуя с ними один ряд. Эти формы представлены сосудами из погребений 91 и 244.

Чашечек в коллекции всего четыре (рис. 5). Возможно, глиняные сосуды не были основными в этой категории, более массовыми были деревянные, берестяные (?). Приземисто-вогнутая форма двух чашек может на это указывать. Две другие чашечки копируют в уменьшенном виде глиняные кубок и горшок.

Предложенная методика представления керамической коллекции, на мой взгляд, имеет плюсы. Мы видим весь спектр вариаций форм, степень обоснованности типологии наглядна.

\section{Литература}

Городияов В.А., 1914. Археологические исследования в окрестностях г. Мурома в 1910 году // Древности. Тр. Московского археологического общества. T. XXIV. M. C. 40-216.

Зеленцова О.В., 2014. Новые исследования Под- болотьевского могильника // КСИА. № 236. С. 219-229.

Леонтьев A.E., 1992. Отчет о разведках во Владимирской области в 1991 г. / Архив ИА РАН. Р-1. № 16009-16011. С. 6-8, 10-11. 
О.В. Зеленцова

Институт археологии РАН, г. Москва

\section{О ранней дате и месте гривен глазовского типа в древностях поволжских финнов}

Существует устойчивое мнение, что гривны глазовского типа имели наибольшее распространение в Прикамье (Леонтьев, 1996. С. 16), не случайно в иностранной литературе они еще именуются пермскими (Hårdt, 2007; 2016). Однако статистика показывает, что не меньше эти украшения были распространены в могильниках мордвы и муромы Волго-Окского междуречья (Вихляев и др., 2008. С. 18; Бейлекчи, 2005. С. 44; Гришаков, Седыпев, Сомкина, 2016. С. 10).

Сейчас можно говорить о находках в могильниках мордвы и муромы 254 экземпляров гривен: в Крюковско-Кужновском - 68 экземпляров, Елизавет-Михайловском - 29, Пановском - 25, Втором Журавкинском-6, Втором Старобадиковском -7, Лядинском (из раскопок Р.Ф. Ворониной) и Ляча по 9 в каждом, Стексовском -5, Кельгиниском -2, Шокшинском - 64, Подболотьевском (раскопки 2012-2014 гг.) - 19 экз. и Чулковском - 11 экземпляров$^{1}$. Гривны глазовского типа найдены в 197 захоронениях. В половине случаев в костюме присутствует одна гривна, нередко на шею надевалось два-три экземпляра, в погребении 249 Крюковско-Кужновского могильника их было пять, а в погребении 434 Шокшинского могильника-девять. Глазовские гривны являлись принадлежностью женского костюма (95\%), в мужские захоронения они помещались в составе женского дарственного комплекса (9 погребений). Как часть мужского костюма гривны были найдены только в десяти случаях.

Гривны глазовского типа представляют собой кольцо из дрота круглого сечения, утончающегося и гладкого в центральной части, а у концов орнаментированного спиральной нарезкой, имитирующей перекручивание (тордирование). Размеры гривен приблизительно соответствует обхвату го- ловы взрослого человека: в среднем их диаметр составляет 20-22 см, хотя встречаются экземпляры и меньшего размера. Замок оформлен в виде петли и крючка с многогранной шляпкой. В большинстве случаев замок не нес функциональной нагрузки, играл чисто декоративную роль и располагался на груди. Традиционно под гривнами глазовского типа подразумевают изделия из серебра (рис. 1). Но в нашей выборке только 32 экземпляра серебряные (12,5\%), остальные изготовлены из бронзы.

Массовые находки серебряных гривен стандартного веса (около 200 и 100 г) в составе денежно-вещевых кладов на территории Пермского края и в целом в Восточной и Северной Европе, а также совпадение ареала их распространения с монетными кладами дают основание считать их не столько украшением, сколько средством платежа в трансъевропейской средневековой торговле пушниной (Иванов, 1998. С. 76, рис. 24; Hårdt, 2006. С. 144; Calmer, 2015. C. 16).

Временем наибольшего распространения гривен глазовского типа считается IX-X вв. (Леонтьев, 1996. С. 164). Эту датировку подтверждают многочисленные находки гривен в составе кладов - Лесогуртского с сасанидскими и куфическими монетами, Железницкого, Супрутского и др., где присутствуют монеты IX в. (историографию и список кладов см.: Иванов, 1998. С. 75; Hårdt, 2016, С. 20-29). О бытовании их в Х и доживании до XI в. свидетельствуют находки глазовских гривен в составе Рябиновского клада (Даркевич, 2010. С. 8) и клада у д. Собачьи Горбы около Великого Новгорода (Дубов, 1989. С. 252). В Поволжском регионе известны находки гривен в комплексах с монетами в марийских могильниках Ветлуж-

${ }^{1}$ Могильники Подболотьевский и Чулковский относятся к древностям муромы, остальные - мордовские. 


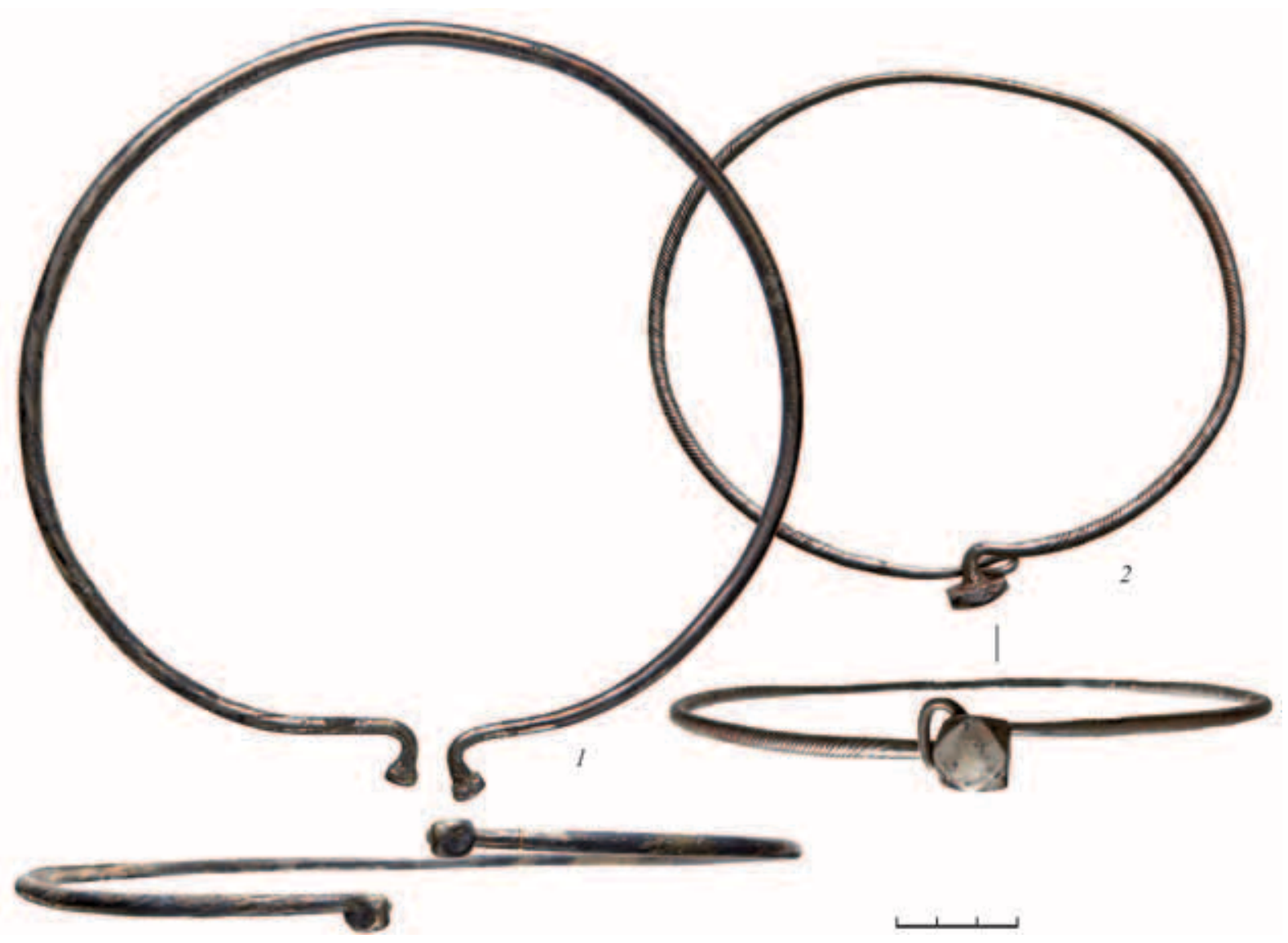

Рис. 1. Серебряные гривны глазовского типа

1 - Пановский могильник, погр. 26; 2 - Елизавет-Михайловский могильник, погр. 106

ско-Вятского междуречья-в Дубовском в четырех погребениях с саманидскими дирхемами второй половины - середины Х в. (Никитина, 2002. С. $316,318,320,321)$; в погребении 23 могильника Нижняя Стрелка с западноевропейским денарием первой трети XI в. (Никитина, 2002. С. 314). Таким образом, время наибольшего распространения гривен глазовского типа приходится на эпоху викингов и связано с функционированием ВолгоБалтийского торгового пути (Hårdt, 2016. S. 63-64; Иванов, 1998. С. 101).

Вопрос о времени и месте появления этого типа гривен, а также центров их изготовления не раз ставился в литературе. В советский период их появление связывалось с восточно-балтским ареалом, откуда происходят гривны с полусферическими головками (Moоra, 1928, S. 158; Смирнов, 1970. С. 179). Об их возможных прототипах в древностях Поволжья и Прикамья, где тордированные гривны известны в Кошибеевском, Пьяноборском и других могильниках первой половины I тысячелетия н. э., в свое время писал А.Г. Иванов (1998. С. 100).
Действительно, тордированные гривны находят в рязано-окских и мордовских древностях первой половины I тысячелетия н. э. (Ахмедов, 2007. С. 166-168; Белоиерковская, 2007. С. 209-210; Ставицкий, 2015. С. 45-46), но хронологический разрыв более чем в три столетия не позволяет говорить о прямой преемственности между этими украшениями. В то же время в рязано-окских древностях и у мордвы существовала длительная традиция ношения гривен, в том числе бытовали типы дротовых гривен с замком в виде двух крючков; с замком в виде петли и небольшой головки, а также с обмоткой у концов (Шитов, 1988. С. 26. Табл. VIII, 32; Ахмедов, 2010. С. 29; Вихляев и др., 2008. С. 166-167), которые могли стать прототипами для ложновитых экземпляров. Очевидно, что появление нового типа гривен связано с Поволжско-Камским ареалом, и, как замечено исследователями, в общих чертах этот ареал совпадает с ареалом распространения «неволинских» поясов (Иванов, 1998. С. 100). Й. Каллмер считает, что гривны глазовского типа появились у пермских 


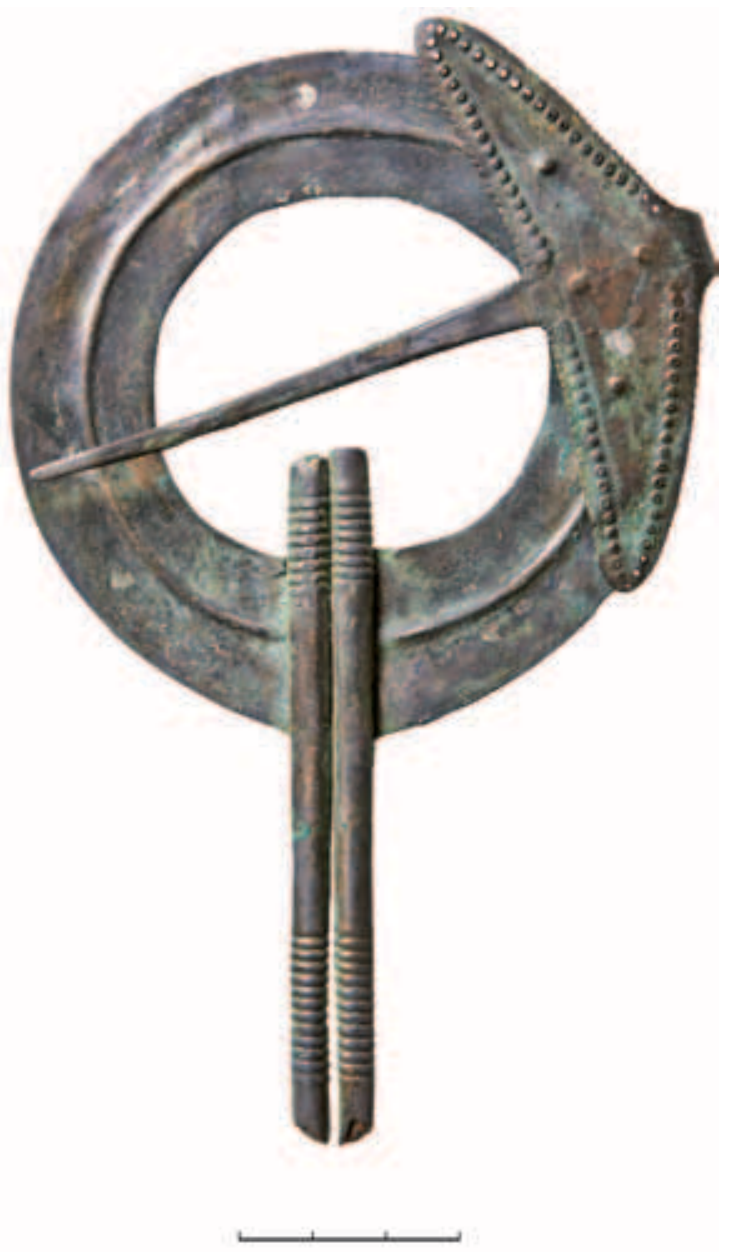

Рис. 2. Серебряная застежка с «крылатой» иглой из п. 26 Пановского могильника

финнов, откуда вместе с «неволинскими» поясами распространились на запад, в том числе во второй половине VIII в. они попадают к мордве и муроме (Calmer, 2015. C. 16-17).

Действительно, в погребении 68 Чулковского могильника гривна глазовского типа с замком в виде петли и крючка с многогранной головкой найдена в комплексе с «неволинским» поясом (Гришаков, Седьпев, Сомкина, 2016. С. 161, рис. 50). Хронологию «неволинских» поясов обосновала Р. Д. Голдина, в ранних работах относившая такие пояса к деменковской стадии и датировавшая их, в том числе и по находкам монет, концом VII-VIII в. (Голдина, 1985. С. 128-130, рис. 16). В одной из последних работ, посвященной Неволинскому могильнику, эти поясные наборы автор отнесла к 3-й группе погребений, датируемой в целом VIII в. (Голдина, 2012. С. 54 , рис. 207). И. О. Гавритухин считает, что «неволинские» пояса частично синхронизируются с «агафоновскими», о чем свидетельствует как со- встречаемость элементов гарнитуры этих наборов, так и их развитие: финал геральдической гарнитуры и прорезных геральдических накладок на «неволинские» пояса приходится на рубеж VII-VIII вв. (Гавритухин, Обломский, 1996. С. 86-89, рис. 88). В погребении 26 Второго Старобадиковского могильника в комплексе с «неволинским» поясным набором и застежкой с «крылатой» иглой присутствуют шляпкоконечные браслеты, сюлгамы с короткими концами и височные подвески с бипирамидальным грузиком с выемкой (Петербургский, 2011. Рис. 26). Этот набор украшений характерен для стадии 9 мордовских древностей, датируемой концом VII - первой половиной VIII в. (Вихляев и др., 2008. С. 140-141).

Хронологическим репером для определения времени появления гривен глазовского типа у поволжских финнов правобережья Волги служат застежки с «крылатой» иглой, найденные вместе с ними (погр. 63, 68- Чулковский, погр. 26 - Пановский, погр. 26 - Старобадиковский могильники). Пластинчатые кольцевидные застежки с иглой, основание которой расковано в виде «крыльев», являются воинскими фибулами и встречаются исключительно в мужских погребениях (рис. 2). Это украшение появляется в рязано-окских могильниках в последней четверти I тысячелетия н.э. и становится характерным атрибутом мужского костюма мордвы и муромы. Пик бытования таких фибул приходится на время распространения геральдических поясов (Шитов, 1988. С. 31; Ахмедов, 2010. С. 12-13). Типология застежек с «крылатой» иглой не разработана, но их эволюция идет в направлении увеличения размеров рамки от 5-6 см в ранних рязано-окских могильниках, до крупных экземпляров с диаметром рамки до 11-13 см и размахом «крыльев» до 10 см в мордовских и муромских древностях. Крупные экземпляры в Цнинских могильниках встречаются с геральдическими поясными наборами второй стилистической линии, по И.О. Гавритухину, которые датируются концом VII - первой половиной VIII в. (Гавритухин, Обломский, 1996. Рис. 84-85). В опубликованных материалах Чулковского могильника с гривнами глазовского типа сопряжены застежки таких развитых форм (Гришаков, Седьлшев, Сомкина, 2016. Рис. 47, 50). Гривны в этих погребениях, как и застежки с «крылатой» иглой, серебряные (Гришаков, Седымев, Сомкина, 2016. С. 88, 91). О воинском характере погребенных, где присутствуют гривны, помимо фибулы и поясов свидетельствуют многочисленные находки оружия: наконечников копий, проушных топоров, кельтов и стрел. В погребениях 


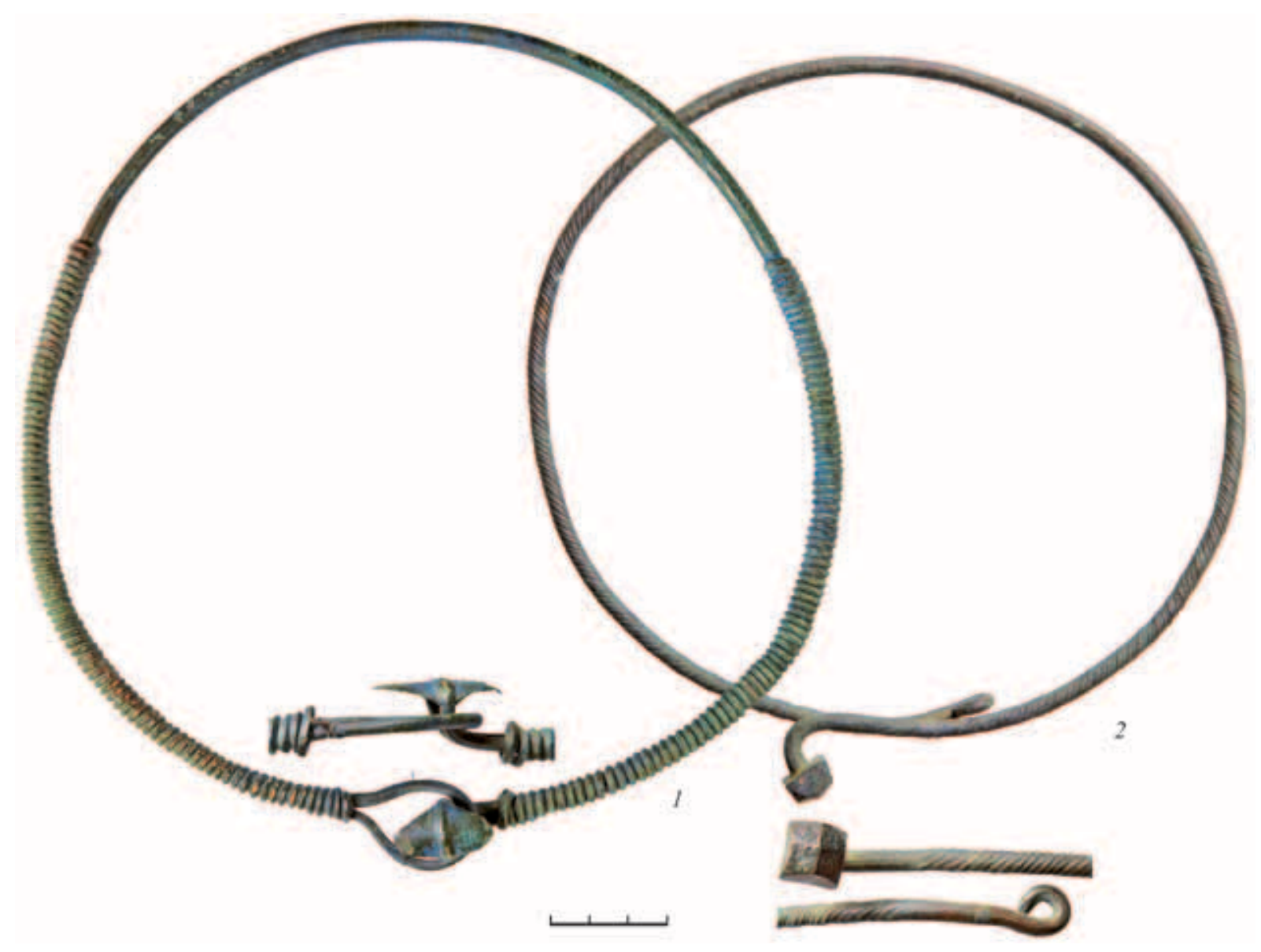

Рис. 3. Бронзовая гривна с замком-«лодочкой» и гривна глазовского типа из погр. 205 Крюковско-Кужновского могильника

179 и 209 Второго Старобадиковского могильника массивные гривны глазовского типа найдены в комплексах с мечами, боевыми топорами, копьями, стрелами и конским снаряжением (Петербургский, 2011. С. 291, 289-291, 310-311). Вероятно, на этом этапе глазовские гривны, как и застежки с «крылатой» иглой, выполняли функцию определенного социального маркера и не случайно фиксируются у хорошо вооруженной и наиболее мобильной части общества. Свидетельством мобильности является находка застежки с «крылатой» иглой на средней Вятке (Голдина и др., 2007. С. 138). Воинская фибула найдена в Тат-Боярском могильнике еманаевской археологической культуры, где, судя по датировкам памятника VI-VIII вв., присутствуют и наиболее ранние экземпляры гривен глазовского типа (Лещиинская, 1991. С. 63; 2016. С. 102).

Таким образом, мы можем сделать вывод об импортном для мордвы и муромы характере этого украшения, которое, появившись в виде престиж- ного элемента, получает развитие в менее дорогих бронзовых вариантах в составе женского костюма.

В 188 женских захоронениях мордвы и муромы найдено 238 гривен. Серебряных из них только 28, остальные изготовлены из бронзы. Почти в половине захоронений (42\%) присутствует по несколько экземпляров, причем это больше характерно для мордвы; у муромы только в двух погребениях было по две, а в одном три гривны (погр. 57, 143 и 154 Подболотьевского могильника). В девяти случаях с гривнами глазовского типа найдены гривны с замком-«лодочкой». Это также круглодротовые гривны, у концов обмотанные тонкой проволокой треугольного сечения и с замком в виде петли и крючка с перстневидной застежкой (рис. 3,1$)$. Обращаясь к гривнам с замком«лодочкой», исследователи ссылаются на находку гривны с подобной застежкой в погребении 46 Серповского могильника с 12 византийскими монетами середины-конца VII в. (Алихова, 1959. 


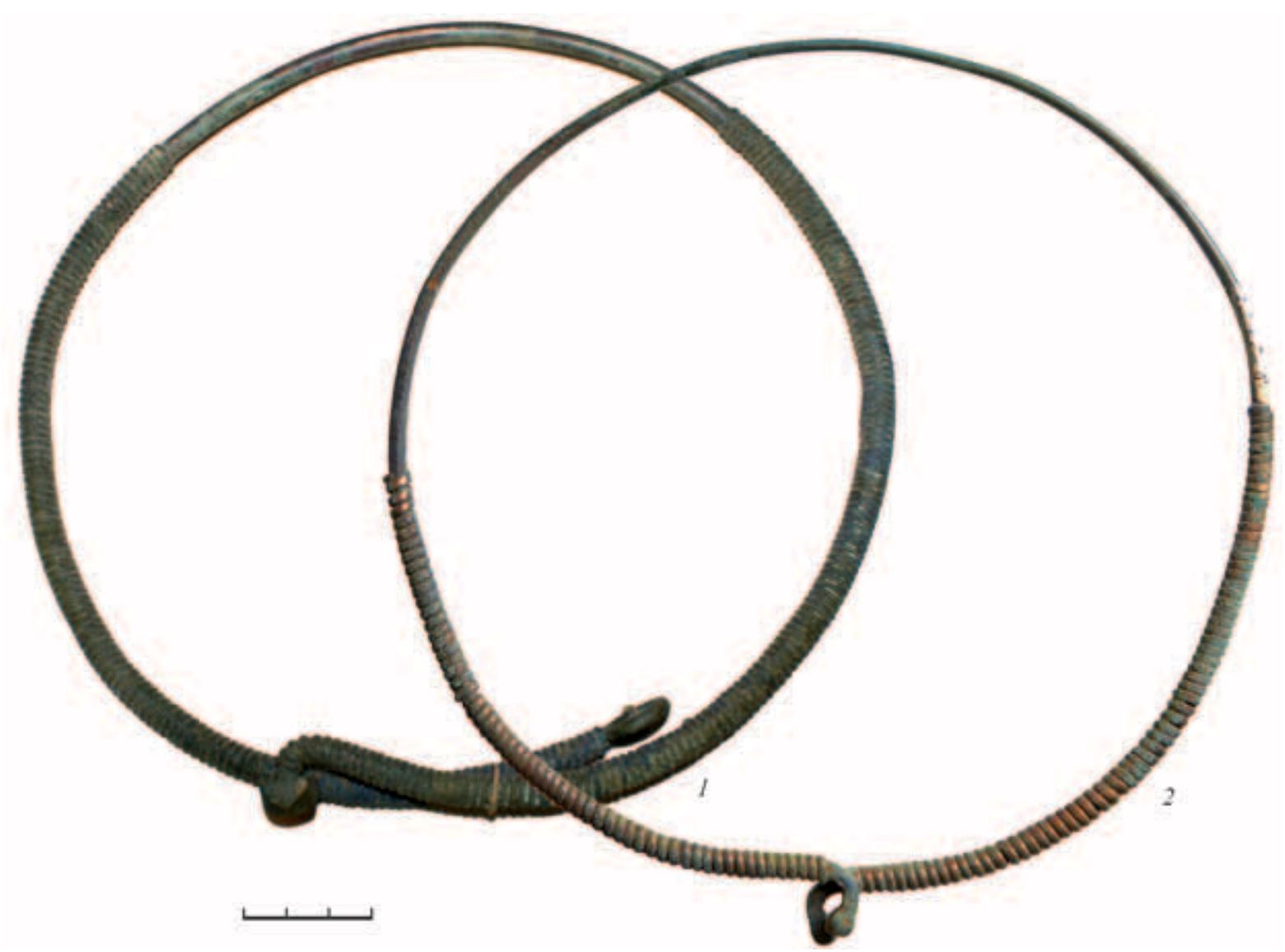

Рис. 4. Дротовые гривны с обмоткой

1 - Елизавет-Михайловский могильник, погр. 63; 2 - Крюковско-Кужновский могильник, погр. 2

С. 119). В мордовских могильниках такие гривны бытуют в течение VIII в., но преимущественно в его первой половине (Вихляев и др., 2008. С. 140). В Крюковско-Кужновском и во Втором Старобадиковском могильниках они известны с поясными наборами, выполненными по византийским традициям с большими шарнирными пряжками и массивными рельефными накладками, которые относятся к раннесалтовскому горизонту Столбище-Старокорсунская и датируются в рамках середины - второй половины VIII в. (Материалы... 1952. Табл. XXX, 6; XXXI, 6, 7, 8; XXXIV, 9; Комар, 1999. С. 123-128, 132). С таким поясом найдена гривна глазовского типа в погребении 86 Чулковского могильника (Гришаков, Седьлиев, Сомкина, 2016. С. 171). Совместное бытование гривен глазовского типа и гривен с застежкой-«лодочкой» демонстрирует погребение 205 Крюковско-Кужновского могильника, где обе гривны найдены в комплексе с куфическим дирхемом Аль-Мансур 139 г. х. (756 г.) (рис. 3; Материалы... 1952. С. 71).

В этот же период у мордвы встречается еще один тип гривен с обмоткой, который выглядит как гибридный вариант; они выполнены из круглого дрота, у концов имеют обмотку из трехгранной или плосковыпуклой проволоки, а замок оформлен как у глазовских гривен - в виде петли и крючка с многогранной головкой или в виде двух крючков с небольшими шляпками (рис. 4). Безусловно, типологически между этими гривнами и глазовскими есть связь, но гибридных немного, всего 9 экз., к тому же бытуют они на протяжении VIII в., поэтому хронологической преемственности между ними нет, и вряд ли они могут быть прототипами глазовских.

На первый взгляд глазовские гривны довольно стандартны, но исследование такой объемной выборки позволяет разделить их на несколько вариантов. Гривны первого варианта (5 экз.) можно отнести к глазовским достаточно условно, так как они изготавливались путем перекручивания дрота. Винтообразная нарезка на их теле более рельефна и расположена реже. Замок оформлен в виде петли и крючка с многогранной шляпкой, небольшой шляпки-пуговки, реже - уплощенной шляпки. Это так называемые тордированные гривны, к кото- 


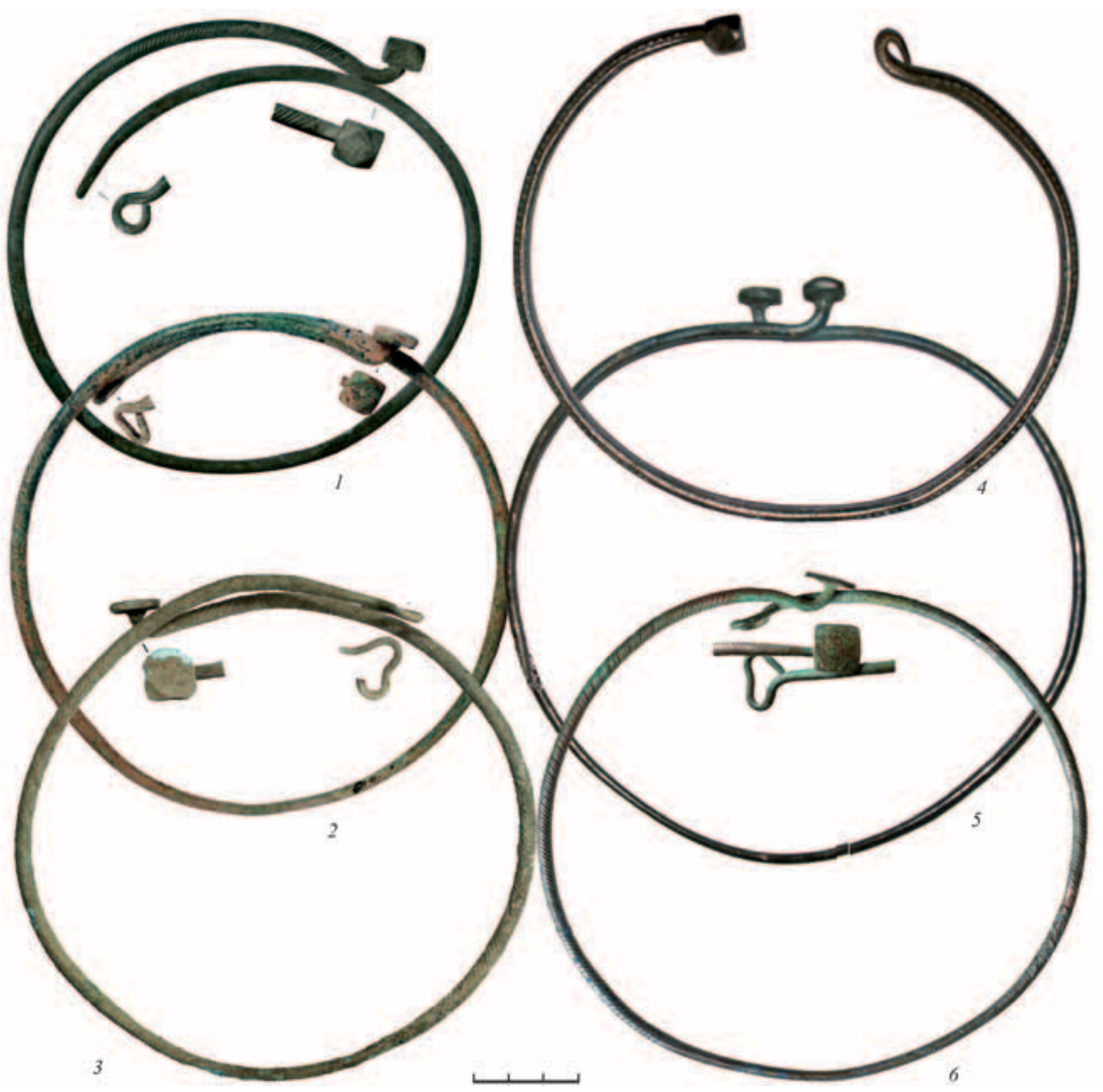

Рис. 5. Гривны глазовского типа из Подболотьевского (1-3) и Крюковско-Кужновского (4-6) могильников 1 - погр. 148; 2 - погр. 16; 3 - погр. 143; 4 - погр. 544; 5 - погр. 72; 6 - погр. 216. 1-3, 6 - бронза; 4, 5 - серебро

рым в свое время М.В. Фехнер отнесла все глазовские (Фехнер, 1967. С. 56). С вопросами техники изготовления этого варианта гривен еще предстоит разбираться, но в материалах кладов Верхнего и Среднего Прикамья крученые гривны также выделяются (Лещзенко, 1971. С. 10).

Классический вариант гривен глазовского типа, именуемый в литературе также ложновитыми гривнами, изготавливался отливкой, о чем свидетельствует продольная ложбинка на отдельных экземплярах, сглаженный рельеф спиральной «нарезки» и более частое расположение ее гребней.
Ложновитые гривны по устройству замка делятся на две почти равные группы. Часть из них (112 экз.) имеют замок в виде петли и крючка с уплощенной многогранной или простой шляпкой (рис. 5, 3, б). У другого типа (123 экз.) замок оформлен в виде петли и крючка с многогранной головкой (рис. 5, $1,2)$. Более редки гривны с концами в виде двух крючков с многогранными головками (15 экз.; рис. 1,$1 ; 6,5)$. Еще две отличаются от глазовских оформлением тела кольца: дрот декорирован так называемым волчьим зубом, весьма характерным для древнерусских изделий (рис. 6, 4). При 


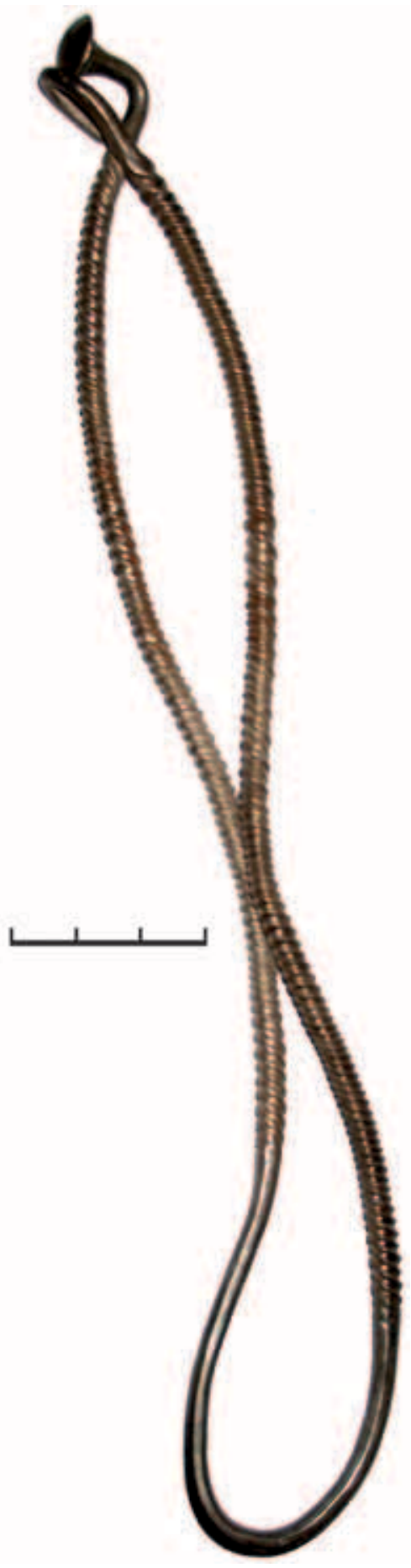

Рис. 6. Серебряная гривна глазовского типа из погр. 416 Крюковско-Кужновского могильника

этом многогранная головка замка гривны из погребения 544 Крюковско-Кужновского могильника расположена в плоскости кольца, что не типично для гривен Поволжья и Прикамья, но характерно для древнерусских территорий (Фехнер, 1967. С. 59-60. Рис. 8, 4, 5).
Анализ показывает, что устройство замка и массивность граненой головки являются хронологическими признаками. Гривны глазовского типа с массивной граненой головкой имеют более раннюю хронологическую позицию, именно они встречаются с «неволинскими» поясами, застежками с «крылатой» иглой, гривнами с замком-«лодочкой», ранними типами сюлгам. Они продолжают бытовать во второй половине VIII-IX в. одновременно с коваными и литыми сюлгамами с длинными «усами», нагрудными бляхами с круглой крышечкой, шляпкоконечными массивными браслетами (Вихляев и др., 2008. С. 142-144). В погребении 349 Крюковско-Кужновского могильника подобный комплекс сопровождается ожерельем из четырех абассидских дирхемов, которые датируются первой половиной IX в. (Гомзин, 2013. С. 119).

Это не значит, что в последующий период глазовские гривны с массивной головкой не встречаются, но в целом их развитие идет в сторону уплощения многогранной головки и постепенного превращения ее в шляпку. В погребениях Цнинской мордвы, датируемых VIII-IX вв., присутствует 46 гривен с массивной головкой и всего пять с уплощенной, а в погребениях следующего периода с массивной головкой 22 против 62 с уплощенной шляпкой.

Тенденция изменения гривен глазовского типа в направлении уплощения шляпки подтверждается и на материалах марийских могильников Ветлужско-Вятского междуречья, откуда происходит 38 экземпляров (Никитина, 2012. Рис. 39, 8; 217, 12; 224,$12 ; 227,5$, и др.). Гривны с массивной граненой головкой присутствует в погребении 25 могильника Нижняя Стрелка, которое относится к наиболее ранней группе и датируется IX в.; в погребениях Х в. встречаются гривны обоих типов (Веселовский 3,5 ; Нижняя Стрелка, ЖК4), а в XI в. бытуют уже только гривны с уплощенной шляпкой (Нижняя Стрелка 11, 16, ЖК12, Веселовский 22) (Никитина, 2012. С. 73). Материалы марийских могильников подтверждают еще одно наблюдение: глазовские гривны у поволжских финнов получают наибольшее распространение в X-XI вв. Так в погребениях 1-й группы марийских могильников, датируемых IX в., найдено всего две гривны, остальные происходят из погребений групп 2-4, т. е. X-XI вв. (Никитина, 2012. С. 73).

У мордвы и муромы в погребениях конца VII первой половины VIII в. найдено 18 гривен, что составляет 7\% от общего количества, в погребениях второй половины VIII-IX в. $-37 \%$ гривен (90 экз.), на X-XI вв. приходится 56\% (139 экз.). Это интересная тенденция, и за ней, очевидно, сто- 
ят общие процессы, происходившие на территории Восточной Европы и заключавшиеся во все большей вовлеченности лесных территорий в систему международных отношений. В настоящее время общепризнано, что серебряные гривны глазовского типа стандартного веса играли роль крупных денег в международной торговле (Hårdt, 2016. C. 65). Насколько в это были включены мордовские и муромские племена, пока не совсем ясно. В таком качестве мы можем рассматривать пока только одну гривну из наших материалов. В погребении 416 Крюковско-Кужновского могильника похоронена женщина в полном традиционном уборе (Материалы... 1952. C. 133). Часть украшений костюма выполнены из серебра - это налобный венчик, парные височные привески, перстень с сердоликом и серповид- ная гривна. Серебряная гривна глазовского типа, согнутая пополам, лежала в изголовье погребенной (рис. 6). На фоне большого количества качественных украшений личного костюма очевидно, что в данное погребение гривна была положена не как украшение, а как атрибут богатства.

Количественно преобладавшие у мордвы и муромы бронзовые экземпляры гривен глазовского типа вряд ли можно рассматривать как объекты торговых операций. Скорее всего, это украшение, появившись у элитной части общества, постепенно, в том числе в результате широкого хождения и особой популярности у мордвы и муромы гривен вообще, становится традиционным элементом женского костюма, но при этом сохраняет функцию престижного объекта.

\section{Литература}

Алихова A.E., 1959. Серповский могильник // Из древней и средневековой истории мордовского народа. Саранск: Красный октябрь. С. 117-130.

Ахмедов И.Р., 2007. Инвентарь мужских погребений // Восточная Европа в середине I тысячелетия н.э. М.: ИА РАН. С. 137-185.

Ахмедов И.Р., 2010. Проблема «финального» периода культуры рязано-окских финнов (к современному состоянию вопроса) // Археология Восточной Европы в I тысячелетии н.э. Проблемы и материалы. М.: ИА РАН. С. 7-34. (Раннеславянский мир. Вып. 13).

Бейлекчи В. В., 2005. Древности летописной муромы. Погребальный обряд и поселения. Муром: Изд. Московского психолого-социального института. 278 с.

Белоичерковская И.В., 2007. Инвентарь женских погребений // Восточная Европа в середине I тысячелетия н. э. М.: ИА РАН. С. 186-213.

Вихляев В.И., Беговаткин А.А., Зеленцова О.В., Шитов В.Н., 2008. Хронология могильников населения I-XIV вв. западной части Среднего Поволжья. Саранск: Красный Октябрь. 352 с.

Гавритухин И. О., Обломский А. М., 1996. Гапоновский клад и его культурно исторический контекст. М.: ИА РАН. 298 с.

Голдина Р.Д., 1985. Ломоватовская культура в Верхнем Прикамье. Ижевск: Изд-во Иркутского университета. 280 с.

Голдина Р.Д., 2012. Неволинский могильник VIIIX вв. н. э. в Пермском Предуралье. Ижевск: Удмуртский гос. унив. 470 с. (Матер. и иссл. Камско-Вятской археологической экспедиции).
Голдина Р.Д., Лещчинская Н.А., Ч Черных Е.М., Берни В. А., 2007. Наследие народов Прикамья. Ижевск: Удмуртский гос. унив. 194 с.

Гомзин А.А., 2013. Восточное монетное серебро IX - начала XI в. в среднем и нижнем Поочье. Дисс. ... канд. ист. наук. М.: ИА РАН. 499 с.

Гришаков В.В., Седьишев О.В., Сомкина А.Н., 2016. Муромские племена правобережья Оки в последней четверти I тыс. н. э. Чулковский могильник. Саранск: Мордовский гос. пед. ин-т. 178 с.

Даркевич В. П., 2010. Художественный металл Востока VIII-XIII вв. Произведения восточной торевтики на территории европейской части СССР и Зауралья. М.: Книжный дом «ЛИБКОРОМ». $186 \mathrm{c}$.

Дубов И. В., 1989. Волжский путь. Л.: Наука. 256 с.

Иванов А.Г., 1998. Этнокультурные и экономические связи населения бассейна Чепца в эпоху средневековья. Ижевск: Удм. ИИЯЛ; УрО РАН. 309 c.

Комар А.В., 1999. Предсалтовские и раннесалтовские горизонты Восточной Европы // VitaAntiqua. № 2. C. 111-136.

Леонтьев А.Е., 1996. Археология мери. К истории Северо-Восточной Руси. М.: Геоэко. 340 с.

Лещенко В.Ю., 1971. Восточные клады на Урале в VII-XIII вв. (по находкам художественной утвари). Автореф. дисс. ... канд. истор. наук. Л. 22 с.

Лещчинская Н.А., 1991. Исследования Тат-Боярского могильника // Археологические открытия Урала и Поволжья. Ижевск: Удм. ИИЯЛ. С. 61-64.

Лещинская Н.А., 2016. «Жертвенные комплексы» как элемент погребальных традиций населения 
Вятского края в раннем средневековье // Поволжская археология. № 1 (15). С. 102-120.

Материалы по истории мордвы VIII-XI вв. Дневник археологических раскопок П.П. Иванова. Моршанск: Изд. Моршанского краев. музея, 1952. $232 \mathrm{c}$.

Никитина Т.Б., 2002. Марийцы в эпоху средневековья. Йошкар-Ола: МарНИИ. 432 с.

Никитина Т.Б., 2012. Погребальные памятники IX-XI вв. Ветлужско-Вятского междуречья. Казань: Изд. дом «Сельские вести». 408 с. (Археология евразийских степей).

Петербургский И. М., Аксенов В. Н., 2008. Древние памятники на реке Ляча. Саранск: Тип. «Красный Октябрь». 168 с.

Петербургский И. М., Вихляев В.И. Святкин С.В., 2010. Второй Журавкинский могильник. Саранск: Тип. «Красный Октябрь». 132 с.

Петербургский И. М., 2011. Материальная и духовная культура мордвы в VII-X вв. Саранск: Тип. «Красный Октябрь». 408 с.

Смирнов А.П., 1970. О культурных связях Прибалтики со Средним Поволжьем и Приуральем в эпоху древности и средневековья // Studia archaeologic aim memoriam Harri Moora. Tallin. S. $176-179$.

Ставиикий В.В., 2015. Тордированные гривны из древнемордовских могильников I тысячелетия н. э. // История и археология. № 2. С. 44-48.
Фехнер М.В., 1967. Шейные гривны // Очерки по истории русской деревни X-XIII вв. М.: Советская Россия. С. 55-88. (Тр. ГИМ. Вып. 43).

Шитов В.Н., $\quad$ 1988. Старокадомский могильник // Материалы по археологии Мордовии. Саранск: Мордовское книжное изд. С. 23-71.

Calmer J., 2015. The background and the early history of the neck rings of the Glazov type (also called Permian) and the beginning of East-West connections in early Medieval Northern Europe in the $8^{\text {th }}$ and $9^{\text {th }}$ centuries // Small Things Wide Horizons. Studies in honour of Birgitta Hårdt. Oxford: Archaeopress Publishing LTD. S. 13-19.

Hårdt B., 2006. Money in large units in East and West // Transformatio mundi. The transition from the late Migration Period to the early Viking Age in the East Baltic. Kaunas. S. 143-159.

Hårdt B., 2007. Oriental-Scandinavian contacts on the Volga as manifested by silver rings and weight systems // Silver economy in the Viking Age / Graham-Campbell, J. et al. (eds.), London. P. 135-147.

Hårdt B., 2016. The Perm `/Glazov rings. Contacts and Economy in the Viking Age between Russia and the Baltic Region // Acta archaeologica lundensia. Lind. Series in 8, No. 67.

Moora H., 1928. Bemerkunden über einige ostbaltische Schmucksachen den jungeren Eisenzeit // Sitzungberichte der Gelerten Estnischen Gesellschaft. Opetatud Eesti Selst Aastraamat. I. Tartu. 


\section{Принятые сокращения}

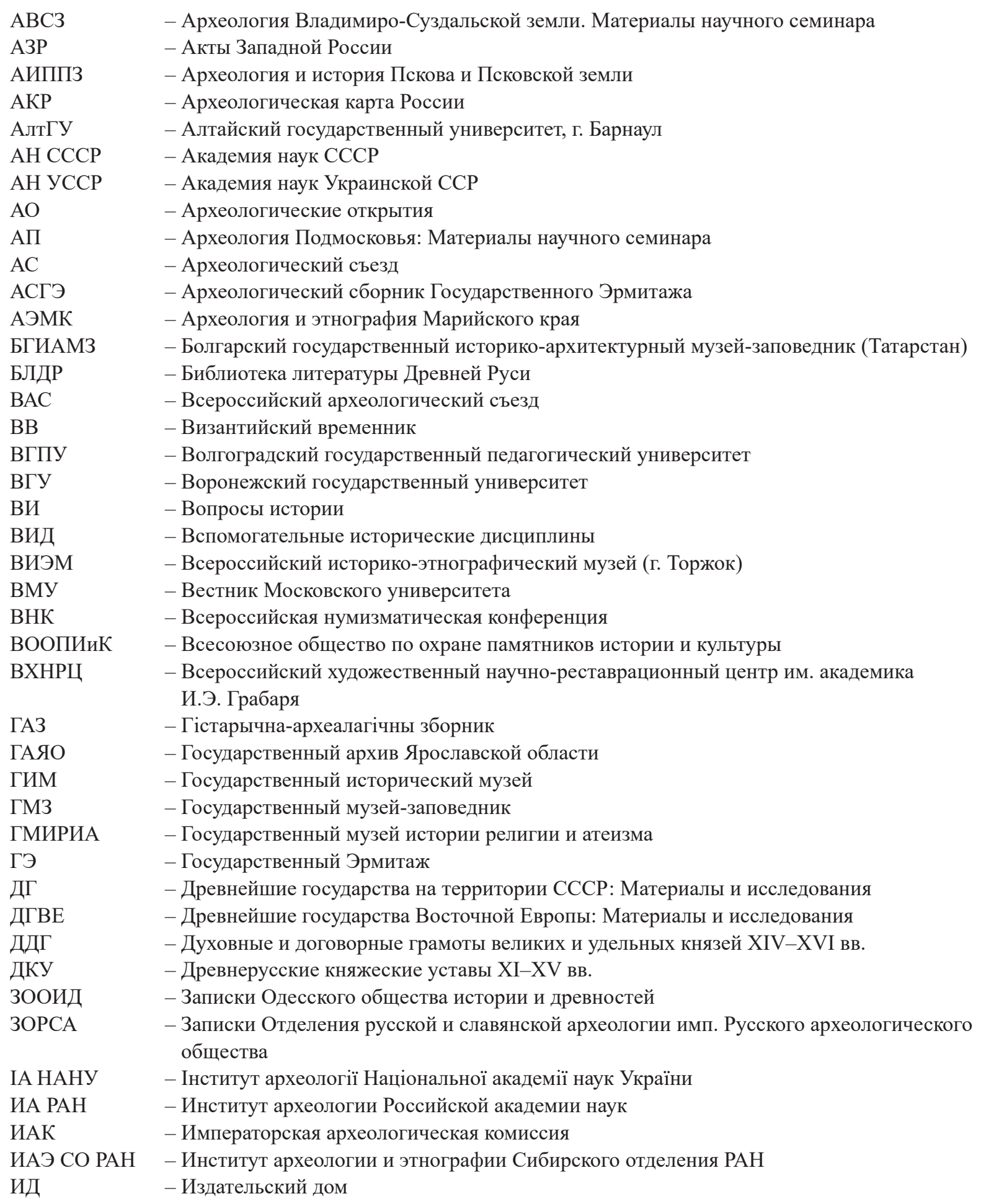




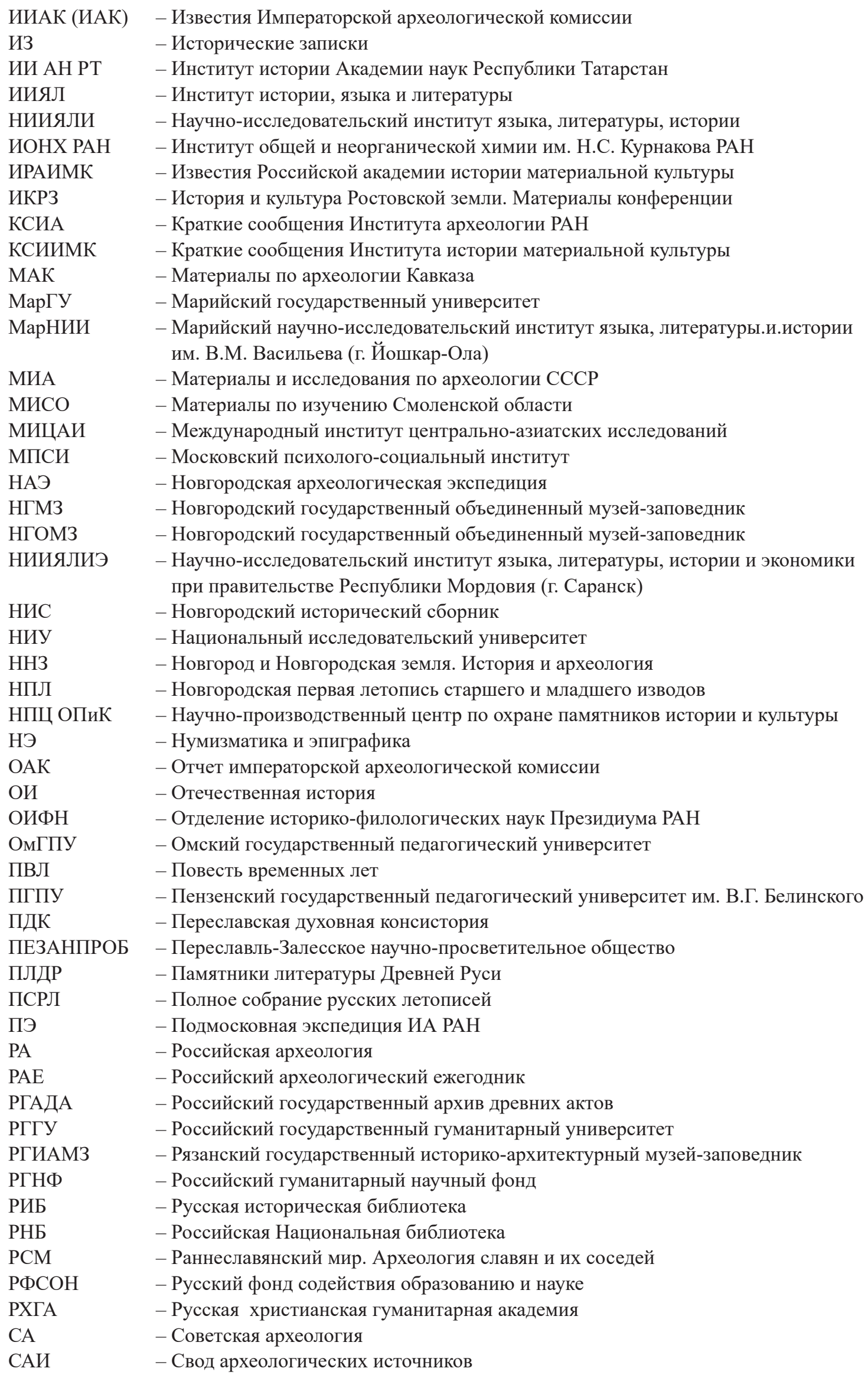


СГАИМК - Сообщения Государственной академии истории материальной культуры

СГЭ - Сборник Государственного Эрмитажа

СИРИО - Сборник Императорского русского исторического общества

СО АН СССР - Сибирское отделение АН СССР

СПбГУ - Санкт-Петербургский государственный университет

СРМ - Сообщения Ростовского музея

СЭ - Советская этнография

TAC - Тверской археологический сборник

ТвГУ (ТГУ) - Тверской государственный университет

ТГОМ - - Тверской государственный объединенный музей

ТГУ - Томский государственный университет

ТT3

- Тверь, Тверская земля и сопредельные территории в эпоху средневековья

УдГУ $\quad$ - Удмурсткий государственный университет

УІЖ - - Український історичний журнал

УрО РАН - - Уральское отделение РАН

ЧГУ - - Челябинский государственный университет

ЯРК - - Языки русской культуры

ЯСК - - Языки славянских культур

BAR - British Archaeological Report

EAA - European Association of Archaeologists 

Научное издание

Земли родной минувшая судьба...

Сборник статей к юбилею А. Е. Леонтьева

Автор обложки: А. С. Загрядская

Верстка: В. Б. Степанов

Художник: А. В. Голикова

Корректор: Е. В. Буйда

Подписано в печать 28.11.2018

Формат 60×84/8. Печать офсетная

Бумага мелованная. Усл. печ. л. 60,4. Уч.-изд. л. 61,7

Тираж 150 экз. Заказ №

Институт археологии РАН

117036, Москва, ул. Дмитрия Ульянова, 19

Отпечатано с готового оригинал-макета

в типографии ООО «Красногорский полиграфический комбинат»

107140, г. Москва, пер. 1-й Красносельский, д. 3, оф. 17

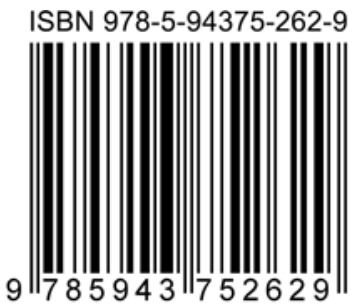


